Religious Changes and Cultural Transformations in the Early Modern Western Sephardic Communities 


\section{Studies in Jewish History and Culture}

Edited by

Giuseppe Veltri

Editorial Board

Gad Freudenthal

Alessandro Guetta

Hanna Liss

Ronit Meroz

Reimund Leicht

Judith Olszowy-Schlanger

David Ruderman

Marion Aptroot

VOLUME 54

The titles published in this series are listed at brill.com/sjhc 


\title{
Religious Changes and Cultural Transformations in the Early Modern Western Sephardic Communities
}

\author{
Edited by
}

Yosef Kaplan

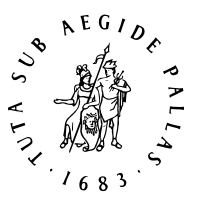

B R I L L 
This is an open access title distributed under the terms of the prevailing CC-BY-NC License at the time of publication, which permits any non-commercial use, distribution, and reproduction in any medium, provided the original author(s) and source are credited.

Cover illustration: Interior of the residence of Jacob Henriques de Granada in Amsterdam, Nieuwe Herengracht 99. Photo: Pieter Vlaardingerbroek.

Library of Congress Cataloging-in-Publication Data

Names: Kaplan, Yosef, editor.

Title: Religious changes and cultural transformations in the early modern western Sephardic communities / edited by Yosef Kaplan.

Description: Leiden ; Boston : Brill, [2019] | Series: Studies in Jewish history and culture | "The twenty-four articles in this volume are based on lectures given at the conference that took place at the Hebrew University in Jerusalem from November 14 through 16, 2016"-Preface. | Includes bibliographical references and index.

Identifiers: LCCN 2018049620 (print) | LCCN 2018050644 (ebook) | ISBN 9789004392489 (E-book) | ISBN 9789004367531 (hardback)

Subjects: LCSH: Jews—Europe, Western-History—Congresses. | Sephardim-Europe, Western-History-Congresses. | Europe, Western-Ethnic relations-Congresses.

Classification: LCC DS135.E82 (ebook) | LCC DS135.E82 R45 2019 (print) | DDC 305.892/40409031-dc23

LC record available at https://lccn.loc.gov/2018049620

The research leading to these results has received funding from the European Research Council under the European Union's Seventh Framework Programme (EP7/2007-2013)/ERC grant agreement No. 295352.

Typeface for the Latin, Greek, and Cyrillic scripts: “Brill”. See and download: brill.com/brill-typeface.

\section{ISSN 1568-5004}

ISBN 978-90-04-36753-1 (hardback)

ISBN 978-90-04-39248-9 (e-book)

Copyright 2019 by the Authors. Published by Koninklijke Brill NV, Leiden, The Netherlands.

Koninklijke Brill NV incorporates the imprints Brill, Brill Hes \& De Graaf, Brill Nijhoff, Brill Rodopi,

Brill Sense, Hotei Publishing, mentis Verlag, Verlag Ferdinand Schoningh and Wilhelm Fink Verlag.

Koninklijke Brill NV reserves the right to protect the publication against unauthorized use and to authorize dissemination by means of offprints, legitimate photocopies, microform editions, reprints, translations, and secondary information sources, such as abstracting and indexing services including databases. Requests for commercial re-use, use of parts of the publication, and/or translations must be addressed to Koninklijke Brill NV.

This book is printed on acid-free paper and produced in a sustainable manner. 


\section{Contents}

Preface IX

Acknowledgments XXXIII

List of Figures and Tables XXXIV

Notes on Contributors XXXVI

\section{PART 1 \\ Markers of Converso Identities}

1 A Crisis of Judeoconverso Identity and Its Echoes, 1391 to the Present 3 David Graizbord

2 A Family of the Nação from the Atlantic to the Mediterranean and Beyond (1497-1640) 22

James Nelson Novoa

3 Conversos versus Recusants: Shaping the Markers of Difference (1570-1680) 43

Natalia Muchnik

4 Richelieu in Marrano Garb: Conversos as Agents of the French Confessional Model, c. $1640 \quad 71$

Claude B. Stuczynski

5 Semi-Clandestine Judaism in Early Modern France: European Horizons and Local Varieties of a Domestic Devotion 113

Carsten L. Wilke

6 Prison Revelations and Jailhouse Encounters: Inquisitorial Prisons as Places of Judaizing Activism and Cross-Cultural Exchange 137

Ronnie Perelis 


\section{PART 2 \\ Mechanisms of Social Discipline in the Sephardic Communities}

7 Defining Deviance, Negotiating Norms: Raphael Meldola in Livorno, Pisa, and Bayonne 157

Bernard Dov Cooperman

8 A Sephardic Saga in the Dutch Republic: The Cohen Pallache Women on Love, Religion, and Social Standing 195

Tirtsah Levie Bernfeld

9 Dispute Resolution and Kahal Kadosh Talmud Torah: Community Forum and Legal Acculturation in Eighteenth-Century

Amsterdam 228

Evelyne Oliel-Grausz

10 The "Livro de Pleitos": The Leadership of the Spanish and Portuguese Community of London in the Eighteenth Century as a Court of Requests 258

Alex Kerner

\section{PART 3}

Economy and Community among Italian Sephardim

11 Jews in the Papal States between Western Sephardic Diasporas and Ghettoization: A Trial in Ancona as a Case Study (1555-1563) 291

Serena Di Nepi

12 The Sephardic Community and Social Practices in the Circuit of Money: Social Implications of Payment Networks in the Context of the Livorninas 323

Mauricio Dimant

13 Charity Begins at Home: Reflections on the Dowry Society of Livorno 346

Nourit Melcer-Padon 


\section{PART 4 \\ The Boundaries of Rabbinical Authority}

14 Jacob Sasportas and Problems of Discipline in the Ets Haim Yeshiva 383

Yaacob Dweck

15 A Letter's Importance: The Spelling of Daka(h) (Deut. 23:2) and the Broadening of Western Sephardic Rabbinic Culture 393 David Sclar

16 Hakham Yaakov Athias-A Portuguese Rabbi Facing the Winds of Enlightenment and Secularization $\quad 414$

Yocheved Beeri

\section{PART 5}

\section{Varieties of Cultural Creativity}

17 On the Role of Hebrew Grammars in the Western European Diaspora and the New World 431

Moisés Orfali

18 New Jews in Amsterdam: Some Social Aspects Reflected in the Thesouro dos Dinim by Menasseh ben Israel $\quad 45^{2}$

Aliza Moreno-Goldschmidt

19 Penso de la Vega and the Question of Jewish Baroque $\quad 469$

Einat Davidi

\section{PART 6}

Crossing the Atlantic-Sephardic Communities in the New World

20 Sea Is History, Sea Is Witness: The Creation of a Prosopographical

Database for the Sephardic Atlantic 487

Michael Studemund-Haléry 
21 Revisiting Blackness, Slavery, and Jewishness in the Early Modern Sephardic Atlantic $5^{12}$ Jonathan Schorsch

22 Feckless Fathers, Fraught Families: Abandonment and Cultural Change in the Early Modern Jewish World 541 Jessica Vance Roitman

23 The Gabay Dynasty: Plantation Jews of the Colonial Atlantic World 565

Stanley Mirvis

24 Patriots at the Periphery: David Nassy, the French Revolution, and the Emancipation of the Dutch Jews 581

Sina Rauschenbach

Index of Names and Places $\quad 611$ 


\title{
Preface
}

\author{
Yosef Kaplan
}

The presence of the Portuguese Jews in the cities of Europe in the early modern period aroused curiosity mingled with enthusiasm and suspicion. For some visitors in cities like Venice and Amsterdam, these were the first flesh and blood Jews they had ever encountered. The Portuguese Jews' splendid dress, cosmopolitan education, and excellent mastery of European languages contradicted the common stereotype of poorly spoken Jews with coarse manners. In contrast, the Portuguese Jews displayed elegance and courtesy, and the best educated among them were used to holding conversations on a broad variety of intellectual subjects. For example, Thomas Coryate, who visited Venice in 1608, wrote about the Jews he met there: "For indeed I noted some of them to be most elegant and sweete featured persons, which gave me occasion the more to lament their religion."1 Alexandre-Toussaint Limojon de Saint Didier found there Jews of various origins, and he particularly emphasized the wealth of the Portuguese: "There are several sorts of Nations among them, Hollanders, Spaniards, Portuguese, Germans and Italians, who have their particular Synagogues. But of all these different Nations, the Portuguese are counted the richest, who likewise esteem themselves to be in the highest degree above all the rest."

In a letter sent from Venice on March 27, 1688, the French tourist, Maximillian Misson outdid himself in describing the wealth of the Portuguese Jews: "There are some Jews at Venice who drive a great Trade, especially the Portuguese, who are very rich here, as well as at Amsterdam and elsewhere." ${ }^{3}$ Following a visit to Amsterdam, he spoke with amazement about the political status of some of the representatives of the Portuguese social elite: "Notwithstanding the Inquisition against the Jews in Spain and Portugal, a Portuguese Jew (Don Jerome Nunez de Costa) was Agent of Portugal at Amsterdam. And another,

1 Thomas Coryate, Coryate's Crudities (London, 1611), 231-32; Benjamin Ravid, "Christian Travelers in the Ghetto of Venice: Some Preliminary Remarks," in Between History and Literature: Studies in Honor of Isaac Barzilay, ed. Stanley Nash (Tel Aviv: Hakibbutz Hameuchad Publishing House 1997), 111-50.

2 Alexandre-Toussaint Limojon de Saint Didier, The City and Republick of Venice (London, 1699), 2: 6o-61.

3 Maximillian Misson, A New Voyage to Italy, English translation from the French original,

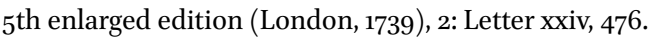


Don Emanuel de Belmonte, Resident of Spain. This last received the Title of Count from the Emperor."

The Italian diplomat, Gregorio Letti, expressed himself in a similar tone and praised them extravagantly: "La sinagoga de' Portoghesi sembra un seggio di Nobili, gente ben fatta, quasi tutta civile, ben vestita, ricca e che fa gran figura" (The synagogue of the Portuguese seems like the seat of nobles, cultivated people, almost all well-mannered, well-dressed, rich and who look impressive). ${ }^{5}$ Though he found the synagogue service repugnant, Letti was enchanted by the Portuguese social elite especially in Amsterdam, but also in Hamburg and London. Their splendid mansions attracted the attention of diplomats and even heads of states. Royalty and aristocrats were entertained there, as in the splendid home of Isaac Teixeira in Hamburg, where Queen Christina of Sweden stayed for a while (Fig 0.1). Letti wrote of Teixeira that he was a "signore cortese e civile," and that his ornate house "seems in every respect a theater, and hostel of refinement." 6

This splendor also characterized Teixeira's mansion in Amsterdam, where he moved in 1698. Letti spared no superlatives in praising Teixeira's mastery of various languages and the fact that he frequently hosted "letterati," and that his son, Don Diogo Texeira de Mattos even outdid his father in his conversational skill and ability to discuss any subject in the world. Their conduct was meant to display "gravidade," formality, a culture of courtesy worthy of a cultured "nation," which sought to be differentiated from other ethnic groups of Jews, whom they regarded as inferior, and especially from the "tudescos" and the "polacos," whom they called "gente barbara." They proudly called their own Jewish way of life "bom judesmo," worthy Judaism, and it was supposed to stand out in the dignity of its synagogue service. It was intended to present Judaism as civilized and cultured, with features befitting the patterns of behavior that had crystallized within European courtly society and been transferred to the bourgeoisie. Strong emphasis was placed on self-control, repression of instinct, restraining anger, and education for virtue, respect, and a culture of politeness.

In the splendid home of Baron Manuel de Belmonte in Amsterdam, during the 1670 and 168 os members of two literary academies met: de los Floridos, and del Temor Divino. Along with physicians and scholars from the Sephardic community, wealthy Portuguese merchants such as Geronimo Nunes da Costa,

4 Ibid., 2nd edition (London, 1699): Letter iii, 25.

5 Gregorio Leti, Il Ceremoniale historico, e politico (Amsterdam, 1685), 5: 725. English translation by Jonathan I. Israel, Diasporas within a Diaspora. Jews, Crypto-Jews and the World Maritime Empires (1540-1740) (Leiden, Boston, Cologne: Brill, 2002), 494.

6 Gregorio Leti, Teatro belgico, o vero ritratti historici, chronologici, politici, e geografici delle Sette Provincie Unite (Amsterdam, 1690), 375. 


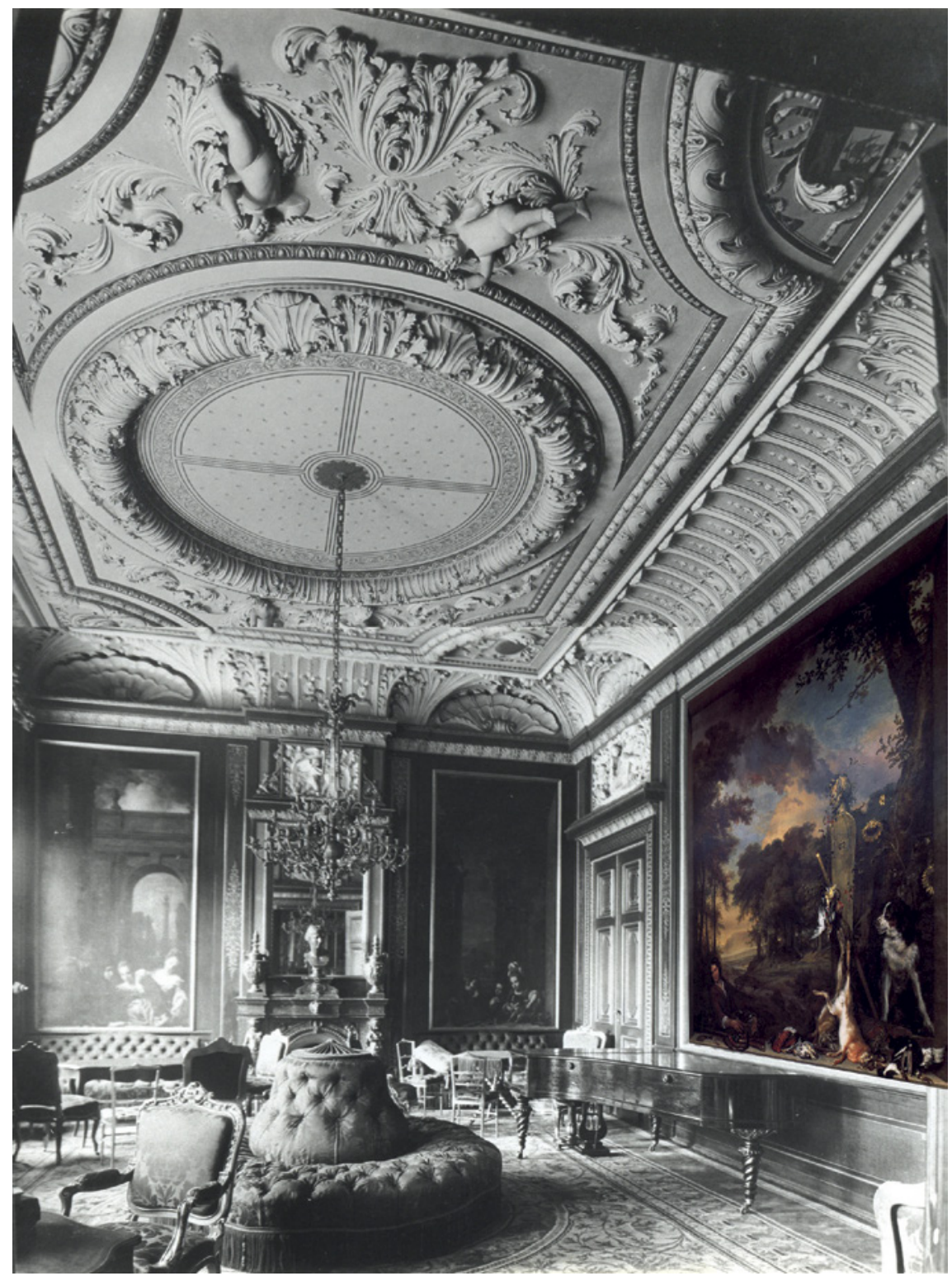

FIGURE 0.1 Interior of the residence of Jacob Henriques de Granada in Amsterdam, Nieuwe Herengracht 99.

PHOTO: PIETER VLAARDINGERBROEK 
Francisco de Lis, Manuel Levi, Moseh Machado, and Moseh Israel Pereyra took part in them. Some of these men also owned luxurious homes outside of the city on the banks of the Amstel and the Vecht, and they maintained gardens that became tourist attractions. Some of the wealthy Sephardim of London also purchased splendid houses far from the city, and the distance from London also sometimes led to distance from the community, and, ultimately, from Judaism.

The libraries of the social elite and of the educated Sephardim contained works in a variety of languages: primarily Spanish and Portuguese, but also French and Italian. The physicians among them and all those who had studied in universities (the large number of university graduates in the community was an unusual phenomenon in Jewish society at that time) also had books in Latin on theology, philosophy, and science.

The Portuguese immigrants who arrived in the cities of Western Europe, mainly beginning at the end of the sixteenth century, and especially during the seventeenth century, were New Christians, that is to say, descendants of Jews who converted to Catholicism during the time of the mass conversions that struck Iberian Jewry between the end of the fourteenth century and their expulsion at the end of the fifteenth century, especially at the time of the forced conversions of all the Jews in Portugal in 1497. The New Christians in both the Iberian monarchies were discriminated against and persecuted, as the laws or purity of blood that were applied in governmental institutions, in religious orders, and in colleges and universities prevented their acceptance. The vigorous persecutions of the Inquisition in Spain and Portugal cast dread upon the New Christians, who were suspected of observing Jewish ceremonies and custom in secret. However, despite the discrimination and the regime of terror, the New Christians underwent a comprehensive process of social mobility and acculturation. Many of them, who belonged to the bourgeoisie, succeeded in amassing huge wealth by participating in the international and colonial trade of Portugal. Quite a few young people, who had received a broad Christian education, sometimes in Jesuit schools, went on to study in the Iberian universities, mainly medicine but also law. The curriculum included courses in philosophy, and thus they acquired broad knowledge of Christian theology and the trends in Catholicism that developed during the Counter Reformation. Those who later emigrated from Iberia and returned to the Jewish religion brought this intellectual heritage with them, and by means of it they formed their conceptions of Judaism.

Their expertise in Christian theology, in many of its currents and sects, was outstanding and found expression in their sharp anti-Christian polemical writings, which were circulated in many manuscript copies. Philosophia Libera by 
the physician Isaac Cardoso, which was printed in Venice in 1673, offers an indication of the breadth of the scientific and philosophical education of the intellectuals among them.

Joseph Attias (1672-1739), a Jewish lover of science and a citizen of the Republic of Letters who lived in Livorno, owned a collection of 1,247 volumes, as we learn from the scholarship of Francesca Bregoli, and only sixteen of these were written by Jews. ${ }^{7}$ The collection included, among other items, books of biblical criticism, which, while they remained within the bounds of Christian orthodoxy, the very act of textual comparison made by their authors was sufficient to challenge scriptural authority. Even more impressive was the series of Galilean and Newtonian texts among the 270 volumes of philosophy, geometry, medicine, and natural sciences that he owned, reflecting his tendency toward Galilean experimentalism. No less surprising is the varied and eclectic collection of books owned by Rabbi David Nunes Torres (166o-1728), a contemporary of Attias. ${ }^{8}$ Nunes Torres was born in Amsterdam and educated at the Ets Haim yeshiva, and he served as the rabbi of the Portuguese Jews in The Hague in the last twenty years of his life. His book collection, which was put on sale immediately after his death, contained 2,148 volumes, not including Hebrew books. This fascinating collection reflects not only his polyglot education (books in French, Latin, Spanish, Dutch, English, Italian, and Portuguese), but mainly his breathtaking intellectual curiosity. However, in addition to the above, his library also contained a decidedly subversive element: he owned "forbidden" books, some of which had been banned by the Jewish leadership in Amsterdam, including the rare Portuguese work by Uriel da Costa against the oral law. However, it mainly contained various editions of books by Spinoza, including translations into French and Dutch, and about twenty books published between 1671 and 1727 that dealt with Spinoza's thought, mainly in order to refute it and attack him. These books present Spinoza's early reception in exhaustive fashion. Needless to say, this anti-Spinozan literature was one of the main channels for disseminating Spinoza's philosophy in the days of the radical Enlightenment.

In contrast to the impressive number of books in the libraries of these Jewish intellectuals, the collection of books in Spinoza's own library at the time of his death was quite modest: only 159 volumes. However, one of the

7 Francesca Bregoli, Mediterranean Enlightenment. Livornese Jews, Tuscan Culture, and Eighteenth-Century Reform (Stanford: Stanford University Press, 2014), 63-95.

8 Yosef Kaplan, "Spinoza in the Library of an Early Modern Dutch Sephardic Rabbi," in $L a$ centralità del dubbio. Un progetto di Antonio Rotondò, vol. 2, ed. Camilla Hermanin e Luisa Simonutti (Florence: Leo S. Olschki Editore, 2011), 639-62. 
important lessons to be drawn from it is the strong connection of Spinoza, who was born in Amsterdam, to the literature of the Golden Age of Spain, showing that this cultural bond was not weakened even among the descendants of the immigrants from Iberia who were born elsewhere.

The example of Spinoza is indicative of another phenomenon: the excellent Hebrew education that the young men of the Portuguese community in Amsterdam received in its school. It is clear beyond any doubt that he possessed thorough knowledge of the Scriptures and rabbinic sources, which he imbibed in an exceptionally good school, known for the emphasis it placed on the teaching of Hebrew and the Bible.

The rise of the Sephardic social elite was one of the most significant innovations in Jewish society in the early modern age, and the importance of this elite far exceeds that of the Court Jews, who were active among the absolutist rulers of German states. Some of them served the princes and rulers of various states, sometimes as diplomats, and sometimes as financial agents or military suppliers. The economic and political power of the Sephardic social elite played a critical role in the acceptance of the Sephardic Jews in the states of Western Europe.

Jonathan Israel has emphasized the uniqueness of the Western Sephardic diaspora in comparison to three other trade diasporas, which were active in the early modern period: the Greek, the Armenian, and the Huguenot. Of these four diasporas, only the Sephardic one was active simultaneously not only in regions under Catholic, Protestant, Orthodox, and Muslim hegemony, but also in regions that belonged to every one of the six maritime empires of the time (the Venetian, the Portuguese, the Spanish, the Dutch, the English, and the French); and, as if that were not sufficient, they were also active in trans-Atlantic trade. ${ }^{9}$ At that time there was no other Jewish group with similar economic influence and such vast wealth. Only at the peak of the Abbasid Caliphate in the tenth century was there a group of Jewish merchants with a geographical range of similar extent. However, it is very doubtful that the Radanites possessed economic power similar to that of the Sephardic social elite in the early modern period.

Moreover, the Sephardic social elite played a primary role in the process of the confessionalization of the Western Sephardic diaspora. In an essay I wrote several years ago, on the way in which Sephardic centers in the West became distinctive Jewish communities, I sought to place this process in the broad European framework and to see it as consistent with the paradigm of confessionalization (Konfessionalisierung), as developed by historians Heinz

9 Israel, Diasporas within a Diaspora, 1-39. 
Schilling and Wolfgang Reinhard. ${ }^{10}$ The communities of the Western Sephardic diaspora came into being as a result of confessional migration. However, despite the features they shared with other confessional groups in exile, such as the Puritans or the Huguenots, that which set them apart was very significant. In contrast to the other communities of belief, whose religious affiliation was uninterrupted, and no important changes took place in it during their emigration, the Sephardic Jews in Western Europe returned to Judaism after a separation of generations from the religion of their ancestors. Not all of them adopted Judaism for particularly religious reasons. Some among them joined the new Jewish communities because of family connections, or out of social considerations, or because of economic distress. Their adhesion to Judaism did not sever their ties with the larger ethnic group of the Nação, which included many New Christians who had assimilated into Iberian society and entirely cut themselves off from any connection with Judaism. The differences in religion were indeed a source of tension and conflict, but they did not dim the shared ethnic consciousness.

However, contrary to the opinion of certain historians, I do not suggest underestimating their affiliation with Judaism, which persisted for generations among a good number of the New Christians. Even if we take a skeptical view of Inquisition testimony and documents, one cannot deny that among certain concentrations of Portuguese New Christians there was some kind of loyalty to Jewish traditions, which was maintained for many generations. It is no coincidence that the rabbis in the early modern period did not relate to New Christians who wished to adhere to Judaism as Gentiles who had to be converted. They related to the Judeoconverso's adhesion to Judaism as an act of "return to the bosom of Israel." In the Jewish world the communities of the Sephardic diaspora were not regarded as communities of proselytes but as communities of former forced converts who returned to the fold of Judaism. In most cases, the rabbis of these communities did not carry out meticulous investigations to determine the maternal lineage of those who wished to join the Jewish religion. Indeed, in a significant portion of the cases, such an investigation would have certainly raised difficulties, in the light of the exogamous marriages of quite a few converso families. The rabbis related to the Nação as an ethnic entity with a clear connection to Judaism. Moreover, some of the new adherents even claimed to be Kohanim (priests) and Levites, and this aroused

10 Yosef Kaplan, "Between Christianity and Judaism in Early Modern Europe: The Confessionalization Process of the Western Sephardi Diaspora," in Judaism, Christianity and Islam in the Course of History: Exchange and Conflicts, ed. Lothar Gall and Dietmar Willoweit (Munich: R. Oldenbourg Verlag, 2011), 307-41. 
no reservations among the rabbis. The phrase, "return to Judaism," is correct from the halakhic point of view and directly expresses the conception that was prevalent among the Sephardic communities of the early modern period.

Although the confessionalization of the Sephardic Jews could not take place in the framework of a centralized state, it was included in the construction of new communities, which projected exceptional power and imposed a strict regime of social obedience. The Sephardic social elite shaped the regime of the new communities according to a strict hierarchical conception. The Mahamad, which stood at the head of each community, had absolute and incontestable power. Like the rulers and princes in the confessional age, the parnassim of the Sephardic communities exploited to the full the authority that medieval Jewish law accorded to Jewish communities in order to consolidate a regime of Jewish autonomy that leaned upon sacral institutions, even when those who headed it were neither well versed in Jewish law nor possessed halakhic authority. But the parnassim of the communities of the Nação included the rabbis in the autocratic regime they established and used the power of halakha to accord sacrality to their regulations and resolutions. In the eyes of the social elite of the Western Sephardic communities, the function of the parnassim was viewed as analogous to that of the governors of a republic.

The Mahamad had supreme and unchallengeable power, as expressed in the regulations of almost all the Sephardic communities. In regulations approved in Amsterdam with the establishment of the united community in 1639 , we find: "That the Mahamad has supreme authority in all [tera autoridade e superioridade sobre tudo], and no person may act against the decisions that the Mahamad adopts and publishes."

The Mahamad of the Hamburg community received the same degree of authority and a regulation of May $165^{2}$ states explicitly: "The lords chosen [for the Mahamad] will have supreme power and full authority" (terão absoluto poder e autoridade plena).

The regulations of the Sha'ar Hashamayim Sephardic community of London, adopted in 1663, repeated the ordinance of the Amsterdam community almost word for word, and there too, emphasis was placed on the absolute obligation to cleave to the instructions of the parnassim, who were the "supreme body in governing the community" (supremo no governo da nação). About sixty years later, although the actual power of the Mahamad had been weakened, the glow of authority that still radiated from it was preserved, at least on the symbolic level. The parnassim were then called "Paes da Naçâo," the fathers of the nation.

In the Bordeaux community as well, though it began to be consolidated as a recognized Jewish community only toward the end of first quarter of the 
eighteenth century, things were no different. On March 25, 1723, it was formally proclaimed there that the parnassim and the gabay (treasurer), and the other members of the Mahamad who were joined with them, were "the absolute rulers in the general administration of our nation" (dueños absolutos para lo que toca al govierno del general de nuestra Nación).

Those chosen to be members of the Mahamad of the Sephardic communities had to be independent enough financially to devote their time to public concerns. The position also demanded constant attendance of the synagogue, and at least the chairman (a rotating position) had to be present in the building during prayers. Although the regular meetings of the Mahamad took place only once a week, the chairman usually summoned the other members to additional meetings when circumstances demanded them. Craftsmen and wageearners, even small-scale merchants, were naturally unable to undertake such a responsibility. By contrast, the position suited entrepreneurial investors, who could make time for public affairs when necessary. Indeed, this is one of the main characteristics of those who wielded authority in the urban government of Europe at that time. Max Weber called this Abkömmlichkeit (availability), the possibility of setting aside one's business at home and at work, to devote time to public affairs, and those who were chosen for administrative positions in the Sephardic communities largely belonged to the strata of independent merchants and financiers in the community. In this respect, the communities of the Western Sephardic diaspora were no different from Christian ethnic and religious diaspora communities of the time. In the Huguenot communities in Holland, Germany, and England, as well as the English Reform Church in Amsterdam, and the Dutch and Walloon Protestants who settled in London, the wealthy merchants administered the matters of their churches with a high hand.

Generally, things changed during the eighteenth century, and the power of the Sephardic leadership grew weaker. But throughout most of the seventeenth century and in the early part of the eighteenth century, these communities managed to maintain effective communal government, which was based on rather strict social discipline.

The American sociologist Phillip Gorski, in his book The Disciplinary Revolution, presented the challenging idea that the relation between disciplinary revolution and the modern state is similar to the relation between the industrial revolution and capitalism: like the industrial revolution, the disciplinary revolution transformed the material and technological bases of production; it created new mechanisms for the production of social and political order. And "like the industrial revolution, the disciplinary revolution was driven by a key technology, the technology of observation: self-observation, 
mutual observation, hierarchical observation. For it was observationsurveillance - that made it possible to unleash the energies of the human soul $[\ldots]$ and harness them for the purposes of political power and domination. [...] What steam did for the modern economy," Gorski claims, "discipline did for the modern polity [...] by creating more obedient and industrious subjects with less coercion and violence, discipline dramatically increased, not only the regulatory power of the state, but its extractive and coercive capacities as well."11

Gorski attributes the main turning point to the Protestant Reformation, and especially to its Calvinist version. In his opinion, this explains why two of the least centralized and least monarchical states in the early modern world-the Netherlands and England-were also among the most orderly and powerful. And why Brandenburg-Prussia, one of the most fragmented and backward monarchies of Europe, became one of the most unified and advanced of the great powers. ${ }^{12}$

Without necessarily accepting all the details of Gorski's historical and theological analysis but following his sociological distinctions, I can state with confidence that it is doubtful whether any Jewish communities in the early modern period maintained such a strong hierarchical structure as the Sephardic community in Amsterdam and imposed such rigorous communal discipline. Although the social control in no other Western Sephardic community was as tight and comprehensive as in Amsterdam, at the same time, it is doubtful whether in the Jewish world of that time, beyond the circle of communities of the Nação, there were any communities where mechanisms of social control were in force to an extent similar to that of the Western Sephardic diaspora. In no other Jewish communities have we found such widespread use of the punishment of excommunication as in the Sephardic communities of Amsterdam and Hamburg. In London, too, and even in some of the communities in the colonies in the New World, such as Curaçao and Suriname, efforts were made to install strict methods of communal discipline. These efforts did not always attain their aims, but discipline, as a supreme social goal, existed in all these communities.

The process of confessionalization in the communities of the former conversos was bound up in a general reformation: insistence on church-like discipline, the effort to create a confessional identity, and the demand for uniformity in dogma and religious practice. It would be no exaggeration to state that in Northwest Europe, the Sephardic communities were influenced by the 
patterns of social control practiced in the local Protestant churches. Without doubt, the Sephardic community of Amsterdam was influenced by the Dutch Calvinist church.

Confessionalization was founded upon the principle of the unity of the group and the peace prevailing among its members. As in the Calvinist church, for example, where care was taken to reconcile individuals embroiled in controversy before celebration of the Lord's Supper, which symbolized, among other things, the unity of the denomination as a community where the sacral spirit prevailed, so, too, in the Sephardic communities, care was taken to reconcile controversies among the members, so that these would not impair the unity of the community or destroy its integrity.

A considerable number of the regulations instituted by these communities were intended to condemn any kind of behavior that was liable to infringe upon public order, not only in and around the synagogue, but everywhere within the boundaries of the city, and sometimes even beyond it. As in both Calvinist communities of belief and Catholic societies during the CounterReformation, in the communities of the Nação a technology of observation and surveillance, pointed out by Gorski (with the influence of Foucault) was employed as a key technology in the disciplinary revolution of the early modern period. The many examples of disciplinary affairs, which were investigated in the chambers of the Mahamad of these communities, and which were recorded in detail in the community registers, illustrate the drive to inquire into every scrap of information regarding deviant behavior, departure from religious norms, and from communal discipline. Not only incidents touching upon deviance from the tenets of faith (about which much has been written in scholarship) were investigated with inquisitorial thoroughness (as, for example, the Prado-Ribera case or the Karaite incident of 1712), but also, and mainly, deviance from religious norms that were expressed in daily life, and especially deviance in sexual behavior and morality, which were sometimes documented down to the last detail. Surveillance also played a central role in the educational institution of the community, and in Amsterdam, there is extensive documentation of this in the registers of the Ets Haim confraternity. The purpose of surveillance also lay behind the prohibition against synagogue attendance by unmarried women, except on the Day of Atonement, as well as the prohibition imposed on all women against coming to the synagogue in the evening. Public requests for forgiveness, ceremonies which were very frequent in Amsterdam, were intended, among other things, to bring out and emphasize the surveillance to which every single individual was subject. Members of the community who traveled to the "Lands of Idolatry" were also required to reveal what they had done in those forbidden places; after their return, they 
had to beg forgiveness from the pulpit of the synagogue, saying where they had gone, for how much time, and what religious prohibitions they had violated, and so on. The poor, about whom Tirtsah Levie Bernfeld has written outstanding research, ${ }^{13}$ were also closely supervised, and recipients of assistance who lapsed and violated communal discipline risked reduction in the relief they received from the community treasury, or even its cessation.

The Calvinist church in Amsterdam is a prime example for Gorsky of what he calls the disciplinary revolution in early modern Europe. From Herman Roodenburg's thorough scholarship, we have learned that between 1578 and $1700,5,754$ cases of violation of discipline were adjudicated in that church, but in only thirty-three cases were the delinquents excommunicated. ${ }^{14}$ It is impossible to sum up all the instances of disciplinary infractions adjudicated in the Sephardic community of Amsterdam, but during the seventeenth century it imposed more excommunications than the Calvinist church: at least forty instances-although, during that time, the Sephardic Jews constituted less than two percent of the city's population! ${ }^{15}$

The data about Hamburg is less complete, but the picture that emerges is even more impressive: from the establishment of the united community of Beit Israel in $165^{2}$ to the 1680 s (a period from which two registers have been preserved), that is, in only three decades forty-one individuals were excommunicated in Hamburg in forty-five incidents of excommunication, a huge number for a community numbering between six hundred and eight hundred members. ${ }^{16}$

For various reasons, there were relatively few cases of excommunication in London, but, not only was the threat of excommunication a constant presence, but various other kinds of punishment were employed until the end of the eighteenth century, and the principle of surveillance guided the leadership all along the way. The case of the young Isaac Coronel, who was punished with shamta (the most severe kind of excommunication) in 1710, for abducting the young girl, Rebecca Pereyra, in order to marry her, gives us a glimpse of the efforts used by this community to obtain testimony in many places outside of London, where there were no Jews, and to gather incriminating

13 Tirtsah Levie Bernfeld, Poverty and Welfare among the Portuguese Jews in Early Modern Amsterdam (Oxford and Portland, OR: The Littman Library of Jewish Civilization, 2012).

14 Herman Roodenburg, Onder censuur. De kerkelijke tucht in de gereformeerde gemeente van Amsterdam, 1578-1700 (Hilversum: Verloren, 1990), 137, 148 and see 146-204.

15 Kaplan, An Alternative Path to Modernity, 108-54.

16 Ibid., $168-95$. 
evidence against the young delinquent, the son of one of the wealthiest families in the community. ${ }^{17}$

In Bordeaux as well as in the satellite communities of Amsterdam in Surinam and the Caribbean, efforts were made to maintain stringent surveillance mechanisms. The partial material that has come to us from Livorno in this matter also shows that the principled approach was no different there.

The communities of the Nação apparently continued to maintain their traditional organization until the time of the French Revolution, and the communal institutions ostensibly preserved their original character. Perusal of the regulations of the Amsterdam community from the eighteenth century gives one the impression that the community even became stricter in the enforcement of its regulations, the wording of which is often more severe than in the past. However, as I have noted elsewhere, this severity is an optical illusion. The Amsterdam community, as well as other Sephardic communities, underwent a most significant metamorphosis. Because many Sephardic Jews removed themselves from communal life, membership in the congregations dwindled. Those remaining were the hardcore loyalists, and the orthodox discourse found in the communal decisions reflects the new atmosphere that was created in response to the threat of assimilation into the gentile surroundings, mixed marriages, and conversions. Unlike the typical situation during the seventeenth century, when the communities were constantly absorbing new immigrants not all of whom showed a high degree of identification with Judaism, during the eighteenth century, following the departure of those with weaker links to Judaism, orthodox elements exerted a stronger influence on the community, and the strict tone of the regulations and sermons reflected this religious and cultural change.

The Amsterdam community came increasingly to resemble the Calvinist community, in the sense that in it, too, the status of the preciezen, that is to say, the "precisionists," grew stronger, and the liefhebbers, that is, those who had a weak connection with synagogue life, were shunted to the margins. The rabbis' status also increased, seeing that the Sephardic social elite had fallen into decline, and in large part had left the community.

Since I introduced these remarks by discussing the social elite, I will also conclude with reference to it. In Europe after the Treaty of Utrecht in 1713, the political and diplomatic role played by court Jews declined, and the diplomats

17 Yosef Kaplan, "The Abduction of a Girl in Order to Marry Her and Other Clandestine Marriages in the Sephardic Community of London in the Early Eighteenth Century," in Portuguese Jews, New Christians and New Jews. A Tribute to Roberto Bachman, ed. Claude Stuczynski and Bruno Feitler (Leiden and Boston: Brill, 2018), 385-98. 
among the Sephardic social elite no longer thrived. The status of the Teixeira family of Hamburg fell, and the Amsterdam Agencies of Spain and Portugal were removed from the hands of Jewish agents, in the wake of the wave of anti-Semitism that inundated the Iberian Peninsula in the 1720s. Manuel Levi Ximenes was the last Sephardic Jew to hold the post of the Spanish residente in Amsterdam, for after 1725 only Spanish Catholics were appointed to this position. The agency of the Portuguese Crown remained in the hands of the Nunes da Costa family only until 1737 , and after that, the Portuguese refused to appoint Jews to that position. The economic situation of the Sephardic communities in Venice and Hamburg weakened severely, and, although in Holland the social elite retained its economic power, it withdrew from its activity in international commerce, and the majority of the wealthy Sephardim thrived on the profits from their shares in the Dutch colonial companies. They did retain a commercial tie with Cadiz and especially with the Dutch colonies in the Caribbean, but their economic impetus declined precipitously.

Moreover, with respect to the involvement of the social elite in community life, no one would deny that a highly significant withdrawal took place. The years had passed in which their representatives had served as parnassim and provided almost all the members of the Mahamad, and they, in fact, had governed community life. The registers show that many of them refused to accept the post after having been chosen, and, instead they preferred to pay the high fine, which the community imposed on those who refused. The distancing of this stratum of the society from management of communal affairs in London was even more extreme, as shown by the cases of Joseph da Costa Villa Real and Samson Gideon.

The departure of the great magnates from communal leadership brought out even further the increased presence of rabbinical figures, who progressively seized the center stage and contributed to the creation of the optical illusion of which I have spoken. Just as the monetary fine was accepted as a substitute for the actual presence of the members of the social elite in leadership, so, too, it increasingly became a substitute for the sanction of excommunication. The practice of resgate do herem (ransom from the herem) became more deeply rooted. That is to say, many of those condemned to excommunication, both those actually banned and those reprieved at the last minute, merely paid a fine to purchase either withdrawal of the decree of excommunication or its cancellation before implementation.

Indeed, significant changes took place in Western Sephardic culture and religious life during the eighteenth century. After the flow of refugees arriving from Spain in the 1720s, following the last wave of persecution by the Inquisition, which began in 1715 , it dwindled toward the end of the 1720 s, and 
almost no more New Christians joined the Sephardic communities. In all the communities of the Nação there was significant demographic stagnation, which influenced the social and cultural profile of Sephardic Jewish society in general. The Portuguese community in Amsterdam, which numbered about 4,400 toward the end of the seventeenth century, shrank toward the end of the eighteenth century to only about 2,500. In Livorno, where all the Jews of the city prayed in a single synagogue from the beginning, in the first half of the eighteenth century the city ceased to be a Sephardic citadel. The arrival of Jewish families from other parts of Italy and North Africa reduced the preponderance of the Western Sephardim even further. In consequence of these demographic changes, the attachment of the members of these communities to Iberian culture was weakened, and hardly any original literature was written in Spanish or Portuguese by the Western Sephardic Jews in the eighteenth century. Although a number of prominent and somewhat influential rabbis were active in the course of the century, such as the Hakhamim David Nieto and Moses Cohen d'Azevedo in London, or Selomoh Aylon, and especially David Israel Athias and Isaac Haim Abendana de Britto in Amsterdam, the general picture is one of cultural and religious decline. The Ets Haim yeshiva in Amsterdam was still flourishing in the first half of the century, and the publication of Peri Ets Hayim, a serial publication of halakhic rulings by teachers and advanced students of the yeshiva, testifies to its vitality. Nevertheless, everything indicates that the spiritual ferment and flourishing culture that formerly characterized the previous century had faded away. Toward the time of the Emancipation of the Jews of Europe, the Sephardic moment in Western Europe had come to an end.

The twenty-four articles in this volume are based on lectures given at the conference that took place at the Hebrew University in Jerusalem from November 14 through 16, 2016. The idea for the conference emerged from the discussions of the research group under my direction on the Western Sephardic Diaspora in the Early Modern Period, which was awarded a grant from the European Research Council (ERC).

The articles cover a great variety of issues and subjects connected with the history and culture of the Sephardic diaspora in the early modern period. They present a colorful and variegated picture, not always harmonious, of a cosmopolitan and vital diaspora, whose communities were established by New Christians who returned to the Jewish religion, usually in places where there had not been a Jewish settlement before their arrival. With the assistance of veteran Sephardic communities in North Africa and the Ottoman Empire, they reinvented their Sephardic-Jewish identity, while maintaining a connection with their historical and cultural roots in the Jewry of medieval Iberia. 
Adhesion to the Jewish religion did not erase their familial, social, and economic ties to members of the Nação who remained Christian, either in the Iberian kingdoms or in France and Italy.

The six articles in the first section of the book, Markers of Converso Identities, deal with the identity of the Judeoconversos from a variety of perspectives. David Graizbord challenges the approach that sees the Iberian New Christians as latent Jews. He regards the incidence of Judaizing among the New Christians after the beginning of the sixteenth century not as an "attenuated or a residual form of Jewish life" but as a "dissident offshoot of Iberian Christianity." In his opinion, the members of the Nação were "a religiously diverse ethnos." When conditions made it possible, some of them chose to be Jews and to join a Jewish community. But this should not be seen as "a natural preference." Members of the Nação were simultaneously "potential Jews and potential Christians."

James Nelson Novoa presents the case of Bento Teixeira, the first Portuguese poet in Brazil. By considering the story of his life and that of several of his relatives and associates, he sheds light on the familial and social connections among various branches of the Nação, from the Mediterranean to the Atlantic. The Teixeira family was split between those who identified heart and soul with the Catholic religion and others who shed Christianity and leaned toward Judaism. But some of them also denied religious belief of any kind. The story of this family shows that many of its members preferred to remain Christian even when they could live openly as Jews in places where this was possible such as Pisa in the duchy of Tuscany.

Natalia Muchnik compares the Iberian Marranos to the Recusants, English Catholics who, beginning with the reign of Elizabeth I, refused to take part in the ceremonies of the Anglican Church and practiced Catholicism in secret. In quite similar fashion, repression and secrecy shaped the social organization of both the Marranos and the Recusants. The religiosity of both groups was highly creative and far from the syncretism and diluted spirituality and ritual attributed to them in historiography.

Claude Stuczynski analyzes the open sympathy shown toward the French Gallican confessional model by two well-known Judeoconversos of the seventeenth century, the Portuguese diplomat Manuel Fernandes Vila Real, and the author Antonio Enríquez Gómez. The French regime was characterized by political centralization, religious autonomy independent of the Pope, and by a considerable degree of freedom of conscience, although the state publicly remained Catholic. This enabled the Portuguese New Christians to maintain a crypto-Jewish style of life in the private sphere, so long as they did not observe Jewish ceremonies in public. The two authors in question sought to bring 
about a change in the attitude toward the New Christians in the Iberian kingdoms, in the spirit of the French approach, especially after the granting from $155^{\circ}$ on of lettres patentes for the Nation portugaise.

Carsten Wilke also focuses on the special status of the New Christians in France, but in his article, he presents the religious and social profile of the two thousand New Christians who lived in the French kingdom during the seventeenth century. He examines the regional differences in their status with respect to the degree of freedom they enjoyed to observe Jewish ceremonies discreetly, and sometimes even openly. Many of the Portuguese merchants in France traveled to Spain regularly for their business, stayed there for long times, and lived as Catholics in every sense. But, upon their return to France (usually in the season of the Jewish holidays), they lived as Jews, obedient to the halakha. Wilke emphasizes how the French model became an "important player in the dynamic network of the Western Sephardic diaspora."

The Inquisitors used to introduce secret agents in the cells of those suspected of heresy. Usually these agents were prisoners themselves, sentenced for less serious crimes. Their job was to spy on the suspects, to get them to talk, and to elicit confessions of their criminal connection with Judaism. The Inquisition protocols contain detailed accounts of the conversations held in the cells of various prisoners, surprising revelations that the prisoners made to the informers, and even theological discussions that took place among them. Ronnie Perelis analyzes a number of such interactions, which took place in the prison of the Inquisition, concentrating on two figures who left behind detailed confessions: Luis de Carvajal the Younger, who was tried by the Inquisition in Mexico, and Manuel Cardoso Macedo, a Portuguese Calvinist in the Azores Islands, who, because of the influences to which he was exposed in the Inquisition prison in Lisbon, ultimately converted to Judaism in Hamburg. He settled in Amsterdam, where he wrote about the vicissitudes of his life.

The four articles in the second section of the book deal with Discipline, Conflict and Dispute Settlement in the Western Sephardic Communities. They present the means at the communities' disposal to maintain a Jewish way of life, preserve social discipline, and settle disputes. Bernard Dov Cooperman focuses on the activities of Rabbi Raphael Meldola of Livorno (1685-1748), the author of four volumes of rabbinical responsa, Mayim Rabim, which was published in 1737. Cooperman regards this work as a profoundly "modern" book, especially because of the techniques Meldola used to defend the halakha and to disseminate it both in local communities and over a widening international circle.

Jews like the wealthy Cohen Pallache family, whose story is told by Tirtsah Levie Bernfeld, were not among those who sought the opinions of rabbis in 
managing their daily life. Nor did the rebellious girl, Eva Cohen from Delft, who fled to London from The Hague with the Christian servant of her brother. Against her opinionated mother's will, she ultimately managed to marry her lover, after converting to Calvinism and a saga that continued for several years. This episode became a cause célèbre, in which wealthy Sephardic Jews from Holland and England were involved, along with the mayor of Amsterdam, and even a number of diplomats. In 1684 , the couple finally won its legal battle and they were allowed to marry, despite the opposition of the Cohen family. The Portuguese community proved to be powerless in cases of this kind.

Evelyne Oliel-Grausz examines the role of the Portuguese community in Amsterdam after 1632 as a forum for dispute settlement and processes of community arbitration. By examining documents surviving from the eighteenth century, she managed to trace the development of this forum and to propose a relevant interpretative framework congruent both with Sephardic history and the Dutch legal context. Oliel-Grausz shows that the forms and scope of the functions of the kehilla in dispute settlement in Amsterdam testify to mechanisms of social discipline that, while rooted in Jewish traditions of mediation and arbitration, are best explained within the general context of Dutch selfruled churches.

In the Sephardic community of London, a similar mechanism for resolving conflicts existed as well. Alex Kerner examines the subject on the basis of archival material that had not been examined previously. Before bringing their claims before external courts, the disputing parties were required to present them to the Mahamad, so that it would appoint arbitrators. Only if the arbitrators failed to bring the parties to a compromise were they permitted to address any external tribunal they wished. The power of this mechanism was rather limited, because in nearly a third of the cases, the plaintiffs refused to appear before the Mahamad.

The articles in the third section deal with topics connected with Economy and Community among Italian Sephardim. The Jewish settlements in Italy played a central role in the history of the Sephardic diaspora. Hundreds of those driven out of Spain fled to the Papal States immediately after the expulsion in 1492, where they encountered a quite tolerant attitude. This was also true of the refugees who left Spain and Portugal after forced baptism. The turn for the worse took place under Pope Paul IV, who, in 1555, published the bull Cum nimis absurdum, which imposed severe religious and economic restrictions on the Jews in the Papal States. At that time, the Jews of Rome were consigned to a ghetto based on the model of the ghetto of Venice. The rather tolerant policy came to a gruesome end with the burning at the stake of twenty-four Jews in Ancona, former Marranos who returned to Judaism. Serena Di Nepi discusses a wideranging court case that was heard between 1555 and 1563 before the regular 
Christian magistracy, in which Jews, apostates, and Christians were involved. This trial took place following the breaking of an engagement that was celebrated in the winter of 1555 in Ancona between Sarah, the daughter of Yacob Belcayro and Emanuel Montolmo. The proceedings of this trial show that the walls of the ghetto did not separate the Jews of Ancona from those of Italy or beyond or from economic and social contacts with the Christian population. Despite the ghetto walls, the Sephardic networks continued to play a role in the Papal States and in Italy exactly as they did in the rest of the Jewish world.

From the end of the sixteenth century, Livorno became one of the most prosperous centers of the Sephardic diaspora. The Jewish community developed following the issue of charters, known as the Livornine of 1591 and 1593, issued by Ferdinand I de Medici, Grand Duke of Tuscany, to the Jewish merchants, inviting them to settle in the port city and develop its commerce. Within a few years the Sephardic community of Livorno was flourishing. According to the historian, Francesca Trivellato, "it began to occupy important niches in the competitive trade encompassing the Mediterranean and Atlantic Europe."18 Mauricio Dimant relates to the harsh criticism written by Yehiel Nissim da Pisa in his Hayye Olam (Eternal Life, 1559), of the social implications of money practices on Jewish life, especially the uses of interest in the circuit of payment. His article argues that the success of the Livornine in encouraging the immigration of members of the Nação was related to their capacity to resolve the challenges of their participation in the circuit of payment, which allowed articulation of economic and Jewish practices in a context of socio-economic change.

In 1644, the Sephardic Jews of Livorno established a confraternity intended to provide dowries for orphaned and virtuous Jewish girls. Nourit MelcerPadon presents the social and economic functions filled by this confraternity over the generations. It was the most important and wealthiest among the sixty confraternities founded by the Jews of Livorno, and its members were among the most highly respected in the community. Like other confraternities of this type in the general Italian society, it served as an instrument for maintaining the governing class. The regulations of the confraternity were based on the model of confraternities with the same purpose established by the Sephardic Jews in Venice (1613) and Amsterdam (1615).

The fourth section containing three articles is entitled The Boundaries of Rabbinical Authority. In the communities of the Nação the rabbis were subject to the Mahamad. The authority to excommunicate was placed in the hands of

18 Francesca Trivellato, The Familiarity of Strangers. The Sephardic Diaspora, Livorno, and Cross-Cultural Trade in the Early Modern Period (New Haven and London: Yale University Press, 2009), 3 . 
the parnassim alone, and there were very few instances in which a rabbi expressed indignation about this situation. The first rabbis of these communities came from the Near East, North Africa, or the veteran communities in Italy. But with the establishment of the Ets Haim yeshiva in Amsterdam, it became the main supplier of rabbis for the Sephardic diaspora in Western Europe and the New World. Rabbi Jacob Sasportas, about whom Yaacob Dweck has written, was one of the most important Talmudic scholars who were active in the Western Sephardic communities. He was born in Oran, Algeria, and after serving as rabbi in Tlemcen and Salé, he arrived in Amsterdam for the first time in 1653 . He served, by turns, as the rabbi of the Sephardim in London, Hamburg, and Livorno, and toward the end of his life, he was appointed the Hakham of the Amsterdam community. At the peak of the Sabbatean messianic ferment, he waged a determined struggle against the believers in Sabbetai Zevi. Dweck analyzes Sasportas's response to the rebellion of students that took place in the Ets Haim yeshiva while he was teaching there. His vigorous response is typical of the assertive way in which he defended the honor of rabbis.

David Sclar focuses on a halakhic decision by Moses Israel, a veteran scholar who was active in Amsterdam, which was published in the community's Hebrew periodical Peri Ets Hayim, the serial publication of halakhic rulings by teachers and advanced students of the yeshiva. In a learned ruling, Israel relates to the difference between Sephardim and Ashkenazim in the spelling of $(\operatorname{Daka}(h)$ [Deut. 23:2], and the question of whether an Ashkenazic Jew was permitted to read from the congregation's Torah scrolls, where the word is written דקה, with the letter heh at the end, according to the Sephardic tradition, and not דקא, with an alef at the end, according to the Ashkenazic tradition. Sclar points out that, "increased intellectual and social engagement with Ashkenazic culture in the eighteenth century broadened Portuguese rabbinic culture and eroded existing sentiments of communal exclusivity." Following the lettres patentes of 1722, the Portuguese in Bordeaux in southwestern France, were recognized for the first time as Jews in every respect, which made them into the first Jewish community that was allowed to hold Jewish ceremonies in public. Yocheved Beeri writes about the Hakham Yaakov Athias who played a central role in the first generation of this transition. Athias tried by various means to impose the halakha and to struggle against those who violated it, in response to the winds of Enlightenment that influenced some of the members of the community. For the purposes of his struggle he occasionally sought assistance from the heads of the Amsterdam community.

The three articles in the fifth section treat the Varieties of Cultural Creativity of the members of the Nação. Quite conspicuously, not only were they polyglot and capable of reading and expressing themselves in a number of languages, 
but their original literary productions, in various genres, were also written in several languages. Although Portuguese was their spoken language in daily use, and the language they used (in most cases) in the community registers, and despite the strong attachment they displayed to Spanish literature of the Golden Age, they stood out especially in fostering use of the Hebrew language and in teaching it to the younger generation. In the educational institutions of their communities, and especially in the school of the Amsterdam community, they insisted strongly on systematic instruction in Hebrew, emphasizing correct pronunciation and good knowledge of grammar and syntax. It is no coincidence that several rabbis in the Amsterdam community wrote books on Hebrew grammar, usually in Portuguese, which they used for teaching. Moisés Orfali writes about the character and function of several of these grammar books. The two examples about which he writes at length are the grammar book written by Rabbi Isaac Aboab da Fonseca in Hebrew, while he was living in Pernambuco, Brazil. The work was intended for his use in teaching Hebrew, for the benefit of pupils in the study of Torah; and the grammar written by Baruch Spinoza in Latin, by means of which he sought to separate Hebrew from the Bible and to teach the language independently, for its own sake.

In the early modern period, a series of halakhic manuals were written in Spanish and Portuguese, which were intended to serve the members of the Nação who returned to Judaism and needed books of instruction for maintaining a Jewish way of life according to halakha. After the publication of the Shulhan Arukh by Rabbi Joseph Karo, these works of popular instruction, which were mainly written in Italy and Holland, were based on it. Aliza Moreno-Goldschmidt writes about Thesouro dos Dinim, a halakhic instruction manual in Portuguese, which was mainly based on the Shulhan Arukh. Her article points out the way in which the work dealt with the most pressing issues for the Judeoconversos who returned to the Jewish religion.

Einat Davidi examines the work of Joseph Penso de la Vega, one of the most gifted writers of the Sephardic community in Amsterdam, who wrote works in prose and poetry, both in Spanish and in Hebrew. Although the Baroque is identified with seventeenth-century Iberian Catholicism, Davidi demonstrates Penso's unequivocal attachment to this style, by examining three of his works: the Hebrew play that he wrote in his youth, Asirei ha-Tikva (Prisoners of Hope); Rumbos Peligrosos (Dangerous Paths), a collection of short fiction that he wrote in Spanish; and his best known work, a three-way conversation about the activities of the Bourse in Amsterdam, Confusión de confusiones (Confusion of Confusions).

The history of the Sephardic communities in Western Europe is connected with the colonial enterprises initiated by the European powers during the early 
modern period. The five articles in the final section of the book Crossing the Atlantic-Sephardic Communities in the New World discuss various aspects of the Nação across the Atlantic, especially in the Caribbean. The article by Michael Studemund Halévy offers a panoramic survey of the possibilities inherent in systematic analysis of the information provided by the ten thousand gravestones in the Jewish cemeteries in the Caribbean region. The sample of findings presented in the article are part of a comprehensive project that seeks to form a detailed data base of all the men and women buried in these cemeteries, with a systematic analysis of the inscriptions and decorations on the gravestones. Jonathan Schorsch discusses the attitude of the Jews in the Caribbean colonies to the black population. He criticizes the tendency that exists, in his opinion, among some of the Jewish historians who tend to emphasize "inclusion" and "coexistence," while in fact the attitude of the Jews toward the blacks was discriminatory and conflictual. Black and mixed-race Jews were not seen as equal. In the Jewish communities across the Atlantic, most of them were relegated to second-class status, and Jews who owned slaves did not convert most of them. The black Jews were a very small minority among the blacks and mixed-race slaves belonging to Sephardic Jews.

Jessica Vance Roitman relates to the phenomenon of abandoned wives. Men who sailed to the colonies in the New World in search of economic gain often left their wives behind. Many of these women were abandoned without being divorced, and some of them became involved in extra-marital relationships and gave birth to children who were regarded as mamzerim (children of incestuous or adulterous unions). This phenomenon gave rise to moral panic in Sephardic Jewish society.

The Sephardic Jews in the colonies were mainly traders in merchandise and slaves. However, Stanley Mirvis reminds us that there were also many poor people among them, Jews who were regarded as a financial burden on the community back in Amsterdam and were sent overseas as despachados, in order to be rid of them. While the Jews did not stand out among the owners of sugar plantations, Mirvis seeks to contradict the "port Jew model," which emphasizes the connection of the Jews of the Caribbean to commerce, and especially to international trade. The Gabay family in Jamaica, for example, which he presents, was involved in sugar plantations for several generations. This example clarifies the influences of this phenomenon on the "creolization" of the plantation Jews.

Sina Rauschenbach, in the article that concludes the volume, focuses on David de Isaac Cohen Nassy's Lettre theologico-politico morale sur les Juifs, which was written in 1795. Nassy, who was born in Suriname, was a pharmacist and physician, who was taken with Enlightenment philosophy. Not only did 
he defend the right of the Jews to emancipation, he also expressed discontent with the decadence of the Dutch Sephardim, in that they imported practices of intolerance from Iberia and used them against their most honorable community members. His writing contained more than a hint of criticism of the excommunication of Spinoza, Uriel da Costa, and other Sephardic free-thinkers.

David Nassy was a central and leading figure in one of the most fascinating phenomena in the history of the Nação: the Suriname Jewish Enlightenment. In Paramaribo, far from the intellectual centers of Europe, a group of young Sephardic Jews initiated a daring cultural project, in the spirit of the ideas of the philosophical Enlightenment. They established a Jewish literary and learned society called Docendo docemur (By Teaching We are Taught), which met twice a week in the home of the Portuguese Jew Salomon de Montel, for philosophical and literary discussions. Montel was in contact with a publisher and bookseller in Amsterdam, from whom he imported dozens of books for his library, which was open to the public. In the last twenty years of the eighteenth century, about a dozen literary societies were active in Suriname, and Jewish intellectuals participated in several of them. According to the late Robert Cohen, the influence of these Sephardic intellectuals on the cultural ferment in Paramaribo was decisive, though it was nipped in the bud: "When they died Surinam quickly regressed to the intellectual wasteland of earlier times."19 Thus, one of the most significant cultural transformations in the Western Sephardic diaspora took place "at the end of the West," in Suriname, a Dutch colony where about a thousand Jews were living by the end of the eighteenth century. This revolutionary development emerged in a short period of time, about a generation before the Jews of Suriname were given equal rights, in 1825 . But by then, the Jewish settlement in Suriname was already receding economically and demographically, like most of the other centers of the Western Sephardic diaspora.

\section{Bibliography}

Bregoli, Francesca. Mediterranean Enlightenment. Livornese Jews, Tuscan Culture, and Eighteenth-Century Reform. Stanford: Stanford University Press, 2014.

Cohen, Robert. Jews in Another Environment. Surinam in the Second Half of the Eighteenth Century. Leiden, New York, København, Cologne: Brill, 1991.

Coryate, Thomas. Coryate's Crudities. London, 1611.

19 Robert Cohen, Jews in Another Environment. Surinam in the Second Half of the Eighteenth Century (Leiden, New York, København, Cologne: Brill, 1991), 105-6. 
Gorski, Philip S. The Disciplinary Revolution. Calvinism and the Rise of the State in Early Modern Europe. Chicago and London: The University of Chicago Press, 2003.

Israel, Jonathan I. Diasporas within a Diaspora. Jews, Crypto-Jews and the World Maritime Empires (1540-1740). Leiden, Boston, Cologne: Brill, 2002.

Kaplan, Yosef. An Alternative Path to Modernity. The Sephardi Diaspora in Western Europe. Leiden, Boston and Cologne: Brill, 2000.

Kaplan, Yosef. "Between Christianity and Judaism in Early Modern Europe: The Confessionalization Process of the Western Sephardi Diaspora." In Judaism, Christianity and Islam in the Course of History: Exchange and Conflicts. Edited by Lothar Gall and Dietmar Willoweit, 307-41. Munich: R. Oldenbourg Verlag, 2011.

Kaplan, Yosef. "Spinoza in the Library of an Early Modern Dutch Sephardic Rabbi." In La centralità del dubbio. Un progetto di Antonio Rotond. Edited by Camilla Hermanin and Luisa Simonutti, 2: 639-62. Florence: Leo S. Olschki Editore, 2011.

Kaplan, Yosef. "The Abduction of a Girl in Order to Marry Her and Other Clandestine Marriages in the Sephardic Community of London in the Early Eighteenth Century." In Portuguese Jews, New Christians and New Jews. A Tribute to Roberto Bachman. Edited by Claude Stuczynski and Bruno Feitler, 385-98. Leiden and Boston: Brill, 2018.

Leti, Gregorio. Il Ceremoniale historico, e politico. 5 vols. Amsterdam, 1685.

Leti, Gregorio. Teatro belgico, o vero ritratti historici, chronologici, politici, e geografici delle Sette Provincie Unite. 2 vols. Amsterdam, 1690.

Levie Bernfeld, Tirtsah. Poverty and Welfare among the Portuguese Jews in Early Modern Amsterdam. Oxford-Portland, OR: The Littman Library of Jewish Civilization, 2012.

Limojon de Saint Didier, Alexandre-Toussaint. The City and Republick of Venice. London, 1699 .

Mission, Maximilian. A New Voyage to Italy. English translation from the French origi-

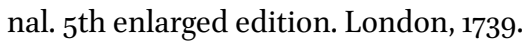

Ravid, Benjamin. "Christian Travelers in the Ghetto of Venice: Some Preliminary Remarks." In Between History and Literature: Studies in Honor of Isaac Barzilay. Edited by Stanley Nash, 111-50. Tel Aviv: Hakibbutz Hameuchad Publishing House, 1997 .

Roodenburg, Herman. Onder censuur. De kerkelijke tucht in de gereformeerde gemeente van Amsterdam, 1578-170o. Hilversum: Verloren, 1990.

Trivellato, Francesca. The Familiarity of Strangers. The Sephardic Diaspora, Livorno, and Cross-Cultural Trade in the Early Modern Period. New Haven and London: Yale University Press, 2012. 


\section{Acknowledgments}

I wish to thank all the institutions and people who helped in preparing this book for publication: the European Research Council, for its generous grant to the research group on Diaspora in Transition-The Religious and Cultural Changes in the Early Modern Western Sephardic Communities; the Hebrew University of Jerusalem for hosting the conference that led to the publication of this book; Dean of the Faculty of Humanities Professor Dror Wahrman and head of the School of History Professor Moshe Sluhovsky, for their advice and assistance. In addition, I would like to express heartfelt gratitude to Ms. Jenia Yudkevitch, the devoted administrative manager of the research project who spared no effort in organizing the conference. Last but not least, deep gratitude is due to Dr. Sharon Assaf for her careful copy-editing of the book and seeing it to press.

Jerusalem, 29 November 2017 


\section{Figures and Tables}

\section{Figures}

0.1 Interior of the residence of Jacob Henriques de Granada in Amsterdam, Nieuwe Herengracht 99. Photo: Pieter Vlaardingerbroek XI

2.1 Permission for printing of Naufragio que passou Jorge de Albuquerque Coelho, Capitão e Governador de Pernambuco and Prosopopeia. Courtesy of the Biblioteca Nacional de Portugal. Shelfmark REs. $392 \mathrm{P} \quad 27$

2.2 Title page of Naufragio, Lisbon, Antonio Alvarez, 1601. Courtesy of the Biblioteca Nacional de Portugal. Shelfmark REs. $392 \mathrm{P} \quad 27$

2.3 Tombstone of Rui Teixeira, Chiesa di San Martino, Pisa. Photo: James Nelson Novoa, enhanced courtesy of Marta Raïch 34

6.1 Latin Decalogue illuminated in gold leaf by Luis de Carvajal el mozo, Mexico, $1590 \mathrm{~s} \quad 140$

8.1 Frontispiece of the pamphlet The Conversion \& Persecutions of Eve Cohan, Now called Elizabeth Verboon [...], by Gilbert Burnet, London, 1680, National Library of Israel, Jerusalem 197

8.2 Johannes Vermeer, View of Delft, c. 1660-1661, Mauritshuis, The Hague 202

8.3 Gerard Houckgeest, New Church in Delft, 1651, Mauritshuis, The Hague 211

8.4 Jan Havicksz. Steen, Adolf and Catharina Croeser, known as "The Burgomaster of Delft and His Daughter," 1655, Rijksmuseum, Amsterdam 214

15.1 Pesak written by Moses Israel, Bibliotheca Rosenthaliana, Special Collections of the University of Amsterdam, HS Ros. 579398

15.2 Pesak written by Moses Israel, Peri Ets Hayim (Amsterdam: Proops, 1761), $\mathrm{EH} 4 \mathrm{~F} 11$, fol. $117 \mathrm{r} \quad 400$

15.3 Ashkenazic script on klaf, produced in the seventeenth or eighteenth century, Portuguese Synagogue, Amsterdam, T45 407

15.4 Sephardic script on klaf, probably produced in Amsterdam or Hamburg in the eighteenth century, Portuguese Synagogue, Amsterdam, T29 408

15.5 Sephardic script on gevil, produced in the eighteenth century, Portuguese Synagogue, Amsterdam, T66 408

20.1 Gravestone of Bella Barrow, wife of Simon Barrow, died 1 October 1773, aged 53 years, Barbados (detail). Photo: Michael Studemund-Halévy, 2017499

20.2 Gravestone of Hakham Mehir Cohen Belinfante, died 25 September 1752, aged 48 years, Barbados (detail). Photo: Michael Studemund-Halévy, 2017500

20.3 Gravestone of Rabbi Refael Haim Ishac Carigal, died 19 May 1777, aged 48 years, Barbados (detail). Photo: Michael Studemund-Halévy, $2017 \quad 501$ 
20.4 Gravestone of Elias Valverde, son of David and Simha Valverde, died 22 August 1725, aged 37 months, Barbados (detail). Photo: Michael Studemund-Halévy, $2017 \quad 502$

\section{Tables}

22.1 Cases of Adultery, Protestant Reformed Church, Amsterdam, Herman Roodenburg, Onder Censuur, De kerkelijke tucht in de gereformeerde gemeente van Amsterdam, 1578-1700. Hilversum: Verloren, 1990, 281556 


\section{Notes on Contributors}

Yocheved Beeri

is a postdoctoral fellow in the ERC project "A Diaspora in Transition" at the Hebrew University of Jerusalem.

\section{Bernard Dov Cooperman}

is Louis L. Kaplan Associate Professor of Jewish History at the University of Maryland.

\section{Einat Davidi}

is an assistant professor in the Department of Hebrew and Comparative Literature, University of Haifa.

\section{Mauricio Dimant}

is a postdoctoral fellow in the ERC project "A Diaspora in Transition" at the Hebrew University of Jerusalem.

\section{Serena Di Nepi}

is an assistant professor of Early Modern History and Director of the Advanced Specialization course in Jewish History at Sapienza University of Rome.

\section{Yaacob Dweck}

is an associate professor of History and Judaic Studies at Princeton University.

\section{David Graizbord}

is an associate professor of Judaic Studies at the Arizona Center for Judaic Studies, the University of Arizona.

\section{Yosef Kaplan}

is Bernard Cherrick Emeritus Professor of Jewish History at the Hebrew University of Jerusalem.

\section{Alex Kerner}

is a postdoctoral fellow in the ERC project "A Diaspora in Transition" at the Hebrew University of Jerusalem.

\section{Tirtsah Levie Bernfeld}

is an independent scholar residing in Amsterdam, The Netherlands. 


\section{Nourit Melcer-Padon}

is a postdoctoral fellow in the ERC project "A Diaspora in Transition" at the Hebrew University of Jerusalem.

\section{Stanley Mirvis}

is a postdoctoral fellow in the ERC project "A Diaspora in Transition" at the Hebrew University of Jerusalem.

\section{Aliza Moreno-Goldschmidt}

is a postdoctoral fellow in the ERC project "A Diaspora in Transition" at the Hebrew University of Jerusalem.

\section{Natalia Muchnik}

is an associate professor at the École des Hautes Études en Sciences Sociales.

\section{James Nelson Novoa}

is an associate professor of Spanish and Medieval and Renaissance Studies at the University of Ottawa.

\section{Evelyne Oliel-Grausz}

is an associate professor of Early Modern History and Director of the Diplôme Universitaire d'Etudes Juives at the Université Paris 1 Panthéon, Sorbonne.

\section{Moisés Orfali}

is a professor of Jewish History at Bar-Ilan University, Ramat Gan.

\section{Ronnie Perelis}

is the Chief Rabbi Dr. Isaac Abraham and Jelena (Rachel) Alcalay Chair and associate professor of Sephardic Studies at Yeshiva University.

\section{Sina Rauschenbach}

is a professor of Religious Studies and Jewish Thought at Potsdam University.

\section{Jessica Vance Roitman}

is a researcher at the Royal Netherlands Institute of Southeast Asian and Caribbean Studies (KITLV).

Jonathan Schorsch

is a professor of Jewish Religious and Intellectual History at Potsdam University. 


\section{David Sclar}

is an associate research scholar and lecturer in the Program in Judaic Studies at Princeton University.

Claude B. Stuczynski

is an assistant professor in the Department of General History at Bar-Ilan University, Ramat Gan and a board member of the Center for the Study of Conversions and Inter-Religious Encounters (csos).

\section{Michael Studemund-Halévy}

is a senior research fellow at the Institut für die Geschichte der deutschen Juden, Hamburg.

Carsten L. Wilke

is a professor of Jewish History and Culture at Central European University, Budapest. 
PART 1

Markers of Converso Identities 
Yosef Kaplan - 978-90-04-39248-9

Downloaded from Brill. com $04 / 26 / 2023$ 10:36:49AM via free access 


\title{
A Crisis of Judeoconverso Identity and Its Echoes, 1391 to the Present
}

\author{
David Graizbord
}

In the fall of 1674, Luis Aguilar, a traveling merchant of seventeen years of age, was staying at a hostel in a small Castilian village. A local officer of the law entered the hostel and ordered Luis and his traveling companions to recite Christian doctrine and to cross themselves. According to the policeman, Luis did not know how to do this. Furthermore, Luis spoke Spanish with a Portuguese accent, so the policeman surmised that Luis was a New Christian "Judaizer" and arrested him. Shortly thereafter, lay authorities transferred Luis to the custody of the Holy Office in Valladolid. Under interrogation, Luis declared that he was "a Jew by nation," not a New Christian, and that his parents belonged to one of the many small communities of Portuguese expatriates in the French Basque country. It also became clear that Luis had been born in France and had never been baptized. Crucially, there was no evidence that Luis himself had practiced what the Holy Office and the Iberian Churches called "Judaism" while he was in Spain. No one had accused Luis of promoting this "Judaism" or of aiding anybody who wished to practice it secretly in Iberia or anywhere else. This meant that although Luis was liable for deportation or another punishment as an unwanted alien, technically he fell entirely-or almost entirely_outside the jurisdiction of the Holy Office. Yet, instead of releasing him to secular authorities, which would have been a logical step, the inquisitors did something that may seem surprising, and as far as I know, was out the ordinary: in July of 1675 , they ordered that Luis be baptized. ${ }^{1}$

For the past several decades, it has been quite common for scholars to interpret stories like that of Luis Aguilar in relation to the tumultuous development of the Western Sephardic diaspora from the late sixteenth to the end of the seventeenth century. That is the period on which I will focus here. To this day, specialists in early modern history commonly assert that people such as Luis Aguilar were products of a "return to Judaism" among judeoconversos (also known as New Christians) who fled the Iberian domains. Often, modern

1 Archivo Histórico Nacional (Spain), Inquisición de Toledo, Legajo 183, Expediente 4 (16721678), fol. 1r. The defendant in this case was Teresa de Salazar.

(C) DAVID GRAIZBORD, 2019 | DOI:10.1163/9789004392489_002

This is an open access chapter distributed under the terms of the prevailing CC-BY-NC License at the time of publication. 
academics refer to Judaism much as the émigré polemicists "of the [JudeoPortuguese] Nation" did, namely as a "faith" that the expatriates had yearned to practice in freedom beyond the "Lands of Idolatry." To cite but one example, a prominent scholar stated at a conference in Jerusalem in 2015, that she believes that a majority of judeoconversos who settled in Amsterdam had preexisting "Jewish loyalties." 2 Such assertions are accurate in several individual cases. Yet, I think they are globally inaccurate in a double sense: first, judeoconversos who became Judaicized in exile, by and large, did not quite return "to the faith of their ancestors" themselves; that is because most of them had never known or experienced Jewish life at all; thus, prior to becoming Jews they had no realistic notion of, or relationship to, what one might call a lived, normative Jewish culture, a culture that is, by its very nature, historical, public, and collective, as I will explain below.

Second, Judaism was not and is not a "faith." What I mean is that Judaism was not and is not a creedal "religion" in the Christian sense; furthermore, to the best of my knowledge, in the premodern centuries Jews (as distinct from judeoconversos) generally did not call their culture and way of life "Judaism"that, after all, is a Greek pagan term, one that by the early modern centuries Christians had inherited and made part of their intramural cultural lexicon.

The balance of this paper will be devoted to elaborating on these deceptively simple and perhaps provocative points. My aim will be to suggest that we need to carefully calibrate our understanding and our use of key cultural terms such as "Jew," "Jewish," "Judaism," and even "Sephardic," in order to properly depict and explain the early modern "Western Sephardic diaspora." Toward the end of the exposition, I will return briefly to the case of Luis Aguilar and provide an interpretation that I hope will illustrate how what one might call "the usual" conceptual markers of judeoconverso identity, do not quite capture the cultural vagueness of the New Christians who comprised the New Jewish diaspora. More importantly, these terms do not shed light on what is actually the sociological solidity and relative fixity of those self-same subjects.

Let me begin by recalling that the first and arguably most significant mass conversions of Iberian Jews to Christianity from 1391 to 1415 were a culmination of what Jeremy Cohen has called "Anti-Judaism" and William Chester Jordan has simply characterized as a fateful hardening of Christian attitudes toward

2 I am referring to Miriam Bodian, comment at 7:35-7:36 minutes into the presentation, "Theology and Ideology of Conversos," a paper she delivered at the conference on "The Political Dimensions of the Converso Phenomenon in Portugal and Beyond," 26 May 2015, Van Leer Jerusalem Institute, https://www.youtube.com/watch?v=AG32Z8it5TY (accessed 9 May 2017). 
Jews in the Latin West. ${ }^{3}$ According to the theologians who expressed these attitudes, Jews were dangerous to the wellbeing of Christian communities because Jews believed in, observed, and even preached a "law" called "Judaism," or "The Law of Moses." This "erroneous" faith was supposedly, based on a literal understanding of biblical (or Mosaic) Law combined with grotesque and blasphemous rabbinic readings of the "Old Testament." ${ }^{4}$ The bottom line of this highly invidious approach to cultural difference was that Jews were intolerable as believers in and professors of that faith.

Viewed through the dualistic lens of anti-Jewish theology, "Judaism" was therefore like a dark or inverted mirror image of Christianity-in other words, it was a "religion," albeit a false, diabolical one. Therefore, "Judaism" fit neatly into the sphere of experience that Christian thinkers assigned to the innermost recesses of the heart and the mind. Accordingly, being Jewish meant (supposedly) being persuaded that "Judaism" was the "truth," which—again, supposedly-led to the perdition of the blundering believerin the Law of Moses. By the same token, belief in Christian dogma saved the soul of the adherent. It is hardly surprising that inquisitorial discourse on crypto-Judaism replicated this mistaken analogy between Jewish culture and Christianity and attributed the analogy to New Christians. ${ }^{5}$ An Edict of Faith from seventeenth-century

3 Cohen introduced the term "anti-Judaism" to designate a particular form of late medieval conversionist animus in The Friars and the Jews: The Evolution of Medieval Anti-Judaism (Ithaca: Cornell University Press, 1982); Cohen then defended his conception of it in Jeremy Cohen, Living Letters of the Law: Ideas of the Jew in Medieval Christianity (Berkeley and Los Angeles: University of California Press, 1999). For Jordan's contrasting view, which focuses on political and social developments in France, see for instance William Chester Jordan, The French Monarchy and the Jews: From Philip Augustus to the Last Capetians (Philadelphia: University of Pennsylvania Press, 1989); see also Jordan's review of Cohen's Living Letters of the Law in The Jewish Quarterly Review 91, nos. 1-2 (July-October 2000): 217-19, which, however, only hints of Jordan's broader disagreement with Cohen on the supposed Anti-Jewish turn among Christian theologians of the High Middle Ages.

4 Never mind that the Hebrew Bible and the Old Testament are far from identical, and that Jewish tradition does not recognize anything like an "Old Testament" for the simple reason it does not recognize a "new" one. Such were Christian projections of non-Jewish concepts onto Jewish culture.

5 The late Wilfred Cantwell Smith explained that conventional, modern definitions of "religion" adhere to a Western paradigm that emerged under the impact of the Protestant Reformation. Variants of the paradigm assume that human experience is comprehensible in terms of separate religious ("spiritual") and secular ("material" or "worldly") spheres. These variants also emphasize the elements of theology and inner or spiritual persuasion as essential to religion. See Smith, The Meaning and End of Religion (Minneapolis: Fortress Press, 1962; 1991). In American law, for instance, religion occupies a protected private sphere allotted to faith and worship, while the civic sphere is, in theory, religiously neutral, though individuals may act within that sphere inspired by their religious convictions. To the degree that 
Cuenca states: "By this document we [Inquisitors against heretical wickedness and apostasy ...] exhort you and require [to reveal] if any of you knows [...] that any person [...] has said or affirmed [...] any of the heretical ideas against what our Holy Mother, the Roman Catholic Church teaches. [... To wit,] if any of you has seen or heard it said [...] that the Law of Moses is as good as that of our redeemer Jesus Christ." ${ }^{6}$ (Emphasis added)

In a similar vein, formulaic testimony recorded for purposes of a heresy trial in seventeenth-century Portugal imputes to judeoconverso families a tribal propensity to believe in the salvific power of the Law of Moses: "[ In New Christian families] everyone together and each one on his own, believed in and lived by the Law of Moses, and in it they expected to be saved, and they performed the aforementioned ceremonies in order to observe [that Law], one trusting the others because they were relatives and friends, and of the same nation."7

There is an additional aspect to consider in what concerns Ibero-Christian conceptions of Jews, and therefore of judeoconverso markers of identity: as David Nirenberg has observed, the formation of a class of New Christians from 1391 to 1415 initiated a crisis of social, political, and cultural classification in Castile and Aragon. ${ }^{8}$ I would go even further: Christian and Jewish authorities certainly faced the challenge of classifying New Christians and assigning to them a place in a changing society; but in addition to that, judeoconversos themselves, and their "Old Christian" counterparts, had to navigate uncharted cultural territory on their own. The crisis, therefore, was one of identity, not merely of classification. Each adolescent and adult judeoconverso had to decide who and what he or she was. For their part, neither the "Old Christians" nor the surviving Iberian Jews (that is, those who had resisted conversion) quite knew what to make of the New Christians' identity, and therefore found existing, normative socio-cultural borderlines insufficient, at least in practice if not in theory. To put it simply, virtually everyone-especially New Christianshad to grapple in one way or another with the question of who and what was

Jews have become westernized and secularized in modern times, this conventional, Western model, which compartmentalizes religion and tends to separate it conceptually and practically from political, social, and economic life, is at least partly applicable to them-but not to premodern Jews.

6 Appendix, Edict of Faith (Cuenca, 1624), trans. David M. Gitlitz (here cited with my emendations); Gitlitz, Secrecy and Deceit: The Religion of the Crypto-Jews (Philadelphia: Jewish Publication Society, 1996), 625-27.

7 Arquivos Nacionais/Torre do Tombo, Inquisição de Évora, Processo de André Soito, fol. 15, quoted in Maria Benedita Araujo, "Familia e grupo social no criptojudaísmo português (século XVII)," Oceanos 29 (January 1997): 49-66; here 54.

8 David Nirenberg, "Mass Conversion and Genealogical Mentalities: Jews and Christians in Fifteenth-Century Spain," Past and Present 174, no. 1 (2002): 3-41. 
"Christian"; and who and what was "Jewish." Thus, when scholars who are trying to explain phenomena of religious change and cultural transformation in the early modern Western Sephardic communities, write of New Christian ethnicity as a shared feeling of belonging to a group, as a form of shared culture, we are not just talking about New Christians' and New Jews' familial alliances, economic behavior, shared vernaculars, or consciousness of the group's homeland. Rather, in the case of judeoconversos, we are talking about the shared psychological experience of having been made aware, in one way or another, that they and their families descended from Jews, and of having to face that vexing question of definition unlike anyone else in their milieu, save perhaps for Moriscos. I believe that for purposes of historical interpretation, it is crucial to distinguish that consciousness, that experience of distinctiveness, from New Christians' actual or merely imputed desire to "be Jewish," whatever that meant to them and to others.

But to return briefly to the question of the crisis of identity: to my knowledge there was never a total consensus among Iberian rabbis on the question of whether judeoconversos as a group fit the legal category of אנוסים (anousimcoerced ones; namely, subjects who consciously sin under duress); משומדים (meshummadim - תינוקות שנישבו (tinokot she-nishbu — captured infants; in other words, unwitting sinners); or גוים גמורים (goyim gemurim - complete Gentiles). In the first century or so after the conversions, the responsa vary, sometimes dramatically.

To cite but two examples: in the immediate aftermath of the mass conversions, Rabbi Saadia ben Maimon ibn Danan of Muslim Granada maintained, quite plausibly, that judeoconversos הם אחינו בלי ספק ("hem aheynu bli safek"they are our [Jewish] brethren without a doubt). ${ }^{9} \mathrm{~A}$ few decades later, by contrast, Yaakov Berav of Castile (d. 1546) issued a decision signaling that any judeoconversos found in Iberian Christian realms-even those who avoided sexual contact with Old Christians-were non-Jews by definition. ${ }^{10}$

On the Christian side, evidence of the crisis of identity includes the writing of Father Andrés Bernáldez. Below is an excerpt from his chronicle, entitled Historia de los Reyes Católicos Don Fernando y Doña Isabel (1497). ${ }^{11}$

$9 \quad$ Quoted in Benzion Netanyahu, The Marranos of Spain from the Late 14th to the Early 16th Century, According to Contemporary Hebrew Sources, 3rd ed. (Ithaca: Cornell University Press, 1999), 61.

10 Ibid., 70-71.

11 Andrés Bernáldez, Historia de los Reyes Católicos D. Fernando y Da. Isabel, crónica inédita del siglo XV (Granada: D. José María Zamora, 1856), 1: 97-99. 
The heretical Mosaic depravity reigned hidden and lurking in corners for a long time. [...] It had its beginning [...] in the year 1390 [...] which is when the sacking of the judería took place as a result of the preaching of Friar Vincent [Ferrer, ...] who at that time wished to convert all the Jews in Spain, and thus put an end to the entrenched and foul-smelling synagogue. Yet, their mouths were filled with that gloss, the Talmud, that the rabbis made four-hundred years after the birth of our Redeemer. In that gloss there were [sic.] many great lies; therefore they deny the truth and remain ignorant of $i$. Consequently, Friar Vincent was able to convert but very few; so the people, with resentment, put many to the sword in Castile, and killed many. Then many of them came to the churches, to be baptized themselves; and those who were baptized became Christians, and they were called the Conversos. It is from this that the name "converso" had its beginning. [The name is applied to those] converted to the Holy Faith, which they kept very badly; and those among them who came from it [sic.] for the most part were and remained, secret Jews; and they were neither Jews nor Christians, as they were baptized yet were heretics and without law. That is how that heresy was born. It was so elevated in heresy [sic.], that the learned ones were about to preach the Law of Moses, and the common people could not hide their being Jews.

You may be sure that according to what we saw, that at any time this egregiously wild animal is heresy, and that at that time the disgraceful Jew-heretics fled from ecclesiastical doctrine, and thus fled from the customs of the Christians. [Emphasis added]

Elsewhere I have analyzed the above excerpt word for word. ${ }^{12}$ Suffice it for purposes of the present exposition to note that Bernáldez's portrait of judeoconversos is an intellectual morass. The terminology of identity that he thinks is going to help him pin down the New Christians like a spear-terms like "Jews," "Judaism," "Christianity," "conversos," "heretics," etc.—in fact does nothing besides reveal his own bewilderment. Bernáldez's thinking about New Christians was so muddled that he depicts them incongruously as, errant Christians; as Jews; and as neither Christians nor Jews; as culturally mutable; as almost entirely resistant to cultural change-thus culturally immutable; as surreptitiously subversive; and then as conspicuously, openly subversive. To make things worse, Bernáldez cannot distinguish consistently in his text

12 David Graizbord, "Who and What Was a Jew? Some Considerations for the Historical Study of New Christians," Anais de História de Além-Mar 14 (2013): 15-44. 
between three distinct types: an infidel, an apostate, and a heretic. Significantly, this is the same confusion that shaped the very language of the Holy Office as it approached New Christian suspects. ${ }^{13}$ We recall, for instance, the phrase "Judio Judaizante" (Judaizing Jew) which appears in countless inquisitorial accusations and verdicts. As I have noted elsewhere in my work, ${ }^{14}$ this expression is a contradiction by the very basic terms of Christian theology, according to which a Jew is an infidel who would typically not be subject to inquisitorial investigation (unless he or she were suspected of aiding and abetting the commission of heresy), while a "Judaizer" is a heretic, in other words, a Christian subject, not an unbeliever, who deviates from orthodoxy by supposedly thinking and behaving like a Jew. Another verbal formula that reveals inquisitorial confusion regarding the religious identity of New Christian Judaizers is the common condemnation, "hereje apóstata" - heretic-apostate. The latter conveys the incoherent message that a person who is an undisciplined or dissenting believer in a religion is indistinguishable from a person who renounces belief in that religion altogether.

Such conceptual inconsistency and slippage between ostensibly equivalent terms was a primary symptom of the "crisis of classification" and identity. At the heart of that crisis was the fact that the mass conversions erased the hard and fast cultural demarcations that had for long separated Jews and Christians. At the same time, the conversions had the effect of disconnecting within the life of individuals the reality of familial kinship on one hand, from beliefs and rituals that had marked a Jewish social identity on the other hand. Notably, the mass conversions had the additional effect of introducing a disjuncture between interiority and publicity in the construction and enactment of selfidentity — and thus of driving a wedge between individual self and community.

As I intimated earlier, normative Jewish culture assumes that Jewish identity is public, communal, and historical. Not only the revelation at Sinai, but also the covenant and the ideal images of Jewish national redemption, conform to these three conditions; that is: revelation, the forging of the covenant with God, and redemption all take place in the open and not primarily within the individual soul; they occur in time, and they involve the entire Israelite (and hence Judean) community. By the same token, in premodern Jewish culture, personal identity was coextensive with communal belonging. To be a Jew in sociological and psychological fact had nothing to do with proving one's matrilineal descent (notwithstanding tannaitic injunctions on the subject), or with

13 This paragraph reworks another one in ibid., 23.

14 David Graizbord, Souls in Dispute: Converso Identities in Iberia and the Jewish Diaspora, 1580-1700 (Philadelphia: University of Pennsylvania Press, 2004), 117-18. 
confessing belief in certain theological propositions per se. It simply meant being born into, or joining, and living life within a kehillah kedoshah, that is, a normatively-structured and internally autonomous ethnic and political corporation built in order to allow its members to fulfill their halakhic duties, and thus to sanctify the life of a particular people as a collective.

From all this it follows that the clandestine "Judaism" that the Iberian churches and the Holy Office imagined and claimed to find among judeoconversos, was, in a sense, impossible, if by Judaism we mean the lived culture of medieval and early modern Jews. In fact, "Judaism" was merely figural, even chimerical, inasmuch as it did not bear more than a passing resemblance to an openly Judaic way of life. Yes, educated New Christians had access to some rabbinic sources in the Peninsula, as Yosef Yerushalmi and others have amply proven, ${ }^{15}$ but I hazard that a vast majority of judeoconversos did not have such access, and in any case, to read forbidden books is not the same thing as living in a public Jewish community. Thus, even when one can prove the incidence of "Judaizing" among New Christians after the early sixteenth century - and that is often a big "if" because of the problematic nature of the inquisitorial records - that phenomenon is usually better understood not as an attenuated or residual form of Jewish life, but as a dissident offshoot of Iberian Christianity. Indeed, if we may generalize, what crypto-"Judaism" after the first generations of converts to Christianity had passed on was a cluster of ideas and practices based on, parallel, and opposite to Christian ones, that gave its adherents a sense of dignity, even a makeshift spiritual identity, when the stigma of an imputed Jewishness fell heavily upon their shoulders. In that sense at least, I think Claude Stuczynski is right in saying that patterns of judeoconverso dissidence in Iberia were "counter-cultural," and not merely forms of hybridity. ${ }^{16}$ To that, I would add that crypto-Judaism may also be seen as an exercise in counter-historical narration in the terms suggested years ago by Amos Funkenstein; that is, dissident judeoconversos narrated a type of dissent that was so reliant on the dominant Christian story that they sought to overthrow, that their subaltern narratives of rebellion lacked any independent existence. ${ }^{17}$ To be sure, we can speak at length about mutual cultural formation

\footnotetext{
15 See in particular Yosef H. Yerushalmi, "Marranos Returning to Judaism in the Seventeenth Century: Their Jewish Knowledge and Psychological Readiness" [Hebrew], in Proceedings of the Fifth World Congress of Jewish Studies (Jerusalem: Magnes Press, 1969), 2: 201-9.

16 Claude Stuczynski, "Not Hybridity but Counterculture: Portuguese New Christian Judaizers: Confronting Christianity and Islam in Bragança," in Conversos, marrani e nuove comunità ebraiche in età moderna, ed. Myriam Silvera (Florence: Giuntina, 2015), 61-70.

17 Amos Funkenstein, "History, Counter-History and Memory," in Perceptions of Jewish History (Berkeley and Los Angeles: University of California Press, 1993), 22-49, esp. 36-40.
} 
between Jews and Christians in the pre-modern centuries, but I think that for obvious reasons open Jewish life in Western Christendom, a life that had deep roots in the Orient, was never merely derivative of Christianity, and therefore was neither exclusively countercultural nor counterhistorical. Simply put, premodern European Jews were not dissenting Christians.

From all this it follows, again, that the Jewish culture that exiled judeoconversos absorbed in established Jewish communities of the West such as Venice and Salonika was not the inquisitorial travesty of Jewish culture. The New Jews of the West did not adopt "Judaism." Instead, what they ultimately internalized - some refugees more quickly than others depending on whether they settled among the "Old" Sephardim or among fellow New Christians-was the comprehensive civilization of the nation called Israel. Unlike Christianity, that civilization did not distinguish, at least not sharply, between religiousspiritual and secular spheres of experience.

These observations may seem too obvious to even discuss-or too much like semantic hairsplitting. Yet, unfortunately, our problem is that scholarly literature on the judeoconverso phenomenon does not always do justice to premodern Jewish civilization, and therefore, has some difficulty in interpreting the behavior of New Christians both inside and outside the Iberian Peninsula. To wit: modern scholars have tended to treat Jewish culture as a "faith," and Jews as a "faith-community."

It is only fair to provide a few examples of this tendency. ${ }^{18}$ In 1895 , Joaquim Mendes dos Remédios wrote that Jews and therefore judeoconversos were distinguishable solely by their "religion" — what he called their "beliefs." As late as 1992, Julio Valdeón Baruque, an important medievalist from the Universidad Complutense de Madrid, echoed that general understanding. Valdeón wrote that the conflict between Jews and Christians in Iberia before the general expulsions of 1492-1498 was a struggle "between members of two religious creeds." ${ }^{19}$ This statement begs the question: What was the Jewish "creed"? Was it perhaps Maimonides's list of thirteen principles of faith? Medieval and early modern Sephardic authorities would probably disagree; after all, it was they who kept those selfsame thirteen principles out of the standard Sephardic liturgy. Meanwhile, Valdeón's colleague, the French scholar Joseph Pérez, wrote in a book published in 2007 that medieval Iberian Jews were different from their Muslim neighbors merely "from the religious point of view; but in every

18 I first provided these examples in Graizbord, "Who and What Was a Jew?".

19 Julio Valdeón Baruque, "Motivaciones socioeconómicas de las fricciones entre viejocristianos, judíos y conversos," in Judíos, Sefarditas, Conversos: La Expulsión de 1492 y sus consecuencias, ed. Angel Alcalá, (Valladolid: Ámbito, 1995), 70. 
other way," Pérez argues, they adopted the dominant Arab and Muslim cultural models (emphasis added). ${ }^{20}$ So, for example, according to Pérez, Maimonides was simply an Arab who happened to profess the Mosaic faith. ${ }^{21}$ In other words, he was a kind of early Reform Jew, as it were.

The problem of liberal presentism to which I am pointing is not limited to Hispanists. It extends even to scholars of judeoconversos and of Jewish culture more generally. I recall, for instance, the surprising assertion that one prominent scholar made in 1987 in an attempt to explain the pietistic literature of the Judeo-Portuguese Nation in Amsterdam: "La salvación del alma," he wrote, "es la preocupación máxima del judaísmo" (The salvation of the soul is the highest preoccupation of Judaism). ${ }^{22}$ This assertion is a symptom of a classic, yet nonetheless, false analogy between Jewish culture and Christianity. More accurately, the statement reveals a conflation of the way of life of Jews who lived in autonomous kehillot (communities), with their unique system of law and their socio-political and religious institutions on one hand, and the decorous, austere, contrite and conformist sort of moralism, tinged with a Christian-like emphasis on spirituality, that lay leaders of the Amsterdam Judeo-Portuguese and Judeo-Spanish community espoused during the heyday of the merchant Nação in the 16oos on the other. As Yosef Kaplan's analysis suggests, this latter religion and social ethos, called bom judesmo, helped expatriate judeoconversos negotiate the transition to a full-fledged, Jewish national life. ${ }^{23}$ Yet bom judesmo was itself understandably makeshift and instrumental in nature. ${ }^{24}$

20 Joseph Pérez, History of a Tragedy: The Expulsion of the Jews from Spain, trans. Lisa Hochroth (Urbana: University of Illinois Press, 2007), 11-12.

21 Ibid.

22 He continues, "Un alma que es juzgada cada año en los dias terribles que transcurren entre Rosh Hashana y Yom Kippur. Recordemos también el juicio final.” Henry Méchoulan, Hispanidad y Judaísmo en Tiempos de Espinoza: Estudio y edición anotada de La certeza del camino de Abraham Pereyra, Amsterdam 1666 (Salamanca: Ediciones Universidad de Salamanca, 1987), 62 .

23 Yosef Kaplan, "Bom Judesmo: The Western Sephardic Diaspora," in Cultures of the Jews, ed. David Biale, 3 vols. (New York: Schocken, 2002), 2: 337-67.

24 Scholars of Jews and Jewish civilization find Bom Judesmo interesting, I think, partly because it was one expression of the remarkable creativity and sheer discipline that propelled the merchant Nação throughout the seventeenth century. And this fascination holds true, despite the fact that "The Men of the Nation" were not all New Christians in the first place, let alone New Jews or Jewishly-oriented New Christians. If Daviken StudnickiGizbert is right, close to half of the twenty thousand or so people "of The Nation" in the mid-16oos were not of Jewish ancestry at all. Studnicki-Gizbert, A Nation Upon the Ocean Sea: Portugal's Atlantic Diaspora and the Crisis of the Spanish Empire (Oxford: Oxford University Press, 2007), 10. 
There are, I think, at least two reasons that account for the false analogy to which I have referred. The first is that judeoconversos at large, and in particular newly Judaicized apologists (Isaac Cardoso, Daniel Levi de Barrios, Isaac Orobio de Castro, and others), as well as New Jewish pietists such as the parnass Abraham Pereira - all of whom usually wrote in Western languages-made frequent recourse to the Christian vocabulary of "religion," "faith," and "the soul," to describe the culture of the Jews. Notably, these cosmopolitan authors sometimes portrayed that culture in doctrinal or quasi-doctrinal terms. In the process, they injected key Ibero-Catholic concerns, ideas, and rhetorical styles into the intellectual and devotional life of the "Judeo-Portuguese and Spanish Nation."

It is all well and good to acknowledge a phenomenon of cultural interpenetration between Iberian Christianity and diasporic Judaism in the life of the Nação. Yet the question I wish to pose here is how scholarship might properly understand the complex dynamics of that interpenetration in the lives and identities of New Jews. I think that an incisive portrait of the Judaicization of New Christians in exile, at the very least, demands that historians and literary scholars of cultural transformation in the Western Sephardic diaspora refrain from internalizing the Christian conceptual categories and terminology that judeoconversos took for granted as they entered the Jewish communal fray in Amsterdam, Venice, and similar hubs of the Judeo-Portuguese Nação. Else, scholarship runs the risk of merely parroting the self-justifications that New Jewish writers provided to explain their recently acquired Jewish ardor as something ancient and innate.

The second reason that I believe accounts for the misconception that early modern New Jews in the West comprised a faith-community in the Christian sense is the modern, enlightened viewpoint that has underwritten many historical studies since the nineteenth century. According to a liberal version of that approach, Jews must be defended from racism, and are thus to be understood as a merely "religious" or "confessional" minority, not as a people apart. Jews' ancestral culture therefore need not stand as a "tribal" or "racial" obstacle to their dignity and enjoyment of civic and political rights within the nonJewish nation-state. ${ }^{25}$ It would be a mistake to rest on the victory laurels of

25 As I observe in "Who and What Was a Jew?": "Proponents of the Enlightenment from the eighteenth century onward did not inquire how Jews regarded themselves, and for the most part had no intention of condoning their traditional way of life, which these enlightened men viewed as backward and obscurantist; rather, they prescribed that Jews compartmentalize, privatize, and spiritualize their all-encompassing culture into a 'religion' as a (pre)condition for enjoying political equality. The price of toleration, then, was the Jews' traditional group identity" (25). 
this liberal outlook if, for no other reason that, in some ways, it replicates the artificial separation of Jewish ethnicity and Jews' religious ideology, practice, and social membership that resulted from the mass conversions of 1391, and hence, distorts our perception of medieval and early modern Jewish culture as the New Jews encountered and absorbed it.

Scholarly interest in and misreadings of the Nação have been buoyed over the past few decades by a third factor. I am speaking of scholars' interest in the fluidity and contingency of self-definition. The liminal quality of judeoconverso identities has recently allowed for a scholarship in which essentialism and reductionism give way to more flexible and nuanced conceptions of the self in relation to the social universe. The upshot is a current fascination with the possibility that New Christians and New Jews could thoroughly compartmentalize and spiritualize religion, keep it at arm's length, and then, when it may be useful, activate and deactivate it as if with an electrical switch, according to circumstance.$^{26}$ Some might call this a kind of (proto-) "modern" feature of New Christian and New Jewish identities.

One problem with this last conception is that it does not fully account for the relatively high levels of Jewish acculturation - genuine and deep acculturation into a fundamentally traditional way of life-that members of the Nação eventually achieved in the Atlantic strongholds of bom judesmo, and particularly, in older, more established diasporic centers by the eighteenth century. From that deep acculturation, scholars as wise as Yosef Yerushalmi and Daniel Swetschinski have concluded that New Christian émigrés must have held deep Jewish commitments prior to leaving the Iberian Peninsula. ${ }^{27}$ Thus, the scholars have tended to validate Israël Révah's famous opinion that these persecuted subjects had always been latent Jews. ${ }^{28}$

As someone whose work has focused attention on "New Jews" who were marginal or who dissented from the behavioral ideals of bom judesmo, I am conscious that ideological solidarity and discipline among members of the Nação were sometimes more apparent than real. At the same time, I am aware that such solidarity did exist in general, and that it drew in even ambivalent types who were not sure of who and what they were, in terms of their ideological loyalties. Yet I hazard that the coalescence of communities of New Jews "of the nation" in exile has less to do with any desire to practice a supposed

26 I count myself among the proponents of this kind of interpretation. In fact, the observation that cultural commuters "of The Nation" turned religion on and off as if by an electric switch is mine. Graizbord, Souls in Dispute, 102.

27 Yerushalmi; Daniel M. Swetschinski, Reluctant Cosmopolitans: The Portuguese Jews of Seventeenth Century Amsterdam (London: Littman Library of Jewish Civilization, 2000).

28 Israël Salvator Révah, "Les Marranes," Revue des études juives 118 (1959-1960): 29-77, here 55. 
religion called "Judaism" per se, or with the inculcation of normative Judaic ritual and belief, than with the dynamics of ethnic and political belonging with which New Christians were already familiar from their experience within Iberian contexts.

It is important to underscore that New Christians in Spain and Portugal were reared in a cultural environment in which many if not all Old Christians regarded them viscerally as "Jews" rather than as true co-religionists. Over time, through the practices of endogamy and homogamy, as well as through the concomitant forging of commercial relationships, this sense of social estrangement and genealogical difference coalesced as one of the imaginary bases of the transoceanic Nação, complete with its own merchant houses, religious institutions, patrões (or bosses), an elite of political representatives, sophisticated systems of monetary and non-monetary collection and payment, ${ }^{29}$ and certain mores and unique patterns of sociability firmly anchored in those systems, as well as in such distinctive practices as the use of the Portuguese and Castilian languages. Again, an affinity toward the non-Jewish construct of "Judaism" does not seem to me to have been a cause of that coalescence.

John Hutchinson and Anthony Smith identify an "ethnic group" as a network of people who exhibit six main features: first, common, proper names; second, narratives that explain the common ancestry of the group and proffer a perception of kinship for the group's members, indeed a sense of forming part of a "super-family" (we may view persecution by the Inquisition, and the bloodbased, discriminatory system of genealogical probanza, as stimulants of this perception in the case of New Christians); third, shared historical memories; fourth, elements of a common culture, usually but not necessarily including such aspects as language and customs, ideas about the transcendent, rituals, and so on; fifth, a link with a homeland, articulated as a symbolic attachment when the ethnic group does not actually occupy that place; and sixth, a sense of solidarity on the part of at least some sections of the ethnic population. ${ }^{30} \mathrm{To}$ this definition, I would add that the endurance of these six aspects of ethnicity does not mean that they are static and unchanging, much less "primordial," but rather, that successive generations of people who are somehow socialized into the group receive a knowledge of these aspects, internalize them, and reinvent them according to various circumstances. The bottom line here is that by the

29 See Mauricio Dimant's contribution to this volume. On the dynamics of commercial relationships forged by members of the Nação, see also Studnicki-Gizbert; and Francesca Trivellato, The Familiarity of Strangers: The Sephardic Diaspora, Livorno, and CrossCultural Trade in the Early Modern Period (New Haven: Yale University Press, 2012).

$3^{0}$ John Hutchinson and Anthony D. Smith, eds., "Introduction," in Ethnicity (Oxford: Oxford University Press, 1996), 6-7. 
standards of Hutchinson and Smith's anthropological definition, the Nação was indeed an ethnos, albeit a religiously diverse one.

What, then, should scholars make of the newly acquired Jewish "religion" of the Hebrews of the Portuguese and Spanish Nation? To paraphrase Yosef Kaplan's question in his contribution to this volume, why davka did the New Jews of the Western Sephardic diaspora wish to become Jewish? I cannot answer the question fully, yet it may be helpful to approach facets of the problem in stages.

At this point, it might be apposite to note that early modern Jews seldom, if ever, called their way of life "Judaism" in any language. To the best of my knowledge, they did not have a favorite designation for that culture in any event. Here and there, historians encounter sweeping rabbinic phrases in the documentary sources, such as "The Life of Torah (חיי התורה), "accepting the yoke of heavenly authority" (קבלת עול מלכות השמיים), and "fear of God" ('יראת ה), but I really cannot say that these phrases even come close to what one might call a "standard" designation for an entire culture. It is as though the practical, public, and communal emphases of the culture obviated the need to name it, not to mention the need to define it as a truth-claiming ideology or an "-ism."

Is this to say that the normative Jewish way of life that conversos absorbed outside of the Ibero-Catholic realms cannot be called a "religion"? I have already touched on this question, but it is worthwhile to return to it now. Iberian rabbis before and after the expulsion(s) did, on occasion, use words like dateynu (דתיינו, translatable as "our law" or "our decree") to describe the Jews' ideally comprehensive way of life. In an as-yet unpublished article, I have gone so far as to argue that this use of the word dat during the late Middle Ages was a sign that the rabbis were inching closer to defining their own civilization in the spiritualized terms provided to them by their persecutors, especially by Christian polemicists from the mendicant orders. All the same, I doubt that such linguistic usages erased the sociological and historical anchors of Jewish collectivity. Those anchors existed well before the era of Enlightenment and political emancipation, and have eroded only since then. Those structural bases seem to me to have been ethnic and political in character. In other words, they mirrored - and were thus capable of assimilating — the preexisting sociological underpinnings of the Nação.

To the degree that some New Christians became Judaicized in the "Lands of Liberty," then, they were actually adopting a communal way of life founded on a sense of kinship that they already shared. The principal difference between the diasporic and the Iberian contexts, one might say, was "superstructural," not structural. Specifically, the move to an open or semi-open Jewish life was for New Christian refugees chiefly a matter of adopting and elaborating 
what to the members of the Nação were relatively new narrative justifications and poetic representations of that preexisting sense of ethnic uniqueness. New Christian identities had already been informed by the need to grapple with the genealogical origins and imputed Jewishness of the judeoconverso ethnos.

What I am proposing is that the move from Christianity to open, normative Judaism, did not entail the creation of a religious community per se, or for that matter, the forging of totally disparate individuals into a new ethnic cohort. Rather, it entailed the creative continuation of a kin-group "under new management" (so to speak). Several of the subjects I have studied who settled in France, among other refugees of the Nação, admitted as much in candid-sounding statements. When pressed, they said that they had turned into professing Jews not because they had become persuaded of some great, transcendent truth, but because people in their adopted diasporic communities all spoke Portuguese or Spanish, like them, and were of Iberian origin, like them, and because behaving in accordance with Mosaic Law was "what they [meaning, the resident Iberian expatriates] did over there." One informant, for instance, declared the following: "I don't know for certain what cause [my neighbors in Saint-Esprit, near Bayonne] may have had for catechizing me and persuading me to keep the Law of Moses [...] but I suspect it may have been the fact that over there [that] Law is observed publicly among the Portuguese, and [the fact] that they all know each other and are Portuguese."31

New Christians who became New Jews preserved their own sense of ethnic distinctiveness, I suspect, partly because it fit rather well with the established Jewish model of collective identity as both public, collective, and most of all, ethnic or kin-based.

But, speaking of ethnicity, were the New Jews-or did they become"Sephardim" in the diaspora? The matter is complex. Yes, the Nação originated in Iberian countries that diasporic Jews knew as Sepharad by the 1600 . It is also true that the main diasporic communities of the Nation adopted at least key aspects of minhag Sepharad (custom of Sepharad). Yet, as Ross Brann and Jonathan Ray have shown, the label "Sephardi" was a diasporic, not an Iberian construct. ${ }^{32}$ It was certainly not an adjective or a noun that Jews in the Peninsula had generally used to describe themselves before 1492. There

31 Archivo Histórico Nacional, Inquisición de Toledo, Legajo 177, Expediente 1 (1664-70), fol. $16 \mathrm{v}$.

32 See for example Ross Brann, Power in the Portrayal: Representations of Muslims and Jews in Eleventh- and Twelfth-Century Islamic Spain (Princeton, NJ: Princeton University Press, 2002); Jonathan Ray, After Expulsion: 1492 and the Making of Sephardic Jewry (New York: New York University Press, 2013). 
was something retrospective and idealizing about the "Sephardi" label. This is evidenced by the fact that a few isolated individuals such as Maimonides and Avraham Ibn-Ezra adopted the signifier "ha-Sephardi" only after they had fled the Andalusian-Muslim polity for greener pastures and felt the need to draw up and assert some sort of cultural pedigree.

Miriam Bodian has made the argument that over the centuries New Christians in Iberia lost their connection to the world of the Iberian megorashim and their descendants who took on the Sephardic label. Leaders of the Judeo-Portuguese diaspora abroad tried to rebuild that connection, but ultimately what remained for the New Jews as a social glue, Bodian maintains, is the memory of the converso past, not the Jewish past as such. ${ }^{33}$ If we follow Bodian, then, we must conclude that the New Jews were not really Sephardim far beyond the liturgical sense.

Where would this leave our understanding of "cultural transformation" in the early modern Western Sephardic diaspora? Specifically, if the Jewish culture that the émigré conversos internalized was not a "faith" that "saved" the individual soul; and if it took the New Jews one or more generations to become fully Sephardicized, if at all (especially in the North Atlantic, far away from the Eastern Sephardic diaspora), then what are we cultural historians to make of the Western Sephardic diaspora of the seventeenth century, that economic and cultural apogee of the Men of the Nation? We can turn for part of the answer-an oblique answer - to the anecdote with which I began, namely the strange case of young Luis Aguilar. People like him are significant to the task of rewriting the history of the Western "Sephardic" diaspora precisely because he was not a typical protagonist of that history as its leaders and as modern historians have told it. Luis was not a merchant magnate; he was not a conquistador; he was not a poet or political essayist; he was not a physician, or a pietist, or an intellectual defender of the "excellencies of the Hebrews." He was no martyr, no defender of a nascent ideology of "freedom of conscience," declaiming at an auto-da-fe that the Law of Moses was the true one and that he was ready to die for that faith. Luis was an ordinary bloke. But so were the majority of his fellow nationals. He was far more typical of the Nação than, say, the cultural luminaries Isaac and Avraham Cardoso. And to make matters difficult for him, Luis Aguilar came from a culturally arch-liminal community of Iberian exiles. At that time, his home country, France, unlike the Netherlands, was both a "land of idolatry" and "a land of freedom": there was anti-Portuguese

33 Miriam Bodian, "Hebrews of the Portuguese Nation: The Ambiguous Boundaries of SelfDefinition," Jewish Social Studies 15, no. 1 (2008): 66-80. 
and anti-Jewish sentiment at the local level; "Judaism" was officially illegal. Yet, the regional nobility and the French crown welcomed Portuguese merchants as an economic asset and did not get too involved in the internal life and self-definition of the immigrant population. Some of the members of that population were avid Judaizers; others were not. Many of them oscillated between cultures. In a very real sense, the community of Nouveaux Chrétiens as a whole was neither here nor there, and was both here and there.

As I mentioned at the outset, Luis Aguilar was arrested because a policeman thought that he was a Judaizer. Yet all we really know about Luis is that he called himself a "Jew by nation." Any active ideological or spiritual allegiances and opinions he may have had are actually obscure. The inquisitors who interrogated Luis correctly perceived that he was a kind of cultural blank slate-someone from a "bad" nation of errants, yes, but not especially villainous himself; neither articulate nor inscrutable; neither egregiously offensive nor totally inoffensive. This indeterminacy the Holy Office evidently could not tolerate. For the inquisitors, identity must be integral, clear, and it must always be a matter of declaiming one's subservience to some grand truth-or, alternately, some grand lie. Thus, they took the unusual step of manufacturing Luis Aguilar's social self by having him baptized. But what is lost in that story, and in many of our studies - if we rely too comfortably upon the rhetoric of "Jews" and "Judaism" that predominated in the early modern centuries, and especially if we take the socio-religiously insecure New Jewish leaders and luminaries of the Nação at their word-is that Luis Aguilar, like Bento (not "Baruch," not "Benedictus") de Spinoza, was indeed something and somebody in the streets of his native diasporic Jewish community: Luis and his parents formed part of a commercial and political corporation of long-standing. Despite its actual diversity, that imagined community, the New Christian Nação, already counted with a firm ethnic identity in the terms outlined by Hutchinson and Smith. Old Christians and many Jews associated the New Christian corporation to which Luis belonged with the Jewish people. This was the key circumstance to which the men and women of the Nation were forced to adapt throughout their existence. For better or worse, like the Nação, the Jewish diasporic collective rested on the foundations of ethnicity and relative political autonomy. Whenever social and political winds allowed the men of the nation to explore, to appropriate, and to transvalue that real or supposed Jewish "inheritance," some of them did just that. Yet there was nothing preordained about that outcome. Elective affinities are not indicative of natural preferences. Like Luis Aguilar, the men and women of the Nation were potential Jews and potential Christians simultaneously. 


\section{Bibliography}

Araujo, Maria Benedita. "Familia e grupo social no criptojudaísmo português (século XVII)." Oceanos 29 (January 1997): 49-66.

Archivo Histórico Nacional (Spain), Inquisición de Toledo, Legajo 183, Expediente 4 (1672-1678).

Archivo Histórico Nacional, Inquisición de Toledo, Legajo 177, Expediente 1 (1664-70), fol. $16 \mathrm{v}$.

Bernáldez, Andrés. Historia de los Reyes Católicos D. Fernando y Da. Isabel, crónica inédita del siglo XV. Vol. 1. Granada: D. José María Zamora, 1856.

Bodian, Miriam. "Hebrews of the Portuguese Nation: The Ambiguous Boundaries of Self-Definition." Jewish Social Studies 15, no. 1 (2008): 66-80.

Bodian, Miriam. "Theology and Ideology of Conversos." In “The Political Dimensions of the Converso Phenomenon in Portugal and Beyond," 26 May 2015, Van Leer Jerusalem Institute, at: https://www.youtube.com/watch?v=AG32z8it5TY.

Brann, Ross. Power in the Portrayal: Representations of Muslims and Jews in Eleventhand Twelfth-Century Islamic Spain. Princeton, NJ: Princeton University Press, 2002.

Cohen, Jeremy. Living Letters of the Law: Ideas of the Jew in Medieval Christianity. Berkeley and Los Angeles: University of California Press, 1999.

Cohen, Jeremy. The Friars and the Jews: The Evolution of Medieval Anti-Judaism. Ithaca: Cornell University Press, 1982.

Funkenstein, Amos. Perceptions of Jewish History. Berkeley and Los Angeles: University of California Press, 1993.

Gitlitz, David M. Secrecy and Deceit: The Religion of the Crypto-Jews. Philadelphia: Jewish Publication Society, 1996.

Graizbord, David L. Souls in Dispute: Converso Identities in Iberia and the Jewish Diaspora, 1580-1700. Philadelphia: University of Pennsylvania Press, 2004.

Graizbord, David L. "Who and What Was a Jew? Some Considerations for the Historical Study of New Christians." Anais de História de Além-Mar 14 (2013): 15-44.

Hutchinson, John, and Anthony D. Smith. Ethnicity. Oxford: Oxford University Press, 1996.

Jordan, William Chester. The French Monarchy and the Jews: From Philip Augustus to the Last Capetians. Philadelphia: University of Pennsylvania Press, 1989.

Jordan, William Chester. Review of Jeremy Cohen, Living Letters of the Law. The Jewish Quarterly Review 91, nos. 1-2 (July-October 2000): 217-19.

Kaplan, Yosef. “Bom Judesmo: The Western Sephardic Diaspora." In Cultures of the Jews. 3 vols. Edited by David Biale, 2: 337-67. New York: Schocken, 2002.

Méchoulan, Henry. Hispanidad y Judaísmo en Tiempos de Espinoza: Estudio y edición anotada de La certeza del camino de Abraham Pereyra, Amsterdam 1666. Salamanca: Ediciones Universidad de Salamanca, 1987. 
Netanyahu, Benzion. The Marranos of Spain from the Late 14th to the Early 16th Century, According to Contemporary Hebrew Sources. 3rd ed. Ithaca: Cornell University Press, 1999.

Nirenberg, David. "Mass Conversion and Genealogical Mentalities: Jews and Christians in Fifteenth-Century Spain." Past and Present 174, no. 1 (2002): 3-41.

Pérez, Joseph. History of a Tragedy: The Expulsion of the Jews from Spain. Translated by Lisa Hochroth. Urbana: University of Illinois Press, 2007.

Ray, Jonathan. After Expulsion: 1492 and the Making of Sephardic Jewry. New York: New York University Press, 2013.

Révah, Israël Salvator. "Les Marranes." Revue des etudes juives 118 (1959-1960): 29-77.

Smith, Wilfred Cantwell. The Meaning and End of Religion. Minneapolis: Fortress Press, 1962; repr. 1991.

Stuczynski, Claude. "Not Hybridity but Counterculture: Portuguese New Christian Judaizers: Confronting Christianity and Islam in Bragança." In Conversos, marranie nuove comunità ebraiche in età moderna. Edited by Myriam Silvera, 61-70. Florence: Giuntina, 2015.

Studnicki-Gizbert, Daviken. A Nation Upon the Ocean Sea: Portugal's Atlantic Diaspora and the Crisis of the Spanish Empire. Oxford: Oxford University Press, 2007.

Swetschinski, Daniel M. Reluctant Cosmopolitans: The Portuguese Jews of Seventeenth Century Amsterdam. London: Littman Library of Jewish Civilization, 2000.

Trivellato, Francesca. The Familiarity of Strangers: The Sephardic Diaspora, Livorno, and Cross-Cultural Trade in the Early Modern Period. New Haven: Yale University Press, 2012.

Valdeón Baruque, Julio. "Motivaciones socioeconómicas de las fricciones entre viejocristianos, judíos y conversos." In Judíos, Sefarditas, Conversos: La Expulsión de 1492 y sus consecuencias. Edited by Angel Alcalá. Valladolid: Ámbito, 1995.

Yerushalmi, Yosef H. "Marranos Returning to Judaism in the Seventeenth Century: Their Jewish Knowledge and Psychological Readiness." [Hebrew] In Proceedings of the Fifth World Congress of Jewish Studies. Jerusalem: Magnes Press, 1969. 


\title{
A Family of the Nação from the Atlantic to the Mediterranean and Beyond (1497-1640)
}

\author{
James Nelson Novoa
}

At some point in late 1595, a ship arrived in Lisbon carrying several prisoners on their way from Brazil to face trial through the tribunal of the Inquisition of Lisbon, which oversaw Portugal's Atlantic possessions in the matters of faith. The accused were individuals who came under scrutiny in the first inquisitorial visitation in the northeast of Brazil under Frei Heitor Furtado de Mendoça who had arrived there in June 1591. As there never was an independent tribunal of the Portuguese Inquisition in Brazil, it was dependent on the tribunal of Lisbon, and this visitation was the way in which the tribunal could impose orthodoxy in the overseas territory. ${ }^{1}$ Among the prisoners who arrived was a native of Porto, Bento Teixeira, who would go on to be hailed as Brazil's first

1 On the visitation, see José Antônio Gonsalves de Mello, "Um tribunal da inquisição em Olinda, Pernambuco (1594-1595)," in Revista da Universidade de Coimbra 36 (1991): 369-74; Luiz Mott, Primeira visitação do santo ofíicio a Bahia (1591) (EDUFBA, 2010), 1-26, http:// books.scielo.org/id/yn/pdf/mott-9788523208905-03. Emanuel Luiz Souza e Silva, "Juntos à Forca': A Família Lopes e a Visitação do Santo Oficio à Bahia (1591-1593)," Master's thesis, Universidade Estadual de Feira de Santana, 2010; Angelo Adriano Faria de Assis, "O licenciado Heitor Furtado de Mendonça, inquisidor da primeira visitação do Tribunal do Santo Ofício ao Brasil," in Anais do XXIII Simpósio Nacional de História (Londrina: ANPUH, 2005) cd-rom. The texts of the confessions and denunciations gathered during the visitation are published in Primeira visitação do santo ofício as partes do Brasil pelo licenciado Heitor Furtado de Mendoça, Confissões da Bahia 1591-1592, ed. João Capistrano de Abreu (São Paulo: Homenagem de Paulo Prado, 1922); Primeira visitação do santo ofício as partes do Brasil pelo licenciado Heitor Furtado de Mendoça, Confissões da Bahia 1591-1593, ed. João Capistrano de Abreu (São Paulo: Homenagem de Paulo Prado 1925); Primeira visitação do santo ofício as partes do Brasil pelo licenciado Heitor Furtado de Mendoça, Confissões da Bahia 1593-1595, ed. João Capistrano de Abreu (São Paulo: Homenagem de Paulo Prado, 1929). Recently the confessions in Bahia from 1591-1593 were published in Santo Oficio da Inquisição de Lisboa. Confissões da Bahia, ed. Ronaldo Vainfas (São Paulo: Companhia das Letras, 1997). On New Christians in Brazil during the period see Bruno Feitler, Inquisition, juifs et nouveaux-chrétiens au Brésil. Le Nordeste XVII et XVIII'̀me siècles (Louvain: Presses Universitaires de Louvain, 2003); José Antônio Gonsalvez de Melo, Gente da nação (Recife: Editora Massangana, 1996); the following books by José Goncalves Salvador, Os cristãos novos. Povoamento e conquista do solo brasileiro (1530-1680) (São Paulo: Livraria Pioneira Editora, Editora da Universidade de São Paulo, 1976); Os cristãos novos e o comércio no Atlântico meridional (São Paulo: Livraria

(C) JAMES NELSON NOVOA, 2019 | DOI:10.1163/9789004392489_003

This is an open access chapter distributed under the terms of the prevailing CC-BY-NC License at the time of publication. 
published poet. Teixeira was but one component of this New Christian family whose run-ins with inquisitiorial justice were to be ongoing. The family's links were to extend from continental Portugal to Brazil and Italy and eventually to the Sephardic community of Amsterdam, a show of the kind of interconnectedness of kin and sociability in the New Christian diaspora that extended from the Mediterranean to the Atlantic.

The case closely mirrors that of other individuals who were part of extended family connections that brought together both the worlds of the Mediterranean and the Atlantic. Increasingly, scholarship that is indebted to economic and social history is bridging this gulf, concentrating on bringing these two worlds together, showing their interconnectedness. The New Christian diaspora and its manifold, often sinewy, networks within this Mediterranean-Atlantic divide has increasingly been the subject of research for scholars in a variety of fields. ${ }^{2}$ The concrete case of this family at the end of the sixteenth century and beginning of the seventeenth serves as an example of the connections of kin across this great divide. The case of the family also evinces the complexity of attributing a hegemonic religious identity to the New Christian diaspora. Over the space of two centuries it included members who were accused of being heretics by both Catholic and Jewish authorities and others who apparently held steadfast to religious orthodoxy. The example demonstrates the many contours that New Christian identity could take, from the full embrace of the Christian faith forcibly assumed by Portugal's Jews in 1497, to its lukewarm acceptance, and its rejection.

Since the study of the New Christian phenomenon began in earnest close to a hundred years ago, there has often been a tendency to conceive of them as inevitable potential Jews, individuals who, given the chance, would necessarily embrace the faith of their ancestors. This return to the faith of their forefathers in Sepharad has often been posited as something essential, as the only real option available to them. Recently, scholars such as David Graizbord, ${ }^{3}$ Lucia

Pioneira Editora, Editora da Universidade de São Paulo, 1978); Anita Novinsky, Cristão novos na Bahia (São Paulo: Editora da Universidade de São Paulo, 1972).

2 See, for example, Jonathan I. Israel, Diasporas within a Diaspora: Jews, Crypto-Jews and the World Maritime Empires, 1540-1740 (Leiden: Brill, 2002); Richard L. Kagan and Philip D. Morgan, eds., Atlantic Diasporas. Jews, Conversos and Crypto-Jews in the Age of Mercantilism, 1500-1800 (Baltimore: The Johns Hopkins University Press, 2009); Daviken Studnicki-Gizbert, A Nation upon the Ocean Sea. Portugal's Atlantic Diaspora and the Crisis of the Spanish Empire, 1492-1640 (New York: Oxford University Press, 2007); Francesca Trivellato, The Familiarity of Strangers: The Sephardic Diaspora, Livorno, and Cross-Cultural Trade in the Early Modern Period (New Haven: Yale University Press, 2009).

3 David Graizbord, “Religion and Ethnicity among 'Men of the Nation': Towards a Realistic Interpretation," Jewish Social Studies: History, Culture, Society 15, no. 1 (2008): 32-65. 
Frattarelli Fischer, ${ }^{4}$ Federica Ruspio, ${ }^{5}$ and Ignacio Pulido Serrano have called for a decidedly mitigated interpretation of religious identity, which allows for various readings and interpretations. ${ }^{6}$

The case I wish to dwell on, of a family from Porto over the span of two centuries, reveals the broad spectrum of religious options that were possible for members of the Nação in various locales. Some of them chose the route of some form of adherence to Jewish belief and practice, however nuanced or vague, even at the risk of reputation, livelihood, and physical wellbeing. Others, even when the choice of an embrace of the Jewish faith did not occasion danger, chose to hold steadfast to the faith they had been reared in. This variety within this family from Porto is a telling testimony to how the religious identity of the Nação is multilayered and complex, and evades facile definitions.

\section{1 \\ Bento Teixeira: A Study in Ambiguity}

According to the account of his life which appears in his inquisitorial trial by the tribunal of Lisbon held in the Torre do Tombo archive as trial 5206, Bento Teixeira was born around 1560 in Porto, the son of one Bento Mendez, a New Christian merchant, and Leonor Rodriguez. ${ }^{7}$ At the age of three, after leaving Lisbon, where his family settled for a few years, he left Portugal, along with a brother, Fernando Rodríguez da Paz, whose name could indicate his possible links to the well-known New Christian Paz family based in Porto, for Brazil. He first settled in the captaincy of Espiritu Santo, then Tapera, and Rio de Janeiro, being privy to a Jesuit formation all the while, which trained him in Latinidade, something which was to be at the heart of his activities throughout his troubled existence. ${ }^{8}$ He received schooling in the Classics and the Bible along with the rudiments of Italian and Spanish, which put him into contact with the literary trends then predominant in the Italian and Iberian peninsulas, something

4 Lucia Frattarelli Fischer, "Ebrei a Pisa fra Cinquecento e Settecento," Gli ebrei di Pisa (secoli IX-XX). Atti del Convegno internazionale. Pisa, 3-4 ottobre 1994 (Pisa: Pacini editore, 1998), 89-115; "Cristiani nuovi e nuovi ebrei in Toscana fra Cinque e Seicento: Legittimazioni e percorsi individuali," in L'identità dissimulata. Giudaizzanti iberici nell'europa dell'età moderna, ed. Pier Cesare Ioly Zorattini (Florence: Olschki, 2000), 217-31; Vivere fuori dal Ghetto. Ebrei a Pisa e Livorno (secoli XVI-XVIII) (Turin: Silvio Zamorani Editore, 2008), 15-68.

5 Francesca Ruspio, La nazione portoghese. Ebrei ponentini e nuovi cristiani a Venezia (Turin: Silvio Zamorani editore, 2007); "Una comunità di marrani a Venezia," Zakhor 5 (2001): 53-85.

6 Juan Ignacio Pulido Serrano, "Plural Identities: The Portuguese New Christians," Jewish History 25 (2011): 129-51.

7 Processo da Inquisição de Lisboa, 5206 .

8 Ibid., fols. 10or-v. 
borne out in the literary work he is associated with and which would be published posthumously, the Prosopopeia, an epic poem in ninety-four strophes.

Settling for a time in Ilheus, near Bahia, he married a woman of Old Christian stock, one Felipa Raposa. From there he moved to the city of Olinda, which boasted an important New Christian community at the time. He quickly became known as a teacher of Latin grammar and set up his own school, which provided children with Classical learning. ${ }^{9}$ He subsequently opened a school for children in the town of Igarassu. It was there that his wife's adulterous behavior began with the connivance of the local population until Teixeira killed her. ${ }^{10} \mathrm{He}$ took refuge in a Benedictine monastery after being offered hospitality from a sympathetic Benedictine brother. ${ }^{11}$ It was upon leaving the confines of the monastery though that he was apprehended for an entirely different reason. Frei Hurtado de Mendoça, who had undertaken his visitation of the northeast of Brazil as the representative of the tribunal of the Inquisition of Lisbon ordered his arrest on 19 August 1595 after having gathered information on him. ${ }^{12}$

He came under scrutiny on account of the testimony of several people who knew him to be an inciter to Jewish belief and practice, a blasphemer, and heretic. There were multiple accounts of his disbelief from both Old and New Christians. He refused to teach on Saturdays according to one Domingos Fernandes, an old Christian from Rio da Janeiro who had been a pupil of Teixeira's in his Latin school. ${ }^{13}$ João da Rosa, a New Christian, claimed that he had heard him repudiate the doctrine of the Trinity. ${ }^{14}$ Another New Christian, Antonio da Rosa, brought forward a similar allegation. ${ }^{15}$ Braz de Matta, an Old Christian, claimed he had said that his home was just as sacred as a church. ${ }^{16}$ Gaspar Rodrigues claimed that Teixeira possessed a copy of Jorge de Montemayor's (150-1561) pastoral poem La Diana that was listed among the Index of Forbidden Books. When confronted by Rodrigues, Teixeira claimed that he was aware and that he would burn it. ${ }^{17}$ One Jorge Thomas Pinto, a New Christian from Porto who lived in Bahia, depicted him as a blasphemer who put into question the validity of the sacraments even if he was not sure that he

Processo da Inquisição de Lisboa, 5206, fol. 101r. On New Christians in Olinda at the time, see José Luiz Mota Menezes, A recriação do paraíso. Judeus e cristão-novoa em Olinda e no Recife nos séculos XVI e XVII (Recife: Companhia Editora de Pernambuco, 2016).

10 Processo da Inquisição de Lisboa, 5206, fols. 101v-103v.

11 Ibid., fol. 103v.

12 Ibid., fol. 3 r.

13 Primeira Visitação, 2: 40.

14 Ibid., 2: 42-43.

15 Ibid., 2: 291-93.

16 Ibid., 2: 129-30.

17 Ibid., 2: 170. 
observed Judaic ceremonies and practices. ${ }^{18}$ While in the refuge of the monastery, he had apparently spoken frequently with one Frei Damião da Fonseca with whom he engaged in erudite exchanges. The friar had diligently taken note of some of Teixera's positions which were suspect. The New Christian teacher apparently claimed that Adam would have died independently of original sin, and he cast doubt on the Trinity. To this was added the poet and grammarian's origins which the friar caught on to. ${ }^{19}$

These warranted his formal accusation and dispatch to Portugal, leaving from Recife in October 1595. The saga would drag on for years, only ending in 1599 with Teixeira's confessing to having adopted some aspects of Jewish belief and which he reneged. He died shortly after, his Prosopopeia appearing posthumously along with Naufragio que passou Jorge de Albuquerque Coelho, Capitão e Governador de Pernambuco, a work about a shipwreck, which was dedicated to Jorge d'Albuquerque Coelho (1539-c. 1596), the governor of the captaincy of Pernambuco at the time, whose ship was attacked by French pirates and who was left at sea only to miraculously survive (Figs. 2.1 and 2.2). ${ }^{20}$ In his epic poem, also dedicated to Jorge d'Albuquerque Coelho, who had gone on to Lisbon where he died during Teixeira's imprisonment, he presents the adventures of the Albuquerque family, as recounted by Proteus to several Greek gods who meet in the port of Recife. The work, along with the Naufragio, was seen by critics as a servile act of ingratiation by an author hoping to curry favor with the Albuquerque family, perhaps even to be able to return to Brazil. Curiously, the censor's note allows for the publication of the work, apparently oblivious to the stricture that persons condemned by the Inquisition should not be allowed to publish books. ${ }^{21}$

18 Ibid., 2: 289-90.

19 Ibid., 2: 453-54. Teixeira's account of the discussions between the two come out in his trial. Processo da Inquisição de Lisboa, 5206, fols. 103v-104r.

20 Naufragio, que passou Jorge D'Albuquerque Coelho, capitão e governador de Pernambuco (Lisbon: por António Alvarez, vendemse em casa de António Ribeyro livreyro em a Rua Nova, 1601). Subsequent editions are Bento Teixeira, Prosopopea, ed. Benjamin Franklin Ramiz Galvão (Rio de Janeiro: Tipografia do Imperial Instituto Artístico, 1873); Prosopopea, ed. Afrânio Peixoto (Rio de Janeiro: Academia Brasileira, 1923); Naufrágio que passou Jorge de Albuquerque Coelho vindo do Brasil para este reino do ano de 1565, ed. Augusto César Pires de Lima (Porto: Livraria Simões Lopes de Domingos Barreira, 1938). On Albuquerque, see Charles Ralph Boxer, "Jorge d'Albuquerque Coelho: A Luso-Brazilian Hero of the Sea, 1539-1602," Luso-Brazilian Review 6, no. 1 (1969): 3-17.

21 "Vi e examinei este discurso e Naufragio, que passaou Jorge d'Albuquerque. Hé tratado pio e catholic e que não tem cousa que offenda as orelhas cristãs. Vay junto a elle huma Prosopopéia feyta por Bento Teyxeyra, dirigida ao mesmo Jorge D’Albuquerque. Não tem cousa por onde se não possa imprimir. Frey Manoel Coelho." On censorship in Portugal at 

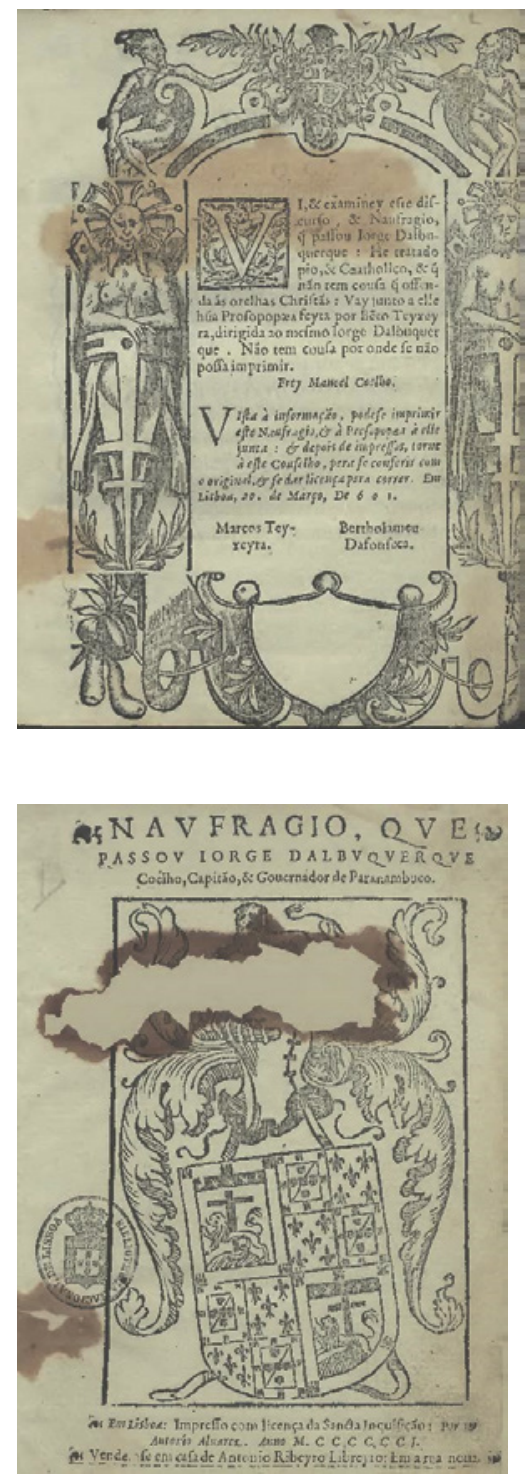

FIGURE 2.1

Permission for printing of Naufragio que passou Jorge de Albuquerque Coelho, Capitão e Governador de Pernambuco and Prosopopeia COURTESY OF THE BIBLIOTECA NACIONAL DE PORTUGAL. SHELFMARK RES. 392 P
FIGURE 2.2

Title page of Naufragio, Lisbon, Antonio Alvarez, 1601 COURTESY OF THE BIBLIOTECA NACIONAL DE PORTUGAL. SHELFMARK RES. $392 \mathrm{P}$

Bento Teixeira has received little critical attention. He appears generally as an almost anecdotal figure in Brazilian letters, a decidedly minor character in the literary landscape of the Portuguese language. It was Gilberto Freyre who first tentatively identified Teixeira the writer with the man denounced in Mendoça's

the time, see Jesus Maria de Bujanda, ed., Index de l'Inquisition portugaise 1547, 1551, 1564, 1581 (Sherbrooke: Centre d'Études de la Renaissance, 1995). 
visitation when the relevant texts were first published in $1925 .{ }^{22}$ Since then, he has been the subject of several articles, doctoral theses, and even books. ${ }^{23}$ The entire trial, made up of 401 folios, has yet to be fully and systematically studied, and it provides a fascinating glimpse into early colonial Brazilian society and the place of New Christians in it. The wealth of information it provides lays bare the complexity of social relations in that society with its divisions, rivalries, disputes, suspicions, and accusations.

In it, he provides a portrait of himself as a divided soul, similar in kind to other New Christians. His Judaizing was, he claimed, inculcated in him by his mother, while his father had done all he could to rear him in the Christian faith and dissuade him from his wife's coaxing. While his Jesuit teachers all recalled him as a studious and dutiful Christian who complied with the requirements of religious practice, other people provided an alternative take on Teixeira's character. He apparently lived a parallel life, true to the Jewish heritage his mother had passed onto him. At the trial, he provided an eloquent refutation of what he called "his errors," laced with erudite allusions to the Church Fathers and Saint Thomas Aquinas, warranting his being sentenced, on 31 January 1599, to Catholic indoctrination in the so-called "cárceres da penitencia," in the Estaus palace. ${ }^{24} \mathrm{He}$ was released shortly afterwards, with inquisitorial officials making note of his exemplary behavior, and regular attendence at church.

22 Gilberto Freyre, “Acerca da Prosopopéia," Revista de Pernambuco 1, no. 1 (1927): 2-61.

23 José Antônio Gonsalves de Melo, "Bento Teixeira, autor da Prosopopéia," in Estudos Pernambucanos. Crítica e problemas de algumas fontes de história de Pernambuco (Recife: Fundarpe, Direitoria de Assuntos Culturais, 1986), 13-52, Elvira Cunha de Azevedo Mea, “Os cristãos-novos, a Inquisição e o Brasil. Séc. XVI," Revista da Faculdade de Letras do Porto 2, no. 4 (1987): 151-77; Luiz Roberto Alves, Confissão, poesia e inquisição (São Paulo: Ática, 1983); Rogério Chociay, “Bento Teixeira e Camões: o verso no verso," Revista de Letras 31 (1991): 17-32; Gilberto Vilar de Carvalho, O primeiro brasileiro (São Paulo: Marco Zero, 1995); Lúcia Helena Costigan, Through Cracks in the Wall. Modern Inquisitions and New Christian Letrados in the Iberian Atlantic World (Leiden and Boston: Brill, 2010); Costigan, "Empreendimento e resistência do cristão-novo face à política de Filipe II: O processo inquisitorial de Bento Teixeira," Colonial Latin American Review 12, no. 1 (2003): 37-61; Costigan, "A experiência do converso letrado Bento Teixeira: Um missing link na história intelectual e literária do Brasil-colônia," Revista de Crítica Literaria Latinoamericana 2040 (1994): 77-92. Eneida Beraldi Ribeiro, "Bento Teixeira: Inquisição e sociedade colonial," WebMosaica 4, no. 1 (2012): 50-56; and Ribeiro, "Bento Teixeira e a 'Escola de Satanás.' O Poeta que teve a 'prisão por recreação, a solidão por companhia e a tristeza por prazer'," PhD diss., University of São Paulo, 20o6; Lucinéa Rinaldi, "Entre a Prosopopeia e a viagem: Poética e narrativa por letras coloniais," PhD diss., University of São Paulo, 2016.

Processo da Inquisição de Lisboa, 5206, fol. $401 v$. 
Destitute and stricken ill with fever, he presented himself anew to the prison of the Inquisition in April 1600 . He died in August of that year. ${ }^{25}$

\section{A New Christian Family from Porto}

Among the individuals mentioned in the trial was a relative and fellow native of Porto, Miguel Fernandes. In December 1597, Teixeira related some conversations held with Old and New Christians in Brazil that were the source of religious controversy. He recollected a conversation held one evening after a dinner in 1580, in Miguel Fernandes's Bahian home. A group of New Christians had gathered there and the conversation shifted to whether the Messiah had come or not. Miguel Fernandes, Gonçalo Mendes, Lionel Mendes, and Diogo Fernandes Teves, especially, sought out the opinion of Bento Teixeira regarding the matter, alluding to his erudition, which they all held in great esteem. The conclusion of all those present was that the Messiah had not yet arrived and that the Law of Moses was their only path to salvation. It also transpired that, whenever possible, they held steadfast to some form of Jewish practice, including fasting and abstinence from pork. At the end of his deposition, the Brazilian poet clearly identified Treves and Fernandes as cousins on his mother's side. ${ }^{26}$

Israël Salvator Révah's painstaking archival work has provided us with a breakdown of Miguel Fernandes's family origins, which firmly situated him, as Teixeira, in Porto. Fernandes's Judaizing tendencies did not only come to be known during Bento Teixeira's trial. The arrival of Frei Mendoça was also an occasion to make what was considered Fernandes's deviant behavior known to the inquisitorial authorities. He was accused of irreverent behavior in church and his New Christian origins were no secret. ${ }^{27}$

Révah identified Fernandes's parents as Dinis Aenes (1510?-1565?) and Florença Fernandes (died 1570?), New Christians from Porto. ${ }^{28}$ Dinis Aenes was a prominent figure among his fellow merchants thanks to a trade network

\footnotetext{
25 A note on the first folio of the trial states "He falecido Bento Teixeira, e falleçeo andando com [...] e no fim de Julho de 16oo." Ibid., fol. rr.

26 The conversation has been presented and translated into French in Israël Salvator Révah, Uriel da Costa et les marranes de Porto. Cours au Collège de France 1966-1972, ed. Carsten L. Wilke (Paris: Fundação Calouste Gulbenkian, 2004), 344-47. The relevant passages are to be found in Inquisição de Lisboa, processo 5206 , fols. 308v-310r.

27 Révah, Uriel da Costa, 349-50.

28 Ibid., 126-27.
} 
that spanned the Mediterranean and the Atlantic. ${ }^{29}$ It was also well known that Aenes was a New Christian, the son of one Alvaro Rodrigues and Violante Rodrigues, Jews who had converted to Christianity in the general conversion of $1497{ }^{30}$ Suspicions regarding Aenes's orthodoxy and that of his parents and first wife, Isabel Nunes, led to his arrest in April 1543 by the tribunal of the shortlived Inquisition of Porto, one of a few tribunals to exist in Portugal from 1541 to $1547 .{ }^{31}$ Aenes was made to publicly renounce his alleged Jewish practices on 3 September 1543, with a display of public penance at the cathedral of Porto and a monetary contribution to be made for pious works, a light sentence, which Révah interpreted as a reflection of the dubious veracity of the accusations brought forward by witnesses of suspicious intent and character. ${ }^{32}$

Miguel Fernandes was the son of Aenes's second marriage with Florença Fernandes, one of five children including Margarida Dinis, Branca Dinis, Álvaro Rodrigues, and Jácome Rodrigues, born and raised in that New Christian hub of the rua de São Miguel in Porto. ${ }^{33}$ In a deposition before the tribunal of the Roman Inquisition, a trial from 1595, to be addressed more fully below, Miguel declared that he was forty-two years of age, which places his birth in the year 1553. The declarations in the Roman trial complement the information gathered by Révah regarding Fernandes and the family. In childhood, he had his first direct experience of the workings of inquisitorial justice when, in 1565, the tribunal of the Holy Office investigated his mother, by then a widow, on allegations of Judaizing, though it was concluded that there was insubstantial evidence of Jewish practices. ${ }^{34}$

He left Portugal for Brazil at the age of seventeen in pursuit of fortune. He returned to his homeland for a short time after participating in the disastrous battle of Alcácer Quibir in 1578. He then went back to Brazil, where he fought alongside Cristovão de Barros in the conquest of Sergipe, earning him a knighthood. It was during this second sojourn in Brazil that he lived in Bahia,

29 On Porto's merchants and Porto in the sixteenth century, see Amândio Jorge Morais Barros, "Barcos e gentes do mar do Porto (séculos XIV-XVI)," Revista da Faculdade de Letras 14 (1997): 167-230.

30 Révah, Uriel da Costa, 149.

31 On the tribunal, see Elvira Cunha de Azevedo Mea, "A Inquisição do Porto," Revista de História 2 (1979): 215-27 and Giuseppe Marcocci and José Pedro Paiva, "Inquisizione di Porto," in Dizionario storico dell'Inquisizione (Pisa: Edizioni dela Normale, 2010), 3:1240-41.

32 Révah, Uriel da Costa, 155-76.

33 Ibid., 188-89.

34 Ibid., 190-94. 
where he apparently married Feliciana Teixeira, the daughter of his cousin, Rui Teixeira, who was, in turn, married to one Branca De Nis. ${ }^{35}$

To date, little is known of Rui Teixeira's presence in Brazil, his activities there, or his relations in the territory. His name, however, does surface in the denunciations compiled by Frei Mendoça during his sojourn to Brazil, though he was no longer living there at the time. In 1591, an Old Christian from Porto by the name of Paulo Moreira claimed that Rui was then living in Lisbon but that four years before he had been present in Brazil where he acted as the agent of a merchant from Lisbon, one Bento Dias Santiago. He was accused of declaring that he believed as much in his black servant as in the Gospel of Saint John. His words, overheard by other people, had been a cause of scandal. ${ }^{36} \mathrm{~A}$ similar accusation was leveled against him by an Old Christian from the Algarve, Francisco Roiz Castilho. ${ }^{37}$ Like Miguel Fernandes and his cousin Bento Teixeira, the accusations of some form of allegiance to the Jewish faith were thus made against Rui Teixeira as well during the investigations undertaken in that remote territory of the Hispanic empire.

\section{Tuscan Reinvention}

Fernandes's second stay in Brazil lasted from 1587 to 1593 , after which he returned to Portugal where he lived but briefly. From there he made his way to Pisa, where he was sought after by Granduke Ferdinando I (1587-1609), who entreated the resident apostolic collector in Portugal, Fabio Biondi (1533-1618), to secure his safe passage to the Tuscan town along with his father-in-law and their families. They apparently settled there in February 1594, a year before Bento Teixeira was apprehended. ${ }^{38}$ Ferdinando had recently been a force behind the so-called Livornine of 1591 and 1593 intended to attract international merchants to the port of Livorno and turn it into a maritime commercial hub by extending to Portuguese New Christian merchants the privilege to settle in the town free from inquisitorial prying on possible past accusations

35 James Nelson Novoa, "The Many Lives of Two Portuguese Conversos: Miguel Fernandes and Rui Teixeira in the Tribunal of the Holy Office in Rome," HispaniaJudaica 12 (2016): 134. On Fernandes and Teixeira see, in addition, Nelson Novoa, "Negotiating Identity Among the Nação in Early Modern Rome," in Early Modern Ethnic and Religious Communities in Exile, ed. Yosef Kaplan (Newcastle upon Tyne: Cambridge Scholars Publishing, 2017): $242-76$.

36 Testimony given on 7 August 1591, Primeira Visitação [...], 2: 292-93.

37 Ibid., 2: 292-93.

38 Nelson Novoa, "The Many Lives," 133-34. 
of unorthodoxy. The measures also allowed for a crucial modification: the possibility for Jews to create a new Jewish community with a synagogue and for baptized Iberians to convert to Judaism and join it. ${ }^{39}$ This measure echoed a similar one undertaken in 1589 in Venice where the authorities allowed Iberian Jews, known as ponentini, by definition converts to Judaism from Christianity, the possibility to settle in the city. ${ }^{40}$

It was the Brazilian historian Sergio Buarque de Holanda who first drew the attention of historians to the fact that Ferdinando was especially keen on securing ties to Brazil, making plans for an elaborate scheme of Tuscan colonization of the Amazon that never materialized. The project aimed at securing a series of commercial privileges for the grand duchy in the New World during the Iberian Union (1580-1640), the period that saw Spain and Portugal united under the same crown. ${ }^{41}$ Men like Fernandes and Teixeira, who had also been in Brazil, could potentially provide the grand duke with important information about Brazil, its topography, and the current state of its population. Miguel Fernandes in particular could boast a knighthood earned in military exploits in Brazil and the social capital that it entailed in the Iberian world, something that could be useful to the grand duchy if it were to try to make inroads into Brazil. Men like Teixeira and Fernandes could also be instrumental in securing Ferdinando's interest to make inroads into Atlantic commerce, especially as they hailed from the prominent commercial center of Porto. As the son of Dinis Aenes, someone like Miguel Fernandes would also have had the added benefit of belonging to an international mercantile network of over two generations. ${ }^{42}$

Shortly after arriving in Pisa, Fernandes and his father-in-law came to the grand duke's attention. Their troubles began in May 1595 during their journey

39 On the Livornine see Lucia Frattarelli Fischer, "Cristiani nuovi e nuovi ebrei in Toscana fra Cinque e Seicento: Legittimazioni e percorsi individuali," in L'identità dissimulata. Giudaizzanti iberici nell'europa dell'età moderna, ed. Pier Cesare Ioly Zorattini (Florence: Olschki, 200o), 217-31, and Vivere fuori dal Ghetto [...], 15-68.

40 On the ponentini and Venice see the following studies by Benjamin Ravid, "The First Charter of the Jewish Merchants of Venice, 1589," AJs Review 1 (1976): 187-222, and "Venice, Rome and the Reversion of New Christians to Judaism: A Study in Ragione di Stato," in L'identità dissimulata. Giudaizzanti iberici nell'europa dell'età moderna, ed. Pier Cesare Ioly Zorattini (Florence: Olschki, 2000), 151-93.

41 Sergio Buarque de Holanda, "Os projetos de colonização e comércio toscanos no Brasil ao tempo do grão duque Fernando (1587-1609)," Revista de História (2000): 95-122; Carlos Alberto de Moura Ribeiro Zeron and Carlos Ziller Camenietzki, "Nas sendas de Sérgio Buarque de Holanda. Documentos sobre uma expedição florentina a Amazônia em 1608," Revista de História 142-143 (2000): 123-211; Alírio Cardoso, "Um piccolo astaccio al rio dell'amazzoni': Pirataria europeia e projetos italianos na Amazônia na época da monarquia hispânica," Revista de História 170 (2014): 170-99.

42 Nelson Novoa, "The Many Lives," 151-53. 
to Rome in order to secure a home for Fernandes and his wife. They were to be assisted on their way by a prominent Portuguese New Christian, Jerónimo da Fonseca. Expressing his annoyance after not being able to find a house, Fernandes was overheard by a relative of Fonseca's who construed what he heard as a blasphemous remark warranting the attention of the Inquisition. This led to Fernandes's inquisitorial confinement over the spring and summer of 1595 and his release in October 1595, two months after the release of Rui Teixeira, thanks to the diplomatic and financial assistance of the Tuscan grand duke. The great number of Portuguese residents of Pisa who provided testimony in their defense serves to show their standing in the city, where they had only been living for a year. Ironically, their unfortunate brush with the Inquisition coincided with Bento Teixeira's arrest in Pernambuco. During his trial, he mentioned having spoken to one Diogo d'Orta, a New Christian who traveled widely and, at one point, had met up with Rui Teixeira in Pisa, and described him as a practicing Catholic. He mentioned that Rui had heard about Bento's imprisonment. His reaction was not one of surprise but the opposite, that it was to be expected, as he said "ele quis, ele otenha," he got what he was looking for, which would seem to indicate that he had known about his cousin's Judaizing. ${ }^{43}$

After their run-in with the Inquisition in Rome, son- and father-in-law settled into their roles as prominent Portuguese merchants in Pisa. Rui Teixeira's life is relatively well documented. He settled in the parish of San Martino in Kinzica, an important church whose origins date back to the eleventh century, located on the other city of the Arno river from Pisa's most important buildings, but which by then had become a New Christian hub. The Stati delle anime, the parish records of marriages and deaths, the gathering of which became obligatory after the council of Trent $\left(1545^{-1563)}\right.$ provides ample evidence of the Portuguese presence. The parish records show that Teixeira died there on 18 October 1601 ( 1602 according to the Pisan year), and was buried the next day. ${ }^{44}$ The elegant tombstone can still be seen in the church (Fig. 2.3).

43 "E embarcando-me pera Itália vim ter a Pisa, aonde esta o senhor seu primo com irmão Ruy Teixeira, que ia la. Sabia de sua prisão e disse por muitas vezes, 'ele quis, ele otenha,' e justamente estão com ele das portas adentroos dous primos mais de Vossa Mercede Senhor Sebastião Ferreira e Manuel Fernandes, ambos casados com cada huma sua filha de Ruy Teixeira. E perguntando-lhe eu se vivia la catholica e exemplarmente respondeu que sim sed hoc quo ad me implicat et dictione ut pet in mea confessione de Michaele Fernandez, alii vero duo Senhor Ruy Teixeira et Bastião Ferreira fama tantum mihi noti sunt" (fol. 121v). His deposition is dated 14 December 1597.

44 "Addì 18 d'ottobre 1602 al pisano. Morì Messer Rui Tesera portoghese et il seguente giorno fu sepolto in nostra Chiesa di San Martino e pagò per li funerali." San Martino in Kinzica, morti dal 1566 al 1631, Archivio Arcivescovile di Pisa, unnumbered folio. 


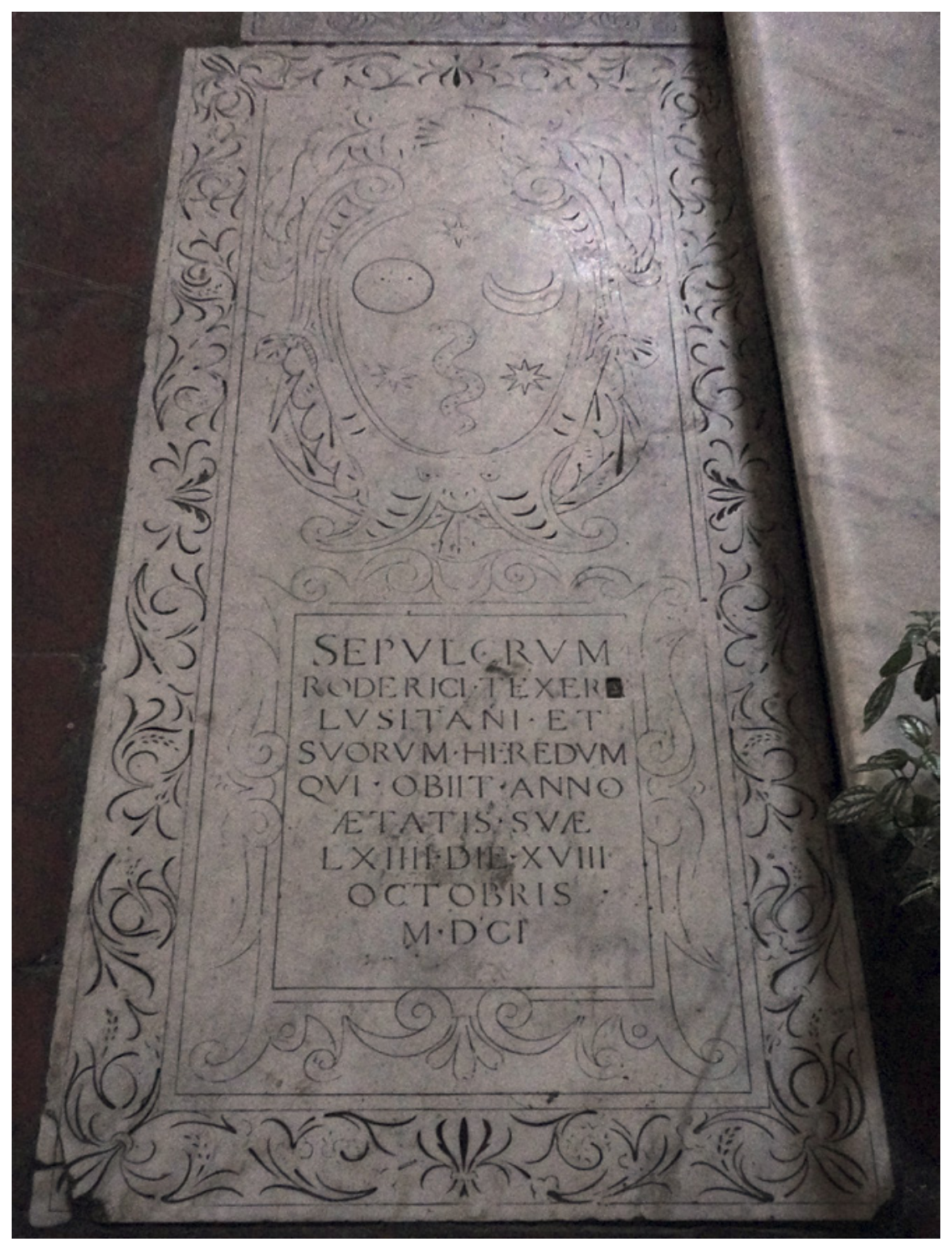

FIgure 2.3 Tombstone of Rui Teixeira, Chiesa di San Martino, Pisa PHOTO: JAMES NELSON NOVOA, ENHANCED COURTESY OF MARTA RAÏCH

\section{$4 \quad$ Lingering Doubts and New Horizons}

Traces of Miguel Fernandes's footsteps seem to end in Pisa. We know that he fathered three children with his wife: Dinis, Branca, and Florença, all names derived from family members. While his orthodoxy would seem to have been 
cleared, the suspicions regarding the family continued to haunt his descendants. Years later, his son Dinis married his cousin Beatriz Dias on 21 December 1622. In 1625, Dias was tried by the tribunal of the Inquisition of Milan, where she had taken up residence. She claimed that they had been married in the home they were to inhabit near the church of San Sepolcro in close vicinity to San Martino. In the room where the wedding took place there was a Bible in Spanish on a table and some kind of blessing was read out loud in Portuguese by her future husband ${ }^{45}$ The trial, transcribed and published by Pier Cesare Ioly Zorattini, provides us with the version of events presented by Beatriz to the Inquisition. As the daughter of Clara Teixeira and grandaughter of Rui Teixeira, she had believed that they had been married with a papal dispensation of consanguinity. She claimed that her husband in reality had no religion, being like the beasts, without a law, only going through the motions at mass and going to confession in order to get along with his mother and sister all the while practicing Jewish fasts at home. ${ }^{46}$

The trial was part of a series of inquisitorial investigations that dogged the female members of the family from 1618 to 1626 from Pisa to Milan to Venice, offering differing versions of events. Dinis's mother Feliciana (by then Miguel Fernandes's widow we assume since there is no mention of Miguel being alive), confessed to having induced her son into Jewish practice. She herself claimed that she was led into error by the Jewish doctor Eliahu Montalto (1567-1616) during his sojourn in Tuscany in 1606-1609. Dinis had apparently been indoctrinated into his Judaizing heresy after a stint in Brazil where he had followed his father's footsteps, presumably in the sugar trade. Feliciana claimed that she reinforced these heretical beliefs in her son upon his return.

The investigations pitted various female members of the Teixeira family against each other. Beatrice, having settled in Milan, denounced her mother and a sister, Clara, as Judaizers while admitting her own apostasy, claiming that they had been lead astray by their mother, Branca de Nis, Rui Teixera's wife. All ended up being condemned to prison for different intervals in order to expiate their crimes of faith.

The truth of inquisitorial trials is a continuous source of academic debate and it cannot be assumed that what was confessed was necessarily factual truth. We can postulate as to the actual intentions and beliefs of the people

45 "Et il matrimonio seguì in casa nostra, che si chiama la casa di San Sepolcro, nella sala sopra un tavolino dov'era una Bibbia aperta in lingua spagnola, e mi marito legè un foglio scritto a mano in lingua portoghese [...]" Processi del S. Uffizio di Venezia contro ebrei e giusaizzanti (1633-1637), ed. Pier Cesare Ioly Zorattini (Florence: Olschki, 1992), 315-16.

46 " $[\mathrm{C}]$ ome le bestie, che non fa a modo né d'una Legge né dell'altra, cioè lui va alla messa et si confessa ma, per non farsi mal volere dalla madre e dalla sorella, in casa fa a modo loro, che li detti digiuni all'hebrea li fa ancora lui [...]." Ibid., 221-22. 
involved and attempt to match these with independent accounts. The case of the Teixeira family nonethless provides, I believe, an interesting sampling of the many faces of the New Christian diaspora across its full geographical range from the Iberian Peninsula to Brazil, and to Italy. In the space of three generations and across these geographical divides spanning the better part of the globe, we see individuals who, at least publicly, adamantly did all they could to attest to their Catholic faith. Others admitted to their Judaizing tendencies, generally invoking their being coaxed into it by family members, especially their mothers.

As Révah's fundamental scholarship has shown, the individuals mentioned here belonged to the same family as Uriel da Costa (1581?-1640), one of the most emblematic and tragic figures of the Sephardic diaspora in one of its most important communities in the early modern period. Reared as a Christian, who received ecclesiastic benefices in the north of Portugal and a humanistic education at the storied university of Coimbra, only to later embrace Judaism, da Costa went on to question the very foundations of rabbinical Judaism during the foundational period of the community of Amsterdam..$^{47}$ One of Miguel Fernandes's siblings, Branca Dinis, married one Bento da Costa Brandão, a New Christian though called "cavaleiro fydallgo da casa da Infante Dona Maria" in notorial documents, were residents of Porto in the rua de São Miguel. It was in that New Christian hub at its parish of Nossa Senhora da Vitória that Gabriel da Costa, who would go on to be called Uriel da Costa, was presumably born sometime in $1581 .^{48}$ As Révah has shown, even though the future author of the Exemplar humanae vitae had been brought up by his father apparently as a practicing Christian, there were also inquisitorial trials that gathered accusations against Bento da Costa Brandão. Révah has speculated as to whether the

47 The literature on Uriel da Costa is considerable. For the sake of brevity we cite only the following: On the community of Amsterdam in these years, see Matt Goldish, "Perspectives on Uriel da Costa's 'Example of a Human Life," Studia Rosenthaliana, 42-43 (2010-2011): 1-23; Israel Salvator Révah, "La religion d'Urel da Costa, Marrane de Porto (D’après des documents inédits)," Revue de l'histoire des religions 161, no. 1 (1962): 45-76; Révah, Uriel da Costa; Uriel da Costa, Examination of Pharisaic Traditions Supplemented by Semuel da Silva's Treatise on the Immorality of the Soul, Translation, notes and introduction H.P. Salomon and I.S.D. Sasson (Leiden and Boston: Brill, 1993); Carl Gebhardt, Die Schriften des Uriel da Costa mit Einleitung, Uebertagung und Regesten (Amsterdam: Menno Hertzberger/Heidelberg: Carl Winters Universitätsbuchhandlung/Oxford University Press, 1922). On the formative years of the Sephardic community of Amsterdam, see the following titles by Yosef Kaplan, Judios nuevos en Amsterdam. Estudios sobre la historia social e intelectual del judaismo sefardí en el siglo XVII (Barcelona: Gedisa, 1996); "From Apostasy to Return to Judaism: The Portuguese Jews in Amsterdam," Binah 1 (1989): 99-117.

Révah, Uriel da Costa, 229-35. 
charges were examples of the constant and random accusations that hovered over all members of the Nação or whether there could have been some truth to his having some degree of attachment to Jewish belief and practice. Doubts nonwithstanding, Costa Brandão died in Porto in 1608 , where he was buried in his parish church of Nossa Senhora da Vitória as a bona fide Catholic. ${ }^{49}$ As with so many members of the Nação, doubt and suspicion were part of the condition of the New Christian in the Peninsula.

Révah has insisted on the importance of Uriel da Costa's formative years in Portugal in understanding his subsequent intellectual and spiritual development. In the Exemplar humanae vitae, he made clear that the skepticism that led him to question the immortality of the soul and the authority and legitimacy of rabbinical Judaism had begun with his doubts regarding Christianity, which had been awakened during his university years in Coimbra. ${ }^{50}$ Uriel da Costa was brought up in a family that belonged to the Nação with firm roots in Porto and was suspected of attachment to Jewish belief for several generations, drawing the attention of inquisitorial authorities in Brazil and Portugal. The consciousness of that belonging, from his childhood in the New Christian hub of São Miguel, to his years in Coimbra, and later on in the midst of the Portuguese Jewish community of Amsterdam, a community which was imposing its own models of confessionalization over its denizens, must have accompanied this fiercely independent and original thinker throughout his lifetime.

The family considered here exemplifies the many possibilities open to New Christians in terms of public expression of their religious allegiances throughout the various locales of the Western diaspora which they encountered. In the Hispanic world, concealment, some degree of attachment to Jewish belief, or total disregard or disavowal of it were the only paths available. Tuscany and Venice, at the end of the sixteenth century offered them the possibility of embracing Judaism and joining the incipient Sephardic communities there. None of the members of the family chose that path, living at least formally as Catholics and suffering inquisitorial justice when they failed to do so completely.

In the cases of Rui Teixeira, Miguel Fernandes, and Bento Teixeira, Portuguese inquisitorial justice was to follow them from Porto to Brazil as a lingering reminder of their membership in the Nação. In the case of the first two, it even followed them to Rome. In spite of their being ostensibly cleansed of their family blemish by having settled in Tuscany and, indeed, by having been summoned there by its ruler, their New Christian origins continued to haunt them as is evinced in their trial. Though it was not in principle directly

49 Ibid., 242-46.

50 Ibid., 531-41. 
on account of their adherence to Jewish belief but rather on account of blasphemy, nevertheless, throughout the proceedings, the suspicions of their continued allegiance to Judaism was constant. It was an occasion for them to present and evoke members of the Nação in Portugal, Brazil, Pisa, and Rome, to the inquisitorial authorities. Their own Roman ordeal occurred shortly before Bento Teixeira was apprehended in Pernambuco, making Rui Teixeira's subsequent affirmation about his cousin's provocation, which resulted in his imprisonment, all the more ironical. Rui's brush with inquisitorial justice in Rome alongside his son-in-law must have made him appreciate the weight of the travail which would be endured by Bento in Pernambuco and later in Lisbon. Branca de Nis and Beatriz Dias, related to the family by kin or marriage, suffered the attention of the Inquisition in Pisa, Milan, and Venice. None chose to openly practice Judaism, even when such a possibility was available to them under the provisions for this in Venice and Tuscany. Uriel da Costa, in turn, renounced his Christian upringing and joined the ranks of the newly minted Jewish community of Amsterdam where he experienced the brunt of communal Jewish religious discipline, which resulted in his exclusion from it and then his tragic suicide.

The cases of these families demonstrate the complexity of the problems of identity that the members of the Western Sephardic diaspora had to contend with, posed by the Christian society they were part of, and by the newly-formed Jewish communities of Sephardic origin. In the myriad cities and towns from the Mediterranean and beyond that saw the creation of New Christian or New Jewish communities, decisions regarding how members chose to live their religious identity were often dictated by the conditions and contexts in which they found themselves. The members of the family that has been considered here were made to contend with the diverse options of public display of religious adherence in different places over several generations. How they did, provides us with an interesting case study of some of the options of belief and practice engaged in by the men and women of the Nação. Alongside the many who constituted the ranks of the great Jewish communities of Livorno, Venice, Amsterdam, and Hamburg, there were also those who were content, determined, or resigned to live in Christian guise.

\section{Bibliography}

Alves, Luiz Roberto. Confissão, poesia e inquisição. São Paulo: Ática, 1983.

Beraldi Ribeiro, Eneida. "Bento Teixeira e a 'Escola de Satanás.' O Poeta que teve a 'prisão por recreação, a solidão por companhia e a tristeza por prazer." $\mathrm{PhD}$ diss., University of São Paulo, 2006. 
Beraldi Ribeiro, Eneida. "Bento Teixeira: Inquisição e sociedade colonial." WebMosaica 4, no. 1 (2012): 50-56.

Boxer, Charles Ralph. "Jorge d'Albuquerque Coelho: A Luso-Brazilian Hero of the Sea, 1539-1602." Luso-Brazilian Review 6, no. 1 (1969): 3-17.

Buarque de Holanda, Sergio. "Os projetos de colonização e comércio toscanos no Brasil ao tempo do grão duque Fernando (1587-1609)." Revista de História (2000): 95-122.

Bujanda, Jesus Maria de., ed. Index de l'Inquisition portugaise 1547, 1551, 1564, 1581. Sherbrooke: Centre d'Études de la Renaissance, 1995.

Capistrano de Abreu, João, ed. Primeira visitação do santo ofício as partes do Brasil pelo licenciado Heitor Furtado de Mendoça, Confissões da Bahia 1591-1592. São Paulo: Homenagem de Paulo Prado, 1922.

Capistrano de Abreu, João, ed. Primeira visitação do santo ofício as partes do Brasil pelo licenciado Heitor Furtado de Mendoça, Confissões da Bahia 1591-1593. São Paulo: Homenagem de Paulo Prado 1925.

Capistrano de Abreu, João, ed. Primeira visitação do santo ofício as partes do Brasil pelo licenciado Heitor Furtado de Mendoça, Confissões da Bahia 1593-1595. São Paulo: Homenagem de Paulo Prado, 1929.

Cardoso, Alírio. "Um piccolo astaccio al rio dell'amazzoni': Pirataria europeia e projetos italianos na Amazônia na época da monarquia hispânica." Revista de História 170 (2014): 170-99.

Chociay, Rogério. "Bento Teixeira e Camões: o verso no verso." Revista de Letras 31 (1991): 17-32.

Costa, Uriel da. Examination of Pharisaic Traditions Supplemented by Semuel da Silva's Treatise on the Immorality of the Soul. Translation, notes and introduction H.P. Salomon and I.S.D. Sasson. Leiden and Boston: Brill, 1993.

Costa, Uriel da. Die Schriften des Uriel da Costa mit Einleitung, Uebertagung und Regesten. Edited by Carl Gebhardt. Amsterdam: Menno Hertzberger/Heidelberg: Carl Winters Universitätsbuchhandlung/Oxford Universitz Press, 1922.

Costigan, Lúcia Helena. "A experiência do converso letrado Bento Teixeira: Um missing link na história intelectual e literária do Brasil-colônia." Revista de Crítica Literaria Latinoamericana 2040 (1994): 77-92.

Costigan, Lúcia Helena. "Empreendimento e resistência do cristão-novo face à política de Filipe II: O processo inquisitorial de Bento Teixeira." Colonial Latin American Review 12 , no. 1 (2003): 37-61.

Costigan, Lúcia Helena. Through Cracks in the Wall. Modern Inquisitions and New Christian Letrados in the Iberian Atlantic World. Leiden and Boston: Brill, 2010.

Cunha de Azevedo Mea, Elvira. “A Inquisição do Porto." Revista de História 2 (1979): $215^{-27}$.

Cunha de Azevedo Mea, Elvira. "Os cristãos-novos, a Inquisição e o Brasil. Séc. XVI." Revista da Faculdade de Letras do Porto 2, no. 4 (1987) 151-77. 
Faria de Assis, Angelo Adriano. "O licenciado Heitor Furtado de Mendonça, inquisidor da primeira visitação do Tribunal do Santo Ofício ao Brasil." In Anais do XXIII Simpósio Nacional de História. Londrina: ANPUH, 2005 cd-rom.

Feitler, Bruno. Inquisition, juifs et nouveaux-chrétiens au Brésil. Le Nordeste XVII et XVIII ${ }^{\text {ème }}$ siècles. Louvain: Presses Universitaires de Louvain, 2003.

Frattarelli Fischer, Lucia. "Cristiani nuovi e nuovi ebrei in Toscana fra Cinque e Seicento: Legittimazioni e percorsi individuali." In L'identità dissimulata. Giudaizzanti iberici nell'europa dell'età moderna. Edited by Pier Cesare Ioly Zorattini, 217-31. Florence: Olschki, 2000.

Frattarelli Fischer, Lucia. "Ebrei a Pisa fra Cinquecento e Settecento." In Gli ebrei di Pisa (secoli IX-XX). Atti del Convegno internazionale. Pisa, 3-4 ottobre 1994. Pp. 89-115. Pisa: Pacini editore, 1998.

Frattarelli Fischer, Lucia. Vivere fuori dal Ghetto. Ebrei a Pisa e Livorno (secoli XVIXVIII). Turin: Silvio Zamorani Editore, 2008.

Freyre, Gilberto. “Acerca da Prosopopéia." Revista de Pernambuco 1, no. 1 (1927): 2-61.

Goldish, Matt. "Perspectives on Uriel da Costa's 'Example of a Human Life." Studia Rosenthaliana 42-43 (2010-2011): 1-23.

Gonsalves de Mello, José Antônio. "Bento Teixeira, autor da Prosopopéia." In Estudos Pernambucanos. Crítica e problemas de algumas fontes de história de Pernambuco. Pp. 13-52. Recife: Fundarpe, Direitoria de Assuntos Culturais, 1986.

Gonsalves de Mello, José Antônio. "Um tribunal da inquisição em Olinda, Pernambuco (1594-1595)." Revista da Universidade de Coimbra 36 (1991): 369-74.

Gonsalves de Mello, José Antônio. Gente da nação. Recife: Editora Massangana, 1996.

Goncalves Salvador, José. Os cristãos novos. Povoamento e conquista do solo brasileiro (1530-1680). São Paulo: Livraria Pioneira Editora, Editora da Universidade de São Paulo, 1976.

Goncalves Salvador, José. Os cristãos novos e o comércio no Atlântico meridional. São Paulo: Livraria Pioneira Editora, Editora da Universidade de São Paulo, 1978.

Graizbord, David. "Religion and Ethnicity among "Men of the Nation: Towards a Realistic Interpretation." Jewish Social Studies: History, Culture, Society 15, no. 1 (2008): $3^{2-65}$.

Ioly Zorattini, Pier Cesare, ed. Processi del S. Uffizio di Venezia contro ebrei e giusaizzanti (1633-1637). Florence: Olschki, 1992.

Israel, Jonathan I. Diasporas within a Diaspora:Jews, Crypto-Jews and the World Maritime Empires, 1540-1740. Leiden: Brill, 2002.

Kagan, Richard L., and Morgan, eds. Atlantic Diasporas. Jews, Conversos and CryptoJews in the Age of Mercantilism 1500-1800. Baltimore: The Johns Hopkins University Press, 2009.

Kaplan, Yosef. "From Apostasy to Return to Judaism: The Portuguese Jews in Amsterdam." Binah 1 (1989): 99-117. 
Kaplan, Yosef. Judíos nuevos en Amsterdam. Estudios sobre la historia sociale intelectual del judaísmo sefardí en el siglo XVII. Barcelona: Gedisa, 1996.

Marcocci, Giuseppe and Paiva, José Pedro. "Inquisizione di Porto." In Dizionario storico dell'Inquisizione. Vol. 3: 1240-41. Pisa: Edizioni dela Normale, 2010.

Morais Barros, Amândio Jorge. "Barcos e gentes do mar do Porto (séculos XIV-XVI)." Revista da Faculdade de Letras 14 (1997): 167-230.

Mota Menezes, José Luiz. A recriação do paraíso. Judeus e cristão-novoa em Olinda e no Recife nos séculos XVI e XVII. Recife: Companhia Editora de Pernambuco, 2016.

Mott, Luiz. Primeira visitação do santo ofíicio a Bahia (1591). 1-26. EDUFBA, 2010. http:// books.scielo.org/id/yn/pdf/mott-9788523208905-03.

Moura Ribeiro Zeron, Carlos Alberto de and Ziller Camenietzki, Carlos. "Nas sendas de Sérgio Buarque de Holanda. Documentos sobre uma expedição florentina a Amazônia em 1608." Revista de História 142-143 (2000): 123-211.

Nelson Novoa, James. "Negotiating Identity Among the Nação in Early Modern Rome." In Early Modern Ethnic and Religious Communities in Exile. Edited by Yosef Kaplan, 242-76. Newcastle upon Tyne: Cambridge Scholars Publishing, 2017.

Nelson Novoa, James. "The Many Lives of Two Portuguese Conversos: Miguel Fernandes and Rui Teixeira in the Tribunal of the Holy Office in Rome." Hispania Judaica 12 (2016): 127-84.

Piloto, Afonso Luiz. Naufragio, que passou Jorge D'Albuquerque Coelho, capitão e governador de Pernambuco Lisbon: por António Alvarez, vendemse em casa de António Ribeyro livreyro em a Rua Nova, 1601.

Processo da Inquisição de Lisboa, 5206, Arquivo Nacional da Torre do Tombo, Lisbon.

Pulido Serrano, Juan Ignacio. “Plural identities: The Portuguese New Christians," Jewish History 25 (2011): 129-51.

Ravid, Benjamin. "The First Charter of the Jewish Merchants of Venice, 1589." AJs Review 1 (1976): 187-222.

Ravid, Benjamin. "Venice, Rome and the Reversion of New Christians to Judaism: A Study in Ragione di Stato." In L'identità dissimulata. Giudaizzanti iberici nell'europa dell'età moderna. Edited by Pier Cesare Ioly Zorattini, 151-93. Florence: Olschki, 2000.

Révah, Israël Salvator. "La religion d'Urel da Costa, Marrane de Porto (D’après des documents inédits)." Revue de l'histoire des religions 161, no. 1 (1962): 45-76.

Révah, Israël Salvator. Uriel da Costa et les marranes de Porto. Cours au Collège de France 1966-1972. Edited by Carsten L. Wilke. Paris: Fundação Calouste Gulbenkian, 2004.

Rinaldi, Lucinéa. Entre a Prosopopeia e a viagem: Poética e narrativa por letras coloniais. PhD diss., University of São Paulo, 2016.

Ruspio, Francesca. La nazione portoghese. Ebrei ponentini e nuovi cristiani a Venezia. Turin: Silvio Zamorani editore, 2007.

Ruspio, Francesca. “Una comunità di marrani a Venezia.” Zakhor 5 (2001): 53-85. 
San Martino in Kinzica, morti dal 1566 al 1631. Archivio Arcivescovile di Pisa, Pisa.

Souza e Silva, Emanuel Luiz. "Juntos à Forca': A Família Lopes e a Visitação do Santo Oficio à Bahia (1591-1593)." Master's thesis, Universidade Estadual de Feira de Santana, 2010.

Studnicki-Gizbert, Daviken. A Nation upon the Ocean Sea. Portugal's Atlantic Diaspora and the Crisis of the Spanish Empire, 1492-1640. New York: Oxford University Press, 2007.

Teixeira, Bento. Naufrágio que passou Jorge de Albuquerque Coelho vindo do Brasil para este reino do ano de 1565. Edited by Augusto César Pires de Lima. Porto: Livraria Simões Lopes de Domingos Barreira, 1938.

Teixeira, Bento. Prosopopea. Edited by Afrânio Peixoto. Rio de Janeiro: Academia Brasileira, 1923.

Teixeira, Bento. Prosopopea. Edited by Benjamin Franklin Ramiz Galvão. Rio de Janeiro: Tipografia do Imperial Instituto Artístico, 1873.

Trivellato, Francesca. The Familiarity of Strangers: The Sephardic Diaspora, Livorno, and Cross-Cultural Trade in the Early Modern Period. New Haven: Yale University Press, 2009.

Vainfas, Ronaldo, ed. Santo Oficio da Inquisição de Lisboa. Confissões da Bahia, São Paulo: Companhia das Letras, 1997.

Vilar de Carvalho, Gilberto. O primeiro brasileiro. São Paulo: Marco Zero, 1995. 


\title{
Conversos versus Recusants: Shaping the Markers of Difference (1570-1680)
}

\author{
Natalia Muchnik*
}

In 1582, in Naburn, a town near York, England, Elizabeth Coulson, suspected of crypto-Catholicism, was caught hiding her Protestant communion bread, claiming that "a pain in her side and a cough" were preventing her from swallowing it. ${ }^{1}$ A few decades later, in 1619, the conversa Catarina Fernandes was burned alive by a mob in Saint-Jean-de-Luz, France, after she was seen concealing her communion wafer instead of consuming it. The event prompted the town's remaining crypto-Jews to flee. Those efforts to avoid conforming to the dominant religion illustrate the tension between simulation and dissimulation that permeated the lives of English crypto-Catholics (known as Recusants), ${ }^{2}$ following the English religious reformation in the sixteenth century, and those of Spanish crypto-Jews or Marranos, ${ }^{3}$ in this case in exile in

* I wish to thank John Angell and Sebastien Le Pipec for their assistance in translating this article.

1 John Cedric H. Aveling, Catholic Recusancy in the City of York, 1558-1791 (London: Catholic Record Society, 1970), 197. Elizabeth was employed as a maid in the Manor House of the Palmes who remained Catholic.

2 See, inter alia, John Cedric H. Aveling, The Handle and the Axe: The Catholic Recusants in England from Reformation to Emancipation (London: Blond and Briggs, 1976); John Bossy, The English Catholic Community, 1570-1850 (London: Darton, Longman and Todd, 1975); Lisa McClain, Lest We Be Damned. Practical Innovation and Lived Experience among Catholics in Protestant England, 1559-1642 (New York: Routledge, 2004); Michael Mullet, ed., English Catholicism: 1680-1830, 6 vols. (London: Pickering \& Chatto, 2006); Michael Questier, Conversion, Politics, and Religion in England, 1580-1625 (Cambridge: Cambridge University Press, 1996); Peter Lake and Michael Questier, The Antichrist's Lewd Hat. Protestants, Papists and Players in Post-Reformation England (New Haven: Yale University Press, 2002); Alexandra Walsham, Church Papists. Catholicism, Conformity and Confessional Polemic in Early Modern England (London: Boydell \& Brewer, 1999 [1993]).

3 See, inter alia, Julio Caro Baroja, Los judíos en la España moderna y contemporánea, 3 vols. (Madrid: ISTMO, 2000 [1961]); David M. Gitlitz, Secrecy and Deceit. The Religion of the CryptoJews (Albuquerque: University of New Mexico Press, 2002 [1996]); David L. Graizbord, Souls in Dispute: Converso Identities in Iberia and the Jewish Diaspora, 1580-170o (Philadelphia: University of Pennsylvania Press, 2004); Richard L. Kagan and Philip D. Morgan, eds., Atlantic Diasporas: Jews, Conversos, and Crypto-Jews in the Age of Mercantilism, 1500-1800 (Baltimore: The Johns Hopkins University Press, 2008); Charles Meyers and Norman Simms,

(C) NATALIA MUCHNIK, 2019 | DOI:10.1163/9789004392489_004

This is an open access chapter distributed under the terms of the prevailing CC-BY-NC License at the time of publication. 
France. Both groups were subject to harsh repressive measures and forced to worship in secret, but they also displayed a remarkable degree of internal religious and socio-economic diversity.

Indeed, at a time when religion was a significant determiner of social position and socio-cultural practices, these dissident groups possessed an impressively wide array of expressions of belonging. This is particularly true if we cease to focus on the period's celebrated and heroic figures who were doomed to the gallows or the stake because they refused to compromise. Historiography has long concentrated on these cases and neglected such groups as the "Church Papists" who sometimes participated in Anglican practices while proclaiming themselves Catholics. The majority of these religious "deviants" held unstable beliefs and participated in changeable worship practices, but they often remained deeply attached to a sense of community. ${ }^{4}$ They are usually defined by negative attributes as well as positive practices, because dissimulation and simulation tended to blur boundaries, even between ostensibly wellestablished categories. Because dissimulation shaped their social and religious lives, Marranos and crypto-Catholics shared certain features with the secret societies studied by Georg Simmel ${ }^{5}$ in terms of the centrality of private space and family, language codes, and a dialectical relationship with the types of repression that shaped their allegiances. Secret life also transformed roles in religious practices and induced ritual displacements in ways that went beyond mere adaptations to risk or to the lack of normative religious institutions.

As this essay will argue, secrecy helped both these minorities to function as groups despite internal diversity. The elasticity of the groups' religious practices clearly contributed to the emergence of new methods of worship and the creation of new ritual objects. It ultimately appears that Marranos

eds., Troubled Souls: Conversos, Crypto-Jews, and Other Confused Jewish Intellectuals from the Fourteenth through the Eighteenth Century (Hamilton: Outrigger Publishers, 2001); Israël S. Révah, Des marranes à Spinoza (Paris: Vrin, 1995); Nathan Wachtel, La foi du souvenir. Labyrinthes Marranes (Paris: Éditions du Seuil, 2001); Yirmiyahu Yovel, The Other Within. The Marranos. Split Identity and Emerging Modernity (Princeton, NJ: Princeton University Press, 2009).

4 Natalia Muchnik, De paroles et de gestes. Constructions marranes en terre d'Inquisition (Paris: Éditions de l'EHESS, 2014); Michael Questier, "Conformity, Catholicism and the Law," in Conformity and Orthodoxy in the English Church, c. 1560-1660, ed. Peter Lake and Michael Questier (Woodbridge: Boydell, 2000), 237-62, and Alexandra Walsham, "England's Nicodemites: Crypto-Catholicism and Religious Pluralism in the Post-Reformation Context," in The Adventure of Religious Pluralism in Early Modern France, ed. Keith Cameron, Mark Greengrass, and Penny Roberts (Oxford: Peter Lang, 2000), 292-94.

5 Georg Simmel, "The Sociology of Secrecy and of Secret Societies," American Journal of Sociology 11 (1906): 441-98. 
and crypto-Catholics were closely linked to their respective diasporas and that they existed as cohesive groups not only because their members shared religious practices but also because of the diasporic culture of martyrdom. As martyrs for the faith, they were thus fully integrated into the diaspora, despite the negative interpretations of their dissimulation and simulation strategies.

\section{1 \\ Secrecy as a Way of Life}

Despite their similarities, Marranos and Recusants (and Church Papists) have seldom been the object of joint investigation by researchers. Of course, there were important differences between the two groups, especially in terms of their respective socio-political contexts and the intensity of the repression that they experienced. Many Marranos were conversos who had been stigmatized by blood purity statutes that divided the Hispanic society between Old and New Christians from the 1550 on onward. ${ }^{6}$ The Marranos, however, turned the stigmatization of their blood into an asset, as the sign of a sort of ethnic superiority. ${ }^{7}$ But there was no analogous stigmatization or "pride of lineage" among the Recusants, who-with the exception of priests-endured milder forms of repression. Although crypto-Judaism is not a consequence of the Inquisition, as some historiographical accounts have suggested, ${ }^{8}$ repression is, in actuality, both a destructive and a creative force.

6 See, inter alia, Albert Sicroff, Les controverses des statuts de pureté de sang en Espagne (Paris: Didier, 1960); Juan Hernández Franco, "El pecado de los padres: construcción de la identidad conversa en Castilla a partir de los discursos sobre limpieza de sangre," Hispania 64 (2004): 515-42; Ruth Pike, Linajudos and Conversos in Seville. Greed and Prejudice in Sixteenth- and Seventeenth-Century Spain (New York: Peter Lang, 200o); and François Soyer, Popularizing Anti-Semitism in Early Modern Spain and Its Empire. Francisco de Torrejoncillo and the Centinela contra Judios (1674) (Leiden: Brill, 2014).

7 Miriam Bodian, 'Men of the Nation': The Shaping of Converso Identity in Early Modern Europe," Past and Present 143 (1994): 48-76, and "Hebrews of the Portuguese Nation: The Ambiguous Boundaries of Self-Definition," Jewish Social Studies 15, no. 1 (2008): 66-80; David Graizbord, "Religion and Ethnicity Among 'Men of the Nation': Toward a Realistic Interpretation," Jewish Social Studies 15, no. 1 (2008): 32-65; and Natalia Muchnik, "Being Against, Being With: Marrano Self-Identification in Inquisitorial Spain (16th-18th c.). An Essay," Jewish History 25 (2011): 153-74.

8 We will not comment further on the controversies raised by António J. Saraiva's (The Marrano Factory. The Portuguese Inquisition and Its New Christians, 1536-1765 [Leiden: Brill, 2001]) and Benzion Netanyahu's works (The "Marranos" of Spain from the Late XIVth to the Early XVIth Century [New York: American Academy for Jewish Research, 1966] and The Origins of the Inquisition in Fifteenth-Century Spain [New York: Random House, 1995]). 
Because of highly variable ritual practices and group configurations, the sense of religious belonging — or self-definition — was more determined by social and identity-related variations. ${ }^{9}$ Like the Recusants, the Marranos, and to an even greater extent the Church Papists, did not have clearly established group boundaries. Bonds were formed through encounters, but also through reputation and hearsay. It is therefore difficult to establish how many there were, in part because numbers fluctuated according to the intensity of repression. Starting in the 1570s, the arrivals of missionaries from seminary colleges on the Continent helped maintain or even reactivate crypto-Catholicism. Likewise, waves of immigration of Portuguese conversos to Spain from the 1580 os (especially during the Iberian Union) ${ }^{10}$ revived crypto-Judaism, which had worn away in Spain. It is nevertheless important to stress the importance and visibility of crypto-Catholics, who counted in the tens of thousands throughout England, living generally in the countryside ${ }^{11}$ when Spanish Marranos consisted of no more than a handful of families usually concentrated in urban areas.

Moreover, beliefs and practices could also vary in the course of a single individual's life or depending on the social environment. ${ }^{12}$ This was particularly the case among crypto-Jews, especially the "Portuguese," many of whom were traders and were highly mobile, unlike Recusants, who often appear to have been more rooted in their local communities, especially the landed gentry around whom crypto-Catholic circles revolved. Another factor is that the sources containing this kind of information are biased, whether judicial documents, which were double-filtered through interrogations and court recorders' own prejudices and categories, as well as apologetic writings from the two diasporas.

Lucy E.C. Wooding, Rethinking Catholicism in Reformation England (Oxford: Clarendon Press, 2003), 3-6. We will not go over the concept of identity and the problems of its use here; they gave rise to a vast literature. See, inter alia, Rogers Brubaker and Frederick Cooper, "Beyond 'Identity', in Rogers Brubaker, Ethnicity without Groups (Cambridge, MA: Harvard University Press, 2004), 28-63; Craig Calhoun, ed., Social Theory and the Politics of Identity (Oxford: Blackwell, 1994); Carmel Camilleri et al., eds., Stratégies identitaires (Paris: PUF, 1990); Anthony Giddens, Modernity and Self-Identity: Self and Society in the Late Modern Age (Cambridge: Polity Press, 1991).

10 See, inter alia, Rafael Carrasco, "Inquisición y judaizantes portugueses en Toledo (segunda mitad del siglo XVI)," Manuscrits 10 (1992): 41-6o and "Preludio al "Siglo de los portugueses.' La Inquisición de Cuenca y los judaizantes lusitanos en el siglo XVI," Hispania 47 (1987): 503-59.

11 There were about forty thousand Catholics in England at the beginning of the seventeenth century and approximately sixty thousand in 1640 according to Bossy, The English Catholic Community, 191-93 and 422 and Walsham, Church Papists. Catholicism. 
There was a significant mirroring effect produced by the broader society in the identification processes and cohesive elements found in these clandestine communities. Indeed, in both cases, religious minorities were stigmatized because of their so-called lack of loyalty toward the Church and the monarchy; heresy was considered a crime of lèse-majesté. They were often considered to be traitors who were acting on behalf of foreign powers. Conversos were thought to be helping the "rebels" in Portugal or in the Low Countries, where many conversos had relatives. The Recusants, on the other hand, were perceived as being aligned with the Pope and the Spanish monarchy, particularly during armed conflicts such as the Anglo-Spanish War (1585-1604). In the case of cryptoJews, their reputation as outsiders was accentuated by the issue of ethnicity, as well as by the stateless status typically attributed to Jews. For the Recusants, this phenomenon was related to the highly political nature of Anglicanism and to the latent fears crystallized along the alleged "plots" to assassinate the reigning monarch (Gunpowder Plot in 1605, Popish Plot in 1678, etc.). The social environment of the Recusants thus resembled an enclave that was in permanent resistance to State authority and that existed outside the law..$^{13} \mathrm{~A}$ similar pattern was observable among conversos, who were suspected-often accurately — of participating in smuggling, a significant source of loss for the Spanish monarchy's tax revenues. The international circulation of individuals, objects, and ideas emphasized their image of foreignness. They were perceived as being simultaneously similar and different, triggering the vague sensation of "troubling strangeness" described by Freud. ${ }^{14}$

Repression clearly played a critical role in mobilizing hidden religions and in the formation of secret societies. Solidarity, codes, and initiation rituals bound groups together, while conferring a sense of superiority. ${ }^{15}$ Insiders could

13 Julian Yates, "Parasitic Geographies: Manifesting Catholic Identity in Early Modern England," in Catholicism and Anti-Catholicism in Early Modern English Texts, ed. Arthur F. Marotti (Houndsmills: Macmillan Press, 1999), 63-65.

14 Frances E. Dolan asserts that, "by remaining in, or returning to, England, Catholics troubled the very notion of Englishness," in "Gender and the 'Lost' Spaces of Catholicism," The Journal of Interdisciplinary History 32 (2002): 643. See also Alison Shell, Catholicism, Controversy and the English Literary Imagination, 1558-1660 (Cambridge: Cambridge University Press, 1999).

15 Simmel, "The Sociology of Secrecy," 464: "subjective possessions of the most various sorts acquire a decisive accentuation of value through the form of secrecy, in which the substantial significance of the facts concealed often enough falls into a significance entirely subordinate to the fact that others are exclued from knowing them"; 486: "As a consequence of the fact that those who want to distinguish themselves enter into combination, there results an aristocracy which strengthens and, so to speak, expands the self-consciousness of the individuals through the weight of their sum." 
enter the community and become acquainted with group members and, because the collectivity was of a religious nature, they could appear to be both inspired by true faith and among the elect, secure in the knowledge of sharing a Messianic destiny. Both Recusants and Marranos formed a single body in the Pauline sense of the term, as summarized by formulas such as "all are one" (todos son uno) that were often used to describe the inter-dependent relationships among crypto-Jews. ${ }^{16}$

Shared meals also provided significant opportunities to express group solidarity, as described below by the Jesuit Robert Persons in August 1581: "Sometimes when we are sitting at table quite cheerfully [...] if it happens that someone rings at the front door a little more insistently than usual so that he can be put down as an official, immediately [...] all stand to attention, stop eating, and commend themselves to God [...] and if it turns out that there is no danger, after the scare they have had, they become still more cheerful. It can truly be said of them that they carry their lives always in their hands."17 And each in the hands of the other one might add. Here we find the cohesion instituted by a shared fear and the communion over a meal that symbolizes the cosubstance of the participants within the community; "the group is a mouth."18

Inside these secret societies, certain individuals played significant roles. In Spain, this was true of physicians and other professionals who were involved in traveling such as traders, because mobility permitted to maintain networks and spread information. Because of the aura that surrounded doctors due to their medical skills, they possessed a certain authority in the religious lives of crypto-Jews. Their mobility enabled them to operate as the keepers of ceremonies and rituals and, in effect, as proselytizers, thus ultimately contributing to the territorial organization of Marranos communities. Physicians were also able to keep the members of family networks in Spain and throughout the diaspora informed about one another, this being the basis of a Marrano "virtual diaspora" that coexisted with the real diaspora. ${ }^{19}$ Recusant missionaries played similar roles because their mobility and positions within an itinerant

16 Muchnik, De paroles et de gestes, 57-60.

17 Robert Persons's letter to father Alphonsus Agazzari, rector of the English College in Rome, is printed in Letters and Memorials of Father Robert Persons, SJ, vol. I (to 1588), ed. Leo Hicks (London: Catholic Record Society, 1942), 86.

18 Didier Anzieu, Le groupe et l'inconscient: l'imaginaire groupal (Paris: Dunod, 1999 [1975]), 99. See in particular Simmel, "The Sociology of Secrecy," 475: "the fact that the spring of knowledge flowed only from within the society [...] attached the individual member with unique intimacy to the community. It gave him the feeling that if he were detached from this substance, he would lose his own, and would never recover it elsewhere."

Muchnik, De paroles et de gestes, 210-14. 
religious practice ensured a degree of cohesiveness among scattered clandestine communities. The stately homes of the Catholic gentry harbored priests, who became chaplains for their hosts and neighbors. Because they were able to come and go freely, traders were also ideal passeurs who were able to conceal books and other religious items amid their cargoes. They were also effective because their stores, which sometimes distributed religious objects, also functioned as communication nodes for nearby communities. A Fleet Street wholesaler named James Tailor who lived in the Catholic neighborhood of London, for example, housed priests during the late sixteenth century. He also acted as a messenger between the English Catholic elite and the diaspora and helped disseminate books that were published abroad. ${ }^{20} \mathrm{~A}$ similar case was that of Fernando Montesinos, a well-known converso trader who was born in Portugal and served as an asentista (financier-lender) to Philip IV of Spain, and departed for Antwerp in 1656 after undergoing a second trial at the hands of the Inquisition. Montesinos played a key role in the crypto-Jewish community by distributing significant amounts of alms among the poor and helping convey news to and from their relatives in the diaspora. ${ }^{21}$

Geographical mobility and dissimulation in public spaces also highlighted social categories that were frequently marginalized. Because of the secrecy and sanctification of the home, for example, women's visibility was enhanced as they adopted more prominent roles in worship ceremonies, although it would be an over-simplification to argue that there was a clear distinction drawn between a masculine public sphere and private, feminine spaces. ${ }^{22}$ Evidence for the argument that women occupied significant positions in Marrano communities can be found in the many charges of crypto-Judaism brought against women during the sixteenth and the seventeenth centuries. In the case of the Recusants, women martyrs celebrated in the martyrologies published by the Recusant diaspora provide similar evidence. In fact, the legal status endowed to women allowed them to enjoy certain forms of freedom-for

$20 \quad$ McClain, Lest We Be Damned, 169-71.

21 Bernardo J. López Belinchón, Honra, libertad y hacienda (Hombres de negocios y judios sefardíes) (Alcalá de Henares: Universidad de Alcalá, 2001); James C. Boyajian, Portuguese Bankers at the Court of Spain, 1626-1650 (New Brunswick, NJ: Rutgers University Press, 1983), 56; and Markus Schreiber, Marranen in Madrid, 1600-1670 (Stuttgart: Franz Steiner, 1994).

22 See, inter alia, Renée Levine Melammed, Heretics or Daughters of Israel? The Crypto-Jewish Women of Castile (Oxford: Oxford University, 1999), and Natalia Muchnik, "De la ville inquisitoriale à la ville de tolérance: identités féminines judaïsantes en Europe occidentale (XVII ${ }^{\mathrm{e}}$ siècle)," Annales de Bretagne et des pays de l'Ouest 113 (2006): 29-42. 
instance, until 1593, they could not be sentenced to paying fines. ${ }^{23}$ One example is the home of Margaret Clitherow, who was executed in 1586, and whose life and martyrdom were celebrated by her fellow Recusants. A manuscript relating her story, which circulated among Recusants, ${ }^{24}$ reported that she possessed an altar, a chalice, numerous books, and that her home became known as the place to hear mass in York between 1570 and 1580. One of Clitherow's acquaintances named Dorothy Vavasour, a doctor's wife, housed pregnant women and young mothers and helped them to baptize their children. ${ }^{25}$

The singular role played by such women in clandestine practices was reflected in the imaginaries of the two communities, which centered on two important biblical figures, Esther and Mary. On the one hand, Esther, whose name derives from the word seter (secret), was the quintessential cryptoJudaic woman and an emblem of Marrano destiny. She had concealed her Jewish identity, but when she learned that the lives of the Empire's Jews were endangered, she intervened on their behalf. By making a virtue of dissimulating her Jewishness - which was highly criticized by the diaspora - and turning it into an instrument of salvation, Esther legitimized or even transfigured the Marrano experience. It was for this reason that the fast that honors her, a relatively minor festival in normative Judaism, became an important holiday for the crypto-Jews. Similarly, the Recusants represented the figure of Mary as a warrior and the protector par excellence of English Catholics for her actively intervening on their behalf, especially through the rosary. This image of Mary contrasted both with the contemporary vision of docility and humility promoted by Rome and the more contemplative, passive image of Mary that dominated in the Middle Ages. ${ }^{26}$

23 In fact, prior to 1593, married women legally possessed neither property nor money. See Walsham, Church Papists, 78-81; Elizabeth Ferguson, "The Role of Women in the Survival of Catholicism in Post-Reformation Lancashire and Yorkshire, 1559-1603," Master's thesis, Carleton University (Ontario), 2006, 10; Mary Rowlands, "Recusant Women (1560-1608)," in Women in English Society, 1500-180o, ed. Mary Prior (London: Methuen, 1985), 114-15; Roland Connelly, The Women of the Catholic Resistance in England 1540-1680 (Durham: Pentland Press, 1997).

24 Anne Dillon, The Construction of Martyrdom in the English Catholic Community, 1535-1603 (Aldershot: Ashgate, 2002), 277-322, and Peter Lake and Michael Questier, The Trials of Margaret Clitherow. Persecution, Martyrdom and the Politics of Sanctity in Elizabethan England (London: Continuum, 2011).

25 Ferguson, The Role of Women, 53.

26 McClain, Lest Be Damned, 103-12, and Donna Spivey Ellington, From Sacred Body to Angelic Soul. Understanding Mary in Late Medieval and Early Modern Europe (Washington, DC: Catholic University of America Press, 2001), 142-87. 
Like women, the poor also acquired a specific function in the community by begging in the streets and receiving alms from the religious community, an activity that enabled them to spread information within the group. It is not surprising that a certain Darby Bantre, an Irishman arrested in 1639 in Euston, Northeast London, for being in possession of thirty rosaries, five copies of the Office of the Blessed Virgin, and over three pounds in change (quite a significant sum), had disguised himself as a beggar. Whether he was genuinely poor or not, he operated as a supplier of Catholic ritual objects from the Continent. ${ }^{27}$ Among Marranos, fasting was an essential aspect of their religious life, and the poor were paid to fast for other members of the community. Most professional fasters were women, often widows, who ensured collective salvation, in the wake of Esther. In Madrid, those professional fasters were distributed according to the neighborhoods they lived in. In the mid-seventeenth century, Beatriz Rodríguez, the widow of a silversmith, and her daughters Ana, Escolastica, and Isabel, as well as Leonor Gómez, another widow, belonged to the same milieu and frequented the same houses. They were required to fast, for example, for the sake of deceased's souls, so that a sick child may recover and, more generally, on occasion of the main holidays of the Mosaic calendar. That is why, when the converso Manuel Cortizos, asentista of Philip IV, died, Leonor received some reales to fast for the sake of his soul. ${ }^{28}$ Orphan girls were also liable to be professional fasters because they had little dowries or no dowry at all and, therefore, were less likely to get married. By traveling from house to house, these widows acted as vectors of group identity and cohesion by maintaining relationships across the community. At the same time, being paid was thought to dissuade them from denouncing community members to the Inquisition.

Repression and secrecy shaped the basic social organization of the Recusant and Marrano communities, increasing the prominence of certain individuals, either real or spiritual. These forces also directly influenced individual beliefs and practices. But because of the absence of normative institutions, practices were ever flexible, achieving a form of legitimacy through creativity.

One extremely significant difference between the two groups resides in the fact that the Recusants defined themselves as Christians and lived in a Christian environment. Therefore, in comparison to the Marranos, the Recusants had

27 McClain, Lest We Be Damned, 92.

28 Madrid, Archivo Histórico Nacional [AHN], Inquisition Section [INQ], Book 1113. 
considerably more room to maneuver and a wider array of resources that they could either exploit or distort. Nevertheless, the example of the coexistence of Lutherans and Calvinists within the Holy Empire confirmed that similarity paradoxically compelled the two faiths to emphasize their differences. The fact remains that in both cases, adaptation ruled daily life.

The necessity of occasionally participating in official religious activities, the criticisms of the diaspora notwithstanding, entailed a certain amount of compromise and negotiation in terms of social imperatives. In England, for example, heads-of-household and elder sons were often required to be seen conforming to social conventions in public as a way of preserving their property as well as their dignity. For example, a Sussex gentleman named Garret Kempe encouraged his eldest son to conform "and did very often urge and persuade him to go to the protestant churches,"29 while at the same time discouraging his spouse and younger children from participating in ceremonies at the temple. Similarly, the strong preference for a spouse of the same faith and the constraints of clandestine living often tended to dissolve in the face of socio-economic imperatives. Lorenzo Angel and his wife Gracia Rola, for example, were crypto-Jews from Badajoz who raised their children within the faith but who gave their three daughters in marriage to Old Christian hidalgos in exchange of significant dowries and false evidence of pure blood, while preferring on the other hand that their son married a crypto-Jewish woman. The couple and two of their daughters were later tried and convicted by the Holy Office in 1569.30

The absence of a central authority to ensure conformity with religious norms, at least not always in the case of the Recusants, meant that individuals were masters of their own practices in the eyes of the clandestine group. Depending on possibilities, obligations, and the rites that individuals considered important, they adopted traditions that developed over time depending on the possibilities and contacts they had. An individual might adopt ritual objects and practices that were not common in the Jewish or Catholic orthodoxies, but that fitted life in clandestinity, such as food habits among the Marranos. From this perspective, the religiosity of these groups appears highly creative and quite remote from the syncretism or spiritual and ritual impoverishment long attributed to Marrano practices by historiography and interpreted as signs of assimilation. Marranos were clearly aware of the imperfections of their rituals from an orthodox point of view, but they seem to have fully

29 Quoted in Walsham, Church Papists, 78.

$30 \quad$ Jaime Contreras, "Criptojudaísmo en la España moderna. Clientelismo y linaje," Areas 9 (1988): 91 . 
accepted these divergences. In 1619, when Ana Mendez described how she and her family in Monsanto, Portugal, and later in Jativa (near Valencia), celebrated the "great day" [Yom Kippur], she recorded that "everyone had to pray what he knew of the Law of Moses."31 But this flexibility did not exclude adopting a high degree of strictness: Marrano fasts, for example, could be extremely rigorous, and crypto-Jews were scrupulous in thoroughly enacting any slightest ritual gesture.

Adaptation and ritual invention appear to have been encouraged by the diaspora, whose members adopted an understanding attitude while officially remaining critical. At least, this was the case for those who had once been forced to hide or had been led to do so under certain circumstances. Former Marranos converted to Judaism in the diaspora, but who were visiting Spain for business, provided very specific instructions about how to conduct ceremonies with whatever means at one's disposal. In 1648-1649, while staying in Andujar for business, Manuel Díaz Pimentel, a New Jew from Pisa or Livorno, was often questioned about Jewish rituals by the conversos. He gave many specifics on how Judaism was practiced in Italian communities, always trying to adapt his discourse to his audience though, and providing them with the tricks to perform the rituals, especially those concerning food and food preparation, so that the Inquisition's suspicion should not be aroused. Thus, "in Spain, to eat a partridge who has been shot with an arquebus, it has to be roasted and its inside greased with oil because that is how you can compensate the fact that its throat has not been slit." Likewise, on Friday evening, they "had to eat as much good food [as] they could: in Spain, fish, in order to conceal [from the Inquisition]; in Italy, France, Flanders or other places, where one can judaize freely, [one could eat] meat prepared according to the [Jewish] usage and observance." 32

Moreover, English missionaries' instructions clearly took the need for secrecy and the absence of priests into account, particularly from the 1590s onward. The highly popular A Catechisme or A Christian doctrine necessarie for children \& the ignorant people [...] (Louvain, 1568) by Laurence Vaux, a refugee on the Continent, which forbade hiding one's religious affiliation and recommended to attend mass every Sunday and take communion regularly, stood

\footnotetext{
31 "[A]bia cada uno de reçar lo que sabia," in AHN INQ, Legajo 164 (4).

32 "[P]ara comer la perdiz siendo muerta al alcabuzazo en españa ha de ser asada y untada con açeyte por de dentro porque deste modo dijo que se suplia el no estar degollada [...] havian de çenar todo lo que pudiesen de buenas comidas en España de pescado por disimular y en Ytalia o Françia y Flandes y otras partes donde libremente pueden Judayzar carnes dispuestas a su modo y observançia," in AHN INQ, Book 1112, fols. 31r-32V and Muchnik, De paroles et de gestes, 206-7.
} 
remarkably in contrast to A Shorte Rule of Good Life. To direct the devout christian in a regular and orderly course (Douai?, 1595) by the Jesuit missionary Robert Southwell (who was executed in 1595), which explained how to sanctify a house in one's mind, dedicating rooms to certain specific saints. The aim was not to mimic mainstream forms of worship, but to approximate the functions of the Catholic sacraments through content rather than through form. ${ }^{33}$ The teaching offered at seminary colleges encouraged flexibility and pragmatism, for missionaries - how to celebrate mass without the customary sacred utensils, taking confession from occasional reformed members, etc.-and worshippers alike. ${ }^{34}$ William Allen, the founder of the College of Douai, for example, urged English Catholics to join the Society of the Rosary in 1592-popularized by the Jesuits to develop interior devotion - relaxing the requirements for membership while ensuring its members of the indulgence associated with it. ${ }^{35}$

Other publications from the diaspora or printed locally on clandestine presses (in the case of the Recusants) ${ }^{36}$ provided instruments that were fit for secrecy, including the image of a rosary inserted into a prayer book that could replace the object itself. This was the case, for example, in the ... Instructions for the use of the beades, conteining many matters of meditacion or mentall prayer [...] where unto is added a figure or forme of the beades portrued in a Table [...] for the benefite of unlearned [...], which was published by John Bucke in Louvain in 1589 and which indicated the exact times when particular prayers should be recited. ${ }^{37}$ Similarly, the calendars published singly or as annexes to religious books for the Nação, listed the dates for major Jewish festivals and their equivalents in the Christian calendar, documents that were obviously less necessary in Jewish congregations. Nor were calendars uncommon among the English, including the example of a monthly calendar that indicated the Catholic celebrations and the Saint's days and the dates of the "moveable" festivals between 1743 and 1762 . This calendar was included in the sixth edition

33 McClain, Lest We Be Damned, 46-47, and 116, and Southwell, A Short Rule of Good Life, 128-33.

34 Peter Holmes, Resistance and Compromise. The Political Thought of the Elizabethan Catholics (Cambridge: Cambridge University Press, 1982), 117; McClain, Lest We Be Damned, 48; and Walsham, Church Papists, 65-66.

35 McClain, Lest We Be Damned, 98, and Ellington, From Sacred Body, 226-34.

36 Antony Francis Allison and David Morrison Rogers, A Catalogue of Catholic Books in English Printed Abroad or Secretly in England, 1558-1640 (Bognor Regis: Arundel Press, 1956), and Alfred C. Southern, Elizabethan Recusant Prose, 1559-1582. A Historical and Critical Account of the Books of the Catholic Refugees Printed and Published Abroad and at Secret Presses in England together with an Annotated Bibliography of the Same (Glasgow: Sands, 1950).

McClain, Lest We Be Damned, 93-95. 
of the Daily exercise of the devout Christian. Containing several moving practices of piety [...], by Thomas Vincent and Anselm Crowder, which was published in Dublin in 1743. Social networks were the place where such documents circulated both in Spain and in England. Such texts include the well-known Calendario de las fiestas que celebran los Hebreos, published by Juda Machabeu in Amsterdam in 1638; this ritual book's appendix was traced back to Malaga the following year. ${ }^{38}$ Other texts were hand-copied, relatively faithfully in the case of crypto-Catholics because they had access to learned scribes, or in more fragmented and blatantly highly altered ways among Spanish crypto-Jews.

Often small in size and brimming with practical details, these texts were easy to conceal and sometimes obviously designed for secret communities as the well-known post-face to the Orden de las oraciones del mes [...], by Menasseh ben Israel, printed in Amsterdam in 1636 proves: "[...] everything that is obligatory [...] is contained in this book, and so clearly in the notes, that not only those who are accustomed can very easily use them, but also those who are outside of the bosom [gremio], after having consulted it just once and by learning how it is organized."39

This desire for simplicity and clarity recalls the adjustments authorized by English authors like John Radford who explains in the preface to A Directorie Teaching the Way to the Truth in a Briefe and Plaine Discourse against the heresies of this time [...], which was printed clandestinely in 1605 , that he wrote "this little treatise, to inform especially an ignorant, and unlearned man: therefore I have accommodated my self as much as I could, to his understanding, using plain words, and now \& then often [sic] repetition of things that to the learned be not needfull." William Stanney, in A treatise of penance with an explication of the rule, and maner of living [...] of the Third Order of St. Frauncis [...] ordained for those which desire to leade a holy life, and to doe penance in their owne houses (Douai, 1617), also clearly changed Franciscan instructions to fit for the Recusants' situation. ${ }^{40}$ In fact, the diaspora appears to have accepted that the ritual ought to be changed for the sake of secrecy. For example, the

38 AHN INQ, Legajo $163(14)$.

39 "[Q]ue todo lo obligatorio [...] se contiene en este volumen, y con tanta claridad en las notas, que no solamente los que estan acostumbrados, con gran facilidad se podran aprovechar, mas aun los que estan fuera del gremio, haziendo una sola experiencia y conosciendo el orden," in Madrid, Biblioteca Nacional de España [BNE], R. 27290, fol. 548, and Carsten L. Wilke, "Un judaïsme clandestin dans la France du XVII ${ }^{e}$ siècle. Un rite au rythme de l'imprimerie," in Transmission et passages en monde juif, ed. Esther Benbassa (Paris: Publisud, 1997), 296.

$40 \quad$ Quoted in McClain, Lest We Be Damned, 49 . 
emphasis placed on the rosary among Recusants, which led ecclesiastical authorities to prescribe new norms like those included in Bucke's Instructions for the use of the beades.

These books, far from being mere emblems of belonging, acquired a certain degree of sacredness and played a role in the religious lives of the groups, both individually and collectively. A manifestation of this tendency to depend on books was the somewhat "bookish" character of the ritual knowledge and practices among the crypto-Jews of southwestern France. ${ }^{41}$ Among Recusants, the text became, to some extent, an intercessor, a vector of grace, which functioned almost like a virtual priest during services. ${ }^{42}$ Although we ignore how and to what extent such texts were read or what knowledge derived from them, they clearly widely served as objects of worship both in England and in Spain. They were also often endowed with a certain degree of holiness.

\section{3}

\section{New Places/New Objects}

The title of William Stanney's volume (A treatise of penance [...] to doe penance in their owne houses) reveals that secret turned the family home into the locus of the sacred. The Catholic gentry built chapels in their houses, while kitchens became central in Marrano homes because of the importance of their food habits. As Luisa de Carvajal y Mendoza, a Spanish Aristocrat helping the London Recusants in the 1610s, stated: "In the primitive Church the homes of the Christians were their churches and were the parishes of the others; in [Stuart] England, they are those of the Catholics." ${ }^{\text {43 }}$ Clandestine religious practice was therefore organized around domestic hubs and networks-of information, priests, etc.- transforming supposedly private spaces into quasicommunal territory. More than specific locations, however, this phenomenon entailed a process of separation as well as the consecration of new spaces. The separation was as physical as it was ritual or spiritual, using objects of worship, ideas, or words. ${ }^{44}$ In the 1720 in Madrid, for example, the house of Francisco de Córdoba was called the "synagogue" because of the status of Francisco, whose father had been condemned by the Inquisition. Francisco was known as the

41 Carsten L. Wilke ("Un judaïsme clandestin," 288) stresses that they seem to know the biblical names of the feasts but they don't know the corresponding rites.

42 McClain, Lest We Be Damned, 51.

43 "Las casas de los cristianos eran sus Iglesias en la primitiva Iglesia y parroquias de otros; y en Inglaterra, las de los católicos." Luisa de Carvajal y Mendoza, Epistolario y poesías (Madrid: Atlas-Biblioteca de Autores Españoles, 1965), 339 [letter 137].

McClain, Lest We Be Damned, 61. 
"rabbi," and even as the "principal rabbi of Spain" elected by an assembly, which, allegedly, was confirmed in Livorno afterwards. ${ }^{45}$ Accordingly, the functions attributed to Francisco and his aura ensured the sacred character of his home, almost regardless of its actual use as a place of worship. Similarly, Southwell, in A Shorte Rule of Good Life, appealed for the consecration of the home in one's mind, a spiritual exercise also conducted in the vicinity of the house, "in the walkes, gardens and orchardes [...] and so make my walkes as it were shorte pilgrimages to visite such Saints as are patrons of the place I go unto."46

Secret places of worship were not limited to houses, however. Other familiar spaces were constructed by networks of solidarity and religious sociability and nurtured by forms of concentration, both in the close-knit social fabric of the cities and the looser weaving of the social organization in rural areas. Demographic concentration could lead to the privatization of certain public spaces. This spatial appropriation was made possible by both cohabitation and spatial grouping as well as by the trajectories of individuals who circulated within the territory such as missionary priests and women fasters. The Spitalfields neighborhood in London functioned as a Recusant district: families from East Anglia had their London homes there, some of which were built on the sites of the Priory and the Augustine Saint Mary Hospital. There were clandestine chapels, and there were scribes to keep them supplied with religious texts. There were also priests, among them Henry Garnet and Robert Southwell, who installed his clandestine printing presses in the home of the Countess of Arundel. ${ }^{47}$

Although meetings were easier to organize in the countryside, the interstitial spaces of the city ("free places" as Erving Goffman called them ${ }^{48}$ ) also allowed meetings that brought together people from outside the family. These transitional zones included spaces at the edge of the city or vacant plots of land that could sometimes be appropriated for religious purposes or social gatherings. Such spaces allowed closer contact with nature-Marrano rituals, for example, often involved observing the sun or the stars—outside the family

45 AHN INQ, Legajo 157 (11) and BNE Ms. 9304, quoted in Michael Alpert, "The Secret Jews of 18th-Century Madrid," Revue des Études Juives 156 (1997): 153-54, and Rafael de Lera García, "La última gran persecución inquisitorial contra el criptojudaísmo: el tribunal de Cuenca, 1718-1725," Sefarad 47 (1987): 93.

46 Southwell, $A$ Short Rule of Good Life, 131.

47 Nancy Pollard Brown, "Paperchase: The Dissemination of Catholic Texts in Elizabethan England," in English Manuscript Studies, 1100-1700, ed. Peter Beal and Jeremy Griffiths (Oxford: Basil Blackwell, 1989), 1: 122-33.

48 Erving Goffman, Asylums: Essays on the Social Situation of Mental Patients and Other Inmates (New York: Anchor Books, 1961), 230-38. 
circle in order to enter the community's territory. These collective practices were often held in gardens, including one belonging to Pedro Onofre Cortés beyond the walls of Palma de Majorca. Cortés was convicted of crypto-Judaism in 1679 and condemned to be burned at the stake in 1691. Crypto-Jews apparently met regularly in his garden in the 1670 s to share meals or to celebrate major Jewish holidays. That is why, on 16 April 1679, the Inquisition salted the garden soil the very same day of the auto-da-fé when Pedro was reconciled. A column was erected that bore a plaque stating "year 1679. The garden was leveled, plowed, and sown with salt by order of the Holy Inquisition, because the Law of Moses was taught here. May no one ever remove or touch this column on pain of excommunication."49

Some spaces also enjoyed legal privileges that allowed a certain degree of freedom, such as the chapels in certain royal properties, including the chapels belonging to Henriette Marie de France, Charles I's wife, and Catherine de Bragance, Charles II's wife. The London embassies of Catholic countries such as France, Spain, the Kingdom of Sardinia, or the Republic of Venice served as refuge in which Recusants could worship. ${ }^{50}$ The Inns of Court in London were similarly immune to the local jurisdiction and reportedly contained their own chapels. Although there was no known equivalent of such spaces for Marranos, it seems that inns functioned in a similar way, in particular a category of Spanish posadas called secretas (as opposed to públicas) that were not required to register guests, thus permitting a certain level of secrecy and discretion. The small size of these inns and the comings and goings of travelers helped create semi-public locations where people enjoyed a form of invisibility. For example, when he was staying in Medina de Rioseco in November 1649, Vasco Fernández, a converso trader from Andujar, conversed about the Mosaic Law with another Portuguese merchant, Simon Rodríguez de Silva, from Málaga. At the time, they were both sojourning in the mesón de la Cabeza del ozo. Vasco also declared that he observed how Rodríguez de Silva's brother, Manuel, celebrated the Judaic rites on Friday evenings and Saturdays, during the three weeks they were living together in the mesón del Toro, in Andujar, on

49 Archivo General Histórico de Palma de Mallorca, Anales judaicos de Mallorca (1847), quoted in Juan de la Puerta Vizcaíno, La sinagoga balear ó historia de los judios de Mallorca (Valencia: Vicente Civera, 1857), 1: 61, and Angela Selke, Los chuetas y la Inquisición. Vida y muerte en el ghetto de Mallorca (Madrid: Taurus, 1972), 80-81.

5o Dolan, "Gender and the 'Lost' Spaces," 648-51; William Raleigh Trimble, "The Embassy Chapel Question, 1625-166o," The Journal of Modern History 18 (1946): 97-107; and Albert J. Loomie, "London's Spanish Chapel before and after the Civil War," Recusant History 18 (1987): 402-10. 
the occasion of the April 1648 fair. ${ }^{51}$ Such sites functioned as the heterotopias or "other spaces" analyzed by Foucault; "real places" established "within the very foundation of society." 52

The physical body was the holy space par excellence for secret religious communities, probably because it enshrined the most intimate spaces. The consecration of rooms in homes to specific saints, as recommended by Southwell, was extended to the human body, which, through an imaginative leap, "shall represent unto me some vertew or some vice: so that when I see them I may in one remember and practise humility, in an other patience." ${ }^{53}$ The sacred investment of the body was generally interpreted as suggesting a sense of austerity, which was expressed through the Recusants' penances and the Marranos' fasts - whose effectiveness was judged by the degree of physical weakness suffered by those who were fasting. Like the body, certain practices and objects were singled out by clandestine life, such as rosaries and holy water among Recusants, and food and candles for Marranos. But while in such cases, this implied the intensification of their pre-existing sacred dimension, certain other profane objects were consecrated by the process of ritualization itself. Indeed, any element of everyday life could become a potential "source of religious energy," to use Durkheim's words, ${ }^{54}$ that had only to be activated, such as the wicks of the candles that Marranos lighted on Friday evenings. For instance, María González, from Badajoz, declared in 1653 that she had learned that:

These wicks were manufactured when one was fasting, on Friday morning, and the woman who had to make them was seated [...] with the twine upon her skirt, from which she drew seven strands (because it had to be made of twine and not of fabric) for the Friday evening, and for each strand that was to be pulled, she held it in her hand, but without putting it with the others, and the following prayer was said: "Be blessed, Adonay, King of Kings, Lord of Lords [...] who made this wick for the holy night of Saturday at night" [...] and the person who made them asked

\footnotetext{
$5^{1}$ AHN INQ, Book 1112, fols. 5V-7r.

52 Michel Foucault, "Dits et écrits 1984. Des espaces autres. Hétérotopies (Conférence au Cercle d'études architecturales, 14 mars 1967)," Architecture, Mouvement, Continuité 5 (1984): 46-49.

53 Southwell, $A$ Short Rule of Good Life, 134.

54 Emile Durkheim, Les Formes élémentaires de la vie religieuse. Le système totémique en Australie (Paris: PUF, 1968 [1912]), 599.
} 
God whatever she desired. And once the prayer was recited seven times, it was repeated for each of the seven strands that were pulled. ${ }^{55}$

The precision of the movements and the scrupulous respect of their sequence counted as much as the prayers themselves, because it was the multiplication of the gestures that sacralized the items. Conversely, some instruments of worship such as the communion wafer and communion bread of our earlier examples, or pork for the Marranos, served as negative poles that accentuated the sacredness of their positive counterparts.

The power of these items could actually increase by the aura of orthodoxy and the prestige of the diaspora independently of their ritual function. Exiles were well aware of this, including a refugee in Louvain named Thomas Stuckley who sent some crucifixes to England after he had had them blessed by the Pope. It was sufficient for a Recusant to look at one of the crucifixes with devotion to earn fifty days of indulgence. ${ }^{56}$ There is some question as to whether the redemptive power of the indulgences was transferrable by virtue of the contagious nature of sacredness. In fact, any object from the diaspora, such as books, provided the impression of being in proximity to Judaism or Catholicism, and thus to the purity of orthodoxy. Even the tiniest fragment or artifact could become an amulet useful for many ritual purposes. In the 1570s, this was the case of a piece of paper that Diego de San Juan, from Baeza, in Andalusia, received from a soldier in Italy. Each of his six sisters had a copy of the paper, which was described in highly varied ways at the inquisitional tribunal in Córdoba in 1572. One sister asserted that the page held "the names of the Messiah, Emmanuel, and God's other names in Hebrew."57 It is difficult to capture the Hebrew, Greek, and Latin resonances of the words on the page from the phonetic transcription made by the inquisitional notary, but what is most significant is how the San Juan sisters used the sacred document. One

55 “Ásense las dichas torcidas estando en ayunas por la mañana en los viernes y estando sentada la mujer que las ha de hacer [... y teniendo estopa sobre las faldas se saca la dicha estopa siete perpellones della (porque no se ha de hacer de lienzo sino de estopa) para el dicho viernes en la noche y que en cada perpellón que se saca teniéndole en la mano sin juntarle con los demás se dice la oración siguiente: 'Bendito tu Adonaï, Rey de los Reyes [...] que hiciese esta torcida sancta para la noche sancta del santo sabado' [...] y prosigue la persona que la hace y pide a Dios lo que quiere. Y dicha la oracion siete veces se repite en cada uno de los siete perpellones que se saca," in AHN INQ, Book 1117, quoted in Pilar Huerga Criado, En la raya de Portugal. Solidaridad y tensiones en la comunidad judeoconversa (Salamanca: Universidad de Salamanca, 1993), 182-83.

56 McClain, Lest We Be Damned, 37.

57 AHN INQ, Legajo 1856 (11), fol. 14v printed in Rafael Gracia Boix, Autos-da-féy causas de la Inquisición de Córdoba (Córdoba: Diputación Provincial de Córdoba, 1983), 134. 
of them explained that the soldier had instructed her brother that "by bearing this paper with him, he would be protected from his enemies," while she herself, "believing that they were God's names in the Law of Moses, often recited them, and when some of her brothers were ill, pronounced them in order to cure them." 58

This paper served as a talisman whose power was an outgrowth of its content, but also of the fact that it originated in the diaspora. This ensured that the document could serve an infinite variety of purposes and be adapted to the varying practices of the group, like the relics and body parts of people perceived as martyrs and venerated, which all became religious focal points that created a sense of community identity. This was made possible, in turn, by the fact that the culture of martyrdom, like in other religious minorities, filled the imaginaries and practices of Recusants and Marranos alike.

It is no surprise that a sense of martyrdom developed in groups that were subjects of repression over long periods of time..$^{59}$ This included the Marranos, who were profoundly influenced by Catholicism. While the Recusants linked their sufferings with the early Christian martyrs, ${ }^{60}$ including Christ and the Apostles to whom they, as a result, felt closer, the Marranos identified with the Hebrews enslaved by pagans. They conferred an aura of victimhood that was even echoed in anti-Jewish treatises such as the anonymous Verdades catholicas contra ficçiones Judaicas, origen de la Jente de la naçion Hebrea (c. 1637-1639): "People condemned by the Holy Office are assisted by alms, with the oldest designating those who were the most valiant to deny, as are those who carry the insignia of fire and who only confessed at the last moment, they integrate them into their affairs and commissions so that no one needs to beg;

$5^{8} \quad$ "Trayendo aquel papel consigo sería liberado de sus enemigos," while she, "entendiendo que eran nombres de dioses en la ley de Moisés los rezaba muchas veces y cuando habia algunos de sus hermanos enfermos se los decian para que sanasen." AHN INQ, Legajo 1856 (11), fols. $12 \mathrm{r}, 14 \mathrm{r}-\mathrm{v}$ and $16 \mathrm{r}$, printed in ibid., 132, 134, and 136 .

59 There is a vast literature on early modern English martyrdom: Alice Dailey, The English Martyr from Reformation to Revolution (Notre Dame: University of Notre Dame Press, 2012); Thomas S. Freeman and Thomas F. Mayer, eds., Martyrs and Martyrdom in England, c. 1400-1700 (Woodbridge: Boydell Press, 2007); Susannah Monta, Martyrdom and Literature in Early Modern England (Cambridge: Cambridge University Press, 2005).

60 See for instance Persons's Letter to Agazzari, printed in Hicks, ed., Letters and Memorials, 86: "The Catholics in various parts of their houses have a number of secret places (as we read was the custom in the primitive church)." 
because neither begging, nor the sambenitos are offenses in their eyes; furthermore, those who have a sambenito are held in the greatest esteem and they want them to be husbands to their daughters." ${ }^{\prime 61}$

The singularity of this culture of martyrdom, beyond the fact that it defined their imaginaries and how they constructed their sense of identity, stems from the fact that it formed the core of their relationship to the diaspora. Indeed, it built a shared culture and a collective memory that connected them to the Homeland, the front line of the Faith, and to the scattered members of the diaspora in order to shape an "imagined community." This justified the circulation of missionaries, texts, and ritual objects, despite the criticisms of their practices of simulation and dissimulation. The captivity of the Recusants and the Marranos, who experienced oppression and lived in clandestinity, is interpreted in Messianic terms, with their suffering bearing witness to the Election of the new Israel and to the oncoming end of time. These martyrs are portrayed in frescoes by Circignani, also known as Pomarancio, that were distributed via engravings from 1584 onward, and that covered the walls of the church of the English College in Rome. The frescoes were particularly striking because of their realistic depictions of suffering. In the center of the Church stood the "painting of the martyrs," painted by Durante Alberti in 1581 when the seminary was founded. This painting represents the Trinity, with the blood of Christ flowing over a map of Great Britain, surrounded by the earliest martyrs-Saint Thomas of Canterbury and Saint Edmund. The frescoes imbued seminary students with the spirit of sacrifice and the "purity of martyrdom." 62

Further support for this culture of martyrdom was contained in the martyrologies written and usually published by diaspora communities that celebrated the victims of the repression in Spain and in England. ${ }^{63}$ In the Nação, there was the Romance al divin Mártir Juda Creyente, martirizado en Valladolid, which was written in memory of Lope de Vera, the archetypal Marrano martyr, around 1648 in Amsterdam by Antonio Enríquez Gómez, who later died in the prisons of the Inquisition in Seville in $1663 .{ }^{64}$ Another Marrano martyr narrative was the Contra la Verdad no hay Fuerça. Panegírico a los tres

61 BNE, Ms. 18756 , fol. 6 r.

62 Dillon, The Construction of Martyrdom, 172-227; Carol M. Richardson, "Durante Alberti, the Martyrs' Picture and the Venerable English College, Rome," Papers of the British School at Rome 73 (2005): 223-63; and Anthony Kenny, "From Hospice to College," in The English Hospice in Rome, ed. John Allen (Leominster: Gracewing, 2005 [1962]), 218-73.

63 See Miriam Bodian, Dying in the Law of Moses. Crypto-Jewish Martyrdom in the Iberian World (Bloomington: Indiana University Press, 2007).

64 Israël S. Révah, Antonio Enríquez Gómez. Un écrivain marrane (v. 16oo-1663), ed. Carsten L. Wilke (Paris: Chandeigne, 2003). 
bienaventurados mártires Abraham Athias, Yahacob Rodrigues Caseres et Raquel Nuñez Fernandez que fueron quemados vivos en Cordova por santificar la unidad divina (1665), written by Miguel (alias Dani Levi) de Barrios, the well-known Amsterdam writer exiled from Andalusia. In this text, he celebrated the "sacrifice" of the seventy-five-year-old Jorge Méndez de Castro, father of the Amsterdam printer Josef Athias, of Domingo Rodríguez de Cáceres, a trader from Plasencia, and of Leonor María (Núñez) Enríquez, a young woman from Utrera, whose agony had touched the audience of the auto-da-fé.

The martyrologies were far more numerous among Catholics and were sometimes illustrated. They were usually published in the form of annual calendars of religious celebrations and were originally written in English or Latin - and sometimes in Spanish-but were quickly translated. Two such titles included A Brief History of the Glorious Martyrdom of XII Reverend Priests [...], executed within these twelve monthes for confession and defence of the catholike faith [...], written by Cardinal William Allen (who founded the first missionary-college in Douai in 1568) in Rheims in 1582, and A catalogue of martyrs in England: for profession of the Catholique faith, since the yeare of our Lord, 1535 [...], composed in Douai in 1608 by Thomas Worthington, the head of the College of Douai. In addition to published examples, a far greater number of handwritten texts were undoubtedly created locally, particularly among Recusants. These texts contained narratives that were often filled with supernatural elements that presented martyrdom as a gift from God and a high privilege. Such stories could be read aloud and commented upon, which rendered them highly accessible and ensured their role as important vectors of the group cohesion. ${ }^{65}$

Under these circumstances, it is understandable that relics such as human remains or objects that had belonged to martyrs took on great value in Recusant, Marrano, and diasporic communities. Such artifacts represented the group memory by making the sacrifices of the martyrs actual and immediate, legitimating their resistance and ensuring the group's survival. These relics were even included in ceremonies given their power of intercession, which was supported by accounts of miracles that grew richer in details as they were repeated. ${ }^{66}$ Executions of missionary priests thus supplied Recusants with an inexhaustible supply of relics that were precious both for their simultaneity in time and place and connotations of shared experience. Written accounts

65 Dillon, The Construction of Martyrdom, 99-101 and 375-97.

66 See, inter alia, Alexandra Walsham, ed., Relics and Remains, Past \& Present, 206, suppl. 5 (Oxford, 2010), and Pierre-Antoine Fabre, Philippe Boutry and Dominique Julia, eds., Corps saints, lieux sacrés. Le culte des reliques à l'époque moderne (Paris: Éditions de l'EHESS, 2009). 
describing the details of the auto-da-fés in Spain, as well as the ashes scooped from the stakes, spread throughout the Nação in similar way. One witness told the Inquisition that "when the Holy Office celebrated the great auto-da-fé [in Madrid in July 1632] four or five years ago, [he] learned that a box containing the ashes of those who were burned had been sent as relics [por reliqueas] to the Jewish community in Amsterdam." Another witness, Manuel Fernandez, explained that the ashes were sent to Rouen "and to other places." ${ }^{77}$ We nevertheless ignore if other remains such as hair and clothes were also collected in Spain, as it was the case in England.

Executions obviously provided the opportunity for the condemned to be heroic, to the great discontent of the authorities responsible for repressing them, naturally. But their communities "glorified" their death and wrote to disseminate their stories, particularly when they included miraculous events. This accounts for the circulation of the last words of Edmund Campion in 1582, which were duly recorded and quickly printed in London. Execution sites and the ceremonies surrounding them were elaborately staged by the authorities, adding to a sense of group cohesion and religious identity. Such events, especially in the English case, provided opportunities for groups to express their faith more openly than customary, thanks to the protection offered by the crowd, forming a quasi-mystical circle. Indeed, the execution sites were special community spaces that extended to the city via the procession of the condemned through the streets. For crypto-Catholics, these processions that celebrated martyrs could also be seen as the stations of the cross. Dozens of Catholics followed the condemned, ritualizing their connection to the martyrs, praying for and with them and touching them to profit from their power for divine intercession, receiving blessings or removing pieces of clothing to be turned into relics. ${ }^{68} \mathrm{John}$ Cecil stated to Robert Persons, in 1594, that "three hundred ladies and women of good position [...] all with black hoods" followed John Boste to the gallows in Durham, "as the Marys did for Christ" they said (a probable reference to Mary and Mary-Magdalene). ${ }^{69}$ Beyond this kind of learning-by-example, these executions supplied elements that were integrated into worship ceremonies, whether through readings from the Inquisition's edictos de fé, accusations or sermons that the English priests gave from the gallows. When Thomas Bullaker preached in October 1642, one witness reported that his sermon "penetrated

67 AHN INQ, Book 1102, fols. 2v-3r and $4 \mathrm{v}$.

68 McClain, Lest We Be Damned, 76-82, 84, 157-59, 161, 163-67 and "Without Church, Cathedral, or Shrine: The Search for Religious Space among Catholics of England, 15591625," The Sixteenth Century Journal 33 (2002): 392-97.

69 Printed in John H. Pollen, Unpublished Documents relating to the English Martyrs (London: Catholic Record Society, 1908), 1: 285-86. 
many a heart, and greatly affected even the hardened heretics. ${ }^{70}$ The actual execution sites could also be perceived as sacred, generating pilgrimages, as the Recusants did with Tyburn in London. ${ }^{71}$

\section{5}

\section{Conclusion}

In the introduction to this essay, Catarina Fernandes was reported to have hidden her communion wafer, and Elizabeth Coulson her communion bread. These acts meant not only a rejection of the Catholic conception of incarnation, but they also reflected shared religious practices. The many similarities between Recusants and Marranos that this comparison has brought to light clearly demonstrate that these two secret communities functioned in similar ways. Their rituals were flexible and marked by a close attention to gestures as well as the diversity of sources of what they considered sacred. New practices and objects that were crucial for maintaining the group's cohesion could be validated by diasporic belief systems. Nevertheless, rituals coexisted with the emphasis placed on interiority and intentionality that permitted a form of individual creativity that spread throughout the diaspora. This included the spiritualization of consecration, symbolized by the process described by Robert Southwell intended for English Catholics, as well as the quasi-ethnic interpretation of Judaism among the Marranos, which suggests a sense of belonging that goes beyond ritual. Besides, this back-and-forth movement between new religious needs and secret practices, and their validation by the normative authorities in exile, produced a constant creative process. Therefore, despite the criticisms that simulation and dissimulation prompted, these secret communities functioned as significant vectors of change in how their entire religious groups practiced their faiths. It is evident that these communities were as diverse and changeable as their rituals. But this diversity and adaptability leads to draw a difference between what it means to belong to a community defined by faith and actual religious practices. It also suggests the need for a more social understanding of religious communities.

70 Quoted in Timothy J. McCann, "Some Unpublished Accounts of the Martyrdom of Blessed Thomas Bullaker, OSF, of Chichester in 1642," Recusant History 19 (1988): 174 and 179. 


\section{Bibliography}

Allison, Antony Francis, and David Morrison Rogers. A Catalogue of Catholic Books in English Printed Abroad or Secretly in England, 1558-1640. Bognor Regis: Arundel Press, 1956.

Alpert, Michael. "The Secret Jews of 18th-Century Madrid." Revue des Études Juives 156 (1997): 135-171.

Anzieu, Didier. Le groupe et l'inconscient: l'imaginaire groupal. Paris: Dunod, 1999 [1975].

Aveling, John Cedric H. Catholic Recusancy in the City of York, 1558-1791. London: Catholic Record Society, 1970.

Aveling, John Cedric H. The Handle and the Axe: The Catholic Recusants in England from Reformation to Emancipation. London: Blond and Briggs, 1976.

Bodian, Miriam. Dying in the Law of Moses. Crypto-Jewish Martyrdom in the Iberian World. Bloomington: Indiana University Press, 2007.

Bodian, Miriam. "Hebrews of the Portuguese Nation: The Ambiguous Boundaries of Self-Definition.” Jewish Social Studies 15, no. 1 (2008): 6f6-80.

Bodian, Miriam. “Men of the Nation': The Shaping of Converso Identity in Early Modern Europe." Past and Present 143 (1994): 48-76.

Bossy, John. The English Catholic Community, 1570-1850. London: Darton, Longman \& Todd, 1975 .

Boyajian, James C. Portuguese Bankers at the Court of Spain, 1626-1650. New Brunswick, NJ: Rutgers University Press, 1983.

Brubaker, Rogers, and Frederick Cooper. "Beyond 'Identity'. In Ethnicity without Groups. Edited by Rogers Brubaker, 28-63. Cambridge, MA: Harvard University Press, 2004.

Caro Baroja, Julio. Los judios en la España moderna y contemporanea. 3 vols. Madrid, ISTMO, 2000 [1961].

Carrasco, Rafael. "Inquisición y judaizantes portugueses en Toledo (segunda mitad del siglo XVI)." Manuscrits 10 (1992): 41-60.

Carrasco, Rafael. "Preludio al 'Siglo de los portugueses.' La Inquisición de Cuenca y los judaizantes lusitanos en el siglo XVI." Hispania 47 (1987): 503-59.

Contreras, Jaime. “Criptojudaísmo en la España moderna. Clientelismo y linaje." Areas 9 (1988): 77-100.

Dillon, Anne. The Construction of Martyrdom in the English Catholic Community, 15351603. Aldershot: Ashgate, 2002.

Dolan, Frances E. "Gender and the 'Lost' Spaces of Catholicism." The Journal of Interdisciplinary History 32 (2002): 641-65.

Durkheim, Emile. Les Formes élémentaires de la vie religieuse. Le système totémique en Australie. Paris: PUF, 1968 [1912]. 
Fabre, Pierre-Antoine, Philippe Boutry, and Dominique Julia, eds. Corps saints, lieux sacrés. Le culte des reliques à l'époque moderne. Paris: Éditions de l'EHESS, 2009.

Ferguson, Elizabeth. "The Role of Women in the Survival of Catholicism in Post-Reformation Lancashire and Yorkshire, 1559-1603." Master's thesis, Carleton University, Ontario, 2006.

Foucault, Michel. "Dits et écrits 1984. Des espaces autres. Hétérotopies (Conférence au Cercle d'études architecturales, 14 mars 1967)." Architecture, Mouvement, Continuité 5 (1984): 46-49.

Gitlitz, David M. Secrecy and Deceit. The Religion of the Crypto-Jews. Albuquerque: University of New Mexico Press, 2002 [1996].

Goffman, Erving. Asylums: Essays on the Social Situation of Mental Patients and Other Inmates. New York: Anchor Books, 1961.

Gracia Boix, Rafael. Autos-da-fé y causas de la Inquisición de Córdoba. Córdoba: Diputación Provincial de Córdoba, 1983.

Graizbord, David L. "Religion and Ethnicity Among 'Men of the Nation': Toward a Realistic Interpretation." Jewish Social Studies 15, no. 1 (2008): 32-65.

Graizbord, David L. Souls in Dispute: Converso Identities in Iberia and the Jewish Diaspora, 1580-1700. Philadelphia: University of Pennsylvania Press, 2004.

Hernández Franco, Juan. "El pecado de los padres: construcción de la identidad conversa en Castilla a partir de los discursos sobre limpieza de sangre." Hispania, 64 (2004): 515-42.

Hicks, Leo, ed. Letters and Memorials of Father Robert Persons, SJ. Vol. 1 (to 1588). London: Catholic Record Society, 1942.

Holmes, Peter. Resistance and Compromise. The Political Thought of the Elizabethan Catholics. Cambridge: Cambridge University Press, 1982.

Huerga Criado, Pilar. En la raya de Portugal. Solidaridad y tensiones en la comunidad judeoconversa. Salamanca: Universidad de Salamanca, 1993.

Kagan, Richard L and Philip D. Morgan, eds. Atlantic Diasporas: Jews, Conversos, and Crypto-Jews in the Age of Mercantilism, 1500-180o. Baltimore: The Johns Hopkins University Press, 2008.

Kenny, Anthony. "From Hospice to College." In The English Hospice in Rome. Edited by John Allen, 218-73. Leominster: Gracewing, 2005 [1962].

Lake, Peter, and Michael Questier. The Antichrist's Lewd Hat. Protestants, Papists \& Players in Post-Reformation England. New Haven: Yale University Press, 2002.

Lake, Peter, and Michael Questier. The Trials of Margaret Clitherow. Persecution, Martyrdom and the Politics of Sanctity in Elizabethan England. London-New York, Continuum, 2011.

Lera García, Rafael de. "La última gran persecución inquisitorial contra el criptojudaísmo: el tribunal de Cuenca, 1718-1725." Sefarad 47 (1987): 87-137. 
Levine Melammed, Renée. Heretics or Daughters of Israel? The Crypto-Jewish Women of Castile. Oxford: Oxford University, 1999.

Loomie, Albert J. "London's Spanish Chapel before and after the Civil War." Recusant History 18 (1987): 402-10.

López Belinchón, Bernardo J. Honra, libertad y hacienda (Hombres de negocios y judíos sefardies). Alcalá de Henares: Universidad de Alcalá, 2001.

McCann, Timothy J. "Some Unpublished Accounts of the Martyrdom of Blessed Thomas Bullaker, OSF, of Chichester in 1642." Recusant History 19 (1988): 171-82.

McClain, Lisa. Lest We Be Damned. Practical Innovation and Lived Experience among Catholics in Protestant England, 1559-1642. New York-London: Routledge, 2004.

McClain, Lisa. "Without Church, Cathedral, or Shrine: The Search for Religious Space among Catholics of England, 1559-1625." The Sixteenth Century Journal 33 (2002): 392-97.

Meyers, Charles, and Norman Simms, eds. Troubled Souls: Conversos, Crypto-Jews, and Other Confused Jewish Intellectuals from the Fourteenth through the Eighteenth Century. Hamilton: Outrigger Publishers, 2001.

Muchnik, Natalia. "Being Against, Being With: Marrano Self-Identification in Inquisitorial Spain (16th-18th c.). An Essay." Jewish History 25 (2011): 153-74.

Muchnik, Natalia. "De la ville inquisitoriale à la ville de tolérance: identités féminines judaïsantes en Europe occidentale (XVII ${ }^{\mathrm{e}}$ siècle)." Annales de Bretagne et des pays de l'Ouest 113 (2006): 29-42.

Muchnik, Natalia. De paroles et de gestes. Constructions marranes en terre d'Inquisition. Paris: Éditions de l'EHESS, 2014.

Mullet, Michael, ed. English Catholicism:1680-1830. 6 vols. London: Pickering \& Chatto, 2006.

Netanyahu, Benzion. The "Marranos" of Spain from the Late XIVth to the Early XVIth Century. New York: American Academy for Jewish Research, 1966.

Netanyahu, Benzion. The Origins of the Inquisition in Fifteenth-Century Spain. New York: Random House, 1995 .

Pike, Ruth. Linajudos and Conversos in Seville. Greed and Prejudice in Sixteenth-and Seventeenth-Century Spain. New York: Peter Lang, 2000.

Pollard Brown, Nancy. "Paperchase: The Dissemination of Catholic Texts in Elizabethan England." In English Manuscript Studies, 1100-1700. Edited by Peter Beal and Jeremy Griffiths, 1: 122-33. Oxford: Basil Blackwell, 1989.

Pollen, John H. Unpublished Documents Relating to the English Martyrs. London: Catholic Record Society, 1908.

Puerta Vizcaíno, Juan de la. La sinagoga balear ó historia de los judíos de Mallorca. Valencia: Vicente Civera, 1857.

Questier, Michael. "Conformity, Catholicism and the Law." In Conformity and Orthodoxy in the English Church, c. 1560-166o. Edited by Peter Lake and Michael Questier, 237-62. Woodbridge: Boydell, 2000. 
Questier, Michael. Conversion, Politics, and Religion in England, 1580-1625. Cambridge: Cambridge University Press, 1996.

Raleigh Trimble, William. “The Embassy Chapel Question, 1625-166o." The Journal of Modern History 18 (1946): 97-107.

Révah, Israël S. Antonio Enríquez Gómez. Un écrivain marrane (v. 160o-1663). Edited by Carsten L. Wilke. Paris: Chandeigne, 2003.

Révah, Israël S. Des marranes à Spinoza. Paris: Vrin, 1995.

Richardson, Carol M. "Durante Alberti, the Martyrs' Picture and the Venerable English College, Rome." Papers of the British School at Rome 73 (2005): 223-63.

Rowlands, Mary. "Recusant Women (1560-1608)." In Women in English Society, 1500180o. Edited by Mary Prior, 114-15. London: Methuen, 1985 .

Saraiva, António J. The Marrano Factory. The Portuguese Inquisition and Its New Christians, 1536-1765. Leiden: Brill, 2001.

Schreiber, Markus Marranen in Madrid, 16oo-167o. Stuttgart: Franz Steiner, 1994.

Selke, Angela. Los chuetas y la Inquisición. Vida y muerte en el ghetto de Mallorca. Madrid: Taurus, 1972.

Shell, Alison. Catholicism, Controversy and the English Literary Imagination, 1558-1660. Cambridge: Cambridge University Press, 1999.

Sicroff, Albert. Les controverses des statuts de pureté de sang en Espagne. Paris: Didier, 1960.

Simmel, Georg. "The Sociology of Secrecy and of Secret Societies." American Journal of Sociology 11 (1906): 441-98.

Southern, Alfred C. Elizabethan Recusant Prose, 1559-1582. A Historical and Critical Account of the Books of the Catholic Refugees Printed and Published Abroad and at Secret Presses in England together with an Annotated Bibliography of the Same. Glasgow-London: Sands, 1950.

Southwell, Robert. A Shorte Rule of Good Life. To direct the devout Christian in a regular and orderly course. Douai?, 1595.

Soyer, François. Popularizing Anti-Semitism in Early Modern Spain and Its Empire. Francisco de Torrejoncillo and the Centinela contra Judios (1674). Leiden: Brill, 2014.

Spivey Ellington, Donna. From Sacred Body to Angelic Soul. Understanding Mary in Late Medieval and Early Modern Europe. Washington, DC: Catholic University of America Press, 2001.

Wachtel, Nathan. La foi du souvenir. Labyrinthes Marranes. Paris: Éditions du Seuil, 2001.

Walsham, Alexandra. Church Papists. Catholicism, Conformity and Confessional Polemic in Early Modern England. London: Boydell \& Brewer, 1999 [1993].

Walsham, Alexandra. "England's Nicodemites: Crypto-Catholicism and Religious Pluralism in the Post-Reformation Context." In The Adventure of Religious Pluralism in Early Modern France. Edited by Keith Cameron, Mark Greengrass, and Penny Roberts, 292-94. Oxford: Peter Lang, 2000. 
Walsham, Alexandra, ed. Relics and Remains, Past \& Present, 206, suppl. 5 (Oxford, 2010).

Wilke, Carsten L. "Un judaïsme clandestin dans la France du XVII ${ }^{\mathrm{e}}$ siècle. Un rite au rythme de l'imprimerie." In Transmission et passages en monde juif. Edited by Ester Benbassa, 281-311. Paris: Publisud, 1997.

Wooding, Lucy E.C. Rethinking Catholicism in Reformation England. Oxford: Clarendon Press, 2003.

Yates, Julian. "Parasitic Geographies: Manifesting Catholic Identity in Early Modern England." In Catholicism and Anti-Catholicism in Early Modern English Texts. Edited by Arthur F. Marotti, 63-65. Houndsmills: Macmillan Press, 1999.

Yovel, Yirmiyahu. The Other Within. The Marranos: Split Identity and Emerging Modernity. Princeton, NJ: Princeton University Press, 2009. 


\title{
Richelieu in Marrano Garb: Conversos as Agents of the French Confessional Model, c. 1640
}

\author{
Claude B. Stuczynski
}

\section{1 French Confessional Experience through Converso Lenses}

During a visit to his native city of Bragança in northeastern Portugal, the converso Baltazar Fernandes informed his friends and relatives that: "In France there is no Inquisition, and men live according to the Law as they wish, because there is no justice which constrains them; and it will be a good thing if everybody will go there."1 Fernandes was right. Ever since the Inquisition of Coimbra began to systematically investigate the religious behavior of Bragança's New Christian population, particularly after 1585 , local conversos had lived with a growing sense of besiegement and suffocation. This led many of them, including Fernandes, to leave the city for safer places such as France, even if Judaism had been officially forbidden there since the medieval expulsions of the Jews. ${ }^{2}$ In fact, from the sixteenth century onward, France was a major spot for converso immigration, whether as a temporary sojourn or as a final destination. During the seventeenth century, it was one of the most attractive Sephardic diasporas for New Christian Judaizers, skeptics, and even for converso committed Catholics. ${ }^{3}$ On the one hand, the geographical contiguity of France to Spain

1 "Baltesar Frz. q avia pouco que viera de França lhes dise a todos como em França não avia Inquisiçam e os homes viviam na lei que queriam p q não avia justiça que os constragese e qo bom era irem se pera laa todos." Arquivos Nacionais/Torre do Tombo, Inquisição de Coimbra, processo n. 9269 , fols. $4 \mathrm{v}-5$ r.

2 William Chester Jordan, The French Monarchy and the Jews: From Philip Augustus to the Last Capetians (Philadelphia: Pennsylvania University Press, 1989), 214; Béatrice Leroy, ed., Les édits d'expulsion des juifs; 1394, 1492, 1496, 1501 (Biarritz: Atlantica, 1998); Gilbert Dahan and Élie Nicolas, eds., L'expulsion des Juifs de France, 1394 (Paris: Cerf, 2004); Céline Balasse, 1306. L'expulsion des juifs du royaume de France (Brussels: de Boeck, 2008).

3 Gérard Nahon, "The Sephardim of France," in The Sephardi Heritage; Essays on the History and Cultural Contribution of the Jews of Spain and Portugal, ed. R.D. Barnett and W.M. Schwab (Grendon, Northamptonshire: Gibraltar Books, 1989), 2: 46-74; idem, "From New Christians to the Portuguese Jewish Nation in France," in Moreshet Sepharad; The Sephardi Legacy, ed. Haim Beinart, 2 vols. (Jerusalem: Magnes Press and The Hebrew University, 1992), 2: 336-64; Anne Zink, "Une niche juridique: l'installation des Juifs à Saint-Esprit-lès-Bayonne au XVII

(C) CLAUDE B. STUCZYNSKI, 2019 | DOI:10.1163/9789004392489_005

This is an open access chapter distributed under the terms of the prevailing CC-BY-NC License at the time of publication. 
and Portugal, as well as its strategic position between southern and northern Europe bordering the Atlantic, offered unique economic and networking advantages for converso merchants, smugglers, entrepreneurs, and other travelers and adventurers. ${ }^{4}$ Especially in the seventeenth century, when it emerged as a contesting power to hegemonic Habsburg Spain, France became an appealing pole of attraction. Nonetheless, for mostly economic-mercantile reasons, from $155^{\circ}$ on, Portuguese New Christians were legally permitted to live in southwestern France as a group of merchants protected by the Crown. ${ }^{5}$ No wonder if during an inquisitorial interrogation, another late sixteenth-century Bragança converso, Martim Rodrigues, nicknamed "o Ciabrés," confessed that when he was living with his family in Saint-Jean-de-Luz: "they praised God for dwelling in a land where they could live freely according to the Law of Moses, without fearing the thieves of the Portuguese Inquisitions." ${ }^{\text {F }}$ From other inquisitorial files and historical sources, we learn that in these geographical spaces, New Christian Judaizers could practice at ease their "Marrano" traditions without being molested by any local Inquisition, as in their motherland. ${ }^{7}$ This enabled some of them, like Francisco Mendes, to meet for the first time: "a Jewish rabbi who came there to convert and teach them the belief of the Law of Moses."

siècle," Annales - Histoire, Sciences Sociales 49 (1994): 639-69; idem, "Bayonne arrivées et départs au XVII e siècle," in 1492, L'expulsion des Juifs d'Espagne, ed. Roland Goetschel (Paris: Maisonneuve et Larose, 1996), 37-47.

4 Nicolás Broens, Monarquía y capital mercantil: Felipe IV y las redes comerciales portuguesas (1627-1635) (Madrid: Ediciones de la Universidad Autónoma de Madrid, 1989); Bernardo J. López Belinchón, "'Sacar la sustancia al reino,' Comercio, contrabando y conversos portugueses, 1621-1640," Hispania 61 (2001): 1017-50.

5 Gérard Nahon, Les 'nations'Juives portugaises du sud-ouest de la France (1684-1791). Documents (Paris: Fundação Calouste Gulbenkian-Centro Cultural Português, 1981), 21-27. Cf. Brigitte Bedos-Rezak, "Tolérance et raison d'État: le problème Juif," in L'Etat baroque. Textes réunis sous la direction d'Henry Méchoulan, étude préliminaire d'Emmanuel Le Roy Ladurie, préface de André Robinet (Paris: Librairie philosophique J. Vrin, 1985), 243-87.

6 “[...] [D]arem graças a Deos de se verem em terra onde livremte. podiam viver na sua lei de Moises sem temor dos ladrões das Inquisições de Portugal." Arquivos Nacionais/Torre do Tombo, Inquisição de Coimbra, processo n. 6602, fols. 8r-v.

7 Claude B. Stuczynski, A "Marrano Religion"? The Religious Behavior of the New Christians of Bragança Convicted by the Coimbra Inquisition in the Sixteenth Century (1541-1605), 2 vols. (Ramat-Gan: Bar-Ilan University, 2005), chap. 5; Gérard Nahon, "Le modèle français du marranisme: perspectives nouvelles," in Inquisição; ensaios sobre mentalidade, heresias e arte, ed. Anita Novinsky and Maria Luiza Tucci Carneiro (Rio de Janeiro: Expressão e Cultura, 1992), 227-65; idem, "D'un singulier désir à la Loi du Dieu d'Israël: les nouveaux-chrétiens portugais en France XVI ${ }^{\mathrm{e}}-\mathrm{XVIII} \mathrm{e}^{\mathrm{e}}$ siècles," Arquivos do Centro Cultural Calouste Gulbenkian 48 (2004): $73^{-102 .}$

8 "[...] q quando for a acompanhar a seu pai e a sua madrasta que fugiram pera França estando todos iaa no ditto Reino de França viera a ter com eles hum judeu rabino pera os converter 
He was taking part in a gradual process of rabbinic indoctrination which ultimately led to an official acknowledgement of open Portuguese Jewish communities in the eighteenth century. ${ }^{9}$

Late sixteenth-century Bragança conversos seemed to believe that God blessed those who left inquisitorial Lusitania for a Jewish permissive Gallia. And when Isabel Rodrigues and Luis Nunes happened to meet Manuel Fernandes in Bragança, after he was smuggled into the city bringing money and letters from relatives and siblings living on the other side of the Pyrenees, "they said [to] him that these were good relatives and since they lived in the good Law, God helped them."10 This episode echoed a widespread converso equation between Judaism and wealth, which aimed to demonstrate that the children of Israel were still God's most cherished people, despite religious coercion and inquisitorial persecution. ${ }^{11}$ If this rationale relied on the premise that the better the Law of Moses is fulfilled the more its followers will be rewarded by Providence, it appears that France was perceived as a paradise for enrichment, due to the religious freedom enjoyed by the converso immigrants and their offspring. At the same time, the inquisitorial data clearly indicates that Bragança's New Christians were aware of the limitations of such liberty. Thus, Belchior Álvares, who had visited a group of New Christians established in Saint-Esprit-lès-Bayonne, remembered that even if nobody there feared denunciation, they still concealed their Judaic proclivities from their neighbors: "keeping them hidden from the French."12 According to another Bragança New Christian named Diogo Guerreiro, what characterized the French religious landscape he personally knew was that everyone, whether converso Judaizers

e ensinar a crença da lei de Moises." Arquivos Nacionais/Torre do Tombo, Inquisição de Coimbra, processo n. 484 .

9 Carsten L. Wilke, "Un judaïsme clandestin dans la France du XVII e siècle: un rite au rythme de l'imprimerie," in Transmission et passages en monde juif, ed. Esther Benbassa (Paris: Publisud, 1997), 281-311. Cf. Gérard Nahon, "Prospective des 'Portugais' du sudouest de la France à la veille de la Révolution," in Politique et religion dans le judaïsme moderne, des communautés à l'émancipation, ed. Daniel Tollet (Paris: Presses de l'Université de Paris-Sorbonne, 1987), 85-104.

10 "[...] que aqueles erão bons parentes e que assi como viviam em boa lei, assi os ajudava Deos [...]." Arquivos Nacionais/Torre do Tombo, Inquisição de Coimbra, processo n. 8798, fols. $28 \mathrm{r}-\mathrm{v}$.

11 Claude B. Stuczynski, "Judaïcité et richesse dans l'apologétique des Conversos portugais: un argument contre-culturel," Atalaya 14 (2014): http://atalaya.revues.org/1295.

12 "[...] posto q se escondião dos franceses." Arquivos Nacionais/Torre do Tombo, Inquisiçãa de Coimbra, processo n. 7934, fol. $5^{2 v}$. 
or Protestant Huguenots, could live side by side with their Catholics neighbors, provided their religious practices were kept indoors: "portas adentro."13

These few examples, taken from more than five hundred trials of the Coimbra Inquisition against late-sixteenth- and early-seventeenth-century New Christians living in Bragança I studied years ago, of a city called by Israël Salvator Révah "métropole de crypto-judaïsme" for the impressive numbers of convicted Judaizers by the Holy Office, addresses an idealized portrait of Iberian conversos living under the early modern French confessional umbrella. ${ }^{14}$ In these sources, one finds no mention of those numerous moments of tension, hostility, and incertitude experienced by converso emigres, including local expulsions and circumscribed violence. ${ }^{15}$ Moreover, there is no word concerning the brutal persecutions and bloody massacres suffered by the Huguenot minority during the wars of religion, such as around the St. Bartholomew's Day of 1572. At the same time, nothing is said regarding the rights granted by the French monarchy to the Huguenot minority in the Edict of Nantes of 1598, which included freedom of public worship in specific geographic areas, as well as safe havens, which were military strongholds, such as La Rochelle. ${ }^{16}$ In the above-mentioned inquisitorial files, there is no echo of the tensions found in rabbinic and Sephardic communal sources between those converso emigres who were satisfied with the minimalistic, concealed, and informal forms of Judaism they could practice in France, and those exconverso "New Jews" who, living in official Sephardic communities, argued that the Law of Moses is inherently maximalist and could only be properly practiced in "lands of Judaism" (terras de Judesmo) such as Amsterdam. ${ }^{17}$ Moreover, New Christians who continued to live in France as committed Catholics, as

13 Arquivos Nacionais/Torre do Tombo, Inquisição de Coimbra, processo n. 880o, fol. 39r.

14 Israël Salvator Révah, "Aux origines de la rupture spinozienne: nouvel examen des origines du déroulement et des consequences de l'affaire Spinoza-Prado-Ribera," Annuaire du Collège de France 71 (1971): 584. Stuczynski, A "Marrano Religion"? Cf. Elvira Cunha de Azevedo Mea, A Inquisição de Coimbra no século XVI: a Instituição, os Homens e a Sociedade (Porto: Fundação Engenheiro António de Almeida, 1997), passim.

15 E.g., Jacques Blamont, Le lion et le moucheron. Histoire des Marranes de Toulouse (Paris: Odile Jacob, 2000).

16 Bernard Cottret, 1598, L'Édit de Nantes (Paris: Perrin, 1997); Bernard Barbiche, "L'Édit de Nantes et son enregistrement: génèse et publication d'une loi royale," in Paix de armes, paix des âmes, ed. Paul Mironneau and Isabelle Pébay-Clottes (Paris: Imprimerie nationale, 2000), 251-26; Christian Jouhaud, "Religion and politics in France during the period of the Edict of Nantes," in Religious Differences in France: Past and Present, ed. Kathleen P. Long (Kirksville, MO: Truman State University Press, 2006), 73-90.

17 Yosef Kaplan, "Wayward New Christians and Stubborn New Jews: The Shaping of a Jewish Identity," Jewish History 8 (1994): 27-41. 
well as those who discovered outside the Iberian Peninsula that they were not only "potential Jews" but also "potential Catholics" inculcated with IberianCatholic values, left no written traces in the vast inquisitorial data I consulted. ${ }^{18}$ Beyond an epistemic explanation for these omissions related to the inquisitorial-bureaucratic notarial writing genre and the juridical-procedural method of rhetorical bargaining that took place between the inquisitor and the inquired, I argue that such incomplete and distorted ways of perceiving the early modern French confessional model reflect two pervasive historical realities. On the broader level, it echoes the intermediary stages between the violent wars of religion in the sixteenth century and the imposition of "enlightened" confessional policies in eighteenth-century Western and Central Europe. At such times, different confessional communities beyond the Alps and the Pyrenees managed to negotiate a certain modus vivendi. ${ }^{19}$ The result was the relatively peaceful, albeit fragile religious coexistence, which late-sixteenth- and earlyseventeenth-century Bragança conversos met in southwestern France, a region densely populated by a vibrant Huguenot community. ${ }^{20}$ More specifically, it is worth remembering that for Portuguese New Christians, whether cryptoJewish or not, Gallicanism was an extremely appealing alternative to Iberian Catholicism. I refer here neither only to the special privileges New Christians enjoyed in early modern France as a protected group of merchants and then as members of a Portuguese "nation," from the "lettres patentes" issued in $155^{\circ}$ by Henri II and expanded by subsequent monarchs nor to the fact that men of immense power, such as the minister of King Louis XIII, Cardinal Richelieu, welcomed the conversos, supported the New Christian Judaizer sub-group, and employed them as an economic, political, and logistical means to weaken the Spanish-Habsburg hegemony. ${ }^{21}$ No wonder if from 1627 Rouen, the exiled

18 Natalia Muchnik, "Du judaïsme au catholicisme: les aléas de la foi au XVIIe siècle," Revue Historique 623 (2002): 571-6o9; idem, "Du catholicisme des judéoconvers: Rouen, 1633," XVII e siècle 231 (2006): 321-43; David L. Graizbord, Souls in Dispute Converso Identities in Iberia and the Jewish Diaspora, 1580-1700 (Philadelphia: Pennsylvania University Press, 2004).

19 Benjamin J. Kaplan, Divided by Faith: Religious Conflict and the Practice of Toleration in Early Modern Europe (Cambridge, MA: Belknap Press of Harvard, 2007). Cf. Keith T. Luria, Sacred Boundaries. Religious Co-existence and Conflict in Early Modern France (Washington, DC: The Catholic University of America Press, 2005).

20 Philip Benedict, "The Huguenot Population of France, 1600-1685: The Demographic Fate and Customs of a Religious Minority," Transactions of the American Philosophical Society 81 (1991): 1-164; Philippe Chareyre, "Démographie et minorités protestantes," Bulletin de la Société de l'Histoire du Protestantisme Français 148 (2002): 867-89.

21 Israël Salvator Révah, Le Cardinal de Richelieu et la restauration du Portugal (Lisbon: Institut Français du Portugal, 1950); Françoise Hildesheimer, "Une créature de Richelieu: 
Portuguese converso writer João Pinto Delgado dedicated his "Poema de la Reina Ester" along with other biblical works to Cardinal Richelieu, for protecting "wanderers" (peregrinos) like himself. Pinto Delgado's noble and generous portrait of Louis XIII's minister was close to the image of Ahasuerus's most devoted minister, Mordecai, in times when the figure of Haman was evoked in political discourses to criticize the employment of ministers and favorites by European princes. ${ }^{22}$ Rather, in this paper, I aim to show that for many early modern conversos and pro-converso elements, the French-Gallican confessional model was an attractive, alternative way of combining the political and the religious domains in order to solve the persistent "converso problem" in the Iberian Peninsula, without altering the Catholic and corporate character of the society. This phenomenon of converso and pro-converso political agency, which I call "Richelieu in Marrano garb," became tangible at a very specific historical moment: between Portugal's dynastic independence from the Spanish Habsburgs on 1 December 1640 and the Peace of the Pyrenees of 7 November 1659, which ended warfare between France and Spain. More precisely, "Richelieu in Marrano garb" crystallized when the newly "restored" Portuguese dynasty of Braganza under John IV desperately sought diplomatic support and military assistance from France to avoid Spanish-Habsburg retaliation. ${ }^{23}$ Under these historical circumstances, two conversos living in France, the Portuguese diplomat Manuel Fernandes Vila Real (1608-1652) and the Spanish-born and partly converso writer Antonio Enríquez Gómez (160o-1661), were propelled to join that ephemeral Portuguese-French alliance by offering the Gallican confessional model to meet Portugal's pressing needs. Both writers have been exhaustively studied by leading scholars.

Alphonse Lopez, le 'Seigneur Hebreo', in Les Juifs au regard de l'histoire. Mélanges en l'honneur de Bernhard Blumenkranz, ed. Gilbert Dahan (Paris: Picard, 1985), 293-99. João Pinto Delgado, Poema de la Reina Ester, Lamentaciones del Propheta Ieremias, Historia de Rut, y varias poesias (Rouen: chez David du Petit Val, imprimeur ordinaire du Roy, 1627), introduction; Israël Salvator Révah, "Autobiographie d'un marrane. Édition partielle d'un manuscript de João (Moseh) Pinto Delgado," Révue des Études Juives 119 (1961): 41-13o, esp. 115-16. Cf. John H. Elliott and Laurence W.B. Brockliss, eds., The World of the Favorite (New Haven and London: Yale University Press, 1999), passim.

23 João Franco Barreto, Relação da embaixada a França em 1641, por João Franco Barreto. Reimpressa com noticias e documentos elucidativos por Carlos Roma Du Bocage e Edgar Prestage (Coimbra: Imprensa da Universidade, 1918); Edgar Prestage, The Diplomatic Relations of Portugal with France, England and Holland from 1640 to 1668 (Watford: Voss \& Michael, 1925); Moses Bensabat Amzalak, As relações diplomaticas entre Portugal e a França no reinado de D. João IV (1640-1656): documentos e notas (Lisbon, n.p. 1934); Eduardo Brazão, A diplomacia portuguesa nos séculos XVII e XVIII (Lisbon: Editorial Resistência, 1980). 
Initially, the affinities of Vila Real and Enríquez Gómez were explored vis-àvis their support for the Franco-Portuguese alliance, ${ }^{24}$ their common opposition against the Iberian Inquisitions, ${ }^{25}$ and the more controversial question of their crypto-Jewish allegiances. ${ }^{26}$ More recently, they have been investigated through the prism of hybridity. Enríquez Gómez is now portrayed as a halfconverso-Castilian-pro-Portuguese-Francophile-libertine, whereas Vila Real

24 Constance H. Rose, "Portuguese Diplomacy Plays a Role in the Printing of Some Peninsular Works in Rouen in the Seventeenth Century," Archivos do Centro Cultural Português 9 (1975): 523-41; Michèle Gendreau-Massaloux and Constance H. Rose, "António Enríquez Gómez et Manuel Fernandes de Villareal: deux destins parallèles, une vision politique commune," Revue des études juives 136 (1977): 368-87; Luís Reis Torgal, Ideologia política e teoria do Estado na Restauração: contributo para o seu estudo (Coimbra: Biblioteca Geral da Universidade de Coimbra, 1981-1982), 1: 412-19; 2: 32-36, 213-23; Iva Delgado, "Manuel Fernandes Vila Real, polemista da Restauração," Revista da Biblioteca Nacional 3 (1983): 27-46; António Borges Coelho, "Manuel Fernandes Vila Real no discurso político dos primeiros anos da Restauração," in A união ibérica e o mundo atlântico, ed. Maria da Graça A. Mateus Ventura (Lisbon: Colibri, 1997), 285-306; Henry Méchoulan, "Manuel Fernandes Vila Real, un marrane en politique," Nova Renascença 67 (1998): 305-16; João Pedro da Silva Gomes, "O ‘Epítome genealógico' de M. Fernandes Vila Real e a 'Política angélica' de Antonio Enríquez Gómez: o pensamento político de dois cristãos-novos na década de 1640" (master's thesis, Universidade Nova de Lisboa, 2008); Jaime Galbarro García, "Manuel Fernández Villareal y la propaganda de la 'nação' Portuguesa," Versants 60 (2013): 131-42; idem, El 'Triumpho lusitano' de Antonio Enríquez Gómez (Seville: Editoral Universidad de Sevilla, 2015).

25 Israël Salvator Révah, "Manuel Fernandes Vilareal, adversaire et victime de l'Inquisition portugaise," Ibérida 1 (1959-1960): 33-54, 181-207; Maximiliaan Paul Adriaan Maria Kerkhof, "La 'Ynquisiçion de Luzifer y uisita de todos los diablos.' Texto desconocido de Antonio Enríquez Gómez: edición de unos fragmentos," Sefarad 38 (1978): 319-31; Michael McGaha, "Divine Absolutism vs. Angelical Constitutionalism: The Political Theories of Quevedo and Enríquez Gómez," in Studies in Honor of Bruce W. Wardropper, ed. Dian Fox, Harry Sieber and Robert Ter Horst (Newark, DE: Juan de la Cuesta, 1989), 181-92; Nechama Kramer-Hellinx, Antonio Enríquez Gómez: literatura y sociedad en El siglo pitagórico y Vida de don Gregorio Guadaña (New York: Peter Lang, 1992); Constance H. Rose, "Dios hará inquisición de vuestros juicios': Antonio Enríquez Gómez' Search for Justice," Sefarad 61 (2001): 169-86.

26 Timothy Oelman, "The Religious Views of Antonio Enríquez Gómez: Profile of a Marrano," Bulletin of Hispanic Studies 41 (1983): 201-9; Herman P. Salomon, "Nova luz sobre a condenação à fogueira a Manuel Fernandes Vila Real (1. XII. 1652)," in Inquisição, ed. Maria Helena Carvalho dos Santos, 3 vols. (Lisbon: Universitária Editora, 1989), 2: 765-73; Constance H. Rose, "Fiel a la antigua ley: 'La política angélica' de Enríquez Gómez," in Antonio Enríquez Gómez, ed. Gema Ortega (Cuenca: Diputación de Cuenca, departamento de cultura, 1996), 105-10; Israël Salvator Révah, Antonio Enríquez Gómez, un écrivain marrane (v. 16oo-1663), ed. Carsten L. Wilke (Paris: Chandeigne, 2003); Matthew Warshawsky, "A Spanish Converso's Quest for Justice: The Life and Dream Fiction of Antonio Enriquez Gómez," Shofar 23 (2005): 1-24; Herman Prins Salomon, "Was Antonio Enríquez Gómez (1600-1663) a Crypto-Jew?" Bulletin of Hispanic Studies 88 (2011): 397-421. 
is viewed as the embodiment of interstitiality, the converso as "productive intermediary" between different religions, cultures, social classes, and family networks. ${ }^{27}$ In this article, I seek to show that beyond these circumstantial and biographical considerations, conversos and their allies longed to impart to the Iberian Peninsula two intertwined traits they found in early modern France: a dose of freedom of conscience and a more assertive way to govern a centrifugal corporate society. While I endorse Joseph Bergin's dynamic and variegated portrait of early modern French politics and religion, I argue that seen from the Iberian Peninsula, the question of whether the French confessional model evolved from a "church in the state" to "the state in the church" is not an "otiose matter." 28 Whereas the latter option countered the political and religious foundations of the early modern Iberian Peninsula, the former was a more feasible way to incorporate the French confessional model into Iberian society, without undermining its traditional basis. Precisely for this reason, those who promoted "Richelieu in Marrano garb" stressed their commitment to the first option, while accusing the Spanish Habsburgs and the Portuguese Inquisition of employing the latter in a disguised and hypocritical manner.

\section{2 The Public versus the Private}

But why the French confessional model? More than in any other early modern Catholic country, in France there existed a clear distinction between religious crimes committed publicly, in foro externo, and those committed discreetly, in foro interno. ${ }^{29}$ According to a "caesaro-papistic" interpretation of the verse: "Render therefore unto Caesar the things which are Caesar's and unto God the things that are God's" (Matthew 22:20-22), in early modern France the

27 Carsten L. Wilke, Jüdisch-Christliches Doppelleben im Barock (Frankfurt: Peter Lang, 1994); Valentina Nider, "La doppia simulazione di Enríquez Gómez: 'La culpa del primer peregrino'," in Alle radici dell'Europa. Mori, guide e zingari del mediterraneo occidentale, vol. 2, secoli XVII-XIX, ed. Felice Gambin (Florence: Seid, 2010), 195-210; J. Ignacio Díez and Carsten Wilke, eds., Antonio Enríquez Gómez. Un poeta entre santos y judaizantes (Kassel: Eva Reichenberger, 2015); Carsten L. Wilke, "Manuel Fernandes Vila Real at the Portuguese Embassy in Paris, 1644-1649: New Documents and Insights," Journal of Levantine Studies 6 (2016): 153-76.

28 Joseph Bergin, The Politics of Religion in Early Modern France (New Haven and London: Yale University Press, 2014), 299-307.

29 According to Paolo Prodi, such dualistic way of conceiving the foro interno as the domain left by the public foro externo, was a "modern" idea which contributed to the separation between juridical and moral norms (Paolo Prodi, Una storia della giustizia. Dal pluralismo dei fori al moderno dualismo tra coscienza e diritto [Bologna: Il Mulino, 2000], 332-89). 
monarch was perceived as the ultimate instance to judge crimes committed in foro externo, including heresy. Unreserved heresy, after all, was a "scandal" (scandale) openly committed against the political order and thus was considered after the Roman law an act of treason against the king and the state ("crimen lesae maiestatis"). In 1540, Francis I established an extraordinary court of justice to deal with such public "scandals," called "the Burning Chamber" (la Chambre ardente). The Burning Chamber was attached by the king to the Parliament in collaboration with the Faculty of Theology of Paris. The methods and outcomes of this institution were harsher than the more "pedagogic" and confessional-reconciling aims of the Inquisition. ${ }^{30}$ At the same time, only a limited number of individuals was prosecuted by the Burning Chamber, especially after the Edict of Nantes, which was an exceptional political compromise made by the French sovereign with his Huguenot "heretic" subjects to obtain civil appeasement. Crimes perpetrated discreetly in foro interno traditionally belonged to the sphere of conscience (foro conscienciae) and were considered by Christian lawyers and theologians as the domain of God and His Church. ${ }^{31}$ In inquisitorial lands, such as early modern Iberia and Italy, a priest-confessor was not able to acquit in the name of God a crime of heresy committed in foro interno, because it also deserved Church excommunication. Therefore, it had first to be absolved by the confessional-penitential ecclesiastical instance for heretical crimes, which was the Holy Office. ${ }^{32}$ In early

$30 \quad$ Nethanël Weiss, La Chambre ardente: Étude sur la liberté de conscience en France sous François Ier et Henri II (1540-1550), suivie d'environ 500 arrêts inédits rendus par le Parlement de Paris de mai 1547 à mars 1550 (Geneva: Slatkine Reprints, 1970); Nicola Mary Southerland, "Was there an Inquisition in Reformation France?" in idem, Princes, Politics, and Religion, 1547-1589 (London: The Hambledon Press, 1984), 13-29; William Monter, Judging the French Reformation: Heresy Trials by Sixteenth-Century Parliaments (Cambridge, MA: Harvard University Press, 1999); Alain Tallon, "Inquisition romaine et monarchie française au XVI ̀̀ siècle," in Inquisition et pouvoir, ed. Gabriel Audisio (Aix-enProvence: Publications de l'Université de Provence, 2004), 311-24.

31 E.g., "In foro conscientiae causa agitur inter hominem et Deum; in foro autem exterioris iudicii causa agitur hominis ad hominem; et ideo absolutionis vel ligatio quae unum hominem obligat quo ad Deum tantum, pertinent ad forum poenitentiae; sed illa quae hominem obligat in comparationes alios homines, ad forum publicum exterioris iudicii pertinent." Thomas Aquinas, Sententiae, IV, d.18, q.3, a. 2. An effort to distinguish the juridical category of foro interno from the moral foro conscienciae is to be found in Velasio de Paolis, "Natura e funzione del foro interno," in Investigationes Theologico-canonicae, ed. U. Navarrete (Rome: Università Gregoriana Editrice, 1978), 115-42. Cf. Stephan Kuttner, "Ecclesia de occultis non iudicat. Problemata ex doctrina poenali decretistarum et decretalistarum a Gratiano usque ad Gregorium PP. IX," in Acta congressus iuridici internationalis, Romae 1934 (Rome: Libr. Pont. Institutis Utriusque Iuris, 1936), 3: 225-46.

32 Prodi, Una storia della giustizia, 92-97. These procedures did not exhaust the uncertainties, tensions, and negotiations in inquisitorial lands between hidden "heretic" crimes 
modern France, however, such secret misdeeds were basically absolved by the traditional spiritual guardian and shepherd of the Christian flock, namely, the bishop. Following a failed attempt in 1550 to introduce in France an inquisition after the Iberian model by Henry II, the Edict of Chateaubriand of ${ }^{1551}$ stressed that every punishable crime should fall under the jurisdiction of the French Parliament. According to Ellena Brambilla, the consequence was that heresies committed in foro interno ceased to be prosecuted by the bishops, because they lost any effective means of dissuasion. ${ }^{33}$ These measures of juridical secularization and monopolization by the merging state were often coupled with an elaboration upon the traditional Capetian idea that the French monarch was divinely chosen by God. Having a sacral dimension, French monarchs could claim secular rights or regalia concerning the Church and appeared as the most committed supporters of the Gallican bishopric autonomies vis-àvis the Pope. ${ }^{34}$ Early modern French state-building thus combined political centralistic inclinations, religious autonomy from the Pope, and a certain freedom of conscience, while publicly remaining Catholic. These traits enabled Portuguese conversos established in France to live indoors unmolested, provided they behaved as Catholics in foro externo by attending church, being baptized and buried as Catholics, and avoiding public "scandals" (e.g., public acts of Judaism). From the first "lettres patentes" of naturalization of 1550 , New Christian merchants were considered by Henry II as his "good and loyal subjects" (bons et loyaulx subiectz), deserving the same rights and privileges enjoyed by their French neighbors ("de tous et chacuns les privileges, franchises et libertés dont ont accoustumé joy et user nos propres subiects et mesmes habitans des villes où se seront retirez lesdits Portugais"), including in criminal domains. ${ }^{35}$ In the royal privilege of 1574 issued by Henry III on behalf of the New Christians living in Bordeaux, it was stated that conversos should live in the city peacefully in full liberty: "without having their lives or other aspects

committed "in foro conscienciae," the role of confessor-priest and that of the Holy Office. See Adriano Prosperi, Tribunali della coscienza: Inquisitori, confessori, missionari (Turin: Einaudi, 1996); Stefania Tutino, Shadows of Doubt: Language and Truth in Post-Reformation Catholic Culture (New York: Oxford University Press, 2014), esp. 12-34.

33 Ellena Brambilla, Alle origini del Sant'Uffizio. Penitenza, confessione e giustizia spirituale dal medioevo al XVI secolo (Bologne: Il Mulino, 200o), esp. 411-36; idem, La giustizia intollerante. Inquisizione e tribunali confessionali in Europa (secoli IV-XVIII) (Rome: Carocci, 2006), 169-72.

34 Jonathan Powis, "Gallican Liberties and the Politics of Later Sixteenth-Century France," The Historical Journal 26 (1983): 515-30.

35 Nahon, Les 'nations' Juives portugaises du sud-ouest de la France (1684-1791). Documents, 23-24. 
inquired into" (sans estre recherchés en leur vie ni autrement). ${ }^{36}$ I will argue that this explicit mention must be understood as a reaction to some "calumnious denunciations" mentioned in the document, which aimed to expel the conversos from the city on the basis of crypto-Jewish behavior. However, like the failed attempt of Marie of Medicis in 1615 to expel the "Jews" and "disguised Jews" from France and the sui generis "auto-da-fe" held against conversos in Toulouse in $1685,{ }^{37}$ these exceptional initiatives stemmed from efforts to ban discreet forms of "Judaism" from the unpunishable domain of the foro interno after the Iberian confessional model. In this respect, freedom of conscience in early modern France was open to different interpretations: whether in lato sensu, as internal religious behavior, or in stricto sensu, as mere freedom of opinion and belief. However, such freedom had little to do with broader forms of freedom of conscience practiced by ex-converso "New Jews" in "terras de judesmo," such as in Amsterdam or Livorno, in which they could legally live as practicing Jews, as well as regarding the circumscribed religious liberties exceptionally conceded by French monarchs to the Huguenot minority.38

This French or Gallican separation of the public from the private domain was promoted by Manuel Fernandes Vila Real, in his del eminentíssimo cardenal Duque de Richelieu (1641) and António Enríquez Gómez, especially in his Política angélica (1647). ${ }^{39}$

36 Ibid., 30. See a confirmation in the "lettres patentes" of 1656 by Louis XIV: "[...] ni être recherchez de façon quelconque en leur vie, ou autrement inquiétez ou molestez en leur personnes \& biens, en quelque manière que ce fût." Ibid., 33 .

37 Zosa Szajkowski, "An Auto-da-Fé against the Jews of Toulouse in 1685," The Jewish Quarterly Review 49 (1959): 278-81; Gérard Nahon, "Exception française et réponse au modèle ibérique: Marie de Médicis et la 'Déclaration qui expulse les Juifs du Royaume de France' du 23 avril 1615," in L'expulsion des Juifs de Provence et de l'Europe méditerranéenne (XV $-X V I^{e}$ siècles); exils et conversions, ed. Danièle Iancu-Agou (Paris and Leuven: Peeters, 2005), 111-28.

38 Lucia Frattarelli Fischer, Vivere fuori dal ghetto. Ebrei a Pisa e Livorno (secolo XVI$X V I I I)$ (Turin: Silvio Zamorani Editore, 2008); Miriam Bodian, "The Portuguese Jews in Amsterdam and the Language of Liberty," Journal of Levantine Studies 6 (2016): 313-32. In the case of Amsterdam, religious liberty was limited and circumscribed to the community space of the synagogue and home (Cf. Yosef Kaplan, "Between Calvinists and Jews in Seventeenth-Century Amsterdam," in Conflict and Religious Conversation in Latin Christendom: Studies in Honor of Ora Limor, ed. Ram Ben-Shalom and Israel J. Yuval [Brepols: Turnhout, 2014], 289-9o).

39 Manuel Fernandes Vilareal, Epítome genealógico del eminentissimo Cardenal Duque de Richelieu y discursos politicos sobre algunas acciones de su vida, Pamplona: Iuan Antonio Berdun, 1641 (hereafter, Epitome genealógico). I also consulted the modern Portuguese edition of António Borges Coelho, Epítome Genealógico do Eminetissimo Cardeal Duque de Richelieu e Discursos Políticos sobre Algumas Acçõesa da Sua Vida (Lisbon: Caminho: 2005). Concerning Antonio Enríquez Gómez, his political views and criticism of the 
Scholarship has awarded these tracts a certain amount of comparative attention. ${ }^{40}$ For our purposes, I will simply mention that both were presented as tributes to French authorities. The Epitome genealógico was dedicated to Cardinal Richelieu, while the first part of the Política angélica was offered to Jean Louis Faucon, president of Normandy's Parliament and counselor of Louis XIII. ${ }^{41}$ Vila Real's laudatory biography of Richelieu, later known as El político cristianisimo (1642), almost coincided with the death of Louis XIII's minister on 4 December 1642. Perhaps for this reason, it became a tool of French propaganda and was translated into French and Italian. In glossing Richelieu's life and deeds, Vila Real praised the way he combined Catholic values with successful politics. And when he was imprisoned by the Inquisition of Lisbon in 1649 on grounds of crypto-Judaism, Vila Real argued that the book was reviewed by Cardinal Mazarin and by members attached to Portugal's embassy in Paris, such as Friar Francisco de Santo Agostinho. Since he did not have any intention to harm Portugal's Holy Office, but only to praise Richelieu's Catholic policies, the Epitome genealógico is not to be seen as a heretical book. ${ }^{42}$ Enríquez Gómez's Política angélica was less concerned with Richelieu's life. Rather, it celebrated the way France promoted "angelic politics" and most particularly, it criticized Iberian "diabolic politics" epitomized by the Inquisition. According to Israël Salvator Révah, the second part was written with Iberian

Iberian Inquisitions and one of his social debased byproducts, the "malsín" appear in many of his works. In this article I will focus on both the first part of his "Política Angelica" (Antonio Enríquez Gómez, Política angélica, primera parte dividida en 5. Dialogos [Rouen: L. Maurry, 1647], hereafter, Política angélica) and the second, published by Israël Salvator Révah, "Un pamphlet contre l'Inquisition. La seconde partie de 'La política angélica' de Antonio Enríquez Gómez (Rouen, 1649)," Revue des Études Juives 121 (1962): 81-168 (hereafter, Révah, "Un pamphlet." Only occasionally I will refer to Enríquez Gómez's, Luis dado de Dios a Luis y Ana Samuel dado de Dios a Elcana y Ana [Paris: René Baudry, 1645], hereafter, Luis dado de Dios).

40 In the second poem written by Enríquez Gómez at the beginning of the "Epítome Genealógico" to celebrate Vila Real's book he said: "Dió a un epitome forma/ De aquella mente Angelica y Divina; / Y tu Pluma Política, camina/ Alinear los conceptos, que te informa." Was this a restrospective allusion to Enríquez Gómez's future claims in Política angélica?

41 Antonio Enríquez Gómez, Política Angélica, primera parte dividida en 5. Dialogos (Rouen: L. Maurry, 1647).

42 José Ramos Coelho, Manuel Fernandes Villa-Real e o seu processo na Inquisição de Lisboa (Lisbon: Empreza do Ocidente, 1894), 52-53. Cf. António Baião, Episódios dramáticos da Inquisição portuguesa (Rio de Janeiro: Álvaro Pinto Editor, 1924), 2: 364-68; Révah, "Manuel Fernandes Vilareal, adversaire et victime de l'Inquisition portugaise." 
authorities in mind, although formally dedicated to every Catholic sovereign ("dedicado a todos los Principes Christianos, Columnas de la Militante Iglesia de Roma") to suggest a more appropriate way to deal with converted subjects and heretics ("sobre el govierno, que se deve tener con los Reduzidos a la Fe Catholica, y con los que se apartaron della"), than the rigor employed in "some kingdoms" ("[d]eseando con piadoso celo dar un medio sobre el gobierno riguroso que se ejecuta en algunos Reinos sobre los delitos de religion"). ${ }^{43}$ Presented as a sort of Catholic confessional guide, the second part of the Política angélica dealt specifically with the Inquisition. It was no wonder that the book was immediately condemned in Iberia and its second part banned in France through the intervention of Portugal's ambassador in Paris, the Marquis of Niza. Vila Real informed the inquisitors that he had tried to dissuade his friend from publishing the second part, because it overtly questioned the Holy Office, an institution supported by the papacy. ${ }^{44}$ The Epitome genealógico and the Política angélica were written as Catholic tracts by two Iberian New Christians who opted for the Gallican confessional model over the Iberian. They expressed similar views, although they employed different emphases and rhetorical devices. The former glorified Richelieu's life and deeds, while making comments in the form of morals inferred from the Cardinal's actions. The latter was straightforward in its condemnation of Spain and Portugal, but much more laconic regarding Richelieu's achievements.

In the introduction of the Epitome genealógico, Vila Real explained his decision to write a biography of Louis XIII's favorite: because Richelieu's political wisdom deserved to be known by Spanish readers, until now ignored because of linguistic and political estrangement. ${ }^{45}$ Following Plutarch's biographic-didactic historiography, Vila Real portrayed the Cardinal, mostly to underscore how he successfully managed religion in France's political life. After reminding the reader of Richelieu's noble ascendancy and upbringing by stressing his virtuous personality and ecclesiastical probity, he concluded: "[s]omeone who rightly observes the divine laws, cannot err in human (laws); nor could be a bad counselor to a prince who is a good minister of God."46 Accordingly, Richelieu's political wisdom emanated from theological knowledge and pious behavior and not from aleatory savoir faire. This comment was intended to

\footnotetext{
43 Révah, "Un pamphlet," 10o. Cf. Luis Reis Torgal, "A literatura 'marrânica' e as 'edições duplas' em Antonio Henriques Gomes (160o-1663)," Biblos 55 (1979): 197-228.

44 Révah, "Un pamphlet," 93-98.

45 "Ten en tu gracia, pues te hago participe en tu lengua de lo que ignoravas, por estar en otras que no entendias, ò de aquello que no amavas, por no saber era digno de amarse" (Vila Real, Epítome genealógico, "Al Lector" n.p.). 
contrast Richelieu's successful government with the by-then failing ministry of his Spanish rival, the favorite of King Philip IV, the Count-Duke of Olivares. ${ }^{47}$ That said, only occasionally did Vila Real censure the Spanish monarch (e.g., for living idly at court hidden from his subjects) and critique Olivares (e.g., because his centralist policy of "Unión de Armas" exacerbated civil antagonism instead of support). ${ }^{48}$ For the most part, Epitome genealógico strove to celebrate Richelieu's policies as a model to be emulated. Something similar could be said regarding Enríquez Gómez, in his criticism of Iberia. In the introduction to Part One of the Política angélica, he mentioned en passant the name of Virgilio Malvezzi, the author of an acclaimed biography of Olivares: "Il ritratto del privato politico Cristiano" (1635). This work probably prompted Vila Real to write his biography of Richelieu, ${ }^{49}$ and it was one of Enríquez Gómez's possible sources of inspiration in comparing monarchs with God, ministers with angels, and a virtuous government with "angelic politics." ${ }^{50}$ However, here again Philip IV and Olivares were occasionally attacked as such. ${ }^{51}$ On a theoretical level, the Política angélica dismissed Niccoló Machiavelli for supporting cunning and fraud as a legitime political means of government, and Jean Bodin for enabling envy between the prince's ministers to avoid intrigues against the sovereign according to the unethical ("non-angelical") principle of "divide

47 Cf. John H. Elliott, Richelieu and Olivares (Cambridge: Cambridge University Press, 1991).

48 "Añadir vn Reyno, y otro Reyno, a vna Monarchia grande sin sugetar los animos, no es aumentar el dominio si no arriesgarle, es grangear enemigos ocultos, quando pudieran ser menos dañosos descubiertos. Solo deve llamarse vnion la que forman los coraçones, no la que establecen las Armas." Vila Real, Epítome genealógico, 216. Vila Real was alluding to Olivare's centralistic policy of "Unión de Armas" (cf. John H. Elliott, The Count-Duke of Olivares. The Statesman in an Age of Decline [New Haven and London: Yale University Press, 1986], 124, 244-46, 270-77).

49 "La estimacion, que los escritos de vn Moderno Politico, han merecido la opinion de muchos, despertó mi Pluma, en vna dilatada ociosidad, a la traduccion del vltimo retrato de su doctor pinsel. Pero considerando en las acciones de vn gran Ministro, el original de aquella copia, y que en el era execucion, lo que en el otro discurso, que aquel repetia lo que devia hazerse, y que este obrava lo que los otros enseñavam; mudando de intento, dexé la explicacion de agenos conceptos, para repetir los mios, o los de mis estudios en la composission deste discurso." Vila Real, Epitome genealógico, "Al Lector," n.p.

$50 \quad$ E.g., "Philonio: Pues que politica en potencia le conviene tener al Principe en el estado? Theogonio: La que tiene Dios con los Angeles" (Enríquez Gómez, Política Angélica, 17). Cf. "Sono talvolta figura di Dio con noi gli angeli; degli angeli i favoriti co' principi, di Dio i principi con gli uomini" (Virgilio Malvezzi, Il Ritrato del Privato Politico Cristiano, ed. Maria Luisa Doglio [Palermo: Sellerio editore, 1993], 35).

51 Cf. Michael D. McGaha, "Antonio Enríquez Gómez and the Count-Duke of Olivares," in Texto y espectáculo: nuevas dimensiones críticas de la "comedia," ed. Arturo Pérez-Pisonero and Ana Semidey (El Paso: University of Texas, 1990), 47-54. 
and rule."52 In spite of the efforts made by the Spanish translator of Bodin's Six Books of the Republic (1590), to disassociate the book from the bête noire of early modern political thought, Machiavelli (by stressing Bodin's personal commitment to Christian values and by removing or modifying from the original some equivocal excerpts), ${ }^{53}$ the book was included in the Spanish Index of Prohibited Books in 1612. Moreover, several Iberian writers, from Pedro de Ribadeneyra to Francisco de Quevedo, accused Bodin of being the main muse for Machiavelli's followers. ${ }^{54}$ Enríquez Gómez praised the more accepted neostoic and "Tacitian" views of Justus Lipsius as an alternative to Machiavelli and Bodin. This was mostly done without mentioning Lipsius, by quoting his elaborations on the Roman historian Publius Cornelius Tacitus. ${ }^{55}$ Lipsius aimed to conciliate Christian moral values with political efficacy and his "Tacitism"

52 Enríquez Gómez, Política angélica, 26, 79, 132. Vila Real was probably quoting Bodin when he wrote: "La obseruancia de la Religion y el exercicio de buenas costumbres, dize vn Filosofo y gentil; haze florecer màs la Monarchia, que la fuerça de poderosos exercitos." Vila Real, Epitome genealógico, 148.

53 See Gaspar Añastro Ysunza's explanations in the dedication of his translation to King Philip III (Jean Bodin, Los seis libros de la republica de Ivan Bodino, traducidos de lengua Francesa, y enmendados catholicamente por Gaspar de Añastro Ysunza [Turin: Herederos de Bevilaqua, 1590], n.p.).

54 Martim de Albuquerque, Jean Bodin na Peninsula Ibérica, Ensaio de Historia das Ideias Políticas e de Direito Pùblico (Paris: Fondation Calouste Gulbenkian, 1978); Harald E. Braun, "Making the Canon? The Early Perception of the République in Castilian Political Thought," in The Reception of Bodin, ed. Howell A. Lloyd (Leiden: Brill, 2013), 257-92. In this sense, it is worthy to note that Política angelica was written in polemical conversation with Quevedo's Politica de Dios, Gobierno de Cristo y Tiranía de Satanás (1617-1626). We know that Quevedo was very influential on Enríquez Gómez's variegated literary work. Quevedo's Politica de Dios shared similar anti-Machiavellian and theocentric views, but it disagreed on the role of the Church within the State, the Spanish monarchy, and the use of the Gospel as a source of political wisdom, instead of the Old Testament. According to Felice Gambin: "[e]s inevitable, por supuesto, a la hora de escribir sobre la Política angelica de Enríquez Gómez, tener en presente el volume quevediano [...]."Felice Gambin, "Es doblar el vivir': La Política angelica entre escritura divina y satánica," in Antonio Enrique Gómez: un poeta entre judaizantes, 143, n. 13. Already Francisco Manuel de Melo in his Hospital das Letras (1657) noticed this influence (Révah, "Un pamphlet," 88-89) Cf. Michael D. McGaha, "Divine' Absolutism vs. 'Angelic' Constitutionalism: The Political Theories of Quevedo and Enríquez Gómez."

55 Lipsius was tremendously influential in the Iberian Peninsula. Perceived as a Catholic anti-Machiavellian thinker, some of his views related to confessional issues were censored by the Inquisition. Cf. Alejandro Ramírez, Epistolario de Justo Lipsio y los Españoles (1577-1606) (Madrid: Castalia, 1966); Beatriz Antón Martínez, "El humanista flamenco J. Lipsio y la receptio del Tacitismo en España," in Humanismo y pervivencia del mundo clásico: actas del I Simposio sobre Humanismo y pervivencia del mundo clásico (Alcañiz, 8 al 11 de mayo de 1990), ed. José María Maestre Maestre and Joaquín Pascual Borea (Càdiz: Universidad de Cádiz, Servicio de Publicaciones, 1993), 1: 237-50. 
saluted strong political regimes and respected freedom of belief. ${ }^{56}$ Lipsius's advice to princes to rule with virtue and prudence, while asking his subjects to remain obedient, departed from a fundamental anthropological division between an external or political and an internal non-political self, which was very appealing to conversos. ${ }^{57}$ Being overtly anti-Bodinian because anti-Machiavellian, Enríquez Gómez endorsed Bodin's notion of "sovereignty" limited by Lipsius's prudence and constancy. ${ }^{58}$ As we shall see, Enríquez Gómez supported absolutist, albeit self-restrained regimes, because only these could fulfill his ideal of "angelic politics" by safeguarding the autonomy of inner conscience from an intrusion of the external sphere. That said, the main personal target of Política angélica was an anonymous churchman called "politico bastardo," who blurred the boundaries of the inner and outer spheres through the cunning cruelty of the Inquisition. This unnamed clergyman was depicted by Enríquez Gómez as an ambitious anti-French Spanish author, who sought to reinforce converso segregation..$^{59}$ Accordingly, "[t]he apostles honored nations by means of baptism and this political author (Estadista) seeks to dishonor sons of the Church who already received baptism. The apostles bound together the Christian community in a mystical body, and this author wishes to disunite them through division and envy." ${ }^{60}$ One of Enríquez Gómez's

56 Quoting Tacitus via Lipsius, Enríquez Gómez reminded that political dissimulation is "the soul of the State" ("el Alma del estado"), provided it is employed with proper means and ethical ends (Enríquez Gómez, Política angélica, 76-81). Also Vila Real praised "el gran Estadista Cornelio Tazito" through Lipsius's interpretations (Vila Real, Epítome genealógico, 146). Enríquez Gómez quoted Tacitus's tyrannical portrait of Nero to compare him with the Inquisition (Révah, "Un pamphlet," 149, 154; Enríquez Gómez, Luis dado de Dios, 10).

57 Cf. Robert Bireley, The Counter Reformation Prince: Anti-Machiavellianism or Catholic Statecraft in Early Modern Europe (Chapel Hill and London: University of North Carolina Press, 1990), 72-100. Cf. the introductions of Jan Waszink and Domenico Taranto: Justus Lipsius, Politica: Six Books of Politics or Political Instruction, ed. Jan Waszink (Assen: Van Gorcum, 2004); Giusto Lipsio, La Constanza, ed. Domenico Taranto (Naples: Bibliopolis, 2004), 9-47.

58 E.g., "que a los Reyes se deue mirar con dos respectos, a sauer, el entendimiento a la soberania; y el sentido al temor" (Enríquez Gómez, Política angélica, 72); “[n]o es buena materia de estado, anteponer la Soberania al bien de la República, querer subir de punto la grandeça por que vaxe el eftado, es romper las cuerdas al ystrumento del buen gouierno, o diuidir enpieças la rueda prinçipal del Relox de la lusítiçia" (Enríquez Gómez, Luis dado de Dios, 13).

59 Enríquez Gómez, Política angélica, 120, 150-51. According to Rèvah (Révah, "Un pamphlet," 86 n. 1), this anonymous anti-converso author also appears cryptically in "Luis dado de Dios," 131.

6o "Los Apostoles honrauan las naciones con el Bauptismo; y eses Estadista dice que se deshonren los hijos de la Iglesia que receuieron el Bauptismo. Los Apostoles vnian en vn 
fictional characters named "Theogonio," revealed that he personally knew the man who disguised his own debased origins by attacking the converso group, thus following the popular dictum: "from the mountains comes he who burns it."61 From information gathered from the book, I will suggest that Enríquez Gómez was referring to the General Inquisitor Juan Adam de La Parra: author of a fierce anti-converso tract (1630), a condemnation of Richelieu's "heretical" alliances with Protestant princes (1634), and a refutation of Braganza's dynastic legitimacy over the Portuguese Crown (1642). ${ }^{62}$ Reasons related to personal prudence might explain such omission. That said, the way Enríquez Gómez addressed the most tangible Iberian counter-example of "angelic politics," the

cuerpo Mistico la congregacion Christiana; $Y$ ese auctor la quiere desunir con la diuision y con la imbidia." Enríquez Gómez, Política angélica, 122.

61 "Philonio. Acuerdome de vn Auctor, mal Politico y peor Christiano, por lisongear vn Ministro de estado, a quien dedico su libro, ya quien adula y lisonjea como quien deseaua alcanzar vna dignidad (q no llebó) dice, tratando sobre esta materia, que no solo no se deue premiar la sangre que por naturaleza esta indiziada en delicto de Religion (defetos de sus passados) pero que se les deue señalar la ynfamia que no cometieron, y cargalles doblados tributos que a las demas, naciones del imperio. Theogio. Ese Auctor conosco yo muy bien, y no os admireis de que condene la virtud, pues nunca la profesó (aun q profeso) ni menos se os haga nouedad el lenguaje que gastó en ese capitulo, por que no ay mayor enemigo del proximo que el que se quiere librar de lo que posee por nacimiento, a ese auctor le fue necessario para calificar su linaje, decir mal de la sangre que le dexaron sus Padres por herencia, y por tales sugetos se dixo, del Monte sale quien al Monte queme. Y Todo quanto esse escribio fue escrito con la pluma de la passion, en el papel del odio, no trato de la tinta que fue la embidia, por que esta la tubo siempre desde la cuna." Ibid., 119-20, 150-51. "Del monte sale quien el monte quema" was also the title of a comedy written in 1627 by Lope de Vega (ed. Ana María Porteiro Chouciño [Santiago de Compostela: Universidad de Santiago de Compostela, 2007]).

62 Juan Adam de la Parra, Pro cautione christiana, in supremis Senatibus Sanctae Inquisitionis, \& ordinum, ecclesia toletana, \& coetibus scholarium obseruata, adversus christianorum proselytos, \& sabbatizantes, nomine, \& specie christianorum (Madrid [?], 163o); idem, Conspiración herético-cristianísima, ed. Joaquín de Entrambasaguas (Madrid: Consejo Superior de Investigaciones Científicas, 1943); idem, Apologetico contra el tirano y rebelde Verganza, y coniurados, arzobispo de Lisboa, y sus parciales: en respuesta a los doze fundamentos del padre Mascareñas (En Zaragoza: por Diego Dormer, 1642). For an analysis of Adam de la Parra's anti-converso tract, see Antonio Domínguez Ortíz, "Una obra desconocida de Adam de la Parra," Revista bibliográfica y documental, 5 (1951): 97-115. For a biography of the General Inquisitor, see Kimberly Lynn, Between the Court and the Confessional. The Politics of Spanish Inquisitors (Cambridge: Cambridge University Press, 2013), 191-237. This name appears in the humoresque disguised form of "devil Parrafiscotado" (el diablo Parrafiscotado), in one of Enríquez Gómez's undated satirical fictions: "La Inquisición de Lucifer y visita de todos los diablos," to denounce "satanic" inquisitors as robbers of their victims (Antonio Enríquez Gómez, La Inquisición de Lucifer y visita de todos los diablos. Critical Edition, Study and Notes by Constance Hubbard Rose and Maxim P.A.M. Kerkhof [Amsterdam-Atlanta, GA: Rodopi, 1982], 5, 10-11). 
Holy Office, shows that he was less interested in attacking concrete inquisitors than in castigating the institution itself. Moreover, by comparing the ecclesiastical estate with the angelic sphere (the nobility with the sublunary sphere and the plebeians with the elements of earth), we can infer that by "angelic politics" he particularly meant the proper relationship of the religious vis-à-vis the political. In this sense, both the Epitome genealógico and Política angélica shared a proclivity to implicitly compare two competing Catholic confessional models, the French versus the Iberian. ${ }^{63}$

Unsurprisingly, Vila Real invoked Richelieu's successful policies with the Huguenot minority and celebrated his peaceful advancement of Catholicism in a religiously divided country. ${ }^{64} \mathrm{He}$ reminded his readers that the Cardinal founded a chair of polemics to lead disputations with Protestant leaders and theologians, on grounds that, "[ $\mathrm{t}]$ he smoothest means to establish the true religion in a kingdom suffering from a disgraceful division is debate." 65 While supporting Catholic education for adults and children, he rewarded leading converted Huguenots to Catholicism with public charges and honors. ${ }^{66}$ For

63 Without explicitly mentioning the Habsburgs, in "Luis dado de Dios," Enríquez Gómez made the following negative overall portrait, which accordingly will inevitably lead to the fall of the Spanish monarchy: "Que fin puede aguardar vn Reyno, que premia malsines, alimenta Cuadrillas de ladrones, como dice S. Agustin, destierra vasallos, deshonrra linajes, ensalza libelos, multiplica ministros, destruye el comerçio, ataxa la poblaçion, ama arbitrios, roba los pueblos, consifca bienes, hace juicios fecretos, no oye las partes, calla los testigos, vende noblezas, condena nobles, alienta gabelas, y aruina el derecho de las gentes: Bien puede floreçer por algún tiempo esta Monarchia, pero entender, que se puede conserbar entre las naçiones, no se yo si abra juiçio humano que lo diga? (Enríquez Gómez, Luis dado de Dios, 118-19).

64 According to Vila Real, Richelieu's: “[o]bligava a sus subditos con el exemplo, y reduzialos con la dotrina [... y] por no faltar en nada, al dever de un Perfecto Prelado, compuso una instruccion Cristiana, en que, con el candor de su virtud, más que con el adorno de la eloquencia, enseña todo lo que conviene a la salud del Alma" (Vila Real, Epítome genealógico, 35). In the preface of a tract written by Richelieu to persuade Protestants to "convert" to Catholicism, which was posthumously published in 1651, the Cardinal claimed that the idea of writing such a book was already conceived when he became the bishop of Luçon in 1606 (Armand-Jean du Plessis Cardinal duc de Richelieu, Oeuvres théologiques, tome II. Traité qui contient la méthode la plus facile et la plus assure pour convertir ceux qui se sont séparés de l'Église, ed. Stéphane-Marie Morgain and Françoise Hildesheimer [Paris: Honoré Champion, 2005], 99).

65 Vila Real, Epítome genealógico, 78.

66 Enriquez Gómez, Política angèlica, 114-15, 138-42. 
Enríquez Gómez, this integrative policy contrasted with the stagnant situation of the conversos in Iberian lands. Accordingly, whereas Richelieu was consistent with Christian values, the segregation of New Christians according to "laws of purity of blood" was unchristian, because it contravened the hospitality of the Bible (e.g., Exodus 11:22), the call to enforce Judaeo-Gentile fraternity in Paul's Epistles, and the positive papal attitude vis-à-vis converted neophytes (such as Nicholas V's condemnation of converso segregation in Toledo in 1499). ${ }^{67}$ Gallicanism thus appears as more authentically Catholic than its Iberian counterpart. Moreover, a comparison of the French and the Iberian experiences not only show that, "to try to reduce the faith of the subjects with violence or severity, even by vanquishing and subjecting them, cannot suppress their opinions [...]." Vila Real and Enríquez Gómez opined that such abuse at the hands of religious power is self-injurious, since "[w]hen a subject knows that he is subdued by taking from him his belongings, he understands that this behavior proceeds from greed and not from charity."68 The Holy Office and the "laws of purity of blood" appear in both books as the worst enemies of the Gospel, for being antithetic, useless, and noxious. In other words, not only was the biased Inquisition a paradoxical "factory of Jews" for pressing many innocent New Christians to confess heretical Jewish behavior to escape harsher punishment, as claimed the Jesuit pro-converso Father António Vieira. ${ }^{69}$ It also teaches actual and potential victims to regard Catholic institutions with cynical contempt and disenchanted eyes. In light of these observations, Vila Real and Enríquez Gómez called for the adoption in Iberia of a minimal dose of freedom of conscience after the example of Richelieu's success in multi-confessional France, since, " $[\mathrm{n}]$ ot all the human hearts are tied by one religion, one loyalty or one faith. Provided only the religion of the prince will be kept and observed in public; families should not be ruined only by signs of envy."70

Let us note, however, that the analogy between French Huguenots and Iberian conversos was not accurate. It is true that much like Iberian New Christians, Huguenots became a disarmed community after the Peace of Alais

67 Ibid., 115; Révah, "Un pamphlet," 140-43.

68 Implicitly, Vila Real criticized the Inquisition's biased machinery: "porque que cosa no ay menos conforme a la rason que querer haser de complisses Profetas, y de delictos enigmas; que por un yerro del entendimiento se castigue la hazienda, no la propia sino la agena, la de su Muger, la de sus hijos que no son culplados. Es apetecer antes riquezas que desear enmienda" (Vila Real, Epitome genealógico, 77-78).

69 António José Saraiva, The Marrano Factory: The Portuguese Inquisition and Its New Christians, $1536-1765$, trans., revised and augmented by H.P. Salomon and I.S.D. Sassoon (Leiden: Brill, 2001), esp. 66-83.

Vila Real, Epitome genealógico, 126; Enriquez Gómez, Política angèlica, 146. 
of 1629, in which they lost their military force and strongholds granted by the Edict of Nantes (as a consequence of Richelieu's successful besiegement of La Rochelle in repression of a Protestant rebellion). At the same time, neither Vila Real nor Enríquez Gómez mentioned the fact that French Protestants retained the right of public worship in many regions, contrasting with the humbler demands to grant freedom of private belief to the New Christian Iberian population..$^{71}$ Hence, the depiction of a tolerated hidden religious community better fitted the actual situation of conversos living in France. It must be borne in mind, however, that such comparison was not new. Already in 1619, the Spanish pro-converso arbitrista Martín González de Cellorigo did much the same. ${ }^{72}$ I think that a contrived analogy between Iberian conversos and French Huguenots aimed to stress the urgency of a full integration for the former, in order to avoid the explosive unrest caused by the latter in France's recent past. Without speaking of civil war, Vila Real and Enríquez Gómez still argued that converso bashing profoundly damaged the socio-economic structures of Iberia, especially Portugal. For, instead of rewarding the ablest among them and reinforcing international commerce and the navy, as Richelieu did in France, the persecution and exclusion of the converso "men of the nation" was economically and demographically disastrous for the country. ${ }^{73}$ Furthermore, the catastrophic consequences of the recent expulsion of the hard-working Morisco minority from Spain, was invoked by Vila Real and Enríquez Gómez as a warning. ${ }^{74}$ Perhaps, paraphrasing the converso arbitrista Duarte Nunes Solis,

71 Menna Prestwich, "The Huguenots under Richelieu and Mazarin, 1629-1661: A Golden Age?" in Huguenots in Britain and their French Background 1550-180o (Basingstoke: Macmillan, 1987), 75-197; Philippe Chareyre, "Trente ans après: de la paix à la grâce: lédit de Nîmes, juillet 1629," in Paix de armes, paix des âmes, 867-89.

72 Claude B. Stuczynski, "Harmonizing Identities: The Problem of Integration of the Portuguese Conversos in Early Modern Iberian Corporate Politics," Jewish History 25 (2011): 229-57.

73 Vila Real, Epitome genealógico, 126. "Anadió coronas à su Corona con la fuerça de sus Armadas, su conservacion consiste en la misma fuerça. Enriqueció sus vassallos con la libertad del Comercio, mientras pues faboreciere a los que le exercitan, durará e aumento de sus riquesas." Ibid., 132; "[d]e las confiscaciones y deshonras de linajes, como habernos dicho, nacen otros danos mayores, como son el turbarse en primer lugar la Republica; pues, cesando el comercio y la poblacion, faltan las navegaciones y las manifacturas; sinm ellas, las rentas reales padecen quiebra, las alcabalas y derechos mueren; y cuando el Principe quiera proveer las armadas, no hallara sino los pastores del campo con quien hacer sus asientos." Révah, "Un pamphlet," 159.

74 Vila Real, Epítome genealógico, 103-7; Enriquez Gómez, Política angèlica, 149-50. The expulsion of the Moriscos from Spain was a major reference in the Iberian Peninsula in debates held around the conversos' fate. Cf. Juan Ignacio Pulido Serrano, "The Unexecuted Plans for the Eradication of Jewish Heresy in the Hispanic Monarchy and the Example 
Vila Real declared that since "[c]ommerce is one of the nerves of the Republic," companies of commerce should be supported by the Iberian monarchs. ${ }^{75}$ That said, whereas by the 1620 s Nunes Solis asked the Habsburg kings to restore Portugal's lost imperial grandeur of the time of King Manuel 1st, by reinvesting in Indian trade with the help of converso merchants, ${ }^{76}$ and Father Vieira was claiming that Portugal's imperial and missionizing vocation would be restored under the new Braganza's monarchs provided they call converso entrepreneurs to invest in the Company of Commerce of Brazil,77 Vila Real and Enríquez Gómez argued that this awaited revival would be implemented by adopting Richelieu's meritocratic Mercantilism. ${ }^{78}$ For the Cardinal understood that meritocracy was one of the main pillars of every enduring regime. ${ }^{79}$ Looking at both books from a converso apologetic perspective, it turns out that both the Epitome genealógico and the Política angélica were innovative in invoking the French model and conservative in elaborating on traditional Paulinian and Mercantilist pro-converso leitmotifs. ${ }^{80}$

of the Moriscos: The Thwarted Expulsion of the Judeoconversos," in The Expulsion of the Moriscos from Spain: A Mediterranean Diaspora, ed. Mercedes García Arenal and Gerard Wiegers (Leiden and Boston: Brill, 2014), 179-96.

75 E.g., "[...] nerbios de vn cuerpo mistico qual es el comercio" (Duarte Gomes Solis, Discursos sobre los comercios de las dos Indias, ed. Moses Bensabat Amzalak [Lisbon: Gráfica Lisbonense, 1943], 153,171. Gomes Solis compared merchants to the "eyes of the Republic" [ibid., 36]).

$7_{6}$ Claude B. Stuczynski, "Portuguese Conversos and the Manueline Imperial Idea: A Preliminary Study," Anais de História de Além-Mar 14 (2013): 45-61.

77 Charles R. Boxer, "Padre António Vieira, S.J., and the Institution of the Brazil Company in 1649," The Hispanic American Historical Review 29 (1949): 397-403.

78 Vila Real, Epitome genealógico, 139. According to Enríquez Gómez: “[...] el Principe que quisiere ver su monarquia prospera, no deshonre los vasallos con libelos infamatorios; antes, a los que se reducieren a la ley del Principe debe honrar y a los hijos en mayor grado, dandoles (si son capaces por su juicio y virtud) oficios nobles en la Republica; pues, con ellos, se levantan los animos a grandes acciones, y a la segunda o tercera generacion, vendran a ser honra ilustre del Imperio. De este gobierno se valio el justo y cristianisimo Rey de Francia Luis XIII, por consejo del Eminente Cardenal Richelieu, el mayor Ministro de Estado que tuvo el orbe, admitiendo en honores publicos a todos aquellos que de la contraria religion se volviesen hijos de la Iglesia: no solo a los hijos que no pecaron, sino a los mismos padres que publicamente observaban la contraria." Révah, "Un pamphlet," 158.

79 "Este prudentisimo Cardenal, gloria de la Francia, conocio que el Imperio adonde se excluia de honor a los vasallos, se habia de perder, como lo sintieron todos los graves politicos." Ibid.

8o Claude B. Stuczynski, "Converso Paulinism and Residual Jewishness: Conversion from Judaism to Christianity as a Theological-Political Problem," in Bastards and Believers: Converts and Conversion between Judaism and Christianity, ed. Pawel Maciejko and Theodore Dunkelgrün (Philadelphia: University of Pennsylvania Press, forthcoming). 
Scholars who have studied Vila Real's and Enríquez Gómez's political views have rightly identified in their writings a political proclivity for French absolutism. ${ }^{81}$ I will argue that these centralistic penchants are intimately intertwined with their confessional aspirations. As mentioned before, Enríquez Gómez claimed an affinity between God's government and the king's politics, in terms of analogy (e.g., God governs the angelical, celestial, and material domains, whereas the king rules over his three Estates: the Church, the Nobility, and the People), emanation (e.g., of the spiritual into the earthly spheres), legitimation (i.e., monarchs are designed by God and are only responsible before Him), and imitation (e.g., monarchs must follow God's teachings and example).$^{82}$ At the same time, a fundamental split occurs in the created world between matter and spirit, leading to a separation between the domain of Caesar and that of God. As a consequence of this duality, the political sphere is separated from the spiritual domain located in human conscience. Therefore, "as human beings, kings have the power over actions of life, by punishing bodies; but they did not receive from the Creator any right upon the souls and freedom of will." 83 The same hold true with respect to the Church. Being God's representatives on earth, members of the clergy must be released from any material consideration. ${ }^{84}$ For, when each member of the mystical body is satisfied with its deserved role ("cada uno esta contento con su imperio"), the king as the head and the Church as the soul, a harmonious "angelical politics" is established. ${ }^{85}$ Elaborating upon Augustine's City of God, Enríquez Gómez explained that the original sin happened when Adam, "the first statesman and

81 By arguing that public religious sins committed by the prince are only to be reprehended secretly and never publicly (Enríquez Gómez, Política angélica, 74), Enríquez Gómez was perhaps reminding the role of the personal confessors of French Kings, which in this sense was different to the more pedagogic task of the Spanish royal confessors (cf. Nicole Reinhardt, Voices of Conscience: Royal Confessors and Political Counsel in SeventeenthCentury Spain and France [Oxford: Oxford University Press, 2016]).

82 Enríquez Gómez, Política angélica, 3-5. "Philonio: Pues que politica en potencia le conviene tener al Principe en el estado? Theogonio: La que tiene Dios con los Angeles." Ibid., 17. Enríquez Gómez also compares the prince with the sun, whose rays, understood as his ministers, give the light to his realm (ibid., 24).

83 "[L]os Reyes como criaturas humanas tienen poder en las acciones de la vida, castigando los cuerpos; pero, sobre las almas y libre albedrio ningun poder les concedio el Criador." Révah, "Un pamphlet," 117.

84 Enríquez Gómez, Política angélica, 40.

85 Ibid., 45 . 
politician of grace lost it, for turning religion into [a matter of] State." ${ }^{\prime 6}$ Other episodes of the Bible supported the claim that (d)evil emerges on earth when the primordial division between the political and the spiritual is transgressed. Thus, the sin committed by the sons of Aaron the priest, Nadav and Avihu, by offering a "strange fire before the Lord, which he commanded them not" (Leviticus 10:1), was interpreted as the intrusion of non-spiritual considerations into the divine. ${ }^{87}$ By adducing these examples, Enríquez Gómez argued against the opinion held by "many political thinkers" (muchos politicos) such as Machiavelli, "who claim that the prince can make of religion a matter of state $[. .$.$] in order to preserve his dominion." At the same time, this intrusion is$ precisely what characterizes the "diabolical politics" in the Iberian Peninsula. ${ }^{88}$ This theological and juridical infringement led Vila Real and Enríquez Gómez to recall the basic Christian right of freedom of conscience, for being the domain of God, while asking conversos to publicly conform to the policies endorsed by the prince, including in religion. By claiming that such principles were inferred from Richelieu's political wisdom, Vila Real was referring to that Gallican juridical tradition of separating the foro externo from the foro interno. That said, I will argue that Vila Real's and Enríquez Gómez's main literary and ideological source was probably Lipsius's Six Books of Politics, or Political Instruction (Politica sive civilis doctrinae libri VI qui ad principatum maxime spectant, 1589). Addressed to "the Emperor, the Kings and the Princes," this book of governance was translated into several languages, including Spanish and French. In Book 4 (of which, predictably, chapters 3, 4, and 13, were deleted by the Spanish "Index of Forbidden Books" of 1612), Lipsius treated the two types of civic prudence of the Prince: human and religious. ${ }^{89}$ Concerning the latter, he argued that social peace and political unity is achieved by allowing in public only the prince's religion. Overt religious diversity will necessarily lead to civil strife, as shown in the religious bloodshed in Europe. Having no juridical rights over sacred matters, the prince should also take in mind the words of the Roman historian Quintus Curtius Rufus: "no King can control

86 "Adan primer estadista y politico de la Gracia la perdio por hazer estado la Religion." Ibid., 42.

87 Enríquez Gómez, Política angélica, 32-34.

88 Ibid., 39, 41.

89 Lipsius, Politica: Six Books of Politics or Political Instruction, 4.2, 387. Both the Latin and the Spanish translation of Lipsius's Politica-i.e., Seis Libros de las Políticas o Doctrina civil, traducidos al castellano por D. Bernardino de Mendoza (Madrid: Imprenta Real, 1604) were also expurgated in 1632 and in 1640. Cf. Jesús Martínez de Bujanda, El Índice de Libros Prohibidos y Expurgados de la Inquisición Española (1551-1819): evolución y contenido (Madrid: Biblioteca de Autores Cristianos, 2016), 101-2, 742. 
hearts as much as he can control tongues." The intrusion of the political into the domain of conscience is both illegal and chimeric. ${ }^{90}$ Therefore, Lipsius distinguished two sorts of religious dissenters: the overt and the hidden..${ }^{91}$ On the one hand, public heretics deserved to be severely punished by the prince for harming civic unity. On the other hand, in chapters 3 and 4 , he suggested that those who keep their "erroneous" beliefs within the private domain of conscience, while externally conform to the prince's religion, should be tolerated. They will progressively change their minds through patient admonition and education. By comparing the Prince to a music player-which was an early modern methaphoric leit-motif-Lipsius reminded that: "[i]f strings are out of tune, you don't tear them out of anger, but step by step bring them back in harmony." Only in this way the Prince will fulfill the Gospel: to make "the multitude of believers have one heart and one mind" (Acts 4:32)..$^{92}$ In chapter 13 Lipsius even approved the fact that the Prince should use "a bit of the sediment of deceit" to virtuously rule his subjects, since human beings are often cunning and bad. Therefore, a seeming policy of religious toleration employed as a deceitful means to obtain gradual religious homogeneity appeared to Lipsius as honorable and useful. ${ }^{93}$ Following Lipsius, Vila Real and Enríquez Gómez acknowledged the political harm caused by public religious deviance, but commended the help given by Richelieu to "heretical" Protestants outside France, on grounds that international alliances belonged to the political domain of the "Law of Nations" (Ius Gentium). ${ }^{94}$ For the same reason, Vila Real endorsed Richelieu's prohibition of Roberto Bellarmino's Tractatus de potestate Summi Pontificis in rebus temporalibus, adversus Gulielmum Barclay (1610), for granting the Pope indirect power ("potestas indirecta") over secular affairs, thus encouraging sedition and political unrest. ${ }^{95}$ French absolutism was one of Janus's faces of Gallican confessionalism.

In fact, these views were also related to a well-established tradition of French skepticism promoted by Michel de Montaigne on the necessity of adhering to norms dictated by the public sphere (au dehors) while maintaining

\footnotetext{
90 Lipsius, Politica: Six Books of Politics or Political Instruction, 4.4, 395.

91 Ibid., 4.3, 391.

92 Ibid., 4.4, 397. On the historical conditions which explains the dissemination of the analogy between the political ruler and the music player in early modern times, see: Ruth HaCohen and Yaron Ezrahi, Composing Power, Singing Freedom: Overt and Covert Links between Music and Politics in the West (Tel Aviv: Van Leer Institute Press-Hakibbutz Hameuchad Publishing House, 2017), 26-97 [Hebrew].

93 Ibid., 4.13, 507.

94 Vila Real, Epitome genealógico, 115; Enríquez Gómez, Política angélica, 51-54.

95 Vila Real, Epitome genealógico, 135-36.
} 
freedom of thinking within the inner-self (au dedans). ${ }^{96}$ Pierre Charron's $O f$ Wisdom (De la sagesse, 1601), a committed follower of Montaigne and an enthusiastic reader of Lipsius, further elaborated on this distinction. Accordingly, political obeisance must never be confused with inner truth or justice, even if public accommodation stems from the simple wish to live wisely in peace. ${ }^{97}$ Charron's views contributed to the development of concealed forms of doubt and unbelief and the crystallization of erudite forms of libertinism in seventeenth-century France. ${ }^{98}$ One of these libertine savants was François de La Mothe Le Vayer, a supporter of Richelieu and a notorious anti-Spaniard. ${ }^{99}$ In his De la contrariété d'humeurs qui se trouve entre certaines nations, et singulièrement entre la Française et l'Espagnole, ou De l'antipathie des Français et des Espagnols (1636), he responded to Spanish criticism against France's toleration of Huguenots and political alliances made with Protestant princes by arguing that these were more appropriate ways to advance Catholicism than the Iberian hypocritical mode. He recalled Machiavelli's explanation of the expulsion of the Jews from Spain in 1492 in chapter 21 of The Prince. Purportedly grounded on religious zeal, it stemmed from purely political motivations ("ne pouvoient pas avoir d'autre fondement que la consideration d'Estat"). As proof of this ruse, he noted that many Catholic princes, including the Pope, accepted

96 Anna Maria Battista, Politica e morale nella Francia dell'età Moderna, ed. Anna Maria Lazzarino Del Grosso (Genoa: Name, 1998), 251-91.

97 In the second chapter of the second book of Of Wisdom titled: "An universal and plain liberty of spirit, both in Judgement and Will, the second disposition to Wisdom," Charron argued: "[f]or I will that in all outward and common actions of our life, and in whatsoever is ordinarily used, a man should agree and accommodate himself to the common sort; for our rule extendeth not itself to that which is outward, and to the action, but to that which is within, the thought, and secret of and inward judgement" (Pierre Charron, Of Wisdom: Three Books; Made English by George Stanhope from the Best Edition, Corrected and Enlarged by the Author a Little Before his Death [London: Printed for M. Gillyflower, 1697], 217). Cf. Domenico Taranto, Pirronismo e assolutismo nella Francia del'6oo. Studi sul pensiero politico dello scetticismo da Montaigne a Bayle (1580-1697) (Milan: Franco Angeli, 1994), 63-105.

98 French Libertines generally supported absolutist regimes and endorsed dissimulation as a way of living separated from the mob. See René Pintard, Le Libertinage érudit dans la première moitié du XVII ème siècle. Nouvelle édition augmentée d'un avant-propos et de notes et réflexions sur les problèmes de l'histoire du libertinage (Geneva and Paris: Slatkine, 1983), 539-64; Jean-Pierre Cavaillè, Dis/simulations. Jules-César Vanini, François La Mothe Le Vayer, Gabriel Naudé, Louis Machon et Torquato Accetto: religion, morale et politique au $X V I I^{e}$ siècle (Paris: Honorè Champion, 2002).

99 On La Mothe Le Vayer's pro-Richelieu, libertine and anti-Spanish views see Taranto, Pirronismo ed assolutismo nella Francia del'6oo. Studi sul pensiero politico dello scetticismo da Montaigne a Bayle (1580-1697), 107-29; François de La Mothe Le Vayer, Dialogues faits à l'imitation des Anciens, ed. Bruno Roche (Paris: Honoré Champion, 2015), 12-17. 
Jews in their domains. ${ }^{100}$ Moreover, he labelled the Spanish Inquisition an impious mockery against God and men (“[...] c'est vouloir avec impieté prendre Dieu pour crédule aussi bien que les hommes") which was inefficacious, for everybody knows that converso Judaizers, Moriscos, as well as heterodox alumbrados still prosper in Iberia (sic!) ${ }^{101}$ Quoting Lactance's Divine Institutes (book 5, chapter 19), La Mothe Le Vayer encapsulated the reason for Spain's confessional failure: "when religion is imposed it ceases to be religious." ${ }^{102}$ Vila Real and Enríquez Gómez were probably acquainted with such libertine voices. However, it ought to be kept in mind that almost every early modern political thinker was aware that religion was (also) a serious political matter. Thus, the Spanish diplomat and writer Diego de Saavedra Fajardo grounded his defense of Spain's religious homogeneity on such premises. ${ }^{103}$ Moreover,

100 François de La Mothe Le Vayer, "De la contrariété d'humeurs qui se trouve entre certaines nations, et singulièrement entre la Française et l'Espagnole, ou De l'antipathie des Français et des Espagnols," in Oeuvres de François de La Mothe Le Vayer, Tome 2 (Paris: Louis Billaine, 1669), 22-23. In the posthumously published pamphlet: En quoi la piété des François diffère de celle des Espagnols, dans une profession de même Religion, he similarly argued: “[...] car de vouloir faire passer pour oeuvres de pieté de grandes expulsions, tantost des Juifs, \& tantost des Morisques, hors de l'Espagne, c'est se moquer de Dieu \& du Monde; où personne n'a ignoré qu'il n'y eust plus de crainte, d'avarice \& d'inhumanité en tout cela, que de Religion, qui souffre les Juifs dans Rome, \& en assez d'autres lieux trés Catholiques" (117).

101 "Il n'y a donc pas beaucoup de quoi les Espagnols se puissant vanter d'avoir tant exterminé de creatures humaines sous un faux pretexte de Religion, comme ils n'ont pas non plus grand sujet de vouloir passer pour bien meilleurs Chréstiens que les autres, n'y ayant pas cent cinquant ans que le Mahumetisme \& l'infidelité possedoient encore les plus considerable parties de l'Espagne. Aussi que nonobstant ce zele inconsideré des nouveaux Chrétiens, ou plustost cette precaution craintive \& ordinaire aux Conquerans, chacun sçait qu'il n'y a pas moins des Maranes, d'Alumbrados, de Juifs, \& des Mahometans secrets en Espagne, qu'il peut avoir de Huguenots reconnus, \& par consequent moins à craindre dans la France." Idem, "De la contrariété d'humeurs qui se trouve entre certaines nations, et singulièrement entre la Française et l'Espagnole," 22-23, 24-25.

102 Ibid., 24.

103 E.g., "Aunque (como hemos dicho) la justicia armada con las leyes, con el premio y castigo, son las colunas que sustentan el edificio de la república, serían colunas en el aire si no se asentasen sobre la base de la religión, que es el vínculo de las leyes [...] tan necesario es en las repúblicas este temor, que a muchos impíos pareció invencióm política la religión. [...] El pueblo se dividirá en opiniones, la diversidad dellas desunirá los ánimos, de donde nacerán las sediciones y conspiraciones, y dellas las mudanzas de repúblicas y dominios. Mas píncipes vemos despojados por las opiniones diversas de religión que por las armas. Por resto el Concilio Toletano sesto ordenó que a ninguno se diese posesión de la corona si no hubiese jurado primero que no permitiría en el reino quien no fuese cristiano. [...] Si tal ficción es arte política para unir los ánimos y mantener la república, mejor se alcanzará con la verdadera religión que con la falsa, porque ésta es caduca y aquella eternamente durable." Diego de Saavedra y Fajardo, Empresas políticas, ed. Sagrario López Poza (Madrid: Cátedra, 1999), 388-9o. "La religión, si bien es vínculo de república (como 
according to Giovanni Botero's The Reason of State (1589), an extremely influential book in Iberia, Christianity is the best means to govern, because through this specific religion the prince has access to his subjects' inner consciences. ${ }^{104}$ However, Saavedra Fajardo and Botero never intended to transform religion into a mere political tool, nor did Lipsius, Montaigne, or Charron. Richelieu, who was deeply influenced by these writers, promoted religious unity in his country while upholding Catholic truth. ${ }^{105}$ By adhering to the idea that faith depends upon personal conviction, he masterfully leveraged the political sphere as a way of indirectly influencing the inner sphere of his subjects' consciences. Richelieu was the very embodiment of the Gallican politique, and Vila Real and Enríquez Gómez followed closely in his footsteps. The former acknowledged that: " $t]$ here is no more harmful thing in a republic than religious diversity," because: "one always lives with suspicion, having the enemy inside (teniendo de las puertas adentro el enemigo). Many think that it is impossible to preserve the State in such diversity," he added, since: "this way of believing differently is a continuous reason to make rebellion [...]."106 Acutely aware of the dangerous potential of freedom of conscience, Richelieu appears as a model to be followed. Whereas the Cardinal violently suppressed the military power of the rebellious Huguenots in La Rochelle, he was lenient with his docile unarmed "heretical" subjects and advanced "sweet" means to convert the pacified

hemos dicho) es la que más la desune y reduce a varias formas de gobierno, cuando no es una sola, porque no puede haber concordia ni paz entre los que sienten diversamente de Dios. Pues si la diversidad en las costumbres y trajes hace opuestos a los ánimos, qué hará la inclinación y fidelidad al Autor de lo criado, y la rabia de los celos del entendimiento del modo de entender lo que tanto importa? La ruina de un Estado es la libertad de consciencia." Ibid., 708.

104 Giovanni Botero, The Reason of State, ed. P.J. and D.P. Waley (New Haven: Yale University Press, 1956), Book 2, chapter 16.

105 Jean Daniel Charron, The "Wisdom" of Pierre Charron. An Original and Orthodox Code of Morality (Chapel Hill: The University of North Carolina Press, 1960); Anna Maria Battista, Alle origini del pensiero politico libertino: Montaigne e Charron (Rome: Universita' degli Studi di Roma Istituto di Studi Storico-Politici della Facolta' di Scienze Politiche, 1966); William F. Church, Richelieu and Reason of State (Princeton, NJ: Princeton University Press, 1972), 75-78; Bergin, The Politics of Religion in Early Modern France, 124-32.

106 Vila Real, Epitome genealógico, 100-1. Acknowledging the difference between the spiritual and the material spheres, Enríquez Gómez pleaded for a convergence between the two ("todo el grave peso de una Monarquia consiste en la Religion, y toda la conservacion del Estado consiste en que la Religion se conserve intacta y sin mancha alguna. La fe pide pureza de animo, el Reino conformidad de corazones"). Heresy disturbs political and religious tranquility but it is inevitable ("[p]ero, como no hay cuerpo sin humores ni materia sin dolor, asi es fuerza que, por pecados del pueblo, se levanten hereticas opiniones que turben la paz del espiritu y traigan en perpetuo desasosiego el estado espiritual y temporal" [Révah, "Un pamphlet," 119]). The task of the prince is to remediate this impasse with justice and moderation. 
Huguenot community. Without abrogating the Edict of Nantes, Richelieu aimed to progressively obtain the unity of the Catholic faith, so crucial to political stability and spiritual salvation. Vila Real and Enríquez Gómez probably paraphrased Lipsius, personally experienced the foro interno/foro externo juridical tradition when living in France, and perhaps they were acquainted with libertine views, but they openly embraced Richelieu's Catholic-politique sense of confessional "prudence." "Richelieu in Marrano Garb": Meaning and Implication

Moreover, both Enriquez Gómez and Vila Real followed almost verbatim the anti-Spanish propaganda then propagated by Richelieu and his advocates, in which the cruelties and corruption of the Inquisition represented a perfidious way of using religious piety to obtain political and economic gains. "In my opinion," repeated Enríquez Gómez ad nauseam, "the worse crimes are committed under the cloak of religion." 107 Therefore, the real Machiavellians are not the French politiques, as the Spanish claimed, but the Spaniard devotees. In the words of Paul Hay Du Chastelet, one of Richelieu's partisan writers, in Spain: "the religious appearance greatly serves the case of the princes" (Lapparence de religion sert grandement aux affaires des Princes). ${ }^{108}$ Seventeenth-century French political discourse was polemically constructed vis-à-vis the Spanish and vice versa. ${ }^{109}$ Attacks against the Iberian Inquisitions, then, were neither solely a converso obsession nor mere episodic outbursts of anti-Spanish feeling. Such belligerence was one of the major ways of distinguishing the French from the Iberians. Paradoxically, then, when the time came to offer concrete solutions, neither Enríquez Goméz nor Vila Real asked for the complete abrogation of the Holy Office. Rather, they sought to transform this well-established Iberian institution, while insisting on friendlier ways to correct and convert heretics. ${ }^{110}$ Even if they were inspired by an idealized image of Richelieu's

107 "[P]or que a mi ver los mayores delitos que se cometen, es con capa de Religion" (Enríquez Gómez, Política angélica, 102).

108 Quoted by Etienne Thuau, Raison d'État et pensée politique à l'époque de Richelieu (Paris: Armand Colin, 1966), 294.

109 Henry Méchoulan, "L'Espagne dans le miroir des textes français," in L'Etat baroque, 42146; Jean-Frédéric Schaub, La France espagnole. Les racines hispaniques de l'absolutisme français (Paris: Éditions du Seuil, 2003). María Soledad Arredondo, Literatura y propaganda en tiempo de Quevedo: guerras y plumas contra Francia, Cataluña y Portugal (Madrid: Vervuert, 2011), esp. 92-109.

110 Stefania Pastore, "A proposito di Matteo 18, 15: 'Correctio fraterna' e Inquisizione nella Spagna del Cinquecento," Rivista Storica Italiana 113 (2001): 323-68. 
Catholic evangelization of the Huguenots, Vila Real and Enríquez Gómez called to implement the peaceful missionary methods employed by Jesuits with "heathens" in distant colonial lands for the New Christians living in Portugal, much as Father Vieira was then striving to do. ${ }^{111}$ In doing so, they propagated an old pro-converso aspiration: that New Christians should be converted by the word and not by the sword. Enríquez Gómez suggested that tribunals of the Holy Office will be led by three members of the clergy (a Jesuit, a Capuchin, and a secular priest) carefully chosen by the king. Only after being secretly admonished and pardoned twice, "stubborn heretics" will be judged publicly, without employing anymore anonymous denunciations, confiscation of property, or secret and unlimited stays in prison. Those found hopelessly guilty will be punished to death without mercy (only the king could exceptionally change the sentence with exile). ${ }^{112}$ During the Habsburg dynastical period (1578-1640) pro-converso elements in Portugal sought to reform the biased Inquisition after the more reliable Castilian model and under Braganza's dynastical "restoration," this was permuted by invoking the Roman Holy Office. ${ }^{13}$ Vila Real and Enríquez Gómez called to combine the French confessional experience (e.g., the "Burning Chamber") and the old evangelical tradition of "fraternal emendation" (correctio fraterna) after Matthew 18:15, with the Iberian overseas ideal of evangelization (e.g., the Jesuits). ${ }^{114}$ Such creative adaptations wonderfully encapsulate what I meant by "Richelieu in Marrano garb."

Finally, I will briefly argue against those scholars who insist on the hierocratic-sacred character of the French monarchy, as portrayed by Vila Real and Enríquez Gómez. It is true that in the latter's Luis dado de Dios (1645), the French king was depicted as the embodiment of the ideal biblical monarch. ${ }^{115}$ The title of Politica angélica is highly telling in this respect. However, like most French political thinkers, at least until Jacques-Bénigne Bossuet, the divine nature

111 Révah, "Un pamphlet," 152-53. E.g., António Vieira, Escritos sobre os Judeus e a Inquisição, ed. José Eduardo Franco and Pedro Calafate (Lisbon: Temas e Debates, 2015), 31-46.

112 Révah, "Un pamphlet," 162-68.

113 Ana Isabel Lopez-Salazar Codes, "'Che si riduca al modo di procedere di Castiglia.' El debate sobre el procedimiento de inquisitorial portugués en tiempos de los Austrias," Hispania Sacra 59 (2007): 243-68.

114 Pastore, "A proposito di Matteo 18, 15"; idem, Il Vangelo e la spada. L'Inquisizione di Castiglia e i suoi critici (1460-1598) (Rome: Edizioni di Storia e Letteratura, 2003), 214-18.

115 "La Competencia en el estado, fue siempre causa de fatales ruynas, por que donde falta la vnion falta la virtud, y faltando ella sobra el odio, ydra tan dificultosa de cortar sus cabeças, como lo es querer retroceder el cursode la naturaleza: El inferior quando se ve faboreçido, no respeta al superior, y es yndigna acción del poder, conçeder esta licençia al subito. Raçon de estado sera anteponer lo Soberano al valimento, no dando lugar á que se quexe el monte, de la Soberanía del valle" (Enríquez Gómez, Luis dado de Dios, 44-45). 
of kings served more as a juridical starting point than as a modus operandi. ${ }^{116}$ Already in Luis dado de Dios, the good monarch was defined as a prince who firmly governs his kingdom with justice and disinterested piety. Whereas a strong and unrestrained government is a tyranny, a weak prince who is led by a divided Court and disobedient society cannot ensure those moral and religious values. A limited idea of sovereignty can be detected throughout Vila Real's and Enríquez Gómez's writings, as a means to solve the converso problem of integration. It is unsurprising if Enríquez Gómez commented on the same emblem of "Alliances" from Andrea Alciato's Book of Emblems (first edition, 1531), which was previously invoked by the pro-converso Cellorigo. ${ }^{117}$ Both authors chose to illustrate Bodin's sense of royal sovereignty by using Alciato's image of the prince as a lute-player and the strings as the different estates of the kingdom. ${ }^{118}$ That said, whereas Cellorigo claimed that the string of the plebeian "third estate" artificially created a New Christian string-less estate from hatred and envy, Enríquez Gomez argued that the too-dominant and intruding string of the clergy destroyed the entire musical instrument. ${ }^{119}$ In order to solve the converso problem in a disharmonious society, the king must firmly intervene: as a lute player, according to Cellorigo, and as a lute-maker, according to

116 Nicholas Henshall, The Myth of Absolutism: Change and Continuity in Early Modern European Monarchy (London: Longman, 1992); Richard Tuck, The Sleeping Sovereign: The Invention of Modern Democracy (New York: Cambridge University Press, 2015), chapter 1.

117 Stuczynski, "Harmonizing Identities: The Problem of Integration of the Portuguese Conversos in Early Modern Iberian Corporate Politics."

118 Much like the lute's strings, loyalty and trust in the lute player or sovereign are required from the subjects as the basis of political legitimacy: "[e]l edificio de la potencia ideal sera fundado sobre las fuertes columnas de la lealtad: las cuerdas de la republica haran perfecta la musica en el instrumento del gobierno, Porque siendo su verdadero Orpheo el Principe, la armonia de las vozes acudira al temple de su maestro" (Enríquez Gómez, Política angelica, 26-28). Cf. Enríquez Gómez, Luis dado de Dios, 45.

119 "De nuestra Politica Angelica quereis sacar el gobierno que debe tener el Principe Cristiano para castigar los delitos de religion; yo os dire los medios por donde se puede conseguir una ley justa y, para venir en conocimiento de ella, nos valdremos de aquel emblema del sabio Alciato que dice: 'El imperio ha de ser un istrumento templado.' Y los mejores escritores, o estadistas por mejor decir, quieren que sea de tres Ordenes Eclesiasticas, Nobles y Plebeyas; estas ha de tocar el Principe con tanta orden que cada una ocupe su lugar: la primera voz Eclesiastica suave, la segunda Noble grave, la tercera Plebeya baja, con cuya armonia andara el Imperio concertado; pero si la cuerda Eclesiastica sonare fuerte y la Noble baja y la Plebeya alta, ni el oido de la razon podra escuchalla ni la prudencia oilla. Asentada esta razon por basa de este edificio, decimos que si los Ministros Eclesiasticos subieren de punto el orden y tiraren la cuerda del estado espiritual, es fuerza que se han de llevar la puente y tapa del istrumento." Révah, “Un pamphlet," 161-62. 
Enríquez Gómez. ${ }^{120}$ I think that such differences in diagnosis and prognosis did not solely stem from a different interpretation of sovereignty after the political models employed by the two authors (the corporatist Habsburg model of Cellorigo vs. the more centralistic French of Enríquez Gómez). The rise of the Braganza royal dynasty, instead of the Habsburgs, aroused initial enthusiasm and expectation among pro-converso elements, including Vila Real and Enríquez Gómez. These believed that by adapting the French confessional model into the Iberian contexts the converso problem would finally be solved. Being "liberated" from the "tyrannical" Habsburgs, the Portuguese Braganza dynasty would receive from the powerful French military, economic, and diplomatic assistance and political inspiration. However, whereas French concrete help was insufficient, brief, and disappointing, the new, weak Portuguese monarchs could not overcome the power of the Holy Office and the anti-converso elements within the kingdom. Despite the protestations of the Inquisition and the clergy, the Luso-Dutch treaty (of 12 June 1641) enabled Dutchmen staying in Portugal to practice religious worship on the ships and in the homes of official emissaries and ambassadors, thus enlarging the inquisitorial immunity obtained by English traders in $1630 .{ }^{121}$ None of Vila Real's and Enríquez Gómez's suggestions could be fulfilled, despite support given by King John IV to obtain the integration of the New Christian group for economic and state-building reasons. Portugal's Holy Office was a powerful institution supported by most of the nobility, the clergy, and the "people" represented in the Parliament, because it was perceived as the ultimate defender of its most traditional sociopolitical and religious institutions. ${ }^{122}$ Mostly through Father Vieira's and Jesuit efforts, from 1649 to 1656 , the Inquisition temporarily suspended the confiscation of the detainee's belongings. ${ }^{123}$ However, no concession was given to conversos' rights of freedom of conscience as was pleaded by Vila Real and

120 In the first part of his Politica Angélica, Enríquez Gómez depicted Alciato's emblem in the following way: "Aplicó Alciato el gouierno, y Politica del Principe a un instrumento Templado; El que acuerda este instrumento es la sabiduria; si el Principe haze mas estimacion de vna cuerda, que de otra, subiendo de punto esta y bajando aquella, muy malsonará el instrumento, Peligrosa disonancia hará necessario es que con sabiduria fauoresca el merito, y con cordura castigue el delicto" (ibid., 95).

121 Ana Isabel López-Salazar Codes, "Puderão mais os inquisidores que o rey.' Las relaciones entre el Santo Oficio y la Corona en el Portugal de la Restauración (1640-1668)," Cuadernos de Historia Moderna 39 (2014): 143. Cf. Leslie M.E. Shaw, Trade, Inquisition and the English Nation in Portugal (Manchester: Carcanet, 1989).

122 Giuseppe Marcocci and José Pedro Paiva, História da Inquisição Portuguesa, 1536-1821 (Lisbon: A esfera dos Livros, 2013), 173-75.

123 Israël Salvator Révah, "Les Jésuites portugais contre l'Inquisition: la campagne pour la création de la Compagnie Générale du Commerce du Brésil," in Etudes portugaises, ed. 
Enríquez Gómez. As I have tried to show, "Richelieu in Marrano garb" required a major transformation of Iberian political structures and confessional policies. Without a "Portuguese Richelieu," a Gallican adaptation could never be implemented on Iberian soil.

In his edition of the second part of Enríquez Gómez's Política angélica, Révah argued that only questions related to "purity of blood" and the Inquisition "revealed an essential aspect of Marrano thought."124 Such a view accounts for his decision to privilege this section over the first part of the Politica angélica and Vila Real's Epitome genealógico. Burning questions, such as the confiscation of the detainee's belongings by the Holy Office, did stand at the center of pro-converso political agency at those historical moments. Even Vila Real confessed to the inquisitors to have written a tract on the subject. ${ }^{125}$ In this sense, Vila Real, Enríquez Gómez, Father Vieira, and other Jesuits and converso "men of the nation" living in Iberia or in the French Sephardic diaspora, were intimately interrelated. ${ }^{126}$ In this article, however, I aimed to reassess what the Portuguese writer Francisco Manuel de Melo ironically meant in his Hospital das Letras (1657), by calling Vila Real and Enríquez Gómez "two Portuguese grafted as French" (esses dous Portugueses enxertados em Galos) and "Gallicized political writers" (politicos franceses), through the fictional characters of "Quevedo," "Lipsius," and himself. ${ }^{127}$ I suggested that, along with other converso and pro-converso elements, such as New Christians living in late-sixteenth-century Bragança, Vila Real and Enríquez Gómez were highly selective, creative, and sophisticated thinkers of French and Iberian confessionalism. ${ }^{128}$ At the same time, their broad French-Gallican experiences and European confessional knowledge emerge as a major converso concern. Not satisfied to be merely "victims" of Iberian confessionalism, they became creative "agents" of French Gallicanism in the Iberian Peninsula. In doing so,

Charles Amiel (Paris: Centre Calouste Gulbenkian, 1975), 155-83; Marcocci and Paiva, História da Inquisição Portuguesa, 1536-1821, 185-86.

124 "Au fond, seul le Quatrieme Dialogue de cette première partie (pp. 106-153) révélait un aspect essentiel de la pensée du Marrane." Révah, "Un pamphlet," 91.

125 "Tambem escreveu por ordem do marquez de Niza uma memoria sobre a conveniencia de S.M. tirar o confisco aos culpados e presos pelo Santo-Officio, tanto de sus bens, como dos alheios que em seu poder tivessem, para assim se augmentar o comercio." Ramos Coelho, Manuel Fernandes Villa Real e o Seu Processo na Inquisição de Lisboa, $5^{2}$.

126 Natalia Muchnik, "Antonio Vieira y la diaspora sefardí en el siglo XVII," in António Vieira, Roma e o universalismo das monarquias portuguesa e espanhola, ed. Pedro Cardim and Gaetano Sabatini (Lisbon: Centro de História de Além-Mar, 2011), 97-119.

127 Quoted by Révah, "Un pamphlet," 87-88.

128 "Au fond, seul le Quatrieme Dialogue de cette première partie (pp. 106-153) révélait un aspect essentiel de la pensée du Marrane." Ibid., 91. 
they sought to contribute, in their own particular ways, to political and religious modernity.

\section{Bibliography}

Adam de la Parra, Juan. Apologetico contra el tirano y rebelde Verganza, y coniurados, arzobispo de Lisboa, y sus parciales: en respuesta a los doze fundamentos del padre Mascareñas. En Zaragoza: por Diego Dormer, 1642.

Adam de la Parra, Juan. Conspiración herético-cristianísima. Edited by Joaquín de Entrambasaguas. Madrid: Consejo Superior de Investigaciones Científicas, 1943.

Adam de la Parra, Juan. Pro cautione christiana, in supremis Senatibus Sanctae Inquisitionis, \& ordinum, ecclesia toletana, \& coetibus scholarium obseruata, adversus christianorum proselytos, \& sabbatizantes, nomine, \& specie christianorum. Madrid (?), 1630.

Albuquerque, Martim de. Jean Bodin na Peninsula Ibérica, Ensaio de Historia das Ideias Políticas e de Direito Pùblico. Paris: Fondation Calouste Gulbenkian, 1978.

Amzalak, Moses Bensabat. As relações diplomaticas entre Portugal e a França no reinado de D. João IV (1640-1656): documentos e notas. Lisbon, n.p. 1934.

Antón Martínez, Beatriz. "El humanista flamenco J. Lipsio y la receptio del Tacitismo en España." In Humanismo y pervivencia del mundo clásico: actas del I Simposio sobre Humanismo y pervivencia del mundo clásico (Alcañiz, 8 al 11 de mayo de 199o). Edited by José María Maestre Maestre and Joaquín Pascual Borea, 1: 237-50. Càdiz: Universidad de Cádiz, Servicio de Publicaciones, 1993.

Arquivos Nacionais/Torre do Tombo. Inquisição de Coimbra, processos ns. 484, 66o2, $7934,8798,8800,9269$.

Arredondo, María Soledad. Literatura y propaganda en tiempo de Quevedo: guerras y plumas contra Francia, Cataluña y Portugal. Madrid: Vervuert, 2011.

Baião, António. Episódios dramáticos da Inquisição portuguesa. Rio de Janeiro: Álvaro Pinto Editor, 1924.

Balasse, Céline. 1306. L'expulsion des juifs du royaume de France. Brussels: de Boeck, 2008.

Barbiche, Bernard. "LÉdit de Nantes et son enregistrement: génèse et publication d'une loi royal." In Paix de armes, paix des âmes, ed. Paul Mironneau and Isabelle Pébay-Clottes, 251-26. Paris: Imprimerie nationale, 2000.

Barreto, João Franco. Relação da embaixada a França em 1641, por João Franco Barreto. Reimpressa com noticias e documentos elucidativos por Carlos Roma Du Bocage e Edgar Prestage. Coimbra: Imprensa da Universidade, 1918.

Battista, Anna Maria. Alle origini del pensiero politico libertino: Montaigne e Charron. Rome: Universita degli Studi di Roma Istituto di Studi Storico-Politici della Facolta di Scienze Politiche, 1966. 
Battista, Anna Maria. Politica e morale nella Francia dell'età Modern. Edited by Anna Maria Lazzarino Del Grosso. Genoa: Name, 1998.

Bedos-Rezak, Brigitte. “Tolérance et raison d'État: le problème Juif." In L'Etat baroque. Textes réunis sous la direction d'Henry Méchoulan, étude préliminaire d'Emmanuel Le Roy Ladurie, préface de André Robinet, 243-87. Paris: Librairie philosophique J. Vrin, 1985.

Benedict, Philip. "The Huguenot Population of France, 160o-1685: The Demographic Fate and Customs of a Religious Minority." Transactions of the American Philosophical Society 81 (1991): 1-164.

Bergin, Joseph. The Politics of Religion in Early Modern France. New Haven and London: Yale University Press, 2014.

Bireley, Robert. The Counter Reformation Prince: Anti-Machiavellianism or Catholic Statecraft in Early Modern Europe. Chapel Hill and London: University of North Carolina Press, 1990.

Blamont, Jacques. Le lion et le moucheron. Histoire des Marranes de Toulouse. Paris: Odile Jacob, 2000.

Bodian, Miriam. "The Portuguese Jews in Amsterdam and the Language of Liberty." Journal of Levantine Studies 6 (2016): 313-32.

Bodin, Jean. Los seis libros de la republica de Ivan Bodino, traducidos de lengua Francesa, y enmendados catholicamente por Gaspar de Añastro Ysunza. Turin: Herederos de Bevilaqua, 1590.

Botero, Giovanni. The Reason of State. Edited by P.J. and D.P. Waley. New Haven: Yale University Press, 1956.

Boxer, Charles R. "Padre António Vieira, S.J., and the Institution of the Brazil Company in 1649." The Hispanic American Historical Review 29 (1949): 397-403.

Brambilla, Ellena. Alle origini del Sant'Uffizio. Penitenza, confessione e giustizia spirituale dal medioevo al XVI secolo. Bologna: Il Mulino, 2000.

Brambilla, Ellena. La giustizia intollerante. Inquisizione e tribunali confessionali in Europa (secoli $I V-X V I I I)$. Rome: Carocci, 2006.

Braun, Harald E. "Making the Canon? The Early Perception of the République in Castilian Political Thought." In The Reception of Bodin. Edited by Howell A. Lloyd, 257-92. Leiden: Brill, 2013.

Brazão, Eduardo. A diplomacia portuguesa nos séculos XVII e XVIII. Lisbon: Editorial Resistência, 1980.

Broens, Nicolás. Monarquía y capital mercantil: Felipe IV y las redes comerciales portuguesas (1627-1635). Madrid: Ediciones de la Universidad Autónoma de Madrid, 1989. Cavaillè, Jean-Pierre. Dis/simulations. Jules-César Vanini, François La Mothe Le Vayer, Gabriel Naudé, Louis Machon et Torquato Accetto: religion, morale et politique au XVII ${ }^{e}$ siècle. Paris: Honorè Champion, 2002. 
Chareyre, Philippe. "Démographie et minorités protestantes." Bulletin de la Société de l'Histoire du Protestantisme Français 148 (2002): 867-89.

Chareyre, Philippe. "Trente ans après: de la paix à la grâce: l'édit de Nîmes, juillet 1629." In Paix de armes, paix des âmes. Edited by Paul Mironneau and Isabelle PébayClottes, 867-89. Paris: Imprimerie nationale, 2000.

Charron, Pierre. Of Wisdom: Three Books; Made English by George Stanhope from the Best Edition, Corrected and Enlarged by the Author a Little Before his Death. London: Printed for M. Gillyflower, 1697.

Church, William F. Richelieu and Reason of State. Princeton, NJ: Princeton University Press, 1972.

Coelho, António Borges. "Manuel Fernandes Vila Real no discurso político dos primeiros anos da Restauração." In A união ibérica e o mundo atlântico. Edited by Maria da Graça A. Mateus Ventura, 285-306. Lisbon: Colibri, 1997.

Coelho, José Ramos. Manuel Fernandes Villa-Real e o seu processo na Inquisição de Lisboa. Lisbon: Empreza do Ocidente, 1894.

Cottret, Bernard. 1598, L'Édit de Nantes. Paris: Perrin, 1997.

Dahan, Gilbert, and Élie Nicolas, eds. L'expulsion des Juifs de France, 1394. Paris: Cerf, 2004.

De Paolis, Velasio. "Natura e funzione del foro interno." In Investigationes Theologicocanonicae. Edited by U. Navarrete, 115-42. Rome: Università Gregoriana Editrice, 1978.

Delgado, Iva. "Manuel Fernandes Vila Real, polemista da Restauração." Revista da Biblioteca Nacional 3 (1983): 27-46.

Delgado, João Pinto. Poema de la Reina Ester, Lamentaciones del Propheta Ieremias, Historia de Rut, y varias poesias. Rouen: chez David du Petit Val, imprimeur ordinaire du Roy, 1627.

Díez, J. Ignacio, and Carsten Wilke, eds. Antonio Enríquez Gómez. Un poeta entre santos y judaizantes. Kassel: Eva Reichenberger, 2015.

Domínguez Ortíz, Antonio. "Una obra desconocida de Adam de la Parra." Revista bibliográfica y documental 5 (1951): 97-115.

Du Plessis Cardinal duc de Richelieu, Armand-Jean. Oeuvres théologiques, tome II. Traité qui contient la méthode la plus facile et la plus assure pour convertir ceux qui se sont séparés de l'Église. Edited by Stéphane-Marie Morgain and Françoise Hildesheimer. Paris: Honoré Champion, 2005.

Elliott, John H. Richelieu and Olivares. Cambridge: Cambridge University Press, 1991.

Elliott, John H. The Count-Duke of Olivares. The Statesman in an Age of Decline. New Haven and London: Yale University Press, 1986.

Elliott, John H., and Laurence W.B. Brockliss, eds. The World of the Favorite. New Haven and London: Yale University Press, 1999. 
Enríquez Gómez, Antonio. La Inquisición de Lucifer y visita de todos los diablos. Critical Edition, Study and Notes by Constance Hubbard Rose and Maxim P.A.M. Kerkhof. Amsterdam-Atlanta, GA: Rodopi, 1982.

Enríquez Gómez, Antonio. Luis dado de Dios a Luisy Ana Samuel dado de Dios a Elcana y Ana. Paris: René Baudry, 1645 .

Enríquez Gómez, Antonio. Política angélica, primera parte dividida en 5. Dialogos. Rouen: L. Maurry, 1647.

Frattarelli Fischer, Lucia. Vivere fuori dal ghetto. Ebrei a Pisa e Livorno (secolo XVIXVIII). Turin: Silvio Zamorani Editore, 2008.

Galbarro García, Jaime. El 'Triumpho lusitano’ de Antonio Enríquez Gómez. Seville: Editoral Universidad de Sevilla, 2015.

Galbarro García, Jaime. “Manuel Fernández Villareal y la propaganda de la 'nação’ Portuguesa." Versants 60 (2013): 131-42.

Gambin, Felice. "Es doblar el vivir': La Política angelica entre escritura divina y satánica." In Antonio Enríquez Gómez. Un poeta entre santos y judaizantes. Edited by J. Ignacio Dìez and Carsten Wilke, 138-6o. Kassel: Eva Reichenberger, 2015.

Gendreau-Massaloux, Michèle, and Constance H. Rose. “António Enríquez Gómez et Manuel Fernandes de Villareal: deux destins parallèles, une vision politique commune." Revue des études juives 136 (1977): 368-87.

Gomes, João Pedro da Silva. “O 'Epítome genealógico' de M. Fernandes Vila Real e a 'Política angélica' de Antonio Enríquez Gómez: o pensamento político de dois cristãos-novos na década de 1640." Master's thesis, Universidade Nova de Lisboa, 2008.

Graizbord, David L. Souls in Dispute. Converso Identities in Iberia and the Jewish Diaspora, 1580-170o. Philadelphia: Pennsylvania University Press, 2004.

HaCohen, Ruth, and Yaron Ezrahi. Composing Power, Singing Freedom: Overt and Covert Links between Music and Politics in the West. Tel Aviv: Van Leer Institute PressHakibbutz Hameuchad Publishing House, 2017. [Hebrew.]

Henshall, Nicholas. The Myth of Absolutism: Change and Continuity in Early Modern European Monarchy. London: Longman, 1992.

Hildesheimer, Françoise. "Une créature de Richelieu: Alphonse Lopez, le 'Seigneur Hebreo'." In Les Juifs au regard de l'histoire. Mélanges en l'honneur de Bernhard Blumenkranz. Edited by Gilbert Dahan, 293-99. Paris: Picard, 1985.

Jordan, William Chester. The French Monarchy and the Jews: From Philip Augustus to the Last Capetians. Philadelphia: Pennsylvania University Press, 1989.

Jouhaud, Christian. "Religion and politics in France during the period of the Edict of Nantes." In Religious Differences in France: Past and Present. Edited by Kathleen P. Long, 73-9o. Kirksville, MO: Truman State University Press, 2006.

Kaplan, Benjamin J. Divided by Faith: Religious Conflict and the Practice of Toleration in Early Modern Europe. Cambridge, MA: Belknap Press of Harvard, 2007. 
Kaplan, Yosef. "Between Calvinists and Jews in Seventeenth-Century Amsterdam." In Conflict and Religious Conversation in Latin Christendom: Studies in Honor of Ora Limor. Edited by Ram Ben-Shalom and Israel J. Yuval, 289-9o. Brepols: Turnhout, 2014.

Kaplan, Yosef. "Wayward New Christians and Stubborn New Jews: The Shaping of a Jewish Identity." Jewish History 8 (1994): 27-41.

Kerkhof, Maximiliaan Paul Adriaan Maria. "La 'Ynquisiçion de Luzifer y uisita de todos los diablos.' Texto desconocido de Antonio Enríquez Gómez: edición de unos fragmentos." Sefarad 38 (1978): 319-31.

Kramer-Hellinx, Nechama. Antonio Enríquez Gómez: literatura y sociedad en El siglo pitagórico y Vida de don Gregorio Guadaña. New York: Peter Lang, 1992.

Kuttner, Stephan, "Ecclesia de occultis non iudicat. Problemata ex doctrina poenali decretistarum et decretalistarum a Gratiano usque ad Gregorium PP. IX." In Acta congressus iuridici internationalis, Romae 1934 - 3: 225-46. Rome: Libr. Pont. Institutis Utriusque Iuris, 1936.

La Mothe Le Vayer, François de. Dialogues faits à l'imitation des Anciens. Edited by Bruno Roche. Paris: Honoré Champion, 2015.

La Mothe Le Vayer, François de. Oeuvres de François de La Mothe Le Vayer. Tome 2. Paris: Louis Billaine, 1669 .

Leroy, Béatrice, ed. Les édits d'expulsion des juifs; 1394, 1492, 1496, 1501. Biarritz: Atlantica, 1998.

Lipsio, Giusto. La Constanza. Edited by Domenico Taranto. Naples: Bibliopolis, 2004.

Lipsius, Justus. Politica: Six Books of Politics or Political Instruction. Edited by Jan Waszink. Assen: Van Gorcum, 2004.

López-Salazar Codes, Ana Isabel. “'Che si riduca al modo di procedere di Castiglia.' El debate sobre el procedimiento de inquisitorial portugués en tiempos de los Austrias." Hispania Sacra 59 (2007): 243-68.

López-Salazar Codes, Ana Isabel. “Puderão mais os inquisidores que o rey.' Las relaciones entre el Santo Oficio y la Corona en el Portugal de la Restauración (1640-1668).” Cuadernos de Historia Moderna 39 (2014): 137-63.

López Belinchón, Bernardo J. “'Sacar la sustancia al reino,' Comercio, contrabando y conversos portugueses, 1621-1640." Hispania 61 (2001): 1017-50.

Luria, Keith T. Sacred Boundaries. Religious Co-existence and Conflict in Early Modern France. Washington, DC: The Catholic University of America Press, 2005.

Lynn, Kimberly. Between the Court and the Confessional. The Politics of Spanish Inquisitors. Cambridge: Cambridge University Press, 2013.

Malvezzi, Virgilio. Il Ritrato del Privato Politico Cristiano. Edited by Maria Luisa Doglio. Palermo: Sellerio editore, 1993.

Marcocci, Giuseppe and José Pedro Paiva. História da Inquisição Portuguesa, 1536-1821. Lisbon: A esfera dos livros, 2013. 
Martínez de Bujanda, Jesús. El Índice de Libros Prohibidos y Expurgados de la Inquisición Española (1551-1819): evolución y contenido. Madrid: Biblioteca de Autores Cristianos, 2016.

McGaha, Michael. "Antonio Enríquez Gómez and the Count-Duke of Olivares." Texto y espectáculo: nuevas dimensiones críticas de la "comedia." Edited by Arturo PérezPisonero and Ana Semidey, 47-54. El Paso: University of Texas, 1990.

McGaha, Michael. "Divine Absolutism vs. Angelical Constitutionalism: The Political Theories of Quevedo and Enríquez Gómez." In Studies in Honor of Bruce W. Wardropper. Edited by Dian Fox, Harry Sieber and Robert Ter Horst, 181-92. Newark, DE: Juan de la Cuesta, 1989.

Mea, Elvira Cunha de Azevedo. A Inquisição de Coimbra no século XVI: a Instituição, os Homens e a Sociedade. Porto: Fundação Engenheiro António de Almeida, 1997.

Méchoulan, Henry. "L'Espagne dans le miroir des textes français." In L'Etat baroque. Textes réunis sous la direction d'Henry Méchoulan, étude préliminaire d'Emmanuel Le Roy Ladurie, préface de André Robinet, 421-46. Paris: Librairie philosophique J. Vrin, 1985.

Méchoulan, Henry. "Manuel Fernandes Vila Real, un marrane en politique." Nova Renascença 67 (1998): 305-16.

Monter, William. Judging the French Reformation: Heresy Trials by Sixteenth-Century Parliaments. Cambridge, MA: Harvard University Press, 1999.

Muchnik, Natalia. “Antonio Vieira y la diaspora sefardí en el siglo XVII." In António Vieira, Roma e o universalismo das monarquias portuguesa e espanhola. Edited by Pedro Cardim and Gaetano Sabatini, 97-119. Lisbon: Centro de História de Além-Mar, 2011.

Muchnik, Natalia. "Du catholicisme des judéoconvers: Rouen, 1633." XVIIe siècle 231 (2006): 321-43.

Muchnik, Natalia. "Du judaïsme au catholicisme: les aléas de la foi au XVII e siècle." Revue Historique 623 (2002): 571-609.

Nahon, Gérard. “D’un singulier désir à la Loi du Dieu d'Israël: les nouveaux-chrétiens portugais en France XVI - XVIII e siècles." Arquivos do Centro Cultural Calouste Gulbenkian 48 (2004): 73-102.

Nahon, Gérard. "Exception française et réponse au modèle ibérique: Marie de Médicis et la 'Déclaration qui expulse les Juifs du Royaume de France' du 23 avril 1615." In L'expulsion des Juifs de Provence et de l'Europe méditerranéenne ( $X V^{e}-X V I^{e}$ siècles); exils et conversions. Edited by Danièle Iancu-Agou, 111-28. Paris and Leuven: Peeters, 2005.

Nahon, Gérard. "From New Christians to the Portuguese Jewish Nation in France." In Moreshet Sepharad; The Sephardi Legacy. Edited by Haim Beinart, 2: 336-364. 2 vols. Jerusalem: Magnes Press and The Hebrew University, 1992. 
Nahon, Gérard. "Le modèle français du marranisme: perspectives nouvelles." In Inquisição; ensaios sobre mentalidade, heresias e arte. Edited by Anita Novinsky and Maria Luiza Tucci Carneiro, 227-65. Rio de Janeiro: Expressão e Cultura, 1992.

Nahon, Gérard. Les “Nations” Juives Portugaises du sud-ouest de la France (1684-1791). Documents. Paris: Fundação Calouste Gulbenkian-Centro Cultural Português, 1981.

Nahon, Gérard. "Prospective des 'Portugais' du sud-ouest de la France à la veille de la Révolution." In Politique et religion dans le judä̈me moderne, des communautés à l'émancipation. Edited by Daniel Tollet, 85-104. Paris: Presses de l'Université de Paris-Sorbonne, 1987.

Nahon, Gérard. "The Sephardim of France." In The Sephardi Heritage; Essays on the History and Cultural Contribution of the Jews of Spain and Portugal. Edited by R.D. Barnett and W.M. Schwab, 2: 46-74. 2 vols. Grendon, Northamptonshire: Gibraltar Books, 1989 .

Nider, Valentina. “La doppia simulazione di Enríquez Gómez: 'La culpa del primer peregrino'." In Alle radici dell'Europa. Mori, guide e zingari del mediterraneo occidentale. Vol. 2. Secoli XVII-XIX. Edited by Felice Gambin, 195-210. Florence: Seid, 2010.

Oelman, Timothy. "The Religious Views of Antonio Enríquez Gómez: Profile of a Marrano." Bulletin of Hispanic Studies 41 (1983): 201-9.

Pastore, Stefania. "A proposito di Matteo 18, 15: 'Correctio fraterna' e Inquisizione nella Spagna del Cinquecento." Rivista Storica Italiana 113 (2001):323-68.

Pastore, Stefania. Il Vangelo e la spada. L'Inquisizione di Castiglia e i suoi critici (14601598). Rome: Edizioni di Storia e Letteratura, 2003.

Pintard, René. Le Libertinage érudit dans la première moitié du XVII ème siècle. Nouvelle édition augmentée d'un avant-propos et de notes et réflexions sur les problèmes de l'histoire du libertinage. Geneva and Paris: Slatkine, 1983.

Powis, Jonathan. "Gallican Liberties and the Politics of Later Sixteenth-Century France." The Historical Journal 26 (1983): 515-30.

Prestage, Edgar. The Diplomatic Relations of Portugal with France, England and Holland from 1640 to 1668 . Watford: Voss \& Michael, 1925.

Prestwich, Menna. "The Huguenots under Richelieu and Mazarin 1629-1661: A Golden Age?" In Huguenots in Britain and their French Background 1550-1800. 75-197. Basingstoke: Macmillan, 1987 .

Prodi, Paolo. Una storia della giustizia. Dal pluralismo dei fori al moderno dualismo tra coscienza e diritto. Bologna: Il Mulino, 2000.

Prosperi, Adriano. Tribunali della coscienza: Inquisitori, confessori, missionary. Turin: Einaudi, 1996.

Pulido Serrano, Juan Ignacio. "The Unexecuted Plans for the Eradication of Jewish Heresy in the Hispanic Monarchy and the Example of the Moriscos: The Thwarted 
Expulsion of the Judeoconversos." In The Expulsion of the Moriscos from Spain: A Mediterranean Diaspora. Edited by Mercedes García Arenal and Gerard Wiegers, 179-96. Leiden and Boston: Brill, 2014.

Ramírez, Alejandro. Epistolario de Justo Lipsio y los Españoles (1577-1606). Madrid: Castalia, 1966.

Reinhardt, Nicole. Voices of Conscience: Royal Confessors and Political Counsel in Seventeenth-Century Spain and France. Oxford: Oxford University Press, 2016.

Révah, Israël Salvator. Antonio Enríquez Gómez, un écrivain marrane (v. 16oo-1663).

Edited by Carsten L. Wilke. Paris: Chandeigne, 2003.

Révah, Israël Salvator. "Autobiographie d'un marrane. Édition partielle d'un manuscript de João (Moseh) Pinto Delgado." Révue des Études Juives 119 (1961): 41-130.

Révah, Israël Salvator. "Aux origines de la rupture spinozienne: nouvel examen des origines du déroulement et des consequences de l'affaire Spinoza-Prado-Ribera." Annuaire du Collège de France, 71 (1971): 574-89.

Révah, Israël Salvator. Le Cardinal de Richelieu et la restauration du Portugal. Lisbon: Institut Français du Portugal, 1950.

Révah, Israël Salvator. "Les Jésuites portugais contre l'Inquisition: la campagne pour la création de la Compagnie Générale du Commerce du Brésil.," In Etudes portugaises. Edited by Charles Amiel, 155-83. Paris: Centre Calouste Gulbenkian, 1975.

Révah, Israël Salvator. "Manuel Fernandes Vilareal, adversaire et victime de l'Inquisition portugaise." Ibérida 1 (1959-1960): 33-54, 181-207.

Révah, Israël Salvator. "Un pamphlet contre l'Inquisition. La seconde partie de 'La política angélica' de Antonio Enríquez Gómez (Rouen, 1649).” Revue des Études Juives 121 (1962): 81-168.

Rose, Constance H. “Dios hará inquisición de vuestros juicios': Antonio Enríquez Gómez' Search for Justice.” Sefarad 61 (2001): 169-86.

Rose, Constance H. "Fiel a la antigua ley: 'La política angélica' de Enríquez Gómez." In Antonio Enríquez Gómez. Edited by Gema Ortega, 105-10. Cuenca: Diputación de Cuenca, departamento de cultura, 1996.

Rose, Constance H. "Portuguese Diplomacy Plays a Role in the Printing of Some Peninsular Works in Rouen in the Seventeenth Century." Archivos do Centro Cultural Português 9 (1975): 523-41.

Saavedra y Fajardo, Diego de. Empresas políticas. Edited by Sagrario López Poza. Madrid: Cátedra, 1999.

Salomon, Herman P. "Nova luz sobre a condenação à fogueira a Manuel Fernandes Vila Real (1. XII. 1652)." In Inquisição. Edited by Maria Helena Carvalho dos Santos, 2: 765-73. 3 vols. Lisbon: Universitária Editora, 1989.

Salomon, Herman P. “Was Antonio Enríquez Gómez (1600-1663) a Crypto-Jew?” Bulletin of Hispanic Studies 88 (2011): 397-421. 
Saraiva, António José. The Marrano Factory: The Portuguese Inquisition and Its New Christians, 1536-1765. Translated, revised and augmented by H.P. Salomon and I.S.D. Sassoon. Leiden: Brill, 2001.

Schaub, Jean-Frédéric. La France espagnole. Les racines hispaniques de l'absolutisme français. Paris: Éditions du Seuil, 2003.

Shaw, Leslie M.E. Trade, Inquisition and the English Nation in Portugal. Manchester: Carcanet, 1989 .

Solis, Duarte Gomes, Discursos sobre los comercios de las dos Indias. Edited by Moses Bensabat Amzalak. Lisbon: Gráfica Lisbonense, 1943.

Southerland, Nicola Mary. Princes, Politics, and Religion, 1547-1589. London: The Hambledon Press, 1984.

Stuczynski, Claude B. “A 'Marrano Religion'? The Religious Behavior of the New Christians of Bragança Convicted by the Coimbra Inquisition in the Sixteenth Century (1541-1605)." [Hebrew] 2 vols. PhD diss. Ramat-Gan: Bar-Ilan University, 2005.

Stuczynski, Claude B. "Converso Paulinism and Residual Jewishness: Conversion from Judaism to Christianity as a Theological-Political Problem." In Bastards and Believers: Converts and Conversion between Judaism and Christianity. Edited by Pawel Maciejko and Theodore Dunkelgrün. Philadelphia: University of Pennsylvania Press, forthcoming.

Stuczynski, Claude B. "Harmonizing Identities: The Problem of Integration of the Portuguese Conversos in Early Modern Iberian Corporate Politics." Jewish History 25 (2011): 229-57.

Stuczynski, Claude B. “Judaïcité et richesse dans l'apologétique des Conversos portugais: un argument contre-culturel." Atalaya 14 (2014): http://atalaya.revues.org/1295.

Stuczynski, Claude B. "Portuguese Conversos and the Manueline Imperial Idea: A Preliminary Study." Anais de História de Além-Mar 14 (2013): 45-61.

Szajkowski, Zosa. "An Auto-da-Fé against the Jews of Toulouse in 1685." The Jewish Quarterly Review 49 (1959): 278-81.

Tallon, Alain. "Inquisition romaine et monarchie française au XVI è siècle." In Inquisition et pouvoir. Edited by Gabriel Audisio, 311-24. Aix-en-Provence: Publications de l'Université de Provence, 2004.

Taranto, Domenico. Pirronismo e assolutismo nella Francia del'6oo. Studi sul pensiero politico dello scetticismo da Montaigne a Bayle (1580-1697). Milan: Franco Angeli, 1994. Thuau, Etienne. Raison d'État et pensée politique à l'époque de Richelieu. Paris: Armand Colin, 1966.

Torgal, Luís Reis. “A literatura 'marrânica' e as 'edições duplas' em Antonio Henriques Gomes (1600-1663)." Biblos 55 (1979): 197-228.

Torgal, Luís Reis. Ideologia política e teoria do Estado na Restauração: contributo para o seu estudo. 2 vols. Coimbra: Biblioteca Geral da Universidade de Coimbra, 1981-1982. 
Tuck, Richard. The Sleeping Sovereign: The Invention of Modern Democracy. New York: Cambridge University Press, 2015.

Tutino, Stefania. Shadows of Doubt: Language and Truth in Post-Reformation Catholic Culture. New York: Oxford University Press, 2014.

Vieira, António. Escritos sobre os Judeus e a Inquisição. Edited by José Eduardo Franco and Pedro Calafate. Lisbon: Temas e Debates, 2015.

Vilareal, Manuel Fernandes. Epítome genealógico del eminentissimo Cardenal Duque de Richelieu y discursos politicos sobre algunas acciones de su vida. Pamplona: Iuan Antonio Berdun, 1641.

Vilareal, Manuel Fernandes. Epítome Genealógico do Eminetissimo Cardeal Duque de Richelieu e Discursos Políticos sobre Algumas Acçõesa da Sua Vida. Edited by Antònio Borges Coelho. Lisbon: Caminho: 2005.

Warshawsky, Mathew. "A Spanish Converso's Quest for Justice: The Life and Dream Fiction of Antonio Enriquez Gómez." Shofar 23 (2005): 1-24.

Weiss, Nethanël. La Chambre ardente: Étude sur la liberté de conscience en France sous François Ier et Henri II (1540-1550), suivie d'environ 500 arrêts inédits rendus par le Parlement de Paris de mai 1547 à mars 1550. Geneva: Slatkine Reprints, 1970.

Wilke, Carsten L. Jüdisch-Christliches Doppelleben im Barock. Frankfurt: Peter Lang, 1994.

Wilke, Carsten L. "Manuel Fernandes Vila Real at the Portuguese Embassy in Paris, 1644-1649: New Documents and Insights." Journal of Levantine Studies 6 (2016): $153-76$.

Wilke, Carsten L. "Un judaïsme clandestin dans la France du XVII e siècle: un rite au rythme de l'imprimerie." In Transmission et passages en monde juif. Edited by Esther Benbassa, 281-311. Paris: Publisud, 1997.

Zink, Anne. "Bayonne arrivées at départs au XVIIe siècle." In 1492, L'expulsion des Juifs d'Espagne. Edited by Roland Goetschel, 37-47. Paris: Maisonneuve et Larose, 1996.

Zink, Anne. "Une niche juridique: l'installation des Juifs à Saint-Esprit-lès-Bayonne au XVII" siècle." Annales — Histoire, Sciences Sociales 49 (1994): 639-69. 


\title{
Semi-Clandestine Judaism in Early Modern France: European Horizons and Local Varieties of a Domestic Devotion
}

\author{
Carsten L. Wilke
}

If historians of the Portuguese Jewish diaspora share a mental map of their subject, this is due in part to a famous text from 1631 that the Amsterdam rabbi Saul Levi Mortera wrote in reply to the questions of a Spanish priest from Rouen. In this unpublished manuscript, Mortera outlines a three-tiered Jewish geography of Europe: he praises those conversos who had left Spain and Portugal and joined Jewish communities; he pities and excuses those who were trapped on the Iberian Peninsula by the Inquisition's control of emigration; and he severely blames those who had managed to cross the Pyrenean border but were reluctant to officially become Jews, preferring to settle in safe countries where they could officially be Christians and secretly Jews.

This last named category on the moralized map of Sephardic residence options was obviously that of the Portuguese merchant colonies in France, the Southern Netherlands, and several Italian cities, where New Christian immigrants had to conform to public Catholic worship, but were not threatened by inquiries into their private practice. What is remarkable about Mortera's text is that this region is not described as an intermediary zone between the realms of the Kahal and of the Inquisition, but as an extreme situation suigeneris in religious terms.

Those who live in countries where emigration is allowed and from where they can leave freely and without any obstacle to any destination of their choice are in total abjection with the Lord and destined to damnation, because they are truly the worshippers of money. Caught in a vile desire to accumulate wealth, they cheat God (or believe to cheat Him) for the love of the world, and they cheat the world for the love of God, because they believe that they have fulfilled their duty by holding Him dear in their hearts. ${ }^{1}$

1 Amsterdam, Ets Haim cod. 48A21: "Aquellos que habitan en reinos donde no se les impide la salida y libremente sin ningún impedimiento pueden ir donde mejor les parezca, estos tales

(C) CARSTEN L. WILKE, 2019 | DOI:10.1163/9789004392489_006

This is an open access chapter distributed under the terms of the prevailing CC-BY-NC License at the time of publication. 
Mortera's tripartite picture is inevitably shared by the historian in one respect, namely that of archival documentation. All research on crypto-Judaism in the Iberian countries has its underpinning in the fund of Inquisition files in the national archives of Lisbon, Madrid, and Mexico City, just as any serious historiography on the Portuguese community of Amsterdam explores the Jewish community records in that town's public archives. Historiography on the French crypto-Judaism can occasionally draw information from these two collections, but it is mainly left with the dispersed documents that must be painfully gleaned and put together from the archives of French jurisdictions, notaries, and parish churches, producing sources that offer information only in a very unsatisfactory quantity and quality for a historian of religion.

My subject in this essay, namely the religious and social profile of the approximately two thousand New Christians settling in seventeenth-century France, leads into a historical environment that is characterized by a weak community organization, much institutional improvisation, and rather dynamic forms of symbolic identity. Describing them with the two source categories at our disposal - those produced by the Inquisition of Madrid and the Kahal of Amsterdam - confronts us with the heavy bias of their authors. Both points of view need to be compared with each other, as well as with new archival and literary sources.

Let me start with a few remarks on the state of the art. Not unlike Mortera, other seventeenth-century Jews have fit the migratory history of the Portuguese Jews into a schematic model, which locates French crypto-Jewry on a timeline of progress from apostasy to normative Judaism, or on a hierarchy of space from the clandestine periphery to the center in Amsterdam. A few years after Mortera lambasted crypto-Judaism in France, the merchant-poet João Pinto

son totalmente abominados del Señor y aparejados para perdición, porque son verdaderamente adoradores del oro, siendo así que por un vil interés de acomular hacienda engañan, o piensan engañar a dios por amor del mundo, y al mundo por amor de dios, y piensan estos que teniendo el corazón bueno con el Señor tienen satisfecho a su obligación." They have to practice and not only to believe the law, and it would be better for them not to have any idea of the truth than to deny it: "debían considerar cuán grande ingratitud usan con su creador que los sacó del fuego de Sedom, y ellos como la mujer de Lot, en lugar de seguir el camino que deben y ponerse en salvo, miran atrás y quedan en medio hechos estatuas de sal." An interesting variant reading in manuscript Ets Haim 48C20 redirects Mortera's polemics against those who do not observe the law, though they live "en reinos donde no se les impide la libertad en su religion y libremente sin ningun impedimento pueden observar lo que mejor les pareciere." On this text, see the debate between H.P. Salomon, "Haham Saul Levi Morteira en de Portugese Nieuw-Christenen," Studia Rosenthaliana 10 (1976): 127-41, and Yosef Kaplan, From Christianity to Judaism: The Story of Isaac Orobio de Castro, trans. Raphael Loewe (Oxford: The Littman Library of Jewish Civilization, 1989), 328-29. 
Delgado described his retrospective itinerary from Lisbon via Rouen to the Dutch city of Naarden in an apologetic tone, giving all three stations clearly outlined religious meanings: "I came from that city [of Rouen], though it was in no way the destination of my desires, but only a way station (escala) for other more sublime ones."2 Still in 196o, Pinto Delgado's theological geography appeared convincing to Israël Salvator Révah, who believed that France was for most New Christian migrants a mere "way station" (escale) on the flight from the Inquisition to the northern Jewish communities. ${ }^{3}$ Inversely, Zosa Szajkowski placed the Sephardim of France on a no less schematic downward road toward assimilation. ${ }^{4}$

Overcoming these teleological views, Gérard Nahon insisted since the $1980 \mathrm{~s}$ on the idea that the Iberian Jewish diaspora in seventeenth-century Western Europe was built around "two geographic poles: the 'legal' one in Amsterdam and the 'clandestine' one in France." In a perspective of religious history, the type of crypto-Judaism practiced under these circumstances can thus be characterized as the "French model of Marranism" 6 and researched in its own right on an equal footing with the religious culture of Dutch Sephardic Jewry. ${ }^{7}$

In order to explore the socioeconomic context of this religious model, researchers have taken two complementary directions. French urban historians

2 Israël Salvator Révah, "Autobiographie d'un Marrane: Edition partielle d'un manuscrit de João (Moseh) Pinto Delgado," Revue des études juives 119 (1961): 41-130, esp. 103: "Llegando a aquella ciudad, no meta de mis deseos, escala, si, para otros mayores."

3 Israël Salvator Révah, "Les Marranes," Revue des études juives 118 (1959-1960), 29-77, esp. 66. A more recent author who subscribes to the same interpretation is Michèle Escamilla-Colin, "Rouen et la diaspora ibérique," Cahiers du C.R.I.A.R. 15 (1995): 27-48, esp. 46.

4 Zosa Szajkowski, "Population Problems of Marranos and Sephardim of France," Proceedings of the American Academy for Jewish Research 27 (1958): 83-105; "The Marranos and Sephardim of France," in The Abraham Weiss Jubilee Volume, ed. Samuel Belkin (New York: The Abraham Weiss Jubilee Committee, 1964), 107-127.

5 Gérard Nahon, Métropoles et périphéries séfarades d'Occident:Kairouan, Amsterdam, Bayonne, Bordeaux, Jérusalem (Paris: Cerf, 1993), 97.

6 Gérard Nahon, "Le modèle français du marranisme (XVIe-XVIII ${ }^{\mathrm{e}}$ siècles)," Annuaire de l'École Pratique des Hautes Études, Cinquième section: Sciences religieuses 90 (1982): 264; Nahon, "Le modèle français du marranisme: Perspectives nouvelles," in Inquisição: Ensaios sobre mentalidade, heresias, e arte, ed. Anita Novinsky and Maria Luiza Tucci Carneiro (Rio de Janeiro: Edusp, 1992), 227-65; Nahon, "La 'Nation portugaise' de Saint-Esprit-lès-Bayonne du XVI ${ }^{\mathrm{e}}$ au XVIII ${ }^{\mathrm{e}}$ siècle: Escale ou havre de grâce?" in 1492/1992: L'Exode des juifs d'Espagne vers Bayonne, ed. Maïté Lafourcade (Bayonne: Université de Pau, 1993), 1-30, 165-91.

7 This approach is most notably followed by Renée Levine Melammed, A Question of Identity: Iberian Conversos in Historical Perspective (New York: Oxford University Press, 2004), 81-93. 
such as Anne Zink, ${ }^{8}$ Jacques Blamont, ${ }^{9}$ and Jacques Bottin ${ }^{10}$ have laid the stress on the Portuguese's incomplete and problematic insertion into French urban society. Historians of the Jews have rather tended to see the French New Christians as a node in the far-flung merchant networks of the Nação, the Portuguese-Jewish "Nation." Jonathan Israel most aptly describes this position as a kind of in-between-ness on the trans-imperial map of Hispano-Dutch colonial confrontation, as a frontier zone between Amsterdam and Madrid.11 Economic history thus extends Nahon's bipolar model of the Nação to a triangular scheme connecting the Netherlands with France and the Iberian world.

Since Yosef Kaplan's studies, ${ }^{12}$ there has been an increased readiness to focus on nonlinear migration patterns as a major problem of Sephardic history and to interpret them as "evidence of disaffection and nonconformity." I am quoting David Graizbord, who highlighted "the mercantile matrix of renegade behavior,"13 meaning the frequent economic constraints of Franco-Spanish trade that undercut the Jewish integration of individuals and confessional discipline at large. ${ }^{14}$ "The needier the merchant, the more likely he was to

8 Anne Zink, "Une niche juridique: L'installation des Juifs à Saint-Esprit-lès-Bayonne au XVII siècle," Annales—Histoire, Sciences Sociales 49, no. 3 (1994): 639-70; Zink, "Communautés et corps social: Les juifs à Saint-Esprit-lès-Bayonne du XVII ${ }^{\mathrm{e}}$ au début du XIX ${ }^{\mathrm{e}}$ siècle," in Les Étrangers dans la ville: Minorités et espace urbain du bas Moyen Age à l'époque moderne, ed. Jacques Bottin and Donatella Calabi (Paris: Éditions de la Maison des Sciences de l'Homme, 1999), 313-28.

9 Jacques Blamont, Le lion et le moucheron: Histoire des marranes de Toulouse (Paris: Odile Jacob, 2000), 331 .

10 Jacques Bottin, "La redistribution des produits américains par les réseaux marchands rouennais (1550-1620)," in Dans le sillage de Colomb: L'Europe du Ponant et la découverte du Nouveau Monde (1450-1650), ed. Jean-Pierre Sanchez (Rennes: Presses universitaires de Rennes, 1995), 27-39.

11 Jonathan I. Israel, Diasporas within a Diaspora:Jews, Crypto-Jews, and the World Maritime Empires (1540-1740) (Leiden: Brill, 2002), 245-68, in the chapter titled "Crypto-Judaism in 17th-Century France: An Economic and Religious Bridge between the Hispanic World and the Sephardic Diaspora."

12 See especially Yosef Kaplan, "Wayward New Christians and Stubborn New Jews: The Shaping of a Jewish Identity," Jewish History 8, nos. 1-2 (1994): $27-41$.

13 David L. Graizbord, Souls in Dispute: Converso Identities in Iberia and the Jewish Diaspora, 1580-1700 (Philadelphia: University of Pennsylvania Press, 2004), 12: "I devote considerable attention to the mercantile matrix of renegade behavior. By consciously placing the economic activities of returnees at the center of my interpretation I attempt to ground an understanding of the mentality of these dissidents in their mundane circumstances and interests."

14 Ibid., 176: "In the context of seventeenth-century Iberia and Sephardi France, border crossing was highly 'transgressive,' not because it defied cultural or spatial demarcations that were actually rigid, but because such behavior violated imaginary models of social and religious conformity $[. .$.$] The fact remained that as economic actors and as products$ 
cross the border into Spain - and to do so often."15 From a point of view of religious anthropology, Natalia Muchnik has tried to detect in this flexible religious practice the mechanisms of clandestine collective self-fashioning. This includes linguistic marks of belonging to the "Nation," as well as the semantics of physical bodies and geographical spaces, which suggest that diaspora religiosity should be seen in a very broad transnational range. ${ }^{16}$ The internal diversification of the "Portuguese Nation" between various religious attitudes resembles, as Yosef Kaplan has recently shown, a pattern known from the dynamic of confessionalization in post-Reformation Christianity. ${ }^{17}$

From my side I have, likewise, tried to underscore the systemic character of the apparent religious nonconformity, focusing on the specific functions that the Franco-Portuguese merchant communities fulfilled in the short-term economic cycles of the seventeenth century ${ }^{18}$ Religious flexibility was a highly productive strategy in these merchants' involvement in the contraband trade of the 1630 s, or in the Spanish tobacco monopoly during the 1650s. Literary sources show that the Portuguese Jews did not demonize Spain: the solemn synagogue formula of the "land of idolatry" did not deter anyone from traveling to the Iberian countries in the guise of good Catholics. ${ }^{19}$ The Portuguese "Nation" was certainly extreme, but not at all exceptional in this respect, as Christian merchant groups also showed some degree of pliability in their denominational identity. ${ }^{20}$ Canadian historian Gayle Brunelle has similarly exemplified the idea that the brokerage position of the Portuguese merchant

of Iberian and Judaic cultures, these so-called 'renegades' were an integral part of peninsular society as well as the Sephardi diaspora."

15 Ibid., 89.

16 Natalia Muchnik, De paroles et de gestes. Constructions marranes en terre d'Inquisition (Paris: Éditions de l'EHESS, 2014), 249. Muchnik, ibid., 195, on "l'impact du contexte spatio-temporel sur la religiosité crypto-judaisante et, partant, sur les processus identitaires"; ibid., 198: "On ne saurait isoler les groupements crypto-judaisants péninsulaires et impériaux de la diaspora, en dépit des critiques qu'ils essuient."

17 Yosef Kaplan, "Between Christianity and Judaism in Early Modern Europe: The Confessionalization Process of the Western Sephardi Diaspora," in Judaism, Christianity, and Islam in the Course of History: Exchange and Conflicts, ed. Lothar Gall and Dietmar Willoweit (Munich: Oldenbourg, 2011), 307-41, on France see esp. 319-20.

18 Carsten Wilke, Jüdisch-christliches Doppelleben im Barock: Zur Biographie des Kaufmanns und Dichters Antonio Enríquez Gómez (Frankfurt: Peter Lang, 1994), 31-74.

19 Wilke, "Contraband for the Catholic King: Jews of the French Pyrenees in the Tobacco Trade and Spanish State Finance," in Purchasing Power: The Economics of Modern Jewish History, ed. Rebecca Kobrin and Adam Teller (Philadelphia: University of Pennsylvania Press, 2015), 46-70, esp. 54-55.

20 Gayle Brunelle, The New World Merchants of Rouen, 1559-1630 (Kirksville, MO: Sixteenth Century Journal Publishers, 1991), 156-59. 
community strongly favored an "ambiguous public identity."21 The confrontation between Jewish and Christian believers in the New Christian merchant colonies of Rouen and Bordeaux may in some cases express a deep religious hostility. ${ }^{22}$ However, members of both groups worked together in the same enterprises, and the Catholic denunciations against the crypto-Jews arose as a largely tactical manoeuver at the moment when the Spanish Inquisition started to act against the New Christian fugitives irrespective of their individual persuasions. ${ }^{23}$ Economic cooperation thus led to an attitude that was strongly in conflict with prevailing ideals of confessional borderlines.

Just as Rabbi Mortera hated hypocrites more than renegades, French Catholics' fear of these boundary-crossers was far bigger than their dislike of plain Judaism. As early as 1568, an unpublished French polemical poem against a Portuguese of Nantes first denies him the qualities of the Old Testament saints, then describes him as one of the bleak and bearded Jewish figures that Church frescoes of the Passion use to display in grey colors, and finally affirms that he is even worse than those biblical anti-heroes, namely a Marrano (Maran) who by financial tricks preys on the king's finances. ${ }^{24}$ From the point of view of Christian morals, it was better to deal with a real Jew who wears a yellow hat than with a disguised one. In a polemical book published in 1622, Pierre de Lancre, lawyer at the Parliament of Bordeaux, profusely expressed his dismay at the dangerous infiltration of Judaizers into France. ${ }^{25}$ The Parliament

21 Brunelle, "Jewish Jews and Catholic Jews: Confessionalization and Portuguese New Christians in Early Modern Rouen," in Trouver sa place: Individus et communautés dans l'Europe moderne, ed. Antoine Roullet, Olivier Spina and Nathalie Szczech (Madrid: Casa de Velázquez, 2011), 101-16, esp. 110. See also Brunelle, "Migration and Religious Identity: The Portuguese of Seventeenth-Century Rouen, "The Journal of Early Modern History 7 , nos. 3-4 (November, 2003): 283-311.

22 Brunelle, "Jewish Jews and Catholic Jews," 104: "There clearly was no love lost between the third or so of the Portuguese who adopted an ardent Catholic assimilationist stance and the other two-thirds who were either active Judaizers or ambivalent in their religious leanings and it likely was very difficult for the two groups to live together as one community in Rouen."

23 Muchnik, "De la défense des 'impurs' à la critique du Saint-Office: Le plaidoyer de Juan Bautista de Villadiego (1636)," Revue d'histoire ecclésiastique 101 (2006): 1014-38.

24 "Satyre contre un Juif, 1568," Bulletin du bibliophile et du bibliothécaire 33 (1867): 175-80, esp. 175: "puis ton poil gris et ton visage blesme / teust faict juger issu de Nicodesme / ou de Ioseph ou de ces peres sainctz / que on voyt grissars en nos eglizes painctz"; 176: "Maran trompeur masquant ung fainct courage / de beausemblant et de farde langaige / qui plain de ruse as seullement changé / de tes parans le bonnet orrangé." See also JeanJoël Bregeon and Yves de La Villetanet, "Le judaïsme à Nantes du XVI e siècle à la fin du XVII ${ }^{\mathrm{e}}$ siècle," Master's thesis, Université de Nantes, 1970, 133-35.

25 Pierre de Lancre, L'incredulité et mescreance du sortilege plainement convaincue (Paris: Nicolas Buon, 1622), 445-501. 
of Brittany justified its inquiry into the religious persuasion of candidates for naturalization with the need "to prevent people without faith and religion [...] from corrupting and infecting the integrity of good Christians with a false doctrine and bad example." ${ }^{26}$ Hostility erupted in the form of several local expulsions, two cases of popular riots, which occurred in St-Jean-de-Luz in 1619 and in Nantes in 1636,27 and repeated attempts at collective accusation, undertaken by the Parliament of Rouen in $1633^{28}$ and by the royal attorney in Toulouse in $1685^{29}$

However repulsive religious insincerity was for pious Catholics and rabbis, it was nothing short of a precondition for the general line of absolutist politics, which on the one hand imposed outward obedience to the ruler's religion, but on the other hand denied churches and tribunals the power to sanction private acts and beliefs. The political thereby created for a dissident minority has been described as a legal oxymoron ("une équivoque juridique"): ${ }^{30}$ on the one hand, professing Jews were officially banned from French soil since 1394 (with the exceptions of Metz and Avignon); on the other hand, "New Christians" had been welcomed and given economic privileges by the charter of Henry II since 1550 and, since 1574, were explicitly protected against inquiries regarding their religious life. ${ }^{31}$ These lettres patentes meant a privilege that should not be underestimated. By inviting explicitly and exclusively "les marchans et autres portugaiz appelez nouveaulx-chrétiens,"32 they granted a fiscal priority to Portuguese immigrants of Jewish ancestry over those who had none. At the same time, the otherwise comfortable situation of these New Christians in France during the seventeenth century was basically characterized by the illegality of any public manifestation of Jewish practice.

26 Guy Saupin, "Un mouvement de xénophobie anti-portugaise à Nantes dans les années 1630," in Monarchies, noblesses et diplomaties européennes: Mélanges en l'honneur de JeanFrançois Labourdette, ed. Jean-Pierre Poussou et al. (Paris: PUPS 2005), 49-6o, esp. 50: "pour empescher que gens sans foy et religion [...] ne viennent par faulce doctrine ou mauvais exemple à corrompre et infermer l'intégrité des vrays Chrestiens et gens de bien."

27 Jules Mathorez, "Notes sur l'histoire de la colonie portugaise à Nantes," Bulletin Hispanique 15 (1913): 316-39; esp. 332-34.

28 Cecil Roth, "Les marranes à Rouen: Un chapitre ignoré de l'histoire des Juifs de France, Revue des études juives 68 (1929): 113-55; Révah, “Autobiographie," 58-85.

29 Blamont, Le lion et le moucheron, 340-52.

$30 \quad$ Brigitte Bedos-Rezak, "Tolérance et Raison d'Etat: le problème juif," in L'État baroque 1610-1652: Regards sur la pensée politique de la France du premier XVII e siècle, ed. Henry Méchoulan (Paris: Vrin 1985), 243-87, esp. 248.

31 See the texts in Gérard Nahon, Les "Nations" juives portugaises du Sud-Ouest de la France (1684-1791) (Paris: Fundação Calouste Gulbenkian, 1981), 21-31.

Ibid., 22. 
This legal status corresponded to a restricted type of religious pluralism that European states practiced widely in the wake of the Reformation wars. In this model, authorities of the ruling faith offered to certain dissident groups a modus vivendi based on the legal protection of private religion (devotio domestica) or simply on tacit toleration. Willem Frijhoff has called attention to the fact that liberty of conscience was everywhere seen as a necessity rather than an ideal principle of state law (which it would only become at the turn of the eighteenth century). In the famous Dutch polemics between Justus Lipsius and Dirck Coornhert in the 1590s, the former had demanded that "the state should impose religious unity for the benefit of public order," while the latter, as Protestant politics in general, was wary to force minority members to either emigrate or perform sacred acts against their conscience. ${ }^{33}$ In Hamburg especially, a restricted interpretation of toleration prevailed among the Lutheran clergy and municipal authorities until 1785 , which accorded non-Lutherans the devotio domestica, but not more than this. ${ }^{34}$ This model was applied to the Sephardim, from the first contract the municipal powers made with them in $1612,{ }^{35}$ and it was again applied in Oliver Cromwell's famous letter to the Portuguese Jews of London in 1656. In France, however, where marriages and other personal status matters were handled by the two recognized churches, tacit toleration meant participation in the Catholic worship at least for life cycle events and periodical confession. The meaning of devotio domestica is thus fundamentally different in the Protestant and in the Catholic environment. In the Protestant countries, New Christian immigrants formed communities of a second-zone status, while Catholic monarchies de facto institutionalized a model of double religious practice, which allowed (or imposed) a cleavage of religious norms between the public and the domestic sphere.

This minority status could mean very different realities according to the time period and the city that we are talking about. Concerning the chronological cycles of greater or lesser liberty in France, it is well known that the reign of Henry IV, especially during the years $1603-1607$, as well as the subsequent regency of Marie de Medici between 1610-1617, tolerated Jewish deviance, even its public expressions, to a large extent. On the basis of a papal letter, the

33 Willem Frijhoff, "Religious Toleration in the United Provinces," in Calvinism and Religious Toleration in the Dutch Golden Age, ed. Ronnie Po-Chia Hsia and Henk Van Nierop (Cambridge: Cambridge University Press, 2002), 27-52, see 46.

34 Joachim Whaley, Religious Toleration and Social Change in Hamburg, 1529-1819 [1985] (Cambridge: Cambridge University Press, 2002); 35 .

35 Hiltrud Wallenborn, Bekehrungseifer, Judenangst und Handelsinteresse: Amsterdam, Hamburg und London als Ziele sefardischer Migration im 17. Jahrhundert (Hildesheim: Olms, 2003). 
queen's physician Elijah Montalto obtained his demand of public Jewish practice in Paris; "il n'entendoit se desguiser et contrefaire en sa profession, ains exercer librement sa religion judaïque." ${ }^{36}$ At the same time, but on the opposite corner of the kingdom, the big community of Saint-Jean-de Luz practiced the Jewish laws in a quite visible manner until the expulsion of $1619 .{ }^{37}$

The regency was followed by a restoration of strict religious control under Richelieu, who offered, at the same time, his protection to foreign merchants. The years of the Fronde after 1648 inaugurated a new period of relative religious openness, which allowed the regularization of Jewish life in the major Portuguese colony of the time, Saint-Esprit-lès-Bayonne. The pendulum swung back around the war year 1672, when the Catholic party of the "Dévots" came to power. From this moment, the church-oriented politics of Louis XIV also included harsh anti-Jewish measures against the Portuguese merchants in Marseille, Toulouse, and the Caribbean colonies. Double religious practice remained inevitable for the Jews of Bordeaux, who abandoned Christian life cycle rites for births only in the 1690 and for weddings in 1711; a distinctive Jewish cemetery was only acquired in $1724 .{ }^{38}$ As late as 1723 , the French kingdom, for the first time, officially recognized the presence of Portuguese Jews.

The important geographical differences between French regions in their Jewish policy should not be overlooked either. The Dukes of Gramont, who reigned over large territories in the southwestern border region and were, for a time, the royal governors of Bayonne, invited Jewish immigrants no less openly than Polish or Hungarian aristocrats did at the same time. Under the protection of the Duke, the big suburban community of Saint-Esprit-lès-Bayonne turned to a clearly confessionalized practice of Judaism in the middle of the century. ${ }^{39}$

36 Bedos-Rezak, "Tolérance et Raison d'Etat," 259. In 1614, the Parliament asks for a "recherche de toute nouvelles sectes et gens infâmes qui se sont coulez à Paris, es maisons des grands, pres de vostre cour, depuis peu d'annees, comme Anabaptistes, Juifs, magiciens et empoisonneurs." See ibid., 263.

37 Carsten L. Wilke, "Le rapport d'un espion du Saint-Office sur sa mission auprès des crypto-juifs de Saint-Jean-de-Luz (1611)," Sigila 16 (2006): 127-41.

38 Carsten L. Wilke, "Un moraliste rabbinique parmi les marranes de Bordeaux: Abraham de Oliveira et son Celo del temor de Dios (1661)," in L'Écriture de l'Histoire juive: Mélanges en l'honneur de Gérard Nahon, ed. Danièle Iancu-Agou and Carol Iancu (Paris and Louvain: Peeters, 2012), 355-72, esp. $35^{6}$.

39 Wilke, "Un judaïsme clandestin en France au XVIIe siècle: Un rite au rythme de l'imprimerie," in Transmission et passages en monde juif, ed. Esther Benbassa (Paris: Publisud, 1997), 281-311, esp. 307-10. See also Gérard Nahon and Michèle Escamilla, "Matines juives à Bayonne au XVII e siècle au filtre du Saint Office," in Non solo verso oriente: Studi sull'ebraismo in onore di Pier Cesare Ioly Zorattini, ed. Magdalena Del Bianco Cotrozzi, Riccardo Di Segni and Marcello Massenzio (Florence: Casa Editrice Leo S. Olschki, 2014), 295-344. 
The Portuguese hired a rabbi and opened a synagogue in his house (1653), ${ }^{40}$ bought a cemetery (1654), obtained a new royal charter banning inquiries into their way of life $(1656),{ }^{41}$ and called a circumciser from Amsterdam, who circumcised hundreds of men and boys (1658). Hebrew first names appear henceforth on the tombstone inscriptions. The congregation itself used the name NefusotJeudah (Dispersed of Judah, from Is 11:12) in Hebrew correspondences, ${ }^{42}$ but refrained from mentioning it in public documents. The Jews of Saint-Esprit opened separate registers (now lost) for births, marriages, and deaths, which were started around the same time, the parish church being indemnified for the lost fees.

The arrival of the rabbi and circumciser in Saint-Esprit was reported in rabbinical sources as well as in inquisitorial informers' reports, of which I quote a portion:

What they name synagogue is the residence of the hakham [rabbi], who is the mentioned Isaac Israel de Avila. There was no particular place destined to the use as a synagogue, until the said Isaac Israel came to live in Bayonne; then they rented a big house for him to live in, which is the most remote of the village. Inside there is a big hall which they call the synagogue, it has the tabernacle, the Law, and many glass lamps around it. Here they all go to perform their prayers and other ceremonies. They call it explicitly the synagogue; in Spanish they say escuela [school] and in Hebrew medras. ${ }^{43}$

However, a witness attests that there was one significant restriction to religious freedom. "There is more freedom in Amsterdam than in Bayonne and Bordeaux, because in France, one has to baptise [the newborn children] for fear of the Catholic Frenchmen, even though they are circumcised afterwards, but in Amsterdam, Livorno, Pisa, and Florence one does not have to baptise

\footnotetext{
$40 \quad$ Kaplan, "Wayward New Christians," 31.

41 Nahon, Les "Nations" juives portugaises, 32-35.

42 Ibid., 261.

43 João Marques, 1672, in AHN, Inq., lib. 1145, fol. 31r-v: "Se a de aduertir q' la llamada sinagoga la casa en q' viue el jajan q' es el dho Isac Israel Dauila, porq avnq' de antes no auia lugar

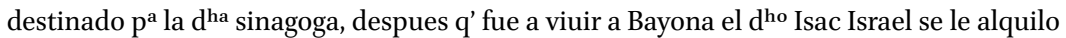
vna casa grande en q' viuiese, q' es la vltima del lugar, y en ella ay vna sala grande, a q' llaman la sinagoga, donde estan el tavernaculo y la ley y muchas lamparas a alrededor de vidrio, y aqui acuden todos a hacer sus rezas y demas zeremonias y la llaman y apelidan la sinagoga, y en lenguaje española Escuela, y en el hebreo Megas."
} 
[them]." ${ }^{m 4}$ In practice, male children were handed from baptism by the priest immediately to circumcision by the rabbi.

Such a highly standardized degree of double life was impossible for the crypto-Jews of Bordeaux, Nantes, Paris, and Rouen, as there was no aristocratic lord to protect them in these places, and the ruling powers, that is, the regional parliament and the municipality, were lukewarm in their support (as in Bordeaux), or even hostile (as in Nantes). But even here, clerics sometimes agreed to free Portuguese persons from Catholic rituals as long as the corresponding fees were paid. Around 1638 in Bordeaux, the Franciscans became angry at the Jews who did not buy enough masses and requiems for their deceased. In protest, the monks started vandalizing tombstones in the part of their cemetery that was reserved for the Portuguese. This entire issue was resolved with the payment of two hundred silver ducats: the masses were paid without being held. ${ }^{45} \mathrm{~A}$ prisoner of the Spanish Inquisition who, in 1649, denounced the poet Antonio Enríquez Gómez, describes the conditions in Rouen with a characteristic anecdote: "The present witness stayed at his house whenever he visited Rouen, and there he remarked that they did all housework according to Hebrew ceremonies, or at least, this is what they affirmed. During one of these visits, the parish priest came in and asked the mentioned Antonio Enríquez Gómez why he did not come to confession, because not a single male member of his household had come for three years. Antonio Enríquez then went out with the priest, and when he returned, he said that he had dispatched the man with a doubloon." 46

44 Joseph Garcia de Leão, 1661, in AHN, Inq., lib. 1129, fols. 612v-613r: "en Bayona los judios, ni cumplen con la parrochia, ni confiesan, ni oyen misa, ni hacen offiçios a los difuntos ni los entierran en la Iglessia, y solo los acompaña los cuerpos sola la cruz y vn clerigo hasta el sitio donde los entierran en tierra virgen que tienen comprado para dicho efecto, y dejan alli los cuerpos, y los entierran los judios, y ha extrañado este tan gran maldad en los clerigos catholicos en acompañar la cruz los cuerpos de los Hebreos en semejantes entierros, ni tampoco se desposan ni velan con las çeremonias de la Iglesia, solo bautiçan los niños, para çircunçidarlos luego, por mano de vn Ministro, q tienen para eso"; 617v: "ay mas liuertad en Absterdam que en Bayona y Burdeos; porque en Françia se bautiçan por miedo de los Françeses catholicos, aunq' luego los çircunçidan, pero en Absterdam no los bautiçan, ni en Liorna, Pisa, ni Florençia."

45 Bartolomeu Vieira, 1642, in AHN, Inq., lib. 1103, fol. 122v, 142r; cf. Wilke, Jüdisch-christliches Doppelleben, 205.

46 Bartolomé López Coletero, 1649, in AHN, Inq., lib. 1111, fols. 2v-3r: "las diuersas vezes que estubo allí en Ruan este declarante, fue por posar sienpre en su cassa, y en ella les bio obrauan todo lo que azían con zeremonias ebreas, según ellos dezían; y vino vna bez $<3 r>$ en su presençia el cura de la peroquia; y dijo a dicho Antonio Enrríquez Gómez que cómo no se yva a confesar, pues auía tres años que no yva él ni ningún barón de su cassa; y el dicho Antonio Rodríguez [sic] fue con el dicho cura fuera de cassa; y quando boluió dijo que con vn doblón le auía despachado." See Wilke, Jüdisch-christliches Doppelleben, 314. 
João Pinto Delgado urges his coreligionists to move from France to Amsterdam in order to acquire salvation; but his poetic image of the Judaism practiced in France attests that the essential minimum of the Jewish festive calendar was practiced even there: the yearly fast on the Day of Atonement, the Passover ritual including the lamb's blood and the unleavened bread, and finally the observances connected to the Sabbath. ${ }^{47}$ This is confirmed by the Inquisition records, which remark the ubiquity of printed rituals and other Jewish books. In the Rouen bookstores, Amsterdam imprints by Rabbi Menasseh ben Israel were publicly on sale;48 and the commercial correspondents in the Sephardic community of Amsterdam sent prayer books on demand. ${ }^{49}$

There is no need, however, to suppose that Jewish customs only followed these texts, since visitors from Jewish communities in the Netherlands and Italy were quite frequent guests in the Franco-Portuguese communities. ${ }^{50}$ The sons of the above-mentioned doctor Montalto, who were living in Amsterdam, came for business visits. ${ }^{51}$ In 1631 , one of the sons celebrated Passover in Rouen with local Portuguese and with Estêvão Ares de Fonseca, another visitor from Amsterdam. As the latter would tell the Inquisition, the dinner was interrupted by the parish priest who had received a notice from an informer, and the foreign Jews had to leave the scene precipitously. ${ }^{52}$ The French travels of Dutch Jews became less risky since they collectively received a safe-conduct in March $1637 .^{53}$ Spinoza biographers even reflect a rumor that the philosopher was sent as a business agent to La Rochelle and Nantes at age eighteen. ${ }^{54}$

Révah, “Autobiographie," 106-7; Wilke, "Un judaïsme clandestin," 293.

48 Manuel Fernandes Vila Real, 1650, in Innocêncio da Silva, Dicionário bibliográfico português (Lisbon: Impr. Nacional, 1893), 16 (= vol. 9 of the supplement by Brito Aranha): 198: "em Ruão se vendiam dois dos seus livros publicamente, um de Resurreição dos mortos, e outro De Termino vitae."

49 Wilke, Jüdisch-christliches Doppelleben, 364 .

5o Natalia Muchnik, "Amsterdam et les groupements judéo-ibériques de France au XVII siècle," in Entre calvinistes et catholiques: Les relations religieuses entre la France et les PaysBas du Nord (XVI ${ }^{e}-X V I I I^{e}$ siècle), ed. Yves Krumenacker (Rennes: Presses Univ. de Rennes, 2010), 299-313.

51 Nicolás Broens, Monarquía y capital mercantil: Felipe IV y las redes comerciales portuguesas (1627-1635) (Madrid: Ediciones de la Universidad Autónoma de Madrid, 1989), 59.

52 Estêvão Ares de Fonseca, 1635, in AHn, Inq., lib. 1104, 79r-v; cf. Wilke, "Un judaïsme clandestin," 302.

53 Gérard Nahon, "Les rapports des communautés judéo-portugaises de la France avec celle d'Amsterdam au XVII e et au XVIII e siècles," Studia Rosenthaliana 10, no. 1 (1976): 37-78; 10, no. 2 (1976): 151-88, esp. 159 .

54 Jacques Dubarry, "Ephraïm Bueno, ami de Rembrandt, docteur en médecine de l'Université de Bordeaux," Revue d'histoire de la médecine hébräque 5 (1950): 17-23, esp. 23; reprinted in Mélanges d'histoire de la médecine hébraïque: Études choisies de la Revue 
In sum, the members of the Franco-Portuguese "Nation" self-consciously gave their religious life different degrees of "thickness" and publicity in accordance with the stable yet diverse local conditions that they encountered at the French destinations of converso immigration. Each one of those ten settlements followed its own rite and rhythm, Saint-Esprit living in the most Jewish and Nantes in the most Catholic way. But in all of them, crypto-Judaism was a semi-clandestine practice, which was publicly manifest in certain signs that attentive observers knew how to read. The Spanish agent Juan Bautista Villadiego could write that in France, a crypto-Jew was as recognizable as a black man among whites, "un negro entre los blancos." 55

How, then, must we imagine the public self-organization of this heterogeneous religious community? Its central framework was, of course, the "Nation portugaise," but we all know the multifaceted meanings this key term could have among early modern Sephardim. ${ }^{56}$ Simplifying things a bit one may detect a triple sense in the word: the "Nation" was the focus of an imaginary ethnic community (there is indeed a terminological coincidence with the "imagined communities" of modern nationalism, but this does not mean that there is an equivalence or even a continuity between the premodern and the modern meanings of the word); second, the "Nation" was a merchant corporation clearly defined in its rights and functions by the economic customs of the age; and thirdly, it took over various religious tasks and thus became in many cases the nucleus of a Jewish community.

In seventeenth-century trade cities, the different merchant nations were autonomous organizations that had regular assemblies and elected judges, arbiters, and syndics who negotiated with the authorities. In Antwerp, as this is well known through the studies by Jean-Albert Goris and Hans Pohl, the Portuguese "Nation" possessed a building and regular officials, called consuls. ${ }^{57}$

d'histoire de la médecine hébrä̈que (1948-1985), ed. Gad Freudenthal and Samuel S. Kottek (Leiden: Brill, 2003), 217-22, esp. 222.

55 Juan Bautista Villadiego, 16 March 1633, in AHN, Inq., leg. 171, exp. 4, vol. I, fol. 8or: "de la manera y con la certeça que se distingue y pareçe vn negro, entre los blancos con la misma se saue y se conoçen en estas partes por los de su naçion los que son o no judios."

56 Miriam Bodian, Hebrews of the Portuguese Nation: Conversos and Community in Early Modern Amsterdam (Bloomington: University of Indiana Press, 1999), 6; Federica Ruspio, La nazione portoghese: Ebrei ponentini e nuovi cristiani a Venezia (Turin: Silvio Zamorani editore, 2007), 15; Daviken Studnicki-Gizbert, A Nation upon the Ocean Sea: Portugal's Atlantic Diaspora and the Crisis of the Spanish Empire, 1492-1640 (Oxford: Oxford University Press, 2007), 9-11.

57 Jan Albert Goris, Étude sur les colonies marchandes méridionales (Portugais, Espagnols, Italiens) à Anvers de 1488 à 1567: Contribution à l'histoire des débuts du capitalisme moderne (Louvain: Librairie Universitaire, 1925); Hans Pohl, Die Portugiesen in Antwerpen, 15671648: zur Geschichte einer Minderheit (Wiesbaden: Steiner, 1978). 
As notarial records show, the Portuguese merchants in France also elected local representatives for certain tasks, but the (still unresearched) internal organization of their "Nation" seems to have been of a much more informal kind. The most ancient conserved register of deliberations of the Jewish "Nation" of Bordeaux, edited by Simon Schwarzfuchs, starts only in 1711 and mentions a community leadership composed of one president (sindic or gabbay) and two deputies (adjoints or parnassim). ${ }^{58}$ Certain patterns of this organization may go back to the time when the "Nation" had merely economic tasks. For example, in Bordeaux, on 22 July 1641, the Portuguese merchants gathered and elected a syndic who would negotiate the naturalization tax at the royal court of Paris, a board of eight men who had to decide on the share of every member in the tax rolls, one receptor who was entitled to collect the money, plus various members who would send the sum in bills of exchange to António Pereira da Silva, court banker in Paris. ${ }^{59}$

More than formal self-organization, rituals related to time and space shaped the Franco-Portuguese "Nation" in the seventeenth century. We must first take into account that in the urban space Portuguese merchants observed a degree of clustering that is atypical for merchants of the time. The joint settlement of Portuguese traders near the bridge and square of Saint-Esprit-lès-Bayonne shows this clustering most perfectly. The Portuguese of Bordeaux mostly lived in two parishes slightly outside the city center. ${ }^{60}$ Preferred neighborhoods in Rouen were the streets near the port and in Nantes, the western faubourg of La Fosse. In Paris, most of the Portuguese merchants lived in the parish of SaintEustache near the Halles, which formed a kind of financial district.

In Nantes, the members of the Spanish merchant corporation, the Contratación, congregated for deliberations in the chapel "Nostre Dame des Espaignols" in the Franciscan church of the rue St Jean. ${ }^{61}$ In Bordeaux, the Franciscans offered a similar facility for the Iberian merchants; Cecil Roth's

$5^{8}$ Simon Schwarzfuchs, Le registre des délibérations de la Nation Juive Portugaise de Bordeaux (1711-1787) (Paris: Fundação Calouste Gulbenkian, 1981), 11-12.

59 Bordeaux, Archives départementales de la Gironde, $3 \mathrm{E}-15241,22$ July 1641: "Ilz ont esté choisis \& nommes par la Nation portugoise residante aud bourd $^{\mathrm{x}}$ pour faire la taxe sur jcelle nation pour la naturalisation [...] lade nation ont esleu et nommé, eslisent et nomment le sieur Jean da Costa Fortade lui donnant pouuoir de recepuoir desds portugois les sommes a quoy ilz ont esté par lade taxe et en bailler quittance a chascun deux."

6o Bertrand Gautier and Peter Voss, "Les communautés marchandes étrangères dans l'espace urbain bordelais (1620-1715)," in Les étrangers dans la ville, ed. Bottin et Calabi, 329-46, esp. 334 .

61 Paul Jeulin, "Une page de l'histoire du commerce nantais du XVI ${ }^{\mathrm{e}}$ siècle au début du XVIII ${ }^{\mathrm{e}}$ siècle: Aperçus sur la Contractation de Nantes (1530 environ-1733)," Annales de Bretagne 40 (1932): 284-331, esp. 289-9o. 
suspicion of crypto-Jewish gatherings here seems to be far-fetched. ${ }^{62}$ Indeed our sources from French cities attest unanimously that the Portuguese merchants used to gather outdoors. In Bordeaux, they met around the "Medusa Fountain" on the Place du Mirail, a small triangular place in the middle of their neighborhood, which they seem to have turned into an Iberian exclave. ${ }^{63}$ The Portuguese of Rouen met at the merchants' exchange, a place lined with trees that stretched between the riverside and the city walls outside of the Porte de l'Estrade. ${ }^{64}$ In the eyes of a local poet, the mustached Iberians, nick-named bourgais de Ierusalem, "burgers of Jerusalem," strutted across their section on the quay as gallantly as if each of them were "a cock among his hen."65

Distinctive leisure venues seem to have played a role for the social and even religious life of the communities. Some of the Portuguese at Saint-Esprit ran private gambling-houses where their coreligionists used to meet in clandestine prayer-rooms on the upper floor. ${ }^{66}$ One witness declared that the crypto-Jews of Saint-Esprit congregated around 1642 in "the house next to the poplar."67 A poem enumerating the beer-houses of Rouen and their clients evokes a similar picture, reporting that "the salt traders and the Portuguese" had their special taverns near the Old Arsenal (Clos des Gallées) on the southern side of the river. ${ }^{68}$ Further afield in that suburban neighborhood, Manuel Rodrigues Nunes rented a country house (vna huerta) where larger groups could spend the Jewish holidays. ${ }^{69}$ Correligionists in Bordeaux customarily celebrated the

62 Cecil Roth, History of the Marranos (New York: Schocken, 1974), 224.

63 Wilke, "Un judaïsme clandestin," 300.

64 On the history of the square, see [François Farin,] Histoire de la ville de Rouen (Rouen: Louis du Souillet, 1731), 2: 147 .

65 David Ferrand, La Muse Normande, publiée d'après les livrets originaux, 1625-1653, avec introduction, notes et glossaire par A. Héron (Rouen: Imprimerie Espérance Cagniard, 1891), 2: 191: "Ces circoncis qui ont le dequay / de faire ichite les brauaches, / Qui se pourgaudent su su quay / Leuant les croqs de leu moustaches" [Those circumcized ones who have the wealth to play the brave guys here, strutting on their quay with the ends of their moustaches turned upwards]. See also 2: 91: "Se brauant comme vn cocq sieuuy de ses gueline / O comme vn Portugais dans la bourse o marchands."

66 Wilke, "Un judaïsme clandestin," 306.

67 Francisco López Villanueva, 1667, in AHN, Inq., leg. 162, exp. 1, fol. 116r: "se juntaban en la casa que està junta al alamo en el varrio de santispiritus y que se tratauan publicam ${ }^{\text {te }}$ como judios."

68 Jules Mathorez, "Notes sur les Espagnols en France depuis le XVIe siècle jusqu'au règne de Louis XIII," Bulletin Hispanique 16 (1914): 337-71, esp. 361, quotes the popular verses: "Les tavernes de Saint-Gervais / Sont pour les Cauchois [coachmen] et Bouveetz [oxmen]. I Hors le Pont, au clos des Gallez, / Pour Sannietz [salt traders] et Portugallais."

69 Wilke, Jüdisch-christliches Doppelleben, 325 . 
Sabbath "going for a walk in the countryside during the afternoon."70 Sabbath gatherings in Saint-Esprit needed less discretion, yet the rabbi's house that served as synagogue was on the outskirts of the suburb, and circumcisions were hosted by a Portuguese in the country town of Peyrehorade "para mayor secreto."71 Crypto-Jewish sociability and religious practice thus relied not only on private homes as in the Iberian countries, but on a complicated imbrication of spaces. The Portuguese appropriated and, in a way, Judaized their preferred trading sites near the port, their meeting places in residential areas, certain semi-public houses of entertainment, and protected areas of evasion out of town.

It is difficult to reconstruct how in the southern French cities the "Nation" evolved from a Christian merchant corporation into a local Jewish community. The care for the ethnic cemeteries was always a task of the "Nation," but there was not, as far as I know, any communal organization of prayer during the first half of the century. Private schools for children, with a more or less pronounced Jewish content, were offered by various individuals, but all documents about them come from Bordeaux. ${ }^{72}$ Around 1648 , the white-bearded Simão Rodrigues Bueno is mentioned there as the schoolmaster of the Portuguese. ${ }^{73}$

It would be, in sum, a mistake to separate too clearly between the economic and the religious life of the "Nation." Its flexible religious identity responded to the specific political situation of the French localities as well as to the commercial broker function within the Catholic world. However, the "Nation's" adjustment to the circumstances was not a zero-sum balance between pious fervor and adverse conditions, as the surprising development in the 1650 s shows. At the time, most of the men of Saint-Esprit worked over long stretches of the year in Spain as merchants and tax-collectors, and they obviously led a life in conformity with Catholic public ritual. This regular wandering in a land which outlawed Judaism might be expected to relax Jewish religious discipline at home. But the exact opposite is true. During the years around 1660 in which the phenomenon of "return to Spain" was strongest, when the entire economy of the community in Saint-Esprit was shaped by systematic border-crossing, risk-taking, and religious duplicity, precisely at that point, as we have already seen, a halakhic framework of religious identity emerges. It was for traders that came back from Spain only around the High Holidays and Passover that the synagogue service was given a more normative shape. It was for families that

70 Afonso Lopes, 1662, in AHN, Inq., lib. 1131, fol. 197r.

71 Simão Nunes Neto, 1665, in AHN, Inq., lib. 1139, fol. 275v.

72 Wilke, “Un judaïsme clandestin," 301-2.

73 António Martins, 1661, in AHN, Inq., lib. 1129, fol. 344v-346v, 356v-357r. 
were separated most of the year, the men working in Spain and the women staying on the French side, that rabbinic marriage was seen as important.

An interesting case in point is the adoption of the normative circumcision rite. Among the French Portuguese, circumcision was practiced in an incomplete way, or by mere puncturing of the foreskin. ${ }^{74}$ One witness, who had been in Rouen, declared in 1635 that business travelers had a small piece of flesh cut from the left side of the foreskin, in the form of a letter C, so that if these men were arrested in Spain, the inquisitors could not use this lesion as formal evidence of apostasy. ${ }^{75}$ However, around the year 1658 , precisely when most young men went to work in Spain, the halakhic practice of full circumcision was generalized. In some cases, a young man would be asked to submit to circumcision and a Jewish marriage before being allowed to travel to Spain. ${ }^{76}$ Circumcision was not the rite of passage symbolizing the final adoption of a Jewish way of life, but inversely an insurance policy that should prevent a traveler from staying too long in Spain and from becoming too intimate with its inhabitants.

It becomes clear at this point that there was a complementary relationship between the more developed Jewish religious ritual in France and the dissimulation practiced in Spain. To put it in the terminology of Gérard Nahon, the more bipolar the biographies of the Pyrenean traders became, the more their community leaders tended to strengthen the Jewish pole. And the more French Jewish practice became regularized, the more Spanish crypto-Judaism could be reduced to secret "declarations" between its adherents, that is, to a meta-ritual practice of talking about Judaism instead of actually practicing it.

This compensation strategy may also account for the rich literary creativity that developed among the French crypto-Jews. The printed and the clandestine

74 Yosef Kaplan, "This Thing Alone Will Preserve Their Nation. Forever': Circumcision and Conversion in the Early Modern Western Sephardic Communities," in The Conversos and Moriscos in Late Medieval Spain and Beyond, vol. 3, Displaced Persons, ed. Kevin Ingram (Leiden: Brill, 2015), 218-43, esp. 228.

75 Estêvão Arês da Fonseca, 1635, in AHN, Inq., lib. 1107, fol. 41r: "y el segundo modo de circuncision, que se executa en los que an de ir y venir por aca para que no sean conoçidos por circuncidados, y que sean conoçidos de los judios, es cortarles de la parte izquierda del prepuçio vna pequeña parte a modo de media luna, $\mathrm{v}$ de una $\mathrm{C}$, y que aduirtiendo en ello los inspectores es facil de conoçer, excluyendo la excusa ordinaria que suelen dar de que aquella scissura se les a causado de alguna enfermedad o achaque del miembro."

76 Wilke, "Un judaïsme clandestin," 309; Nahon, Juifs et judaïsme, 53; Wilke "Contraband for the Catholic King," 68. See also, unaware of these publications, Aliza MorenoGoldschmidt, "Integración religiosa y social de los conversos en las comunidades de la diáspora sefardí occidental a la luz de fuentes inquisitoriales," Sefarad 76, no. 1 (2016): 159-96, esp. $166-71$. 
works include the published poetry by João Pinto Delgado, Antonio Enríquez Gómez, and his son Diego Enríquez Basurto, where the reader often finds biblical references and reflections on religion in such a cryptic and ambiguous style that readers of both religions can accommodate them. The extant literary production also includes some clandestine polemical writings against the Inquisition, the Catholic Church, or the Christian religion at large. Intense theological controversies flared up periodically during the quarter century that elapsed between Rabbi Mortera's correspondence in 1631 and the missionary intervention of Jérôme Lopes, a Bordeaux churchman stemming from one of the major families of the "Nation." The latter's missionary campaign was assisted by the more protracted efforts of the Rouen merchant António da Cunha, author in 1656 of a printed pamphlet defending the Christian interpretation of Isaiah $53 .{ }^{77} \mathrm{~A}$ few years later, a literary circle among the Jews of Bordeaux left two manuscript works with meditations on religious morals. ${ }^{78}$

Two of the writers belonging to the "Nation," Manuel Fernandes Vila Real and Antonio Enríquez Gómez, were also authors of political treatises. In them, they express creative cultural compromises typical of the age of confessionalization. In particular, they defend the absolutist doctrine that imposed a unique religion on public life, but demanded liberty of conscience for the private sphere, endorsing exactly the policy adopted by France toward its semi-clandestine Jews. Successful cross-confessional options of early modern thought, such as introverted piety, esotericism, and skepticism, are also manifest in these authors' symbolic self-image. ${ }^{79}$ Enríquez Gómez's cousin finds warm words for the situation in France even when he reports it to the Inquisition: "Having communicated with the mentioned practicing Jews, he has noticed that all of those whom the Inquisition has [imprisoned and] released return to Judaism when they arrive in a free country such as France. Many of them justify this because they had been mistreated and despised by the Old Christians, and they see that the Jews give them hospitable reception and honor, particularly in France, where even the Christians give them help and a warm welcome."80

77 Carsten L. Wilke, "Midrashim from Bordeaux: A Theological Controversy inside the Portuguese Jewish Diaspora at the Time of Spinoza's Excommunication," European Journal of Jewish Studies 6, no. 2 (2012): 207-47.

78 Wilke, "Un moraliste rabbinique," 360.

79 Carsten L. Wilke, "Políticos franceses, criptojudíos portugueses y un poeta español desterrado," in Antonio Enríquez Gómez, un poeta entre santos y judaizantes, ed. J. Ignacio Díez and Carsten L. Wilke (Kassel: Reichenberger, 2015), 204-27.

80 Francisco Luis Enríquez de Mora, 1663, in AHN, Inq., lib. 1139, fol. 320v: "Y como quien a comunicado con los dichos obserbantes, a reconoçido que todos se buelben en saliendo 
There is no doubt that many of the clandestine Jews were fully content with staying in France and did so of their own will. For moralists such as Mortera, it was important to present this outcome as the result of a misguided religious choice. Out of greed, he claimed, some compatriots had picked the wrong attitude from a wide range of Judaisms, the complete one of Amsterdam, the almost complete one of Saint-Esprit, the rather incomplete one of Bordeaux and Rouen, and the almost inexistent practice in Spain. When migratory facts had to be translated into the mindset of rabbis or inquisitors, the trips across the Franco-Spanish border were inevitably interpreted as expressions of religious doubt, just as in the retrospective perception of Pinto Delgado, the move to Amsterdam was seen as the outcome of a sincere religious quest. The historian, however, should complicate such moralistic interpretations with the help of a life-worldly approach, which would allow to understand the "French model" as a religious attitude in its own right and as an important node in the dynamic network of the Western Sephardic diaspora. We should take note of the fact that migrants generally adapted their religious ideas and feelings to a complex framework of French religious policy, local conditions, the family enterprise strategy, the evolution of global commerce, and the group dynamics of their ethnic trade network. This does not mean that their approach to religion was merely opportunistic. Such an interpretation is contradicted by the important and intense religious debates that shook the clandestine Jews of France. Passionate dogmatic controversies and a marked curiosity for things Jewish prove the undiminished relevance of matters of creed inside this social world of manifold compromises.

\section{Bibliography}

Amsterdam, Ets Haim, cod. 48 A 21.

Anonym. "Satyre contre un Juif, 1568." Bulletin du bibliophile et du bibliothécaire 33 (1867): 175-80.

Bedos-Rezak, Brigitte. “Tolérance et Raison d'Etat: le problème juif." In L'État baroque 1610-1652: Regards sur la pensée politique de la France du premier XVII'e siècle. Edited by Henry Méchoulan, 243-87. Paris: Vrin 1985.

de las Inquisiciones al judaísmo, si se hallan en parte libre como lo es Françia. Y muchos dellos se fundan en que se ben avatidos y menospreçiados de los cristianos biejos, y ben que los judios los haçen buena acojida y los honran, y en Françia en particular, donde avn los cristianos les dan lado y buen lugar." 
Blamont, Jacques. Le lion et le moucheron: Histoire des marranes de Toulouse. Paris: Odile Jacob, 2000.

Bodian, Miriam. Hebrews of the Portuguese Nation: Conversos and Community in Early Modern Amsterdam. Bloomington: University of Indiana Press, 1999.

Bordeaux, Archives départementales de la Gironde, ${ }_{3} \mathrm{E}-15241$.

Bottin, Jacques. "La redistribution des produits américains par les réseaux marchands rouennais (1550-1620)." In Dans le sillage de Colomb: L'Europe du Ponant et la découverte du Nouveau Monde (1450-1650). Edited by Jean-Pierre Sanchez, 27-39. Rennes: Presses universitaires de Rennes, 1995.

Bregeon, Jean-Joël, and Yves de La Villetanet. "Le judaïsme à Nantes du XVI e siècle à la fin du XVIIe siècle." Master's thesis, Université de Nantes, 1970.

Broens, Nicolás. Monarquía y capital mercantil: Felipe IV y las redes comerciales portuguesas (1627-1635). Madrid: Ediciones de la Universidad Autónoma de Madrid, 1989.

Brunelle, Gayle. "Jewish Jews and Catholic Jews: Confessionalization and Portuguese New Christians in Early Modern Rouen." In Trouver sa place: Individus et communautés dans l'Europe modern. Edited by Antoine Roullet, Olivier Spina and Nathalie Szczech, 101-16. Madrid: Casa de Velázquez, 2011.

Brunelle, Gayle. "Migration and Religious Identity: The Portuguese of SeventeenthCentury Rouen." The Journal of Early Modern History 7, nos. 3-4 (November, 2003): 283-311.

Brunelle, Gayle. The New World Merchants of Rouen, 1559-1630. Kirksville, MO: Sixteenth Century Journal Publishers, 1991.

Dubarry, Jacques. "Ephraïm Bueno, ami de Rembrandt, docteur en médecine de l'Université de Bordeaux." Revue d'histoire de la médecine hébraïque 5 (1950): 17-23. Reprinted in Mélanges d'histoire de la médecine hébraïque: Études choisies de la Revue d'histoire de la médecine hébraïque (1948-1985). Edited by Gad Freudenthal and Samuel S. Kottek, 217-22. Leiden: Brill, 2003.

Escamilla-Colin, Michèle. "Rouen et la diaspora ibérique." Cahiers du C.R.I.A.R. 15 (1995): 27-48.

Farin, François. Histoire de la ville de Rouen. 2 vols. Rouen: Louis du Souillet, 1731.

Ferrand, David. La Muse Normande. Publiée d'après les livrets originaux, 1625-1653, avec introduction, notes et glossaire par A. Héron. 5 vols. Rouen: Imprimerie Espérance Cagniard, 1891-1894.

Frijhoff, Willem. "Religious Toleration in the United Provinces." In Calvinism and Religious Toleration in the Dutch Golden Age. Edited by Ronnie Po-Chia Hsia and Henk Van Nierop, 27-52. Cambridge: Cambridge University Press, 2002.

Gautier, Bertrand, and Peter Voss. "Les communautés marchandes étrangères dans l'espace urbain bordelais (1620-1715).” In Les Étrangers dans la ville: Minorités et espace urbain du bas Moyen Age à l'époque moderne. Edited by Jacques Bottin and Donatella Calabi, 329-46. Paris: Éditions de la Maison des Sciences de l'Homme, 1999. 
Goris, Jan Albert. Étude sur les colonies marchandes méridionales (Portugais, Espagnols, Italiens) à Anvers de 1488 à 1567: contribution à l'histoire des débuts du capitalisme moderne. Louvain: Librairie Universitaire, 1925.

Graizbord, David L. Souls in Dispute: Converso Identities in Iberia and the Jewish Diaspora, 1580-1700. Philadelphia: University of Pennsylvania Press, 2004.

Israel, Jonathan I. "El comercio de los judíos sefardíes de Amsterdam con los conversos de Madrid a través del suroeste francés." In Familia, religión y negocio: El sefardismo en las relaciones entre el mundo hispánico y los Países Bajos en la Edad Moderna. Edited by Jaime Contreras et al., 373-90. Alcalá: Centro de Estudios Carlos de Amberes y el Instituto Internacional de Estudios Sefardíes y Andalusíes, Universidad de Alcalá, 2003.

Jeulin, Paul. "Une page de l'histoire du commerce nantais du XVI ${ }^{\mathrm{e}}$ siècle au début du XVIII ${ }^{\mathrm{e}}$ siècle: Aperçus sur la Contractation de Nantes (1530 environ-1733)." Annales de Bretagne 40 (1932): 284-331.

Kaplan, Yosef. "Between Christianity and Judaism in Early Modern Europe: The Confessionalization Process of the Western Sephardi Diaspora." InJudaism, Christianity, and Islam in the Course of History: Exchange and Conflicts. Edited by Lothar Gall and Dietmar Willoweit, 307-41. Munich: Oldenbourg, 2011.

Kaplan, Yosef. From Christianity to Judaism: The Story of Isaac Orobio de Castro. Trans. Raphael Loewe. Oxford: The Littman Library of Jewish Civilization, 1989.

Kaplan, Yosef. “This Thing Alone Will Preserve Their Nation. Forever:' Circumcision and Conversion in the Early. Modern Western Sephardic Communities." In The Conversos and Moriscos in Late Medieval Spain and Beyond. Vol. 3. Displaced Persons. Edited by Kevin Ingram, 218-43. Leiden: Brill, 2015.

Kaplan, Yosef. "Wayward New Christians and Stubborn New Jews: The Shaping of a Jewish Identity." Jewish History 8, nos. 1-2 (1994): 27-41.

Lancre, Pierre de. L'incredulité et mescreance du sortilege plainement convaincue. Paris: Nicolas Buon, 1622.

Madrid, Archivo Histórico Nacional [AHN], Inq., leg. 162, exp. 1.

Madrid, AH N, Inq., leg. 171, exp. 4.

Madrid, AHN, Inq., lib. 1103 .

Madrid, AH N, Inq., lib. 1104.

Madrid, AHN, Inq., lib. 1107.

Madrid, AH N, Inq., lib. 1111.

Madrid, AH N, Inq., lib. 1129.

Madrid, AHN, Inq., lib. 1131.

Madrid, AH N, Inq., lib. 1139.

Madrid, AH N, Inq., lib. 1145 .

Mathorez, Jules. "Notes sur l'histoire de la colonie portugaise à Nantes." Bulletin Hispanique 15 (1913): 316-39. 
Mathorez, Jules. "Notes sur les Espagnols en France depuis le XVI ${ }^{\mathrm{e}}$ siècle jusqu'au règne de Louis XIII." Bulletin Hispanique 16 (1914): 337-71.

Melammed, Renée Levine. A Question of Identity: Iberian Conversos in Historical Perspective. New York: Oxford University Press, 2004.

Moreno-Goldschmidt, Aliza. "Integración religiosa y social de los conversos en las comunidades de la diáspora sefardí occidental a la luz de fuentes inquisitoriales." Sefarad 76, no. 1 (2016): 159-96.

Muchnik, Natalia. "Amsterdam et les groupements judéo-ibériques de France au XVII ${ }^{\mathrm{e}}$ siècle." In Entre calvinistes et catholiques: Les relations religieuses entre la France et les Pays-Bas du Nord (XVI ${ }^{e}-X V I I I^{e}$ siècle). Edited by Yves Krumenacker, 299-313. Rennes: Presses Univ. de Rennes, 2010.

Muchnik, Natalia. "De la défense des 'impurs' à la critique du Saint-Office: Le plaidoyer de Juan Bautista de Villadiego (1636)." Revue d'histoire ecclésiastique 101 (2006):1014-38.

Muchnik, Natalia. De paroles et de gestes. Constructions marranes en terre d'Inquisition. Paris: Éditions de l'EHESS, 2014.

Nahon, Gérard. Juifs et judaïsme à Bordeaux. Bordeaux: Mollat, 2003.

Nahon, Gérard. "La 'Nation portugaise' de Saint-Esprit-lès-Bayonne du XVI e au XVIII ${ }^{\mathrm{e}}$ siècle: Escale ou havre de grâce?" In 1492/1992: L'Exode des juifs d'Espagne vers Bayonne. Edited by Maïté Lafourcade, 1-30. Bayonne: Université de Pau, 1993.

Nahon, Gérard. "Le modèle français du marranisme: Perspectives nouvelles." In Inquisição: Ensaios sobre mentalidade, heresias, e arte. Edited by Anita Novinsky and Maria Luiza Tucci Carneiro, 227-65. Rio de Janeiro: Edusp, 1992.

Nahon, Gérard. "Le modèle français du marranisme (XVI ${ }^{\mathrm{e}}-\mathrm{XVIII}{ }^{\mathrm{e}}$ siècles)." Annuaire de l'École Pratique des Hautes Études, Cinquième section: Sciences religieuses 90 (1982): 264 .

Nahon, Gérard. Les “Nations” juives portugaises du Sud-Ouest de la France (1684-1791). Paris: Fundação Calouste Gulbenkian, 1981.

Nahon, Gérard. "Les rapports des communautés judéo-portugaises de la France avec celle d'Amsterdam au XVII ${ }^{\text {e }}$ et au XVIII ${ }^{\text {e }}$ siècles." Studia Rosenthaliana 10, no. 1 (1976): 37-78; 10, no. 2 (1976): 151-88.

Nahon, Gérard. Métropoles et périphéries séfarades d'Occident: Kairouan, Amsterdam, Bayonne, Bordeaux, Jérusalem. Paris: Cerf, 1993.

Nahon, Gérard, and Michèle Escamilla. "Matines juives à Bayonne au XVII e siècle au filtre du Saint Office." In Non solo verso oriente: Studi sull'ebraismo in onore di Pier Cesare Ioly Zorattini. Edited by Magdalena Del Bianco Cotrozzi, Riccardo Di Segni and Marcello Massenzio, 295-344. Florence: Casa Editrice Leo S. Olschki, 2014.

Pohl, Hans. Die Portugiesen in Antwerpen, 1567-1648: zur Geschichte einer Minderheit. Wiesbaden: Steiner, 1978.

Révah, Israël Salvator. "Autobiographie d'un Marrane: Edition partielle d'un manuscrit de João (Moseh) Pinto Delgado." Revue des études juives 119 (1961): 41-130. 
Révah, Israël Salvator. "Les Marranes.," Revue des études juives 118 (1959-1960), 29-77.

Roth, Cecil. History of the Marranos. New York: Schocken, 1974.

Ruspio, Federica. La nazione portoghese: Ebrei ponentini e nuovi cristiani a Venezia. Turin: Silvio Zamorani editore, 2007.

Salomon, Herman P. "Haham Saul Levi Morteira en de Portugese Nieuw-Christenen." Studia Rosenthaliana 10 (1976): 127-41.

Saupin, Guy. "Un mouvement de xénophobie anti-portugaise à Nantes dans les années 1630." In Monarchies, noblesses et diplomaties européennes: Mélanges en l'honneur de Jean-François Labourdette. Edited by Jean-Pierre Poussou et al., 49-6o. Paris: PUPS 2005 .

Schwarzfuchs, Simon. Le registre des délibérations de la Nation Juive Portugaise de Bordeaux (1711-1787). Paris: Fundação Calouste Gulbenkian, 1981.

Silva, Innocêncio da. Dicionário bibliográfico portugués. Vol. 16 (= vol. 9 of the supplement by Brito Aranha). Lisbon: Impr. Nacional, 1893 .

Studnicki-Gizbert, Daviken. A Nation upon the Ocean Sea: Portugal's Atlantic Diaspora and the Crisis of the Spanish Empire, 1492-1640. Oxford: Oxford University Press, 2007.

Szajkowski, Zosa. "The Marranos and Sephardim of France," in The Abraham Weiss Jubilee Volume, ed. Samuel Belkin (New York: The Abraham Weiss Jubilee Committee, 1964), 107-127.

Szajkowski, Zosa. "Population Problems of Marranos and Sephardim of France." Proceedings of the American Academy for Jewish Research 27 (1958): 83-105.

Wallenborn, Hiltrud. Bekehrungseifer, Judenangst und Handelsinteresse: Amsterdam, Hamburg und London als Ziele sefardischer Migration im 17. Jahrhundert. Hildesheim: Olms, 2003.

Whaley, Joachim. Religious Toleration and Social Change in Hamburg, 1529-1819. Cambridge: Cambridge University Press, 2002 [1985].

Wilke, Carsten L. "Contraband for the Catholic King: Jews of the French Pyrenees in the Tobacco Trade and Spanish State Finance." In Purchasing Power: The Economics of Modern Jewish History. Edited by Rebecca Kobrin and Adam Teller, 46-70. Philadelphia: University of Pennsylvania Press, 2015.

Wilke, Carsten L. Jüdisch-christliches Doppelleben im Barock: Zur Biographie des Kaufmanns und Dichters Antonio Enríquez Gómez. Frankfurt:, Peter Lang, 1994.

Wilke, Carsten L. "Le rapport d'un espion du Saint-Office sur sa mission auprès des crypto-juifs de Saint-Jean-de-Luz (1611)," Sigila 16 (2006): 127-41.

Wilke, Carsten L. "Midrashim from Bordeaux: A Theological Controversy inside the Portuguese Jewish Diaspora at the Time of Spinoza's Excommunicatio." European Journal of Jewish Studies 6, no. 2 (2012): 207-47.

Wilke, Carsten L. "Políticos franceses, criptojudíos portugueses y un poeta español desterrado." In Antonio Enríquez Gómez, un poeta entre santos y judaizantes. Edited by J. Ignacio Díez and Carsten L. Wilke, 204-27. Kassel: Reichenberger, 2015. 
Wilke, Carsten L. "Un judaïsme clandestin en France au XVII e siècle: Un rite au rythme de l'imprimerie." In Transmission et passages en monde juif. Edited by Esther Benbassa, 281-311. Paris: Publisud, 1997.

Wilke, Carsten L. "Un moraliste rabbinique parmi les marranes de Bordeaux: Abraham de Oliveira et son Celo del temor de Dios (1661)." In L'Écriture de l'Histoire juive: Mélanges en l'honneur de Gérard Nahon. Edited by Danièle Iancu-Agou and Carol Iancu, 355-72. Paris and Louvain, Peeters, 2012.

Zink, Anne. "Communautés et corps social: Les juifs à Saint-Esprit-lès-Bayonne du XVII ${ }^{\mathrm{e}}$ au début du XIX ${ }^{\mathrm{e}}$ siècle." In Les Étrangers dans la ville: Minorités et espace urbain du bas Moyen Age à l'époque moderne. Edited by Jacques Bottin and Donatella Calabi, 313-28. Paris: Éditions de la Maison des Sciences de l'Homme, 1999.

Zink, Anne. "Une niche juridique: L'installation des Juifs à Saint-Esprit-lès-Bayonne au

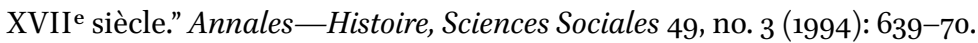




\title{
Prison Revelations and Jailhouse Encounters: Inquisitorial Prisons as Places of Judaizing Activism and Cross-Cultural Exchange
}

\author{
Ronnie Perelis
}

Prisons are a special site of cross-cultural encounter and religious illumination. People from different ethnic and socio-economic backgrounds meet each other and inevitably share ideas and experiences. The space of the prison, especially the inquisitorial prison, places an identity upon the prisoner and he or she can either embrace, dissimulate, or reject that identity. The Inquisition is concerned with identity; its interrogations are meant to unmask the "true" intention and beliefs of the accused and transform the heretic back into a child of the church. This stress on the performance of identity informs the social encounters within prison cells.

Prison and the prolonged process of interrogation can, in many cases, push the accused to examine their lives and their religious commitments. This is true even for someone who never gave too much thought to his or her religious choices. While in that place of religious questioning, the prisoner's encounter with someone outside his or her normal ethnic or religious group can catalyze already latent religious rumblings and push the individual in a new direction. While these prison transformations might be a rare occurrence-I am at this point unaware of any macro study of this phenomenon - they feature prominently in two cases that I have studied carefully: the case of Luis de Carvajal el mozo from late sixteenth-century New Spain and that of Manuel Cardoso de Macedo, aka Abraham Peregrino Guer from Lisbon in the early part of the seventeenth century. I believe that these cases can serve as indicators of a wider phenomenon that can tell us much about the social experience of accused heretics and the ways that their religious ideas and social networks developed in response to their experience as prisoners in the jails of the Holy Office.

In this chapter we will look at the autobiographical writings and inquisitorial trials of two individuals who underwent profound spiritual experiences while in prison and, in both cases, the encounter with the other in prison inspired a series of important "prison revelations" and fed their evolving religious identity. I believe that looking at these encounters will deepen our understanding of social boundaries within the Western Sephardic, Iberian

(C) RONNIE PERELIS, 2019 | DOI:10.1163/9789004392489_007

This is an open access chapter distributed under the terms of the prevailing CC-BY-NC License at the time of publication. 
converso and Iberian Old Christian worlds because, in both cases, we have individuals who cross their ethnic boundaries in order to embrace Judaism. This paper is part of a larger study looking at inquisitorial prisons as spaces of cross-cultural exchange. ${ }^{1}$ As the project unfolds, I hope to develop an overarching understanding of these encounters and a better appreciation of the role of the inquisitorial prison to facilitate and inform them. At this stage I wish to share some insights from these two concrete cases, a micro-history of sorts. To the extent possible, I will be shuttling between the way these encounters are described by the subjects themselves in their autobiographical narratives and how they appear in the trial records, with an emphasis on the self-fashioning at play in the autobiographical texts.

Carvajal's story is rather well known within inquisitorial studies and the study of Colonial Mexico. ${ }^{2}$ He was arrested along with most of his family in Mexico under suspicion of Judaizing in 1589 . He spent several months in prison eventually confessing to being a Judaizer and he pleaded for mercy. In 1595, he was re-arrested along with his mother and sisters and, eventually, was burnt at the stake as an unrepentant Judaizer. Luis was a central animating force within the crypto-Jewish underground in New Spain, and this is certainly how he presents his persona in his autobiography and in his second trial testimony.

1 Solange Alberro's important research on the workings of the Holy Office in Mexico in her Inquisición y sociedad en México 1571-170o (México: Fondo de Cultura Económica, 1988) and Jonathan Schorsch's micro studies of inter-racial encounters in inquisitorial prisons in his Swimming the Christian Atlantic: Judeoconversos, Afroiberians and Amerindians in the Seventeenth Century (Leiden: Brill, 2009), are useful models for my own approach to the subject. Another important study, also from the Mexican Inquisition is Boleslao Lewin's Confidencias de dos criptojudios en las cárceles del Santo Oficio, México, 1645-1646 (Buenos Aires: Talleres Gráficos, Julio Kaufman, 1975).

For a better understanding of the function and the place of prisons in early modern Europe, see Pieter Spierenburg and Elisabeth Lissenberg, Prison Experience: Disciplinary Institutions and Their Inmates in Early Modern Europe (Amsterdam: Amsterdam University Press, 2007). For a focus on the architecture of the prison see Norman Johnston, Forms of Constraint: A History of Prison Architecture (Chicago: University of Illinois Press, 2000). Edward Peters provides some important background to the rise of the early modern prison in his "Prison Before the Prison: The Ancient and Medieval Worlds," in The Oxford History of the Prison, eds. Norval Morris and David Rothman (New York: Oxford University Press, 1998), 26.

2 See the two classic treatments of his life, Alfonso Toro, La Familia Carvajal (México DF: Editorial Patria S.A., 1977 [1944]) and Martin A. Cohen, The Martyr (Albuquerque: University of New Mexico Press, 2001). For an analysis of his religious thought, especially in the context of his martyrdom, see Miriam Bodian's Dying in the Law of Moses (Bloomington: Indiana University Press, 2007). For an appreciation of Carvajal within his wider Iberian context, see Lúcia Helena Costigan's Through Cracks in the Wall: Modern Inquisitions and New Christian Letrados in the Iberian Atlantic World (Leiden: Brill, 2010). My recent book, Narratives from the Sephardic Atlantic: Blood and Faith, features two chapters dedicated to Carvajal and his family network. 
Luis crafted a spiritual autobiography that spanned his childhood initiation into crypto-Jewish belief and practice in Benavente, Spain, his family's move to New Spain in 1579, and his idiosyncratic textually-fueled spiritual exploits before and after his first arrest by the Holy Office in 1589 . The autobiography traces his experience up until his second arrest in 1595: it was confiscated after his arrest and used as evidence against Carvajal and his circle. It was preserved as part of the proceso of the Carvajal family and was transcribed by the Mexican historian Alfonso Toro just a few years before it was stolen from the Mexican National Archives by a mysterious foreigner-a certain Professor Jac Nachbin in 1932-this text (almost) miraculously resurfaced in the past year and was repatriated to the Mexican Government with the help of the FBI and the collector of Americana Leonard Milberg. After a brief exhibition at the New York Historical Society, it has finally returned home to Mexico (Fig. 6.1). Between the trial records and Carvajal's Vida, we are able to appreciate the place of prison in Carvajal's spiritual development. ${ }^{3}$ In his Vida, he gives pride of place to his unlikely friendship with a wayward monk, Fray Francisco Ruiz de Luna, and it is to this relationship we will now turn.

In the prisons of the Inquisition Luis undergoes some of his most transformative experiences. As described in his Vida, prison is a site of prophetic dreams where Solomon, Jeremiah, and Job reveal divine secrets to him through parables. ${ }^{4}$ Luis presents himself as a noble servant of the Divine, willing to suffer and sacrifice for his faith in the dark depths of the Inquisition's secret prisons. It is also a site of friendship and communion of a most surprising sort. ${ }^{5}$ The inquisitors place a monk who was arrested for minor religious infractions into Luis's cell. The monk, Fray Francisco Ruiz de Luna, was ordered to not reveal his religious title to Luis in the hope that he will be able to spy on him and provide the inquisitors with more evidence of his heresy. ${ }^{6}$ Early on however,

3 Carvajal's Vida as well as the records from his two inquisitorial trials can be found in Luis González Obregón, ed. Procesos de Luis de Carvajal, el mozo (México: Talleres gráficos de la nación, 1935). I have designated the Vida as LCMA (Luis de Carvajal, el Mozo Autobiography) and his trial records as LCM I and II (Luis de Carvajal, el mozo, first or second trial). Toro's transcription of the Vida can also be found in the Appendix of Toro's La Familia Carvajal.

4 LCM II, 695-96.

5 My reading of the relationship between Fray Francisco and Luis is enriched by some ideas developed by Professor Thomas Cohen of York University in his keynote address to the Early Modern Workshop in Jewish History (Brown University, 26 February 2012) entitled, "Entanglement: How the Whole World Worked and How Jews Joined In." In particular, his idea of the relationship between sacrifice and communion was very illuminating and provocative.

6 See Cohen, The Martyr, 166-67; Bodian, Dying in the Law of Moses, 63-64. Luis asserts that he was placed in the cell because of the inquisitors' concern over his poor health and depressed spirits, LCMA, 476 . 


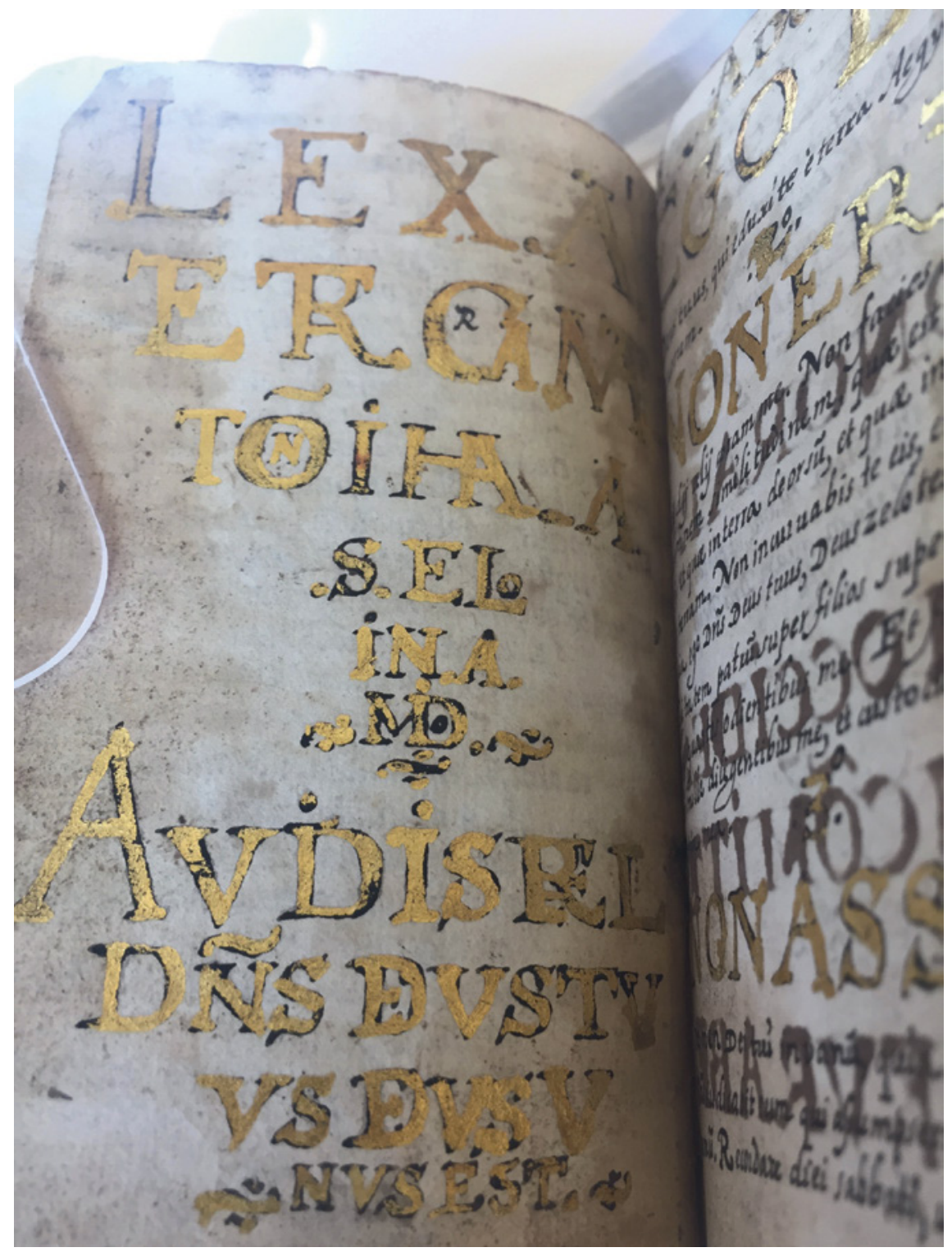

FIGURE 6.1 Latin Decalogue illuminated in gold leaf by Luis de Carvajal el mozo, Mexico, $1590 \mathrm{~s}$

the wayward monk and the Judaizing heretic discover a unique bond in their shared captivity.

From their earliest moments together, Luis describes an easy and amicable relationship: after the two prisoners began to speak for a while, he was 
gladdened by the company.7 They are both happy to have social contact, to share a conversation as a respite from the dark loneliness of their imprisonment. But as all things in Luis's Vida, the arrival of this monk is no mere coincidence, neither is it really about the poorly executed plans of the inquisitors, but rather it is all part of a divine plan. Luis prefaces the arrival of Fray Francisco into his cell with a lament over being cut off from his holy books while in prison. He desires above all else to be able to pray and study the Bible. Sure enough, while Luis is denied access to books, this monk requests and promptly receives a breviary with which to pray. To Luis this is a great salvation; now, he is able to access the Psalms included as part of his cellmate's Catholic prayer book and pour out his soul to the God of Israel. Luis describes his deep joy at seeing the prison warden enter their cell with the breviary: with supreme delight and joy, he saw how the Lord his God through that request sent him that which he desired which was to be able to recite the Psalms, as was his custom. ${ }^{8}$

At first, however, Luis was unable to fully express his Judaism because of the presence of his "compañero," the monk. However, through Divine intervention, the monk was "enlightened and converted to the true God." ${ }^{9}$ Luis describes how they engaged in theological discussions and how, after a few days, the monk began to see the truth of the Law of Moses. Their relationship was transformed from simply one of prison camaraderie born of boredom and loneliness into a spiritual bond. In the course of a few days, Luis went from hiding his Judaism to celebrating the God of Israel with the lapsed monk: "They would rejoice and console each other and would sing hymns and praises to the Lord [...]."10 They would dance and praise God for having enlightened the monk and allowing them both to share in the divine service.

They also bonded over sacred texts. Fray Francisco lent Luis his breviary, allowing him to "poach"11 passages from the Hebrew Bible out of the Catholic text for his own Judaizing ends. Luis describes them both spending hours in their cells discussing "sagradas historias."12 During one such exchange, the monk was hungrily drinking in Luis's words when he declares: "What would

"Despues de los dos presos aberse comunicado un rato y alegrado de la junta y compañia." LCMA, 478.

8 "Con sumo gozo y alegria de ver que el s[eño]r $\mathrm{D}[$ ios] suyo abia ymbiadole por aquella orden lo que deseaba tanto que era tener por donde rezar los ps[alm]os como solia." LCMA, 476 .

9 "Alumbrado y convertido." LCMA, 478.

10 "Se alegraba y consolaba y cantaba himnos y loores al s[eño]r." LCMA, 478.

11 Michel De Certeau, "Reading as Poaching," in The Practice of Everyday Life, trans. Steven I. Rendal (Berkeley: University of California Press, 1984).

12 Presumably these were stories from the Hebrew Bible, but quite possibly this general category might include a wider array of religiously edifying stories. It is important to notice 
I have given to have been enlightened by the truth of God outside of this prison, to have encountered it [the divine truth] while in the monasteries, which generally have open libraries filled with the sacred Scriptures and many other good books."13

This bizarre off-hand comment made by Francisco-his desire to have been a Judaizer in a monastery so at least he could spend his time reading the Hebrew Bible-plants a seed in Luis's mind. He asks, "are those books open to all?" (479). ${ }^{14}$ Luis is struck by the idea of having access to vast libraries of religious works and echoes his friend's sentiment and declares: "Oh how I wish I was in one of those."15 Eventually this wish comes true-after his release Luis is placed to work in a monastery where he had access to a library of religious works, but even at this moment in the narrative, the two cellmates share the same dream of free access to religious texts.

Luis tells the reader of the Vida that in addition to prayer and study of the Bible, Luis and Fray Francisco share in another more primal religious act. Despite their hunger, the two Judaizers discard the pork products in their meager rations and bury them in the dirt floor of their cells as a "sacrifice."16 Luis describes how they would suffer great hunger by passing up on this "forbidden food." These shared acts of devotion and sacrifice serve to bring the two inmates together and transform the monk from a "good stranger" into "a confessant of the true God and His holy law" who eventually will wear "the martyr's crown. ${ }^{17}$ Luis is amazed at this transformation because of Fray Francisco's Old Christian background. He repeatedly mentions the fact that Fray Francisco took to the Law of Moses as if he were raised by Judaizing parents: "It was engraved on the soul of this good foreigner the divine truth as if he was raised in it all of his life and was taught it by pious parents."18

Fray Francisco's embrace of the "truth," his bravery, and sacrifice are described as almost miraculous - the divine truth has been inscribed on his soul, without the usual dialectic between nature and nurture. I have not located indications in Fray Francisco's proceso where any of these practices come

that in this case in particular, Luis is the teacher: $\mathrm{He}$ is the one regaling Francisco with the stories.

13 "Quien me dierra sido alumbrado en la berdad de Dios fuera de esta carzel y caido en ella estando en los monasterios, que solyan donde tienen librerias abiertas con la sagrada escriptura y otros muchos buenos libros." LCMA 478-9.

14 LCMA, 479.

15 "A quien me diera en unas de ellas." Ibid.

16 "Bamos a hacer el sacrificio" (Let's make the sacrifice). LCMA, 479.

17 "Confesor de D[ios] verdadero y de su ley s[antis]ma [...] corona de martir." LCMA, 479.

18 "Imprimiosele tambien en el anima a este buen estrangero la berdad divina como si toda su vida ubiera sido criado en ella y enseñado por fieles p[adr]es." LCMA, 479. 
up - or any indication that during this time together he gives any indication to the inquisitors of his budding Jewish affinities - this remains a desideratum. However, we know that after his release he served on a royal galley as penitence for his previous heretical deeds-belittling the sacraments by administering without the proper authority. While serving on a galley ship, he breaks down, desecrates a crucifix, and declares his belief in the Law of Moses, and thus this renegade monk ended his life at an auto-da-fé as an obdurate Judaizer. Luis praises the monk for his bravery and integrity: Joseph's companion confessed the truth of the God of Israel before the tyrants with such a courageous spirit that has never been seen in someone of a foreign nation. ${ }^{19}$

The Vida describes Francisco telling the inquisitors to their face that only the God of Israel is true and all other gods are frauds and tricks of the Devil. He audaciously claims that the "king and the inquisitorial dogs" know this but their hearts are hardened to the truth like the heart of Pharaoh. ${ }^{20}$ It is not only that Francisco is pious, passionate, and brave; his commitment to Judaism is remarkable because of the way that it breaks with his ethnic past. He is of an "estraña nación," an Old Christian, but becomes a crypto-Jewish martyr. Through his sacrifice, he gains communion with Luis and his people. ${ }^{21}$

Luis and his family were arrested a second time for backsliding into their old pernicious ways in 1595. The inquisitors again placed a spy into his cell in the hopes that the new cellmate would give them confidential information. Things turned out very differently for Luis and the inquisitors this time. Instead of another opportunity for cross-cultural encounter and another victory for Luis's

19 "El compañero de Joseph confeso aquella vez al $\mathrm{D}$ [ios] del cielo delante de los tyranos con tan valerosos animo q[uan] to no se a vista semejante cosa en ho[mbr]e de estraña nacion." LCMA, 486-87.

20 It is not clear if this exchange is the invention of Luis's fertile imagination or not. How Luis knew that Francisco used this creative piece of biblical exegesis before the inquisitors is hard to know. However, the application of the Exodus story to the plight of the conversos before the inquisitors could very well be an indication of the extent to which this monk had already begun to absorb Luis's bibliocentric hermeneutic.

The calling of the inquisitors "dogs" is a fascinating reversal or appropriation of the classic anti-Jewish epithet "perro judio." This is just one of many examples whereby Luis's Judaism is actually a Judaizing of Christianity, a reorientation of Catholic ideas and terminology toward an idealized vision of the Law of Moses.

21 Manuel Cardoso de Macedo, another Old Christian convert to Judaism whom I will discuss later in this essay, is deeply troubled by his Old Christian blood and felt that it was a hindrance to his full conversion. While Cardoso is accepted by the Jewish community in Amsterdam, he himself carries an anxiety about his place within that community because of his ethnic origin. For Luis, however, Francisco's conversion is all the more wondrous because of his Old Christian background. 
faith, in this case the cellmate was a clever and manipulative spy, abusing the trust and gullibility of his target.

Luis Díaz, a wayward cleric, was placed in Carvajal's cell to function as a spy. ${ }^{22}$ Because of Carvajal's success in turning the monk Ruiz de Luna into a sincere and heroic crypto-Jew during his first trial, Luis might have been predisposed to believe in Díaz's openness to crypto-Judaism. Carvajal's desire to connect with Díaz might also suggest his own loneliness and desire (inspired by his earlier prison experience) to share his spiritual life with a fellow believer. Solange Alberro has shown how the inquisitors often placed prisoners alone for a while in order break them psychologically. Thus, he not only quickly tells Díaz about his own religiosity, but he goes on to recount, with great detail and excitement, the courageous deeds and spiritual activities of his wider cryptoJewish network. His goal is to convince this cleric who seems to have lost his way with Catholicism not only that the Law of Moses is the true law, but that there is a vibrant community of the faithful whom he could join. This community is more than a group of like-minded individuals - they are like a family; in embracing the Law of Moses, Díaz would also be part of that family of enlightened believers.

Díaz picks up on the deep bonds between the crypto-Jews and uses it as a way to get more information about this large and interconnected network. He tells Carvajal that he wants to know who the Judaizers are in order to "get to know them and love them like brothers." ${ }^{23}$ Later on he uses similar terminology when he asks Carvajal, "Would you tell me who are your brothers?" 24 Díaz is able to push Carvajal for more information because he says he wants to meet his "brothers." He gives the impression of desiring to be a part of the spiritual brotherhood that is so essential to Carvajal's religious world. He perceptively hits Luis where he is vulnerable. When Luis finally realizes that Díaz is a spy he is despondent, but not only because of the damage he has done to the people he loves, but because of the wound left by Díaz's deception and betrayal. Díaz records Carvajal's lament: "Where was my judgment when I opened my heart to you?" ${ }^{25} \mathrm{He}$ realizes that he let himself be tricked by this deception: he

22 Regarding this aspect of inquisitorial protocol, see Boleslao Lewin's Confidencias de dos criptojudios, 11-12. Lewin points out that the Mexican tribunal's use of spies was often criticized by the Suprema in Madrid because it was too invasive. Also see Solange Alberro's Inquisición y sociedad en México, 229-35. Diaz, like Ruíz de Luna, was imprisoned on light charges. However, these would have been enough for the inquisitors to use as pressure to force him into spying.

23 "Para conocerlos y amarlos como a hermanos." LCM II, 164.

24 "Me diréis quién son tus hermanos [... ?]." LCM II, 165.

25 "Donde tenía yo mi juicio cuando os descubrí mi pecho." LCM II, 157. 
revealed his heart; he allowed himself to be vulnerable to someone who called himself a brother; and he was taken advantage of. ${ }^{26}$ At the same moment that Carvajal believed that he was welcoming another stranger into the fold, of inviting another searcher into his spiritual family, he endangered the entire community.

Crossing boundaries is neither safe nor easy. Luis successfully manages other important relationships with people outside his social network, most notably his complex relationship with Fray Pedro de Oroz, the rector of the Colegio de Santiago de Tlaltelolco where Luis taught Latin and was Fray Pedro's personal scribe. Luis appreciated Fray Pedro's kindness and his love of books. There is a palpable sense of respect and a shared love of ideas in Luis's description of the rector. But ultimately, Luis had to hide his true religious feelings and practice subterfuge throughout his time with Fray Pedro, so it is a compromised sort of encounter. His encounter with Luis Diaz during his second trial lies on the opposite end of the spectrum. He was completely open with him, vulnerable and eager to connect, and the spy used that vulnerability to his maximum advantage, completely abusing his trust in the guise of a wayward Christian eager to see the true light of the Law of Moses.

Most conversos were deeply rooted within converso social networksregardless of actual crypto-Jewish activity. To a great extent, they did business with, got married to, and socialized with other conversos, often from related families. In prison, however, they would meet people of other socio-economic and ethnic groups. In the Mexican context, these spies offer the historian a unique window into select encounters with a social or ethnic other. Because of the tight quarters of the prison cell, the long hours alone without other distractions, and the highly charged nature of the space, cellmates had an opportunity to get to know the other, to share, and be vulnerable. But the spy, if he remains true to his mission, needs to use that proximity and to capitalize on the desire to share in order to obtain information that the prisoner might not want to share with the inquisitor. By feigning interest and cultivating trust, the spy can reach into the "soul" of the prisoner. Conversos encounter other individuals outside their social network in prison, cellmates, guards, and maids, etc., and these cases are important to consider as well. However, the cases involving a spy have the advantage for the historian of leaving a record- the testimony of the spy to the inquisitor-of at least a version of their cross-cultural interaction.

In the Vida, Carvajal regales his readers with the story of his cellmate's embrace of the Law of Moses and their shared religious devotion. He is the 
master and he is in control of the narrative; it is Carvajal who gives voice to his cellmate's experience and praises the neophyte's passion. In the case of Manuel Cardoso Macedo, however, it is the convert to Judaism, Cardoso the Old Christian outsider, who tells his own story of cross-cultural encounter.

Manuel Cardoso de Macedo (1585-1652) was an Azorean Old Christian who found his way to Judaism after first embracing Calvinsim and then discovering "the Law of Moses" in a cell he shared with an accused Judaizer in the prison of the Lisbon Holy Office. Cardoso eventually escapes Portugal along with members of a large converso family that he met in prison, and he converts to Judaism in Hamburg, taking the Hebrew name of Abraham Pelengrino Guer. He settles in Amsterdam where he lives within the Portuguese community until his death in $1653 .^{27}$

Cardoso's religious odyssey begins in England. His father was in the dye and textile trade and conducted extensive business with England. He sent his teenage son, Manuel, to England in 1599 to master the language and apprentice with some business associates, presumably in preparation for a life in the family business. While in England, he encountered the Bible in English translation. This, according to his telling in the Vida, changed his life, setting off a series of

27 Cardoso wrote a spiritual autobiography later in his life while he was living openly as a converted Jew in Amsterdam. The text was titled, "Vida do bemaventurado Abraham Pelengrino" and has survived in a beautifully copied manuscript from 1769 in the collection of the Ets Haim Library in Amsterdam (EH_49_A_15; http://etshaimmanuscripts.nl/ eh_49_a_15/). Prof. Yosef Kaplan disentangled the identity of this Old Christian convert to Judaism from another convert with a similar Jewish name, Abraham Guer but with a different Christian name who lived at a slight remove from our Pelengrino. See his "Jewish Proselytes from Portugal in 17th-Century Amsterdam-The Case of Lorenzo Esudero," [Hebrew] Proceedings of the World Congress of Jewish Studies (1977): 87-101.

Bernard Teensma published a transcription of the autobiography with a Dutch translation and very helpful biographical and linguistic annotations: "Manuel Cardozo de Macedo, 'La Vida del buenaventurado Abraham Pelengrino,' edited by B. Teensma," Studia Rosenthaliana 10 (1976): $1-36$. My citations are from this transcription and all translations are my own (hereafter, Vida). I also make occasional use of the records from Cardoso's two inquisitorial trials found in the Torre de Tombo archive in Lisbon: Processo de Manuel Cardoso. Tribunal do Santo Ofício, Inquisição de Lisboa, Instituto dos Arquivos Nacionais / Arquivo Nacional Torre do Tombo. PT-TT-TSO-IL-28-319 and PT-TT-TSO-IL-28-319-1. I have abbreviated these to CM PT-TT for the first trial and CM PT-TT II for the second trial. In Chapter 4 of my Narratives from the Sephardic Atlantic, I analyze Cardoso's selffashioning and religious transformations in light of his social dynamics.

Currently Dr. Alexander van der Haven at the Center for the Study of Conversion and Inter-Religious Encounters at Ben-Gurion University of the Negev is working on some very exciting research into the life of Cardoso de Macedo. I look forward to his forthcoming work. 
independently inspired religious inquiries. He writes: "Scripture was the first thing that they placed in my hand after the AвC."28

He soon became enthralled with Protestant ideas, eventually rejecting "the religion of his parents" for Calvinism. On trips back to the Azores to visit his family, he managed to keep his heresy a secret, but eventually word got out and he was arrested while visiting São Miguel and was eventually sent to the Lisbon Holy Office in 1608. It is in prison where he rejects Calvinism after his discovery of Judaism. Cardoso eventually was released from prison and, after connecting with a group of Portuguese conversos he knew from his time in prison, he escaped Lisbon for Hamburg where he formally converted, eventually settling in Amsterdam. Around the 1620s, he composed his spiritual autobiography La Vida del buenaventurado Abraham Pelengrino Guer. Like Carvajal, Cardoso's autobiography can be read in light of his trial records found at the Torre de Tombo. I will make reference to those inquisitorial records, but our main focus for the remainder of this paper will be the way Cardoso's crosscultural encounter in prison is depicted in his Vida and its central role in his religious self-fashioning.

In Cardoso's Vida, he describes himself as a defiant Protestant during his time in the jails of the Inquisition. "I am a Calvinist and I will die a Calvinist, unless you can convince me with reasons, ${ }^{29}$ he tells the Azorean bishop who first apprehends him. He describes polemical back-and-forths he had with the inquisitors, which all concluded, not surprisingly, in his vindication over the hapless inquisitors. ${ }^{30}$ At one point, Cardoso tells the reader that the inquisitors gave up on convincing him and decided to move Cardoso to the house of a respectable and honored man whose good Christian example would inspire Cardoso. They voiced the hope that, "There you will be touched by the Holy Spirit, so that you will turn toward the milk of the Church that you suckled [as a child]." ${ }^{31}$ Because of his Old Christian background, Cardoso is treated with considerable flexibility and mercy. The inquisitor's starting point is that he will eventually return to his former religious identity. The Bishop in the Azores tells Cardoso, "We know of your lineage"; in other words, we know your

28 "Consideray na Escritura, que foy a primeira couza que me meterão na mão depois de ABC." Vida, 7 .

29 "Eu sou Calvino, e Calvino ei-de morer." Vida, 8.

30 Vida, 9-11. In the actual inquisitorial records, we see no indication of this. Rather the inquisitors are mostly concerned with identifying how he fell into the clutches of "Lutheranism" and if there were other Catholics living in England infected with this.

31 "Ahy vos tocará o Espírito S[an]to, para que vos convertais ao leyte da Ygreja que mamasteis." Vida, 12. 
family, your blood is pure and thus this heresy is only skin deep and will pass. He was a teenager after all.

However, the plan never has a chance to take off. Before he was actually moved to the home of this upstanding family, he was placed in a holding cell with an accused Judaizer, Henrique Dias Milão, a New Christian who vehemently denied being a crypto-Jew to the inquisitors despite the evidence they had proving a long history of active Judaizing. ${ }^{32}$ It was through this temporary cellmate that Cardoso first came into contact with a written account of Judaism in the form of a small "booklet of his crimes," compiled by the inquisitors recording Dias Milão's Judaizing. When Cardoso began to read the practices cataloged in this "Libello" he was shocked to find out that there were still people in the world who actually kept the laws of the Bible: "There were people who kept that religion, because all that was [recorded] there was in accordance with Scripture." ${ }^{33} \mathrm{He}$ spent the entire night reading the pamphlet and considering its implications on his own religious life. The next morning, he found himself again at a religious crossroads, unsure of his next step: "I awoke without any form of religion, wiping out all of the

32 As is often the case in trials of Portuguese conversos, it is very hard to ascertain the veracity of the accusations of Judaizing. That his children work hard to leave Lisbon in the years following their father's execution at the auto-da-fé of 1609 only proves that they feared being caught in the Inquisition's web a second time. On the other hand, that many of the Dias Milão children move to Northern Europe and become members of open Jewish communities does indicate some awareness of and commitment to Jewish belief and practice. This consciousness, however, might have been inspired by their brush with the Inquisition. Regardless of the veracity of the inquisitor's accusations, what is of interest to our present discussion is how Cardoso describes this encounter with the booklet listing Dias Milão's "Judaizing crimes."

33 "Libelo de suas culpas, [...] se havia gente que guardasse aquela religão, porque tudo o que aly estava concordava com a Escritura." Vida, 12. Regarding the attraction of some radical Protestants to Judaism see the collection of essays edited by Martin Mulsow and Richard H. Popkin, Secret Conversions to Judaism in Early Modern Europe (Leiden: Brill, 2004.) and Richard H. Popkin and Gordon M. Weiner's Jewish Christians and Christian Jews (Dordrecht: Kluwer Academic Publishers, 1994). In The Dutch Revolt (Ithaca, NY: Cornell University Press, 1977), Geoffrey Parker mentions that many conversos of Antwerp served as an important resource for the Protestant cause in the Low Countries. In addition to providing monetary support, some conversos converted to Calvinism and shared strategies of dissimulation with their fellow "brethren." Parker cautions, however, against seeing too much religious sincerity in these moves, "for many of them [the Marranos] it was no more than a façade for crypto-Judaism. It is significant that few marranos became Protestants in 1577-1584 when it was easy but there was no persecution" (6o, n. 36). See chapter 4 of my recent book, Narratives from the Sephardic Atlantic: Blood and Faith (Indiana University Press, 2016), for an analysis of Cardoso's conversion within the wider context of Christian religious experimentation in the early modern period. 
Scriptures, not believing any of them, and seeing it all as a fable. In the end, I was turned into a libertine."34

His newfound agnosticism allows him to cynically dissimulate a change of heart to the inquisitors. He appeals to their mercy and forgiveness. He claims to have been possessed by a devil and likens himself to a drunk who when seduced by wine becomes somebody else only to wake up in the morning and not remember any of the previous evening's disastrous exploits. Cardoso fed the inquisitors exactly what they were hoping to hear, and they welcomed him back to the fold. He was asked to repent his sins and was penanced at the auto-da-fé of 5 April 16og. In addition to the sambenito he was obliged to wear, Cardoso was sent to the Escolas Gerais, a reform school for penitent heretics for rehabilitative instruction in the Christian faith. ${ }^{35}$

Cardoso's discovery of Judaism calls into question his once solid belief in Calvinism. He is profoundly confused and enters a brief period of radical agnosticism, and it is during this time that Cardoso is able to feign remorse for his heretical "nonsense," plead disingenuously for the Holy Office's mercy, and ultimately save his life. ${ }^{36}$ As he confesses in his Vida: "Following this I decided to go to the [inquisitors'] table and retract [un-say myself] in order to not die." ${ }^{37}$ This "un-telling" of his past life was possible only because of the spiritual emptiness and lack of conviction he now felt.

However, in time, Cardoso was not paralyzed by his agnosticism. Upon his release from prison, he was placed in the Escolas Gerais, the reform school set up for inquisitorial penitents in the Santa Marinha neighborhood of Lisbon, where his inquisitors hoped that he would be shepherded back to the flock of the faithful. All penitents who were not sentenced to death or the galleys

"He deitando-me amanhesi sem hum modo de religão, borando todas as Escrituras e não creher nada dellas, e ter tudo por fábula. Finalmente fiquey libertino formado." Vida, 13. In the trial record, we do not see any sudden shift in his testimony along these lines. There is also no mention of his being placed in Dias Milão's cell—not that this would necessarily make it into the record. What is interesting is that the role of the remorseful penitent that Cardoso describes in this section of the Vida, a persona he claims to adopt only after his crisis of faith, is how he appears throughout his first trial. From the very beginning he recounts his heretical beliefs and rejection of Catholic practice, but only as part of a confession leading to his petition for mercy and his desire to return to the church. In the trial records, there are no theological debates with the inquisitors. The only bold proclamations of his Calvinism come from testimony of others who met him in England. These are two irreconcilable images that point to the very different rhetorical contexts of his prison testimony and of his Vida. Cardoso writes the Vida as a retrospective, and in that retelling he crafts his present self-image.

36 "Disbarates." Vida, 13.

"Ao seguinte determiney a hir à Meza e desdezir-me por não morer." Ibid. 
were placed in these schools. After several months they would be allowed to leave but had to reside in the nearby Santa Marinha neighborhood so that inquisitorial officials could check up on them and ensure their full reintegration. Cardoso was successful at convincing the officials of his piety, and he was soon released. ${ }^{38}$

Prisons are often the best schools for criminality, and this "reform school" was no exception. In the Vida, Cardoso describes how he made use of the high percentage of conversos there to deepen his understanding of Judaism: "And with my conscience never being at peace, I would approach certain individuals who would appear to me [as possible crypto-Jews], and I would ask them: "Why did they arrest you?" And when they would say to me that they were arrested for being a Jew, I would continue to ask them if it was so. If they would say "yes" I would try to extrapolate from [what they told me] what I saw fit." ${ }^{39}$

Cardoso points to two essential characteristics of how he understood his religious transformation. His search to understand Judaism is self-directed. He decides which conversos to approach as potential sources, and he is the one who carefully extracts the information that he finds relevant for his own religious quest: "I would try to extrapolate from [what they told me] what I saw fit." At the same time, Cardoso bonds with his informants. Most strikingly in this passage, we see how he begins to transform himself into not only a Jew, but a crypto-Jew. In order to get the information he wants, Cardoso must act like a crypto-Jew, even before becoming a Jew. He practices stealth and dissimulation in order to reconstruct the religious world of which he received an earth-shattering glimpse in the jail of the Inquisition a few weeks back. His choice to learn more about Judaism leads him along a path where he not only encounters a new social circle, that of the New Christians, but also must adopt the subversive practices characteristic of crypto-Judaism because of inquisitorial surveillance.

38 In his second trial two officials from the escolha testified that they knew Cardoso from his time at the school and were aware that he moved into the Santa Marinha neighborhood. They do not explicitly vouch for his piety, but they do not say anything to contradict it. Their main focus is on Cardoso's close relationship with Fernão Lopes and his mother. They describe Cardoso as a servant of this family and their acquaintances, setting their table and preparing their meals. See the testimonies of Jorge DaCosta, the director (alcalde) of the school and Antonio de Ruiz, a former guard, in CM-PT-TT II, 50-54.

"E nunca aqueitando com o juizo me chegava a algumas pessoas que me paresião, y lhes preguntava: 'Porquê vos prenderão?' e dizendo-me por Judeu lhe tornava a preguntar se o avia sido. Se me dezia que sy. Tirá-lla delle couza era, y dizendo-mo tomava dahy o que me paresia." Vida, 14. 
After two months in the reform school, Cardoso is released and moves in with the children of his former cellmate, Henryque Diaz Milão. Cardoso refers to Milão, who was sentenced to death for his Judaizing practices, as his "comp [anheiro]o." Cardoso decides to stay with Milão's children because he wants to learn more about Jewish ritual and belief. Thus, he went "with the goal of keeping the Sabbath and going little by little taking notice of the Law of Moses, because it appeared to me to be the true [law], of which I did not have any knowledge because in my father's house it was said that the Jews adored a heiffer [toura, a female touro]." ${ }^{40} \mathrm{He}$ has discovered the true nature of Judaism only recently because growing up in his father's house, the only knowledge of Judaism he had was a bizarre refrain claiming that the Jews adore the "toura," not the Torah..$^{41}$ Again, Cardoso cites his family legacy as the primary obstacle on his path to religious truth. It is thanks to his cellmate, and then later on the inmates at the school, that Cardoso comes to see the truth of Judaism.

Not only does Cardoso gravitate toward the Jews for religious knowledge; he also begins to identify himself with them: "I was acquiring affection for the Men of the Nation, and [I began to] take upon myself their troubles as my own." 42 He describes his move toward Judaism as grounded in intellectual rigor, but it is also intimately tied up with his empathy for the Jews, his taking their "troubles as his own."43 This expression of empathy reflects his (desired) identification with both the God and the people of Israel and his willingness to share in their destiny.

40 "Fuy com presuposto de guardar o Sabat e yr pouco a pouco tomando nottísia da Ley de Mosseh, porque me pareseu ser a verdadeira, da qual de antes não havia tido nottísia, por cuidar que os Judeos adoravão huma toura, como em caza de meo pay se dezia" (Vida, 13). For more on the Diaz Milão family see H.P. Salomon's Portrait of a New Christian: Fernâo Álvares Melo, 1569-1632 (Paris: Fundaçâo Calouste Gulbenkian, 1982.).

41 In his edition of La vida del buenaventurado Abraham Pelengrino, Teensma defines the word "Toura" to mean wooden disc or chopping block (30, n. 13). My reading is supported by the straightforward definition found in the Dicionário du Língua Portuguesa Contemporânea: Academia das Ciências de Lisboa, 2.2 (Lisbon: Verbo, 2001), and other Portuguese dictionaries. This definition also supports an allusion to the "Golden Calf" implied by word play.

42 "Fuy tomando afeisão à gente da Nasão, e pasar-me a seus trabalhos como própios." Vida, 13 .

43 This seems to be a clear allusion to Ruth, the righteous convert, who told her mother-inlaw, Naomi, "Wherever you go, there shall I go, and wherever you will sleep, I will sleep, your people are my people and your God my God" (Ruth 1:16). Ruth left the comfort of her homeland to return with her impoverished and widowed mother-in-law to a strange land. Her commitment to Naomi on a personal level was intimately tied to her relationship with Naomi's God. 
In his Vida, Cardoso includes several examples of his self-sacrifice for his fellow Jews: he arranges an escape from Lisbon for members of the Dias Milão family in 1609, and when the plot is foiled, he takes the blame, suffering abuse at the hands of the authorities and shielding his New Christian companions. He manages to arrange a second escape, which was successful, bringing members of the Diaz Milão family and himself to the safety of Hamburg in 1611. Each of these instances form pivotal moments in his spiritual peregrinação; they signify movement toward a fuller integration into the Jewish community and a more complete transformation into his new religious identity. In these cases, prison is a place where he not only discovers the tenets of Judaism, but he transforms himself through shared experiences and sacrifice into a member of the Nação.

Carvajal's encounter with Francisco Ruiz de Luna, the wayward monk who saw the light of the Law of Moses in their shared inquisitorial prison cell in Mexico City, is essential to Carvajal's self-fashioning as a spiritual leader and enlightening teacher of the "Truth." He managed to bring this Old Christian, with no roots in the people of Israel, to the God of Israel and His Law. Carvajal and Ruiz de Luna bond over their shared commitment to Judaism and form a powerful connection that transcends blood. Within the narrative economy of the Vida, this relationship is a testament to Luis's prophetic power and his ability to help reveal the Judaic truth to even a "stranger."

For Manuel Cardoso de Macedo, his encounter with a stranger in prison is essential to his religious trajectory. From the first instances of his autobiography, Cardoso presents himself as a brave and determined searcher after the truth. In each case, his enlightenment is facilitated by an encounter with religious and ethnic others-in England it involved his Protestant hosts, while in Lisbon it is a group of conversos accused of Judaizing who radically reorient his religious journey. Despite his passionate commitment to Calvinism throughout his time in prison, he is still open to the truth, from wherever it comes. His revelatory encounter with Diaz Milão and his subsequent connection with the wider Diaz Milão family, his self-sacrifice and involvement in their escape, all serve to transform Manuel Cardoso de Macedo into Abraham Pelengrino, Abraham the Searcher. His Jewish name is encoded in his autobiography; the Vida maps his spiritual peregrination unto the figure of the first JewAbraham - who gave up his bonds of affection and the comforts of home to wander in search of the True God.

In both cases, the encounters with ethnic and religious others within the warped "third space" of the inquisitorial prison allow for much more than an exchange of new ideas or the forging of new friendships. These encounters allow for religious transformations and a radical shift in the subjects' sense of self. 


\section{Bibliography}

Alberro, Solange. Inquisición y sociedad en México, 1571-170o. México: Fondo de Cultura Económica, 1988.

Bodian, Miriam. Dying in the Law of Moses: Crypto-Jewish Martyrdom in the Iberian World. Bloomington: Indiana University Press, 2007.

Certeau, Michel de. "Reading as Poaching." In The Practice of Everyday Life. Translated by Steven I. Rendal. Berkeley: University of California Press, 1984.

Cohen, Martin A. The Martyr: Luis de Carvajal, a Secret Jew in Sixteenth-Century Mexico. Albuquerque: University of New Mexico Press, 2001.

Costigan, Lúcia Helena. Through Cracks in the Wall:Modern Inquisitions and New Christian Letrados in the Iberian Atlantic World. Leiden: Brill, 2010.

Johnston, Norman. Forms of Constraint: A History of Prison Architecture. Chicago: University of Illinois Press, 2000.

Kaplan, Yosef. "Jewish Proselytes from Portugal in 17th Century Amsterdam-The Case of Lorenzo Esudero." [Hebrew] Proceedings of the World Congress of Jewish (1977): $87-101$.

Lewin, Boleslao. Confidencias de dos criptojudios en las cárceles del Santo Oficio, México, 1645-1646. Buenos Aires: Talleres Gráficos Julio Kaufman, 1975.

Mulsow, Martin, and Richard H. Popkin, eds. Secret Conversions to Judaism in Early Modern Europe. Leiden: Brill, 2004.

Obregón, Luis González, ed. Procesos de Luis de Carvajal, el mozo. México: Talleres Gráficos de la Nación, 1935 .

Parker, Geoffrey. The Dutch Revolt. Ithaca, NY: Cornell University Press, 1977.

Perelis, Ronnie. Narratives from the Sephardic Atlantic: Blood and Faith. Bloomington: Indiana University Press, 2016.

Peters, Edward. "Prison Before the Prison: The Ancient and Medieval Worlds." In The Oxford History of the Prison. Edited by Norval Morris and David Rothman, 26. New York: Oxford University Press, 1998.

Popkin, Richard H., and Gordon M. Weiner, editors. Jewish Christians and Christian Jews: From the Renaissance to the Enlightenment. Dordrecht: Kluwer Academic Publishers, 1994.

Salomon, H.P. Portrait of a New Christian: Fernâo Álvares Melo, 1569-1632. Paris: Fundaçâo Calouste Gulbenkian, 1982.

Schorsch, Jonathan. Swimming the Christian Atlantic:Judeoconversos, Afroiberians and Amerindians in the Seventeenth Century. Leiden: Brill, 2008.

Spierenburg, Pieter, and Lissenberg, Elisabeth. Prison Experience: Disciplinary Institutions and Their Inmates in Early Modern Europe. Amsterdam: Amsterdam University Press, 2007.

Toro, Alfonso. La familia Carvajal: Estudio histórico sobre los judíos y la Inquisición de la Nueva España. México: Patria, 1944. 
Yosef Kaplan - 978-90-04-39248-9

Downloaded from Brill. com $04 / 26 / 2023$ 10:36:49AM via free access 
PART 2

Mechanisms of Social Discipline in the Sephardic Communities 
Yosef Kaplan - 978-90-04-39248-9

Downloaded from Brill. com $04 / 26 / 2023$ 10:36:49AM via free access 


\title{
Defining Deviance, Negotiating Norms: Raphael Meldola in Livorno, Pisa, and Bayonne
}

\author{
Bernard Dov Cooperman*
}

\section{1 \\ The Secularization Thesis}

The link between modernization and secularization has long been a staple of Jewish historiography. Secularization was the necessary prerequisite for, and the inevitable response to, Jews' "emancipation" from discriminatory legal provisions. It was evidenced in the abandonment of Jewish ritual observance, an intentional imitation of external norms that was either to be praised as "enlightenment" or decried as "assimilation," and the abandonment of Jewish "authenticity." The decline in observance was accompanied by, or justified by, a parallel abandonment of traditional religious beliefs and theological concepts. And at the same time, the kehilla, the autonomous Jewish community, lost its ability to enforce religious discipline and suppress unacceptable religious ideas. ${ }^{1}$ Thus the transition to modernity was equated with a decline in rabbinical and communal authority, the abandonment of traditional behaviors, and the collapse of orthodox mentalities. In a famous article published almost a century ago, the young historian Salo Baron questioned whether modernization had been worth such a great cultural and communal cost. ${ }^{2}$ But he did not question the narrative itself; if anything, his regret over what was lost reinforced the assumption that modernization and secularization were one.

* My thanks to Professors Gérard Nahon and Peter Nahon as well as to Doctor Nimrod Gaatone for their thoughtful comments on this paper. While I was unable to take up their several excellent suggestions here, I hope to do so in further work on Meldola. Of course, all errors are my own.

1 This approach to modernization, including the emphasis on the ideological justification for deviance and the breakdown of communal authority, was clearly articulated by Jacob Katz in a number of seminal studies: Tradition and Crisis (1955; complete translation, New York University Press, 1993); Out of the Ghetto (Cambridge, MA: Harvard University Press, 1973); and see also the introduction to his edited volume, Toward Modernity: The European Jewish Model (New Brunswick, NJ: Transaction Books, 1987), 1-12. For the debate over his views see my Afterword to Tradition and Crisis as well as The Pride ofJacob: Essays on Jacob Katz and His Work, ed. Jay M. Harris (Cambridge, MA: Harvard University Press, 2002).

2 Salo W. Baron, "Ghetto and Emancipation," Menorah Journal 14 (1928): 515-26.

(C) BERNARD DOV COOPERMAN, 2019 | DOI:10.1163/9789004392489_008

This is an open access chapter distributed under the terms of the prevailing CC-BY-NC License at the time of publication. 
This approach to the Jewish experience drew directly on then generally accepted understandings of European modernization as a whole: the Weberian disenchantment of the world, the gradual spread of rationalism and skepticism, and the democratic liberalization that granted ever-wider rights and freedoms to the individual. But the so-called "secularization thesis" is no longer as dominant as it once was, challenged on many fronts, including by the growing scholarly acknowledgment of the links between institutional religion and the modern state in European history. ${ }^{3}$ Treatments of "confessionalization" have highlighted not the supposed waning of religious practice but the definition of stronger and more rigid boundaries between denominations and religious communities in both Protestant and Catholic lands. ${ }^{4}$ The open, cosmopolitan liberalism supposedly at the heart of European secular modernity is increasingly seen as a chimera - a self-interested justification for empire and the basis for racist colonialism. ${ }^{5}$ Nor has the expected universal victory of scientific rationalism over myth, superstition, and religious credulousness proven as "inevitable" as was once thought. The narrative of modernity has changed: whiggish titles that trumpeted liberal progress (one thinks of J.B. Bury's 1913 A History of Freedom of Thought) have given way to titles that portray a tentative and complex world of uncertain direction and unintended consequences (for example, Brad Gregory's 2012 volume on The Unintended Reformation: How a Religious Revolution Secularized Society).

Truth to tell, the assumptions of the old model never fit neatly with the specifics of Jewish history. European secularization was built around institutional differentiation, with the state taking over functions formerly ascribed to religion. This pattern simply does not apply in the Jewish case. Jews did not have religious institutions parallel to the Catholic Church with its attendant wealth,

3 Steve Bruce, ed., Religion and Modernization: Sociologists and Historians Debate the Secularization Thesis (Oxford: Clarendon Press, 1992), provides a convenient starting point. I intentionally ignore here, primarily for reasons of space, the wide debate in contemporary scholarship over the very meaning of secularization and secularism. These issues, as they apply to the study of Jewish history, were taken up in a year-long workshop at the Herbert D. Katz Center for Advanced Judaic Studies, University of Pennsylvania, that produced the stimulating volume, Secularism in Question:Jews and Judaism in Modern Times, ed. Ari Joskowicz and Ethan B. Katz (Philadelphia: University of Pennsylvania Press, 2015). The extent to which they apply to the early modern period remains to be explored.

4 For an introduction to Heinz Schilling's path-breaking studies of confessionalization see his Early Modern European Civilization and Its Political and Cultural Dynamism. The Menahem Stern Jerusalem Lectures (Hanover, NH: Brandeis University Press, 2008), especially chap. 2.

5 See for example Talal Asad, Formation of the Secular: Christianity, Islam, Modernity (Stanford: Stanford University Press, 2003), especially chap. 1: "What Might an Anthropology of Secularism Look Like?". 
bureaucracies, and hierarchies, nor was the state seeking to take over Jewish religious functions. Unable to focus on institutional change, therefore, historians of the Jewish transition to modernity have focused on the secularized experience of individuals. They rooted the Jews' collective abandonment of tradition in the "rebellion" of intellectuals-those enlightened maskilim who freed themselves from "the discipline demanded by the rabbinical elite." 6 The result was to portray what was often a gradual and contradictory process of cultural shift over several generations as an ideological conflict between proponents of the new ideas and the rabbis, defenders of the old. ${ }^{7}$ The conflict was presented as far more sudden, more intense, and more fully articulate than it may have seemed at the time. The rabbis, whose condemnatory and polemical writings are often the major source for our knowledge of the deviance of the maskilim and their followers, emerged in this schema as simple reactionaries, stubborn opponents of all change who were bent on protecting their own prerogatives and defending the system of categories through which they had learned to order experience.

But was the world of Jewish tradition as adamant as described, as monolithically stable in its reactionism? There has, as yet, been relatively little scholarship devoted to the class of rabbinic intellectuals on a par with the recent investigations of the modernizers, their real-world contexts, their intellectual and literary networks, and their varied interests and skills. ${ }^{8} \mathrm{New}$

6 Shmuel Feiner, The Origins of Jewish Secularization in Eighteenth-Century Europe (Philadelphia: University of Pennsylvania Press, 2011 [Hebrew original 2010]), xi. Feiner's book, the most recent overview of the broad process of "secularization," succeeds in widening the circles and themes of Jewish modernization without, however, abandoning the view of the eighteenth century as a period of confrontation marked by the collapse of tradition. See also his programmatic essay, "From Renaissance to Revolution: The Eighteenth Century in Jewish History," in Sepharad in Ashkenaz, ed. Resianne Fontaine, Andrea Schatz, and Irene Zwiep (Amsterdam: Royal Netherlands Academy of Arts and Sciences, 2007), pp. 1-10. Azriel Schochat's Im Hilufei Tekufot [Changing Eras] (Jerusalem: Mossad Bialik, 1960), sharply criticized when it appeared because it equated modernization with forms of social deviance that were not justified ideologically, was never translated into English, but its positions are summarized clearly in Chimen Abramsky, "The Crisis of Authority within European Jewry in the Eighteenth Century," Studies in Jewish Religious and Intellectual History presented to Alexander Altmann on the Occasion of His Seventieth Birthday, ed. Siegfried Stein and Raphael Loewe (Tuscaloosa: University of Alabama Press, 1979), 13-28.

7 In treating The Jews of Georgian England 1714-1830: Tradition and Change in a Liberal Society (Philadelphia: Jewish Publication Society, 1979), Todd M. Endelman seemed able to avoid this polarized view of modernization. But his argument, built on the special social and demographic circumstances of Jews in England, has not been easily applied to the rest of European Jewry.

8 On the literary circles of the modernizers see the important contribution by Shmuel Feiner, Zohar Shavit, Natalie Naimark-Goldberg, and Tal Kogman, eds., Ha-Sifriya shel Tenu'at 
scholarly approaches - in particular those loosely referred to as the "history of the book" - have allowed us to appreciate the shifts and changes in the content and motivations of writings by the reformers. When intellectual historians have taken on rabbinical writings, they have tended to search out the rare demonstrations of interest in natural science ${ }^{9}$ or the surprising statements of "heretical" thought within the traditional system..$^{10}$ In other words, the focus has been on examples of dissidence, skepticism, or outright religious disbelief, especially in communities of the Western Sephardic diaspora. But the mainstream of rabbinic thought has been largely ignored, with most rabbis assumed to be spokesmen for the enforcement of social and religious discipline. ${ }^{11}$ The

ha-Haskala. Yetziratah shel Republikat ha-Sefarim ba-Hevra ha-Yehudit ba-Merhav haDover Germanit (Tel Aviv: Am Oved, 2014); Shmuel Feiner, "Seductive Science and the Emergence of the Secular Jewish Intellectual," Science in Context 15, no. 1 (2002): 121-35. On the effort to construct a Jewish "republic of letters" among sixteenth-century intellectuals, see my "Amicitia and Hermeticism: Paratext as Key to Judah Moscato's Nefutsot Yehudah," in Rabbi Judah Moscato and the Jewish Intellectual World of Mantua in the 16th17th Centuries, ed. Giuseppe Veltri and Gianfranco Miletto (Leiden: Brill, 2012), 79-104.

9 David B. Ruderman, Jewish Thought and Scientific Discovery in Early Modern Europe (Detroit: Wayne State University Press, 1995).

10 Shalom Rosenberg, "Emunat Hakhamim," in Jewish Thought in the Seventeenth Century, ed. Isadore Twersky and Bernard Septimus (Cambridge, MA: Harvard University Press, 1987), 285-341; Yosef Kaplan, "Karaites' in the Early Eighteenth Century," Sceptics, Millenarians and Jews, ed. David S. Katz and Jonathan I. Israel (Leiden: Brill, 1990), 196-236, reprinted in Kaplan, An Alternative Path to Modernity: The Sephardi Diaspora in Western Europe (Leiden: Brill, 2000), 234-79. Criticism of the authority of Jewish tradition from within the rabbinic world is a promising area of new research; see the important studies by Talya Fishman, Shaking the Pillars of Exile: "Voice of a Fool," An Early Modern Jewish Critique of Rabbinic Culture (Stanford: Stanford University Press, 1997), and Yaacob Dweck, The Scandal of Kabbalah: Leon Modena, Jewish Mysticism, Early Modern Venice (Princeton, NJ: Princeton University Press, 2011).

11 It seems to me that a great deal about the nature and effectiveness of religious discipline within the traditional Jewish community remains to be clarified. I am not convinced, for example, that the decree of herem (excommunication) was as widely used as is sometimes assumed, much less that it was actually enforced, at least with regard to matters of religious doctrine and practice. See my very tentative remarks in "Legitimizing Rhetorics: Jewish 'Heresy' in Early Modern Italy," Études Épistémè: Revue de littérature et de civilisation (XVI ${ }^{e}-X V I I I^{e}$ siècles) 31 (2017): https://episteme.revues.org/1764. Yosef Kaplan's detailing of the extensive use of herem by the Jewish communal authorities in Amsterdam may be yet another indication of the special nature of that community, rather than a broadly characteristic feature of religious discipline among Jews, or even Sephardic Jews, everywhere; "The Social Functions of the Herem" and "Deviance and Excommunication in the Eighteenth Century," both reprinted in his Alternative Path to Modernity, 108-54. See also Mark Saperstein, Exile in Amsterdam: Saul Levi Morteira's Sermons to a Congregation of "New Jews" (Cincinnati: Hebrew Union College Press, 2005), esp. 181-225. On ethnic aspects of the enforcement of public observance see Adam Ferziger, "Between 'Ashkenazi' 
content and style of halakhic writing - the hermetic, difficult terminology of a legal system, the insistent claims to an unbroken chain of traditional authority, and the repeated invocation of precedent-have tended to discourage investigation into the dynamics of halakhic discourse itself. But halakha was not simply a closed system of authoritative citations and fixed ideas. Under the influence of cultural studies, historians have learned to see the processual and fluid aspects of religion and ritual. Even the apparently obdurate textuality of responsa must be understood as the articulations of a negotiated and changing set of terms and values. ${ }^{12}$

We should not dismiss traditional rabbis on the eve of modernity as simply parroting long-established and carefully memorized rules. As individuals, they too were engaged in an intellectual, spiritual, and personal progression through life, a progression that was shaped and misshaped by the daily problems and dynamics of the communities in which they lived and with which they were deeply engaged. It is crucial then to gain an appreciation of their personal lives and careers if we wish to hear the nuances and implications of their halakhic statements. As a group, moreover, these rabbinic intellectuals formed a collectivity far larger than that of the "modernizers" and "rebels" on whom so much historiographical effort has been lavished, and it is therefore vital to understand their group dynamic. They formed a true "republic of Jewish letters," gathering in publicly and privately supported institutions in the newly emerging, larger communities of the day, and also engaged in extensive correspondence with each other wherever they lived. They also took advantage of the printing revolution to publish an ever-growing library: classics with new commentaries, systematic treatises, and anthologies of correspondence in

and Sepharad: An Early Modern German Rabbinic Response to Religious Pluralism in the Spanish-Portuguese Community," Studia Rosenthaliana 35, no. 1 (2001): 7-22.

A cultural approach informs such volumes as David Biale, ed., The Cultures of the Jews: A New History (New York: Schocken, 2002) and David B. Ruderman, Early Modern Jewry: A New Cultural History (Princeton, NJ: Princeton University Press, 2010). The thrust of the cultural approach varies with each scholar who has claimed it, but it almost always implies a rejection of one or another "orthodoxy" of past historiography and past Jewish identity. In this paper, however, my intent is less to reject, and more to expand, the interpretive ground of halakhic literature, and to take its jurisprudential and literary aspects more seriously than has often been the case in historical treatments. Moshe Rosman, How Jewish Is Jewish History? (Oxford: Littman Library of Jewish Civilization, 2007), and especially chap. 5: "Prolegomenon to the Study of Jewish Cultural History," 131-53, is one of the few explorations of the theoretical challenges of the method. See also my "Global History and Jewish Studies. Paradoxical Agendas, Contradictory Implications," in Giornale di Storia 9 (2016): http://www.giornaledistoria.net/index.php?Articoli=557Do301220A740 $32104060 B 777327$. 
volume after volume of rabbinic responsa. Like other guilds of highly trained experts, the halakhists in their intellectual pursuits questioned accepted views, thrust and parried with each other, cited and rejected past authorities while elevating the opinions of present ones, and developed an ever-more complex set of "standard" texts, references, and concepts. Scholarship on early modern Judaism has focused on challenges to rabbinic thought from the outside and mystical theologies and messianic movements from within. Rather than using this sort of polarized "challenge and response" approach, in this paper I shall try to capture the excitement and ferment of the process through which authorities defined and redefined the norms of their society through the quotidian practice of religious life.

The task is a delicate one. I am trying to catch sight of the cultural assumptions and implications behind rulings that I can know only from a few, highly stylized texts. I am trying to offer a "thick description" of "the webs of significance" in the practices of a society I cannot observe directly. ${ }^{13}$ My justification lies only in my basic assumption that traditional Judaism, like every human culture, is a set of rituals and interactions performed in public and in private in ways that had to create meaning and satisfaction for both performers and observers.

\section{$2 \quad$ Rabbi Raphael Meldola}

The career and writings of Raphael Meldola (1685-1748) provide an excellent starting point for our examination of the dynamics of religious normativity in the Mediterranean areas of the Western Sephardic diaspora. ${ }^{14}$ Born into

13 The reference is of course to Clifford Geertz, The Interpretation of Cultures (New York: Basic Books, 1973), chap. 1: “Thick Description: Toward an Interpretive Theory of Culture," 3-30. The influence on my approach of Geertz's view of "Religion as a Cultural System" (chapter 4) will be obvious to the reader.

14 On Meldola and his collected responsa see Maier Zipser in a series of articles "Lebensgeschichte Rafael Meldola's und ein Bild der jüdischen Zustände in Italien zu seiner Zeit," in Literaturblatt des Orients: Berichte, Studien und Kritiken für jüdische Geschichte und Literatur, the literary supplement to Julius Fürst's Der Orient 8 (1847), nos. 36: 571-576; 37: 580-85; 38: 597-602; 40: 627-31; and 42: 657-63. More recently Simon Schwarzfuchs explored Meldola's responsa from his years in France in "Notes sur les Juifs de Bayonne au XVIII' siècle," REJ 125 (1966): 352-64. Gérard Nahon, who has treated Meldola's writings in several of his studies concerning the New Christians/Jews of Bayonne, including his PhD dissertation "Communautés judéo-portugaises du sud-ouest de la France: Bayonne et sa region, 1684-1791," (Paris, Centre d'études juives and Ecole pratique des hautes études, 1969), provided important new documents in his Hebrew article "Rabbi 
a long-established rabbinic family, ${ }^{15}$ Meldola received his education in his native Livorno at the height of that Tuscan Jewish community's prosperity and cultural efflorescence. ${ }^{16} \mathrm{He}$ climbed the rabbinic ladder steadily, beginning as a teacher in the community Talmud Torah school, later giving regular classes to various advanced groups (a confraternity's yeshiva as well as various midrashim), and finally gaining an appointment as dayan or rabbinic advisor to the community's lay court once he reached age twenty-five (27 March 1710). Two years later, he would "be called" — as he put it — to the smaller community in nearby Pisa where he served as rabbi until 1729. His next position was as rabbi of Nefusot Jeudah (Dispersed of Judah), the Jewish community established by Portuguese conversos who crossed the border into France and were allowed to settle in Saint-Esprit-lès-Bayonne. ${ }^{17}$ Finally, in 1741 , he returned to

Rafael b. Elazar Meldola in Bayonna, 1728-1741," in Lo Yasur Shevet mi-Yhuda: Hanhaga, Rabanut u-Kehila be-Toldot Yisrael: Mehkarim mugashim le-Prof. Shim'on Shvarzfuks [The Scepter Shall Not Depart from Judah: Leaders, Rabbinate and Community in Jewish History. Studies Presented to Professor Simon Schwarzfuchs], ed. Joseph R. Hacker and Yaron Harel (Jerusalem: The Bialik Institute, 2011), 271-99.

15 An elaborate family tree tracing the origins of the Meldola family through generations of rabbis and intellectuals back to the Middle Ages on the Iberian Peninsula, appears in the Jewish Encyclopedia (1904), s.v. "Meldola”; see below n. 24. On Raphael's grandfathers who served in rabbinical positions in Pisa and Livorno see below, nn. 19-20. Raphael's first cousin and brother-in-law, David ben Abraham Meldola, was cantor, dayan, and senior rabbinical teacher (rosh metivta) in Livorno; Mayim Rabim, Orah Hayim (1735-36), §8. He was also signatory to the Livornese rabbinic "imprimatur" and copyright issued for Mayim Rabim in late 1736 .

16 On the history of Jewish Livorno of this period, see Renzo Toaff, La Nazione ebrea a Livorno e a Pisa (1591-170o) (Florence: Leo S. Olschki, 1990); Francesca Bregoli, Mediterranean Enlightenment: Livornese Jews, Tuscan Culture, and Eighteenth-Century Reform (Stanford: Stanford University Press, 2014), on which see my review, AJs Review 39, no. 2 (2015): 452-54. Lucia Frattarelli Fischer is undoubtedly the premier guide to archival history. Many of her articles are summarized in Vivere fuori del Ghetto. Ebrei a Pisa e Livorno (secoli XVI-XVIII) (Turin: Zamorani, 2009). On the city generally, see recently Corey Tazzara, "The Masterpiece of the Medici: Commerce, Politics, and the Making of the Free Port of Livorno, 1574-1790," PhD diss., Stanford University, 2011. On rabbinic culture in early modern Livorno, the classic study remains Alfredo Toaff and Aldo Lattes, Gli studi ebraici a Livorno nel secolo XVIII: Malahi Accoen (1700-1771) (Livorno 1909; repr., Bologna: Forni, 1980).

17 Much work remains before we can understand the religious life of this community. Especially important are Gérard Nahon, "Bayonne dans la diaspora sefarade d'Occident (XVII ${ }^{\mathrm{e}}-\mathrm{XVIII} \mathrm{e}^{\mathrm{e}}$ siècle)," Proceedings of the Seventh World Congress of Jewish Studies (1977), vol. 4, History of the Jews in Europe, 47-55, reprinted in his Métropoles et Périphéries sefarades d'Occident: Kairouan, Amsterdam, Bayonne, Bordeaux, Jérusalem (Paris: Cerf, 1993), 253-59; Nahon, "Les Rapports des communautés judéo-portugaises de France avec celle d'Amsterdam aux XVII e et XVIII siècles," Métropoles et Périphéries, 95-183 [an expanded 
Livorno where we find him in senior positions as a member of the Isur veHeter rabbinical council until his death in 1748. Meldola's entire career was thus spent in Portuguese- and Spanish-speaking communities where former conversos formed a significant, even dominant, element. But the communities of Livorno and Pisa were rooted as well in the Mediterranean Sephardic world, with well-established traditions of religious practice and rabbinic learning tied to other respected centers in Italy, North Africa, the Land of Israel, and elsewhere in the Ottoman Empire. Meldola's task was to delineate Jewish law in what must have seemed a religious and cultural minefield. Mayim Rabim, the four-volume anthology of rabbinic responsa that Meldola collected over his lifetime and published in 1737, can be read as a roadmap to his ongoing effort to negotiate the not always congruent assumptions of his multiple audiences. ${ }^{18}$

Mayim Rabim presents special challenges - and opportunities- to the historian seeking to penetrate the rabbinic culture of this era. First, the volume is a multi-generational anthology that preserves and highlights the intellectual accomplishments of a single family. Most of the responsa are attributed, as we would expect, to Raphael Meldola himself, but several are by his grandfathers-David Israel ben Elazar Meldola in Livorno, ${ }^{19}$ and Jacob b. Moses Senior in Pisa. ${ }^{20}$ Many more responsa are authored by Raphael's own son David. In at least some cases, these were questions that had been posed to David in Amsterdam, and the young man forwarded his answers to his father

version of a talk delivered at the Sixth World Congress of Jewish Studies and published in its proceedings, 1973], as well as the articles cited above in n. 14 .

18 Amsterdam: Yosef Dayan [Dajn] Metzuyan, 1736-37. The volumes were ready for the printer at least a year earlier. Spanish dedicatory letters to volumes 2 (Yore Déah) and 3 (Even ha-Ezer), addressed respectively to the lay leaders of the Jewish communities in Bayonne and Livorno, are dated Rosh Hodesh Quisleu [Kislev] 5496 — that is, late fall, 1735 . My thanks to Heide Warnke, curator of the Ets Haim Library, and Rachel Boertjens, curator of the Bibliotheca Rosenthaliana, for their help in clarifying which volumes had dedicatory letters.

19 Rabbi David Israel ben Elazar Meldola was a member of Livorno's yeshiva klalit in the mid-seventeenth century; Mayim Rabim, Yore De'ah, $\S 5^{2}$, fol. 4 ob. Responsa by him are to be found in Mayim Rabim, Yore De'ah, §§20 and 24; Hoshen Mishpat, §44. The first of these texts, dating from 1647 , includes a rather lengthy description of the writer's great anxiety over the unsuccessful circumcision of Raphael's father Elazar. For Raphael, then only a teenager, finding his grandfather's writings among the papers of his own, recently deceased father was a source of significant comfort, as he mentions in the introduction to Mayim Rabim.

20 E.g., Mayim Rabim, Yore De'ah, $\S \S 5^{1}$ and 70 . At least the second of these, as we shall see, dates back to the earliest years of Senior's appointment in Pisa which began in 1635 . 
for review. ${ }^{21}$ In other cases, the questions were initially addressed to the father and David had prepared preliminary responses. (Meldola, as we shall see, believed in the pedagogical value of setting halakhic "research questions" to his pupils and asking them to write out formal answers.) Raphael may have felt it was a little odd to include his son's work in the anthology. In the Introduction he seems a little embarrassed, and hastens to assure his readers first that David, not he, was the true author, and second that he had enormous faith in the boy's future rabbinical excellence. But for our purposes, what is important is that the responsa by grandfathers and son are not simply archived in Mayim Rabim. In every case, Raphael has added his own response. The book thus became both a rabbinic genealogical record generated by three generations of a single family and a diachronic picture of halakhic thought over a full century. The close link between family and rabbinic scholarship, a sociological phenomenon not unique to the Meldolas, deserves historical investigation in its own right. ${ }^{22}$ But here I stress that Raphael was doing more than indulging in what he liked to call "the pride of ancestral family." Past family scholarship served him as a springboard for his own. As he wrote after one of his reviews of his grandfather's opinion, "This is what I have observed and thought about the

21 See for example, Mayim Rabim, Hoshen Mishpat, §§2-3, fols. 1a-2a: David modestly declares that he has taken the trouble to write out an opinion on a well-known proposition "at the command of great men." Mayim Rabim, Orah Hayim, §31 shows us what may have often been the progression of such correspondence. The halakhic permissibility of carrying mechanical watches on the Sabbath had been debated by two students in the Ets Haim yeshiva in Amsterdam after they witnessed an am ha-aretz (a term I would translate here as "lay person") doing so. The two young men forwarded their opinions to Meldola who then wrote his own opinion, rejecting David's permissive view and forbidding winding, or even carrying, the new watches on the Sabbath). See also Benjamin Diaz Brandon, Emek Binyamin (Amsterdam, 1753; reprint Borgóprund, 1912), §7. Abraham Hezekiah Bassan, editor of Brandon's volume, adds that the topic was later taken up again by his own father, Jacob Bassan in Hamburg, and the latter's opinion, which sided with David, was printed in Peri Ets Hayim, the collected volumes of student opinions that were one of the hallmarks of the new educational methodology in Amsterdam (according to Bassan as vol. 4, fol. 100-n.v.).

22 Though the prosopography of rabbinic intellectuals remains largely in the hands of bibliographers and hagiographers, the importance of genealogy to a critical history of rabbinic training is clear. There are many examples of this family dynamic. In this era in Livorno, for example, we can point to the halakhic work Pri Hadash of Hezkia da Silva (b. Livorno, 1656) and to the collection of responsa, Halakhot Ktanot, of Israel Jacob Hagiz (in Livorno 1652-1655; pupil of Meldola's grandfather Jacob Senior, Mayim Rabim, Even Ha-Ezer, §§28-29; at some point, rabbi in Pisa, ibid., Orah Hayim, §39). Each book was published by its author's son: the former by David da Silva (Amsterdam, 1706 and 1730); the latter by Moshe Hagiz (Venice, 1704). Each of these sons, David Meldola included, became a well-known scholar in his own right. Examples could be easily multiplied. 
issue [...] and I have written it down in a book for the sake of intellectual practice [in preparation] for some other occasion." ${ }^{23}$ Raphael, and his son David after him, took it as their moral obligation to preserve a familial intellectual tradition that would otherwise have been lost to the exigencies of time. ${ }^{24}$ They engaged with that tradition and enthusiastically elaborated upon it. ${ }^{25}$ Their passion has left historians with a rare opportunity to watch halakhic thought develop over time within the intimate circle of a single family.

This leads to a second point: both the structure and content of Mayim Rabim clearly underscore a view of halakha as an ongoing discussion and debate. The literary back and forth between grandfathers and grandson, and the active correspondence between father and son, remind us that we are now in an era when halakhic discussion is an active universe of intellectual discourse. The legalisms of Mayim Rabim come alive, turning the book from a collection of magisterial rulings into the record of an interactive dialogue. Unfortunately, much of Meldola's oeuvre has not survived. He tells his reader that what made it into print was only a small portion of the original, and most was lost "owing to the troubles of the times." His son David had located and recopied what he could, but the book had had to be heavily edited. David had had also to translate many responsa from Spanish and Italian, leaving open the question of how much the content may have been changed in the process. Even so, we can see clearly in what has survived in Mayim Rabim that, for Meldola, halakha was a

23 "[L]ehitlamed le-makom aher," in Mayim Rabim, Hoshen Mishpat, §45, reviewing an opinion by Rabbi David Israel ben Elazar Meldola (\$44) disputing the view of Isaac ben Eliyahu Montalto (\$43).

24 He uses the Talmudic expression "shevah beit avi" [cf. Ketubot $79 \mathrm{~b}$ ] referring to property that a bride brings with her into marriage and which cannot be alienated because it is the heritage of her father's house. Family pride among Italian Jews (and not just Sephardim) in the early modern period, as well as its connection with writing and publishing deserves scholarly attention. Genealogy is not only a framework, for example, at the start of Leon Modena's famous memoir, Life of Judah (The Autobiography of a Seventeenth-Century Venetian Rabbi, ed. Mark R. Cohen [Princeton, NJ: Princeton University Press, 1988]). It provides, in my opinion, the key to the structure and flow of the entire work. It was apparently Meldola's father who in 1679 initiated Toldot Adam, the family genealogical record that would be continued for hundreds of years and be a major source for C.I. De Sola's article on the family in The Jewish Encyclopedia (New York: Funk \& Wagnalls Co., 1904), 6: 454. Note also Raphael Meldola's remark cited in the next note below.

25 In his introduction, Raphael reports as well that while still a teen-ager, when going through his father's papers after the latter had died suddenly, he had found solace in discovering responsa and other rabbinic writings by his paternal grandfather, David Israel ben Elazar Meldola (as well as from other deceased rabbis). These had "enlivened me and strengthened my soul, for [even casual] conversations of the fathers become the Torah [or teachings] of the children." 
collaborative project and a field for intellectual debate within the family and, as we shall see, within a broader community of scholars. ${ }^{26}$

Finally, it is crucial to take note of the literary aspects of Mayim Rabim. The book is actually written in two different registers: one the legalese of formal citation and argumentation, and the other a dense, ornate, and allusive idiom favored by Sephardic rabbis of the era. ${ }^{27}$ I will try to give the reader a sense of the former style as we make our way through specific cases below, though a full treatment will require a careful bibliographical mapping of the sources and authorities Meldola and his correspondents cite. But if we restrict ourselves to the workaday sections and language of halakhic precedent, we would miss the cultural meaning contained within, and written around, the book's legalism and legal rhetoric. In the introductory sections in particular, Meldola's very literary prose assumes that the reader has extensive and intimate familiarity with both the biblical and the rabbinic sources being quoted and intentionally "misquoted" for effect. Investigation of this literary style is still a scholarly desideratum, and I do not claim to have always caught the implications of Meldola's complex rhetorical conventions and techniques. ${ }^{28}$ Still, the story flows with considerable facility, and reveals the individual behind the stylistics. He clearly wanted to be understood.

26 According to a list prepared by Schwarzfuchs, over sixty scholars make appearances in Mayim Rabim; "Notes sur les juifs de Bayonne," $362 \mathrm{ff}$.

27 Meir Benayahu, ed., Dor Ehad ba-Arets: Igrot Rabi Shmu'el Aboab ve-Rabi Moshe Zacut be-Inyenei Erets-Yisrael [5]399-[5]426 [A Single Generation in the Land: Letters of R. Shmuél Aboab and R. Mošeh Zacuto Concerning the Affairs of Erets Yisraél 1639-1666] (Jerusalem: Yad Ha-Rav Nissim, 1988) provides an excellent, edited example of this type of espistolary style a generation earlier.

28 For example, in the introduction to Mayim Rabim, Meldola refers metaphorically to his own youthful studies in preparation for a career as a teacher of Torah as "filling one's own belly with fatted meat from a golden tray (or table)." I have not been able to locate a classical source for the Aramaic phrase "bisra shamina a-ptura de-dahava," but it is used in exactly the same sense in the introduction to Isaac Arama's Akedat Yitshak (the early sixteenth century) as well as in two other slightly later works identified in the Bar-Ilan University Responsa data base (https://www.responsa.co.il), suggesting a widely shared store of idioms and associations. Another direction for research into this literary style is provided by the poetic conventions of North African rabbis. Thus, Meldola uses the phrase "ve-shabhu rabanan le-de-tsv"i," a play on Gittin $56 \mathrm{a}$, to praise his son David who had been instrumental in raising the funds needed to publish the book. The last word is here an abbreviation for tsair be-yisrael, and the phrase is thus a call to rabbis to praise a young Jewish man. But note that half a century later, the same phrase is used in a laudatory poem about the scholarship of a shadar, a representative of the Jewish community in Palestine, who had come to Morocco. See Ephraim Hazan, "Shluhei Erets-Yisrael ba-Shira u-va-Fiyut shel Yehudei Tsfon Afrika," Peamim: Studies in Oriental Jewry 24 (1985): 99-116, here 102, line 14. I thank Professor Hazan for his help. 
Examination of one paragraph out of the fifteen that make up the book's carefully crafted autobiographical introduction will give the reader a sense of Mayim Rabim's literary style.

"Sustain me with raisin cakes, refresh me with apples, for I am faint with love." 29 I have so far been unable "to give preference to the son of the beloved,"30 to realize my yearned-for goal, "for the food in [my] bag is all gone." ${ }^{31}$ [I am a] poor man who has nothing. ${ }^{32}$ "With no food or clothing in my own house, I shall not be a scholar"33 for my days have been used up $^{34}$ pursuing fiery snakes ${ }^{35}$ - [that is,] the temporal concerns [yelidei ha-zman] that have canceled out any thoughts or ideas that arise from intellectuality. ${ }^{36}$ I have walked through this world's sea storms, the waves roaring like "great waters."

The book's title phrase, "mayim rabim" (many waters) provides the refrain and the dominant image in this, as in every, paragraph of the introduction. ${ }^{37}$ Meldola will use the metaphor to explore his passionate devotion to an intellectual and religious vocation on the one hand, and his emotionally turbulent youth, his difficult life, and the course of his career on the other. Floods, he declared at the start, using the language of the Song of Songs, cannot quench the fire of his love for the study and teaching of Torah. ${ }^{38}$ Now, in this second paragraph, he draws again on the language of that biblical book to explain why he had been so far unable to publish his own work. His poverty has forced him to preoccupy himself with this-worldly concerns. He has weathered the storms of life-but at a cost. The paragraph is an intricate thicket of biblical and Talmudic references, plays on words and associations, but through it all we get a clear statement of the author's own life and the financial difficulties of his chosen career, a point to which he returns often.

\footnotetext{
29 Song of Songs 2:5.

30 Deuteronomy 21:16.

$31 \quad 1$ Samuel 9:7.

$32 \quad 2$ Samuel 12:3.

33 Isaiah $3: 7$ following the traditional Jewish explanations for the biblical phrase.

34 Playing on Job 7:6 with homophones and other words marked when they are substituted for the original.

$35 \quad$ Numbers 24:1 and 21:6.

36 Here Meldola plays on a standard phrase in Jewish divorce and contract legal documents (Shulhan Arukh, Even ha-Ezer, §154:20) to describe the life of the mind he has lost.

37 The phrase is also a coded reference to his own initials: רבים contains within it i.e., Raphael Meldola.

38 Song of Songs 8:7.
} 
What conclusions can we draw about Meldola's education and his intellectual world from this dense and allusive text, from his facility with such an ornate Hebrew style, and from his deep familiarity with its sources? The language of our text is, of course, a claim to status and authority within the learned rabbinic hierarchy. But perhaps its unabashedly erudite Hebrew intellectualism is not as straightforward a claim as we might think. Remember that Hebrew was not this society's, or Meldola's, only literary language. The community in which he was raised spoke Spanish, Portuguese, and Italian. When he preached in Livorno (and most likely in Pisa and Bayonne as well), he would have been required to use Spanish. He and his contemporaries also knew and used Latin; for instance, in a Spanish letter to the parnassim of Bayonne he quotes Seneca, De vita beata, in Latin. ${ }^{39}$ Meldola's slightly older contemporary, Joseph Attias, is famous in Livornese history for his broad secular scholarship, wide circle of non-Jewish intellectual friends, and enormous scholarly library in European languages. Attias's secular knowledge was no doubt influenced, his protests to the contrary notwithstanding, by the fact that his father had grown up as a Christian in Iberia, had practiced law in Salamanca, and had Spanish plays and literature on the bookshelves of their home in Livorno. ${ }^{40}$ But we should not assume that there was any sharp division between Hispanic and Hebrew cultures in the Tuscan city. Attias would be appointed one of Livorno's five rabbis in 1733, while Meldola would be commissioned by the community to translate into Hebrew a volume of Spanish hymns commemorating the earthquake of 1742 (Shever Metzarim). There are, in other words, two competing literary languages in this community. We should not even take it for granted that Hebrew was the language of rabbinics while Spanish was reserved for recent converso immigrants or the community's lay leadership. ${ }^{41}$ Halakhic communication

39 Parashat ha-Ibbur (Amsterdam, 1733-34). The letter has been preserved in the digitized copy of the book available at http://www.hebrewbooks.org/45146.

40 On Attias (born 1672), see Lucia Frattarelli-Fischer, Vivere Fuori del Ghetto, 307-38 and Francesca Bregoli, Mediterranean Enlightenment, chaps. 2-3. Professor Bregoli translated Attias's description of his own education in her "Jewish Scholarship, Science, and the Republic of Letters: Joseph Attias in Eighteenth-Century Livorno," ALEPH: Historical Studies in Science and Judaism 7 (2007): 97-181, here 175-79, and in slightly different form in the online proceedings of the Eighth Early Modern Workshop (2011): https://fordham .bepress.com/emw/emw2011/emw2011/6/. Though we have information only about Attias's non-Hebrew library and know nothing of his holdings in Hebrew and rabbinics, his appointment as a member of Livorno's rabbinic council indicates that he had a very strong rabbinic education as well. He is one of the five rabbinic signatories to the Livornese haskama and copyright given to Mayim Rabim in late fall, 1736.

41 As is well known, the Jewish communities of Pisa and Livorno kept all of their records first in Portuguese, and then later in Spanish through the eighteenth century. Only ketubot were kept in Hebrew. 
was, surprisingly, not exclusively in Hebrew. As we have already mentioned, Meldola's son David reports that his father wrote many of his responsa in Spanish or Italian, from which languages he - that is, David - had to translate them into Hebrew for the publication of Mayim Rabim. ${ }^{42}$ Whatever the circumstances that determined language choice, it is clear that Hebrew faced real competition as the language of religious self-expression and piety, and that cultural literacy and prestige were a complex affair in Livorno, Pisa, and Bayonne, just as in other centers of the Western Sephardic diaspora.

In noting the formality of Meldola's language I do not wish to obscure the everyday realities and tensions that he described. Bits of biographical information scattered through Mayim Rabim and other surviving letters allow us to reconstruct something of his world and give his opinions social concreteness beyond their halakhic abstraction. Most important, I think, is the fact that Meldola was never financially secure, and he remained always dependent upon the not-always-liberal generosity of the communities that employed him. ${ }^{43}$ His father Elazar had been a rubi, that is a teacher of lower-level classes, in Livorno's Talmud Torah for forty years. ${ }^{44}$ Raphael remembers himself as not an especially dedicated student, and perhaps, as a disciplinary measure, he was married off at sixteen to his first cousin, daughter of his father's brother. ${ }^{45}$ Meldola describes his uncle and father-in-law Abraham as learned, wise, elderly, honored, and a "pleasant singer in Israel"-presumably indicating that Abraham served as a cantor in Livorno. But marriage did not solve the boy's financial problems, for Elazar died almost immediately, leaving the young Raphael as sole support for his new wife, his widowed mother, and his three sisters. The community elders, he says, were kind enough to give him a job teaching in the community's school—that is, as his father's replacement. He would remain at the school for eleven years, gradually working his way up through the various levels of responsibility, and supplementing his salary by

42 Mayim Rabim, Orah Hayim, §2, fol. 2b. This of course also leaves open the question to what extent David also edited his father's writings.

43 Except where indicated, the autobiographical details in this paragraph are taken from Meldola's introduction to Mayim Rabim.

44 In 1676, the elder Meldola was identified as teaching one of the two lower-level classes in the community school; Guido Sonnino, "Il "Talmud Torà' di Livorno," Rassegna Mensile di Israel 10 (1935): 183-96, here 187. We do not know whether he ever progressed to a higherlevel teaching assignment because the records of the Livorno Talmud Torah were apparently destroyed during World War II; R. Toaff, La Nazione ebrea a Livorno e a Pisa, 337, n. 7. A few years before Joseph Attias was similarly betrothed at age sixteen "to a little niece," daughter of his older half-brother. Attias père had hoped thus to cement family relations between his offspring, though Attias hints that this ultimately hadn't worked out as intended. See the sources mentioned above, n. 29 . 
giving regular classes as "head of the yeshiva of the confraternity Torah $\mathrm{Or}^{46}$ as well as in a number of other "midrashim." When he reached the age of twenty-five, the Livornese parnassim appointed Meldola to the rank of dayan or rabbinical advocate (1710).

Why did he leave for the much smaller community in Pisa, twenty-five kilometers to the north? Was the salary better there? Was he attracted by the chance of being the main rabbi? Whatever his motives, Pisa proved no easy job. It was certainly not an undemanding schedule: he taught three hours each morning and then another three in the afternoon, he led the services on Sabbaths and holidays, he gave sermons on special Sabbaths, and of course he had to be available to rule on any and all questions of ritual that arose in the community. ${ }^{47}$ Meldola struggled to perform his duties while supporting a growing family of seven children. Years later he would remember himself becoming as "weak as a woman" and aging prematurely. In Bayonne, Meldola's salary was apparently adequate: "They gave me what I asked," he wrote to an old teacher, and there were also the special fees he received to supplement his monthly wages. ${ }^{48}$ But in that remarkably frank letter, Meldola admits that Bayonne had not been his first choice. He had actually hoped to obtain a position in Livorno but was refused. There had moreover also been some sort of scandal there about his son Elazar's relations with women, and at least some in the community had tried to block the rabbi altogether from the city. ${ }^{49}$ At fifty, his hair turning white, he could not afford to publish his writings, and had to rely on his son David, whom he had sent to Amsterdam, to collect the needed funds. His own repeated requests to the rabbinic council of Amsterdam for

46 On this privately sponsored academy, one of several in Livorno, see Sonnino, "Talmud Torà," 192. In this period there were apparently financial tensions in the community schools. Senior students staged a public "rebellion" against the "gabai dos povres del Talmud Tora," the schools' financial manager, in 1715; ibid., 188.

47 Whether Pisan Jewry in the eighteenth century maintained a lay civil court with rabbinic advisors (dayanim) as did the daughter community in Livorno is not clear. Thus we cannot say whether Meldola had judicial duties in Pisa. He refers to himself as av bet din and more tsedek - that is, judge and teacher (Mayim Rabim, Orah Hayim, §22). Attached to that responsum is a letter from the Safed rabbinical emissary Samuel ha-Levi, who inadvertently gives us a sense of the marginality of the Pisan community. He uses a Talmudic expression to describe coming through Pisa and discovering the young rabbi who was a "scroll of the law set down in a dark corner" (Kiddushin 66a). He stresses Meldola's double duties there as more tsedek and shaliah tsibur (cantor).

48 Letter to R. Elazar ha-Cohen, back in Pisa in Nahon, "Rabbi Rafael b. Elazar Meldola in Bayonna," (above n. 14), 288. In 1736, his base salary was 740 livres; ibid., 274 f. Note that Meldola also arranged that his son-in-law, Joshua Milo, serve as a teacher in the community school; ibid., 275 .

Nahon, "Rabbi Rafael b. Elazar Meldola in Bayonna," 287. 
financial help were absolutely refused.$^{50}$ We should certainly take with a grain of salt the flowery gratitude for past support that Meldola included in the elaborate letters of dedication to the parnassim of Bayonne and Livorno prefaced to volumes two and three respectively of Mayim Rabim..$^{51}$ Such obsequious sentences were obligatory in appeals for financial support, the genre to which these letters certainly belonged.

\section{3} Normativity and Deviance

Let us now turn to Meldola's halakhic opinions. By its very nature, a responsa collection such as Mayim Rabim will include efforts to address religious deviance, using the language of halakha to define, critique, and call for suppression of unacceptable behaviors. Deviance is of course an umbrella term, so capacious that it can subsume almost any social problem, any crime, any personal confrontation, any mistake. Mayim Rabim tells us about a cheese merchant whose employee cut corners making the resulting product not kosher; could any of the product still be acceptable? ${ }^{52}$ There are men suspected of themselves drinking gentile wine; may they be employed to press grapes for kosher wine ${ }^{53}$ There is an abused wife who had fled to the Christian authorities; could she now be allowed to return to her husband and family? ${ }^{54}$ There are people carrying the new mechanical watches or taking snuff. ${ }^{55}$ Are they desecrating the Sabbath? Do these vignettes demonstrate anything more than human emotions or the vagaries of fashion? Is there broader social significance to such everyday deviance? Can these cases, individually or collectively, give us an overall sense of continuity and rupture, of how strictly tradition was observed and of how widely it was ignored?

Jewish historians have tended to decide the significance of such "misdemeanors" by asking whether they were tolerated as the unavoidable result of human imperfection or whether the "misdemeanors" themselves became a new norm to be justified by some new ideology. But perhaps there is another

5o Ibid. Meldola requested, and had difficulty obtaining, financial support for David's stay in Amsterdam; ibid., $279 \mathrm{f}$. In 1741 he also requested help with a dowry for his youngest daughter Simha from Amsterdam's Society for Dowering Orphans and Poor Girls; ibid., 273 .

$5^{1} \quad$ On this letter see above, n. 18.

52 Mayim Rabim, Yore De'ah, §2.

53 Ibid., §24-25.

54 Mayim Rabim, Even ha-Ezer, §1. The original case was raised no later than 1635 before Meldola's grandfather, Jacob Senior. Meldola's opinion is ibid., §3.

55 Mayim Rabim, Orah Hayim, §28 (Meldola allows the taking of snuff) and §31 (he forbids carrying mechanical watches). On the latter case, see above, n. 25 . 
possible approach. Why, after all, should we assume that the "normative" was stable, and that the deviant had to articulate a justificatory ideology? Perhaps it was those who claimed to be defending tradition that were forced to create an ideological justification to legitimate their "rigidity" in the face of inevitable social change. Rather than imagining a host of barbarians breaking down the walls of custom, perhaps we should visualize a crew of wall builders designing and constructing barriers to the natural flow of time. Let us test this approach by examining just a few cases of halakhic deviance that are featured in Mayim Rabim.

The first is a case that arose in Pisa quite early in Raphael Meldola's tenure there. Pisan Jews employed non-Jewish laborers in their leather tanneries. The Christians were day laborers-paid for each day they worked, including the Jewish Sabbath. This was an infraction of rabbinic law, ${ }^{56}$ and Meldola urged the Jewish owners to revise their contracts with the workers and to pay them on a monthly or annual basis. This was the standard halakhic "work-around." Payment for work on the Sabbath would then be "swallowed" or hidden within the larger payment, and therefore be permitted. Moreover, because he was not being paid specifically for Saturday work, the Gentile was at least in theory choosing on his own to work on that day rather than doing it at the Jews' command. But Meldola was still uncomfortable. Halakhic authorities had allowed this arrangement so long as the Gentile was not working on the Jew's property, lest other Jews coming by and observing the labor misunderstand and think that it was permitted to order a Gentile directly to do on the Sabbath what was forbidden to the Jew himself. In this case, the workshops were known to belong to Jews, and thus the salary arrangement was an insufficient solution. Meldola apparently did not raise this issue with his congregants but he did mention his concern to a fellow rabbi, Joseph Ergas, and in the fall of 1713 the two men undertook a lengthy correspondence over the halakhic issues involved. ${ }^{57}$

$5^{6}$ Here I use the term "rabbinic law" (Hebrew: de-rabanan) in the technical sense of something not forbidden by the Torah itself but on a secondary level by later rabbis. In certain cases, this distinction provided a way of massaging or even forgiving prohibitions.

Responsa Mayim Rabim, Orah Hayim, §§14-17, fols. 9b-14a. A slightly different version of the first letter from Ergas to Meldola is preserved in Divre Yosef, §9, fols. 2ob-21b. We cannot be exactly sure of the dates, but the discussion that began during Tabernacles, 1713, went on for over three months. 
How shall we understand this question and the correspondence? Jacob Katz, the first historian to discuss this case, saw in it the impact of Italian Jews' participation in the early stages of industrialization. He collected a number of similar cases from Mantua, Venice, Emilia, and Gorizia, each involving Gentiles employed as day laborers in Jewish-owned light industries such as leather tanning and silk weaving. ${ }^{58} \mathrm{Katz}$ was interested in these cases as part of his investigation of the internal logic of halakhic discourse in the face of modernization. He traced the complicated principles that came into play in each successive case in order to understand the internally determined response of what was still a halakhically observant society to changing economic times. Although he saw the number of these cases as significant, he felt that the real cataclysm remained in the future, and the Jewish authorities did not yet imagine themselves facing an existential crisis.

But is the main factor a new form of Jewish economic activity? At least in Pisa the factories were not at all new. Jews in Pisa and Livorno had maintained such workshops ever since their community was established at the end of the sixteenth century. ${ }^{59}$ If the economic activities of Pisan Jews had not changed, what then had suddenly made them religiously problematic? I would suggest that it was Rabbi Meldola himself. In the fall of 1713 the twenty-eight-year-old had literally just taken up his position in Pisa. He would have come across the Jewish leather workshops almost immediately. They were located in public places in what was, after all, a small town. He was troubled and gave the owners the standard halakhic instructions. But this did not yet resolve the issue for Meldola. Two weeks after the New Year, during the intermediate days of the feast of Tabernacles, he went back to Livorno-possibly to spend a few days with family, and there he mentioned his concerns to his old classmate and friend, Joseph Ergas. The two young men initiated an exchange of legal essays. Both men were clearly enjoying themselves: they wrote with exaggerated formality, begging each other's forgiveness for not responding more quickly and meanwhile managing to highlight how busy each was in his career. Ergas attests: "I swear I have four rabbinic questions that I haven't even opened" (§14, fol. $9 \mathrm{~b})$, to which Meldola replies: "A rich man has asked for my opinion on a judgment involving monetary damages, and I couldn't push it off" $(\S 15$, fol. 10a). The letters are bravura displays of intellectual prowess, as each

$5^{8}$ See Jacob Katz, Goy shel Shabbat (Jerusalem: Zalman Shazar Center, 1983), chap. 7, 84-93. Translations below are my own, and differ at points from The "Shabbes Goy": A Study in Halakhic Flexibility (Philadelphia: Jewish Publication Society, 1989).

59 Bernard Dov Cooperman, "Trade and Settlement: The Establishment and Early Development of the Jewish Communities in Leghorn and Pisa (1591-1626)," PhD diss., Harvard University, 1976. 
writer in turn took up every twist and turn of the argument at length and with enthusiasm. But note that the point of this epistolary exchange-it went on for three or four months - was never a halakhic verdict. Meldola had already ruled in Pisa using the long-established Maimonidean remedy of giving the Gentile worker ostensible power to decide on which day he would work. He would make a minor modification in his instructions to the employers (fol. 1ob), but from his words it seems he remained convinced that the arrangement was actually impermissible. ${ }^{60}$ This intellectual exercise was therefore not a response to some changed practice in Pisa, to a sudden innovation in either the business activities or the social values of the city's Jews. What had changed was the arrival of the new young rabbi, full of book learning and eager to make his mark on the community.

And we have not yet gotten to the bottom of what happened in 1713. If I am correct that the workshops were not a new phenomenon, why had they only now become religiously problematic? Surely the community's earlier rabbis, including Azariah Picho and Meldola's own grandfather Jacob Senior, had also known about the halakhic issues and given exactly the same advice to the factory owners. I would suggest therefore that there is more here than the reforming enthusiasm of a young rabbi. Something had changed in the way religious authorities saw such establishments, and it was expressed in a new understanding of the halakhic relevance of Jewish space. As we noted, the well-established mechanisms for contracting with Gentiles had left hanging the problem of appearances. The labor could not be done on the Jew's property lest other Jews be misled. (This is why, if the Jew's property lay out of town and "beyond the Sabbath pale" - that is, outside the zone within which Jews were allowed to walk on the Sabbath-the work was permitted since it could not be observed by a Jew.) But in the late seventeenth century, rabbis had become concerned about non-Jews witnessing such labor, and this for an interesting reason. As the influential Venetian rabbi Samuel Aboab had put it several decades earlier, Christians might invidiously compare the Jews' shops open for business on Saturdays with Christian firms that closed on Sundays and other holy days. This, he felt, was derogatory to Judaism, since it would give Christians the impression that Jews did not rigorously observe their own religious precepts. Aboab's concern about how Jewish actions were perceived in

6o Katz suggests that he is not sure what Meldola finally ruled. In fact, Meldola told his friend what he had ruled in the very first responsum and then, in responsum $\S 16$, added that he would urge the party to go even further. 
the public - that is, the non-Jewish — space is an early indication of a cultural sensitivity that will be fundamental to Jewish modernity. ${ }^{61}$

Aboab's sensitivity to the impression Jews made in the public space may have been heightened by his own experience living in the walled ghettos of Verona and Venice, where he had learned to value separate Jewish spaceswhat he referred to with the biblical phrase, "the camp of the Hebrews." ${ }^{2}$ But Aboab was not unique, and his attempt to cope with the halakhic implications of where an action occurred would have an impact also in Pisa and Livorno where there was no ghetto. It was, I would argue, what lay behind Meldola's objections to the workshops, even if he did not express it directly to the owners, perhaps because he knew that his predecessors had never raised this issue. Finally, it is the distinction between Jewish and non-Jewish space that lies behind a rather startling argument proposed by Joseph Ergas in his correspondence with his friend. Perhaps, Ergas suggested, the rabbinical ruling about appearances applied only to a Jew's domestic space but not to separate industrial space! Meldola does not take up his friend's suggestion, and seems to have remained highly skeptical of the permissibility of the arrangement. Still, Aboab and Ergas, though standing on opposite sides on the issue at hand,

61 For an introduction to recent historiographical investigation of the significance of space see Beat Kümin and Cornelie Usborne, "At Home and in the Workplace: A Historical Introduction to the 'Spatial Turn," History and Theory $5^{2}$ (October, 2013): 301-18; Doris Bachmann-Medick, Cultural Turns: New Orientations in the Study of Culture (Berlin: Walter de Gruyter, 2016): chapter 6: "The Spatial Turn," 211-44. On the various notions of Jewish space in this period see my "Jewish Space in Early Modern Pisa," in Diversi angoli di visuale fra storia medievale e storia degli Ebrei. In ricordo di Michele Luzzati, ed. Anna Maria Pult Quaglia and Alessandra Veronese (Pisa: Pacini, 2016), 103-22. The definition of Jewish space in the early modern city presented new challenges in connection with the laws of carrying on the Sabbath, an issue to which Meldola devoted considerable attention in his Parashat ha-Ibbur (Amsterdam, 1734). See Boaz Hutterer, "The 'Courtyard Eruv' in the Urban Space, Its Development from the Times of the Mishna and the Talmud to the Twentieth Century," PhD diss., Bar-Ilan University, 2013 [Hebrew]; Hutterer, "The Schlagbaum-A Chapter in the History of Eruvin in Western Europe," [Hebrew], http://www.biu.ac.il/JS/JSIJ/13-2015/Hutterer.pdf; and with special reference to Meldola, "Parashat ha-Ibbur u-Farashat ha-Tsiyur," https://safranim.com (issue 38: accessed 16 July 2017). I hope to explore this aspect of Meldola's concern with Jewish space and its specific relevance to Pisa and Livorno in a separate article.

62 Samuel Aboab of Venice had treated the case of a Jews' silk factory that ran on the Sabbath in Mantua; Dvar Shmuel (Venice, 1702), §192, fol. 48f. Aboab's impractical "solution" was to rent the entire manufacturing operation-building, equipment, and goods- to a Gentile, limiting the Jew to no more than a capitalist or rentier role. He does not even mention the technological expertise that the Jew presumably possessed or the supervisory role he played. On his protective attitude to ghetto space as the "camp of the Hebrews" see ibid., §4, fol. 2 a. 
can be seen as exploring a common sense of inside/outside, a perception that would eventually allow the sort of dual identity encapsulated in J.L. Gordon's famous nineteenth-century cry to his co-religionists that they be Jews in their homes and human beings on the street. ${ }^{63}$

Let us now look at a second case of tension between public practice and the position adopted by the young Raphael Meldola in Pisa. Again, we are confronted with an issue related to Sabbath observance, and again there is a technical consideration upon which the young rabbi chooses to state an opinion. But in this case, it would appear that his stance was far more vocal, and he was unwilling to compromise. Once again, however, there is a break between his views and the community's norms of Jewish practice. It may not be irrelevant that the issue once again had to do with a subtle change in the cultural sense of space - in this case, recreational space.

In the spring of 1718 Meldola wrote to the rabbinic council, the Pekidei Isur $v e$-Heter, in Livorno about a recurrent problem he faced in Pisa. Each year more and more Jewish tourists were coming to Pisa for the opening of the thermal baths that dotted the region. (Though Meldola does not specify, we can assume that the overwhelming majority of these tourists were from nearby Livorno. ${ }^{64}$ ) Jews attended the baths not only on weekdays, but even on the Sabbath, and Meldola was appalled. His objections were technical: first, medical treatments were forbidden on the Sabbath except for emergencies; second, bathing should be forbidden because it had an enervating effect that required revival with cakes and fruits; and finally the bathers might wring out the towels or bathing attire, and might carry drops of water or their bathing paraphenalia without an eruv from property to property (reshut to reshut). He was not accusing the

63 Judah Leib Gordon, "Hakitza Ami" [Awake My People!], Ha-Karmel 7, no. 1 (1866).

64 Meldola's description suggests that going to the baths was not just medicinal; it was recreational - a vacation for entire families, that involved, as he admits, not just the somewhat enervating baths, but also the subsequent lounging about on the grass, restoring oneself with sweets and fruits. On Jews' attendance at the baths as an upper-class activity that could lead to friction with non-Jewish patrons, see Francesca Trivellato, The Familiarity of Strangers: The Sephardi Diaspora, Livorno, and Cross-Cultural Trade in the Early Modern Period (New Haven: Yale University Press, 2009), 89 and n. 111. But as we shall see, Livornese rabbis were unwilling to challenge this activity. We should not take it as a given, as Trivellato and many other scholars have done, that rabbinic authorities were opposed to such "transgression of social boundaries" and participation in the surrounding culture. 
bathers of total religious ignorance ("lav be-shoftani askinan"), but there were women and children who might not be familiar with the rules, "for not everyone is learned." He had confronted the bathers but to no avail: "I swear that I screeched like a rooster about this, but I was unable to correct this distortion. It has become accepted as permitted; they inform their teachers that earlier authorities did not object. 'He who wishes to lie calls on distant witnesses.' They issue false tales about the early authorities, the holy ones in the land, saying that they were lenient. 'He who wishes to choke himself hangs himself from a high tree." Meldola now turned to the senior scholars in Livorno to back up his authority; as he put it in liturgical terms, to "sanctify him in the eyes" of the rebellious bathers. He laid out his halakhic logic in detail and begged the Livornese authorities to respond in writing by adding their names to his responsum. Their support would allow him to eradicate the problem. ${ }^{65}$

No doubt to Meldola's surprise and chagrin, however, the authorities in Livorno refused to back him up. About a month after he wrote, he received a brief and somewhat elliptical note back from Raphael Barukh, apparently then a member of the rabbinic council. He had shown Meldola's letter around to the rabbis of the various yeshivot in Livorno; they had agreed that there was a halakhic problem with therapeutic bathing on the Sabbath. But they refused to sign the letter that had not, after all, been addressed to them. In Livorno this sort of official act was the prerogative of the community-appointed Pekide Issurve-Heter, not lower level schoolteachers. As for the three councilors, one was out of town and could not be reached. Another, Meldola's uncle Moses Senior, disagreed on the substantive point. There were well-established precedents for allowing Sabbath bathing, and he did not see the therapeutic aspect as significant, possibly because he knew it was incidental to the bathers' real purpose: a holiday with their wives and children complete with picnics on the lawns. As for Raphael Barukh, he himself agreed with Meldola, but he could not, on his own, sign the responsum. ${ }^{66}$

It is hard not to read this as a polite but firm brush-off to the thirty-threeyear-old Meldola. His uncle, a prominent rabbi in Livorno, did not agree with his stringency. And those rabbis who did were unwilling to get involved, no doubt for fear of offending wealthy members of their own community who would have been among the prime clientele at the baths. In eighteenth-century Livorno, even a conversation conducted within the traditional four cubits of halakhic rhetoric did not necessarily lead to increased religious rigor.

65 Mayim Rabim, Orah Hayim, §25, fols. 18b-19a.

66 Ibid., §26, fol. $19 a$. 
But what is especially striking for the cultural historian is the nature of the lay response to Meldola's normative demands. Even if we can hear them only through the version provided by the rabbi, the bathers' arguments sound out loud and clear. The bathers do not see themselves as libertines; they are simply following tradition. "The first settlers in the kingdom allowed it. ${ }^{67}$ We rely on the ancient ones, and you," they admonish the rabbi, are overstepping when you "come to add" strictures. This is hardly a community of new Jews unsure of themselves who feel ignorant about the past. Quite to the contrary, at least in this part of the Western Sephardic diaspora the lay members of the community have a strong sense of lived Jewish tradition, and they resent the innovations and strictures being introduced by their rabbi. This attitude can be heard again and again in Meldola's responsa. They are not arguing for a secular value system, nor for a loosing of the bonds of tradition. In their eyes, he was the innovator, not they.

Tradition then was not a simple matter in the eighteenth-century Jewish world - at least not in the communities where Meldola served. It was a claim to authority that could work in multiple directions depending on who was laying claim to past precedent. And this is crucial to understand when interpreting the halakhic literature of this period which seems to discuss the concept of tradition with special frequency. ${ }^{68}$ It is no simple matter to ferret out the cultural significance of these halakhic discussions if only because the Hebrew term for custom (minhag) has a broad range of often contradictory connotations. Minhag was binding, but to what degree was it open for discussion? Meldola distinguishes, for example, between "the customary order of [Torah] readings" which, he claims, "derives originally [me-ikara] from the regulations [takanot] issued by Moses and by Ezra and his court and is the universal norm [minhag pashut]"69 and the less binding "custom concerning [a special Torah reading in honor of] bridegrooms [...] that does not derive from any takana and was not universally adopted."70 Minhag could be "correct" or "mistaken,"

67 "Ha-yoshvim rishona ba-malkhut hitiruhu." An alternative interpretation might read: "those who were pre-eminent in the kingdom allowed it"-i.e., rabbis who had preceded Meldola had allowed this. In the end, the argument would be the same: Meldola is an unacceptable religious innovator.

68 See, for example, the treatments of minhag in Hizkia da Silva, Pri Hadash to Shulhan Arukh, Orah Hayim, §§468.4 and 496. Da Silva was born in Livorno (1656) and studied there under Samuel Costa who would later also be Raphael Meldola's teacher.

69 Minhag pashut would most commonly be translated as "simple custom" but here Meldola seems to be using pashut in the sense of "dispersed" since in the next line he uses another form of the verb, nitpashet.

70 Mayim Rabim, Orah Hayim, §8. David Meldola, Raphael's brother-in-law and himself a rabbi and cantor in Livorno, had been invited to lead the service in Pisa on the Sabbath 
and therefore establishing correct minhag, for example in the liturgy, was a source of concern. One of Meldola's first tasks when he moved to Bayonne was to establish the proper method for synagogue recitation of the "Hear $\mathrm{O}$ Israel" prayer. ${ }^{71}$ In another responsum he took up the Bayonne minhag not to allow haircuts from the first of Av until after the fast day on the ninth of the month. Meldola assumes that this was an erroneous custom adopted out of ignorance by the earliest converso settlers who were then still living outwardly as Christians.

Perhaps they heard from someone passing through that it was forbidden to have one's hair cut or to wash one's clothes during the week in which the fast day fell. They erred and thought that it was forbidden from the New Moon of Av. Or perhaps some Jew passed through their land with a wild growth [of hair] because he conducted himself as an ascetic and did not cut his hair [for the three weeks] from the 17th of Tamuz or from the New Moon of Av, and the people of the city erred and thought that this was a practice required of everyone. ${ }^{72}$

The concern over correctness was not limited to ritual. Minhag was also the guide to acceptable public behavior-for instance, whether unmarried young women might appear in public without their hair covered. Problems arose when different Jewish "ethnicities" with different traditions in this regard came together in a single city. ${ }^{73}$ And finally local minhag could quickly coalesce into a mechanism for ritualizing and regularizing ambiguities of social status. For example, only a half-century after its establishment, Livorno was known to have developed a minhag for a protracted process through which New Christian couples arriving from the Iberian Peninsula might solemnize

preceding a wedding, but his procedures had offended a Pisan named Eliezer ben Jacob Supino. On the furor that arose, see below n. 86.

71 Mayim Rabim, Orah Hayim, §1. The concern in Bayonne for correct liturgical practice was also highlighted, ibid., §10; the community had carefully preserved a responsum they had received from the rabbis of Amsterdam on the question of whether a blind man could participate in the service.

72 Mayim Rabim, Yore De'ah, §67.

73 Mayim Rabim, Even ha-Ezer, §§28-30, concerning the custom of Italiani young women to appear with their hair uncovered in public. Jacob ben Moses Senior in Pisa wrote to his student Jacob ben Samuel Hagiz: "The point is, if the halakha is not certain, follow minhag, for Jewish custom is considered binding, and if Jews are not prophets, they are at least [considered] the descendants of prophets." Raphael Meldola added his own opinion. On Jacob Hagiz, see Elisheva Carlebach, The Pursuit of Heresy: Rabbi Moses Hagiz and the Sabbatian Controversies (New York: Columbia University Press, 1990), 19-29. 
their Jewish marriage and thus also legitimize any children born to them in the "Lands of Idolatry." So firmly entrenched was this customary norm even in that still young community, that in the 165 os Rabbi Moses Benveniste, writing in distant Istanbul, could solve the status problems faced by one conversa and her children based on what must have happened in Livorno a decade earlier even though there were no living witnesses to the events. ${ }^{74}$ Rabbis knew the authority of local tradition and custom even when not formally written down. They called upon collective memory when it was useful. And they realized that they could challenge collective memory only at great risk. The historian's task lies therefore not simply in distinguishing between a rabbi's intellectualist and literary approach and a communal conception of propriety. It is the even more delicate obligation to understand the shifts in the norms articulated by the rabbis in their apparently stylized language as they continuously negotiated with their communities.

\section{Defining the Unacceptable}

We come now to our third case through which to investigate broad conceptions of deviance in Meldola's halakhic rulings: how did he react to the presence of former (New) Christians in his community? Historians have emphasized that rabbinical opinions on the "converso question" must be understood in their real-world context rather than as expressions of abstract principles. When conversos left Iberia and "returned," often at considerable danger to themselves, to a Jewish way of life, rabbis sought ways to allow the process and ease the transition. When it came, therefore, to deciding whether conversos were Jewish sinners seeking to atone for their sins or non-Jews who now sought to join the Jewish people as converts, the latter position was favored since it neatly resolved all the problems that might arise from the conversos' marriages on the Iberian Peninsula. If they had not been Jews, then the strict rules about divorce, levirate marriage, and legitimacy simply did not apply to them, and they could now get on freely with establishing families and building new lives for themselves. ${ }^{75}$

74 Moses Benveniste, Pnei Moshe (Constantinople, 1674), 1, §61.

75 See the summary by Simon Schwarzfuchs, "Le retour des marranes au judaïsme dans la litérature rabbinique," Xudeus e Conversos na Historia: Actas do Congreso Internacional Ribadavia 14-17 de outubro de 1991 (Santiago da Compostela: La Editorial de la Historia, 1994), 1: Mentalidades e Cultura, 339-48. Fundamental treatments were prepared by H.J. Zimmels, Die Marranen in der rabbinischen Literatur (Berlin: R. Mass, 1932); Simha Assaf, "Anusei Sefarad u-Fortugal be-Sifrut ha-Teshuvot," Me'assef Zion 5 (1933), reprinted in his 
Mayim Rabim includes a responsum issued in Bayonne in 1729-30 that seems to exemplify this approach. The halakhic issue before Meldola was not marriage but wine. Faced with a converso who had undergone circumcision and behaved outwardly as a Jew but continued to desecrate the Sabbath and to swear by Christian saints in private, Meldola insisted on regarding the man as nevertheless a fully observant Jew for halakhic purposes. Even though the converso had eventually reverted to Christianity, wine that he had owned during his Jewish years was still to be considered kosher. Meldola does not elaborate on his thinking, but it is not difficult to see his logic. No matter the evidence, to question the converso's Jewishness retroactively would have effectively put the status of every converso returnee into permanent contingency. The facts of the particular case were apparently less significant than Meldola's need to assuage his community's psychic insecurity. ${ }^{76}$

Of course the question of converso identity did not always present itself in such stark terms. Established halakhic discourse could deal in a straightforward manner with most issues, even if they arose out of implicitly existential questions of identity and involved large sums of money. In 1715, for example, a newly arrived and very wealthy converso had his will drawn up in Bayonne by the Jewish community secretary. He made sure, however, to satisfy also the legal conventions of the state. The will was now being contested. Should the will be executed according to secular or Jewish law? An (unnamed) rabbi in Bayonne, backed up by a colleague in Florence, had recognized the validity of the secular will. "Their Excellencies, the memunim and lay leaders of the Jewish community ruled correctly $[\ldots]$ and we should not reverse their ruling." ${ }^{77}$ But Meldola, in a review, rejected that position, insisting that halakhic norms were paramount. ${ }^{78}$

collected essays, Be-Ohalei Yaakov (Jerusalem: Mosad Ha-Rav Kook,1943), 145-80; and Benzion Netanyahu, The Marranos of Spain from the Late Fourteenth to the Early Sixteenth Century According to the Hebrew Sources (New York: American Academy for Jewish Research, 1966), 5-76. Yosef Hayim Yerushalmi, From Spanish Court to Italian Ghetto. Isaac Cardoso: A Study in Seventeenth-Century Marranism and Jewish Apologetics (New York: Columbia University Press, 1971), 24-31 stresses the real-world thrust of the rabbinic view of the conversos as not Jews.

76 Mayim Rabim, Yore De'ah, §27.

77 The will, dated 21 Adar 5475 [1715], was originally drawn up in la'az (non-Hebrew, presumably Portuguese) before eight witnesses "as is the custom of the Christians so that it would be done also as is required for them" [kdei she-yihye asui gam ka-ra'ui lahem]. A Hebrewlanguage summary is included in the appeal which based itself on the conventions of halakha; Mayim Rabim, Hoshen Mishpat, §46. The rabbi rejected the appeal, and was backed up by Raphael ben Samuel Corcos in Florence.

78 Ibid., §47. Meldola's opinion, issued presumably after he had come to Bayonne, was quite likely an exercise in jurisprudential study rather than an applied ruling since the case had been resolved years before. 
But in between black-and-white halakhic categorizations of converso Jewishness and the more prosaic procedural conflicts over jurisdiction, there was also a muddier area of identity, that liminal zone in which members of a society practice difference by labeling those who belong and those who do not, and in which rituals are created to mark the passage from one status to the other. And here, as before, we will see that public practice and rabbinic opinion do not necessarily coincide.

The issue revolved around the implications of circumcision, an operation that at least some converso men sought to delay, arguing that this mark on their bodies would put them in mortal danger should they, for financial reasons, have to return to Spain or Portugal. ${ }^{79}$ Meldola's grandfather, Jacob Senior, was asked about a converso who had put off circumcision for this reason. So far, the converso had been allowed to participate in every Jewish ritual, and had done so eagerly, with the exception of wearing phylacteries during morning prayers. To touch the sacred parchments was forbidden him until he was circumcised. But the converso had forgotten himself. Seeing himself as a regular participant in the community, he had participated in the auction for honors during the holy day services and had "purchased" the honor of opening the Sacred Ark. The congregation was put into a quandary. Should the uncircumcised man be allowed to touch the scroll, even if only to hand it over to the person who would carry it to the reader's desk? Senior, for his part, altogether dismissed the logic of the ritual distinction that had kept the man from donning phylacteries in the first place, and he ruled emphatically that there was no reason for the converso not to touch the Torah scroll. For one thing, the genuineness of the converso's repentance was unquestioned, and the reason that he was not yet circumcised - "to return and save his money" - was fully legitimate and "not, God forbid, an unworthy motive." And for another thing, the great medieval sage Moses ben Maimon had clearly ruled that a Torah scroll could not be rendered impure, even by a non-Jew or a menstruating woman..$^{80}$

The published text does not provide either a date or a location, but there seems little doubt that what we have here is an event that occurred in Pisa quite soon after Senior's appointment there as hakham and hazan just before the High Holy Days of 1635 . Senior mentions in passing that he has heard

79 Yosef Kaplan, "Ha-Mitzva ha-Rishona ve-ha-Yoter Ikarit: Brit ha-Mila be-Olamam shel ha-Anusim she-Hazru la-Yahadut ba-Et ha-Hadasha ha-Mukdemet [Attitudes toward Circumcision among the Early Modern Western Sephardim]," in From Sages to Savants. Studies Presented to Avraham Grossman, ed. Joseph Hacker, Yosef Kaplan, and Benjamin Z. Kedar (Jerusalem: The Zalman Shazar Center, 2009), 355-92.

8o Mayim Rabim, Yore De'ah, §51. Senior's opinion is clear in his remarkable final sentence: “[...] conversos [...] are not considered 'other.' Their hearts are directed towards heaven. They are Jews, descended from our ancient forefathers [...]." 
directly from people who know the man and attest to his devotion to Judaism, suggesting that the case was a local one. Thus, although he frames his opinion as a response to a question that someone had sent him, it is likely that the case arose in his own synagogue in Pisa as he himself was officiating. He was still quite young. (Indeed, the parnassim recorded their discomfort about his youth in the communal pinkas when they first decided to appoint him-perhaps using that to justify offering Senior a very low salary. ${ }^{81}$ ) Unsure of his ruling, therefore, the new rabbi forwarded his opinion to the Livornese yeshiva klalit (council of senior rabbis) asking for their approval. ${ }^{82}$

The four Livornese rabbis proved less flexible than Senior toward uncircumcised conversos, but not because they disagreed with his halakhic reasoning. Rather, they were looking for a way to use access to public Jewish space- that is, to the synagogue - as a lever with which to enforce social discipline on the newcomers. Senior's ruling, they said, should be applied only to this one individual whose good faith was well attested. In general, however, those who had not undergone circumcision should be publicly marked, prevented not only from donning phylacteries but even from attending synagogue services altogether. The Livornese rabbis insisted that maximal social pressure be put upon the conversos to undertake the ceremony quickly, especially if their hesitation stemmed merely from "laziness." 83

If the Livornese response seems rigid, its effort at social engineering is nevertheless straightforward. But by the time Raphael Meldola reviewed the issue possibly three-quarters of a century later, social discipline had turned into religious taboo. He accepts his grandfather's argument, but then questions its

81 Jacob Senior (Señor, Siñior) was appointed "hahan y guazan" (that is, hakham and hazan or rabbi and cantor) of the community on 9 September 1635 , an election confirmed by a general vote a month later, on 9 October 1635 . The initial decision stressed that "despite his youth, his works, knowledge and actions surpass his young age, leading one to consider him as a mature man, especially today when he is getting married which earns him the title of a 'complete human being'" [pois naõ estante a edade naõ ser muta suas obras siencia y aççions supplen a ydade devindose estimar como se for a vello de muytos años maxima oje que ten tomado estado con que fica aquistando o titulo de varon perfecto]. The last term is a reference to Midrash Bereshit Rabba, $\$ 17$ which argues that an unmarried man is not even considered a "complete human being" [adam shalem]. (CAHJP, Film HM887, fol. 91v [94v]). Senior's initial monthly salary of six scudi proved inadequate, and he repeatedly petitioned the community for a raise saying he couldn't support his family. Finally, eighteen months later, his salary was finally raised to eight scudi, and he was promised that he would be paid regularly.

82 Just a few months later, the young man sought a second opinion from Isaac Calo, the rabbi or Florence, on another matter; Mayim Rabim, Hoshen Mishpat, §§1-2.

83 Mayim Rabim, Yore De'ah, $\$ 52$. One of the signatories is Meldola's other grandfather, David Israel ben Elazar Meldola. 
textual basis. Meldola was less interested in the motives of the converso than in the impurity that attached to him. He devotes much of his legal opinion, therefore, to a survey of post-Maimonidean halakhic views that forbade a menstruating woman from touching the Torah or even attending the synagogue. And then he moves on to the converso:

We have to keep a Torah Scroll far away from a place of filth because that would seem like desecrating the Scroll. [...] It is logical, therefore, that we must also protect the Torah Scroll from the touch of an uncircumcised person, for there is nothing as disgusting as a foreskin. No one is as naked as the person who is not "clad" in the commandment of circumcision. True, [the converso in the original question] intended and meant only to adore the Torah and honor it by purchasing the honor of opening the doors of the Torah ark at a high price. Moreover, we know the Torah in fact cannot be made impure, and none of the disgusting aspects of the person holding it can cling to it. [...] Even so, [to let him touch the Torah] would be considered a blemish on us and on our children, in that we are not being careful about the honor of the Torah and are not cautious [haredim] to protect what is in our custody by keeping the imperfect and impure away from it. [...] It is obligatory on us to insist and take care that only proper and clean people touch it. For all these reasons, I prefer to be strict about this. ${ }^{84}$

Shall we say that Meldola's astonishingly harsh terminology here is indicative of a radical shift in the rabbinic attitude towards the conversos? It seems not; we have already mentioned his resolute acceptance, years later in Bayonne, of the Jewishness even of a converso who would later revert to Christian practice. More arguably, his emphasis on the crucial importance of circumcision can tell us how, for Meldola and his generation, halakhic rules had become a symbolic language with which to articulate purity and belonging. It is this shift that helps to explain the virulent opposition that Meldola's positions often raised in the communities he served.

The cases we have examined demonstrate that at least in the corner of the Western Sephardic diaspora where Raphael Meldola and his family lived,

84 Mayim Rabim, Yore De'ah, §53. 
traditional Judaism was not a static, stable continuum. On the one hand, norms had to be defined and promulgated to each new generation as well as to the "penitents" who newly joined the community. But as well, in the seventeenth and early eighteenth centuries cultural practices and values that had long been acceptable were becoming problematic. Space was ascribed new valence. Recreational activities were subjected to new supervision. And wellestablished halakhic principles were given new symbolic freight and meaning. What strikes us now is not only the frequency of the debates that we hear about in Meldola's responsa, but the astonishing bitterness that they engendered.

What might seem to a twenty-first-century observer as a minor alteration in the liturgy, for example, could quickly lead to endless ad hominem attacks, the ostensible legalistic debates barely masking relentless struggles over status and authority. Meldola provides us with an unusually detailed description of such a case from early in his career.

When I came here to Pisa to be head of its court and preacher, God gave me grace in the eyes of the inhabitants. All as one, from least to most important, happily and contentedly relied upon me to establish religious rules and prohibitions as needed. My luck! I found one person who opposed me [...]. For some reason, [whenever I suggested a modification] he always wanted to support the existing practice. He may have been trying to flatter [the members of the community], to gain favor in their eyes, or to make me somehow detestable. Or perhaps he was trying to protect his own reputation, since he had not previously rebuked them about this, or simply hadn't known the law. Or maybe it was all of the above.

As for poor me, I tried my best with all my strength to seek peace [...]. With regard to any small quibble that he might raise, I swallowed my pride and paid no attention in order not to stir up argument. But when it came to binding halakhic issues [piskei dinim], I stood my ground, dictating the correct path to people in accordance with the traditions of my fathers and teachers of blessed memory. I wanted to do my duty and know that I would not be ashamed. ${ }^{85}$

The rivalry came to a head on the Jewish festival of Shavuot (Pentecost) in a dispute as to how the synagogue honors of maftir (the last verses read from the Pentateuch) and haftara (the accompanying prophetic portion) should be assigned. In Sephardic synagogues such as those in Livorno and Pisa, these portions were often read by a minor — that is, a boy who had not yet reached 
the age of bar mitzvah, because the maftir and haftara were, in a certain sense, "extras" to the main service. But on the festival, the special maftir was obligatory and could not be treated as "extra." Could it then be read by a minor? In Pisa the custom was to assign the maftir to an adult and then to have the minor repeat the reading and go on to the prophetic portion. Meldola pointed out that such repetition had been rejected by most authorities, and he therefore ruled that one adult or one minor should read both portions. Accordingly, the next day, also a festival, he first led a boy through the Torah verses and then the same boy read the haftarah: "I immediately heard muttering and mockery whispering against me, gathering and arguing in the city streets, and accusing me of acting improperly and contravening a rabbinic ruling. They contradicted my words as if they had received a prophetic inspiration ${ }^{86}$ using trivial words [...] maligning me by saying I wanted to annul an ancient custom." ${ }^{87}$

It is difficult to draw general conclusions from such a fierce debate over what seems a minor ceremonial detail and an arcane halakhic issue that had, moreover, already been widely discussed and decided in the halakhic literature. As Meldola tells the story, the entire affair arose because of the personality of one unusually difficult individual. It is worth noting that an even more ferocious rivalry would break out just a few years later when Meldola's replacement as rabbi in Pisa, the Livornese Eliezer ben Jacob Supino, vociferously denounced Meldola's brother-in-law David for going against proper order in reciting a special reading for a bridegroom during the Sabbath services before the wedding. (David had been invited to Pisa to act as cantor.) When Meldola included the back-and-forth correspondence in his Mayim Rabim, Supino published his own pamphlet, attacking both David and Raphael (Amsterdam, 1742), though the family managed to have that pamphlet seized and almost every copy destroyed. ${ }^{88}$ Personalities aside, however, we must also take it into consideration that the hothouse atmosphere of the small Jewish community

86 Cf. Eruvin 6ob and cf. Bekhorot 45a.

87 Mayim Rabim, Orah Hayim, §22, fols. 16a-b.

88 See above n. 70. Mayim Rabim, Orah Hayim, $\S \S 6-8$, record the Meldola side of this intense argument, leaving the Pisan religious scholar unnamed. Raphael's son David later included many more responsa concerning the affair in his own Divrei David (Amsterdam, 1753), §§21-38. For Supino and his pamphlet, see most recently Samuel Glick, Kuntres al Inyan Shabbat ha-Hatuna le-MOHR"R Eliezer B"R Ya'akov Supino ZLH"H (Jerusalem: Mosad Ha-Rav Kook, 2007); Meir Benayahu, Rabi Hayim Yosef David Azulai (Jerusalem: Ben-Zvi Institute, 1959), 345; Mordechai Ha-Cohen, “Goralo shel Sefer," Sinai 34 (1954): 110-21. I have been unable to determine whether Eliezer ben Jacob Supino was part of the influential clan of merchants and scholars who came from Empoli to Pisa in the early years of the community and gained prominence there, in Livorno, London, and several ports of the eastern Mediterranean; I Supino: Una dinastia di ebrei pisani fra mercatura, arte, 
in Pisa seems to have been especially prone to fostering fierce animositiesover governance and the rights of membership ${ }^{89}$ as well as over the religious direction of the community. But neither specific personalities nor the dynamics of a small-town community should blind us to the central importance that religious custom and practice held for these Jews, or to the cultural anxieties that fueled their fierce opposition to any change or deviation. We need not be surprised that these debates exploded over the synagogue service, for this was the community's primary forum for the performance and recognition of personal status. Debates over an apparently trivial liturgical issue are testimony to the huge cultural investment Pisan Jews had made in the "authenticity" of their tradition.

Where then does all this leave us? We began with a claim that historians are reconsidering the "secularization thesis" as an explanation for modernization generally and for Jewish modernization in particular. Our reading of just a few of the responsa in Mayim Rabim demonstrates that any assumption of a sharp breakdown of tradition at least in the Western Sephardic diaspora of the early eighteenth century is too simplistic. Meldola is no traditionalist rabbi barricading himself within the "four cubits" of the halakha against the onslaught of a secularizing laity. To the extent that practices and attitudes are changing, it would seem that it is the rabbinate that is introducing new norms, while the laity is resisting, seeking to defend traditional patterns of behavior. And while we can easily pull out examples of Meldola responding to new technologies such as mechanical watches or new social fashions such as the taking of snuff when these seem to infringe upon Jewish law, that is not the main thrust of his writing. He does not seem threatened by any sense of a new libertinism or of radical ideas that threaten tradition. To look for a crisis of secularization, I would suggest, is to look in the wrong place for the nature of modernization.

I would rather suggest that we look at Mayim Rabim itself as a profoundly "modern" book — not in the enemies it fights, but in the techniques it uses to advocate for, and to disseminate, halakhic sophistication and rigor both in local communities and over a widening international circle. Its modernity lies in several of the features we have seen. First, Raphael Meldola is shown in this anthology to be a professional rabbi in the sense we might use the term today - clearly an employee of his community and dependent on the goodwill of a powerful, officially elected, lay leadership. Second, he uses correspondence

politica e diritto (secoli XVI-XX), ed. Franco Angiolini and Monica Baldassarri [=Società Storica Pisana, Biblioteca del "Bollettino Storico Pisano" 3] (Pisa: Pacini, 2015).

89 Our interest here is focused on religious norms, but I have prepared a separate study of "Ethnic Rivalries and Social Conflict" that I hope to publish soon. 
and especially print to create halakhic consensus across multiple centers, turning in particular to organized rabbinical committees in large centers like Livorno and Amsterdam. And third, he seeks to demonstrate his own scholarly abilities and thus gain status in a world of Jewish letters through the systematic display of literary eloquence in a sophisticated genre that he and his colleagues have developed. The main point is that Meldola's approach to halakha itself is new. His concerns with Jewish behavior in the public space, his attempts to impose a universal Jewish set of norms over local custom, and his concern with the symbolic weight of halakhic categories are all representative of the new values expressed in the everyday practice of Jewish life in the early modern period. Seen properly, then, Mayim Rabim is a combined effort by two Jewish scholars, father and son, to articulate and publicize a sophisticated set of transgenerational and trans-national discussions about Jewish norms and practices.

Mayim Rabim reveals as well another modern aspect of Meldola's careerthe efforts he made to shape the religious practices and perceptions of the communities he served. His pedagogical mission was typical of the modern Jewish community that had to accommodate enormous differences in the levels of Jewish knowledge and behavior among its members. Meldola could take nothing for granted. He quickly realized that he could not simply dictate "authentic" Judaism. If he tried to rule against customs like "buying" the maftir and haftara for rich people's sons, he knew that "they would not listen to us." When he could, he made compromise his guiding principle for "the ideal can become the enemy of the acceptable." ${ }^{90}$ But he never gave up on the effort to teach, and it is this "outreach" that is perhaps the clearest mark of his modernity. One example will suffice.

When Meldola first came to Pisa he discovered that his congregants did not know basic rules about the Sabbath. When he told them it was forbidden to reheat cooked food in a hot oven, "they did not believe that such a thing would be written in a book. ${ }^{91} \mathrm{He}$ therefore hit upon an ingenious scheme to publicize the rules he wanted to teach. When his friend, Joseph Ergas, came to visit in Pisa, Meldola asked him to "drop in" on his upper-level class. Ergas "casually" asked the boys to research this issue, presenting it as an instructional exercise. Meldola then selected two of the boys to write out their answers. Next, he arranged for the boys to read their essays aloud at a public meeting of the community council. At the ceremony, Ergas gave a lecture about the authenticity of the Jewish biblical, and especially rabbinic, tradition and then went on to

9o Literally: "out of good [do not be called evil]." The phrase, from BT Brakhot 3oa, is a standard rabbinic expression for accepting the minimum.

91 Mayim Rabim, Orah Hayim, §18, fol. 14a. 
comment on the boys' papers. Finally Meldola too rendered his critique of the boys' work. ${ }^{92}$ In what seems a remarkably modern mechanism for "adult education," Meldola seized upon the formal institutionalization of Pisan Jewish self-government-itself a considerable innovation. Ingeniously he used civic government as a stage from which to promote his views of halakha, views that he no doubt felt would have been ignored if stated directly. To note that Jewish tradition was to be taught through schoolboy essays at a town council meeting is to recognize that in Meldola's world, tradition itself was being negotiated.

\section{Bibliography}

Aboab, Samuel. Dvar Shmuel. Venice, Vendramina, 1702.

Abramsky, Chimen. "The Crisis of Authority within European Jewry in the Eighteenth Century." In Studies in Jewish Religious and Intellectual History presented to Alexander Altmann on the Occasion of His Seventieth Birthday. Edited by Siegfried Stein and Raphael Loewe, 13-28. University, Alabama: University of Alabama Press, 1979.

Angiolini, Franco, and Monica Baldassarri, eds. I Supino: Una dinastia di ebrei pisanifra mercatura, arte, politica e diritto (secoliXVI-XX). Società Storica Pisana, Biblioteca del "Bollettino Storico Pisano" 3. Pisa: Pacini, 2015.

Asad, Talal. Formation of the Secular: Christianity, Islam, Modernity. Stanford: Stanford University Press, 2003.

Assaf, Simha. “Anusei Sefarad u-Fortugal be-Sifrut ha-Teshuvot." Me'assefZion 5 (1933). Reprinted in Simha Assaf, Be-Ohalei Yaakov, 145-80. Jerusalem: Mosad Ha-Rav Kook, 1943 .

Bachmann-Medick, Doris. Cultural Turns: New Orientations in the Study of Culture. Berlin: Walter de Gruyter, 2016.

Baron, Salo. "Ghetto and Emancipation." Menorah Journal 14 (1928): 515-26.

Benayahu, Meir, ed., Dor Ehad ba-Aretz: Igrot Rabi Shmu'el Aboab ve-Rabi Moshe Zacut be-Inyenei Erets-Yisrael [5]399-[5]426 [A Single Generation in the Land: Letters of R. Shmuél Aboab and R. Mošeh Zacuto Concerning the Affairs of Erez Yisraél 16391666]. Jerusalem: Yad Ha-Rav Nissim, 1988.

Benayahu, Meir. Rabi Hayim Yosef David Azulai. Jerusalem: Ben-Zvi Institute, 1959.

Benveniste, Moses. Pnei Moshe. Constantinople, 1674.

Biale, David, ed. The Cultures of the Jews: A New History. New York: Schocken, 2002.

92 It is typical of Mayim Rabim that all four opinions were published; ibid., §§19-21. The two boys were Eliezer Leucci, scion of one of the oldest Jewish families in Pisa, and Joshua ben Attar Milo who was to become Meldola's son-in-law. The two boys were assigned another educational exercise in Mayim Rabim, Orah Hayim, §29. 
Bregoli, Francesca. "Jewish Scholarship, Science, and the Republic of Letters: Joseph Attias in Eighteenth-Century Livorno." ALEPH: Historical Studies in Science \& Judaism 7 (2007), 97-181.

Bregoli, Francesca. Mediterranean Enlightenment: Livornese Jews, Tuscan Culture, and Eighteenth-Century Reform. Stanford: Stanford University Press, 2014.

Bruce, Steve, ed. Religion and Modernization: Sociologists and Historians Debate the Secularization Thesis. Oxford: Clarendon Press, 1992.

Carlebach, Elisheva. The Pursuit of Heresy: Rabbi Moses Hagiz and the Sabbatian Controversies. New York: Columbia University Press, 1990.

Cohen, Mark R., ed. The Autobiography of a Seventeenth-Century Venetian Rabbi. Princeton, NJ: Princeton University Press, 1988.

Cooperman, Bernard Dov. “Afterword." In Jacob Katz, Tradition and Crisis. New York: New York University Press, 1993, 237-253, 351-359.

Cooperman, Bernard Dov. "Amicitia and Hermeticism: Paratext as Key to Judah Moscato's Nefutsot Yehudah." In Rabbi Judah Moscato and the Jewish Intellectual World of Mantua in the 16th-17th Centuries. Edited by Giuseppe Veltri and Gianfranco Miletto, 79-104. Leiden: Brill, 2012.

Cooperman, Bernard Dov. "Global History \& Jewish Studies. Paradoxical Agendas, Contradictory Implications." Giornale di Storia 9 (2016). http://www.giornaledistoria.net/index.php?Articoli=557Do301220A7403210406oB777327.

Cooperman, Bernard Dov. "Jewish Space in Early Modern Pisa." In Diversi angoli di visuale fra storia medievale e storia degli Ebrei. In ricordo di Michele Luzzati. Edited by Anna Maria Pult Quaglia and Alessandra Veronese, 103-122. Pisa: Pacini, 2016.

Cooperman, Bernard Dov. "Legitimizing Rhetorics: Jewish 'Heresy' in Early Modern Italy." Études Épistémè: Revue de littérature et de civilisation (XVI ${ }^{e}-X V I I I^{e}$ siècles) 31 (2017). https://episteme.revues.org/1764.

Cooperman, Bernard Dov. "Trade and Settlement: The Establishment and Early Development of the Jewish Communities in Leghorn and Pisa (1591-1626)." PhD diss., Harvard University, 1976.

De Sola, C.I. "Meldola." The Jewish Encyclopedia. New York: Funk \& Wagnalls Co., 1904. 6: 454 .

Diaz Brandon, Benjamin. Emek Binyamin. Amsterdam, 1753; reprint Borgóprund, 1912.

Dweck, Yaacob. The Scandal of Kabbalah: Leon Modena, Jewish Mysticism, Early Modern Venice. Princeton, NJ: Princeton University Press, 2011.

Endelman, Todd M. The Jews of Georgian England 1714-1830: Tradition and Change in a Liberal Society. Philadelphia: Jewish Publication Society, 1979.

Feiner, Shmuel. "From Renaissance to Revolution: The Eighteenth Century in Jewish History." In Sepharad in Ashkenaz. Edited by Resianne Fontaine, Andrea Schatz, and Irene Zwiep, 1-10. Amsterdam: Royal Netherlands Academy of Arts and Sciences, 2007. 
Feiner, Shmuel. "Seductive Science and the Emergence of the Secular Jewish Intellectual." Science in Context 15, no. 1 (2002): 121-35.

Feiner, Shmuel. The Origins of Jewish Secularization in Eighteenth-Century Europe. Philadelphia: University of Pennsylvania Press, 2011.

Feiner, Shmuel, Zohar Shavit, Natalie Naimark-Goldberg, and Tal Kogman, eds. $\mathrm{Ha}$ Sifriya shel Tenu'at ha-Haskala. Yetziratah shel Republikat ha-Sefarim ba-Hevra ha-Yehudit ba-Merhav ha-Dover Germanit. Tel-Aviv: Am Oved, 2014.

Ferziger, Adam. "Between 'Ashkenazi' and Sepharad: An Early Modern German Rabbinic Response to Religious Pluralism in the Spanish-Portuguese Community." Studia Rosenthaliana, 35:1 (2001), 7-22.

Fishman, Talya. Shaking the Pillars of Exile: "Voice of a Fool," an Early Modern Jewish Critique of Rabbinic Culture. Stanford: Stanford University Press, 1997.

Frattarelli Fischer, Lucia. Vivere fuori del Ghetto. Ebrei a Pisa e Livorno (secoli XVIXVIII). Turin: Zamorani, 2009.

Geertz, Clifford. The Interpretation of Cultures. New York: Basic Books, 1973.

Glick, Samuel. Kuntres al Inyan Shabbat ha-Hatuna le-MOHR"R Eliezer B"R Ya'akov Supino ZLH"H. Jerusalem: Mosad Ha-Rav Kook, 2007.

Harris, Jay M., ed. The Pride of Jacob: Essays on Jacob Katz and His Work. Cambridge MA: Harvard University Press, 2002.

Ha-Cohen, Mordechai. "Goralo shel Sefer." Sinai 34 (1954): 110-21.

Hazan, Ephraim. "Shluhei Erets-Yisrael ba-Shira u-va-Fiyut shel Yehudei Tsfon Afrika." Peamim: Studies in Oriental Jewry 24 (1985), 99-116.

Hutterer, Boaz. “The 'Courtyard Eruv' in the Urban Space, Its Development from the Times of the Mishna and the Talmud to the Twentieth Century" [Hebrew]. PhD diss., Bar-Ilan University, 2013.

Hutterer, Boaz. "Parashat Ha-Ibbur u-Farashat ha-Tsiyur." https://safranim.com, Issue 38. Accessed 16/7/2017.

Hutterer, Boaz. "The Schlagbaum-A Chapter in the History of Eruvin in Western Europe," [Hebrew]. http://www.biu.ac.il/JS/JSIJ/13-2015/Hutterer.pdf.

Joskowicz, Ari, and Ethan B. Katz, eds. Secularism in Question: Jews and Judaism in Modern Times. Philadelphia: University of Pennsylvania Press, 2015.

Kaplan, Yosef. An Alternative Path to Modernity: The Sephardi Diaspora in Western Europe. Leiden: Brill, 2000.

Kaplan, Yosef. "Deviance and Excommunication in the Eighteenth Century." In Dutch Jewish History. Edited by Jozeph Michman, 3: 103-15. Jerusalem: The Institute for Research on Dutch Jewry, 1993. Reprinted in Kaplan, An Alternative Path to Modernity, 143-54.

Kaplan, Yosef. "Ha-Mitzva ha-Rishona ve-ha-Yoter Ikarit: Brit ha-Mila be-Olamam shel ha-Anusim she-Hazru la-Yahadut ba-Et ha-Hadasha ha-Mukdemet" [Attitudes toward Circumcision among the Early Modern Western Sephardim]. In From Sages 
to Savants. Studies Presented to Avraham Grossman. Edited by Joseph Hacker, Yosef Kaplan, and Benjamin Z. Kedar, 355-92. Jerusalem: The Zalman Shazar Center, 2009.

Kaplan, Yosef. “'Karaites' in the Early Eighteenth Century." In Sceptics, Millenarians and Jews. Edited by David S. Katz and Jonathan I. Israel, 196-236. Leiden: Brill, 1990. Reprinted in Kaplan, An Alternative Path to Modernity, 234-79.

Kaplan, Yosef. "The Social Functions of the Herem." In Dutch Jewish History. Edited by Jozeph Michman, 1: 111-55. Jerusalem: The Institute for Research on Dutch Jewry, 1984. Reprinted in Kaplan, An Alternative Path to Modernity, 108-142.

Katz, Jacob. Goy shel Shabbat. Jerusalem: Zalman Shazar Center, 1983. English: The "Shabbes Goy": A Study in Halakhic Flexibility. Philadelphia: Jewish Publication Society, 1989 .

Katz, Jacob. Out of the Ghetto. Cambridge, MA: Harvard University Press, 1973.

Katz, Jacob. ed. Toward Modernity: The European Jewish Model. New Brunswick: Transaction Books, 1987 .

Katz, Jacob. Tradition and Crisis, expanded translation by Bernard D. Cooperman. New York: New York University Press, 1993.

Kümin, Beat, and Cornelie Usborne. "At Home and in the Workplace: A Historical Introduction to the 'Spatial Turn." History and Theory $5^{2}$ (October, 2013): 301-18.

Meldola, Raphael. Parashat ha-Ibbur. Amsterdam: Yosef Dayan [Dajn] Metzuyan, 1733-34.

Meldola, Raphael. Responsa Mayim Rabim. 4 vols. Amsterdam: Yosef Dayan [Dajn] Metzuyan, $1735^{-} 36$.

Nahon, Gérard. "Communautés judéo-portugaises du sud-ouest de la France: Bayonne et sa region, 1684-1791." PhD diss., Paris, Centre d'études juives and École pratique des hautes études, 1969 .

Nahon, Gérard. Métropoles et Périphéries sefarades d'Occident: Kairouan, Amsterdam, Bayonne, Bordeaux, Jérusalem. Paris: Cerf, 1993.

Nahon, Gérard. "Rabbi Rafael b. Elazar Meldola in Bayonna, 1728-1741." In Lo Yasur Shevet mi-Yhuda: Hanhaga, Rabanut u-Kehila be-Toldot Yisrael: Mehkarim mugashim le-Prof. Shim'on Shvarzfuks [English title: The Scepter Shall Not Depart from Judah: Leaders, Rabbinate and Community in Jewish History. Studies Presented to Professor Simon Schwarzfuchs]. Edited by Joseph R. Hacker and Yaron Harel, 271-99. Jerusalem: The Bialik Institute, 2011.

Netanyahu, Benzion. The Marranos of Spain from the Late Fourteenth to the Early Sixteenth Century according to the Hebrew Sources. New York: American Academy for Jewish Research, 1966.

Rosenberg, Shalom. "Emunat Hakhamim." In Jewish Thought in the Seventeenth Century. Edited by Isadore Twersky and Bernard Septimus, 285-341. Cambridge, MA: Harvard University Press, 1987. 
Rosman, Moshe. How Jewish Is Jewish History? Oxford: Littman Library of Jewish Civilization, 2007.

Ruderman, David B. Early Modern Jewry: A New Cultural History. Princeton, NJ: Princeton University Press, 2010.

Ruderman, David B. Jewish Thought and Scientific Discovery in Early Modern Europe. Detroit: Wayne State University Press, 1995.

Saperstein, Mark. Exile in Amsterdam: Saul Levi Morteira's Sermons to a Congregation of "New Jews." Cincinnati: Hebrew Union College Press, 2005.

Schilling, Heinz. Early Modern European Civilization and Its Political and Cultural Dynamism. The Menahem Stern Jerusalem Lectures. Hanover, NH: Brandeis University Press, 2008.

Schochat, Azriel. Im Hilufei ha-Tekufot [English title: Beginnings of the Haskalah among German Jewry]. Jerusalem: Bialik Institute, 1960.

Schwarzfuchs, Simon. "Notes sur les Juifs de Bayonne au XVIII siècle." Révue des Études Juives 125 (1966): 352-64.

Schwarzfuchs, Simon. "Le retour des marranes au judaïsme dans la litérature rabbinique." In Xudeus e Conversos na Historia: Actas do Congreso Internacional Ribadavia 14-17 de outubro de 1991. Vol. 1. Mentalidades e Cultura, 339-348. Santiago da Compostela: La Editorial de la Historia, 1994.

Sonnino, Guido. “Il ‘Talmud Torà' di Livorno.” La Rassegna Mensile di Israel 10 (1935): $183-96$.

Tazzara, Corey. "The Masterpiece of the Medici: Commerce, Politics, and the Making of the Free Port of Livorno, 1574-179o." PhD diss., Stanford University, 2011.

Toaff, Alfredo and Aldo Lattes. Gli studi ebraici a Livorno nel secolo XVIII: Malahi Accoen (1700-1771). Livorno: 1909; reprint, Bologna: Forni, 1980.

Toaff, Renzo. La Nazione ebrea a Livorno e a Pisa (1591-1700). Florence: Leo S. Olschki, 1990.

Trivellato, Francesca. The Familiarity of Strangers. The Sephardic Diaspora, Livorno, and Cross-Cultural Trade in the Early Modern Period. New Haven: Yale University Press, 2009.

Yerushalmi, Yosef Hayim. From Spanish Court to Italian Ghetto. Isaac Cardoso: A Study in Seventeenth-Century Marranism and Jewish Apologetics. New York: Columbia University Press, 1971.

Zimmels, H.J. Die Marranen in der rabbinischen Literatur. Berlin: R. Mass, 1932.

Zipser, Maier. “Lebensgeschichte Rafael Meldola's und ein Bild der jüdischen Zustände in Italien zu seiner Zeit." Literaturblatt des Orients: Berichte, Studien und Kritiken für jüdische Geschichte und Literatur (Literary Supplement to Julius Fürst's Der Orient) 8 (1847), nos. 36: 571-576; 37: 580-85; 38: 597-602; 40: 627-31, and 42: 657-63. 


\title{
A Sephardic Saga in the Dutch Republic: The Cohen Pallache Women on Love, Religion, and Social Standing
}

\author{
Tirtsah Levie Bernfeld
}

\section{Introduction}

The Portuguese community in the Dutch Republic carefully guarded the image it presented to the outside world. The parnassim and rabbis repeatedly reminded members to act with decorum and bom judesmo. Yet, the Sephardim in the Dutch Republic had their fair share of scandal. The true story of the clandestine courtship of Eva Cohen, the petite, dark-haired daughter of the wealthy Cohen Pallache family that resided in Delft from the late 166os till the early 1680s, and Michiel Verboon, a young, tall, fair-skinned, blond and curly-haired Gentile servant in the household of Eva's brother Jacob in The Hague, has all the makings of a novel of historical fiction: family upheaval, risk of family honor, status, and wealth, tarnishing of faith, and even high court drama.

The affair began in secret, but its subsequent handling over the course of four years eventually became a very public matter, reaching the "Hoge Raad," the Supreme Court of the Dutch Republic. ${ }^{1}$ Rebecca Pallache Cohen, Eva's widowed mother challenged the young couple's intended union in a lawsuit that was brought in front of the Dutch courts. Though the young woman was an adult and could marry without the consent of her parents, according to Dutch law the alliance could be protested if objections of substance could be shown. ${ }^{2}$ Rebecca Pallache complained of the inequality of the alliance, though

1 National Archives The Hague (henceforth: NL-HaNA), Hof van Holland entry no. 3.03.01.o1, inv. no. 5331. 29, different documents dated 1680-1684; NL-HaNA, Hoge Raad van Holland en Zeeland, entry no. 3.03.02, inv. no. 267, scan no. 17, 1682 [no date, most probably January]; ibid., inv. no. 903, 9 July 1683, scan no. 135; ibid., inv. no. 903, 8 July 1684, scan no. 216; ibid. inv. no. 903, 22 July 1684, scan no. 221; see for a description of the affair in the paper "Den Galanten Mercurius" (1684), 18-23; a more extensive analysis of the judicial trial and procedure of the affair between Eva Cohen and Michiel Verboon, both before Dutch and English courts will be discussed by the author at a later stage.

2 For a discussion of the restrictions on marriage see Lambertus J. van Apeldoorn, Geschiedenis van het Nederlandsche huwelijksrechtvóór de invoering van de Franschewetgeving (Amsterdam: Holland, 1925), 126-70. Donald Haks, Huwelijk en Gezin in de 17de en 18de Eeuw (Assen: van

(C) TIRTSAH LEVIE BERNFELD, 2019 | DOI:10.1163/9789004392489_009

This is an open access chapter distributed under the terms of the prevailing CC-BY-NC License at the time of publication. 
this would not have been considered sufficient reason for the court to prevent the marriage from taking place. ${ }^{3}$ The case generated a large number of court documents and archival files and also a small printed pamphlet published in English and in Dutch (Fig. 8.1). ${ }^{4}$ The Amsterdam Portuguese community, likely aware of the situation concerning the Cohen Pallache family, kept its distance from the matter, though the London Portuguese community had no choice but to become publicly involved in it. ${ }^{5}$

The wealthy Sephardic family that Eva belonged to maintained close connections with the elite circles of Jewish and non-Jewish society in the Dutch Republic and beyond. ${ }^{6}$ Eva's father Abraham Cohen had links to the Amsterdam

Gorcum, 1982), 115; Eva must have been more than twenty years old by then and thus did not need to ask for permission to marry (see Burnet, De ware bekeringe, 3: Eva's father having died before she was twelve; her father died in 1671 which was around nine years before the pamphlet was written). Michiel, on the other hand, was older, but at age twenty-three in 1680 he was not able to marry without the permission of his parents. Still, he told friends that it was only a short time until he would be twenty-five, and could marry without their consent; see interview with Jacobus Bradly, NL-HaNA, Hof van Holland entry no. 3.03.01.01, inv. no. 5331. 29, 26 June 1681.

3 See for a similar case of unequal partners in a non-Jewish milieu, Machiel Bosman, Elisabeth de Flines. Een onmogelijke liefde in de achttiende eeuw (Amsterdam: Athenaeum-Polak and Van Gennep, 2008), 46-47, 97-98; the files of the Hof van Holland contain many cases of unequal couples consisting of wealthy women and men of lower status, see Haks, Huwelijk en Gezin, 117-19, 128-35.

4 Gilbert Burnet, De ware bekeringe en violente vervolgingen van Eva Cohen, nu genaemt Elisabeth. Zijnde een persoon van qualiteyt vande Joodsche gesintheyt geweest, ende gewoont hebbend tot Delft; dewelke gedoopt is den 10. October, 1680 in St. Martins Kerck, des Coninghs Parochie van Whitehall, door den seer Eerwaardieghen Heer William Floid, bisschop van St. Asaph (n.p., n.d.). Uytgegeven in het Engels door den Hoogeleerden Heer Gilbert Burnet, Theologiae Professor en Doctor, nu getranslateert in het Nederduyts[London], [1681], 3-4; the original English title: G. Burnet, The Conversion \& Persecutions of Eve Cohan, Now called Elizabeth Verboon A Person of Quality of the Jewish Religion. Who was Baptized the roth of October 1680, at St. Martins in the Fields, By the Right Reverend Father in God, William, Lord Bishop of St. Asaph (London, 1680). For the description of the appearance and clothing of Eva Cohen and Michiel Verboon, see NL-HaNA, Hof van Holland entry no. 3.03.01.01, inv. no. 5331.29, testimony of Jeronimo Poens, Mechelen, 19 July 1681; for that of Michiel Verboon, see also ibid., testimony of Francois Valentijn, the innkeeper of Court of Spain in Brussels, 8 July 1681; and ibid., the testimony of a neighbor of the Cohen family in Delft, Andries Coster and his wife Anna Cupers before notary Cornelis Ouwendijck of Delft, Delft, 13 June 1681.

5 Or rather, its representative responsible for contact with the local authorities. See Albert M. Hyamson, The Sephardim of England, A History of the Spanish and Portuguese Jewish Community 1492-1951 (London: Methuen, 1951), 56.

6 Aernout van Woestinghove, a former cornet of the guard of Prince Johan Maurits van Nassau, refused to elaborate about Michiel having often spent the night with Eva when she stayed in his home. For this reason he also had prohibited his wife to talk about it or to report it to Jacob Cohen, even though he had his suspicions (NL-HaNA, Hof van Holland, entry no. 


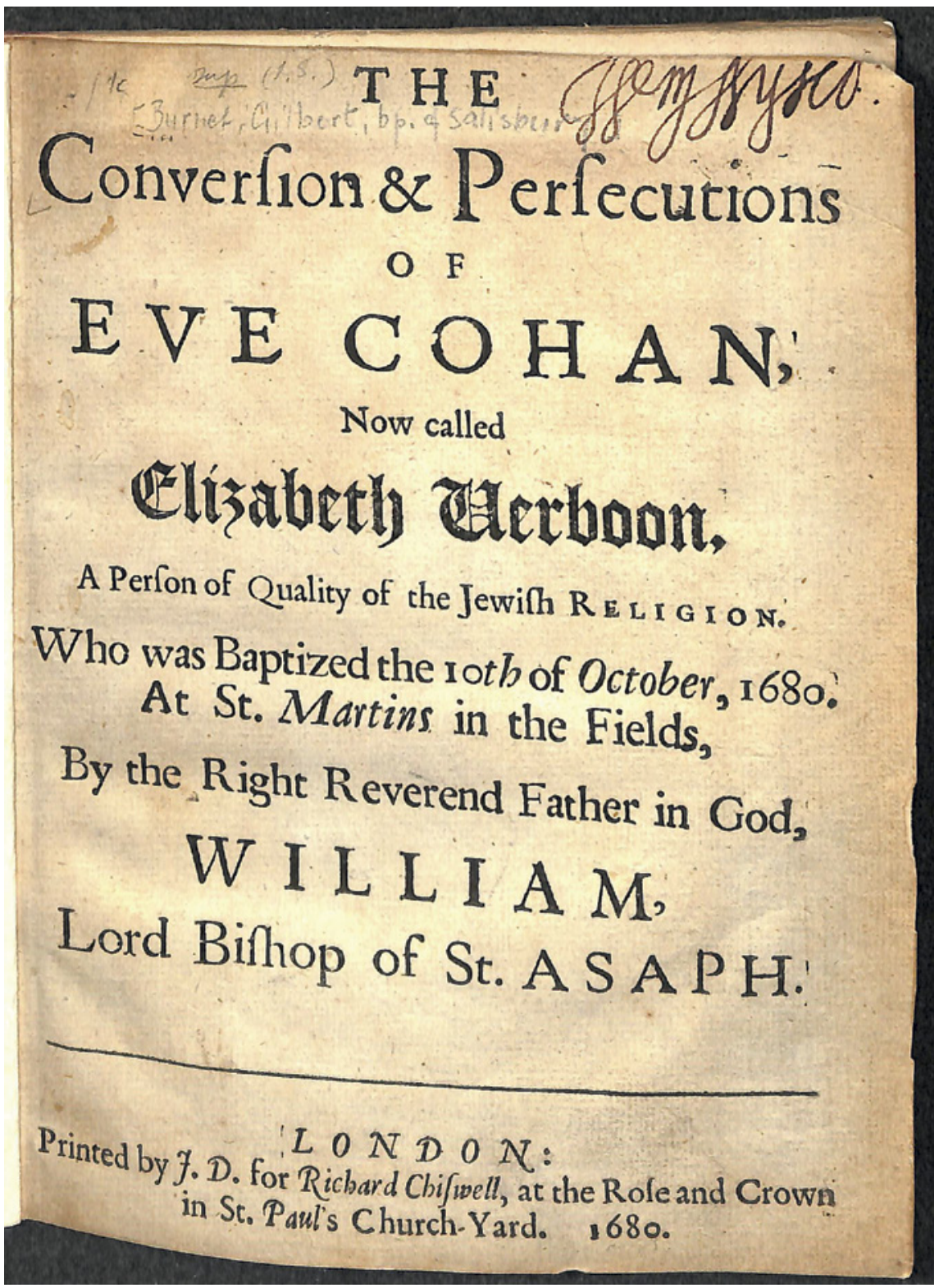

FIGURE 8.1 Frontispiece of the pamphlet The Conversion \& Persecutions of Eve Cohan, Now called Elizabeth Verboon [...], by Gilbert Burnet, London, 1680, National Library of Israel, Jerusalem 
Portuguese community but it is not certain he was ever officially a member. The community's records list his attendance at a funeral in 1629 , and in 1656 , he took over a relative's membership in the Amsterdam-based international dowry society, Dotar. ${ }^{7}$ While he lived for a time in Amsterdam, his name does not appear regularly on the list of the communal taxpayers though he is listed as having made voluntary contributions (promessas) during synagogue services. A possible explanation for his lack of membership is that he was often abroad on business. Stationed in Dutch Brazil until 1654, his signature, in Hebrew, appears in the communal registers of the Portuguese Jews there. ${ }^{8} \mathrm{He}$ eventually returned to the Netherlands, and settled in Delft in 1669. Besides the Dotar membership and the infrequent voluntary contributions, his name appears again in the Amsterdam Portuguese community registry in 1671, when his widow, Rebecca Pallache, sent money to the Amsterdam Portuguese synagogue for prayers to be recited in his memory on the eves of the new months and during the nights of Yom Kippur. She also insisted that mention of this legacy be made on each Shabbat ha-Gadol (the Sabbath before Passover), her wish expressing family pride and a notion of social standing. ${ }^{9}$

3.03.01.01, inv. no. 5331. 29, testimony of Aernout van Woestinghove, before notary Jeremias Stael, The Hague, 16 June 1681).

7 Stadsarchief Amsterdam [hereafter SAA] 334, inv. no. 1, p. 54v/88, 5389. Relating to Dotar see: SAA 334, inv. no. 1141, p. 7/5, 14 Adar 5375; in 5416 Abraham Cohen is admitted as a member of Dotar-apparently after his return from Brazil—instead of his "father Joseph Cohen" (sic! his father was called Mordechay; in 1661 Abraham was described only as the descendant of Joseph Cohen) and signs in Latin letters: SAA 334, inv. no. 1143, p. 254/119, 13 Adar 5416; see also SAA 334, inv. no. 1143, p. 21/3, 5421 "Notta de Hirmaons que the oje [...] hao emtrado na santa companhia de dottar orphans e donçelas povres": no. 14: "Abraham Cohen, dezte de Josseph Cohen." Abraham's father was called Mordechay as can be read on the text of his tombstone: Isaac S. Emmanuel, "Seventeenth-Century Brazilian Jewry: A Critical Review," American Jewish Archives 14, no. 1 (April 1962): 62: Abraham ben Mordechay do Brazil (אברהם בן מרדכי כהן דו בראזיל). For further data on Abraham Cohen see sources and literature mentioned in Egon and Frieda Wolff, Dicionário Biográfico, Judaizantes e Judeus no Brasil 1500-1808 (Rio de Janeiro: E. \& F. Wolff, 1986), 1: 40-41. On Dotar see Miriam Bodian, "The 'Portuguese' Dowry Societies in Venice and Amsterdam: A Case Study in Communal Differentation within the Marrano Diaspora," Italia 6, nos. 1-2 (1987): 30-61; Tirtsah Levie Bernfeld, Dowries and Dotar. An Unbroken Chain of 400 Years (Amsterdam: Menasseh ben Israel Institute, 2015).

8 On Abraham Cohen as a member of the Portuguese Zur Israel community in Brazil, see Arnold Wiznitzer, Jews in Colonial Brazil (New York: Columbia University Press, 1960), 137; for him signing in Hebrew see below n. 60.

9 See Livro de Escamot SAA 334, inv. no. 19, p. 645, 21 Tevet 5432: 200 guilders; ibid., inv. no. 174, p. 857,7 Adar II 5432 . On charity sustained by piety and charity given out of considerations of prestige see Tirtsah Levie Bernfeld, Poverty and Welfare among the Portuguese Jews in Early Modern Amsterdam (Oxford: The Littman Library of Jewish Civilization, 2012), 159-71, 178-80. 
After Abraham's death, his oldest son Jacob became a member of the Amsterdam Portuguese community, and as of 1672 , he was registered as paying ten guilders per year in communal taxes. ${ }^{10}$ Eva's parents and siblings are buried at the cemetery in Ouderkerk aan de Amstel, the burial place for members of the Amsterdam Portuguese community, another proof of their connection to the Sephardic milieu. ${ }^{11}$

The Pallache family's affiliation with Judaism is less straightforward. A few members of this well-known family of diplomats of Moroccan Jewish descent had converted to Christianity. ${ }^{12}$ Isaac Pallache, Eva's grandfather, converted in Jutphaas (near Utrecht) in 1627, and apparently, he had some, if not all, of his children baptized, including Rebecca Pallache, Eva's mother. His conversion

10 Some of the persons mentioned on the list in the Escamot, were registered as persons coming from outside ("alguas pessoas vindas de fora"). Others had not been taxed before. It is not clear what case could be applied to Jacob. I assume the first option. This Jacob apparently attended services at the Portuguese synagogue of Amsterdam quite often since he regularly paid contributions there, while a relatively high sum was promised during services around his mother's death (for the amount of $f 63$, 10 given as promessas see SAA 334, inv. no. 175, p. 311, 1 Elul 5445); for Jacob Cohen assessed for paying the finta tax: SAA 334 , inv. no. 19, p. 656,5 Elul $5432 f$ 10: just a few months apparently after his father died. Jacob continued to pay taxes during the 1670 os and ' 80 s as Jacob Cohen de Abraham and also attended synagogue services regularly, as he paid promessas: see for example: SAA 334, inv. no. 174, p. 1002, 1 Hesvan 5434; ibid., p. 1019, 7 Nisan 5434; ibid., p. 1040, 7 Tishri 5435; SAA 334, inv. no. 175, p. 16o, 29 Elul 5441; ibid., p. 174, 1 Nisan 5442; ibid., p. 230, 26 Elul 5443; ibid., p. 285, 5445 [s.d.]; ibid., p. 311, 1 Elul 5445; ibid., p. 329, 18 Adar 5446; ibid., inv. no. 19, p. 717, 24 Shevat 5435; I could find no trace of him as a member of the Dotar dowry society.

11 For Abraham's grave see: https://www.dutchjewry.org/phpr/amsterdam/port_isr_gem _ burials/amsterdam_port_isr_gem_burials_view.php?editidı=5262; 5432 is given as the year of death; apparently his tombstone was made of marble, and was engraved with two hands, the symbol of kohanim, as well as a skull and bones. For notes on the burial of Rebecca Pallache at the Portuguese Jewish cemetery in Ouderkerk, see SAA 334, inv. no. 916, p. 49/17: "em 28 ditto se enterou a mulher de Abraham Coem de Brazil." For the sons Joseph, Jacob, Moses, and Mordechay and daughter Ester, also called Hester, see https://www.dutchjewry.org/phpr/amsterdam/port_isr_gem_burials/amsterdam_port_ isr_gem_burials_view.php?editidı=19141. The burial place at Ouderkerk of Mordechay, who married a non-Jew, was described as a place "worse than that for the slaves." Yet apparently it was very important for the family to have his body laid to rest at a Jewish cemetery: Mercedes García-Arenal and Gerard Wiegers, Samuel Pallache. Koopman, kaper en diplomaat tussen Marrakesh en Amsterdam (Amsterdam: Amsterdam University Press 2014), 231; see also for the epitaphs of Abraham and Rebecca, Emmanuel, "SeventeenthCentury Brazilian Jewry," 62.

García-Arenal and Wiegers, Samuel Pallache, $136-38$. 
might have been motivated by economic or political factors, which calls its sincerity into question, especially in light of his later return to Judaism. ${ }^{13}$

Despite his purported baptism, Isaac's children received a Jewish education at home. This fact was attested to by Hakham Samuel Tardiola, a rabbi originally from Jerusalem who was active among the Portuguese community in Amsterdam. Hakham Tardiola affirmed that Isaac had told him that his children knew nothing about Christianity but knew all the Jewish prayers in Hebrew. Moreover, Isaac had confided in him that in Leiden, where Isaac Pallache resided with his family, they observed the Jewish Sabbath, holidays, and dietary laws. ${ }^{14}$

Eva's father, Abraham Cohen, an important and highly esteemed figure in Brazil, married his niece Rebecca Pallache, daughter of Isaac Pallache, in Brazil around the year 1652 . He was an overseer of Dutch plantations as well as a plantation and ship owner, army provider, broker, and slave trader. ${ }^{15}$ Cohen

13 Isaac Pallache called himself a professor of Hebrew at Leiden University, yet might have been just a student there: ibid., 220-26, 282-84. Hugo de Groot, Remonstrantie nopende de ordre dije in de landen van Hollandt ende Westvrieslandt dijent gestelt op de Joden, ed. (with an introduction) by Jaap Meijer (Amsterdam, 1949 [5709]), 29-30, n. 57; the sister of Rebecca, Hester Pallache, was described by the Reformed Church as a child born from Christian parents: SAA 376, inv. no. 12, p. 319, 6 July 1673. Isaac Pallache is also discussed in the pamphlet about Eva Cohen, Burnet, De ware bekeringe, 3-4.

14 García-Arenal and Wiegers, Samuel Pallache, 221-26. On Isaac Pallache see further Herman Roodenburg, Onder Censuur. De kerkelijke tucht in de gereformeerde gemeente van Amsterdam, 1578-1700 (Hilversum: Verloren, 1990), 188-89; see also notes and literature mentioned in Hugo de Groot, Remonstrantie, 29-30, n. 57.

15 On Abraham Cohen and Rebecca Pallache in Brazil: Wolff, Dicionário Biográfico, 1: 40-41, 149-50; José A. Gonsalves de Mello, Gente de Nação: Cristãos-Novos e Judeus em Pernambuco, 1542-1654 (Recife: Massangana, 1989), index Cohen, Abraão Martensen and summary of his political and economic activities in Dutch Brazil on 372-73; on Abraham Cohen as a member of the Portuguese Jewish community in Brazil, see Wiznitzer, Jews in Colonial Brazil, 126, 137, 171, 174; García-Arenal and Wiegers, Samuel Pallache, 222, 227, 230; for Abraham Cohen and his contacts with Prince Johan Maurits, A. Hulshof, "Een Duitsch econoom in en over ons land omstreeks 1670," Onze Eeuw 10 (1910): 73; for Abraham Cohen as a main shareholder of the West Indian Company and as someone having great influence in that company who could introduce the German economist Johan Joachim Becher to the other shareholders in 1669, see again Hulshof, "Een Duitsch econoom," 73. Apparently Cohen was paid for his intervention: ibid., 78. On Abraham Cohen as a slave trader and his relations to the West Indian Company see also Jaap Meijer, Encyclopaedia Sefardica Neerlandica (Amsterdam: Portugees-Israelietische Gemeente Amsterdam, 5709-5710 [1948-1950]), 1: 152. See also the poem on Abraham Cohen by Daniel Levi de Barrios, Gonsalves de Mello, Gente de Nação, 373; for the value of property claimed in the 166os from the Portugese empire after the surrender of Dutch Brazil, see Emmanuel, "Seventeenth-Century Brazilian Jewry," 51; Abraham Cohen was one of the five most 
was also the agent of the Dutch government in Brazil whose headquarters were in Recife, and consequently he had excellent contacts with the governor of Dutch Brazil, Johan Maurits van Nassau. His marriage to Rebecca Pallache appears to have been his second, and must have been officiated by the famous Hakham Isaac Aboab da Fonseca who, a few months earlier, had performed the hupah (Jewish wedding ceremony) of Cohen's other niece Eva, Rebecca's sister, who had married an Ashkenazic Jew by the name of Simon Mayer. ${ }^{16}$ Eva's wedding was performed in Cohen's house in Recife. Cohen apparently paid for her dowry (which included one of his houses in Recife and a slave girl) and wrote the marriage settlement in Portuguese, which was translated into Hebrew by Aboab. ${ }^{17}$ Abraham and Rebecca kept in touch with Hakham Isaac Aboab da Fonseca, even after their return to the Dutch Republic. In fact, as late as 1681, Aboab made a declaration in Amsterdam at the request of Rebecca Pallache. ${ }^{18}$ Arriving from Brazil to Amsterdam, the Cohen Pallache family first took up residence in St Antonibreestraat, in the heart of Amsterdam's Jewish district. ${ }^{19}$ Abraham, still a leading figure in the Dutch West Indian company, continued to travel abroad for business and was involved in the colonization of overseas territories of Cayenne, Guyana, and Curaçao. ${ }^{20}$ Later, for unknown reasons, the family moved to Delft. One possible explanation for the move was it being at the time the third largest city in the Dutch Republic with a chamber of the West Indian Company in addition to offices and warehouses of the East Indian Company (Fig. 8.2). It was also in proximity to The Hague with its diplomatic

prominent Jews in Dutch Brazil: ibid., 157; also in the pamphlet on the conversion of Eva Cohen, her father Abraham Cohen is described as a very wealthy merchant: Burnet, $D e$ ware bekeringe, 3 .

16 Meijer, Encyclopaedia Sefardica, 1: 152; See on this Eva Pallache in Wolff, Dicionário Biográfico,1: 149-50; Gonsalves de Mello, Gente de Nação, 247, 422.

17 SAA 5075, inv. no. 3686, Not. F. Tixerandet, pp. 666-68, June 1681 [date of day impossible to read]: Declaration of Isaac Aboab da Fonseca on behalf of Rebecca Pallache, widow of Abraham Cohen: on 20 Elul 5412/25 August 1652 at home with Abraham in Brazil the marriage was performed between Eva Pallache and Simon Mayer. For houses and ground bought by Abraham Cohen in Recife: Gonsalves de Mello, Gente de Nação, 347-48; see also pages via index Cohen, Abraão Martensen.

18 García-Arenal and Wiegers, Samuel Pallache, 222, 314, n. 72.

19 Richard Kagan and Philip D. Morgan, eds., Atlantic Diasporas. Jews, Conversos and CryptoJews in the Age of Mercantilism, 1500-1800 (Baltimore:The Johns Hopkins University Press, 2009), 34, 48; for the family of Abraham Cohen living in St. Anthonibreestraat, Hulshof, "Een Duitsch econoom," 73; Meijer, Encyclopaedia Sefardica, 1: 152.

20 Herbert I. Bloom, "The Dutch Archives with Special Reference to American Jewish History," Publications of the American Jewish Historical Society 32 (1931): 16. 


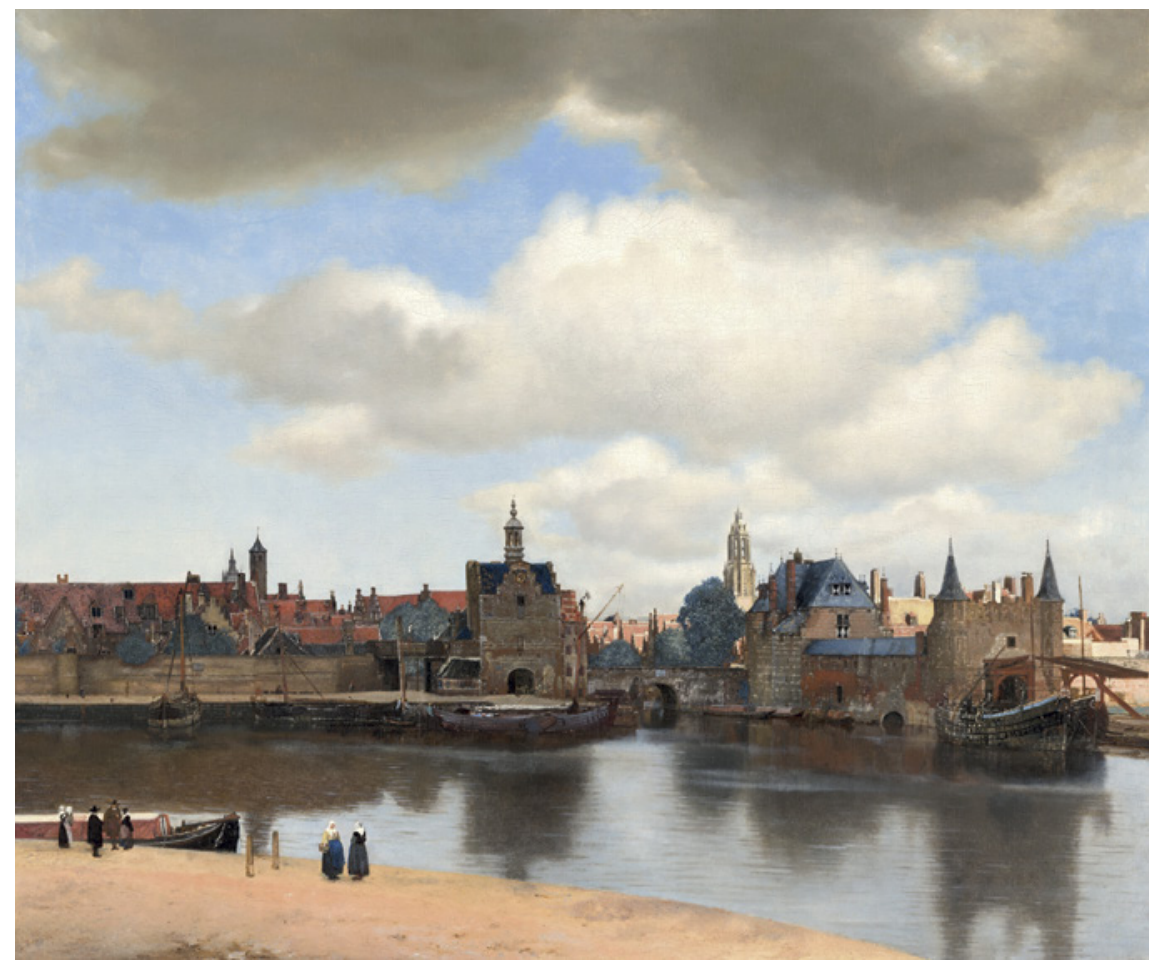

FIGURE 8.2 Johannes Vermeer, View of Delft, c. 166o-1661, Mauritshuis, The Hague

circles and was within easy reach of Rotterdam, Leiden, and Amsterdam. ${ }^{21}$ The family frequently traveled to The Hague and Amsterdam to visit family

21 Delft, together with Rotterdam and Dordrecht, formed one of the five chambers of the West Indian Company (WIC). Isaac Pallache, Abraham's brother-in-law and father-in-law had been involved in wIC Delft: García-Arenal and Wiegers, Samuel Pallache, 229-30. This chamber of the wic was called "Kamer van Maze": six out of the fourteen seats of this "Kamer van Maze" were reserved for The Hague; two seats, each in its turn, represented this chamber in the head office. Margaretha E. van Opstall, "De kamer van de Maze tot Delft," De stad Delft. Cultuur en Maatschappij van 1572 tot 1667, ed. Ineke V.T. Spaander (Delft: Stedelijk Museum "Het Prinsenhof", 1981), 2: 94-96. In 1674 the wIC was refounded, now with only thirty members; two represented Delft; one of them represented the "Kamer van Maze" at the headquarters: Gerrit Verhoeven, De derde stad van Holland. De geschiedenis van Delft tot 1795 (Zwolle: WBOOKS, 2015), 1: 299. As of 1669 most activities were transferred to Rotterdam. The Delft office was sold (Verhoeven, De derde stad van Holland, 299-300). As far as the East Indian Company (VOC) is concerned, since 1602, there was a chamber in Delft representing this company with seven members out of the total of sixty: Loet Schledorn, "De kamer van Delft van de voc: een rijke bron," in Burgers verzamelen, 1600-1750 Schatten in Delft 1602-2002; 400 jaar Verenigde Oost-Indische 
and friends. ${ }^{22}$ Abraham Cohen died in Delft in 1671 and, as mentioned, was buried in the Portuguese Jewish cemetery in Ouderkerk. Rebecca Pallache remained in Delft for another ten years where she continued to raise five of her six children. Her eldest son Jacob Cohen, perhaps at his father's recommendation, had become chief administrator of the above-mentioned former governor of Brazil, Prince Johan Maurits van Nassau and moved to The Hague, close to the palaces of Johan Maurits. ${ }^{23}$

It was on one of the family visits to Jacob in The Hague that Eva Cohen met Jacob's servant Michiel Verboon, a Christian from a respectable but lower class family. ${ }^{24}$ The legal case files, interviews, and printed pamphlet detail the

Compagnie, ed. Ellinoor Bergvelt, Michiel Jonker, Agnes Wiechmann (Zwolle: Waanders, 2002), 31-45. For offices and warehouses of the voc on Oude Delft since 1631 (the canal on which the Cohen family resided): Verhoeven, De derde stad van Holland, 296. Luc L.M. Eekhout, "De Delftse Kamer van de voc," De stad Delft, 90-94.

On the first Portuguese Jews in The Hague between 1650 and 1670 see Jac. Zwarts, "De Joodse gemeenten buiten Amsterdam," in Geschiedenis der Joden in Nederland, ed. Henk Brugmans and Abraham Frank(Amsterdam: Van Holkema \& Warendorf, 1940), 399-500; Yosef Kaplan, "De joden in de Republiek tot omstreeks 1750: religieus, cultureel en sociaal leven," in Geschiedenis der Joden in Nederland, ed. Hans Blom, David Wertheim, Hetty Berg, Bart Wallet (Amsterdam: Balans, 2017), 144-46.

23 David Franco Mendes, Memorias do estabelecimento e progresso dos judeos portuguezes e espanhoes nesta famosa citade de Amsterdam, ed. Lajb Fuks and Reina G. Fuks-Mansfeld; commentary Benjamin N. Teensma (Assen: van Gorcum,1975), 9o: Jacob was apparently appointed to be his chief accountant and administrator in 1677 (see more in Koninklijk Huisarchief A 4-1455-s.n. documents of Jacob Cohen 1675-1677); Franco Mendes relates to the fact that Jacob's appointment was due to the many services his family had given him and the population of Dutch Brazil, whether Christians or Jews, during the years of siege of Dutch Brazil (1645-1654) by the Portuguese; see on Jacob's whereabouts in New Amsterdam between 1655 and 1658: Samuel Oppenheim, "The Early History of the Jews in New York, 1654-1664," Publications of the American Jewish Historical Society 18 (1909): 19 (1655: request to buy burial ground), 27 (1655: request to Director General and Council of New Netherland for Jews to "travel, reside and trade" in New Netherland), 60 (1658 conflict concerning goods purchased by Cohen to Grytie Maas), 61 (litigation in 1656 for the possession of a canoe with some Dutch merchants), (litigation in 1658 concerning a shipment of tobacco), 75 (request for a Jewish cemetery, 1655); Jacob might have moved to Amsterdam at a later stage, perhaps in 1672 (see above n. 10); for Jacob Cohen as a member of the Honen Dalim society in Amsterdam in 1683 see Wilhelmina Chr. Pieterse, Daniel Levi de Barrios als geschiedschrijver van de Portugees-Israelietische gemeente te Amsterdam in zijn "Triumpho del govierno popular" (Amsterdam: Publikaties van de Gemeentelijke Archiefdienst van Amsterdam, 1968), 124. Jacob apparently died in 1712 and was buried near the Pallaches in the Portuguese Jewish cemetery in Ouderkerk: Emmanuel, "Seventeenth-Century Brazilian Jewry," 62.

24 Michiel Verboon's former employers are mentioned in the pamphlet: Burnet, De ware bekeringe, 5 . He left his last master Jacob with a letter of recommendation and proof of good conduct dated 17 May 1680 . Burnet, De ware bekeringe, 5 . 
development of their relationship behind the back of Rebecca Pallache and beyond the borders of the Dutch Republic via Belgium, England, and back. Was Eva and Michiel's a true love story? We know that she signed some of her early letters to him with her own blood, in which she promised never to leave him. ${ }^{25}$ We also know that Eva followed Michiel to Brussels. ${ }^{26}$ However, in the pamphlet, it was suggested that her flight was a means to escape the reach of her controlling mother. ${ }^{27}$ Did religious motives play a role in the events? ${ }^{28}$ And what of Michiel's intentions? Was he in love with Eva or was he hoping for material gain?

The affair, which erupted some time in 1680 , less than ten years after Abraham Cohen's death, most likely came as a shock to Rebecca. However, as the documentation reveals, as matriarch of this wealthy and well-integrated Dutch Sephardic family, she spared no expense to put a stop to what she believed was a ruinous liaison.

The attitude of the Sephardic widow Rebecca Pallache was not exceptional when it came to choosing marriage partners for her children. In the early modern period social-economic motives were most prominent in this respect. In general, marriages were intended to preserve the material wellbeing of the family or, still more, to increase it. The elite, in particular, was very keen to keep wealth within its own circles and enlarge it, if possible, through arranged marriages. ${ }^{29}$ Love was not, typically, a priority in the negotiations. Yet, human

25 NL-HaNA, Hof van Holland entry no. 3.03.01.01, inv. no. 5331. 29, 26 June 1681, interview with Jacobus Bradly.

26 NL-HaNA, Hof van Holland, entry no. 3.03.01.01, inv. no. 5331. 29, testimony of Jeronimus Moens, 19 July 1681: as a guest at the inn in Brussels, Jeronimus witnessed the arrival of Eva Cohen and the intimate way Michiel, also a guest at the same inn, welcomed and embraced her in the early morning hours of 26 or 27 May 1680 . Benjamin Torens, a friend of Michiel, had informed Eva earlier about Michiel's departure for Brussels, after he received his letter from there, ibid., Testimony of Benjamin Torens before notary Jeronimus Stael, The Hague, 16 July 1681. On marriages for the sake of love among non-Jews in the Dutch Republic, mostly in the eighteenth century, see Haks, Huwelijk en Gezin, 138-40.

27 Burnet, De ware bekeringe, 6.

28 If we are to believe Todd Endelman, religious motives in the premodern and early modern world were never the sole reason for conversion: Todd M. Endelman, Leaving the Jewish Fold. Conversion and Radical Assimilation in Modern Jewish History (Princeton, NJ: Princeton University Press, 2015), 47-48.

29 In last wills and other documents of members of the Dutch Sephardic community, we can further read about relatives applying this strict policy, prearranging the marriages of 
nature sometimes intervened and marriages for the sake of love did take place. Some were of a clandestine nature and occurred less frequently in Jewish society, though among the Amsterdam Sephardim, such marriages appear to have increased over the course of the eighteenth century. ${ }^{30}$ Only a herem (ban) imposed by the Jewish community leaders on its members or legal restrictions in the marriage laws in the Dutch Republic could deter such clandestine unions.

To stop her daughter from what she clearly viewed as a bad match, Rebecca Pallache had no recourse but to turn to the Dutch courts, which she did with fervor. As a widow in the Dutch Republic Rebecca Pallache had complete authority over her affairs. ${ }^{31}$ In my previous studies I have shown that even though Sephardic women in Dutch society adhered to the Iberian cultural mores that relegated women to the background, they were, in practice, assertive and enterprising figures inside the home and outside it, just like their Dutch counterparts, albeit somewhat more withdrawn. ${ }^{32}$ Rebecca Pallache offers another example: her last will shows her skill in handling investments in the West Indian Company and maintaining international contacts that extended across

their kin or preventing certain liaisons. See the example the de Prado family as discussed in Tirtsah Levie Bernfeld, "Sephardi Women in Holland's Golden Age," in Sephardi Family Life in the Early Modern Period, ed. Julia R. Lieberman (Waltham, MA: Brandeis University Press, 2010): 193. For material considerations of contracting marriages among non-Jewish families in the Dutch Republic, Haks, Huwelijk en Gezin, 136-40.

On clandestine marriage in non-Jewish society, see Beatrice Gottlieb, The Family in the Western World from the Black Death to the Industrial Age (New York: Oxford University Press, 1993), 84-87, 240; Haks, Huwelijk en Gezin, especially chap. 4; see also Henk Th. M. Roosenboom, Ontvoerd of gevlucht? Religieuze spanningen in Brabant en de zaak Sophia Alberts 1700-1710 (Hilversum: Verloren, 2016); on secret marriage and clandestine betrothal in Jewish society see Jacob Katz, Tradition and Crisis. Jewish Society at the End of the Middle Ages, translated and with an afterword and bibliography by Bernard D. Cooperman (Syracuse, NY: Syracuse University Press, 2000), 119-20; on parents or other family members arranging matches, ibid., $115^{-16}$; see for secret marrriages among the Portuguese Jews in Amsterdam, Yosef Kaplan, "The Social Functions of the Herem in the Portuguese Jewish Community of Amsterdam in the Seventeenth Century," in Dutch Jewish History, ed. Jozeph Michman and Tirtsah Levie [Bernfeld] (Jerusalem: Institute for Research on Dutch Jewry, 1984), 1: 123, and for the eighteenth century, Kaplan, "Moral Panic in the Eighteenth-Century Sephardi Community of Amsterdam: The Threat of Eros," in Dutch Jewry: Its History and Secular Culture, ed. Jonathan I. Israel and Reinier Salverda (Leiden: Brill, 2002), 103-23; Kaplan, "Clandestine Marriage in Amsterdam, Broken Hearts in Hamburg and a Kidnapping in London," [Hebrew] in Tov Elem: Memory, Community and Gender in Medieval and Early Modern Societies, Essays in Honor of Robert Bonfil, ed. Elisheva Baumgarten, Amnon Raz-Krakotzkin, Roni Weinstein (Jerusalem: Mosad Bialik, 2011), 171-90.

31 Ariadne Schmidt, "Vrouwen en het recht. De juridische status van vrouwen in Holland in de vroegmoderne tijd," Jaarboek van het Centraal Bureau voor Genealogie 58 (2004): 27-44. See e.g., Levie Bernfeld "Sephardi Women," 177-222. 
the Atlantic to Suriname, Jamaica, and Martinique. ${ }^{33}$ Other documents reveal her to have been an uncompromising maternal figure who tried to lead her children along the path she and her late husband had set for them.

Apparently, Rebecca had an uneasy relationship with her daughter Eva; both seem to have been strong-willed. ${ }^{34}$ She tried hard to limit her daughter's freedom of movement and, according to the pamphlet, had confined Eva to her room at one point for a period of six months. ${ }^{35}$ Eva's harpsicord teacher Dirck Scholl, who was also the chief organist and carillonist of the Nieuwe Kerk (New Church) in Delft, had once suggested to Rebecca that to improve relations between mother and daughter she should consider giving Eva more freedom of movement like other young Dutch girls in the city. ${ }^{36}$ Rebecca had

33 See inventory Rebecca Pallache 25 September 1685 before Not. F. Tixerandet, sAA 5075, inv. no. 3697 [page numbers unknown]. For Rebecca's network that spanned the Atlantic, and contacts with the chief governor of the Jewish society in Suriname, Samuel Nassy, see her involvement in solving the conflict that arose between her son Mordechay, who was sent to Suriname in 1683 , and the skipper of his boat. The latter refused to hand over Mordechay's goods upon arrival: Meijer, Encyclopaedia Sefardica, 1: 152; Rebecca asked Samuel Nassy to interfere: SAA 5075, inv. no. 3689A, Not. F. Tixerandet, pp. 195-96, 1 October 1683 (power of attorney given by Rebecca Pallache to Samuel Nassy); the Nassy and Cohen families must have known each other through the colonial activities of David Nassy (Samuel's father) and Abraham Cohen: Emmanuel, "Seventeenth-Century Brazilian Jewry," 62; Noah L. Gelfand, "To Live and to Trade. The Status of Sephardi Mercantile Communities in the Atlantic World during the Seventeenth and Eighteenth Centuries," in The Jews in the Caribbean, ed. Jane S. Gerber (Oxford: The Littman Library of Jewish Civilization, 2014), 53-55, 59; Kagan and Morgan, Atlantic Diasporas, 44-49; Bloom, "The Dutch Archives," 15-18; Jonathan I. Israel, Diasporas within a Diaspora. Jews, Crypto Jews and the World Maritime Empires (1540-1740) (Leiden: Brill, 2002), 400-2. On life in Dutch Brazil, see also Charles R. Boxer, The Dutch in Brazil, 1624-1654 (Oxford: The Clarendon Press, 1957).

34 Eva was not entirely innocent. She was reported as having treated her mother with contempt, spitting in her face, and insulting her: NL-HaNA, Hof van Holland entry no. 3.03.01.01, inv. no. 5331. 29, 17 July 1681, interrogation of Dirck Scholl and his wife Jacoba van Heck. For other examples of Eva's irascible character see the testimony of Andries Coster and Anna Cupers (NL-HaNA, Hof van Holland, entry no. 3.03.01.01, inv. no. 5331. 29, 13 June 1681, notary Cornelis Ouwendijck of Delft): her neighbors in Delft; Eva scolded them when they saw how Michiel tried to sneak into Eva's house with her assistance.

35 Burnet, De ware bekeringe, 4-5. History repeats itself: Eva's grandfather Isaac had been confined by his father Joseph in a castle in Purmerend or Purmersteijn because of rebellious behavior: García-Arenal and Wiegers, Samuel Pallache, 220.

36 NL-HaNA, Hof van Holland entry no. 3.03.01.01, inv. no. 5331. 29, 17 July 1681, interrogation of Dirck Scholl and his wife Jacoba van Heck. For more on Dirck Scholl and his influence on musical life in Delft, see Maarten A. Vente, "Aspecten van de Delftse Muziekgeschiedenis," in De stad Delft, 234; Laura J. Meilink-Hoedemaker, "Uurwerken, Luidklokken en Klokkenspellen te Delft," De stad Delft, 240. 
him fired from his post as Eva's music tutor. She also suspected him of influencing Eva toward the Christian faith. ${ }^{37}$

Immediately after Eva's disappearance, Rebecca mobilized a veritable army of laymen and authorities to search for her daughter in Holland and the surrounding countries, ${ }^{38}$ and she was quickly traced to London. ${ }^{39}$ In the lawsuits that followed, Rebecca used every connection she could muster in order to secure her daughter's return. The list of people she sought help from included servants, tutors, tailors, innkeepers, shopkeepers, notaries, and lawyers in Delft, The Hague, Voorburg, Amsterdam, Brussels, Mechelen, and London. ${ }^{40}$ She contacted the burgomasters of Amsterdam, the commissioners of marriage in Delft and The Hague, the Dutch ambassador in England, and rich Sephardic Jews in London, including Michael Levy who was the community's representative to the local authorities. ${ }^{41}$ The list shows the sweep of Rebecca's control over her immediate environment, enabling her to rally assistance from the lower echelons to the highest elite and diplomatic circles. The extent of her contacts should not be surprising given her upbringing in a wealthy, wellconnected family of merchants and diplomats and her marriage to an influential merchant with business and political ties at home and overseas.

It was likely at the urging of Rebecca and other well-connected members of her family that the burgomasters of Amsterdam wrote a letter to the Dutch ambassador in England, which included a formal and explicit accusation of Michiel Verboon "of low-class origin" for seducing and abducting Eva "in an improper and indecent way" on Ascension day 1680. The letter also contained a request for assistance for Moses Cohen (Eva's brother) and Samuel van der Zee (Eva's cousin), who had been sent to England to trace her whereabouts and return the young woman to her mother's care. ${ }^{42}$

37 NL-HaNA, Hof van Holland entry no. 3.03.01.01, inv. no. 5331. 29, 17 July 1681, interrogation of Dirck Scholl and his wife Jacoba van Heck; see also Burnet, De ware bekeringe, 4.

38 As the letter written by the Amsterdam burgomasters relates: NL-HaNA, Hof van Holland entry no. 3.03.01.01, inv. no. 5331. 29, 16 August 1680.

39 In such cases, a couple fleeing was usually detected quickly: Haks, Huwelijk en Gezin, $126-28$.

40 See list in inventory of the file in NL-HaNA, Hof van Holland, entry no. 3.03.01.01, inv. no. 5331. 29.

41 For the position of Michael Levy in London see Hyamson, Sephardim of England, 54, 56, 64,71 .

42 NL-HaNA, Hof van Holland entry no. 3.03.01.01, inv. no. 5331. 29, letter by burgomasters of Amsterdam, written on 6 August 1680. According to the pamphlet, Moses and Samuel stayed for five weeks, from 27 July 168o, in the same inn as the one in which Eva was lodged: Burnet, De ware bekeringe, $7-8$. 
In the case Rebecca brought before the Hof van Holland in The Hague, she accused Michiel Verboon of theft, lechery, and seeking material gain by seducing and illegally marrying her daughter. ${ }^{43}$ The religious issue (it was illegal for a Christian to seduce a Jewess) was reason enough for Rebecca to object to the liaison, ${ }^{44}$ but it would not have mattered since by the time of the trial, Eva had already converted and taken the name Elisabeth.

In the verdict rendered by the Hof van Holland in July 1681 it was decided that Michiel and Eva be denied the right to cohabit. Eva was to live with an honest, well-mannered Reformed family in order to reconsider her position, and her mother would pay for her upkeep. Michiel was not to have any contact

43 Theft: Michiel Verboon was accused of taking the family's jewelry and clothes: NL-HaNA, Hof van Holland entry no. 5331. 29, testimony of Jacobus Duternoy, 26 June 1681; ibid., testimony of Jeronimo Poens, Mechelen, 19 July 1681; in the last will of Rebecca Pallache, Eva is accused of taking jewelry and clothes when she ran away, used by her mother as an excuse, among others, to disinherit her: SAA 5075, inv. no. 3696, Not. F. Tixerandet, 20 August 1685 .

Marriage: Michiel and Eva seem to have married in England via the Church of England on 29 July 1680 (see interview with Jacobus Bradly NL-HaNA, Hof van Holland entry no. 3.03.01.01, inv. no. 5331. 29, 26 June 1681). Apparently, the validity of the marriage was fought in an English court and it was subsequently annulled: Burnet, De ware bekeringe, 7, 12; see also the plea on behalf of Rebecca Pallache by Adriaen Sterrevelt on 15 July 1681, NL-HaNA, Hof van Holland entry no. 3.03.01.01, inv. no. 5331. 29: "hij Verboom met desselfs Eva Cohen naar Engelandt vertrocken aldaer in pretense houwelijcke gansch onwettelijcke wijse heeft begeeven." Almost one year later the couple tried again to register their intended marriage (so-called: "ondertrouwakte") in Delft on 28 June 1681, Doop-TrouwBegraafboeken (henceforth DTв) Delft ARoo14_00132, Ondertrouwboek Gerecht 16751682: 28 June 1681 and in The Hague the next day, 29 June 1681(Haags Gemeentearchief 0377-01, inv. no. $75^{2}$, p. $3^{22}$., 29 June 1681). Remarkable here is the fact that Eva already considered herself as being married to Michiel Verboon: she first signed "Elisabeth Verboon," which is blotted out, and then signed with the name "Elisabeth Cohen; ibid., inv. no. 0351-01, 29 June 1681 [no page number]: the case of marriage registration in The Hague was postponed for forty days by the commissioners of marriage: ibid., inv. no. 777, [no page number], 29 June 1681 .

Lechery: Their marriage in England declared illegal, Rebecca's representative accused Michiel of living with Eva in lechery. A so-called "oneerlijk leven," lechery could be used as another reason for a parent to refuse the marriage of an adult child: Haks, Huwelijk en Gezin, 117-119.

44 Shame and anger were also at stake here, as her daughter had an affair with a Christian: such was also the impression of Michiel's colleagues who warned Michiel that also for religious reasons the mother nor his master would ever agree to accept him as Eva's partner: NL-HaNA, Hof van Holland entry no. 3.03.01.01, inv. no. 5331. 29, 26 June 1681, interview with Jacobus Bradly; ibid., testimony of Jacobus Duternoy, 26 June 1681; see for similar conflicts, but between Protestants and Catholics in Benjamin J. Kaplan, Divided by Faith. Religious Conflict and the Practice of Toleration in Early Modern Europe (Cambridge, MA: The Belknap Press of Harvard University Press, 2007), 268-76. 
with Eva. ${ }^{45}$ The verdict seemed a fair compromise to Rebecca who viewed it as a reasonable starting point for her plan to return Eva to the family fold. Rebecca's partial victory, however, was short-lived. Michiel not only continued to visit Eva, ${ }^{46}$ but the couple appealed to the Hoge Raad and in 1684 , after a lengthy trial, Michiel and Eva were granted permission to proceed with their intended marriage. Rebecca had lost her case.

Rebecca had done all she could to restore her daughter. She had reached out to as many people as she was able at home and abroad. ${ }^{47}$ But also aware of the need to preserve the rest of her family, at the height of the affair, in 1681, she moved from Delft to Amsterdam. Her decision to relocate might have been motivated by her fear that the remainder of her family could fall outside influences as Eva had, and she preferred to raise her other children closer to organized Portuguese Jewish life, away from the dangers of crossing borders into the Christian world. ${ }^{48}$

\section{Eva Cohen in between Judaism and Christianity}

Eva grew up in a home that included instruction in the basic tenets and observance of normative Judaism. According to the testimony of Dirck Scholl and his wife at the trial in The Hague, Eva had expressed feelings of guilt when she gave a monetary donation to a sexton of the New Church on a visit to the

45 Rebecca suggested such a proposition in her plea of 15 July 1681: NL-HaNA, Hof van Holland entry no. 3.03.01.01, inv. no. 5331. 29, 15 July 1681. Apparently her suggestion was taken over by the Hof: ibid., verdict Hof van Holland, 31 July 1681. A similar policy was followed in the case of Elisabeth de Flines, see Bosman, Elisabeth de Flines, 97: Elisabeth was to stay in her father's home (not somewhere else as in Eva's case; the court apparently was not going to put back Eva into a Jewish home after her conversion) for three months in order to give her time to consider her future without having any contact with her lover; if she persisted in her intentions to marry him, she was to be allowed to proceed with the marriage.

46 NL-HaNA, Hof van Holland, entry no. 3.03.01.01, inv. no. 284, 3 December 1681.

47 See for example the interview with Jeronimo Poens from Mechelen, guest at the inn called Court of Spain in Brussels, 19 July 1681; and also the interview with the innkeeper of Court of Spain Francois Valentijn and his wife Petronella Verlijden in Brussels, 8 July 1681: NL-HaNA, Hof van Holland entry no. 3.03.01.01, inv. no. 5331. 29.

48 Eva relates to her mother's move from Delft to Amsterdam, which she regrets, in an undated letter: NL-HaNA, Hof van Holland, entry no. 3.03.01.01, inv. no. 5331. 29, undated letter Eva Cohen. The extent of Rebecca's desire to ban conflicts from her family is evident in her last will, in which she admonished her children to show each other brotherly love: last will of Rebecca Pallache: SAA 5075, inv. no. 3696, Not. F. Tixerandet, 20 August 1685: "aanbevolen $[\ldots]$ een onderlinge broederlijke liefde." 
church on a Saturday (Fig. 8.3), the Jewish Sabbath. ${ }^{49}$ The Jewish dietary laws appear to have been kept in Eva's home and among her extended family. On their expedition to England in order to retrieve her, Eva's brother and cousin were apparently provided with kosher food. ${ }^{50}$ From Scholl's interrogation, we also learn that Eva was aware that she was eating forbidden food when she dined at his home. ${ }^{51}$ In one of Eva's letters that was entered in evidence at the trial she had asked for sweets [?] for Purim, which showed that she was familiar with the observance of Jewish festivals and rituals. ${ }^{52}$ Further proof of Eva's family's upholding of Jewish tradition was their observance of the Jewish mourning rituals at the death of Eva's brother Joseph, in 1680: the family sat shiva "in the Jewish manner" in the house of relatives on Verversgracht in Amsterdam. ${ }^{53}$ From the wording of the text that appears on his tombstone, Joseph most likely belonged to the Tipheret Bajurim society, an Amsterdam study circle for young men from rich Portuguese families. ${ }^{54}$ Jacob, Eva's oldest brother was active in the Amsterdam Portuguese community's charitable Honen Dalim society. 55

49 NL-HaNA, Hof van Holland entry no. 3.03.01.01, inv. no. 5331. 29, 17 July 1681, interrogation of Dirck Scholl and his wife Jacoba van Heck.

5o For kosher food being delivered in London see Burnet, De ware bekeringe, 8; Eva's brother Mordechay was supplied with special food (e.g., meat) as well on his journey to Suriname in 1683: Meijer, Encyclopaedia Sefardica, 1: 152. On the other hand, Abraham Cohen attended dinners at the West Indian Company headquarters in Amsterdam and apparently was not all that strict in keeping kosher outside of the house or when traveling abroad, Daniel M. Swetschinski, Reluctant Cosmopolitans, The Portuguese Jews of SeventeenthCentury Amsterdam (London: The Littman Library of Jewish Civilization, 2000), 214 and n. 161. Hulshof, "Een Duitsch econoom," 77.

51 NL-HaNA, Hof van Holland entry no. 3.03.01.01, inv. no. 5331. 29, 17 July 1681, interrogation of Dirck Scholl and his wife Jacoba van Heck.

52 NL-HaNA, Hof van Holland, entry no. 3.03.01.01, inv. no. 5331. 29: letter Eva Cohen, 4 February 1681: in the document it is difficult to read what exactly she is requesting.

53 NL-HaNA, Hof van Holland, entry no. 3.03.01.01, inv. no. 5331. 29, testimony of Samuel van der Zee and Nathan Samuels, Sara Pallache and Abraham Nathans before Notary Nicolaes Hemmich in Amsterdam, 18 June 1681. They relate, among others, to the fact that Eva's brothers Jacob, Moses and Mordechay (Marten) were just returning from the cemetery in Ouderkerk and that the family observed the mourning period according to Jewish custom ("volgens de Jootsche manieren").

54 For Joseph Acohen who died 30 Adar II 5440 see the Hebrew text on his grave: https:// www.dutchjewry.org/phpr/amsterdam/port_isr_gem_burials/amsterdam_port_isr_gem_ burials_view.php?editid1 $=5595$. On the Tipheret Bajurim society, see Levie Bernfeld, Poverty and Welfare, $128-30$.

55 Pieterse, Daniel Levi de Barrios, 124; see more on this society in Levie Bernfeld, Poverty and Welfare, 122, 125-27, 131. 


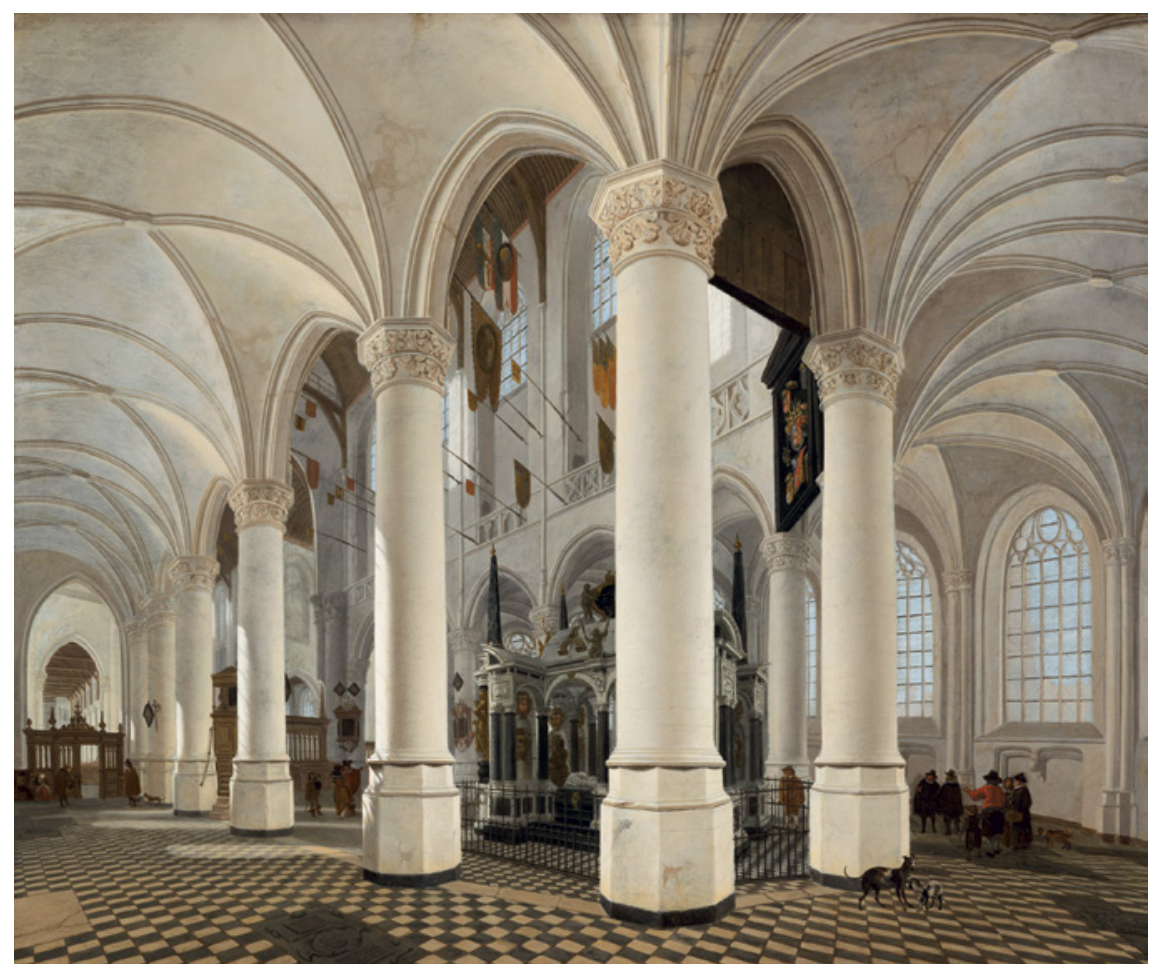

FIGURE 8.3 Gerard Houckgeest, New Church in Delft, 1651, Mauritshuis, The Hague

In Rebecca's last will there were no gifts to be distributed among the Portuguese poor or any public or private Portuguese Jewish organization, ${ }^{56}$ which is consistent with the loose connection of the family to organized Jewish life in general and to the Amsterdam Portuguese community in particular, already noted at the beginning of this study. Yet, as was also mentioned above, Rebecca did give the sum of two hundred guilders to the Amsterdam Portuguese community in 1671 for escabot prayers (prayers for the repose of the soul of the dead) to be recited for her husband "Abraham Cohem do Brazil."57 Also, among the contents in her home was a book of Flavius Josephus, apparently in Hebrew. ${ }^{58}$ In fact, more than twenty years earlier, in 166o, Abraham Cohen had given instructions to the Amsterdam publishing house of Uri Phoebus Halevi to print four thousand copies of "Josephus" in Hebrew, to be delivered to him

56 See last will of Rebecca Pallache: SAA 5075, inv. no. 3696, Not. F. Tixerandet, 20 August 1685 .

$57 \quad$ See above n. 9 .

$5^{8}$ See inventory Rebecca Pallache, above n. 33. 
by no later than 31 June 1661, most likely for the purposes of trade. ${ }^{59}$ The copy found in Rebecca's house must have been from that order.

During their lifetimes, Abraham and Rebecca signed various documents in Hebrew, ${ }^{60}$ which could be seen as evidence of the importance of their Jewish identity. Furthermore, the inscriptions on their gravestones at the Bet Haim cemetery in Ouderkerk are in Hebrew, which was not a common phenomenon. ${ }^{61}$ Finally, Rebecca's recommendation to her children in her last will and testament that they have fear of God is proof of her sincere belief in her faith. ${ }^{62}$ In all, there is enough evidence to suggest that Eva was surrounded by a Jewish atmosphere at home and that the family lived by the rules of normative Judaism.

Still, the inventory of the contents of Rebecca Pallache's house, which was drawn up after her death in 1685 , includes few material pieces of a Jewish connection. ${ }^{63}$ There were no ceremonial objects explicitly mentioned as such, even though the silver and copper candelabrums on the list could have been used for lighting candles on Sabbaths and holidays. The "paasbrood" (matsot) mentioned in the inventory suggests that Jewish holidays were celebrated at her home as we have surmised earlier from Eva's remarks on Purim. ${ }^{64}$

In all other aspects, the contents of Rebecca Pallache's house contained objects that could have been found in the home of any member of Dutch elite society: silver objects decorated with coats of arms, paintings-about fifty in all, more than the average in a Dutch residence of the times-including landscape, mythological, vanitas, and genre scenes, family portraits, and portraits of emperors and local rulers, like Prince Maurits. ${ }^{65}$ The Spanish chairs,

59 Meijer, Encyclopaedia Sefardica, 1: 152.

6o For Cohen's signing in Hebrew of the imposta regulations as well as the statutes of the Portuguese Jewish community in Recife, Brazil, see SAA 334, inv. no. 1304, p. 11, 5409, 15 Kislev; Wiznitzer, Jews in Colonial Brazil, 137. Rebecca Pallache signed her last will with her Hebrew first name (SAA 5075, inv. no. 3696, Not. F. Tixerandet, p. 294, 20 August 1685). Her father Isaac Pallache could have instructed his children into Hebrew (García-Arenal and Wiegers, Samuel Pallache, 222-23; Hugo de Groot, Remonstrantie, 30, n. 57). Then, members of the Pallache and Cohen families might traditionally have learned Hebrew at an early age, both originating from Jewish worlds, i.e., North Africa and the Levant (Emmanuel, "Seventeenth-Century Brazilian Jewry," 49, 61: Abraham Cohen is described here as a Sephardic Levantine Jew).

61 See above n. 11 .

62 See last will of Rebecca Pallache: SAA 5075, inv. no. 3696, Not. F. Tixerandet, 20 August 1685 , "aanbevolen des vreese Godes."

63 See inventory Rebecca Pallache, above n. 33.

64 Ibid.

65 See for example the painting by Michiel van Mierevelt in the Stedelijk Museum "Het Prinsenhof". 
Spanish lace, Turkish table carpet, East Indian chest, silken bedcover, and Delft porcelain that completed the inventory hint at the international DutchSephardic nature of this household.66

The Cohen Pallache's may have been a Jewish home, but it was situated in Delft, where there was no Jewish community to speak of at the time. The Reformed churches, just a few steps from Rebecca's house on the affluent Oude Delft canal were a lure for Eva and helped to spark her interest in Christianity (Fig. 8.4) ${ }^{67}$ Stories about the conversion of her grandfather, and the baptisms of her mother, aunts, and uncles, could also have stimulated her interest in the Christian faith. As a teenager, she would have known the story of her aunt Hester Pallache who had converted to Christianity along with her husband Simon Samuel, but had their sons circumcised nevertheless. The governors of the Reformed Church, upon hearing about the circumcision, summoned the parents. Hester explicitly blamed "her sister" (could the sister have been Rebecca?), but the church nevertheless placed the parents under strict supervision. ${ }^{68}$

66 Levie Bernfeld, "Matters Matter: Material Culture of Dutch Sephardim," Studia Rosenthaliana 44 (2012): 203-13. In the middle of the seventeenth century forty to fifty thousand paintings were hanging in four thousand Delft houses, which comes to an average of ten per Delft house, while Rebecca Pallache owned around fifty paintings, far above average. On the basis of 1,224 Delft inventories around 1679, fourteen percent of these paintings were of religious themes; landscapes counted for forty-one percent; still lives for seventeen percent; portraits for fifteen percent (portraits of stadholders, monarchs, admirals and preachers were popular in the middle of the seventeenth century); genre paintings for seven percent; allegory two and a half percent; in the inventory of Rebecca Pallache, the subject category of the paintings are not easily readable especially since the paper was burned on the sides; we could identify twenty-seven paintings with specific subjects out of which no religious themes were to found, yet twenty-six percent were genre scenes, twenty-two percent were allegories, nineteen percent were landscapes, eleven percent were portraits, another eleven percent were maps, and seven percent were mythological subjects; see further John Michael Montias, Artists and Artisans in Delft. A Socio-Economic Study of the Seventeenth Century (Princeton, NJ: Princeton University Press, 1982), chap. 8. One son, Mordechay, is described as the painter of two of the paintings: "nog twee schilderijen zijnde een oud mannetje en vrouwtje door Mordehay Cohen zelf geschilderd."

67 One of Eva's letters mentioned the address in Delft: "Mevrouw Cohen op het Oude Delft het tweede huys van het Begijnhof" (NL-HaNA, Hof van Holland, entry no. 3.03.01.01, inv. no. 5331. 29: Letter Eva Cohen, 4 February 1681); for young people being lured to other religious denominations, Benjamin Kaplan, Divided by Faith, 273-74.

68 Hester explained how she was severely threatened, wording it thus: "seer quaelick [...] met smadelicke benaemingen en harde bedreijgingen." For the supervision the Reformed Church placed on the couple who lived on the Nieuwe Keizersgracht in Amsterdam, see SAA 376, inv. no. 1, no. 12, pp. 317 and 319, 15 June and 6 July 1673; ibid., no. 13, p. 45, 2 August 1674; see also Roodenburg, Onder Censuur, 188-189, and Jac. Zwarts, "Assimilatiepogingen 


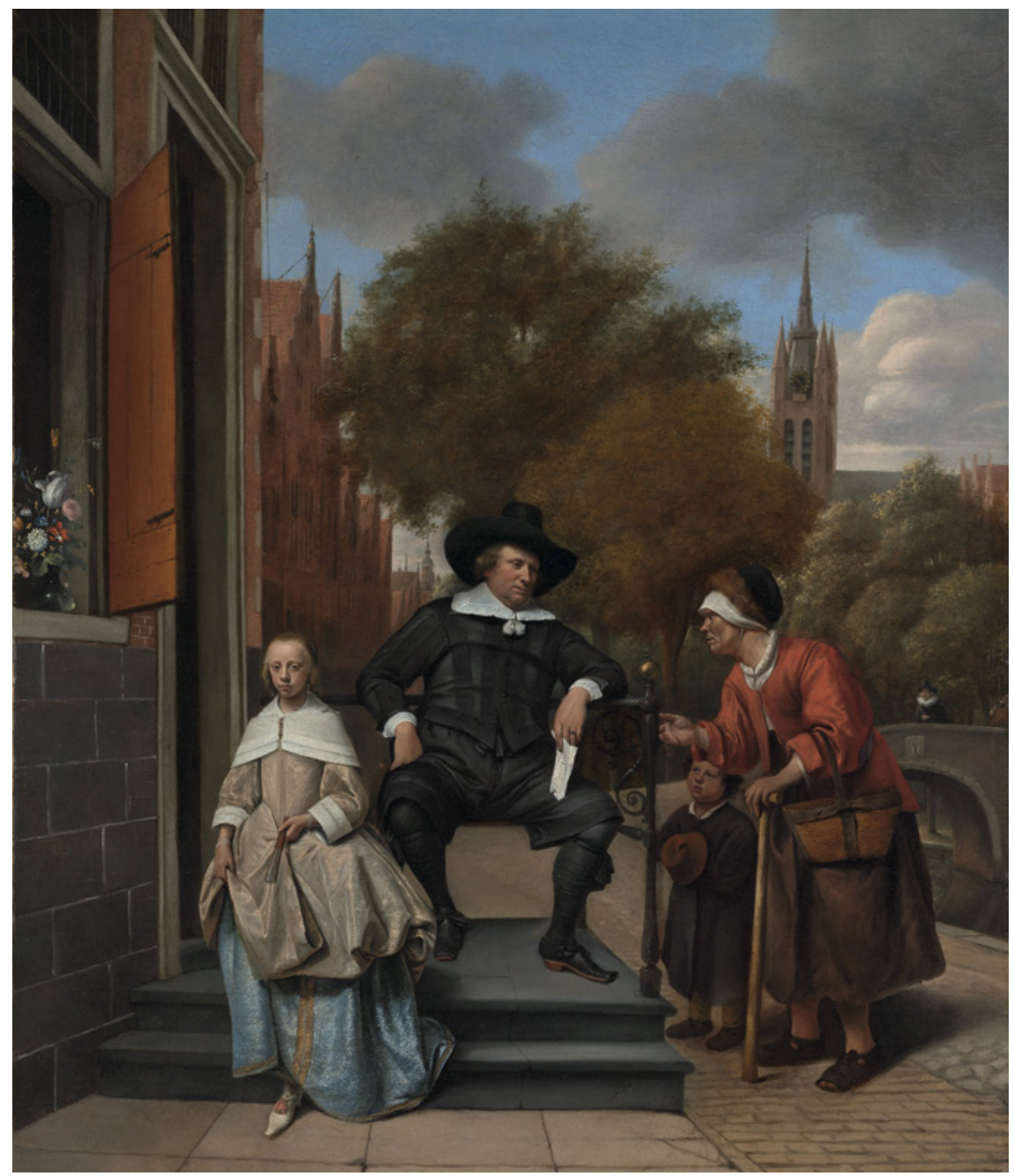

FIGURE 8.4 Jan Havicksz. Steen, Adolf and Catharina Croeser, known as "The Burgomaster of Delft and His Daughter," 1655, Rijksmuseum, Amsterdam. Eva Cohen and her family lived along this same canal, "Oude Delft," nearby the Old Church visible in the background.

Given Eva's rebellious nature, her own attraction to Christianity may have been a reaction to her mother's obvious devotion to Judaism, and a way to escape

van overheidswege," in Hoofdstukken uit de Geschiedenis der Joden in Nederland, ed. Jac. Zwarts (Zutphen: W.J. Thieme, 1929), 139: Apparently, Hester Pallache did receive welfare from the Reformed Church following her conversion, which must have taken place before 1669 . 
her control. ${ }^{69}$ She was reported to have spoken disrespectfully about Judaism in the company of people outside of her family, saying she had no inclination to marry a Jew and hoped one day to eat non-kosher food like shrimps. But, being aware of the sensitivity of the subject among her family, she kept her thoughts secret from them..$^{70}$

It was not difficult for Eva to mix with Gentile circles in Delft through daily interactions with servants, shopkeepers, and tutors. ${ }^{71}$ Eva's music tutor Dirck Scholl taught her at home, but Eva apparently also visited his house, from where he took her to the New Church to hear the playing of the organ. At church, she would have listened to the sermons, heard the reading of the New Testament, the singing of the psalms, and seen the performance of various ceremonies. ${ }^{72}$ Scholl apparently discussed the New Testament with her in the presence of her siblings, and Eva warned him against this fearing that word would get back to her mother. ${ }^{73}$ During his interrogation in court, Scholl said that he was not aware that Eva had deliberately come to him to learn about the Christian religion. Yet, despite Scholl's credulousness regarding Eva's visits to his home and the church, these outings did awaken her interest in the Christian religion. ${ }^{74}$ In fact, according to the pamphlet, Eva enjoyed reading the New Testament and had become convinced that Jesus was the savior. She had, since then, declared that she wanted to embrace Christianity and rejected Judaism. ${ }^{75}$ It is possible that she was in touch with the vicar of the New Church, but the latter had declined to answer any questions in the matter. ${ }^{76}$

Eva fled from Brussels to London in May 1680 and converted to Christianity in London on 10 October 1680. According to the pamphlet, the clergy in London allowed some time to pass before her conversion in order to test the sincerity of

69 Elisheva Carlebach also shows that conversion from Judaism might have had to do with rebellion against the environment in which the converts were brought up: Elisheva Carlebach, Divided Souls: The Convert Critique and the Culture of Ashkenaz, 1750-180o (New York: Leo Baeck Institute, 2003), 8.

70 NL-HaNA, Hof van Holland entry no. 3.03.01.01, inv. no. 5331. 29, 17 July 1681, interrogation of Dirck Scholl and his wife Jacoba van Heck.

71 Ibid.

72 Ibid.

73 Ibid.

74 Ibid.

75 Burnet, De ware bekeringe, 4-5. If we are to believe the report in the pamphlet, Scholl gave her the New Testament: ibid.

76 For the questions addressed to the vicar Hansselaer see NL-HaNA, Hof van Holland entry no. 3.03.01.01, inv. no. 5331. 29, 14 July 1681: the vicar asked for time to think about the questions but did not make the time to meet the clerk in order to give the answers. Thus it is not known whether he had ever been in the house of Eva Cohen to inquire about her inclination to convert; see also Burnet, De ware bekeringe, 6 . 
her desire, in the interim offering her protection at the home of a pastor. ${ }^{77}$ Eva's decision to convert was not exceptional. Other Jews converted to Christianity in the early modern period, causing scandals and uproar in both the Jewish and Gentile communities. ${ }^{78}$ Though Eva did not return to Judaism after her conversion, the language she uses betrays the fact that she did not completely leave the Jewish fold either. ${ }^{79}$

Little is known about the education and upbringing of girls in the Western Sephardic milieu in the early modern period. The story of Eva Cohen, however, offers an opportunity for a closer look at the rearing of a daughter in an elite Sephardic family. In the Portuguese community in the Dutch Republic, there were no official religious or secular educational institutions for girls. Sephardic girls from less fortunate families were thus often illiterate. ${ }^{80}$ Girls from wellto-do families, however, generally received private tutoring at home. ${ }^{81}$ Eva was taught to read, write, and speak Dutch and received instruction in the basic laws of Judaism. She also received private music lessons from a famous musician as noted above.

Portuguese girls like Eva were closely supervised. The statutes of the Amsterdam Portuguese community and various notarial deeds contain decisions limiting the freedoms of the community's female members. They were to remain at home and were not to go out unaccompanied, not even to the synagogue, where they were explicitly prohibited from going in the evenings

77 Burnet, De ware bekeringe, 13; for protection offered to youngsters encouraged to convert, Benjamin Kaplan, Divided by Faith, 273-74; for supervising and inspection of the behavior of candidates for conversion, ibid., 277-78; Roodenburg, Onder Censuur, 124-41.

78 See for Amsterdam the cases of conversion from Judaism to the Reformed Church mentioned in Roodenburg, Onder Censuur, 186-89 as well as Levie Bernfeld, Poverty and Welfare, 215-16, 221, 477-78, n. 403; Carlebach, Divided Souls, 5; Benjamin Kaplan, Divided by Faith, $268-93$.

79 After her conversion she continued to talk about Jewish festivals and tradition: see as cited above her letter dated 4 February 1681: NL-HaNA, Hof van Holland, entry no. 3.03.01.01, inv. no. 5331. 29. Converts in the early modern world tend to be part of an ambiguous group, often navigating between different religious denominations: Benjamin Kaplan, Divided by Faith, 291-92, 313, 315-16. Endelman, Radical Assimilation in English Jewish History, 1656-1945 (Bloomington: Indiana University Press, 1990), 9-33.

80 Levie Bernfeld, Poverty and Welfare, 100-1.

81 Ibid., 98. 
and early mornings with the exception of certain holidays. ${ }^{82}$ On visits to The Hague and Amsterdam, Eva was escorted by her siblings.

Despite the limitations placed on their movement by the communal religious authorities, the lifestyle of wealthy Sephardic women was unconstrained and privileged in other ways. The relatively tolerant society of which the Dutch Republic was an example, allowed Eva, a Jewess, freedom of movement, which enabled her contact with the wider world. ${ }^{83}$ Affluent Sephardic women were attended by servants in and outside of the home, including to and from the synagogue. ${ }^{84}$ When Eva traveled to Brussels in order to meet Michiel, a servant accompanied her and carried her baggage. ${ }^{85}$ Sephardic women were also known for their fashionable dress and lack of restraint in this regard, which the rabbis and communal elders often decried. ${ }^{86}$ Indeed, Eva was reported as wearing expensive clothing and jewelry at the inn in Brussels where she joined Michiel after she fled from home. ${ }^{87}$

82 Levie Bernfeld, "Sephardi Women," 182; Levie Bernfeld, "Religious Life among Portuguese Women in Amsterdam's Golden Age," in The Religious Cultures of Dutch Jewry, ed. Yosef Kaplan and Dan Michman (Leiden: Brill, 2017): 95. Also in Christian milieus of the seventeenth century, upbringing of children was often strict and harsh. See for example Roosenboom, Ontvoerd of gevlucht, $54-58$.

83 Benjamin Kaplan, Divided by Faith, 293.

84 At least one maid in Delft was mentioned in the sources who almost discovered Michiel sneaking into Eva's room in Delft: NL-HaNA, Hof van Holland entry no. 5331. 29, testimony of Jacobus Duternoy, 26 June 1681; for servants in the synagogue, SAA 334, inv. no. 19, p. 165/80, undated [most likely 18 Elul 5401]; see also on servants, Levie Bernfeld, "Sephardi Women," 188. See also Levie Bernfeld, "Masters, Maids and Mistresses: Aspects of Domestic Life among the Portuguese Jews in the Seventeenth-Century Dutch Republic," in Sephardische Perspektiven: Viertes Jahrbuch des Selma Stern Zentrums Jüdische Studien Berlin-Brandenburg, ed. Sina Rauschenbach (Berlin/Leipzig: Hentrich \& Hentrich, forthcoming: 2019).

85 NL-HaNA, Hof van Holland entry no. 3.03.01.01, inv. no. 5331. 29, testimony of Jeronimo Poens, Mechelen, 19 July 1681. The baggage apparently also included clothes for Michiel. That fact was confirmed by Rebecca who noted in her last will that Eva took several pieces of jewelry with her as well as clothes when she ran away with Michiel in 1680: last will of Rebecca Pallache: SAA 5075, inv. no. 3696, Not. F. Tixerandet, 20 August 1685.

86 Levie Bernfeld, "Religious Life," 94-95.

87 At least her dresses made quite an impression on the inn's guests in Brussels, when she arrived to join Michiel in that city. NL-HaNA, Hof van Holland, entry no. 3.03.01.01, inv. no. 5331. 29, testimony of Jeronimo Poens, 19 July 1681. 
During the period of Eva's stay in London, between the years 1680 and 1681, Eva and her mother exchanged a series of letters. ${ }^{88}$ Of the four surviving letters from Eva, two were written during the summer of 1680 , before her conversion. While this correspondence makes clear that Rebecca intended to maintain contact with her daughter, it also appears that she sent Eva money in an attempt to lure her home. ${ }^{89}$ She used that tactic again in October 1684 before the verdict of the Supreme Court, when she transferred a monetary gift to Eva "out of motherly love and tenderness." 90

The language of Eva's letters is ambiguous. On the one hand, she shows remorse for having caused her mother pain and expresses her love for her. Explaining that she acted out of desperation, she promises to be obedient ${ }^{91}$ and to return to the family and to her mother's supervision. ${ }^{92}$ She does not relate to the events surrounding her running away, dismissing them as unimportant. ${ }^{93}$ On the other hand, without mentioning the name of Michiel Verboon, Eva tries to justify her desire to marry someone of a lower class by offering comparisons of a king's daughter marrying a count and of a princess marrying a nobleman. ${ }^{94}$

The letters suggest that Eva is torn between her love for Verboon and loyalty toward her mother and family. She admits her joy at receiving her mother's letters and writes of her great love for her siblings, especially for her sister, who was then around eight years old, ${ }^{95}$ and her brother Jacob, ${ }^{96}$ and of dreaming of her brother Joseph, who had died a few months before. In this respect, she apparently felt the growing isolation and alienation that could overcome

88 Burnet, De ware bekeringe, 7. Eva's brother Moses who was sent to London to try to bring her back acted as courier for one of Rebecca's letters in which she apparently asked that Eva leave Michiel and return home.

89 See letter written by Eva Cohen, 4 February 1681, reacting to her mother's letter dated 28 January.

90 Last will of Rebecca Pallache: SAA 5075, inv. no. 3696, Not. F. Tixerandet, 20 August 1685: "niettegenstaande de comparante uit moederlijke teerheid en mededogenheid bewogen zijnde alsoo Eva Cohen haar dochter tot uiterste armoede vervallen was en anders niet bestaan konde aande sulx nog bij seeker verdrag of accoord voor mij notaris en zekere getuigen op 9 oktober 1684 de somme heeft gegeven van 3140 guldens."

91 NL-HaNA, Hof van Holland, entry no. 3.03.01.01, inv. no. 5331. 29, Letter Eva Cohen, 23 August 1680; Letter Eva Cohen, 4 February 1681.

92 Ibid., Letter Eva Cohen, 7 August 168o; Letter Eva Cohen, February 4, 1681.

93 Ibid., Letter Eva Cohen, 7 August 1680.

94 Ibid., Letter Eva Cohen, 13 August 1680.

95 Ibid., Letter Eva Cohen, 4 February 1681. She even warns her mother where she must especially watch out for her sister: in the garden and to keep her from going near the well.

96 Ibid., Letter Eva Cohen, 13 August 168 o. 
converts on the verge of leaving behind a close-knit family and familiar environment. ${ }^{97}$

Eva's efforts to soothe her mother, ${ }^{98}$ could have been part of a strategy intended to stop her mother from taking legal steps to disinherit her, ${ }^{99}$ and at the same time maintain her relationship with Verboon. Eva's intention to convert is not addressed in her letters or in her mother's. Perhaps her conversion is the "matters" she mentions in the letters, which, aware of the sensitivity of the subject, she cautiously prefers to discuss with her mother in person.

The letters between Eva and her mother were written in Dutch. Eva and Michiel Verboon must also have communicated in Dutch. ${ }^{100}$ From her letters we know that Eva was trying to learn English and had even hired a private teacher for that purpose soon after she arrived in London. ${ }^{101}$ In one of her letters, Eva uses the Hebrew terms "Poeriem" and "Vesalom," but writes these in Latin characters. ${ }^{102}$ We cannot be certain whether she knew how to write Hebrew.

\section{Michiel Verboon's Motives}

Michiel Verboon, a servant in the employ of Jacob Cohen, actively courted Eva Cohen, the sister of his wealthy master. ${ }^{103}$ He wrote her letters, brought

97 Ibid., Letter Eva Cohen, 13 August 1680; on isolation of converts from Judaism, Carlebach, Divided Souls (2003), 10, 19; Endelman, Leaving the Jewish Fold, 34-37.

98 She asked her mother whether she might stay in England in order to learn more English (Letter Eva Cohen, 7 August 1680 NL-HaNA, Hof van Holland, entry no. 3.03.01.01, inv. no. 5331. 29) and to send her Dutch cheese or fine linen, since she is in need of those products and they are either not to be found in England or very expensive (ibid., Letter Eva Cohen, 4 February 1681).

99 On widows' last wills and inheritance in Dutch law, see Schmidt, Overleven na de dood. Weduwen in Leiden in de Gouden Eeuw (Amsterdam: Prometheus/Bakker, 2001), 113-20.

100 One witness from Mechelen told his interviewer that Eva spoke in Dutch: "op zijn Hollands" (NL-HaNA, Hof van Holland, entry no. 3.03.01.01, inv. no. 5331. 29, testimony of Jeronimo Poens, Mechelen, 19 July 1681); on the exchange of letters between Eva and Michiel see below n. 104.

101 NL-HaNA, Hof van Holland, entry no. 3.03.01.01, inv. no. 5331. 29, letter Eva Cohen, 7 August 1680.

102 NL-HaNA, Hof van Holland, entry no. 3.03.01.01, inv. no. 5331. 29, letter Eva Cohen, 4 February 1681. Among Sephardim, the term "Vesalom" commonly appears at the end of documents: see for example the petition of Ester Fonseca de Liorne in Levie Bernfeld, Poverty and Welfare, 461, n. 245 .

103 Jacobus Duternoy confirmed the fact that while he was a servant with Jacob Cohen, Michiel Verboon told him he was trying to lure Eva Cohen: NL-HaNA, Hof van Holland entry no. 5331. 29, testimony of Jacobus Duternoy, 26 June 1681. 
her gifts, and sneaked visits with her in her home in Delft and on trips to The Hague. ${ }^{104} \mathrm{He}$ insisted that he was in love with Eva. ${ }^{105}$ Rebecca's mother, however, was convinced that Michiel's interest was not Eva, but her fortune. ${ }^{106}$ Supporting her intuition were remarks of friends of Michiel interviewed for the trial. For example, on a trip from London to Rotterdam, Michiel had told his good friend Benjamin Torens that by courting Eva he tried to make his fortune. He told his colleague Jacobus Bradly likewise. ${ }^{107}$ He maintained that he was even willing to embrace the Jewish faith for such a purpose. ${ }^{108} \mathrm{He}$ also said that he was waiting for Eva's mother to die so he could cash in the inheritance. ${ }^{109}$

In an attempt to impress the Cohen Pallache family Michiel went so far as to devise a ruse involving a sick uncle on his deathbed who was about to leave him a fortune. While accompanying his master Jacob Cohen to the shiva for his

104 Presents: Michiel bought special gifts for her like ribbons and sweets (see interview with Jacobus Bradly: NL-HaNA, Hof van Holland entry no. 3.03.01.01, inv. no. 5331. 29, 26 June 1681). According to Aernout van Woestinghove, Michiel frequently arrived late at night at Aernout's house where Eva was staying, under the pretext of being sent by his master Jacob Cohen, bringing her sweets and ribbons (NL-HaNA, Hof van Holland, entry no. 3.03.01.01, inv. no. 5331. 29, before notary Jeremias Stael, The Hague 16 June 1681). Michiel also asked Jacobus Duternoy for money to buy Eva presents (NL-HaNA, Hof van Holland entry no. 5331. 29, Testimony of Jacobus Duternoy, 26 June 1681).

Letters: Jacobus Bradly was one of the intermediaries who acted as a courier for their letters (NL-HaNA, Hof van Holland entry no. 3.03.01.01, inv. no. 5331. 29, 26 June 1681, interview with Jacobus Bradly).

Waiting in front of her house: A tailor and his wife claimed they had seen Michiel waiting across from Eva's house in Delft. He made signs to Eva who was watching from the window. Then he moved across the bridge over the water to talk to her, after which he was let into the house by her through the window (NL-HaNA, Hof van Holland entry no. 5331. inv. no. 29, Testimony of Andries Coster and Anna Cupers before notary Cornelis Ouwendijck of Delft: NL-HaNA, Hof van Holland, entry no. 3.03.01.01, inv. no. 5331. 29, 13 June 1681).

Michiel took Jacobus Duternoy to Delft so Michiel could bring Eva to him while she was standing in a grocery shop across the street from her house (NL-HaNA, Hof van Holland entry no. 5331. 29, Testimony of Jacobus Duternoy, 26 June 1681).

Spending nights together: Michiel had told Jacobus Duternoy he managed to sneak into Eva's room at her mother's house. Also, he managed to get Eva to stay in Jacob's house in the room where her brother Moses was supposed to stay and thus managed to see her in her room. He insisted that it be kept a secret (NL-HaNA, Hof van Holland entry no. 5331. 29, testimony of Jacobus Duternoy, 26 June 1681). Michiel deceived his master on more occasions with false letters in order to get close to Eva Cohen (ibid.).

105 NL-HaNA, Hof van Holland entry no. 3.03.01.01, inv. no. 5331. 29, 26 June 1681: interview with Jacobus Bradly.

106 Ibid., plea of Adriaen van Sterrevelt on behalf of Rebecca Pallache, 15 July 1681.

107 Ibid., testimony of Benjamin Torens before notary Jeronimus Stael, The Hague 16 July 1681. For the interview with Jacobus Bradly see ibid., 26 June 1681.

108 Ibid., testimony of Jacobus Duternoy, 26 June 1681.

109 Ibid., interview with Jacobus Bradly, 26 June 1681. 
and Eva's brother Joseph at a Pallache family member's home in Amsterdam, Michiel arranged for a servant to deliver a letter to him on behalf of this imaginary rich uncle. This make-believe uncle was summoning Michiel to his home in Voorburg in order to bestow upon him a large sum. Michiel asked his master for permission to leave in order to attend the signing of the last will. Michiel naively assumed that the Pallache Cohens would be impressed by his impending inheritance, and thereby increase his chances of marrying Eva. ${ }^{110}$ To people he met on his travels to Brussels and London, he claimed he worked as a cornet (officer in the army), producing as proof an orange scarf with silver fabric from his travel bag. He also showed off gold rings studded with diamonds and blue stones, apparently taken from, or given to him by, Eva. ${ }^{111}$

In many respects, Michiel was a simple dreamer and a highflyer, yet he was also stubborn and brave. Supported by his lover, he was ready to appeal his case to the highest court, though both he and Eva likely knew that their chances of success were relatively good.

Eva Cohen and Michiel Verboon spent four years (1680-1684) battling for recognition of their relationship and for their marriage to be legalized, which it finally was following an appeal of the decision of the Hof van Holland to the Supreme Court of the Dutch Republic. In July 1684, the Supreme Court granted the couple the right to marry. ${ }^{12}$ Fearing an outcome where part of her family's wealth would have to be surrendered to the servant, Rebecca Pallache took the unusual step of disinheriting her daughter already in $1682 .{ }^{113}$ She reiterated her

110 Ibid., testimony of Samuel van der Zee and Nathan Samuels, Sara Pallache and Abraham Nathans before Notary Nicolaes Hemmich in Amsterdam, 18 June 1681. This trick was meant to impress the family.

111 Ibid., testimony of Jeronimo Poens, Mechelen, 19 July 1681.

112 For the request of appeal to the Dutch Hoge Raad see ibid., 4 September 1681; see also ibid., 18 November 1681; for the final sentence NL-HaNA, Hoge Raad van Holland en Zeeland, entry no. 3.03.02, ibid. inv. no. 903, 22 July 1684, scan no. 221.

113 Rebecca Pallache refers to the first decision to disinherit her daughter in her last will: "ende vooral $t$ approberen van waarde te houden als sulke testamente als zij compt voor de ed Heere Benjamin Fagel y Francois Ketelaer raden van den hove van Hollant [...] heeft gepasseert gelast in dato 29 juni 1682." In fact, Rebecca might have followed the policy of her grandfather toward her father Isaac, who was deprived of his mother's part of the inheritance because of his conversion to Christianity. A lengthy lawsuit ensued between father and son like the one between Rebecca and her daughter, see García-Arenal and Wiegers, Samuel Pallache, 223-24. Hugo de Groot, Remonstrantie, 29-30, n. 57. For parents disinheriting their children in case they disagreed with the choice of a marriage partner, 
decision in her last will just before she died in 1685 , and justified her decision by citing her daughter's repeated complaints and reproaches despite the fact that she had helped her by sending money to relieve her financial situation. ${ }^{114}$ In order to ensure that what happened with Eva will not be repeated, she further stipulated that should any of her other children marry without permission of the guardians she appointed to take over their care after her death, they would lose their inheritance as well. ${ }^{115}$ Her son Mordechay unsuccessfully tested this provision a few years later.116

see Haks, Huwelijk en Gezin, 116. Ariadne Schmidt, “'Touching Inheritance'. Mannen, vrouwen en de overdracht van bezit in Holland in de 17e eeuw," Holland 33, no. 3 (2001): 177.

114 Last will of Rebecca Pallache: SAA 5075, inv. no. 3696, Not. F. Tixerandet, 20 August 1685.

115 This way Rebecca limited and directed the rights of inheritance of her children: she was ready to give them legacies under strict conditions and supervision only. She allocated supreme power to the guardians she appointed, till her sons would reach the age of thirty. Even after that age, these guardians would keep some influence if the children remained unmarried. If her sons would get married before the age of 30 then they could only marry with complete consent of the guardians (SAA 5075, inv. no. 3696, Not. F. Tixerandet, 20 August 1685). No word about restriction for her daughter Ester in this respect; for her a large sum and gifts in natural including many pieces of silverwork, jewelry and linen were reserved. Apparently her partner was already chosen and all settlements arranged: we have yet to find them. Eventually, Eva's sister Ester, married in 1694, then 22 years old: see registration of intended marriage SAA DT в 698, p. 284, 23 April 1694. The groom she married was Samuel de Nathan Pallache (Eva's intended spouse?; the one who chased her in London), a merchant 36 years old, living in Oude Zijds Houttuinen in Amsterdam, while Ester was living at Nieuwe Herengracht, in Amsterdam at the time of her marriage. Her guardian Isaac Abrabanel was present at the registration and contrary to what happened at the registration of the marriage of Mordechay, one of Rebecca's sons, six years earlier, in 1688, gave his consent in agreement with Rebecca's last will. Ester died young, in 1699, at the age of around 27. Therefore it is written on her grave "incurtada": http://www.dutchjewry .org/P.I.G./image/o19180o1.jpg; for the registration of her burial SAA 334, inv. no. 916, p. 119, 12 Adar II 5459. Twelve days later, on 24 Adar II, her husband Samuel Pallache reserved two graves next to her, for himself and their child? (ibid., 24 Adar II). In accordance with Rebecca's will, the guardians refused to approve to the registration of marriage of son Mordechay who converted to Christianity and married a non-Jewish woman in 1688 (sAA Dтв 517, p. 167, 10 July 1688: Franciesco Pedro de Cohen alias Mordochaij Cohen, 22 years old, living at Singel and Maria Catharina Vakeles alias Catharina Vakeles, living at the same address, father abroad); the commissioners looked into the matter and the registration was therefore delayed. Meanwhile, to get the matter moving and apparently under pressure of the guardians, three days after his first effort to get his marriage registered, Mordechay renounced his mother's inheritance as he did not want to comply with her conditions (SAA entry no. 5075, inv. no. 3704, Not. F. Tixerandet, pp. 106-109, 13 July 1688). Only on 22 July the city commissioners gave permission and on 28 July the matter was finally settled through an agreement with Mordechay's guardians. For inheritance law in Holland see Schmidt, “'Touching inheritance," $175^{-89}$.

116 For Mordechay marrying a non-Jewish woman without consent of his guardians, see above n. 115 . 
Michiel and Eva lived in poverty. ${ }^{117}$ The couple eventually settled in England, but the exact location and date remain unknown. Michiel died around fifteen years after the verdict of the Supreme Court, apparently as a soldier, sometime in the 169os, certainly before 1699. In that year, one Elisabeth Cohen widow of Michiel Verboon is mentioned in a deed before an Amsterdam notary, Mr. Pelgrom. Eva was remarried to one Francois van Spijck, and apparently was trying to extract some financial benefits from her father's assets. ${ }^{118} \mathrm{Her}$ whereabouts are still unclear at this point: did she live in Holland or England or elsewhere? Most likely, she lived in England: a document from 1720 from Chester, England deals with the inheritance of Elisabeth Verboon to be handed over to her daughter Catherine Verboon. ${ }^{119}$ We can assume then that Elisabeth Verboon, nee Eva Cohen died around that time.

\section{8}

\section{Conclusion}

The dispute surrounding Eva Cohen offers us an extraordinary opportunity to look behind the coulisses into Sephardic family life over the course of the seventeenth century. In this specific case, but which is applicable to quite a few other Sephardic families, connections to the organized Jewish community were not strongly fixed, social status was high on the agenda, and signs of integration into Dutch society were easily visible.

The study also exposes the motivations behind conversion at that time, which seem to have been a blend of religious, economic, social, and emotional parameters. Among the Portuguese Jews, the reaction to conversion to Christianity was vehement and harsh, and was even more so when it involved a well-to-do family that saw its wealth threatened, its Jewish heritage negated, and its Sephardic pride tarnished.

At the same time, the case offers an opportunity to gather new data on the neglected field of research into the status of women among the Dutch Sephardim in early modern times. It particularly highlights the position of the

117 This fact was already attested to in the last will of Rebecca Pallache: SAA 5075, inv. no. 3696, Not. F. Tixerandet, 20 August 1685: "alsoo Eva Cohen haar dochter tot uiterste armoede vervallen was."

118 Eva's second husband went to the notary on her behalf to ask for authentic extracts out of the books of the West Indian Company, Chamber of Amsterdam, relating to a deal involving salt from Portugal, in which Eva's father, Abraham Cohen apparently had an interest: SAA 5075, inv. no. 4774, Not. S. Pelgrom, pp. 729-730, 8 December 1699. With many thanks to Ton Tielen who provided me with these documents.

119 Elizabeth Verboon of Chester, February 1720: Chester Archives and Local Studies, WS 1720. Elizabeth did not leave a will so that her daughter Catherine needed legal assent to dispose of Eva's money and belongings. 
community's young girls and widows, their background, education, and skills, their interactions within the family and with the world at large, and their ability to strike a path of their own despite obstacles on the way. The extraordinary documents that survive from this case, like the letters and interviews, offer rare insights into female emotions and expressions, all of which further our knowledge about the complexities of Sephardic identity in early modern times.

\section{Bibliography}

Apeldoorn, Lambertus J. Van. Geschiedenis van het Nederlandsche huwelijksrecht vóór de invoering van de Fransche wetgeving. Amsterdam: Holland, 1925.

Bloom, Herbert I. "The Dutch Archives with Special Reference to American Jewish History." Publications of the American Jewish Historical Society 32 (1931): 7-21.

Bodian, Miriam. “The 'Portuguese' Dowry Societies in Venice and Amsterdam: A Case Study in Communal Differentiation within the Marrano Diaspora." Italia 6, nos. 1-2 (1987): 30-61.

Bosman, Machiel. Elisabeth de Flines. Een onmogelijke liefde in de achttiende eeuw. Amsterdam: Athenaeum-Polak \& Van Gennep, 2008.

Boxer, Charles R. The Dutch in Brazil, 1624-1654. Oxford: The Clarendon Press, 1957.

Burnet, Gilbert. De ware bekeringe en violente vervolgingen van Eva Cohen, nu genaemt Elisabeth. Zijnde een persoon van qualiteyt vande Joodsche gesintheyt geweest, ende gewoont hebbend tot Delft; dewelke gedoopt is den 10. October, 1680 in St. Martins Kerck, des Coninghs Parochie van Whitehall, door den seer Eerwaardieghen Heer William Floid, bisschop van St. Asaph (no place; no date).

Burnet, Gilbert. The Conversion \& Persecutions of Eve Cohan, Now called Elizabeth Verboon, a Person of Quality of the Jewish Religion, Who was Baptized the roth of October, 1680, at St. Martins in the Fields by the Right Reverend Father in God, William, Lord Bishop of St. Asaph (London, 1680).

Carlebach, Elisheva. Divided Souls: The Convert Critique and the Culture of Ashkenaz 1750-180o. New York: Leo Baeck Institute, 2003.

Eekhout, Luc L.M. “De Delftse Kamer van de VOC.” In De stad Delft. Cultuur en Maatschappij van 1572 tot 1667. Vol 2. Edited by Ineke V.T. Spaander, 2: 90-94. Delft: Stedelijk Museum "Het Prinsenhof," 1981.

Emmanuel, Isaac S. "Seventeenth-Century Brazilian Jewry: A Critical Review." American Jewish Archives 14, no. 1 (April 1962): 32-68.

Endelman, Todd M. Leaving the Jewish Fold. Conversion and Radical Assimilation in Modern Jewish History. Princeton, NJ: Princeton University Press, 2015.

Endelman, Todd M. Radical Assimilation in English Jewish History, 1656-1945. Bloomington: Indiana University Press, 1990. 
Franco Mendes, David. Memorias do estabelecimento e progresso dos judeos portuguezes e espanhoes nesta famosa citade de Amsterdam. Edited by Lajb Fuks and Reina G. Fuks-Mansfeld; commentary Benjamin N. Teensma. Assen: van Gorcum, 1975 .

García-Arenal, Mercedes, and Gerard Wiegers. Samuel Pallache. Koopman, kaper en diplomaat tussen Marrakesh en Amsterdam. Amsterdam: Amsterdam University Press, 2014 .

Gelfand, Noah L. "To Live and to Trade. The Status of Sephardi Mercantile Communities in the Atlantic World during the Seventeenth and Eighteenth Centuries." In The Jews in the Caribbean. Edited by Jane S. Gerber, 45-64. Oxford: The Littman Library of Jewish Civilization, 2014.

Gonsalves de Mello, José A. Gente de Nação: Cristãos-Novos e Judeus em Pernambuco, 1542-1654. Recife: Massangana, 1989.

Gottlieb, Beatrice. The Family in the Western World from the Black Death to the Industrial Age. New York: Oxford University Press, 1993.

De Groot, Hugo. Remonstrantie nopende de ordre dije in de landen van Hollandt ende Westvrieslandt dijent gestelt op de Joden. Edited with an introduction by Jaap Meijer. Amsterdam: Joachimsthal's Boekhandel, Uitgevers-en Drukkerbedrijf N.V., 1949 [5709].

Haks, Donald. Huwelijk en Gezin in de 17de en 18de Eeuw. Assen: van Gorcum, 1982.

Hulshof, A. "Een Duitsch econoom in en over ons land omstreeks 1670." Onze Eeuw 10 (1910): 5-96.

Hyamson, Albert M. The Sephardim of England, A History of the Spanish and Portuguese Jewish Community 1492-1951. London: Methuen, 1951.

Israel, Jonathan I. Diasporas within a Diaspora. Jews, Crypto Jews and the World Maritime Empires (1540-1740). Leiden: Brill, 2002.

Kagan, Richard, and Philip D. Morgan, eds. Atlantic Diasporas. Jews, Conversos and Crypto-Jews in the Age of Mercantilism 1500-180o. Baltimore: The Johns Hopkins University Press, 2009.

Kaplan, Benjamin J. Divided by Faith. Religious Conflict and the Practice of Toleration in Early Modern Europe. Cambridge, MA: The Belknap Press of Harvard University Press, 2007.

Kaplan, Yosef. "Clandestine Marriage in Amsterdam, Broken Hearts in Hamburg and a Kidnapping in London." (Hebrew). In Tov Elem: Memory, Community and Gender in Medieval and Early Modern Societies, Essays in Honor of Robert Bonfil. Edited by Elisheva Baumgarten, Amnon Raz-Krakotzkin, Roni Weinstein, 171-90. Jerusalem: Mosad Bialik, 2011.

Kaplan, Yosef. "De joden in de Republiek tot omstreeks 1750: religieus, cultureel en sociaal leven." In Geschiedenis der Joden in Nederland. Edited by Hans Blom, David Wertheim, Hetty Berg, Bart Wallet, 131-96. Amsterdam: Balans, 2017. 
Kaplan, Yosef. "Moral Panic in the Eighteenth-Century Sephardi Community of Amsterdam: The Threat of Eros." In Dutch Jewry: Its History and Secular Culture. Edited by Jonathan I. Israel and Reinier Salverda, 103-23. Leiden: Brill, 2002.

Kaplan, Yosef. "The Social Functions of the Herem in the Portuguese Jewish Community of Amsterdam in the Seventeenth Century." In Dutch Jewish History. 2 vols. Edited by Jozeph Michman and Tirtsah Levie [Bernfeld], 1: 111-55. Jerusalem: Institute for Research on Dutch Jewry, 1984.

Katz, Jacob. Tradition and Crisis. Jewish Society at the End of the Middle Ages. Translated and with an afterword and bibliography by Bernard D. Cooperman. Syracuse, NY: Syracuse University Press, 2000.

Levie Bernfeld, Tirtsah. Dowries and Dotar. An Unbroken Chain of 400 Years. Amsterdam: Menasseh ben Israel Institute, 2015.

Levie Bernfeld, Tirtsah. "Masters, Maids and Mistresses: Aspects of Domestic Life among the Portuguese Jews in the Seventeenth-Century Dutch Republic." In Sephardische Perspektiven: Viertes Jahrbuch des Selma Stern Zentrums Jüdische Studien Berlin-Brandenburg. Edited by Sina Rauschenbach. Berlin/Leipzig: Hentrich \& Hentrich, forthcoming: 2019 .

Levie Bernfeld, Tirtsah. "Matters Matter: Material Culture of Dutch Sephardim." Studia Rosenthaliana 44 (2012): 191-216.

Levie Bernfeld, Tirtsah. Poverty and Welfare among the Portuguese Jews in Early Modern Amsterdam. Oxford: The Littman Library of Jewish Civilization, 2012.

Levie Bernfeld, Tirtsah. "Religious Life among Portuguese Women in Amsterdam's Golden Age." In The Religious Cultures of Dutch Jewry. Edited by Yosef Kaplan and Dan Michman, 57-99. Leiden: Brill, 2017.

Levie Bernfeld, Tirtsah. "Sephardi Women in Holland's Golden Age." In Sephardi Family Life in the Early Modern Period. Edited by Julia R. Lieberman, 177-222. Waltham, MA: Brandeis University Press, 2010.

Meijer, Jaap. Encyclopaedia Sefardica Neerlandica 2 vols. Amsterdam: Portugees-Israelietische Gemeente Amsterdam, 5709-5710 [1948-1950].

Meilink-Hoedemaker, Laura J. "Uurwerken, Luidklokken en Klokkenspellen te Delft." In De stad Delft. Cultuur en Maatschappij van 1572 tot 1667. Vol. 2. Edited by Ineke V.T. Spaander, 238-241. Delft: Stedelijk Museum "Het Prinsenhof," 1981.

Montias, John Michael. Artists and Artisans in Delft. A Socio-Economic Study of the Seventeenth Century. Princeton, NJ: Princeton University Press, 1982.

Oppenheim, Samuel. "The Early History of the Jews in New York, 1654-1664," Publications of the American Jewish Historical Society 18 (1909): 3-91.

Opstall, Margaretha E. van."De kamer van de Maze tot Delft." In De stad Delft. Cultuur en Maatschappij van 1572 tot 1667. Vol 2. Edited by Ineke V.T. Spaander, 2: 94-100. Delft: Stedelijk Museum "Het Prinsenhof," 1981. 
Pieterse, Wilhelmina Chr. Daniel Levi de Barrios als geschiedschrijver van de PortugeesIsraelietische gemeente te Amsterdam in zijn "Triumpho del govierno popular." Amsterdam: Publikaties van de Gemeentelijke Archiefdienst van Amsterdam, 1968.

Roodenburg, Herman. Onder Censuur. De kerkelijke tucht in de gereformeerde gemeente van Amsterdam, 1578-170o. Hilversum: Verloren, 1990.

Roosenboom, Henk Th. M. Ontvoerd of gevlucht? Religieuze spanningen in Brabant en de zaak Sophia Alberts 1700-1710. Hilversum: Verloren, 2016.

Schledorn, Loet. "De kamer van Delft van de VOC: een rijke bron." In Burgers verzamelen, 1600-175o Schatten in Delft 1602-2002; 400 jaar Verenigde Oost-Indische Compagnie. Edited by Ellinoor Bergvelt, Michiel Jonker, Agnes Wiechmann,143-155. Zwolle: Waanders, 2002.

Schmidt, Ariadne. Overleven na de dood. Weduwen in Leiden in de Gouden Eeuw. Amsterdam: Prometheus/Bakker, 2001.

Schmidt, Ariadne. “Touching Inheritance'. Mannen, vrouwen en de overdracht van bezit in Holland in de 17e eeuw." Holland 33, no. 3 (2001): 175-189.

Schmidt, Ariadne. "Vrouwen en het recht. De juridische status van vrouwen in Holland in de vroegmoderne tijd." Jaarboek van het Centraal Bureau voor Genealogie $5^{8}$ (2004): 27-44.

Swetschinski, Daniel M. Reluctant Cosmopolitans, The Portuguese Jews of SeventeenthCentury Amsterdam. London: The Littman Library of Jewish Civilization, 2000.

Vente, Maarten A. "Aspecten van de Delftse Muziekgeschiedenis." In De stad Delft. Cultuur en Maatschappij van 1572 tot 1667. Vol. 2. Edited by Ineke V.T. Spaander, 232-35. Delft: Stedelijk Museum "Het Prinsenhof," 1981.

Verhoeven, Gerrit. De derde stad van Holland. De geschiedenis van Delft tot 1795. Zwolle: WBOOKS, 2015.

Wiznitzer, Arnold. Jews in Colonial Brazil. New York: Columbia University Press, 1960.

Wolff, Egon and Frieda. Dicionário Biográfico, Judaizantes e Judeus no Brasil 1500-1808. Rio de Janeiro: E.\&F. Wolff, 1986.

Zwarts, Jac. "Assimilatiepogingen van overheidswege." In Hoofdstukken uit de Geschiedenis der Joden in Nederland. Edited by Jac. Zwarts,130-55. Zutphen: W.J. Thieme, 1929.

Zwarts, Jac. “De Joodse gemeenten buiten Amsterdam." In Geschiedenis der Joden in Nederland. Edited by Henk Brugmans and Abraham Frank, 382-453. Amsterdam: Van Holkema \& Warendorf, 1940. 


\title{
Dispute Resolution and Kahal Kadosh Talmud Torah: Community Forum and Legal Acculturation in Eighteenth-Century Amsterdam
}

\author{
Evelyne Oliel-Grausz
}

Introduction

This contribution focuses on a little known aspect of Sephardic history: the role of the kehilla or community, and its related institutions, as a forum for the settlement of disputes in Amsterdam in the seventeenth and eighteenth centuries. Whereas general depictions of the emergence of the Western diaspora are common in the historical literature of the past decades, in-depth analyses of the functional similarities and dissimilarities of the Sephardic kehillot are too rarely conducted. ${ }^{1}$ As is well known, the Western Sephardic diaspora communities evolved from shared models into distinctive communal entities through a process of differentiation shaped both by internal and external dynamics. The early seventeenth-century Portuguese kehillot on the Elbe and Amstel adopted and adapted the Venetian community model and, in turn, Amsterdam's institutions inspired the London community's 1663 statutes. Further West, rippling influences from the Dutch and English models shaped the New World and Caribbean communities. With each step of this evolution,

1 For a historical introduction to the genesis and development of the Western Sephardic Diaspora, see Yosef Kaplan, "The Sephardim in North-Western Europe and the New World," in Moreshet Sepharad: The Sephardic Legacy, ed. Haim Beinart (Jerusalem: Magnes Press, 1992), 240-87; for a comparison of the communal enactments regarding excommunication in Amsterdam and Hamburg, see Yosef Kaplan, "The Place of the Herem in the Sephardic Community of Hamburg during the Seventeenth Century," in Die Sefarden in Hamburg. Zur Geschichte einer Minderheit, ed. Michael Studemund Halévy (Hamburg: Helmut Buske Verlag, 1994), 63-88; for a topical comparative analysis of communal institutions, see Miriam Bodian, "The Escamot of the Spanish Portuguese Jewish Community of London, 1664," Michael 9 (1985): 9-15; and Bodian, "The 'Portuguese' Dowry Societies in Venice and Amsterdam. A Case Study in Communal Differentiation within the Marrano Diaspora," Italia $6(1987): 30-61$.

(C) EVELYNE OLIEL-GRAUSZ, 2019 | DOI:10.1163/9789004392489_010

This is an open access chapter distributed under the terms of the prevailing CC-BY-NC License at the time of publication. 
local constraints and opportunities interacted with and influenced these shared socio-religious institutional models. ${ }^{2}$

Looking at the Portuguese community as a legal forum seems to run counter to the impression that the Dutch and Western Sephardim often resorted to secular legal resources to settle their commercial or family disputes, such as private arbitration and local or superior Dutch courts. Sifting through Amsterdam notarial deeds for documents pertaining to the Portuguese, E.M. Koen has produced numerous instances of notarial deeds of arbitration, ${ }^{3}$ and several case studies have emphasized the common use of ordinary courts made by the Sephardim. ${ }^{4}$ Without denying the reality of the presence of the Sephardim in these better known legal forums, the purpose of this study is to further our knowledge of community involvement in dispute settlement in Amsterdam while, at the same time, to provide a relevant interpretative framework congruent both with Sephardic history and the legal Dutch context. How important was the Jewish community forum for dispute resolution? How did it function, who resorted to it, and why? How should we interpret the enduring existence of that forum into the eighteenth century? Does it testify to some form of judicial and communal autonomy? Or should the very notion and category of autonomy be revisited or dismissed and a new interpretative framework proposed?

2 These processes feature at the heart of the European Research Council Program led by Professor Yosef Kaplan whom I thank warmly for inviting me twice: in March 2015 for a seminar and in November 2016 for the final conference. The stimulating exchanges with the post doctoral research team, enhanced by everyone's firsthand and utter familiarity with Western Sephardics' mores and lore, left me with fond memories.

3 "Notarial Records Relating to the Portuguese Jews in Amsterdam up to 1639," Studia Rosenthaliana (1973-2001).

4 See the references to Jewish cases tried by Dutch courts: Arend H. Huussen, "The Legal Position of the Jews in the Dutch Republic c. 1590-1796," in Dutch Jewry. Its History and Secular Culture (1500-200o), ed. Jonathan Israel and Reinier Salverda (Leiden: Brill, 2002), 37, n. 33; Swetschinski, Reluctant Cosmopolitans, chap. 5, 225 ff.; for major cases of litigation between Jewish merchants in the early seventeenth century, Jessica Vance Roitman, The Same but Different?: Inter-Cultural Trade and the Sephardim (Leiden: Brill, 2011); for a few cause célèbres, see Leo Fuks, "Litigation among Amsterdam Sephardim in the 17th Century," in Aspects of Jewish Life in the Netherlands. A Selection from the Writings of Leo Fuks, ed. Renate G. Fuks-Mansfeld (Assen: Van Gorcum, 1995), 65-80; Oscar Gelderbloom mentions the involvement of arbiters in fifty-seven business conflicts between 1602 and 1627 to be found in notarial deeds that survive belonging to Portuguese merchants in Amsterdam, see Oscar Gelderbloom, Cities of Commerce: The Institutional Foundations of International Trade in the Low Countries, 1250-1650 (Princeton, NJ: Princeton University Press, 2013), 106; for general reflections on business practices and litigation, cross and intracultural, see Catia Antunes, "On Cosmopolitanism and Cross-Culturalism: An Enquiry into the Business Practices and Multiple Identities of the Portuguese Merchants of Amsterdam," in Cosmopolitanism in the Portuguese-Speaking World, ed. Francisco Betencourt (Leiden: Brill, 2017) 23-39. 
This contribution will argue that the forms and scope of the functions of the kehilla in dispute settlement in Amsterdam testify to mechanisms of social discipline that, while rooted in Jewish traditions of mediation or arbitration, are best explained within the general context of Dutch self-ruled churches. The issue of dispute settlement may also help shed some light on a paradigm of confessionalization applicable to early modern Jewish societies.

The study presented here originated in my research on community, trade, and family networks in the Sephardic diaspora, which brought to light many forms of intersection between the communal and economic sphere. This led me to investigate further-and to question - the widely held notion that the kehilla and its institutions had little to do with economic issues or mercantile matters, that, as Yosef Kaplan phrased it in the introduction to his collection of essays, the community restricted its realm of intervention to the sacred and "conferred almost full autonomy of values in the economic sphere." The traditional viewpoint may have stemmed from the fact that few of the community's ordinances deal directly with mercantile or economic matters, and those that do concern only compliance with Dutch monetary or customs regulations, as emphasized in Daniel Swetchinski's work. ${ }^{6}$ The facts and analysis presented here challenge the idea that the early process of secularization of the Amsterdam Portuguese community went hand in hand with a segregation of the spheres of communal and of economic life. Dispute settlement is an area where these spheres intersected significantly. A little known cache of documents in the Portuguese community archives in Amsterdam relating to community mediated or arbitrated disputes provided the first trigger to an investigation that was later extended to Hamburg, London, Bordeaux, and Livorno. The broad geographical spectrum spanned by the investigation, which includes kehillot developing within political and legal contexts as different as Amsterdam, Hamburg, London, Bordeaux, or a fortiori Livorno, where the community court functioned as a first instance Jewish court, may seem unusual in a field still characterized by a monographic or compartimentalized approach. But such a comparative approach produces an analytical toolkit with application beyond the realm of community dispute resolution in the diaspora, providing a useful methodology for understanding the process of transformation of the many functions of the kehilla.

5 Yosef Kaplan, An Alternative Path to Modernity. The Sephardi Diaspora in Western Europe (Leiden: Brill, 2000), 21.

6 Daniel M. Swetschinski, Reluctant Cosmopolitans. The Portuguese Jews of Seventeenth-Century Amsterdam (London: Littman Library of Jewish Civilization, 2000), 184, 218-19. 
I will begin by tracing the seventeenth-century history of community regulations and procedures in Amsterdam regarding dispute resolution processes and the issue of taking cases to local Gentile courts. I will then present the community forum and settlement process as it is documented in the corpus of eighteenth-century sources presented below, and will illustrate it with selected cases. Finally, I will propose an interpretation of this data grounded in the double context of Jewish and Dutch traditions and cultures of arbitration, using the approach of legal anthropology.

\section{Early Community Regulations and Dispute Settlement}

Tracing the origins and evolution of the kehilla's normative production on disputes involving Jewish parties and judicial action constitutes a necessary preliminary. ${ }^{7}$ At the end of the sixteenth century, Portuguese New Christians and Jews had begun to settle in Amsterdam, gaining tacit recognition from the magistrates in 1614 with the acquisition of a burial ground in Oudekerk. The legal framework of their establishment, interaction with Dutch authorities, and gradual organization was best described as "a favourable mixture of explicit restrictions and implicit freedoms," ${ }^{8}$ and the absence of an overall statute or charter, befitting the Dutch model of a "tolerance sans édit." During the first decades of the seventeenth century, the Sephardim established three distinct kehillot, Beit Yaacov, Neveh Shalom, and Beit Israel, which merged into a united community in 1639, Talmud Torah. In 1632, a twenty-article code relating to dispute-handling was drawn up by the board of the Imposta, which served as a steering committee for the three congregations, and which is the most extensive attempt at regulating internal conflicts and access to courts. ${ }^{10}$ The numerous motives that prompted its redaction are described in the preamble: the need to act in defense of the Law in the face of the frequent and sinful resort to local judges, the will to conform to the mores of other Jewish

7 Our own analysis is greatly indebted in this task to Yosef Kaplan's article, "EighteenthCentury Rulings by the Rabbinical Court of Amsterdam's Community and Their SocioHistorical Significance," [Hebrew] in Studies in the History of Dutch Jewry 5 (1988): 1-54.

8 Swetschinski, Reluctant Cosmopolitans, 24, and 12-25 on these and the few legal enactments regarding the Jews.

9 Willem Frijhoff, "La tolérance sans édit: la situation dans les Provinces-Unies," in L'acceptation de l'autre. De l'Edit de Nantes à nos jours, ed. Jean Delumeau (Paris: Fayard, 2000), 86-107.

10 Stadsarchief Amsterdam (hereafter, SAA) 334, 13, fols. 88-91, 15 Kislev 5393 [28 November 1632], large excerpts from this code are quoted in Kaplan, "Eighteenth-Century Rulings," $2-3$. In this case the page numbering is the pencilled one. 
communities, relieving the burden imposed on local judges, and avoiding the high expenses incurred in lawsuits, particularly where the parties lacked sufficient knowledge of the language. The last article states that the code be read publicly from the pulpit twice a year, once on "sabat agadol," the Saturday preceding Passover, and once on "sabat tesuba," between Rosh Hashana and Yom Kippur.

Article 1 describes in great detail the stages of the procedure. If a dispute arises between Jews and they cannot reach agreement, the plaintiff appears before the deputados, the appointed representatives of the three congregations. The opposing party is then summoned by the relevant samas (beadle). ${ }^{11}$ If the opposing party fails to appear in response to the first summons, a fine of hu soldo is imposed. The fine increases to a florin for failure to appear in response to the second summons. After the three unsuccessful summonses, a ruling is made in absentia. Anyone who refuses to comply within thirty days is effectively put under ban, which may refer to a minor form of excommunication ("apartado de todo Israel en todas as enosgas"). ${ }^{12}$

If both parties appear for the hearing, either can reject deputados based on perceived bias due to kinship (article 4). If the deputados cannot bring the parties to agreement, they attempt to appoint at least three judges acceptable by the parties. Any party who fails to agree to at least three mutually-acceptable proposed judges within fifteen days is "separated" (banned) from the three communities (article 5). The judges must do their utmost to produce a compromise consistent with the [Jewish] Law as well as with the "juizo dos jentes," which could refer here to the jus gentium. Those who do not abide by the compromise face the penalty of "separation."

Deputados are also responsible for implementing private compromises drawn without their intercession. These private compromises also carry the penalty of "separation" for a defaulting party (article 7). When a party claims lack of sufficient resources to pay the amount required under a fine, compromise or ruling, the deputados organize a proclamation in the three congregations, including a call for anybody holding assets belonging to the party to come forward (article 13).

Article 9, fully quoted and translated by Kaplan, is of particular importance for our understanding of the Amsterdam kehilla dispute resolution process,

11 The beadle from the congregation in charge at that time of the returns of the imposta, a tax on imports and exports.

12 On the vocabulary regarding excommunication, and the often equivalent use of herem or apartar, see Kaplan, "The Place of the Herem in the Sefardic Community of Hamburg during the Seventeenth Century," 71. 
and for comparison with other community regulations. It states that although the deputados, or the judges they select, shall decide as much as possible according to Jewish law, and consult with experts knowledgeable about Jewish law, they may also consider "ho estilo mercantile," mercantile usage when they consider it relevant. ${ }^{13}$

The 1632 code provides that, in general, any Jew who does not follow its procedures, and takes a fellow Jew to a secular court, even when both parties agree to take their dispute to said court, will be separated "da nasao em todas as 3 esnogas" (from all three congregations of the Nation), and will be reunited only upon payment of a heavy fine of twenty florins (article 11). If, despite the ban, a Jew persists in seeking justice or execution outside the fold, the deputados will grant permission to the opposing party to defend itself in a court of the realm, but will prohibit all other Jews from testifying for, or helping, the noncompliant party (article 12). However, in cases concerning seizure of property, letters of exchange, insurance matters, or distant courts, the parties may use a Gentile court after obtaining permission from community officials (article 14).

The lengthy and detailed 1632 code contrasts sharply with the extreme brevity of the dispute resolution provisions included in a single article of the 1639 merger agreement that served as the basis for the governance of the united community, Kahal Kadosh Talmud Torah. These stipulations, besides being terse, are also less stringent and ambitious. The merger agreement stipulates that, should a dispute arise between two Jews on an issue other than letters of exchange or seizure, after a summons delivered by the beadle, the parties appear in front of the Mahamad, which encourages them to choose judges-arbitrators. If, within eight days, they fail to do so, or, if once chosen, the arbitrators do not achieve their mission, the parties are free to take their case to court. A penalty is implied for those who go to the regular courts without permission. ${ }^{14}$

13 Kaplan, "Eighteenth-Century Rulings," 3.

14 SAA 334-19, Escamoth A (5398-5440), fol. 84 [4 v], article 33 of the merger agreement, 28 veadar 5399 [3 April 1639]: "quoalquer yudeo que tenha pertencoins ou duvidas com seu companhejro sobre materia de fazendas como nao seya sobre letras de cambeo e arestos em que adilacao lhe pode peryudicar sera obrigado mandar pelo semas sitalo pera o mamad diente de quem ambos averao de apareser e dito mamad os persuadira nomem juizes louvados diante de quem porponhao sua cauza e den suas rezoins pera que fasao todo o posivel por acordalos ecompolos em termo de 8 dias e nao consentido as partes en que se lhe dem louvados, ou nao podendo os louvados acordalos ficarao as partes livres pera porcurarem e defenderem sua justiça aonde quizerem e bem lhes pareser e susedendo que algum sem preceder esta deligensia chame a seo companhejro diante da justica se procedera contra elle como pareca." The merger agreement has been published by Wilhelmina Christina Pieterse, Daniel Levi de Barrios als geschiedschrijver van de Portugees-Israelietische gemeente te Amsterdam in zijn "Triumpho del govierno 
Article 20 of the merger agreement specifies that "denims," an appellation indicating cases bearing a clear relation to Jewish law, will be examined and studied by the salaried hakhamim (rabbis) of the community, and if their vote is a tie, the Mahamad (the governing body of the community) will decide. ${ }^{15}$

Numerous notable and significant changes occurred between the dispute resolution provisions of the 1639 merger agreement and those of the 1632 code. The scope of the self-proclaimed jurisdictional authority of the kahal appears much more limited in 1639. In the merger agreement, all matters may be taken to a secular court after a first communal intercession has been attempted, while the 1632 code allows explicitely only time and enforcement-sensitive mercantile issues to be taken there. More strikingly, the merger agreement omits the threat of separation or excommunication, which occupied a prominent place in several articles from the 1632 code, and mentions only a generic "sanction" for litigants who go to court without permission (likely referring to either to a ban or a fine).

Interpreting these differences requires caution and conjecture. One possible interpretation relies on local factors. The less stringent formulation of 1639 may be ascribed to a process of adaptation to the local environment. Kaplan has suggested in his nuanced analysis of the functions of the herem that the threat of excommunication was removed from some types of ordinances due to pressure from the community elites or to topical religious trends; ;1 it is not

popular" (Amsterdam: Scheltema en Holkema, 1968), 155-167. The initial ascamot feature SAA 334-19, Escamoth A, fols. 106-111 [21-26], 22 Tamuz 5399: this second group does not contain a similar article on jurisdiction, and merely mentions that the nation will not incurr expenses towards Jews condemned by local judges for offenses). As for the translation of "juizes louvados," I propose to opt for judges-arbitrators instead of "honorable judges" (Swetschinski, Reluctant Cosmopolitans, 226). SAA 334-19, Escamoth A (5398-5440), fol. 81 [3], Pieterse, Daniel Levi de Barrios, 160.

16 On the issue of herem see Kaplan, An Alternative Path, 108-42, 168-195; Kaplan, "Deviance and Excommunication in the Eighteenth Century: A Chapter in the Social History of the Sephardic Community of Amsterdam," in Dutch Jewish History: Proceedings of the Fifth Symposium on the History of the Jews in the Netherlands, ed. Jozeph Michman (Assen: Van Gorcum, 1993), 103-115; Kaplan, "Bans in the Sephardic Community of Amsterdam in the Late Seventeenth Century," in Exile and Diaspora: Studies in the History of the Jewish People Presented to Professor Haim Beinart, ed. A. Mirsky et al. (Jerusalem: Ben Zvi Institute, 1988), 517-40 [Hebrew]; see in particular on the erosion of the threat of excommunication in Amsterdam, Yosef Kaplan, "Confessionalization, Discipline and Religious Authority in the Early Modern Western Sephardic Diaspora," in Religious Movements and Transformations in Judaism, Christianity and Islam, ed. Yohanan Friedmann (Jerusalem: The Israel Academy of Sciences and Humanities, 2016), 90-103; see also Anne Oravetz Albert, "The Rabbi and the Rebels: A Pamphlet on the Herem by Rabbi Isaac Aboab da Fonseca," Jewish Quarterly Review 104 (2014): 171-191. 
unreasonable to think that the issue of dispute settlement connected with herem may have seemed a sensitive one in a Dutch context where permission to pronounce bans was at that time granted implicitly only, and where the voluntary nature of the community made enforcement of stringent jurisdictional resolutions impossible. As well, one should remember that the first third of the seventeenth century was a period of intense demographic, social change in Amsterdam and of theological and political turmoil. This was the time of boundary setting for such new groups as the Jews, who settled in a climate marked by toleration and defiance from the Reformed clergy. ${ }^{17}$ Discretion, adaptation, and pragmatism were the key words during these defining precarious decades.

An alternative line of interpretation relies on conjecture regarding non-local events, far away from the Amstel. Research has shown that early Amsterdam kehillot borrowed most of their institutional structure from Italian models, Venice in particular, this imitation being enacted within a context of significant immigration and intense cultural and economic exchanges. ${ }^{18}$ Since the communal Jewish records of Venice have been lost, we cannot compare the 1632 code to Venetian ordinances to seek a putative matrix. But various lacunary sources give some basis for conjecture.

In the Libro Grande, an Italian translation of the community record book for the years 1607-1624 requested by the Venetian government, we find several key features shared by the 1632 Amsterdam code such as the role of judges-arbitrators and the prominent use of excommunication as a sanction or a deterrent. ${ }^{19}$

Moreover, there are reasons to suppose that the Portuguese Jews of Amsterdam received word of the contemporary developments in Venice surrounding the exercise of Jewish community autonomy and autonomous

17 Peter van Rooden, "Jews and Religious Toleration in the Dutch Republic," Calvinism and Religious Toleration in the Dutch Golden Age, ed. R. Po-Chia Hsia et al. (Cambridge: Cambridge University Press, 2002), 132-47.

18 Julie-Marthe Cohen, Judith C.E. Belinfante, "The Ponentini and the Portuguese: The Influence of Venetian Jewry on the Portuguese Jews in Amsterdam," in Het Getto van Venetië-The Ghetto in Venice: Ponentini, Levantini and Tedeschi, 1516-1797, ed. J.-M. Cohen (The Hague: SDU, 1990), 106-24; Jonathan Israel, "The Jews of Venice and Their Links with Holland and with Dutch Jewry (1600-1710)," Gli Ebrei e Venezia, secoli XIV-XVIII, ed. Gaetano Cozzi (Milan: Edizioni Comunita, 1987), 95-116.

19 See David Joshua Malkiel, A Separate Republic. The Mechanics and Dynamics of Venetian Jewish Self-Government, 1607-1624 (Jerusalem: Magnes Press, 1988), 31 ff.; Malkiel, "The Ghetto Republic," in The Jews in Early Modern Venice, ed. Robert C. Davis and Benjamin Ravid (Baltimore: The Johns Hopkins University Press, 2001), 135-42. These features were not specific to Venice, and were to be found elsewhere in Italy, but the Amsterdam-Venice route remains a possible channel of influence. 
justice. A theological jurisconsult, Gaspar Lonigo, described the Venetian Jewish community of the time as "a republic separated from any other dominion." In the early 1630s, an internal feud drew the attention of the Venetian Senate toward the community, and the communal record book of the Venitian kehillot was confiscated, translated, and examined. ${ }^{20}$ The affair culminated years of concern among Venetian authorities concerning Jewish self-government and Jewish courts. The Cattaveri, a Venetian magistracy that had been granted jurisdiction over the ghetto, denounced the community's attempt to prohibit its members access to the local courts. While several aspects of the affair remain unclear, we know that the Jewish community attempted to conceal some incriminating ordinances, resulting possibly in the imprisonment of community officials in $1633 .{ }^{21} \mathrm{~A} 1636$ charter created limitations on the juridictional autonomy of Venetian Jews, required prior permission of authorities for excommunication, and threatened prosecution for violations. ${ }^{22}$

It is reasonable to assume that news of these events traveled to Amsterdam, either through correspondence or as a byproduct of mobility. The flow of exchange between Venice and Amsterdam was cardinal in the early years of Sephardic presence in Holland, as shown by the endeavor of a composite group of merchants who applied to Haarlem for privileges in 1604-5. Communal, rabbinical, private, and commercial correspondence circulated abundantly. Assuming news of events in Venice reached Amsterdam, these worrying developments, either independently or in concert with the local factors described above, could explain the differences between the dispute resultion provisions of the 1632 code and those of the 1639 merger agreement. ${ }^{23}$ Thus, both local and extra-local processes of influence and adaptation may explain why the first construct of a would-be autonomous justice in Amsterdam was toned down between 1632 and 1639 .

Some aspects of the evolution of communal involvement in dispute resolution in Amsterdam up to the early eighteenth century remain unclear. Besides

20 David Joshua Malkiel, "The Tenuous Thread: A Venetian Lawyer's Apology for Jewish SelfGovernment in the Seventeenth Century," AJs Review 12 (1987): 223-50, esp. 225-26.

21 A very favorable report was drafted by Fulgenzio Micanzio, the appointed jurisconsult, in defense of the Jews and Jewish autonomy, but not published it seems. In his report, Micanzio refutes a series of nine objections that can be made to the Libro Grande and the government of the Jews. Objection 8 accuses the Jews to meet as a tribunal, with judicial acts, thus usurping Venetian jurisdiction: see Malkiel, $A$ Separate Republic, $5^{1-52}$.

22 Ibid., 226-32.

23 See for instance the figure of Abraham Aboab (Antonio Faleiro), who had moved from Hamburg to Venice in 1625 , who was corresponding assiduously with Hamburg and Amsterdam into the 1640 s about the remitttance of funds to the Holy Land and the ransom of captives, Israel, “The Jews of Venice," 107-8. 
Yosef Kaplan's abovementioned article on the beit din's rulings, the issue has attracted limited historical attention. Kaplan understands the hakhamim (rabbis) as being the "juizes louvados" (judges-arbitrators) mentioned in the 1639 merger agreement. Swetschinski emphasizes that "There existed little by way of an independent court to adjudicate in communal conflicts, whether between individuals or between yehidim (community members) and parnassim (community leaders). The records do occasionally refer to a rabbinical court, but its mandate appears to have been limited to strictly religious matters. ${ }^{24} \mathrm{He}$ further mentions two instances of supervised arbitration, as being "entirely voluntarily," in 1641 and $1671 .{ }^{25}$ Indeed, if we are to draw conclusions from the material found in the normative compendia of the community, is seems that few cases were submitted to the mediation or arbitration of the community. I am convinced however that besides the cases referred to the hakhamim and to a gradually emerging beit din, there were forms of secular mediation or arbitration under the aegis of the community, for which the records did not survive. Reasoning from the absence of documents is a path not easily favored by the historian. As a support for my argument, I will use a rare occurrence of a dispute that does surface in the seventeenth-century community register. In 1641, two brothers, Abram Israel Pereira Chuchon and Isack Israel Pereira, intent on settling a discord regarding their accounts, appear in front of the Mahamad in order to take a solemn oath. This case offers a glimpse of the ordinary path of settlement from which they slightly deviate: they have agreed to submit to the arbitration of "juizes," i.e., the "judges or arbiters" mentioned in the 1639 regulations (in this case, Daniel de Cassuto and David Salom) and commit to accepting their sentence. The reason explaining their appearance in front of the Mahamad (and in the community register) is that they request a solemn oath: the Hakham Saul Levi Mortera is summoned to administer the said oath upon the book of Scriptures showing the Ten Commandments. ${ }^{26}$ Were it not for this unusual request, the case would have gone unheeded, since little communal material has survived from these early years. As for the abovementioned article 20 describing the referral of cases to the rabbis, I think it describes only a fraction of the existing case load, i.e., the issues potentially involving a din torah. It cannot be inferred from it that all cases were submitted to the rabbis, or that the latter were automatically the "juizes louvados." That article features in the midst of the job description of the community rabbis, and should not be understood as a normative exposition

24 Swetschinski, Reluctant Cosmopolitans, 225.

25 Ibid., 227.

26 SAA 334, 19, fol. 101, 4 Ab 5401 [11 July 1641]. 
regarding jurisdiction. My argument may be summarized in three points: (i) there did exist already in the seventeenth century a community forum for dispute settlement and processes of community arbitration and mediation, the records of which were not preserved, the abovementioned examples and the beit din cases being but a part of it; (ii) the normative process has continued to evolve away from the 1639 pattern into the system described below which confers a central role to the parnassim; and (iii) it became, at the same time, simpler in terms of procedure and more complex in terms of its relations to local courts.

The Communal Forum in the Eighteenth Century: Scope, Practice, Cases

Fast forwarding a few decades, it becomes possible to reconstruct the role of the Amsterdam kehilla in intracommunal dispute settlement using a series of untapped registers and bundles which constitute the central corpus of this contribution. It has been argued that communal dispute settlement predates in an organized manner the period discussed here despite the fact that no such sources have been preserved for the seventeenth century. This contention admittedly jars with the exceptional concern for archives consistently displayed by the Talmud Torah community, and to a lesser extent other Sephardic kehillot. Our corpus consists of sources consigning submission of disputes of all kinds between local Jews, and consequent mediation, arbitration, or adjudication by the community lay leaders, parnassim, sometimes with the assistance of the rabbinical court and sometimes involving local courts in complex patterns of interaction. These sizable sources comprise altogether well over a thousand pages spanning the years between 1710 and 1806 . The contents range from the mere mention of summoning two individuals for community arbitration to full accounts of disputes, sometimes court documents and beit din decisions. ${ }^{27}$

These sources fall into two categories. The first one consists in books of summons and resolutions ("Livro de citaçoes e resoluçoes"), covering the period between 1717 to 1816 with an emphasis on the second half of the eighteenth

27 There is no beit din register in the archives of Talmud Torah of Amsterdam, no real collection of rulings. From the eighteen cases published by Yosef Kaplan from the first half of the eighteenth century, three are to be found as well in the corpus of sources I present here. Beit din rulings are otherwise scattered between the pinkassim (community registers), the correspondence, these particular registers, and random locations. 
century. These registers, written in Portuguese, contain mostly summons and resolutions about disputes between yehidim, but also other items such as adjudication of matsot production and of supply contracts for the poor or charity matters such as the admission of indigents. A second category comprises registers or bundles containing cases referred to the parnassim by local courts. ${ }^{28}$

Between the 1639 article on resolving cases, and the practice aimed at dispute settlement that emerges from this abundant documentation, salient changes have occurred. The process of appointing "juizes louvados," which still exists when cases are referred to the hakhamim, has been replaced by a rather simple configuration, with the potential litigants coming before the gentlemen of the Mahamad. If the latter cannot resolve the dispute, then the parties are allowed to go to (a Gentile) court. A financial penalty remains for those who go to court without permission. A copy of a community resolution found on a loose piece of paper within a file relating to a 1780 case may well illustrate the final stage of the evolution of the procedure, from a failed attempt at imposing compulsory community arbitration in the early seventeenth century to the community deliverance of permission to go to court albeit not without an attempt of settlement:

[N]ao podra nenhù Jahid deste K.K. citar aoutro Jahid em p-a Justiça diante de Eschavins ou outre Tribunal nesta cid[ad]e sem anticipadam[en]te aver pidido licensa aoss[enho]res do $\mathrm{M}[\mathrm{aha}] \mathrm{M}[\mathrm{ad}]$. os quaes nao podendo ajustar as partes concederao a licensa e $\mathrm{q}[\mathrm{ue}] \mathrm{m}$ contravier esta ord $[\mathrm{e}]$ $\mathrm{m}$ sera condenado em $\mathrm{f} .6$ de pena $\mathrm{p}[\mathrm{ar}] \mathrm{a}$ sedaca.

This resolution embodies continuity and change: the enduring feature is thus that the Mahamad grants permission to go to court when no solution is found. The main difference is that the gentlemen of the Mahamad have come to handle the disputes themselves; they do not, in general, appoint arbitrators, but they do refer some cases to the beit din. They have somehow become default arbitrators or mediators. The basic pattern, with many variations, is therefore a two-stage summons, followed, if the summoned party fails to appear or if the parties do not reach an agreement, by license to litigate in court. Transgressors are fined, six guilders, or sanctioned economically for those depending on the kehilla charity.

Such is the basic pattern with many variations. These sources are eloquent both on the fact that in many cases the parnassim merely grant permission to

28 They are part of the archives of the Portuguese Community of Amsterdam, SAA 334, $875^{-880 .}$ 
go to court after a formal attempt at conciliation, but also on their role in those cases willingly submitted by both parties or in which the defendant responds to the summons. No serial treatment of these sources maybe undertaken since the information about the nature of the dispute is very haphazardly provided. Sometimes we have no more than the mere mention, "se ficou ajustado," an arrangement was reached, without further details. A very simple case will illustrate this elementary pattern. In 1731 upon the request of Ishac Lopes Dias and Abraham de Paz who appeared in front of the Mahamad, Moseh Levy Maduro is summoned, presumably by the beadle upon the pretention that he is indebted to them for a large shipment of cod that they sold him. The two names appear with the mention " $1-a$ [primeira] vez." In this case a tentative settlement is reached, and Maduro is granted three months to repay his debt; if he fails to comply, the plaintiffs will be free to go to court. ${ }^{29}$ On the same page, a very common type of notation is to be found, indicative of the procedure but not of the nature of the case: Selomo de Rocha assigns the widow of Ishac Cohen Peixotto, "1-a vez, 2-a vez," after which license [to go to court] is granted in view of the absence of the other party. ${ }^{30}$

What matters were handled by the parnassim? First of all, it is interesting to emphasize that the parnassim fulfill a variety of social-economic functions often connected with the settlement of conflicts, such as notarial functions, certificating and witnessing the signature of agreements, the authentification of documents, the cancellation of contracts, the dissolution of partnerships, and the destruction of receipts; they also provide a communal safe for documents.

Next, parnassim handled certain categories of disputes. A large part of the cases relates to a generic category involving debts and the recovery of money. Many simple cases give little information about the nature of the debt: in settling the dispute, the parnassim decide on the legitimacy of the claim, and often on installment plans for the reimbursement. A second less generic category concerns family-related disputes: cases of contested inheritance, of marital discord sometimes with monetary claims, ketubah claims, disputes about the maintenance of widowed mothers or young children, family feuds, often with money at stake. A third category comprises commercial transactions gone afoul (which somehow overlaps with the first category). Of these, a small number of cases involve international trade and traveling merchandise, between North Africa and Holland, as well as letters of exchange, a practice that seems

$29 \quad$ SAA 334875 , fol. 70 .

3o Ibid.: "se deu licensa por nao aver paresidos na contraparte." 
to conflict with the community ordinance dating back to the early days of the kehilla mentioned earlier which excluded letters of exchange from the scope of the imposed community arbitration. These cases simply illustrate the voluntary dimension of the resort to the community intercession for solving disputes. A fourth category includes a broad spectrum of professional disputes, such as discords in the diamond industry; disputes about apprenticeship or wages; contested ownership of equipment, such as a diamond grinder for instance; disputes arising in the world of brokers about brokerage fees, or in the printing business; disagreement about work contracts between the community and its employees or subcontractors for cheese, meat, and between an emissary from Jerusalem and his assistant.

In contrast then with the original merger agreement of the Portuguese community which stipulated that the plaintiff would have the beadle summon the other party, that the Mahamad would encourage them to choose arbitrators, and if they fail to agree they would then be free to take their case to court, in these eighteenth-century situations, the parnassim have become the statutory arbiters or mediators in most cases.

Many different patterns of settlement or attempts at settlement and legal itineraries emerge from this corpus, which involve a variety of actors: litigants, lay leaders, rabbis, local courts, sometimes Jewish solicitors. The processes span a spectrum from simple to complex. The most common and simple pattern is one party appearing to have the other party summoned and, after two ineffective summons, getting permission to go to court. When both parties show up voluntarily or after a summons, the role of the parnassim in the attempt to reach a solution may take several forms: mediation, arbitration, referral to the beit din, which can be analyzed under the halakhic categories of pesharah, brirah, or psak - agreement, arbitral sentence, and rabbinical decision. However, the boundaries between these categories-between mediation and arbitration-are sometimes clear, and sometimes blurred: the parties may reach an agreement with the mediation of the Mahamad, which then functions as would a notary, by recording the agreement signed by both parties, or they sometimes explicitely underwrite a submission to the arbitration of the parnassim. Often, submissions written by the parties themselves are included in the registers, but this is not always the case. For example, the following appears in a 1736 document signed by Ester, widow of Davi Suzarte, and Mosseh Delgado: "we undersigned by this document submit all our differences to the Gentlemen of the Mahamad with full power and authorize them as boms homems to decide and draw an agreement on these differences, which decision and agreement we promise to fulfill and observe inviolably as 
if they had been passed by the Supreme Court of Holland, submitting to the agreement as of right [...]." ${ }^{31}$ Delgado is condemned to repay his debt within six months. My understanding is that even in cases without a similar document indicating the submission of the parties, there is an implicit submission of the parties, in conformity with the ascamot; as to the reference to the Supreme Court of Holland, it is probably to be understood as a commitment not to take the case elsewhere, not to appeal it.

In situations involving the reimbursement of debts, when both parties agree to the communal arbitration, the parnassim often decide on practical installment plans. In these cases, the parnassim provide what can be read as a convenient infrajudicial forum of settlement, an alternative locus of dispute resolution that does not involve going to court. But not all parties agree to conform to the local communal modes of mediation and arbitration. In a few cases, involving North African Jews, the parties are not satisfied with the abovementioned pattern and require a halakhic arbitration procedure, by which each party chooses an arbitrator and both arbitrators choose a third one $(z a v l a): 32$ in a document from 1736 , Semuel and David Abendalak, possibly having a brotherly feud, sign a compromise in front of the Mahamad stipulating that they will appoint two persons who will appoint a third person in order to solve a dispute on business accounts, as "birurim," the (Hebrew word being used here in the Portuguese text, which is uncommon) ${ }^{33}$ In this case we see the encounter of different legal cultures within the world of Jewish litigants themselves.

31 "Nos abaixo firmados declaramos pella presentes comprometer aossr-es do Mahamad do KK de TT todas as nossas diferenças, com amplio poder que p. esta otorgamos aditos ssrs como boms homens para decidilas \& ajustalas, cuio decisao e ajuste prometimos cumprir e observar inviolavelm-te como se fosse pasado pella Corte Suprema de Holanda, submetendonos ao cumprimento como de direito feito a boa fee em Amsterdam 2 de Janeiro 1736." SAA 334, 875, fol. 164 .

32 The Mishnah (Sanhedrin 3:1) records a dispute between R. Meir and other scholars, the former stating that each party chooses one arbitrator and both choose the third, while the other scholars hold that the two arbitrators choose the third. The scholars sought to lend to arbitration proceedings the appearance of a Jewish court, composed generally of three judges, in contrast with the single arbiter customary under Roman law; see also Encyclopedia Talmudit (Jerusalem, 1965), 12: 684-697, s.v. zavla [Hebrew].

33 SAA 334, 875, fol. 69: "Semuel Abendalak y David Abendalak. Em 30 de sebat 5496 nos abaixo firmados nos comprometemos pella presente p. intervensao doss-rs do Mahamad, que nomearemos dentro de $8 \mathrm{~d}$. duas pessoas com faculdade q. possao nomear hum terceiro p-a que como berurim difinao nossas contas $\&$ ajustem as diferensas q. sobre ellas temos, com todo o poder como se fosse pasado pella Corte Suprema. Em I de Adar declarao oss-rs dittos nomearem p. berurim Jacob Azulay \& R. Hiya Cohen. שמואל דלאק דוד, ו דלאק [signatures]." 
More complex legal paths involve a referral from local courts to the parnassim: in such elaborate cases the parnassim's intervention is but one of the stages in the litigation process. Most of these referrals come from the small claims court, some from the aldermen court, the municipal court of Amsterdam. It maybe useful to recall that the Amsterdam court landscape is quite different from that of other European port cities, for there never was a merchant court in Amsterdam, similar to consular justice in Bordeaux for instance or to the Consoli di Mare in Pisa, and foreign merchants were not granted jurisdictional privileges. Instead, the local court adjudicated on all matters, with the help of subsidiary specialized courts that were created between the end of the sixteenth and the middle of the seventeenth century: the Orphan Chamber (1578), the Insurance Chamber (1598), the commissioners of Small Claims (kleine zaken) (1611), the Chamber of Insolvent Estates (1627), and finally the commissioners of Maritime Affairs (1641). ${ }^{34}$ The so-called small claims court was created at the end of the sixteenth century to relieve the city court, and handled litigation involving up to six hundred guilders during our period, which was obviously not such a small claim. ${ }^{35}$

Two different patterns of referral may occur: the case may be referred to the parnassim only, or to the parnassim and then to the rabbinical court, the former always reporting back to the court with the opinion of the beit din. The word opinion is chosen with care, since the beit din works here as a consultant body, the ultimate sentence being passed by the court at the end of the referral process. Naturally, large numbers of cases escaped the arbitration of the parnassim, either because the summoned party refused to appear, or because they were simply not submitted for arbitration and went directly to court or to private arbitration, voluntary or court ordered.

The following case from 1781 provides an illustration of a complex pattern of settlement involving local courts, parnassim, and rabbis. Isaac Pretto Henriques has signed an obligation in the amount of 2,200 guilders to Daniel Spinoza and Rachel Chumaceiro, a married couple, and has committed himself to paying it when his mother dies. Now the lenders claim that, besides the original amount, he owes them sixty guilders a year for the five years that have elapsed since the signature of that obligation. The borrowers, who have already started paying some of the requested "interest," claim that it is illegal

34 See Oscar Gelderbloom, Cities of Commerce: The Institutional Foundations of International Trade in the Low Countries, 1250-1650 (Princeton, NJ: Princeton University Press, 2013), $121-26$.

35 At the beginning of the eighteenth century, a sailor in Amsterdam earned a monthly salary of approximately fifteen guilders a month. 
interest according to Jewish law (ribit); the lenders object to that definition, asserting that it is not a loan but rather a sort of life annuity since it was connected to the life of the borrower's mother. Reconstructed from the documents emanating from the the kahal-the beit din sentence and the report from the parnassim to the small claims court — the legal path develops as follows: the case is submitted to a local court, the court of small claims (kleine zaken), and that court refers it to the Portuguese parnassim. They try to bring the parties to an agreement, and when that does not work, they refer the case to a beit din of five. A beit din of five decides that it is indeed a loan, a case of outright ribit (forbidden interest), and that whatever has been payed already as interest has to be reimbursed. Their sentence is sent back to the court. ${ }^{36}$ Judging from the scarce documentation we have on that case, the forum of first choice for the borrowing couple was not the community but the local court. The global amount of the loan exceeds the limits of the said court, but the sum at stake is lower here, since the disagreement only bears on interest. The intervention of the parnassim and of the beit din happens as one of the stages of the original legal procedure. Once involved, the parnassim attempt at serving as an alternative forum for settlement by trying to bring the parties to agree, and therefore terminate the legal action by their mediation. Interestingly, the case refers to a distinctive normative system, the Mosaic law, on which the parnassim and subsequently the din, are called upon.

\section{The Community as a Legal Resource: Categories of Interpretation} and Contextualization

The brief presentation of the corpus and the few examples developed attest to a significant function of mediation, arbitration, and adjudication activity of the Portuguese community, adding a novel dimension to our previous understanding of its dynamics. The analysis of that role can be conducted along several frameworks of historical interpretation.

The category most naturally conjured up and most easily associated with pre-emancipation Jewish communities is the notion of autonomy. Yosef Kaplan emphasizes that over the course of the seventeenth century the authorities acknowledged the autonomous rights of the Jewish communities (both

36 SAA 334,880 , fols. $58-60$. The beit din sentence is dated 5 Tamuz 5541 [28 June 1781], and signed by Shelomo Shalem, Yehuda Piza, Moshe de Shemuel Yisrael, Moshe Rodriges Lopes, Abraham son of David Fidanque. 
Ashkenazic and Sephardic) and their full authority upon their members. ${ }^{37}$ At the same time, since the community was but a voluntary association and not a compulsory corporate entity (like the Bordeaux Nation for instance), the de facto authority was curbed. What precisely did that autonomy imply? Huussen, describing a complex picture of some form of autonomy that went together with the interference of the authorities in the internal affairs of the group, formulates the idea that "the Jews were autonomous - more than any other second-rate group of inhabitants of the Republic, such as the Roman Catholics and the Protestant dissenters-but not independent"; a separate group subject to a few restrictions and enjoying special exemptions, but also recognized as enjoying the ordinary status of subject and inhabitant of the Republic (1657). ${ }^{38}$ The most comprehensive, though concise, discussion of the nature of the autonomy enjoyed by Amsterdam Jews is to be found in Swetschinski, ${ }^{39}$ who notes that in the absence of historical precedents to Jewish presence in Amsterdam and of a charter, there was "obscurity surrounding the degree of autonomy exercised by the Jewish community." 40 The main issues about which that degree of autonomy was tested and measured were the use of herem and the authority of the Mahamad in a series of matrimonial disputes, which led to sometimes contradictory sentences and statements by the local and superior courts and by the municipal authorities, revealing the difficulty for the burgomasters themselves in formulating a clear cut policy. The clearest statement was the one formulated by the representatives of the Burgomasters of Amsterdam with the States of Holland in May 1683 in which they supported the use of excommunication noting the "freedoms, rights and prerogatives" enjoyed by the Jews, including "the exercise of synagogal [or church] discipline [that] has always been one of the most important."41 The area of exercise of autonomy was thus defined by the notion of "Church affairs," church discipline, and was explicitly foreign to any notion of judicial autonomy. There was no corporate judicial autonomy that could be compared with the autonomy bestowed upon Italian kehillot, even when setting aside the

37 Yosef Kaplan, “Mokum' and 'Mediene': Jewish Autonomy in the Dutch Republic," [Hebrew] in Kehal Yisrael. Jewish Self-Rule Through the Ages, vol. 2, The Middle Ages and Early Modern Period, ed. Avraham Grossman and Yosef Kaplan (Jerusalem: The Zalman Shazar Center, Jerusalem, 2004), 324-25.

38 Huussen, "The Legal Position," 35-38.

39 Swetschinski, Reluctant Cosmopolitans, 15-20.

40 Ibid., 15.

41 Ibid., 16. 
exceptional case of Livono, or upon Ottoman Jewry. ${ }^{42}$ From the point of view of the communal institutions, as mentioned above, there was however a normative propensity of the Amsterdam kehilla to try and encompass or supervise intra Jewish conflicts.

It seems that despite its prevalent use, the traditional notion of autonomy may not be the most relevant framework of interpretation to understand the involvement of the community and the existence of an internal forum of dispute settlement. An alternative and more fruitful interpretation calls for a reflection upon the notions of legal cultures, legal acculturation, and their relevance to the early modern Jewish world. The field had been relinquished to jurists or specialists of halakha, but of late it has been reclaimed by historians, and the renewed interest in Jews and the judiciary garnered much attention, indicating a "judicial turn" in Jewish studies. ${ }^{43}$

The analysis of these litigation patterns is best achieved through the approach of legal anthropology, shifting from the description of legal institutions to a focus on the "use of justice" 44 from bottom up, with the idea that the role of judicial and infrajudicial institutions is also determined and modeled by those who use it. The complexity of these paths to settlement comes from the fact that resorting to a judicial forum is sometimes only part of a strategy to achieve some form of settlement, whether in court or out of court. Early

42 Attilio Milano, "L'amministrazione della giustizia presso gli ebrei di Livorno nel Seisettecento," in Scritti in memoria di Leone Carpi, ed. Daniel Carpi et al. (Jerusalem: Sally Meyer Foundation, 1967), 133-64; Renzo Toaff, La Nazione ebrea a Livorno e a Pisa (1591-170o) (Florence: Olschki, 1990), 205-39; on the Ottoman Empire, see the important article of Joseph Hacker, who reasseses critically the scope of de facto judicial autonomy, "Jewish Autonomy in the Ottoman Empire, Its Scope and Limits: Jewish Courts from the Sixteenth to the Eighteenth Centuries," in The Jews of the Ottoman Empire, ed. Avigdor Levy (Princeton, NJ: Darwin Press/Institute of Turkish Studies, 1994), $165 \mathrm{ff}$.

43 Among the most important publications related to this "judicial turn," see Jay R. Berkovitz, Protocols of Justice. The Pinkas of the Metz Rabbinic Court (Leiden: Brill, 2014), 2 vols.; Edward Fram, A Window on Their World: The Court Diary of Rabbi Hayyim Gundersheim, Frankfurt Am Main 1773-1794 (Cincinnati: Hebrew Union College Press, 2012); Verena Kasper-Marienberg, "Vor Euer Kayserlichen MayestätJustiz-Thron": die Frankfurterjüdische Gemeinde am Reichshofrat in josephinischer Zeit (1765-179o) (Innsbrück: StudienVerlag, 2012); A. Gotzmann, "At Home in Many Worlds? Thoughts about New Concepts in Jewish Legal History," Jahrbuch des Simon-Dubnow-Instituts (2003): 413-36; Jessica Marglin, Across Legal Lines. Jews and Muslims in Modern Morocco (New Haven: Yale University Press, 2016).

44 See for the notion of "use of justice," Martin Dinges, "The Uses of Justice as a Form of Social Control in Early Modern Europe," in Social Control in Europe, 1500-180o, ed. Herman Roodenburg (Columbus: Ohio State University Press, 2004), 159-75, and John Jordan, "Rethinking Disputes and Settlements: How Historians Can Use Legal Anthropology," in Cultures of Conflict Resolution in Early Modern Europe, ed. Stephen Cummins and Laura Kounine (London: Routledge, 2016), 17-50. 
modern societies can be characterized by environments of legal pluralism, which can be simply defined as the existence of more than one legal order or legal system in a given society. For a given contentious situation, various options for settlement were available, some involving litigation, some not. Jewish socio-religious institutions and legal systems added yet further options, and community arbitration or mediation should be understood as part of a wider spectrum of legal pluralism. A vast array of options was thus open to the Jews of Amsterdam, and elsewhere. For a non-judicial settlement, they could choose private arbitration, using a notary, sometimes resorting to the kahal officials for notarial type functions. For an infrajudicial settlement, they could resort to semi formal forms of arbitration such as the community parnassim, or forums that verged on the infrajudicial, such as the small claims court (kleine zaken). Other infrajudicial forums of settlement existed that were not available for Jews, such as guilds. For a judicial settlement, Jews could access the ordinary and extraordinary courts, and they made regular use of the Court and of the Supreme Court of Holland, often, but not exclusively, in intercultural circumstances. ${ }^{45}$

The notion of "legal pluralism" casts no magical light on our understanding, and it is of limited analytical use unless broken up into subnotions and categories. The ${ }_{1781}$ Pretto/Chumaceiro interest case related above can conveniently illustrate that idea. If the parties had gone from the parnassim to the local court, it could have indicated a situation of jurisdictional legal. But because the only jurisdiction at work was the small claims court, it should be more relevantly described as normative legal pluralism, the coexistence of systems of norms within the same society or group. This case could be read as an instance of "norm-shopping" rather than "court-shopping" since the plaintiff invokes in front of a secular court the Mosaic law forbidding interest between fellow Jews. Of course, in this case as in many others, it is also plausible that the resort to Jewish law halfway through the payment of the debt is but a strategy to get a better settlement.

45 A.J.B. Sirks, "The Supreme Court of Holland and Zeeland Judging Cases in the Early Eighteenth Century," in Judges and Judging in the History of the Common Law and Civil Law: From Antiquity to Modern Times, ed. Paul Brand and Joshua Getzler (Cambridge: Cambridge University Press, 2012), 234-56. On the Jews and the Supreme Court in Holland and the States General, see the cases analyzed in Jessica Roitman, "A Flock of Wolves Instead of Sheep: The Dutch West India Company, Conflict Resolution, and the Jewish Community of Curaçao in the Eighteenth century," in The Jews in the Caribbean, ed. Jane S. Gerber (London: Littman Library of Jewish Civilization, 2014), 85-105; Cátia Antunes, Jessica Roitman, "A War of Words: Sephardic Merchants, (Inter)National Incidents, and Litigation in the Dutch Republic, 1580-1640," Jewish Culture and History 16 (2015): 24-44. 
Because of the possible interplay between legal systems, Jewish and nonJewish, and sometimes local and extra local Jews had more legal options than other groups. ${ }^{46}$ But it is difficult to ascertain whether the Jews did more "court hopping" and "court shopping" in hope of better settlements than their contemporaries.

In Amsterdam, the concerns voiced in the early 1632 regulations regarding the ignorance of the local language hardly seem a relevant motive in the second half of the eighteenth century, and it would appear that potential litigants lacked none of the needed skills for navigating the system. In Livorno, where the issue of jurisdiction always occupied a central place in the life and the politics of the kehilla, proclamations were often made from the pulpit about community regulations, and about proper and improper ways to seek justice and address the authorities, and public readings fostered indirectly some form of legal acculturation and education. The register of the Livorno community contains a number of deliberations enjoining the reading of legal enactments in public, from the teba (pulpit) at the synagogue, usually on the Sabbath, and sometimes on issues somewhat technical. ${ }^{47}$

How is the relatively widespread use of intra-community arbitration to be understood in a city where the community is ultimately a voluntary association? As a third and final line of interpretation, it seems that these situations may be best understood within the context of a strong local culture of arbitration, which has been well studied recently. ${ }^{48}$ It is noteworthy that the small claims court also commonly referred numerous cases to the arbitration of "goede mannen," boni homines, specialized by profession, thus requesting a form of professional peer arbitration ${ }^{49}$ It could be argued that the Portuguese community was here used as a particular forum of arbitration, among others, by the civil courts. In that sense, the community arbitration, as well as the judicial referrals to the parnassim, would point to a process of acculturation to the

46 Diasporic or mobile Sephardim added still to this potential interplay between legal systems: an inheritance dispute from Bayonne, brought before the Amsterdam parnassim, invoked local Bayonese customs, Dutch law, and Jewish law.

47 Livorno, ACEL Deliberaçoims do governo, $1715^{-25}$, fols. 4-5: a proclamation is read to remind the merchants featuring on the list from which the additional judges for the court of appeal of the massari that they cannot default when they are summoned.

48 Aries van Meeteren, Op hoop van akkord: instrumenteel forumgebruik bij geschilbeslechting in Leiden in de zeventiende eeuw (In Hope of Agreement. Use of Forums for Dispute Settlements in Seventeenth-Century Leiden) (Hilversum: Uitgeverij Verloren, 2006), 236-270.

49 See for instance the "Register van Goede mannen," in which Jews are listed as arbitrators for professional areas such as Spanish or Gibraltarian trade (SAA 5061, 818, for the year 1704). 
Dutch culture of arbitration within a segmented society, which converges with Jewish traditions or fantasies of autonomy.

Stepping away from the supposedly self-explanatory and often taken for granted framework of ancien regime "autonomy," the role of the kehilla in dispute settlement has to be reexamined within the context of a Dutch society segmented in a variety of self-ruled churches, a segmentation that is a powerful instrument of social control through church discipline. In many ways, the role of the parnassim may be read as a Jewish version of church discipline, and it should be compared to similar forms of social control exercised by other Dutch churches, such as the consistories of the Reformed church of Amsterdam analyzed by Roodenburg. ${ }^{50}$ One of the most convincing comparisons is with the Mennonite practice as it appears from fairly recent research conducted on the largest Mennonite church in Amsterdam and its discipline records between the seventeenth to mid-eighteenth century. ${ }^{51}$ In line with Roodenburg's work on the Dutch Reformed church, Osborne depicts the mechanisms of surveillance set up by and for the Mennonites, the horizontal forces of honor and shame, and the visits paid by the Elders to the home of the congregants, the faults sanctioned often relating to a combination of religious sins and departure from societal norms, as was often the case in Sephardic congregations. ${ }^{52}$ The consistory of the English Reformed church in Amsterdam, studied by Alice Clare Carter, or the Lutheran church studied by Estié, played similar functions. ${ }^{53}$ Alice Clare Carter shows how the Begynhof consistory of the English reformed church in the seventeenth century directly intervened to settle business disputes between its members, providing arbiters, ensuring the payment of a debt, or settling disputes between masters and apprentices.

These studies revolve around the notion of disciplining of a religious group, and enforcing social control through arbitration in a variety of domains,

$50 \quad$ Herman Roodenburg, Onder censuur: de kerkelijke tucht in de gereformeerde gemeente van Amsterdam, 1578-1700 (Hilversum: Verloren, 1990); Roodenburg, "Social Control Viewed from Below: New Perspectives," in Social Control in Europe, 1500-180o, ed. Herman Roodenburg and Pieter Spierenburg (Columbus: Ohio State University Press, 2004), $145^{-158 .}$

$5^{1}$ Troy Osborne, "Mennonites and Social Discipline in Dutch Golden Age" (PhD diss., University of Minnesota, 2007.

$5^{2}$ Ibid., $5^{0-} 5^{2}$.

53 Paul Estié, Het Vluchtige bestaan van de eerste Nederlandse Lutherse gemeente: Antwerpen 1566-1567 (Amsterdam, Rodopi, 1986); Estié, Van afgescheiden gemeente tot kerkgenootschap: geschiedenis van de Hersteld Evangelisch-Luthersen in Amsterdam, 1791-1836 (Hilversum: Verloren, 2007). 
including economic matters such as wages, contracts, or bankruptcies. ${ }^{54}$ Departing from the original paradigm of confessionalization in which church and state worked closely together in shaping the life and beliefs of early modern men and women of three main Christian creeds in what could be called a vertical process of confessionalization, these mechanisms of social discipline depict, on the contrary, a horizontal process of confessionalization in which local churches play a similar role as that played by the State. As Kaplan has emphasized in his seminal article on confessionalization and the early modern Sephardic diaspora, that paradigm allows for a new approach to the notions of community building and group discipline. ${ }^{55}$ The Calvinist "disciplinary revolution from below" finds a Jewish echo in the mechanisms of social controls implemented by the parnassim, with the parnassim functioning like the consistory and the church Elders of the Dutch reformed church. ${ }^{56}$ Within this comparative and contextualized approach, the Sephardic community forum of arbitration or mediation fits into the local pattern of church discipline exercised both by the majority consistories and by the minority churches.

This analysis allows us to describe the role of the Portuguese nation in the settlement of disputes as that of a self-ruled church, or sometimes even an aspiring self-ruled church, implementing an infrajudicial forum of settlement. That forum is embedded in the local court system by a process of mutual legal acculturation, a combination of a strong local and Jewish culture of arbitration, shaped here by the institutional predominance of the Mahamad. When examined within the local Dutch context, the Portuguese community settlement of disputes exhibits the following distinctive features. In terms of a processual-centered perspective, it is an infrajudiciary forum, a Jewish court of small claims of sorts, which aims at reaching a settlement in order to prevent litigation, often catering to claimants who are of modest means. In terms of a norm-centered perspective, it is embedded in the city's legal culture and system of arbitration. Finally, it offers a mechanism of peacemaking and social discipline through which Kahal Kadosh Talmud Torah acts as a self-ruled

54 There are important differences though: unlike the consistories of the English Reformed Church, or unlike well-known Quaker practices, the Jewish community did not ostracize bankrupt merchants or exercise moral control over merchant practices.

55 Yosef Kaplan, "Between Christianity and Judaism in Early Modern Europe: The Confessionalization Process of the Western Sephardic Diaspora," in Judaism, Christianity and Islam in the Course of History: Exchange and Conflicts, ed. Lothar Gall, Dietmar Willoweit (Munich: Oldenbourg Wissenschaftsverlag, 2011), 331-40.

56 Philip Gorski, The Disciplinary Revolution. Calvinim and the Rise of the Early Modern State in Europe (Chicago: University of Chicago Press, 2003), 55-59. 
church that resembles the many other self-ruled churches of this multiconfessional port city.

There is no denying that the activity of mediation and arbitration implementing by the Sephardic nation was modelled by Dutch legal culture, in form and meaning. However, just like caring for the poor was at the same time the enactment of a religious mandate and the fulfillment of a civic duty incumbent upon all local and minority churches, ${ }^{57}$ so was the peace making and dispute settling. Beyond legal acculturation, it was, concomitantly, the implementation of Jewish traditions of mediation and arbitration and a social control mechanism shared by the many self-ruled churches, that developed instruments of social discipline to keep their members in rank.

As a conclusion, a few comparative remarks will be formulated about the various loci of the Sephardic diaspora on the role of the kehilla and its related institutions in dispute settlement.

First, it should be emphasized that there is no correlation between the existence and acknowledgement of the kehilla as a corporate entity on the one hand, and jurisdictional privileges or even a strong measure of internal arbitration on the other, as is shown with the case of Bordeaux or even Bayonne: traces of the parnassim settling disputes are extant, but they are fleeting, not very present, independently of the lacunary state of the documentation. The apparent weakness of community sponsored arbitration finds its explanation first in the fact that community life and institutions remained semi-clandestine until the early eighteenth century (the official Jewish community was not officially acknowledged until 1723), and in the fact that Jews commonly resorted to the merchant court, which answered the need of merchants for a summary and expeditive justice, and to notarial arbitration. ${ }^{58}$ In southwestern France, legal culture and resources combine with a very distinctive historical context to explain the limited scope of internal mediation or arbitration.

Second, the existence of a charter and of privileges does not necessarily imply jurisdictional autonomy, just as their absence, like in London and

57 On the comparison with Mennonites, the governance of the group and the handling of its poor, with the distinction of the deserving poor, see Mary Sprunger, "Mennonites and Sectarian Poor Relief in Golden-Age Amsterdam," in The Reformation of Charity. The Secular and the Religious in Early Modern Poor Relief, ed. Peter Safley (Leiden: Brill, 2003), 151-53.

58 Pierre Damas, Histoire de la juridiction consulaire de Bordeaux (Bordeaux: impr. de Delmas, 1947); for an enlightening approach to Paris consular court, see Amalia D. Kessler, A Revolution in Commerce. The Parisian Merchant Court and the Rise of Commercial Society in Eighteenth-Century France (New Haven: Yale University Press, 2007). 
Amsterdam where the communities are essentially voluntary associations, does not necessarily imply the absence of a forum of dispute settlement.

Third, the historian should not be abused by the apparent institutional similarities of the Sephardic kehillot whose legal functions cannot be understood without a precise knowledge of the local legal environment and culture. Similar practices and similar institutions call for different historical interpretations, as appears from a comparison between Hamburg, London, and Amsterdam. When reading the pleitos and the citaçoes of the Amsterdam kehilla, the procedure, the vocabulary, the conceptual framework often feels almost identical. ${ }^{59}$ And yet, the historical interpretation that is called for is thoroughly different. The activity of the London parnassim cannot be understood without special reference to English harsh legislation on debts; ${ }^{60}$ it is an alternative forum disconnected from the local courts, to be understood within an English legal context and culture which sees the multiplication of justices of peace, of courts of conscience or requests. ${ }^{61}$

Fourth, one major criteria for the interpretation of the role of the kehilla in conflict resolution is whether its activity is articulated to local courts and institutions, or if it is what I call "embedded justice". This is not the case for the London community of Shaar Hashamayim, it's partly the case for Hamburg's Beit Israel where the arbitral sentences passed have the full force of corporate arbitral sentences that can be executed by the local tribunals, and it's partly the case for Amsterdam where as suggested, the Portuguese kehilla functions as a self-ruled church implementing mechanisms of social discipline and at the same time embedded in the local court structure and culture of arbitration. Even in Livorno, despite the extent of the jurisdictional privileges granted to the Jews, the court of the massari (community leaders, equivalent to the parnassim) is anything but an autonomous court; its a Tuscan Jewish court fully embedded in the Tuscan legal architecture, and the massari are often but one stage only in the litigation process.

59 It is part of our current work in progress on dispute resolution and the kehilla institution, "Entre juif et juif."

6o Lamar M. Hill, "Extreme Detriment': Failed Credit and the Narration of Indebtedness in the Jacobean Court of Requests," in Law and Authority in Early Modern England. Essays Presented to Thomas Garden Barnes, ed. Buchanan Sharp and Mark Charles Fissel (Newark: University of Delaware Press, 2007), $136-56$.

61 On London, and the courts of requests for the recovery of small debts that develop during the eighteenth and nineteenth century, William Hutton, The Court of Request (Edinburgh: William and Robert Chambers, 1840); Michelle Slatter, "The Norwich Court of Requests. A Tradition Continued," in Custom, Courts and Counsel. Selected Papers of the 6th Legal British History Conference, ed. K.R. Kiralfi, Michelle Slatter, and Roger Virgoe (London: Routledge 2014), 97-107, in particular 105, n. 2. 
Notions of legal acculturation and interpenetration of legal cultures are far more relevant interpretative tools for conflict resolution in the early modern Jewish world than notions of autonomy. Autonomy may be useful as a depiction of a communal fantasy, or a historical fantasy of Jewish history seen as a self-enclosed autarchic entity, but not as a relevant interpretative category.

\section{Bibliography}

Antunes, Catia. "On Cosmopolitanism and Cross-Culturalism: An Enquiry into the Business Practices and Multiple Identities of the Portuguese Merchants of Amsterdam." In Cosmopolitanism in the Portuguese-speaking World. Edited by Francisco Betencourt, 23-39. Leiden: Brill, 2017.

Antunes, Cátia, and Jessica Roitman. "A War of Words: Sephardic Merchants, (Inter) National Incidents, and Litigation in the Dutch Republic, 1580-1640." Jewish Culture and History 16 (2015): 24-44.

Berkovitz, Jay R. Protocols of Justice. The Pinkas of the Metz Rabbinic Court. 2 vols. Leiden: Brill, 2014.

Bodian, Miriam. "The Escamot of the Spanish Portuguese Jewish Community of London, 1664." Michael 9 (1985): 9-26.

Bodian, Miriam. "The 'Portuguese' Dowry Societies in Venice and Amsterdam. A Case Study in Communal Differentiation within the Marrano Diaspora." Italia 6 (1987): 30-61.

Cohen, Julie-Marthe, and Judith C.E. Belinfante. "The Ponentini and the Portuguese: The Influence of Venetian Jewry on the Portuguese Jews in Amsterdam." In Het Getto van Venetië-The Ghetto in Venice: Ponentini, Levantini and Tedeschi, 1516-1797. Edited by J.-M. Cohen, 106-24. The Hague: SDU, 1990.

Damas, Pierre. Histoire de la juridiction consulaire de Bordeaux. Bordeaux: impr. de Delmas, 1947 .

Dinges, Martin. "The Uses of Justice as a Form of Social Control in Early Modern Europe." In Social Control in Europe, 1500-1800. Edited by Herman Roodenburg, 159-75. Columbus: Ohio State University Press, 2004.

Estié, Paul. Het Vluchtige bestaan van de eerste Nederlandse Lutherse gemeente: Antwerpen 1566-1567. Amsterdam, Rodopi, 1986.

Estié, Paul. Van afgescheiden gemeente tot kerkgenootschap: geschiedenis van de Hersteld Evangelisch-Luthersen in Amsterdam, 1791-1836. Hilversum: Verloren, 2007.

Fram, Edward. A Window on Their World: The Court Diary of Rabbi Hayyim Gundersheim, Frankfurt Am Main 1773-1794. Cincinnati: Hebrew Union College Press, 2012.

Frijhoff, Willem. "La tolérance sans édit: la situation dans les Provinces-Unies." In L'acceptation de l'autre. De l'Edit de Nantes à nos jours. Edited by Jean Delumeau, 86-107. Paris: Fayard, 2000. 
Fuks, L. "Litigation among Amsterdam Sephardim in the 17th Century." In Aspects of Jewish Life in the Netherlands. A Selection from the Writings of Leo Fuks. Edited by Renate G. Fuks-Mansfeld, 65-80. Assen: Van Gorcum, 1995.

Gelderbloom, Oscar. Cities of Commerce: The Institutional Foundations of International Trade in the Low Countries, 1250-1650. Princeton, NJ: Princeton University Press, 2013.

Gorski, Philip. The Disciplinary Revolution. Calvinim and the Rise of the Early Modern State in Europe. Chicago: University of Chicago Press, 2003.

Gotzmann, Andreas. "At Home in Many Worlds? Thoughts about New Concepts in Jewish Legal History." Jahrbuch des Simon-Dubnow-Instituts (2003): 413-36.

Hacker, Joseph. "Jewish Autonomy in the Ottoman Empire, Its Scope and Limits: Jewish Courts from the Sixteenth to the Eighteenth Centuries." In The Jews of the Ottoman Empire. Edited by Avigdor Levy, 153-202. Princeton, NJ: Darwin Press/Institute of Turkish Studies, 1994.

Hill, Lamar M. "Extreame Detriment': Failed Credit and the Narration of Indebtedness in the Jacobean Court of Requests." In Law and Authority in Early Modern England. Essays Presented to Thomas Garden Barnes. Edited by Buchanan Sharp and Mark Charles Fissel, 136-56. Newark: University of Delaware Press, 2007.

Hutton, William. The Court of Request. Edinburgh: William and Robert Chambers, 1840.

Huussen, Arend H. "The Legal Position of the Jews in the Dutch Republic, c. 1590-1796." In Dutch Jewry. Its History and Secular Culture (1500-2000). Edited by Jonathan Israel and Reinier Salverda, 25-41. Leiden: Brill, 2002.

Israel, Jonathan, I. "The Jews of Venice and Their Links with Holland and with Dutch Jewry (1600-1710)." Gli Ebrei e Venezia, secoli XIV-XVIII. Edited by Gaetano Cozzi, 95-116. Milan: Edizioni Comunita, 1987.

Jordan, John. "Rethinking Disputes and Settlements: How Historians Can Use Legal Anthropology." In Cultures of Conflict Resolution in Early Modern Europe. Edited by Stephen Cummins, Laura Kounine, 17-50 London: Routledge, 2016.

Kaplan, Yosef. An Alternative Path to Modernity. The Sephardi Diaspora in Western Europe. Leiden: Brill, 2000.

Kaplan, Yosef. "Bans in the Sephardi Community of Amsterdam in the Late Seventeenth Century." [Hebrew] In Exile and Diaspora: Studies in the History of the Jewish People Presented to Professor Haim Beinart. Edited by A. Mirsky et al., 517-40. Jerusalem: Ben Zvi Institute, 1988.

Kaplan, Yosef. "Between Christianity and Judaism in Early Modern Europe: The Confessionalization Process of the Western Sephardic Diaspora." In Judaism, Christianity and Islam in the Course of History: Exchange and Conflicts. Edited by Lothar Gall, Dietmar Willoweit, 331-40. Munich: Oldenbourg Wissenschaftsverlag, 2011. 
Kaplan, Yosef. "Confessionalization, Discipline and Religious Authority in the Early Modern Western Sephardic Diaspora." In Religious Movements and Transformations in Judaism, Christianity and Islam. Edited by Yohanan Friedmann, 90-103. Jerusalem: The Israel Academy of Sciences and Humanities, 2016.

Kaplan, Yosef. "Deviance and Excommunication in the Eighteenth Century: A Chapter in the Social History of the Sephardi Community of Amsterdam." In Dutch Jewish History: Proceedings of the Fifth Symposium on the History of the Jews in the Netherlands. Edited by Jozeph Michman, 103-15. Assen: Van Gorcum, 1993.

Kaplan, Yosef. "Eighteenth-Century Rulings by the Rabbinical Court of Amsterdam's Community and Their Socio-historical Significance." [Hebrew] In Studies in the History of Dutch Jewry, 5 (1988): 1-54.

Kaplan, Yosef. “Mokum' and 'Mediene': Jewish Autonomy in the Dutch Republic." [Hebrew] In Kehal Yisrael. Jewish Self-Rule Through the Ages. Vol. 2. The Middle Ages and Early Modern Period. Edited by Avraham Grossman and Yosef Kaplan, 311-27. Jerusalem: The Zalman Shazar Center, Jerusalem, 2004.

Kaplan, Yosef. "The Place of the Herem in the Sefardic Community of Hamburg during the Seventeenth Century." In Die Sefarden in Hamburg. Zur Geschichte einer Minderheit. Edited by Michael Studemund Halévy, 63-88. Helmut Buske Verlag, Hamburg, 1994.

Kaplan, Yosef. "The Sephardim in North-Western Europe and the New World." [Hebrew] In Moreshet Sefarad: The Sephardic Legacy. 2 vols. Edited by Haim Beinart, 240-87. Jerusalem: Magnes Press, 1992.

Kasper-Marienberg, Verena. "Vor Euer Kayserlichen Mayestät Justiz-Thron": die Frankfurter jüdische Gemeinde am Reichshofrat in josephinischer Zeit (1765-179o). Innsbrück: StudienVerlag, 2012.

Kessler, Amalia. A Revolution in Commerce. The Parisian Merchant Court and the Rise of Commercial Society in Eighteenth-Century France. New Haven: Yale University Press, 2007.

Koen, E.M. "Notarial Records Relating to the Portuguese Jews in Amsterdam up to 1639." Studia Rosenthaliana (1973-2001).

Malkiel, David. A Separate Republic. The Mechanics and Dynamics of Venetian Jewish Self-Government, 1607-1624. Jerusalem: Magnes Press, 1988.

Malkiel, David. "The Ghetto Republic." In The Jews in Early Modern Venice. Edited by Robert C. Davis, Benjamin Ravid, 135-42. Baltimore: The Johns Hopkins University Press, 2001.

Malkiel, David. “The Tenuous Thread: A Venetian Lawyer's Apology for Jewish SelfGovernment in the Seventeenth Century." AJs Review 12 (1987): 223-50.

Marglin, Jessica. Across Legal Lines. Jews and Muslims in Modern Morocco. New Haven: Yale University Press, 2016. 
Milano, Attilio. "L'amministrazione della giustizia presso gli ebrei di Livorno nel Seisettecento." In Scritti in memoria di Leone Carpi. Edited by Daniel Carpi et al., 13364. Jerusalem: Sally Meyer Foundation, 1967.

Oravetz Albert, Anne. "The Rabbi and the Rebels: A Pamphlet on the Herem by Rabbi Isaac Aboab da Fonseca." Jewish Quarterly Review 104 (2014): 171-91.

Ornan Pinkus, Ben Zion. "The Portuguese Community of Hamburg and Its Leadership in the Seventeenth Century." Master's thesis, Bar Ilan University, 1983.

Osborne, Troy. "Mennonites and Social Discipline in Dutch Golden Age." PhD diss., University of Minnesota, 2007.

Pieterse, Wilhelmina Christina. Daniel Levi de Barrios als geschiedschrijver van de Portugees-Israelietische gemeente te Amsterdam in zijn "Triumpho del govierno popular." Amsterdam: Scheltema en Holkema, 1968.

Roitman, Jessica Vance. The Same but Different? Inter-Cultural Trade and the Sephardim. Leiden: Brill, 2011.

Roitman, Jessica Vance. "A Flock of Wolves instead of Sheep": The Dutch West India Company, Conflict Resolution, and the Jewish Community of Curaçao in the Eighteenth Century." In The Jews in the Caribbean. Edited by Jane S. Gerber, 85-105. London: Littman Library of Jewish Civilization, 2014.

Roodenburg, Herman. Onder censuur: de kerkelijke tucht in de gereformeerde gemeente van Amsterdam, 1578-170o. Hilversum: Verloren, 1990.

Roodenburg, Herman. "Social Control Viewed from Below: New Perspectives." In Social Control in Europe, 1500-1800. Edited by Herman Roodenburg and Pieter Spierenburg, 145-58. Columbus: Ohio State University Press, 2004.

Samuel, Edgar. "The Mahamad as an Arbitration Court." Jewish Historical Studies 41 (2007): 9-30.

Schwarzfuchs, Simon. Le Registre des délibérations de la nation juive portugaise de Bordeaux (1711-1787). Paris: Fundação Calouste Gulbenkian, Centro Cultural Português, 1981.

Sirks, A. "The Supreme Court of Holland and Zeeland judging cases in the early eighteenth century." In Judges and Judging in the History of the Common Law and Civil Law: From Antiquity to Modern Times. Edited by P. Brand and J. Getzler, 234-56. Cambridge: Cambridge University Press, 2012.

Slatter, Michelle. “The Norwich Court of Requests. A Tradition Continued." In Custom, Courts and Counsel. Selected Papers of the 6th Legal British History Conference. Edited by A.K.R. Kiralfi, Michelle Slatter, and Roger Virgoe, 97-107. London: Routledge, 2014.

Sprunger, Mary. "Mennonites and Sectarian Poor Relief in Golden-Age Amsterdam." In The Reformation of Charity. The Secular and the Religious in Early Modern Poor Relief. Edited by Peter Safley, 151-53. Leiden: Brill, 2003. 
Swetschinski, Daniel M. Reluctant Cosmopolitans. The Portuguese Jews of Seventeenth Century Amsterdam. London: Littman Library of Jewish Civilization, 2000.

Toaff, Renzo. La Nazione ebrea a Livorno e a Pisa (1591-170o). Florence: Olschki, 1990.

Van Meeteren, Aries. Op hoop van akkord: instrumenteel forumgebruik bij geschilbeslechting in Leiden in de zeventiende eeuw (In hope of Agreement. Use of Forums for Dispute Settlements in Seventeenth-Century Leiden). Hilversum: Uitgeverij Verloren, 2006.

Van Rooden, Peter. "Jews and Religious Toleration in the Dutch Republic." Calvinism and Religious Toleration in the Dutch Golden Age. Edited by Ronnie Po-Chia Hsia et al., 132-47. Cambridge: Cambridge University Press, 2002. 


\title{
The "Livro de Pleitos": The Leadership of the Spanish and Portuguese Community of London in the Eighteenth Century as a Court of Requests
}

\author{
Alex Kerner*
}

On 15 August 1725, Abraham Tuby appeared before the Mahamad of the Spanish and Portuguese community of London, sitting as litigation court, to complain against Ishac Lopes. Tuby accused Lopes of mistreating him and his family. After hearing from both Tuby and Lopes, the Mahamad ordered Lopes to ask for Tuby's forgiveness and give ten shillings as charity to be paid before Rosh Hashanah. ${ }^{1}$

Earlier the same year, Abraham Lopes Cardozo, in a heated disagreement with his father-in-law Abraham Alvares Núnes, made the claim that his wife, Alvares Núnes's daughter, was in fact not his legitimate daughter. In other words, he questioned his mother-in-law's fidelity to her husband. After Alvares Núnes stated his grievance against his son-in-law in front of the Mahamad,

* This article is based on a research presented at the international conference "Religious Changes and Cultural Transformations in the Early Modern Western Sephardi Communities," held at the Hebrew University of Jerusalem in November 2016. An extended version of the article will be published in two separate articles in: Jewish Historical Studies: Transactions of the Jewish Historical Society of England, volumes 49 and 50. This research has received funding from the European Research Council under the European Union's Seventh Framework Programme (FP/2007-2013)/ERC grant agreement no 295352 11). It was written as part of the "Religious and Cultural Changes in the Western Sephardi Diaspora in the Early Modern Period" project at the Hebrew University of Jerusalem under the direction of Professor Yosef Kaplan. I wish to thank the very helpful staff of the National Archives of the United Kingdom (TNA), and the London Metropolitan Archives (LMA) for facilitating access to relevant materials as well as the staff of the Central Archives for the History of the Jewish People in Jerusalem (CAHJP). Special thanks to the Shaar Hashamayim Spanish and Portuguese Jews' Congregation of London for permission to research and copy its archival materials held at the LMA. Finally, I wish to thank Naomi Tadmor, Edgar Samuel and Yosef Kaplan, for reading a first draft of the article and for their valuable remarks.

1 London Metropolitan Archives, City of London (henceforth: LMA) 4521/A/o1/21/oo1, Tuby v. Lopez, 15 August 1725.

(C) ALEX KERNER, 2019 | DOI:10.1163/9789004392489_011

This is an open access chapter distributed under the terms of the prevailing CC-BY-NC License at the time of publication. 
the wardens reconciled the estranged members of the family, convincing Lopes Cardozo to retract his accusations, declare Alvares Núnes's daughter to be his legitimate offspring, and promise that henceforth he will respect his father-in-law. ${ }^{2}$

On 18 April 1784, Joseph Habilho claimed six shillings from Joseph Barda, as payment for five pairs of slippers that Barda had bought from him previously. The Mahamad ordered Barda to return the slippers to Habilho. But, at the same time it ordered Habilho to give back to Barda his tefillin and two prayer books that Habilho allegedly took from Barda in order to coerce him to pay. ${ }^{3}$

These are only three out of over two thousand three hundred cases that the Mahamad of London, sitting as an inner court of law, judged in almost six hundred sessions held between 1721 and 1799. The existence of a legal instance implies a degree of legal autonomy conferred upon the community by the government, in the case of London, by the Queen or the King. However, such a legal autonomy was never officially granted. The closest to any kind of official recognition of the existence of the Sephardic community in the early modern period, which might have implied a kind of legal autonomy, was Charles II's statement given in 1664, shortly after the community was established that the Jews "may promise themselves the effects of the same favour as formerly they have had, so long as they demean themselves peaceably and quietly with due obedience to his majesty's laws and without scandal to his government." ${ }^{4}$ This declaration was reaffirmed in 1685 by Charles's brother, James $\mathrm{II}^{5}{ }^{5}$ and later quoted in various official documents as well as by the congregation itself whenever addressing the authorities. These statements, however important, did not address specifically the issue of legal autonomy, and this naturally affected the character of the inner court of litigation of the congregation, making of it a voluntary instance with no coercion tools, notwithstanding the aspirations of absolute power of the Mahamad, as these transpire from the wording of the first Ascamot (communal ordinances) issued in 1664.

Article 25 of the Ascamot stipulated the establishment of an internal mechanism for settling disputes between members of the community:

Any person of the yehidim [individuals] of this kahal [congregation] who may have matters of dispute with his fellow on an affair of business, as

\footnotetext{
2 LMA/4521/A/o1/21/oo1, Alvares Núnes v. Lopez Cardozo, 18 March 1725.

3 LMA/4521/A/o1/21/oo3, Habilho v. Barda, 18 April 1784.

4 LMA $/ 45^{21} / \mathrm{A} / 03 / 01 / 001-009$.

5 LMA/4521/A/03/01/005.
} 
long as it is not about letters of exchange and detention of goods, wherein delay may be harmful to him, shall be bound to have him summoned by the samas [beadle] before the Mahamad, into whose presence they shall both have to come and appear; and the said Mahamad shall urge them to take arbitrators before whom they may lay their case and give their reasons, in order that on hearing them they may do all that is in their power to bring them to agreement and concord in eight days; and if the parties should not assent to arbitrators being given to them, or if, though they have them, they should not be able to bring them to agreement, they shall be free to seek and defend their rights before whom they may please; and if it happen that without this effort preceding any one summon his fellow, action shall be taken against him as may seem fit. ${ }^{6}$

We can see from the article that the mechanism for settling disputes was established in order to resolve business quarrels between members, making it a tool that could be of benefit mainly to the wealthy members of the congregation. The rationale in this case was not essentially different from similar arbitration mechanisms found in guilds and in other minority religious communities. This was the preferred course for resolving commercial and other disputes in England in the eighteenth century, thus circumventing the slower and more costly route of adjudication in the courts of the land. ${ }^{7}$ The Mahamad's involvement in the legal process was limited at this stage to summoning the litigants to appear before it and having them agree to nominate arbitrators who would make the necessary effort to arrive at a compromise. ${ }^{8}$ The wardens, then, were not supposed to get involved in the nitty gritty work of the negotiations. The

6 Lionel D. Barnett, El Libro de Los Acuerdos, Being the Records and Accompts of the Spanish and Portuguese Synagogue of London, from 1663 to 1681 (Oxford: Oxford University Press, 1931), 9-10. I use Barnett's translation. However, a correction is called for. Barnett's translation runs as follows: "such as letters of exchange and detention of goods" while the Spanish original refers to "an affair of business, as long as it does not concern letters of exchange and detention of goods" [my italics]: "[... como no sea letras de cambio y aresto de effettos" [my italics]. The Central Archives for the History of the Jewish People [CAHJP] HM2/99o, article 25.

7 Angus J.L. Winchester, ed., The Diary of Isaac Fletcher of Underwood, Cumberland, 1756-1781 (Winchester, UK: The Cumberland and Westmorland Antiquarian and Archaeological Society, 1994), xxvii.

8 A good example of this kind of arbitration mechanism can be seen in a case from 1693, found by Edgar Samuel in the Amsterdam City Archives [PA334/684/50], in which two arbitrators were nominated in order to rule on a dispute between Francisco de Cáseres and Francisco de Córdova over a sum of 110 Guinees (see Edgar Samuel, At the End of the Earth. Essays on the History of the Jews of England and Portugal [London: The Jewish Historical Society of England, 2004], 233-34). 
resulting ruling of the arbitrators was not binding. If a compromise was not found, the litigants were free to seek a solution elsewhere. Although not stated in so many words, this meant license to proceed to the courts of the land. The only obligatory stage was for the litigants to address themselves to the Mahamad before any other legal steps were taken.

Later versions of the Ascamot reveal a gradual change in the logic and scope of the article, making more central the involvement of the Mahamad in the legal procedure. In the 1693 version, Mahamad members were to make "all the diligences and means possible" to arrive at a compromise between the litigants, or, alternatively, to convince them to agree upon arbitrators to resolve the dispute. Importantly, while the 1664 version referred specifically to business disputes, this version broadened the scope to "doubts and disagreements," which in fact could imply any kind of disagreement. A rationale was offered in this version for the condition of appealing to the Mahamad prior to any approach to the courts of the land: "[...] and the gentlemen of the Mahamad shall by all ways available strive to adjust the controversies that can cause scandal and profanation of the name of God." Thus, we see how disputes between individuals developed into communal concerns. They were perceived as a threat to the wellbeing of the community and as such, the concern of the Mahamad. "Dirty laundry" was to be aired within the congregational walls, only to be taken to a court of the land with the express permission of the Mahamad. An important addendum was made in 1700 following a resolution by the elders of the community: if a compromise was not reached between the litigants, the Mahamad was to try to convince them to apply to din torah, that is, to agree to be judged by a religious court (not necessarily a rabbinical one) according to Jewish law. ${ }^{10}$ This could have meant the formation of an ad hoc religious court whenever agreed between the litigants. However, in 1705, the Mahamad decided to form a permanent religious court in order to judge in accordance with Jewish law between litigants who would agree to resort to this kind of adjudication. This religious court, whose members were to be elected by the Mahamad, was to judge cases in the manner customary in other diaspora communities. That is, the adjudication was to follow the model of communities in which legal autonomy was translated into the establishment of courts whose terms of reference were halakhic principles. ${ }^{11}$ This religious court ought not to be confused with

9 LMA/4521/A/o1/01/oo3—Livro Das Ascamot—nf [no folio] - 4 Tishry 5454 [4 October 1693].

10 Ibid.

11 LMA/4521/A/01/02/o01-Orders and Resolutions of the Mahamad, Nisan 5438 to 28 Elul 5484, fol. 52b, 29 Shevat 5465 [23 February 1705]. 
the regular rabbinical beit din, which dealt with purely religious issues such as dietary laws, marital relations, and so on. However important the establishment of such a religious court was, it was seldom used, as we will see below. The secular legal instance of the Mahamad remained the procedure available to the vast majority of those community members who opted to use the legal services of the Mahamad.

A further refinement of the Ascama was issued in 1733 stressing that license to approach a court of the land was to be made by the Mahamad as an entity. License granted by a single member of the Mahamad was not enough. The litigants had to go through the motions as detailed in the Ascama, and sanctions were to be applied against any member of the Mahamad who unilaterally granted such license. ${ }^{12}$

The first version of the Ascama was drafted when the community was just established and numbered not more than a few dozen members. ${ }^{13}$ The challenge then, was more of a theoretical one and, in any case, the measures in the 1664 version were sufficient to settle disputes between its few adherents. By the end of the eighteenth century, the community was much bigger, and its fabric had changed. From a few wealthy merchants it had become a community comprised mainly of poor people who had endless petty arguments. The 1784 version of the Ascama reflects this wider scope of disputes brought to the judgment of the Mahamad. Now it encompassed "doubts and disputes, be it due to offences or insults received or because of debts or differences over accounts." The role of the Mahamad also was broadened and the sanctions against violators hardened. If in the past the Mahamad would seek for arbitrators to make, or would itself make, the effort to reach a compromise between litigants, now it became its sole responsibility "to see if they can settle that dispute through amicable means." While the scope of disputes and the responsibility of the Mahamad were enlarged, the rulings still were not binding and when a solution was not reached, the Mahamad was to grant the sides the right to appeal to the courts of the land.

In all four versions of the Ascama, an exemption was made for cases involving letters of exchange or any issue involving serious financial loss, but in the

\footnotetext{
12 LMA/4521/A/01/01/o05—Livro Das Ascamot A.M. 5493-5535—nf-23 Elul 5492/approved 6 Iyar 5493 [21 April 1733].

13 Until the last part of the seventeenth century, the community never numbered more than five hundred members. By the mid eighteenth century, the Spanish and Portuguese Jews' congregation in London numbered about two thousand five hundred people (see Todd M. Endelman, The Jews of Britain, 1656 to 2000 [Berkeley: University of California Press, 2002], 41).
} 
1784 version this exemption is further stressed. ${ }^{14}$ These exemptions were evidently convenient for the upper classes of the community, probably those of its members who were regular finta and imposta payers, the only ones who might find themselves involved in such kinds of disputes. By exempting them from the legal procedure at the Mahamad, the community was in fact creating two classes, the rich merchant elite and the poor rank and file members, with at least de facto, different internal legal privileges. As we will see below, the wealthier members of the community did not care at all to go through the motions and applied directly to the courts of the land, especially the Chancery Court, without passing through the Mahamad. All the versions of the Ascama include the option to apply to the courts of the land in the absence of suitable compromise. In some cases, litigants came to the Mahamad in agreement to request license to resolve their dispute in court, skipping the arbitration stage within the community. ${ }^{15}$ In other cases, defendants did not appear before the Mahamad when summoned, but sent a message through the beadle asking the Mahamad to grant the plaintiff license to sue the defendant in the court of the realm. ${ }^{16}$ Application to court, then, was considered legitimate, provided it was done with the permission of the Mahamad. This is especially so because the Mahamad lacked coercive powers to summon members as parties to a suit, or as witnesses.

The members of the congregation in London could opt to resolve their disputes in a religious court, a beit din. Such institution, as we saw above, was established in 1705, although apparently it was not frequently used. An appeal to din torah was optional, but the rules of the beit din were clearly delineated by the Mahamad. Apparently, its rulings became binding once this procedure was willingly entered into by the litigants. The basic legal terms of reference of the beit din were to be "din torah" (as Jewish law was described in this context), and in addition, what is customary for its function in the Diaspora of Israel ("o q' se estila lhe sua função no galut de Israel"). ${ }^{17}$ This last addendum is important,

\footnotetext{
14 LMA/4521/A/01/01/007, Book of Ascamot Passed 5545-fols. 40-41-1 Tishry 5545 [16 September 1784].

15 LMA/4521/A/o1/21/oo1, Méndes Monforte v. Rodrigues, 9 Tevet 5506 [1 January 1746].

16 LMA/4521/A/01/21/oo2, Méndes do Valle v. Pinheiro Furtado, 27 Adar I 5537 [6 March 1777].

17 LMA/4521/A/o1/o2/oo1 - Orders and Resolutions of the Mahamad, Nisan 5438 to 28 Elul 5484 - fol. 52b-29 Shevat 5465 [23 February 1705].
} 
because it takes into account issues not expressly addressed by religious law, and especially issues related to modern commerce and the like. The reference to what is customary in other communities probably relates to the policy of ruling according to "din o carob la-din," as was customary in other Sephardic centers, such as Livorno, for instance. ${ }^{18}$ In other words, when an issue with no corresponding article in Jewish law was adjudicated, the aim was to issue a ruling that reflected, to the greatest extent possible, the spirit of Jewish law.

The hakham was the head of the beit din. Its other members were elected by the elders. These were to be three members of the community (or more, depending upon the gravity of the dispute) considered to be "competent and deserving." Importantly, according to halakha, a beit din can be made up of any three observant, worthy, adult male members of the community. In principle, a rabbinical authority is not needed. It seems that the addition of the hakham to the religious court was intended to ensure that the rulings were made with the active participation of one erudite in Jewish law. The hakham functioned as a sort of religious-legal advisor, a duty defined by the Ascamot. In cases that required more than three "judges," the members of the beit din (and not the elders) were to choose the additional members. If the post of hakham was vacant (as was often true in London), the beit din itself could issue rulings. This meant, from a practical point of view, that rulings could be issued without proper legal-religious advice. Apart from that, the hakham was to issue halakhic rulings ("declare the din," meaning give his binding opinion on religious matters) whenever enquired of by members of the community. He was also to rule on disputes between members of the community, in accordance with Jewish law ("according to din"), either when the litigants opted for the din torah course or when the case was referred to him by the Mahamad. ${ }^{19}$

In practice, as occurred in other Sephardic communities (e.g., Amsterdam), the religious court became a rabbinical court composed of hakhamim who were on the payroll of the community. This implied a degree of subordination of the religious authorities to the wardens of the congregation. No orderly records of the beit din exist (they either did not survive, or, more probably, were not kept). Yet, from the minutes of the Mahamad and from the records of the legal cases dealt with by it we can gain a fairly clear picture of its areas of activity. Naturally, the beit din dealt with purely religious issues: supervision over

18 Milano, "L'Amministrazione Della Giustizia Presso Gli Ebrei Di Livorno Nel SeiSettecento," 144 .

19 LMA/4521/A/o1/o1/oo6, Ascamot as revised by committee appointed 13 and 17 Heshvan 5542 (November 1781 ), fols. $5^{2-53}$. 
the slaughtering of beasts and the supply of kosher meat to the community, ${ }^{20}$ legal issues related to matrimony and divorce, ${ }^{21}$ oaths, ${ }^{22}$ and oversight of the religious conduct of members of the congregation (when instructed to do so by the Mahamad).$^{23}$ It also assisted the Mahamad in approving the publication of books by members of the congregation. ${ }^{24}$

Since no records exist, it is difficult to say whether or not the option of din torah was widely chosen. Judging from what we know about the general fabric of the community, most probably it was not. Yet, the beit din assisted the court of arbitration of the Mahamad and complemented its activity. In some cases what started as a dispute in the Mahamad was referred either by common agreement or by the decision of the Mahamad to the beit din..$^{25}$

When we try to look at the model according to which this court of Pleitos, as it was named, built its mechanism of work and verdict policy, we find that

20 See Ishac Nieto, Recopilação de Varias Cartas \& Actos Autenticos Concernentes a Bedica Ou Examinação Das Rezes Publicadas, a Fim Que Cada Hum Possa Vir, a Conhecimento Da Verdade (London [Salonika], 1761); Albert Montefiore Hyamson, The Sephardim of England. A History of the Spanish and Portuguese Jewish Community 1492-1951 (London: Methuen \& Co., 1951), 182; Evelyne Oliel-Grausz, "Patrocinio and Authority: Assessing the Metropolitan Role of the Portuguese Nation of Amsterdam in the Eighteenth-Century," in The Dutch Intersection, ed. Yosef Kaplan (Leiden: Brill, 2008), 149-72, esp. 163.

21 See, for example: CAHJP/HM2/1088, Minutes of the Elders 1784-1795, 12 Tamuz 5555 [29 June 1795], fol. 340. Another good example is the unhappy marriage of David Genese and Benvenida Mendoza, which will be dealt with below (see LMA/4521/A/01/21/002, Genese v. Mendoza Genese, 20 Heshvan 5533 [16 November 1772] and 30 Sebat 5533 [23 February 1773]).

22 See, for example, the oath that Joseph Mizrahi was required to give regarding his debt to Barukh Sultan and David Zamiro. In this specific case, the option of the oath before the hakham was suggested by the Mahamad. However, the suggestion was not accepted by the litigants and therefore license was given to them to go to court (LMA/4521/A/o1/21/o02, Sultan and Zamiro v. Mizrahi, 12 Tevet 5536 [4 January 1776]).

23 Such was the case with Abraham Rodrigues. In March 1793, following the instructions of the Mahamad, the members of the beit din demanded that Rodrigues cease desecrating the Sabbath in a "scandalous way." Since he did not change his behavior, the beit din recommended that the Mahamad no longer consider Rodrigues a Jew. The beit din's proposal was approved by the council of Elders on 8 May 1793 (LMA/4521/a/o1/02/o04, Livro de velhos-5545/1784-5555/1795, fol. 286).

24 See, for example: CAHJP/HM2/996, Minutes of the Mahamad, 5554-5563 (1794-1803), fol. 286, 14 Elul 556o [4 September 180o].

25 See, for example, LMA/4521/A/01/21/o04, Velasco v. Benatar (29 January 1794). 
it was not following any Jewish custom or any other specific Jewish community (even if such institutions did exist in other communities). In fact, it was a duplicate of the English Court of Requests-a court that dealt with petty litigations over small sums of money, mainly used by poor people, in which there was no legal representation by solicitors, each side appearing in person to expose his or her case.

While the decision that disputes between members of the community were to be presented to the Mahamad was approved upon the establishment of the congregation in 1664, we can only detect systematic activity of the Mahamad as a court of arbitration from 1721 on, when the cases brought before it started to be kept in a separate register. Before that year, it seems that the Mahamad, by and large, did not concern itself with litigation. Hence, we can safely say that the first steps of the court of arbitration were taken in 1721, and even then, not as a regular matter. ${ }^{26}$ Edgar Samuel writes that before 1721 the cases brought to the ruling of the Mahamad were recorded in minute books. ${ }^{27}$ From 1664 until 1721 however, only three cases can be found in the minutes. ${ }^{28}$ Bearing in mind the very few cases registered in the first years after 1721, we may conclude that before 1721 the Mahamad dealt with very little litigation. We recall, in this context, that until the first decade of the eighteenth century the congregation in London did not number more than five hundred people, most of them wealthy merchants, who in the event of commercial disputes may have directly applied to court, as permitted by the Ascama. Only from the second decade of the eighteenth century and on do we see a rapid growth in numbers, by now mainly of poor Sephardim, which naturally made the demand for a working legal mechanism more acute.

This mechanism was active at least until $1864 .{ }^{29}$ In the first years it was not widely used. In 1721 the Mahamad convened as a court of arbitrations only five times and dealt with only five cases. In each of the subsequent years the

26 On the other hand, prior to 1721 we find members of the congregation at the Chancery Court (see TNA/C/9/319/49, Gomes da Costa v. Henriques Bernall, 15 November 1698).

27 Samuel, "The Mahamad as an Arbitration Court," 10.

28 LMA/4521/A/01/02/oo1, Bueno v. Rodrigues, 12 December 1678, De Leon v. Abendanon, 4 Elul 5454 [25 August 1694], and Mahamad v. Musaphia on the issue of Pestana, 4 Kislev 5467 [10 November 1706].

29 The records of the arbitration court are kept at the London Metropolitan Archives (ref. LMA/4521/A/01/21/001-006). It is a corpus of six volumes in which a very brief abstract of the case and the ruling are inscribed. There is no volume for the years $1830-1836$, and it seems that it was lost. As a matter of rule, during the eighteenth century the records were kept in Portuguese, and in a few cases in English. In the early years of the nineteenth century the records begin to be kept in English. 
number of cases never counted more than fifteen (in 1735 and in 1738), and there were several single and sometimes consecutive years in which no sessions or cases are to be found at all (1730-1734, 1761-1768). ${ }^{30}$ Only from 1771 onwards do we see a regular use of the courts. The peak years were $1783-1784$. In 1783 the Mahamad convened as an arbitration court twenty-eight times dealing with 121 cases, and in 1784 there were nineteen sessions during which 128 cases were heard. In the whole of the eighteenth century (the period under research here), a total of 2,307 cases were recorded in 591 sessions. ${ }^{31}$

As a rule, the court convened immediately after the weekly meeting of the Mahamad. In the first years, the court sessions took place at the beginning of the Hebrew month (rosh hodesh). In later years, the rate was approximately every two weeks. The sessions were held at the synagogue building, where the offices of the Mahamad were located. ${ }^{32}$ The court was made up of three members of the Mahamad. If for some reason three members of the Mahamad were not available, complementary "judges" from the elders were called to sit in their place. As can be seen, the court met regularly, and throughout the whole year. Furthermore, this was a service provided gratis. The option to go to an external court was far less attractive. Not only did a fee have to be paid, but courts met only for four (multiple-day) sessions during specific periods throughout the year. It could take up to two years until a case was heard in a court of common law. ${ }^{33}$ As against this, at the court of the Mahamad one could resolve a dispute almost immediately and in a quite efficient way, without the complications that recourse to an external court could entail. At this stage we already can see that besides being a control tool of the Mahamad over the congregation and a device to "avoid scandal," the court was first and foremost a service provided for the benefit of the members of the congregation.

30 These are not years for which the records were lost. The gaps are found in single volumes with the last record of a year immediately followed by the first record of the next.

31 In comparison, in the years $1670-1709$, a period of about forty years, the wardens in Livorno dealt with 5,666 cases, an average of 142 cases per year. In London the average was almost thirty cases per year for a period of almost eighty years (1721-1799). Although the data from Livorno is from an earlier period than the one analyzed in this article, the numbers can provide us with some idea of the magnitude of the use of the court. The number of Sephardim in Livorno was not much bigger than that of London (approx. 3,000 in Livorno, approx. 2,500 in London), but in Livorno, it seems, the arbitration court of the community was used much more widely (the Livorno data was taken from Milano, "L'Amministrazione della giustizia presso gli Ebrei di Livorno nel SeiSettecento," 156).

32 See LMA/4521/A/01/21/oo2, Fernandes v. Núnes de Lara, 27 Elul 5533 [15 September 1773].

33 Baker, An Introduction to English Legal History, 66. 
When a dispute arose between community members, they could agree to come to the arbitration court. Often, the plaintiff would ask the beadle of the congregation to summon the defendant. Generally speaking, both sides appeared on the date accorded. However, in not a few cases, one of the parties, usually the defendant, did not show. Nonattendance was expected to occasion a written or oral excuse, to be delivered through the beadle. Such excuses varied. For instance, some excuses offered very little explanation. ${ }^{34}$ In other cases, the litigant stated that he or she was busy with merchandise or at work, or even was out of the city or abroad..$^{35}$ Health problems were often recruited to explain nonattendance. ${ }^{36}$ And, in some cases, the litigant simply refused to appear. ${ }^{37}$ Most of the excuses were accepted but there were exceptions too. ${ }^{38}$ In general, whenever one of the parties did not attend for a first time (even if no excuse was provided), the Mahamad postponed the hearing for the next session. If one of the parties did not show up upon the second summons, the Mahamad gave the plaintiff license to proceed to a court of the realm, almost without exception..$^{39}$ Contrary to what was stipulated in the Ascama, nonattendance, with very few exceptions, was not punished with any kind of pecuniary or other sanction. Here the advantages of the arbitration court of the community in comparison with the Court of Requests are obvious. In the Court of Requests nonattendance without a satisfactory excuse could end in the imprisonment of the defendant. ${ }^{40}$ What is more, the two-call procedure, which was

34 See, for example, LMA/4521/A/o1/21/oo2, Porto v. Belisario, 28 Kislev 5537 [9 December 1776]; Méndes do Valle v. Pinheiro Furtado, 28 Shevat 5537 [5 February 1777]; Boltibol and Israel v. Sultan, 28 Shevat 5537 [5 February 1777].

35 See, for example, LMA/4521/A/o1/21/oo3, Tedesquy v. Bernal, 26 Nisan 5545 [6 April 1785]; LMA/4521/A/o1/21/oo4, Ish Yemini v. Belisario, 28 Tishry $555^{8}$ [18 October 1797]; LMA/4521/A/o1/21/oo2, Núnes Martines v. Vaz Martines, 28 Iyar 5538 [25 May 1778]; LMA/4521/A/01/21/ oo2, Núnes Martines v. Habilho Fonseca, 26 Shevat 5543 [29 January 1783].

36 See, for example, LMA/4521/A/01/21/o03, Caneo v. Cohen, 28 Heshvan 5547 [18 November 1786]; LMA/4521/A/o1/21/o03, Fonseca v. Baruh, 26 Iyar 5547 [14 May 1787]; LMA/4521/A/o1/21/o04, Levy v. da Costa, 26 Tamuz 5557 [20 July 1797]; LMA/4521/A/o1/21/ oo2, Henriques v. García, 26 Tevet 5538 [25 January 1778].

37 See, for example, LMA/4521/A/o1/21/ oo3, Belilo v. Álvares, 27 Shevat 5546 [26 January $5546]$.

38 See, for example, LMA/4521/A/o1/21/oo3, Alvarenge Franco v. Sanguinetti, 28 Av 5549 [20 August 1789].

39 During 1788 there were several cases in which the litigants were summoned three times and not two, as accustomed (see LMA/4521/A/o1/21/oo3, Sarfaty v. Álvares, 27 Tevet 5548 [7 January 1788]; Mendoza v. Núnes Martines, 11 Adar 5548 [20 March 1788]; Shanon v. Cohen, 25 Tamuz 5548 [30 July 1788]; Paz de Leon v. Soares, 25 Tamuz 5548 [30 July 1788]).

40 David Deady Keane, Courts of Requests, Their Jurisdiction and Powers (London: Shaw \& Sons, 1845), 106. 
used by the Court of Requests and seemingly adopted by the Mahamad, was discontinued sometime in the late $1770 \mathrm{os},{ }^{41}$ while it continued to be used by the Mahamad in subsequent years as well.

Yet, nonattendance was widespread. In approximately a third of the cases in the period between 1721 and 1799, one of the sides did not appear. In some years more than half of the summonses were ignored by one of the sides. ${ }^{42}$ Lacking any enforcement measures, the Mahamad was left to hope that both sides would show up. Its only leverage was the policy of almost automatically granting license to the plaintiff to go to court if the defendant did not show up at court at the second summons. The high level of nonattendance is indicative of the limited practical and moral sway held by the Mahamad over its members. As long as litigants found it convenient, they went to the communal arbitration court. If, however, their interests dictated such, they resolved their disputes at the Court of Requests or at any other court (such as the Chancery Court) without taking into account the Mahamad. In any case, the two-call procedure among Sephardic communities seems to have been unique to London, probably because it mirrored the English practice. ${ }^{43}$

Once convened, the court functioned as a typical alternative dispute resolution mechanism. Each of the litigants presented his or her case, and, with very few exceptions, no solicitors were involved in the process. ${ }^{44}$ If needed, witnesses were called. These could be called at the initiative of one or both of the sides, or summoned by the wardens. ${ }^{45}$ Interestingly, non-Jews could be brought as witnesses too. ${ }^{46}$

Although the original aim of the creation of the arbitration mechanism was to resolve small business disputes between members of the community along

41 The summoning form used by the Court of Requests in the late 1770 s has a note stipulating that contrary to what was previously customary, the summoned have to come on the date stated in the form since a second court day is no longer allowed (see LMA/ CLA/038/03/002, unbound sheet; LMA/CLA/038/02/7, unbound sheet).

42 These numbers include first and second call.

43 However, it seems to have existed also in Amsterdam, as currently researched by Evelyne Oliel-Grausz. On the measures used by other communities and in earlier times in order to coerce defendants that did not want to cooperate with the inner legal procedure, see Assaf, Batei Ha-Din U-Sidreihem Acharei Chatimat Hatalmud, 25-34. On the number of summonses to court in the English legal system in the eighteenth-century see Baker, $A n$ Introduction to English Legal History, 65.

44 See, for example, LMA /4521/A/o1/21/oo2, Pereira v. Franco, 5 Kislev 5543 [11 November 1782 ] and 12 Kislev 5543 [18 November 1782].

45 LMA/4521/A/o1/21/ o03, Núnes Martines v. Sagui, 15 Av 5546 [9 August 1786]; Jonah v. Finzi, 28 Nisan 5547 [16 April 1787]; Cardoso v. Méndes, 26 Heshvan 5549 [26 November 1788]; LMA/4521/A/01/21/o04, Moyal v. Ben Zeraf, 28 Tishrey 5558 [18 October 1797].

$46 \mathrm{LMA} / 4521 / \mathrm{A} / \mathrm{o1} / 21 / 003$, Finzi v. Sebolla, 27 Elul 5550 [6 September 179o]. 
the lines of the Court of Requests and the County Court, ${ }^{47}$ the wardens rapidly found themselves settling arguments on the most varied range of matters: financial, business, and property disputes, employer-employee relationships, familial and marital conflicts, neighbor relations, defamation, and minor cases of non-criminal violence. Compared to the judicial instances that the general public in England had at their disposal during the eighteenth century, the arbitration court of the Mahamad comprised all the fields covered by the Court of Requests, the Summary Courts, the Hearing Courts and to a lesser degree, the Chancery Court. With the exception of the formal Chancery Court, which depended on the Crown, the procedures of the Mahamad as an arbitration court were similar to those of the other English legal instances, characterized by their "rather administrative informality, their semi-private nature, their fluidity and flexibility and their tendency to become forums of negotiation and mediation rather than of formal prosecution." 48

Some fields remained out of bounds. The most obvious was the criminal area. When Abraham Hernandes Dom Fernando accused Judith Romano and Sarah Hernandes Julião of stealing from him, the wardens referred the case to a court of the land, explaining that this was a matter of major crime ("couza de crime mayor"), hence not under the jurisdiction of the Mahamad. ${ }^{49}$ Another area that was not dealt with by the wardens in their capacity as an arbitration court concerned offences against the Mahamad or infractions of Ascamot by members of the congregation. These were handled by the Mahamad, not as a legal instance but as the congregation's supreme authority. Members, however, could sue the Mahamad or more frequently other communal institutions such as charity fraternities, in financial disputes and the like. On these occasions, which were very few (only two percent of the cases from 1721 to 1799), the case was dealt with indeed by the Mahamad as a court of arbitration. In these cases, the Mahamad tended to rule for the fraternity.

In the period between 1721 and 1799, forty-five percent of the cases were related to business in their widest meaning (financial, business, property, employer-employee relationships, etc.). The most frequent though were debts. The policy of the Mahamad was very similar to that of the Court of Requests. Namely, it tried to diminish the economic damage caused to the plaintiff due

47 Baker, An Introduction to English Legal History, 24.

48 Peter King, Crime, Justice, and Discretion in England 1740-1820 (Oxford: Oxford University Press, 2000), 83-84.

49 LMA/4521/A/o1/21/oo2, Hernandes Dom Fernando v. Romano and Julião, 26 Nisan 5542 [10 April 1782]. 
to the defendant's insolvency. Hence, many times the debt was reduced and spread out in installments. This was better than losing the entire sum.

Coming to the court of the Mahamad had its advantages. While at the Court of Requests the verdicts were final, here there was some room for compromise and negotiation. If a defendant could not pay his debt, money could be reduced from the charity he or she received from the community and the sum was transferred to the plaintiff. Scheduled payments could be postponed. In some extreme cases, members of the Mahamad, who as a rule belonged to the rich merchant elite of the community, would step in and cover the debt themselves. This was unimaginable at the Court of Requests.

The rest of the cases were related to what we could define as human relations (brawls, violence, insults, defamation, etc.). The Mahamad always sought to conciliate, mediate, and smoothen relations. Almost no dictates can be found, what stands in contradiction with the image generally held of the Mahamad as an autocratic institution. Recommendations such as "the sides were advised to live in peace as good neighbours," or the same but between wives and husbands or parents and children abound in the records.

Seven percent of the cases were related to family issues, many of them associated with marital relations. Couples could divorce according to religious law (get) and could separate without divorcing, parallel to the mensa et thoro solution in the non-Jewish realm. We have to remember that divorce in England during this period was possible only by a specific ruling of Parliament. However, within the congregation we know that divorces did happen. What we find in the Pleitos are not a few cases in which women separated from their husbands claimed alimony from their spouses. In other words, couples could separate without divorcing, but alimony was still granted to women even if not divorced with a get. This was similar to the custom among the English. This is interesting from a gender point of view, since it grants women economic rights even without going through the legal religious process of divorce. At the same time, this is an interesting phenomenon, because the Mahamad gave couples the permission to live apart and granted alimonies, a field that should have been reserved for the rabbinical authorities of the community. This is an excellent example of the supremacy of the Mahamad over the rabbinical authorities.

Marital relations brings us to the matter of gender relations. Roughly a quarter of the cases involved women in one or another way. Eight percent of lawsuits were brought by men against women, a remarkable thirteen percent of the cases were complaints filed by women against men and five percent of cases were between women. These are impressive figures especially if we bear 
in mind the legal status of women in English society in the eighteenth-century. Women were not regarded as independent legal entities. They depended on their father when of minor age or single, and on their husband when married. However, in the records of the Pleitos we find single, married, and widowed women filing complaints, even against their husbands. In a number of cases, women came to the Mahamad representing their own interests or those of their husbands in disputes against other men or women. Their testimonies were accepted. In short, women were a recognized and independent legal entity in the eyes of the Mahamad, enjoying a better status than their Gentile likes.

In a remarkable thirty-two percent of the cases, one of the sides, generally the defendant, did not care to appear. This tells us something about the rather limited actual authority of the Mahamad. In later years, the percentage of nonattendance increased hinting to the Mahamad's further diminishing status. In 1788,1794 and 1797 , half of the cases were "no shows."

In about twenty percent of the cases, the Mahamad opted to allow the litigants to proceed to an external court. These were, as a rule, the Court of Requests for small sums, ${ }^{50}$ and the Chancery Court for more significant cases. The Mahamad did not specify to which courts the litigants could proceed. Such a decision was considered beyond their purview and was to be made in accordance with the laws of the country. The propensity of the Mahamad to allow the use of external courts is of course indicative of its constraints. As it was a voluntary organization, the leverage wielded by the Mahamad over the members of the congregation was limited; hence, it understood the importance of flexibility. This was a well-known and long-standing problem among Jewish communities that enjoyed a certain level of legal autonomy. The authority of the community over its members was founded on the premise that it was voluntarily accepted by its members who could always opt out of the community, leaving a plaintiff, for example, with no alternative but to address him- or herself to the courts of the land.

This flexibility did not imply that the members of the London congregation always, if at all, cared to go through the motions and receive license from the

$5^{0}$ Originally the Court of Requests was authorized to hear cases on small debts not exceeding forty shillings. In the late eighteenth-century the sum was updated to sums not over ten pounds. 
Mahamad to go to an external court. Quite the contrary, many, if not most members, belonging to all the social strata of the community, went directly to external courts, not bothering to receive first license from the Mahamad. Unfortunately, the court records for London during this period are incomplete; hence reliable statistics are not available. However, the records that survived for the second half of the eighteenth century show a significant participation of members of the community in legal processes at the Court of Requests and at the Chancery Court. ${ }^{51}$ We find in the records of the court of the Mahamad many complaints against members of the congregation who went to court without license. Surprisingly, however, no sanctions are to be found in cases where both litigants went to court without first requesting license to do so..$^{52}$ It seems that the unwritten rule was as follows: If both sides to a dispute agreed a priori to solve their problem at an external court, the Mahamad did not involve itself in the process (in all likelihood, it did not even know when such agreements were made). If, however, one of the sides made a unilateral move to court, then the other side (the defendant, generally), could file a complaint at the court of the Mahamad. Still, in these cases as well, the reaction of the Mahamad was mild. This fact can help explain the numerous appeals made without license to the Court of Requests and to the Chancery Court.

Mahamad members were careful not to render any decision that might stand in opposition to a decision made by a court of the land, and in some cases they even updated the external courts about their internal cases. When the Mahamad decided to allow Samuel Santillana and Jacob Palache to continue with their dispute at court, the beadle (samas) was ordered to appear in court and relate the hearing that took place within the community boundaries. ${ }^{53}$ In not a few cases, when a complaint was already filed at a court, the court of the Mahamad allowed the process to continue. ${ }^{54}$ For example,

$5^{1} \quad$ For the Court of Requests see for example: LMA/CLA/038/02/004, Moravia v. Cohen, 5 May 1762; LMA/CLA/038/02/o05: Rodrigues v. Suarez, 19 September 1772; Levy v. Mendoza, 12 July 1777; LMA/CLA/o38/o2/oog, Shannon v. Jessurun, 12 June 1783. For the Chancery Court see for example: The National Archives of the United Kingdom (henceforward: TNA): TNA/C/12/1911/74, Rodrigues v. Namias, 17 February 1762; TNA/C/11/2108/41, Robles v. Paiba et al. 23 March 1746; TNA/C/11/698/22, Cortisos v. da Costa, 1729 (first document). See for example: LMA/4521/Ao1/21/oo2:Ximenes v. Franco, 5 Sivan 5543 [5June 1783]; Núnes Martines v. Romano, 24 Sivan 5535 [22 June 1775]; Formento v. Genese, 14 Tamuz 5536 [1 July 1776]; LMA/4521/A/o1/21/oo3, Habilho v. Boltibol, 26 Elul 554 [12 September 1784].

53 LMA $/ 4521 / \mathrm{A} / 01 / 21 / 003$, Santillana v. Palache, 14 Tishry 5548 [26 September 1787].

54 See, for example, LMA/4521/A/o1/21/oo3, Núnes Martines v. Habilho, 9 Kislev $555^{1}$ [14 November 179o]; Mendes Chumaceiro v. Cardoso, 25 Av 5551[25 August 1791]; Núnes Martines v. Albo, 8 Iyar $555^{2}$ [30 April 1792]. 
Abraham Baruh summoned Ester Lacour to the court of the Mahamad for several disputes. However, since the issue was already being dealt with by the Court of Conscience (another name for the Court of Requests), the Mahamad "did not find it wise to deal with the case." ${ }^{55}$ When considered fair and possible, plaintiffs were asked to suspend their complaint at the courts of the land. ${ }^{56}$ Yet, there were cases in which the Mahamad even permitted creditors to initiate an arrest procedure against debtors. ${ }^{57}$ License to proceed to court might be granted conditionally, that is, if the ruling of the court of the Mahamad was not fulfilled. In these cases, no further permission was needed, and upon non-fulfillment the plaintiff could automatically proceed to an external court. ${ }^{58}$

Thus, the Mahamad did not object to appeals to the court of the land. On the contrary, this appears to be one of the paths it adopted to promote conflict resolution. Moreover, at the Chancery Court we find members of the Mahamad as parties to legal processes, either as individuals or even representing the communal institution. ${ }^{59}$ However, sometimes the Mahamad could not tolerate members' independent legal procedures. When in August 1783 Moseh Spenco and Joseph Uzily unsuccessfully summoned the Mahamad to the Lord Mayor's Court, they were ordered to publicly request the Mahamad's forgiveness, standing at the tebah of the synagogue between the afternoon (minha) and evening (arbit) prayers. ${ }^{60}$ This was no minor humiliation, but such sanctions enabled the wardens to preserve their prestige.

Furthermore, the Court of Requests had, as a rule, four to six Jewish brokers officially registered as facilitators who would assist members of the community at court. There were generally two Ashkenazim and two Sephardim, always appearing on the last rows of the list of brokers, notwithstanding the alphabetical order in which the rest of it was rendered, marking them as "specialists"

55 LMA $/ 4521 / \mathrm{A} /$ o1/21/o03, Baruh v. Lacour, 27 Elul 5550 [6 September 1790].

56 LMA/4521/A/o1/21/oo3, Arobas v. Martines, 28 Tamuz 5546 [24 July 1786]; Rodrigues Habilho v. Habilho, 15 Av 5546 [9 August 1786]; da Costa v. Rodrigues, 28 Tevet $555^{\circ}$ [3 January 1790].

57 LMA/4521/A/01/21/oo1, Bensancho v. Halfon, Levy, Machado \& Lópes de Oliveira, 7 Tamuz 5498 [25 June 1738].

58 See, for example, LMA/4521/A/o1/21/oo1, de Leao v. Ramos, 4 Sivan 5485 [16 May 1725]; LMA/4521/A/o1/21/oo2, Cortisos v. Hesquiau, 27 Heshvan 5533-23 November 1772; LMA/4521/A/o1/21/oo3, Leon v. García, 28 Nisan 5550 [2 April 1790]; LMA/4521/A/o1/21/o03, Leon v. Valentin, 2 Elul 5550 [12 August 1790].

59 See, for example, TNA/C/11/668/66, da Costa Alvarenga v. de Paiba, Fernandes et al., October 1725. Echoes of the case can be found in the minutes of the Mahamad as well. See: LMA/4521/A/o1/o1/oo1, 27 March 1724 and 2 January 1726 (nf).

6 LMA/4521/o1/o2/o02, 26 Av 5543 [24 August 1783], fol. 211. 
in affairs related to the members of the Jewish community. ${ }^{61}$ The Sephardim were always of the rich merchant elite of the congregation, frequently former or future members of the Mahamad. ${ }^{62}$ This state of affairs only reinforces our assessment that in London the legal autonomy of the Sephardic community was not part of a separate identity-building effort, but a practical tool at the service of the community members, well-coordinated with external courts. Simply put, it was an additional—albeit unofficial—legal instance to which the members could turn to find solutions to their disputes in a cheaper and more efficient way.

As mentioned above, not infrequently, the Court of Requests was approached without license. Nonetheless, in many cases the procedure was duly followed. Let us consider a typical case. On 6 September 1779, the widow of Isaac Carcas was granted license to proceed to court against Judah Boltibol and two days later, they appeared at the Court of Requests. ${ }^{63}$ Some litigants were less straightforward. Perhaps fearing a negative response from the Mahamad or in order to tie up any loose ends, they appealed for license only after they actually addressed the Court of Requests. Gabriel Taitasach and David Aboab appeared at the Court of Requests on 13 June $1795 \cdot{ }^{64}$ However, Taitasach requested license from the Mahamad only two days later. The same happened in the case of Simson Genese and Isaac de Castro. ${ }^{65}$

These last two cases are interesting for another reason. Both appearances at the Court of Requests took place on a Saturday. These were members of the congregation, as their appeal for license proves, and yet they appeared in court on the Sabbath. And these two cases were no exception. The Court of Requests held hearings on Wednesdays and on Saturdays. A party to litigation had to appear exactly at eleven o'clock in the morning on the date he or

61 On the brokers' functions see, Deady Keane, Courts of Requests, Their Jurisdiction and Powers, 100.

62 LMA/CLA/038/03/oo2, Court of Requests-Summons Book, 1779-1780, nf; LMA/ CLA/038/03/004, Court of Requests—Summons Book, 1781-1782, nf; LMA/CLA/038/03/005, Court of Requests-Summons Book, 1782-1783, nf; LMA/CLA/038/o3/oo6, Court of Requests-Summons Book, 1783-1784, nf; LMA/CLA/038/03/oo8, Court of RequestsSummons Book, $1785^{-1786, \text { nf. }}$

63 LMA /4521/A/o1/21/oo2, Carcas v. Boltibol, 27 Kislev 5540 [6 December 1779] and LMA/ CLA/038/02/007, Court of Requests, City of London-Accounts 1784-1785, Carcas v. Bottibol, 8 December 1779, fol. 61 .

64 LMA/CLA/038/03/o13, Court of Requests—Summons Book 1795-1796, Taitasach v. Aboab, 13 June 1795 and LMA/4521/A/01/21/004, Taitasach v. Aboab, 28 Sivan 5555 [15 June 1795].

$65 \mathrm{LMA} / \mathrm{CLA} / 038 / 03 / 013$, Court of Requests-Summons Book 1795-1796, Genese v. de Castro, 9 January 1796 and LMA/4521/A/o1/21/oo4, Genese v. de Castro, 29 Tevet 5556 [9 January 1796]. 
she was summoned. Postponements were possible, but at a certain point in the late 1770 s this ceased to be an option. ${ }^{66}$ For a Jew, this meant that if summoned by a court to come on a Saturday, he or she was compelled to do so. ${ }^{67}$ And indeed Jews did. By the late eighteenth century, the level of religious observance among the Sephardim in London was not particularly high. As such, it would not be utterly shocking to find them attending sessions of court on the Sabbath. Evidently, one could be a member of the congregation, attend synagogue, and abide by the authority of the Mahamad, but at the same time attend to one's own interests, even if this was at the expense of keeping the Sabbath to the letter. ${ }^{68}$ More unexpected though, and even more indicative of the general level of religiosity of the congregation, would be to find at court on the Sabbath preachers (darsantes), and members of important rabbinical families whom we would expect to have observed the Sabbath strictly. ${ }^{69}$ All of them came to the court on the Sabbath, and so seemingly did the brokers, who as indicated above, were former and sometimes incumbent members of the Mahamad. Thus we are dealing with a widespread phenomenon that, while evidently known to the Mahamad, was not addressed by them. ${ }^{70}$

Unlike the Court of Requests, where we find the poor of the community seeking justice for their petty affairs, some with the license of the Mahamad,

66 This can be learned from the citation form used in the late 1770 s. See LMA/CLA $/ 038 / 03 / 002$, unbound sheet; LMA/CLA/038/02/7, unbound sheet.

67 In contrast, since 1659, Amsterdam Jews were officially exempt from attending the courts on the Sabbath. See Daniel M. Swetschinski, Reluctant Cosmopolitans, The Portuguese Jews of Seventeenth-Century Amsterdam (London, Portland, OR: The Littman Library of Jewish Civilization, 2000), 215.

68 In many places Jews were exempt from summonses to court on the Sabbath. It seems that in London this was not the case (see Assaf, Batei ha-Din u-Sidreihem Aharei Hatimat haTalmud, 18 n. 1).

69 Thus we find Isaac Mendes Belisario, one of the most important preachers at the synagogue, and even Pinhas Nietto, the son of the late Haham David Nietto, appearing at court on the Sabbath. Nietto did not avail himself of license granted by the Mahamad. Belisario, for his part, did (LMA/CLA/038/03/oo8, Court of Requests-Summons Book 1785-1786, Belisario v. Belilo, 25 March 1786; LMA/CLA/038/o3/oo6, Court of Requests-Summons Book 1783-1784, Netto [sic] v. Lyon, 17 July 1784).

70 A hundred years earlier, in 1678, the Mahamad issued an Ascama condemning those who went to the post office to deliver and collect letters on the Sabbath. We do not know their approach regarding going to court on that day, which, unlike going to the post office, was obligatory. Yet, already at the end of the seventeenth century we see a measure of laxity in the strict observance of the sanctity of the Sabbath by members of the congregation (see CAHJP/HM2/991, Minutes of the Mahamad 5438-5484, fol. 1r). A similar laxity regarding the observance of the Sabbath can be found in Amsterdam in the last decade of the seventeenth century. There too, the reactions of the Mahamad were rather mild (see Swetschinski, Reluctant Cosmopolitans, 215-16). 
most without it, at the Chancery Court we meet the upper class of the community. The few cases in which we see wealthy members of the congregation at the arbitration courts of the Mahamad is when they were creditors of small sums owed to them by poor members of the congregation. If the sum was not significant, wealthy members also took their cases to the court of the Mahamad. Hananel Mendes de Acosta, for example, was a rich merchant who also rented some apartments to congregation members, and was warden of the charity fraternity Maasim Tobim. We find him in 1765 at the Chancery Court in a major financial dispute with Joseph Salvador, a member of one of the most prominent Anglo-Sephardic families. Years later he appears at the Mahamad's arbitration court, represented by Abraham Julião, reclaiming a tiny sum (for him, at least) of seven shillings. ${ }^{71}$

Although the procedures at the court of the Mahamad were far simpler and faster, the upper classes preferred the royal instances of law. ${ }^{72}$ Here we see litigations worth tens of thousands of pounds, stock shares, securities and annuities, cases involving Sephardic merchants from England, the Netherlands, Gibraltar and North Africa, and family disputes regarding the execution of wills worth fortunes big and small. All dealt with, of course, by professional solicitors, almost all without license from the Mahamad. In one case at least, although the Mahamad ordered that it not proceed to court, the plaintiff did so anyway. Moreover, the plaintiff, if not a member of the current Mahamad, was at least a former one. ${ }^{73}$ Were we to follow the prevailing image of the Sephardic congregations in the West, this is precisely the kind of court where we would expect to find its members, and not the Court of Requests, which was the court to which the majority actually appealed. ${ }^{74}$ Let us recall, however, that disputes related to letters of exchange and cases involving large sums were exempted a priori from the need of license granted by the Mahamad.

Here too we can identify interesting phenomena. In certain cases, the members of the Mahamad as individuals and the Mahamad as an institution appear as parties to litigation or as testators of wills. Thus, in the case of Costa

71 See: TNA/C/12/2058/12a, Mendes de Acosta v. Salvador, April 1765; LMA/4521/A/o1/21/oo2, Mendes de Acosta v. Finse, 26 Iyar 5540 [31 May 1780].

72 Compare the simple procedures described here with the procedures at the Court of Chancery described by Radcliffe and Cross (G. Radcliffe and G. Cross, The English Legal System [London: Butterworths, 1971], 146-47.

73 TNA/C/12/174/19, Brandon v. da Costa, August and October 1791; LMA/4521/A/o1/21/oo3, Brandon v. da Costa, 26 Iyar 5551 [20 May 1791].

74 Some examples, TNA/C/12/1911/74, Rodrigues v. Namias, 17 February 1762; TNA/C/11/2108/41, Robles v. Paiba, 26 March 1746; TNA/C/11/508/27, Lindo v. Lindo, 1732; TNA/C/11/778/21, Gabay Villareal v. Pereira et al., 1733 . 
Alvarenga v. de Paiba, Fernandes, Ximenes and others, mention is made of several names who were "the then wardens or elders of the Portuguese Jews' Synagogue in London." ${ }^{\prime 75}$ More intriguing, as wills had to be deposited at an ecclesiastical court (in our case, at the court of the Bishop of Canterbury), the jurisdiction of the Mahamad was rendered irrelevant, even in a field that could easily be dealt with according to Jewish law and tradition. In some cases, the person writing a will wished it to be executed according to the Jewish law, creating strange situations in which a non-Jewish court, judging between Jews, was asked by a party to issue a ruling according to halakhic principles. In one case, for example, a request was made that the inheritance of a deceased person "should be divided between nearests $[$ sic] relations according to the holy law of Moses"76 In another case mention was made of "the custom and the usage of the Jews" or to rules "according to the custom and the usage of the Jews he being of that persuasion." 77 Moreover, issues that seem to properly belong within confines of the community made their way to the Chancery Court. One of the disputes refers to a thousand "pounds sterling to be appropriated in order to apply and dedicate the revenue of that sum towards establishing a jesiba (yeshiva) or assembly for daily reading the holy law leaving the management thereof to his executors therein named for the same to improve the holy and divine law." One of the inheritors, as was often the case, objected to implementing the charity articles of the will. ${ }^{78}$

\section{Conclusions}

On 23 April 1778, the Mahamad issued the following decree, to be read aloud at the synagogue before the reading of the Torah, and to be posted on the door of the office of the Mahamad:

75 TNA $/ \mathrm{C} / 11 / 668 / 66$, da Costa Alvarenga v. da Costa Alvarenga, October 1725. For an additional example, see TNA/C/11/816/17, de Paz v. Campos, 1742-1743: "and oratrix further shew unto your lordship that the worthy men of the said Portuguese synagogue are usually chosen and appointed every year [...] the gentlemen [...] of the said portuguez synagogue consisted of five persons and no more (that is to say) Abraham mendes Campos, Jacob alvares Pereira, moses gomes lara, Abraham capadoce, and Moses Pereira of London merchants and they continued and were the worthymen of the said portuguez synagogue for a considerable time after the death of the said Hannah d'Avila."

76 TNA/C/12/2053/31, de Paz v. Buzaglo, March-June 1765.

77 TNA $/ C / 11 / 2090 / 40$, Supino v. Supino, January 1742.

78 TNA/C/11/1072/5, da Costa v. Pereira, May 1743. 
In the name of [our] Blessed God, Amen. Having the gentlemen of the Mahamad considered the inconveniency resulting to the members of the congregation and the poverty of our nation due to the present litigations that one has against the other at the court of the land without first being summoned to appear in front of the Mahamad, and wishing the aforesaid gentlemen to avoid this inconvenience conforming the intention of Ascama 16, they have decided that from today on they will proceed with all rigor according to the Ascama, against any person that will infringe [against the said Ascama] it. And peace be upon Israel. ${ }^{79}$

Not surprisingly, no actual change was implemented in the policy against those who went to an external court without license. As in other fields of administration of authority, a clear gap existed between the intentions of the Mahamad and what actually transpired. The same can be said about the whole mechanism of arbitration. Whereas in 1664 the internal legal mechanism was set up with the rich merchants of the congregation in mind, by 1778 , as is clearly reflected by the decree, it was a mechanism devoted to serving the poor. Indeed, the cases that we find in the litigation records are mostly of poor people, struggling for a sack of coal, some bottles of milk, small quantities of flour, some biscuits, a pair of underpants, shoes, coats, and shirts. It was about street brawls and marital violence, small debts of utterly insolvent people who as a matter of rule were dependent on the charity fraternities funded by the rich imposta and finta payers of the congregation. This was definitely not a tool of control as we could have expected from an allegedly ever-more power-seeking body, but rather another kind of charity system or social service, seeking compromise, promoting peace, and saving the poor members of the community the costs and risks of appealing for justice at an external court. Despite the ideals of Bom Judesmo groomed by the founding fathers of the congregation in the second half of the seventeenth century and the aspirations of the wardens throughout the generations to control their flock and make of them a disciplined congregation, the impression is that the majority, the poor and non-privileged, were a quite unruly assemblage of people. This made their control impossible, as we learn from the numerous appeals of members of the congregation to the courts made without license from the Mahamad.

The court of litigations, like the congregation, was far from an isolated institution. On the contrary, the Mahamad was well aware of its constraints, and thus permitted the members of its community to interact with the courts 
of the land, leaving open, despite its official policy, the path to English justice. This receptivity to the English legal system, and its compatibility with it, is also a sign of the modernization, integration, and acculturation processes that the Sephardic congregation in London underwent during the eighteenth century. The adoption of the Court of Request model (with some adaptations) instead of clinging to the old isolationist systems used in other communities to cultivate a unique Jewish identity, further demonstrates the particularity of the Anglo-Sephardic case. This, to borrow Yosef Kaplan's words, was one of the expressions of the "alternative path to modernity" of the Sephardic congregation in London, ${ }^{80}$ or, perhaps, an expression of this congregation's unique path to Englishness.

\section{Bibliography}

Assaf, Simcha. Batei Ha-Din U-Sidreihem Acharei Chatimat Hatalmud. Jerusalem, 1924. Baker, J.H. An Introduction to English Legal History. 4th ed. Bath: Butterworths, 2002.

Barnett, Lionel D. El Libro de Los Acuerdos, Being the Records and Accompts of the Spanish and Portuguese Synagogue of London, from 1663 to 1681. Oxford: Oxford University Press, 1931.

Deady Keane, David. Courts of Requests, Their Jurisdiction and Powers. London: Shaw \& Sons, 1845 .

Endelman, Todd M. The Jews of Britain, 1656 to 2000 . Berkeley, Los Angeles, and London: University of California Press, 2002.

Gotzmann, Andreas. "At Home in Many Worlds? Thoughts about New Concepts in Jewish Legal History." In Jahrbuch Des Simon Dubnow Instituts, 2: 413-36. Munich: Simon Dubnow Institut Leipzig, 2003.

Hyamson, Albert Montefiore. The Sephardim of England. A History of the Spanish and Portuguese Jewish Community 1492-1951. London: Methuen \& Co., 1951.

King, Peter. Crime, Justice, and Discretion in England 1740-1820. Oxford: Oxford University Press, 2000.

Milano, Attilio. "L'Amministrazione della giustizia presso gli Ebrei di Livorno nel SeiSettecento." In Scritti in memoria di Leone Carpi. Edited by Daniel Carpi, Atilio Milano, and Alexander Rofe, 133-64. Gerusalemme: Fondazione Sally Mayer, Milano, 1967 .

8o And compare with the situation in some German cities (see Gotzmann, "At Home in Many Worlds? Thoughts about New Concepts in Jewish Legal History," 429). 
Nieto, Ishac. Recopilação de varias cartas \& actos autenticos concernentes a Bedica ou examinação das rezes publicadas, a fim que cada hum possa vir, a conhecimento da verdade. London (Salonika), 1761.

Oliel-Grausz, Evelyne. "Patrocinio and Authority: Assessing the Metropolitan Role of the Portuguese Nation of Amsterdam in the Eighteenth-Century." In The Dutch Intersection. Edited by Yosef Kaplan, 149-72. Leiden: Brill, 2008.

Radcliffe, G., and G. Cross. The English Legal System. London: Butterworths, 1971.

Samuel, Edgar. At the End of the Earth. Essays on the History of the Jews of England and Portugal. London: The Jewish Historical Society of England, 2004.

Samuel, Edgar. "The Mahamad as an Arbitration Court." Jewish Historical Studies 41 (2007): 9-30.

Swetschinski, Daniel M. Reluctant Cosmopolitans, The Portuguese Jews of SeventeenthCentury Amsterdam. London. Portland, OR: The Littman Library of Jewish Civilization, 2000.

Winchester, Angus J.L., ed. The Diary of Isaac Fletcher of Underwood, Cumberland, 1756-1781. Winchester (UK): The Cumberland and Westmorland Antiquarian and Archaeological Society, 1994. 
Appendix: Case Statistics (\%) for the Years 1721-1799*

\begin{tabular}{|c|c|c|c|c|c|c|c|}
\hline Year & Sessions & Cases total & Finance & Family & Defamation & Neighbors & Community \\
\hline 1721 & 5 & 5 & 5 & - & - & - & - \\
\hline 1722 & 5 & 6 & 6 & - & - & - & - \\
\hline 1723 & 2 & 2 & 2 & - & - & - & - \\
\hline 1724 & 6 & 8 & 7 & - & - & - & - \\
\hline 1725 & 10 & 27 & 20 & 4 & 1 & 1 & 4 \\
\hline 1726 & 3 & 3 & 3 & - & - & - & - \\
\hline 1727 & - & - & - & - & - & - & - \\
\hline 1728 & 2 & 2 & 1 & - & - & - & - \\
\hline 1729 & 2 & 4 & 4 & - & - & - & - \\
\hline 1730 & - & - & - & - & - & - & - \\
\hline 1731 & - & - & - & - & - & - & - \\
\hline 1732 & - & - & - & - & - & - & - \\
\hline 1733 & - & - & - & - & - & - & - \\
\hline 1734 & - & - & - & - & - & - & - \\
\hline 1735 & 12 & 15 & 14 & - & - & - & - \\
\hline 1736 & 3 & 3 & 2 & - & - & 1 & - \\
\hline 1737 & 3 & 3 & 3 & - & - & - & - \\
\hline 1738 & 9 & 15 & 13 & - & - & - & - \\
\hline 1739 & 6 & 7 & 6 & - & - & 1 & - \\
\hline 1740 & - & - & - & - & - & - & - \\
\hline 1741 & 2 & 2 & 2 & - & - & - & - \\
\hline 1742 & 1 & 1 & 1 & - & - & - & - \\
\hline 1743 & - & - & - & - & - & - & - \\
\hline 1744 & 1 & 1 & 1 & - & - & - & - \\
\hline 1745 & - & - & - & - & - & - & - \\
\hline 1746 & 1 & 1 & 1 & - & - & - & - \\
\hline 1747 & - & - & - & - & - & - & - \\
\hline 1748 & 1 & 3 & 3 & - & - & - & - \\
\hline 1749 & - & - & - & - & - & - & - \\
\hline $175^{\circ}$ & 4 & 4 & 4 & - & - & - & - \\
\hline $175^{1}$ & 3 & 3 & 3 & - & - & - & - \\
\hline
\end{tabular}

* Numbers in parenthesis represent percentage; $\mathrm{M}_{2} \mathrm{M}=$ male vs. male; $\mathrm{M}_{2} \mathrm{~F}=$ male vs. female; $\mathrm{F}_{2} \mathrm{M}=$ female vs. male; $\mathrm{F}_{2} \mathrm{~F}=$ female vs. female 


\begin{tabular}{|c|c|c|c|c|c|c|}
\hline Other & M2M & $\mathrm{M} 2 \mathrm{~F}$ & $\mathrm{~F}_{2} \mathrm{M}$ & $\mathrm{F}_{2} \mathrm{~F}$ & Ley de terra & No shows \\
\hline- & $4(80)$ & - & $1(20)$ & - & - & - \\
\hline- & $6(100)$ & - & - & - & - & - \\
\hline- & $2(100)$ & - & - & - & - & - \\
\hline 1 & $8(100)$ & - & - & - & $1(13)$ & - \\
\hline - & $21(78)$ & - & $1(4)$ & - & $1(4)$ & - \\
\hline- & $3(100)$ & - & - & - & - & - \\
\hline- & - & - & - & - & - & - \\
\hline 1 & $1\left(5^{0}\right)$ & - & - & - & - & - \\
\hline- & $1(25)$ & - & - & - & - & - \\
\hline- & - & - & - & - & - & - \\
\hline- & - & - & - & - & - & - \\
\hline- & - & - & - & - & - & - \\
\hline- & - & - & - & - & - & - \\
\hline- & - & - & - & - & - & - \\
\hline 1 & 14(93) & - & - & - & $1(7)$ & - \\
\hline- & $2(66)$ & - & - & - & $1(33)$ & - \\
\hline- & $3(100)$ & - & - & - & - & - \\
\hline 2 & $10(66)$ & $4(27)$ & $1(7)$ & - & $2(13)$ & - \\
\hline- & $6(100)$ & - & - & $1(14)$ & - & - \\
\hline- & - & - & - & - & - & - \\
\hline- & $2(100)$ & - & - & - & - & - \\
\hline- & $1(100)$ & - & - & - & - & - \\
\hline- & - & - & - & - & - & - \\
\hline- & $1(100)$ & - & - & - & - & - \\
\hline- & - & - & - & - & - & - \\
\hline 1 & $1(100)$ & - & - & - & $1(100)$ & - \\
\hline- & - & - & - & - & - & - \\
\hline- & $2(67)$ & - & $1(33)$ & - & - & - \\
\hline- & - & - & - & - & - & - \\
\hline- & $3(75)$ & $1(25)$ & - & - & $2(50)$ & - \\
\hline- & $3(100)$ & - & - & - & - & - \\
\hline
\end{tabular}


Appendix (cont.)

\begin{tabular}{|c|c|c|c|c|c|c|c|}
\hline Year & Sessions & Cases total & Finance & Family & Defamation & Neighbors & Community \\
\hline $175^{2}$ & 3 & 3 & - & - & - & 3 & - \\
\hline 1753 & 6 & 8 & 3 & - & - & 3 & - \\
\hline 1754 & 2 & 2 & 2 & - & - & - & - \\
\hline 1755 & 3 & 3 & 3 & - & - & - & - \\
\hline $175^{6}$ & 2 & 2 & 2 & - & - & - & - \\
\hline 1757 & 1 & 1 & - & - & - & 1 & - \\
\hline $175^{8}$ & - & - & - & - & - & - & - \\
\hline 1759 & 2 & 2 & 2 & - & - & - & - \\
\hline 1760 & 1 & 1 & 1 & - & - & - & - \\
\hline 1761 & - & - & - & - & - & - & - \\
\hline 1762 & - & - & - & - & - & - & - \\
\hline 1763 & - & - & - & - & - & - & - \\
\hline 1764 & - & - & - & - & - & - & - \\
\hline 1765 & - & - & - & - & - & - & - \\
\hline 1766 & - & - & - & - & - & - & - \\
\hline 1767 & - & - & - & - & - & - & - \\
\hline 1768 & - & - & - & - & - & - & - \\
\hline 1769 & 2 & 2 & 2 & - & - & - & 1 \\
\hline 1770 & - & - & - & - & - & - & - \\
\hline 1771 & 1 & 1 & 1 & - & - & - & 1 \\
\hline 1772 & 3 & 18 & 13 & 4 & 1 & 3 & - \\
\hline 1773 & 19 & 50 & 34 & 9 & 3 & 8 & - \\
\hline 1774 & 17 & 50 & 37 & 10 & 3 & 6 & - \\
\hline 1775 & 13 & 44 & 23 & 4 & 2 & 5 & - \\
\hline 1776 & 15 & 37 & 25 & 3 & 2 & 7 & \\
\hline 1777 & 17 & 63 & 32 & 2 & 1 & 6 & 2 \\
\hline 1778 & 19 & 79 & 43 & 4 & 1 & 5 & 1 \\
\hline 1779 & 16 & 105 & 57 & 7 & 1 & 8 & - \\
\hline 1780 & 14 & 78 & 37 & 3 & 1 & 2 & 2 \\
\hline 1781 & 25 & 104 & 63 & 9 & 4 & 8 & - \\
\hline 1782 & 21 & 107 & 53 & 3 & 2 & 10 & 4 \\
\hline 1783 & 28 & 121 & 68 & 4 & 2 & 12 & 2 \\
\hline 1784 & 19 & 128 & 62 & 9 & - & 7 & - \\
\hline 1785 & 21 & 94 & 38 & 6 & 1 & 8 & 1 \\
\hline 1786 & 23 & 96 & 45 & 10 & 3 & 11 & - \\
\hline
\end{tabular}




\begin{tabular}{|c|c|c|c|c|c|c|}
\hline Other & M2M & $\mathrm{M}_{2} \mathrm{~F}$ & $\mathrm{~F}_{2} \mathrm{M}$ & $\mathrm{F}_{2} \mathrm{~F}$ & Ley de terra & No shows \\
\hline- & $2(67)$ & - & $1(33)$ & - & - & - \\
\hline- & $8(100)$ & - & - & - & $1(12)$ & - \\
\hline- & $2(100)$ & - & - & - & $1\left(5^{0}\right)$ & - \\
\hline- & $3(100)$ & - & - & - & - & - \\
\hline- & $2(100)$ & - & - & - & - & - \\
\hline 1 & - & - & - & $1(100)$ & - & - \\
\hline- & - & - & - & - & - & - \\
\hline- & $2(100)$ & - & - & - & - & - \\
\hline- & $1(100)$ & - & - & - & - & - \\
\hline- & - & - & - & - & - & - \\
\hline- & - & - & - & - & - & - \\
\hline- & - & - & - & - & - & - \\
\hline- & - & - & - & - & - & - \\
\hline- & - & - & - & - & - & - \\
\hline- & - & - & - & - & - & - \\
\hline- & - & - & - & - & - & - \\
\hline- & - & - & - & - & - & - \\
\hline- & $2(100)$ & - & - & - & $1\left(5^{0}\right)$ & - \\
\hline- & - & - & - & - & - & - \\
\hline- & $1(100)$ & - & - & - & - & - \\
\hline- & $15(83)$ & $3(16)$ & - & - & $8(44)$ & - \\
\hline 5 & $37(74)$ & $5(10)$ & $7(14)$ & - & $20(40)$ & $2(4)$ \\
\hline 3 & $39(78)$ & $7(14)$ & $2(4)$ & $3(6)$ & $16(32)$ & $2(4)$ \\
\hline 13 & $24(55)$ & $3(7)$ & $4(9)$ & $8(18)$ & $11(25)$ & $12(27)$ \\
\hline 4 & $25(67)$ & $3(8)$ & $7(19)$ & $1(3)$ & 14(37) & $5(14)$ \\
\hline 21 & $48(76)$ & $3(5)$ & $6(10)$ & $3(5)$ & $15(24)$ & $27(43)$ \\
\hline 32 & $59(75)$ & $5(6)$ & $9(11)$ & $7(9)$ & $14(18)$ & $31(39)$ \\
\hline 34 & $61\left(5^{8}\right)$ & $13(12)$ & $20(19)$ & $9(9)$ & $30(29)$ & $39(37)$ \\
\hline 30 & $39\left(5^{0}\right)$ & $13(17)$ & $15(19)$ & $7(9)$ & $16(20)$ & $36(46)$ \\
\hline 26 & $63(61)$ & $11(11)$ & $22(21)$ & $6(6)$ & $33\left(3^{2}\right)$ & $31(30)$ \\
\hline 32 & $5^{6}\left(5^{2}\right)$ & $11(10)$ & $21(20)$ & $5(5)$ & $24(22)$ & $37(35)$ \\
\hline 37 & $88(73)$ & $10(8)$ & $16(13)$ & $8(7)$ & $24(20)$ & $38(31)$ \\
\hline 53 & $103(80)$ & $6(5)$ & $11(9)$ & $6(5)$ & $34(27)$ & $55(43)$ \\
\hline 41 & $76(81)$ & $7(7)$ & $7(7)$ & $2(2)$ & $27(29)$ & $30\left(3^{2}\right)$ \\
\hline 35 & $70(73)$ & $9(9)$ & $12(12)$ & $3(3)$ & $16(17)$ & $31(32)$ \\
\hline
\end{tabular}


Appendix (cont.)

\begin{tabular}{lcclcccc}
\hline Year & Sessions & Cases total & Finance & Family & Defamation & Neighbors & Community \\
\hline 1787 & 22 & 97 & 39 & 7 & 2 & 20 & 4 \\
1788 & 20 & 73 & 21 & 13 & - & 4 & - \\
1789 & 16 & 80 & 39 & 5 & 4 & 6 & - \\
1790 & 26 & 124 & 52 & 8 & 5 & 15 & 2 \\
1791 & 17 & 104 & 50 & 8 & 1 & 8 & 4 \\
1792 & 18 & 70 & 24 & 6 & 1 & 9 & 1 \\
1793 & 18 & 88 & 14 & 1 & 2 & 2 & - \\
1794 & 13 & 58 & 22 & 2 & - & 6 & 1 \\
1795 & 13 & 53 & 19 & 3 & 1 & 4 & 2 \\
1796 & 14 & 55 & 31 & 3 & - & 6 & - \\
1797 & 14 & 92 & 26 & 3 & 3 & 8 & - \\
1798 & 14 & 62 & 25 & 2 & 2 & 7 & 3 \\
1799 & 12 & 37 & 13 & 4 & 1 & 9 & - \\
Total: & $\mathbf{5 9 1}$ & $\mathbf{2 3 0 7}$ & $\mathbf{1 0 3 1}(\mathbf{4 5 )}$ & $\mathbf{1 5 6 ( 7 )}$ & $\mathbf{5 0}(\mathbf{2})$ & $\mathbf{2 2 0}(\mathbf{1 0})$ & $\mathbf{3 5}(\mathbf{2})$ \\
\hline
\end{tabular}




\begin{tabular}{lrccccc}
\hline Other & M2M & M2F & F2M & F2F & Ley de terra & No shows \\
\hline 30 & $66(68)$ & $8(8)$ & $18(18)$ & $5(5)$ & $11(11)$ & $28(29)$ \\
37 & $43(59)$ & $5(7)$ & $19(26)$ & $6(8)$ & $10(14)$ & $36(49)$ \\
43 & $62(77)$ & $10(12)$ & $13(16)$ & $2(2)$ & $13(16)$ & $37(46)$ \\
52 & $91(73)$ & $8(6)$ & $15(12)$ & $5(4)$ & $27(22)$ & $41(33)$ \\
37 & $78(75)$ & $4(4)$ & $16(15)$ & $5(5)$ & $9(9)$ & $31(30)$ \\
35 & $51(73)$ & $11(16)$ & $6(9)$ & $1(1)$ & $10(14)$ & $28(40)$ \\
27 & $29(33)$ & $7(8)$ & $6(7)$ & $2(2)$ & $4(4)$ & $23(26)$ \\
28 & $46(79)$ & $3(5)$ & $5(9)$ & $3(5)$ & $12(21)$ & $29(50)$ \\
24 & $35(66)$ & $4(8)$ & $6(11)$ & $6(11)$ & $19(36)$ & $19(36)$ \\
17 & $39(71)$ & $3(5)$ & $9(16)$ & $3(5)$ & $11(20)$ & $17(31)$ \\
52 & $68(74)$ & $7(8)$ & $8(9)$ & $6(7)$ & $16(17)$ & $46(50)$ \\
26 & $44(71)$ & $4(6)$ & $8(13)$ & $4(6)$ & $14(23)$ & $26(42)$ \\
13 & $23(62)$ & $3(8)$ & $5(14)$ & $6(16)$ & $9(24)$ & $9(24)$ \\
$794(34)$ & $\mathbf{1 5 9 5 ( 6 9 )}$ & $\mathbf{1 9 1 ( 8 )}$ & $\mathbf{2 9 8}(\mathbf{1 3})$ & $\mathbf{1 2 4}(5)$ & $\mathbf{4 7 9}(\mathbf{2 1})$ & $746(32)$ \\
\hline
\end{tabular}


Yosef Kaplan - 978-90-04-39248-9

Downloaded from Brill. com $04 / 26 / 2023$ 10:36:49AM via free access 
PART 3

Economy and Community among

Italian Sephardim 
Yosef Kaplan - 978-90-04-39248-9

Downloaded from Brill. com $04 / 26 / 2023$ 10:36:49AM via free access 


\title{
Jews in the Papal States between Western Sephardic Diasporas and Ghettoization: A Trial in Ancona as a Case Study $\left(1555^{-1563)}\right.$
}

\author{
Serena DiNepi*
}

In recent years, the history of the Jews in Italy in the early modern era has been at the center of many studies that are beginning to painstakingly trace the affairs of this minority group within the major events of the period. Based on sources that have long been overlooked by studies on this subject and on a renewed scientific sensibility, a profile is beginning to emerge of a history built on a range of interactions between Jews and Christians, notwithstanding the centuries-old discrimination to which the second subjected the first. The phenomenon of the ghetto, which was without a doubt the most characteristic and significant experience of the period, is now being investigated "beyond" and "across" the walls. On to the well-known history of discrimination, marginalization, and the pressures of Catholic proselytizing, a narrative which is full of nuances is being superimposed, where, at the center, are the tumultuous relations between Christians and Jews and the infinite individual stories that animated them. In depth investigations of administrative, economic, and judiciary documents (including those of the Roman Inquisition), together with innovative studies of objects, collections, and libraries, as well as more traditional research on notary registries now portray a complex and stratified society, in continuous contact with the external world yet capable of firmly maintaining its otherness. If, on the one hand, this now flourishing historiography of the ghetto — which is even a bit "revisionist" — is finally

* This paper revolves in part around a mid-sixteenth-century trial, the documents of which are conserved in the Archivio di Stato di Roma. The events at the heart of this litigation (which lasted eight years) are presented in detail in my article: "Relazioni oltre le mura. Un processo ad Ancona all'epoca dei ghetti (1555-1563)," Special issue, Rivista di Storia del Cristianesimo 14, no. 1 (2017): 27-48. I am especially grateful to Professor Thomas Y. Cohen, who discovered these unique documents many years ago and who has been so generous to share them with other scholars. Furthermore, I would like to thank Dr. Luca Andreoni, Professor Bernard Dov Cooperman, and Dr. Martina Mampieri for their continuous support and precise suggestions on Jews and Ancona at that time. English translation by Paul M. Rosenberg.

(C) SERENA DI NEPI, 2019 | DOI:10.1163/9789004392489_012

This is an open access chapter distributed under the terms of the prevailing CC-BY-NC License at the time of publication. 
succeeding at putting the Jews "on the map" of Italian history, on the other hand the great attention paid to the position of the group in national affairs has, perhaps, contributed to relegating this research to the margins of the international discussion about Jewish history. ${ }^{1}$

The political fragmentation among states that characterized Italian history until 1861 plays an important role in this trend. Studies of the Jewish communities of central and northern Italy (after the final expulsions from Sicily and the south during the first half of the sixteenth century) have often assumed a local character, ultimately describing a history of ghettos and communities where each case seems to stand alone, always remaining separate and cut off from more general events. ${ }^{2}$ The evident disparity between the general conditions assured to the Jews from place to place and from time to time, which in turn were the result of ongoing negotiations on a dual track-the Jews with the authorities and the Jews with ecclesiastic institutions - translates into a history of infinite exceptions. It is a history of individual cities and individual communities, each with its leaders and its particular capacity to be a part of general events; but each also cut off from the rest of Jewish Italy and, as a consequence, from the rest of the Jewish world. In this fashion, the walls of the ghetto have ended up constructing the dominant interpretative view of Jewish

1 The massive bibliography on Italian ghettos has been consistently augmented in recent years. Among the most recent works, the majority of which are in Italian, see Luciano Allegra, Identità in bilico. Il ghetto ebraico di Torino nel Settecento (Turin: Zamorani Editore, 1996); Kenneth R. Stow, Theater of Acculturation. The Roman Ghetto in the 16th Century (Seattle, London: University of Washington Press, 2011); Marina Caffiero, Forced Baptism. Histories of Jews, Christians and Converts in Papal Rome (Berkeley: University of California Press, 2012); id., Legami pericolosi. Ebrei e cristiani tra eresia, libri proibiti e stregoneria (Turin: Eianudi, 2012); id., Storia degli ebrei nell'Italia moderna (Rome: Carocci, 2015); Stephanie Siegmund, The Medici State and the Ghetto of Florence. The Construction of an Early Modern Jewish Community (Stanford: Stanford University Press, 2006); Lucia Frattarelli Fisher, Vivere fuori dal ghetto. Ebrei a Pisa e Livorno (secc. XVI-XVIII) (Turin: Zamorani Editore, 2008); Marina Caffiero and Anna Esposito, eds., Gli ebrei nello Stato della Chiesa. Insediamenti e mobilità (secoli XIV-XVIII) (Padua: Esedra Editrice, 2012); Serena Di Nepi, Sopravvivere al ghetto. Per una storia sociale della comunità ebraica nella Roma del Cinquecento (Rome: Viella, 2013); Angela Groppi, ed., Gli abitanti del ghetto. La descriptio hebreorum del 1733 (Rome:Viella, 2014); Micol Ferrara, Dentro e fuori dal ghetto. I luoghi della presenza ebraica a Roma tra XVI e XIX secolo (Milan: Mondadori Università, 2015); Donatella Calabi, Venezia e il ghetto. Cinquecento anni del recinto degli Ebrei (Turin: Bollati Boringhieri, 2016); Giacomo Todeschini, La banca e il ghetto. Una storia italiana (Rome-Bari: Laterza, 2016); Marina Caffiero and Serena Di Nepi, eds., "I ghetti nell'Italia moderna." Special issue, Rivista di Storia del Cristianesimo 14, no. 1 (2017).

2 For an overview, see Marina Caffiero, Serena Di Nepi, "The Relationship between Jews and Christians. Toward a Redefinition of the Ghetto." Introduction to Special issue, Rivista di Storia del Cristianesimo 14, no. 1 (2017): http://primolevicenter.org/printed-matter/not-that-ghetto/. 
Italy, and obscuring for the modern era the paradigm of inter-Jewish networks and of uninterrupted mobility that has been convincingly proposed regarding medieval history by Michele Luzzati ${ }^{3}$ and by many others. ${ }^{4}$ Now, however, the scene is changing. On one side, there are important results emerging from investigations regarding relations between Jews and Christians, and, on the other, there is renewed attention on relations between Jews, within the Italian ghettos, but also and foremost outside the cramped confines of the pre-Unity regional States. ${ }^{5}$ Research on the circulation of books and objects, which is

3 Michele Luzzati outlined the convincing paradigm on Jewish mobility and Christian-Jewish interactions in Italy in the Middle Ages and the Renaissance in a multitude of articles and books. Among them La casa dell'ebreo. Saggi sugli ebrei a Pisa e in Toscana nel Medioevo e nel Rinascimento (Pisa: Nistri Lischi, 1985); "Banchi e insediamenti ebraici nell'Italia centrosettentrionale fra tardo Medioevo e inizi dell'Età moderna," in Storia d'Italia, Annali 11, Gli ebrei in Italia, ed. Corrado Vivanti, vol. 1, Dall'alto Medioevo all'età dei ghetti (Turin: Einaudi, 1996): 175-235; "Una famiglia e quattro cognomi toponimici nel corso di un secolo: contributo alla storia degli ebrei d'Italia nel tardo Medioevo in una prospettiva interlocale," in Quel mar che la terra inghirlanda. In ricordo di Marco Tangheroni, ed. Franco Cardini and Maria Luisa Ceccarelli Lemut (Pisa: Pacini 2007): 469-77; with Giuliano Lazzarini, "Lorizzonte "italiano" di una famiglia ebraica laziale: prime note sui da Toscanella," in Gli ebrei nello Stato della Chiesa. Insediamenti e mobilità, secc. XIV-XVIII, ed. Marina Caffiero and Anna Esposito (Padua: Esedra, 2012), 51-62. For an outline of his important work within the frame of both general history and Jewish history, see Alessandra Veronese, "Michele Luzzati e la storia degli ebrei come specchio della storia medievale," in "Diversi angoli di visuale" fra storia medievale e storia degli ebrei. In ricordo di Michele Luzzati, ed. Anna Maria Pult Quaglia and Alessandra Veronese (Pisa: Pacini Editore, 2016), 59-71.

4 On this topic, see at least a short selection of classical works: Ariel Toaff, Il vino e la carne. Una comunità ebraica nel Medioevo (Bologna: Il Mulino, 1989); Robert Bonfil Rabbis and Jewish Communities in Renaissance Italy (Oxford: Oxford University Press, 1990); and Anna Esposito Un'altra Roma. Minoranze nazionali e comunità ebraiche tra Medioevo e Rinascimento (Rome: Il Calamo, 1995). Most recently, Alessandra Veronese, Una famiglia di banchieri ebrei tra XIV e XVI secolo. I da Volterra: reti di credito nell'Italia del Rinascimento (Pisa: ETs, 1998); Rachele Scuro, "La presenza ebraica a Vicenza e nel suo territorio nel Quattrocento," Reti medievali rivista 6, no. 1 (2005): http://www.rm.unina.it/rmebook/dwnld/ebrei/Ebrei_07_Scuro.pdf; Mafalda Toniazzi, I Da Camerino: una famiglia ebraica italiana fra Trecento e Quattrocento (Teramo: Palumbi, 2015); Miriam Davide and Pietro Ioly Zorattini, eds., Gli Ebrei nella storia del Friuli Venezia Giulia. Una vicenda di lunga durata (Florence: Giuntina, 2016); Pierre Savy, "Les 'politiques juives' en Italie du Nord avant les ghettos," in Religious Minorities, Integration and the State. État, minorités religieuses et integration, ed. Ivan Jablonka, Nikolas Jaspert, Jean-Philippe Schreiber and John Victor Tolan (Turnhout: Brepols, 2016), 35-47; and "Entre peuple et communauté: remarques sur l'idée de nation chez les Juifs d'Italie $\left(\mathrm{XV}^{\mathrm{e}}-\mathrm{XVI}{ }^{\mathrm{e}}\right.$ siècles)," Revue de l'histoire des religions 234, no. 2 (2017): 297-314. The Lexicon directed by Shlomo Simonsohn also offers a summary of Jewish history in Italy on a geographical basis, from antiquity to the present: http://www7.tau.ac.il/omeka/italjuda/.

5 The series Documentary History of the Jews in Italy offers a wide range of sources in Latin, Hebrew and Italian translated into English; as a result, it is often possible to follow people day 
a subject that in large part remains unexplored, is bearing first fruits in this direction, revealing how, exactly, the connections across the wall constitute a central (and until now neglected) aspect of the history of the Italian ghettos in the modern era. ${ }^{6}$

The impact of the Western Sephardic diasporas on Jewish Italy, in turn, plays a role, at least in part, in this discussion. Studies on the arrival of the Sephardim have achieved their best results concerning Ferrara and Venice in the early 150os, starting from the saga of Dona Gracia Nasi and on, thanks to the extraordinary work undertaken in the archives of the Estense city by Aron di Leone Leoni. ${ }^{7}$ In general, and outside of these small exceptional cases, investigations are concentrated on the moment of settlement and the first checks on the religious identities of the refugees, emphasizing their hybrid allegiances and their negotiations with power at many levels. Furthermore, at least for the period of the 150os, great attention has been dedicated to the cultural ferment and to the innovations brought by the Spanish and Portuguese, who, arriving in Italy during the golden era of Hebrew printing, knew how to contribute to it in a significant way. In this case as well, however, a local interpretation has prevailed, centered on the paradigm of the exceptional benevolence or extraordinary aversion of Princes and Cities; as a result, the broader importance of these events has been overshadowed, both with respect to the

by day and generation by generation. See for now Shlomo Simonsohn, The Jews in the Duchy of Milan, 4 vols. (Jerusalem: The Israel Academy of Science and Humanities, 1982-1986) and The Jews in Sicily, 18 vols. (Leiden: Brill, 1997-); Renata Segre, ed., The Jews in Piedmont (Jerusalem: The Israel Academy of Sciences and Humanities, 1986-199o); Ariel Toaff, ed., The Jews in Umbria (Leiden: Brill, 1992-1994); Rossana Urbani and Guido N. Zazzu, eds., The Jews in Genoa (Leiden: Brill, 1999); Kenneth R. Stow, ed., The Jews in Rome, 1536-1551 (Leiden: Brill, 1995-1996).

6 See Joseph R. Hacker and Adam Shear, eds., The Hebrew Book in Early Modern Italy (Philadelphia: University of Pennsylvania Press, 2011); Scott Mandelbrote and Joanna Weinberg, eds., Jewish Books and Their Readers. Aspects of the Intellectual Life of Christians and Jews in Early Modern Europe (Leiden: Brill, 2016). See also the journeys of books and culture outlined by the Italian entries in the project: Footprints. Jewish Books through Time and Place: https://footprints.ccnmtl.columbia.edu.

7 See the monumental collection by Pier Cesare Ioly Zorattini, ed., Processi del S. Uffizio di Venezia contro ebrei e giudaizzanti (Florence: Olschki, 1980-1999). Most recently, Robert C. Davis and Benjamin Ravid, eds., The Jews of Early Modern Venice (Baltimore; London: Johns Hopkins University press, 2001); Federica Ruspio, La nazione portoghese. Ebrei ponentini e nuovi cristiani a Venezia (Turin: Zamorani, 2007); Aron di Leone Leoni, La nazione ebraica spagnola e portoghese di Ferrara (1492-1559). I suoi rapporti col governo ducale e la popolazione locale ed i suoi legami con le nazioni portoghesi di Ancona, Pesaro e Venezia, ed. Laura Graziano Secchieri (Florence: Olschki, 2011); Pier Cesare Ioly Zorattini, Michele Luzzati and Michele Sarfatti, eds., Studi sul mondo sefardita. In memoria di Aron Leoni (Florence: Olschki, 2012). 
overall phenomenon of the Western Sephardic diasporas and with respect to their interest, at the same time, as the cause of Sephardic settlement across a large majority of the lands of Italy. Yet, if one begins to observe with attention the life of the communities who were called upon to contend with the Sephardim, even over a long time and in fully functioning ghettos, themes and problems emerge which are less uniquely Italian than is too often imagined. Questions related to relations between the Sephardim and the local Jews, to the formation of relations with Christian institutions and society, to the role of a group of cultural, familial, and economic international networks, and to the conduct between Jews, as well as between Jews and non-Jews permit, in fact, the productive insertion of Italian affairs into this markedly global history. ${ }^{8}$ The work of Francesca Trivellato on the international and intercultural commerce to and from Livorno in the 170os, after all, speaks for itself. ${ }^{9}$

Based on the analysis of a case study from Ancona, this article proposes to reason precisely along these lines, concentrating on the difficult years that accompanied the publication of the papal bull Cum nimis absurdum. The breaking of an engagement that was celebrated in the winter of 1555 (and therefore in the months which preceded the birth of the ghettos and the opening of proceedings against Marranos), and the lengthy legal controversy that followed it, which was argued in front of a regular Christian magistracy between 1555 and 1563, offers ideas for an effort to answer important questions: What relations were there, if any, with Jews who lived outside the national borders? Is it possible to recognize behaviors typical of the many other communities involved in the Western Sephardic diasporas within the ghettos of the Papal States as well? What was the reaction of Italian Jewry to the process of ghettoization?

The article begins with the problems encountered in Italy, and in the Papal States in particular, between 1492 and 1493, when the old regional States had to make difficult decisions regarding Jewish refugees in search of welcome.

8 A tiny group of innovative works is paving this way. See Luca Andreoni, ed., Ebrei nelle Marche. Fonti e ricerche (secoli $X V-X I X$ ) (Ancona: Il lavoro editoriale, 2012); Luca Andreoni, "'Sono molto delicati li Ebrei di questo ghetto.' Conversioni e strategie di difesa degli ebrei ad Ancona e nella marca pontificia (secoli XVII-XVIII)," Materia Giudaica 19 (2014): 291-302; Evelyne Chayes and Giuseppe Veltri, Oltre le mura del ghetto. Accademie, scetticismo e tolleranza nella Venezia barocca (Palermo: New Digital Press, 2016); Paolo Pellegrini, ed., Presenza ebraiche in Umbria dal Medioevo all'età contemporanea (Perugia: Editoriale Umbra, 2017); Benedetto Ligorio "Ragusa. Un ghetto solo mercantile in Adriatico orientale (1546-1667)"; and Nourit Melcer Padon, "Free Jews in a Free Port City: Livorno, The City without a Ghetto," both in the special issue of Rivista di Storia del Cristianesimo 14, no. 1 (2017):53-70 and 71-88, respectively.

9 Francesca Trivellato, The Familiarity of Strangers. The Sephardic Diaspora, Livorno, and CrossCultural Trade in the Early Modern Period (New Haven: Yale University Press, 2010). 
The second section presents the Ancona trial, with a focus on the question of the building of trust and of good conduct by the Jews, and then returns to the general subject, and to the possibility of re-reading the events of the 1500 s from a perspective that finally weaves the birth of the ghetto and the diasporas of the Sephardim into the larger history of these years, between wars in Italy, and the explosion of the Protestant reform.

Papal States, the Pope and the Jews in the Sixteenth Century: The Sephardic Issue in Context

Beginning in the summer of 1492 and increasing in the following years, waves of Jewish refugees, first from Spain and Sicily, and then from Portugal, sought refuge in Italian cities. ${ }^{10}$ With the arrival of the Sephardim, the communities of the Italian peninsula and the Christian authorities found themselves facing a demanding test. ${ }^{11}$ The fall of Charles VIII in Italy in 1494 and the opening of the French-Spanish conflict for supremacy on the peninsula made the decision to grant or refuse welcome to the exiles a diplomatic and political issue of great relevance. It is worth summarizing the principal aspects of this issue. On the political level, on one hand, the explicit rejection of Spanish policy regarding the Jews would have displeased Iberian royalty at a time when they were preparing military action for supremacy on the peninsula; on the other hand, taking this position could have been read as a signal of openness toward the French and, therefore, Venice. Internally the Italian Jews themselves did not underestimate the problem, and they well understood the general environment into which the requests of their brethren would enter, and the impact that these might have, fearing the opening of Iberian style investigations into the faith and identity of the migrants.

Between 1493 and 1494, Spanish Pope Alexander VI's decision resolved, in part, these doubts. The fugitives were admitted to Rome and the Papal States without a formal measure and notwithstanding the objections of the

10 For a general picture on the Iberian expulsions and on their consequences, see Anna Foa, The Jews of Europe after the Black Death (Berkeley and Los Angeles: University of California Press, 200o); Yosef Kaplan, An Alternative Path to Modernity. The Sephardic Diaspora in Western Europe (Leiden: Brill, 200o); Yosef Kaplan, ed., The Dutch Intersection. The Jews and the Netherlands in Modern History (Leiden: Brill, 2008); David Ruderman, Early Modern Jewry. A New Cultural History (Princeton, NJ: Princeton University Press, 2010).

11 For the arrival of Sephardim in Italy, see Caffiero, Storia degli ebrei nell'Italia moderna, 77-93. 
ambassadors of the Catholic Kings. ${ }^{12}$ The tacit hospitality that was accorded to the Spanish Jews at that juncture clearly demonstrated what Borgia's position was regarding the delicate subjects of the management of religious minorities, and which proselytizing strategies to employ when dealing with the most recalcitrant among the groups of infidels. ${ }^{13}$ At least for the moment, the Pope declared, the Iberian approach would not be replicated elsewhere. Though avoiding open conflict with Spain (while the winds of war blew over half of Italy), Alexander vi reiterated that the final word on the Jews and all things Jewish came from Rome, and that the Church would never accept the delegation of any aspect of the subject to others. The coincidental timing between the settlement of the Sephardim in the capital of the Papal States and the drafting of the so-called Bull of Donations raises important questions (which are still overlooked by historiography). In both cases, in fact, different considerations weighed and interacted, related as much to the State, with its borders and its temporal interests, as to the universal mission of the Church itself. On the one hand, there was Italian politics, where among dynastic quarrels and impossible balances the Pope played a dangerous game through his own son, as Niccolò Macchiavelli told us. ${ }^{14}$ On the other, there was the ongoing effort to protect the autonomy and universal authority of the Church, and therefore of the States which it governed and the spiritual subjects which it claimed as its own. ${ }^{15}$

From this point of view, the period of the fifteenth to the sixteenth century in Rome proves to be of great interest for the history of the Jews. Major historical trends compelled the Pope and the Church to have to reckon very quickly with each new manifestation of religious otherness, at the theoretical level as well as in the daily governing of the Pontifical lands. The Jews had to reckon with their ancient community and the Spanish emergency. Muslims had to deal with war at sea and the ever more aggressive policy of the Turks. Obviously, the discovery of the new American peoples, ignorant and wild but ready (with a bit of pressure) to welcome the Good News of the Evangelist was

12 Anna Foa discussed this topic in depth. See "Il nuovo e il vecchio: l'insorgere della sifilide (1494-1530)," Quaderni storici 19, no. 55 (1984): 11-34; "Un vescovo marrano: il processo a Pedro de Aranda," Quaderni storici 99 (1998): 533-551; "La prospettiva spagnola: il papa e gli ebrei nell'età di Carlo V," in L'Italia di Carlo V. Guerra, religione e politica nel primo Cinquecento, ed. Francesca Cantù and Maria Antonietta Visceglia (Rome: Viella, 2003), 509-22. Most recently, James Nelson Novoa investigated the settlement by Portuguese refugees and conversos: Being the Nação in the Eternal City. New Christian Lives in SixteenthCentury Rome (Peterborough: Baywolf, 2014).

13 Foa, "La prospettiva spagnola."

14 The protagonist of The Prince was Cesare Borgia, the Duke of Valentinois and the illegitimate son of the Pope Alexander VI.

15 Di Nepi, Sopravvivere al ghetto, 24-25. 
another important development. The central issue was the unresolved matter of the conversion of the infidels, the strategies for which were being modified based on current experiences but also, clearly, on results achieved up to that time. Thus, the Church had to evaluate cases of baptisms, successful and unsuccessful. At their disposal was a fifteen-hundred-year history of converting infidels, most of them Jews. This rich historical background furthermore demonstrated how less traumatic options than expulsion or violence could be viable. This expanded perspective clarifies, then, the serious considerations that pushed Alexander vi to take the path of silent compromise. The result was that the Sephardim settled in the holy city, but without causing disruptive rifts with the Spanish monarchy. Subsequently this model of quiet tolerance became a possible, and perhaps even desirable, model to export to the rest of the peninsula.

The explicit aversion of the local Jews is the other side of this history. Ibn Verga, in his celebrated account, offers a picture of the severe reaction of the Roman Jews and of the failed attempt of the community leaders to buy off the hostility of Alexander VI in gold. The decades long discussion regarding how much veracity should be granted to this passage has ended up limiting studies on the impact of the Western Sephardic diasporas in the Papal States to the first phase of this history, thus obscuring the political and ideological questions of general importance which doubtlessly guided the choices and solutions adopted in those years. ${ }^{16}$ Whatever interpretation one wishes to give

16 There are contrasting opinions, many scholars, and a multitude of research on this topic. Ariel Toaff stressed both the factionalism of the author and the sad feelings that he had to deal with: "Gli ebrei a Roma," in Storia d'Italia, Annali n, Gli ebrei in Italia, ed. Corrado Vivanti, vol. 1, Dall'alto Medioevo all'età dei ghetti (Turin: Einuadi, 1996), 123-52, esp. 148. Robert Bonfil pointed out the impossibility of embracing Ibn Verga's narrative as historical truth, asserting that it should be regarded as a clue to Sephardic sufferings: "How Golden Was the Age of Renaissance in Jewish Historiography?" in id., Cultural Change among the Jews of Early Modern Italy (Farnham: Ashgate, 2010), 85. On the contrary, Kenneth Stow highlighted the literary elements of this famous account: "Prossimità o distanza: etnicità, sefarditi e assenza di conflitti etnici nella Roma del sedicesimo secolo," $L a$ Rassegna Mensile di Israel 58, nos. 1-2 (1992): 61-74. For a general outline on the arrival of Sephardic refugees in Rome, see Simon Schwarzfuchs, "Controversie nella Comunità di Roma agli inizi del secolo XVI," in Scritti in memoria di Enzo Sereni, ed. by Daniel Carpi, Attilio Milani, and Umbero Nahon (Jerusalem: Fondazione Sally Mayer, 1970), 95-100 (Italian part); Ariel Toaff, "Lotte e fazioni tra gli ebrei di Roma nel Cinquecento," Studi romani 27 (1979): 25-32; Anna Esposito, "The Sephardic Communities in Rome in the Early Sixteenth Century," Imago temporis. Medium Aevum 1 (2007): 177-85; Bernard Dov Cooperman, "Ethnicity and institution building among Jews in Early Modern Rome," AJs Review 30 (2006): 119-45; and "Licenses, Cartels, and Kehila. Jewish Moneylending and the Struggle against Restraint of Trade in Early Modern Rome," in Purchasing Power. 
it, the fact remains that the literary topos of Jewish misfortunes-which Ibn Verga shrewdly used to emphasize what place the expulsion from Spain had in the destiny of the people of Israel-finds indisputable confirmation in the documentation of the Christian notaries. As Anna Esposito has clearly demonstrated, in fact, the Sephardim as a group remained separate from the Roman Jews both in the organization of their synagogues and, on the other hand, in their daily lives, with their businesses and their commitments. Starting in 1496, the Spanish established a Communitas hebreorum hispanorum in Urbe commorantium, which in the following years became the model for the Communitates and Universitates that were similarly created by other foreign groups in the first decade of the 150os: Germans, French, and, naturally, Sicilians, as well as by the subgroupings of the Spanish themselves as Aragonese, Castilian, or Catalan. ${ }^{17}$ This situation was fertile ground for the rise of a tangle of legal conflicts over the distribution of taxes and regarding the modes of representation of the Jews to the pontifical institutions. Finally, in 1524, thanks to a decisive intervention by Pope Clement VII, the Jews who lived in Rome-whatever their origin might be - were given a statute which was destined to last for centuries. The famous Capitoli di Daniel da Pisa, which were issued with a brief pontifical, resolved the question, organizing political representation based on the edoth, but also (and above all) on the fragmented social composition of the community, in which the bankers obtained a position of absolute prominence. ${ }^{18}$

Three years later, the Sack of Rome once again rearranged the cards on the table. During nine months of occupation, the city was first put to steel and fire and then struck by the plague. The Jews suffered equally with the other inhabitants of Rome, to the point where it became difficult to find the ten

The Economics of Modern Jewish History, ed. R. Kobrin and Adam Teller (Philadelphia: University of Pennsylvania, 2015), 27-45. For a different opinion, see the numerous works by Kenneth Stow and especially “Ethnic Rivalry or Melting Pot: The 'Edoth' in the Roman Ghetto," Judaism 41 (1992): 286-96 and Theater of Acculturation, 24-25.

17 Among her vast scholarship on this topic, see Anna Esposito, "The Sephardic Communities in Rome in the Early Sixteenth Century"; "Gli ebrei di Roma prima del ghetto: nuovi spunti," in Monaci, ebrei, santi. Studi per Sofia Boesch Gajano, ed. Antonio Volpato (Rome: Viella, 2008): 377-94; and "Conflitti interni alla comunità ebraica di Roma tra Quattro e Cinquecento," in Judei de Urbe. Roma e i suoi ebrei: una storia secolare, ed. Marina Caffiero and Anna Esposito (Rome: Ministero per i Beni e le Attività Culturali, 2011), 69-79.

18 See the text of the Capitoli in Attilio Milano, "I Capitoli di Daniel da Pisa e la comunità di Roma," La Rassegna Mensile di Israel 10, nos. 7-8 (1935): 324-38 and 10, nos. 9-10 (1936): 409-26. I am currently working on a new edition of the text with Bernard Dov Cooperman and Anna Esposito, and it will be based on new sources. For a quick presentation of the topic, see Cooperman, "Ethnicity and Institution Building among Jews in Early Modern Rome," 124, n. 10; and Cooperman, "Licenses, Cartels, and Kehila," n. 36; Di Nepi, Sopravvivere al ghetto, 29-33. 
men necessary for a minyan, and families once divided by traditional enmities found themselves forced, by the state of things, to pray together. ${ }^{19}$ The devastation of those days left lasting traces, which surely played a role in the overcoming of old rifts. ${ }^{20}$ Although with our current knowledge it is not possible to draw an exact demographic picture of the community after 1527, the trauma of the Sack cannot be underestimated and should serve as a watershed moment for any research on the relations between edoth, starting with, obviously, the always interesting studies on matrimonial strategies as well as the strategies for transmitting and conserving estates. ${ }^{21}$ The years that followed the Sack were marked by the long papacy of Paul III Farnese, and by bad relations between the Pope and Charles v. The Emperor, committed on at least three fronts (Italy, Germany, and the Mediterranean), had hoped to find in the Pope an ally, but instead he found an indomitable rival, intent on defending the Papal States, and, most of all, the ascent of the Farnese. There was a decades long struggle between the Italy of the Pope and the Italy of the Emperor - according to Elena Bonora's useful definition - which involved the material consideration of the political destiny of the peninsula as much as it did the spiritual consideration of the fate of the Church after the outbreak of Protestantism. ${ }^{22}$ In this context, the Italian Jews, while not at the center of the authorities' attention (the countering of heresy and political dissent was considered to be more urgent), found themselves living in a time of convulsive transition: 1541 , the final expulsion from the Kingdom of Naples and the enlarging of the Ghetto of Venice; 1542, the institution of the new Congregation of the Holy Office; 1543, the opening of the Casa dei Catecumeni of Rome; 1543-1544, the imposition of the double tax on the Jews of the Papal States for the war against the Turks, and so on. ${ }^{23}$

Just a few years later, the publication of the bull Cum nimis absurdum and the establishment of Venetian-Ragusan style ghettos in the Papal States seemed to

19 Toaff, Gli ebrei a Roma, $15^{2}$.

20 For instance, in 1555 the long-lasting consequences of 1527 were part of a trial that involved the family of the famous Rabbi Ovadiah Sforno: Di Nepi, Sopravviere al ghetto, $5^{2-}$ 75. The first trial against the Sforno family dated back to the years 1548-1555; see Micaela Procaccia, "Non dabarà.' Gli ebrei di Roma nelle fonti giudiziarie della prima metà del Cinquecento, in Italia Judaica VI, Gli ebrei nello Stato Pontificio fino al Ghetto (1555) (Rome: Ministero per i Beni e le Attività Culturali, 1998), 80-93.

21 For a general outline on Roman Jewish demography in the eighteenth century, see Michael Gasperoni, "Note sulla popolazione del ghetto di Roma in età moderna: lineamenti e prospettive di ricerca," in Groppi, Gli abitanti del ghetto, 69-115.

22 Elena Bonora, Aspettando l'imperatore. I prinicipi italiani tra il papa e Carlo V (Turin: Einaudi, 2014).

23 See Caffiero, Storia degli ebrei in Italia, 95-115, with updated and complete references to recent scholarship. 
settle things. Pope Paul IV Carafa decided that the Jews would be welcomed, but in a limited way, and among a host of discriminations, in the expectation that they would ultimately present themselves at the baptismal font. Historiography has long discussed the reasons behind this decision, at times insisting that it was fully attributable to the theological line of discrimination adversus iudaeos, which dated back to Augustine, ${ }^{24}$ and at times emphasizing the growing weight of the pressure for the conversion of the Jews during this period. ${ }^{25}$ However one wishes to see it, it is irrefutable that the publication of the bull served to clarify, once and for all, what the Pope's position was on the subject, and how that position stood firmly within the Catholic tradition of well thought out discrimination: the Jews had a place within Catholic society but, in the logic of the time, could not have been treated otherwise than being forced into a space built on humiliation and marginalization. ${ }^{26}$ From this moment on, for more than three centuries, the Jews continued to live as Jews in Central Italy, in their condition as guests who were somewhat unwelcome to a hostile majority. With the birth of the ghettos, this state of familiar otherness, regulated by shared rules, was reinforced, but without leading to an absolute separation between Jews and Christians. The rules of discrimination and humiliation constituted the unspoken foundation around which the interactions between majority and minority would develop. From 1555 and on, the porosity of the walls of the ghetto, which after all was fully expected by the law that had created them, permitted the survival of the same networks of relations between Jews and Christians and among the Jews themselves that had animated the preceding period and in which, certainly, the Sephardic networks continued to play a role in the Papal States and in Italy exactly as they did in the rest of the Jewish world.

24 Kenneth R. Stow, Catholic Thought and the Papal Jewry Policy (New York: The Jewish Theological Seminar of America: 1977), with an English translation of the bull and of other relevant Catholic sources since the Middle Ages.

25 Caffiero, Storia degli ebrei in Italia, 100-2, 112-16 and Forced Baptisms. For an outline of the Catholic perspective on Jews and the development of Anti-Judaism in Italy in the midsixteenth century, see Piero Stefani, L'antigiudaismo. Storia di un'idea (Roma-Bari: Laterza, 2004), 163-96. See also Renata Segre, "La Controriforma: espulsioni, conversioni, isolamento," in Storia d'Italia, Annali 11, Gli ebrei in Italia, ed. Corrado Vivanti, vol. 1., Dall'alto Medioevo all'età dei ghetti (Turin: Einaudi, 1996), 709-78.

26 For a discussion on the consequences of the Cum nimis absurdum in the rest of Italy, see David Berger, "Cum Nimis Absurdum and the Conversion of the Jews," Jewish Quarterly Review 70, no. 1 (1979): 41-49; Benjamin Ravid, "Cum Nimis Absurdum and the Ancona Auto-da-Fé Revisited: Their Impact on Venice and Some Wider Reflections," Jewish History 26 (2012): 85-100. 
In recent years, historiography has paid much attention to the Jewish/ Christian relationship, unequivocally demonstrating its long duration and complexity. The other side of the subject — and that is the relations among the Jews themselves and their behavior as Jews_instead remains partially in the shadows, especially regarding the Papal States. The question in search of an answer is this; to what extent did ghettoization - which was, obviously, a specifically Italian phenomenon ${ }^{27}$-result in a consistent and measurable exceptionality in the history of the Italian Jews, as compared with Jews elsewhere. From this perspective, a critical reevaluation that contextualizes the ghettos and the Sephardic diasporas together can yield one of the keys to a reading that is more significant, and until now more overlooked. The Anconian case study I present here offers points for such a reading, revealing how it is possible to insert the story of the ghettos within that of the Western Sephardic diasporas (and vice-versa), even outside the scope of the celebrated investigations of the first phase of the Spanish and Portuguese settlement and of the burning of the Marranos of Ancona.

A Trial and a Ghetto under Construction: Ancona $\left(1555^{-1563)}\right.$

In the winter of 1555 , the messenger of the Italian synagogue made the rounds of the Jewish quarter of Ancona to invite anyone who so desired to attend the celebration at the home of Yacob Belcayro in honor of his daughter Sara's engagement to Emanuel Montolmo. It was a happy occasion and many accepted the offer. Dancing, music, and good food accompanied the ceremony, and the two youths committed to tying the knot in the presence of Rabbi Yohannan Treves and a good part of the Jews of Ancona. To seal the pact, the girl was given a precious necklace and the families spent a pleasant evening together making plans for the future. Then something changed, and the father of the bride decided to break the pact, declaring himself prepared to pay the penalty prescribed in such cases. The groom and his family contested the decision, and undertook a lengthy legal proceeding to demonstrate that the ceremony of 1555 had been a genuine marriage ceremony and not the simple drawing up of only kiddushin. ${ }^{28}$

27 Todeschini, La banca e il ghetto; Caffiero, Di Nepi, "The Relationship between Jews and Christians."

28 Archivio di Stato di Roma, Tribunale Criminale del Governatore, Processi, 84, case 1, Anconitanis falsitatis hebreorum contra Jacob Bel Cayri hebreum [hereafter: Trial]. The trial dossier is composed of 154 pages recto and verso (that is more than three hundred pages); it started in 1555 and ended only eight years later. My article "Relazioni oltre le mura" 
The case would drag out until 1563 , and was closely followed by the young Cardinal Carlo Borromeo who, at the time, was the attentive governor of the region and thanks to whose involvement, probably, the documents ended up arriving in copy to and for the information of the Uffici del Tribunale del Cardinal Governatore di Roma. ${ }^{29}$ Within the three hundred plus documents of the Roman copy of the trial are conserved all of the passages and the comings and goings of testimonies and opinions that, in the course of eight years, ultimately enabled agreement upon a shared answer to this question: were Sara and Emanuel married, or did they only commit to an engagement? At first, the argument was heard in the form of rabbinical arbitration and then was passed, after the failure of the Jewish procedure, to the Christian courts, amidst a tangle of accusations of false assertions or of undermined testimonies. The words of twenty-seven testimonies, which included Jews, Christians, and three rabbinic arbiters, as well as the involvement of ecclesiastical authorities and of a pair of illustrious persons, did not obtain any result. The majority of those called to testify, in fact, clearly recalled how just and only an engagement had been involved, and agreed as well on the indisputable differences between the two ceremonies, which, moreover, were described in detail. As most maintained, the girl had merely nodded her consent to the engagement, and received the blessing of her parents, but no formula of marital commitment had been pronounced. The only opposing position was expressed by a certain David Caspi, a shifty character whose bad faith was proven beyond the shadow of doubt in 1561, thanks to the intervention of the new Christian convert Giacomo Giraldini, who was formerly Rabbi Joseph Arli, and was at the time the auditor of Hebrew books in Ferrara. ${ }^{30}$ The investigations that followed put

provides a detailed description of its development and biographical references to people who were involved in it. For a description of Jewish marriage in early modern Italy, see Roni Weinstein, Marriage Rituals, Italian Style. A Historical Anthropological Perspective on Early Modern Italian Jews (Leiden: Brill, 2004).

29 On Carlo Borromeo and the Jews, see Renata Segre, "Il mondo ebraico nel carteggio di Carlo Borromeo," Michael. On the History of the Jews in the Diaspora 1 (1972): 163-26o.

30 Di Nepi, "Attraverso le mura," 37-38. On Giraldini see Shlomo Simonsohn, The Apostolic See and the Jews. History (Toronto: Pontifical Institute of Medieval Studies, 1991), 28485, n. 138; Andrea Yaakov Lattes, "Gli ebrei di Ferrara e le imposte per i Catecumeni," $L a$ Rassegna Mensile di Israel 65, no. 3 (1999): 41-54, n. 10; di Leone Leoni, La nazione ebraica spagnola e portoghese: doc. 1154: 1027-1028; docc. 1185-1186: 1040, 10141; doc. 1559: 1168. In previous years, Iosef Arli da Siena, at the time when he was still a Jew and a rabbi, kept close contact with Rabbì Treves himself: Shlomo Simonsohn, "I banchieri da Rieti in Toscana," La Rassegna Mensile di Israel 38, no. 9 (1972): 406-23. For his work as censor, see now Piet van Boxel, "Hebrew Books and Censorship in Sixteenth-Century Italy," in Jewish Books and Their Readers, 75-99. 
a strain on Caspi-but not on those who presumably induced him to lie-that is, the groom and his family. With his retraction, which was given on 25 May 1561 in front of the final rabbinic triad and then sent in sworn translation to the Christian authorities that were following the case, the affair found its conclusion: Emanuel and Sara were never married, and therefore there was no get to celebrate nor gifts to return. ${ }^{31}$

The historical backdrop alone underlines the relevance of this case. The marriage was, in fact, arranged during the final days of the papacy of Julius III, when there was not yet any talk of ghettos, and the burnings of Marranos did not yet appear on the horizon. Yacob Belcayro changed his mind during the course of the following year, as attested to in the documents from between the autumn of 1555 and the winter of 1556 . Therefore, his rethinking occurred during the months in which the Jews of the Papal States completed their relocation into the newly instituted ghettos, and during which trials against Marranos began at Ancona. The final steps in the dispute came in 1563, after the publication of the bull Dudum felicis, which, at least in part, mitigated Carafa's provisions and that, for Ancona, seemed to signal a break with the dramatic period of the immolation and a return to the normal life that would follow it. The birth of the ghetto and the investigations of the Portuguese directly affected the Belcayro and Montolmo families, and it is possible that in some way they contributed to the undermining of the nuptial project. The father of the bride was the factotum for Francisco Barboso, the most important Portuguese banker in the city, who dramatically fled to Salonica while still remaining closely connected to the networks of Marranos. ${ }^{32}$ The family of the groom could also be found among the restricted circles of elite Jewish citizens: it is no accident that in February of 1556 Montolmo, while preparing to argue with his almost in-law Belcayro, was included among the members of the Jewish delegation that would negotiate with the bishop of the city regarding the promulgation of laws governing the renting of homes in the ghetto (to which we will return further below). ${ }^{33}$

$31 \quad$ Trial: $148 \mathrm{v}-152 \mathrm{r}$.

32 Luca Andreoni "Perché non se habbia più a tribulare.' Gli ebrei della Marca fra spazi economici e conflitti giudiziari alla metà del XVI secolo," in Caffiero, Esposito, eds., Gli ebrei nello Stato della Chiesa, 109-47; Bernard Dov Cooperman, "Portuguese Conversos in Ancona. Jewish Political Activity in Early Modern Italy," in Iberia and Beyond. Hispanic Jewry between Cultures, ed. Bernard Dov Cooperman (Newark: University of Delaware Press, 1998), 297-313.

33 National Archives for the History of Jewish People (Jerusalem), IT/ An 547, Strumenti, sentenze e documenti vari riguardanti la scuola italiana, Copia conferme dei Capitoli di Ancona prodotta su richiesta di Simone Gattegna procuratore seu Fattore dell'Università degli ebrei italiani nel 1616. 
Of all these affairs, which doubtlessly concerned the Jews in Italy and outside of Italy, not a word can be found in the trial. The explicit mention of the bull Dudum felicis in the summary is the only reference contained in the dossier concerning the evolution of the rules that regulated the presence of the Jews in the Papal States. ${ }^{34}$ The tensions that had gripped the community beginning in 1555 - between trial, immolation, and attempted boycott ${ }^{35}$ - do not appear in the course of the long debate, notwithstanding the contemporaneity of the events and the direct participation of some of the witnesses in many of them. This silence offers a glimpse of the reactions (and perhaps also of the emotions) of the Jews of Ancona to the double trauma through which they were living. According to the information reported in these documents, the ghetto and the condemnation of the Marranos represented issues in and of themselves, in some way marginal to the daily life of the Jews of Ancona and of their friends, acquaintances, and business partners in and out of Italy. It is worth advancing some hypotheses on these subjects, beginning precisely with the rules concerning the rents in Ancona.

The construction of the seraglio and the reorganization which followed it were considerable challenges for the community and its leaders, who made every effort to assure the Jews of the city an easy transition. The absence of a law and the disparity of conditions which the promulgation of the first privileges of the Levantine Jews in 1546 had established could possibly have created an irreparable rift between Italians, Levantines, and Ponentines. ${ }^{36}$ In the course of assigning the best homes as well as the reduction of some types of privileges vis-à-vis the authorities, social tensions between national and socialeconomic groups might have become unmanageable; it must be noted that

\footnotetext{
34 On this, see still Attilio Milano, Il ghetto di Roma (Roma: Carucci Editore, 1984), 71-78.

35 As is well known, Dona Gracia Nasì tried to organize a general blockade of the port of Ancona from Turkey, with the goal of applying pressure on the Pope in order to save the Marranos.

36 Cooperman, "Portuguese Conversos in Ancona." On Ancona and the Jews at this time and in addition to the works by Andreoni and by Cooperman, see also Giuseppe Laras, "Intorno al 'ius cazacà' nella storia del ghetto di Ancona," Quaderni storici delle Marche 7 (1968): 27-55; Viviana Bonazzoli, Adriatico e Mediterraneo orientale. Una dinastia mercantile ebraica del secondo '6oo: i Costantini (Lint: Trieste, 1998); id., "Sulla struttura familiare delle aziende ebraiche nella Ancona del '70o," in "La presenza ebraica nelle Marche. Secoli XIII-XX," ed. Sergio Anselmi andViviana Bonazzoli, Proposte e ricerche 14 (1993): 139-154; id., Commerciare nel ghetto. La società Oef-Magistri in Ancona a metà Seicento (Ancona: Archivio di Stato di Ancona, 2000). And now, Martina Mampieri, "Living Under the Evil Pope': Paul IV and the Jews in the Hebrew Chronicle by Benjamin Nehemiah ben Elnathan from Civitanova Marche (16th cent.)," PhD diss., Università degli Studi "Roma Tre"-Universität Hamburg, 2017. I am especially grateful to Dr. Mampieri for having permitted me to read her unpublished research.
} 
the Anconian groups worked intelligently to prevent this from happening. The draft of the previously cited document of 1556 regarding the regulation of rents, which was in complete agreement with the bishop of the city, was an essential instrument of this policy of cautious and organized adaptation to the transformations that were underway. ${ }^{37}$ The experiences of Venice and Ragusa, already decades old, had taught just how disruptive the question of housing was. Based on these precedents, the Jews of Ancona decided to create regulations, and to guarantee that these had the maximum legal force possible by ensuring the direct involvement of the Ecclesiastical authorities and the local government. The legislative plan followed for the ghetto of Ancona replicated, in part, that successfully applied in Rome with the Capitoli di Daniel da Pisa three decades earlier. Both at Rome in 1524 and Ancona in 1556, the successful negotiation of Jewish internal regulations depended on close collaboration between the Church and the Jewish leadership. The choices made in Rome between 1555 and 1556 confirm, if from an unusual perspective, this interpretation. In Rome, in fact, the presence of shared rules, which had been approved by the Pope personally and which had already survived the tests of the Sack of 1527 and the burning of the Talmud of 1553, made the opening of new negotiations with the Church a bad bet, if not dangerous. As at Rome, so too at Ancona there was, therefore, the elaboration of a political strategy for surviving the convulsive transformations and violent pressures of those years, taking account of precedents (between expulsions and ghettos) and aimed at keeping the community strong and united, at least in the eyes of the Ecclesiastical authorities. ${ }^{38}$

Generally speaking, furthermore, these Anconian capitoli add an element to the history of the close relations of the Adriatic city with Venice and Ragusa, whose already decades long experience was certainly taken as an example in the drafting of the text. ${ }^{39}$ Exchanges and contacts between the Jews of the city and other nations were not limited to the web of commercial and matrimonial networks but also encouraged the circulation of ideas, news, and models of behavior. The Belcayro-Montolmo case offers many confirmations along these lines, which aid in fully inserting Ancona, but more generally the Papal States as a whole, into the history of the Western Sephardic diasporas and of their multitude of networks, which were as much mercantile as they were, perhaps in a more elusive fashion, socio-cultural. The calculated removal of the Portuguese affair, so evident in the lengthy testimonies of this trial, illustrates the attitude of the Jews: having failed to save the unfortunates who had been

Strumenti, sentenze e documenti vari riguardanti la scuola italiana [...].

38 Di Nepi, Sopravvivere al ghetto, 29-33.

39 Ligorio, "Ragusa." 
investigated, and having put the boycott behind them, life resumed as beforeincluding continued relations with the Jews of the Ottoman Empire ${ }^{40}$ - and the entire business was filed away, with its unhappy memories. They had to move forward.

The Belcayro-Montolmo conflict unfolded precisely during this "move forward." The silence regarding the frightening events of the two-year period $1555^{-155^{6}}$ stands in contrast with the incessant chatter that accompanied all phases of the case. The trial developed around three lines of inquiry: the gathering of information about the contested and uncertain facts which had given rise to the case; a continuous search for information regarding the people who were involved; and the urgent task of unequivocally defining Jewish marriage customs, and of the subsequent comparison between those followed in Ancona, in other Italian cities, and even in Turkey. The words of the many testimonies which offered responses and opinions on these points carry with them a wealth of information about happenings in other places, which allows for the tracing of a map of the relations and the movements of Jews in the first years of the ghetto. At the center was Ancona, with its relationships with all of Jewish Italy and with the Adriatic, including, preponderantly, the Ottoman cities of Smyrna and Salonica. News circulated quickly in the vast network that connected, directly and indirectly, the Jews and the Christians (and also the converts) who in some way had something to do with Ancona. This polyphony of narratives determined the reputation of business partners, an intangible asset of inestimable value, one that could be created, modified, or destroyed by even an isolated rumor. The elusive and subjective terms of good and bad conduct contributed to the shaping of the space of intercultural commerce in the Adriatic, a space in which Jews, Catholics, Eastern Christians, and Muslims were contemporaneous actors ${ }^{41}$ It is in this context that one must view the appearance of Christian merchants at a trial concerning the breaking of a marriage agreement between Jews as much as the appearance of a description of the nuptial parties of the Jews of Turkey in an argument which was completely internal to the Italian community. In both cases, the main point is this: mobility, exchanges, and information built a far-reaching network of relations, which was not limited to this intercultural commerce but, rather, was strengthened

40 On Jews, Ancona, and the Ottoman areas, see Luca Andreoni, "Riscatto degli schiavi cristiani e intermediari ebrei. Un caso di studio tra Ancona e Ragusa (XVIII secolo)," Dimensioni e problemi della ricerca storica 2 (2013): 109-33.

41 Giuseppina Minchella, Frontiere aperte. Musulmani, ebrei e cristiani nella Repubblica di Venezia (XVII secolo) (Rome: Viella, 2016); Luca Andreoni, 'Una nazione in commercio.' Gli ebrei di Ancona (sec. XVI-XVIII)," PhD diss., University of San Marino, 2014. 
by it day after day. The story of David Caspi tells us something about these very subjects.

\section{Good versus Bad Jews}

It was the testimony of the illustrious convert Giacomo Giraldini that put David Caspi and his past under the spotlight. In the course of his interrogation, Giraldini first pointed out how the Montolmo's claims rested exclusively on the contrary testimony of this "Levantino" Jew. Then, in an attempt to bring this ambiguous character into focus, the Ferraran convert and auditor raised the stakes, bringing to light an old story of thefts in Venice in which Caspi had been involved. From that moment on, the trial entered a new phase, which was concentrated on profiling those involved in the case. On one side, there were the good Jews (Belcayro and his associates and Montolmo himself); on the other were the untrustworthy Jews, with obscure backgrounds; in other words, Caspi and those like him. The life and works of David de Caspi "hebreo levantino che habita in casa di Lazzaro di Zucharo"42 were attentively reviewed in many of the testimonies. The first stone was thrown by Giraldini himself, who would bring to light an old Venetian scandal, which he had heard about in Ferrara from a member of the prominent Abravanel family. A look back to the recent past allowed a reconstruction of this affair, which though distant both geographically and chronologically from the events in Ancona, proved to be essential for establishing who, and in whom one could trust, in a trial which revolved around the trust that could be placed in the words of the witnesses.

Three and a half years earlier, at Venice, Leone Abravanel, a Ferraran and son of the celebrated scholar Abravanel, found his home burglarized. ${ }^{43}$ Following the victim's complaint, a balio of the Republic publicly announced the crime at the Rialto Bridge, and offered a significant reward to anyone who would cooperate with the investigation into the disappearance of furniture and other items from the Abravanel home. Within a short period of time, one Coen of Corfu, also a Jew, gave the authorities the names of Mometto Calonimos and Moisè Todeschino, both of whom were by then missing, and both of whom had already for some months been the object of insistent rumors that placed them at the center of a network of illicit trafficking. The two fugitives, who were immediately banned from the territories of the Serenissima, would meet different fates. Mometto was arrested in Venice and sent for three years at the oar on the Republic's ships, after which he returned home free, thanks to the benevolent

42 Trial, 11v. List of witnesses in favor of Jacob Belcayro.

43 I am especially grateful to Professor Bernard Dov Cooperman for this identification. 
intercession of Abravanel himself, who, when made aware of the criminal's poor condition, renounced the compensation which he was owed. Todeschino, instead, as far as those in Ancona who had heard could recall, was captured in Ferrara where he was condemned to death. Once free, or perhaps before (the chronology is not clear), Mometto ended up being involved in another unpleasant incident, this time at Salonica, where, together with David Caspi, they stole containers of Anconian merchandise from customs, getting into trouble some of the very Anconian Jews who now-between 1560 and 1562 - could be found arguing over a marriage/engagement and restitution of gifts and dowry. ${ }^{44}$ The crime committed in Salonica helped to define Caspi, and definitively placed him alongside and as an accomplice of those he had helped in Turkey, who were at the moment in the Venetian galere, entangled in another equally disgraceful incident. Surrounded by such a negative reputation, David Caspi returned to the center of the collective attention when, as the only witness to swear to having attended the celebration of an actual wedding in February of 1555, he was dramatically exposed by the convert Giraldini, who, furthermore, was familiar with many of the stories that circulated about him and which were promptly presented in court.

A range of testimonies contributed to the assembling of a portrait of an untrustworthy and villainous man, presenting a pointed, and carefully calibrated list of the evil merchant's vices. The narration of David's life followed a pattern. It was said that he had been born to a good family in Salonica, and that his father had left him a thousand scudi but that, regardless of having inherited money, contacts and social position, he had preferred to associate with the wrong kind of people and that, due to this, he had survived only thanks to the charity of his coreligionists. ${ }^{45}$ His progressive social and economic decline resulted in a general condition of poverty, where, in addition to the lack of money were amoral behaviors: playing cards, and drinking and eating to excess, in open violation of every norm of good Jewish conduct. ${ }^{46}$

44 Trial, $68 \mathrm{v}$.

45 "Samuel Baruchus, hebreus orientalis" witness: "E' figliolo di un uomo da bene che era savio nella nostra legge ma lui è reputato tra noi per una mala persona et stando io pare che anni sono in Salonichio intesi pubblicamente che l'articulato Davit have levato dalla Dogana di quel luogo doi balli d'ostrafini et che quando li patroni andorno per volerle repigliar non ce le trovarono et così fu cercato et trovate a lui et gli furono rivolte altro non vi posso dire e ben vero che lui dopo questo fatto si partì da Salonichio ma non so per chè causa." Trial, 93r-v.

46 "David Codava hebreus orientalis" witness: "Davit e povero e mendico et di mala vita et fama et che qui si conosce che havenoli lassiati in Salonichio suo patre che era huomo di buona faculta per ottocento o mille ducati doppo la sua morte quel Davit si portato talmente nel giocare mangiare et bevere disordinatamente ch'ha sprecato ogni cosa et non ha più niente et di più per vender vera ragione della sua vita et qualità vi dico che 
On the contrary, Yacob Belcayro, a well-known rabbi and merchant, enjoyed an excellent reputation among Jews as well as Christians. The witnesses who were called to the bench after the unveiling of the hidden aspects of Caspi and his statements drew a portrait of Belcayro as the good merchant. "Samuel Baruchus, hebreus orientalis" spoke of Belcayro, relating stories of a lengthy patronage, and focusing on their mutual business and his standing as "a wealthy and reliable person of good conduct and attitude." ${ }^{\text {"7 }}$ The testimonies of the Christian merchants who did business with Belcayro were decisive. One after the other appeared in front of the court, attesting that they knew Belcayro personally and to have had friendly dealings with him in his dual roles as businessman and doctor. The five men- "Dominus Franciscus Gabriel civis anconitanus,"48 "Antonius Marghanettus civis Anconitanus," 49 "Dominus Antonius Maninus Anconitanus mercator,"50 "Nicolaus Barberinus

havendo lui fatto sposalitio in Salonichio con una hebrea deli intese ch'hebbe le qualita di costui non volse più et fu dismesso il parentato che accosi volsero li parenti della sposa che dall'anno ${ }^{155^{8}}$ poco prima o poi l'articulato Davit ho inteso che stando in Salonichio ando alla dogana et si piglio due balle d'ostrafini dicendo che erano li suoi et li porto via. Attalche andato il patrone per repigliarli trovò che non v'erano et così fu cercato contra esso Davit et gli furono ritolti et per bastardo spergiuro povero et persona di mala conditione e stato sempre et e di presenti fra tutti noi altri hebrei havuto temuto et reputato ed di presente s'hatiene et reputa publicamente." Trial, 8ov.

"Io ho conosciuto Jacob qui in Ancona di continuo et di continuo ho praticato et negoziato con lui diverse faccende mercantili et in tutto questo tempo ho trovato persona di buona condizione pro bono reale et de bene per tale et come tale pubblicamente si tiene et reputa da noi altri hebrei così levantini come italiani che lo conoscono." Trial, 92r.

48 "Pratica et conversatione et ho fatto con lui varie faccende mercantili di dar et havere et sempre per hebreo lo trovato et esperimentato buon da bene giusto et reale in tutte le sue attiene $[. .$.$] mi impicciarei più tosto con lui che con qual si voglia altro hebreo del mondo$ $[\ldots]$ in questa città è stato sempre come medico havuto tenuto et riputato tra quegl'huomin et mercanti di Ancona." Trial, 112r.

49 "Io ho avuto da fare con lui per conto di mercanti nel dar et nell'haver et sempre io l'ho conosciuto et trovato huomo da bene per hebreo reale et fidele di buona condizione et vita ne mai nella nostra cosa ce stata una discrepanza ne per un minimo contrasto che lui con me e andato tanta realmente sempre quant'altro persona ch'habbi mai praticato in tempo della mia vita et per per la sua fidelità et buona natura nelle mie faccende mi fiderei si di lui come di qual si voglia altra persona et pure questi di passati senza altra scrittura [...] Mi sono fidato di lui di scudi cento et otto non mi sono securato d'altra cautela ma me ne son stato sopra la sua parola perche buono che non mancherebbe mai di quanto promette et a me mi e riuscito sempre così come mediche e noto me ho mai intesa che abbia fatto comunella ne altra cosa brutta et per tale et per tale et come tale in questa città tra noi altri gentilhuomini et mercanti e stato sempre havuto, tenuto et reputato per tutto questo tempo et di presente s'hatiene et reputa con Salamon da Cagli." Trial, 113v-114v (my emphasis).

"Et in questa città per mercanti et altre genti è in buonissimo conto et credito et volentieri mi sono impicciato et mi impicciarei ancora con lui [...] Tutti lo conoscono specialmente 
civis Florentine mercator Anconae,"51 and "Simone Ranuccinus mercator Florentinus Anconae degens"52_ confirmed the universal esteem which the Jew enjoyed among the merchants of the city (and also outside of it) and his full membership among the elites who in Ancona controlled both the traffic of merchandise along the Italian peninsula as well as the international commerce that crossed the eastern Mediterranean in every direction. Antonius Marghanettus and Nicolaus Barberinus had actually done business with him for years based solely on his word, without putting the agreements in black and white before a notary and notwithstanding the fact that the merchandise had to travel outside of the Papal States. The phrase "freely without documents" implied that the parties operated in an environment of reciprocal and unconditional trust, capable of withstanding the jar of a legal controversy, which evidently was considered improbable. In the event of a dispute, in fact, it would have been difficult to prove the case of one or the other, and it would have ended up involving their circle of friends and acquaintances, just as was happening around Belcayro and Montolmo, perhaps with negative consequences for the good reputations of the parties.

Therefore, the full and undisputed inclusion of Belcayro and of few others in the restricted group of Jews who might be called "persona bonae conditionis et famae inter ipsos hebraeos pacifica et quieta aliena delictis" - according to the Latin formula used by the defense lawyer - passed for the intercultural attestation of his trustworthiness. The processes of building a good reputation in the Mediterranean contact zone simultaneously concerned Jews, Christians, and Muslims, who were residents on one coast or the other, and in continuous movement between Christian and Muslim territories. As has been seen with regard to David Caspi, this uninterrupted circulation of things, news, and people fostered the overcoming of rigid social and confessional divisions, which in theory must have distinguished one from the others. The proper functioning of the economic networks rested upon the trustworthiness of the parties involved. The physical motions of give and take were made possible by the trust placed in the counterpart, both to those known in person or, instead, via the guarantee offered by a third party. Within the small zone of the Adriatic of the third quarter of the 1500s, devastated by the consequences of the burning

fra noi mercanti sloggia con lì quali pratica di continuo per il suo ufficio della senseria et di tutto questo ch'io vi dico n'è pubblica nova et fama et pubblico et notorio qui in Ancona massime tra quelli ne hanno pratica con lì ditti Jaacob et Salamone et li conosco tanto più tra mercanti." Trial, $116 \mathrm{r}-117 \mathrm{r}$.

$5^{1}$ As they had been friends and business partners for years, he sent him to Pesaro "senza scrittura." Trial, 119v (my emphasis). 
of the Marranos in Ancona, news traveled quickly. In an already tense political and military environment, every scrap of information carried weight. To remain within the limits of the Belcayro trial from which we began, Caspi's "bad reputation," over and over again confirmed by the Jews, rendered him persona non grata in Salonica, as well as among the Christian merchants and groups of Muslims, to the point that he was forced to try his luck in Italy. In Italy, however, his broken engagement in Salonica in 1558 was well known, and the business of the fabrics which had been taken from customs illegally had also not been forgotten; it is no accident that some years later Caspi was found to be involved, even if only at the level of gossip, in the crimes against the Abravranels in Venice. As the Jews repeated, Caspi, and those like him, could not be trusted.

The "good Jews" and the "bad Jews" built their fortunes within the group and found validation outside it. ${ }^{53}$ In one case as in another, one necessarily proceeded in concentric circles, and the first word belonged, as was the nature of things, to the group closest to the subject. The osmosis between inside and outside did the rest: a Jew in good relations with other Jews came across in the best possible way outside the Jewish world; a Jew in good relations with the surrounding society could strengthen and consolidate his reputation and consequent position within the group. ${ }^{54}$ The question of what defined a good Jew and what conduct was expected of those who wished to fully bear the title of "good Jew" once again suggests the need, and a methodology, for a thorough investigation of the majority-minority relations within the porous spaces of the Italian ghettos. In this context, identifying the boundaries between what is exclusively within the ghetto and that which takes place exclusively outside the ghetto becomes extremely complex. The Belcayro-Montolmo case is clear proof of this. A dispute between Jews, born around a Jewish ceremony, which focused on the correctness of the formulas that were imposed on the Jews for swearing oaths, was ultimately resolved thanks to the opinions of Christians with whom these Jews had relations, and by a convert, all of this taking place during years in which the laws separating the one from the other should have indicated prudence, at least in Ancona, the city of the immolation. For the participants in the trial, the institution of the ghettos certainly did not interrupt the exchanges and interactions between Jews and Christians, notwithstanding the fact that they lived in one of the communities most impacted by Carafa.

53 On bom judesmo as a social, cultural and political tool, see Kaplan, An Alternative Path to Modernity, 108-94.

54 On Rome, in the same period and in a very similar situation, Di Nepi, Sopravvivere al ghetto, $15^{-205}$. 
The affair in Ancona, with its Roman vestiges and its national and international connections, illuminates the years of the birth of the ghettos from an unprecedented perspective, starting from the city of the immolation. The calculated absence of any reference to the transformations of 1555 and the tragic events of 1556 cannot be underestimated. If, on the level of the sentiments of the Jews who were directly and indirectly swept up in the storm, one can and should form conjectures that revolve around the individual and collective responses to the upheavals in progress, or attitudes of prudence in a phase of disruptive reassessment, perhaps, from a broader perspective, other and more general hypotheses can be advanced. The Belcayro vs. Montolmo case, for example - with its lengthy duration (eight years are a lot for a hearing about an engagement) and its vast geographical backdrop-suggests more general interpretations. The Anconian testimonies, which were collected several times by Jewish arbiters and Christian judges between 1555 and 1563, and which involved people of various faiths and innumerable provenances, tell a story about the ghetto even without ever explicitly mentioning it, and allow a wider view outside of the specific case being discussed. We will try to see how.

On the level of majority-minority relations, the trial narrates the story of a revolution avoided. The reshaping of Jewish spaces which followed the promulgation of Cum nimis absurdum forced Jews and Christians to reorganize these relations, but did not succeed in breaking them (and probably was not meant to). Business partnerships and interpersonal relationships survived without great difficulty and, in the specific case of Ancona, continued their progress on a daily basis and with success in the wide and intertwined space of the Christian-Ottoman Adriatic. The processes of establishing good and bad reputations as they are presented in the documents of this dispute, after all, seem to me to speak for themselves.

At the individual level, men and women were asked to change residences in order to concentrate in the traditional Jewish quarters, which had a serious impact on that part of the population that had homes and shops in other parts of the city. In this case as well there are stories about which we do not know enough and, given the current state of research, of which it is possible to look at only a few small aspects that are known with certainty, and which suggest looking at the pontificate of Carafa as the beginning of a slow transformation. Regarding the living conditions of the Jews in the ghettos and the resettlement of the Jewish population, the partial expulsions by Pius $\mathrm{v}$ in 1569 and then by Clement VIII in 1593 would weigh even more heavily, and, by definitively limiting the permanent residence of the Jews of the Papal States to the ghettos of 
Rome, Ancona, and Avignon, resulted in the concentration of the entire Jewish population of the State into a few hundred square meters. However, at this juncture as well, the resettlement, as defined on paper after 1593, did not lead to the disappearance of Jews from the rest of the territory. ${ }^{55}$ Even after the final restrictions of Pope Aldobrandini, Jews continued to live and work in cities that had no ghetto, taking advantage of the ambiguous rules and jurisdictional overlaps that were typical of an institutional system of the Old Regime. A map showing the points of this Jewish life outside the walls and without ghettos in the Papal States would surely allow a more precise definition, outside of rhetorical schemes, of the place of the ghettos in the modern era. For now, it is sufficient to note how the erection of the enclosures did not interfere with either the individual mobility of the Jews or, even less, with the relations between Jews in the ghettos and Jews on the outside. Thus, the result was a metamorphosis more than a revolution.

On the professional level as well, it should be recalled that the requirement of Jews to adapt their professional activities to the limits prescribed by the bull left intact for all of the 1500 and most of the following century the lending and trade that were the heart of Jewish business. Likewise, in this case, the most significant changes would arrive later: for Rome after the suppression of the Jewish banks in 1682 and for Ancona, perhaps, never in so radical a fashion. The documentation contains innumerable signs in this direction, which clearly indicate how, exactly, definitions of the ghetto as a physical space of identity that was closed and complete in and of itself must be rethought despite the serious discriminations, while not ever forgetting them. A separation over a long period of time resulted, which certainly brought about a profound adaptation, but which never implied a condition of absolute isolation or, even less, a definition of the Jews as foreign. The Jewish condition existed, somehow, in a vague space when it came to the lines of citizenship (so complex to determine in this period) and of inclusion, which were always achievable via conversion, an option that was certainly available to the Jews but rarely used: it was an apartness regulated by rules which were known and subject to some variation, which created for the Jews, their experiences, their lives, and their customs a familiar otherness.

The business of the ghetto had, however, more protagonists: the ghettoized Jews, the Christians who lived and worked around them, the popes who wanted

55 It should be noted that when Sixtus v again admitted Jews in the Papal States, Jewish families decided to come back to the previous areas of residency or to settle in new zones: Archivio di Stato di Roma, Camerale I, Diversorum del camerlengo, r. 394: Introitus cum habitatione: $6 \mathrm{or} / 73 \mathrm{v}$. 
to ghettoize them. In the background, for Paul IV, his predecessors, and successors was the Church's traditional objective of the universal conversion of the Jews. In the first place, however, the facts and challenges of the moment had to be taken into consideration, and these help us to understand the reasons for Carafa's declination of classic Catholic eschatology. While this doubtlessly constitutes a central element of papal policy towards the Jewish minority dating back to Augustine and Gregory Magno, this watershed moment in the 1500 also calls other aspects into question. Once again, the Belcayro versus Montolmo dispute offers points for reflection. On the one hand, the discrepancy between what the trial tells us about the daily life of the Jews of Ancona (national and international networks, close and trusting relations with Christians across the peninsula, continuous news from the outside and from the Ottoman Empire) and the major events of which there are no mention (ghetto and immolation), brings to light the continuation of a lifestyle which we have discussed above. On the other hand, these three hundred documents cause one to wonder what the Pope was really trying to do when deciding to raise walls in the Papal States forty years after the creation of the Venetian institution (in a markedly different key), and immediately afterwards launching a ferocious investigation of conversos, who had prospered undisturbed in Ancona for some time already. That Carafa had little love for the Jews is beyond question; that his choices regarding the subject oscillated between different positions is as well. On the one hand — and first of all — the institution of the ghettos, for all their well-known limitations and ambiguities, offered welcome; on the other, persecution and violence, which indicated, instead, a completely different direction. In other words, one might say, there was the way of Venice and Ragusa, and the Iberian approach. Two opposing poles, but together the bearers of a precise political significance in the Italy of those years and, above all, during the papacy of Paul IV, the last pope to make war against the Hapsburgs and to seek, by any means, to thwart Spanish dominance on the Italian peninsula. ${ }^{56}$ It leads one to question whether if in his choices regarding the Jews, made immediately after his enthroning, it is also possible to read a message directed at his allies - that is to Venice and to France - and to his enemies - which is to say Charles v and Phillip II. And that message, drafted at a Council already in session, at the height of the final stage of the Franco-Imperial wars, after the peace of Augusta (1555), of which the Pope greatly disapproved, but

56 Iberian Kings ordered the "Last Spanish expulsion" at the end of the century and after the signature of peace agreements in both Italy (1559) and Germany (1555). See Flora Cassen, "The Last Spanish Expulsion in Europe: Milan, 1565-1597," AJs Review 38, no. 1 (2014): $59-88$. 
before the peace of Cateau Cambresis (1559), could have gone like this: the last word on the governing of faith and the faithful belonged to the one and only Catholic sovereign, the Pope, who ruled based on history and traditions, and that because of this, when it came to the hot and always delicate subject of the Jews, he had explicitly chosen the path of "tolerance." Meanwhile, however, at Ancona there would once again be a reminder of how this tolerance had its clear limits in baptism, however celebrated, and always held to be valid. For their part, the Jews of Italy read clearly between those lines, continuing to live their lives in the Papal States and drawing, as much as was possible, a firm line of demarcation between before (and its unrests) and after. Just as Manuello Montolmo, Yacob Belcayro, and their friends and acquaintances all did, they resumed doing business, communicating, and traveling, notwithstanding the revolutions that they had witnessed.

\section{Bibliography}

Allegra, Luciano. Identità in bilico. Il ghetto ebraico di Torino nel Settecento. Turin: Zamorani Editore, 1996.

Andreoni, Luca. "Perché non se habbia più a tribulare.' Gli ebrei della Marca fra spazi economici e conflitti giudiziari alla metà del XVI secolo." In Gli ebrei nello Stato della Chiesa. Insediamenti e mobilità. Edited by Marina Caffiero and Anna Esposito, 109-47. Padova, Esedra Editrice: 2013.

Andreoni, Luca. "Riscatto degli schiavi cristiani e intermediari ebrei. Un caso di studio tra Ancona e Ragusa (XVIII secolo)." Dimensioni e problemi della ricerca storica 2 (2013):109-33.

Andreoni, Luca. "Sono molto delicati li Ebrei di questo ghetto." Conversioni e strategie di difesa degli ebrei ad Ancona e nella marca pontificia (secoli XVII-XVIII)." Materia Giudaica 19 (2014): 291-302.

Andreoni, Luca. "Una nazione in commercio.' Gli ebrei di Ancona (sec. XVI-XVIII)." $\mathrm{PhD}$ diss., University of San Marino, 2014.

Andreoni, Luca, ed., Ebrei nelle Marche. Fonti e ricerche (secoli XV-XIX). Ancona: Il lavoro editoriale, 2012.

Berger, David. "Cum Nimis Absurdum and the Conversion of the Jews." The Jewish Quarterly Review 70, no. 1 (1979): 41-49.

Bonazzoli, Viviana. Adriatico e Mediterraneo orientale. Una dinastia mercantile ebraica del secondo '6oo: $i$ Costantini. Lint: Trieste, 1998.

Bonazzoli, Viviana. Commerciare nel ghetto. La società Oef-Magistri in Ancona a metà Seicento. Ancona: Archivio di Stato di Ancona, 2000. 
Bonazzoli, Viviana. "Sulla struttura familiare delle aziende ebraiche nella Ancona del '700." In "La presenza ebraica nelle Marche. Secoli XIII-XX." Edited by Sergio Anselmi and Viviana Bonazzoli, Special Issue. Proposte e ricerche 14 (1993): 139-54.

Bonfil, Robert. "How Golden Was the Age of Renaissance in Jewish Historiography?" In Cultural Change among the Jews of Early Modern Italy. Farnham: Ashgate, 2010.

Bonfil, Robert. Rabbis and Jewish Communities in Renaissance Italy. Oxford: Oxford University Press, 1990.

Bonora, Elena. Aspettando l'imperatore. I prinicipi italiani tra il papa e Carlo V. Turin: Einaudi, 2014.

Caffiero, Marina. Forced Baptism. Histories of Jews, Christians and Converts in Papal Rome. Berkeley: University Press of California, 2012.

Caffiero, Marina. Legami pericolosi. Ebrei e cristiani tra eresia, libri proibiti e stregoneria. Turin: Eianudi, 2012.

Caffiero, Marina. Storia degli ebrei nell'Italia moderna. Rome: Carocci, 2015.

Caffiero, Marina, and Anna Esposito, eds. Gli ebrei nello Stato della Chiesa. Insediamenti e mobilità (secoli XIV-XVIII). Padua: Esedra Editrice, 2012.

Caffiero, Marina, and Serena Di Nepi. "The Relationship between Jews and Christians. Toward a Redefinition of the Ghetto. Introduction to Special issue, Rivista di Storia del Cristianesimo 14, no. 1 (2017): http://primolevicenter.org/printed-matter/ not-that-ghetto/.

Caffiero, Marina, and Serena Di Nepi, eds. "I ghetti nell'Italia moderna." Special issue, Rivista di Storia del Cristianesimo 14, no. 1 (2017).

Calabi, Donatella. Venezia e il ghetto. Cinquecento anni del recinto degli Ebrei. Turin: Bollati Boringhieri, 2016.

Cassen, Flora. "The Last Spanish Expulsion in Europe: Milan, 1565-1597." AJs Review 38, no. 1 (2014): 59-88.

Chayes, Evelyne, and Giuseppe Veltri. Oltre le mura del ghetto. Accademie, scetticismo e tolleranza nella Venezia barocca. Palermo: New Digital Press, 2016.

Cooperman, Bernard Dov. "Ethnicity and Institution Building among Jews in Early Modern Rome." AJs Review 30 (2006): 119-45.

Cooperman, Bernard Dov. "Licenses, Cartels, and Kehila. Jewish Moneylending and the Struggle against Restraint of Trade in Early Modern Rome." In Purchasing Power. The Economics of Modern Jewish History. Edited by Rebecca Kobrin and Adam Teller, 27-45. Philadephia: University of Pennsylvania Press, 2015.

Cooperman, Bernard Dov. "Portuguese Conversos in Ancona. Jewish Political Activity in Early Modern Italy." In Iberia and Beyond. Hispanic Jewry between Cultures. Edited by Bernard Dov Cooperman: 297-313. Newark: University of Delaware Press, 1998.

Davide, Miriam, and Ioly Zorattini, Pietro, eds. Gli Ebrei nella storia del Friuli Venezia Giulia. Una vicenda di lunga durata. Florence: Giuntina, 2016. 
Davis, Robert C., and Benjamin Ravid, eds. The Jews of Early Modern Venice. Baltimore and London: Johns Hopkins University Press, 2001.

di Leone Leoni, Aron. La nazione ebraica spagnola e portoghese di Ferrara (1492-1559). I suoi rapporti col governo ducale e la popolazione locale ed $i$ suoi legami con le nazioni portoghesi di Ancona, Pesaro e Venezia. Edited by Laura Graziano Secchieri. Florence: Olschki, 2011.

Di Nepi, Serena. “Relazioni oltre le mura. Un processo ad Ancona all'epoca dei ghetti (1555-1563)." Special issue, Rivista di Storia del Cristianesimo 14, no. 1 (2017): 27-48.

Di Nepi, Serena. Sopravvivere al ghetto. Per una storia sociale della comunità ebraica nella Roma del Cinquecento. Rome: Viella, 2013.

Esposito, Anna. "Conflitti interni alla comunità ebraica di Roma tra Quattro e Cinquecento." In Judei de Urbe. Roma e i suoi ebrei: una storia secolare. Edited by Marina Caffiero and Anna Esposito: 69-79. Rome: Ministero per i Beni e le Attività Culturali, 2011.

Esposito, Anna. "Gli ebrei di Roma prima del ghetto: nuovi spunti." In Monaci, ebrei, santi. Studi per Sofia Boesch Gajano. Edited by Antonio Volpato: 377-94. Rome: Viella, 2008.

Esposito, Anna. "The Sephardic Communities in Rome in the Early Sixteenth Century." Imago temporis. Medium Aevum 1 (2007): 177-85.

Esposito, Anna. Un'altra Roma. Minoranze nazionali e comunità ebraiche tra Medioevo e Rinascimento. Rome: Il Calamo, 1995.

Ferrara, Micol. Dentro e fuori dal ghetto. I luoghi della presenza ebraica a Roma tra XVI eXIX secolo. Milan: Mondadori Università, 2015.

Foa, Anna. "Il nuovo e il vecchio: l'insorgere della sifilide (1494-1530)." Quaderni storici 19, no. 55 (1984): 11-34.

Foa, Anna. "La prospettiva spagnola: il Papa e gli ebrei nell'età di Carlo V." In L'Italia di Carlo V. Guerra, religione e politica nel primo Cinquecento. Edited by Francesca Cantù and Maria Antonietta Visceglia: 509-22. Rome: Viella, 2003.

Foa, Anna. The Jews of Europe after the Black Death. Berkeley and Los Angeles: University of California Press, 2000.

Foa, Anna. "Un vescovo marrano: il processo a Pedro de Aranda." Quaderni storici 99 (1998): 533-51.

Frattarelli Fisher, Lucia. Vivere fuori dal ghetto. Ebrei a Pisa e Livorno (secc. XVI-XVIII). Turin: Zamorani Editore, 2008.

Gasperoni, Michael. "Note sulla popolazione del ghetto di Roma in età moderna: lineamenti e prospettive di ricerca." In Gli abitanti del ghetto. La descriptio hebreorum del 1733. Edited by Angela Groppi, 69-115. Rome: Viella, 2014.

Groppi, Angela, ed. Gli abitanti del ghetto. La descriptio hebreorum del 1733. Rome: Viella, 2014. 
Hacker, Joseph R., and Adam Shear, eds. The Hebrew Book in Early Modern Italy. Philadelphia: University of Pennsylvania Press, 2011.

Ioly Zorattini, Pier Cesare, ed., Processi del S. Uffizio di Venezia contro ebrei e giudaizzanti. Florence: Olschki, 1980-1999.

Ioly Zorattini, Pier Cesare, Michele Luzzati, and Michele Sarfatti, eds., Studi sul mondo sefardita. In memoria di Aron Leoni. Florence: Olschki, 2012.

Kaplan, Yosef. An Alternative Path to Modernity. The Sephardic Diaspora in Western Europe. Leiden: Brill, 2000.

Kaplan, Yosef, ed., The Dutch Intersection. The Jews and the Netherlands in Modern History. Leiden: Brill, 2008.

Laras, Giuseppe."Intorno al 'ius cazacà' nella storia del ghetto di Ancona." Quaderni storici delle Marche 7 (1968): 27-55.

Lattes, Andrea Yaakov. "Gli ebrei di Ferrara e le imposte per i Catecumeni." La Rassegna Mensile di Israel 65, no. 3 (1999): 41-54.

Ligorio, Benedetto. "Ragusa. Un ghetto solo mercantile in Adriatico orientale (15461667)." Special issue, Rivista di Storia del Cristianesimo 14, no. 1 (2017): 53-70.

Luzzati, Michele. "Banchi e insediamenti ebraici nell'Italia centro-settentrionale fra tardo Medioevo e inizi dell'Età moderna." In Storia d'Italia, Annali 11, Gli ebrei in Italia. Edited by Corrado Vivanti. Vol. 1. Dall'alto Medioevo all'età dei ghetti: 175-235. Turin: Einaudi, 1996.

Luzzati, Michele. La casa dell'ebreo. Saggi sugli ebrei a Pisa e in Toscana nel Medioevo e nel Rinascimento. Pisa: Nistri Lischi, 1985.

Luzzati, Michele. "Una famiglia e quattro cognomi toponimici nel corso di un secolo: contributo alla storia degli ebrei d'Italia nel tardo Medioevo in una prospettiva interlocale." In Quel mar che la terra inghirlanda. In ricordo di Marco Tangheroni. Edited by Franco Cardini and Maria Luisa Ceccarelli Lemut: 469-77. Pisa: Pacini 2007.

Luzzati, Michele, and Giuliano Lazzarini. 'L'orizzonte 'italiano' di una famiglia ebraica laziale: prime note sui da Toscanella." In Gli ebrei nello Stato della Chiesa. Insediamenti e mobilità, secc. XIV-XVII. Edited by Marina Caffiero and Anna Esposito: 51-62. Padua: Esedra, 2012.

Mampieri, Martina. "Living Under the Evil Pope': Paul IV and the Jews in the Hebrew Chronicle by Benjamin Nehemiah ben Elnathan from Civitanova Marche (16th cent.)." PhD diss., Università degli Studi "Roma Tre"-Universität Hamburg: 2017.

Mandelbrote, Scott, and Joanna Weinberg, eds. Jewish Books and Their Readers. Aspects of the Intellectual Life of Christians and Jews in Early Modern Europe. Leiden: Brill, 2016.

Milano, Attilio. "I Capitoli di Daniel da Pisa e la comunità di Roma." La Rassegna Mensile di Israel 10, nos. 7-8 (1935): 324-38 and 10, nos. 9-10 (1936): 409-26. 
Milano, Attilio. Il ghetto di Roma. Rome: Carucci Editore, 1984.

Minchella, Giuseppina. Frontiere aperte. Musulmani, ebrei e cristianinella Repubblica di Venezia (XVII secolo). Rome: Viella, 2016.

Melcer Padon, Nourit. "Free Jews in a Free Port City: Livorno, The City without a Ghetto." Special issue, Rivista di Storia del Cristianesimo 14, no. 1 (2017): 71-88.

Novoa, James Nelson. Being the Nação in the Eternal City. New Christian Lives in Sixteenth-Century Rome. Peterborough (Ontario): Baywolf, 2014.

Pellegrini, Paolo, ed. Presenza ebraiche in Umbria dal Medioevo all'età contemporanea. Perugia: Editoriale Umbra, 2017.

Procaccia, Micaela." Non dabarà.' Gli ebrei di Roma nelle fonti giudiziarie della prima metà del Cinquecento." In Italia Judaica VI, Gli ebrei nello Stato Pontificio fino al Ghetto (1555). 80-93. Rome: Ministero per i Beni e le Attività Culturali, 1998.

Ravid, Benjamin. "Cum Nimis Absurdum and the Ancona Auto-da-Fé revisited: their impact on Venice and Some Wider Reflections." Jewish History 26 (2012): 85-100.

Ruderman, David. Early Modern Jewry. A New Cultural History. Princeton, NJ: Princeton University Press, 2010.

Ruspio, Federica. La nazione portoghese. Ebrei ponentini e nuovi cristiani a Venezia. Turin: Zamorani, 2007.

Savy, Pierre. "Entre peuple et communauté: remarques sur l'idée de nation chez les Juifs d'Italie (XVe-XVI e siècles)." Revue de l'histoire des religions 234, no. 2 (2017): 297-314.

Savy, Pierre. "Les 'politiques juives' en Italie du Nord avant les ghettos." In Religious Minorities, Integration and the State. État, minorités religieuses et integration. Edited by Ivan Jablonka, Nikolas Jaspert, Jean-Philippe Schreiber and John Victor Tolan, 35-47. Turnhout: Brepols, 2016.

Schwarzfuchs, Simon. "Controversie nella Comunità di Roma agli inizi del secolo XVI." In Scritti in memoria di Enzo Sereni. Edited by Daniel Carpi, Attilio Milani, and Umbero Nahon, 95-100 (Italian part). Jerusalem: Fondazione Sally Mayer, 1970.

Scuro, Rachele. "La presenza ebraica a Vicenza e nel suo territorio nel Quattrocento." Reti medievali rivista 6, no. 1 (2005): http://www.rm.unina.it/rmebook/dwnld/ebrei/ Ebrei_07_Scuro.pdf.

Segre, Renata. "Il mondo ebraico nel carteggio di Carlo Borromeo." Michael. On the History of the Jews in the Diaspora 1 (1972): 163-26o.

Segre, Renata. "La Controriforma: espulsioni, conversioni, isolamento." In Storia d'Italia, Annali 11, Gli ebrei in Italia. Edited by Corrado Vivanti, t. I, Dall'alto Medioevo all'età dei ghetti: 709-78. Turin: Einaudi, 1996.

Segre, Renata, ed. The Jews in Piedmont. Jerusalem: The Israel Academy of Sciences and Humanities: 1986-1990. 
Siegmund, Stephanie. The Medici State and the Ghetto of Florence. The Construction of an Early Modern Jewish Community. Stanford: Stanford University Press: 2006.

Simonsohn, Shlomo. "I banchieri da Rieti in Toscana." La Rassegna Mensile di Israel 38, no. 9 (1972): 406-23.

Simonsohn, Shlomo. The Apostolic See and the Jews. History. Toronto: Pontifical Institute of Medieval Studies, 1991.

Simonsohn, Shlomo. The Jews in the Duchy of Milan. 4 vols. Jerusalem: The Israel Academy of Science and Humanities: 1982-1986.

Simonsohn, Shlomo. The Jews in Sicily. 18 vols. Leiden: Brill 1997-.

Stefani, Piero. L'antigiudaismo. Storia di un'idea. Rome-Bari: Laterza, 2004.

Stow, Kenneth R. Catholic Thought and the Papa Jewry Policy. New York: The Jewish Theological Seminar of America: 1977.

Stow, Kenneth R. "Ethnic Rivalry or Melting Pot: The 'Edot' in the Roman Ghetto." Judaism 41 (1992): 286-96.

Stow, Kenneth R. "Prossimità o distanza: etnicità, sefarditi e assenza di conflitti etnici nella Roma del sedicesimo secolo." La Rassegna Mensile di Israel 58, nos. 1-2 (1992): 61-74.

Stow, Kenneth R. Theater of Acculturation. The Roman Ghetto in the 16th Century. Seattle, London: University of Washington Press, 2011.

Stow, Kenneth R., ed., The Jews in Rome, 1536-1551. Leiden: Brill, 1995-1996.

Toaff, Ariel. "Gli ebrei a Roma”. In Storia d'Italia, Annali n, Gli ebrei in Italia. Edited by Corrado Vivanti. Vol. 1. Dall'alto Medioevo all'età dei ghetti: 123-52. Turin: Einuadi, 1996.

Toaff, Ariel. Il vino e la carne. Una comunità ebraica nel Medioevo. Bologna: Il Mulino, 1989.

Toaff, Ariel. "Lotte e fazioni tra gli ebrei di Roma nel Cinquecento." Studi romani 27 (1979): $25^{-32 .}$

Toaff, Ariel, ed., The Jews in Umbria. Leiden: Brill, 1992-1994.

Todeschini, Giacomo. La banca e il ghetto. Una storia italiana. Rome-Bari: Laterza, 2016.

Toniazzi, Mafalda. I Da Camerino: una famiglia ebraica italiana fra Trecento e Quattrocento. Teramo: Palumbi, 2015.

Trivellato, Francesca. The Familiarity of Strangers. The Sephardic Diaspora, Livorno, and Cross-Cultural Trade in the Early Modern Period. New Haven: Yale University Press, 2010.

Urbani, Rossana, and Guido N. Zazzu, eds. The Jews in Genoa. Leiden: Brill, 1999.

van Boxel, Piet. "Hebrew Books and Censorship in Sixteenth-Century Italy." In Jewish Books and Their Readers. Aspects of the Intellectual Life of Christians and Jews in 
Early Modern Europe. Edited by Scott Mandelbrote and Joanna Weinberg, 75-99. Leiden: Brill, 2016.

Veronese, Alessandra. "Michele Luzzati e la storia degli ebrei come specchio della storia medievale." In "Diversi angoli di visuale" fra storia medievale e storia degli ebrei. In ricordo di Michele Luzzati. Edited by Anna Maria Pult Quaglia and Alessandra Veronese, 59-71. Pisa: Pacini Editore, 2016.

Veronese, Alessandra. Una famiglia di banchieri ebrei tra XIV e XVI secolo. I da Volterra: reti di credito nell'Italia del Rinascimento. Pisa: E TS, 1998.

Weinstein, Roni. Marriage Rituals, Italian Style. A Historical Anthropological Perspective on Early Modern Italian Jews. Leiden: Brill, 2004. 


\title{
The Sephardic Community and Social Practices in the Circuit of Money: Social Implications of Payment Networks in the Context of the Livorninas
}

\author{
Mauricio Dimant
}

On 15 April 1559 ("twenty-eight days in the month of Nisan"), Yehiel Nissim da Pisa published Hayye Olam (Eternal Life), a treatise on the social implications of money practices on Jewish life, especially the use of interest in the circuit of payment. ${ }^{1}$ He explained his reasons for writing the treatise thus, "[I]n these days and in these lands, since the matter of loans has become the common vocation of the people and the chief source of their livelihood, it became essential to compose a short treatise that would, as best as possible, include in it all the laws of interest, so that he who soweth righteousness will have a surer reward and by the wisdom of the righteous will escape from this serious iniquity."2

Da Pisa analyzed the uses of interest in the circuit of payment because he understood that in trade, and economic activities in general, a business's success was affected principally by the ability of payment. Therefore, he evaluated situations where, for example, "a person who needs money and has no partner in Lyons or in another state willing to pay money for him, or lacks credit with the merchants, may give pawns to a banker and say to him: 'Lend me a thousand ducats at the prevailing rate and I will pay the amount asked in Lyons."”

But at the same time, da Pisa found it necessary to probe the uses of interest in the circuit of payment because, according to him, these practices were not clearly defined in Jewish religion: "The Torah only prohibits interest that comes from the borrower to the lender, or by the authority of an agent, specifically for the purpose of interest." 4

1 ח F 13445 MSS-D 5214 System no. 000070787-1, The National Library of Israel. The English translation used in this article, Gilbert S. Rosenthal, ed., Banking and Finance among Jews in Renaissance Italy: A Critical Edition of Eternal Life (Hayye Olam) by Yehiel Nissim da Pisa, Florence, Italy, 1507-ca. 1574 (Cincinnati: Bloch Publishing Company, 1962) [hereafter: Rosenthal, Eternal Life (Hayye Olam)].

2 Ibid., 41.

3 Ibid., 126.

4 Ibid., 53 .

(C) MAURICIO DIMANT, 2019 | DOI:10.1163/9789004392489_013

This is an open access chapter distributed under the terms of the prevailing CC-BY-NC License at the time of publication. 
Although the application of interest rates was an ancient economic practice, da Pisa understood that, from the sixteenth century, interest rates in the circuit of payment had intensified, but without any relation to the system of loan, and therefore had begun to affect social practices like trust relations. In this context, and as a result of the lack of definition in Jewish religious law of these new practices of uses of interest rates, da Pisa lamented that Jews, "fail to differentiate between the permitted and the prohibited, and there is none to save them. Everything is equal in their eyes, for the path of the Torah is hidden from them, the east wind fills their bellies and falsehood and deception is under their tongues." 5

Da Pisa was intimately familiar with these practices because he belonged to a family associated with merchant banks in Italy, mainly in Florence and Pisa, and was himself married to the daughter of Asher Meshullam del Banco, a Padua banker. Born in 1507 in Pisa, da Pisa had "received a secular and religious education, as well as training in the banking profession."6 He wrote his treatise while living in Pisa with his family, where he was a prominent member of the local Jewish community.

The context in which da Pisa wrote his treatise extends beyond the different crises that affected the banking system in Italy and Western Europe in those years, such as the crisis of the Florentine bankers in $1557 .{ }^{7}$ With regard to the use of interest in the payment system from the sixteenth century onward, it is worth noting that since the development of trade relations through ports and markets in Europe, Africa, Asia, and America, practical changes emerged alongside the change in the perception of trade and business relationships. It had become more difficult for merchants not only to travel and to meet their buyers or sellers in person in new and more remote places, but also to ensure that there would be a person in those places who could guarantee payment on their behalf. 8

In order to improve the trans-border circuit of money and make the payment chain in international trade more efficient, especially in the matter of trust in the transfer of money, three important changes affected use of interest in the circuit of money, turning bills of exchange into a central payment instrument (a quasi-international currency): endorsement; bank control on the

5 Ibid., 35 .

6 Ibid., 24.

7 Victoria N. Bateman, Markets and Growth in Early Modern Europe (London: Routledge, 2015), 20.

8 Jonathan I. Israel, European Jewry in the Age of Mercantilism 1550-1750, 3rd ed. (LondonPortland, OR: The Littman Library for Jewish Civilization, 1998). 
cross-border market of bills of exchange; and use of special kinds of interest rates related to the expiration date of the bill of exchange. ${ }^{9}$

These changes had a positive effect on trust relations in the circuit of money according to Da Pisa, by building a sense of security among participants in the payment chain, thus enabling unlimited transfer of money based on relations between the parties:

Suppose, for example, R., who resides in the city of Florence, had a hundred ducats which he wanted to spend in the Venetian Republic. He goes to S. and says to him: "I will give you one hundred ducats in our city; you will draw up a draft on your partner in Venice so that he will pay the sum to me or to the person who comes to Venice in my name." S. agreed, took the money, and drew up the document in Venice. S. may receive two or three per cent or some similar amount. This is surely permitted because this is not considered a loan. R. does not want to send the money to Venice lest he be liable for transit or other dangers. He therefore gives it to S. who converts it there for a certain number of ducats, as he agreed. Were he to hire an agent to take the money, he would be obliged to pay for expenses or damage. ${ }^{10}$

This article sets out to analyze Yehiel Nissim da Pisa's treatise in light of the concerns of the Jews in Tuscany regarding their socio-economic relations in the circuit of payment, and especially practices of trust-building, in order to better understand the context of the decision of the Grand Duke of Tuscany to invite Sephardic merchants to settle in the region-a decision officially set out in the Letters of Patent of 1591 and 1593, known as the Livorninas.

While the roles of trade and merchants in the consolidation of Livorno as a city and free port (and not only in the case of the Sephardic diaspora) have been analyzed extensively, they were not examined sufficiently in the framework of social practices in the circuit of payment. A consideration of this aspect - especially by analyzing the use of bills of exchange - will allow for a deeper understanding of the development of Livorno society in general and of the Western Sephardic community in particular.

This article argues that the success of the Livorninas in encouraging the immigration of members of the Nação - and thus their impact on characteristics of the Sephardic community — was related to their capacity to resolve the 
challenges the Jews themselves perceived through their participation in the circuit of payment, which allowed articulation of economic and Jewish practices in a context of socio-economic change. Therefore, this article proposes to use "payment networks," as an analytical category in order to examine the history of the Sephardic community of Livorno in the early modern period.

\section{Bills of Exchange as a Tool in the Study of the Jews in Tuscany during the Early Modern Period}

The bill of exchange, a commercial instrument of payment used also as a merchant credit document, tried to solve the dangers and difficulties of transporting money from one place to another, thereby decreasing through this "piece of paper" the risk of traveling with cash and precious metals via ports and on the open seas.

Simón Ruiz, for example, issued a bill of exchange on 17 October 1558, to Pedro Álvarez in Medina del Campo, the main market for these activities according to Yehiel Nissim da Pisa, where participants in the money circuit issued their payment documents in Spanish or Tuscan. In the bill of exchange, signed by Simón Ruiz we read, "Not having paid for the others you will pay for this bill of exchange in the payments of the next fair of August from Bezençon to Andrés Rruiz or eight hundred escudos for the value of this bill of exchange to me and paying in my name to Juan de Sarribiarte. Christ with all."11

Originally, bills of exchange improved the payment system in trade through the simple practice of allowing delivery of a product in exchange for a payment commitment. The cash would be received by the seller after a period of time with money delivered by another local merchant in the name of the buyer. Initially, this practice meant that merchants knew and trusted each other, thus making it possible for them not to pay immediately upon delivery of merchandise. ${ }^{12}$ However, being limited to close contacts in order to be able to participate in the payment chain reduced the commercial possibilities for

\footnotetext{
11 "No habiendo pagado por las otras pagarán vuestras mercedes por esta quarta de cambio en los pagos de la próxima feria de agosto de Bezençon a Andrés Rruiz o a sí mismos ochocientos escudos de marco por la balor contada conmigo mismo y pónganlos por quenta de Juan de Sarribiarte sobre de mí. Christo con todos." Ferias y finanzas: el mercado del dinero, siglos XVI y XVII. Medina del Campo (Madrid: Fundación Museo de las Ferias, 2007), 38-39.

12 Ana Sofia Ribeiro, "Letras de câmbio e correspondência comercial como materiais da história: o acto de cooperar sob olhares distintos," CEM 2 (2011).
} 
trade development in the early modern period. ${ }^{13}$ Hence, new uses of bills of exchange rapidly developed in a sphere where it was necessary to make the payment system more efficient. Da Pisa's Hayye Olam, which sought to discuss the implications on Jewish life of socio-economic practices in the circuit of payment, was therefore especially relevant in the context of redefining social relationships between Jews and non-Jews, and especially New Christians, in Tuscany.

From the middle of the sixteenth century, international trade became increasingly complex, and the use of bills of exchange involved a financial circuit made up of a large number of people who could take on multiple roles. ${ }^{14}$ These roles consisted principally of four functions, for which it was not always necessary to involve different people and sometimes only one person per function. The first was the "beneficiary," that is, the person who eventually received payment for the transaction in his role as the provider. It is important to understand that the beneficiary was not necessarily the producer of the commodity, but the person in charge of sending it from the port of origin. Next was the "deliverer," the person who advanced the money to the "drawee," who would have guaranteed payment to the beneficiary and maintained a current account with the deliverer. Finally, there was the "drawer," who was in charge of the trade, and can be viewed as a reseller of sorts. He would issue the bill of exchange to the beneficiary and inform the drawee. ${ }^{15}$ Consequently, a bill of exchange constituted a special kind of trust relationship in the payment chain - a link of a financial nature between beneficiary, deliverer, drawer, and drawee, all of whom shared in a current account. ${ }^{16}$

Ever since the massive use of endorsement, the acceptance of bank control on the cross-border market of bills of exchange, and the use of interest as a tool of trust-building in the payment chain, relationships between participants in the circuit of money no longer needed to be based solely on ethnic, familial, or trade networks. The reason being that these changes offered mechanisms for dealing with different situations in the use of bills of exchange: when it was

13 The ethnic-religious and family networks were not always enough to ensure the transfer of money between buyers and sellers located in different areas, and at the same time this kind of relationship reduced the possibilities of finding new clients in new places.

14 The opportunity for enrichment in the circuit of payment through bills of exchange motivated new people to participate in the payment chain through their relationship with some of the persons performing the roles mentioned before; these people were not necessarily related to trade, production or the sale of products.

15 Markus A. Denzel, Handbook of World Exchange Rates, 1590-1914 (Surrey, UK: Ashgate Publishing, 2010), XxxI.

16 Ribeiro, "Letras de câmbio e correspondência comercial," 163. 
accepted (when the drawee agreed to pay the amount stipulated in the letter to the beneficiary); when it was rejected (when the drawee refused to pay the amount to the beneficiary, or because he had not been ordered by the deliverer to pay him, or because the drawee had not received enough money from the deliverer to do it); when the bill of exchange was protested for lack of agreement at the time of payment (usually by the beneficiary); when it was accepted under protest (usually when the debt was paid after a formal protest); or when it was endorsed (when the beneficiary transferred to a different beneficiary who was originally named in the first draft of the bill of exchange. ${ }^{17}$

Another matter was the variety of currencies, taxes, and different places of payment that were involved in the use of bills of exchange and the need for their standardization in order to ensure payment and make the circulation of money in the early modern period more efficient. ${ }^{18}$ However, use of the bill of exchange meant that the supplier of the goods agreed to receive payment not at the time of delivery, but at a future date.

The period of time between delivery of goods and payment is central to understanding the social implications of the use of bills of exchange and how they motivated new socio-economic practices. This especially, since new forms of enrichment were generated from these practices..$^{19} \mathrm{Da}$ Pisa explained it thus:

It is a known fact that most transactions or merchants and traders are [done] on installments or on credit. Almost all of them sell clothing, silk, and other merchandise on credit for a year's time or some similar arrangement. They cannot collect their money until after the elapsed time and even after that, the time of payment is delayed further. Meanwhile, the merchants must find money in order to carry on their business in clothing or in silk and in order to pay usual expenses, such as the rental of ships, the payments of customs and other things that require ready cash. If they were not able to find someone to supply them with a specific sum of money for their needs the entire business would bog down. ${ }^{20}$

In historical studies, however, forms of payments—or in other words, moneyare generally considered poor primary sources, precisely because of the characteristics that permit their social use: the standardized character of the body of the text and the absence of information about the context of its use. As a

\footnotetext{
17 Ibid., 164.

18 Ibid.

19 Denzel, Handbook of World Exchange Rates, 1590-1914, XXVI.

20 Rosenthal, Eternal Life (Hayye Olam), 123.
} 
document, money does not contain references, for example, to social motivations or conditions of use. Therefore, the presence of money and forms of payment in different historical contexts has been assumed to be a document without any special information that would be useful in an analysis or description of social process and practices.

In his work on the use of bills of exchange in Italy during the sixteenth century, Denzel explains that:

In general, a bill of exchange contained the following pieces of information:

(1) the three or four persons involved in the transaction [...]

(2) the sum of money over which the bill of exchange was issued;

(3) the currency in which the value of the bill had to be repaid, the exchange rate and the possible coinage in which the payment had to be affected;

(4) [the commercial custom at a place] or the term of the bill [...]

(5) the date the bill of exchange was issued; and, finally,

(6) the signature of the issuer. ${ }^{21}$

In other words, in the study of socio-cultural processes during the early modern period through analysis of bills of exchange, the problem is precisely in the information that these documents present. Nevertheless, payment is not only a social practice of economic negotiation; it is a central mechanism of motivation and articulation of social behaviors and relations between individuals and different social actors, and thus, its analysis cannot be reduced to the textual information provided in the document.

The circuit of payment allows the historian to examine not only the payment, exchange, and/or financing of activities between individuals, but also, and principally, social practices, forms of relations, motivations, values, and norms as the articulation of complex social behaviors such as ways of trust-building or forms of social prestige in certain historical contexts, which affected also religious practices. Therefore, I would argue that money ought to be considered as a source for examining social practices and behaviors through analysis of the practices in the circuit of payment.

In this framework, it is possible to see that the social practices within Sephardic communities during their organization, or immigration, were not entirely separate from the social practices implicit in (and motivated by) the circuit of money. One example that serves to illustrate this point is the crucial

21 Denzel, Handbook of World Exchange Rates, 1590-1914, XXIV. 
role bills of exchange played in the transfer of wealth to other cities by members of the $\mathrm{Naçãoo}^{22}$ especially during their immigration, as well as use of the bills in the organization of the community within the new host society. ${ }^{23}$

Study of bills of exchange used for transferring money from one place to another help us to shed light on the history of the Sephardic communities in Tuscany in the early modern period in general and regarding Livorno in particular in its becoming a destination for immigration, even though it was a new city still in the process of developing. ${ }^{24}$ Indeed, circuit of money practices were considered part of the conditions for immigration in the Livorninas, which includes the following provision: "you will be able to freely sell your real estate, summarily recover all of your debts and leave here with your merchandise, household utensils, jewels, objects of gold and silver, and other items, all of which shall be free of all customs duties." 25

Da Pisa dedicated an entire chapter of his treatise to the characteristics of bills of exchange and their role and function in the socio-economic context of the sixteenth century, citing examples in which bills of exchange could be used: "Suppose someone needs ten gold marks in Lucca of Florence. He obtains them according to the value of the mark in that place, let us say, 61 or $61^{1 / 2}$ or 63 ducats or some similar sum. He thereupon draws up a bill of exchange on his partners in Lyons so that they shall pay at the time of the coming fair ten marks." 26

According to Rosenthal, the translator of Hayye Olam into English, "Chapter fifteen is particularly illuminating because it contains a fine analysis of bills of exchange and the money bourses that were beginning to appear in his day. In this respect, Yehiel Nissim da Pisa displays an appreciation of economics and money that is decidedly modern in spirit."27

22 In other words, this article examines not only bills of exchange, commercial communications and data of economic activities in Tuscany during the early modern period, but principally public discussions between Jews in Tuscany regarding their practices in the payment chain, discussions published originally in Hebrew.

23 David B. Ruderman, Early Modern Jewry: A New Cultural History (Princeton, NJ: Princeton University Press, 2011).

24 Ibid. See also Francesca Trivellato, "The Port Jews of Livorno and Their Global Networks of Trade in the Early Modern Period," in Jews and Port Cities, 1590-1990: Commerce, Community, and Cosmopolitanism, ed. David Cesarani and Gemma Romain (LondonPortland, OR: Vallentine Mitchell, 2006).

25 Bernard Dov Cooperman, "Trade and Settlement: The Establishment and Early Development of the Jewish Communities in Leghorn and Pisa (1591-1626)," PhD diss., Harvard University, 1976, 431.

26 Rosenthal, Eternal Life (Hayye Olam), 124.

27 Ibid., 28. 
However, da Pisa's main concern in writing his treatise was not economic, but social: how the use of money affected the social relations of Jews in his time. From his place of residence in Pisa, he worried that circuit of payment practices not only generated social tensions for Jews, but also violated religious laws. His concerns enable the modern historian to contextualize his criticism of the practices of interest and money lending, particularly, how an instrument of payment and negotiation, namely the bill of exchange, began to become a value in itself.

Da Pisa's treatise reveals how socio-economic relationships and networking among the Jews were based not only on trade or ethnic, religious, or diasporic connections, but also on social practices in the payment system. This is a relevant distinction, as there are differences between social practices in "trading networks" and "payment networks." ${ }^{28}$ Especially, since social practices (like forms of trust or ways of negotiation) in the payment chain made boundaries between ethnic and religious identities even less obvious than in "trading networks."

For example, according to the payment network practices, if a Portuguese Jew of Livorno needed to maintain continuous commercial contacts and agreements with non-Jews he did not know personally, ${ }^{29}$ it was not necessary to maintain any kind of stable relationship in order to participate or play a role in the circuit of payment and thus in trade. This characteristic was an outcome of the impersonal ${ }^{30}$ and standardized nature of the payment chain through bills of exchange.

While much scholarly attention has been devoted to economic aspects of the history of the Jews in Livorno and Tuscany during the early modern period - and especially the relationship between socio-economic practices and Jewish-Sephardic community life ${ }^{31}$ - the social practices in the circuit of payment are still in need of research. For instance, how did practices of

28 Amélia Polónia, Amândio Barros, and Miguel Nogueira, "Now and Then, Here and There ... On Business": Mapping Social/Trade Networks on First Global Age," in Mapping Different Geographies, ed. Karel Kriz, William Cartwright, Lorenz Hurni (Berlin: Springer, 2010): 105-28.

29 Francesca Trivellato, "Images and Self-Images of Sephardic Merchants in Early Modern Europe and the Mediterranean," in The Self-Perception of Early Modern Capitalists, ed. Margaret C. Jacob, Catherine Secretan (New York: Palgrave Macmillan, 2008), 49-74. Trivellato, The Familiarity of Strangers: The Sephardic Diaspora, Livorno, and CrossCultural Trade in the Early Modern Period (New Haven: Yale University Press, 2014).

$30 \quad$ Francesca Trivellato, "Credit, Honor, and the Early Modern French Legend of the Jewish Invention of Bills of Exchange," The Journal of Modern History 84, no. 2 (2012): 289.

31 Ruderman, Early Modern Jewry: A New Cultural History. 
payment affect the social relations among the members of the $N a c ̧ a \tilde{a} 0^{32}$ - practices that were related to (and also motivated by) ways of enrichment? Or, how did practices of trust building in the payment chain affect relations between Jews and non-Jews at the local level?

\section{Changes in the Use and Circulation of Bills of Exchange and Their Social Implications on Jewish Life in Tuscany in the Context of the Livorninas}

Acceptance of endorsement of bills of exchange affected social practices in the payment chain because it implied that the payer would no longer need to know the final recipient of the document, thus allowing new ways of enrichment, such as new forms of loans and financial speculation, since this document could be exchanged several times and not necessarily for cash. ${ }^{33}$ For example, the bill of exchange issued by Simón Ruiz on 17 October 1558 to Pedro Álvarez was endorsed to Dominus Antonio y Herederos de Ludovico Bonbisi. ${ }^{34}$ There are many cases showing that endorsement of the bill of exchange allowed it to become a document that could be used as a form of loan to finance new commercial ventures and not only to pay for a previous purchase. In this sense, one of the new ways of enrichment created through endorsement was that bills of exchange could be lent again at a higher rate of interest, and thus could finance new business, a practice that was more difficult and almost impossible through cash. That is, a person could request or use a bill of exchange at an interest rate and then lend it to another person at a higher rate. ${ }^{35}$ Therefore, some bills of exchange were issued to be included in the payment system, but not as a payment tool for a specific commercial operation. In a letter of exchange from Enberes on 26 November 1561, Antonio Fucar wrote, "At the time of the payments of the next fair on October in Medina del Campo you will pay for this bill of exchange to Gregorio and to Andres Gutierrez four thousand ducats of

32 Regarding the social relations of the members of the Nação during the early modern period, see, for example, Yosef Kaplan, "Between Christianity and Judaism in Early Modern Europe: The Confessionalization Process of the Western Sephardic Diaspora," in Judaism, Christianity, and Islam in the Course of History: Exchange and Conflicts, ed. Lothar Gall, Dietmar Willoweit (Munich: R. Oldenbourg Verlag, 2011), 328.

33 Kohn, Bills of Exchange and the Money Market to 1600.

34 Ferias y finanzas: el mercado del dinero, siglos XVI y XVII. Medina del Campo, Fundación Museo de las Ferias, 2007, 38-39.

35 Trivellato, "Credit, Honor, and the Early Modern French Legend of the Jewish Invention of Bills of Exchange," 295; Kohn, Bills of Exchange and the Money Market to 1600. 
gold or its value out of bank control, or in it but with five per cent of the value to Alonso Gutierrez of Ayala on account."36

This financial characteristic of the bill of exchange-wherein the signer of the document and final recipient of the cash did not necessarily have to sustain any contact with each other-implied that this document did not always represent the trading of a product, but sometimes signified capital in its purest and simplest form. Researchers term this a "dry exchange": something used to reconcile financial statements between different agents or loans without the exchange of products. ${ }^{37}$

This practice in the use of bills of exchange, where the money could go "virtually" to different people who did not need to know each other, was seen by Yehiel Nissim da Pisa as a threat to Jewish ties. This economic practice posed a challenge to the norms of social relations among Jews and between Jews and non-Jews since it was now more complicated to know who could participate in a business relationship, and thus how to behave. He offered different examples to the reader in order to explain how to deal with this kind of situation: "A Jew took money from a Gentile at interest and sought to return it to him. He found another Jew to whom he said, 'Give him the money and I will pay you for it and for whatever you give to the Gentile.' This is prohibited because it is a kind of stipulated interest since the Jewish borrower has no dealing with the Gentile but actually gives the interest to his Jewish friend." 38

The characteristics of the economic practices through the endorsement of bills of exchange also affected relations between Jews and non-Jews at the local level. If "a Jew said to his neighbor: 'Lend me money for these pawns which a Gentile lent to me,' or 'Lend me money and afterwards I will send you the pawns through a Gentile,' the Gentile subsequently came and brought the pawns and gave the money to the borrower. It is obvious that this is surely stipulated interest and the lender may not take interest because the Gentile is

$36 \quad$ "Al tiempo de los pagamientos de proxima feria de hoctubre de medina del campo pagaran vuestras mercedes por esta primera de cambio A Gregorio $\mathrm{E}$ andres gutierrez ducados quattro mil de oro o su valor fuera de banco o en el con cinco al millar por la valor de Alonso gutierrez de Ayala y pónganlos A quenta por lo de auisso cristo con todos." Julián Paz and Cristóbal Espejo, Las antiguas ferias de Medina del Campo (Valladolid: Imprenta la Nueva Pincia y Tipografía del Colegio de Santiago, 1908), 113.

37 The massive increase in the use of the endorsement allows for contextualization of the changes in the legal systems in different ports and cities, particularly regarding cases where the payer and the supplier did not necessarily maintain any long term commercial relationship.

38 Rosenthal, Eternal Life (Hayye Olam), 93. 
a mere agent with the purpose of bringing the pawn to the Jewish lender and returning the money to the borrower." ${ }^{39}$

Da Pisa sought to explain the meanings of these economic practices also according to halakha, that is, with what was permissible or not according to Jewish law. Hence, he explained that, "If the transaction is a loan and the borrower gives the lender an additional amount for the time allotted him for the use of the money, this is called Biblical interest. There is no difference whether they have stipulated such payment at the origin of the loan or at the conclusion of the loan, since both are prohibited by the Torah."40

The second characteristic in the circuit of payment that occurred in the early modern period through the uses of bills of exchange, was the intensification and consolidation of the cross-border European financial market of this document, where bills of exchange came to be seen not only as an instrument of trade or loan, but also of value in itself. This financial market allowed for increasing people's participation in economic activities without having to be involved in the buying and selling of products. According to Benjamin Arbel, this capital market was so important that, "not only merchants, but any person who had saved some money, including women and ecclesiastic institutions, was able to invest in the cambio market. For example, around 1595, the capital invested in this market by inhabitants of Venice has been estimated at around nine million ducats." ${ }^{41}$

Regarding this economic activity, which was becoming a more common practice of enrichment in Western Europe, Da Pisa wrote,

The entire matter is very intricate and they must possess a great deal of shrewdness because there are clever traders who can anticipate future events in their mind's eye. [...] There are many people who have become enormously rich in this fashion. The Christian scholars are divided on this point: there are those who say that it is prohibited to give money in this manner because it is interest, while others permit it. [...] This manner of selling money through a bill of exchange has spread to all the lands of Christendom and there is no one who protests against it. ${ }^{42}$

\footnotetext{
$39 \quad$ Ibid., 101.

$40 \quad$ Ibid., 51.

41 Benjamin Arbel, "Mediterranean Jewish Diasporas and the Bill of Exchange: Coping with a Foreign Financial Instrument (14th-17th Centuries)," in Union in Separation: Diasporic Groups and Identities in the Eastern Mediterranean (1100-180o), ed. Georg Christ et al. (Rome: Viella, 2015), 531.

42 Rosenthal, Eternal Life (Hayye Olam), 125-26.
} 
While the practice started earlier, from the early modern period onward the financial market of bills of exchange evidently began to be controlled by merchant banks in collaboration with local rulers: "In every city and state, they have decrees and laws concerning it and they have special courts so that anyone may complain about his neighbor taking interest from him and he is judged and fined one hundred ducats in addition to the fact that he must return the interest which he took." ${ }^{33}$ In the case of Tuscany, the report of the commission of exchange in 1573 showed the intention of the rulers to order and control the commercial activity and the forms of negotiation. ${ }^{44}$

This characteristic affected social relations in the payment chain, since the merchant bank, with the support of the local authorities, began to provide security for payment — and also for the transfer of money through bills of exchange - and thus familial, ethnic, or communal relations became less significant in the circuit of money: "in order to avoid these problems [of payment security], he gives the draft to a banker and pays him a small fee in order that he might pay him in the place where he has need of the money."45

This process of monetization in the use of bills of exchange, in which the banks provided security in the payment system and took interest for it, also affected social relations according to da Pisa, because it modified practices of trust in trade and economic relations. He cautioned that this change also challenged the norms of socio-economic relations among Jews and between Jews and the non-Jewish population. As an example, he offered the case where "money belonging to a Gentile was deposited in the possession of a Jew who lent it to another Jew on interest. If the Jew accepted responsibility for the money, it is considered as his and he may not take interest. If he did not accept responsibility then the money is considered the Gentile's, and he may lend it on interest." 46

According to da Pisa, these economic practices not only motivated a kind of individualism among Jews ${ }^{47}$ — challenging community ties and sometimes

43 Ibid., 150.

44 "Per ordine di Vostra Altezza Serenissima ci fu commesso che sopra il modo del cambiare noi facessimo chamare alquanti mercanti pratichi con intendere quanto ne cicevano tanto in voce quanto per scrittura a fine che si provvedessi et ovviasse a' disrdini che perció ne potessino succedere, dove che per esecutione di quanto ce ne fu commesso habbiamo fatto ragunare nel Arte del Cambio la maggior parte de' mercanti che oggi negotiano in mercato nuovo et che trafficano giornalmente la cosa de' cambi." Carlo M. Cipolla, Money in Sixteenth-Century Florence (Berkeley: University of California Press, 1989), 134.

45 Rosenthal, Eternal Life (Hayye Olam), 123.

46 Ibid., 103-4.

47 Robert Bonfil, "Change in the Cultural Patterns of a Jewish Society in Crisis: Italian Jewry at the Close of the Sixteenth Century," Jewish History 3, no. 2 (1988): 11-30, here 14. 
religious laws - but also affected relations with new members of the Jewish community: "Interest which is proscribed by the Torah is that which is lent from one Jew to another Jew, as is written, "Thou shalt not lend on interest to thy brother.' This means that anyone who enters into the realm of the Torah of Moses and takes upon himself the yoke of God's commandments, even if he be originally a Gentile and subsequently became a righteous proselyte, is in the category of 'thy brother' and one may not lend him upon interest."48

Da Pisa was concerned about this practice in the circuit of money since it was not clear how this lucrative economic activity could affect the livelihood of Jews. According to Arbel, "The conditions imposed by rabbis on the use of cambio in transactions carried out among Jews rendered credit within the Jewish trading network more expensive than credit outside it, since it could not be separated from shipments of wares overseas, with all the overhead expenses involved in such an operation [...] At least in theory, such hindrances could have encouraged Jewish entrepreneurs to enter into cambio deals with partners outside the ethnic trading network to which they belonged."49 Da Pisa considered that "the general principle is that customs that are against the Religion and its laws should be removed from the world, such as this bitter and thoughtless practice of lending money from one person to another with the addition of interest." 50

There were attempts by rabbinical authorities in the Italian Peninsula to punish with excommunication those who participated in these economic practices without local permits, as opposed to Jews who had those permits. In addition to seeking answers through the responsa literature, rabbinical conclaves took place in the Italian Peninsula during the sixteenth century that attempted to deal with Jewish participation in the payment chain through the loan market without permission from local authorities. This was of special concern, because this kind of participation, which was motivated by the possibility of economic profit in the use of bills of exchange, also affected local social relations and matters of economic trust.

In the Ferrara conclave of 1554 , the rabbinical authorities declared: "We fully agree that no man may dare to infringe upon the franchise of his neighbor in order to lend money in a community where his neighbor already possesses a condotta from the rulers of the city. We therefore declare in firm and severe terms that no one may lend money without the consent of the established

48 Rosenthal, Eternal Life (Hayye Olam), 89.

49 Arbel, "Mediterranean Jewish Diasporas and the Bill of Exchange," 541.

5o Rosenthal, Eternal Life (Hayye Olam), 143. 
banker, and the sages of Venice, Padua, and Bologna, whose names are affixed at the end of this document are agreed on this point."51

However, these economic practices through bills of exchange were so lucrative that rabbinical authorities failed to stop those considered to be negative and that had been prohibited by them. In the conference of Cremona in 1582, for example, the rabbinical authorities decreed that, "on threat of excommunication that no person, either young or old, may infringe upon the loan franchise in a place where a Hebrew man or woman has already received such a charter from the local ruler to practice the money profession. 52

The third development that took place in the circuit of money through bills of exchange during the sixteenth century, and which concerned Yehiel Nissim da Pisa for its social implications on Jewish life, was the massive use of interest rate that only sought to improve the security of payment. This kind of interest implied that the interest rate was reduced in the event that the payer repaid the debt before the time stipulated in the document and increased when payment was delayed or conditions were changed at the time of payment. Therefore, the interest began to be seen as a useful instrument to improve the circuit of payment, and thus was a legitimate way of enrichment, affecting norms of socio-economic relations:

Suppose wax is worth eleven ducats and he [the beneficiary] sold it for eleven and one half to be paid in six months - this is called indirect interest. But if he sold him merchandise which has no fixed value, such as a silk garment or a cloak, he may sell it to him for more than its value because there is no known stipulated value, since someone who needs the merchandise may come at that time and may be willing to pay more for it. [...] Nevertheless, should the seller raise the price of these items exorbitantly, so that it is obvious to all that the increase is for the extra time given for payment, this is prohibited; it is permitted, however, to raise the price slightly. ${ }^{3}$

This use of interest promoted new ways of enrichment that motivated and affected a wide range of social relationships among Jews at the local level. For example, "If a man lends money to his neighbor and says to him: 'Dwell in my house, rent free, until I pay you your money or pay rent at a lower rate'-this is considered stipulated interest as prescribed by the Torah, since he stipulates

$51 \quad$ Ibid., 21.

$5^{2}$ Ibid., 21, 22.

53 Ibid., 62-63. 
the amount of deduction from the rent to cover the loan of money. This applies, even if the owner is not wont to rent his property. Since the stipulation was made at the moment of the transaction, it is prohibited as interest." ${ }^{4}$

In this context, the networks configured in the payment chain did not motivate any special relation among those who exchanged money, even in the case of paying to guarantee the sending of money:

[I]f a man rents his house and says to the tenant: "If you pay me now for the year, you may have it for ten ducats per annum. If you pay at the end of the year, you may have it for one ducat per month" - this is permitted. The reason for this is that the obligation for rental is due at the expiration of the time and this is comparable to the person who sells his debt at a lower price. But this practice is not allowed in a sale. For example, if he sold him his field and said to him: "If you pay me now, you may have it for one hundred ducats; but if you pay me after a year, it is yours for a hundred and ten ducats" - that is forbidden because he arises the value of the field for delay in payment and it is obvious that this is interest because sales are payable without delay in time and the seller should immediately receive his money. Because of the delay in time payment, he raises the price and the transaction is considered interest. ${ }^{55}$

Da Pisa was concerned that these economic practices negatively affected community ties often making them not only diffuse and unstable, but also sometimes even unnecessary. Consequently, relations among Jews and between Jews and non-Jews would be more difficult to regulate. According to him, "if the Gentile has already received the money from a Jew and gives it to another Jew, there is no fear of interest here because the Jewish lender is not an agent of the Jew and his business dealings are only with the Gentile. It is even permitted for him to give money and interest to the first Jew because he receives it for a Gentile." 56

In other words, these ways of earning money sometimes led Jews to maintain social relations with other Jews in ways similar to their relations with nonJews. This was especially so because in those practices the collective identities sometimes became invisible or irrelevant. For this reason, he found it necessary to clarify that, "A Jew who is the trustee for a Gentile and is the administrator of his properties may borrow from him on interest because it is obvious

54 Ibid., 61.

55 Ibid., $55^{-56 .}$

56 Ibid., 93 . 
that the money belongs to a Gentile. A Gentile who is the trustee of a Jew may not borrow from him on interest because it is obvious that the money belongs to a Jew.".57

Da Pisa was critical of Jews who participated in these economic practices because he viewed them as moving away from Judaism. He considered that their economic power led to the weakening of ties among Jews:

These blasphemers who stretch out their hands with scorners and run like deer to satisfy their evil inclination say other things as well. They declared: "What is so terrible if we lend money on interest to our fellow men? Behold, custom has spread amongst them and no one pays attention to them for in all labor there is profit, and this practice is permitted $a b$ initio. If there were no possible way of permitting such practices then numerous nobles and leaders would not lend money on interest. But their houses are filled with goods and their pails are full of milk. We are like them, for we follow in their footprints and walk in their paths. ${ }^{58}$

Moreover, he viewed the Jews who participated in these economic practices in the circuit of money as being "guilty of another evil because sometimes when the specified time elapses and the creditor lacks the ability to pay them their money on time, he takes an oath by the name of the Eternal (from Whom nothing is hidden) that he will pay him the interest for the time of delay, up to the last penny." 59

Da Pisa was also highly critical of the Jewish community's spiritual leaders in this regard:

Many of those people who are called by the title "rabbi" are the first to lend their money on interest and they increase their wealth through usury and interest. The people see their deeds and follow their paths; they are contemptuous of the words of the Torah without any rhyme or reason and without any support. Can that which has no savour be eaten without salt? [...] For the people look to them to learn from their actions and they say: "If this were not permitted, then Rabbi so-and-so would not lend his money on interest for he would surely perish!"60

$57 \quad$ Ibid., 102

58 Ibid., $136-37$.

59 Ibid., 144.

6 Ibid., $138-39$. 
In his view, the challenges to the Jewish way of life were the result of larger economic practices that could no longer be prevented, for, "there would be no stability or prosperity to the states or cities if the laws and religions provided that every man should abstain from gainful pursuits, for his hand will not gain much since it is the hand of the diligent that becomes rich while he who loves wine and oil will not become affluent. God has not created the world to be a void but has formed it to be inhabited, He established it, and searched it out."61

Though resigned to the fact that these economic practices could not be stopped, he did propose that in order to reinforce the ties between the "children of Israel," those Jews who, with the intention of obtaining profits through these practices in the circuit of payment, and "used the money incorrectly," should be severely condemned. After quoting numerous religious sources showing that such economic practices were opposed to Jewish law, especially interest among siblings, he concluded that,

From all of this it is obvious how serious this sin was in the eyes of the prophets of Israel. Moreover, there is excellent and valid reason for taking this position, following the dictates of human intellect, for this is in the category of those matters which, had they had not been written down in the Torah, would have been worthy of being written. This law is in the category of the rational precepts, since its violation could lead to the destruction of political society and the ruin of states. For this reason, the wise philosophers used to expel usurers from the cities lest they destroy the accepted customs and decrees of the states as is seen in the Republic of Plato and others besides him. Likewise, the sages of Israel wrote at length on the subject for the Torah has warned us against it and has called it usury. ${ }^{62}$

It is in the context of this discussion regarding the social implications of the economic practices in the circuit of money among the Jews in Tuscany, which were motivated by new forms of enrichment, that the Grand Duke of Tuscany, Ferdinando I de' Medici, initiated the Letters of Patent in 1591 and in 1593, known as the Livorninas, in order to increase the number of inhabitants in Livorno and ensure the city's economic development. ${ }^{63}$

$61 \quad$ Ibid., 149 .

62 Ibid., $163-64$.

63 Thus, examining the Livorninas in light of the changes in the social practices in the circuit of money in the sixteenth century in Europe, motivated by the development and modernization of the payment system of bills of exchange, it is possible understand more fully their success in the consolidation of the Jewish community of Livorno. 
One decision in particular in the Livorninas - legal autonomy within a framework of ballotazioni-allowed (and motivated) Sephardic Jews to articulate their Jewish economic practices and ties. This decision was especially relevant because in order to receive safe-conduct in Livorno, membership in the Sephardic community was mandatory and not voluntary. In other words, in order to receive the benefits offered by the Grand Duke, which allowed advantageous participation in the circuit of payment, the Jews had to be accepted by the authorities of the community in a balloting process that maintained communal control over the socio-economic behavior of the Jews.

The kind of legal protection that the Livorninas provided in the payment chain meant support for participation in these economic activities: the Livorninas not only invited immigrants to continue in these economic practices despite their previous legal problems, but it offered them support and protection in their future participation in the circuit of payment, under the condition of being accepted by the community authorities.

For example, chapter 4 of the Livorninas states: "We grant you, as said, a free and most ample safe conduct and real and personal security against those debts and misdemeanors from [the moment] when you shall have entered Our States and have been nominated by the Stewards of your synagogue and shall dwell in Pisa or Leghorn." 64

The Livorninas considered the legal protection in the payment chain as a central aspect that can promote the arrival of new Jewish inhabitants. In chapter 13, the Livorninas recognized that, "It may happen that by some ill fate some of you may go bankrupt, come upon bad (times) or be ruined, God forbid, and leave debts owing to individuals. In such a case We do not desire that the goods, merchandise, letters of exchange, etc. of your consigners and correspondents shall be attached, detained or sequestered on that account unless by order and decree." 65

Moreover, in chapter 15 the legal protection for those who participated in these economic practices was even clearer, giving them protection against common conflicts in the payment system: "We desire that anyone who may have your [goods] sequestered or distrained or may otherwise [impose] upon your property, merchandise or other household items. Shall have to truly justify his sequestration or distrain and prove [your] debt to him within one month. Otherwise, that period of time having passed, the sequestration or distrain

64 Cooperman, "Trade and Settlement," 419.

65 Ibid., 424. 
shall be considered ipso iure null. Nevertheless, it shall remain up to the discretion of the judge to prolong [the period] for just cause."66

Nonetheless, along with this legal support to participate in economic activities related to the circuit of payment, the Livorninas reinforced the community ties of the Jewish immigrants, especially in the case of those wishing to receive the benefits of safe-conduct and others proposed by the Grand Duke. Chapter 25 of the Livorninas decreed that, "your Jewish Stewards in your Synagogues shall have the authority to decide, sentence, and impose penalties as seems proper to them according to your Jewish rite and manner in all differences which may arise between one Jew and another. Furthermore [We desire] that they may apply your usual sentences and other censures in their manner [i.e., in the way in which such punishments are usually applied]. We desire by this to limit the jurisdiction and authority of your said judge. The Stewards shall have the power de facto to send into exile all those Jews who appear scandalous to them." ${ }^{\prime 67}$

The authority and power accorded by the Grand Duke to the Jewish community leaders to grant the benefits of safe-conduct, and later to be in charge of the acceptance of Jews as subjects of Tuscany, allowed the participation in profitable economic activities within the circuit of payment, but in the framework of the Jewish community ties, in light of the fact that being a member of the community was a mandatory condition in order to receive the benefits of the Livorninas. In this way, Jews were stimulated to participate in the circuit of payment by maintaining ties and community control.

Therefore, the successful consolidation of the Sephardic community of Livorno from the late sixteenth century onward must also be viewed in terms of the role that the Livorninas played in the circuit of payment, which allowed for articulation of the practices of the payment networks and of Jewish communal ties.

\section{Conclusions}

Yehiel Nissim da Pisa's treatise Hayye Olam enables a better understanding of the socio-economic practices and relations among the Jews in Tuscany in the second half of the sixteenth century. His work highlights the complexities for Jewish merchants given the nature of the circuit of payment, which sometimes forced them to establish economic relationships or maintain economic contacts with unknown players.

$\begin{array}{ll}66 & \text { Ibid. } \\ 67 & \text { Ibid., } 428 .\end{array}$


This kind of socio-economic uncertainty was resolved through the use of interest, enabled by new uses of bills of exchange. The interest was applied in a standardized way in order to regulate the behavior of the participants in the payment chain, and thereby motivated the continuity of these impersonal practices in addition to new lucrative businesses.

Da Pisa viewed this use of interest as a challenge to community ties, which were based on religious perceptions and, according to him, were maintained in commercial activities due to the familiarity among participants in the network relationships. In other words, according to da Pisa, this familiarity was a regulating factor in the behavior of Jewish merchants enabling them for example, to apply different economic conditions with Jews and non-Jews. It is in this light that we must view his proposition to regulate the practices of interest in the circuit of payment.

The economic and religious practices of the Jewish merchants and the associated tensions during the early modern period have been extensively studied. ${ }^{68}$ Yehiel Nissim da Pisa's treatise shows that these practices were also articulated in administrative decisions by rulers, as demonstrated by the success of the Livorninas.

Da Pisa did not necessarily view religion and trade as contradictory, despite the tensions between them. Rather, he viewed them as complementary, and suggested that economic and religious motivation (and not necessarily punishment) could be used to foster practices of trust-building.

The members of the Nação who immigrated to Livorno for commercial purposes and the local Jewish community were organized in a context of consolidation of new socio-economical practices and relationships in the circuit of payment, thanks, among others, to the standardization of the use of bills of exchange. The attention to the social practices in the payment system makes visible that trade in this context had social implications, contradictions and tensions, more complex than those that can be analyzed through the category of trade networks-complexity that allows us to rethink not only the networks, but also the practices and relationships of the Sephardic merchants who arrived in Livorno.

The use of "payment networks" as an analytical category in the study of the Sephardic community during the early modern period enables the reconsideration not only of the characteristics of diasporic practices of Sephardic merchant Jews, but particularly the meaning of the legal protection granted through the Livorninas, especially with regard to the Jewish merchants

68 See for example, Francesca Trivellato, Leor Halevi, and Cátia Antunes, eds. Religion and Trade: Cross-Cultural Exchanges in World History, 1000-190o (Oxford: Oxford University Press, 2014), 13 . 
in supporting their participation in the circuit of payment with the control of the Jewish community.

\section{Bibliography}

F 13445 MSS-D 5214 System no. 000070787-1, The National Library of Israel.

Arbel, Benjamin. "Mediterranean Jewish Diasporas and the Bill of Exchange: Coping with a Foreign Financial Instrument (14th-17th Centuries)." In Union in Separation: Diasporic Groups and Identities in the Eastern Mediterranean (1100-180o). Edited by Georg Christ, 527-42. Rome: Viella, 2015.

Bateman, Victoria N. Markets and Growth in Early Modern Europe. London: Routledge, 2015.

Bonfil, Robert. "Change in the Cultural Patterns of a Jewish Society in Crisis: Italian Jewry at the Close of the Sixteenth Century." Jewish History 3, no. 2 (1988): 11-30.

Cipolla, Carlo M. Money in Sixteenth-Century Florence. Berkeley: University of California Press, 1989.

Cooperman, Bernard Dov. "Trade and Settlement: The Establishment and Early Development of the Jewish Communities in Leghorn and Pisa (1591-1626)." PhD diss., Harvard University, 1976.

Denzel, Markus A. Handbook of World Exchange Rates, 1590-1914. Surrey, UK: Ashgate Publishing, 2010.

En el nombre de Dio Bendito, Liorne a 13 de Adar Rison de 5437 Qve corresponde a 14 de febrero de 1677, The National Library of Israel, Microfilm, F 38115.

Ferias y finanzas: el mercado del dinero, siglos XVI y XVII. Medina del Campo. Madrid: Fundación Museo de las Ferias, 2007.

Ferrara degli Uberti, Carlotta, “The 'Jewish Nation' of Livorno: A Port Jewry on the Road to Emancipation." In Jews and Port Cities, 1590-1990: Commerce. Community, and Cosmopolitanism. Edited by David Cesarani and Gemma Romain, 157-70. London/ Portland, OR: Vallentine Mitchell, 2006.

Frattarelli Fischer, Lucia. "Jews in Tuscany in the Modern Age." In RacialDiscrimination and Ethnicity in European History. Edited by G. Hálfdanarson, 49-62. Pisa: Edizioni Plus, 2003.

Frattarelli Fischer, Lucia. "Livorno città nuova 1574-16o9." Società e Storia 46 (1989): $873-93$.

Frattarelli Fischer, Lucia, and Stefano Villani. “People of Every Mixture.' Immigration, Tolerance and Religious Conflicts in Early Modern Livorno." In Immigration and Emigration in Historical Perspective. Edited by Ann Katherine Isaacs, 93-107. Pisa: Edizioni Plus, 2007.

Israel, Jonathan I. European Jewry in the Age of Mercantilism 1550-1750. London-Portland, OR: The Littman Library for Jewish Civilization, 1998. 
Kaplan, Yosef. "Between Christianity and Judaism in Early Modern Europe: The Confessionalization Process of the Western Sephardic Diaspora." In Judaism, Christianity, and Islam in the Course of History: Exchange and Conflicts. Edited by Lothar Gall, Dietmar Willoweit, 307-41. Munich: R. Oldenbourg Verlag, 2011.

Kohn, Meir. Bills of Exchange and the Money Market to 1600 (February 1999). Dartmouth College, Department of Economics Working Paper No. 99-04. https://ssrn.com/ abstract $=\mathbf{1 5} 1849$.

Paz, Julián and Espejo, Cristóbal. Las antiguas ferias de Medina del Campo. Valladolid: Imprenta la Nueva Pincia y Tipografía del Colegio de Santiago, 1908.

Polónia, Amélia, Amândio Barros, and Miguel Nogueira. "Now and Then, Here and There ... On Business": Mapping Social/Trade Networks on First Global Age.” In Mapping Different Geographies. Edited by Karel Kriz, William Cartwright, Lorenz Hurni, 105-28. Berlin: Springer, 2010.

Ribeiro, Ana Sofia. "Letras de câmbio e correspondência comercial como materiais da história: o acto de cooperar sob olhares distintos." CEM 2 (2011): 159-69.

Rosenthal, Gilbert S., ed. Banking and Finance among Jews in Renaissance Italy: A Critical Edition of Eternal Life (Hayye Olam) by Yehiel Nissim da Pisa Florence, Italy, 1507ca. 1574. New York: Bloch Publishing Company, 1962.

Ruderman, David B. Early Modern Jewry: A New Cultural History. Princeton, NJ: Princeton University Press, 2011.

Toaff, Renzo. "Statuti e leggi della 'Nazione ebrea' di Livorno. 1. Gli statuti del 1655." Rassegna Mensile di Israel 34, no. 11 (1968): 33-51.

Toaff, Renzo. "Statuti e leggi della 'Nazione ebrea' di Livorno. 2. La legislazione dal 1655 al 1677." Rassegna Mensile di Israel 38, no. 4 (1972): 17-32.

Trivellato, Francesca. "Credit, Honor, and the Early Modern French Legend of the Jewish Invention of Bills of Exchange." The Journal of Modern History 84, no. 2 (2012): 289-334.

Trivellato, Francesca. "Images and Self-Images of Sephardic Merchants in Early Modern Europe and the Mediterranean." In The Self-Perception of Early Modern Capitalists. Edited by Margaret C. Jacob, Catherine Secretan, 49-74. New York: Palgrave Macmillan, 2008.

Trivellato, Francesca. The Familiarity of Strangers: The Sephardic Diaspora, Livorno, and Cross-Cultural Trade in the Early Modern Period, New Haven: Yale University Press, 2014.

Trivellato, Francesca. "The Port Jews of Livorno and Their Global Networks of Trade in the Early Modern Period." In Jews and Port Cities, 1590-199o: Commerce, Community, and Cosmopolitanism. Edited by David Cesarani and Gemma Romain, 31-48. London-Portland, OR: Vallentine Mitchell, 2006.

Trivellato, Francesca, Leor Halevi, and Cátia Antunes, eds. Religion and Trade: CrossCultural Exchanges in World History, 1000-19oo. Oxford: Oxford University Press, 2014. 


\title{
Charity Begins at Home: Reflections on the Dowry Society of Livorno
}

\author{
Nourit Melcer-Padon*
}

For many years, the Sephardic Jewish community of early modern Livorno prospered thanks to the welcoming conditions offered by the Tuscan Grand Duchy on the one hand and the ingenuity and expertise of its prominent merchant members on the other. Having arrived in Livorno following the invitation of Cosimo I, the Jews enjoyed privileges, which became known as the Livornine. These privileges allowed them to live freely, neither confined by the walls of a ghetto nor restricted by outward distinguishing signs on their clothing or headdress. They were exempt from various taxes, allowed to buy and own property, and to employ Christian servants and wet-nurses. ${ }^{1}$ They established many community institutions, a sumptuous synagogue, a ritual bath, several academies, and boasted celebrated printing houses and a literary academy.

As in many other Jewish communities of the time, the massari, the lay leaders of the community, were in charge of social assistance, and one or more gabbaim (beadles) collected weekly fees for the various needs of community members, such as care of the sick, burial of the dead, and provisions of food and clothes for the poor, among others. The massari tried to maintain a centralized control of the assistance to ensure its fair distribution. ${ }^{2}$ The flourishing community also became known for its numerous confraternities, which provided beneficial aid of various kinds to its members. The first confraternities were set up after the separation of the Livorno community from its "mother"

* The research for this paper was written within the framework of the European Research Council, and received funding from the ERC under the European Union's Seventh Framework Programme (FP7/2007-2013) / ERC grant agreement $\mathrm{n}^{\circ} 29535^{2}$.

1 The Livornine were granted in 1592 and confirmed with additions in 1593. Based on these privileges, the Jewish nation could consider itself a separate body, governed by its own laws, though subjected to the Grand Duke, locally represented by the Governor of Pisa and Livorno, the Pisa Commissary and the Judge for Jewish affairs. See Renzo Toaff, La nazione Ebrea a Livorno e a Pisa (1591-170o) (Florence: Olschki, 1990), 47. For an in-depth study of the Livornine, and English translation of the privileges, see Bernard Dov Cooperman, "Trade and Settlement: The Establishment and Early Development of the Jewish Communities in Leghorn and Pisa (1591-1626)," PhD diss., Harvard University, 1976.

2 Toaff, La nazione Ebrea a Livorno e a Pisa, 257.

(C) NOURIT MELCER-PADON, 2019 | DOI:10.1163/9789004392489_014

This is an open access chapter distributed under the terms of the prevailing CC-BY-NC License at the time of publication. 
community of Pisa in $1613 .{ }^{3}$ The number of confraternities grew during the seventeenth and eighteenth centuries, when the community eventually upheld some sixty different confraternities_-an outstanding number ${ }^{4}$ — especially for a community that comprised between two thousand five hundred to three thousand people at its peak, toward the end of the seventeenth century, mostly of Portuguese background, ${ }^{5}$ when it represented about ten percent of the population of the town. ${ }^{6}$

In what follows, I would like to concentrate on an examination of the founding statutes of the most important and richest confraternity of the Livorno community: the dowry society, or the Hevra de Cazar Orfãs e Donzelas, founded in 1644-5, with the approval of the Grand Duke. ${ }^{7}$ This Hevra, was a kind

3 In 1597, the Jewish community of Livorno obtained partial independence from the Pisa community; complete autonomy was only obtained in 1613. See Toaff, La nazione Ebrea a Livorno e a Pisa, 115; See also Lucia Frattarelli Fischer, "Tipologia abitativa degli ebrei a Livorno nel Seicento," La Rassegna Mensile di Israel 1 (1984): 586.

4 Public assistance existed in the smallest of Jewish communities, yet the combined public and private assistance of the Livorno community constituted a genuine social state. See Cristina Galasso, Alle origini di una communità: ebree ed ebrei a Livorno nel Seicento (Florence: Olschki, 2002), 123. Two Jewish confraternities in Rome devoted to the study of the Torah may have already existed before 1520 . See Elliott Horowitz, "Processions, Piety, and Jewish Confraternities," in The Jews of Early Modern Venice, ed. Robert C. Davis and Benjamin Ravid (Baltimore and London: Johns Hopkins University Press, 2001), 231. There were more than thirty Jewish confraternities in Rome in the sixteenth and seventeenth centuries. See Cecil Roth, The History of the Jews of Italy (Philadelphia: Jewish Publication Society of America, 1946), 364. A point of comparison is the number of contemporary Christian northern Italian confraternities, which proliferated in the fourteenth and fifteenth centuries and were still popular in the sixteenth century. See Brian Pullan, Poverty and Charity: Europe, Italy, Venice, 1400-1700 (Aldershot: Variorum, 1994), 183, 186. In sixteenth-century Rome, about eighty-five Christian confraternities were founded. By the end of the century, most of the large villages and urban parishes had a confraternity. See Christopher F. Black, Italian Confraternities in the Sixteenth Century (Cambridge: Cambridge University Press, 1989), 57.

5 Toaff, La nazione Ebrea a Livorno e a Pisa, 277.

6 Lucia Frattarelli Fischer, "Ebrei a Pisa e Livorno nel sei e settecento tra inquisizioni e garanzie granducali," in Le inquisizioni cristiane e gli ebrei, Atti dei convegni Lincei 191 (Rome: Lincei Acc., 2003), 255. In 1601, there were 130 Jews in Livorno, and 701 in 1622; in 1642, out of a population of 12,300 Livornese, 1,211 were Jews. See Lucia Frattarelli Fischer, "Reti locali e reti internazionali degli ebrei di Livorno nel Seicento," in Commercial Networks in the Early Modern World, ed. Diego Ramada Curto and Anthony Molho (Florence: European University Institute, 2002), 151. The Jewish Community numbered about 4,500 people by the end of the eighteenth century. See Roth, The History of the Jews, 352. No other foreign community in Livorno grew as fast as the Jewish one. See Michele Cassandro, Intolleranza e accettazione: gli ebrei in Italia nei secoli XIV-XVIII, lineamenti di una storia economica e sociale (Torino: Giappichelli, 1996), 212.

7 For the request for the Duke's permission to establish the dowry confraternity, see Toaff, $L a$ nazione Ebrea a Livorno e a Pisa, 699-700. 
of confraternity ${ }^{8}$ that functioned uninterruptedly for a period of almost three centuries. ${ }^{9}$ Interestingly, as its statutes demonstrate, the Hevra combined various aspects of community life for its members: membership provided recognition of the member's social status as one of the wealthy leaders of the community and guaranteed a respectful burial usually reserved for important people; it gave members the opportunity to work for a morally worthy cause in line with both the community mores and the Duke's sanction; no less important, while the Hevra actually assisted young girls and their families, it also provided a safe and apparently profitable channel of investment.

\section{Adhering to Local Mores}

Jews in Italy were as concerned about family honor as were the Catholics. ${ }^{10}$ This was certainly true for Italian Jews, and especially for Sephardic Jews, whose "obsession with lineage" fashioned by their Iberian heritage, made "any taint on a family name and pride a most serious matter."11 The explicit aim of the Italian Sephardic dowry confraternities was to provide dowries for Jewish maidens of good moral character and conduct, 12 "virtuous, poor orphans and damsels who are not orphans," as stated in article 17 of the Livorno Hevra de Cazar Orfãs e Donzelas. Jewish and Christian communities alike were anxious to secure formal, institutionalized marriages for their flocks, and did their utmost to discourage clandestine marriages. ${ }^{13}$ Consequently, article 26 of the

8 The influences of Christian confraternities on Jewish ones, as well as differences and similarities between them, will be addressed in a more extensive version of this essay.

9 Toaff, La nazione Ebrea a Livorno e a Pisa, 263.

10 Elliott Horowitz, "Jewish Confraternal Piety in Sixteenth-Century Ferrara: Continuity and Change," in The Politics of Ritual Kinship in Late Medieval Florence, ed. Nicholas Terpstra (Cambridge: Cambridge University Press, 2000), 16o. Regarding the Jewish mitzvah of assisting maidens' marriage (hakhnasat kala), see Elliott Horowitz, "The Dowering of Brides in the Ghetto of Venice: Between Tradition and Change, Ideas and Reality," [Hebrew] Tarbiz 56 (1987): $348-5^{2}$.

11 Matt Goldish, Jewish Questions: Responsa on Sephardic Life in the Early Modern Period (Princeton, NJ: Princeton University Press, 2008), 130.

12 Similarly, the Amsterdam dowry confraternity was a "quintessentially 'Portuguese' institution," allowing illegitimate daughters of Jewish fathers (presumably of Christian mothers) to enter the lottery, but not those born of a Jewish mother. A woman's honor was considered extremely important, before and after she married. See Miriam Bodian, Hebrews of the Portuguese Nation: Conversos and Community in Early Modern Amsterdam (Bloomington: Indiana University Press, 1997), 115.

13 From the end of the Middle Ages, growing social and geographical mobility, as well as religious upheavals, led to increased preoccupation of various communities with clandestine 
Livorno dowry confraternity, itself an elite institution, states that only if a girl marries and receives the berakha (blessing) of a rabbi "according to our Holy law," would she be eligible for assistance. If she "married in any other way," she would have to return any money received. Importantly, as Yosef Kaplan points out, regulations regarding the sanctification of marriage that were adopted by Western Sephardic communities, even more so than those of other Jewish communities in the early modern period, "played a primary social role $[\ldots]$ in protecting the interests of the social elite," denying "members of the common classes the possibility of breaking into the social elite," while reflecting the "great degree of class differentiation" among Spanish and Portuguese Jews. ${ }^{14}$ The Italian Sephardic dowry confraternities employed a system that bore certain financial similarities to that of the Florentine Christian Monte delle Doti fund, ${ }^{15}$ though naturally on a much smaller scale than the Florentine government could boast. The Livorno dowry confraternity was comparable to

marriages. See Matt Goldish, "Passion at the Periphery: The Context of a Clandestine Converso Conjunction," Zutot (2001): 129. Regarding the Christian Venetian society's "disciplined sexuality," see Guido Ruggiero, The Boundaries of Eros: Sex Crimes and Sexuality in Renaissance Venice (Oxford: Oxford University Press, 1985), 9. The cost of a church wedding was one of the factors in the kind of marriage people performed. See Andrew J. Finch, "Parental Authority and the Problem of Clandestine Marriage in the Later Middle Ages," Law and History Review 8 (1990): 200.

14 Class struggles proliferated in Sephardic communities from Amsterdam to the New World until the 1730s. The socio-economic changes the Amsterdam community underwent in the eighteenth century fueled the struggle against outsiders, aimed at protecting not only the community's much impoverished fortunes, but its "values of lineage, status symbols and memories of a splendid past." See Yosef Kaplan, An Alternative Path to Modernity: The Sephardic Diaspora in Western Europe (Leiden: Brill, 2000), 289-92.

15 The importance of securing a dowry allowed Florentine rulers to enjoy the monies they encouraged people to invest in the Monte delle Doti, the first dowry fund of its kind, established in 1425, despite clerics' condemnations of usury. See Julius Kirshner, Pursuing Honor While Avoiding Sin: The Monte delle Doti of Florence (Milano: Giuffre, 1978), 16, 3059. See also Anthony Molho, Florentine Public Finances in the Early Renaissance 1400-1433 (Cambridge, MA: Harvard University Press, 1971), 136-41. Significantly, only tax-paying citizens of Florence could invest in the Monte; thus, girls who enjoyed the fruits of these investments had wealthy parents. The fund later became popular among members of all social strata, though the number of investors was limited again in the 1470 s and 80 s due to the fund's difficulties. See Anthony Molho, Marriage Alliances in Late Medieval Florence (Cambridge, MA: Harvard University Press, 1994), 82-83; Christiane KlapischZuber, Women, Family, and Ritual in Renaissance Italy, trans. Lydia G. Cochrane (Chicago: University of Chicago Press, 1987), 191. When the Monte delle Doti collapsed in the mid sixteenth century, Duke Alessandro de' Medici allowed the Monte di Pietà to pay interest on deposits it received, and it became a substitute for the dowry fund. See Carol Bresnahan Menning, “The Monte's 'Monte': The Early Supporters of Florence's Monte di Pietà," The Sixteenth Century Journal 23, no. 4 (1992): 671-72. 
the initial Monte delle Doti, insofar as its members belonged to the community oligarchy, ${ }^{16}$ and the main beneficiaries were their daughters and relatives. ${ }^{17}$

The Jewish dowry provided the bride with her share of her father's estate, especially critical if she was later divorced or widowed, since it would then constitute the woman's entire wealth. ${ }^{18}$ The ketubah, or marriage contract, ${ }^{19}$

16 Some Christian institutions, such as the Bolognese Monte del Matrimonio, set up in 1583, were more popular, and had a much broader scope of beneficiaries than that of the "Florence élite Monte delle Doti." See Mario Carboni, "The Economics of Marriage: Dotal Strategies in Bologna in the Age of Catholic Reform," The Sixteenth Century Journal 39 (2008): 372 .

17 In Rome, by contrast, Jewish dowries ranged between 1000 to 2000 scudi at most, "well below the principal Christian fortunes." See Léon Poliakov, Jewish Bankers and the Holy See: From the Thirteenth to the Seventeenth Century, trans. Miriam Kochan (London: Routledge, 1977), 18f, 126, 253. Contrary to Christian society, seventeenth and eighteenthcentury dowries in the Roman Ghetto did not point to the couple's families' social status, and generated great social mobility. See Michael Gasperoni, "La misura delle dote: alcuni riflessioni sulla storia della famiglia ebraica nello Stato della Chiesa in età moderna," in Vicino al focolare e oltre. Spazi pubblici e privati, fisici e virtuali della donna ebrea in Italia (secc. XV-XX), ed. Laura Graziani Secchieri, La Giuntina, 2015, https://hal.archives-ouvertes.fr/hal-01225374/document, accessed 26 January 2017. See also Attilio Milano, "The Private Life of a Family of Jewish Bankers at Rome in the Sixteenth Century," The Jewish Quarterly Review 30, no. 2 (1939): 16o. The reality of Livorno Jews was very different: they enjoyed financial prosperity at a time when ghettoized Jews were experiencing increasing difficulties. The rich Jews of Livorno could even strive to compete with the local Christian nobility in the size of their daughters' dowries.

18 Two famous cases of Jewish women who had to fend for themselves come to mind: Licoricia of Winchester, widowed in 1244, and Glikl of Hamelin widowed in 1689. See, respectively Reva Berman Brown and Sean Mc Cartney, "David of Oxford and Licoricia of Winchester: Glimpses into a Jewish Family Life in Thirteenth-Century England," Jewish Historical Studies 39 (2004): 1-34; Glikl, Zikhronot, 1691-1719, trans. and ed. Chava Turniansky (Jerusalem: The Zalman Shazar Center and the Hebrew University of Jerusalem, 2006). Sephardic women, involved in economic life in the sixteenth-century in the Ottoman Empire, were mostly older women, who managed their property according to their marriage contracts (ketubot). See Ruth Lamdan, "Jewish Women as Providers in the Generations Following the Expulsion from Spain," Nashim: A Journal of Jewish Women's Studies \& Gender Issues 13 (2007): 52. Of interest among seventeenth-century testaments from Livorno are wills left by women who maintained their husbands' commercial activities once widowed. See Galasso, Alle origini di una communità, 78 and n. 78 , 79 and n. $79,138 \mathrm{n}$. One particularly gripping will was written or dictated in 1662 by Raquel Gutieres Pegna, the richest woman of Livorno. She took care of the family business and her minor children for many years in the absence of her husband, presumed dead. See my article "She has them coming to Judaism': Tradition and Jewish Affinity in Jewish Wills of 17th-Century Livorno," European Journal of Jewish Studies 12, no. 2 (2018): 168-202.

19 The standardization of the wording of Jewish dowries dates from twelfth-century Spain, in Sefer ha-Shetarot, and France, in Mahzor Vitri, both considered "the forerunners of the Sephardic and Ashkenazic standards of dowry in vogue today." See Louis M. Epstein, 
was also meant to set the newlyweds on a viable economic path, and its total amount, made up of the bride's dowry and the groom's tosefet (addition or dower), ${ }^{20}$ were written down in the husband's business ledger. Francesca Trivellato points out that "Livornese Sephardim relied on dowries more than on external investors to finance their business ventures," and demonstrates that the ketubah could become a crucial component of a couple's livelihood in cases of bankruptcy, a common occurrence at the time. ${ }^{21}$ A 1582 Florentine law stipulated that in such cases, "a merchant has to repay his wife before he could pay any debts to third parties," and this rule applied to both Christian and Jewish Tuscan merchants, ${ }^{22}$ as reiterated and granted in article 14 of the 1593 Livornina. ${ }^{23}$ Jewish women were entitled to the restitution of their dowries as well as to all or most of the dower, and their ketubah therefore provided greater protection for a large part of a merchant's assets in cases of bankruptcy. ${ }^{24}$ Thus the ketubah, in addition to the Sephardic custom of consanguineous marriages, fortified the inextricable link between marriage and business. ${ }^{25}$ Dowries, as amply evident in the fascinating case Trivellato investigates, appear to have been extremely important for Livorno Jews, not only in the period of the subsequent eighteenth century discussed by her, but already for the founders of the dowry confraternity of 1644 .

\section{$2 \quad$ The Model of Previous Sephardic Dowry Confraternities}

The statutes of the Livorno dowry confraternity were mainly modeled on its sister Sephardic dowry confraternities of Venice and Amsterdam, founded in $1613^{26}$ and 1615 , respectively. The differences between these first Sephardic

The Jewish Marriage Contract: A Study in the Status of the Women in Jewish Law (New York: Jewish Theological Seminary of America, 1927), 102. Specifically regarding dowries, ibid., 89-106.

20 For the particularity of the ketubah, see Deborah Greniman, "The Origins of the Ketubah: Deferred Payment or Cash Up Front?" Nashim: A Journal of Jewish Women's Studies and Gender Issues 4 (2001): 84-118.

21 Francesca Trivellato, The Familiarity of Strangers: The Sephardic Diaspora, Livorno, and Cross-Cultural Trade in the Early Modern Period (New Haven: Yale University Press, 2009), 263 .

22 Ibid., 262.

23 Cooperman, "Trade and Settlement," 2: 424.

24 Trivellato, The Familiarity of Strangers, 263.

25 Ibid., 133, 139.

26 The 1613 Venetian dowry confraternity was founded by the Ponentines; the Levantines founded another in 1652 . These societies were open to members from both communities, 
dowry societies resulted from conditions "unique to each area and the contacts that emerged between these communities and the crypto-Jews who arrived from the Iberian peninsula," as Moisés Orfali writes. ${ }^{27}$ Bodian, for her part, finds that variations between Venice and Amsterdam resulted from both external and internal "essential and structural differences." ${ }^{28}$ Indeed, the Amsterdam community studied the Venetian confraternity's regulations in order to found its own, "especially tailored to the Amsterdam situation," ${ }^{29}$ while Livorno later used the Venetian one as a model.

The Amsterdam Dotar represented the elite's "most ambitious and original" effort to turn Amsterdam into the center of the entire Portuguese Nation, ${ }^{30}$ though an implicit agreement appears to have existed between the Venice and Amsterdam confraternities to operate "within different geographical spheres." 31 Thus, while the Venice confraternity targeted girls from the Mediterranean area, from Constantinople to North Africa and Gibraltar, Amsterdam focused on northwestern Europe. ${ }^{32}$ The Amsterdam Dotar even had representatives in various places, from Danzig to Saint Jean-de-Luz and later in the New World, who discreetly informed families about the possibility of application to the lottery. ${ }^{33}$ The dowry confraternities' main purpose, especially of the Amsterdam confraternity, was clearly to attract "maidens to the Jewish world, marry a Jewish partner, and save them and their families for Judaism." ${ }^{34}$ Amsterdam candidates, whether they resided in places where they were still compelled to lived outwardly as Christians, or had arrived in Amsterdam and

attesting to the strong relations between these two groups, due to social conditions produced by life in the ghetto. See Miriam Bodian, "The Portuguese Dowry Society in Venice and in Amsterdam: A Case Study in Communal Differentiation within the Marrano Diaspora." Italia 6 (1987): 48. Nonetheless, the Venetian Italian-Ashkenazic confraternity Hasi Betulot, founded in 1576, was not only the first dowry society among the Italiani, but also the first among European Jews. See Elliott Horowitz: "The Dowering of Brides," 353.

27 Moisés Orfali, "The Portuguese Dowry Society in Livorno and the Marrano Diaspora," Studia Rosenthaliana 35, no. 2 (2001): 147.

28 Miriam Bodian, "The Portuguese Dowry Society in Venice and in Amsterdam: A Case Study in Communal Differentiation within the Marrano Diaspora," Italia 6 (1987): 46.

29 Tirtsah Levie Bernfeld, Dowries and Dotar: An Unbroken Chain of 400 Years (Amsterdam: Menasseh Ben Israel Institute and Jewish Historical Museum of Amsterdam, 2015), 15.

30 Miriam Bodian, Hebrews of the Portuguese Nation: Conversos and Community in Early Modern Amsterdam (Bloomington: Indiana University Press, 1997), 134.

31 Bodian, "The Portuguese Dowry Society in Venice and in Amsterdam: A Case Study," 54.

32 Levie Bernfeld, Dowries and Dotar, 19-20.

33 Ibid., 23.

34 Ibid., 16-17. 
returned to Judaism, were thus required to confess their belief in "the unity of the Lord of the universe and the truth of his Sacred Law."35

It seems that the purpose of the Amsterdam dowry confraternity was the "re-judaization" of those who had remained in places where they still lived as Christians, such as in the south of France: while candidates could be New Christians, they would only receive the money once they celebrated their marriage in a Jewish community. ${ }^{36}$ The Venetian society statutes also had provisions for secret New Christians living outside Judaism. ${ }^{37}$

Both the Venice and Amsterdam confraternities were soon compelled to limit their scope, and give priority to local girls in their cities, in view of the growing demand made on their funds. ${ }^{38}$ By the time the Livorno confraternity was set up, each of the other confraternities had already restricted its activities, and it thus stands to reason that from its inception, the Livorno confraternity concentrated its efforts in providing dowries for local girls, either born or residing in the town, or "from it in any other place" (article 17).

The Livorno dowry confraternity statutes reflect the connections maintained between members of the community and their families and business partners who had remained in Iberia, so much so that the confraternity leaders sought ways to protect members who considered traveling there, concomitantly protecting the investments of the confraternity. The danger was clearly very great, as attested by many cases of conversos who, having lived in Livorno as Jews, returned to Spain and were subsequently burned at the stake in Madrid. ${ }^{39}$ The effort to dissuade members from traveling to Iberia is apparent in the phrasing of the revised 1727 statutes ${ }^{40}$ which are similar to regulations of other

35 Israël Salvator Révah, "Le premier règlement imprimé de la 'Santa Companhia de dotar orfãs e donzelas pobres," Boletin internacional de bibliografia luso-brasilliera 4 (1963): 664 . The leadership of the Amsterdam community accorded all members of the extended Nação "social legitimacy" if not "ideological legitimacy," an attitude apparent in the openness of the Amsterdam dowry confraternity to Jews and conversos alike (Yosef Kaplan, An Alternative Path to Modernity: The Sephardi Diaspora in Western Europe [Leiden: Brill, 200o], 18). The Amsterdam Dowry society considered brides and grooms eligible for support even if they lived as New Christians in southern France, Flanders, England and Germany, "yet specifically excluding the Iberian Peninsula." See Levie Bernfeld, Dowries and Dotar, 15 .

36 Révah, "Le premier règlement," 66o, 664.

37 Bodian, "The Portuguese Dowry Society in Venice and in Amsterdam: A Case Study," 44.

38 Levie Bernfeld, Dowries and Dotar, 19-20.

39 Cecil Roth, "I marrani di Livorno, Pisa e Firenze," La Rassegna Mensile di Israel 9 (1933): 395, 405.

40 Article 27 of the 1727 dowry society states that any member returning to Spain or Portugal for more than a year would be considered dead and be succeeded by his closest kin in the society. See Toaff, La nazione Ebrea a Livorno e a Pisa, 267. This regulation guaranteed that 
communal organs ${ }^{41}$ and to other communities. Another conspicuous connection to Iberia is noticeable in the fact that the aid given by the early Sephardic confraternities in Venice, Amsterdam, and Livorno was overtly exclusive and aimed at Sephardic girls. ${ }^{42}$ The confraternities accepted the candidacy of girls of Portuguese or Castilian lineage, either on their father or mother's side. ${ }^{43}$ In the three confraternities, the capital was considered kodesh and the members made sure that it would increase by collecting dues from new members as well as from various fines. The members were not allowed to touch the capital in any way, invest it or distribute its revenues to eligible candidates, unless there was a surplus allowing them to do so. ${ }^{44}$

Livorno's confraternity openly claimed to be based on its Venetian predecessor; ${ }^{45}$ accordingly, its annual meetings were held during Passover rather than on Purim, when the Amsterdam meetings were held, though both dates point to the converso character of these institutions. ${ }^{46}$ Other similarities

the society's capital remained in Livorno and continued to increase, as already reflected in article 10 of the $1644-5$ statutes.

41 According to Haskama 25 of Livorno's community book of regulations, whoever traveled to the "lands of idolatry" would not be called to read from the Torah in the synagogue, nor perform the ha-gomel rite (a prayer of thanks, usually after a person is saved from danger) for two years after his return; the returnee would not be allowed to hold public office for two years, and would remain under observation for that time. See Toaff, La nazione ebrea a Livorno e a Pisa, 561 ; see also Renzo Toaff, "Statuti e leggi della 'Nazione Ebrea' di Livorno," La Rassegna Mensile di Israel 34 (1968): 25, 46-47.

42 In 1670-1704, fourteen percent of the girls assisted by the Livorno dowry society were from other Sephardic communities, such as Alexandria, Jerusalem, Smyrna, Aleppo, Tunisia, Genoa, Amsterdam, and Venice; ten percent were of Italian-Ashkenazic origin. See Galasso Alle origini di una communità, 126. The Venetian Italian-Ashkenazic confraternity did not grant dowries based on ethnic origins, yet its revival in 1617 was linked to the preferential practice of the Sephardic confraternity in Venice. See Horowitz, "The Dowering of Brides in the Ghetto of Venice: Between Tradition and Change, Ideas and Reality," Tarbiz $5^{6}(1987): 361$.

43 Article 17 of the 1644-5 statutes; see also Bodian, "The Portuguese Dowry Society," 43, 46 and id., Hebrews of the Portuguese Nation, 136.

44 For Venice see Toaff, La nazione ebrea a Livorno e a Pisa, 265; for Livorno, see article 10 of the 1644-5 statutes; for Amsterdam, see Miriam Bodian, "The Santa Companhia de Dotar Orfans e Donzelas Pobres in Amsterdam, 1615-1639," PhD diss., Hebrew University of Jerusalem, 1988, 44-45.

45 As explicitly stated in the community's request for a permission to found the society. See Toaff, La nazione ebrea a Livorno e a Pisa, 699-700. See also in the preamble to the 1644-5 statutes, which I intend to publish in the longer version of this work.

46 There is no explanation why Passover was chosen as the time for the Venetian confraternity's annual meeting, though Passover certainly symbolized a release from slavery and freedom. The Amsterdam Dotar statutes justify choosing Purim "because on this day the Lord of the Universe gave such a good lot (sorte) to his people." See Bodian, "The 
were the number of officials responsible for the operations of the confraternities, and the way the lottery was conducted.

The most important similarity for our present discussion, is that like the Venetian confraternity, ${ }^{47}$ the Livorno Hevra was established as a charitable society whose major role was to assist its members who could reside in Livorno and in other places. ${ }^{48}$ This was particularly noticeable regarding the Livorno society's members, who "were principally concerned with the welfare of their own confraternities and relatives."49

\section{3}

\section{The Livorno Dowry Confraternity}

The Livorno dowry confraternity was a latecomer on both the Sephardic and the economic scene. Since it primarily targeted Livorno girls, the dowry confraternity can be viewed as one of the key elements in the consolidation of the local Sephardic community. The town of Livorno had remained a remote outpost so that for several years, Jewish merchants would continue to live in nearby Pisa while conducting their affairs in the port of Livorno. The performance of a proper Jewish wedding must have been particularly important for a community whose members were former conversos, and wished to encourage and fortify the Jewish character of the nascent community.

The Jewish community of Livorno was a close-knit one, administered by five massari, elected for a one-year term. The massari of 1644 were themselves among the founding members of the dowry confraternity. ${ }^{50}$ Membership in the confraternity was a sign of belonging to the dominant class, and among

Portuguese Dowry Society," 45. Conversos elevated Purim to "the status of a major holiday" since it celebrates "the Jews' victory over their enemies." See Bodian, Hebrews of the Portuguese Nation, 10.

47 Regarding Venice, see Cecil Roth, Gli ebrei a Venezia (Rome: Cremonese, 1933), 180-82.

48 Bodian, Hebrews of the Portuguese Nation, 137.

49 Orfali, "The Portuguese Dowry Society in Livorno and the Marrano Diaspora," 156. Having resumed its activity in 1617 , the Venetian Italian-Ashkenazic confraternity operated more as a mutual aid society than a charitable organization, though it still assisted some needy girls. See Horowitz, "The Dowering of Brides," 366-69. The Amsterdam Dotar can be considered a mutual aid society too, since "membership was seen as an investment for children and family members." See Levie Bernfeld Dowries and Dotar, 30.

5o Community leaders often belonged to more than one confraternity, donating to many charitable functions and exhibiting joint responsibility for the running of the community. The massari of 1642 were elected by a system that ensured their families' continued dominance. See Lucia Frattarelli Fischer, "Reti locali e reti internazionali degli ebrei di Livorno nel Seicento," in Commercial Networks in the Early Modern World, ed. Diego Ramada Curto and Anthony Molho (Florence: European University Institute, 2002), 153-54. The Duke 
the names appearing on the 1645 list of members, thirteen (or twenty percent) were massari, and of those, seven were elected massari no less than four times over the years; twenty-four other members (or thirty-six percent) held a number of community offices, and most were prominent merchants. ${ }^{51}$

The system of the dowry society of Livorno, as it was laid down in its initial statutes of $1644^{-5}$, was profitable enough to continue functioning until it was dismantled by the Italian state in World War I, when assets of all charitable organizations were confiscated for war orphans. ${ }^{52}$ The statutes of the Livorno Hevra were altered several times over the years, though they remained similar in principle to the founding statues of 1644-5. A more thorough comparison of the changes is beyond the scope of the present study.53

The procedure of casting the ballot and electing the yearly beneficiaries was as follows: maidens fourteen or older who wished to be considered had to present their candidacy to the deputies during the month of Adar, before Passover, and no later than the first day of Nisan. The deputies would write each girl's name on a ballot, and these would be placed in a box. Another box contained silver and golden balls. A ball would be randomly drawn along with each name. The procedure would be repeated a number of times. Each time, the name and the color of the ball drawn with it were recorded, and eventually the total number of times that a name appeared along with a golden ball was tallied. A name that appeared with a golden ball in three quarters of the total number of draws was declared a successful candidate.

The Hevra would distribute as many dowries as the revenues of that year allowed, but only entire dowries were given (as opposed to the Venetian Ashkenazic confraternity for example, which continuously decreased the amount of money given per dowry in order to provide dowries to as many girls as possible). Orphan girls only needed two-thirds of the draws, and they received further preference over the others since they would not be subjected to a second balloting, as could happen to a girl who was not an orphan.

This confraternity was apparently particularly successful for several reasons: the founders of the confraternity took into account the interests of the Grand Duke of Florence, and hence could rely on his support. Thus, as stated in the Italian preamble to the statutes addressed to the Duke and signed by the Governor of Livorno on 27 May 1644, the founders of the confraternity assert their aim is not only to "benefit the poor" but also to "better attach our

tried to change the election system to ensure it was not hereditary. See Toaff, La nazione Ebrea a Livorno e a Pisa, 179 .

$51 \quad$ Ibid., ${ }^{15}{ }^{1-53}$.

$5^{2}$ Ibid., 268.

53 Nine subsequent amendments to the statutes were made in the years $1684-1831$. See Orfali, "The Portuguese Dowry Society in Livorno," 156. 
nation to the most felicitous action" of the Duke. The official aim was to assist the virtuous poor, a morally commendable purpose that enabled keeping the poor under the control of the community leaders. The Duke, satisfied that they maintained an honorable community that took charge of its female members and promised to be lucrative to boot, sanctioned the centralized authority of the community leaders. ${ }^{54}$

In addition, the confraternity was conceived in order to help its members face the many adversities threatening them all. Recurrent waves of plague, highway robbery, piracy and shipwreck, bad investments and other misfortunes of trade, and the menace of bankruptcy were all part and parcel of their reality. The need for stability was particularly acute if they were to continue to develop new financial ventures, which benefited their families, the community, and indeed the town. Most importantly, the Hevra was a source of strength for the wealthy members of the ruling oligarchy. ${ }^{55}$ Thus, being a member was not just a sign of prestige, but also an indication of financial credibility.

The daughters of the rich founders not only had precedence in receiving dowries, as stated in article 20 of the statutes, but their dowries were significantly larger than those of the needy girls. They could receive three hundred pieces of gold, six to seven years after their fathers had entered the Hevra, and even up to ten years after a father renounced his membership (article 18). Members' granddaughters and nieces received one hundred and fifty pieces of gold (article 20). Although in principle, only one girl from each family could benefit from the Hevra each year, if there were enough revenues two sisters could receive the same amount (article 18). Only in the absence of members' daughters, granddaughters or nieces, could "poor meritorious girls" present themselves to the confraternity, though again, servant girls who worked in members' houses would be preferred (article 23), and receive as many dowries of one hundred pieces of gold as available funds permitted (article 21).

Seen in a broader context, this phenomenon can be construed as similar to the raison-d'être of Christian confraternities in the sense that they served as "an instrument for maintaining the governing class." ${ }^{56}$ Richard Trexler's exposition challenges modern notions of social classes and presents an alternative

54 Toaff, La nazione Ebrea a Livorno e a Pisa, 264.

55 Similarly, the Venetian Italiani Hasi Betulot society's main function was to provide dowries to daughters of members in financial difficulty. See Horowitz, "The Dowering of Brides in the Ghetto of Venice," 353. See also Orfali, "The Portuguese Dowry Society in Livorno," 149. Amsterdam's Dotar also gave advantages to dowry candidates related to members. See Levie Bernfeld, Dowries and Dotar, 30.

56 Richard C. Trexler, "Charity and the Defence of Urban Elites in the Italian Communes," in The Rich, the Well Born, and the Powerful: Elites and Upper Classes in History, ed. Frederic Cople Jaher (Urbana: Illinois UP, 1973), 64. 
definition by which economic situation (or one's net worth) defined what kind of poor a person was. An impoverished rich person would thus become a povero vergognoso, an "ashamed poor," rather than having to join the ranks of the "born-poor." Although inclusion in this group depended on the person being regarded as dignified-a status whose nature it is difficult to establish precisely today — here were certainly poor nobles, as well other people in need of assistance, according to their own or others' standards. ${ }^{57}$ Economic fluctuation was great and solidarity among the oligarchy was a necessity if they were to preserve their status, which was sanctioned not only by the ruling classes but also by the society at large. The reason was likely grounded in the belief, prevailing since the middle ages, that there was a natural link between virtue and high social standing, ${ }^{58}$ but one could surmise there was also a pragmatic motivation: the rich must remain rich in order to keep the economic system functioning, and to assist the poor to some extent.

The decision (referred to as "decreto" in the text, since it was to be approved by the Duke) to found the dowry society was signed on the 27th of March 1644, at a meeting of twenty-nine of the members of the community of Livorno. The seven regulators of the Hevra who were chosen at this meeting were Abraam de Pax with 18 ballots in favor, 9 against, and 2 abstentions; Isaque Ergas de Venetia with 22 in favor, 4 against, and 3 abstentions; Abraam Vaas Peña who received 17 votes in favor, 10 against, and 2 abstentions; Ishaq Ergas de Liorne with 19 votes in favor, 7 against, and 3 abstentions; Jacob Israel Amnom who received 17 in favor, 10 against, and 2 abstentions; Jacob Israel de Tunes with 15 in favor, 12 against, and 2 abstentions; and David Bueno who received 19 votes in favor, 9 against, and 1 abstention.

57 Christopher F. Black, Italian Confraternities in the Sixteenth Century (Cambridge: Cambridge University Press, 1989), 147.

$5^{8}$ Richard C. Trexler, "Charity and the Defence of Urban Elites in the Italian Communes," 70. Although this outlook was especially true for confraternities of earlier times, the "deserving poor" in Christian terms, "were never set aside," as stressed by Pullan. See Brian Pullan, Poverty and Charity: Europe, Italy, Venice, 1400-1700, 181. For his part, Nicholas Terpstra mentions the communal government's efforts "at separating the 'legitimate' from the 'illegitimate' poor, who were forced to wear an identifying symbol representing their dependency on charity." See Nicholas Terpstra, Lay Confraternities and Civic Religion in Renaissance Bologna (Cambridge: Cambridge University Press, 1995), 203. 
The list shows that no single member received a unanimous vote. This fact, as well as the breakdown of the votes, demonstrates that there was no one dominant leader in the community but rather a group of men about whom there was a consensus. The document is duly signed by Daniel di Jacob Serrano, the community Cancelliere. ${ }^{59}$

Fifteen months later, in June 1645 , the confraternity was formally set up, with forty-seven signatories. ${ }^{60}$ In their previous meeting, the regulators had elected Isach de Abram Ergas as depositary and the members were required to present their contributions to him in cash in return for a receipt. Their names and their contributions were duly recorded in the minute book of the Hevra. Initially, the list contained one more name, Daniel Jeosua, but since he did not pay his membership fees, his name was stricken from it. Accordingly, the total sum that constituted the society's initial capital was written at the bottom of the preamble to the statutes as "a total of two thousand three hundred and fifty Pieces of Eight." ${ }^{\prime 61}$

Of particular interest among the signatories is Dr. Mose Cordovero, one of the most prominent figures in the community, ${ }^{62}$ whose name appears at the top of the list of the first forty-seven members. Like two other members

59 Regarding attempts to remove Serrano from office after many years, and the role played by the Duke, see Toaff, La nazione Ebrea a Livorno e a Pisa, 236-39, 452.

6o The number of founding members rose to 194 by end of the sixteenth century, and to 219 in 1727. See Orfali, "The Portuguese Dowry Society," 149.

61 Giuseppe Vivoli places the number of founding members at three hundred. Based on this figure, the initial capital would have been considerably higher: 15,000 scudi. To the best of my knowledge, there is no other corroboration for this figure. See Giuseppe Vivoli, Annali di Livorno: dalla sua origine sin all'anno di Gesù Cristo 1840, colle notizie riguardanti I luoghi più antichi e moderni dei sui contorni (Livorno: Sardi, 1846), 4: 569. In the list of members published by Toaff, there are eighty-two members. See Toaff, La nazione Ebrea a Livorno e a Pisa, 463-64.

62 Dr. Mose Cordovero was born in Castile of a Portuguese New Christian family, perhaps related to the famous kabbalist, Rabbi Moshe Cordovero (1522-1570) of Safed. Having probably studied medicine in a Spanish university, he became the first Jewish doctor in Livorno, esteemed by both Jews and Christians. From 1598 until 1626, together with his brother Daniel, he operated a bank, the Monte de Moisé Cordovero, with permission to loan money at 8.5 percent to Livornese and fifteen percent to foreigners, a much higher rate than the Monte di Pietà of Pisa was taking at the time. Cordovero also headed a prosperous import/export firm and owned several properties. He was a central figure in the social life of the community, elected three times massaro, in 1604, 1616 and 1644. For forty-five years, he enjoyed an almost complete hegemony over the Sephardic community, though his past as a New Christian was not forgotten, and he was denounced as a heretic by the Lisbon inquisition in 1641 . See Toaff, La nazione ebrea a Livorno e a Pisa, 114, 200, 279; Michele Cassandro, Intolleranza e accettazione, 220; Frattarelli Fischer, "Reti locali e reti internazionali degli ebrei di Livorno nel Seicento," 152. 
on the list, he paid the membership fees but renounced his place in favor of his son Jacob, probably due to his advanced age. This seems to be an explicit indication that appearing on the list of the founding members of the society was in itself a mark of social status, even though the membership was not the father's but the son's. Similarly, another family member paid membership fees for twelve others on the list, and apparently, D.I. Bueno paid for the memberships of four others. What appears as careful bookkeeping could also be construed as a way to get the names of two family members on the list for the "price" of one member, while boasting the benevolence of the actual donor.

The first three deputies elected by the confraternity for a term of one year were David Bueno, Jacob Franco Albuquerque, and Isac Ergas. ${ }^{63}$ During the first years of the Livorno Jewish community, the appointed massari were always members of the same twelve founding families. This situation was loudly contested with the Duke in 1628 , when the community comprised about one hundred families of wealthy merchants and ship owners, all claiming their right to take part in the governing of the community. ${ }^{64}$ The list of founding members and first officials of the dowry confraternity thus clearly reflects the state of affairs in the community and the elitist nature of this confraternity as well as the division of power among members.

\section{$5 \quad$ Financial Background}

Frattarelli Fisher has examined the relation between economic wealth and living conditions in a detailed study of Livorno's proprietors, and considered

63 David Bueno was a wealthy merchant and lived in Livorno from 1612. In 1652, he bought seven shops in the "New Venice" quarter for 5,053 scudi. He was massaro three times, in 1644, 1650, and 1653. Jacob Franco Albuquerque manufactured silk threads with his brother Abram, obtaining the concession in 1632. Jacob was massaro in 1646 . His name is also mentioned in a petition the massari sent to the Grand Duke in 1645 , to be permitted to judge a case between Jews and Christians (probably New Christians) living in Spain. Isac Ergas was massaro in 1646, 1651, 1655, 1659, and 1667 . See Toaff, La nazione ebrea a Livorno e a Pisa, 148, 359, 455-57, and 661.

According to the coda of the statutes, their election proceeded in this way: a first round produced the name of Isac Ergas of Venice, with twenty-six votes in favor and six votes against, and three abstentions of relatives. A second draw did not produce the required three-quarters of the votes, but finally, Jacob Franco Albuquerque was chosen in the third round, and David Bueno was chosen in the fourth round.

64 Michele Cassandro, "Gli ebrei di Livorno nel seicento: aspetti economici e sociali," $L a$ Rassegna Mensile di Israel 50, no. 9/12 (1984): 570. 
the kinds of houses they owned and rented, and their location, which is especially interesting given that Livorno never enclosed its Jews in a ghetto. ${ }^{65}$ She found that while the Jews, like other foreign nationals residing in the town, tended to concentrate along one main street from 1603 onward, their choice of living quarters depended on economic possibilities and domestic necessities rather than on national origins. ${ }^{66}$ Although there was an effort on the part of Tuscan Dukes to concentrate the Jews in one quarter, the privileged families were allowed to live on Via Ferdinanda, the main street in Livorno to this day, though the name was since changed to Via Grande. ${ }^{67}$ In 1645 , the Jewish community numbered about 1,250 people living in 170 houses, with a low average of one person per room. ${ }^{68}$ The financial situation of the merchants can also be appraised from the list of donations demanded of the community as a wedding "gift" upon the marriage of Ferdinand, the son and heir of Cosimo III, with Violante, Princess of Bavaria, in $1688 .{ }^{69}$

The main economic activity of the Jews in Livorno comprised loan banks, ${ }^{70}$ liberal professions, industry (such as soap production, sugar refinery, leather, silk, feathers and coral work), land and maritime commerce, including financing, currency exchange, and insurances. ${ }^{71}$ Alongside great risks, sea loans

65 See my article: "Free Jews in a Free Port City: Livorno, the City without a Ghetto," in I Ghetti nell'Italia moderna. Relazioni oltre le mura, ed. Marina Caffiero and Serena di Nepi, special issue of Rivista di Storia del Cristianesimo, 1 (2017): 71-88.

66 Lucia Frattarelli Fischer, "Tipologia abitativa degli ebrei a Livorno nel Seicento," La Rassegna Mensile di Israel 50, no. 9/12 (1984):584. Toaff found a clear correlation between the ruling classes and their financial situation, measured by ownership of real estate (Toaff, La nazione ebrea a Livorno e a Pisa, 150). Ownership of real estate demonstrates that the seventeenth-century Livorno community experienced continuous numerical growth and economic flourishing, though precise data is not available. See Michele Cassandro, Aspetti della storia economica e sociale degli ebrei di Livorno nel seicento (Milan: Dott. A. Giuffrè, 1983), 54 .

67 Frattarelli Fischer, "Tipologia abitativa," 586.

68 Ibid., 598.

69 Frattarelli Fischer, Vivere fuori dal ghetto: Ebrei a Pisa e Livorno (secoli XVI-XVIII) (Turin: Zamorani, 2008), 171-75.

70 Although loan business was officially forbidden in Florence, it existed under other forms. Between 1598 and 1626, the Dukes allowed the Banco di Pegni to function, to boost the new city. See Frattarelli Fischer, Vivere fuori, 159. The first authorization for a Jewish bank (which dealt with value exchanges) in Livorno was given to Abram Israel in 1595, before the concession in 1596 to the Cordovero brothers' loans bank. See Cassandro, Intolleranza e accettazione, 220.

71 Cassandro, "Gli ebrei di Livorno," $573-74$. 
could produce between twelve and twenty-five percent profit. ${ }^{72}$ Other longterm economic ventures in which Livorno Jews were particularly active were government tenders for commodities such as wood and coal, paper (probably related to the Jews' printing activity), and tobacco. ${ }^{73}$ The monopoly for the manufacture and sale of tobacco in the entire Duchy was received in 1645 by Jacob and David de Tunis and Abram Vais della Pegna who were among the founding members of the Hevra, as well as two Italian Jews, David Vigevano and David Falcone. ${ }^{74}$ Their initial investment of an annual payment of ten thousand scudi for ten years produced a business that, in 1672, was worth 34,000 scudi per annum. In effect, they created a market for the new product, imported from Brazil through Portugal. The importance of this business grew to the extent that the Jewish merchants were able to provide work for the villagers surrounding the city, and some of them settled in various agricultural centers, or could afford to buy houses in Livorno. ${ }^{75}$ In 1642 , taxation imposed on some eighty Livorno merchants reveals that the Jewish merchants' share provided the Duke with 4,622 scudi, a third of all the taxes imposed on foreign merchants, including the English, who were taxed to the tune of 1,400 scudi. $^{76}$

The life span of various businesses run by Livorno merchants of all nations was relatively short, and few lasted longer than a century. Bankruptcy was a regular occurrence, and could affect both old and new houses of commerce. Merchants were compelled to work in precarious conditions, often without being able to ascertain the solvency of third parties, and decisions regarding buying and selling merchandise were hazardous, not to mention the innumerable sea incidents, especially nefarious, due to the habit of under-insuring cargo. ${ }^{77}$ Livorno capitalism was based on family capital, and the common strategy was to take part in several ventures concurrently. ${ }^{78}$

\footnotetext{
72 Michele Cassandro, Aspetti della storia, 80.

73 Cassandro, "Gli ebrei di Livorno," 580-81.

74 Frattarelli Fischer, Vivere fuori, $15^{2-54}$.

75 Frattarelli Fischer, "Reti locali e reti internazionali degli ebrei di Livorno," 162-63.

76 Ibid., 155 .

77 Insurance usually ranged between six hundred to one thousand ducats. Particularly noted was one large cargo of Spanish wool destined for Tunis insured at ten thousand ducats. See Cassandro, "Gli ebrei di Livorno," 580.

${ }_{78}$ See Jean Pierre Filippini, Il porto di Livorno e la Toscana (1676-1814) (Naples: Edizioni Scientifiche Italiane, 1998), 1: 88-90.
} 
The dowry confraternity functioned as an actual commercial company, ${ }^{79}$ as article 10 of the $1644-5$ statutes visibly demonstrates. ${ }^{80}$ The capital of the confraternity in its first years consisted of a joining fee of fifty scudi per member, initially amounting to 2,350 scudi, private donations and legacies, fines imposed on members for various reasons, and dowries returned to the fund, if indeed such cases occurred; all these sums were accrued and considered kodesh, as mentioned earlier, and could not be used for private purposes. The statutes posit that the initial capital could only grow and should never be allowed to decrease. The dowries were distributed solely out of the revenues, and the society's expenses were covered by fines imposed on members who did not attend meetings (article 12). Deputies were personally responsible for the monies, and any mishap would not only lead to their loss of office, but funds lost would also have to be reimbursed from their own pocket, with an additional ten percent fine, which would then be added to the capital, as were all other fines (article 10).

In addition, a dowry could only be issued to a daughter or relative of a member after six to ten years of membership. This meant that the deputies could use the capital for a long period of time, perhaps for long-term investments. Probably for the same reason, it was decided that twelve years must pass before any changes could be made to the founding statutes (article 35), allowing the deputies ample freedom of operation. The regulators further stated in the decision of 27 March 1644, that no institution similar to the dowry confraternity could be established in Livorno, under pain of herem (ban), as well as a fine of five hundred Pieces of Eight, which would be distributed equally between charity for the community and for the Land of Israel, and the Duke's treasury. Officially, the reason for this precaution was to allow the confraternity to do its work in an orderly manner, though clearly the regulators wanted to ascertain that this confraternity would not have any competition, thereby strengthening the authority of the confraternity deputies, sanctioning their financial operations, and securing the confraternity's future validity.

79 Cassandro, Aspetti della storia, 118.

8o Article 10 deals specifically with economic ventures permitted by the society, yet it is relatively difficult to decipher. This article was written in the kind of "shorthand" that would probably have been clear to merchants of the time, but there might also have been an intentional obfuscation on the part of the writer/s. Despite this, important details regarding the finances of this organization can be surmised from this article, as well as from several others. I would like to thank Prof. Francesca Trivellato, to whom I am indebted for clarifications regarding these issues, specifically the reading of article 10. 
The founding members were well-versed in legal matters and financial procedures, as is clearly attested in the statutes setting up the Hevra, for all its religious and charitable aspects. The regulators insisted that the initial capital would be physically in their hands, in cash, and ready to use, rather than accept promises of future contributions. Accordingly, by signing, a candidate had fourteen days within which to pay in order to formally become a member. To ensure that the monies were dealt with appropriately, a number of mutual safeguards were put in place: all the money and small pawned possessions would be kept in a box that was placed in the synagogue and could only be opened with three keys, each of a different design, one for each deputy, and only when all three were present (article 10); should pawned goods be too big to fit in the box, the deputies would decide on a safe place to keep them; ${ }^{81}$ in addition, investments would be decided upon based on agreement of all three deputies. Article 31 states that in the event that most or all of the confraternity's members leave Livorno, a common decision will be reached in advance regarding the necessary measures to be taken, provided the capital remained togetherperhaps outside of Livorno-and the profits will continue to be used for the provision of dowries. As immigrants and descendants of conversos, the regulators were well aware that changes in political and economic circumstances might lead to further emigration. Yet the Hevra's economic strength depended on keeping the capital intact, hopefully continuously increasing, over a long period, hence the inclusion of this article.

Like other financial companies, the Hevra operated in various trade sectors in Livorno, and its importance grew apace with the continually increasing number of leading figures of the Nação who joined it. Most of the trade handled by the Jewish merchants of Livorno was with the Levant and North Africa, areas in which they reached outstanding commercial success. ${ }^{82}$

81 The sheer mass of pawned goods was no small matter. For example, in Mantua, when Jews were threatened with enclosure in a ghetto, the bankers among them claimed they would not have enough space for pawns in their shops there. The first Monti di Pietà faced similar problems. See Léon Poliakov, Jewish Bankers and the Holy See: From the Thirteenth to the Seventeenth Century, 89 .

82 Cassandro underlines the Jewish merchants' commercial role in the Levant and North Africa. See Cassandro, Aspetti della storia, 117-18, 123. Filippini stresses the Jewish merchants' centrality to the city, as well as to the overall lively international traffic of goods in the port of Livorno. Over subsequent years (1763-1792), the volume of traffic to and from the Levant and North Africa fluctuated, with an overall higher volume of traffic with North Africa. See Filippini, Il porto di Livorno, 35, 56 . 
Article 10 of the statutes details the kind of investments and maximum values allowed for each, as well as the period of the loans: if any of the Hevra's money was available, up to one thousand Pieces of Eight could be lent without pawns for two weeks; more money could be lent with pawns for up to a year, on condition that all three deputies were in agreement. ${ }^{83}$ The article also instructs the deputies to further invest the monies of the Hevra only when the revenues reach four thousand scudi or more. Pawns of up to two thousand scudi could be made against merchandise held by the Duke's customs office. In addition, article 11 of the statutes stipulates that should the capital diminish for any reason, a quarter of "the advances" 84 would be added to the capital every year until the account was once again balanced. The inclusion of this instruction in the founding statutes may point to the fact that such an occurrence could be expected, given the nature of the Hevra's investments.

Specifically, the Hevra invested in currency exchanges, land and marine commerce, provided interest loans for various commercial transactions, issued mortgages for real estate, ${ }^{85}$ and insurance policies for a wide maritime activity. A ship carrying five hundred pieces of gold could be sent to Barbary or the Levant, but not to Ponente, that is Iberia, indicating that the Hevra was not eager to take great risks that could put a ship and its crew under the Inquisition's scrutiny. Similarly, sending five hundred pieces of gold to or from Livorno would entail the personal insurance of all the members. The Hevra dealt in cambio maritimo (maritime exchange), ${ }^{86}$ the kind of contract especially used in port cities: an investor would give the owner, who could also be

83 Article 10 mentions descontos deals and ganancia deals: descontos deals could be concluded with one or more persons, up to one thousand Pieces of Eight and no more, for a period of one or two fairs of reknown; in a ganancia deal, the same amount could be advanced for a year, and such a transaction could also be done from Florence. A ganancia deal is differentiated from interesse, the first being an increase in the matter in question, such as merchandise, and the second being gains from moving it, pawning it, and so on. See Cláudia Maria das Graças Chaves, "Arte dos negócios: saberes, práticas e costumes mercantis no império luso-brasileiro," América Latina en la Historia Económica 16, no. 1 (2009): 169-93. A ganancia deal involved a bill of exchange whose sum could be deducted from a future financial engagement. See Claudio Marsilio, "The Genoese Exchange Fairs and the Bank of Amsterdam: Comparing Two Financial Institutions of the 17th Century," História Econômica \& História de Empresas 18, no. 1 (2015): 49.

84 The original text refers to "avansos," with no further context or explanation. One can surmise that it refers to moneys collected during a specific year, not yet invested in any way.

85 Toaff, La nazione Ebrea a Livorno e a Pisa, 265.

86 The first record of Cambio Maritimo bills in Jewish sources can be found in seventeenthcentury responsa of rabbis active in the Ottoman Empire. See Benjamin Arbel, "Jews, the Rise of Capitalism and Cambio: Commercial Credit and Maritime Insurance in the Early Modern Mediterranean World," Zion (2004): 162. 
the captain of a cargo ship, a sum of money in the local rate, which the owner/ captain would return with interest at the port of arrival and in the currency of the port of arrival. The collateral was the ship and its cargo; should the ship and cargo sink or be lost for any reason, the owner/captain of the ship would owe nothing to the original investor. ${ }^{87}$ Manifestly, the risks were extraordinarily great, ${ }^{88}$ as were the potential profits. ${ }^{89}$

As also stated in article 10, the Hevra's bills of exchange could be traded in the fairs ${ }^{90}$ of Florence, Besançon, ${ }^{91}$ or Verona. Bills traded at fairs, or Lettres

87 Giuseppe Felloni, Moneta, credito e banche in Europa: un millenio di storia (Genoa: Genoa University Press, 1999), http://docplayer.it/2228955-Moneta-credito-e-banche-in-europaun-millennio-di-storia.html, 86. Accessed 15/4/17.

88 Medieval merchants adopted this form of investment, based on Greek and Roman practices, with the Church's sanction, since the interest was recognized as a kind of retribution for risks taken in shipping the merchandise, and therefore not considered usurious. See Arbel, "Jews, the Rise of Capitalism and Cambio," 164.

89 Jewish and Christian use of cambio maritimo was meant to circumvent accusations of usury: the initial contract was completed when another contract, the ricambio, was drafted, in order to return both investment and profit to the original investor. The interest was masked as coverage for potential risks. See Arbel, "Jews, the Rise of Capitalism and Cambio," $163-65$. The fifth Lateran Council of 1515 already found risk was a mitigating factor, and released the lender from accusations of usury. On the connection between usury and risk, see Manuel Menezes, "Instrumentos Antemodernos de Mediação dos Riscos: Oposição e Contributos da Igreja para o Desenvolvimento das Protoformas dos Seguros," Gestão e Desenvolvimento 20 (2012): 193-211, esp. 206.

Article 38 of the 1727 dowry confraternity statutes still required strict guarantees for maritime exchanges, and loans were only given to ships leaving Livorno in order to return; the insurance for the cargo had to be issued in Livorno itself. The ship's owner or captain had to provide a guarantor on land, approved by the deputies by a signed contract (Toaff, La nazione Ebrea a Livorno e a Pisa, 265-66). The 1644-5 statutes do not contain these instructions, though the need to phrase them some eighty years later proves the issue was still relevant to the society's financial activities, although by then the cambio maritimo was generally less in use.

9o Fairs proliferated across Europe in late medieval times. Most of their activity was centered around commodities traded on a regional, rather than international level. See S. R. Epstein, "Regional Fairs, Institutional Innovation, and Economic Growth in Late Medieval Europe," The Economic History Review 47, no. 3 (1994): 461, 476. At the time under discussion here, financial fairs operated independently of commodities.

91 The name that appears on the original document of the statutes is "Visanção." It seems closest to Besançon both graphically and phonetically, if one takes into account a Portuguese pronunciation. The fair became known as Bisenzone, according to Italian pronunciation.

The location of the financial fair at Besançon was decided on by a Genoese senate act in 1535, replacing the fair of Lyon; the seat was moved to Piacenza in 1579, to Novi in 1619, and to Verona in 1631 . Some of the fairs took place at the same time as others, creating a network of independent exchange fairs. See Marsilio, "The Genoese Exchange," 43-44. 
de foire, were credit instruments that have no exact modern analogues, and were in use since the Middle Ages. ${ }^{92}$ Such a letter was a written confirmation on the part of a merchant in one location, instructing another person in a different location (often a member of the merchant's family, or his agent), to pay a specific sum of money on his behalf to a third person, at a future time and place. Classic bills of exchange, dating from the thirteenth century, had several advantages, since they allowed for transfer of money safely and in the needed currency, combined with a loan. ${ }^{93}$ By the sixteenth century, these bills had developed into tools that were more sophisticated and allowed "highly complex transactions that were independent of the physical exchange of goods"; bills of exchange enabled the extension of short-term credit, and were also used for speculations on the exchange rates of currency which varied from one place to another, and could be remitted, thereby producing a chain of transactions. ${ }^{94}$

Since there was a limited possibility to enforce financial contracts, a clearing mechanism of debts became necessary. Such a mechanism, developed from medieval times and perfected in the late-sixteenth and seventeenth-century financial fairs, settled bills from all over Europe. Using a rescontre procedure, merchants first cancelled reciprocal debts, and then used clearing cycles and clearing chains, which often included many parties. Eventually, when a merchant could not find a willing partner and no further chains could be formed, the bills would either be cashed in, or new bills would be drawn to extend them. ${ }^{95}$ Bills of exchange themselves thus became the traded merchandise, heralding modern financial tools used by centralized banks. Importantly, trade in bills of exchange allowed financial operations in different currencies in a

92 The earliest letters of credit are traced to 1191. In the thirteenth century a new bill appeared, since many partnerships were formed to meet the increase in scale of business. Interestingly, members of early trading and banking companies were all on an equal footing, and each was liable to the full extent of "his property for any and every debt of the others." See Abbott Payson Usher, "The Origin of the Bill of Exchange," Journal of Political Economy 22, no. 6 (1914): 569-70. Most members of such companies were connected by family ties. The Hevra seems to have been quite close to this model.

93 See Francesca Trivellato, "Credit, Honor, and the Early Modern French Legend of the Jewish Invention of Bills of Exchange," The Journal of Modern History 84, no. 2 (2012): 294-95. See also Luciano Pezzolo and Giuseppe Tattara, 'Una fiera senza luogo': Was Bisenzone an International Capital Market in Sixteenth-Century Italy?" The Journal of Economic History 68, no. 4 (2008): 1103.

94 Trivellato, "Jewish Invention of Bills of Exchange," 295.

95 For an in-depth discussion of clearing mechanisms, see Lars Börner and John William Hatfield, "The Design of Debt Clearing Markets: Clearinghouse Mechanisms in PreIndustrial Europe," (forthcoming), especially 3-4, 8-9. http://staticı.squarespace.com/ static/551c6o8ce4bof5016a1edcof/t/572612f837013b4a807498b8/1462113017327/Debt+Clear ing+Mechanisms+20161009.pdf. Accessed 15/4/17. 
variety of places, thereby concealing the interest in the rate of exchange, and circumventing concerns of usury, reminding one of earlier arguments regarding the legitimacy of cambio maritimo. ${ }^{96}$

Halakha regards charging interest on loans with Jews usurious, yet not on loans between Jews and Gentiles. ${ }^{97}$ Yehiel Nissim da Pisa (1507-1574), a banker himself and from a family of famous bankers, ${ }^{98}$ possessed extensive knowledge of both Hebrew law and banking. In 1559, he published a treatise on usury entitled Hayye Olam (The Eternal Life), in which he criticized the Italian Jewish bankers who did not adhere to the principles laid down by Rabbenu Tam (1100-1171), among other Tosafists, and charged interest from Jews too. ${ }^{99}$ Chapter 15 of this work specifically concerns bills of exchange. ${ }^{100}$ Da Pisa defined various kinds of bills of exchange, and dealt with the question of whether they are permitted for use.

96 Both Christians and Jews masked financial activities that could be considered usurious by using each other as silent partners or secret bankers for tax evasions for example. See Poliakov, Jewish Bankers, $53^{-70 .}$

97 Ibid., 16. For examples of whether or not taking interest from a gentile was permitted see Haym Soloveitchik, "Pawnbroking: A Study in Ribbit and of the Halakah in Exile," Proceedings of the American Academy for Jewish Research 38-39 (1970-1971): 209, 217-18, 227-28, 268.

98 The da Pisa were Italian Jews, originally from Rome, who became very successful bankers in Tuscany. In 1406, following the newly established dominion of Florence over Pisa, Yehiel, the most noteworthy member of the family at the time, received the concession to open a bank in Pisa, and moved his residence to Pisa (hence the family name became "da Pisa"). A man of letters and a pillar of the Jewish community, he had personal access to Lorenzo Medici. He died in 1490, and was Yehiel Nissim's great-great grandfather. See Umberto Cassuto, La Famiglia da Pisa, extract from Rivista Israelitica, V-VII (Rome: Galletti e Cassuto, 1910), 13, 28, 32, 6o. By 1450, this large family already owned businesses in Pisa, Luca, San Gimigniano, Monte San Savino, Rimini, and Forli, as well as shares in Florence, Venice, Siena, Arezzo, and Prato. The total number of Jewish banks, according to papal registers, is estimated at 279 in 16oo, though Attilio Milano assumes the number was closer to five hundred, and Poliakov believes it was even higher. See Poliakov, Jewish Bankers, $85^{-86 .}$

99 In view of the increase in volume of money trade already witnessed in the twelfth century, and the Jews' inescapable immersion in Christian society, Rabenu Tam found that it could no longer be forbidden to trade with Christians. His sanctioning of an existing state of affairs received halakhic validity. See Poliakov, Jewish Bankers, 17, 20.

100 Rosenthal translated and edited da Pisa's original Hebrew text, adding a biography and a commentary. See Gilbert Rosenthal, Banking and Finance among Jews in Renaissance Italy: A Critical Edition of The Eternal Life (Hayye Olam) by Yehiel Nissim da Pisa (New York: Bloch, 1962), 26. For an earlier translation of chapter 15, with an introduction, see Alexander Marx, "A Description of Bills of Exchange, 1559," The American Economic Review 6, no. 3 (1916): 610-14. 
Da Pisa believed that "bills of exchange, which are called in Italian cambio [...] are not current among the Jews of our time,"101 yet he exhibits a banker's foresight regarding Northern Italy, ${ }^{102}$ since by the time under discussion here, these were instruments the Jews of Livorno not only knew well, but also used. ${ }^{103}$ Da Pisa's text seems to be halfway between a rabbinical responsum and a banker's manual, and is certainly not an exhaustive depiction of the rabbinical attitude to usury, particularly bills of exchange. Yet the writer, as well as the time and place of writing, make the text invaluable when reflecting on his co-religionists' activities a century later in nearby Livorno, who seem to be untroubled by halakhic doubts regarding their financial activities. The reason Livorno's Jews used bills quite freely is probably based on the opinion of two prominent Venetian rabbis, Leon Modena (1571-1648) and Simha Luzzatto (1582-1663), whose respective responsa tore down already frayed barriers erected by previous rabbinical stands regarding credit instruments. ${ }^{104}$ Luzzatto's ruling allowed the Jewish merchants to use the bills their Christian counterparts were already using, updating their relevance on the market place. Rabbi Luzzatto was probably under increasing pressure from Jewish merchants, who had to compete with Christian merchants to survive financially, but he was motivated, evidently, by his wish that his flock remain faithful in a changing reality. 105

101 Jewish merchants had to use different and more archaic techniques than their Christian cohorts, more similar to cambio maritimo, probably due to the rabbinical stance. Arguments raised in response to questions prove the rabbis' embarrassment, and such transactions were treated as suspicious, foreign infiltrations into the Jewish world. See Arbel, "Jews, the Rise of Capitalism and Cambio," 178, 180-85.

102 Bills of exchange were used by Jews in Sicily long before they were used by Jews in Pisa, in transactions with Christians as well as with Jews. See Shlomo Simonsohn, "International Trade and Italian Jews at the Turn of the Middle Ages," in The Italia Judaica Jubilee Conference, ed. S. Simonsohn and J. Shatzmiller (London: Brill, 2013), 234f.

103 Da Pisa also mentions ship insurance and the differentiated rates taken in accordance to distance. These he finds permissible "to take place between Jews" since they have "nothing to do with a loan" when the insurer takes the risk as well as the gain. See Marx, "A Description of Bills of Exchange," 614. The insurer thus becomes a partner in the transaction and does not merely loan the money, which was only permissible between Jews and Christians.

104 Luzzatto's conclusion diverges completely from the Sephardic rabbis residing in the Ottoman Empire, since he proclaims the cambio reale (or bills of exchange) admissible, whereas they considered it usurious and were only willing to condone the cambio maritimo. See Arbel, "Jews, the Rise of Capitalism and Cambio," 188-92.

105 Ibid. A humorously hyperbolic manual by an anonymous fifteenth-century Venetian Ashkenazic writer provided instructions for lenders and borrowers and advice on how to set up a pawn shop. The writer claims a lender must secure an interest or a pledge on a loan, not because of the law, but because the times requires him to do so. For an 
Usury was a serious and well-known concern for the Church and one of the principal accusations it held against the Jews for centuries, legitimizing their continuous expulsions. The Jews were not the sole target of the Church, and the development of "public and private financing" in Italy, "was strongly influenced by ecclesiastical prohibition of usury."106 In 1571, Pope Pius V issued the bull In eam pro nostro, that forbade the use of exchange bills. Nonetheless, confronted with the continuously increasing volume of commerce, the Church introduced exceptions and flexible interpretations beginning in 1625, although canonical legitimacy was only declared in 1745 , when Benedict XIV admitted modest interests on private loans. Eventually, the market place dictated-to

annotated edition with ample historical commentary, see Reuven Bonfil, Sefer Malveh ve-Loveh (Jerusalem: The Zalman Shazar Center, 2015).

106 Luciano Pezzolo, and Giuseppe Tattara, 'Una fiera senza luogo': Was Bisenzone an International Capital Market in Sixteenth-Century Italy?" The Journal of Economic History 68, no. 4 (2008): 1100 . As mentioned earlier, in the mid fifteenth century the Franciscans established the Monti di Pietà, public loans banks that charged particularly low interest rates (about seven percent on average), in an effort to demolish the Jewish loan business. The first Monte was established in 1458 in Marche, shortly followed by another in Perugia in 1462. The endeavor was particularly successful: by 1494 there were already thirty Monti in central and northern Italy, and 214 by 1562 . The theological opposition they created was resolved by Leo $\mathrm{x}$, who issued a papal bull in the fourth Lateran Council of 1515, condemning usury on the one hand, and condoning the activity of the Monti on the other hand, though he also imposed norms to limit these activities. See Riccardo Milano, "Social Banking: A Brief History," in Social Banks and the Future of Sustainable Finance, ed. Olaf Weber and Sven Remer (London: Routledge, 2011), 19-20. Civil Tuscan authorities intervened to counter the impact of Bernardino da Feltre's inflammatory preaching. One of the activist Franciscan priests who promoted the creation of the Monte in Florence and the expulsion of its Jews, he was ultimately chased from the city; yet from the day the Florence Monte was instituted in April 1496, the Jewish loan business ended. See Umberto Cassuto, Gli ebrei a Firenze nell'età del Rinascimento (Florence: Galletti e Cocci, 1918), 56-67. The Florence Monte at first lent money at six percent and later at ten percent, transforming into a regular bank that accepted deposits of five percent, despite Church opposition. See Cassandro, Intolleranza e accettazione, 195. By the 1540 , the Florence Monte offered all forms of accounts that other banks did; the Medicis' own accounts in the Monte of Florence were significant and affected state finance. Cosimo I especially, used the Monte to exercise his patronage over the Florentine elite. See Carol Bresnahan Menning, Charity and State in Late Renaissance Italy: The Monte di Pietà of Florence (Ithaca and London: Cornell University Press, 1993), 2-3, 244, 258. The Monte di Pietà of Pisa was founded in 1496; of the two thousand ducats with which it was started, 1050 ducats were contributed by the Jewish da Pisa family. See Umberto Cassuto, $L a$ Famiglia, 37. The Monte's "loans to the poor moved into the background and continued to exist only as a pretext," while the Monte became the "principal bank [...] a tool of the Dukes." See Poliakov, Jewish Bankers, 169. 
Christians as well as to Jews ${ }^{107}$ - the acceptance of various mercantile operations ${ }^{108}$ that became necessary following the massive increase in trade volumes experienced from the thirteenth century onward. ${ }^{109}$

Financial fairs attracted investors who had ready cash, and hoped to make large profits, yet only professional merchant bankers and their agents could carry out the transaction. ${ }^{110}$ Tribunals held at fairs handled problematic bills, and provided a significant measure of regulation. To succeed in financial operations at the fairs, a banker had to be both well acquainted with the exchange rates of the main markets, and have access to valuable information that allowed him to estimate correctly the future value of various currencies, and pocket the difference.

Besançon, one of the fairs where the Hevra proposed to conduct its business, was dominated by the Genoese and had a sizeable turnover. At these fairs, the Genoese collected liquid capital from Italian investors from Milan, Florence, or Venice, mainly in order to provide short-term credit to the Spanish Crown. In essence, they converted silver originating in the Americas into gold, the currency necessary for the Spanish King's military operations in the Low Countries, and made the gold available on the King's behalf at Antwerp

107 Jews' and Christians' attitudes to money diverged exponentially from medieval times on: Jews admitted no separation between the value of the coin and its physicality, while Christians considered it as an abstract value. The Talmud and the Roman Canon law were thus opposed, in terms of the logic of mercantile exchange versus that of investments. See Giavomo Tedeschini, La ricchezza degli ebrei: merci e denaro nella riflessione ebraica e nella definizione christiana dell'usura alla fine del Medioevo (Spoleto: Centro italiano di studi sull'alto medioevo, 1989), 72.

108 Giuseppe Felloni, Moneta, credito, e banche in Europa, 95 .

109 Specifically, what the Church opposed were "dry exchange" transactions, for which the return on the money was not stipulated in advance, and changed according to the fluctuation of exchange rates, for the purpose of hiding interest on what was essentially a loan, and thus considered usurious. Church prohibition on usury greatly influenced business practices until the eighteenth century and interest "had to be concealed [...] by all kinds of sophisticated or fallacious arguments." See Raymond de Roover, "What is Dry Exchange? A Contribution to the Study of English Mercantilism," Journal of Political Economy 52, no. 3 (1994): 252. Merchants stressed the possibility of loss and the uncertainty of gain on bill transactions so as not to address interest issues, and canonists accepted this at face value. Nonetheless, many canonists denounced bankers as usurers. See Raymond de Roover, Business, Banking, and Economic Thought in Late and Early Modern Europe: Selected Studies of Raymond de Roover, ed. Julius Kirshner (Chicago: University of Chicago Press, 1974), 198-99.

110 Particularly pertinent to the present subject is an example of a "chain of bankruptcies" in 1608 Venice, "generated by naive speculators" on a quest for dowries for their daughters. See Trivellato, “Jewish Invention of Bills of Exchange," 297-98. 
by means of bills of exchange payable there. ${ }^{111}$ Livorno was also involved in Spanish silver shipments and its bankers were therefore as affected by failures to abide by the agreements on the part of the Spanish Crown as were the bankers of Genoa, though the contracts were ultimately safeguarded when the Spanish were made to transform their bankruptcies into debt rescheduling. ${ }^{112}$ The irony (that could also be termed poetic justice), is that Livorno's Jewish Sephardic merchants were in effect participating in the financing of the Spanish wars in Northern Europe, ${ }^{113}$ thanks to their expertise and connections in Spain, which allowed them to maintain agents there. ${ }^{114}$ The Sephardic bankers thereby proved they did not shy away from major, intricate transactions. Quite the contrary, they were fully equipped not only to compete in the marketplace, but also to cooperate with fellow merchants of every origin and creed, in line with the latest requirements of financial operations involving clearing mechanisms of bills of exchange. These operations would have doubtlessly been frowned upon by da Pisa a hundred years earlier, but by the time the statutes of the Hevra were drawn up, the Livorno massari could safely rely on the rulings of the Venetian Rabbis Leone da Modena and Simha Luzatto, mentioned earlier. These operations hinged on merchants' reputations, on a wide network of relations, and on collective liability, involving entire communities. ${ }^{115}$ The Jewish community of Livorno thus provided the backing for its leaders' financial activities and enjoyed the fruits of their international endeavors.

\footnotetext{
111 Pezzolo and Tattara, “'Una fiera senza luogo," 1098-99.

112 Ibid., 1115, 1118.

113 Jonathan I. Israel, The Dutch Republic and the Hispanic World, 1606-1661 (Oxford: Oxford University Press, 1982); see also J. Alcalá-Zamora y Queipo de Llamo, España, Flandes y el Mar del Norte, 1618-1639 (Barcelona: Planeta, 1975).

114 The disciplinary measures the massari implemented in order to dissuade community members from putting themselves at risk when traveling to "Ponente" were not only preventive but also reactive, and based on a continuous exchange with Spain and Portugal, which on rare occasion enticed them to travel there. The financial relations the Jews of Livorno maintained in many different markets, including in their countries of origin, resulted in the current use of double names by many, accepted by both Ducal officials and the community. Nonetheless, they seldom traveled on their ships or on ships carrying their merchandise, since they could rely on their agents in other ports. See Frattarelli Fisher, "Reti locali e reti internazionali degli ebrei di Livorno," $157-58$.

115 Börner and Hatfield, "The Design of Debt Clearing Markets," 35-36.
} 
Further research is necessary to complement the study of the statutes in order to provide a broader as well as more detailed picture, especially regarding the finances of the Livorno dowry society. ${ }^{116}$ Nonetheless, it seems that the examination of the founding statutes attempted here already lends itself to a few comments.

While the commendable aim of providing dowries to poor maidens was certainly achieved, ${ }^{117}$ the confraternity's financial targets were no less important. The society provided a safety net for its members, bearing certain similarities to what would perhaps be known today as a trust fund, whose assets were managed for the mutual benefit of its members, especially the generations to come. Such a fund was crucial for the safeguarding of its members' finances, in view of the dangers inherent to the period's transactions, although bankruptcies in the mid-16oos were not synonymous with going completely out of business. ${ }^{118}$ It is interesting to recall that older financial tools, namely women's dowries, were used for several purposes, and provided financial protection not just for the bride but also for the entire family's business. Dowries indeed gave daughters a share of their father's wealth, and they were used as the initial capital for the groom's business. In addition, they represented a legally sanctioned protection in cases of bankruptcy, as demonstrated by Trivellato, when married women could claim their dowries as debt reimbursement, thereby saving their families from destitution. The dowry confraternity, for its part, assured that members' daughters received assistance to marry, even if their fathers had

116 At this point, it is hard to estimate exactly how much money the society handled, since the initial capital was not necessarily of fifty scudi for each member, but could have been higher for certain people, for example those whose balloting procedure was not straightforward (articles 15, 29). The sums collected from fines are unknown, as are the number of beneficiaries each year, and the number of dowries that were returned if there were such cases. The profits are also not known, but what we do know is that the Hevra continued to function for many years, long after prominent members of the community had already emigrated to London, Amsterdam, North Africa, or elsewhere.

117 Italian Christian and Jewish confraternities often boasted their charitable intentions in their names and their statutes, without actually carrying this professed intention out, stressing the wide gap between ideals and reality that was typical of them (Horowitz, "The Dowering of Brides in the Ghetto of Venice," 370). This appears to have also been the case of the Livorno dowry society.

118 Cassandro, "Gli ebrei di Livorno," 90-91. 
been unlucky in their affairs. Three hundred scudi may not have been a fortune, but it secured a dwelling and a basis for the newlyweds' common life. ${ }^{119}$

Doubtless, the assistance offered by the wealthy among the community to the poor and needy was of tremendous help. Indeed, the dowry society provided support to girls who may not have been able to conduct a normative and socially acceptable life without it, and as stated in the Shulhan Arukh, there is "no charity greater than this." ${ }^{120}$ It is also doubtful that such help would have been possible without the capital these rich people could afford to set aside for the future of their own children as well as for those less fortunate children of the community, toward whom they obviously felt morally obliged, and for whose livelihood they assumed responsibility. Bearing this in mind, one cannot ignore the role of the dowry confraternity in assuring the continuation and safeguarding of the status of its rich members, as well as at least a part of their wealth. The monies invested in the confraternity served not only to provide a kind of social security for poor unmarried girls, but more so was an investment fund. The members of the confraternity were fluent in the latest financial instruments: organically interwoven in the international mercantile activity of the time, they actively cooperated in the advancement of secular financial practices in the modern age. Membership in the society was hereditary, further upholding the social hierarchy for future generations: if a member had no living children, his grandchildren or even nephews could take his place (article 27). ${ }^{121}$

The oligarchs of the community looked after each other's interests and ensured the continuation of their inner circle. Since only members of the oligarchy would be full beneficiaries of the monies invested in the confraternity, the system assured that even in case of financial adversity they would be able at least to survive financially and perhaps also to resurrect their business. It was of crucial importance that they be able to continue their financial activities, not only to them and to their own family members, but for sake of the whole community, whose members were sustained by this activity. If the Livorno

119 Annual rents in 1646 ranged from 31.2 to 154 scudi. See Cassandro, Aspetti della storia, 134. In 1645 , most rich Jewish merchants in Livorno still lived in rented houses, a situation that the extended welcome of the Dukes and the merchants' prosperity soon changed. See Lucia Frattarelli Fischer, "Proprietà e insediamento ebraici a Livorno dalla fine del Cinquecento alla seconda metà del Settecento," Quaderni Storici 54 (1983): 884. The values of assets that appear in seventeenth- and eighteenth-century testaments of Livorno Jews range from one hundred to two thousand pezze, with a few outstanding sums reaching ten thousand pezze. See Galasso, Alle origini di una communità, 72-73.

120 Shulhan Arukh, Yore Deah, §249.15.

121 Women were first admitted as members in 1656 , and seven joined by the end of 1727 , paying one hundred pezze each. See Orfali, "The Portuguese Dowry Society," 150. 
merchants belonged, as Filippini has characterized them, to two spheres-the ethnic-religious and the financial ${ }^{122}$ - then the dowry confraternity bridged both. Undoubtedly, the most interesting aspect of this confraternity's founding statutes is that they embody and mirror at the same time various social, religious, and financial features of the life of the Livorno Sephardic community in the early modern period.

\section{Bibliography}

Alcalá-Zamora Queipo de Llano, José. España, Flandes y el Mar del Norte, 1618-1639. Madrid: Centro de Estudios Políticos y Constitucionales, 1975.

Arbel, Benjamin. "Jews, the Rise of Capitalism and Cambio: Commercial Credit and Maritime Insurance in the Early Modern Mediterranean World." Zion 69, no. 2 (2004): 157-202.

Berman Brown, Reva, and Sean McCartney. "David of Oxford and Licoricia of Winchester: Glimpses into a Jewish Family Life in Thirteenth-Century England." Jewish Historical Studies 39 (2004): 1-34.

Berzen, Rainer. "The Meaning of Tzedakah for Jewish Self-Organization within a NonJewish Environment." History of the Jewish People and Contemporary Jewish Society 2 (2005): 7-17. Accessed 15/4/17. http://www.jstor.org/stable/23538311.

Black, Christopher F. Italian Confraternities in the Sixteenth Century. Cambridge: Cambridge University Press, 1989 .

Bodian, Miriam. Hebrews of the Portuguese Nation: Conversos and Community in Early Modern Amsterdam. Bloomington: Indiana University Press, 1997.

Bodian, Miriam. "The Portuguese Dowry Society in Venice and in Amsterdam: A Case Study in Communal Differentiation within the Marrano Diaspora." Italia 6 (1987): 30-61.

Bodian, Miriam. "The Santa Companhia de Dotar Orfans e Donzelas Pobres in Amsterdam, 1615-1639." PhD diss., The Hebrew University of Jerusalem, 1988.

Bonfil, Reuven. Sefer malveh ve-loveh. Jerusalem: The Zalman Shazar Center, 2015.

Börner, Lars, and J.W. Hatfield. "The Design of Debt Clearing Markets: Clearinghouse Mechanisms in Pre-Industrial Europe." Forthcoming. http://statici.squarespace. com/static/551c6o8ce4bof5016aredcof/t/572612f837013b4a807498b8/1462113017327/ Debt+Clearing+Mechanisms+20161009.pdf.

Bresnahan Menning, Carol. Charity and State in Late Renaissance Italy: The Monte di Pietà of Florence. Ithaca and London: Cornell University Press, 1993.

122 Filippini, Il porto di Livorno e la Toscana, 83. 
Bresnahan Menning, Carol. “The Monte's 'Monte': The Early Supporters of Florence's Monte di Pietà." The Sixteenth Century Journal 23 (1992): 661-76.

Carboni, Mario. "The Economics of Marriage: Dotal Strategies in Bologna in the Age of Catholic Reform." The Sixteenth Century Journal 39 (2008): 371-88.

Cassandro, Michele. Aspetti della storia economica e sociale degli ebrei di Livorno nel seicento. Milan: Giuffrè, 1983 .

Cassandro, Michele. "Gli ebrei di Livorno nel seicento: aspetti economici e sociali." $L a$ Rassegna Mensile di Israel 50, no. 9/12 (1984): 567-82.

Cassandro, Michele. Intolleranza e accettazione: gli ebrei in Italia nei secoli XIV-XVIII, lineamenti di una storia economica e sociale. Turin: Giappichelli, 1996.

Cassuto, Umberto. La Famiglia da Pisa - excerpt from Rivista Israelitica 5-7 (1910).

Cassuto, Umberto. Gli ebrei a Firenze nell'età del Rinascimento. Florence: Galletti e Cocci, 1918.

Cooperman, Bernard Dov. "Trade and Settlement: The Establishment and Early Development of the Jewish Communities in Leghorn and Pisa (1591-1626)." PhD diss. Harvard University, 1976.

das Graças Chaves, Cláudia Maria. "Arte dos negócios: saberes, práticas e costumes mercantis no império luso-brasileiro." América Latina en la Historia Económica 16, no. 1 (2009): 169-93.

de Roover, Raymond. Business, Banking, and Economic Thought in Late and Early Modern Europe: Selected Studies of Raymond de Roover. Edited by Julius Kirshner. Chicago: University of Chicago Press, 1974.

de Roover, Raymond. "What is Dry Exchange? A Contribution to the Study of English Mercantilism." Journal of Political Economy 52, no. 3 (1994): 250-66.

Epstein, Louis M. The Jewish Marriage Contract: A Study in the Status of the Women in Jewish Law. New York: Jewish Theological Seminary of America, 1927.

Epstein, S.R. "Regional Fairs, Institutional Innovation, and Economic Growth in Late Medieval Europe." The Economic History Review 47, no. 3 (1994): 459-82.

Felloni, Giuseppe. Moneta, credito e banche in Europa: un millenio di storia. Genoa: Genoa University Press, 1999. http://docplayer.it/2228955-Moneta-credito-e-banche -in-europa-un-millennio-di-storia.html.

Filippini, Jean Pierre. Il porto di Livorno e la Toscana (1676-1814). Vol. 1. Napoli: Edizioni Scientifiche Italiane, 1998.

Finch, Andrew J. "Parental Authority and the Problem of Clandestine Marriage in the Later Middle Ages." Law and History Review 8 (1990): 189-204.

Frattarelli Fischer, Lucia. "Ebrei a Pisa e Livorno nel sei e settecento tra inquisizioni e garanzie granducali." In Le inquisizioni cristiane e gli ebrei, Atti dei convegni Lincei 191, 253-95. Rome: Lincei Acc., 2003.

Frattarelli Fischer, Lucia. "Proprietà e insediamento ebraici a Livorno dalla fine del Cinquecento alla seconda metà del Settecento." Quaderni Storici 54 (1983): 879-96. 
Frattarelli Fischer, Lucia. "Reti locali e reti internazionali degli ebrei di Livorno nel Seicento." In Commercial Networks in the Early Modern World. Edited by Diego Ramada Curto and Anthony Molho, 93-116. Florence: European University Institute, 2002.

Frattarelli Fischer, Lucia. "Tipologia abitativa degli ebrei a Livorno nel Seicento." La Rassegna Mensile di Israel 50, no. 9/12 (1984): 583-6o5.

Frattarelli Fischer, Lucia. Vivere fuori dal ghetto: Ebrei a Pisa e Livorno (secoli XVIXVIII). Turin: Zamorani, 2008.

Galasso, Cristina. Alle origini di una communità: ebree ed ebrei a Livorno nel Seicento. Florence: Olschki, 2002.

Gasperoni, Michael. "La misura delle dote: alcuni riflessioni sulla storia della famiglia ebraica nello Stato della Chiesa in età moderna." In Vicino al focolare e oltre. Spazi pubblici e privati, fisici e virtuali della donna ebrea in Italia (secc. $X V-X X$ ). Edited by Laura Graziani Secchieri. La Giuntina, 2015. https://hal.archives-ouvertes.fr/hal -01225374/document.

Glikl of Hameln. Glikl, Zichronot, 1691-1719. Edited and translated by Chava Turniansky. Jerusalem: The Zalman Shazar Center, 2006.

Goldish, Matt. Jewish Questions: Responsa on Sephardic Life in the Early Modern Period. Princeton, NJ: Princeton University Press, 2008.

Goldish, Matt. "Passion at the Periphery: The Context of a Clandestine Converso Conjunction." Zutot (2001): 124-32.

Greniman, Deborah. "The Origins of the Ketubah: Deferred Payment or Cash Up Front?" Nashim: A Journal of Jewish Women's Studies and Gender 4 (2001): 84-118.

Horowitz, Elliott. "Jewish Confraternal Piety in Sixteenth Century Ferrara: Continuity and Change." In The Politics of Ritual Kinship in Late Medieval Florence. Edited by Nicholas Terpstra, 150-71. Cambridge: Cambridge University Press, 2000.

Horowitz, Elliott. "Processions, Piety, and Jewish Confraternities." In The Jews of Early Modern Venice. Edited by Robert C. Davis and Benjamin Ravid, 231-47. Baltimore and London: Johns Hopkins University Press, 2001.

Horowitz, Elliott. "The Dowering of Brides in the Ghetto of Venice: Between Tradition and Change, Ideas and Reality." Tarbiz 56 (1987): 347-71.

Israel, Jonathan I. The Dutch Republic and the Hispanic World, 1606-1661. Oxford: Oxford University Press, 1982.

Kaplan, Yosef. "Amsterdam, the Forbidden Lands, and the Dynamics of the Sephardi Diaspora." In The Dutch Intersection: The Jews and the Netherlands in Modern History. Edited by Yosef Kaplan, 33-62. Leiden: Brill, 2008.

Kaplan, Yosef. An Alternative Path to Modernity: The Sephardi Diaspora in Western Europe. Leiden: Brill, 2000.

Kaplan, Yosef. "Devianza e punizione nella diaspora sefardita occidentale del XVII secolo: i portoghesi ad Amsterdam." La Rassegna Mensile di Israel 58 (1992): 163-202. 
Kaplan, Yosef. "The Struggle against Return to Iberia in the Spanish Diaspora." [Hebrew] Zion 64 (1999): 65-100.

Kaplan, Yosef. "The Travels of Portuguese Jews from Amsterdam to the 'Lands of Idolatry' (1644-1724)." In Jews and Conversos. Edited by Yosef Kaplan, 197-224. Jerusalem: Magnes Press, 1985 .

Kirshner, Julius. Pursuing Honor While Avoiding Sin: The Monte delle Doti of Florence. Quaderni di Studi Senesi 41. Edited by Domenico Maffei. Milan: Giuffre, 1978.

Klapisch-Zuber, Christiane. Women, Family, and Ritual in Renaissance Italy. Translated by Lydia G. Cochrane. Chicago: University of Chicago Press, 1987.

Lamdan, Ruth. "Jewish Women as Providers in the Generations Following the Expulsion from Spain.” Nashim: A Journal of Jewish Women's Studies \& Gender Issues 13 (2007): 49-67.

Levie Bernfeld, Tirtsah. Dowries and Dotar: An Unbroken Chain of 400 Years. Amsterdam: Menashe Ben Israel Institute and Jewish Historical Museum of Amsterdam, 2015 .

Marsilio, Claudio. "The Genoese Exchange Fairs and the Bank of Amsterdam: Comparing Two Financial Institutions of the 17th Century." História Econômica \& História de Empresas, 18, no. 1 (2015): 39-59. http://www.abphe.org.br/revista/index.php?jou rnal $=$ rabphe $\&$ page $=$ article $\&$ op $=$ view $\&$ path $\%{ }_{5} \mathrm{~B} \% 5 \mathrm{D}=425$.

Marx, Alexander. "A Description of Bills of Exchange, 1559." The American Economic Review 6, no. 3 (1916): 610-14.

Melcer-Padon, Nourit. "Free Jews in a Free Port City: Livorno, the City without a Ghetto." In I Ghetti nell'Italia moderna. Relazioni oltre le mura. Edited by Marina Caffiero and Serena di Nepi. Special issue of Rivista di Storia del Cristianesimo 1 (2017): $71-88$.

Menezes, Manuel. "Instrumentos Antemodernos de Mediação dos Riscos: Oposição e Contributos da Igreja para o Desenvolvimento das Protoformas dos Seguros." Gestão e Desenvolvimento 20 (2012): 193-211.

Milano, Attilio. "The Private Life of a Family of Jewish Bankers at Rome in the Sixteenth Century." The Jewish Quarterly Review 30 (1939): 149-86.

Milano, Riccardo. "Social Banking: A Brief History." In Social Banks and the Future of Sustainable Finance. Edited by Olaf Weber and Sven Remer, 19-20. London: Routledge, 2011.

Molho, Anthony. Florentine Public Finances in the Early Renaissance 1400-1433. Cambridge, MA: Harvard University Press, 1971.

Molho, Anthony. Marriage Alliances in Late Medieval Florence. Cambridge, MA: Harvard University Press, 1994.

Orfali, Moisés. "The Portuguese Dowry Society in Livorno and the Marrano Diaspora." Studia Rosenthaliana 35 (2001): 143-56. 
Pezzolo, Luciano and Tattara, Giuseppe. “Una fiera senza luogo': Was Bisenzone an International Capital Market in Sixteenth-Century Italy?” The Journal of Economic History 68, no. 4 (2008): 1098-122.

Poliakov, Léon. Jewish Bankers and the Holy See: From the Thirteenth to the Seventeenth Century. Translated by Miriam Kochan. London: Routledge, 1977.

Pullan, Brian. Poverty and Charity: Europe, Italy, Venice, 1400-170o. Aldershot: Variorum, 1994.

Révah, Israël Salvator. "Le premier règlement imprimé de la 'Santa Companhia de dotar orfãs e donzelas pobres." Boletin internacional de bibliografia luso-brasilliera, 4 (1963): 650-91.

Rosenthal, Gilbert. Banking and Finance among Jews in Renaissance Italy: A Critical Edition of The Eternal Life (Hayye Olam) by Yehiel Nissim da Pisa. New York: Bloch, 1962.

Roth, Cecil. Gli ebrei a Venezia. Rome: Cremonese, 1933.

Roth, Cecil. "I marrani di Livorno, Pisa e Firenze." La Rassegna Mensile di Israel 9 (1933): 394-415.

Roth, Cecil. The History of the Jews of Italy. Philadelphia: Jewish Publication Society of America, 1946.

Ruggiero, Guido. The Boundaries of Eros: Sex Crimes and Sexuality in Renaissance Venice. Oxford: Oxford University Press, 1985.

Simonsohn, Shlomo. "International Trade and Italian Jews at the Turn of the Middle Ages." In The Italia Judaica Jubilee Conference. Edited by Shlomo Simonsohn and Joseph Shatzmiller, 223-38. London: Brill, 2013.

Soloveitchik, Haym. "Pawnbroking: A Study in Ribbit and of the Halakah in Exile." Proceedings of the American Academy for Jewish Research 38-39 (1970-1971): 203-68.

Tedeschini, Giacomo. La ricchezza degli ebrei: merci e denaro nella riflessione ebraica e nella definizione christiana dell'usura alla fine del Medioevo. Spoleto: Centro italiano di studi sull'alto medioevo, 1989 .

Terpstra, Nicholas. Lay Confraternities and Civic Religion in Renaissance Bologna (Cambridge: Cambridge University Press, 1995).

Trexler, Richard C. "Charity and the Defence of Urban Elites in the Italian Communes," in The Rich, the Well Born, and the Powerful: Elites and Upper Classes in History. Edited by Frederic Cople Jaher (Urbana: Illinois University Press, 1973).

Trivellato, Francesca. "Credit, Honor, and the Early Modern French Legend of the Jewish Invention of Bills of Exchange." The Journal of Modern History 84, no. 2 (2012): 289-334.

Trivellato, Francesca. The Familiarity of Strangers: The Sephardic Diaspora, Livorno, and Cross-Cultural Trade in the Early Modern Period. New Haven: Yale University Press, 2009. 
Toaff, Renzo. La nazione Ebrea a Livorno e a Pisa (1591-170o). Florence: Olschki, 1990.

Toaff, Renzo. “Statuti e leggi della 'Nazione Ebrea' di Livorno." La Rassegna Mensile di Israel 34 (1968): 1-51.

Usher, Payson. "The Origin of the Bill of Exchange." Journal of Political Economy 22, no. 6 (1914): 566-76.

Vivoli, Giuseppe. Annali di Livorno: dalla sua origine sin all'anno di Gesù Cristo 1840, colle notizie riguardanti I luoghi più antichi e moderni dei sui contorni. Vol. 4. Livorno: Sardi, 1846. 


\section{PART 4}

\section{The Boundaries of Rabbinical Authority}


Yosef Kaplan - 978-90-04-39248-9

Downloaded from Brill. com $04 / 26 / 2023$ 10:36:49AM via free access 


\title{
Jacob Sasportas and Problems of Discipline in the Ets Haim Yeshiva
}

\author{
Yaacob Dweck
}

Jacob Sasportas (c. 1610-1698), is known as the primary opponent and critic of Sabbetai Zevi, the Jewish Messiah of the mid-seventeenth century. In his Hebrew masterpiece, Zizath Novel Zvi (The Fading Flower of Zvi), he composed a chronicle and study of the Sabbatian messianic movement as it was occurring in the middle of the 166 os. $^{1}$ This paper focuses on another aspect of Sasportas's long and colorful life: his relationship with the Ets Haim yeshiva in Amsterdam. In doing so, it picks up where Matt Goldish left off in his study of Sasportas and the conversos. ${ }^{2}$ As Goldish showed, Sasportas's relations with his co-religionists in the Western Sephardic diaspora were often fraught. In the case studied by Goldish, a responsum from Ohel Ya'akov on returning conversos and the rites of penitence, Sasportas was at odds with the Portuguese Jewish community in London, a city in which he lived for slightly more than a year in 1664 and 1665 . Sasportas had fought bitterly with the parnassim in London as well, as Isaiah Tishby demonstrated in $1988 .^{3}$ Decades earlier, Tishby had examined the conflict between Sasportas and the parnassim in Livorno. ${ }^{4}$ Both articles had resulted from his work on Sasportas in the preparation of his edition of Zizath Novel Zvi, a monument of scholarship that remains the fundamental point of departure for any and all work on Sasportas.

This article concentrates on a different responsum within Ohel Ya'akov, Sasportas's collected responsa printed posthumously in 1737, and a different community in the Western Sephardic diaspora, Amsterdam itself. ${ }^{5}$ Sasportas

1 Jacob Sasportas, Zizath Novel Zvi, ed. Isaiah Tishby (Jerusalem: Mossad Bialik, 1954).

2 Matt Goldish, "Hakham Jacob Sasportas and the Former Conversos," Studia Rosenthaliana 44 (2012): 149-72.

3 "New Information on the 'Converso' Community in London According to the Letters of Sasportas from 1664/1665," [Hebrew] in Galut Ahar Golah: Mehkarim be-Toldot Am Yisrael Mugashim le-Professor Haim Beinart li-Melot Lo Shivim Shanah, ed. Aharon Mirsky et al. (Jerusalem: Ben Zvi Institute, 1988), 470-96.

4 "Letters by Rabbi Jacob Sasportas against the Parnassim of Livorno from 1681," [Hebrew] Kovets Al Yad (4) 1946: 143-60.

5 Jacob Sasportas, Ohel Ya'akov, ed. David Meldola (Hertz Levi Rofe: Amsterdam, 1737).

(C) YAACOB DWECK, 2019 | DOI:10.1163/9789004392489_015

This is an open access chapter distributed under the terms of the prevailing CC-BY-NC License at the time of publication. 
lived in Amsterdam for extended periods of time between his arrival from Tlemcen, North Africa, to Northern Europe in the late 1640 os or early 165 os and his death half a century later in 1698. Indeed, more than any other city he lived in over the final five decades of his life-Salé, London, Hamburg, The Hague, and Livorno-Amsterdam was his most frequent place of residence. It was in Amsterdam that he first arrived around the middle of the century. It was there that his family joined him somewhat later, when the community paid the ransom to redeem them from their captivity. ${ }^{6}$ And it was in Amsterdam in the 1650 s where he found work as a corrector in the print shop of Menasseh ben Israel and patronage from the Mercado family.

Between 1658 and 1675 , a period of nearly two decades, Sasportas lived in a number of other places. Unlike so many of the other wandering rabbis of the seventeenth century, Sasportas actually returned to the region from which he came. Between 1658 and 1663 , Sasportas lived in North Africa. This time, though, he was in Salé on the Atlantic coast, rather than Oran and Tlemcen, cities on or near the Mediterranean coast. During this period, however, his connections with the Jews of Amsterdam did not cease. A notarial deed in the city archives in Amsterdam indicates that Sasportas continued to engage with the Mercado family in Amsterdam while he was in Salé. ${ }^{7}$ When he fled a famine in Salé in 1664, Sasportas made his way to London where he served for slightly over a year as rabbi to the fledgling Portuguese Jewish community. In the summer of 1665 he fled the plague in London and ended up in Hamburg, where he lived for the next seven years and where he wrote Zizath Novel Zvi. Yet, even while he was living in Hamburg, he continued to receive charity from the Portuguese Jews of Amsterdam. ${ }^{8}$ In Zizath Novel Zvi itself, he recounts a journey he made from Hamburg to Amsterdam in the midst of the messianic frenzy to collect his son Samuel who had managed to escape from London only after his father. ${ }^{9}$ Sasportas returned to Amsterdam in the early 167os, and, after

6 Stadsarchief Amsterdam [hereafter SAA], 334 no. 19, p. 342. On the nature of this source, see Yosef Kaplan, "The Social Function of the Herem," in An Alternative Path to Modernity: The Sephardi Diaspora in Western Europe (Leiden: Brill, 2000), 110. On the ransom of the Sasportas family, see the note by Fuks and Fuks-Mansfeld in David Franco Mendes, Memorias do estabelecimento e progresso dos Judeos Portuguezes e Espanhoes nesta famosa citade de Amsterdam, ed. L. Fuks and R.G. Fuks-Mansfeld, Studia Rosenthaliana 9, no. 2 (1975): 16o, n. 122.

7 SAA 5075, no. 2205, Not. A. Lock, 23 September 1658, fol. 466.

8 SAA 334, no. 174, p. 733, 21 Tebet 5426. "A mandej pagar ao H. Sasportas em Hamb." I owe this reference to the kindness of Dr. Tirtsah Levie Bernfeld. On the phenomenon of people who had left Amsterdam receiving poor relief abroad, see Tirtsah Levie Bernfeld, Poverty and Welfare among the Portuguese Jews in Early Modern Amsterdam (Portland, OR: The Littman Library of Jewish Civilization, 2012), 89.

9 Sasportas, Zizath Novel Zvi, 70. 
a brief stint in Livorno between 1678 and 1680, he returned to Amsterdam in the fall of 1680 , where he lived for the final eighteen years of his life.

It this last period of his life that is the focus of this paper. On the face of it, this was a period in Sasportas's life when he had finally arrived, so-to-speak. His name appears regularly in the scheduled payments of rabbinic personnel in the archives of the Portuguese Jewish Community in Amsterdam. In the Livro Longo he appears as one who regularly received a salary for his teaching in the 1680 os and 169os, when he had a position as a teacher in the Ets Haim yeshiva. He began to issue haskamot to a plethora of Hebrew books as well as some Yiddish books that appeared at the Hebrew presses in Amsterdam in the 1680 s and 1690 s. Of his four sons who lived well into adulthood-Samuel, Moseh, Isaac, and Abraham - three lived in Amsterdam. Abraham was married with children. Three of Sasportas's four living daughters were married and lived in Amsterdam as well. His son Samuel's death in London in 1692 had left him a relatively wealthy man. ${ }^{10}$ In 1693 , after having served for nearly a decade as a teacher in Ets Haim and after having lived in Amsterdam on and off for forty-five years, he became the Hakham of the Portuguese community. He had finally acquired the authority and the respect that he had craved for so long. From the vantage point offered by Sasportas's career, the rabbinate after Sabbatianism was looking quite robust.

All was not quite as it seemed. From a report in the travel diaries of Hayim Yosef David Azulai first highlighted by S.Z. Havlin, it emerges that Sasportas was not the community's first choice to become chief rabbi upon the death of Hakham Isaac Aboab da Fonseca in $1693 .{ }^{11}$ Only after Hezekiah de Silva, a Talmudic scholar who was in his early thirties had turned the job down, did the communal elders turn to the eighty-three-year-old Sasportas. To add to this, one can point to a striking and deafening silence. Sasportas was an intellectual who was keenly aware of the power of the printed word and who nursed considerable ambitions as an author. Yet throughout this entire period of his life, very few of his own writings appeared in print. While the polemical nature of Zizath Novel Zvi may go a considerable way to explaining his reticence to print it, neither his responsa nor a now lost commentary he wrote on the Mishnah appeared in print during this interval, a period when he still had considerable

10 London, PRO, Prob/11/411, Samuelis Saportas.

11 Sefer Ma'agal Tov ha-Shalem, ed. Aron Freimann (Jerusalem: Mekize Nirdamim, 1934), 157. As cited by S.Z. Havlin, "On the History of the Talmudic Academies in Jerusalem and Their Scholars at the End of the Seventeenth and Early Eighteenth Centuries," [Hebrew] Shalem 2 (1976): 146-47. 
connections to the world of Hebrew books in Amsterdam as one who issued approbations. ${ }^{12}$

With all of this in mind, the incident recounted in responsum number 60 in Ohel Ya'akov appears to demonstrate how difficult Sasportas found his job in Ets Haim at certain points. ${ }^{13}$ Responsum number 60 appears toward the end of Ohel Ya'akov. It does not contain a date, but internal evidence suggests it was written at some point between Sasportas's return from Livorno in 1680 and the death of Hakham Isaac Aboab de Fonseca in 1693. In one passage the names of Isaac Uziel and Saul Levi Mortera appear followed by the phrase "of blessed memory," indicating their death, while Aboab's did not. Furthermore, the putative author Moseh Sasportas refers to his father Jacob as an old man at the time of writing. Without too much exegetical strain but without making too firm a commitment, responsum 60 appears to date from the 168 os or early 1690 s.

The responsum is long, occupying roughly three folio pages of Ohel Ya'akov. In it Moseh Saportas recounts a rebellion of the students against his father who had served as their teacher. Unlike many of the other responsa in Ohel Ya'akov, which name an addressee and which attempt to resolve a specific and relatively delineated legal problem, responsum number 60 reads as if it is a report of an incident rather than a letter written to a given individual. At times, the rebellious students seem to be the addressee, at others, Jacob Sasportas, and at still others, no one in particular. In terms of the legal issue: the most recurring legal problem appears to be one of issuing instruction before one's teacher. This legal matter takes on two manifestations, the first (and the ostensible cause for the writing of the responsum) pertains to the students flouting the authority of Jacob Sasportas in the Ets Haim yeshiva; the second to Moseh Sasportas's ability to write such a responsum in the presence of his father. In a sense, the second problem was simply one of rhetoric. But the rhetorical choices were significant. Responum 61 in Ohel Ya'akov, which immediately follows, is actually a coda to this one, in which Jacob Sasportas applauded his son's efforts on his own behalf. ${ }^{14}$

The description of a student rebellion against Sasportas in Ets Haim bears a number of striking parallels to Sasportas's own account of Sabbatianism in Zizath Novel Zvi. The two central issues broached in the responsumSasportas's authority as a rabbi and the honor of his position and his person-were veritable leitmotifs within Zizath Novel Zvi. In fact, one might

\footnotetext{
12 For his commentary on the Mishnah and his hopes for its appearance in print, see Zizath Novel Zvi, 229.

13 Sasportas, Ohel Ya'akov, 65a-68a.

14 Ibid., 68a-68b.
} 
even go so far as to say that Sabbatianism as understood by Sasportas was by and large a crisis of authority at the level of the Jewish community and an affront on his own personal honor at the level of his own experience. Thus, to a certain degree, what happened in the Ets Haim yeshiva in the 168 os or 169os was narrated in terms that were strikingly similar to the way Sasportas described Sabbatianism in the 1660 os.

Much of the language used in this responsum echoed various passages in Zizath Novel Zvi. Thus in the responsum, Moseh Sasportas lamented the reversal of social hierarchies: "The order has been reversed and those on top are now on the bottom, and those on the bottom are now on top."15

At the height of the Sabbatian frenzy, Aaron Zarfati wrote to Sasportas: "If you were here [in Amsterdam] you would see a world turned upside down."16 In his own description of life in Hamburg at the same time, Sasportas recounted, "And the rabble have overcome their leaders, and there is no one to respond to them."17 Just as the reversal of traditional social hierarchies in the period of Sabbatian enthusiasm had led Sasportas to put pen to paper and embark on an epistolary campaign, the unbecoming impudence of the students in Ets Haim had compelled Moseh Sasportas to defend his father's honor.

Much of the discussion in this responsum concerned respect for rabbinic authority. In discussing the story, Moseh Sasportas wrote: "Let someone look at this with his mind's eye, at even the most superficial level, what punishment is given to those who are arrogant before their teachers."18 In Zizath Novel Zvi, Sasportas had responded in a very similar style to one of Nathan of Gaza's letters: "Let someone look with the fine eye of Jewishness at the words of this denier." 19

Furthermore, in another passage toward the end of the responsum, Moseh Sasportas dwelled at relative length on another affront to his father's honor. He writes:

As if it were not enough what they had done in the study house with their instruction, denigration and seizure of authority in front of the rabbi, but even in the synagogue, in public, they sought to malign his honor. When he rose to the lectern and was summoned to the Torah, the members of the study house would usually stand in his honor for the duration

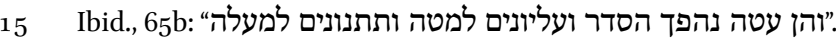

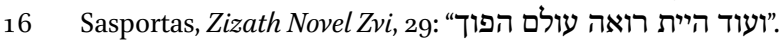

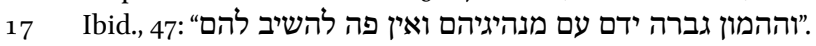

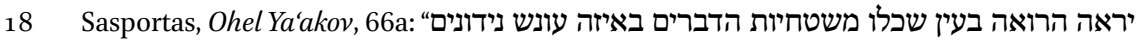
זהותם אשר בפני הרב מתיהרים"

19 Sasportas, Zizath Novel Zvi, 201: "יראה הרואה בעין יפה של היהדות בדברי הכופר הזיר." 
of the time he read from the Torah scroll. Although by law they were not required to do so, apart for the moment when he passed in front of them, nonetheless, since the founding of this congregation, the days of Rabbi Isaac Uziel and Rabbi Saul Levi Mortera, of blessed memory, and Rabbi Isaac Aboab, all the students behaved modestly before their teachers and stood as long as they were at the lectern as a sign of respect and honor. And they used to do this for my father as well. But this time, they refused, since they had determined that they were greater than their colleagues and they no longer needed a rabbi. [Since] he was no longer their rabbi, they sat in their places while some of their colleagues stood. ${ }^{20}$

The rebellion was partial rather than total. Not all of the students openly flaunted Sasportas's authority. Some continued to stand out of respect for their teacher, while others sat in defiance. Moreover, the rebellion had to do with the curriculum and a sentiment among some of the students that they no longer had any need for Sasportas's instruction. If this incident took place in the $1680 \mathrm{~s}$ or 169os, it hardly comes as a surprise that a group of students, not always the most staid stratum within society, found the teaching of an irascible old man somewhat cumbersome.

Moseh Sasportas drew a clear distinction between the study house, the beit midrash, and the synagogue, the beit ha-knesset. There can be little doubt that Ets Haim yeshiva was an elitist institution meant to provide in-depth training for a number of outstanding students. Admission was difficult in the seventeenth century and remained competitive well into the eighteenth century. ${ }^{21}$ Instruction was rigorous. One of the remarkable facts about the Portuguese Jews of Amsterdam was their ability to found and maintain a yeshiva that within a few generations could produce its own rabbinic elite, although this in no way stemmed the flow of rabbis from elsewhere who served the same

20 Sasportas, Ohel Ya'akov, 67b:

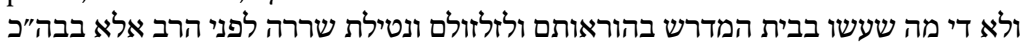

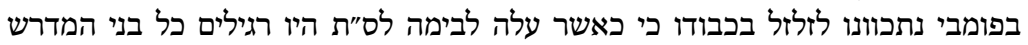

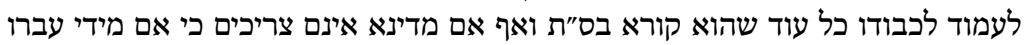

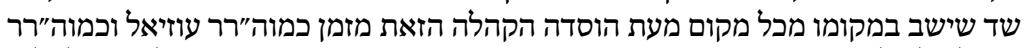

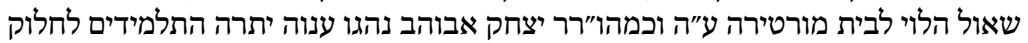

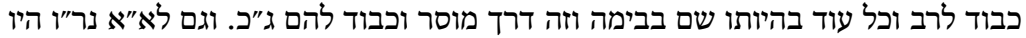

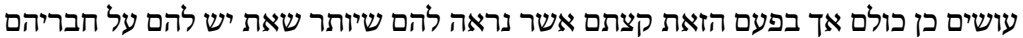

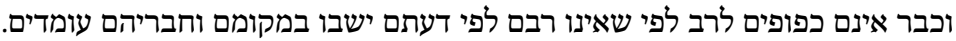

21 Gerard Nahon, "R. Rafael b. Eleazar Meldola in Bayonne, 1728-1741," [Hebrew] in Lo Yasur Shevet mi-Yehuda: Hanhaga, Rabanut, ve-Kehila be-Toledot Yisrael Mehkarim Mugashim leProfessor Simon Schwarzfuchs, ed. Joseph R. Hacker and Yaron Harel (Jerusalem: Mossad Bialik, 2011), 279-80. 
community. But the yeshiva was its own world and relatively closed off from the rest of the community. To a certain extent, what happened in the study hall stayed in the study hall. The synagogue, however, was an altogether different story. Almost by its very nature, the synagogue was a public institution. Gentiles came to visit the synagogue; deals were made in its courtyard; the community came together as a community in the synagogue. ${ }^{22}$ Even though the Ets Haim yeshiva of the 168 os and 16 gos was in the same physical complex as the Esnoga, the one was a private, elitist place of instruction, the other was a raucous, boisterous display of power and wealth. Thus when the yeshiva students took the liberty of breaking publicly with established custom and sitting while their teacher was called to the Torah in the synagogue, this was an affront of an altogether different order from their contempt for Sasportas's instruction in the halls of the study house. It was a public humiliation of a kind which neither Sasportas nor his family could suffer in silence.

Moreover, this distinction between the synagogue and the study house had already appeared within Zizath Novel Zvi. In the aforementioned letter by Aaron Zarfati to Sasportas that described the world turned upside down, Zarfati wrote, "If you could see with your own eyes, you would certainly say it was the hand of God. All day and all night, they fill the synagogue as if it were a day of atonement to God; ten thousand florins were pledged on the holy Sabbath; several benches were added to our yeshiva on that very day. Furthermore, you would see a world turned upside down." 23

Zarfati took care to distinguish between the messianic response of the synagogue and the study house. He separated the synagogue, a space where all members of the community convened for worship, from the study house, an academy where the learned elites studied Talmud in seclusion. The synagogue was theoretically open to all Jewish men; the study house was reserved for the elite who studied in splendid isolation. Excitement about the Messiah seems to have cut across all sectors of the Jewish community in such a dramatic fashion that the synagogue and the study house were alike transformed. Following the explosion of messianic excitement, both witnessed a dramatic increase in their respective constituencies. In order to impress upon Sasportas the radical break represented by Sabbatianism, Zarfati emphasized that it cut across two opposing institutions, the study house and the synagogue. So too Moseh

22 Yosef Kaplan, "Order and Discipline in the Portuguese Synagogue of Amsterdam," in Jewish Studies and the European Academic World, ed. Albert van der Heide and Irene E. Zwiep (Paris and Louvain: Peeters, 2005), 1-14.

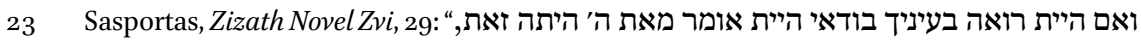

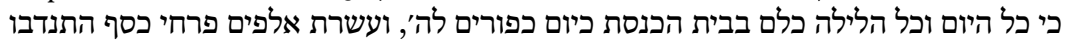
ביום שבת קדש וכמה ספסלים הלם הוסיפו בישיבתנס כיום כפורים כו בו ביום. ועשרת היית רואה עולם כסף הפוך." 
Sasportas, in emphasizing the affront to his father's honor, concluded the responsum with an account of the disrespect to Jacob Sasportas in public, meaning the synagogue, and not only in the semi-public sphere of the study house.

Responsum 6o thus reads somewhat like one of Sasportas's own letters included in Zizath Novel Zvi. In terms of language, many of the very same phrases used in Sasportas's letters reappeared in this responsum; the density of allusions that characterized Saportas's own writing repeated itself; and the acerbic criticism, the penchant and almost relish for intellectual combat that characterized Zizath Novel Zvi held true for the depiction of the rebellious students. Equally significant was the overlap in terms of content. Fear of social chaos and concern for his own honor were two of the central themes throughout Sasportas's account of Sabbatianism.

If this responsum reads as if it were right out of Zizath Novel Zvi, I suggest that Jacob Sasportas, rather than Moseh Sasportas, was its actual author. Two additional pieces of information appear to support this suggestion. The first has to do with style and the second with material evidence. In terms of style, Sasportas had adopted this technique of ventriloquizing himself in at least one instance. Toward the end of Zizath Novel Zvi, a full two years after Sabbetai Zevi's conversion, Sasportas had learned that the Jews of several communities in North Africa had continued to celebrate the ninth of Av as a holiday in Sabbatian style. He wrote a long letter condemning their practice and put the letter in the name of one of his own fictitious students and repeatedly discussed himself in the third person. Sasportas was thus fully capable of hiding behind someone else or using the voice of one of his own subordinates in the service of polemic. ${ }^{24}$

At the level of material evidence, a number of factors point to Jacob as the author. Ohel Yaakov survives in a single manuscript now at the Mendel Gottesman Library of Yeshiva University in New York. ${ }^{25}$ This manuscript shows many of the telltale signs of having been used as the copy text for the 1737 printing of the first and only edition. Many of the pages have the marks of a corrector; paragraph breaks correlate between the manuscript and printed edition; when the printed text includes a note that the responsum ends abruptly, the text in the manuscript ends abruptly as well. In his preface to Ohel Ya'akov Abraham Sasportas indicates that the manuscript used by the printer was in Sasportas's own hand, a handwriting that he conceded was appallingly difficult to read. ${ }^{26}$ Responsum number 60 is in the same semi-cursive hand as the rest

24 Sasportas, Zizath Novel Zvi, 358.

25 YU MS 1251, vol. 2.

26 Sasportas, Ohel Ya'akov, $4 \mathrm{~b}$. 
of the manuscript and as the other known samples of Sasportas's handwriting. Furthermore, there is complete continuity between responsum 60 and responsum 61 , which is acknowledged to have been written by Jacob. ${ }^{27}$ It seems that Sasportas himself rather than Moseh wrote it.

There are a number of possible objections to this hypothesis. First, Moseh may have had awful handwriting like his father. This is certainly possible, but given that no manuscripts written by Moseh appear to have survived, it is impossible to know; one might add that Sasportas's one son in whose hand Hebrew manuscripts survive, Isaac, wrote in a perfectly legible script. ${ }^{28}$ Second, the YU manuscript may be a copy of the printed book, rather than vice versa. A companion manuscript to the one of Ohel Ya'akov that contained Sasportas's notes for Zizath Novel Zvi (and that served as one of the most important sources for Tishby's edition) survives. ${ }^{29}$ It seems that these two manuscripts contained the bulk of Sasportas's writings and were preserved by his family after his death. Abraham Sasportas hired David Meldola as he reported in his preface to cull from these notebooks a collection of his legal responsa that appeared as Ohel Ya'akov and a selection of letters on Sabbetai Zevi that appeared as an appendix to the same volume entitled Kitzur Zizath Novel Zvi. In short, the manuscript that contains Ohel Ya'akov appears to have been the source for the printed text rather than vice-versa.

Does it make a difference if Sasportas or his son Moseh wrote the account of the student rebellion contained in responsum 6o? Sasportas was an old man at the time of his contest with the students of Ets Haim. About this, there is no dispute. He may have ventriloquized himself through Moseh because it would have been conduct unbecoming for someone of his age and stature to defend himself in public. But the offense by the students was so great, particularly once it had spilled out into the synagogue that some form of defense was absolutely necessary. And who better to defend the honor of a maligned rabbinic luminary than that luminary's son?

\section{Bibliography}

Azulai, Hayim Joseph David. Sefer Ma'gal Tov ha-Shalem. Edited by Aron Freimann. Jerusalem: Mekize Nirdamim, 1934.

27 YU MS 1251, vol. 2. 107a-112a.

28 See his eulogy for his father in Amsterdam, Ets Haim, MS $47 \mathrm{C}_{36}$, 4a-1ob.

29 YU MS 1251, vol. 1. 
Franco Mendes, David. Memorias do estabelecimento e progresso dos Judeos Portuguezes e Espanhoes nesta famosa citade de Amsterdam. Edited by L. Fuks and R.G. FuksMansfeld. Special Issue of Studia Rosenthaliana 9, 1975.

Goldish, Matt. "Hakham Jacob Sasportas and the Former Conversos." Studia Rosenthaliana 44 (2012): 149-72.

Havlin, S.Z. "On the History of the Talmudic Academies in Jerusalem and Their Scholars at the End of the Seventeenth and Early Eighteenth Centuries." [Hebrew] Shalem 2 (1976): 113-92.

Kaplan, Yosef. "Order and Discipline in the Portuguese Synagogue of Amsterdam." In Jewish Studies and the European Academic World. Edited by Albert van der Heide and Irene E. Zwiep, 1-14. Paris and Louvain: Peeters, 2005.

Kaplan, Yosef. "The Social Functions of the Herem." In An Alternative Path to Modernity: The Sephardi Diaspora in Western Europe. Pp. 108-42. Leiden: Brill, 2000.

Levie Bernfeld, Tirtsah. Poverty and Welfare among the Portuguese Jews in Early Modern Amsterdam. Portland, OR: The Littman Library of Jewish Civilization.

Nahon, Gerard. "R. Rafael b. Eleazar Meldola in Bayonne, 1728-1741." [Hebrew] In Lo Yasur Sshevet mi-Yehuda: Hanhaga, Rabanut, ve-Kehila beToledot Yisrael Mehkarim Mugashim le-Professor Simon Schwarzfuchs. Edited by Joseph R. Hacker and Yaron Harel, 271-99. Jerusalem: Mossad Bialik, 2011.

Sasportas, Isaac. Writings. Amsterdam, Ets Haim Library, MS 47 C 36.

Sasportas, Jacob. Ohel Ya'akov. Edited by David Meldola. Hertz Levi Rofe: Amsterdam, 1737 .

Sasportas, Jacob. Writings. New York, Yeshiva University, Mendel Gottesman Library, MS 1251, vols. 1-2.

Sasportas, Jacob. Zizath Novel Zvi. Edited by Isaiah Tishby. Jerusalem: Mossad Bialik, 1954.

Tishby, Isaiah. "Letters by Rabbi Jacob Sasportas against the Parnassim of Livorno from 1681. [Hebrew]) Kovets al Yad 4 (1946): 143-6o.

Tishby, Isaiah. "New Information on the 'Converso' Community in London according to the Letters of Sasportas from 1664/1665." [Hebrew] In Galut Ahar Golah: Mehkarim be-Toldot Am Yisrael Mugashim le-Professor Haim Beinart li-Melot Lo Shivim Shanah. Edited by Aharon Mirsky et. al, 470-96. Jerusalem: Ben Zvi Institute, 1988. 


\title{
A Letter's Importance: The Spelling of Daka(h) (Deut. 23:2) and the Broadening of Western Sephardic Rabbinic Culture
}

\author{
David Sclar*
}

On 5 February 1744 (22 Shevat 5504), David Franco Mendes, a young Portuguese Jew drawn to the study of the Hebrew language, wrote to the Italian poet and kabbalist Moses Hayim Luzzatto, who had recently emigrated to Acre after spending the previous eight years in Amsterdam. ${ }^{1}$ In the letter, Franco Mendes explained to his literary mentor ${ }^{2}$ that he had encountered a challenge to Portuguese religious and cultural sensibilities: a fellow Sephardi had purchased a Torah scroll from an Ashkenazic man, only to discover later that the word daka in Deuteronomy 23:2 was spelled with a heh (דכה) rather than with an alef (דכא) as dictated by community tradition. Franco Mendes, and presumably the Portuguese rabbinate, was unsure if Sephardim could use the scroll for ritual purposes. He apparently hoped that Luzzatto, a native of Padua, knew of similar issues of cultural conflict and halakhic resolution in the Italian Peninsula.

Seventeen years later, Moses Israel, a long-standing scholar in the Ets Haim yeshiva and former colleague of Luzzatto, published a ruling (pesak) in the

* Thanks to Jesse Abelman, Edward Fram, Matt Goldish, Jordan Penkower, and Pinchas Roth for their insight and helpful suggestions. I am grateful to Rachel Boertjens, Emile Schrijver, and Heide Warncke for assistance, and to the Mahamad of the Portuguese Jewish community in Amsterdam for permission to peruse their collection of Torah scrolls. Special thanks to Onno Voitus van Hamme, Project Researcher at the Jewish Historical Museum, for spending hours with me rolling scrolls in search of a single letter. I dedicate this article to my father, Abe Sclar, whose interest in the spelling of $d a k a(h)$ and similar curiosities sparked my love for historical minutia and the endlessness of knowledge.

1 Amsterdam, Ets Haim/Montezinos Livraria (hereafter EH), 47B3, p. 38 . On Luzzatto in Amsterdam, see David Sclar, "Adaptation and Acceptance: Moses Hayim Luzzatto's Sojourn in Amsterdam among Portuguese Jews," Association for Jewish Studies Review 40, no. 2 (November 2016): $335^{-5} 8$.

2 Nearly four decades later, Franco Mendes described Luzzatto as his teacher of all things poetic; see Moses Hayim Luzzatto, Derekh Hokhmah (Amsterdam, 1783), fol. 5v, and Irene E. Zwiep, “An Echo of Lofty Mountains: David Franco Mendes, a European Intellectual," Studia Rosenthaliana 3 , no. 2 (2001): 293.

(C) DAVID SCLAR, 2019 | DOI:10.1163/9789004392489_016

This is an open access chapter distributed under the terms of the prevailing CC-BY-NC License at the time of publication. 
community's Hebrew legal periodical, Peri Ets Hayim (Fruit of the Tree of Life), on an inverse case. ${ }^{3}$ An Ashkenazic man was publicly reading the Torah for a Sephardic congregation when he noticed that daka was spelled with a heh (דכה) rather than with the alef (דכא) he expected. He stopped reading and requested a different scroll, assuming he had discovered a singular mistake and that he could continue the ritual recitation from another Torah. The congregation rejected the man's request, stating that the word was spelled according to Sephardic tradition. The case hinged on whether the man could continue reading for the congregation despite the variant spelling that he assumed disqualified the scroll's suitability for himself and for Ashkenazim in general.

At first glance, Franco Mendes's 1744 letter and Israel's 1761 pesak contradict one another, with each claiming contrasting customs for the same Portuguese community in Amsterdam. Although the divergence hinged on a mere letter, the spiritual and cultural significance was high. Religious conviction required Torah scrolls, believed to be written manifestations of divine will, to match tradition. Inaccuracy in a scroll, or even an inadvertent slip of the pen that deformed a letter, disqualified the object for ritual use. Rabbinic scholars had been debating spelling and pronunciation for centuries, and as juxtaposed sources, Franco Mendes and Israel could appear to represent a local disagreement.

In fact, each author's words expressed Portuguese custom at the time of their respective compositions. A deeper view of the documents, in tandem with the community's surviving Torah scrolls from the period, reveals a historical development in which Portuguese Jewry altered its custom in imitation of contemporary rabbinic norms. That change reflected a transformation in Portuguese Jewry's socio-religious outlook. Sephardim and Ashkenazim in Amsterdam had long existed side by side but not as an integrated cultural body. The cases described by Franco Mendes and Israel indicate that in the mid-eighteenth century sufficient intimacy existed to exchange precious ritual objects and to pray together, though with some degree of religious and cultural discord.

This article explores some ramifications of and reactions to that conflict. Following a short section on Peri Ets Hayim and Israel's activity in the Portuguese yeshiva, I analyze Israel's rich pesak and the context in which Western Sephardim modified ritual in a small but meaningful way. Although

3 EH 4 Fin, Peri Ets Hayim (Amsterdam: Proops, 1761), ff. 117v-119r; for a synopsis, see Menko Max Hirsch, Frucht vom Baum des Lebens, Ozer peroth Ez Chajim (Berlin-Antwerp: [Soncino-Gesellschaft der Freunde des Jüdischen Buches], 1936), no. 407. A manuscript version, probably prepared for publication, is extant (University of Amsterdam, Bibliotheca Rosenthaliana, HS Ros. 579) (Fig. 15.1). Israel concluded the text with a chronogram that decodes to January 1761 . 
Luzzatto's reply is not extant, ${ }^{4}$ Israel's text amply illuminates the development of Portuguese religious culture in the eighteenth century. The final section addresses the variant spellings of $d a k a$, and, utilizing Torah scrolls in the possession of Amsterdam's Sephardic community, links and resolves the discrepancy between Franco Mendes and Israel. Elucidating the spiritual development, and its presentation in Israel's pesak, I argue that increased intellectual and social engagement with Ashkenazic culture in the eighteenth century broadened Portuguese rabbinic culture and eroded existing sentiments of communal exclusivity. Moreover, changing the spelling of daka signified deeper engagement with larger Jewish trends, suggesting a modernization through tradition that marked a new phase in the history of Portuguese Jewry. ${ }^{5}$

\section{Peri Ets Hayim}

In 1728, David Israel Athias and Isaac Hayim Abendana de Britto became cochief rabbis of Amsterdam's Portuguese Jewish community, replacing the recently deceased Hakham Salomon Ayllion. Whereas Ayllion had been drawn to Kabbalah, adhering to Sabbatianism and at one point publicly celebrating the arrival in Amsterdam of an accused heretic, ${ }^{6}$ Athias and Abendana de Britto advocated intensive rabbinic study. During their decades-long tenures, the Ets Haim yeshiva deepened its Talmudic and halakhic curricula and trained students to serve as rabbis in an expanding Western Sephardic diaspora. Members of the yeshiva manifested their rabbinic aspirations in Peri Ets Hayim, a serial publication of halakhic rulings on issues broadly relevant to the community. Under the direction of Abendana de Britto, who served as rosh yeshiva of the Ets Haim, teachers and advanced students (many of whom became the next generation's instructors) produced approximately four hundred pesakim in the periodical. Even as the community faced financial difficulties, brought on by an economic downturn and increasing numbers of indigent Jews in Amsterdam, the Ets Haim yeshiva remained committed to the costly production of twelve

4 There is no indication that Luzzatto wrote a reply or even received Franco Mendes's letter.

5 On this interplay between tradition and modernity, see David Sclar, "Blending Tradition and Modernity: The Growth of the Ets Haim Library in the 18th Century," in Tradition \& Modernity in Ets Haim, ed. David Wertheim (Amsterdam: Menasseh Ben Israel Institute and the University of Amsterdam, 2017), 19-33, 38-39.

6 On the heresy of Nehemiah Hiya Hayun and his activity in Amsterdam, see Elisheva Carlebach, Pursuit of Heresy: Rabbi Moses Hagiz and the Sabbatian Controversies (New York: Columbia University Press, 1990), chap. 4. 
or thirteen pesakim per year. ${ }^{7}$ Nearly one thousand in total were produced by the time the enterprise ceased in the second decade of the nineteenth century. 8

Broadly, Peri Ets Hayim emulated contemporary collections of responsa. The genre had long been crucial to the halakhic process and rabbinic culture, circulating first in manuscript and then in print. Responsa literature flourished in the middle of the eighteenth century, as the sons and students of living or recently deceased scholars brought writings of practical halakha to press, solidifying in book form the activity of large networks of rabbinic thinkers. ${ }^{9}$ In contrast to the brevity of medieval examples, early modern responsa appeared as essays displaying authors' expansive knowledge and intellectual prowess. Scholars frequently fabricated "questions" themselves and responded with erudition and force in the hopes of establishing their voices as authoritative. ${ }^{10}$

Despite mirroring these trends, Peri Ets Hayim stood uniquely as a multigenerational body of work initiated by an educational system. Ets Haim leadership standardized the publication process, ${ }^{11}$ compelling authors to follow a given format in composing their essays. ${ }^{2}$ Pesakim frequently began with a

7 David Sclar, "Books in the Ets Haim Yeshiva: Acquisition, Publishing, and a Community of Scholarship in Eighteenth-Century Amsterdam," Jewish History 30, no. 3 (2016): 224-26.

8 Most published products appeared in two-columns, between forty and forty-four lines per page, and consisted of at least three thousand words.

9 For instance, Ezekiel Katzenellenbogen's Keneset Yehezkel (Altona, 1732), Isaiah Bassan's Lahme Todah (Venice, 1741), Jacob Poppers's Shav Ya'akov (Frankfurt, 1742), Joseph Ergas' Divre Yosef (Livorno, 1742), and Samson Morpurgo's Shemesh Tsedakah (Venice, 1743), as well as Isaac Lampronti's halakhic encyclopedia Pahad Yitshak (Venice, 1750), which integrated responsa from contemporary scholars.

10 On responsa literature in the early modern period, see Matt Goldish, Jewish Questions: Responsa on Sephardic Life in the Early Modern Period (Princeton, NJ: Princeton University Press, 2008), xlviii-lv; Edward Fram, Ideals Face Reality: Jewish Law and Life in Poland 1550-1655 (Cincinnati: Hebrew Union College Press, 1997), 7-10; and Jay R. Berkovitz, "The Persona of a Poseq: Law and Self-Fashioning in Seventeenth-Century Ashkenaz," Modern Judaism 32, no. 3 (2012): 251-69. On historiographical use of responsa, see Jacob Katz, The "Shabbes Goy": A Study in Halakhic Flexibility, trans. Yoel Lerner (Philadelphia: Jewish Publication Society, 1989); and Haym Soloveitchik, The Use of Responsa as an Historical Source: A Methodological Introduction [Hebrew] (Jerusalem: The Shazar Center and The Hebrew University of Jerusalem, 1990).

11 Likewise, rabbis and students followed a uniform practice in producing sermons. Each of the seven rabbinic talks celebrating the dedication of the Esnoga in 1675, for instance, began with Biblical and Mishnaic quotations before delving into a lengthy exposition of the texts and the glory of the community; see Sermoes que pregaraõ os doctos ingenios do K.K. de Talmud Torah, desta cidade de Amsterdam, no alegre estreamento, \& publica celebridade da Esnoga que se consagrou a Deos (Amsterdam: David de Castro Tartaz, 1675).

12 For an example of how earlier responsa were utilized for a question in Peri Ets Hayim, see Shmuel Glick, ed., Seride Teshuvot of the Ottoman Empire Sages from the Cairo Genizah 
narrative and invariably concluded with a chronogram referring to both the year and week during which it had been composed. ${ }^{13}$ Authors submitted their work to the rosh yeshiva for review, after which a scribe or the author himself rewrote the full text legibly for submission to a print shop (Fig. 15.1).

The publications generally dealt with issues surrounding property, interest, charity, marriage, and additional topics relevant to Portuguese communities engaged in mercantilism and concerned with kinship. Pesakim frequently refer to wealthy men, owners of multiple houses, and individuals engaged in overseas ventures, though it is unlikely that laymen studied the texts or bothered to align business practices with halakha. ${ }^{14}$ Instead the emphasis on applied Jewish law reflected the Mahamad's plan to train communal rabbis and strengthen the bonds of religious segments of Portuguese society.

The extent of this endeavor's success requires further research, but it is nevertheless clear that Peri Ets Hayim served as the intellectual fruit of an elite within the Ets Haim's highest class. Not all students found on the rolls of the Medras Grande submitted halakhic essays. Each generation seems to have had few men interested in, capable of, or tasked with submitting pesakim. In the early decades of the serial's publication, Abraham da Costa Abendana, Aaron Ledesma, Samuel Acatan, David Meldola, Jacob Bassan, and a handful of others-most of whom taught in the Ets Haim or became communal rabbis in the Portuguese diaspora-published dozens of rulings between them. Authors were expected to utilize a wide range of sources, including the Babylonian and Jerusalem Talmuds and their commentaries, halakhic codes, and responsa literature from both Sephardic and Ashkenazic authorities. The latter sources stood not only as exemplars for their own work, but also indicated that the Ets Haim had moved from its origins as a Portuguese seminary, focusing on Bible and literature, to a yeshiva that sought to make itself first and foremost rabbinic.

Moses Israel's long career in the Ets Haim exemplified the activity of the Portuguese religious elite in the eighteenth century. By the time he issued his pesak on the spelling of daka in 1761, Israel had been a fixture of the Ets

Collection of the Cambridge University Library [Hebrew] (Jerusalem: The Schocken Institute for Jewish Research of the Jewish Theological Seminary of America, 2013), 39-41.

13 Chronograms were ubiquitous in medieval and early modern Jewish culture, but authors generally stated a day and date explicitly, leaving the year to be decoded from a quoted verse. In Peri Ets Hayim, authors were tasked with drawing a verse from that week's Torah pericope, indicating (less overtly) the date of authorship.

14 On the latter issue, see Matt Goldish, "Rabbi Jacob Sasportas: Defender of Tradition in an Age of Change," Master's thesis, Hebrew University of Jerusalem, 1990, chap. 3. 


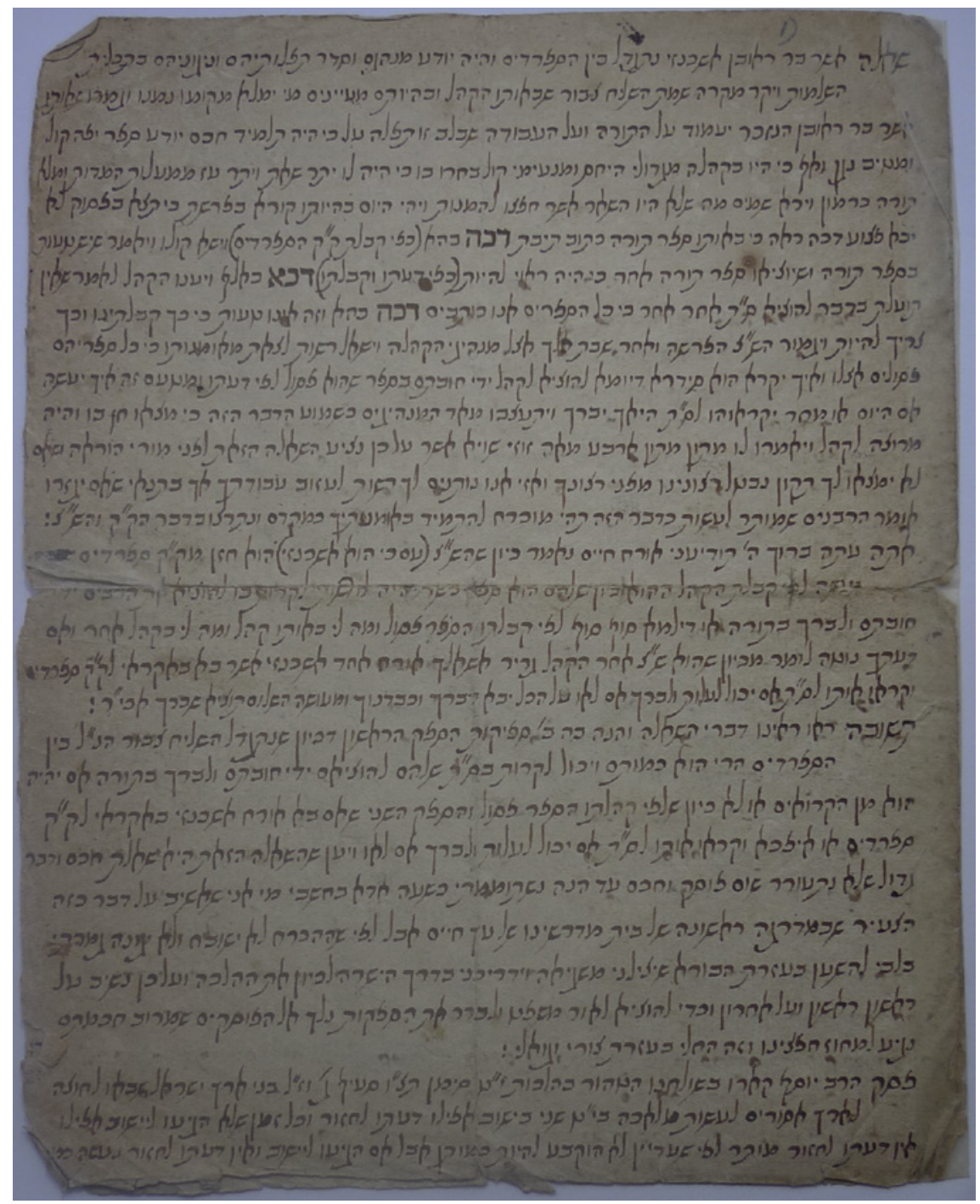

FIGURE 15.1 Pesak written by Moses Israel, Bibliotheca Rosenthaliana, Special Collections of the University of Amsterdam, HS Ros. 579 
Haim for three decades. ${ }^{15}$ He regularly earned a stipend (aspaca) to study in the Medras Grande, and, as early as January 1733, he had been counted among a select group of students additionally funded by the privately-endowed but publicly administered yeshiva, Emet Le Jahacob. ${ }^{16}$ In 1742 , he worked with his Ets Haim colleague, David Meldola, to edit a primer for the study of Talmud by Moses Hayim Luzzatto. ${ }^{17}$ Israel's work on the book demonstrated his proficiency in Talmud and rabbinic literature more broadly, as well as his closeness to Luzzatto, a kabbalist, and to Meldola, the most prolific Western Sephardic scholar of his generation. After two decades of study in the highest class of the Portuguese yeshiva, Israel was well-positioned to produce numerous and diverse halakhic essays. Between 1754 and 1780, he published fifty-seven pesakim on cases of marriage, business, and ritual, including several concerning Torah scrolls.

Although most cases circulated in Peri Ets Hayim were fabricated to facilitate intellectual exercise, questions invariably drew on contemporary Portuguese experience and reflected authors' social and cultural milieu. In his erudite pesak on the spelling of daka, Israel sought to guide Portuguese Jews wrestling with their identity amid increased interaction with Ashkenazic Jews. He conveyed evolving attitudes toward tradition and signified how societal progress initiated new halakhic questions. Despite the legal premise, emotion and personal experience featured prominently in Israel's ruling, and he exhibited both originality and sensitivity in his attempt to steer a religious culture challenged by ritual disparity.

Israel's four-page essay commences with a narrative about a man named Asher bar Reuben Ashkenazi, who, despite the heritage evoked by his surname, had been raised among Sephardic Jews (Fig. 15.2). His age and origin are not detailed, but the text informs the reader that the man came to know Sephardic customs, prayers, and songs as if they were his own. At some point

\footnotetext{
15 Moses Israel's biography has yet to be pieced together; several other men with the same surname studied in the Ets Haim during his tenure, including Abraham, Aharon, Isaac, and Samuel (Archive of the Portuguese-Jewish Community, Stadsarchief Amsterdam [hereafter, SAA] 334, no. 1189, passim).

16 SAA 334, no. 1053, p. 43. Emet Le Jahacob and Oel Jahacob were founded by Jacob Pereira in the late seventeenth century, with numerous men, including the chief rabbis, receiving stipends, but they did not function as separate yeshivot.

17 Derekh Tevunot (Amsterdam: Joseph Dayan, 1742).
} 


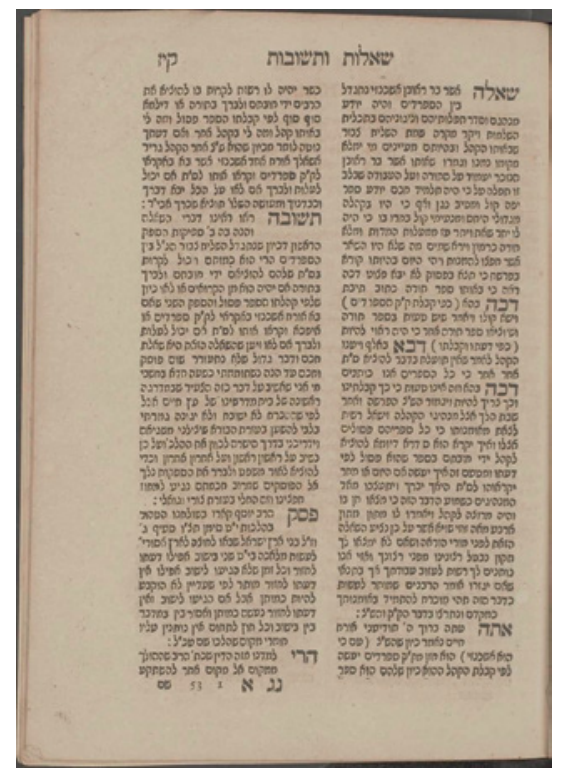

FIGURE 15.2

Pesak written by Moses Israel, Peri Ets Hayim (Amsterdam: Proops, 1761),

$\mathrm{EH} 4 \mathrm{~F} 11$, fol. $117 \mathrm{r}$

in adulthood, his community was left without a prayer leader when the local cantor suddenly died. The congregation turned to Ashkenazi, whom they regarded as a well-informed scholar with a pleasing voice and musical ability. ${ }^{18}$ Although prestigious members of the synagogue objected bitterly, apparently because of the man's ethnicity, Israel's "questioner" explained that most people in the community considered Ashkenazi's dignity, humility, and fear of Heaven to be stellar and of supreme importance.

One day while publicly reciting the Torah portion Ki Tetse, Ashkenazi noticed that the word daka in Deuteronomy 23:2 was spelled with a heh. ${ }^{19} \mathrm{He}$ stopped midsentence to announce that he had found an error in the scrollthe word should have ended with an alef, he claimed - and called for another scroll to be taken from the ark. Despite the congregation's tradition of spelling the word with a heh, the new cantor argued that he, as a man of Ashkenazic descent, was required to follow his own ancestral tradition. The congregation responded that there was no use in taking out a different scroll, because, "as all Sephardim know," the word was appropriately spelled. They informed him

18 היה תלמיד חכם יודע ספר יפה קול ומטיב נגן

19 Israel did not comment on the meaning of the text itself, even though it inspired an unrelated case in Hamburg-Altona; see Maoz Kahana, "An Esoteric Path to Modernity: Rabbi Jacob Emden's Alchemical Quest," Journal of Modern Jewish Studies 12, no. 2 (2013): 253-75. 
that all their scrolls were written likewise, and insisted that Ashkenazi finish the reading.

After the Sabbath, Israel's narrative continues, Ashkenazi asked the community's lay leadership for permission to correct the scrolls. He argued that the current spelling invalidated the Torah scrolls for Ashkenazic Jews, undercutting his ability to fulfill the ritual reading on behalf of the community. In addition, more personally, Ashkenazi questioned how he could recite customary blessings over the scrolls in defiance of the injunction against uttering benedictions over defective ritual items. Hoping to convey the gravity of the exchange, the "questioner" stated that Ashkenazi's statement saddened the leadership, who, like most communal members, valued Ashkenazi's services. They decided to submit the question to competent halakhic authorities: if the latter sided with Ashkenazi, he would be permitted to abandon his work with the community (amending the scrolls was not an option); if they rejected his assessment he would be obligated to abide by the congregation's tradition.

Placing himself in the literary role of arbiter, Israel began his "answer" by articulating two interconnected dilemmas. Was Ashkenazi permitted to read from the congregation's Torah scrolls if it meant he would contradict his own tradition, and, extrapolating more broadly, could Ashkenazim visiting Sephardic congregations ascend to the Torah and recite blessings over a scroll that included a variant spelling? The former inquiry—and the narrative about an Ashkenazic man raised in a Sephardic community retaining his heritage but serving as cantor-seems to have been a deliberate setup for the latter. There is no evidence of an early modern Portuguese community employing an Ashkenazic cantor or sanctioning the adoption of Ashkenazic children. However, with increased social and geographic mobility in the eighteenth century, Jews of diverse origins in Western Europe regularly encountered co-religionist rites that differed from their own. In the 1730s, Ezekiel Katzenellenbogen recorded a query from an Ashkenazic man living (and presumably working) in a Sephardic home in Hamburg. ${ }^{20}$ On Hanukkah, the questioner had attempted to light a menorah in keeping with Ashkenazic custom, only to be rebuffed by his landlord who insisted, based on his own Sephardic custom, that he as head of the household should perform the commandment for all occupants. ${ }^{21}$ Though variations within Jewish religious

$20 \quad$ Keneset Yehezkel (Altona, 1732), no. 17. Thanks to Yigal Sklarin, who analyzed this source in an unpublished research paper for a graduate course at Yeshiva University.

21 Katzenellenbogen ruled in favor of the Ashkenazic man, arguing that the assumption of the owner of the house-that he reserved the right to impose his custom based on a halakhic concept prohibiting factionalism (לא תתגודדו) -was both unfounded and, considering Sephardim arrived in German lands long after Ashkenazim, quite the inverse. 
practice are as old as tradition itself, conflict over ritual and identity intensified in places and times of demographic change.

Still, contemporary responsa are not replete with questions stimulated by inter-communal discord, and Israel's pesak staked a claim in uncharted territory. Addressing both his fictional and actual audiences in a dual role as the narrative's judge and essay's author, Israel remarked that Asher bar Reuben Ashkenazi's query "has not previously arisen among our legalists and sages. I was astounded to consider my position as [the first to] reply to this, a mere juvenile in the first class of our Midrash in the Ets Haim. Out of necessity, not praise or distress, I resolved to lean on the help of the Creator to save me from errors and lead me on the straight path to determine the halakha."22 The observation, in the voice of a humble judge compelled to adjudicate, demonstrated Israel's self-awareness and confidence. With an excellent rabbinic library at his disposal, he correctly concluded that the halakhic corpus recorded no precedent and embarked upon solving a new issue of communal importance.

Ultimately, Israel ruled in the affirmative in both cases: the mythical Ashkenazi could continue to serve as cantor, and Ashkenazim praying with Sephardim (and vice versa) could recite blessings over scrolls with spellings that ran contrary to their own traditions. His argument rested on several halakhic sources, particularly rulings that elevated local tradition above an individual's personal custom (minhag ha-makom). For instance, the Shulhan Arukh codified a law whereby Jews from Palestine who traveled to communities outside the Holy Land were restricted from certain activity on the second day of a festival (yom tov sheni). ${ }^{23}$ (Jews in the Holy Land observe festivals for just one day, in contrast to the two days expected of Jews outside the Land.) By the early modern period, with increasing travel particularly of emissaries seeking alms, ${ }^{24}$ halakhic authorities insisted that Jews visiting communities abroad refrain from open displays of action prohibited to their hosts. Likewise, itinerant rabbis who assumed rabbinic posts were required to follow local traditions rather than their own. ${ }^{25}$ This proved relevant in the Italian Peninsula, where scholars and teachers often roamed from town to town serving congregations of varying ethnicities, ${ }^{26}$ and in Amsterdam itself, where Ashkenazic rabbis Uri

\footnotetext{
22 EH 4 Fi1, Peri Ets Hayim, fol. $117 \mathrm{v}$.

23 Shulhan Arukh, Orah Hayim, Hilkhot Yom Tov, § 496:3.

24 See Matthias B. Lehmann, Emissaries from the Holy Land: The Sephardic Diaspora and the Practice of Pan-Judaism in the Eighteenth Century (Stanford: Stanford University Press, 2014).

25 Arba'ah Turim, Orah Hayim, Hilkhot Pesah, 468.

26 On itinerant rabbis in Italian communities, see Robert Bonfil, Rabbis and Jewish Communities in Renaissance Italy, trans. Jonathan Chipman (Oxford: Littman Library of Jewish Civilization, 1990), 192-206.
} 
Phoebus Halevi and Saul Levi Mortera helped shape the Portuguese Jewish community in the seventeenth century.

Israel bolstered his argument with citations from Talmud tractates Hullin and Pesahim emphasizing the importance of adopting minhag ha-makom in public matters. He debated the issue of whether a visitor differs from a permanent resident, but concluded that the case of Asher bar Reuben Ashkenazi especially necessitated the adoption of community ritual. Raised among Sephardim, the imaginary Ashkenazi was, for all intents and purposes, "like them." Citing the seventeenth-century halakhist Hezekiah da Silva, Israel argued that visitors in general, let alone men in Ashkenazi's predicament, should abide by a given congregation's custom even if the city hosted synagogues operating otherwise. That is, the individual in question could not follow his own custom based on an assumption, true or not, that local Jews were aware and tolerant of alternative practices.

Consequently, Israel rejected the notion that Sephardim and Ashkenazim should or even could function separately and without regard for each other. He sought to preserve divergent traditions in conjunction with frequent crosscultural interaction, and, as such, advocated leniency in this previously unaddressed but socially significant halakhic matter. To support his approach, Israel cited Joseph Karo's reference to a Maimonides responsum permitting blessings over an invalid (pasul) Torah scroll, ${ }^{27}$ and otherwise promoted restraint with respect to faulty scrolls. As conveyed in the narrative, standard practice called for a new scroll to be brought from the ark in instances where a mistake was discovered. If noticed mid-aliyah, following the recitation of the blessing that customarily preceded a reading, the reader would continue where he had left off. Upon completion of that portion of text, the man called for the ali$y$ ah would recite the after-blessing but would not pronounce the first blessing anew. While the discovery of a mistake in the first scroll necessitated the use of a different scroll for the remaining sections of the Torah portion, it did not invalidate previous aliyot or their blessings. An error amid a scroll's 300,000 plus letters could go undetected for months, and it could not reasonably be assumed after the fact that previous readings and blessings had been made in vain. Thus, Israel concluded, an Ashkenazic visitor in a Sephardic community could receive an aliyah without concern for the spelling of daka, because a

27 Kesef Mishnah on Mishneh Torah, Sefer Ahavah, Hilkhot Sefer Torah 10:1. Karo states that Maimonides meant it only when no other scroll was available. Elsewhere, he ruled that a blessing may not be recited in such circumstances; see Shulhan Arukh, Orah Hayim, $\S 143: 2-3$. 
mere letter, so important in the moment of discovery, did not outweigh the importance of ritual practice that assumed the validity of any particular scroll.

In so ruling, Israel sought to establish a precedent for tolerant or permissive ritual interaction between the two ethnic groups. In Israel's telling, Asher bar Reuben Ashkenazi earned his position despite the objection of prominent members in the community, because the majority of the congregation cared less about his ethnicity than his ability. By including such an extraneous comment, irrelevant to the case at hand, Israel expressed his latent conviction that his own community should function likewise. For generations, Portuguese Jewry had lived largely independently from other Jewish societies, forming an identity as a distinct Nação ${ }^{28}$ From the community's inception in the early seventeenth century, communal rules governed social interaction between Sephardim and Ashkenazim, including in matters of education, poor relief, and marriage. Cultural differences contributed to and to some degree ensured communal separation, as Amsterdam's Portuguese Jews were typically wealthier, more cosmopolitan, and less religious than their Eastern European counterparts. Over decades, however, contact between varying ethnicities increased and distinctions lessened. Print shops in particular facilitated greater awareness and even collaboration between Amsterdam's Sephardic and Ashkenazic rabbinates. By the mid-eighteenth century, Ashkenazim (including Luzzatto) were formally permitted to study in the Ets Haim yeshiva, and documents point to Sephardim holding prayer services with their Eastern European coreligionists. ${ }^{29}$ To be sure, the Mahamad infrequently provided Ashkenazic students with stipends and habitually prevented diversity in the synagogue. Perhaps Israel's pesak gave voice to a silent majority objecting to longstanding inflexibility in the Esnoga. Likewise, as an integral member of the Ets Haim with ties to Amsterdam's Hebrew print shops and the city's Ashkenazic intellectual elite, Israel may have wanted to justify his own experience, or sought to motivate communal leadership to expand social and cultural horizons.

Regardless, as an authorized product of PeriEts Hayim, Israel's essay reflected some sort of official policy. His concluding statement suggests lay and rabbinic leadership felt it necessary to respond to entrenched Sephardic-Ashkenazic

28 See Jozeph Michman, "Between Sephardim and Ashkenazim in Amsterdam," [Hebrew] in The Sephardi and Oriental Jewish Heritage, ed. Issachar Ben-Ami (Jerusalem: Magnes Press, 1982), 135-49; Miriam Bodian, The Hebrews of the Portuguese Nation: Conversos and Community in Early Modern Amsterdam (Bloomington: Indiana University Press, 1997), 125-31; Yosef Kaplan, An Alternative Path to Modernity: The Sephardi Diaspora in Western Europe (Leiden: Brill, 2000), 78-107; and Daniel Swetschinski, Reluctant Cosmopolitans: The Portuguese Jews of Seventeenth-Century Amsterdam (London: Littman Library of Jewish Civilization, 200o), 187-96.

Sclar, "Books in the Ets Haim Yeshiva," 226-31. 
integration. "Today, there are places home only to Sephardic congregations, where they call Ashkenazim to the Torah who make the blessings," Israel remarked. "So too are there places home only to Ashkenazic congregations, where they call Sephardim to the Torah, and they recite the blessings. Let them [continue], for [today] there are no prophets or sons of prophets in Israel! It seems that God, in His mercy, will deliver us from error as we seek out His wondrous teachings. Amen." With Jews of varied backgrounds regularly praying together without concern for ritual discrepancy, Israel and his patrons evidently decided to sanction rather than challenge circumstances they had no power to alter. As we shall see, broadened religious and communal interests led to a ritual adaptation, making Israel's erudite pesak as much a proclamation about the narrative's social premise as it was an intellectual exercise.

\section{$3 \quad$ An Altered Letter}

David Franco Mendes's and Moses Israel's concerns over the spelling of daka pertained to a centuries-long process of establishing the Biblical text. Early rabbinic literature refers to the problem of variant readings, and medieval sources, most notably the writings of the masorah, embarked on efforts to determine correct readings. ${ }^{30}$ Scholars during the early modern period argued for the importance of fixing the text, frequently debating the importance of a single letter. Questions arose, for instance, as to whether the word sho'el (שאל) (Deut. 10:12) should retain a $v^{2}{ }^{31}{ }^{31}$ Foreshadowing Israel's pesak by more than a century, Nathan Nata Spira (1585-1633) argued that even though the word should be spelled without a $v a v$ it was acceptable to use the alternative if necessary. By the seventeenth and eighteenth centuries, several treatises on the intricacies of scribal practices had been written, including Meir Abulafia's Masoret Seyag la-Torah, Menahem Lonzano's Or Torah, and Jedidiah Norzi's Minhat Shai. In Israel's own community, Moses Gomez de Mesquita published a pesak on whether the divine name Elohim required a $v a v,{ }^{32}$ and Judah Piza, a colleague of Israel and Luzzatto in the 1740s, commented on issues related to continuing a ritual Torah reading if a scroll were found to be defective. ${ }^{33}$

Even as scholars and scribes resolved textual inconsistencies, the problem of how to spell daka persisted. During the medieval era, most Ashkenazic and

\footnotetext{
$30 \quad$ See B. Barry Levy, Fixing God's Torah: The Accuracy of the Hebrew Bible Text in Jewish Law (Oxford: Oxford University Press, 2001).

31 Ibid., 160-64. Including the letter would enable the verse to consist of one hundred letters.

$32 \quad \mathrm{EH} 4 \mathrm{~F} 8$, Peri Ets Hayim, fol. $163 \mathrm{r}$ (Hirsch, no. 66).

$33 \mathrm{EH} 4 \mathrm{~F}_{15}$, Peri Ets Hayim, fol. 116r (Hirsch, no. 278).
} 
Sephardic manuscripts had retained an alef, ${ }^{34}$ typified by the tenth-century Aleppo Codex and the eleventh-century Leningrad Codex. Sephardic luminaries, including Maimonides and David Kimhi, subsequently recorded an alef. .35 The propagation of Lonzano's Or Torah and Norzi's Minhat Shai in the early modern period, however, influenced many scribes to adopt a heh spelling. ${ }^{36}$ Communities, beginning in the Italian Peninsula and radiating outward, abandoned earlier traditions in favor of contemporary consensus. By the eighteenth century, the divergence had demarcated largely along ethniccultural-communal lines, with Sephardim usually ending daka with a heh and Ashkenazim commonly employing an alef.

In their respective writings from 1744 and 1761 , both Franco Mendes and Israel wrestled with the religious ramifications of this textual inconsistency. They concerned themselves with the permissibility of utilizing a scroll that ran contrary to their cultural norm. Had either been a scholar of Ashkenazic, Italian, Levantine, or North African origin, their juxtaposition would have gone no further than the general issue of what B. Barry Levy has called "fixing God's Torah." However, Franco Mendes and Israel lived simultaneously in the same community as part of the same educated elite. As descendants of conversos, Portuguese Jews had come to formulate their rabbinic tradition collectively and without direct connection to living practice. The unification of Amsterdam's Sephardic population in the 1630 s and the consolidation of power in the Mahamad ensured religious conformity and ritual homogeneity. As such, Franco Mendes and Israel did not and could not represent differing traditions or opinions within the community. Instead, Israel's pesak acted as an articulation of a deliberate cultural development.

A perusal of dozens of Torah scrolls owned by Amsterdam's Portuguese community reveals near uniform use of a heh in spelling daka. To be sure, the

34 See Mordechai Glatzer, "The Massora between East and West," [Hebrew] Pe'amim: Studies in Oriental Jewry 92 (2002): 168-69. On textual emendations in medieval Ashkenazic codices, see Yossi Peretz, "Darkhe Hagahat ha-Tekst ha-Mikra'e be-Kitve Yad Ashkenazim me-Yame ha-Benayim," Talele Orot 15 (2009): 19-34.

35 See Maimonides, Mishneh Torah, Sefer Ahavah, Hilkhot Sefer Torah 8:4, ed. Shabse Frankel (Jerusalem: Hotzaat Shabse Frankel Ltd., 2007) 2: 189; and David Kimhi, Sefer ha-Shorashim / Radicum Liber sive Hebraeum Bibliorum Lexicon (Berlin: Impensis G. Bethge, 1847), 71. Most printed editions of Maimonides' code do not record daka at all, though it does appear in Oxford, Ms. Huntingon 80. The disappearance of the word may reflect a decision by printers to avoid a discrepancy between Maimonides' text and popular practice.

36 See Jordan S. Penkower, Masorah and Text Criticism in the Early Modern Mediterranean: Moshe Ibn Zabara and Menahem De Lonzano (Jerusalem: Magnes Press, 2014); and Yosef Ofer, "Methods and Sources of Yedidya Shelomo Norzi in His Treatise Minhat Shay," Textus 24 (2009): 287-312. 


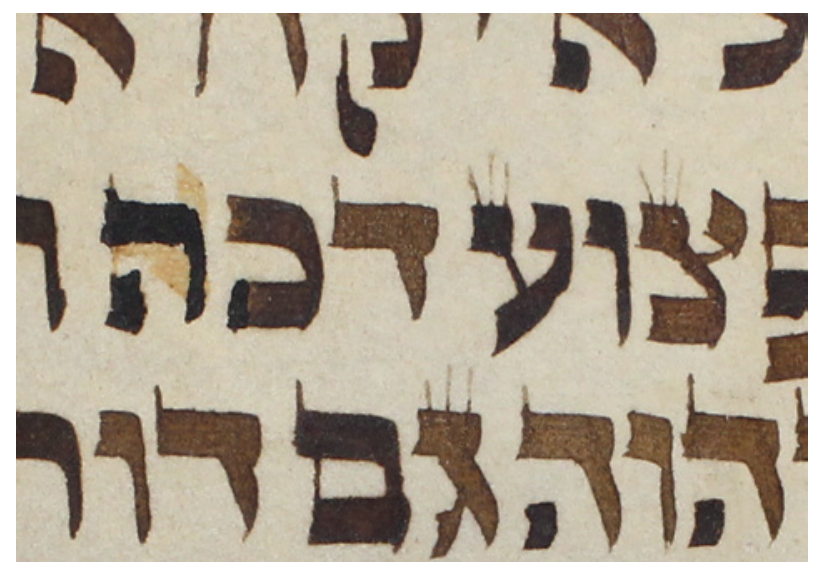

FIGURE 15.3 Ashkenazic script on klaf, produced in the seventeenth or eighteenth century, Portuguese Synagogue, Amsterdam, T45

seventeenth- and eighteenth-century scrolls consulted in this case study were not systematically written by the same scribe or according to the same specifications. The Mahamad and the Ets Haim yeshiva often employed scribes in the community to keep records in large bound codices, but they chose to acquire scrolls on an ad hoc basis rather than retain a regular scribe for ritual purposes. ${ }^{37}$ Both Sephardic and Ashkenazic scripts appear, and parchment varies from brown and pliable gevil to cream-colored and stiffened klaf. Textual layouts are also inconsistent, including the formats of notable passages such as the Song of the Sea, the Ten Commandments, and the Priestly Blessing.

Despite the disparate nature of the collection, three scrolls of different origins share a significant commonality: the word daka was originally penned with an alef before being changed to a heh in the eighteenth century. These Torah scrolls consist of: ${ }^{38}$ an Ashkenazic script on klaf written in the seventeenth or eighteenth century (Fig. 15.3);39 an eighteenth-century Sephardic script on klaf from Amsterdam or Hamburg (Fig. 15.4); ${ }^{40}$ and an eighteenthcentury Sephardic script on gevil (Fig. 15.5). ${ }^{41}$

37 Tirsah Levie Bernfeld has discovered references to men from Belgrade working, not very lucratively, as soferim in Amsterdam; see Tirtsah Levie Bernfeld, Poverty and Welfare among the Portuguese Jews in Early Modern Amsterdam (Oxford: Littman Library of Jewish Civilization, 2012), 36 .

38 Thanks to Jordan Penkower and Shlomo Zucker for confirming my assessment, and for providing more specific paleographic and codicological information.

39 Portuguese Synagogue, Amsterdam, $\mathrm{T}_{45}$.

40 Portuguese Synagogue, Amsterdam, T29.

41 Portuguese Synagogue, Amsterdam, T66. 


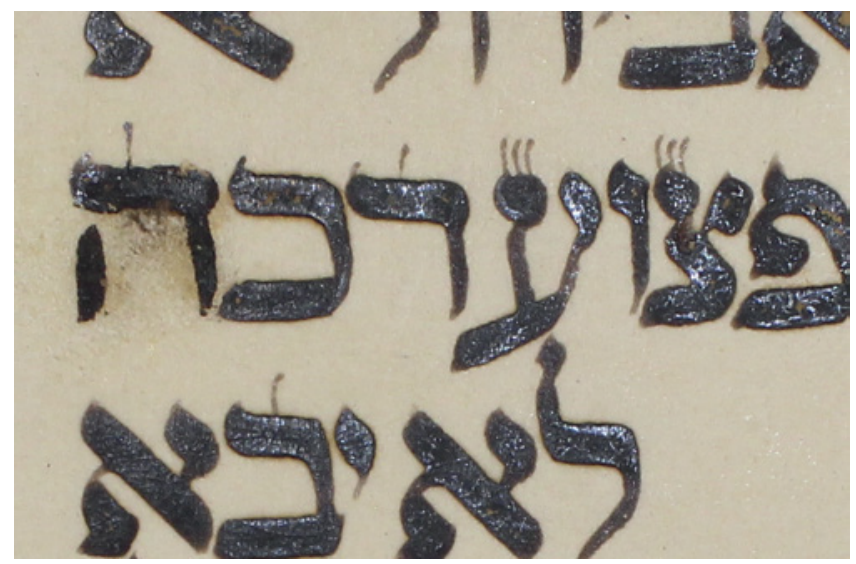

FIGURE 15.4 Sephardic script on klaf, probably produced in Amsterdam or Hamburg in the eighteenth century, Portuguese Synagogue, Amsterdam, T29

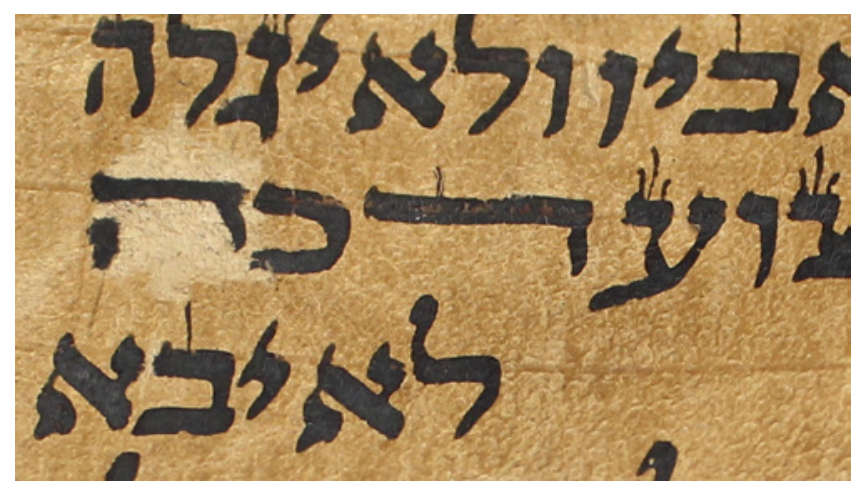

FIGURE 15.5 Sephardic script on gevil, produced in the eighteenth century, Portuguese Synagogue, Amsterdam, T66

In the first two, a faded alef is still visible under the heh, while the latter example shows the heh inscribed atop defaced parchment. The replacement letters appear contemporaneous with the original writing, indicating a calculated program to adopt the heh spelling.

Viewing the sources in tandem reveals that Franco Mendes's query echoed a medieval trend, Israel's pesak reflected modern developments, and the three corrected Torah scrolls (among others?) exemplified the transformation in custom. It is likely that Portuguese Jewry originally implemented the alef spelling based on the tradition of its first rabbi, Uriah Halevi (whose purported 
Torah scroll, still in the community's possession, displays daka with an alef), ${ }^{42}$ and early Sephardic authorities. Subsequent adoption of the heh spelling corresponded, not coincidentally, with the first printing of Norzi's Minhat Shai. Issued in Mantua in 1742, the influential work appeared just two years before Franco Mendes sent his letter to Luzzatto, while Abulafia's Masoret Seyag laTorah, a medieval work that similarly recorded daka with a heh, was published for the first time by a press in Florence in 1750. As I have shown elsewhere, Peri Ets Hayim coincided with an extensive program in the Ets Haim yeshiva to acquire texts from presses far and wide, integrating books from the Italian Peninsula and Central Europe within only a couple of years of printing. ${ }^{43}$ Advanced students in the Medras Grande immersed themselves in newly printed rabbinic texts, authored and edited their own, and pivoted their intellectual horizons toward Talmud, halakha, and cutting-edge rabbinics. In a Jewish culture of learning that regarded publication as supremely authoritative, ${ }^{44}$ Abulafia's and Norzi's shared contention that daka should be spelled with a heh took root and ultimately blossomed on the Portuguese tree of knowledge. That is, in a period of less than two decades, Amsterdam's Portuguese rabbinate absorbed the predominant Masoretic teachings then emanating from Hebrew print shops in Northern Italy, abandoned its earlier adopted custom in favor of contemporary norms, and publicized this development through the community's halakhic serial Peri Ets Hayim. 45

42 Portuguese Synagogue, Amsterdam, T57.

43 See Sclar, "Books in the Ets Haim Yeshiva," 220.

44 On the authority of print, see Fram, Ideals Face Reality, 6-7; and Elchanan Reiner, "Beyond the Realm of the Haskalah-Changing Learning Patterns in Jewish Traditional Society," Simon Dubnow Institute Yearbook 6 (2007): 123-133.

Although Peri Ets Hayim periodically included scholarship on Jews' most important ritual object, the sum amounted to less than one percent of the hundreds of halakhic essays produced during the mid-eighteenth century. Beyond the pesak discussed in this article, and the pesakim by Moses Gomez de Mesquita and Judah Piza mentioned above, Portuguese scholars addressed monetary values of Torah scrolls, as well as their importance to individuals, families, and community; see EH $4 \mathrm{~F} 9$, Peri Ets Hayim, fol. $257 \mathrm{r}$ (Hirsch, no. 94); EH 4 Fin, Peri Ets Hayim, fol. 133 r (Hirsch, no. 415); EH 4 F12, Peri Ets Hayim, fol. 8r (Hirsch, no. 419); $\mathrm{EH}_{4} \mathrm{Fr}_{3}$, Peri Ets Hayim, fol. 4or (Hirsch, no. 503). In addition, in 1768, Israel published a pesak on the writing of Torah scrolls and phylacteries (EH $4 \mathrm{~F} 12$, Peri Ets Hayim, fol. 258 r [Hirsch, no. 485]). 
When viewed on a historical continuum, Franco Mendes's letter and Israel's pesak reflect a larger cultural issue. Apprehension over a Torah scroll's textual validity for one ethnic group but not another indicated that divergent customs, previously in contention only on the pages of halakhic codes, had led to tangible perplexity. Franco Mendes's 1744 letter to Luzzatto, a kabbalist and poet not known for staking claims in halakha, suggests scholars in the Ets Haim yeshiva felt unable to render a decision. Without Luzzatto's response, we can only surmise that Franco Mendes believed that, as a native of Padua where congregations of Ashkenazic, Sephardic, and Italian rites coexisted in one ghetto, Luzzatto had encountered a precedent or could offer religious insight. Some seventeen years passed, during which co-chief rabbis David Israel Athias and Isaac Hayim Abendana de Britto died, before Israel addressed ramifications of ritualistic differences. Perhaps Israel felt compelled to do so by a recent objection to cross-ritual acceptance. Hayim Yosef David Azulai, the prolific legalist and kabbalist who visited Amsterdam in the 1750s, ruled in a book published posthumously that Sephardim called to the Torah in Ashkenazic synagogues should refrain from reciting a blessing. ${ }^{46}$ Neither Azulai nor Israel cited each other, so it is impossible to know whether they were in dialogue, or even whether Azulai levied such a ruling in response to something he observed in Amsterdam. Nevertheless, Israel's validation of joint Ashkenazic-Sephardic prayer services may have emerged from his awareness that rituals evolvedspecifically, that Portuguese Jewry had amended the spelling of daka in their Torah scrolls - and that rabbinic authority would not successfully stem the tide of cultural melding.

Despite Israel's conviction and facility, his pesak seems to have carried no weight beyond Western Sephardic culture. ${ }^{47}$ In the halakhic record, it appears that his essay proved irrelevant. It is not that subsequent authorities disputed or disregarded Israel's opinion; rather, his ruling simply failed to germinate through citations in other rabbinic writings. The reasons for this may have rested on the scarcity of the ephemeral journal format, with few copies surviving and no publisher choosing to reprint the pesakim of Peri Ets Hayim. Moreover, the authors were rarely well-known, and content persuasively argued did not often lead to significant reception without an established rabbinic name or

46 Hayim Yosef David Azulai, Le-David Emet (Livorno, 1820), 11:16.

47 According to Mordechai Glatzer, a Pentateuch published in Amsterdam in 1764 noted for the first time in print that Sephardim spelled daka with a heh and Ashkenazim employed an alef (Glatzer, "The Massora between East and West," 169). 
title behind it. In addition, although Amsterdam itself facilitated intellectual and religious collaboration during Israel's tenure, shifting cultural centers to Eastern Europe in the latter half of the eighteenth century left Portuguese rabbinic scholarship geographically and culturally isolated.

Still, Israel's pesak proved to be surprisingly prescient. Nineteenth- and twentieth-century halakhic works increasingly addressed ritual disparity, as Jews of diverse origins crossed paths in Europe, the Americas, and the State of Israel. In the latter half of the twentieth century, Hakham Ovadia Yosef, the most influential Sephardic halakhist in modern times, ruled that Ashkenazim and Sephardim could freely recite blessings over each other's Torah scrolls. ${ }^{48}$ This latter fact signals a need for further research into Western Sephardic halakha, and beckons questions about how socio-religious circumstances of eighteenth-century Amsterdam foreshadowed Jewish experiences in the modern period.

\section{Bibliography}

Amsterdam, Archive of the Portuguese-Jewish Community, 334.

Amsterdam, Bibliotheca Rosenthaliana, Special Collections of the University of Amsterdam, HS Ros. 579 .

Amsterdam, Ets Haim/Montezinos Livraria (Ets Haim Library), 47B3.

Amsterdam, Portuguese Synagogue, T29, T45, T57, T66.

Azulai, Hayim Yosef David. Le-David Emet (Livorno, 1820).

Berkovitz, Jay R. "The Persona of a Poseq: Law and Self-Fashioning in SeventeenthCentury Ashkenaz." Modern Judaism 32, no. 3 (2012): 251-69.

Bodian, Miriam. The Hebrews of the Portuguese Nation: Conversos and Community in Early Modern Amsterdam. Bloomington: Indiana University Press, 1997.

Bonfil, Robert. Rabbis and Jewish Communities in Renaissance Italy. Translated by Jonathan Chipman. Oxford: Littman Library of Jewish Civilization, 1990.

Carlebach, Elisheva. Pursuit of Heresy: Rabbi Moses Hagiz and the Sabbatian Controversies. New York: Columbia University Press, 1990.

Fram, Edward. Ideals Face Reality: Jewish Law and Life in Poland 1550-1655. Cincinnati: Hebrew Union College Press, 1997.

Glatzer, Mordechai. "The Massora between East and West." [Hebrew] Pe'amim: Studies in Oriental Jewry 92 (2002): 167-74.

48 Ovadia Yosef, Yehaveh Da'at 2:3.19; and Yabia Omer 8, Yoreh De'ah 25. Although Yosef's halakhic writings may be best defined by their encyclopedic nature, even he did not cite Israel's pesak. 
Glick, Shmuel, ed. Seride Teshuvot of the Ottoman Empire Sages from the Cairo Genizah Collection of the Cambridge University Library. [Hebrew] Jerusalem: The Schocken Institute for Jewish Research of the Jewish Theological Seminary of America, 2013.

Goldish, Matt. Jewish Questions: Responsa on Sephardic Life in the Early Modern Period. Princeton, NJ: Princeton University Press, 2008.

Goldish, Matt. "Rabbi Jacob Sasportas: Defender of Tradition in an Age of Change." Unpublished master's thesis. Hebrew University of Jerusalem, 1990.

Hirsch, Menko Max. Frucht vom Baum des Lebens, Ozer peroth Ez Chajim. BerlinAntwerp: [Soncino-Gesellschaft der Freunde des Jüdischen Buches], 1936.

Israel, Moses. Peri Ets Hayim, (Amsterdam: Proops, 1761), EH 4F11, fols. 117r-119v.

Kahana, Maoz. "An Esoteric Path to Modernity: Rabbi Jacob Emden's Alchemical Quest." Journal of Modern Jewish Studies 12, no. 2 (2013): 253-75.

Kaplan, Yosef. An Alternative Path to Modernity: The Sephardi Diaspora in Western Europe. Leiden: Brill, 2000.

Katz, Jacob. The "Shabbes Goy": A Study in Halakhic Flexibility. Translated by Yoel Lerner. Philadelphia: Jewish Publication Society, 1989.

Katzenellenbogen, Ezekiel. Keneset Yehezkel (Altona, 1732).

Lehmann, Matthias B. Emissaries from the Holy Land: The Sephardic Diaspora and the Practice of Pan-Judaism in the Eighteenth Century. Stanford: Stanford University Press, 2014.

Levie Bernfeld, Tirtsah. Poverty and Welfare among the Portuguese Jews in Early Modern Amsterdam. Oxford: Littman Library of Jewish Civilization, 2012.

Levy, B. Barry. Fixing God's Torah: The Accuracy of the Hebrew Bible Text in Jewish Law. Oxford: Oxford University Press, 2001.

Michman, Jozeph. "Between Sephardim and Ashkenazim in Amsterdam." [Hebrew] In The Sephardi and Oriental Jewish Heritage. Edited by Issachar Ben-Ami, 135-49. Jerusalem: Magnes Press, 1982.

Ofer, Yosef. "Methods and Sources of Yedidya Shelomo Norzi in His Treatise Minhat Shay." Textus 24 (2009): 287-312.

Penkower, Jordan S. Masorah and Text Criticism in the Early Modern Mediterranean: Moshe Ibn Zabara and Menahem De Lonzano. Jerusalem: Magnes Press, 2014.

Peretz, Yossi. "Darkhe Hagahat ha-Tekst ha-Mikra'e be-Kitve Yad Ashkenazim me-Yame ha-Benayim." Talele Orot 15 (2009): 19-34.

Reiner, Elchanan. "Beyond the Realm of the Haskalah—Changing Learning Patterns in Jewish Traditional Society." Simon Dubnow Institute Yearbook 6 (2007):123-33.

Sclar, David. "Adaptation and Acceptance: Moses Hayim Luzzatto's Sojourn in Amsterdam among Portuguese Jews." Association for Jewish Studies Review 40, no. 2 (November 2016): 335-358.

Sclar, David. "Blending Tradition and Modernity: The Growth of the Ets Haim Library in the 18th Century." In Tradition \& Modernity in Ets Haim. Edited by David Wertheim, 
19-33, 38-39. Amsterdam: Menasseh Ben Israel Institute and the University of Amsterdam, 2017.

Sclar, David. "Books in the Ets Haim Yeshiva: Acquisition, Publishing, and a Community of Scholarship in Eighteenth-Century Amsterdam." Jewish History 30, no. 3 (2016): 207-32.

Soloveitchik, Haym. The Use of Responsa as an Historical Source: A Methodological Introduction. [Hebrew] Jerusalem: Zalman Shazar Center and Hebrew University of Jerusalem, 1990.

Swetschinski, Daniel. Reluctant Cosmopolitans: The Portuguese Jews of SeventeenthCentury Amsterdam. London: Littman Library of Jewish Civilization, 2000.

Zwiep, Irene E. "An Echo of Lofty Mountains: David Franco Mendes, a European Intellectual." Studia Rosenthaliana 3, no. 2 (2001): 285-96. 


\title{
Hakham Yaakov Athias-A Portuguese Rabbi Facing the Winds of Enlightenment and Secularization
}

\author{
Yocheved Beeri
}

The Jewish community of Bordeaux, like the other Sephardic communities in the southwest of France, emerged from groups of New Christians, decedents of Jewish converts who left Spain and Portugal from the sixteenth century onward and settled in France as Portuguese merchants. ${ }^{1}$ As such, they received certain legal rights in various royal Lettres Patentes along the centuries and were recognized as a "Nation" of merchants. ${ }^{2}$ In the Lettres Patentes of 1722 they were recognized as Jews for the first time. This gradual transition from a kind of clandestine Judaism to established communities acknowledged by the Jewish world reached its completion by the last quarter of the seventeenth century. ${ }^{3}$

In the beginning of the eighteenth century Bordeaux boasted an organized and vibrant Jewish community. It was led by a council of elders, or Assembly of the Nation, which represented the richest and most influential families.

1 On the Bordeaux community, see Louis Francia-Beaufleury, Histoire de l'établissement des Juifs à Bordeaux et à Bayonne depuis 1550 (Paris, an 8 [180o]); Arnaud Detcheverry, Histoire des Israélites de Bordeaux (Bordeaux: Balarac jeune, 1850); Théophile Malvezin, Histoire des Juifs à Bordeaux (Bordeaux: Charles Lefebvre, Libraire, 1875); Georges Cirot, Recherches sur les Juifs espagnols et portugais à Bordeaux (Bordeaux: Feret \& Fils, Éditeurs, 1908); Cirot, Les Juifs de Bordeaux. Leur situation morale et sociale de 1550 à la Révolution (Bordeaux: Feret, 1920); Gérard Nahon, Juifs et judaïsme à Bordeaux (Bordeaux: Mollat, 2003).

2 On the legal status of the New Christians in France, see Peter Sahlins, Unnaturally French: Foreign Citizens in the Old Regime and After (Ithaca: Cornell University Press, 2004), 51-52, $163^{-64 .}$

3 Gérard Nahon, "From New Christians to the Portuguese Jewish Nation in France," in Moreshet Sepharad, ed. Haim Beinart (Jerusalem: Magnes Press, 1992), 2: 336-43; Nahon, Métropoles et périphéries Séfarades d'occident (Paris: Cerf, 1993), 235-38; Frances Malino, The Sephardic Jews of Bordeaux (Tuscaloosa: University of Alabama Press, 1978), 3. On the religious identity of the conversos and how it changed with the migration from the Iberian Peninsula see David L. Graizbord, Souls in Dispute: Converso Identities in Iberia and the Jewish Diaspora, 1580-17oo (Philadelphia: University of Pennsylvania Press, 2004).

(C) YOCHEVED BEERI, 2019 | DOI:10.1163/9789004392489_017

This is an open access chapter distributed under the terms of the prevailing CC-BY-NC License at the time of publication. 
The council met a few times a year and decided on the long-term matters of the community such as securing the renewed approval of the royal privileges, helping the poor, managing the cemetery, and collecting the communal taxes. Once a year it appointed a syndic and two assistants-a gabbay and parnassim — who dealt with the daily affairs. ${ }^{4}$

The community possessed a Jewish cemetery and a ritual bath (mikveh) with a paid attendant. There was a butcher shop that supplied the kosher meat, and several ritual slaughterers, approved or nominated by the community, performed the ritual slaughter of the animals. The community also managed the baking of the matsa, the unleavened bread eaten during Passover, and supplied and subsidized a mostly religious education to its children by an appointed teacher, or later, in a Talmud Torah, a religious school. ${ }^{5}$

The religious life in Bordeaux, apart from the services provided by the leadership and the above-mentioned institutions, emanated as well, or even more, from the public itself. According to an official report by Monsieur Pudeffer from 1733, there were six Portuguese synagogues located in private residences in Bordeaux, each one with its own leadership. Monsieur Pudeffer also related some religious practices of the Jews in Bordeaux:

[On Saturday, the Jews], their leaders, wives, children and servants go regularly to pray in their synagogues. [...] On these days their shops are closed as on Sundays and they refrain from any commerce. All their leaders, their wives, children etc. carry publicly in their hands when they go to the synagogue their prayer books, their white mantles and other adornments required by their religion. Sometimes they go barefoot, with the back of their shoes folded like slippers and knock-kneed, or with their hat-sides dropped down upon their eyes. [...] Their principal Holidays take place in September for the cabins, in March for their Easter, and during forty days they pray from midnight till daybreak. ${ }^{6}$

This last item refers evidently to the Selihot (penitential prayers recited in the period before the High Holidays) according to the Sephardic custom.

Various voluntary societies, or fraternities, were established in the community of Bordeaux. These fraternities, also called "yeshivot," played a central role

4 Simon Schwarzfuchs, Introduction to Registre des deliberations de la Nation juive Portugaise de Bordeaux 1710-1787 (Paris: Fundação Calouste Gulbenkian, Centro Cultural Português, 1981), 9-24; Nahon, "From New Christians to the Portuguese Jewish Nation in France," $348-52$.

5 Schwarzfuchs, Registre, 30.

6 Archives Départementales de la Gironde, C 1090, and Schwarzfuchs, Registre, 600-1. 
in the religious life of the Nation. They served as social associations that took care of the daily religious needs of their members, attended to the poor, or provided for burials and the mourners' necessities. Some researchers suggest that the community's establishment evolved from a society for the support of the poor, the Sedaka. Several fraternities maintained their own synagogues, and probably formed groups to study Torah as well, hence the name "yeshiva." The most important society was the Hevra, an abbreviation for Hevra Kadisha, the burial society. Other societies were the Yeshiva Le-Gmilut Hasadim, Yeshiva Le-Bikur Holim, Tiferet Bahurim, Yeshivat Mishenet Holim, and Tiferet Shalom. ${ }^{7}$

\section{$2 \quad$ Transgressions}

In spite of this lively Jewish religious life, the community of Bordeaux was criticized internally and externally for its religious laxity and frequent transgression of the commandments by some of its members. The community register, which is a collection of the resolutions of the assembly of elders, mentions from 1733 to $175^{1}$ a few members who were punished by the community for leading a disreputable life, for speaking against the Jewish religion and its commandments, and for breaking the Sabbath and holidays. ${ }^{8}$ Hertzberg suggested that the absence of further decisions of punishments for these offences demonstrates the diminishing interest of the community in punishing the offenders rather than their diminishing numbers. ${ }^{9}$

Doubts about the integrity of the Bordeaux community and its full commitment to the Jewish religious laws emerge over the course of the eighteenth century. Recurring conflicts arose between the Jewish communities of Hamburg and Altona and the community of Bordeaux over the supervision and certification of the latter's wine production in 1719, 1737, and again in the early fifties. Bordeaux was understandably an important producer and supplier of kosher wine for a range of Jewish communities throughout Europe. The wine importers of Hamburg placed a supervisor on their behalf in Bordeaux whose mission was to oversee the kosher wine production. Accordingly, they refused to pay

7 Schwarzfuchs, Registre, 29, 113-18, 197-98, 243-46; Nahon, Métropoles et périphéries Séfarades d'occident, 315 .

8 Schwarzfuchs, Registre, 133, 137, 188-90, 213-14, 225.

9 Arthur Hertzberg, The French Enlightenment and the Jews: The Origins of Modern AntiSemitism (New York: Schocken Books, 1968), 160-61. 
the tax to the Bordeaux community for the kosher certification of the wine. ${ }^{10}$ In spite of the obvious economic interests involved in this conflict, it attests also to the suspicions of the Hamburg community regarding the Bordeaux community's strict adherence to halakha.

Another subject of reproach was the women's observance of ritual immersion, an essential part of the family purity laws. In 1728, probably following the visit to Bordeaux of an emissary from the Holy Land, the hakhamim of Safed sent a letter to the gabbay and parnassim of Bordeaux accusing the community's women of neglecting their observance and demanding from the leadership to inquire after those who do not bathe in a mikve according to the rules of purity. This letter initiated an interesting exchange between the hakhamim of Safed, the Mahamad of the Amsterdam community, and the leadership of the community of Bordeaux regarding the ritual bathing of women in Bordeaux. This correspondence has been extensively analyzed by Evelyne Oliel-Grausz. ${ }^{11}$

An allegation about the negligence of ritual bathing appears also in the personal account of Rabbi Haim Yosef Azulay, also known as Hida, regarding his visit to Bordeaux in 1777. Hida, an emissary of Hebron to Europe who visited Bordeaux twice on his journeys, didn't rely on the Bordeaux community's ritual slaughter and didn't eat their meat, despite his examination of the slaughterers on his 1755 visit and his disqualifying of some and approving of others. He didn't even eat dairy or fish at the Portuguese community's communal table. ${ }^{12}$ In 1777 , Hida also accused some members of the community of breaking the Sabbath and of eating forbidden foods in public. ${ }^{13}$

10 On the production of kosher wine and its distribution to the communities of the Sephardic diaspora, see Nahon, "From New Christians to the Portuguese Jewish Nation in France," 344; Nahon, Métropoles et périphéries Séfarades d'occident, 141-42; Evelyne Oliel-Grausz, "Relations et réseaux intercommunautaires dans la diaspora séfarade d'occident au XVIII ${ }^{\mathrm{e}}$ siècle," PhD diss., University of Paris, 1999, 384-90; Malvezin, Histoire des juifs a Bordeaux, 201-6. On the conflicts regarding Kosher wine certification, see Schwarzfuchs, Registre, 96-99, 144-46; Stadsarchief Amsterdam [hereafter SAA] 334/5.1.1.90, Copiador de cartas 1702-1719, 158; Archives Départementales de la Gironde, C 1089, nn. 44, 45, 46, $57,58,59,62,64,65,67,72,74,75$.

11 Schwarzfuchs, Registre, 113-14; SAA 334/5.1.1.107, Borador de cartas 1719-1728, fols. 87-90; Oliel-Grausz, "Relations et reseaux," 507-12; idem, "La diaspora séfarade au XVIII" siècle: communication, espaces, réseaux," Arquivos do Centro Cultural Calouste Gulbenkian 48 (2004): $57-58$.

12 Schwarzfuchs, Registre, 270-71; Haim Yosef David Azulai, Ma'agal Tov ha-Shalem, ed. Aharon Freiman (Jerusalem: Merkaz ha-Sefer, 1983), 35-36. On Hida's visits to Bordeaux, see Nahon, Métropoles et périphéries Séfarades d'occident, 381-84; Matthias B. Lehmann, Emissaries from the Holy Land: The Sephardic Diaspora and the Practice of Pan-Judaism in the Eighteenth Century (Stanford: Stanford University Press, 2014), 73-76. 
The community of Bordeaux acted not only against the transgressions of the commandments but also against intellectual endeavors it considered to be in contradiction with Jewish dogma, learning, and tradition. Such was the punishment of Moize de Paz Dias in 1735, for "being stubborn and obstinate against the law of the Torah."14

The Bordeaux community, as a community of ex-Marranos, characteristically included a substantial number of free thinkers and skeptics. ${ }^{15}$ Unfortunately, our sources do not supply us with sufficient evidence to reconstruct the intellectual reasoning or the critical arguments of these early dissidents. Nevertheless, it is reasonable to assume that the general atmosphere among the elite circles of French society provided them with a rich treasure of critical thought. ${ }^{16}$

As part of the philosophers' attempts to study the various forms of government, social structures, and different social groups composing society and to explore ideas toward social reforms, they discussed the Jewish question. They delved into the stature and morality of the Jewish religion, the characteristics of the Jews, their social status, civil rights, importance in the economy, and the possibility of educating and integrating them as equal citizens in the state. ${ }^{17}$

In Isaac de Pinto's debate with Voltaire regarding the Jews, he argued that the Sephardic Jews were different from the other Jews and did not share their failings (although he defended them all the same). ${ }^{18}$ There was some truth to his allegation, since the characteristics of the Sephardic communities in the eighteenth century were quite different from those of the Ashkenazic communities in this period. Therefore, the new philosophical ideas and the development of the Jewish Enlightenment, the Haskala, influenced them differently. While the Jewish Enlightenment in the Ashkenazic communities of the Habsburg Empire and Prussia manifested itself mainly in a thirst for nonrabbinical knowledge and a demand for reform in the traditional Jewish education and communal hierarchy, ${ }^{19}$ the Sephardic educational tradition did not

\footnotetext{
14 Schwarzfuchs, Registre, 137.

15 On the characteristics of the Sephardi diaspora communities and the challenges they faced, see Yosef Kaplan, From New Christians to New Jews (Jerusalem: The Zalman Shazar Center, 2003).

16 Hertzberg, The French Enlightenment and the Jews, 29-48.

17 Ibid., 268-313.

18 Ibid., 181.

19 Shmuel Feiner, The Jewish Enlightenment (Philadelphia: University of Pennsylvania Press, 2004); David Sorkin, The Transformation of German Jewry, 1780-1840 (New York: Oxford University Press, 1987); Jay R. Berkovitz, Rites and Passages: The Beginnings of Modern
} 
view the pursuit of "external sciences" as being in opposition to the study of the Torah, since the Jewish tradition encompassed all knowledge. ${ }^{20}$ This attitude is exemplified in the person of Jacob Rodrigues Pereire, the representative of the Bordeaux community in Paris who was a practicing Jew and, at the same time, a scientist who initiated the education of deaf-mute children. ${ }^{21}$ Nevertheless, the Enlightenment had its influence on the Sephardic communities, and we shall explore here its manifestation and impact on the Bordeaux community in particular.

As the eighteenth century progressed, the winds of enlightenment and secularization that were blowing in Western Europe manifested themselves ever more clearly in the communities of southwestern France. In the course of Hida's visit in 1755 to the Sephardic community of Bayonne, the leaders showed him a fossil that had been sent from Spain to the Academy in Paris and was later exhibited in different cities. They explained to him that it was a tree that became a stone. In response, he remonstrated them for believing in the wisdom of the Gentiles and not in the Jewish wisdom, pointing out to them that the Talmud knew already of such transformations. ${ }^{22}$ The account of his 1777 visit in Bayonne mentions a señor Julian, one of the leaders of the community, who insinuated that all the Scriptures were a lie. He also mentioned some dignitaries who asked philosophical questions on souls and reward and punishment. ${ }^{23}$

In the account of his visit to Bordeaux, Hida criticized some of its dignitaries such as Shlomo López, the gabbay, and Avraham Gradis for not believing in the Sages, probably influenced by Spinoza's writings. He accused them of further transgressions of the rules of ritual purification and of eating forbidden foods in public, together with Yaakov Isidro, the evildoer, and his heretic sons who used to overtly break the Sabbath. He also mentioned other Sephardic

Jewish Culture in France, 1650-186o (Philadelphia: University of Pennsylvania Press, 2004), $35^{-} 5^{8}$.

20 Francesca Bregoli, Mediterranean Enlightenment: Livornese Jews, Tuscan Culture and Eighteenth-Century Reform (Stanford: Stanford University Press, 2014), 7.

21 On Jacob Rodrigues Pereire, see Renée Neher-Bernheim, "Jacob Rodrigue Pereire," Proceedings of the Seventh World Congress of Jewish Studies, History of the Jews in Europe (Jerusalem: World Union of Jewish Studies, 1977), 57-66; Neher-Bernheim, "Un savant juif engagé: Jacob Rodrigue Pereire (c. 1715-1780)," REJ 142 (1983): 313-451; Evelyne OlielGrausz, "Droit et espace Séfarade: Jacob Rodrigues Pereire et l'extension des privilèges. Du royaume à la Nation," Archives Juives 37, no. 1 (2004): 28-46.

22 Azulai, Ma'agal Tov ha-Shalem, 37.

23 Ibid., 110-13. 
dignitaries who debated with him on philosophy and expressed opinions bordering on heretical thought. ${ }^{24}$

Hida was also deeply disapproving of the Talmud Torah's curriculum for including only the Hebrew Scripture without any rabbinical exegesis, not even Rashi, leading him to claim that they didn't even teach Maimonides. Although in the same account Hida reported seeing the reading of the Bible and a chapter of Maimonides on the Sabbath in the Talmud Torah, his allegations were not altogether unfounded. ${ }^{25}$ As evident from the 1761 statutes of the Talmud Torah, the main subjects were learning to read Hebrew, translating the weekly Torah reading, Prophets, and Psalms from Hebrew to Spanish, as well as studying all the prayers of the year. ${ }^{26}$

The 1774 supplement to the statutes of the Talmud Torah states the curriculum for a future third class would be to comprehend the Hebrew grammar, and "the knowledge of our best commentaries, meaning of those who are the best grammarians, and are the most attached to the literal meaning of the text, which is the only way to understand the real duties that God prescribed us." ${ }^{27}$

These statutes and their supplements reflect the influence of the philosophical ideas of the Enlightenment, for instance the importance attached to understanding the literal meaning of the biblical text. In this context, it is relevant to mention the emphasis given to the cleanliness of the classrooms and the health of the students. But all this remains inside the sphere of traditional Sephardic spiritual culture. The statutes do not represent a radically new approach to Jewish education and to biblical studies, as opposed to the treatise on Jewish education by Hartwig Wessely published in Berlin in $1782 .{ }^{28}$

By the seventies, it appears that the concepts of reason and scientific logic expanded from the domain of a few free thinkers to the conventional way of thinking in the community of Bordeaux. The declaration of Isaac Rodriguez fils upon his appointment in 1772 as the new syndic of the Nation illustrates this influence. He reprehended the moral corruption due to the ignorance of their duties to the Creator prevalent mainly among the lower strata of the Jews, but was rapidly progressing. In order to repress this tendency, he advocated "a consistent education that will instill in our youth religious sentiments and morals appropriate to attract one day the good will of the nations or at least

\footnotetext{
24 Ibid., 114-15.

25 Ibid., 114.

26 Schwarzfuchs, Registre, 297-302.

27 Ibid., 443-51.

28 Feiner, The Jewish Enlightenment, 97-104.
} 
spare us their mockery. That will make them acknowledge their duties to God and to themselves." 29

However, the ideas of enlightenment did not obliterate the Jewish customs and way of life of the community of Bordeaux. Its leaders tried, out of sympathy toward the new ideas, to reconcile them with Jewish precepts and thought. As we shall see, in case of conflict, they preferred reason to tradition. This can be seen in a decision of the council of Elders to refer a divorce case to the consideration of the beit din, while declaring that "they will receive the opinion of the rabbinical court, and then the Nation will decide [on the matter] according to reason."30

This is even clearer in the council's decision in a case of bigamy presented to them. Because of the urgency of the case, they did not even refer it to the rabbinical court as ordinary, but decided on their own to annul the wedding. They justified their decision in these terms: "If it seems that the Torah does not forbid polygamy, the Nation could flatter itself, there has never been in its midst an example so destructive. And if the Easterners sometimes do it, the Nation still sees it as contrary to morality, public order, and the conjugal trust."31

The enlightenment influence can be found even in the words of Rabbi David Athias, Hakham Yaakov Athias's son, when he tried in 1768 to persuade a reluctant brother-in-law (a yavam $^{32}$ ) to release his widowed sister-in-law of her "aginut": 33 he "did his best with the voice of reason and the power of the Torah."34

At the close of the century David Gradis, one of the most influential leaders of the community, published a philosophical treatise in which he opposed the

\footnotetext{
29 Schwarzfuchs, Registre, 411-15.

$30 \quad$ Ibid., 549 .

31 Ibid., 508.

32 The Torah stipulates that in the case of a woman becoming a widow where she and her late husband have no offspring, one of her brothers-in-law must marry her to provide an offspring to his deceased brother. A brother-in-law in such circumstances is called a "yavam." He may fulfill his obligation, or perform the ceremony of "halitsa," in which the widow unties his sandal and spits in front of him (as described in the Torah as expressing her contempt for his refusal to provide her late husband with an offspring), and she is then free to marry someone else. Until then, the "yevama" is forbidden to remarry.

33 According to Jewish law, an "aguna" is a separated woman who is not permitted to remarry, because her husband is not proven dead, or because her husband refuses to deliver her a "get" (a divorce act and document) or has disappeared, putting her in a situation (aginut) where she is still bound by her married status and is unable to legally end her marriage. This situation being tragic, many ways are being explored by rabbinical judges in each case to end this status and allowing the woman to remarry.

Ibid., $382-83$.
} 
Sages' interpretations of the Bible and proposed to rescue the Scriptures from the Talmudists. ${ }^{35}$

During the first phases of this cultural evolution and these religiously challenging times, the community of Bordeaux was led by Hakham Yaakov Athias who had been appointed as the community's rabbi at the death of his predecessor, Hakham Yosef Falcon, in 1738. He served the Bordeaux community until his death in 1760 . The nomination of the son and heir of a Portuguese family of rabbis established at Bidache to officiate as the rabbi of Bordeaux was a significant milestone in the process of building the Bordeaux community. It marked its transition from a group of New Christians who were clandestinely performing Jewish ceremonies to an established Jewish community recognized by the Jewish world. The nomination of a local rabbi proved its ability to lead its own religious life, no longer obliged to import a rabbi from outside, as was Hakham Falcon, who came from Jerusalem.

Hakham Yaakov Athias devoted considerable efforts during his tenure to fighting the transgressions of religious commandments by some members of the community and their contempt for the Torah. His term of office is replete with conflicts between himself and the leadership of the community, as we can see from various resolutions recorded in the register, conflicts which reached their peak with his suspension from office.

According to Nahon, Yaakov Athias originated from the Athias family of Bidache, a little town near Bayonne, which provided circumcisers, cantors, and rabbis to surrounding communities. ${ }^{36} \mathrm{He}$ arrived in Bordeaux in 1725 when he was about forty-five years old. He began his public service as a cantor and in 1732, he was appointed as the teacher of the community school. ${ }^{37} \mathrm{His}$ public role must have been important since already in the 1733 report of Monsieur Pudeffer, he is mentioned along with Hakham Falcon as one of the rabbis of the community. ${ }^{38}$ His signature appears with that of Hakham Falcon on several decisions of the council of Elders as well as on the regulation of the Nation in 1736.39

35 Hertzberg, The French Enlightenment and the Jews, 157-160.

36 Gérard Nahon, "Le registre espagnol des circoncisions de Samuel Gomes Atias (Bidache, 1725-1773)," Bulletin Hispanique 76 (1974): 150.

37 Schwarzfuchs, Registre, 128.

38 Archives Départementales de la Gironde, C 1089, n. 43; Schwarzfuchs, Registre, 6oo-1.

39 Schwarzfuchs, Registre, 126, 137, 138-42. 
Upon the death of Hakham Falcon in 1738, Hakham Athias was appointed as hakham of the community. However, his appointment specified certain conditions that defined and limited his authority, such as a prohibition to impose any sort of punishment or to publish anything against any member of the Nation without the approval of the secular leadership. ${ }^{40}$

Hakham Yaakov Athias assumed the responsibility of supervising the manufacturing of the kosher wine and the baking of the matsot for Passover. He decided on the halakhic aspect of the cases of clandestine weddings in order to annul them, and tested and appointed ritual slaughterers. In most of these functions, he clashed with the council of elders in what seems to have been a struggle about his position in the community's hierarchy. Nevertheless, the epitaph on the stately gravestone of Hakham Yaakov Haim Athias in the cemetery of Bordeaux acknowledges his contribution, praising him for teaching the hakhamim, deepening the knowledge of the commandments of God in the people and lighting the fire of the Torah in their hearts. ${ }^{41}$

\section{5}

\section{Correspondence}

As part of Hakham Athias's tactics or even his strategy to ameliorate his position in the community's leadership and to influence his parishioners in the face of religious challenges, he turned for help to external factors. In a letter to the Intendant of Bordeaux, head of the local royal administration that can convincingly be attributed to Hakham Athias, the Hakham asks the Intendant to "rebuke the head of the Portuguese Nation, on the scarcity of honor and importance in which they hold their rabbi."42 Hakham Athias also corresponded with the hakhamim and the Mahamad of the community of Amsterdam. He begged for their support and wished them to back his efforts in preserving the adherence of his flock to a normative Jewish life on the one hand, and in fighting the dissenters on the other, asking them to admonish his parishioners on the gravity of their actions. Of this correspondence, only the letters of reply from Amsterdam, copied in the "copiador de cartas" of the Talmud Torah Congregation in Amsterdam reached us. These responses testify to the painful and passionate appeals of Hakham Athias for their help.

As expected from the very nature of reply letters, it is often difficult to clearly understand the issue the original letter dealt with. A reply letter signed by the

40 Ibid., 149-50.

41 Cirot, Recherches sur les Juifs espagnols et portugais à Bordeaux, 133.

42 Archives départementales de la Gironde, C 1090, n. 123. 
hakhamim and parnassim of the community of Amsterdam to Hakham Athias from December 1746, reflects the emotional and painful character of Hakham Athias's letter and the problems he was facing: "The contents of the letter your honor wrote us moved us so much that we didn't know what to think. The subject on which his honor with such sad reasons wrote us, excited our souls with the proper tenderness in order to act with his honor to our best ability, to help him in his worthy objective to face effectively the despicable abuses of the observance of the Divine commandments practiced in this community, which he describes so painfully and for which he implores our help."43

They suggest to write to the parnassim and leaders of the community of Bordeaux to induce them to support the Hakham in his goal to find a suitable means to remove the evil, and encourage him that "Since your honor, as an experienced shepherd, knows the individual characters of the transgressors, he will be able to find, with the concurrence of the gentlemen of the Mahamad, the right approach to convince each of them to leave his evil and erroneous way, and wish to return to the Divine grace." ${ }^{44}$

Indeed, on the same day, the hakhamim and parnassim of Amsterdam wrote a more elaborate letter to the parnassim and gabbay of the community of Bordeaux, declaring "the transgressions of our religion, the Divine precepts and their fences instituted by our sages committed by their flock, are famous and notorious." 45

They admonish them about the fact that under their leadership, very serious offenses were committed, including the marriage of a mamzer, ${ }^{46}$ against the ruling of Hakham Athias. They warn them that members of the community, from material reasons, will try to harm the observance of the major religious commandments: observance of the Sabbath, the purity of women, and kosher foods, whose objective is to separate the exiled Jewish people from the surrounding nations. They recommend to appeal to sinners with love and care and to try to persuade them to leave their evil way, while those who refuse should be alienated from the community, "because he who is a Jew only in name, is no Jew." The parnassim should avoid "dealing patiently with such severe and sinful issues." They stress the mutual responsibility of the Jewish

\footnotetext{
43 SAA 334/ 5.1.1.92, Copiador de cartas 1744-1750, pp. 148-49.

44 Ibid.

45 SAA 334/ 5.1.1.92, Copiador de cartas 1744-1750, 29 Kislev 5507, pp. 149-50, and in OlielGrausz, "Relations et réseaux," 504-5.

46 According to Jewish law, mamzer is a Jewish person who was born from a union severely prohibited, such as adultery (a married woman with another man), or incest. Although translated as "bastard," mamzer differs in its legal definition and does not cover the same cases.
} 
people, since the sinners affect the whole people by bringing the wrath of God upon it, while keeping the Torah will ensure God's blessing and his goodness.

The parnassim and gabbay of Bordeaux replied to this letter by rejecting the claims of the hakhamim and the Mahamad of Amsterdam, and indirectly Hakham Athias's claims, and describing the good order prevailing in the community and their observance of the commandments. Nevertheless, the Mahamad of Amsterdam recommended that they heed their reproaches, admonitions that were based on Hakham Athias's depiction of the situation. ${ }^{47}$

The appeal of Hakham Athias to the hakhamim of Amsterdam and their response apparently affected the leadership of the community of Bordeaux. Two years later, in September 1748, we find in the community register the record of a deliberation regarding a certain "Joseph Rodrigues Pereira, advocate, and his son, and Raphael Dacosta, who speak incessantly with intolerable indiscretion against the most sacred dogmas of the religion, and consequently act in a scandalous manner and transgress the Sabbath and our holy days." ${ }^{38}$ The council of elders decided to warn them but since they refused to attend the meeting and continued with their bad behavior in public, they were summoned again to a meeting. They were fined and ordered to come on the Eve of Kippur to a certain place in order to ask for forgiveness from God, and to promise to renounce their sins. As again they didn't comply, the council banned them from the community and forbade the members to have any communication with them. Three days later, the dissenters renounced their opinions, asked for forgiveness from God and the people, and paid the fines to charity, upon which, Hakham Athias, with two other persons, removed the ban. ${ }^{49}$ In $175^{1}$ the council also punished Monsieur Pesoua for transgressing Passover. ${ }^{50}$ Nevertheless, in 1754 Hakham Athias wrote again to Amsterdam and presented "the sad situation of some members of the community who compromise on such essential points of our sacred law [...] especially since they don't adhere to his warnings." ${ }^{51}$

In July 1755 after receiving another letter from Hakham Athias, the parnassim of Amsterdam wrote to their counterparts in Bordeaux and implored them to listen to the good doctrine of Hakham Athias and support his actions, and to punish the transgressors of the sacred law. ${ }^{52}$

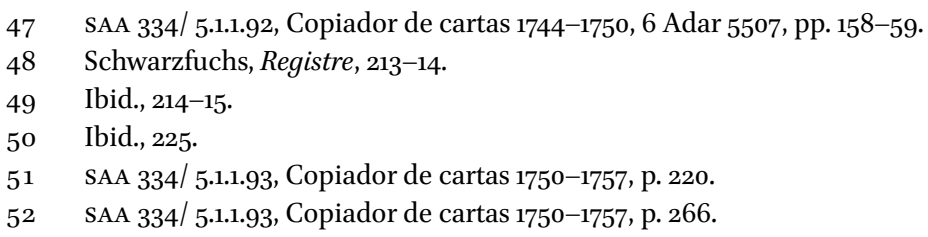


Eventually, the struggle of Hakham Athias against religious laxity and attacks on traditional Jewish thought and dogmas could not stop the advancement and propagation of the ideas of the Enlightenment among the community of Bordeaux. But perhaps, his efforts to maintain the fidelity of his flock to the Torah and to the observance of its precepts did help to consolidate in Bordeaux a certain kind of Judaism. A communal Jewish way of life was preserved: prayers in the synagogues, Sabbaths and holidays with their specific customs, the life-cycle ceremonies, studying Hebrew and the Torah at the communal school, along with a rich social life that was conducted in the various mutual aid religious societies. This commitment, both ritual and social, even without a halakhic observance of Judaism from a growing part of its members, and in spite of the acceptance of the concepts of Enlightenment and the later integration into the French intellectual sphere, enabled the continuing existence of this community.

\section{Bibliography}

Azulai, Haim Yosef David. Ma'agal Tov ha-Shalem. Edited by Aharon Freiman. Jerusalem: Merkaz Hasefer, 1983.

Beaufleury, Louis Francia. Histoire de l'établissement des Juifs à Bordeaux et à Bayonne depuis 1550. Paris, an 8 [1800].

Beinart, Haim, ed. Moreshet Sepharad: The Sephardi Legacy. 2 vols. Jerusalem: Magnes Press, 1992.

Berkovitz, Jay R. Rites and Passages: The Beginnings of Modern Jewish Culture in France, 1650-186o. Philadelphia: University of Pennsylvania Press, 2004.

Bregoli, Francesca. Mediterranean Enlightenment: Livornese Jews, Tuscan Culture and Eighteenth-Century Reform. Stanford: Stanford University Press, 2014.

Cirot, Georges. Les Juifs de Bordeaux. Leur situation morale et sociale de 1550 à la Révolution. Bordeaux: Feret, 1920.

Cirot, Georges. Recherches sur les Juifs espagnols et portugais à Bordeaux. Bordeaux: Feret \& Fils, Éditeurs, 1908.

Detcheverry, Arnaud. Histoire des israélites de Bordeaux. Bordeaux: Balarac jeune, $185^{\circ}$.

Feiner, Shmuel. The Jewish Enlightenment. Philadelphia: University of Pennsylvania Press, 2004.

Graizbord, David L. Souls in Dispute: Converso Identities in Iberia and the Jewish Diaspora, 1580-1700. Philadelphia: University of Pennsylvania Press, 2004. 
Hertzberg, Arthur. The French Enlightenment and the Jews: The Origins of Modern AntiSemitism. New York: Schocken Books, 1968.

Kaplan, Yosef. From New Christians to New Jews. Jerusalem: The Zalman Shazar Center, 2003. [Hebrew]

Lehmann, Matthias B. Emissaries From the Holy Land: The Sephardic Diaspora and the Practice of Pan-Judaism in the Eighteenth Century. Stanford: Stanford University Press, 2014.

Malino, Frances. The Sephardic Jews of Bordeaux. Alabama: University of Alabama Press, 1978.

Malvezin, Thzéophile. Histoire des juifs a Bordeaux. Bordeaux: Charles Lefebvre, Libraire, 1875 .

Nahon, Gérard. "From New Christians to the Portuguese Jewish Nation in France." In Moreshet Sepharad, Edited by Haim Beinart, 2: 336-364. Jerusalem: Magnes Press, 1992.

Nahon, Gérard. Juifs et judaïsme à Bordeaux. Bordeaux: Mollat, 2003.

Nahon, Gérard. "Le registre espagnol des circoncisions de Samuel Gomes Atias (Bidache, 1725-1773)." Bulletin Hispanique 76 (1974): 142-182.

Nahon, Gérard. Les "Nations” juives portugaises du sud-ouest de la France (1684-1791): Documents. Paris: Fundação Calouste Gulbenkian, Centro Cultural Português, 1981.

Nahon, Gérard. Métropoles et périphéries Séfarades d'occident. Paris: Cerf, 1993.

Neher-Bernheim, Renée. "Jacob Rodrigue Pereire." Proceedings of the Seventh World Congress of Jewish Studies, History of the Jews in Europe. Pp. 57-66. Jerusalem: World Union of Jewish Studies, 1977.

Neher-Bernheim, Renée. “Un savant juif engagé: Jacob Rodrigue Pereire (c. 1715-1780).” Revue des Études Juives 142 (1983): 313-451.

Oliel-Grausz, Evelyne. “Droit et espace Séfarade:Jacob Rodrigues Pereire et l'extension des privilèges. Du royaume à la Nation." Archives Juives 37 no. 1 (2004):28-46.

Oliel-Grausz, Evelyne. "La diaspora séfarade au XVIII e siècle: communication, espaces, réseaux." Arquivos do Centro Cultural Calouste Gulbenkian 48 (2004): 55-71.

Oliel-Grausz, Evelyne. "Relations et réseaux intercommunautaires dans la diaspora séfarade d'occident au XVIII' siècle." PhD diss.: University of Paris, 1999.

Sahlins, Peter. Unnaturally French: Foreign Citizens in the Old Regime and After. Cornell University Press, 2004.

Schwarzfuchs, Simon. Registre des deliberations de la Nationjuive Portugaise de Bordeaux 1710-1787. Paris: Fundação Calouste Gulbenkian, Centro Cultural Português, 1981.

Sorkin, David. The Transformation of German Jewry, 1780-1840. New York: Oxford University Press, 1987. 
Yosef Kaplan - 978-90-04-39248-9

Downloaded from Brill. com $04 / 26 / 2023$ 10:36:49AM via free access 
PART 5

Varieties of Cultural Creativity 
Yosef Kaplan - 978-90-04-39248-9

Downloaded from Brill. com $04 / 26 / 2023$ 10:36:49AM via free access 


\title{
On the Role of Hebrew Grammars in the Western European Diaspora and the New World
}

\author{
Moisés Orfali
}

Many of the crypto-Jews who decided to leave Spain and Portugal were received by relatives or friends who had left before them and who provided the newcomers with information and assistance. However, once they left the Iberian Peninsula, these former crypto-Jews found that because they had a Catholic education, their Judaism was inadequate. A dual effort was made to solve this conflict in belief systems: Hebrew grammar texts were written in Spanish (Castilian) and in Portuguese in order to facilitate the study of the Hebrew language. The study of Hebrew was essential for regaining the vast body of traditional liturgy, lore, and Torah learning that had disappeared entirely during their stay in the Iberian Peninsula. ${ }^{1}$

It was necessary to smooth the progress of what Yosef Kaplan² and Miriam Bodian called the rejudaization of "the Nation,"3 that is, the collective enterprise to reeducate all émigrés from the Peninsula in the basics of Jewish belief and the origins of many Jewish daily practices, so that they could participate in the life of the community. The most essential tools for overcoming this Hebrew language deficit were grammar manuals as an aid to acquire the language that is considered indispensable for Jewish religious practice. Some of the spiritual leaders of the Western Sephardic diaspora, including Moseh Abudiente in Hamburg, Isaac de Abraham Uziel, Menasseh ben Israel, Salomon de Oliveyra,

1 On the Iberian Peninsula conversos' knowledge of Judaism, see Yosef Hayim Yerushalmi, From Spanish Court to Italian Ghetto. Isaac Cardoso-A Study in Seventeenth-Century Marranism and Jewish Apologetics (Seattle and London: University of Washington Press, 1981), 276-99; Yerushalmi, "Connaisance du judaïsme et préparation spirituelle chez les marranes revenues au judaïsme au cours du XVII' siècle," in Sefardica. Essais sur l'histoire des juifs, des marranes \& des nouveaux-chrétiens d'origine hispano-portugaise (Paris: Chandeigne, 1998), 235-54.

2 Yosef Kaplan discusses various aspects of the reeducation enterprise in Judios nuevos en Amsterdam: Estudios sobre la historia social e intelectual del judaísmo sefardí en el siglo XVII (Barcelona: Gedisa, 1996); Yosef Hayim Yerushalmi, "The Re-education of Marranos in the Seventeenth Century," in The Third Annual Rabbi Louis Feinberg Memorial Lecture in Judaic Studies, March 26, 1980 (Cincinnati: University of Cincinnati, 1980), 7-11.

3 See Miriam Bodian, Hebrews of the Portuguese Nation: Conversos and Community in Early Modern Amsterdam (Bloomington: Indiana University Press, 1997), 96ff.

(C) MOISÉS ORFALI, 2019 | DOI:10.1163/9789004392489_018

This is an open access chapter distributed under the terms of the prevailing CC-BY-NC License at the time of publication. 
and Mosse Rephael d'Aguilar in Amsterdam, and Isaac Aboab da Fonseca in the New World (Recife), set out to produce the needed texts.

We will deal with the trends spurred by the authors of those Hebrew grammars in terms of the aims of their works: acquisition of passive knowledge of Hebrew only or active mastery of the Holy Tongue. Special attention will be paid to the goal of Rabbi Isaac Aboab da Fonseca whose unpublished Hebrew grammar titled Melekhet ha-Diqduq was meant to teach biblical Hebrew, versus Baruch Spinoza who wrote his Compendium grammatices lingua hebraeae with the objective of inculcating a kind of secularized Hebrew by transforming its rules and practices into the form of a natural language and not as a "Holy Tongue." Spinoza summarized the aim of his work by stating that this grammar was meant to be used by "those who desire to speak Hebrew and not just chant it."

\section{Hebrew Grammar Books}

The Hebrew grammar written by Aboab's educator, Isaac de Abraham Uziel (? Fez-1622 Amsterdam), titled Ma'ane Lashon, was the first Hebrew publication printed in Amsterdam by Menasseh ben Israel (1604-1656) in 1627. This grammar contains a list of Hebrew grammatical terms with their Spanish equivalents in Hebrew script. ${ }^{4}$ In 1633, Moseh Abudiente (1602-1688) published a Hebrew grammar in Portuguese in the city of Hamburg titled: Gramatica hebraica. Parte Primeyra. Onde se mostram todas as regras nesessarias assim para a inteligençia da lingua, como para compor e escrever nella em proza e uerso com a elegançia e medida que conuem 5 (Hebrew Grammar. Part One. In which are given all rules necessary for understanding the language as well as for the composition and writing of it in prose and verse with the appropriate elegance and meter). Menasseh ben Israel claimed, in several of his publications, that he had

4 Isaac de Abraham Uziel was a teacher in the Talmudic school in Amsterdam. He taught both Isaac Aboab da Fonseca and Menasseh ben Israel. See Harm Den Boer, La Literatura sefardí de Amsterdam (Alcalá de Henares: Universidad de Alcalá, 1995), 37. He also wrote Libros Poéticos en Declaración de todos los Equívocos de las Sagradas Letras, in both Hebrew and Spanish, which was praised by Daniel Barrios who describes him as a great poet, a capable musician, and a distinguished mathematician. Joseph Serrano dedicated a poem to Uziel; it is inserted in the Temime Dere.

5 See Anthony J. Klijnsmit, “'Se qual o ouro entre todos os metáis.' Abudiente's Hebrew Grammar (1633)," in Die Sefarden in Hamburg. Zur Geschichte einer Mindehert, ed. Michael Studemund Halévy (Hamburg: Helmut Buske Verlag, 1994), 1: 319-74; Avi Elqayam, Sabbatean Millenarianism in the Seventeenth Century. A Study of Moshe Abudiente's Fin de los Dias (Los Angeles: Cherub Press, 2014), 51-52. 
written a Hebrew Grammar for his pupils, Libro yntitulado Safah Berurah, hoc est Labia clara da grammatica hebrea, in Hebrew and Portuguese. It was never printed, but circulated in manuscript copies. ${ }^{6}$ Only at the beginning of the twentieth century was Ets Haim able to acquire a manuscript of Menasseh ben Israel's grammar. This manuscript was copied by one of his pupils, Selomoh de Oliveyra (c. 1633-1708), as indicated on the title page. ${ }^{7}$ In 166o, Mosse Rephael d'Aguilar (c. 1625-1679) printed his Epitome da Gramatica Hebraica, por breve método composta para uso das escolas do modo que a ensina en portugues, in Portuguese ${ }^{8}$ which was intended for teaching Hebrew in schools, as appears from the title. This grammar has the same contents as Menasseh's grammar except for the syntax, which is not treated by d'Aguilar, but is less extensive. Selomoh de Oliveyra, a well-known copyist of Menasseh's Libro yntitulado Safah Berurah, created a manual of the Hebrew language called Yad LashonDal Sefatayim - Livro da Gramatica Hebraica e Chaldayca, which was printed in Amsterdam in 1689 by David Tartas. ${ }^{9}$ This grammar, similarly to d'Aguilar's, is intended for use in schools. It has a catechism-like appearance because the title of each chapter is a question.

6 In El Conciliador (Francaforte [Amsterdam], [s.i.] 1632), Prologo al lector, 4v, Menasseh Ben Israel refers to his Grammar saying "Y ansi hizimos el año passado la Gramatica Hebrea, diuidida en quatro libros, a la qual dimos nombre (safah berurah en letras hebreas) hoc est, Labia clara." He repeated this information in the Latin edition of The Conciliator (1633). In the second part of El Conciliador (Amsterdam: Nicolaas van Ravenstein, 1641), 3v, he adds that he began writing the grammar when he was seventeen years old and that it is in a manuscript, circulating from hand to hand. At the end of his life, in the edition of his Piedra gloriosa o de la estatua de Nebuchadnesar (Amsterdam: [s. i.], 1655), Menasseh says that he now intends to print the grammar, which he has perfected (con nuevas observaciones).

7 For information on the only known manuscript of this piece, see Lajb Fuks and Renate G. Fuks-Mansfeld, Hebrew and Judaic Manuscripts in Amsterdam Public Collections. II. Catalogue of the Manuscripts of Ets Haim / Livraria Montezinos, Sephardic Community of Amsterdam (Leiden: E.J. Brill, 1975), no. 326. Cf. Adri Offenberg, Menasseh ben Israel (1604-1657): Een Biografische Schets (Amsterdam: Menasseh ben Israel Instituut, 2000), 12-13. An extensive analysis of the grammar can be found in Anthony J. Klijnsmit, "Amsterdam Sephardim and Hebrew Grammar in the Seventeenth Century," Studia Rosenthaliana 22 (1988): 145-49; idem, "Some Seventeenth-Century Grammatical Descriptions of Hebrew," Histoire Epistémologie Language 12, no. 1 (1990): 81-85.

8 See Harm den Boer, Sephardic Editions, 1550-1820. Spanish and Portuguese Books Written and/ or published by Sephardic Jews of Early Modern Europe (Leiden: Brill, 2003-2005). See also Klijnsmit, "Amsterdam Sephardim," 149-153; idem, "Some Seventeenth-Century Grammatical Descriptions," 85-87.

9 Menasseh ben Israel gives his grammar the same title as a medieval grammar written by Abraham ibn Ezra in the twelfth century. A modern edition of Menasseh's work has been released, titled Yad Lashon, Diqduq (New York: Ch. Reich, 1994). On Selomoh de Oliveyra's Yad Lashon, see Klijnsmit, "Amsterdam Sephardim," 153-55. 
Anonymous grammar books for beginners were also printed. However, they were written in Hebrew. One useful instrument was David Cohen de Lara's lexical polyglot, titled Sive De Convenientiam vocabulorum Rabbinicorum Cum Graecis, \& quisbudam allis linguis Europaeis, published in Amsterdam in 1638. This is a synopsis of his Diccionario talmúdico rabinico, printed in Hamburg in 1668. According to the author, it took him twelve years to write this work.10 Two parallel pieces, one in Spanish and one in Hebrew, were added to this grammatical effort: the Ortografía castellana [...] a modo de Diálogo entre dos niños de la escuela, written by Abraham de Fonseca in $1663{ }^{11}$ and the Hebrew grammar titled Melekhet ha-Diqduq written completely in Hebrew, which Rabbi Isaac Aboab da Fonseca (1605-1693) compiled while he was staying in Pernambuco. He may have taught Baruch Spinoza $\left(163^{2-1677)}\right.$ the rudiments of Hebrew grammar prior to leaving for Brazil. Toward the end of his brief life, Spinoza wrote his Compendium grammatices linguae hebraeae (Amsterdam, 1677) in Latin. This is probably one of Spinoza's least known texts. It has been preserved as an unfinished text containing thirty-three chapters, and was not included $^{12}$ in the edition of the posthumous writings of Spinoza that were translated into Dutch and published in 1677 by Jarig Jelles under the title Nagelate Schriften. The reason for this omission was explained by Jelles in the preface to the book: "Apart from what we have already mentioned, Spinoza wrote an incomplete Hebrew grammar or treatise on letters in Latin. Although it has been highly praised by various experts who possess several copies, we did not believe that it would be useful to print it in Dutch here, but rather that

10 See Ángel Sáenz Badillos, "David de Cohen Lara y sus dos vocabularios rabínicos," in Los Judaizantes en Europa y la Literatura Castellana del siglo de Oro, ed. Fernando Díaz Esteban (Madrid: Letrúmero, 1994), 341-49.

11 Abraham de Fonseca's text is modeled after the Jesuit Francisco Pérez de Náxera's Orthographía castellana dividida en primera y segunda parte a modo de Diálogo entre dos niños de la escuela, published by Luis Sánchez in Valladolid in 1604. Náxera includes an Instrucción para enseñar bien a leer y escriuir in this work, in which he insists on the advantage of learning correct pronunciation in order to prevent orthographic mistakes. This Instrucción was included in Abraham de Fonseca's Ortografía.

12 The Compendium grammatices linguae hebraeae was included in the edition of Spinoza's complete works by C. Gebhardt (1925), but only three translations have ever been made of it: a Hebrew translation by Solomon Rubin, Compendium grammatices Linguae Hebraeae (Podgórze-Krakow: Drukiem I nakladem Józefa Plessnera i Ski., 1905); an English translation by Maurice Bloom, Hebrew Grammar (London: Vision Press, 1963) and a French translation by Joël Askénazi and Jocelyne Ashkénazi-Gerson, Abrégé de grammaire hébraique (Paris: J. Vrin, 19683). 
it should be left for the Latin edition, since Hebrew is rarely studied (by us), whereas Latin dominates." ${ }^{13}$

\section{Isaac Aboab da Fonseca's Grammar}

Aboab da Fonseca's elementary Hebrew grammar, Melekhet ha-Diqduq, is a practical introductory manual based on simple rules of Hebrew etymology, the parts of speech, conjugation, and declension tables. It exists in two eighteenthcentury manuscripts, both written by David Franco Mendes $(1713-1792)^{14}$ and dated on the title page with the Jewish year $5+2+400$. Some historians read this as $5402[=1641 / 42]$, since there is no indication "according to the abbreviated era." Others, including J.S. da Silva Rosa and A. Wiznitzer, read it as an abbreviated date, i.e., [5]407 $[=1646 / 7] .^{15}$ In any case, as Adri K. Offenberg already taught in his specific answer to the question of when and where Aboab's grammar was written, both dates suggest that Aboab composed his grammar in Brazil. ${ }^{16}$ For Offenberg, no matter how we read the date, "the text of the grammar was completed in Brazil four years before the famous poem Zekher 'Asiti le-Nifla'ot $E l$ [I made remembrance of the wondrous deeds of God ${ }^{17}$ ] and thus constitutes the first real Hebrew text written in the New World."18 Indeed,

13 De Nagelate Schriften van B.D.S.als Zedekunst, Staat-kunde, Verbetering van 't verstand, Brievben en Antwoorden uit Verscheide Talen in de Nederlandesche Gebracht (Amsterdam: Jan Rieuwertsz, 1677), §75.

14 Both manuscripts 47 E 4 and 47 C 12 repose in the Ets Haim library of the Portuguese Community of Amsterdam. See Fuks and Fuks-Mansfeld, Hebrew and Judaic Manuscripts, nos. 328 and 429. An English translation will appear in Moises Orfali, Isaac Aboab da Fonseca: Jewish Leadership in the New World (Eastbourne: Sussex Academic Press, forthcoming).

15 Jacob S. da Silva Rosa, "Iets over den Amsterdamschen Opperabijin Isaäc Aboab" Centraalblad voor Israelieten in Nederland 29 (1913): nos. 39-41 (list of Aboab's works, no. 2); Arnold Wiznitzer, "The Minute Book of Congregations Zur Israel of Recife and Magen Abraham of Mauricia, Brazil," Publications of the American Jewish Historical Society 42 (1953): 217-302; id., Jews in Colonial Brazil (New York: Columbia University Press, 1960), 169.

16 We owe these data to the innovative study of Adri K. Offenberg, "A Mid-SeventeenthCentury Manuscript of the (Unpublished) Hebrew Grammars of Menasseh Ben Israel and Isaac Aboab da Fonseca Recovered," Zutot 3 (2003): 104.

17 This thanksgiving narrative poem describing the horrors suffered by the Jews during the Portuguese attack on Dutch Recife has been considered as the earliest Jewish poem in the New World. The text was first published by Meyer Kayserling, "Isaac Aboab, the First Jewish Author in America," Publications of the American Jewish Historical Society 5 (1897): 129-31, http://jawutrecht.files.wordpress.com/2012/11/out-26.pdf; Kayserling, "Rabbi Yitzhak Aboab ha-Šeliši," Ha-Goren 3 (1902): 155-174.

18 Offenberg, "A Mid-Seventeenth-Century Manuscript," 106. 
Offenberg is right in deciphering the date on which Aboab finished his grammar based on the chronogram in both manuscripts taken from Lamentations 2:13: "O daughter of Jerusalem." The entire passage is read in synagogues on the Ninth of Av, the traditional day of mourning for the destruction of the Temple in Jerusalem and other torments. Four years earlier, the date on which the thanksgiving hymn was written fell exactly on August 1642, when Aboab was already appointed as rabbi in Recife.

This grammar text is a small treatise of only twelve pages, foliated alephwav, written on the rectos and versos in a Sephardic square and semi-cursive Hebrew hand with blind ruling. It was most probably written from memory and without the help of a reference library. Only once, in the seventh chapter when he deals with the Quadriliteral ${ }^{19}$ verbs, does he refer to the books of the leading Hebrew grammarians and their explanation concerning the reduplication of the third root consonant. Nevertheless, it is well-known that before leaving for northeast Brazil, he was in charge of teaching Talmud in the school of the Jewish community in Amsterdam where he also gave lessons in Hebrew grammar to students in the beit midrash. ${ }^{20}$ Moreover, from Kaplan's study on his library's catalogue we learn that thirty-two of the 524 Hebrew books that Aboab possessed were books on Hebrew grammar and different kinds of lexicography. ${ }^{21}$

Aboab da Fonseca apparently needed a grammar text as a teacher of Hebrew to young children and conversos in Recife. Its aim was to render the study of classical Hebrew simple and interesting. By keeping the grammatical discussion at a relatively unsophisticated level and explaining the rules from the point of view of ordinary speech, and how to correctly read the biblical text, he tried to make the book as serviceable as possible to those who want to study the language without a teacher. As mentioned, this was probably a textbook used by adults and children in Recife.

19 There are a number of verbs in Hebrew which have four root-letters as their basis, an

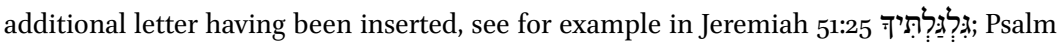

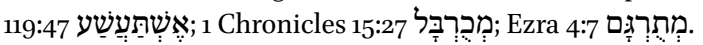

20 Chr. W. Pieterse, Daniel Levi de Barrios als geschiedschrijver van de Portuguees-Israelietiche Gemeente te Amsterdam in zijn "Triumpho del Govierno Popular" (Amsterdam: Scheltema \& Holkema 1968), 160.

21 Yosef Kaplan, "El perfil cultural de tres rabinos sefardíes a través del análisis de sus bibliotecas," in Familia, Religión y Negocio. El sefardismo en las relaciones entre el mundo ibérico y los Países Bajos en la Edad Moderna, ed. Jaime Contreras, Bernardo J. García García, and Ignacio Pulido (Madrid-Alcalá de Henares: Fundación Carlos de Amberes, 2002), 275; id., "The Libraries of Three Sephardic Rabbis in Early Modern Western Europe," [Hebrew] in Libraries and Book Collections, ed. Yosef Kaplan and Moshe Sluhovsky (Jerusalem: The Zalman Shazar Center for Jewish History, 2006), 234. 
Although Aboab's text clearly falls within the category of traditional elementary grammars, it contains several features that require a brief comment. The generous use of transliteration is meant to serve three purposes: enable the perception of Hebrew as a language and not an exercise in decipherment; remove the customary initial obstacle wherein the learner was required to master innumerable pages of rather abstract phonological and orthographic details before learning even a sentence of the language; and facilitate the memorization of the paradigms, where the essential features are, in my opinion, set in greater relief than in the conventional script. ${ }^{22}$

Aboab's grammar embraces the rules of Hebrew etymology, the parts of speech, and presents the morphology of the verb in a way that best exploits the underlying similarities of the various forms, regardless of the root type. This enables introduction of the most common verbs at an early point in the grammar and allows discussions of the derived "conjugations" to be unhampered by restriction to examples from sound roots. ${ }^{23}$ As much space as possible was allocated to the systematic treatment of noun morphology and to the verb with object suffixes. Simplification of this material, which was attempted in many elementary grammars, actually does a disservice to the learner. When he turns to his first page of unsimplified reading, he finds that what he should have learned systematically must instead be learned at random, inefficiently, and with rather great difficulty. Finally, special attention was given to an orderly presentation of prose syntax, beginning with characterization of the various types of individual clauses and ending with sequences of inter-related clauses.

In conclusion, Aboab seems to have made every attempt to make the grammar clear-cut and uncomplicated by being short and snappy and by giving examples for every grammatical explanation. The discussion is as straightforward as possible, for it is his intention that the text should also be useful to those who would study Hebrew without a teacher. It is written in the simplest possible lines, and yet enables the beginner to acquire great familiarity with the Hebrew

22 Hebrew grammar is essentially schematic and, starting from simple primary rules, it is possible to work out the main groups of word-building almost mathematically. In Aboab's grammar, when the reader is confronted with a new point he is usually referred to principles that have already been learned, which produce the required result when applied to the new problem. A typical example is the case of "Weak Verbs": these are explained rationally by the simple method of applying the ordinary rules governing "peculiar" letters to these verbs and thus working out the forms that they, respectively, assume.

23 It is not practicable to attempt to teach Hebrew grammar in all its details to beginners. It is more profitable to deal with the main principles and uses that should form the basis for more advanced study. On this account, Aboab endeavored to avoid references to the minute and manifold exceptions that appear in advanced Hebrew grammars as much as possible and practicable. 
biblical text. In nine chapters, without any introduction, he directly begins to deal with: [chapter one] the two kinds of Shewa, ${ }^{24}$ and the peculiarities of the guttural, palatal, labial, labio-dental, and interdental articulation of Hebrew letters; [chapter two] the Definite $\operatorname{Article}^{25}(h e), " H e$ " interrogative and "He" of surprise cases; [chapter three] the Consonants known as the begad kepat; ${ }^{26}$ [chapter four] the Parts of Speech: Noun, Verb and Particle; [chapter five] the Simple Active $(Q a l)$ and Simple Passive ${ }^{27}$ (Niph'al) stems; ${ }^{28}$ [chapter six] the Intensive Active $\left(\mathrm{Pi}^{\prime} \mathrm{e}^{29}\right)$, Intensive Passive $\left(\mathrm{Pu}^{\prime} \mathrm{a} \mathrm{l}^{30}\right)$ and the Causative

24 When there is a vowel-less letter at the beginning or in the middle of a word in a pointed text, then the sign: called Shewa (שוא), fills the gap under it. Aboab explains the four cases of Simple Shewa as well as the composite representation by shewa and short vowel together which gives rise to the term Composite Shewa.

25 The definite article of Hebrew closely corresponds to the definite article of English in usage and meaning. The basic form of the article is $h a$, plus a doubling of the following consonant. It is prefixed directly to the noun it determines.

26 Two sets of six sounds each are closely related to one another, both in sound and distribution. These are the six stops $b, g, d, k, p, t$ on the one hand, and their spirantized $b, g, d, k$, $p$ and $t$ on the other. Although no rule can be given for the choice between the sounds of one set and those of the other without important exceptions, Aboab's observations provide a safe guide for the majority of occurrences.

27 In some verbs, the Niph'al preserves a "middle" or "reflexive meaning." In such cases the significance of the Niphal oscillates between reflexive and passive. Isaac Aboab does not explain these situations.

28 The first of these has been called Qal, which means "light" by contrast with six stems which are derived from the same root. The verb פעל (pa'al) "did, performed" has been taken to serve as the prototype of the derived forms. Thus, the Simple Passive is the פפעל (niph'al), the Intensive Active is the פעל (pi'el), etc.

29 Pi'el verbs are regularly distinguished by a doubling of the second root consonant and stem patterns quite distinct from those of the Qal. Because the root of a Pi'el verb may not always occur as a Qal verb, it is sometimes difficult to define the meaning of a Piel form by direct comparison. Aboab does not present a representative collection of Piel verbs classified according to the meaning that may be assigned to the Pi' $e$ las a derived type, i.e., secondary to some other form of the language [factitive (transitivizing), dominative and intensive. In addition to the three preceding categories, there are many Piel verbs whose origin is not clear. Some could doubtlessly be placed in the above classifications if Aboab had given the learner more data on the related Qal or nominal forms.

30 There is a passive counterpart that corresponds to every Piel verb which is known as the Pu'al. It is characterized, like the Pi'el, by a doubling of the middle root consonant. The pattern of vowels is more or less consistent throughout, with $u$ in the first stem syllable and $a$ (when not reduced) in the second. 
Active (Hiph'il ${ }^{31}$ ) stems; [chapter seven] the Causative Passive (Huph'a $\left.{ }^{32}\right)$, the Reflexive (Hitpa' ( $^{33}$ ) and Quadriliteral Verbs; [chapter eight] Strong Verbs and Weak Verbs; ${ }^{34}$ [chapter nine] Defective Verbs, ${ }^{35}$ Geminate Verbs and roots.

Aboab da Fonseca's unpublished Hebrew grammar manuscript may also be the first Hebrew text written in the New World. The approach taken in this grammar is to discuss nouns and particles first and then move on to verbs, presenting the essential basics of biblical Hebrew. It concentrates on the norms rather than the exceptions. It emphasizes tool-building and tool-use rather than memorization, so the readers and those who want to study the biblical text will have the basic tools necessary for dealing with most of the textual intricacies. It should be noted that the study of the biblical text in general constitutes a fundamental commandment in Judaism, and is valued as much as the total of all commandments. ${ }^{36}$ Maimonides, for example, considered the study of Hebrew- the language in which the Bible was transmitted-a commandment in its own right. ${ }^{37}$

Furthermore, Rashi and Maimonides (and other classical commentators on the Bible such as Abraham ibn Ezra and David Kimhi) were masters of the Hebrew language and serious students of grammar. These giant teachers, whose place among the sages of Israel of all times is indisputable, drew on their knowledge of Hebrew grammar for clarifying the meaning of the

31 Hiph'il verbs are, for the most part, causatives of the corresponding Qal. The distinctive mark of this conjugational type is prefixed $h$-, but because there is no present in the imperfect and the participle, one must also rely on vowel patterns to identify these forms and distinguish them from the Qal. Here too, Aboab does not mention the different meanings that can be assigned to the Hiph'il which may be grouped as follows: causative, permissive, denominative, and unclassified.

32 As in the Pi'el-Pu'al relationship, there is a passive counterpart of the Hoph'al type for each Hiph'il verb. The form is characterized by an $u$-vowel in the first stem syllable and $a$ in the second. The exact nature of the first vowel depends on the root type.

33 Hitpael verbs are relatively infrequent. They are distinguished by the prefixal element (h) it - and the doubling of the second root consonant. Hitpa'el verbs are intransitive and often have a reflexive or reciprocal meaning of relation to their active counterparts of the Qal, Pi'el, or Hiph'il type from the same root.

34 A verb is said to be weak when it deviates from the regular or normal type, due to (a) a guttural letter, (b) a quiescent letter, or (c) a letter, such as J, which is liable to assimilate, being among the root letters; because adjustments must then be made.

35 Often, when two kindred weak verbs with the same meaning are used, they are both $d e$ fective, i.e., do not occur in all forms. However, since those tenses and forms which are not in use in the one verb are generally supplied by the other, they mutually complete each other, and thus form an entire verb together, as it were, as in Latin fero, tuli, latum, ferre, etc., only in Hebrew the roots of these verbs are almost always closely related.

36 Maimonides, Mishneh Torah, Laws of Talmud Torah, 3: 3 .

37 Maimonides, Commentary on the Mishna, Avot 2: 1. 
Pentateuch text. ${ }^{38}$ Aboab, as a spiritual leader, follows them, trying to make Hebrew accessible not only by acknowledging grammatical tools for correctly understanding and reading the biblical text, but also by commenting on it by way of paraphrases. ${ }^{39}$

Spinoza's Compendium grammatices linguae hebraeae

Spinoza's grammar is the first Hebrew grammar written in Latin by an Amsterdam Sephardic Jew. He wrote it to explain the nature and properties of the language in which the Bible was written and in which its authors were accustomed to speak. He insisted that biblical study must follow the study of the nature and properties of the language in which most of the books of the Bible are written-the Hebrew language. Scriptural interpretation requires knowledge of this language in order to allow a straightforward study of Scripture: "And because all the writers, both of the Old Testament and the New, were Hebrews, it's certain that the history of the Hebrew language is necessary above all others, not only for understanding the books of the Old Testament, which were written in this language, but also for understanding those of the New. For though they've been circulated in other languages, nevertheless they are expressed in a Hebrew manner."40

Spinoza intended to write a Hebrew grammar in accordance with the rules of geometry in order to show the main rules of the Hebrew language and to demonstrate various changes in the language occasioned by its widespread use among all ancient Hebrew sects, which brought about many difficulties in the interpretation of the Bible:

38 There are numerous discussions of grammatical points in the classical Pentateuch commentaries of Rashi, Ibn Ezra, Rashbam, and Maimonides. See many examples in Ezra Zion Melammed's, Mepharshei Ha-Mikra (Jerusalem: Magnes Press, 1975), 1: 398-414; 2: 965-67.

39 In his Paráfrasis comentado del Pentateuco (Amsterdam: Iaacob de Cordova 5441 [1681]), Aboab says that the purpose of the Paraphrase in Spanish was as much for liturgical use as didactic and cultural. See Moisés Orfali, "Observaciones sobre el Paráfrasis comentado del Pentateuco de R. Isaac Aboab da Fonseca y sus fuentes" eHumanista 20 (2012): 21538; idem, "Paraphrastic Commentary to the Pentateuch by Isaac Aboab da Fonseca," in Portuguese Jews, New Christians and "New Jews": A Tribute to Roberto Bachmann, ed. Bruno Feitler and Claude Stuczinsky (Leiden-Boston: Brill, 2018), 334-6o.

40 Benedict de Spinoza, Tractatus Theologico-Politicus, in The Collected Works of Spinoza, ed. and trans. Edwin Curley (Princeton, NJ: Princeton University Press, 2016), chap. 8: 100 [p. 173] [hereafter, TTP]. 
Those who spoke and wrote Hebrew in ancient times left nothing to posterity regarding its foundations and teaching. Or at least we have absolutely nothing from them: no Dictionary, no Grammar, no Rhetoric. Moreover, the Hebrew Nation has lost all its marks of distinction and honor-this is no wonder, after it has suffered so many disasters and persecutions - and has retained only some few fragments of its language and of a few books. For almost all the names of fruits, birds, fish, and many other things have perished in the injustice of the ages. Again, the meaning of many nouns and verbs which occur in the Bible is either completely unknown or is disputed. We lack, not only all these things, but also and especially, a phraseology of this language. For time, the devourer, has obliterated from the memory of men almost all the idioms and manners of speaking peculiar to the Hebrew nation. Therefore, we will not always be able, as we desire, to find out with respect to each utterance, all the meanings it can admit according to linguistic usage. Many utterances will occur whose meaning will be very obscure, indeed, completely incomprehensible, even though they are expressed in well-known terms. ${ }^{41}$

In his Theologico-Political Treatise, Spinoza explained that he determined to examine the Bible in a careful, impartial, and unfettered spirit, making no assumptions about it and attributing no doctrines to it that he did not find clearly set down therein. A clear knowledge of the nature and peculiarities of the language of the Bible was essential for this, and a thorough understanding of the grammar was paramount. The interpretation "must contain the nature and properties of the language in which the books of Scripture were written, and which their Authors were accustomed to speak." ${ }^{42}$ His approach to the Bible seems to be scientific and at the same time properly religious, since he demands that one listen to what the biblical texts have to say, just as a natural scientist is careful to let factual data speak for themselves and not twist meanings according to preconceived notions. The study of the Bible should proceed by the use of the tool of natural reason, and in this effort the study of Hebrew grammar is, of course, most important. ${ }^{43}$

\footnotetext{
41 TTP, chap. 8: 106 [p. 180].

42 Ibid., chap. 8: 100 [p. 173].

43 The main features of Spinoza's Compendium grammatices linguae hebraeae, closely connected with his thought, were studied at length by Guadalupe González Diegez, Baruj Spinoza. Compendio de gramática de la lengua hebrea, Introducción, traducción y notas de [...] (Madrid: Editorial Trotta, 2005) and recently by Giovanni Licata, "Spinoza e la cognition universalis dell'ebraico. Desmitificazione e speculazione grammaticale nel Compendio di grammatical ebraica" Giornale di Metafisica $3^{1}$ (2009): 625-61. See also
} 
The Bible may be Spinoza's only evidence for Hebrew as a spoken, natural language used by Jews in biblical antiquity. However, his goal was not to reveal the language's character as a sacred or mysterious system. Rather, it was to understand its structure as a big language. His is a work for those who desire to speak Hebrew, and not just chant it. ${ }^{44} \mathrm{He}$ intended his grammar to have two parts. Part One was intended to set out the letters of the Hebrew alphabet and to lay out the forms of verbs, nouns, and other parts of speech. Of special interest are the conjugations, declensions, vocalization, and so forth. Part Two would then give an account of sentence structure, syntax, and so forth.

Similarly to Aboab, Part One is composed of chapters, while there are none in Part Two. Those thirty-three chapters deal with: [chapter one] On the Letters and Vowels in General; [chapter two] On the Shape, Significance, Names, Classifications and Peculiarities of the Letters; [chapter three] On the Vowels; to wit, their shape, name, significance and properties; [chapter four] On the Accents; [chapter five] On the Noun; [chapter six] On the Inflection of Nouns from Singular into Plural; [chapter seven] On the Masculine and Feminine Gender; [chapter eight] On the Construct Case of Nouns; [chapter nine] On the Twofold Use of the Noun and of its Declension; [chapter ten] On the Preposition and the Adverb; [chapter eleven] On the Pronouns; [chapter twelve] On the Infinitive Nouns, the Variations of their Forms and Kinds; [chapter thirteen] On the Conjugation; [chapter fourteen] On Verbs of the First Conjugation Paradigms. Simple Active Verbs $\left(Q a l^{45}\right)$; [chapter fifteen] On Passive Verbs (Niph'al ${ }^{46}$ ); [chapter sixteen] On Active Intensive Verbs with a Dagesh (Pie ${ }^{47}$ ); [chapter seventeen] On Passive Intensive Verbs (Pu'al); [chapter eighteen] On the Derivative Active (Causative) Verb (Hiph'il); [chapter nineteen] On the Derivative Passive Verb (Hoph'al); [chapter twenty]

Baruch Spinoza, Hebrew Grammar (Compendium Grammatices Linguae Hebraeae), ed. and trans. Maurice J. Bloom (London: Vision Press Ltd., 1963); Philippe Cassuto, Spinoza hebraisant. L'hebreu dans le "Tractatus theologico-politicus" et le "Compendim grammatices linguae hebrae" (Leuven: Peeters Publishers, 200o); Compendium grammatices linguae hebraeae, in Spinoza, Complete Work, trans. Samuel Shirley, ed. with introduction and notes by Michael L. Morgan (Indianapolis and Cambridge: Hackett Publishing Company, Inc., 2002), 584-675. [Compendium grammatices linguae hebraeae hereafter in notes CGLH.].

That Spinoza aims at an active knowledge of Hebrew can be concluded from a remark in his treatment of the accents in CGLH, chapter 4 [p. 598]: "I do not have anything to say about the fact that the Jews, because of the musical accent $\sim$, which they call a zarka, now bring in a ga'ya into the syllable antecedent to it, because it is not followed by those who either wish to speak Hebrew or to chant it."

45 The term Qal, used by modern Hebrew grammarians, does not appear in Spinoza's work.

46 Here again, the term niph'al is not used by Spinoza.

47 Spinoza does not use this term. 
On Active Reflexive Verbs (Hithpa'el); [chapter twenty-one] On Passive Reflexive Verbs (Hothpa'al); [chapter twenty-two] On Verbs of the Second Conjugation (ל); [ [chapter twenty-three] On Verbs of the Third Conjugation (ל"ל); [chapter twenty-four] Verbs of the Fourth Conjugation ל"ע ל"ל [chapter twenty-five] Verbs of the Fifth Conjugation (פי); [chapter twentysix] On Composite Verbs from this Fifth and Three Preceding Conjugations; [chapter twenty-seven] On Verbs of the Sixth Conjugation (Ayin Aleph, Ayin Vav, and Ayin Yod); [chapter twenty-eight] Verbs of the Seventh Conjugation (Peh Gutturals); [chapter twenty-nine] Verbs of the Eighth Conjugation (Ayin Gutturals); [chapter thirty] On Defective Verbs; [chapter thirty-one] Another Class of Defectives; [chapter thirty-two] Concerning Deponent Verbs, and Quadrilateral Verbs, and Incidentally Concerning the Composition of Verbs, Modes, and Tenses; [chapter thirty-three] On the Nominative Participle.

The need to produce a Hebrew grammar was an explicit concern of Spinoza's, as shown by the statement appearing twice in the Compendium grammatices linguae hebraeae, that many have written a grammar of the Scriptures, but none has written a grammar of the Hebrew language. ${ }^{48}$ It must be said that an awareness that what survived through the biblical texts was only a partial remnant of what was formerly the Hebrew language existed already among the first Hebrew grammarians of the Middle Ages. This issue was discussed in the tenth century by disciples of Menahem ben Saruq (910/920-970), who lamented the situation of the Hebrew language in their dispute against Dunash ben Labrat (920/925-985) ${ }^{49}$ in Moshe ibn 'Ezra's (1055-1135) poetry treatise Kitâb almuhadara wal-mudkâkarara, ${ }^{50}$ and in the second half of the eleventh

48 CGLH, chapter 7 [p. 6o4]: "For, as I said in a word, there are many who wrote a grammar of the Scriptures but none who wrote a grammar of the Hebrew language"; chapter 17 [p. 642]: "To be sure, as we have said, they wrote grammar of the Scriptures, not of the language." Spinoza also tried to explain why this happened: “[...] the difficulties of interpreting Scripture have not arisen from a defect in the powers of the natural light, but only from the negligence (not to say wickedness) of the men who were indifferent to the history of Scripture while they could still construct it," ТтP, chapter 7:112 [p. 186].

49 Talmide Menahem, Tešubot de los díscipulos de Menahem contra Dunaš ben Labrat, ed. and trans. by Santiaga Benavente, rev. by Ángel Saenz-Badillos (Granada: Ediciones de la Universidad de Granada, 1986), 20.

5o Moseh Ibn 'Ezra, Kitâb almuhadara wal-mudk̂kâkara-Sefer ha-Yiunim we-ha-Diyunim ('Al ha-Širah ha-'Tbrit), ed. Abraham Shlomo Halkin (Jerusalem: Mekize Nirdamim, 1975), 28a [p. 53]: "Due to the prolonged exile and its duration, the Hebrew language almost disappeared [...] Its remnants are only twenty-four books that barely contain the essentials of the language" [in Hebrew, translation is mine]. 
century in Moshe ibn Chiquitilla's introduction to his translation of the grammatical treatises by Hayyuy (990-1050). ${ }^{51}$

Although Spinoza drew the bulk of his work in Compendium grammatices linguae hebraeae from biblical texts, following Moseh ibn Ezra, ${ }^{52}$ his great innovation was to consider Hebrew as a living, productive language. He created neologisms, words that did not appear in the Bible, contravening the rules that had been repeated for centuries that dictated that he should deviate from biblical language as little as possible.

Spinoza also dealt with the acute question of the part of the language that was least preserved, and which has posed the greatest uncertainty, specifically the correct pronunciation. It was clear to him that it is difficult to reconstruct the pronunciation of Hebrew as it was spoken in biblical times, and that he had to rely on written material. Spinoza was aware of the fact that "the Scriptures were written by men of various dialects, and that now the dialects are not recognizable, namely from which tribe this or that dialect originated. ${ }^{53} \mathrm{He}$ had to rely on pronunciation traditions and the opinions of other grammarians. This resulted in a mixture of Ashkenazic and Sephardic pronunciations, as shown by Anthony J. Klijnsmit. ${ }^{54}$ Spinoza basically considered the Sephardic pronunciation of the consonants to be correct, and the Ashkenazic pronunciation of the vowels to be correct, as described by J. Buxtorf (in the Thesaurus Grammaticus Linguae Sanctae Hebraeae of 1620). He actually confounded two contemporary "dialects," something he warns against when he says: "Letters of the same organ of speech are often substituted one for the other in the Scriptures, and an $\aleph$ for an $\mathcal{\nu}$, a $\varnothing$ for a $\uparrow, \beth$ for $\unlhd, \cup$ for a $ת$, etc. [...] For the Ephraimites everywhere substituted a $\varnothing$ for a $\boldsymbol{E}$, letters which really are from the same organ of speech. Nevertheless, although in Sacred Scripture occasionally one letter is changed

$5^{1} \quad$ Jehuda Hayug, Two Treatises on Verbs Containing Feeble and Double Letters, trans. into Hebrew from the original Arabic by Moses Gikatilla, ed. from Bodleian Mss. with an English trans. by John W. Nutt (London and Berlin: Asher \& Co. 1870), 1: "And forasmuch as no one is left from whom we may learn the properties of the language, and none remaining from whom we may acquire all its meanings, but only what we may understand from the materials afforded in the holy Scriptures, and learn from the prophetical books; though that is but a small portion of the whole, inasmuch as the prophets did not come to employ the language in its full extent, but only so far as they required for their prophecy and vision."

Ibn 'Ezra, Kitâb almuhadara wal-mudk kâkara, 107b [p. 203]: "Everything you find in it [in the Bible], use it, but do not apply analogy to what you cannot find. Wherever language walks, you should walk, and wherever it stops, you should stop; be an imitator, not a creator; a follower, not an inventor" [in Hebrew, translation is mine].

53 CGLH, chap. 2 [p. 590].

54 Anthony J. Klijnsmit, "Spinoza over taal," Studia Rosenthaliana 19 (1985): 10-26. 
for another of the same organ, one may not follow this example. For if it were otherwise, then the dialects would confuse the language." 55

Since it is known that Spinoza attended the school of the Sephardic community in Amsterdam, it is important to know how grammar was taught for a better understanding of his Compendium grammatices linguae hebraeae. More information on the contents of his grammatical treatise, which happens to be much longer than other Hebrew grammars written by his contemporaries, is found in Antony J. Klijnsmit's studies. ${ }^{56}$

In the following paragraphs I would like to present some details on Spinoza's opinion that the existing grammars were unsatisfactory. Apart from the reproaches he made on the contents of the Hebrew grammars that preceded his, there is a formal aspect worth noting: his was the first Hebrew grammar written in Latin by a Jew. It is likely that, as Jelles said, the Compendium grammatices linguae hebraeae was addressed to some of Spinoza's friends who understood Latin and were interested in being able to directly access the biblical text. ${ }^{57}$

Guadalupe González Dieguez shared the general terms by which Spinoza presented a pejorative image of grammarians who preceded him, with an attitude that she rightly noted was clearly controversial. ${ }^{58}$ She shows a recurring identification in the two works which Spinoza specifically dedicated to linguistic issues (Compendium grammatices linguae hebraeae and the Tractatus Theologico-Politicus) between "grammarians," "idle masoretes," "rabbis," and "pharisees." This distinction was made in the texts as follows: "This is the Syriac script which Ezra preferred over the ancient Hebrew letters, and which the Pharisees superstitiously followed in their holy writings. In reality the authors frequently used other scripts." ${ }^{59}$ Spinoza identifies Masoretes, Pharisees, and Grammarians: "Therefore I will leave their minutiae to the Pharisees and idle

55 CGLH, chap. 2 [p. 590]. Actually, in his extensive treatment of Hebrew pronunciation, Spinoza proves himself an eclectic: He describes the pronunciation of the consonants as was common among the Portuguese in his time, and gives the Ashkenazic pronunciation of the vowels.

56 Klijnsmit, "Spinoza over taal," 1-38; id., "Amsterdam Sefardim," 158-63; Klijnsmit, "Some Seventeenth-Century Grammatical Descriptions," 92-96.

57 "The Concise Grammar of the Hebrew Language which is here offered to you, kind reader, the author undertook to write at the request of certain of his friends who were diligently studying the Sacred Tongue, inasmuch as they recognized him rightly as one who had been steeped in it from his earliest youth, was diligently devoted to it for many years afterward, and had achieved a complete understanding of the innermost essence of the language," CGLH, Notice to the Reader, [p. 587].

58 González Dieguez, Baruj Spinoza, 14-17.

59 CGLH, chap. 2 [pp. 589-9o]. 
Masoretes"; "Grammarians who have not understood anything." About the Masoretes he said: "And although these two things, vowels and punctuation marks, are usually replaced with full stops and accents, we cannot trust them, since they were invented and established by men of later times, whose authority should be worthless to us"; "The difficulty of interpreting Scripture has never arisen from the lack of forces of natural light, but only from the negligence, if not the malice, of men who neglected the history of Scripture, while they developed it"; "Clearly the rabbis were completely delirious, and the commentators that I have read, dream, fantasize and even corrupt language itself from its root." ${ }^{\prime 60}$ If Spinoza attributed ignorance and bad faith to rabbis, Pharisees, Masoretes, and Grammarians, he considered Kabbalists (with whom he did not even come into discussion) to be simply crazy, "I've read nothing in their writings which had the air of a secret, but only childish thoughts. I've also read, and for that matter, known personally, certain Kabbalistic triflers. I've never been able to be sufficiently amazed by their madness." ${ }^{61}$

Following González Diéguez, it is interesting to note that zealous advocates of rabbinic orthodoxy, such as Isaac Aboab da Fonseca himself or Menasseh ben Israel, were Spinoza's grammar teachers in the Ets Haim school in Amsterdam. This makes it easier to understand the relationship between Spinoza and Pharisees and the pejorative appellations he uses to identify them in the context between Phariseeism and Sadduceeism, which was somehow recovered and reactivated during those days in the Western Sephardic diaspora.

This naming results from the spiritual crises that arose within the Western Sephardic communities, a phenomena defined by Kaplan as the "intellectual ferment" that led, inter alia, to the excommunication of Uriel da Costa in 1623, Spinoza in 1656 , and Juan de Prado in $1658 .^{62}$ Those Sephardic communities did not grow and develop in an organic way, with each generation passing on the heritage of its ancestors. Among the so-called "New Jews" members of the

6o A similar position was held in the eleventh century by the great Hebrew linguist Jonah ibn Ğanah in Sefer ha-Riqmah (Kitab al-Luma), 11-12: "Those who take this science [grammar] most lightly and despise its problems, are those devoted to the science of the Talmud. They are arrogant because they have very little understanding of it. [...] They belittle this science and yet they learn what they learn in the Talmud in the wrong way, and study what they study incorrectly. [...] For knowledge of inflection and speech is sorcery for them, not far from heresy." [English translation is mine.].

61 TTP, chap. 9:136 [p. 217]. Possibly reference to Isaac Aboab da Fonseca and Menasseh ben Israel, although they would not have been the only Kabbalists in seventeenth-century Jewish Amsterdam.

62 Yosef Kaplan, "The Intellectual Ferment in the Spanish-Portuguese Community of Seventeenth-Century Amsterdam," [Hebrew] in The Sephardic Legacy, ed. Haim Beinart (Jerusalem: Magnes Press, 1992), 288-314. 
Spanish-Portuguese nation, there were individuals and groups who isolated themselves from normative Judaism by refusing to accept the yoke of Jewish law and rabbinic commandments. They also served as a focus of attraction for others who could join them at any time.

By expressing their uncertainties about the divine character of the Oral Law and the rabbinical regulations, those heterodox thinkers, whose approach was essentially individualistic, undoubtedly created an acute problem that disturbed the Sephardic diaspora in Western Europe. Immanuel Aboab wrote his Nomologia o Discursos legales, a comprehensive and detailed praise of the Oral Law, against those of his people already in Venice, between 1616 and 1625:63 "Who say and argue with stiffness of neck that one should not place one's faith in the true interpretation of the holy Torah, received by the ancient sages of Israel and taught by them, claiming that one understands scripture, whose perfection is beyond measure, from within itself, and that all of them will understand it fully with a little bit of study, and that one need merely read it and observe it as it is written." ${ }^{\prime 4}$

This adherence to the literal Scripture, disregard for Jewish Talmudic exegesis of the Bible, and the desire to be freed from the bonds of the "Pharisaic" tradition and customs subjected to the Oral Law, created the impression that this was a kind of Karaism not only at that time, but also in modern research. Although Imanuel Aboab does not use the name Karaites for those denying the Oral Law in his entire apologetic work, ${ }^{65}$ other authors who defended the authority of the rabbinical tradition mention Karaism in their works. However, as Kaplan showed, it was "not in application to any real group acting in the Spanish Portuguese Jewish society of their time."66

It is clear that Spinoza's controversial ideas concerning his Judaism, biblical criticism and interpretations, religious beliefs and practices, including an

63 The reasons for opposition to rabbinical authority in sixteenth- and seventeenth-century Venice originated in ideological difficulties experienced by some of the returning conversos, contemporary skepticism and political maneuvering in the Venetian community. See Moisés Orfali, "Faith and Power in the Struggle over Rabbinic Judaism in Venice during the Baroque Period," [Hebrew] Péamim 8o (Summer 1999): 44-59.

64 Moisés Orfali, ed., Nomología o Discursos Legales de Imanuel Aboab (Salamanca: Ediciones Universidad Salamanca, 2007), 76.

65 Ibid., 36-41.

66 Yosef Kaplan, "Karaites' in the Early Eighteenth Century," in An Alternative Path to Modernity. The Sephardic Diaspora in Western Europe, ed. Yosef Kaplan (Leiden-BostonCologne: Brill, 2000), 247. Kaplan there clarifies the matter: "In the Sephardic Jewish polemic literature of the seventeenth century the concept 'Karaism' had become synonymous with the schismatics and sectarians, and some writers used it as a general term for heresy and blasphemy." 
imaginary Karaism and more, led to his excommunication. ${ }^{67}$ In spite of his controversial opinions of the Hebrew grammarians before him, there are references to "grammarians" throughout the Compendium grammatices linguae hebraeae, where no polemic intent can be assumed. It should be remembered that some of the grammarians before him, such as Moses ibn Ezra, were regarded very highly by Spinoza, and even if he criticizes his predecessors, he makes crucial use of their achievements: he uses the commentaries of Rashi, Abraham ibn 'Ezra, and the grammatical works of the Qimhi and Abraham ben Me'ir de Balmes. ${ }^{68}$

\section{4}

\section{Conclusion}

In this chapter, I chose Aboab da Fonseca and Spinoza's Grammars as examples for showing the object of their grammar books: the Hebrew language or the language of the Scriptures.

Aboab's explicit concern was a need to produce a grammar of the language of the Scriptures in order to teach biblical Hebrew to children and old persons in the growing Jewish community of Dutch Pernambuco in northeast Brazil. He regarded it impracticable to attempt to teach Hebrew grammar in all its details to beginners. It was more profitable to deal with the main principles and uses which should form the basis for more advanced study. Aboab endeavored to avoid, as much as possible and practicable, references to the minute and manifold exceptions that appear in advanced Hebrew grammars.

Contrary to Aboab, Spinoza's aim was to write a grammar of the Hebrew language and not one of the Scriptures as many grammarians before him had done. Because his grammar was also meant to provide active knowledge of Hebrew, it is normative and prescriptive. Since Spinoza's friends, for whom his grammar was meant, were gentiles, he wrote his grammar in Latin, which was the scientific language outside the Jewish community.

67 Asa Kasher and Shlomo Biderman, "Why Was Baruch de Spinoza Excommunicated?" http://www.tau.ac.il kasher/pspin.htm, indicate that it could also have been related to public discussions he may have had on Cartesian philosophy; Cassuto, Spinoza hebraisant, 233: "A mon avis, l'une des raisons profondes de son excommunication réside dans son étude de la lettre, ce qui le fait apparenter au courant hérétique des défenseurs de la Lettre, c'est à dire les Qaraïtes."

68 See, for example, CGLH: chap. 3 [p. 592]; 7 [p. 6o4, the comment there is not in Rashi's commentary but in Ibn Ezra]. 


\section{Bibliography}

Aboab, Isaac. Paráfrasis comentado del Pentateuco. Amsterdam: Iaacob de Cordova $5441[1681]$.

Askénazi, Joël et Ashkénazi-Gerson, Jocelyne. Abrégé de grammaire hébraique. Paris: J. Vrin, $1968^{3}$.

Bodian, Miriam. Hebrews of the Portuguese Nation: Conversos and Community in Early Modern Amsterdam. Bloomington: Indiana University Press, 1997.

Cassuto, Philippe. Spinoza hebraisant L'hebreu dans l'“Tractatus theologico-politicus" et le "Compendim grammatices linguae hebrae." Leuven: Peeters Publishers, 2000.

Den Boer, Harm. La Literatura sefardí de Amsterdam. Alcalá de Henares: Universidad de Alcalá-Instituto de Estudios Sefardíes y Andalusíes, 1995.

Den Boer, Harm. Sephardic Editions, 1550-1820. Spanish and Portuguese Books Written and/or Published by Sephardic Jews of Early Modern Europe. Leiden: Brill, 2003-2005.

Elqayam, Avi. Sabbatean Millenarianism in the Seventeenth Century. A Study of Moshe Abudiente's Fin de los Dias. Los Angeles: Cherub Press, 2014.

Fuks, Lajb, and Renate G. Fuks-Mansfeld. Hebrew and Judaic Manuscripts in Amsterdam Public Collections. II. Catalogue of the Manuscripts of Ets Haim / Livraria Montezinos, Sephardic Community of Amsterdam. Leiden: Brill, 1975.

Giovanni, Licata. "Spinoza e la cognition universalis dell'ebraico. Desmitificazione e speculazione grammaticale nel Compendio di grammatical ebraica." Giornale di Metafisica 31 (2009): 625-61.

González Dieguez, Guadalupe. Baruj Spinoza. Compendio de gramática de la lengua hebrea. Intr., Trad. y notas de González Dieguez, Guadalupe. Madrid: Editorial Trotta, 2005 .

Ibn 'Ezra, Moseh. Kitâb almuhadara wal-mudk̂k̂kara-Sefer ha'Yiunim we-ha-Diyunim ('al ha-Širah ha-'Ibrit). Edited by Abraham Shlomo Halkin. Jerusalem: Mekize Nirdamim, 1975 .

Ibn Ğanah, Jona. Sefer Hariqma (Kitab Al-Luma'). Translated by Jehuda ibn Tibbon. Edited by Michael Vilenski. Berlin: Akademie-Verlag, 1930.

Kaplan, Yosef. "The Intellectual Ferment in the Spanish-Portuguese Community of Seventeenth-Century Amsterdam." In The Sephardic Legacy. Edited by Haim Beinart, 2: 288-314. Jerusalem: Magnes Press, 1992.

Kaplan, Yosef. Judíos nuevos en Amsterdam: Estudios sobre la historia sociale intelectual del judaísmo sefardí en el siglo XVII. Barcelona: Gedisa, 1996.

Kaplan, Yosef. “'Karaites' in the Early Eighteenth Century." In An Alternative Path to Modernity. The Sephardi Diaspora in Western Europe. Pp. 234-79. Leiden-BostonCologne: Brill, 2000.

Kaplan, Yosef. "El perfil cultural de tres rabinos sefardíes a través del análisis de sus bibliotecas." In Familia, Religión y Negocio. El sefardismo en las relaciones entre el mundo 
ibérico y los Países Bajos en la Edad Moderna. Edited by Jaime Contreras, Bernardo J. García García and Ignacio Pulido, 269-86. Madrid-Alcalá de Henares: Fundación Carlos de Amberes, 2002.

Kaplan, Yosef. "The Libraries of Three Sephardic Rabbis in Early Modern Western Europe." [Hebrew] In Libraries and Book Collections. Edited by Yosef Kaplan and Moshe Sluhovsky, 225-6o. Jerusalem: The Shazar Center, 2006.

Kayserling, Meyer. "Isaac Aboab, the First Jewish Author in America." Publications of the American Jewish Historical Society 5 (1897): 124-136, http://jawutrecht.files.word press.com/2012/11/out-26.pdf.

Kayserling, Meyer. “Rabbi Yitzhak Aboab ha-Šeliši." Ha-Goren 3 (1902): 155-74.

Klijnsmit, Anthony J. "Amsterdam Sephardim and Hebrew Grammar in the Seventeenth Century." Studia Rosenthaliana 22 (1988): 144-64.

Klijnsmit, Anthony J. “'Se qual o ouro entre todos os metáis.' Abudiente's Hebrew Grammar (1633)." In Die Sefarden in Hamburg. Zur Geschichte einer Mindehert. Heraugegeben von Michael Studemund Halévy in Verbindung mit Peter Koj, 319-374. Hamburg: Helmut Buske Verlag, 1994.

Klijnsmit, Anthony J. "Some Seventeenth-Century Grammatical Descriptions of Hebrew." Histoire Épistémologie Langage 12, no. 1 (1990): 77-101.

Klijnsmit, Anthony J. "Spinoza over taal." Studia Rosenthaliana 19 (1985): 1-38.

Melammed, Ezra Zion. Mepharshei Hamikra. 2 vols. Jerusalem: Magnes Press 1975.

Offenberg, Adri. "A Mid-Seventeenth-Century Manuscript of the (Unpublished) Hebrew Grammars of Menasseh Ben Israel and Isaac Aboab da Fonseca Recovered." Zutot 3 (2003): 98-107.

Offenberg, Adri. Menasseh ben Israel (1604-1657): Een Biografische Schets. Amsterdam: Menasseh ben Israel Instituut, 2000.

Orfali, Moisés. "Faith and Power in the Struggle over Rabbinic Judaism in Venice during the Baroque Period." [Hebrew] Pe'amim 8o (Summer 1999): 44-59.

Orfali, Moisés. Isaac Aboab da Fonseca:Jewish Leadership in the New World. Eastbourne: Sussex Academic Press, forthcoming.

Orfali, Moisés. "Observaciones sobre el Paráfrasis comentado del Pentateuco de R. Isaac Aboab da Fonseca y sus fuentes" eHumanista 20 (2012): 215-38.

Orfali, Moisés. "Paraphrastic Commentary to the Pentateuch by Isaac Aboab da Fonseca." In Portuguese Jews, New Christians and "New Jews": A Tribute to Roberto Bachmann. Edited by Bruno Feitler and Claude Stuczinsky, 334-6o. Leiden-Boston: Brill, 2018.

Orfali, Moisés, ed. Nomología o Discursos Legales de Imanuel Aboab. Salamanca: Ediciones Universidad Salamanca, 2007.

Pieterse, W. Chr. Daniel Levi de Barrios als geschiedschrijver van de PortugueesIsraelietiche Gemeente te Amsterdam in zijn "Triumpho del Govierno Popular." Amsterdam: Scheltema \& Holkema NV, 1968. 
Rubin, Solomon. Compendium grammatices Linguae Hebraeae. Podgórze-Krakow: Drukiem I nakladem Józefa Plessnera i Ski., 1905.

Sáenz Badillos, Ángel. "David de Cohen Lara y sus dos vocabularios rabínicos." In Los Judaizantes en Europa y la Literatura Castellana del siglo de Oro. Edited by Fernando Díaz Esteban, 341-49. Madrid: Letrúmero, 1994.

Silva Rosa, Jacob S. da. "Iets over den Amsterdamschen Opperabijin Isaäc Aboab." Centraalblad voor Israelieten in Nederland 29 (1913): nos. 39-41.

de Spinoza, Benedict. Compendium grammatices linguae hebrae, in Spinoza. Complete Works. With translations by Samuel Shirley, edited with introduction and notes by Michael L. Morgan. Indianapolis-Cambridge: Hackett Publishing Company, 2002.

de Spinoza, Benedict. De Nagelate Schriften van B.D.S. als Zedekunst, Staat-kunde, Verbetering van 't verstand, Brievben en Antwoorden uit Verscheide Talen in de Nederlandesche Gebracht. Amsterdam: Jan Rieuwertsz, 1677.

de Spinoza, Benedict. Tractatus Theologico-Politicus, in The Collected Works of Spinoza. Translated and edited by Edwin Curley. Princeton, NJ: Princeton University Press, 2016.

Wiznitzer, Arnold. "The Minute Book of Congregations Zur Israel of Recife and Magen Abraham of Mauricia, Brazil." Publications of the American Jewish Historical Society 42 (1953): 217-302.

Wiznitzer, Arnold. Jews in Colonial Brazil. New York: Columbia University Press, 1960. Yerushalmi, Yosef Hayim. "The Re-education of Marranos in the Seventeenth Century." In The Third Annual Rabbi Louis Feinberg Memorial Lecture in Judaic Studies, March 26, 1980. Pp. 7-11. Cincinnati: University of Cincinnati, 1980.

Yerushalmi, Yosef Hayim. From Spanish Court to Italian Ghetto. Isaac Cardoso-A Study in Seventeenth-Century Marranism and Jewish Apologetics. Seattle and London: University of Washington Press, 1981.

Yerushalmi, Yosef Hayim. "Connaisance du judaïsme et préparation spirituelle chez les marranes revenues au judaïsme au cours du XVII' siècle." In Sefardica. Essais sur l'histoire des juifs, des marranes \& des nouveaux-chrétiens d'origine hispanoportugaise. Pp. 235-54. Paris: Chandeigne, 1998. 


\title{
New Jews in Amsterdam: Some Social Aspects Reflected in the Thesouro dos Dinim by Menasseh ben Israel
}

\author{
Aliza Moreno-Goldschmidt
}

The main goal of the present study is to analyze selected excerpts from Menasseh ben Israel's Thesouro dos Dinim in order to extract his personal approach regarding former conversos who joined the Amsterdam Jewish community, as well as those who remained in the Lands of Idolatry. ${ }^{1}$ In order to understand the relevant background, the paper will include a brief description of the genre, that is to say, the halakhic manuals in Spanish and Portuguese published during the sixteenth and seventeenth centuries. It will also present a concise account of the changes in the halakhic status of the former conversos until the time of Menasseh ben Israel.

Menasseh ben Israel, one of seventeenth-century Jewish Amsterdam's most prominent figures, has also been one of its most studied. However, his halakhic work Thesouro dos Dinim, considered by some to be one of his least original or innovative writings, has aroused little interest. Modern scholars share this disinterest, but it also afflicted Menasseh ben Israel's contemporary colleagues. As Asa Kasher demonstrated, in contrast to the reputation that Menasseh ben Israel gained among non-Jewish intellectuals (who were obviously uninterested in his Jewish legal writings), his reputation as a legal scholar among the rabbinical leaders of his time was hardly outstanding. ${ }^{2}$ Nevertheless, whatever his rabbinical colleagues may have thought, the actual impact of Menasseh's work within the Jewish world — as a writer and communal religious leaderwas significant especially among the New Christians who returned to Judaism in Amsterdam and elsewhere in the Western Sephardic diaspora. Even if his halakhic work (specifically, his Thesouro dos Dinim) fails to be one of the most outstanding halakhic essays of his time, it should be a primary source for the study of the social and religious history of his day. Just as Sina Rauschenbach

1 The common term used at the time referring to those lands where the practice of Judaism was prohibited, and in particular Spain, Portugal and their colonies.

2 Asa Kasher, "How Important was Menasseh ben Israel?" in Menasseh ben Israel and His World, ed. Yosef Kaplan, Henry Méchoulan and Richard H. Popkin (Leiden: Brill, 1989), 220.

(C) ALIZA MORENO-GOLDSCHMIDT, 2019 | DOI:10.1163/9789004392489_019

This is an open access chapter distributed under the terms of the prevailing CC-BY-NC License at the time of publication. 
considers Menasseh's theological writings his method for mediating Jewish knowledge to the non-Jewish intellectuals, ${ }^{3}$ I would propose that Thesouro dos Dinim was Menasseh ben Israel's method of mediating Jewish practice to the former conversos who returned to Judaism.

Were we to ask the author, he would probably also judge Thesouro dos Dinim one of his less original works. In fact, in the book Menasseh explicitly declares his commitment to the rabbinic tradition, asserting that his only intention is to facilitate traditional Jewish practice by writing a book in both the language and style most accessible to his community. Many of his readers only adopted normative Judaism as adults after they arrived from the Iberian Peninsula. In contrast to other philosophical and mystical fields in which Menasseh ben Israel, as Yosef Dan stated, "chose in complete freedom whatever suited him, and rejected other elements,"4 in the realm of Jewish law he was uncompromisingly loyal to traditional Jewish law as he understood it. He had neither any intention nor ambition to propose even the slightest change or innovation.

So, if Menasseh ben Israel did not intend to write an original work, how can we extricate his own voice from the text - a text that was merely meant to translate existing Jewish practice into a language his community members could understand? Although Menasseh did not state what were his rabbinical sources and did not openly proclaim that the Thesouro dos Dinim was largely a literal translation or adaptation of Yosef Caro's Shulhan Arukh ${ }^{5}$ into Portuguese, a comparison between the two texts leads to the undeniable conclusion that this was his main source. In fact, it is interesting that he did not mention even a single time in any of the five parts of the Thesouro, either the Shulhan Arukh or its author Yosef Caro. ${ }^{6}$ Probably by the time Menasseh ben Israel wrote this work, the halakhic authority of the Shulhan Arukh was so spread in his cultural

3 Sina Rauschenbach, "Mediating Jewish Knowledge: Menasseh ben Israel and the Christian Respublica litteraria," Jewish Quarterly Review 102, no. 4 (2012): 561-88.

4 Yosef Dan, "Menasseh ben Israel: Attitude Towards the Zohar and Lurianic Kabbalah," in Menasseh ben Israel and His World, ed. Yosef Kaplan, Henry Méchoulan, and Richard H. Popkin (Leiden: Brill, 1989), 201.

5 The Shulhan Arukh is a practical and detailed manual of Jewish law published in Safed in 1565 by Rabbi Yosef Caro in Hebrew. Since its publication, and with the additions made by Rabbi Moshe Isserles known as the Mapah (that include the Ashkenazic customs, in addition to the Sephardic ones), the Shulhan Arukh became the supreme halakhic authority in the traditional Jewish world, a reality that continues to the present day.

6 In contrast, the author did mention, on few occasions, other rabbinical authorities, mainly Maimonides. See for example, Thesouro dos Dinim, Part IV, Cap. IV; Part v, Cap. IV; Part v, Cap. XXviII. 
and social context that the author felt no need to state what his main source was, but took it for granted that the readers will be aware of this fact.

The present study will be based on a thorough comparison of Thesouro dos Dinim and its main source, the Shulhan Arukh. Since we are trying to extract Menasseh ben Israel's voice, any part of the text that was translated from the Shulhan Arukh won't be useful to us. On the contrary, I will take into account only those parts that differ from Yosef Caro's work, that is to say, any additions or omissions and the cases in which the author utilizes a Jewish source that is not the Shulhan Arukh (cases in which it will be relevant to ask, what were Menasseh's reasons for choosing a different source?).

As Yosef Dan has systematically demonstrated, ${ }^{7}$ if we can determine Menasseh ben Israel's source, we can also learn from his silences. In some contexts, the decision of the Thesouro dos Dinim's author not to include a specific subject can lead us to important conclusions. However, this methodological tool must be used cautiously so as to avoid unfounded speculation. Therefore, I will only point out a few of his omissions and will focus primarily on his additions.

Halakhic Manuals in Ladino, Portuguese, and Spanish

Before beginning the textual analysis, it is also important to understand the sixteenth-century intellectual context of Thesouro dos Dinim and other similar period works. Menasseh ben Israel was neither the first, nor the last, author to publish halakhic manuals in the vernacular in the Eastern and Western Sephardic diasporas. In fact, the publication of various halakhic texts in Ladino, Spanish, and Portuguese may be considered one of the peculiarities of those communities, during a period when halakhic literature was exclusively published in Hebrew or Aramaic in other Jewish centers.

The oldest work of this kind was a translation into Ladino of extracts from Yosef Caro's Shulhan Arukh under the name Meza de el Alma by Meir Ben Shmuel ben Ban Benst (Benbeniste), ${ }^{8}$ published in Salonica in 1568 - around a decade after the Shulhan Arukh's first publication, while Caro was still alive-and reprinted in Venice in 1602 . This was not only the first translation

7 Dan compares Menasseh ben Israel's Nishmat Hayyim with the concepts of the Zohar, and reconstructs its mystical views pointing out the ideas that were adopted from the Zohar and those that were omitted as well. See Dan, "Menasseh ben Israel," 200-2.

8 See Dov Cohen, "The Ladino Bookshelf: Research and Mapping," (Hebrew) PhD diss., BarIlan University, 2011, 178-86. 
into Ladino, but the very first translation of the Shulhan Arukh into any other language. In accord with the norms and customs prevailing in the Ottoman Empire's Sephardic publishing world, this Ladino edition was printed in Hebrew characters. ${ }^{9}$ The selections included in this lengthy work are very much a literal, however sometimes partial, shortened or paraphrased ${ }^{10}$ translation of its source. In 16o9, Moses Altaras published the Libro de Mantenimiento de la Alma in Venice. This work seems to be a revised edition of the Mesa de el Alma ${ }^{11}$ the main difference being the use of Latin characters. ${ }^{12}$

Isaac Athias, who was a religious leader of Hamburg's Portuguese congregation and later settled in Italy, published his Tesoro de Preceptos in Venice in 1627. It was reprinted in Amsterdam in 1649. This book, written in Spanish, details the 613 Jewish precepts, that is to say, the Jewish tradition's 613 biblical commandments. This text analyzes each precept and its significance. As stated in his prologue, Athias bases his book on Maimonides's Sefer ha-Mitzvot, in terms of, among other things, the enumeration, organization, and division of the contents into positive and negative commandments. In his introduction,

$9 \quad$ As mentioned by Levi, the Jews in the Ottoman Empire regularly used both Hebrew and Ladino, but for different purposes. While Hebrew was the language used for religious, liturgical, legal, and official community issues, Ladino was the spoken language used in informal, family, and commercial contexts. In fact, during the first two centuries after the expulsion there were almost no Ladino publications, but a few books and translations of the Bible published on the second half of the sixteenth century. Avner Levi, "The First Translation of the Shulhan Arukh into Ladino," [Hebrew] in History and Creativity, ed. Tamar Alexander et al. (Jerusalem: Misgav Yerushalayim, 1994), 56-57. Thus, it is not surprising that the book Meza de el Alma, which presents halakhic contents in Ladino language, lead to controversy in the community of Salonika prior to its publication. See more details about this controversy in Levi, there, 61-64.

10 The translation of Orah Hayim and Yoreh De'ah is relatively detailed, whereas the translation of Even Ha-Ezer and Hoshen Mishpat is very brief. See Ora (Rodrigue) Schwarzwald, "Ladino Instructions in Meza de el Alma and Seder Nashim from Thessaloniki in the 16th Century," in Around the Point: Studies in Jewish Literature and Culture in Multiple Languages, ed. Hillel Weiss, Roman Katsman and Ber Boris Kotlerman (Newcastle Upon Tyne: Cambridge Scholars Publishing, 2014), 122-33. See also Ora (Rodrigue) Schwarzwald, "The Hebrew Component in the Ladino of Two Books by the Same Author," [Hebrew] in Nit'e Ilan: Studies in Hebrew and Related Fields Presented to Ilan Eldar, ed. Moshe BarAsher and Irit Meir (Jerusalem: Carmel, 2014), 400-1. See also Cohen, "The Ladino Bookshelf," 178 .

11 The similitude between the two texts, led Amzalak to the wrong conclusion that they were in fact the same book. See Moses Bensabat Amzalak, A tradução espanhola do livro de Joseph Caro [Shulhan ha-panim] feita por Mosé Altarás sob a denominação de "Libro de Mantenimiento de la Alma" (Lisbon: Of. Grâf. do Museu Comercial de Lisboa, 1927).

12 In spite of the original author's injunction that the book should never be printed in Latin letters. See Robert Singerman, Jewish Translation History (Amsterdam: J. Benjamin, 2002), 326. 
the author also clarifies that he will mainly deal with the precepts and will only include some, but not all, of the dinim (the details of the laws).

During 1627 , the same year that Athias published his first edition in Venice, Abraham Pharar published a similar text in Amsterdam. While written in Portuguese, his book also focused on the 613 precepts. Like Athias, he also decided to use Maimonides's enumeration; however, he also included a table where he categorized the precepts according to the parshiyot (the weekly Torah reading). This encouraged his readers to learn the precepts corresponding to the weekly Torah reading.

In spite of the fact that Menasseh ben Israel's Thesouro dos Dinim was not the first vernacular manual on Jewish practice written in the Western Sephardic diaspora, it was the first halakhic text that focused on the dinim and pretended to be an original text rather than a literary translation of the Shulhan Arukh. It was the first, but not the last. In 1668, David Pardo, at the time a cantor in London's Portuguese community, published a halakhic work entitled Compendio de Dinim que todo Israel Deve saber y Observar ${ }^{13}$ in Amsterdam. Some years later, in 1671, Hakham Abraham Vaez of Kaal Nefuzot Yehuda of Bayonne published the Arbol de vidas en el qual se contiene los Dinim más necesarios que debe observar todo Ysrael, presumably in Amsterdam. ${ }^{14}$

\section{The Halakhic Status of Former Anusim-Historical Background}

As previously noted, the Thesouro dos Dinim is not an original halakhic work, but an adapted version of the Shulhan Arukh, the main aim of which was to teach the Jewish Law to the former New Christians in order to facilitate their social and religious integration into the normative Jewish community of Amsterdam. In spite of the fact that Menasseh ben Israel did not at any time manifest either an intention to define the halakhic status of the former anusim or pretend to innovate in any of the many relevant particular halakhic aspects, I suggest that a detailed analysis of the Thesouro dos Dinim may lead us to an interesting understanding of the social reality of the New Jews in Amsterdam during the seventeenth century.

13 David Pardo, Compendio de Dinim que todo Israel Deve saber y Observar. Compuesto por estilo fácil y Breve (Amsterdam, 1669).

14 Abraham Vaez (del Kaal de Nefuzot Yehuda, Bayona) Arbol de vidas en el qual se contiene los Dinim más necesarios que debe observar todo Ysrael. Sacados de Varios y Graves autores (Amsterdam?, 1671). 
In order to understand the relevant background and the peculiarities of Menasseh ben Israel's statements, I will present a brief summary of the development of the former-anusim's halakhic status in historical perspective.

The question of the halakhic status, as well as other halakhic issues related to the conversos and former conversos in the peculiar circumstances in Spain between 1391 and 1492 (and even in earlier times), and afterwards among the Sephardic diaspora, was without doubt a topic that occupied the religious leaders of the day. Moreover, many important modern studies have addressed this particular aspect in the cultural history of the Sephardic diaspora. ${ }^{15}$

However, it is fundamental to distinguish the different circumstances among the diversity of communities, as well as the different periods in which the halakhic status of the former conversos was discussed. It is not surprising that most of the modern studies in fact refer to the rabbinical responsa produced between the fifteenth and the sixteenth centuries, close to the mass conversions and expulsions. But was the same law, ruled out for a person who converted to Christianity and returned to a Jewish community during his lifetime, applicable to the case of the conversos who joined a Jewish community in Amsterdam or other western cities more than a century later and after having been disconnected from normative Judaism for generations? Moreover, the great mass of this halakhic literature refers to status of the anusim in specific situations or contexts such as inheritance, wine trade, issues related to family law (divorce, levirate marriage, etc.), ${ }^{16}$ while they were still living in Lands of Idolatry.

15 See for example, Benzion Netanyahu, The Marranos of Spain-From the Late 14th to the Early 16th Century, according to Contemporary Hebrew Sources, 3rd ed. (Ithaca and London: Cornell University Press, 1999); Moisés Orfali, Los conversos españoles en la literature rabinica-Problemas jurídicos y opiniones legales durante los siglos XII-XVI (Salamanca: Universidad Pontificia de Salamanca: Universidad de Granada: Federacion Sefardí de España, 1982); Simon Schwarzfuchs, "Le Retour des Marranes au Judaïsme dans la littérature rabbinique," Xudeus e Conversos na Historía 1 (1994): 339-48; Elias Lipiner, "Spanish and Portuguese Conversos Facing Halakhic Problems," [Hebrew] in Portuguese Jewry at the Stake, ed. Yom Tov Asis and Moisés Orfali (Jerusalem: Magnes Press, 2009), 127-42; Alisa Meyuhas Ginio, "La actitud de los rabinos sefaradíes del imperio Otomano ante los conversos: el caso del Yavam Mesummad," in La mujer judía, ed. Yolanda Moreno Koch (Córdoba: Ediciones El Almendro, 2009), 129-48; Dora Zsom, "The Return of the Conversos to Judaism in the Ottoman Empire and North-Africa," Hispania Judaica Bulletin 7 (2010): 335-47; Juan Bejarano-Gutiérrez, "Rabbinic Responsa and the Jewish Status of Conversos," Journal of Spanish, Portuguese, and Italian Crypto Jews 4 (2012): 35-44; Matt Goldish, "Hakham Jacob Sasportas and the Former Conversos," Studia Rosenthaliana 44 (2012): 149-72.

16 For example, Orfali presents some cases of these and other issues from earlier sources until the sixteenth century. See Orfali, Los conversos españoles, 1-28; Meyuhas Gino 
The most important and influential precedent for the definition of the halakhic status of the conversos were Maimonides's writings and in particular his Iggeret ha-Shemad. ${ }^{17}$ In this epistle Maimonides sent a detailed answer to a group of Jews who were forced to convert to Islam. His halakhic conclusions in this text were: ${ }^{18}$ first, individuals who convert to another religion in times of persecution did not accomplish the mitsvah of kiddush ha-shem, ${ }^{19}$ but nor are they are blamed of hillul ha-shem; ${ }^{20}$ second, if one is obligated to convert to another religion but the conversion implies only a verbal compromise and not acts, and it is possible to keep the Jewish precepts in secret, this is a legitimate way to confront this historical situation. And if a religious authority is asked for advice in this situation, he should counsel the conversion and not the martyrdom; ${ }^{21}$ third, in this situation there is no blame placed on the person that converted to another religion, but only if he violates the Sabbath without being obligated to do so; ${ }^{22}$ fourth, in this situation the obligation of the individual is to keep the tradition and the laws as much as he can. And in the event that he violated a specific law, he should keep all the others (even if it seems to him as less important than those which he has violated); ${ }^{23}$ lastly, this situation is legitimate only in so far as he was unable to leave the lands of persecution. The individual is obligated to move to another place where he will be able to fully practice Judaism at the first opportunity, and if he decides to stay by his own choice, he is then considered to be mehalel ha-Shem. ${ }^{24}$

In contrast to Maimonides's epistle, most of the halakhic literature after the mass conversion in Spain in 1391 and the expulsion in 1492 focused on specific matters. However, it is also true that the general question of the Jewishness of

focuses her study on the laws of levirate marriage in the Ottoman Empire, see Mayuhas Gino, "La actitud de los rabinos sefaradies," 129-48.

17 See an English translation of the epistle, Maimonides, Crisis and Leadership: Epistles of Maimonides, trans. Abraham Halkin, with discussion by David Hartman (Philadelphia: Jewish Publication Society of America 1985), 15-45. Among the many studies on this text, see two different approaches: ibid., discussion by David Hartman, 46-90; Haym Soloveitchik, "Maimonides' Iggeret ha-Shemad: Law and Rhetoric," Collected Essays (Oxford: Littman Library of Jewish Civilization 2014), 2:288-330; and Soloveitchik, "Response to David Hartman," ibid., 331-37.

18 This numeration was added by the article's author in order to emphasis the main points, but is not found in Maimonides original text.

19 Sanctify the name of God (martyrdom).

20 Profane the name of God; Maimonides, Iggrot ha-Rambam (Jerusalem: Mosad HaRav Kook, 1960), 58-59.

21 Ibid., 61-62.

22 Ibid.

23 Ibid., 62-63.

24 Ibid., $64-66$. 
the later generations of anusim might be found in a few places. For example, Rashbash (Rabbi Shimon ben Shelomo Duran, 1361-1444), stated that the general presumption should be that the conversos did not marry Gentiles and that the mother of a returning converso was of Jewish descent. ${ }^{25}$ But was this presumption applicable more than two centuries later? According to Rashbash, as long as their origin can be traced to a Jewish mother, albeit a converted one, they must be considered members of the Jewish people and, as such, regarded as "our brethren."26 Keeping in mind the actual attitude of the Jewish communities two centuries later, we may infer that the main impact of Rashbash's responsa was his call to consider the anusim as a potential part of the Jewish people. In contrast, the requirement to verify the maternal Jewish line was not as much applied.

As far as I have been able to discover, there is no written record of a halakhic attempt to address and define the peculiar seventeenth-century phenomenon. It doesn't mean that the halakhic tradition was not taken into account. On the contrary, the main point is that only the existing law was considered, without taking into consideration the new historical context and reality. Goldish has already pointed out (referring to the Sasportas case) that "most of the precedents concerning the treatment of conversos came from the fifteenth or early sixteenth centuries, or even earlier. This anachronism has consequences in legal decisions because Sasportas and others [halakhic authorities] still appear to be deciding issues based on conditions that had changed significantly since the precedent cases were adjudicated." 27

As mentioned before, the concept of anusim is an old existing legal category that recognizes the special circumstances in times of persecutions. The central point of discussion, in older halakhic discussions as well as in the particular case of Iberian anusim, regards the point when the person can no longer be considered anus, because he could have left the dangerous place but didn't. ${ }^{28}$ From this halakhic perspective, the better sign of compromise with Judaism is the act of leaving the Lands of Idolatry and the will to join a normative Jewish community. One of the most representative texts that reflects the general positive rabbinical attitude regarding the reintegration of the conversos into normative Judaism is found in one of the assertions of the rabbinical judge Binyamin Zeev (Greece, sixteenth century), quoted by Zsom: "we consider them

25 Quoted and translated from Hebrew by Zsom, "Return of the Conversos," 346.

26 The text has been paraphrased and translated into English by Netanyahu, there, p. 45. See the original text in Hebrew, Rashbash, Responsa (Livorno,1742) 89: 17a.

27 Goldish, "Hakham Jacob Sasportas," 157.

28 See, for example, in Ribash, Responsa, 4, 1c. This position is very similar to Rambam's position in Iggeret ha-Shemad. 
[the anusim who stayed in Lands of Idolatry] Jews so that they return, lest we close the doors of repentance before them. But in the strict sense of the Law we should penalize them for staying there." However, it seems strange that this continued to be the focus of the halakhic discourse in the seventeenth century and not the challenge of the very Jewishness of a significant number of former New Christians, who had lived as Christians for over a century—during which time they did not necessarily practice endogamy or preserve the maternal lineage- and were integrated into the Jewish community.

In fact, during the seventeenth century, people coming from Spain and Portugal who regarded themselves as anusim, were integrated into the Western Jewish community without any special theoretical discussion about their particular halakhic status. ${ }^{29}$ In an interesting article already mentioned above, Matt Goldish addressed the approach of Sasportas - one of the prominent rabbinical authorities in the seventeenth-century Western Sephardic diaspora-regarding the way to deal with conversos who had escaped the Iberian Peninsula and now wanted to join the Jewish community. From Goldish's article, it appears that, in contrast to other rabbinical authorities of these communities, this rabbi was particularly critical and severe in the way he conceived the process of return of the conversos to the bosom of normative Judaism. However, his criticism and rigidity had nothing to do with the maternal Jewish lineage of the conversos but with his expectation of an absolute compromise to the Jewish law and faith by the new Jews. As formulated by Goldish, "Sasportas's praise for returning conversos lasted only as long as those persons maintained a legally and theologically impeccable Jewish life."30

Thus, given the fact that the rabbinical authorities of the Western Sephardic diaspora did not openly discuss the peculiar halakhic situation of the seventeenth-century New Jews, let's try to understand their position from another perspective. What requirements did the religious authorities impose on those arriving from the Iberian Peninsula to join the Jewish community? Generally speaking, when a person arrived in the Western Sephardic diaspora communities an informal inquiry took place. The person was asked about his family, the specific place where he came from in Spain or Portugal, and sometimes people from the same native town recalled the newcomer's relatives whom they had known. On other occasions, the arrival of newcomers from Iberia

29 Zsom mentioned some halakhic questions regarding the Jewishness of the conversos found in the context of the responsa in the Ottoman Empire. However, this author did not prove the existence of any systematic inquiry prior to the integration in the community in this geographic area. See Zsom, "Return of the Conversos," 344-45.

Goldish, "Hakham Jacob Sasportas," 159. 
was an opportunity for community members to inquire about their own relatives who had remained in the Lands of Idolatry. However, it would be hard to characterize this custom as a legal inquiry into the New Jews' Jewishness. These converso families had been living as Christians for over a hundred years. Although in specific areas some sort of endogamy was preserved, doubtless in many cases the Jewish maternal lineage was uncertain. This notwithstanding, on the one hand, proving this biological continuity was not a requirement for joining the community. On the other hand, the inclusion of the newcomers, at least the male ones, was not automatic but included a defined rite of passage - circumcision (even those who were already circumcised had to spill a symbolic drop of blood, a process known as hatafat dam). As Kaplan and other scholars have noted, this rite had tremendous importance in its historical context. ${ }^{31}$ However, and in spite of the fact that circumcision is part of the Jewish conversion rite, it is difficult to identify the performance of this rite with a formal conversion because the other elements in the conversion process, especially the immersion in the ritual bath, were not required.

As mentioned above, in spite of the disconnection of generations from normative Judaism, no formal inquiry about the maternal lineage was done as a requirement for the former conversos to join one of the Western Sephardic Jewish communities. Lipiner presented an interesting example, ${ }^{32}$ which should be understood as the exception that proves the rule. In the context of a halakhic inquiry that lasted for more than a decade during the first half of the seventeenth century regarding the right of inheritance of a man named Yaacov Penso who was a former converso and who arrived as a child from Portugal to Venice, several testimonies were collected in Venice and the Ottoman Empire (Istanbul), where he went to study Torah and became a renowned scholar. ${ }^{33}$ The inquest was trying to determine whether Yaacov's mother, who was born in and never left Portugal, was of Jewish origins (m'zera yisrael), in which case, Yaacov will inherit, together with the other sons of his father. Among the testimonies were contradictory versions about Yaacov's mother's origins. This example is extremely significant. On the one hand, these documents constitute conclusive proof that the religious leaders of the Sephardic diaspora communities were aware that not all the anusim in Spain and Portugal had kept a strict endogamous lineage. On the other hand, it draws attention to the fact that

31 Yosef Kaplan, "Attitudes towards Circumcision among the Early Modern Western Sephardim," [Hebrew] in From Sages to Savants—Studies Presented to Avraham Grossman, ed. Joseph Hacker, Yosef Kaplan and Benjamin Z. Kedar (Jerusalem: The Zalman Shazar Center for Jewish History, 2010), 353-89.

32 Lipiner, "Spanish and Portuguese Conversos," 138-40.

33 Simha Assaf, Be-Ohalei Ya'akov (Jerusalem: Mossad Harav Kook, 1965), 160. 
this kind of inquiry, namely, a search of the mother's lineage, was not a matter of routine when a former converso joined the Jewish community, but it took place only in specific and special instances (that were the great minority of the cases), as in the above-mentioned case when an inheritance issue was to be determined. At the time the inquiry began, Yaacov Penso was already living and known as a Jew for many years and never before was he, or any other member of his family, questioned about their maternal lineage.

\section{$3 \quad$ Menasseh ben Israel's Attitude toward Anusim and Former Anusim}

Menasseh ben Israel wrote his practical compendium for a specific audience. He explicitly declared that it was written for the new members of his community who were willing to learn and adopt Jewish law, but couldn't read Hebrew. He wrote it for them, but he had no intention of composing a new guide for the New Jews; rather, he wished to translate the extant, black letter law for them. For that reason, nowhere in his work did he provide a halakhic definition of the New Jews' status. Consequently, in order to understand his position, we will need to extricate it from different parts of his work, building a comprehensive picture from a plethora of different contexts.

Menasseh ben Israel translated the concepts anus and ger as "forçado" and "peregrino," respectively. Regarding the concept "forçado," the author did not maintain his clinical, scholarly distance, but several times became emotionally involved, applying this concept to his own historical reality. In contrast to Yosef Caro, for whom the meaning of the concept was obvious, the first time our author used it, he added a short explanation: "Os forçados, e saõ os que foraõ por força mudados a outra religiaō e vivẽ donde naõ podẽ obseruar a sua" (the forced, that is to say, those who were obligated to adopt another religion and lived where he could not observe his own faith). This notwithstanding, it seems like Menasseh only applied this concept to those who still remained in Spain or Portugal. Once they moved to free lands, this term was evidently not relevant since they were no longer "forced."

Furthermore, Menasseh appears to have had a very negative opinion of the contemporary anusim and his halakhic rulings on this subject were much more stringent than those of the halakhic authorities he was reflecting. For example, the Shulhan Arukh (Yoreh De'ah § 124:9) discusses the anusim's wine and concludes that since they cannot avoid non-Jewish touch, their wine cannot be trusted, but they can be trusted as intermediaries in the kosher wine trade. Rema (Rabbi Moses Isserles), commenting on this law, debated whether 
the anusim's touch makes wine impure or not. Rema distinguished between two different kinds of anusim: those who violate the law in public, but not in private, and those who violate the law in both. Rema rules that the former's touch does not taint the wine, but the latter's does. According to Rema, those anusim who postponed their departure from the lands where they were under duress for economic reasons were appointed among those whose touch did not taint the wine, in other words, according to Rema, economic reasons were legitimate reasons to remain, at least temporarily in the Lands of Idolatry.

Menasseh ben Israel included Rema's commentary but omitted this permissive ruling, stating that remaining in enemy lands can only be legitimized if an individual has made every possible effort to leave and move to a place when he can freely observe all the laws without exception. From this we may infer that according to Menasseh ben Israel, even those anusim who only violate the law in public - but won't leave the oppressive lands despite the fact that they could - also taint the wine. According to Lipiner, the religious leaders of the time ${ }^{34}$ adopted an innovative and more permissive position about the anusim who remained in Lands of Idolatry, considering it a justified situation, even when they only adopted a partial observance of the Jewish law, as best they can ("kefi yekholtam"). ${ }^{35}$ This affirmation may reflect the opinion of some specific religious leaders, but it seems to be irrelevant to generalize as if it was the universally accepted halakhic position among the rabbis of the communities that received and absorbed former conversos. For instance, Menasseh ben Israel's text reflects a much severer position toward those anusim who remained in the Lands of Idolatry, indifferent to whether they partially observed Jewish Law or not. In addition, Lipiner's opinion seems to be mainly founded on the responsa of Rashbash and of Jachin ve-Boaz, but it must be taken into account that Rashbash lived in Spain even before the institution of the Inquisition and the expulsion, and the Jachin ve-Boaz responsa was written in North Africa during the fifteenth century. Evidently these books refer to a halakhic view that reflect a very different historical circumstance.

Both Rema and Menasseh ben Israel discuss anusim again when they address the subject of martyrology, that is to say, cases in which a person should refuse to transgress halakha even at the risk of losing his life. Both authors agree that in such a situation, those who transgress are considered under duress and, therefore, are exempt from punishment despite having profaned God's name. Both agree that if someone transgresses when he could have escaped, then the sin is considered intentional, and the sinner is deemed an intentional sinner.

34 It is not clear what are the chronological and the geographical limits of Lipiner's affirmation.

35 Lipiner, "Spanish and Portuguese Conversos," 137. See also n. 19, there. 
Here, there is no discrepancy between the two authors regarding the law; ${ }^{36}$ however, Menasseh added a passage that is even more extreme in its criticism of this phenomenon: "e tal se chama voluntario idolatra, e he privado da Gloria do outro mundo, e sera condenado ao infimo lugar do inferno" (this is a person who idolizes by choice, and will be deprived of the glory of the other world, and shall be condemned to the lowest place of hell). ${ }^{37}$

Menasseh ben Israel was extremely critical of the Spanish and Portuguese anusim who remained in the Lands of Idolatry, given that, in his opinion, there was no excuse to remain since they all could have moved and joined a normative Jewish community. ${ }^{38}$ However, just as he was critical of those who stayed, he was also extremely anxious to embrace those who left. An interesting and subtle example of this tendency is found in his halakhic discourse on abandoned babies. In the Shulhan Arukh, Even ha-Ezer $§ 4: 33$, Yosef Caro rules on the legal status of an abandoned baby discovered in a place where Jews and nonJews live side by side. Caro rules that such a child will be considered non-Jewish by his contemporaries, that is to say, they will assume that his mother was not Jewish, but if he marries and divorces a Jewish woman, he will be required to write a writ of divorce (get) like a born Jew. (The reason for these two rulings goes unexplained in the Shulhan Arukh, but they are promulgated to avoid creating mamzerim. ${ }^{39}$ ) Menasseh ben Israel included this regulation in his work and remained quite faithful to his source, the Shulhan Arukh, but in contrast to the aforementioned examples, here he omitted Rema's commentary.

While it is true that Menasseh ben Israel did not always include Rema's opinion and that his primary loyalty lay with Caro, in this opportunity he chose to mention a case by Rema, and which Caro had ignored, that was extremely

36 According to Lipiner it was common among the instructors of the former conversos willing to join a Jewish community, to carry out an investigation in order to determine whether the returnees in fact did everything in their power to escape from the lands of idolatry at the first opportunity. Lipiner, "Spanish and Portuguese Conversos," 131. Regrettably the author did not quote any specific case or source nor the time or place were those inquiries occurred. As far as I know there is no evidence of similar trends among the instructors in the community of Amsterdam.

37 Thesouro dos Dinim, Part. II, Cap. XXI, 3.

38 At the time of the expulsion not everyone who opted to leave the Iberian Peninsula was as critical, but some even justified the decision of individuals to remain under certain terms. See, for example, Shelomo Ibn Verga, Shevet Yehuda, ed. Azriel Schochat (Jerusalem: Mosad Bialik, 1947), 56. More about Ibn Verga's perspective about conversos and conversion, see Jeremy Cohen, A Historian in Exile-Solomon ibn Verga, Shevet Yehuda, and the Jewish-Christian Encounter (Philadelphia: University of Pennsylvania Press, 2017), 134-49. Bastard is the translation of the word mamzer in Christian Scripture; the Hebrew Biblical meaning is more complex and refers to a child born of sexual relations forbidden in the Torah, as in Leviticus 18, and Deuteronomy 23. 
relevant to his particular historical reality: Rema states that "it is permissible to marry the anusim that came back to the religion of Israel [that is to say, they are not to be deemed potential mamzerim] in the same way that is permissible to marry any other convert person." It seems strange that Menasseh ben Israel decided not to include this ruling. From a practical point of view, it would have facilitated and legally justified the smooth integration of his audience into the Jewish community. Why, then, did he omit this comment? I would suggest that he probably did so for a personal, not a practical, reason. Rema's comment overcomes a legal challenge, but it does so by comparing and even equating the legal status of the anusim who returned to Judaism to that of a non-Jew who converted. Would Menasseh ben Israel have agreed with Rema's legal reasoning? We cannot know for sure, but probably yes. But in a public work he was loath to make such a comparison. The conversos could not be merely referred to as gerim.

It appears, however, that Menasseh ben Israel demonstrated this kind of sensibility in discussing "converts," in general. For example, citing from an extensive list of rules in the Shulhan Arukh (Even ha-Ezer, chapter 4) concerning permitted and prohibited marriages and mamzerim, Menasseh decided to include the one expressing the most positive sentiments toward converts: the one that states that the progeny of a marriage between a Jew and a converted woman or between a Jewess and a converted man has the same legal status as the progeny of a Jew and a Jewess. ${ }^{40}$ Furthermore, he omitted other clauses that deemed the converts' legal status inferior, such as the rule that a mamzer may not marry a Jew, but he may marry a convert or a freed slave. ${ }^{41}$ Indeed, Menasseh ben Israel's omission of Caro's ruling that a sterile person may marry a convert or a freed slave is even more striking, as he includes Caro's ruling that prohibits marriage with a sterile person, which appears in the same sentence in the Shulhan Arukh. ${ }^{42}$

Do these examples reflect an inherently positive and cautious treatment of the concept of ger, irrespective of Menasseh ben Israel's historical context, or does this ambiguous attitude reflect his period? From one perspective, the conversos who adopted Judaism were seen as a legitimate link in the Jewish chain, but from another one they had a lot in common with the ger, especially during their process of integration into the Jewish community, so his positive treatment of the ger may reflect this reality.

$40 \quad$ Shulhan Arukh, Even ha-Ezer, § 4:23; Thesouro dos Dinim, Part IV, Cap. XXviI, 7 .

41 Shulhan Arukh, Even ha-Ezer, § 4:22.

42 Ibid., § 5:1; Thesouro dos Dinim, Part IV, Cap. XXVII, 10. 
As mentioned before, Menasseh ben Israel avoided creating a new or independent legal category for the New Christians who adopted Judaism and became New Jews, despite the peculiarity of this phenomenon and the fact that the Thesouro dos Dinim specifically addressed this public. However, the author wished to write a practical guide that would be as useful as possible for his readers, so it seems that on several occasions, he did use the term "peregrino," and he did mention some halakhic resolutions that talk about the ger in reference to the new emigrants from Spain and Portugal. Let's examine a representative example.

The Shulhan Arukh is a longer and far more detailed work than the Thesouro. Menasseh ben Israel addresses many subjects, some more comprehensively and some more superficially. One of the subjects he addresses in a manner that is significantly briefer and more concise than Caro's discussion is idolatry. The Shulhan Arukh in Yore De'ah dedicates twenty chapters and hundreds of rules to this subject. ${ }^{43}$ While the Thesouro did not omit this subject entirely, it covers it in three short chapters that contain only a few rules, mainly those regulating prohibited images and superstitions. Among the selected items, Menasseh included a ruling that addresses the unique case of two brothers, one an idolater and the other a ger, who inherit their idolater father's estate. The clause dictates that if the ger has not yet taken physical possession of the objects, he may make a deal with his brother exchanging the idolatrous ones for permitted ones.

Why, among hundreds of rules, did Menasseh ben Israel decide to include precisely this one? We are aware of few cases of converts who lived in Amsterdam, but it seems more likely that he was addressing the many readers likely to find themselves in a similar situation. Many of them had Christian relatives still living in Spain or Portugal, so it seems very likely that inheritance questions were common. Menasseh wanted to stay within Caro's framework and was not willing to add a special rule for Jews (or former anusim) who inherited the estates of their non-Jewish parents, but he decided to leave Caro's formulation as it was. Caro was discussing converts, not Jews or former anusim. However, apparently this distinction did not bother Menasseh when he felt it was necessary to teach an important lesson to the members of his community.

Like other contemporary rabbis, Menasseh ben Israel did not define the halakhic status of his community members. In fact, the main value to be found in the Thesouro dos Dinim is not an innovative halakhic attitude but an interesting and significant example of a social attitude of the time toward the former 
anusim who were joining the Jewish community in Amsterdam and toward those anusim who still remained in the Lands of Idolatry. From the examples mentioned above it seems very likely that Menasseh ben Israel considered the New Jews, former anusim who had returned to normative Judaism; he harshly criticized those who remained in the Lands of Idolatry, apparently continuing Maimonides's opinion, and warmly welcomed those who joined the Jewish community, apparently without obligating them to prove their Jewish origins despite the generations of disconnection. He did not refer to them, even indirectly, as converts. However, he did find himself, on more than one occasion, using the concept of "converts" in an ambiguous way, without clearly distinguishing between the halakhic implications that being a former anus and being a convert might have.

\section{Bibliography}

Amzalak, Moses Bensabat. A tradução espanhola do livro de Joseph Caro [Shulhan hapanim] feita por Mosé Altarás sob a denominação de "Libro de Mantenimiento de la Alma." Lisbon: Of. Grâf. do Museu Comercial de Lisboa, 1927.

Assaf, Simha. Beoholei Ya'akov. Jerusalem: Mossad Harav Kook, 1965.

Bejarano-Gutiérrez, Juan Marcos. "Rabbinic Responsa and the Jewish Status of Conversos." Journal of Spanish, Portuguese, and Italian Crypto Jews 4 (2012): 35-44.

Cohen, Dov ben David. "The Ladino Bookshelf: Research and Mapping." [Hebrew] PhD diss., Bar-Ilan University, 2011.

Cohen, Jeremy. A Historian in Exile - Solomon ibn Verga, Shevet Yehuda, and the JewishChristian Encounter. Philadelphia: University of Pennsylvania Press, 2017.

Cohen, Matty. "A Diachronic and Synchronic Reconsideration of the Term Ger in the Bible." [Hebrew] In Proceedings of the World Congress of Jewish Studies 10: A, 11-8. Jerusalem 1989.

Dan, Joseph. "Menasseh ben Israel: Attitude Towards the Zohar and Lurianic Kabbalah." In Menasseh ben Israel and His World. Edited by Yosef Kaplan, Henry Méchoulan, and Richard H. Popkin, 199-206. Leiden: Brill, 1989.

Goldish, Matt. "Hakham Jacob Sasportas and the Former Conversos." Studia Rosenthaliana 44 (2012): 149-72.

Hartman, David. Crisis and Leadership: Epistles of Maimonides. Translated by Abraham Halkin. Philadelphia: Jewish Publication Society of America 1985.

Kaplan, Yosef. "Attitudes toward Circumcision among the Early Modern Western Sephardim." In From Sages to Savants_Studies Presented to Avraham Grossman. [Hebrew] Edited by Joseph Hacker, Yosef Kaplan, and Benjamin Z. Kedar, 353-89. Jerusalem: Zalman Shazar Center, 2010. 
Kasher, Asa. "How Important was Menasseh ben Israel?" In Menasseh ben Israel and His World. Edited by Yosef Kaplan, Henry Méchoulan, and Richard H. Popkin, 22027. Leiden: Brill, 1989.

Levi, Avner. "Shulhan Arukh First Translation into Ladino." [Hebrew] In History and Creativity. Edited by Tamar Alexander, Abraham Haim, Galit Hazan-Rokem, and Ephraim Hazan, 55-71. Jerusalem: Misgav Yerushalaim, 1994.

Lipiner, Elias. "Spanish and Portuguese Conversos Facing Halakhic Problems.” (Hebrew). In Portuguese Jewry at the Stake. Edited by Yom Tov Asis and Moisés Orfali, 127-42. Jerusalem: Magnes Press, 2009.

Meyuhas Ginio, Alisa. "La actitud de los rabinos sefaradíes del imperio Otomano ante los conversos: el caso del Yavam Mesummad." In La mujer judía. Edited by Yolanda Moreno Koch, 129-48. Córdoba: Ediciones El Almendro, 2009.

Netanyahu, Benzion. The Marranos of Spain-From the Late 14th to the Early 16th Century, According to Contemporary Hebrew Sources. Third Edition, Updated and Expanded. Ithaca and London: Cornell University Press, 1999.

Orfali, Moisés. Los conversos españoles en la literatura rabínica-Problemas jurídicos y opiniones legales durante los siglos XII-XVI. Salamanca: Universidad Pontificia de Salamanca, Universidad de Granada, Federación Sefardí de España, 1982.

Rauschenbach, Sina. "Mediating Jewish Knowledge: Menasseh ben Israel and the Christian Respublica litteraria." Jewish Quarterly Review 102, no. 4 (2012): 561-88.

Rokeah, David. "The Jewish Conversion in Antiquity, Theory and Practice." Beit Mikra: Journal for the Study of the Bible and Its World 4ob (1995): 135-52.

Schiffman, Lawrence H. "Conversion to Judaism in Tannaitic Halakhah." In Conversion, Intermarriage, and Jewish Identity. Edited by Adam Mintz and Marc D. Stern, 189215. New York: The Michael Scharf Publication Trust of the Yeshiva University Press, 2015 .

Schwarzfuchs, Simon. "Le Retour des Marranes au Judaïsme dans la littérature rabbinique." Xudeus e Conversos na Historía 1 (1994), 339-48.

Schwarzwald, Ora. "Ladino Instructions in Meza de el Alma and Seder Nashim from Thessaloniki in the 16th Century." In Around the Point: Studies in Jewish Literature and Culture in Multiple Languages. Edited by Hillel Weiss, Roman Katsman and Ber Boris Kotlerman, 122-33. Newcastle Upon Tyne: Cambridge Scholars Publishing, 2014.

Schwarzwald, Ora. "The Hebrew Component in the Ladino of Two Books by the Same Author." [Hebrew] In Nit'e Ilan: Studies in Hebrew and Related Fields Presented to Ilan Eldar. Edited by Moshe Bar-Asher and Irit Meir, 153-91. Jerusalem: Carmel, 2014. Singerman, Robert. Jewish Translation History. Amsterdam: J. Benjamin, 2002.

Zsom, Dora. "The Return of the Conversos to Judaism in the Ottoman Empire and North-Africa." Hispania Judaica Bulletin 7 (2010): 335-47. 


\title{
Penso de la Vega and the Question of Jewish Baroque
}

\author{
Einat Davidi*
}

Since the second decade of the twentieth century, we have witnessed increasing interest in Baroque writing. However, apart from a few mentions, the concept of Baroque has hardly been applied to the field of Jewish writing, and even less so to the field of Hebrew writing. In this essay, I would like to portray the image of a Jewish Baroque writer by focusing on José Penso de la Vega, ${ }^{1}$ who sophisticatedly represented the Baroque spirit and style in his work. After explicating the concept "Baroque," I will draw a short biobibliography of the author, and then will discuss the Baroque characteristics of three different texts by him. I will conclude by making brief remarks about the prima facie difficulty in characterizing a Jewish writer as a Baroque writer.

\section{$1 \quad$ What is "Baroque"?}

Unlike the term "Renaissance," "Baroque" is not a term employed by contemporaries to designate their epochal innovation or worldview. It is rather an anachronistic term that has been transformed essentially and which underwent modifications of meaning and application. Since my aim is to portray a Jewish Baroque writer, it is necessary to mark the boundaries of this term.

"Baroque" was primarily a pejorative term applied by neo-classical art criticism to seventeenth-century art in order to differentiate this decadent art from Renaissance art. Wölfflin's Renaissance und Barock ${ }^{2}$ marks a change, and for the first time applies the term "Baroque" as a positive attribute. Moreover, this

* The research leading to these results has received funding from the European Research Council under the European Union's Seventh Framework Programme (FP7/2007-2013) / ERC grant agreement $\mathrm{n}^{\circ} 29535^{2}$.

1 The author used different spellings of his name in different occasions and contexts. Besides "Josseph," he also used "José" (in the bibliographical items I used the spellings in the way they appear in Penso's works).

2 Heinrich Wölfflin, Renaissance und Barock: eine Untersuchung über Wesen und Entstehung des Barockstils in Italien (Munich: Theodor Ackermann, 1888).

(C) EINAT DAVIDI, 2019 | DOI:10.1163/9789004392489_020

This is an open access chapter distributed under the terms of the prevailing CC-BY-NC License at the time of publication. 
term began to signify style and to apply not only to art and architecture, but also to literature.

Another crucial turning point was Maravall's La cultura del barroco, ${ }^{3}$ in which "Baroque" is no longer employed as an aesthetic term, but rather as a cultural and historical one-Maravall analyzes Baroque culture in the socioeconomic context of the seventeenth century. This development in the history of the term "Baroque" is ultimately responsible for the use of this term from that moment onwards as a designator of an epoch and a culture. Despite the enormous contribution of this work to the conceptualization of Baroque as a broad cultural phenomenon, it tends to shift the importance attributed to this phenomenon from theology (and especially Counter-Reformation) to the fields of economics and sociology.

In recent decades, we have witnessed a new tendency that emphasizes the socio-religious and theologico-religious conditioning of Baroque as both a worldview and a style. This tendency has emerged not only out of dissatisfaction with Maravall's socio-economic view, but was also inspired by Walter Benjamin's pan-European analysis of Baroque in Ursprung des deutschen Trauerspiels (1928), ${ }^{4}$ with whose interpretation we are still debating. Benjamin analyzes the interaction of secularism and metaphysics in seventeenthcentury allegory, as well as the origin of allegoric theater-the most prominent public art form of seventeenth-century society. The Baroque is a problematic era dominated by a pessimistic secular "modern" view that conceives of history as a process of permanent decay. ${ }^{5}$ Still, there is a desire to overcome melancholy and to return to the harmonic medieval calm, to ordo. In order to reconcile these contradictory tendencies, it was necessary to revive Christian allegory; in other words, to provide a moral interpretation of physical and cultural phenomena in light of their divine origin and hidden spiritual meaning. The internal logic of Baroque is an allegoric transfiguration of reality. The Baroque allegory is an answer to the conflict between the Middle Ages and modernity. ${ }^{6}$

Benjamin's book has been warmly adopted by post-modernist and poststructuralist thinkers. ${ }^{7}$ Moreover, the French neo-Nietzschean philosophical

3 José Antonio Maravall, La cultura del barroco: análisis de una estructura histórica (Barcelona: Ariel, 1975).

4 Walter Benjamin, "Ursprung des Deutschen Trauerspiels" in Gesammelte Schriften, ed. Rolf Tiedemann and Hermann Schweppenhäuser (Frankfurt/Main: Suhrkamp, 1974), 1: 203-431.

5 Ibid., 353 .

6 Ibid., 403 .

7 Benjamin's influence is conspicuous in Baudrillard's theory of simulacrum, see Jean Baudrillard, L'Echange Symbolique et la mort (Paris: Gallimard, 1976), and Gilles Deleuze, The 
school began to use the term "Baroque" in the context of anti-rationalistic criticism, and in order to argue against features of modern rationality such as "representation" and "origin." These scholars contributed immensely to the mapping of Baroque aesthetics, but unlike Benjamin they dealt with Baroque without any historical context. This treatment of Baroque is possibly responsible for the fact that those thinkers ignored, perhaps deliberately, an essential difference between their analysis and the historical spirit of Baroque, which is inextricably linked to the Counter-Reformation. Whereas the neo-Nietzschean philosophical school denies the priority and even the very existence of origin and truth, Baroque inherited the substantialism of the Middle Ages.

According to Benjamin, the immediate threat to Christianity is represented by secularism and paganism, to which the Renaissance gave birth. The Baroque allegory is a reactionary instrument born out of the theological crisis of that epoch. Baroque allegory opposes synthesis and coherence. However, as Kluge explains, the transformation of the historical world into a graceless state of sin and the emphasis on the ephemeral nature of earthly reality form only the first step in the dialectic processes on the way to salvation, a way of revealing the illusionary nature of renaissance vitality, of its earthly hedonistic vitality. Only by affirming the gap between history and grace, and by finally representing it as temporary or illusionary, does the Baroque allegory triumph over the non-transcendent worldview, which it opposes, and integrate it into a restitutive Christian universe. ${ }^{8}$ The Baroque allegory is, therefore, a Christian art that incorporates and transfigures the non-transcendent worldview it opposes. ${ }^{9}$

For that reason, Baroque art is an art of contrasts: secularism and spiritual religion; immanence and transcendence; anthropomorphism and theocentrism; asceticism and hedonism. Thus, theater is the overarching allegory of the Baroque worldview and, consequently, the basic dialectic procedure of Baroque art: engaño y desengaño, masks, hiding, and falsification. Truth is hidden, and hence the genres and subgenres of riddles and emblems are so prominent. Reflections, duplication, mirrors, and the question of simulacrum is always present; bewilderedness as to what is original and what is reflection; this epistemic oscillation is at the very core of Baroque art, but it is always only a phase on the way to the revelation of origin and truth.

Fold: Leibniz and the Baroque (Minneapolis: University of Minnesota Press, 1993). See also, Christine Buci-Glucksmann, La Raison Baroque. De Baudelaire à Benjamin (Paris: Galilée, 1984).

8 See Sofie Kluge, Baroque, Allegory, Comedia. The Transfiguration of Tragedy in SeventeenthCentury Spain (Kassel: Reichenberger, 2010), 22.

9 Benjamin, Ursprung des Deutschen Trauerspiels, 259, 390. 
I will now draw the profile of a Jewish writer who, in my opinion, incorporates more than any other Jewish writer what could be denominated as "Jewish Baroque." José Penso de la Vega was probably born in Hamburg around 1650. He moved to Amsterdam as a child with his family in $1656{ }^{10}$ His father Isaac Penso, born in Espejo, Córdoba, had been imprisoned in inquisitorial jail and had taken an oath to declare himself openly as a Jew were he released. After his release, he arrived at Middelburg, where he reconverted to Judaism and became a pious Jew. He continued to Amsterdam, and then to Hamburg, where he married and his older children, José among them, were probably born. In Amsterdam, he became a very successful merchant and one of the most generous donors of the community. José Penso was educated in the Ets Haim yeshiva, in which he learned Hebrew, the Bible, and Jewish classical biblical exegesis.

At an early age, he composed two texts in Hebrew. The first text is a maqama - a rhymed prose, a series of allegories (meshalim in Hebrew) - in which the polemic theme is prominent. The second text is a drama called Prisoners of Hope (Asire ha-Tikva). I have argued elsewhere ${ }^{11}$ that this drama is in fact an auto-sacramental. This dramatic allegorical genre, a genuine Spanish one, is closely related to the Counter-Reformation. As I show there, Prisoners of Hope is the first auto sacramental work in Hebrew. It is also the first dramatic Hebrew play ever printed: the dramatic genre hardly existed in the Jewish world prior to the seventeenth century. This dramatic work was praised and glorified by the community's prominent leaders and rabbis, and its poets. The rich and extended paratext is a testimony to this admiration. In this oeuvre, the young writer demonstrates his phenomenal knowledge of the Hebrew language and Hebrew sources. Moreover, this work is also a didactic book with moral lessons aimed at the young generation. Thus, it appears that the eloquent Penso paved his way to a career as a preacher and perhaps to a rabbinical career. But life took a different course.

\footnotetext{
10 From 1665 onward, the name Isaac Penso begins to appear regularly in the communal records of the Amsterdam congregation, in the list of the community's taxpayers. The single appearance of his name in $165^{\circ}$ is probably the reason for the assumption that he had settled there by this year. The claim, which appears often in scholarship, that José Penso was born in Espejo, Córdoba, like his father, is implausible, since his father was married after leaving Spain. His mother's death certificate attests to this since according to it she had married in Hamburg.

Einat Davidi, "The Corpus of the Hebrew and Jewish Autos Sacramentales," forthcoming.
} 
At that point, Penso left Amsterdam for Livorno. The information concerning his life there is scarce; there is speculation that he was involved in maritime trade. ${ }^{12}$ Additionally, Penso did not publish anything during that period. However, we have a letter sent by Penso from Livorno to Orobio de Castro, in which he asks him for support to establish a literary academy there. ${ }^{13} \mathrm{We}$ may thus learn something about this period in his life indirectly, from later events. In 1683, immediately after the death of his father, Penso returned to Amsterdam, where he resided until his own death. ${ }^{14}$ During the year of his return, he published a series of manuscripts, but it is highly improbable that these texts were written in that year. Among these texts are a collection of sermons and three short novels. It seems plausible to infer that Penso composed them during his Italian years and only published them in Amsterdam. It is left to speculate whether he published these works in Amsterdam because it was much easier for him to do so in his home community, or since he did not wish to publish his Italian works out of respect for his pious father-after all, many of these works possessed a mundane Renaissance flavor and utilized Roman mythology. These characteristics form part of the references, examples, and metaphors in all the texts, but this holds especially true in the short novel. This (at the time) new, humanistic genre—the short novel—which was identified with Renaissance mundanity, played an entertaining role rather than having any spiritual, didactic, or moral function. All these texts by Penso were written in Spanish, and apart from a couple of early Hebrew texts, Penso never wrote again in Hebrew.

In the years that followed, Penso's life took another turn. He perhaps quit his literary activity for a while and dedicated himself to the financial world. In the year 1688, he published his famous book Confusion of Confusions, and in 1692, he published a collection of twelve rewritings of biblical stories (re-écriture); four texts in this collection are not his own but are translations of Italian pieces. Penso passed away in Amsterdam in 1692.

\footnotetext{
12 Valentina Nider, "José Penso e l'accademia sefardita 'de los sitibundos' di Livorno nella diffusione di un genere oratorio fra Italia e Spagna: Traduzione e limitazione nelle 'Ideas posibles' (1692)," Studi secenteschi 51 (2010): 156-57.

13 Letter from Penso in Miguel de Barrios, Respuesta Panegírica (Amsterdam, 1677).

14 Penso's name is absent in the community's tax records until 17 September, 1683, a few months after his father's death. From this point onward, his name appears regularly in the records until his death.
} 


\section{Baroque Characteristics in Three Works by Penso de la Vega}

I will now show how the Baroque culture and worldview are embodied in three works by Penso. The first, the book that turned out to be Penso's most famous work-Confusion of Confusions (Confusión de confusiones) - is a text with an original structure on an original subject matter. The second is a short novel, and the third is a work of a genuine Spanish Baroque genre: an auto sacramental.

The book Confusion of Confusions was about a never-before written theme: the stock exchange. ${ }^{15}$ This book provoked the interest of economic historians, ${ }^{16}$ and is even considered "an essential reference work in the history of stock markets and even of current financial operations." ${ }^{17}$ It was translated into Dutch, German, and English, and was one of the few historical sources (if not the only one) on the collapse of the Amsterdam stock market in $1688 .{ }^{18}$ It became Penso's most well-known book, and "the most innovative contribution of José de la Vega to universal culture,"19 but was not considered an expression of a Baroque worldview. However, I will argue that there are good reasons to consider it as such.

The text consists in a dialogue between an investor, a merchant, and a philosopher, in which the well-experienced and knowledgeable investor helps his interlocutors to understand the principles of the market. The philosopher seeks to understand the business of the stock exchange and gives in to the temptation to invest in it. He soon becomes the victim of a conspiracy by investors and, in the end, decides to quit. The merchant also seeks to learn about

15 According to Torrente Fortuño, there are six known copies of the book: in the Ets Haim library in Amsterdam, in the National Library in The Hague, in the University Library of Göttingen, in the University Library of Aquisgrán, in the Library of the British Museum in London, and in the National Library in Madrid. See Torrente Fortunio, La bolsa en José de la Vega. Confusion de Confusiones-Amsterdam 1686 (Madrid: Libropolis, 1980).

16 Richard Ehrenberg, Das Zeitalter der Fugger (Hildesheim: Georg Olms Verlagsbuchhandlung, 1963 [Jena, 1896]); Werner Sombart, Die Juden und das Wirtschaftsleben (Leipzig: Verlag von Duncker und Humblot, 1911).

17 José Luís Cardoso, "Confusion de confusions: ethics and options on seventeenth-century stock exchange markets," Financial History Review 9, no. 2 (2002): 114.

18 Jonathan Israel, "Een merkwaardig literair werk en de Amsterdamse effectenmarkt in 1688. Joseph Penso de la Vega, Confusión de confusiones," De Zeventiende eeuw 6 (1990): 159-165; Hermann Kellenbenz's introduction to the English 1957 edition. Penso de la Vega, Confusion of Confusion. Portions Descriptive of the Amsterdam Stock Exchange (Cambridge, MA: Baker Library, Harvard Graduate School of Business Administration, 1957); José Cardoso, "Confusión de confusiones: Ethics and Options on Seventeenth-Century Stock Exchange Markets," Financial History Review 9, no. 2 (2002): 109-23.

19 Fortuño, La bolsa en José de la Vega, 283 (translation mine). 
the purchase of trade company shares in order to increase his gains, and after a failed attempt, he too decides to quit.

This dialogue is an allegorical transfiguration of the reality of the stock market. It is dominated by the idea of the world as a stock market game. Baroque texts frequently include such allegories: the idea of the world as a "labyrinth," the idea of the world as a "roadhouse," and the idea of "life as a dream" are found in many texts of the seventeenth century and are used frequently by Baroque writers and philosophers. Penso adds to these allegories one about the stock market. The book Confusion of Confusions is a satirical dialogue about the stock exchange, which serves as an allegory for human existence. The stock exchange exposes essential elements of reality and human nature. According to Penso, "[t]here is no better hieroglyph of this world but the shares." ${ }^{20}$ Through a synecdoche of the stock market, Penso describes human life and human reality as he views them: first and foremost, he highlights the uncertainty, instability, and permanent changing as essential characteristics of human reality. Human life is characterized by the need to make decisions under conditions of uncertainty, and the helplessness that results from it. Secondly, he elaborates upon the idea of Homo homini lupus - the combative and militant character of human beings - an idea known to him not only from Hobbes but also from Balthasar Gracián's Criticón. Finally, he portrays the stock market as an embodiment of the idea of versatile, opportunistic morality, indifferent to imperatives of religion, integrity, and honor.

The Baroque man is not equipped with a coherent Weltanschauung that serves as a moral compass. He uses adaptive strategies according to everchanging situations at every single moment. Since there is no longer any confidence, faith, or certainty, and the essence of things is not accessible, appearance is the most that we can grasp. He who manages to learn the rules of the game could win the struggle for existence. This idea stands behind the pragmatic and adaptive spirit of this book. The stock market itself is thus portrayed as a microcosm - it is an allegory of the world, and the investor's behavior serves as an allegory for human behavior.

For economic historians, this text might serve as a single document concerning certain historical events—a historical document of a unique type and

20 "[...] no puedo haber mejor geroglífico de las Acciones, que este mundo." Confusión de confusiones Diálogos Curiosos entre un Philósopho agudo, un Mercader discreto, y un Accionista erudito descriviendo el negocio de las Acciones, su origen, su ethimología, su realidad, su juego y su enredo, Compuesto por Don Iosseph de la Vega, Que con reverente obsequio lo dedica al Mérito y Curiosidad del muy Ilustre Señor Duarte Nuñez da Costa. Én Amsterdam Año 1688. This citation and all the others citations that follow are from a copied edition of the original book, published by Ediciones Saetabis, 1977 . 
style. However, Penso, whose words are put in the investor's mouth, justifies his choice of this original and bizarre subject in a different way. Penso mentions Latin medieval authors who devoted works in praise of lice or fleas, and claims that it is just as legitimate for him to write about the stock market and the human behavior it exhibits. ${ }^{21}$ For Penso, the legitimacy of writing about such a prosaic, mundane, and "low" subject is mainly rooted in its value as an allegory.

However, the allegorical transfiguration of the realm of the stock exchange is certainly not the only Baroque aspect of Penso's book. For Penso, with his Baroque sensitivity, the collapse of the stock market in 1688 appeared as an allegory—as a moment of desengaño, a disillusionary event: this historic event perfectly coincides with the aesthetic dialectic of the Baroque. In August 1688, rumors spread about an upcoming war. Panic ensued among investors, and most of them rushed to sell their "ducatón" shares. The market collapsed within one day, "like the statue of Nebuchadnezzar, all at once."22 Penso maintains that the fear of an impending war was the cause of the fall of the East Indian Company.

The rumors of a possible war spread when William the Stadtholder, Prince of Orange, began to reinforce his military navy. It caused a dramatic fall in the price of shares and then panic. However, from September 5 th, when the fog cleared and there was no doubt that William was going to invade England and that France was going to declare a war, experienced and serious investors began to buy shares again, and the remaining investors followed suit. Then the "bulls" and "patriots," as Penso refers to those investors, gained the upper hand and managed to change the market's tendencies precisely at a time when the purpose of the Dutch navy's rearrangement and the enormous risks to which it was exposed had already become evident. Shares of the East Indian Company rose although everybody knew about the upcoming war. Investors took great risk in buying shares of the Dutch company during times of war. Those who gambled on William's success by lending him great amounts of money stood to lose a lot. Still, this act was an expression of their trust in the Republic and its military in this critical hour, a short time before the invasion of England. At last, William of Orange's success, the dethroning of his father-in-law, James II, and the occupation of England, Ireland, and Scotland justified the trust given

21 “Tejió el Calcañino un panegírico a la pulga intitulado 'Encomium Pulicis,' el Luciano una loa a la mosca 'De Musca,' el Melanton un loor a la Hormiga, 'De Laudibus formiga,' el dousa un elogio a la sombra 'In Laudem umbra,' el Bilibaldo un encomio a la Gora 'De Laudibus podagra,' mereciendo por laurel el tema y por premio el asunto. Y todas estas plumas hubieran rendido sus obsequios a mis meditaciones si profesasen el negocio que describe y lezesen lo que pondero sobre el negocio." Penso de la Vega, Confusión, 112. “[...] como la estatua de Nabuco, toda de un golpe." Ibid., 378. 
to him by the patriots and the risk they took. When the crisis was over, shares went up gradually until the end of the year.

Penso started writing the book before the crisis and the collapse. His idea was to allegorize the stock market's reality - to present it as an allegory for the zeitgeist and human behavior. Furthermore, the collapse that he witnessed and documented in his book coincided with the Baroque aesthetic model of illusion and disillusion. The market's sudden crash, which created a psychological atmosphere of disillusionment, inspired the Baroque writer. It was most suitable for exposing the relation between things and their reflection, reality and appearance, man and mask. Deception and self-deception rules everywhere. What had seemed to be a goldmine until August 1688 was revealed within one day to be a tragedy that brought many people to bankruptcy. The collapse of the stock market exposed the illusion of the masses seeking fortune and easy gains.

Symbolically, the philosopher quits the world of the stock exchange after giving a short sermon following his disillusionment and leaves the arena to others. The viewpoint of the philosopher after the disillusion is a moral, ascetic one that denounces passion and endorses the human ideal of temperance. Passion is the origin of the pursuit of easy gains and of a pretentious lifestyle of indulgence and pleasures. It leads to reckless greediness. In order to overcome "confusion," it is necessary to strive for solid and definite aims. The philosopher views passion and obsessive pursuit from the perspective of death and the redemption of the soul. In this way, ascetic ideals and substantialism are manifested. These ideals are the medieval heritage within Baroque culture. Penso, who received a Jewish education in the Ets Haim yeshiva, here expresses a religious attitude. More than being a Jewish or Christian one, it is a medieval one. The philosopher is an old man, wise and learned, a man of the old scholastic order, who has no tools to grasp the new reality, allegorized as the stock exchange.

Penso's collection of short novels Dangerous Paths (Rumbos Peligrosos) was written either during his Italian years or shortly thereafter. ${ }^{23}$ The short novel was at that time a relatively new genre, born in the Italian Renaissance and adopted in Spain by Cervantes, Lope de Vega, and other authors. ${ }^{24}$ Like Cervantes and Lope, Penso gave a Baroque flavor to the through-and-through

23 Regarding the period of the novel's composition, see a discussion by José Fradejas Lebrero, "José de la Vega, novelista cortesano," in Los judaizantes en Europa y la literatura castellana del Siglo de Oro, ed. Fernando Díaz Esteban (Madrid: Letrúmero, 1994), 161.

24 On the adaptation of the short novel by Spanish authors, see David González Ramírez, "En el origen de la novella corta del Siglo de Oro: los novellieri en España," ARBOR Ciencia, Pensamiento y Cultura 187-752 (2011): 1221-43. 
secular genre, but he certainly did it to a much greater extent than those authors-especially with the presumptuous and innovative combination of different genres, but also by combining riddles, enigmas, and homiletic interpretations of names, and by creating a plot consisting in the theatrical game of identity. The story takes place in a Baroque salon sphere, in the elitist and hedonistic leisure culture. Using one of the epoch's secular genres, Penso, who grew up in an observant atmosphere, manifests here the mundane pole of his writing.

In Penso's first short novel, "Delicacy of Friendship and Triumph of the Innocence" ("Fineza de la amistad y triunfo de la inocencia"), Clorinda, a young lady who received a marriage promise in Seville, comes to Naples to look for her fiancé, whose identity is not known to her since she met him in darkness. She finds shelter in the house of Felisberto and his sisters. In a mysterious moment, Felisberto sees the reflection of Clorinda's face in a mirror left in his garden. He is puzzled by her similarity to a woman to whom he himself gave a marriage promise. From that moment on, the novel develops as a game of masks, duplications, reflections, and a confusion of identities. The telos is the disclosure of true identity, as if the classical anagnorisis is here being elevated to a major aesthetic principle and is perpetuated, since there are quickly four masculine and four feminine figures trying to determine who is who and who belongs to whom.

As Fernando Copello showed convincingly, the novel's dominant characteristic is its eclectic hybridity. Penso himself is aware of this aesthetic, and in the introduction to the novels he refers to their style, denominating them "works of jasper, as the Athenians called that to which they 'sprinkled' with different shades and changing concepts; rising now in the News, now in the Sweet, now in the Rhetorical, now in the Fabulous, and now in the Jocund." ${ }^{25}$ The novel reflects a chaotic universe, incoherent and inconsistent, and expresses an unstable and dynamic worldview. It combines poetry, letters, riddles, and even brief sermons in an intergeneric ludic modus, ${ }^{26}$ a sort of genre experimentalism more typical of the twentieth century than of the seventeenth.

A second Baroque feature of the text is its multiplicity of mysterious elements, of the unknown and the hidden, as the force underlying the plot. The

25 “[...] obras de jaspe, como intitulaban los Atenienses a las que salpicaban con diferentes matices y cambiantes sus conceptos; elevándose ya en lo Noticioso, ya en lo Dulce, ya en lo Retórico, ya en lo Fabuloso y ya en lo Jocundo." Penso de la Vega, Rumbos peligrosos, xviii (translation mine).

26 Fernando Copello, "Hibridismo y variedad en una novella corta de Joseph Penso de la Vega y Miguel de Barrios: Fineza de la Amistad y triunfo de la inocencia $(i$-Amsterdam? 1683)," Mélanges de la Casa de Velázquez 43, no. 2 (2013): 119-37. 
dynamics of concealment and disclosure is not a serious dialectic, but rather a ludic, theatrically entertaining, and pleasant game. The riddle was a prominent genre in the Baroque era that was highly refined and developed among Jewish writers in Italy and Holland in the seventeenth century. ${ }^{27}$ Penso himself was a composer and solver of some well-documented riddles. ${ }^{28}$ Many riddles are embedded in the novel, sometimes with possible solutions. For example, a question is raised about the meaning of the enigmatic initials "A.F.," which appear as the name of the letters' mysterious writer. There are many possible solutions: is it an abbreviation of "love and fortune" (amor y fortuna), or "fine love" (amor fino), or "furious Alexander" (Alejandro furioso), or perhaps "fine friendship" (Amistad fina), which is the novel's title?

The riddle is a genre that has a lot in common with theater: their common denominator is the dialectic of concealment and disclosure. But it is also a certain kind of game: the game characterizes not only the writing mode, or the combination of genres, but rather takes up a great part of the plot. When Felisberto finds himself in his salon in the company of four ladies, they discuss how they should pass their time: in comedy, music, dance, or with a game. Afterwards, they consider which game they should play, and conduct a theoretical discussion about different games (chess, backgammon, checkers, cards) and their principles and symbolic value. This reflective discussion about the game as allegory of reality and of society in particular is unprecedented in the history of literature. This discussion represents game theory, but it is also an allegory for the social game (social functions, social strata, and even gender). Furthermore, it is also an allegory of the rhetorical game: it has an auto-poetic dimension.

It is thus not surprising that the game chosen to be played is a card game. Its distinguishing feature is exactly the dynamics of concealment and disclosure. Every player sees his own card but not the others, and during play there are strategies of disclosure. But "carta" in Spanish is a polysemic word that means also "letter." As mentioned, the novel includes several mysterious letters written in a cryptic style. The parlor game thus functions as an allegory of the plot itself, the novel, in which "cards" are concealed and disclosed. This is the game's auto-poetic function. ${ }^{29}$

27 Dan Pagis, A Secret Sealed. Hebrew Baroque Emblem-Riddles from Italy and Holland (Jerusalem: Magnes Press, 1986) [Hebrew].

28 Ibid., 25, 48, 84 .

29 The game of fraud and concealment takes place not only in the text but also in the paratext, which is of course about reality and not a game. The place of publication appears as Brussels, but Den Boer has demonstrated convincingly that the novels were published in Amsterdam. He raises the conjecture that Penso wished to conceal his Jewish identity 
It is therefore only natural that the novel ends with a big masquerade ball, in which the truth is finally disclosed. All riddles meet their solutions, everyone's true identity is exposed, and the entire chaos is brought into order. Similar to Shakespeare's pastoral comedy As You Like It, the eight figures are coupled miraculously into four happy pairs to everyone's satisfaction. As in Confusion of Confusions, the text ends with a colossal, dramatic desengaño and, again, Baroque's substantialist character comes to light.

Nonetheless, the most obvious expression of Penso de la Vega's Baroque worldview and Baroque literary profile is definitely the auto sacramental drama entitled Asirei ha-Tikva (Prisoners of Hope), which he wrote in his youth, and which by itself may grant Penso the title of "the Jewish Baroque writer par excellence." This text, published in $1668,{ }^{30}$ and again in Livorno in $1771,{ }^{31}$ is the first auto sacramental in Hebrew. ${ }^{32}$ Miguel de Barrios would later write a dramatic work with a strong auto sacramental character, ${ }^{33}$ yet Penso's drama, unlike de Barrios's, employs pure allegories-prosopopea, the personification of abstract concepts. Furthermore, the constellation of his figures is much more Calderonian and actually is quite similar to that of Calderón's paradigmatic auto sacramental, La vida es sueño.

As Poppenberg showed, in the paradigmatic auto sacramental plot, there is a special dialectic between the representatives of good and evil that fight over control of the human soul. This is basically a medieval dramatic structure that is known mostly from "Everyman" and similar pieces, and was modified in Siglo de Oro literature. In the midst of the drama, evil gains the upper hand. In this part, fraud, falsification, and disguise are involved: evil disguises itself as good, Satan is disguised as an angel, passion is disguised as reason, etc. ${ }^{34}$ This structure is almost the quintessence of the Baroque dialectic, which is

in order to gain a Spanish non-Jewish audience, to whom this kind of mundane text is addressed. (Harm den Boer, "Ediciones falsificadas de Holanda en el siglo XVII: escritores sefarditas y censura Judaica," in Varia bibliographica. Homenaje a José Simón Díaz [Kassel: Casado Lobato, 1987], 99-104.) Another possible reason for this concealment is that he wanted to avoid censorship by the community's board of governors (Mahamad).

$30 \quad$ Josseph Penso, Pardes Shoshanim (Amsterdam, 1668).

31 Josseph Penso, Asirei ha-Tikva (Livorno, 1771).

32 On Penso's auto sacramental in the context of this genre in Jewish space, see Einat Davidi, "The Corpus of Hebrew and Jewish Autos Sacramentales: Self-Deception and Conversion," European Journal of Jewish Studies 13, no. 2 (2019) (forthcoming).

33 The play Contra la Verdad no hay Fuerza was reprinted by Kenneth R. Scholberg, La poesía religiosa de Miguel de Barrios (Madrid: Ohio State University Press, 1962).

34 For an extensive discussion of the auto sacramental genre in its theological context, see Gerhard Poppenberg, Psyche und Allegorie. Studien zum spanischen auto sacramental von den Anfängen bis zu Calderón (Paderborn: Fink, 2003). 
basically a strategy of delay, the temporary appearance of the lie, engaño, until finally desengaño happens and the divine truth is revealed.

In Prisoners of Hope, the representative of evil is indeed "Satan" and he is accompanied and assisted by "Desire," "Pleasure," and "Woman," while the representative of good is "Reason" (Sekhel), assisted by "Providence," "Truth," and an "Angel." The prologue of the play connects "Reason" with a man of the community's older generation, while "Satan" is associated with a young man. But in this introduction "Satan" is also associated with Christianity, so implicitly "Reason" is also associated with Judaism. Both the constellation of characters and the structure of the plot are typical characteristics of auto sacramental. In this didactic work, the Jewish truth is revealed after being temporarily concealed in a typical Baroque desengaño.

\section{$4 \quad$ Conclusions}

Especially while taking into consideration the Baroque's Counter-Reformation theological background, it would seem that there is a prima facie difficulty in characterizing a Jewish writer as a Baroque writer. Nevertheless, the reading of texts by writers such as Penso de la Vega - that is, New Jews or their descendants - in light of their background of reconversion, gives rise to two observations.

First, as members in communities of New Jews (or their descendants) who lived in Spain and sometimes in Italy during the period of the CounterReformation, these people-despite their multifaceted identity-naturally absorbed the Baroque worldview, whose clearest expression, as Benjamin maintains, is allegorical theater. Thus, after they left Iberia, they became its emissaries and even disseminators in northern Europe. ${ }^{35}$

Second, and more importantly, it is precisely the experience of re-conversion - this specific historical experience of living in Iberia as New Christians and returning to Judaism during the seventeenth century-that coincides with the narrative of illusion and disillusion, concealment and revelation, engaño and desengaño. This experience coincides well with the dialectic process on the way to salvation, which constitutes the very essence of the Baroque worldview. In this paper, I attempted to show the deep extent

35 On the role of Amsterdam Jews in the transmission of Calderón's theater in the Northern countries see Henry W. Sullivan, Calderón in the German Lands and the Low Countries: His Reception and Influence, 1654-1980 (Cambridge: Cambridge University Press, 2009), 62-65. 
to which this characterizes Penso's work, and thus that he is, in a significant sense, a Jewish Baroque writer.

The issues, on the one hand, of Spain as a radiating center of Baroque (as highlighted mainly by Benjamin) and, on the other hand, the affinity between Baroque's dialectic structure and the structure of narrative and historical experience of reconverted Jews and their descendants from the Western Sephardic diaspora, shed light on the question of Jewish Baroque, as well as on the old discussion about the beginnings and origins of early modern Hebrew literature and the question of Sephardic Jews' contribution to it in comparison with that of Italian-Jewish writers. The case of Penso de la Vega is a prominent example of how the specific historical experience not only enabled the creation of Jewish Baroque as both a worldview and style, but intensified it.

\section{Bibliography}

Barrios, Miguel de. Respuesta Panegírica. Amsterdam: Jacob van Velsen, 1677.

Baudrillard, Jean. L'Echange Symbolique et la mort. Paris: Gallimar, 1976.

Benjamin, Walter. "Ursprung des Deutschen Trauerspiels." In Gesammelte Schriften. 7 Vols. Edited by Rolf Tiedemann and Hermann Schweppenhauser, 1: 203-431. Frankfurt/Main: Suhrkamp, 1974.

Buci-Glucksmann, Christine. La Raison baroque. De Baudelaire à Benjamin. Paris: Galilée, 1984.

Cardoso, José Luís. "Confusión de Confusiones: Ethics and Options on SeventeenthCentury Stock Exchange Markets." Financial History Review 9, no. 2 (2002):109-23.

Copello, Fernando. "Hibridismo y variedad en una novella corta de Joseph Penso de la Vega y Miguel de Barrios: Fineza de la Amistad y triunfo de la inocencia (¿-Amsterdam?, 1683)." Mélanges de la Casa de Velázquez 43, no. 2 (2013): 119-37.

Davidi, Einat. "The Corpus of the Hebrew and Jewish Autos Sacramentales," European Journal of Jewish Studies 13, no. 2 (2019) (forthcoming).

Deleuze, Gilles. The Fold: Leibniz and the Baroque. Minneapolis: University of Minnesota Press, 1993.

Ehrenberg, Richard. Das Zeitalter der Fugger [The Age of the Fuggers]. Jena, 1896; Hildesheim: Georg Olms Verlagsbuchhandlung, 1963.

Den Boer, Harm. "Ediciones falsificadas de Holanda en el siglo XVII: escritores sefarditas y censura Judaica." In Varia bibliographica. Homenaje a José Simón Díaz. Edited by Concepción Casado Lobato, 99-104. Kassel: Reichenberger, 1987.

Fortunio, Torrente. La bolsa en José de la Vega. Confusión de Confusiones-Amsterdam, 1686. Madrid: Libropolis, 1980. 
Fradejas Lebrero, José. “José de la Vega, novelista cortesano." In Los judaizantes en Europa y la literatura castellana del Siglo de Oro. Edited by Fernando Díaz Esteban, 155-65. Madrid: Letrúmero, 1994.

González Ramírez, David. "En el origen de la novella corta del Siglo de Oro: los novellieri en España.” ARBOR Ciencia, Pensamiento y Cultura 756 (2011): 13-28; <http:// arbor.revistas.csic.es/index.php/arbor/article/viewFile/1502/1513>.

Israel, Jonathan. "Een merkwaardig literair werk en de Amsterdamse effectenmarkt in 1688. Joseph Penso de la Vega, Confusión de confusiones." De Zeventiende eeuw 6 (1990): 159-65.

Kellenbenz, Hermann. "Introduction." In Penso de la Vega, Confusion of Confusion. Portions Descriptive of the Amsterdam Stock Exchange. Cambridge, MA: Harvard University Press, 1957 .

Kluge, Sofie. Baroque, Allegory, Comedia. The Transfiguration of Tragedy in SeventeenthCentury Spain. Kassel: Reichenberger, 2010.

Maravall, José Antonio. La cultura del Barroco: análisis de una estructura histórica. Barcelona: Ariel, 1975.

Nider, Valentina. “José Penso e l'accademia sefardita 'de los sitibundos' di Lidvorno nella diffusione di un genere oratorio fra Italia e Spagna: Traduzione e limitazione nelle 'Ideas posibles' (1692)." Studi secenteschi 51 (2010): 156-57.

Pagis, Dan. A Secret Sealed. Hebrew Baroque Emblem-Riddles from Italy and Holland. [Hebrew]. Jerusalem: Magnes Press, 1986.

Penso, Josseph. Pardes Shoshanim. Amsterdam: Yosef Atiash, 1668.

Penso, Josseph. Asirei ha-Tikva. Livorno: Santini Presso Carlo Giorgi, 1771.

Penso de la Vega, José. Confusión de confusiones, Ediciones Saetabis, 1977: Confusión de confusiones Diálogos Curiosos entre un Philósopho agudo, un Mercader discreto, y un Accionista erudito descriviendo el negocio de las Acciones, su origen, su ethimología, su realidad, su juego y su enredo, Compuesto por Don Iosseph de la Vega, Que con reverente obsequio lo dedica al Mérito y Curiosidad del muy Ilustre Señor Duarte Nuñez da Costa. Én Amsterdam Año 1688.

Penso de la Vega, José. Rumbos Peligrosos por donde navega con título de Novelas la zozobrante Nave de la Temeridad temiendo los peligrosos Escollos de la Censura. Antwerp, 1683.

Poppenberg, Gerhard. Psyche und Allegorie. Studien zum spanischen auto sacramental von den Anfängen bis zu Calderón. Paderborn: Fink, 2003.

Scholberg, Kenneth R. La poesía religiosa de Miguel de Barrios. Madrid: Ohio State University Press, 1962.

Sombart, Werner. Die Juden und das Wirtschaftsleben. Leipzig: Verlag von Duncker und Humblot, 1911.

Sullivan, Henry W. Calderón in the German Lands and the Low Countries: His Reception and Influence, 1654-1980. Cambridge: Cambridge University Press, 2009.

Wölfflin, Heinrich. Renaissance und Barock: eine Untersuchung über Wesen und Entstehung des Barockstils in Italien. Munich: Bruckmann, 1888. 
Yosef Kaplan - 978-90-04-39248-9

Downloaded from Brill. com $04 / 26 / 2023$ 10:36:49AM via free access 
PART 6

Crossing the Atlantic-Sephardic Communities in the New World 
Yosef Kaplan - 978-90-04-39248-9

Downloaded from Brill. com $04 / 26 / 2023$ 10:36:49AM via free access 


\title{
Sea Is History, Sea Is Witness: The Creation of a Prosopographical Database for the Sephardic Atlantic
}

\author{
Michael Studemund-Haléry*
}

Where are your monuments, your battles, martyrs?

Where is your tribal memory? Sirs,

in that grey vault. The sea. The sea

has locked them up. The sea is History.

DEREK WALCOTT, The Sea Is History, $1979^{1}$

During the Jewish modern period, ships bound for colonies in the Americas not only carried products and lamentably, also slaves, but equally members of the Portuguese nation, among them young and old, poor and rich, adventurers and refugees, forasteiros and itinerant talmidei hakhamim in need of assistance, merchants and speculators, widowers and widows, grooms and brides (and sometimes the ships returned the travelers back to the places from where they had originally embarked). The colonies in the Atlantic, which attracted many members of the recently established Jewish Portuguese communities in Hamburg, Amsterdam, and London, negotiated between different colonial empires at long social, ethnic and cultural boundaries, crossed religious borders and frontiers, and showed the blending of multiple Jewish traditions. ${ }^{2}$

* The generous financial assistance from the zeit Foundation Ebelin and Gerd Bucerius enabled me to carry out fieldwork in Suriname, Curaçao and Barbados. This project would not have been possible without the help of my colleagues Amalia S. Levi and Thomas Kollatz.

1 The sea as guardian and witness of history-few words could serve as a better introduction to the history of the Sephardic Atlantic, see Carmen Birkle and Nicole Waller, eds., "The Sea is History": Exploring the Atlantic (Heidelberg: Winter, 2006).

2 Wim Klooster, "Atlantic and Caribbean Perspective. Analyzing a Hybrid and Entangled World," in The Sea: Thalassography and Historiography in the Twenty-First Century, ed. Peter N. Miller (Ann Arbor: University of Michigan Press, 2013), 6o-83.

(C) MICHAEL STUDEMUND-HALÉVY, 2019 | DOI:10.1163/9789004392489_021

This is an open access chapter distributed under the terms of the prevailing CC-BY-NC License at the time of publication. 
Through the personal stories of these travelers, we learn of the challenges and opportunities that faced the émigré Jews in these new places, and the many ties that bound them to their erstwhile homes across the ocean. ${ }^{3}$ Records of their travels and experiences shed light on a multicultural "Jewish" or "Swimming" Atlantic. ${ }^{4}$

For those who voluntarily made the voyage on a "God-damn floating coffin," the other side of the Atlantic offered escape from hardship and the cares of daily life, with promises of marvel-filled adventure and exotic romance, but also more prosaic hopes for steady sources of employment and income or just the chance for a better life. For the unwilling voyagers, some of whom were banished by the Mahamad never to return and others who were to be allowed back to the motherland after a stipulated number of years, the Atlantic was a place of grief and loss. Only in rare cases was the journey undertaken with the intention to cultivate economic or family ties or establish new commercial ventures. ${ }^{5}$

Global Sephardic networks thus shaped the Atlantic into a Sephardic Atlantic and the Caribbean islands into Sephardic islands by building new cultures and bringing disparate cultures into contact for the first time, hence creating a vast marchland of Jewish civilization in the Americas and a unique Sephardic-Caribbean place, space, and culture. ${ }^{6}$ The Jewish Atlantic, however, was never exclusively Jewish. It included Christian colonists, colonial officials, sailors, soldiers, servants, enslaved men and women, but also indigenous inhabitants and Maroons in the hinterland. The Sephardic component comprised Jews and also New Christians, New Jews, Christian converts to Judaism, ${ }^{7}$ and Jewish converts to Christianity. This diverse group retained family, cultural,

3 Julia Philips Cohen and Sarah Abrevaya Stein, eds., Sephardi Lives. A Documentary History, 1700-1950 (Stanford: Stanford University Press, 2016).

4 Jonathan Schorsch, Swimming the Christian Atlantic. Judeoconversos, Afroiberians and Amerindians in the Seventeenth Century, 2 vols. (Leiden: Brill, 2009).

5 See, for example, for Amsterdam, Vibeke Sealtiel Olsen, Liste des Sépharades Portugais qui furent payés pour quitter Amsterdam, 1757-1813. Amsterdam 1999 [MS]; for Hamburg, see Michael Studemund-Halévy "Across the Waters. Sefardic Pioneers from Hamburg in the Caribbean," in A Sefardic Pepper-Pot in the Caribbean, ed. Studemund-Halévy (Barcelona: Tirocinio, 2016), 183-86.

6 Bernard Baylin, Concept and Contours (Cambridge, MA: Harvard University Press, 2005), 62.

7 See the spiritual odyssey of the seventeenth-century Christian Abraham Perengrino, alias Manuel Cardoso de Macedo $\left(15^{8} 5^{-16} 5^{2}\right)$, to Judaism, Benjamin N. Teensma, "De Levensgeschiedenis van Abraham Perengrino, alias Manuel Cardoso de Macedo," Studia Rosenthaliana 10 (1976): 1-36; Michael Studemund-Halévy, "Les aléas de la foi. Parcours d'un jeune Portugais entre église et synagogue," in Memoria. Festschrift für Michael Brocke, ed. Birgit Klein (Berlin: Metropol, 2005), 363-82; Ronnie Perelis, "Writing His Way into the Jewish People. Faith, Blood, and Community in Manuel Cardoso de Macedo's Vida del 
linguistic, and economic ties throughout most of its history, and eventually encompassed also the mulatto offspring of the Jewish slave owners in Barbados and Suriname. ${ }^{8}$ The strong ethnic endogamy motivated by religious, social, and cultural values coupled with the difficulty of finding spouses in the vicinity, often led to marriages among cross-or parallel cousins. Disapprobation of hypogamy (a female marrying someone of a lower social status or marrying "down") also induced the Sephardim to marry among themselves. ${ }^{9}$ Strong bonds of ethnic kinship hence translated into resilient relationships of commercial trust.

Consequently, the world of Caribbean Jews was, in a sense, a portable social, cultural, and economic sphere sustained by informal ethnic trading networks that functioned as a mode of advancement for its members. Jewish places and cultural spaces were filled with the itinerant Sephardic community that spread out across the Caribbean Sea. Many of these places were established under the shadow of Dutch Brazil-in Dutch-controlled Berbice, Curaçao, Demerara, Essequibo, Curaçao, Suriname (disputed between England and Holland), St. Eustatius, Tobago (disputed among various powers), Cayenne (in what is today French Guiana), English-controlled Barbados, Nevis, and Jamaica, and Danish-controlled St. Thomas. Among the first Sephardim to settle in the Caribbean basin were men and women who had initially fled the Iberian Peninsula and made their way first, either directly or indirectly, to Hamburg or Amsterdam and only later to Dutch Brazil. Among these itinerant families we can note the Abudiente, Cohen Belinfante, de Mercado, $\mathrm{Na}(\mathrm{h})$ mias, Pacheco,

buenaventurado Abraham Pelengrino," in idem, Narratives from the Sephardic Atlantic. Blood and Faith (Bloomington: Indiana University Press, 2016), 74-97.

8 The offspring of Sephardic men and non-Jewish African women were sometimes raised as Jews. The conversion entailed a formal ceremony carefully guided by rabbinical liturgical rites. The prayer book Sefer Berit Yitshak (Amsterdam, 1729), which has enjoyed many additional printings since its original publication, includes instructions for circumcising and ritually immersing male and female slaves for conversion. See also Jonathan Schorsch, Jews and Blacks in the Early Modern World (Cambridge: Cambridge University Press, 2004), 225-26; Brian Britt and Alexandra Cuffel, Religion, Gender, and Culture in the Pre-Modern World (New York: Palgrave Macmillan, 2015), 189.

9 Francesca Trivellato, The Familiarity of Strangers: The Sephardic Diaspora, Livorno, and Cross-Cultural Trade in the Early Modern Period (New Haven: Yale University Press, 2009); Alan F. Benjamin, Jews of the Dutch Caribbean. Exploring Ethnic Identity in Curaçao (London: Routledge, 2002). 
traceable in Recife, ${ }^{10}$ Barbados, Martinique, Antigua, St. Kitts, Nevis, ${ }^{11}$ Boston, New York, Newport, London, and Hamburg. ${ }^{12}$

Sephardic Jewishness thus bridged the Caribbean Sea and reached across the Atlantic to France, England, Amsterdam, Hamburg and the ancestral Iberian Peninsula, mirroring the post-expulsion dispersal of Sephardic conversos and "New Jews."13 The cultural coherence that was the result of multiple and intersecting networks of Jewish groups of Sephardic Jews (Spanish and Portuguese), New Christians (cristãos novos, conversos), crypto-Jews (Marranos), and later Ashkenazim, underpinned the remarkable flexibility of these groups and their capacity to cross religious, political, and cultural divides. This was a boon to the new wave of Jewish exiles to the Caribbean who found themselves in the front row of the European invasion of the New World and the establishment of the first European trade zones in the Americas. ${ }^{14}$

The webs of Sephardic communal affiliation were, however, slow to fall in line with Imperial divisions. Amsterdam long remained the supreme "mothercommunity" for the Sephardim of the Caribbean, as Evelyne Oliel-Grausz's work has shown in detail. ${ }^{15}$ Far from being exemplary "patriots," it could perhaps be argued that in the early modern period, the Sephardim in the Americas were closer to model "non-patriots," as Adam Sutcliffe points out, embedded as they were in particularly complex multiple networks of commerce and kinship, and thus remained necessarily aloof from the political rivalries among the various empires (and in part because of this, were better able to sustain trade

10 José A. de Gonsalves de Mello, Gente da Nação (Recife: Massangana, 1989).

11 Michelle M. Terrell, The Jewish Community of Early Colonial Nevis: A Historical Archaeological Study (Gainesville: University of Florida Press, 2005).

12 Some biographical sketches are part of my article "Across the Waters."

13 I borrow this excellent term from Yosef Kaplan, who uses it to describe the former conversos who embraced Judaism upon their arrival in open Jewish communities in Western Europe, such as Hamburg, Amsterdam, and London, see his article "Wayward New Christians and Stubborn New Jews," in Jewish History 8, nos. 1-2 (1994): 27-41; idem, Zwischen Neuchristen und neuen Juden. Die verschlungenen Wege von Kryptojuden und westlichen Sefarden in der Frühen Neuzeit (Trier: Kliomedia, 2014).

14 Thomas M. Truxes, "Trading Diasporas," in The Princeton Companion to Atlantic History, ed. Joseph C. Miller (Princeton, NJ: Princeton University Press, 2015), 456-62; Christian Cwik, "The Rise of Jewish Merchants Capitalists in the Caribbean: The Triangulation of Barbados, Jamaica and Curaçao," in A Sefardic Pepper-Pot in the Caribbean, ed. StudemundHalévy (Barcelona: Tirocinio, 2016), 13-29.

15 Evelyne Oliel-Grausz, "A Study in Intercommunal Relations in the Sephardi Diaspora: London and Amsterdam in the Eighteenth Century," in Dutch Jews as Perceived by Themselves and Others, ed. Yosef Kaplan and Chaya Brasz (Leiden: Brill, 2001), 41-58; OlielGrausz, "Networks and Communication in the Sephardi Diaspora: An Added Dimension to the Concept of Port Jews and Port Jewries," Jewish Culture and History 7 (2004): 61-76. 
with all parties during periods of conflict). ${ }^{16}$ On the other hand, as Sutcliffe highlights, the exposure of Sephardim "to a wide range of different cultures and religions, and their need to adapt in order to survive in contrasting and changing political regimes, promoted the development of particularly malleable political allegiances, and also of forms of religious heterodoxy,"17 that shaped the evolution of attitudes and values among the Western Sephardim over the course of this period.

The Caribbean basin became then a "New Heaven" for members of the transnational ethnic "nação portuguesa," where they found not only commercial and economic privileges but also religious, political, and civil freedoms and rights. In the Caribbean, the powerless diasporic Jew could be a global trader, merchant, shipper, slave and plantation owner, an equal of his Christian peer. The dispersal throughout the Atlantic world of Sephardim who were not bound by either territorial sovereignties or specific locales, transformed the Caribbean into a Jewish place (bound by location), and a Jewish space (bound by opportunity). ${ }^{18}$ Yet, only a few Jewish Sephardic colonists and merchants who circulated across cultural, linguistic, political, and geographical borders in the Atlantic left behind much in the way of writing. ${ }^{19}$ Fragments of the Sephardic Jews' transatlantic biographies can, however, be gleaned from a variety of sources. Among these are the various communal records such as the intraand inter-communal correspondence (copiador), the communal minute books (livros da nação), ${ }^{20}$ registers of births and deaths, hashkabah books (prayer of

16 See Adam Sutcliffe, "Ideas and Space: Heterodoxy, Circulation and Urban Life in the Western Sephardic Diaspora," unpublished manuscript, Hamburg 2005; id., "Jewish History in an Age of Atlanticism," in Atlantic Diasporas, Jews, Conversos, and Crypto-Jews in the Age of Mercantilism, 1500-180o, ed. Richard L. Kagan and Philip D. Morgan (Baltimore: The Johns Hopkins University Press, 2009), 28-29.

17 Sutcliffe, "Ideas and Space."

18 Julia Brauch, Anna Lipphardt and Alexandra Nocke, eds., Jewish Topographies: Visions of Space, Traditions of Place (Aldershot: Ashgate, 2008).

19 David de Ishac Cohen Nassy, Essai historique sur la colonie de Surinam (Amsterdam: S. Emmering, 1968); Jonathan I. Israel, "The Dutch Jewish Enlightenment in Surinam, 1770-180o," in The Religious Cultures of Dutch Jewry, ed. Yosef Kaplan and Dan Michman (Leiden, Boston: Brill, 2017), 183-206; Gérard Nahon, "Nefusot Yehuda (Bayonne) et Beraha ve-Shaom (Surinam). Livres et lecture au XVIII ${ }^{\text {ème }}$ siècle," in A Sefardic Pepper-Pot in the Caribbean, ed. Studemund-Halévy (Barcelona: Tirocinio, 2016), 362-428.

20 We know of six thousand despachos in the years from 1615 to 1759 and the destination is known for more than four thousand, see Tirtsah Levie Bernfeld, Poverty and Welfare Among the Portuguese Jews in Early Modern Amsterdam (Oxford: Littman Library of Jewish Civilization, 2012), 47. The minute books of Amsterdam and Hamburg contain innumerable references to voluntary or involuntary emigration to the British and Dutch colonies. For Hamburg, see Alfonso Cassuto, "From the Old Minute Book of the Sephardic 
repose), lists kept by ritual circumcisers (mohalim), marriage contracts (ketubot), final wills and testaments, ${ }^{21}$ bequests, family trees, coats of arms, portraits of Sephardic rabbis and merchants, passenger lists, and hand-written genealogies in Mahzorim (prayer books) and the various documentation left by the many itinerant hakhamim and hazzanim, merchants and physicians who island-hopped between the Jewish communities in the Caribbean. ${ }^{22}$ Colonial proceedings and records comprise another important primary source of information, as do also the denunciation reports and Inquisition protocols containing (mini-) egodocuments. ${ }^{23}$ Unfortunately, autobiographical life stories or ethical wills, which can teach us much about the past, are rare, ${ }^{24}$ and very few

Congregation, of Hamburg, Relating to Jews of Barbados," Publications of the American Jewish Historical Society 32 (1931):114-15; Studemund-Halévy, "Across the Waters. Sephardic Pioneers from Hamburg in the Caribbean," in A Sefardic Pepper-Pot in the Caribbean, ed. Studemund-Halévy (Barcelona: Tirocinio, 2016), 150-209. For Amsterdam, see Levie Bernfeld, Poverty and Welfare Among the Portuguese Jews in Early Modern Amsterdam; id., "Exit Amsterdam: Poor Portuguese and Caribbean Horizons," in Studemund-Halévy, $A$ Sefardic Pepper-Pot, 210-29; for London, see Julia R. Lieberman, "New Practices of Sedaca," in Charity on Jewish, Christian, and Islamic Traditions, ed. Julia R. Lieberman and Michal Jan Rozbicki (Lanham: Lexington Books, 2017), 105-29.

21 See, for example, Samuel Oppenheim, "List of Wills of Jews in the British West Indies prior to 180o," in Publications of the American Jewish Historical Society 32 (1931): 55-64; D.M. Zielonka, "A Study of the Life of the Jews in Jamaica Reflected in Their Wills, 1692-1798," MS SC-13489 (term paper, AJA Cincinnati, 1963); Joanne McCrea Sanders, ed., Barbados Records. Wills and Administrations, 3 vols. (Houston:Sanders Historical Publications, 19791981); see also Karl Watson et al., The Wills of the Jews, 1685-1847 (Bridgetown, n.p., n.d.). An innovative source are the selected documents (letters, wills, epitaphs, religious discourses, and literary works about Jewish Life in the Americas), edited by Michael Hoberman, Laura Leibman and Hilit Surowitz-Israel, Jews in the Americas, 1776-1826 (London: Routledge, 2018).

23 A rich source, to date not thoroughly evaluated, are the trials of the Venetian Inquisition, masterfully edited in 14 volumes, by Pier Cesare Ioly Zorattini, Processi del Santo Uffizio di Venezia contro Ebrei e Giudaizzanti, 1608-1632 (Florence: Olschki, 1999); Ioly Zorattini, L'identità dissimulata (Florence: Olschki, 200o); "EPIDAT-Datenbank zur jüdischen Grabsteinepigraphik. Inventarisierung und Dokumentation historischer jüdischer Friedhöfe," in Wenn das Erbe in die Wolken kommt. Digitalisierung und kulturelles Erbe, ed. Eckhard Bolenz, Lina Franken, Dagmar Hänel (Essen: Klartext, 2015), 161-68, 195-248. See, for example, the fascinating story of the Old Christian Fernando Almeida Pereira, who embraced the Jewish faith in Hamburg, Michael Studemund-Halévy, "Les aléas de la foi. Parcours d'un jeune Portugais entre église et synagogue," in Memoria. Festschrift für Michael Brocke, ed. Birgit Klein (Berlin: Metropol, 2005), 363-82; id., "Rückkehr mit Widerruf. Ein junger Portugiese zwischen Kirche und Synagoge," in Tribunal der Barbaren? Deutschland und die Inquisition in der Frühen Neuzeit, ed. Albrecht Burkardt and Gerd Schwerthoff (Konstanz and Munich: UVK Verlagsgesellschaft, 2012), 255-75.

24 Israel Abrahams, ed., Hebrew Ethical Wills (Philadelphia: Jewish Publication Society of America, 1926). 
egodocuments ${ }^{25}$ or biographical sketches have come down to us and can be used by social historians interested in the daily life of these tropical exile Jews. ${ }^{26}$ Another rich primary source is the numerous Jewish graveyards across the Caribbean with their more than ten thousand Jewish gravestones containing important first-hand information about deceased members of the Sephardic communities of the Jewish Atlantic. The gathering and collating of all these sources into a prosopographical database is a project currently being developed in the Hamburg-based Institute for the History of the German Jews.

In the last twenty years, there has been a steady stream of important monographs, ${ }^{27}$ collections of essays, ${ }^{28}$ a broad range of research projects, exhibitions, ${ }^{29}$ and specialized conferences on the subject of the Jewish Caribbean, delineating geographic and thematic areas for further exploration and stimulating an important interdisciplinary discussion about Jewish life in the New World in the first three centuries of European colonialism. This burgeoning interest has led to some Sephardic places being considered for the UNEsco World Heritage list, such as the Jodensavanne (Jewish savanna) in Suriname and the Jewish cemetery at Cassipora, ${ }^{30}$ the oldest extant in the Americas and a reminder of the pioneers of American Judaism. Beth Haim cemetery on the island of Curaçao has already been designated a UNESco World Heritage site. ${ }^{31}$

25 Avriel Bar-Levav, "When I Was Alive. Jewish Ethical Wills as Egodocuments," in Egodocuments and History. Autobiographical Writing in Its Social Context since the Middle Ages, ed. Rudolf Dekker (Hilversum: Verloren, 2002), 45-59.

26 See, for example, the three autobiographical texts in Ronnie Perelis, Narratives from the Sephardic Atlantic. Blood and Faith (Bloomington: Indiana University Press, 2016).

27 Zvi Loker, Jews in the Caribbean. Evidence on the History of the Jews in the Caribbean Zone in Colonial Times (Jerusalem: Misgav Yerushalayim, 199); Mordechai Arbell, The Jewish Nation of the Caribbean (Jerusalem and New York: Geffen, 2002); Jonathan I. Israel, Diasporas within a Diaspora:Jews, Crypto-Jews, and the World of Maritime Empires, 15401740 (Leiden: Brill, 2002).

28 Kagan and Morgan, Atlantic Diasporas; Paolo Bernardini and Norman Fiering, eds., The Jews and the Expansion of Europe to the West, 1450-1800 (New York: Berghahn, 2001); Jane S. Gerber, ed., The Jews in the Caribbean (Oxford: The Littman Library of Jewish Civilization, 2014); Arthur Kiron, ed., Constellation of Atlantic Jewish History, 1555-1880 (Philadelphia: University of Pennsylvania Press, 2014); Studemund-Halévy, ed., A Sefardic Pepper-Pot; Stanley Mirvis, Jewish Treasures of the Caribbean. The Legacy of Judaism in the New World (Atglen: Schiffer Publishing, 2016).

29 Julie-Marthe Cohen, ed., Joden in de Cariben (Zutphen: Walburg Pers., 2015).

30 http://whc.unesco.org/en/tentativelists/1083/.

31 The nomination of the Jewish Cemetery Hamburg-Altona as a World Culture Heritage site stresses the importance of the Sephardic cemetery and Hamburg's importance in the Jewish and Sephardic world, see Michael Studemund-Halévy, "Portuguese Jewish Cemetery," in Nomination for the UNESCO World Heritage List. Nomination Dossier: The 
These cumulative efforts have spurred the creation of a "Relational Prosopographical Database of the Sephardic Atlantic."32 Prosopography is the study of a group through the collective study of its members. The relational database will contain information about all the members of the Sephardic nation who lived during any period of history in the Caribbean and will include the name, sex, date of birth and death, religion, marital status, social and economic class, profession, and offices held for every individual who was a part of one of the Jewish communities. The database will be a collective biography of the Sephardic Jews in the Caribbean, a community that was perpetually in flux, and whose written and material legacy is dispersed in archives and libraries all over the world. The database will be freely accessible to researchers and the broader public on the worldwide web. ${ }^{33}$

The Caribbean Jewish cemeteries constitute a rich primary source for the study of local and global Sephardic history. To date, most of the Caribbean Jewish cemeteries have been scientifically documented. ${ }^{34}$ Using the information

Jewish Cemetery Hamburg-Altona, ed. Agnes Sommer (Hamburg: Free Hanseatic City of Hamburg. Ministry of Culture, 2017).

32 Since the mid-1980s, the non-profit BSRP has spearheaded a series of cultural heritage initiatives in a city block that is part of the UNESCO-designated World Heritage site of historic Bridgetown and its Garrison. These include the restoration of the Nidhe Israel Synagogue (1985); conservation of the adjacent Jewish cemetery (2001); establishment of the Nidhe Israel Museum (2008); unearthing of the mikveh (2009), etc. The last phase of these projects, just completed in November 2016, has been the redevelopment of the whole block surrounding the synagogue. This ambitious undertaking has breathed new life into a series of architectural gems, such as the old Firehouse and Weights and Measures building, and artisans' workshops, and created amenities for locals and tourists alike (such as a cafe and an art gallery). The records of the Bridgetown Synagogue Restoration Project (BSRP) have now been fully processed and digitized. The major part of the collection has been uploaded to the Digital Library of the Caribbean (dLOC) and can be freely viewed online. See, for example, Digitizing Caribbean Jewish Documentary Heritage The Barbados Synagogue Restoration Project (http://dloc.com/p1_nisyn); Digital Library of the Caribbean (http://dloc.com); A Nação: Prosopography of the Portuguese Jewish Nation, 1599-180o (http://nacao.weebly.com/about.html). See also Amanda S. Levi, "Linked Sephardim: A Prosopography of the Sephardic Community of the Island of Barbados, West Indies" (unpublished manuscript).

33 The following three websites are possible sites to host the database: A Nação:Prosopography of the Portuguese Jewish Nation, 1599-180o, the Digital Library of the Caribbean and more particularly, the Jewish Diaspora Collection that is part of the dLOC.

34 With the exception of Tobago, Aruba, St. Eustatius, St. Thomas and St. Croix. For the Sephardic cemeteries, see Surinam: Aviva Ben-Ur and Rachel Frankel, Remnant Stones: The Jewish Cemeteries and Synagogues of Suriname: Essays (Cincinnati: Hebrew Union College, 2012); Barbados: Eustace M. Shilstone, Monumental Inscriptions in the Burial Ground of the Jewish Synagogue at Bridgetown, Barbados (New York, n.p., 1956); Vere Langford Oliver, Monumental Inscriptions: Tombstones of the Island of Barbados (San 
collected from tombstones, historians, social historians, art historians, and genealogists will be able to trace the everyday life of the Sephardic communities in the Caribbean, reconstruct family relationships and population movement, and demonstrate the global nature of the Sephardic Nação and the significance of ethnicity and kin in the development of cross-Atlantic trade relationships.

Gravestones are unique lenses through which the historical developments in a given community become visible. The inscriptions are, as David Malkiel so aptly put it, "snapshots of a society's social and cultural proclivities at particular moments in time. ${ }^{35}$ For researchers focusing on the socio-economic history of a city, region or community, cemeteries are a rich primary source. Beyond the iconographical elements of the tombstone decoration and the spatial elements of the burial ground itself, a tombstone epitaph provides important biographical and prosopographical information. Usually the text is concise, but some provide a detailed accounting of the deceased's life, religious role (rabbi, hazan [cantor], teacher; ${ }^{36}$ or profession (e.g., merchant, trader, shop owner, slave

Bernardino: Borgo Press, 1995); Richard Barnett, "Tombstones in Barbados," Tesoro de los judios sefardies 2 (1959): 45-46; Karl Watson, "New Jewish Tombstones Revealed: Additions to Shilstone's Record of Sephardic Tombstones in Bridgetown, Barbados," Journal of the Barbados Museum \& Historical Society 62 (2016): 152-61; Michael Studemund-Halévy, "New Jewish Epitaphs from Bridgetown, Barbados" (forthcoming); Curaçao: Isaac S. Emmanuel, Precious Stones of the Jews of Curaçao: Curaçao Jewry 1656-1957 (New York: Bloch, 1957); Nevis: Michelle M. Terrell, The Jewish Community of Early Colonial Nevis: A Historical Archaeological Study (Gainesville: University of Florida Press, 2005); Jamaica: Richard D. Barnett and Philip Wright, The Jews of Jamaica. Tombstone Inscriptions, 16631880 (Jerusalem: Ben-Zvi Institute, 1997); Marilyn Delevante, The Knell of Parting Day. A History of the Jews of Port Royal and the Hunt's Bay Cemetery (Kingston: n.p., 2008); St. Thomas: Julius Margolinsky, 299 Epitaphs on the Jewish Cemetery in St. Thomas, W.I., 1837-1916 (Copenhagen: n.p., 1957); St. Croix: Bernard Heller, Epitaphs in the Jewish cemeteries at Christianstad, St. Croix (unpublished manuscript 1958); Jacob Robles, "Names on Stones in Savan Cemetery, Charlotte Amalie, St. Thomas Burials, So Far Located" (unpublished manuscript 1972).

35 David Malkiel, Stones Speak—Hebrew Tombstones from Padua, 1529-1862 (Jerusalem: Ben Zvi Institute, 2014), 1.

36 The only multi-scene panel found in the cemetery in Barbados includes a depiction of a stylishly dressed ba'al tokeah (shofar blower). Could it be a portrayal of an actual individual, namely a portrayal of the venerated hakham, ribi ("rabbi teahe"), scribe, mohel (ritual circumciser), and shofar blower? The beautiful and lavishly decorated gravestone for $\mathrm{Me}(\mathrm{h})$ ir Cohen Belinfante, who passed away $175^{2}$ in Barbados, is an elaborate life cycle carved in Hebrew, Portuguese and English along the borders and depicting the various professions of the deceased. At the top, the hands in a priestly blessing symbolize his being a Kohen; at the bottom are three panels that show aspects of his profession as a rabbi, hazan and mohel. The first panel shows a crown with the hands in the clerical benedictional gesture of a Kohen, the descendant of the high priest Aaron. In the second 
owner, physician). ${ }^{37}$ An epitaph can provide information about the individual and his or her family's lineage, ethnic origins, religion, and religious attitudes, ${ }^{38}$ birthplace (important for studying geographical spread), facts about their life and cause of death (slave uprisings, ${ }^{39}$ crime, death at sea), peregrinations, ${ }^{40}$ marital status, transnational marriages, ${ }^{41}$ number of children, social status (attachment to society and culture), ethnic and kinship connections, ${ }^{42}$ inclusion and exclusion in colonial societies (guilds), magnitude of wealth, distribution of gender, ${ }^{43}$ profession, honorific titles, names (Jewish and/or non-Jewish), ${ }^{44}$

panel, the Hakham Belinfante is depicted in fashionable gentleman's clothing of the day (Rococo), blowing a shofar, one of his duties as hazan, and from biblical times associated with messianic redemption and eschatology — the end of time. This panel reflects the impulse among Sephardim from Venice and Amsterdam to preserve a portrait of the venerable rabbi for "good memory," as an act of respect and a way of safeguarding his image in their minds. The third panel illustrates his profession as sofer (scribe, designation for a rabbinical scholar), commemorated by a hand holding a quill pen. The fourth panel shows the tools of a mohel which he practiced (knife, shield, scissors, pincers, forceps, probe, wine cup, and flacons for substances).

37 Jewish merchants and traders played an important role in the Caribbean, a fact proudly reflected in numerous epitaphs.

38 The Maduro Stichting in Curaçao encompasses an extensive collection of genealogical trees, for example, of the families Abudiente, Brandao, Jessurun, Namias de Crasto, etc. Such resources can be found in the databases of SephardicGen (http://www.sephardic gen.com/), or providers such as Ancestry.com.

39 Suriname experienced repeated and violent clashes during the slave uprisings in the Caribbean. These uprisings were often mentioned on the tombstones, see Michael Studemund-Halévy, "Epitaphs in Blood. Crime and Punishment in Sefardic Tombstones," in Jahrbuch Zentrum Jüdische Studien Berlin-Brandenberg 4 (forthcoming). See, for example, Surinam: $S^{a}$ / do yncurtado / mancebo David $\operatorname{Rod}^{\mathrm{s}}$ / Monsanto que foy / matado / por os crueys negros [...]; Jamaica; $\mathrm{S}^{\mathrm{a}}$ / do manso virtuozo e benigno / Samuel de Lucena que por / mão do cruel Barbaro homecida / foy derramado seu inocente / sangue[...].

40 See, for example, the "Hotten's List," New York 1931, 438-450, see also www.yale.edu/glc/ archive/116o.rtf (accessed 20 March 2014), "English-America: The Voyages, Vessels, People, and Places."

41 A perusal of the Amsterdam marriage contracts (ketubot) shows that among the 15,238 couples that married in that city between 1598 and 1811 there were numerous marriages with brides and grooms from Brazil and the Caribbean: St. Marten: 1; Guyana and St. Croix: 2 each; St. Eustatius and Jamaica: 4 each; Suriname: 19; Brazil: 44, and Curaçao: 48, see Dave Verdooner and Harmen Snel, eds., Trouwen in Mokum: Jewish Marriage in Amsterdam, 1598-1811, 2 vols. (The Hague: Koninklijke Bibliotheek, s.a.).

42 Karl Watson, "Shifting Identities: The Role of Religion, Race and Creolization among the Sephardic Jews of Barbados, 1654 to 1990," in The Jews in the Caribbean, ed. Jane S. Gerber (Oxford: The Littman Library of Jewish Civilization, 2014), 195-222.

43 Since cemetery plots had to be bought for women as well as men, death information tends to be more complete than birth or death registers where entries for women were sometimes recorded in a very incomplete manner.

44 The name change can be a potential problem in constructing networks of family relationships or migrations. 
disambiguity of names, ${ }^{45}$ naming practices (naming the child after a living person), ${ }^{46}$ name change as a result of sickness (rogativa). ${ }^{47}$ The language choice may be testimony to the deceased's peripatetic life as a trader, foreigner, or exile (Hebrew, Spanish, Portuguese, Dutch, English). Epitaphs containing compositions of languages (monolingual, bilingual and polyglot epitaphs), ${ }^{48}$ poetry (rhetorical and poetical devices, gematria poems), and arrangements of letters into acrostics, anagrams, palindromes, pattern poems, mnemonic strings of letters or cryptograms, letter manipulation and permutation, translations (from Hebrew into English, from Portuguese into Hebrew, etc.), biblical and Talmudic quotations, rhetorical formulae and literary devices (such as speaking epitaphs), ${ }^{49}$ are prime sources for studying the community's cultural, social, and literary history, as are the richly decorated gravestones containing a profusion of visual images (Jewish vs. pagan symbols), memento mori symbols (skull, crossed bones, hourglass, butterfly, skeleton, karet [lit. cut down, a hand appearing from the clouds fells the tree of life]), ${ }^{50}$ family trees, biblical

45 Due to naming conventions, many of the individuals in the post-exile Sephardic communities bear more than one name (as a Jew, as a Christian, as a Marrano, etc.).

46 In eighteenth-century Surinam, for example, ninety percent of recorded Jewish births followed this pattern, see Erik R. Seeman, Death in the New World. Cross Cultural Encounters, 1492-180o (Philadelphia: University of Pennsylvania Press, 2010), 249.

47 See, for example, the epitaphs from Barbados for: Abraham Lindo, died 1763: "en su Enfermedad su nombre fue Mudado en Jahacob"; Jacob Haim Carvallo, died 1749: "o cuio nombre fue Mudado en Moseh"; Abraham Pinheiro, died 1755, "que en Su Enfermedad fue mudado su nombre en Jehosua"; Semuel Massiah, died 1751: "que fue mudado Su nombre en Mosseh"; Abraham Hizkiau Valverde, died 1746, reads: "que fue Mudado su Nombre en Ysrael y Despues en Hisquija."

48 The use of Hebrew, Portuguese, Spanish, and later Dutch, English, and Papiamento by Sephardim (and Ashkenazim) in colonial America reflects the regional varieties and the linguistic, cultural, and social status of these languages: high vs. low, spoken vs. written, de facto vs. de jure, holy vs. secular.

49 Curaçao: "Los vivientes que aqui pasaren / y la lectura desta tomaren se desengañen / y se

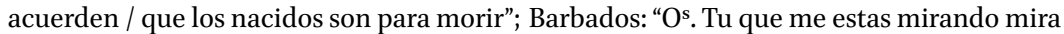
bien / Que bives bien por que no sabes la hora quando / quando te veras a Sy también"; Jamaica: "Porque assi de mi tumba te desvias / moria sin aplicar tu pensamiento [...]; se precuras saber o caminhante / quem se guarda nesta sepoltura [...]." On the dialogue between the deceased and the passer-by, a well-known motif in the Hebrew-Spanish and post-exile Sephardic literature in the Western and Eastern Sephardic Diaspora, see Michael Studemund-Halévy, "Wanderer der Du hierher kommst, lobe ihre Erinnerung. Der Dialog mit dem Verstorbenen in sefardischen Grabinschriften (forthcoming); see also Carsten L. Wilke, "Dialogue of the Dead. Talking Epitaphs by Sephardi and Ashkenazi Rabbis of Hamburg", in Zutot 5, no. 1 (2008): 61-74.

5o The epitaph for Jacob Haim Carvallo from Barbados reads: SEPULTURA / Del Bienaventurado / Jaacob Haim Carvallo / o cuio Nombre fue Mudado / en Mosseh que Fallecio / a los 48 Años de Su edad / en 26 de Tamuz Ano de / 5509 o que Corresponde / a 30 de Junio de 1749. For the Sephardim, the Tree of Life was a widely known Jewish 
narratives (binding of Isaac; Joseph in the pit; David playing the harp; Daniel in the lion's den; Jacob and Rachel, Abigail and David, ${ }^{51}$ depictions of God, ${ }^{52}$ scenes of illness and death, ${ }^{53}$ angels, cherubim, putti, animals and flowers, ${ }^{54}$ lettering (raised versus engraved letters), and the space of the grave itself (individual grave, family grave, grave of honor). Also the quality of stone (stones for Curaçao, Surinam, and for Barbados, for example, were invariably imported from Amsterdam [blue stones], Italy [marble stones], and North America [porphyry], ${ }^{55}$ reveals information about the deceased, the community, and the

symbol and a symbol of messianic hope in the seventeenth century. In Surinam, at least 57 of 134 stones $(42 \%)$ that bear iconography display the theme of karet, and in Barbados at least 66 of 374 stones (17.64\%) display this motif (30 for men, 29 for women). While Altona possesses a relatively higher percentage of illustrated stones $(30 \%)$ than Suriname $(8.12 \%)$, the karet image appears almost twice as often. The Tree of Life, generally symbolized by biblical cypress and palm (in Hamburg and Amsterdam), or tropical pine tree and coconut tree (in Barbados), demonstrates in the Caribbean an affinity with the place of origin of the decedent, see Ben-Ur and Frankel, Remnant Stones: Epitaphs: Cassipora cemetery: 8 karet scenes; Jodensavanne: 16 karet scenes; Sephardi cemetery Paramaribo: 22 karet scenes; Ashkenazi cemetery Paramaribo: 12 karet scenes. As in Altona, karet scenes in Suriname decorate more often the gravestones of women than men.

51 Sephardim of the Western Sephardic diaspora, embracing the iconographic traditions of the lands in which they lived, seem to have exulted in their ability to proclaim to the world their ancestral faith and their varied bequests, see Michael Studemund-Halévy, "The Persistence of Images: Reproductive Success in the History of Sephardi Sepulchral Art," in The Dutch Intersection, ed. Yosef Kaplan (Leiden: Brill, 2008), 123-147; id., "More than Images"; Karl Watson, "The Iconography of Gravestones in the Jewish Graveyard, Bridgetown, Barbados," Journal of the Barbados Museum \& Historical Society 50 (2005): 195-212; Natalie Zeldin, "Skulls, Shields and Narratives," (unpublished manuscript); id., "Imaging Death: Sepulchral Iconography in the Koenigstrasse Cemetery," (unpublished manuscript); Seeman, Death in the New World, 253.

$5^{2}$ See Studemund-Halévy, "More than Images," 429-88.

53 Putrid fever was frequent in the Caribbean, see the epitaph of Samuel Hoheb Brandon, died 1793 in Bridgetown, Barbados: "Here lies the Body of Mr SAMUEL HART / Merch" who died on the 29th day of Tisry / which corresponds with the 15th Day of / October 1773 Aged 53 Years 9 months and 2 / days of a Putrid Fever in Bridgetown / Barbados."

54 Elias Valverde, died on 22 August 1725 in Barbados. His epitaph reads: "SA / Do Anjo ELIAV FILHO / de DAVID \& SIMHA / ABIGAIL VALVERDE / que Faleleceu em do / mingo 24 de Elul / Ano 5485 / de Idade de 37 Meses."

55 Many Jews in the colonies imported tombstones from Amsterdam, London, and Venice. Some stones reveal that gravestones also traveled between the colonies, see for example the tombstone of Samuel Hart, a member of an important Newport Jewish family, died in Barbados of a purtrid fever. This tombstone was recognized by Laura A. Leibman as the work of Williams Stevens, a famous carver from Newport, Rhode Island. Many of Newport's early Jews came via Barbados, and throughout the eighteenth century exchange between Newport and Barbados was a crucial trade route; see also Shilstone, 


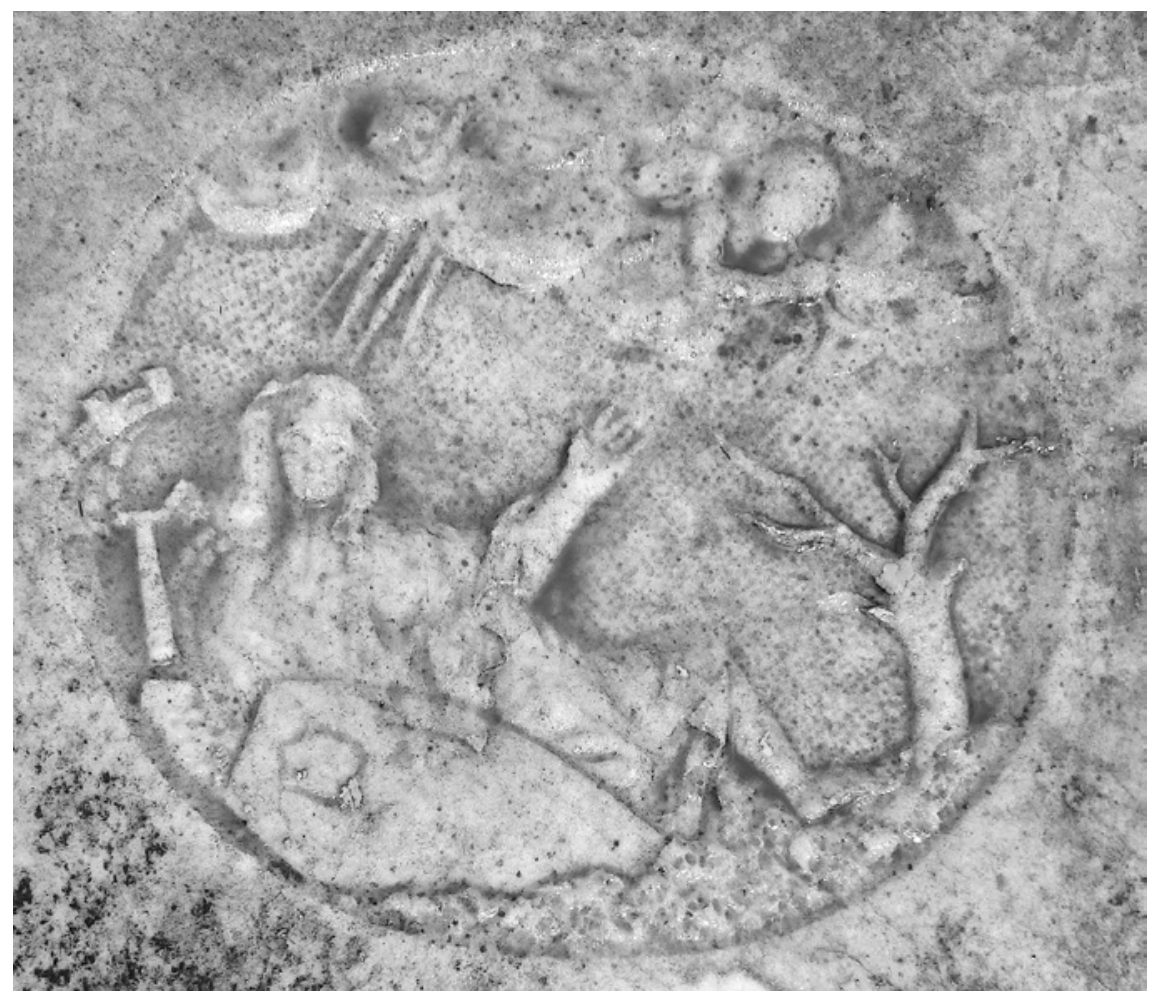

FIGURE 20.1 Gravestone of Bella Barrow, wife of Simon Barrow, died 1 October 1773, aged 53 years, in Barbados, detail PHOTO: MICHAEL STUDEMUND-HALÉVY, BARBADOS, 2017

stonemason, ${ }^{56}$ and more. All the minor and major themes of Jewish Atlantic history-migration and peregrinations, circum-Atlantic world, Iberian roots, re-Judaization, ethnicity, circulation of ideas, European and American identity, Sephardim and Ashkenazim, Jews and Blacks—unfold within in this corpus (Figs. 20.1, 20.2. 20.3 and 20.4). ${ }^{57}$

A tombstone's epigraphy and iconography stand in relation to the specific cemetery in which it is found, but also to neighboring and even distant cemeteries, often across borders, and oceans. All the minor and major themes of

Inscriptions, xxviii; Emmanuel, Precious Stones, 129; Ben-Ur and Frankel, Remnant Stones. Essays, 76-81.

$5^{6}$ The artist or stonecutter, who carved and created the gravestones, generally did not sign his work.

57 Aviva Ben-Ur, "Atlantic Jewish History. A Conceptual Reorientation," in Constellation of Atlantic Jewish History, 1555-1880, ed. Arthur Kiron (Philadelphia: University of Pennsylvania Press 2014), 25-46. 


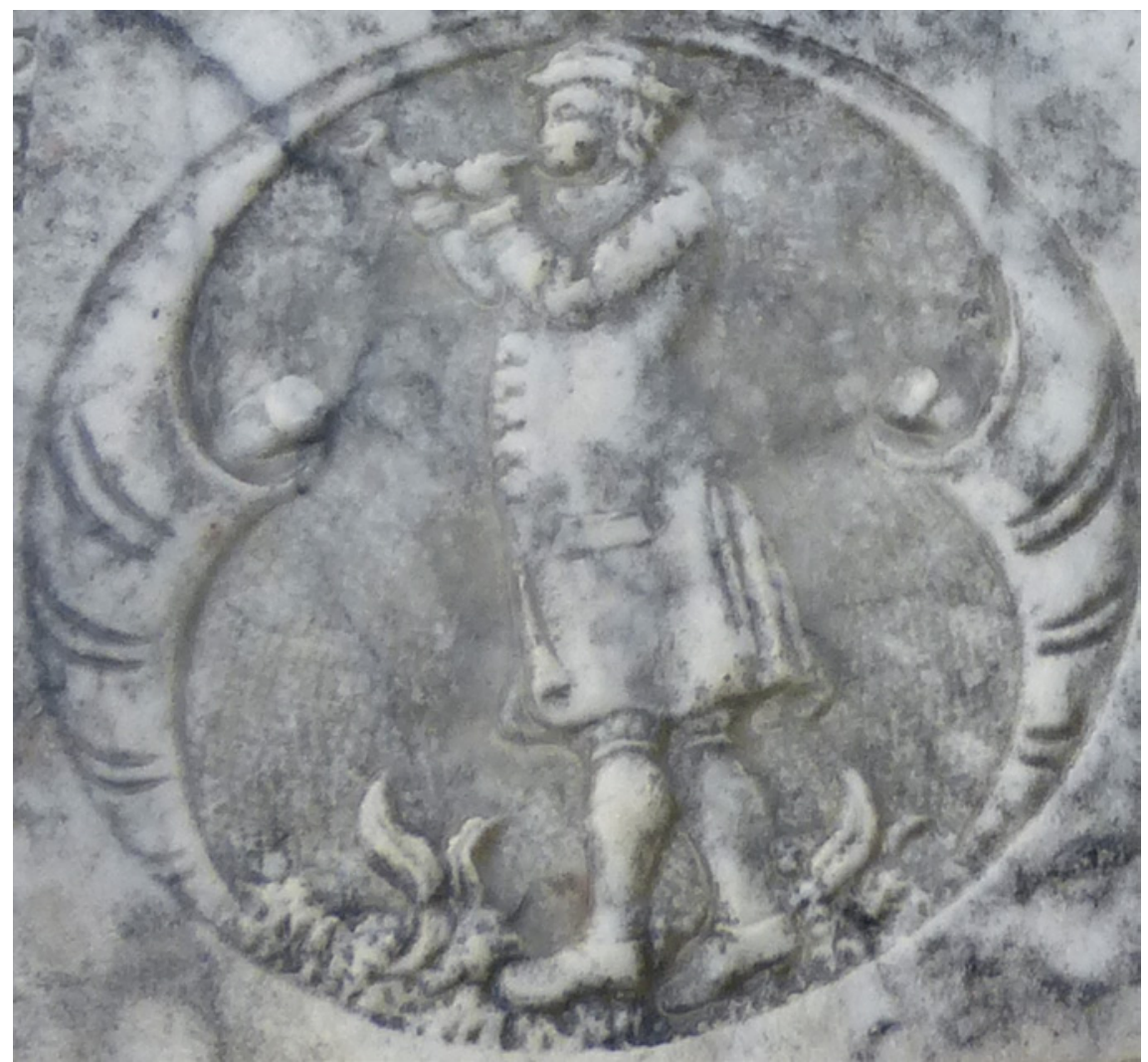

FIGURE 20.2 Gravestone of Hakham Mehir Cohen Belinfante, died 25 September 1752, aged 48 years, in Barbados, detail

PHOTO: MICHAEL STUDEMUND-HALÉVY, BARBADOS, 2017

Jewish Atlantic history-migration and peregrinations, re-Judaization, Iberian roots, race and ethnicity, ${ }^{58}$ circulation of ideas and knowledge, European and American identity, relations between Sephardim and Ashkenazim, between Jews and Blacks - unfold within this corpus. ${ }^{59}$ And because practically all Sephardic communities, whether in Europe or the Caribbean, were interconnected by close family, religious and economic ties, the standardization of Sephardic sepulchral art and language can provide information not only about globalization, both economic and cultural, but also about inter-Caribbean and international trade relations and family networks. A methodological study of

$5^{8}$ See Alan F. Benjamin, Jews of the Dutch Caribbean. Exploring ethnic identity on Curaçao (London: Routledge, 2002).

59 Ben-Ur, "Atlantic Jewish History. A Conceptual Reorientation," 25-46. 


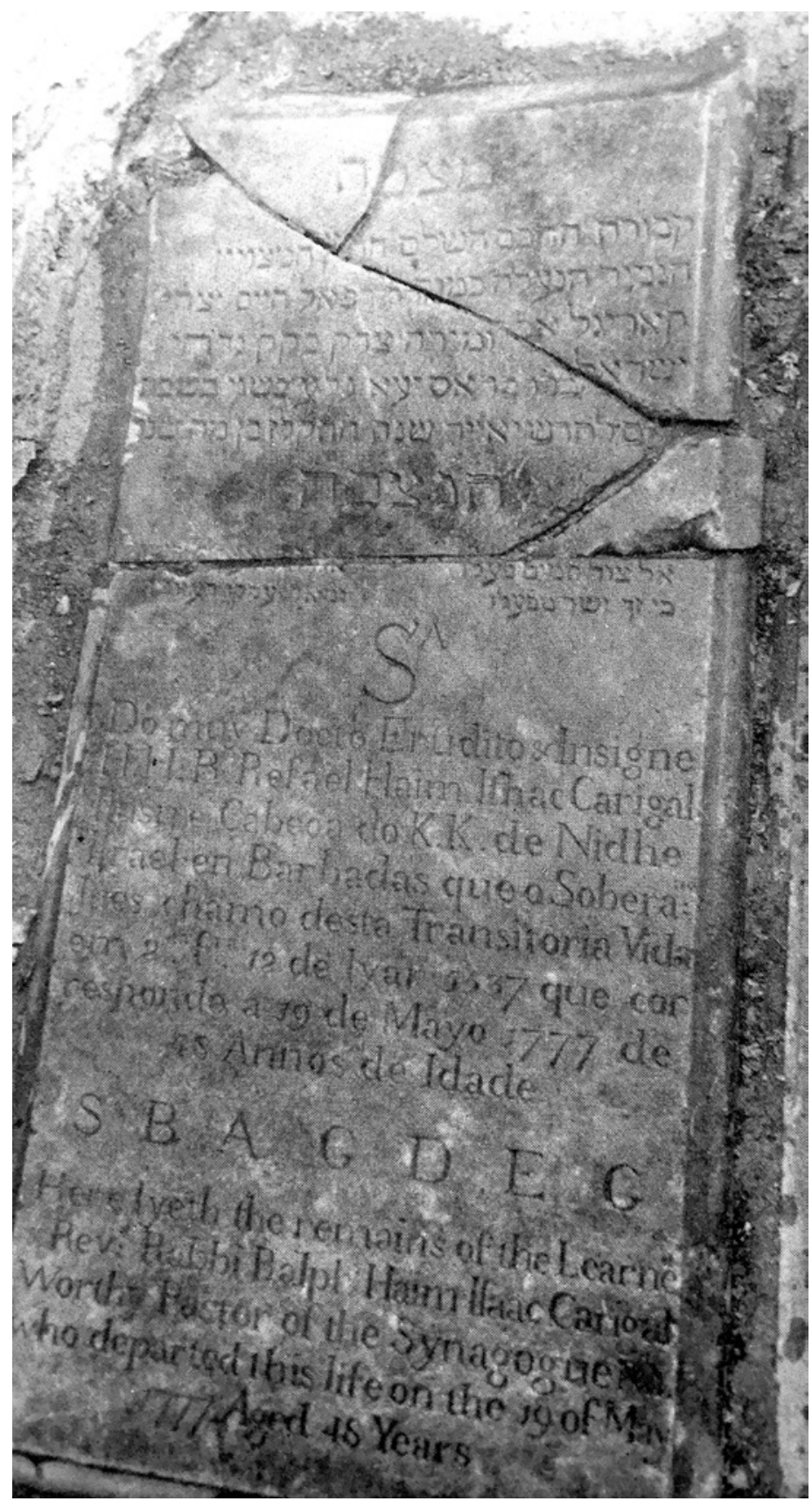

FIGURE 20.3 Gravestone of Rabbi Refael Haim Ishac Carigal, died 19 May 1777, aged 48 years, in Barbados PHOTO: MICHAEL STUDEMUND-HALÉVY, BARBADOS, 2017 


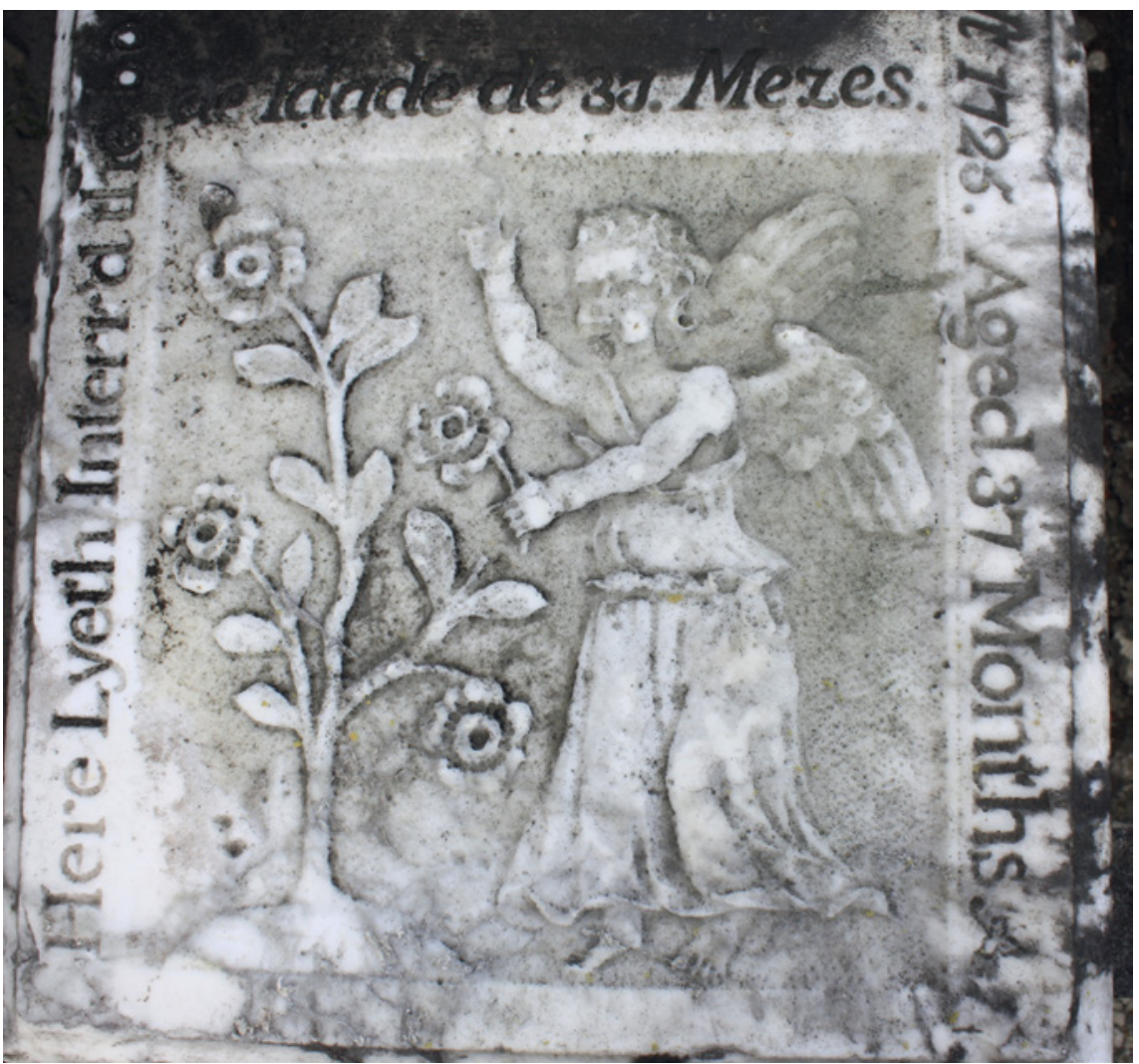

FIGURE 20.4 Gravestone of Elias Valverde, son of David and Simha Valverde, died 22 August 1725, aged 37 months, in Barbados, detail

PHOTO: MICHAEL STUDEMUND-HALÉVY, BARBADOS, 2017

the documentation of the lived experiences of real people, their loves, their suffering, would at long supplant random biographies with solidly established "human truths" and "human belongings."

A cemetery's spatial aspects - the gravestones lying next to and behind one another, the rows and fields - what binds the gravestones in situ and constitutes the cemetery as an ensemble of tombstones, can also yield important information. Placement in a burial compound is rarely accidental. ${ }^{60}$ The database will have an interactive location tool for examining the spatial layout of the gravestones that will be able to highlight regularities and patterns such as rows or groups of gravestones that display the same symbol or a family-specific

6o Hakham Mehir Cohen Belinfante died on 25 September 1752 in Barbados. 
symbol that can be found in a number of Caribbean cemeteries or in cemeteries in Amsterdam, Hamburg, or Glückstadt.

The database will be reachable through a website that will provide access to rich, structured, biographical information relating to the broadest possible number of recorded Sephardic Jews and New Christians in the Caribbean from the mid-seventeenth to the late nineteenth century, drawing initially on primary archives in the Caribbean. This will gradually be enriched by archives from other former Sephardic centers such as Amsterdam, London, and Hamburg. ${ }^{61}$ The database will also be enhanced and refined by associated research projects that will utilize (and in the process, contribute to) the database. ${ }^{62}$ This will require biographical data for large numbers of individuals, and the information available for many individuals may be quite limited, and consist of scattered references in different documents. These will need to be connected and recorded in databases in order to facilitate investigation of larger patterns. In accordance with the model presented by the well-known epigraphic database EPIDAT, all data relating to the Sephardic cemeteries in the Caribbean will be entered into the E PIDAT Cemetery Databases. ${ }^{63}$ Using the programming language TUSTEP and a special EDV program, a full-text search in Hebrew, Portuguese, Spanish, English, Dutch, and German is possible. In addition, there are text-visual levels of documentation (time-based, locationbased, index-based, map-based, full-text-search) as well as the provision of options for detection of biblical quotations, parallel passages, iconography, and rough draft translation of a large number of fixed formulae. Symbols and dated headstones are visualized in the spatio-temporal interface of the

61 Project Relations in Space-Visualization of Topological Microstructures is working on the visualization of cemeteries, including the Jewish cemetery in Hamburg-Altona, see Tobias Arera-Rütenik andThomas Kollatz, "Interdisziplinäre Perspektiven auf Grabmale und Visualisierung räumlicher Strukturen. Ergebnisse eines Projektes zu historischen jüdischen Friedhöfen," in Objekt und Schrift. Beiträge zur materiellen Kultur des Jüdischen, ed. Karin Keßler et al., Jüdisches Kulturerbe 1 (2016): 25-29; see also "Raum-Zeit-Analysen mit DARIAH-Geo-Browser und DARIAH-Datasheet-Editor," in Bibliothek-Forschung und Praxis. 40, no. 2 (2016): 229-33, https://www.degruyter.com/view/j/bfup.2016.40.issue-2/ bfp-2016-0032/bfp-2016-0032.xml?format=INT.

62 See, for example, the recently published online-edition Key Documents of German-Jewish History, developed by the Institute for the History of the German Jews <jewish-historyonline.net>.

63 This Database of Jewish Epigraphy presents the inventory, documentation and editions of epigraphical collections. Currently available online are 179 digital editions with 32,172 epitaphs (63,429 image files), see "EPIDAT-Datenbank zur jüdischen Grabsteinepigraphik. Inventarisierung und Dokumentation historischer jüdischer Friedhöfe," in Wenn das Erbe in die Wolken kommt. Digitalisierung und kulturelles Erbe, ed. Eckhard Bolenz et al. (Essen: Klartext, 2015), 161-68. 
DARIAH-DE Geobrowser Visualization of family relations using the XTripels webservice. With the aid of the EPIDAT database developed at the Duisburg Salomon Ludwig Steinheim Institute ${ }^{64}$ and the Excel Database SEFARAD at the Institute for the History of the German Jews in Hamburg, ${ }^{65}$ into which the epitaphs of all previously studied and published Caribbean Sephardic cemeteries will be entered in the coming years, relations between the Sephardic cemeteries in the Old World and New World can become searchable and visible.

The relational prosopographical database will be an important tool for untangling the complex history of the Jewish Atlantic and the stories and peregrinations of individuals and family networks that Atlantic history might have otherwise forgotten. ${ }^{66}$

\section{Websites and Databases}

A Nação: Prosopography of the Portuguese Jewish Nation, 1599-180o: http://nacao.weebly.com/about.html DIGITAL LIBRARY OF THE CARIBBEAN: http://dloc.com

Digitizing Caribbean Jewish Documentary Heritage: The Barbados Synagogue Restoration Project: http://dloc.com/p1_nisyn

Epidat: http://www.steinheim-institut.de/cgi-bin/epidat

Sefardat: http://www.jüdischer-friedhof-altona.de/sefardat.html

Unesco Tentativelists: http://whc.unesco.org/en/tentativelists/1083/

\section{Bibliography}

Abrahams, Israel, ed. Hebrew Ethical Wills. Philadelphia: Jewish Publication Society of America, 1926.

Arbell, Mordechai. The Jewish Nation of the Caribbean. The Spanish-Portuguese Jewish Settlements in the Caribbean and the Guianas. Jerusalem: Gefen, 2002.

Arera-Rütenik, Tobias and Thomas Kollatz, "Interdisziplinäre Perspektiven auf Grabmale und Visualisierung räumlicher Strukturen. Ergebnisse eines Projektes zu historischen jüdischen Friedhöfen." In Objekt und Schrift. Beiträge zur materiellen

\footnotetext{
64 http://www.steinheim-institut.de/cgi-bin/epidat.

65 http://www.jüdischer-friedhof-altona.de/sefardat.html.

66 See, for example, Karen Racine, and Beatriz G. Mamigonian, eds., The Human Tradition in The Atlantic World, 1500-1850 (Lanham: Rowman \& Littlefield Publishers, 2010).
} 
Kultur des Jüdischen. Edited by Karin Keßler et al. Jüdisches Kulturerbe 1 (2016): 25-29.

Bar-Levav, Avriel. "When I Was Alive. Jewish Ethical Wills as Egodocuments." In Egodocuments and History. Autobiographical Writing in Its Social Context since the Middle Ages. Edited by Rudolf Dekker, 45-59. Hilversum: Verloren, 2002.

Barnett, Richard D. “Tombstones in Barbados.” Tesoro de los judíos sefardíes 2 (1959): $45^{-46 .}$

Barnett, Richard D., and Philip Wright. The Jews of Jamaica. Tombstone Inscriptions, 1663-1880. Jerusalem: Ben Zvi Institute, 1997.

Baylin, Bernard. Concept and Contours. Cambridge, MA: Harvard University Press, 2005.

Ben-Ur, Aviva. "Atlantic Jewish History. A Conceptual Reorientation." In Constellation of Atlantic Jewish History, 1555-1880. Edited by Arthur Kiron, 25-46. Philadelphia: University of Pennsylvania Press, 2014.

Ben-Ur, Aviva, and Rachel Frankel. Remnant Stones: The Jewish Cemeteries and Synagogues of Suriname: Epitaphs. Cincinnati: Hebrew Union College, 2009.

Ben-Ur, Aviva, and Rachel Frankel. The Jewish Cemeteries and Synagogues of Suriname: Essays. Cincinnati: Hebrew Union College, 2012.

Benjamin, Alan F. Jews of the Dutch Caribbean. Exploring Ethnic Identity on Curaçao. London: Routledge, 2002.

Bernardini, Paolo and Norman Fiering, eds. The Jews and the Expansion of Europe to the West, 1450-180o. New York: Berghahn, 2001.

Birkle, Carmen, and Nicole Waller, eds. "The Sea is History." Exploring the Atlantic. Heidelberg: Winter, 2006.

Bowden, Martyn J. "Disasters, Revolutions, and Discriminations in an Era of Economic Depression, 1776-1795: The World of the Sephardic Jews of Bridgetown, Part 3," Journal of the Barbados Museum \& Historical Society 61 (2015): 1-81.

Bowden, Martyn J. "Houses, Inhabitants and Levies: Place for the Sephardic Jews of Bridgetown, Barbados 1679-1729." Journal of the Barbados Museum \& Historical Society 57 (2011): 1-53.

Bowden, Martyn J. "Levels Discrimination and the Making of the Swan District in Bridgetown 1725-1766: Place for the Sephardic Jews in Bridgetown, Barbados, Part 2." Journal of the Barbados Museum \& Historical Society 62 (2016): 77-151.

Bowden, Martyn J. "Three Centuries of Bridgetown: An Historical Geography." Journal of the Barbados Museum \& Historical Society 49 (2003): 3-137.

Brauch, Julia, Anna Lipphardt, and Alexandra Nocke, eds. Jewish Topographies: Visions of Space, Traditions of Place. Aldershot: Ashgate, 2008.

Britt, Brian M., and Alexandra Cuffel. Religion, Gender, and Culture in the Pre-Modern World. New York: Palgrave Macmillan, 2015. 
Burkardt, Albrecht and Gerd Schwerthoff, eds. Tribunal der Barbaren? Deutschland und die Inquisition in der Frühen Neuzeit. Konstanz and Munich: UVK Verlagsgesellschaft, 2012.

Cassuto, Alfonso. "From the Old Minute Book of the Sephardic Congregation of Hamburg, Relating to Jews of Barbados," Publications of the American Jewish Historical Society 32 (1931): 114-15.

Cassuto, Isaac. "Aus dem ältesten Protokollbuch der portugiesisch-Jüdischen Gemeinde in Hamburg." Jahrbuch der Jüdisch-Literarischen Gesellschaft 6 (1908/1909): 1- 54; 7 (1909/1910): 159-210; 8 (1910/1911): 227-90; 9 (1911/1912): 318-66; 10 (1912/1913): 255-95; 11 (1916): 1-76; 13 (1920): 55-118.

Cohen, Julie-Marthe, ed. Joden in de Cariben. Zutphen: Walburg Pers, 2015.

Cohen Nassy, David de Ishac. Essai historique sur la colonie de Surinam: sa fondation, ses revolutions, ses progrès, depuis son origine jusqu'à nos jours [...] avec l'histoire de la nation portugaise. Amsterdam: S. Emmering, 1968.

Cwik, Christian. "The Rise of Jewish Merchants Capitalists in the Caribbean: The Triangulation of Barbados, Jamaica and Curaçao." In A Sefardic Pepper-Pot in the Caribbean. History, Language, Literature, and Art. Edited by Michael StudemundHalévy, 13-29. Barcelona: Tirocinio, 2016.

Delevante, Marilyn. The Knell of Parting Day. A History of the Jews of Port Royal and the Hunt's Bay Cemetery. Kingston: n.p., 2008.

Emmanuel, Isaac S. Precious Stones of the Jews of Curaçao: Curaçao Jewry 1656-1957. New York: Bloch, 1957.

Endelman, Todd M. The Jews of Britain, 1656 to 200o. Berkeley: University of California Press, 2002.

Farrar, P. A. "The Jews in Barbados." Journal of the Barbados Museum \& Historical Society 9 (1942): 131-32.

Gerber, Jane S., ed. The Jews in the Caribbean. Oxford: The Littman Library of Jewish Civilization, 2014.

Gonsalves de Mello, José A. Gente da Nação. Recife: Massangana, 1989.

Heller, Bernard. "Epitaphs in the Jewish Cemeteries at Christianstad, St. Croix." Manuscript, 1958.

Heller, Reginaldo. "Diáspora Atlântica. A Nação Judaica no Caraibe, Séculos XVII e XVIII." PhD diss., Universidade Federal Fluminense, 2008.

Hoberman, Michael, et al., eds. Jews in the Americas, 1776-1826. London: Routledge, 2018.

Ioly Zorattini, Pier Cesare. L'identità dissimulata. Firenze: Olschki, 2000.

Ioly Zorattini, Pier Cesare. Processi del Santo Uffizio di Venezia contro Ebrei e Giudaizzanti, 16o8-1632. 14 vols. Florence: Olschki, 1980-1999.

Israel, Jonathan I. "Menasseh Ben Israel and the Dutch Sephardic Colonization Movement." In The Jews of Britain, 1656 to 2000 . Edited by Todd M. Endelman, 15-38. Berkeley: University of California Press, 2002. 
Israel, Jonathan I. Diasporas within a Diaspora: Jews, Crypto-Jews, and the World of Maritime Empires, 1540-1740. Leiden: Brill, 2002.

Israel, Jonathan I. "The Dutch Jewish Enlightenment in Surinam, 1770-180o." In The Religious Cultures of Dutch Jewry. Edited by Yosef Kaplan and Dan Michman, 183206. Leiden and Boston: Brill, 2017.

Kagan, Richard L., and Philip D. Morgan, eds. Atlantic Diasporas: Jews, Conversos, and Crypto-Jews in the Age of Mercantilism, 1500-1800. Baltimore: Johns Hopkins University Press, 2009.

Kaplan, Yosef. Zwischen Neuchristen und neuen Juden. Die verschlungenen Wege von Kryptojuden und westlichen Sefarden in der Frühen Neuzeit. Trier: Kliomedia, 2014.

Kaplan, Yosef. "Wayward New Christians and Stubborn New Jews." Jewish History 8, nos. 1-2 (1994): 27-41.

Kaplan, Yosef, ed. The Dutch Intersection. Leiden: Brill, 2008.

Kaplan, Yosef, and Dan Michman, eds. The Religious Cultures of Dutch Jewry. LeidenBoston: Brill, 2017.

Kiron, Arthur, ed., Constellation of Atlantic Jewish History, 1555-189o. Philadelphia: University of Pennsylvania Press, 2014.

Kistemaker, Renée and Tirtsah Levie, eds. Portugueses em Amesterdão. 1600-1680. Amsterdam: De Bataafsche Leeuw, 1988.

Klooster, Wim. "Atlantic and Caribbean Perspectives: Analyzing a Hybrid and Entangled World." In The Sea: Thalassography and Historiography in the Twenty-First Century. Edited by Peter N. Miller, 6o-83. Ann Arbor: University of Michigan Press, 2013.

Konijn, Fieke. "As sepulturas do cemitério Bet Haim." In Portugueses em Amesterdão. 16oo-168o. Edited by Renée Kistemaker and Tirtsah Levie, 90-109. Amsterdam: De Bataafsche Leeuw, 1988.

Langford Oliver, Vere. Monumental Inscriptions: Tombstones of the Island of Barbados. San Bernardino: Borgo Press, 1995.

Leonard, Adrian, and David Pretel, eds. The Caribbean and the Atlantic World Economy. Circuits of Trade, Money and Knowledge, 1650-1914. Houndmills: Palgrave, 2015.

Levi, Amalia S. "Linked Sephardim: A Prosopography of the Sephardic Community of the Island of Barbados, West Indies." Unpublished manuscript.

Levie Bernfeld, Tirtsah. "Exit Amsterdam: Poor Portuguese and Caribbean Horizons." In A Sefardic Pepper-Pot. Edited by Michael Studemund-Halévy, 210-29. Tirocinio: Barcelona, 2016.

Levie Bernfeld, Tirtsah. Poverty and Welfare Among the Portuguese Jews in Early Modern Amsterdam. Oxford: Littman Library, 2012.

Lieberman. Julia R. "New Practices of Sedaca: Charity in London's Spanish and Portuguese Jewish Community during the Eighteenth Century." In Charity on Jewish, Christian, and Islamic Traditions. Edited by Julia R. Lieberman and Michal Jan Rozbicki, 105-29. Lanham: Lexington Books, 2017. 
Loker, Zvi. Jews in the Caribbean. Evidence on the History of the Jews in the Caribbean Zone in Colonial Times. Jerusalem: Misgav Yerushalayim, 1991.

Malkiel, David. Stones Speak-Hebrew Tombstones from Padua, 1529-1862. Jerusalem: Ben Zvi Institute, 2014.

Marcus, Jacob Rader. The Colonial American Jew, 1492-1776. Vol. 1. Detroit: Wayne State University Press, 1970.

Margolinsky, Julius. 299 Epitaphs on the Jewish Cemetery in St. Thomas, W. I., 1837-1916. Copenhagen: n.p. 1957 .

Merrill, Gordon. "The Role of the Sephardic Jews in the British Caribbean Area during the Seventeenth Century." Caribbean Studies 4 (1964): 32-49.

Miller, Derek Robert. "A Medley of Contradictions. The Jewish Diaspora in St. Eustatius and Barbados." PhD diss., The College of William and Mary, London, 2013.

Mirvis, Stanley. Jewish Treasures of the Caribbean. The Legacy of Judaism in the New World. Atglen: Schiffer Publishing, 2016.

Nahon, Gérard. "Nefusot Yehuda (Bayonne) et Beraha ve-Shalom (Surinam). Livres et lecture au XVIII ème siècle." In A Sefardic Pepper-Pot in the Caribbean. Edited by Michael Studemund-Halévy, 362-428. Barcelona: Tirocinio, 2016.

Oliel-Grausz, Evelyne. "A Study in Intercommunal Relations in the Sephardi Diaspora: London and Amsterdam in the Eighteenth Century." Dutch Jews as Perceived by Themselves and Others. Edited by Yosef Kaplan and Chaya Brasz, 41-58. Leiden: Brill, 2001.

Oliel-Grausz, Evelyne. "Networks and Communication in the Sephardi Diaspora: An Added Dimension to the Concept of Port Jews and Port Jewries." Jewish Culture and History 7 (2004): 61-76.

Oliel-Grausz, Evelyne. "Relations et réseaux intercommunautaires dans la diaspora d'occident au XVII' siècle." PhD diss., Sorbonne, Paris, 2011.

Oppenheim, Samuel. "A List of Jews Made Denizens in the Reigns of Charles II and James II, 1661-1687." Publications of the Jewish Historical Society 20 (1911): 109-13.

Oppenheim, Samuel. "Last Wills of Jews in the British West Indies prior to $1800 . "$ Publications of the Jewish Historical Society 32 (1931): 55-64.

Perelis, Ronnie. Narratives from the Sephardic Atlantic. Blood and Faith. Bloomington: Indiana University Press, 2016.

Philips Cohen, Julia, and Sarah Abrevaya Stein, eds. Sephardi Lives. A Documentary History, 1700-1950. Stanford: Stanford University Press, 2016.

Racine, Karen, and Beatriz G. Mamigonian, eds. The Human Tradition in The Atlantic World, 1500-1850. Lanham: Rowman \& Littlefield Publishers, 2010.

Robles, Jacob. "Names on Stones in Savan Cemetery, Charlotte Amalie, St. Thomas Burials." Unpublished manuscript 1972. 
Rosenbloom, Joseph R. A Biographical Dictionary of Early American Jews. Colonial Times through 180o. Lexington: University Press of Kentucky, 2015.

Samuel, Wilfred S. A Review of the Jewish Colonists in Barbados in the Year 1680 . London: The Jewish Historical Society of England, 1936.

Sanders, Joanne McCrea, ed. Barbados Records. Wills and Administration. 3 vols. Houston: Sanders Historical Publications, 1979-1981.

Schorsch, Jonathan. Black and Jews in the Early Modern World. Cambridge: Cambridge University Press, 2004.

Schorsch, Jonathan. Swimming the Christian Atlantic. Judeoconversos, Afroiberians and Amerindians in the Seventeenth Century. 2 vols. Leiden: Brill, 2009.

Schreuder, Yda. "A True Global Community: Sephardic Jews, the Sugar Trade, and Barbados in the Seventeenth Century." Journal of the Barbados Museum and Historical Society 50 (2004): 166-94.

Schreuder, Yda. "Evidence from the Notarial Protocols in the Amsterdam Municipal Archives about Trade Relationships between Amsterdam and Barbados in the Seventeenth Century." Journal of the Barbados Museum and Historical Society $5^{2}$ (2006): 54-82.

Schreuder, Yda. "The Influence of the Dutch Colonial Trade on Barbados in the Seventeenth Century." Journal of the Barbados Museum and Historical Society 48 (2002): 143-63.

Sealtiel Olsen, Vibeke. "Liste des Sépharades Portugais qui furent payés pour quitter Amsterdam, 1757-1813." Manuscript. Amsterdam, 1999.

Seeman, Erik R. Death in the New World. Cross-Cultural Encounters, 1492-180o. Philadelphia: University of Pennsylvania Press, 2010.

Shilstone, Eustace M. Monumental Inscriptions in the Burial Ground of the Jewish Synagogue at Bridgetown, Barbados. New York: American Jewish Historical Society, 1956.

Snyder, Holly. "A Sense of Place: Jews, Identity and Social Status in Colonial British America, 1654-1831." PhD diss., Brandeis University, 2000.

Snyder, Holly. "Rethinking the Definition of 'Community' for a Migratory Age, 16541830." In Imagining the American Jewish Community. Edited by Jack Wertheimer, 3-27. Brandeis: Brandeis University Press, 2007.

Studemund-Halévy, Michael. "Across the Waters. Sefardic Pioneers from Hamburg in the Caribbean." In A Sefardic Pepper-Pot in the Caribbean. Edited by Michael Studemund-Halévy, 177-83. Barcelona: Tirocinio, 2016.

Studemund-Halévy, Michael. Biographisches Lexikon der Hamburger Sefarden. Hamburg: Christians, 2000. 
Studemund-Halévy, Michael. "Epitaphs in Blood. Crime and Punishment in Sefardic Tombstones," in Jahrbuch Zentrum Jüdische Studien Berlin-Brandenburg 4 (forthcoming).

Studemund-Halévy, Michael. "Les aléas de la foi. Parcours d'un jeune Portugais entre église et synagogue." In Memoria. Festschrift für Michael Brocke. Edited by Birgit Klein, 363-82. Berlin: Metropol, 2005.

Studemund-Halévy, Michael. "More than Images. Sefardi Sepulchral Iconography in the Jewish Cemetery in Bridgetown, Barbados." In A Sefardic Pepper-Pot in the Caribbean. Edited by Michael Studemund-Halévy, 429-88. Barcelona: Tirocinio, 2016.

Studemund-Halévy, Michael. "Portuguese Jewish Cemetery." Nomination for the UNEsco World Heritage List. Nomination Dossier: The Jewish Cemetery HamburgAltona. Edited by Agnes Sommer. Hamburg: Free Hanseatic City of Hamburg. Ministry of Culture, 2017.

Studemund-Halévy, Michael. "Rückkehr mit Widerruf. Ein junger Portugiese zwischen Kirche und Synagoge." In Tribunal der Barbaren? Deutschland und die Inquisition in der Frühen Neuzeit. Edited by Albrecht Burkardt and Gerd Schwerthoff, 255-75. Konstanz and Munich: UVK Verlagsgesellschaft, 2012.

Studemund-Halévy, Michael. "The Persistence of Images: Reproductive Success in the History of Sephardi Sepulchral Art." In The Dutch Intersection. Edited by Yosef Kaplan, 123-47. Leiden: Brill, 2008.

Studemund-Halévy, Michael. "Wanderer der Du hierher kommst, lobe ihre Erinnerung. Der Dialog mit dem Verstorbenen in sefardischen Grabinschriften" (forthcoming).

Sutcliffe, Adam. "Ideas and Space: Heterodoxy, Circulation and Urban Life in the Western Sephardic Diaspora." Unpublished manuscript, 2005.

Sutcliffe, Adam. "Jewish History in an Age of Atlanticism." In Atlantic Diasporas, Jews, Conversos, and Crypto-Jews in the Age of Mercantilism, 1500-180o. Edited by Richard L. Kagan and Philip D. Morgan, 18-30. Baltimore: The Johns Hopkins University Press, 2009.

Teensma, Benjamin N. "De Levensgeschiedenis van Abraham Perengrino, alias Manuel Cardoso de Macedo." Studia Rosenthaliana 10 (1976): 1-36.

Terrell, Michelle M. The Jewish Community of Early Colonial Nevis. Gainesville: University of Florida Press, 2005. Trivellato, Francesca. The Familiarity of Strangers: The Sephardic Diaspora, Livorno, and Cross-Cultural Trade in the Early Modern Period. New Haven: Yale University Press, 2009.

Truxes, Thomas M. “Trading Diasporas.” In The Princeton Companion to Atlantic History. Edited by Joseph C. Miller, 456-62. Princeton, NJ: Princeton University Press, 2015. Verdooner, Dave, and Harmen Snel, eds. Trouwen in Mokum: Jewish Marriage in Amsterdam, 1598-1811. 2 vols. Den Haag: Koninklijke Bibliotheek, n.d. 
Watson, Karl. "New Jewish Tombstones revealed: Additions to Shilstone's Record of Sephardic Tombstones in Bridgetown, Barbados." The Journal of the Barbados Museum \& Historical Society 62 (2016): 152-61.

Watson, Karl. "The Iconography of Gravestones in the Jewish Graveyard, Bridgetown, Barbados." Journal of the Barbados Museum \& Historical Society 50 (2005): 195-212.

Watson, Karl. "Shifting Identities: The Role of Religion, Race and Creolization among the Sephardic Jews of Barbados, 1654 to 1990." In The Jews in the Caribbean. Edited by Jane S. Gerber, 195-222. Oxford: The Littman Library of Jewish Civilization, 2014. Watson, Karl, et al. The Wills of the Jews, 1685-1847. Bridgetown, n.p., n.d.

Wilke, Carsten L. "Dialogue of the Dead. Talking Epitaphs by Sephardi and Ashkenazi Rabbis of Hamburg." Zutot 5, no. 1 (2008): 61-74.

Williams, Caroline A., ed. Bridging the Early Modern Atlantic World. People, Products, and Practices on the Move. Farnham: Ashgate, 2009.

Zacek, Natalie. "A People So Subtle: Sephardic Jewish Pioneers of the English West Indies." In Bridging the Early Modern Atlantic World. People, Products, and Practices on the Move. Edited by Caroline A. Williams, 97-112. Farnham: Ashgate, 2009.

Zacek, Natalie. Settler Society in the English Leeward Islands, 1670-1776. Cambridge: Cambridge University Press, 2010.

Zeldin, Natalie. "Imaging Death: Sepulchral Iconography in the Koenigstrasse Cemetery." Unpublished manuscript.

Zeldin, Natalie. "Skulls, Shields and Narratives." Unpublished manuscript.

Zielonka, D. M. "A Study of the Life of the Jews in Jamaica Reflected in Their Wills, 16921798." MS SC-13489. AJA Cincinnati 1963. 


\title{
Revisiting Blackness, Slavery, and Jewishness in the Early Modern Sephardic Atlantic
}

\author{
Jonathan Schorsch
}

In their important 2011 book on the small Sephardic communities that existed in the early seventeenth century on the West African coast (today's Senegal), Peter Mark and José da Silva Horta discuss a Portuguese merchant whose success there enabled him to move to Amsterdam. Moisés de Mesquita (also known as António Lopes de Mesquita) indeed makes a fascinating figure. Seemingly born in Oporto, Portugal, he spent some years on the African coast as a young trader before arriving in Amsterdam by 1622. There he became wealthy enough to donate a Torah scroll to the Bet Israel synagogue in the 1630 s and was elected a parnas in 1647. Making De Mesquita's rise even more remarkable is the fact that he was a mulatto. ${ }^{1}$ Though drawing information from my 2004 book, Jews and Blacks in the Early Modern World, Mark and Horta pass over a fact I discussed there, though at the time I myself had been unaware of the background of De Mesquita that they uncovered. In light of Mark and Horta's research, what is for me one of the most noteworthy aspects of his time as parnas is that in that first year, 1647 , he signed off on an ascama (communal ordinance) creating a new, separate row in the Ouderkerk cemetery for the burial of non-Jewish blacks and mulattos. Only blacks and mulattos who were born to parents married according to Jewish law or who married a white Jew according to Jewish law would be permitted burial in the "regular" section of Ouderkerk. $^{2}$

Besides pointing up the need for scholars to learn from and communicate with each other, De Mesquita's example represents some of the complexities of race and religion in the early modern Sephardic Atlantic world. A mulatto who rose about as high as possible both economically and socially in the Amsterdam community, he supported as parnas the exclusion of blacks and

1 At least he was called a mulatto in an Inquisition document, which I have not yet examined directly. Peter Mark and José da Silva Horta, The Forgotten Diaspora:Jewish Communities in West Africa and the Making of the Atlantic World (New York: Cambridge University Press, 2011), 187, 211.

2 Jonathan Schorsch, Jews and Blacks in the Early Modern World (New York: Cambridge University Press, 2004), 196, 201.

(C) JONATHAN SCHORSCH, 2019 | DOI:10.1163/9789004392489_022

This is an open access chapter distributed under the terms of the prevailing CC-BY-NC License at the time of publication. 
mulattos if their Jewishness was not certified. This stance of course served to emphasize his own, presumably proper, Jewishness. Despite his racial status, he sided against other mulattos - and blacks - in favor of the religious norms of the community. Born as a New Christian, being able to vote as a parnas of the Amsterdam Spanish and Portuguese community to uphold "correct" Jewish practice must have felt like an irrevocable arrival. When it came to race, De Mesquita seems to have opted for Europe and a white community over the identity status and people of his black parent. De Mesquita's acceptance and rise within the Amsterdam community showed its relative openness to racial difference - as long as religious norms were upheld—at least in some cases. His signature to the 1647 ascama reflects the way race came to trump religious and halakhic (Jewish legal) values in other cases. His approval of the ascama may be read as a necessary ticket of admission for him; he could be part of the community-increasingly defined as white precisely through the promulgation of ordinances such as this one-if he adhered to its standards, which two decades earlier had begun wielding the language of religion as a means of minimizing the intrusion of non-whites.

In the thirteen years since my book was published, a number of scholars have produced further work on the subject, supplementing and in some cases correcting my findings. In this essay I want to do two things. First, I will highlight the most salient insights from the important and growing body of new work on the Sephardic Atlantic world. ${ }^{3}$ Since most of this new research focuses on specific locales or even individuals, frequently content to remain on the level of the anecdote, I will put its findings into a multi-locational and diachronic Atlantic-world perspective, a necessary step to correct what I feel are the too-often myopic and unsystematic conclusions drawn by these scholars. Race as a governing strategy and social structuration always reflects ambivalence. Too often, even these intelligent, recent investigations seek to resolve the ambiguity of racism by imagining that moments of inclusion erase moments of exclusion. Second, I will summarize the religious issues at work shaping and responding to slavery and race as a central aspect of the Western Sephardic experience in the fifteenth to eighteenth centuries.

We must start with the Portuguese excursions to the western coast of Africa in the fifteenth century. As recent research has shown, New Christians and Sephardim were intimately involved with this overseas expansion, the real beginning of the Atlantic mercantile and colonial system. In a short span of time,

3 I should rightfully include here Iris Idelson-Shein, Difference of a Different Kind: Constructions of Race During the Long Eighteenth Century (Philadelphia: University of Pennsylvania Press, 2014), but since it focuses on Ashkenazic domains I leave it aside. 
Tobias Green has produced one of the most sophisticated and well-researched bodies of literature on the commercial, theo-political, and cultural role of the Portuguese along the West African coast. ${ }^{4} \mathrm{He}$ expertly delves into African perspectives and sources, adding a welcome dialogical lens to the usually solely Western-oriented story.

Beginning with Green's doctoral dissertation on the New Christians of Cape Verde from the late fifteenth through the late seventeenth century, he shows that because the Portuguese and Spanish monarchs opted to continue relying on New Christian merchants the way they had previously relied on Jewish traders, New Christian activities on the West African coast helped forge the wider Atlantic-world commercial and settlement efforts of the far-flung Portuguese networks. Because of their familiarity with and openness to cultural crossing, New Christians were key to intra-African trade and the process of creolization that it spawned. On the mainland, where local societies had long been accustomed to cultural mingling by and with outside traders, New Christians, also used to cultural bricolage due to their own troubled history, were willing to marry African leaders' daughters in order to create alliances and acted as cultural intermediaries, even adopting some of their spouses' host cultural practices. Green sees this New Christian behavior as a subversion of dominant Portuguese attitudes and norms, intentionally or not, and part of what led to their being perceived as a threat. Yet New Christians, including the extended Gramaxo family on which Green focuses in several studies, were also very active in Cape Verdean and inland slave trading from the early sixteenth century. Racialized social and theo-political hierarchies and structures arose rather quickly on Cape Verde and elsewhere, excluding or marginalizing blacks, and positioning mixed-race individuals and New Christians in differing but parallel ways as not quite fully white and Christian. From the beginning of this phase of the Portuguese-African encounter, then, we see a complex, often contradictory set of relationships, in which New Christians played a central role.

Parallel to and continuing Green's explorations, Peter Mark and José da Silva Horta's research, culminating in their book, presents a fascinating and noteworthy study of several communities in West Africa where Portuguese conversos and Portuguese Jews from the Netherlands lived and traded in the late sixteenth and early seventeenth centuries. Joal, Porto d'Ale and Rufisque,

4 See, among his other writings, Tobias Green, "Masters of Difference: Creolization and the Jewish Presence in Cabo Verde, 1497-1672," PhD diss., Centre of West African Studies, University of Birmingham, 2006; Green, "Equal Partners? Proselytising by Africans and Jews in the 17th Century Atlantic Diaspora," Melilah 1 (2008): 1-12; id., The Rise of the Trans-Atlantic Slave Trade in Western Africa, 1300-1589 (Cambridge: Cambridge University Press, 2011). 
ports under Wolof or Wolof-Serer control in coastal Senegambia, as well as Cacheu further south, comprised thriving commercial beachheads of trade between Europe and West Africa, run for the most part by a network of stillChristian conversos and practicing Jews often linked by family ties, some of the latter perhaps derived from New Christians inhabiting Guinea and seemingly openly practicing Judaism there as of the late sixteenth century. Each community seems to have had its own prayer house, enough people to form a minyan and practiced circumcision and kosher slaughtering of meat. The authors suggest that some of the original trader-settlers were the mulatto offspring of New Christians/Sephardic Jews and African women in Portugal, returning to a place where their maternal family connections provided them socio-economic advantage.

Hoping to correct scholarly misimpressions, the authors, specialists in the early modern Portuguese empire and West Africa, argue that the Sephardic diaspora's conversionary and inquisitional oppression forced New Christians and Sephardic Jews to help create the Portuguese Atlantic world; that these Jewish and New Christian merchants and settlers converted and married locals, influenced local Africans, and helped forge a distinctive, in some ways syncretic religious life; and, as is argued by Green, that the broader cultural syncretism brought about by the European presence in West Africa resulted at least in part from Sephardic patterns of social and commercial behavior based on flexible identity generated by the needs of survival.

These were tiny communities, as were almost all such mercantile outposts in the incipient overseas colonies, numbering at their peak perhaps thirty households. Beginning in the 1620s, many of the Jews returned to Amsterdam, having made enough money through trade to do so. The possibility of living openly in the region as a Jew seems to have diminished by the 1630 , due to new, more pro-Portuguese rulers, meaning that the life span of these communities comprised some few decades at most (active Portuguese investigation of these communities commenced only in 1610).

The initial New Christian/Sephardic openness toward alliances with Africans, relations with African women, and inclusion of mixed-race children in the community conforms to the traditional halakhic attitude: as long as the entry procedures are followed, anyone can join the community. ${ }^{5}$ Green, Mark, Horta, along with José Alberto Rodrigues da Silva Tavim, believe that

5 I argued that this attitude seems to have reigned until around the sixteenth century in Schorsch, Jews and Blacks in the Early Modern World, chaps. 3 and 7. 
conversion of Africans and slaves may even have constituted an intentional strategy. ${ }^{6}$ Green, Mark, and Horta use the evidence of such marriages, conversion of offspring and slaves and commercial interaction to argue that New Christians/Sephardim showed a unique openness toward Africans; Green has written that converting Africans was "implicitly — [to] rebel against the developing worldview of Africans emerging in Europe"; ${ }^{7}$ and Mark and Horta argue that race did not exist as a factor in West Africa.

I find it difficult to accept all of these conclusions. Openness to relationships with African women likely stemmed from instrumental motivations and itself hardly negates the fact that Jewish discourse shared already from at least the Middle Ages in a general Muslim/Arab and European/Christian denigration of blackness, even if it was not monolithic. Contrarily, attraction to the exotic Other is frequent, though it does not necessarily eradicate the discursive structures (such as race) that construct the Other as exotic. While convincingly positing a kind of West African non-racial multiculturalism, at least initially, it seems odd that Green, Mark, and Horta barely acknowledge that New Christians and Sephardim might have brought their own convictions with them as outsiders and that their attitude was not only a race-or ethnicityblind openness. As I discuss later, and as Green acknowledges, most of these New Christians, obviously, and even Sephardim likely were not particularly religiously scrupulous. I agree that conversion of free Africans, African slaves, and mixed-race offspring may have been a strategy: a pragmatic choice in remote regions where the communities were minuscule and vulnerable, little more than factories in the original early modern sense of the term; commercial outposts, surrounded by the native population, on which they were nearly completely dependent. The women they had relations with or married were not slaves, it must be kept in mind. New bodies offered a welcome strengthening of the community. The anecdotal evidence of such conversions does not convince me that any "missionary" or expansionist program was at work, except in the minds of some individuals, who were possibly following the

6 Peter Mark and José da Silva Horta, "Catholics, Jews, and Muslims in Early SeventeenthCentury Guiné," Atlantic Diasporas:Jews, Conversos, and Crypto-Jews in the Age of Mercantilism, 1500-180o, ed. Richard L. Kagan and Philip D. Morgan (Baltimore: Johns Hopkins University Press, 2009), 293; José Alberto Rodrigues da Silva Tavim, "Galut and Empire: On the Way to the Final Redemption," The Sephardic Atlantic: Colonial Histories and Postcolonial Perspectives, ed. Sina Rauschenbach and Jonathan Schorsch (New York: Palgrave, forthcoming).

7 Tobias Green, "Amsterdam and the African Atlantic: The Role of Amsterdam Sephardim in Senegal in the Early Seventeenth Century," Proceedings of the Fourteenth British Conference on Judeo-Spanish Studies (26-28 June 20o6), ed. Hilary Pomeroy, Christopher J. Pountain and Elena Romero (Dept. of Hispanic Studies, Queen Mary, University of London, 2008), 93. 
traditional halakhic mandate, which itself comprised an age-old absorptionist mechanism operating on a liminal population of partial insiders, slaves. If anything, the openness of Africans to conversion and the conversions or absorptions themselves acted as a psychological salve and form of one-upmanship for subaltern New Christians/Sephardim against Christian denigration and persecution.

If New Christians/Sephardim evinced a uniquely open attitude toward Africans these scholars need to explain the numerous conversions of Africans to Catholicism at the same time, the marriages of Portuguese to African women (which scholars suggest was far more frequent among the lower classes), and the acceptance of some manumitted slaves into Portuguese and Spanish society. Despite some of his own arguments, Green's findings regarding New Christian slave trading itself rebut the notion that New Christians were characterologically or culturally egalitarian when it came to Africans. Most problematic, to my mind, is that Mark and Horta seem unwilling to recognize that the openness that made functional sense within and took advantage of the religious freedom along the West African coast led to a strong backlash in Amsterdam in the form of a series of ascamot excluding blacks and mulattos from or restricting them within Jewish communal life there. This decadeslong racially-based exclusionary campaign, which spread beyond Amsterdam to other Sephardic communities in the Caribbean, is dialectically related to patterns in West Africa; it is part of the same story. Local specificities do not negate regional or cis-atlantic patterns; both must be taken into account.

The first ascamot promulgated in Amsterdam in the early seventeenth century wielded the language of halakha. (Below I provide a list of all of the communal legislation pertaining to blacks and mulattos from around the Sephardic Atlantic.) Blacks and mulattos who were not born Jewish or properly converted were excluded from or restricted within communal life. This leads me to believe that many of the black and mixed-race individuals coming from the West African coast or arriving with their New Jewish families were not circumcised or converted according to halakha, contra Mark and Horta. The ascamot quickly came to prohibit or restrict non-whites as such, showing a racialist orientation that co-mingled with and at times surpassed halakhic worries. The backlash in Amsterdam against the Africans and mixed-race individuals is palpable. It likely reflects the difference between the relatively open Portuguese attitude toward race and race-mixing and the seemingly more disinterested Dutch approach, as well as between colony and metropole.

In the mid-seventeenth century, due to the fall of Dutch Brazil and new conquests by the Dutch and English in the Caribbean, Sephardic colonial life shifted to the Caribbean. Fresh research by Aviva Ben-Ur, Natalie Zemon Davis, 
Wieke Vink and others has turned up a multitude of new details regarding daily life in the slave and plantation society of Suriname, the single most developed such socio-economic arrangement among Jews, as well as elsewhere. Based on terrific investigation of archival records and informed by developments in studies of slavery, colonization, the Atlantic world, creolization, and the like, these investigations into the Sephardic Caribbean present key new information and offer critical nuance to the portrait of blackness in the Sephardic Caribbean.

In a series of essays, Aviv Ben-Ur has published a great amount of new material that she has dug up on the lives of the Surinamese Sephardim, their slave women, and the mixed-race individuals born when members of these two groups had sex, coerced or not, or romances. ${ }^{8}$ Arguing against my minimization of mixed-race Jewish numbers (she cites me explicitly), Ben-Ur claims that by the second half of the eighteenth century, due to natural growth, there existed "around 100 Jewish Eurafricans in each generation" positing that ten percent of the Jewish community was Eurafrican "by the second half of the eighteenth century." ${ }^{\prime}$ Many of these mixed-race individuals were raised as Jews, acknowledged as children by their fathers, became involved in Jewish communal and religious life, took on their masters' names and sometimes businesses, even inheriting family property. We see the efforts, often successful, that slave women and colored Jews exerted to look out for their own interests, enter into the Jewish community, create support networks, and play the various forces in the colony against one another to their own advantage. Throughout her publications, but particularly in an essay on the cultural heritage of what she calls (following George F. Brooks) "Eurafrican" Surinamese

8 Aviva Ben-Ur, "The Cultural Heritage of Eurafrican Sephardi Jews in Suriname," The Jewish Diaspora in the Caribbean, ed. Jane S. Gerber (Oxford: Littman Library of Jewish Civilization, 2013), 169-93; "A Matriarchal Matter: Slavery, Conversion, and Upward Mobility in Suriname's Jewish Community," Atlantic Diasporas: Jews, Conversos, and Crypto-Jews in the Age of Mercantilism, 1500-180o, ed. Richard L. Kagan and Philip D. Morgan (Baltimore: The Johns Hopkins University Press, 2009), 152-69; "Peripheral Inclusion: Communal Belonging in Suriname's Sephardic Community," Religion, Gender, and Culture in the Pre-Modern World, ed. Alexandra Cuffel and Brian Britt (New York: Palgrave Macmillan, 2007), 185-210; "Still Life: Sephardi, Ashkenazi, and West African Art and Form in Suriname's Jewish Cemeteries," American Jewish History 92, no. 1 (2004): 31-79.

9 Aviva Ben-Ur and Jessica V. Roitman, "Adultery Here and There: Crossing Sexual Boundaries in the Dutch Jewish Atlantic," Dutch Atlantic Connections, 1680-180o: Linking Empires, Bridging Borders, ed. Gert Oostindie and Jessica V. Roitman (Leiden: Brill, 2014), 205. In an earlier study, "Matriarchal Matters," she had estimated the Eurafrican Jewish population at seven percent, while elsewhere, she sets the number at 7.2 percent (Ben-Ur, "Cultural Heritage," 172; "Peripheral Exclusion," 199). It seems Ben-Ur has revised her estimates upward over time. 
Jews, she shows that inclusion in the community frequently defied halakhic norms, while Jewishness constituted an "ethno-religious, rather than a religious identity."10 Ben-Ur rightfully notes that even today there is much left to uncover regarding the lives of mixed-race Jews in the Sephardic Atlantic world.

Ben-Ur provides rich data on the lives and culture of Eurafrican Jews. She argues that Eurafricans increasingly inherited Jewish culture and identity from their mothers, who had been born Jewish. ${ }^{11}$ Mixed-race Jews partook of many aspects of Jewishness "besides 'religion'-language, name-giving practices, historical consciousness, and identification with the Jewish people, both locally and remotely."12 Expanding on the research of Robert Cohen and others, Ben-Ur traces the brotherhood set up by the mixed-race Jews in 1759, later transformed into a prayer house, showing that by this time they had developed their own parallel community and ritual practice. For decades they continued to face denigration and marginalization from the white Sephardic leadership, however, despite what might have been sympathy with their cause. Finally, after a series of conflicts between the two segments of the community in the 1780 s and 9os, the white Sephardic leadership in 1793 curtailed various privileges of the mixed-race group. ${ }^{13}$ In her essay on the cemeteries of Suriname, Ben-Ur speculates on how various Jewish visual symbols on tombstones and elsewhere might have resonated with similar symbols from West Africa, and notes the appearance on wooden grave markers in the cemeteries where mixed-race free individuals - some Jewish — were buried as of the nineteenth century, of heart-shaped symbols of probable Akan provenance (the background of many slaves who ended up in the colony). In some cases, again all from the nineteenth century or later, Jewish and creole symbols were both chosen to decorate a grave marker. Clearly, Jewish authorities permitted the use of such visual imagery.

In an essay co-written with Jessica Roitman, we see that daily life in the eighteenth- and nineteenth-century cities showed much interaction across racial boundaries. Intimacy, friendships, trust, alliances, and knowledge bound together white Jews with free people of color and even slaves. ${ }^{14}$ Such coexistence has to be measured against the aptly-named "peripheral inclusion" (BenUr's term) that non-whites faced. In the Jodensavanne cemetery, the majority

\footnotetext{
$10 \quad$ Ben-Ur, "Cultural Heritage," 170. Here, as well, Ben-Ur is arguing against me by using David Biale's call for use of the term "Jewish culture," rather than "Judaism."

11 Especially in Ben-Ur, "Cultural Heritage."

12 Ibid., 192.

13 Ben-Ur, "Peripheral Inclusion," 192-94.

14 Ben-Ur and Roitman, "Adultery Here and There," 185-223.
} 
of non-whites were buried clustered in the "extreme north-east corner."15 As I also had shown in my book, Eurafrican Jewish children were frequently given biblical or Jewish names, but not ones usually used by white Jews and thus "set their bearers apart from mainstream Portuguese Jews even as they connected them to the broader Sephardic community."16 In the nineteenth century exclusion began to wither, in part due to challenges by the mixed-race Jews. By 1802, racial distinctions were no longer enforced when it came to "pious deeds" connected to burial. As of 1820 , rows in the cemeteries were no longer dedicated to specific classes of people. ${ }^{17}$

In recent years the gifted and prominent historian Natalie Zemon Davis has turned her attention to Suriname and its Portuguese Jewish community. A series of thorough, insightful, and often revelatory essays, based on Davis's usual prodigious research skills, comprise the building blocks of her still-awaited promised study, Braided Histories: Slavery and Sociability in Colonial Suriname. ${ }^{18}$

Treating seventeenth-century phenomena, Davis offers a powerful depiction of the imagined and discursive place of slavery in Sephardic colonization. She speculates that the fact that so many African male slaves arrived circumcised "must have eased the worry of those Jews [in Dutch Brazil] who took seriously the biblical and halakhic requirement of circumcision." ${ }^{19}$ In a noteworthy find, she discovered that Amsterdam Rabbi David Pardo recommended in his 1689 Spanish-language survey of laws Sephardic Jews should follow that plantation owners, in order to "complete" the African circumcisions of their slaves, need merely take a drop of blood, as halakhically required.

A wonderful micro-study of David Nassy (also spelled Nassi), perhaps the elite Portuguese Jewish planter best known to scholars, reveals him expressing the sentiments typical of an ameliorationist. As late as 1795, after three years in Philadelphia and even in the company of mostly Quaker abolitionists, he denied liberty and equality to Blacks, since, he felt, being uncivilized,

15 Ben-Ur, "Cultural Heritage," 171.

16 Ibid., $173-74$.

17 Ben-Ur, "Peripheral Exclusion," 197.

18 Natalie Zemon Davis, "Regaining Jerusalem: Eschatology and Slavery in Jewish Colonization in Seventeenth-Century Suriname," The Cambridge Journal of Postcolonial Literary Inquiry 3, no. 1 (January 2016): 11-38; “Judges, Masters, Diviners: Slaves' Experience of Criminal Justice in Colonial Suriname," Law and History Review 29, no. 4 (November 2011): 925-84; "David Nassy's 'Furlough' and the Slave Mattheus," New Essays in American Jewish History, Commemorating the Sixtieth Anniversary of the Founding of the American Jewish Archives (Cincinnati: American Jewish Archives, 2010), 79-93; "Creole Languages and Their Uses: The Example of Colonial Suriname," Historical Research 82, no. 216 (May 2009): 268-84.

19 Davis, "Regaining Jerusalem," 16. 
they would only serve as negative temptations. Yet he urged masters not to mete out "horrible punishments" to their slaves, but rather offer proper care, in order to prolong their lives and increase their birth rate. ${ }^{20}$ While proper care for slaves in a cruel slave society reflected a call for humane treatment, his concern for slaves' birth rate evinces a concern for the master's commercial wellbeing: more slaves, being his property, means more bodies available for labor or profitable sale. These attitudes informed his demeanor toward the mixedrace Jews in the Portuguese Jewish community. The Enlightenment-influenced Nassy's 1789 reforms of the ascamot, intended to modernize the community's self-governance, made no changes to the rules that kept mixed-race individuals as lesser congreganten and not full members, jehidim, while also insisting on humiliating seating arrangements for them in synagogue. ${ }^{21}$ Yet on a personal level, as an owner of slaves and as plantation owner for a time, in the 1770s Nassy treated his slaves relatively well. Three mulatto slaves, Moses, Ishmael, and Isaac, were all circumcised, brought into Judaism and eventually manumitted. A medical man, Nassy tended to the skin disease of the young slave Mattheus, carpenter and personal attendant, whom he rented and then purchased, looking out for him in general due to Mattheus's good service and loyalty.

During his three years in Philadelphia, from 1792, he came to know the two Quaker-connected, pro-abolitionist Jews at the Mikveh Israel congregation. Nassy freed Mattheus and his own daughter Sarah's ten-year-old slave girl Amina in Philadelphia, maintaining them both as indentured servants for the next seven years in Mattheus's case and eighteen years in the girl's case. While these acts may reflect Nassy's magnanimity, they were law in Pennsylvania. ${ }^{22}$ In a letter from 1795 Nassy wrote of them as part of his family. Mattheus chose not to remain in the United States, returning with Nassy, possibly because he had his own family in Suriname, possibly out of devotion, even affection for his patron and protector. In 1796, back in Suriname, Nassy proposed establishing a college open to boys of all backgrounds, if they were free, seemingly including non-whites, since Nassy's prospectus mentions no prohibition on colored applicants. Mattheus's fate in Suriname remains unknown, but his name does

20 Davis, "Judges, Masters, Diviners," 976. She is citing David Nassy, Memoire sur les moyens d'ameliorer la Colonie de Suriname (ms., 1795), 232-35, 30-31. The words in quotes come directly (in translation) from the text. Davis, "David Nassy's 'Furlough' and the Slave Mattheus," 89 .

21 Ibid., 82.

22 Ibid., 88. 
not appear as one of the colored congreganten. Indeed, it is not at all clear from the evidence Davis cites that he even considered himself Jewish. ${ }^{23}$

Davis has added to evidence regarding Sabbath observance when she discovered that a 1707 slave uprising at Palmeniribo, which was adjacent to Jewish plantations, may have had as one of its contributing factors the resentment felt by the plantation's slaves, owned by non-Jews, that the slaves on nearby plantations owned by Jews had Saturday off as well as Sunday. ${ }^{24}$ Davis also came across "evidence that the rulings of the Mahamad in regard to the cessation of work on the Sabbath and the specified feast days were respected" in the "rare diary of Samuel Bueno Bibaz, manager of a coffee plantation in 1743-1744."25 Although we have little evidence until later in the eighteenth century, Davis infers from the fact that some of the Portuguese Jewish elite of Jodensavanne had the loyalty of many slaves in fighting against the Maroons, both defending against them on their own plantations and also being willing to venture out on sorties against them in the bush, that it "is one of the possible signs of a plantation conducted in a fashion at least tolerable to its workers." ${ }^{26}$

Wieke Vink has written probably the most important book to date on Jewish Suriname, Creole Jews. ${ }^{27}$ She has provided the fullest picture so far of the history of the Sephardic community there as a multi-racial society (she also deals with the Ashkenazic community, but I will not treat that here). With ample evidence from the sources and analysis attuned to communal and colonial politics, Vink explores the ambivalence of white Sephardim toward both slave and free, black and mixed-race individuals. Vink, who works outside of Jewish Studies, corrects for some of the biases often evinced by Jewish scholars (understanding the latter in terms of institutional and communal subject position), offering a corrective to the continued scholarly lightening of the Jewish settlements' darker aspects.

Vink describes the twists and turns of a fledgling and vulnerable community, growing in size, power, and wealth, its decidedly non-linear history of inclusion and exclusion of non-whites, its repeated efforts to set boundaries and enforce identity. She gives us a thorough explanation of the history of Darhe Jesarim (Paths of the Righteous), the study group then congregation of the mixed-race Jews. Originally established by white Sephardim, who obviously

\footnotetext{
23 All the above from Davis, "David Nassy's 'Furlough' and the Slave Mattheus."

24 Davis, "Judges, Masters, Diviners," 952-53, n. 67.

25 National Archief, The Hague, Archief der Nederlands-Portugees-Israelitische Gemeente in Suriname, inv. 493.

26 Davis, "Judges, Masters, Diviners," 945.

27 Wieke Vink, Creole Jews: Negotiating Community in Colonial Suriname (Leiden: KITLV Press, 2010).
} 
wanted the mixed-race Jews out of their own white congregation, they later essentially regulated it out of existence.

Like Ben-Ur, Vink shows us a history of conflicting impulses. Despite restrictions on non-white Jews, in the late eighteenth century the parnassim admitted every request "to admit a certain 'free mulatto' or 'slave bought for freedom"” as a congregant, despite the absence of a Jewish mother. The only "requirement for admission was a basic understanding of Jewish law and custom." 28 This inclusiveness likely was generated by the economic crisis in the colony and the rapid and severe decline of the Sephardic community. Yet this inclusiveness led to even further restrictions.

As Vink shows, in the nineteenth century, as creolization and racial mixture increased, the Sephardic community followed suit. In the years that followed the abolition of discrimination "the number of requests by coloureds to be admitted as congregants tripled." Between 1830 and 1840 , "an estimated 35 to 50 requests were made for the admittance of coloureds or manumitted slaves as congregants in either the Portuguese or the High German community. Moreover, the number of slave requests for admittance increased." Yet this does not mean race ceased to signify. Indeed, now that equality reigned within the community far fewer non-whites were accepted. ${ }^{29}$ Her depiction differs significantly from Ben-Ur's claim that black and mixed-race Jews found admission.

I hope that even my inadequate survey makes clear that this new research has greatly expanded our knowledge about blacks, mixed-race individuals and whites in the Sephardic Atlantic world. ${ }^{30}$ Several problems arise for me from this recent work, however. Too many scholars remain within the realm of synchronic, local anecdotal narratives. Nonetheless, we now collectively know enough to see the movements toward inclusion and exclusion both geographically, temporally, and socio-politically.

While fascinating and important, the existence and experiences of colored Jews seems to me greatly overplayed by Jewish scholars. First there is the

28 Ibid., 225 .

29 Ibid., 241.

30 Other significant contributions include Stanley Mirvis, "Sexuality and Sentiment: Concubinage and the Sephardi Family in Late Eighteenth-Century Jamaica," The Jews in the Caribbean, ed. Jane S. Gerber (Oxford: Littman Library of Jewish Civilization, 2011), 223-40; Karl Watson, "Shifting Identities: Religion, Race, and Creolization among the Sephardi Jews of Barbados, 1654-1900," in Gerber, ed., Jews in the Caribbean, 195-222; Jackie Ranston, Belisario: Sketches of Character: A Historical Biography of a Jamaican Artist (Kingston: The Mill Press, 2008); Tim Barringer, Gilliam Forrester and Barbara MartinezRuiz, eds., Art and Emancipation in Jamaica: Isaac Mendes Belisario and His Worlds (New Haven: Yale University Center for British Art/Yale University Press, 2007). 
matter of numbers. Vink agrees with Ben-Ur that, at least regarding the late eighteenth century, up to ten percent of the Sephardic community was black or mixed-race. However, she finds that in the nineteenth century this ratio declined to around five percent, a far smaller proportion than existed among Protestants (excluding Moravians), which by then reached an incredible sixtyfour percent. ${ }^{31}$

Then there is the question of interpreting the persistent racial tensions. Like too many Jewish scholars, Ben-Ur consistently inclines toward emphasizing inclusion and coexistence over exclusion and conflict. The Bush Negro (Maroon) plates possessed in the early nineteenth century by one Sephardic resident of Jodensavanne "reflect the Jewish community's receptivity to Afro-Suriname influences." ${ }^{32}$ From her own research I see few examples of such influences accepted by the community. She calls the mixed-race "community" "small but influential."33 Such influence far more often than not was resisted by the white Sephardic authorities.

I fully agree with Ben-Ur that the white Surinamese Sephardim stopped following halakha when it came to their slaves and the conversion of non-whites. That was one of the main arguments of my 2004 book. While Jewishness now meant more than halakhic Judaism, white Sephardim and black and mixedrace Sephardim did not seem to agree on what it meant. Ben-Ur traces the conflicts but without addressing the substantive differences. Until late in the nineteenth century, if even then, black and mixed-race Jews were almost never seen as equals and, with so few exceptions that they easily can be counted, most were relegated to second-class status in the community in general and in the religious life around which the community revolved. The limitations placed on them-restricting their choices in marriage, burial, ritual practice, etc. - were real and persistent and must have generated great pain and resentment (we see this boil over in the late eighteenth century). Ben-Ur wants to see colored Jews as fully Jewish, even if not halakhically so, but much of the community itself persistently and successfully worked to limit their rights and status as Jews.

One must also keep in mind the overall context in which the mixed-race Jews arose and struggled. No one denies that these individuals were Jewish, as Ben-Ur asserts (probably with me in mind); what troubles me is that the overwhelming number of slaves belonging to Jews were not made Jewish in any fashion and Ben-Ur consistently ignores this non-assimilation of the overwhelming

31 Vink, Creole Jews, 256.

32 Ben-Ur, "Still Life," 78.

33 Ibid., 36. 
majority of slaves. Colored Jews made up a very small minority of the blacks and mixed-race slaves subject to Sephardic domination-I calculated two percent, but let's say it is even higher. I do not believe that there is a single study of hers where she explores this context. Even if it is true that ten percent of Surinamese Sephardim were mixed-race at some points, she never attends to the other ninety percent of blacks and mixed-race people within the Sephardic sphere! Her emphasis is always on the statistically marginal number of slaves and emancipated slaves who affiliated with the Jewish community. I see two reasons for this: (1) documentation seems to be more plentiful and multidimensional; (2) ideological bias toward a narrative that reflects less negatively on Jews.

Another enormous lacuna, to my mind related to the over-determined question of "colored" Jews, is the question of power and agency. Ben-Ur and Davis insist on complicating concepts such as slavery and race, focusing on interpersonal mutuality, the multi-directionality of agency and contestation of systemic structures from below. While all this is welcome and vital, I sense a deep, recurring unwillingness to acknowledge that while slavery dominated as the socio-political structure, very real inequality pervaded everything: religious life, economic opportunities, personal relations, rights and freedoms. White Sephardim possessed and wielded far greater agency than their black and mixed-race slaves or freed individuals, even when the latter were Jewish. Particularly in Ben-Ur's work, descriptions of slavery among Sephardim, which differed hardly at all from the general tenor of the Caribbean slave system, are mostly anodyne, neutral to the point of avoidance. She devotes next to no analytical energy to Sephardic slave masters, plantation management, participation in the internal colonial slave trade or absence from abolitionism.

The second area of confusion is the question of religion. Ben-Ur and, to a lesser degree, Davis want things both ways. We are to believe that the Surinamese Sephardim named their synagogue after a passage in the Zohar and were kabbalistically-inclined, but didn't follow halakha regarding transmission of Jewish status or many elements of treatment of slaves. Judaism was no longer central to identity, but colored Jews were ritually made Jewish. Jewishness was a question of "civilization" and not "religion," Ben-Ur argues, but her own evidence shows that the Jewish authorities frequently marginalized colored Jews in much of this non-religious sphere as well and, with few exceptions, accepted the colony's racialized structures. Despite Judaism's supposed loss of prominence as a determinant of categories, almost all of the most documented tensions between white and colored Jews revolved around religious matters! Finally, Ben-Ur misses the ironic fact that the nineteenthcentury turn against discrimination (in some forms) was frequently justified 
by religious, even halakhic language, a distinct reversal of the earlier manner in which religion and halakhic worries had justified the marginalization of those who were not purely white. ${ }^{34}$

The double face of slavery shows itself everywhere. Ambiguity, complexity, diversity, all characterized daily life in slave societies; love and loyalty across racial lines, humane masters and whites, slaves and freed slaves assembling and wielding some elements of power over their own lives. But until abolition, as Hannah Arendt wrote, "slavery remained the social condition of laboring no matter how many slaves were emancipated."35 Samuel Nassy, seventeenthcentury community leader in Suriname and son, supposedly kabbalisticallyinclined, of active colonialist David Nassy, also allegedly kabbalistically-inclined due to the influence of their teacher Rabbi Isaac Aboab da Fonseca, operated a plantation with close to two hundred slaves. Davis makes these white Sephardic men the central figures in her meditation on Jewish inclusiveness of slaves. That seventy slaves ran away from Samuel's plantation in 1680, that in 1690 an uprising of slaves on another Sephardic plantation saw the slaves killing their owner, does not inspire in me much confidence about the meaning of Jewish inclusiveness toward slaves. ${ }^{36}$

In this regard, Davis's "imagined" Passover Seder in Suriname, at the end of her essay on the Nassy family, disappoints bitterly, turning from her usual analytic rigor to a rhetorical form closer to fiction. Yes, she wonders whether some of the slaves belonging to Jews might have wished to be back in their own home in Africa. But regarding the masters, "Some Jewish [slave] owners, reciting 'The Egyptians treated us badly, they made us suffer,' may have resolved not to do the same to the slaves on their own lands." ${ }^{37}$ Note the subjunctive case, but also that only the suggestive positive possibility is offered, not the negative possibility of the kind of compartmentalized mental space so ubiquitous in those slave-dependent centuries among Europeans of all denominations, nor the possibility of utter hypocrisy.

The continued rhetorical downplaying by Jewish scholars of the ugly sides of Jewish involvement in the slave system disheartens me. Very few seem willing to acknowledge in analytically significant ways, much less to focus on, the harsh, exclusionary, racialist behavior and attitudes of Jews toward blacks and mixed-race people in the Atlantic world. This aversion, intentional or unconscious, reflects some of the problems of identity politics even among

34 This was true in Barbados as well (Watson, "Shifting Identities," 220-21).

35 Hannah Arendt, The Human Condition (Chicago: University of Chicago Press, 1958), 217.

36 Davis, "Regaining Jerusalem," 32 and n. 76.

37 Davis, "Regaining Jerusalem," 38. 
sophisticated, supposedly critical scholars and the tempting ties of solidarity between scholarship of ethnicities and those ethnic communities. I understand why polities find it hard to acknowledge their failings and to engage in self-criticism. I cannot understand why it should remain so difficult for criticalminded scholars to do so.

A few examples from the religious sphere should suffice to show how easily relevant documents continue to confound scholars and feed questionable readings. It seems possible that a new blessing for the purchase of a slave was penned in the seventeenth century, as I had noted in Jews and Blacks in the Early Modern World. Davis cites it as evidence for the continued conversion of slaves. The siddur put out by Isaac de Mattathias Aboab in 1687, approved by Rabbi Isaac Aboab da Fonseca, has the ritual for circumcising a male slave, ritually immersing a female slave, and a blessing for purchasing a slave for which I was not able to find any halakhic precedent: ${ }^{38}$

Master of this slave, take kind pity and remember to rejoice in his works and to enslave him and his children after him, as it says [Lev. 25:46], you may keep them as a possession for your children after you, for them to inherit as bondsmen for all time. Blessed are You, Lord, who are good and does good.

It could be that this text was written in response to the continued reality of slavery among Sephardim. Yet this is a questionable text to use as proof of inclusion of slaves into Judaism, since it specifically takes the harsher stance, held by many rabbis in the Atlantic world, that it is a positive commandment never to free slaves like the one just bought! Supposedly showing that Sephardim continued to make their slaves Jewish, and treated them kindly, this same text would then have to be read as halakhically forbidding manumission! Is "Judaism" here interpreted as inclusive or tyrannical? It could be both, of course, and that is why investigators then need to provide explanations for the internal discursive contradictions and social/theo-political fault lines.

Another example: In 1767/68, Selomoh Levy Maduro of Curaçao reprinted a pamphlet on circumcision, Brit Yitzhak, that, as I read it, intentionally dispensed with the need for Jews to circumcise their male slaves by relegating the blessing to times when the Jerusalem Temple existed. Brit Yitzhak was (first?) published in Amsterdam in 1729 by Hakham Yitzhak b. Moshe Lopes Pereira,

38 Isaac de Mattathias Aboab, ed., Seder Berakhot. Orden de Bendiciones y las ocaziones en que se deven dezir (Amsterdam: Albertus Magnus, 5447(1686/1687), 184; Davis, "Regaining Jerusalem," 27-28; Schorsch, Jews and Blacks, 155, 412, n. 115. 
with the gentleman (gvir) Yitzhak Yehuda Leon Temple and the physician Daniel b. Avraham Pereira. Importantly, as the text states (but Ben-Ur never mentions), the book reflects practice in Israel and Turkish lands, whose slavery differed vastly from that of the Atlantic world. In several essays, Ben-Ur cites this text as proof of inclusion of slaves in Judaism, since the blessing to be said for circumcising slaves is retained. ${ }^{39}$ As with my first example, what needs to be explained is not the continued appearance of blessings regarding slaves, since conservative religious instincts meant that ritual texts rarely disappeared without good reason. But let us say that I am wrong; perhaps this later edition was used in the Atlantic world for circumcision of slaves, only without a blessing. As I proved already, however, a surprising number of prayer books dropped this blessing and the ritual for slaves in the seventeenth century and it is this jettisoning that requires explanation. ${ }^{40}$ It is the patent dropping of ritual texts pertaining to slaves that begs for elucidation. We might be left, then, with conflicting attitudes even among the religious leadership toward the circumcision of slaves.

More strangely, however, Ben-Ur cites this text to prove circumcision of slaves while quoting the blessing itself, which includes the line, "He that is born in thy house and he that is bought with thy money, must needs be circumcised," ${ }^{\prime 1}$ despite the fact that-as she knows-the historical record shows quite clearly that only some slave boys born to Sephardic slave owners were circumcised and overwhelmingly not slaves who were purchased (i.e., "bought with thy money"). None of the new research has offered evidence to make me change my opinion concerning this. How odd, then, to cite a passage in a prayer book to prove that Jews observed one part of a commandment when the passage cited proves that Jews failed to observe another part of the same commandment. Again, the scholar must ask why and offer some discussion. Is the practice a matter of ethnic ties, as Ben-Ur herself argues? Then why cite a halakhic text to bolster non-halakhic practices?

Moses Levij Maduro (c. 1709-1766), possibly our author's father, was the lover and protector of the "free negress" Mariana Franko. She was employed at the Sorgvliet plantation, owned by the Lamont family. She got into trouble with the authorities for a crime she says she did not commit. All this c. $1760 .^{42}$ Is it

39 Ben-Ur, cites this text in "Peripheral Inclusion," 189.

40 Schorsch, Jews and Blacks, chap. 7. I can add one more title to this list: Yosef Gallego, Imrei No'am (Amsterdam: Menasseh b. Yosef b. Yisrael, 1628), 78a-81b, has the ceremony for a brit, but no mention of slaves anywhere. Gallego was a hazan (cantor)from Salonica.

41 Trans. in Ben-Ur, "Peripheral Inclusion," 189.

42 See Han Jordaan, "Free Blacks and Coloreds and the Administration of Justice in Eighteenth-Century Curaçao," NWIG 81, nos. 1-2 (2010): 72-76. The Selomoh L. Maduro 
possible that our author Selomoh's stance against bringing slaves into Judaism was influenced by what he saw as his own ancestors' too open comportment with non-whites?

Even as fine a scholar as Davis unfortunately falls into this pattern. Despite the fact that Pardo recommended in 1689 that plantation owners "complete" the African circumcisions of their slaves, by taking a drop of blood, as halakhically required, this does not tell us that slave-owners did this. No circumcision manual or prayer book that I know of reflects his suggested approach, though it existed since tannaitic times (it is cited in a baraita in the Babylonian Talmud, Shabbat 134b, among other rabbinic texts). Indeed, Pardo probably came up with this suggestion precisely because slave owners were not circumcising their slaves. Davis cites one 1732 report from a slave, born around 1700, that he had been born on a Jewish plantation and was circumcised on the eighth day. He was sold at eighteen years old when his master died. ${ }^{43}$ Note that this case does not prove that any slave owner followed Pardo's ruling. But it does show the difficulties of using such evidence as proof of Jewish beneficence, since the slave was sold despite having allegedly undergone the sacred ritual marking that made him Jewish! It was precisely to prevent such a transgression against rabbinic law that the Recife Mahamad issued an ascama in 1649 ordering circumcisions to be carried out only after a male slave had been freed. So on the one hand we have the master's supposed punctiliousness and inclusiveness, while on the other the callousness of the sellers, who could well have been members of the master's own family.

Not another example of positive evidence has surfaced that Jewish masters regularly circumcised or immersed or drew a drop of blood from slaves despite the experiences of hundreds of Jewish slave owners with thousands upon thousands of slaves, from several colonies, over the course of several centuries. Let me be clear: obviously some masters must have conducted these rituals. That is not the point. The point is the analytical leap from a small number of exceptions to concluding a general inclusiveness on the part of Jews toward their slaves. This strikes me as wholly unwarranted. Those who make such a leap are guilty of projection rather than reading of the evidence.

A review of the relevant communal ordinances from around the Sephardic Atlantic will allow us to continue the discussion on another level and address the contradictions I have raised.

whose ownership of a plantation in 1722 I mentioned in my book is more likely our author's grandfather, possibly Salomon (Ribi) Levy Maduro (1690-176o).

43 Davis, "Regaining Jerusalem," 30; Jan Willem Kals, Neerlands Hooft-en Wortel-sonde, het Verzuym van de Bekeeringe der Heydenen (Leeuwarden: Pieter Koumans, 1756), 51. 
Ascamot, Amsterdam:

- 1614: separate section in cemetery established "especially for the burial of slaves, servants and 'Jewish girls, who are not of our Nation."

- 1627: "No black person nor mulatto will be able to be buried in the cemetery, except for those who had buried in it a Jewish mother [...] none shall persuade any of the said blacks and mulattos, man or woman, or any other person who is not of the nation of Israel to be made Jews."

- 1641: Mahamad orders that Sephardic women not send their black and mulatto girls (servants or slaves) to reserve seats for them in the synagogue's women's gallery; also that the doors to the women's section of the sanctuary were not to be opened before six in the morning, in order to prevent the "unseemly" congregating of these women and other servants on the street.

- 1644: "circumcised Negro Jews" were not to be called to the Torah or given any honorary commandment to perform in the synagogue, "for such is fitting for the reputation of the congregation and its good government."

- 1647: separate section of the cemetery is established for "all the Jewish blacks and mulattos." Exceptions limited to those "who were born in Judaism, [their parents] having [been married] with quedo$\operatorname{sim}$ [with kiddushin, i.e., properly, according to Jewish law], or those who were married to whites with quedosim."

- 1650: "Renewal of the ascama of 1639 which treats the circumcising of goyim. The Gentlemen of the Mahamad declare that the same penalty of herem [the most stringent form of excommunication] [will apply] to any [person] circumcising blacks or mulattos and also any immersing them or [any who] should be a witness for them [as required by halakha-JS], seeing [their] immersing, or [that of] any other person or woman who is not of our Hebrew nation. The Gentlemen of the Mahamad, having some occasion of a son or daughter of a Jew who should come to the [ritual] bath or give birth [?] [and] who should be raised in his house with his [word unclear] may arrange [to do] as he sees fit."

- 1658: mulatto (and tudesco) boys no longer be admitted for study in the Amsterdam yeshiva of the Sephardim

Ascamot, Suriname:

- 1663 or 1665 : the leadership decides to demote the status of jehi$\operatorname{dim}$ [full members] who marry a mulatta; a jahid [full member] is 
prohibited from circumcising sons born to jehidim who had been demoted to congreganten. The penalty for doing so is herem.

- 1734: Mulatto Jews in Jodensavanne "may not have any Mitsvahs on Holiday or Sabbath days, but only on rosh hodesh [the New Moon] and the minor fasts and are also required to sit behind the teva [the central table whence prayers were led and the Torah read]."

- 1754: "[S]ince experience has taught how prejudicial and improper it would be to admit Mulattos as jehidim [full members], and noting that some of these have concerned themselves in matters of the government of the community, it is resolved that henceforth they will never be considered or admitted as jehidim and will solely be congreganten, as in other communities."

- Members who married a mulatto woman, "either according to our Holy Law or solely in front of the Magistrates," would have their children considered mulattos by the community as punishment.

- Non-white Jews had to sit at the bench of mourners, located at the synagogue's margin.

- Non-white Jews could not receive certain public blessings (mi-she-berakh).

- No woman who was black, mulatto or Indian could enter the prayer hall, not even to tend to her master's children, "considering the Respect of the Holy Place."

By the 1780 s the ascamot accept as congregantes any colored children "who carry the name of, or are known to be descended of the Portuguese or Spanish Nation."

- 1787: further exclusive ascamot, including distinctions between the various categories: karboeger (black and mulatto), mulatto (black and white), mestice (white and mulatto), castice (white and mestice).

- 1794: resolution that jehidim who tried to sit in the seats for congreganten or have congreganten sit next to them in seats reserved for jehidim would be fined one hundred guilders. ${ }^{44}$

- 1797: jehidim cannot sit at the bench for born congreganten behind the teva and the bench in front of the seat of the samas. ${ }^{45}$

44 Ben-Ur, "Peripheral Inclusion," 196, reads this as evidence that some jahidim may have tried to sit with their mixed-race family members.

45 Ibid., reads this as evidence that some jahidim who were demoted from their status for having married a non-white sat with those who had been born as congreganten because of their mixed-race status. 
Ascamot, Curaçao:

- 1702: "women other than the Brides of the Law or of a Marriage, together with their bridesmaids" are barred from sitting "in the front part of the ladies' gallery" of the synagogue.

- 1751: order "not to bring into the synagogue black or mulatto women in order not to remove the devotion which there needs to be."

- 1754: lending money at interest to slaves and whites is forbidden, but Jewish law permits taking interest from free blacks.

This list is not fully complete, it leaves out relevant ordinances from Dutch Brazil, London, and elsewhere, while also ignoring de facto practices—such as a door for blacks (Porta dos negros) in the Jodensavanne synagogue-but hopefully it gives a good sense of the sweep of the legislation that blackness engendered in the Sephardic Atlantic. ${ }^{46}$

If these rules revolve solely around the religious congregation, that is because in Amsterdam it was actually the Spanish and Portuguese Jewish community that initiated racial legislation there and they were concerned to create order within their own sphere, while in the colonies the basic racial laws were already laid down by the colonial authorities.

This list makes it easier to see the question of religion and culture in a more precise manner. What role did Judaism play in all of this? What was its relationship to the increasingly racialized societies of the Americas? Here, too, ambivalence and doubleness mark everything. The ordinances waver between halakhic concerns and social/racial ones, as well as between metropolitan and colonial exigencies. In Amsterdam, the metropole, communal leaders found the Judaizing of non-whites undesirable and legislated against it. The first Surinamese ascama did likewise. On Curaçao the prohibition was unwritten. Despite this, Surinamese masters and the community leadership preferred the communal benefits of additional bodies and the psychological rewards of personal procreative self-expansion.

To this we can add what we know of religious factors that do not appear in communal legislation. The very proliferation of mixed-race children shows that Sephardic men were ignoring halakha and rulings forbidding masters to have sex with slave women. With extremely few exceptions, neither community leaders nor rabbis seem to have complained about this or sought to stop it. ${ }^{47}$ Sephardim ceased manumitting slaves according to halakha, now following

46 Sources can be found in Schorsch, Jews and Blacks, chap. 8, Vink, Creole Jews, as well as in Ben-Ur's studies.

47 I can find only a single case of a rabbi chastising plantation owners for this. Abraham Gabay Yzidro, a conservative figure, who became embroiled in a raging battle against the 
general secular practice and civil law. Manumission of slaves was rare, and it seems that many individuals and communities in the colonies followed, at least de facto, the halakhic opinion that slaves were never to be manumitted. ${ }^{48}$ In these last three cases, then, "religion" had yielded to or supported common practice that in some sense brought advantage: sexual satisfaction, freedom from the burdens of halakhic regulation of slaves, expanded family, economic gain, extended service from slaves. The one relevant halakha that Surinamese Sephardim seem to have followed is letting their slaves rest on Shabbat, the Jewish Sabbath day.

The not surprising conclusion is that the distance maintained by Sephardim in the Caribbean between their religion and their slaves derived from antiblack sentiments and societal objective correlatives-near exclusive reliance on black and colored labor, social, cultural, and economic denigration and exclusion of non-whites-both in the Christian Americas and in Sephardic Amsterdam. I have not come across any explicit communication between the Amsterdam Sephardic leadership and any of the colonial Sephardic congregations regarding slave policy, but there can be no doubt that the written

Jodensavanne parnassim when he was rabbi there in the 1730s, lambasted his enemies for their "ease with women" (facilidad con mujeres) and "evil passions" (negras pasio$n e s$ ), the Spanish pun making it likely that he had slave women in mind (Stadsarchief Amsterdam, inv. nr. 1029, 30; Jonathan Schorsch, "Abraham Gabay Yzidro: A Rabbi Navigating the Eighteenth-Century Atlantic World" [forthcoming]). Such transgressions had led Maimonides to rule that a master who had sex with his slave woman must either free, convert and marry her, or remove her from his possession (Yehoshua Blau, ed., Responsa of Rambam [Hebrew], 3 vols. [Jerusalem: Mekitzei Nirdamim, 1958], no. 211). But frequently Surinamese Sephardic planters did not free their slave women, even when freeing and making Jewish the children they bore from them. As proof of the fact that Sephardic Surinamese converted their mixed-race children, Ben-Ur cites the will of the planter Isaac da Costa (d. 1734), whose six mulatto children by various slave women all were made or chose to become Jewish. But his will, by leaving out any statement of the mothers' Jewishness, seems to indicate that Da Costa did not convert any of these slave women themselves; that is why if this slave-owning patriarch wanted his children to be Jewish he had to have them made Jewish through ritual (Ben-Ur, "Cultural Heritage," 183). See also the list of births, "Registro de Notaçaõ dos nacimentos do K.K. Beraha Ve-Salom," beginning 1777, Nationaal Archief (The Hague), Port.-Israel. Gemeente, no. 417, which lists many mothers of children made Jewish who themselves were neither manumitted nor converted. The question of slave women and sex is extremely complicated; for a good general overview, see Yaron Ben-Naeh, "'And You Will Have a Maidservant Forever', Slavery and Slaves in Ottoman Jewish Society," [Hebrew] Ha-Mizrah Ha-Hadash 50 (2011): 79-82.

48 To add findings from the recent research, on Barbados, the 98 extant eighteenth-century wills mentioning specific bequests inform us that, while Sephardic Jews ordered manumission of their slaves on three occasions, $5^{1}$ Sephardic Jews bequeathed slaves as property to others, usually family members (Watson, "Shifting Identities," 201). Out of Jamaican wills between 1673 and 1814, "the manumission of slaves was stipulated in only twenty-nine-under 12 per cent" (Mirvis, "Sexuality and Sentiment," 229). 
and unwritten slave policies of the Caribbean communities followed those of Amsterdam in letter and in spirit and then added to them based on local, colonial configurations. As in Amsterdam, in Suriname a group of colored Jews arose and became large enough to cause community leaders discomfort. As did Christian attitudes, Sephardic attitudes hardened over time with the mushrooming of a mostly African, often hostile, slave population. These antiblack phobias made for some strange bedfellows, such that groups that became marginalized in white, Christian Europe and neo-Europe often partook in them as a means of shoring up their own noble self-image. The well-known Inca author Felipe Guaman Poma de Ayala writes, ca. 1616, that "If [an Indian woman] marries a black man (whether slave or free) who has received God's curse, she becomes a slave and a black woman like her husband." ${ }^{49}$

By design, community leadership in the Western Sephardic diaspora came to reside almost entirely in the hands of the wealthy elite, through the Mahamad. In 1639, the three newly-combined Amsterdam Spanish and Portuguese communities issued a series of communal ordinances prescribing in many respects how the community was to function. The ninth ordinance stipulated that community leaders and judges should follow, except where it will conflict with Torah, mercantile law or the law merchant. ${ }^{50}$ This formulation gives remarkable power to an essentially secular regime, standing outside of the religious law. This state of affairs has long been known to scholars. As Jonathan Israel put it, "major decisions affecting the life and dealings of the community were made by men who were deeply involved in international trade and finance, acutely sensitive to the intricacies of great power politics, rather than based purely on religious law and rabbinic tradition."51 This power dynamic is reiterated in a first-person description from $165^{\circ}$ by R. Shmuel Aboab: "There is a minority of places where those parnassim who are elected to lead the congregation and are already accepted by them judge the people and they sometimes, according to the nature of the matter, consult with the Rabbi who disseminates Torah among them and they ask of him his opinion regarding that law and they do fittingly by doing so and this is the quality of humility and fear of sin."52 Religious law here serves an ultimately advisory role, as was typical among

49 Felipe Guaman Poma De Ayala, First New Chronicle and Good Government, Abridged, trans. and ed. David L Frye (Indianapolis: Hackett Publishing, 2006), 159.

$5^{0}$ Quoted in Yosef Kaplan, "Eighteenth-Century Rulings by the Rabbinical Court of Amsterdam's Community and Their Socio-Historical Significance" [Hebrew], Studies on the History of Dutch Jewry, ed. Jozeph Michman, 5 vols. (Jerusalem: Magnes Press, 19751988), $5: 3$.

51 Jonathan I. Israel, Diasporas within a Diaspora:Jews, Crypto-Jews and the World Maritime Empires, 1540-1740 (Leiden: Brill, 2002), 78.

$5^{2}$ Quoted in Kaplan, "Eighteenth-Century Rulings," 4. 
the Western Sephardim who derived from Spain and Portugal, but contrary to the generally rabbinical leadership among Eastern Sephardic communities. ${ }^{53}$ That the leaders inquire of the rabbi is a courtesy, not a necessity.

None of the numerous ascamot excluding non-whites was promulgated by a rabbi! Sephardic rabbis in the Atlantic world, when they discussed slavery at all, mostly leaned toward full inclusion in accord with halakha, though this often meant forbidding manumission. Contra Ben-Ur, then, "Judaism" included and excluded non-whites in the Atlantic world in some ways, while "Jewish civilization" moving toward secularization included and excluded them in other ways. Ben-Ur and I agree that the decision-making of the parnassim adjusted Judaism to fit current realities as they saw them. It is not surprising that Sephardic law regarding slaves did not reflect halakha, since the Western Sephardic communities, in some cases because of the Christian upbringing of these formerly-converso "New Jews," had an ambivalent relationship with rabbinic halakha. On the one hand, the communities were officially religious and infractions of religious law were punished. On the other hand, individual observance and practice deviated widely. It is not surprising that most of the individuals who settled the colonies were not particularly observant.

When it comes to mixed-race Jews, Ben-Ur, following the sociological approach of Arnold Eisen, wants to distinguish between what Jews "do" and what they "believe," arguing that only the former should be taken seriously by scholars. ${ }^{54}$ This is an ironic stance to maintain, since much of what white Sephardim did throughout the Atlantic world was to exclude and marginalize non-white Jews - and even more non-white non-Jews - the leadership through official legal ordinances and repeated political efforts to maintain such laws, and much of the Sephardic population by voluntarily or reluctantly adhering to the racialized laws and social structures, which it did with few exceptions. Here, once again, the question is which Jews did what and why.

The responses of the ruling elite still require more nuanced unpacking. Let me return to Moisés de Mesquita. What exactly accounts for the difference between the openness of the merchants in Senegal, the intolerance of

53 Yosef Hacker, "The Jewish Independent Judiciary in the Ottoman Empire in the 17th and 18th Centuries: The Boundaries of Autonomy" [Hebrew], Transition and Change in Modern Jewish History: Essays Presented in Honor of Shmuel Ettinger, ed. Shmuel Almog et al. (Jerusalem: Historical Society of Israel/Zalman Shazar Center, 1987), 353.

54 Ben-Ur, "Cultural Heritage," 19o. She asserts that looking through the lens of religion alone "distorts the picture of what many Jewish slave masters attempted to do when they included slaves in their household" (192), but it is not clear to me through her interpretation what they "attempted to do." Much of the relevant documented language about slaves and mixed-race Jews is religious language or language about religion, while the actual behavior of Jews was at least as often exclusive as inclusive. 
the Amsterdam parnassim, and the ambivalently open parnassim in Suriname makes a good topic for further study. As Mark and Horta show, local attitudes of course play a major role. Green speculates that "Where there were very few Jews, or even crypto-Jews, assimilation into the dominant cultural praxis was an obvious choice. ${ }^{55}$ I suspect that it is more complicated than this. The distinction clearly was not merely economic, a divergence of opinion between elites and commoners. ${ }^{56}$ Are those individuals adventurous enough to travel overseas and engage with foreign, exotic societies and cultures already inclined to "mixing," to acceptance of the Other? Does the travel and immersion itself shape their openness? ${ }^{57}$ Experiences in Africa, Asia, or the colonies hardly produced monolithic responses, however, so individual subjectivities and different kinds of experiences keep us guessing about the mix of causal factors in racial attitudes. Some of the parnassim ruling against the inclusion of non-whites were themselves overseas merchants; some had lived in western Africa or Brazil or lived in the colonies themselves.

Furthermore, we have to keep in mind the often tenuous religiosity or loyalty to rabbinic Judaism evinced by many of the "New Jews" in the Western Sephardic communities of the seventeenth century; as Green continues, those Sephardim (he is actually discussing New Christians, but I want to shift the question) who wanted to be "good Jews" went to the major cities, North Africa or Ottoman lands. ${ }^{58}$ Does this imply that those Sephardim who went to West Africa or the Caribbean cared less to begin with about proper Judaism? This would be a rash but plausible generalization.

Contrarily, are the parnassim reflecting the conservatism of the homebound? Are parnassim elected precisely because they evince a sober, conservative orientation? It could be that issues besides race were at work here. The emphasis that the relatively young Amsterdam community placed on legal and ritual adherence to rabbinic Judaism, given its many members who had been raised as Catholics, is well known. When we get to the parnassim in the colonies, we have a different situation. In Surinamese Jodensavanne these were almost all plantation owners, some open to certain kinds of relationships with non-white Jews. Ben-Ur tries to dissect some of the dissenting views of the parnassim toward mixed-race Jews in the late eighteenth century, but without conclusive results. Certainly divergences between metropole and colony

55 Green, "Equal Partners?," 7.

56 As I erroneously speculated in Schorsch, Blacks and Jews, chap. 8.

57 Green rightly thinks that "personal experience was crucial" ("Amsterdam and the African Atlantic," 93).

$5^{8} \quad$ Green, "Equal Partners?," 7. 
play a key role. Likely, in general, parnassim cared more about the importance of conformity than peripatetic merchants. Perhaps being appointed parnas pressured one, almost structurally, to defend communal norms and perceived honor. Better answers will come from more careful analysis.

Bom Judesmo, the Western Sephardic ideal, was both upheld and subverted by slavery and race. It was upheld insofar as its noble self-image and disciplinary mechanisms were reinforced by the exclusion of lower Others such as slaves and non-whites. It was subverted insofar as this exclusion contradicted its ostensibly halakhic standards, generating an internal subaltern group that understood its exclusion and denigration to be against the very religious principles of the community. One need look no further than the name of the society formed by and for the colored Jews of Suriname, Darhe Jesarim (Paths of the Upright).

In short, we must reconsider the conclusion of the great historian Salo W. Baron. He wrote that "Neither the slave trade, therefore, nor slaveholding seems ever to have been so important a factor in Jewish economic life. ${ }^{n 9}$ While for Jewish history as a whole he is undoubtedly correct, for the early modern Atlantic world, over the course of two or three centuries several Jewish communities in the Americas depended on and participated actively in the general slave economy. Beyond economics, the presence of non-whites and slaves in a number of Sephardic communities was significant enough to influence communal legislation. Slavery and race acted together as forces that helped push Sephardim away from halakha and toward secular law and what we now call cultural Jewishness beginning in the seventeenth century. They functioned as pressures "modernizing" Western Sephardim along an alternative path rather before the Enlightenment, as Yosef Kaplan has discussed. Obviously this particular path of modernization should strike us as paradoxical, if not perverse; yet so it was, as David Brion Davis noted long ago in his path-breaking analysis of Jews and slavery. ${ }^{60}$ Even into the twenty-first century, black and mixed-race Jews have challenged Bom Judesmo for recognition and inclusion, to unfortunately unimpressive degrees of success.

59 Salo Wittmayer Baron, A Social and Religious History of the Jews, 18 vols. (New York/ Philadelphia: Columbia University Press/Jewish Publication Society of America, 195283), 4: 196.

6o David Brion Davis, Slavery and Human Progress (New York: Oxford University Press, 1984), chap. 6 ("Jews and the Children of Strangers"). 


\section{Bibliography}

Aboab, Isaac de Mattathias, ed. Seder Berakhot. Orden de Bendiciones y las ocaziones en que se deven dezir. Amsterdam: Albertus Magnus, 5447[1686/1687].

Arendt, Hannah. The Human Condition. Chicago: University of Chicago Press, 1958.

Ayala, Felipe Guaman Poma de. First New Chronicle and Good Government, Abridged. Translated and edited by David L Frye. Indianapolis: Hackett Publishing, 2006.

Baron, Salo Wittmayer. A Social and Religious History of the Jews. 18 vols. New York/ Philadelphia: Columbia University Press/Jewish Publication Society of America, 1952-83.

Barringer, Tim, Gilliam Forrester and Barbara Martinez-Ruiz, eds. Art and Emancipation in Jamaica: Isaac Mendes Belisario and His Worlds. New Haven: Yale University Center for British Art/Yale University Press, 2007.

Ben-Naeh, Yaron. 'And you will have a maidservant forever.' Slavery and Slaves in Ottoman Jewish Society." [Hebrew] Ha-Mizrah ha-Hadash 50 (2011): 66-9o.

Ben-Ur, Aviva. "A Matriarchal Matter: Slavery, Conversion, and Upward Mobility in Suriname's Jewish Community." In Atlantic Diasporas:Jews, Conversos, and CryptoJews in the Age of Mercantilism, 1500-180o. Edited by Richard L. Kagan and Philip D. Morgan, 152-69. Baltimore: Johns Hopkins University Press, 2009.

Ben-Ur, Aviva. "Peripheral Inclusion: Communal Belonging in Suriname's Sephardic Community." In Religion, Gender, and Culture in the Pre-Modern World. Edited by Alexandra Cuffel and Brian Britt, 185-210. New York: Palgrave Macmillan, 2007.

Ben-Ur, Aviva. "Still Life: Sephardi, Ashkenazi, and West African Art and Form in Suriname's Jewish Cemeteries." American Jewish History 92, no. 1 (2004): 31-79.

Ben-Ur, Aviva. "The Cultural Heritage of Eurafrican Sephardi Jews in Suriname." In The Jewish Diaspora in the Caribbean. Edited by Jane S. Gerber, 169-93. Oxford: Littman Library of Jewish Civilization, 2013.

Ben-Ur, Aviva, and Jessica Vance Roitman. "Adultery Here and There: Crossing Sexual Boundaries in the Dutch Jewish Atlantic." In Dutch Atlantic Connections, 1680-180o: Linking Empires, Bridging Borders. Edited by Gert Oostindie and Jessica V. Roitman, 185-223. Leiden: Brill, 2014.

Blau, Yehoshua, ed. Responsa of Rambam. [Hebrew] 3 vols. Jerusalem: Mekitzei Nirdamim, 1958.

Davis, David Brion. Slavery and Human Progress. New York: Oxford University Press, 1984.

Davis, Natalie Zemon. "Creole Languages and Their Uses: The Example of Colonial Suriname." Historical Research 82, no. 216 (May 2009): 268-84.

Davis, Natalie Zemon. “David Nassy's 'Furlough' and the Slave Mattheus.” New Essays in American Jewish History, Commemorating the Sixtieth Anniversary of the Founding 
of the American Jewish Archives. 79-93. Cincinnati: American Jewish Archives, 2010.

Davis, Natalie Zemon. "Judges, Masters, Diviners: Slaves' Experience of Criminal Justice in Colonial Suriname." Law and History Review 29, no. 4 (November 2011): 925-84.

Davis, Natalie Zemon. "Regaining Jerusalem: Eschatology and Slavery in Jewish Colonization in Seventeenth-Century Suriname." The Cambridge Journal of Postcolonial Literary Inquiry 3, no. 1 (January 2016): 11-38.

Gallego, Yosef. Imrei No'am. Amsterdam: Menasseh b. Yosef b. Yisrael, 1628.

Green, Tobias. "Amsterdam and the African Atlantic: The Role of Amsterdam Sephardim in Senegal in the Early Seventeenth Century." Proceedings of the Fourteenth British Conference on Judeo-Spanish Studies (26-28 June 20o6). Edited by Hilary Pomeroy, Christopher J. Pountain and Elena Romero, 85-94. Dept. of Hispanic Studies, Queen Mary, University of London, 2008.

Green, Tobias. "Equal Partners? Proselytising by Africans and Jews in the 17th-Century Atlantic Diaspora." Melilah 1 (2008): 1-12.

Green, Tobias. "Masters of Difference: Creolization and the Jewish Presence in Cabo Verde, 1497-1672." PhD diss. Centre of West African Studies. University of Birmingham, 2006.

Green, Tobias. The Rise of the Trans-Atlantic Slave Trade in Western Africa, 1300-1589. Cambridge: Cambridge University Press, 2011.

Hacker, Yosef. "The Jewish Independent Judiciary in the Ottoman Empire in the 17th and 18th Centuries: The Boundaries of Autonomy." [Hebrew] In Transition and Change in Modern Jewish History: Essays Presented in Honor of Shmuel Ettinger. Edited by Shmuel Almog et al., 349-88. Jerusalem: Historical Society of Israel/The Shazar Center, 1987.

Idelson-Shein, Iris. Difference of a Different Kind: Constructions of Race During the Long Eighteenth Century. Philadelphia: University of Pennsylvania Press, 2014.

Israel, Jonathan I. Diasporas within a Diaspora:Jews, Crypto-Jews and the World Maritime Empires, 1540-1740. Leiden: Brill, 2002.

Jordaan, Han. "Free Blacks and Coloreds and the Administration of Justice in Eighteenth-Century Curaçao." NWIG 81, nos. 1-2 (2010): 63-86.

Kals, Jan Willem. Neerlands Hooft-en Wortel-sonde, het Verzuym van de Bekeeringe der Heydenen. Leeuwarden: Pieter Koumans, 1756.

Kaplan, Yosef. "Eighteenth-Century Rulings by the Rabbinical Court of Amsterdam's Community and Their Socio-historical Significance." [Hebrew] In Studies on the History of Dutch Jewry. 5 vols. Edited by Jozeph Michman, 5: 1-54. Jerusalem: Magnes Press, $1975^{-1988 .}$

Mark, Peter, and José da Silva Horta. "Catholics, Jews, and Muslims in Early SeventeenthCentury Guiné." In Atlantic Diasporas:Jews, Conversos, and Crypto-Jews in the Age of 
Mercantilism, 1500-180o. Edited by Richard L. Kagan and Philip D. Morgan, 170-94. Baltimore: The Johns Hopkins University Press, 2009.

Mark, Peter, and José da Silva Horta. The Forgotten Diaspora: Jewish Communities in West Africa and the Making of the Atlantic World. New York: Cambridge University Press, 2011.

Mirvis, Stanley. "Sexuality and Sentiment: Concubinage and the Sephardi Family in Late Eighteenth-Century Jamaica." In The Jews in the Caribbean. Edited by Jane S. Gerber, 223-40. Oxford: Littman Library of Jewish Civilization, 2011.

Ranston, Jackie. Belisario: Sketches of Character: A Historical Biography of a Jamaican Artist. Kingston: The Mill Press, 2008.

Schorsch, Jonathan. Jews and Blacks in the Early Modern World. New York: Cambridge University Press, 2004.

Tavim, José Alberto Rodrigues da Silva. "Galut and Empire: On the Way to the Final Redemption." In The Sephardic Atlantic: Colonial Histories and Postcolonial Perspectives. Edited by Sina Rauschenbach and Jonathan Schorsch. New York: Palgrave, forthcoming.

Vink, Wieke. Creole Jews: Negotiating Community in Colonial Suriname. Leiden: KITLV Press, 2010.

Watson, Karl. "Shifting Identities: Religion, Race, and Creolization among the Sephardi Jews of Barbados, 1654-1900." The Jews in the Caribbean. Edited by Jane S. Gerber, 195-222. Oxford: Littman Library of Jewish Civilization, 2011. 


\title{
Feckless Fathers, Fraught Families: Abandonment and Cultural Change in the Early Modern Jewish World
}

\author{
Jessica Vance Roitman
}

For all intents and purposes, it would seem that Selomoh Gomes Soares made a modest success of his nearly four decades in Suriname, the Dutch plantation colony clinging to the edge of the South American mainland. By the time he died in 1805 , he had worked for ten years as the Jewish community's doctor, surgeon, and apothecary to the poor. ${ }^{1}$ He owned a small plot of land, and was at least somewhat active in the life of the community. For instance, he was a member of the choir (adjudante do corro) in the jubilee celebration marking the one hundredth anniversary of Congregation Beraha VeSalom. ${ }^{2}$ Yet had Soares immigrated to America in the early years of the twentieth century instead of Suriname in the mid-eighteenth, he very well might have shown up in "A Gallery of Vanished Husbands." This was a feature that appeared several times a week for decades in the New York-based Yiddish newspaper Der Forverts. This section of the paper exhibited portraits of husbands who had deserted their families, along with abbreviated descriptions of the deserters' circumstances and identifying characteristics in the hopes that they could be found. ${ }^{3}$ You see, Gomes Soares had left his wife, Simha Salom, and at least

1 National Archive of the Netherlands, The Hague (hereafter NL-HaNA), Suriname: Nederlands Portugees-Israëlitische Gemeente (Portugees-Israëlitische Gemeente Suriname), 1.05.11.18, inventory number (hereafter inv. nr.) 3, 29 December 1795. I am grateful to Dr. Aviva Ben-Ur for so generously sharing with me the fruits of her labors in the archives of the Portuguese Jewish community of Suriname. Parts of this chapter have appeared previously in Aviva BenUr and Jessica Vance Roitman, "Adultery Here and There: Crossing Sexual Boundaries in the Dutch Jewish Atlantic," in Dutch Atlantic Connections, 1680-180o: Linking Empires, Bridging Borders, eds. Gert Oostindie and Jessica Vance Roitman (Leiden: Brill, 2014), 216-23.

2 NL-HaNA, Portugees-Israëlitische Gemeente Suriname, 1.05.11.18, inv. nr. 2, 8 September 1785, p. 305 .

3 Bluma Goldstein, Enforced Marginality: Jewish Narratives on Abandoned Wives (Berkeley: University of California Press, 2007), 92.

(C) JESSICA VANCE ROITMAN, 2019 | DOI:10.1163/9789004392489_023

This is an open access chapter distributed under the terms of the prevailing CC-BY-NC License at the time of publication. 
two children behind in Amsterdam while he sought his fortune in the "New World." 4

There has been a compelling myth of the Jewish family as a fundamentally strong and stable institution. This "romantically idealized image of the Jewish family as warm, supportive, and ever-nurturing" has, according to historian Paula E. Hyman, a long history: "In the past two centuries," she writes, "Jewish communal leaders have been quick to celebrate the virtues of Jewish family life for purposes of self-gratification as well as apologetics, but they have been equally quick, in periods of rapid social change, to blame contemporary Jewish families for failing to live up to the standards of a noble past.".5 Indeed, historians of Jewish life have too often overlooked the serious dislocations that Jewish families experienced while privileging an image of Jewish familial solidity. Such a focus is somewhat puzzling because the archives of Jewish communities worldwide are filled with records documenting the large numbers of divorces, adulterous unions, children born out of legally sanctioned wedlock, and abandoned women such as Simha Salom.

In fact, there was no "noble past" for Jewish families, and the early twentieth century "Gallery of Vanished Husbands" was only the most visible manifestation of a phenomenon that had been going on for millennia-spousal abandonment-with poverty, adultery, and illegitimacy as some of its consequences. Gomes Soares was, for instance, hardly the only man to desert his family during the early modern period, and the situation his wife and children found themselves in was all-too-common in early modern Jewish communities. As this chapter will illustrate, the disruptions of early modernity, including demographic shifts, migration, European expansion overseas, the

4 Three births were registered to Selomoh Gomes Soares and Simha Salom: Ester, in 1763, Rachel, in 1764, and Jeudit, in 1766. Amsterdam Municipal Archive (Stadsarchief Amsterdam, hereafter SAA) Portugees-Israëlietische Gemeente, 334, inv. nr. 345 (Geboorteregister [Birth registry]), 108, 112, 120. We must assume that Rachel died at some point before or during the events which transpired, as she disappears from the historical record, though we have found no record of her death. The case of Simha Salom has previously been discussed in Ben-Ur and Jessica Roitman, "Adultery Here and There," in Oostindie and Roitman, Dutch Atlantic Connections and in Yosef Kaplan, "Moral Panic in the 18th-Century Sephardic Community of Amsterdam: The Threat of Eros," in Dutch Jewry. Its History and Secular Culture (1500-2000), ed. Jonathan Israel and Reinier Salverda (Leiden: Brill, 2002), 106-7.

5 Paula E. Hyman, "Introduction: Perspectives on the Evolving Jewish Family," in The Jewish Family: Myths and Reality, ed. Steven M. Cohen and Paula E. Hyman (New York: Holmes and Meier, 1986), 3-4. See also Morris D. Waldman, "Family Desertion," in Proceedings of the Sixth Biennial Session of the National Conference of Jewish Charities in the United States (St. Louis, May 17-19, 1910), 62: "The large proportion of such cases [desertion] among Jews is alarming in the light of our pride in the decency and purity of the Jewish family life." 
beginnings of industrialization, the Enlightenment and haskalah, and the emergence of greater acceptance for Jews in Christian society greatly affected the structure, size, character, economy, customs, and commitments of Jewish families, Ashkenazim and Sephardim alike, and exacerbated the always present problem of abandoned women and children. This problem was in no way isolated to Jewish communities, however, and the chapter will situate the issue within the larger context of early modernity, generally, and the Dutch Republic and its overseas colonies, specifically.

Despite the (self-) image of the Portuguese Jews of Amsterdam as aristocratic and wealthy, more than forty percent of the population was impoverished. ${ }^{6}$ The Sephardic economist and political philosopher, Isaac de Pinto, wrote of this problem of poverty in his Reflexoes Politicas in 1748. In it, he proposed sending impoverished Jews to Suriname. ${ }^{7}$ And, in fact, between 1759 and 1814, 430 so-called despachados (literally, "those who are despatched or sent away") left Amsterdam, a third going to Suriname and the others going as far afield as the Balkans, England, and to various points throughout the Americas. Only nineteen percent of those arriving in Suriname came with their spouses or families. The rest arrived alone, some after leaving a family in their city of origin. ${ }^{8}$

While there is no evidence that Selomoh Gomes Soares was one of these despachados, he certainly had left his family behind to seek his fortune. ${ }^{9} \mathrm{He}$

6 Tirtsah Levie Bernfeld, "Financing Poor Relief in the Spanish-Portuguese Jewish Community in Amsterdam in the Seventeenth and Eighteenth Centuries," in Israel and Salverda, Dutch Jewry, 101.

7 Isaac de Pinto, Reflexoens Politicas, Tocante à Constituiçám da Naçam Judaica, Exposiçam do estado de suas Finanças, causas dos atrasos, e desordens que se experimentam, e meyos de os prevenir (Amsterdam, 1748). On the problem of poverty in the Sephardic Jewish community, in general, see the excellent work of Tirtsah Levie Bernfeld, Poverty and Welfare Among the Portuguese Jews in Early Modern Amsterdam (Liverpool: Littman Library of Jewish Civilization and Liverpool University Press, 2012) and her "Financing Poor Relief," 63-102.

8 Robert Cohen, Jews in Another Environment. Surinam in the Second Half of the Eighteenth Century (Leiden: Brill, 1991), 25. Suriname was the primary destination for these Jews. Cohen's calculations show that 135 poor Jews were sent to Suriname between $1759^{-1814}$, more than to any other single destination.

9 I was not able to find a reference to Gomes Soares in the records of the despachados held in the Portuguese Jewish community of Amsterdam's archives SAA 344, inv. nr. 978, 17591802 (Registro dos despachos [Register of those dispatched]) or in SAA 344, inv. nr. 970-97, 1735-176o, 1772-1792 (Register van uitkeringen aan lidmaten als reisgeld om naar elders te vertrekken). 
may not have been poor enough to qualify as a despachado, but he was also not among the wealthy members of the community. ${ }^{10}$ His reasons for leaving his family behind to go to Suriname may have been financial, though there could also have been some other personal reasons that compelled him to set sail for the tropics. In any case, he must have been away from Amsterdam by 1767 , as the events that are described below show, though the earliest known official record of Soares's presence in Suriname is 1772 , so he could have gone elsewhere first. ${ }^{11}$ Be that as it may, in 1768 , his wife, Simha Salom, was publically accused of adultery by the parnassim of the Portuguese Jewish community in Amsterdam. It was a forceful accusation. She was pregnant, and her husband was known to have been away long enough for the community to calculate that the unborn child could not be his.

Two anonymous witnesses came forward to identify David, the son of Daniel de León, as the father of the fetus. The parnassim coyly refrained from naming the accusers in the communal minutes, writing only that "two people who have asked the President to remain anonymous" have come forward..$^{12}$ These same two unnamed men or women further asserted that David had rented Simha a house in which she could remain concealed for the duration of her pregnancy. But his efforts were to no avail. This is not overly surprising. The Portuguese Jewish community in Amsterdam was not large, equaling around three thousand people, and word traveled quickly.13 Gossip and the informal transfer of information to reinforce community norms were of vital importance within this and, indeed, most early modern (Jewish) communities. ${ }^{14}$

As soon as news of the pregnancy reached the parnassim's ears, they acted quickly to assert control over their wayward members and demand conformity to their rules. Simha and David were called before the august body because it had "come to their knowledge" that they had committed a "great crime against

10 SAA 344 (Register van administratie van de finta [Register of the administration of the obligatory community contribution or tax]), $285^{-287}$.

11 NL-HaNA, Portugees-Isrälitische Gemeente Suriname, 1.05.11.18, inv. nr. 135, p. 67. He received a piece of land valued at two hundred Dutch guilders from Jacob de Abraham de Meza.

12 SAA 334, inv. nr. 22 (Compendio de escamoth [Regulations], 1728-1814), 265. All discussion of this case is based on this file, unless otherwise cited.

13 Hubert Ph. H. Nusteling, "The Jews in the Republic of the United Provinces: Origin, Numbers and Dispersion," in Israel and Salverda, Dutch Jewry, 58.

14 On the importance of informal knowledge transfer and gossip within Portuguese Jewish communities, see Jessica Vance Roitman, "The Repercussions of Rumor: An Adultery Case from 18th-Century Curaçao," in A Sefardic Pepper-Pot in the Caribbean, ed. Michael Studemund-Halévy (Barcelona: Tirocinio, 2016), 124-35. 
our law."15 David de León initially refused to appear in the synagogue to answer the charges against him. In fact, de León managed to avoid coming before the parnassim by absenting himself from the city. For over three weeks, no one knew where to find him. His father, when questioned, claimed not to have seen him and to have no idea where he might be. The regents then instigated a search of the city to locate him. It is not clear if their search was successful, or whether de León finally decided to come forward of his own volition. ${ }^{16}$

In the meantime, Simha did come before the parnassim. According to her testimony to the Mahamad, she was seduced by the young man who slept with her on occasion in his father's home. She confirmed the account of the two anonymous witnesses, and stated that when her pregnancy became known to David, he rented a special house for her to conceal her condition from the public. Simha already had at least two daughters, Ester and Jeudit, and her daughter Rachel may have still been alive at this point, which likely made concealment even harder to accomplish. ${ }^{17}$ Once de León finally appeared in the synagogue, he broke down and confessed his adulterous affair with Simha Salom. On 5 July 1768 (20 Tamuz 5528), David, son of Daniel de León, and Simha Salom, wife of Solomon Gomes Soares, were excommunicated in the Portuguese Synagogue of Amsterdam.

This excommunication was brief. The usual punishments that accompanied such a sentence, including not being allowed to communicate with anyone outside of their immediate families, applied. De León was expected to participate in a very public and highly ritualized act in order to be reconciled with the community. He was required to climb the stairs on the left side of the pulpit within the synagogue, declare his sins, and ask for forgiveness for the scandal

15 “[G]rande crimen conforme nossa ley" SAA 334, 22 (Compendio de escamoth, 1728-1814), 265-267.

16 David de León's attempts to evade the parnassim, and his efforts to dodge an appearance before the body, does not seem to have been uncommon. De León's actions were quite similar to those taken by other accused adulterers within Portuguese Jewish communities. Take, for instance, Abraham Andrade and Sarah Pardo in Curaçao, and Moses Fernandes in Suriname, all of whom were accused of adultery in the latter quarter of the eighteenth century, and all of whom led the parnassim on a wild goose chase for weeks, if not months, before finally appearing to face their accusers. See Ben-Ur and Roitman, "Adultery Here and There."

17 See n. 4, above. SAA 334, inv. nr. 345 (Geboorteregister), 108, 112, 120. Only two children are mentioned as going to Suriname, and there are records of both Ester and Jeudit in Suriname. Ester Gomes Soares sent a letter from Amsterdam to the Portuguese Jewish Mahamad in Suriname in 1820 addressed to the administrators of orphans. NL-HaNA, Portugees-Israëlitische Gemeente Suriname, 1.05.11.18, inv. nr. 10, 16 January 1820. Jeudith de Sel. Gomes Soares was buried in Jodensavanne. NL-HaNA, Portugees-Israëlitische Gemeente Suriname, 1.05.11.18, inv. nr. 422, p. 2, number 8. 
that he had caused. This mantra was to be repeated three times in total. During the month of Elul, he was ordered to refrain from shaving, sit in a proscribed space in the synagogue, and visit the synagogue twice a week. Public acts of penance put penitents such as David de León before the community as a warning to others, while also providing a process by which the offender might be restored fully to the community. In addition, the public staging of penance was a way to regulate social behavior. Simha, however, due to her "great contrition for her crimes and submission to authority," had no penance to make whatsoever. Apparently, her confession to the parnassim and her evident remorse were enough to satisfy them. ${ }^{18}$

This case could indicate that while it was important for the man to perform a ritual of penance publically, women were not expected to carry out such a public act in the sacred space of the synagogue. It was certainly in contrast to general practice in early modern Christian society, where women were part of the culture of public penitence. For instance, in sixteenth- and seventeenth-century Germany women accused of adultery were often forced to wear distinctive clothing and do public penance in the church. Likewise, ecclesiastical authorities in early modern England often sentenced women to public displays of contrition. Women in British America were forced to stand in their local meetinghouse wearing white sheets and holding white wands, a traditional form of public penance for having sex outside marriage. ${ }^{19}$ Simha certainly had no money with which to pay a fine, which could have factored into the sentencing. ${ }^{20}$ However, de León was not fined either, and he was from a wealthier family. ${ }^{21}$

It may seem that Simha initially escaped the worst of the consequences for her "great crime against the law." However, in 1770, two years after the scandal

18 SAA 334 , inv. nr. 22, 267.

19 Joel F. Harrington, The Unwanted Child: The Fate of Foundlings, Orphans, and Juvenile Criminals in Early Modern Germany (Chicago: University of Chicago Press, 2009), 44; Bernard Capp, When Gossips Meet: Women, Family, and Neighbourhood in Early Modern England (Oxford: Oxford University Press, 2003), 101, 240, 247, 272, 298, 379. See also, Jim Sharpe, "Women, Witchcraft, and the Legal Process," in Women, Crime and the Courts in Early Modern England, ed. J.I. Kermode and Garthine Walker (Routledge: London, 1994), 119; Cynthia Lynn Lyerly, "Southern Colonial Protestant Women," in Encyclopedia of Women and Religion in North America, ed. Rosemary Skinner Keller and Rosemary Radford Ruether (Bloomington: Indiana University Press, 2006), 238.

20 She was already living quite precariously on the edges of poverty. SAA 334, inv. nr. 27 (Compendio de escamoth, 1767-1773), 127.

21 SAA 344, inv. nr. 285-287 (Register van administratie van de finta). This is an interesting contrast to the practice in Suriname and Curaçao, where fines seem to have been the norm. See Ben-Ur and Roitman, "Adultery Here and There." 
broke in Amsterdam, a Mr. de Vries arrived in Amsterdam on a ship from Suriname. He had in his possession a letter for the parnassim of the Portuguese Jewish community from Selomoh Gomes Soares. In this letter, Soares requested that they provide every possible assistance in transporting his daughters to him in Suriname. There is no record of any letter to Soares informing him of the events surrounding his wife's excommunication in the relatively complete books of letters sent by the Amsterdam community (uitgaande brieven), so it seems likely that he was notified of the scandal via informal means. ${ }^{22} \mathrm{He}$ asked that his daughters be sent with all possible speed to him so that they could be under his "paternal protection," a possible allusion to the moral unsuitability of his wife as a caretaker for their children, though there is evidence from other cases that fathers or the fathers' families were generally awarded custody. ${ }^{23}$

When the parnassim arrived on her doorstep with her husband's letter in hand, Simha was living on communal assistance and could not afford to feed the children. ${ }^{24}$ Her poverty left her in an extremely vulnerable position. Although she initially refused to relinquish her daughters to their father in Suriname, the parnassim visited several times over the coming weeks using "persuasive and suave" arguments—actually, threats—one of which included cutting off all community charity to her should she refuse. ${ }^{25}$ Simha was completely dependent upon the community's charity, as was her mother, who was mentally ill, her two daughters, and any child that may have been born of her adulterous affair with León. ${ }^{26}$ In the end, Simha acceded to the demands and allowed her daughters to be sent to their father in Suriname. ${ }^{27}$ Simha Salom

22 SAA 334, inv. nr. 1028BB (Documents concerning the Jewish communities in Amsterdam, Curaçao, Suriname, and Constantinople, 1750-1793); inv. nr. 95 (Copiador de cartas [Copies of outgoing letters], 1773-1784).

23 SAA 334, inv. nr. 94 (Copiador de cartas, 1764-1773), 332.

24 SAA 334, inv. nr. 27 (Compendio de escamoth, 1767-1773), 127.

25 "Argumentos suaveis e persuasivos." SAA 334, inv. nr. 27 (Compendio de escamoth, 17671773), 127, 145 .

26 On the mental illness of Simha's mother, see, SAA 334, inv. nr. 61 (Livro de segredos [Confidential book]), 31. Illegitimate children were registered in the community records, though usually with the notation mamzerta next to their names. A mamzer, a child of a forbidden union, is not considered a normative Jew and is permitted to marry only another mamzer or a convert to Judaism. Moreover, the stigma of the mamzer remains with the family indefinitely. See Rivka Haut, "The Agunah and Divorce," in Lifecycles: Jewish Women on Life Passages and Personal Milestones, ed. Debra Orenstein (Woodstock, VT: Jewish Lights Publishing, 1994), 1: 418, n. 4. We could find no record of any child born to Simha Salom or David de León in the birth registers, whether with the notation mamzerta or not. For an example, see SAA 345 (Geboorteregister), 118. The child could have died at birth or, for some other reason, not been registered. 
received a small legacy from her mother in 1787 , but by then, it was too late. ${ }^{28}$ Ester and Jeudit were in Suriname where it seems likely that they stayed for the rest of their lives. Jeudith de Sel. Gomes Soares was buried in Jodensavanne, the Jewish settlement in the interior of Suriname. ${ }^{29}$ It is doubtful that Simha ever saw her children again. ${ }^{30}$

Simha was not alone in her plight. For instance, Leah, the wife of Reuben, was accused of committing adultery with a non-Jewish neighbor or, even more shockingly, with her own brother, when her suspicious pregnancy was discovered in 1721. The couple lived in Nablus (Shechem), Eretz Israel, and Reuben had left her several days after their wedding, apparently to look for work, and not returned. ${ }^{31}$ In the meantime, Leah had gotten pregnant, and no one believed that Reuben could be the father. Simha and Leah's pregnancies, and others that were suspected of being the product of adulterous unions were, of course, scandalous events, and brought the infidelity of couples very publically to light. They were quite clearly the result of these women having been at least temporarily abandoned by their husbands. In fact, as Yosef Kaplan notes, all of the women he profiles in his study "Moral Panic in the Eighteenth-Century Sephardic Community of Amsterdam: The Threat of Eros" who were accused of adultery had been deserted by their spouses. ${ }^{32}$ The problem of the abandoned wife - the agunah, a woman "chained" or "anchored" to her husband because she is unable to divorce or remarry - has been around for millennia. However, the increased mobility of the early modern period, as well as the shifting social fabric of Jewish and non-Jewish communities, alike, also seems to have led to a growth in abandoned women, full stop. ${ }^{33}$

These were women like Simha, or the "bitter and unhappy" deserted wife in Jerusalem whose husband abandoned her three days after she bore him

28 SAA 334, inv. nr. 667 (Rachel Mendes da Costa, weduwe van Jacob Salom, 1757-1787) 1, 7 .

29 NL-HaNA, Portugees-Israëlitische Gemeente Suriname, 1.05.11.18, inv. nr. 422, p. 2, no. 8.

3o One Ester Gomes Soares sent a letter from Amsterdam to the Portuguese Mahamad in Suriname in 1820. It was addressed to the administrators of orphans. If it was Simha's daughter, she would have been fifty-seven at the time. NL-HaNA, Portugees-Israëlitische Gemeente Suriname, 1.05.11.18, inv. nr. 10, 16 January 1820.

Matt Goldish, Jewish Questions: Responsa on Sephardic Life in the Early Modern Period (Princeton, NJ: Princeton University Press, 2008), 136-38, "A Suspicious Pregnancy 1721, Case 37."

32 Kaplan, "Moral Panic in the Eighteenth-Century," 106.

33 Ibid., 111. 
a second daughter "and the woman and her two daughters were left naked and destitute, with no means of support [...] alone and forsaken [...] because there was nothing left to provide for her" according to the community leaders who wrote to see if the father could be found. ${ }^{34} \mathrm{~A}$ responsum written by the Sephardic scholar Moshe Aroquis of Salonika details the case of a Sephardic woman in the Ottoman Empire whose marital status was under consideration. Because of the controversy concerning her marital status, the young woman was considered an agunah. Aroquis was sympathetic to the woman's plight, describing her as an outcast among women, "destined by a rabbi's strict opinion to remain childless and single until her hair turns grey." ${ }^{35} \mathrm{He}$ was apparently referring to the correspondent of Ibn Habib, who had ruled that the young woman must receive a divorce $(\mathrm{get})$ in order to remarry. However, receiving a divorce was, and still is, not always a straightforward task for Jewish women.

In Jewish law, only the husband has the prerogative of executing and delivering a divorce, and there are essentially four reasons why a woman may be unable to obtain a Jewish get: the husband is mentally ill, thus legally incompetent to grant a divorce; a recalcitrant husband refuses to divorce his wife; the husband has died but there is no legally valid evidence of his death; or the husband abandons her and disappears. Of these reasons, the latter two came to the fore most often during the early modern period, and sometimes it was difficult to know if the woman had been intentionally abandoned, or if her husband had died and no word of his demise had reached her. ${ }^{36}$ The

34 Jerusalem, National and University Library, Ms. Jerusalem $8^{\circ} 61$, letter 171, cited in Ruth Lamdan, "Mothers and Children as Seen by Sixteenth-Century Rabbis in the Ottoman Empire," in Sephardic Family Life in the Early Modern Diaspora, ed.Julia Rebollo Lieberman (Waltham, MA: Brandeis University Press, 2011), 86.

35 Joseph R. Hacker, "The Sephardim in the Ottoman Empire in the Sixteenth Century," in Moreshet Sepharad: The Sephardic Legacy, ed. Haim Beinart (Jerusalem: Magnes Press, 1992), 2: 111, and his "Pride and Depression: Polarity and the Spiritual and Social Experience of the Iberian Exiles in the Ottoman Empire," in Culture and Society in Medieval Jewry: Studies Dedicated to the Memory of Haim Hillel Ben Sasson, ed. Menahem Ben Sasson, Robert Bonfil, and Joseph. R. Hacker (Jerusalem: Zalman Shazar Center, 1989) 570-72, cited in Hannah Davidson, "Communal Pride and Feminine Virtue: 'Suspecting Sivlonot' in the Jewish Communities of the Ottoman Empire in the Early Sixteenth Century," in Lieberman, Sephardic Family Life, 32.

36 One explanation for why the rabbis were so reluctant to declare a deserted husband dead even after years of absence and to grant the agunah permission to marry was the fear that, should the wife remarry and the former husband reappear, she would be an adulteress and any offspring of her new marriage would be mamzerim. In such cases, upon the first husband's return, the new husband must divorce the adulterous woman, who is then not permitted to remarry her first husband. Given the grave consequences of adulterous marriage, the rabbis were loath to verify a death without great certainty, even though, from 
Encyclopedia Judaica notes that, "the problem of the agunah is one of the most complex in halakhic discussions and is treated in great detail in halakhic literature." ${ }^{37}$ Moreover, the extensive concern with the ostensibly halakhically insoluble problem of the abandoned agunah highlights the serious repercussions of the gender and power differential operative at the very foundation of the Jewish legal system. The need for absolute certainty in declaring a man deceased placed an undue burden of proof on women, especially in cases of shipwreck or war, when finding an identifiable body was well-nigh impossible.

For instance, in the case of a man lost in a shipwreck, even though a survivor of the shipwreck testifies that he saw the husband drown, Jewish law does not consider him dead so long as the witness does not testify unequivocally that he saw him lying dead. ${ }^{38}$ Thus, when David Cunha declared to the members of the Mahamad on the 25th of December 1783 that his son-in-law, David Nunes Paiba had died in the warship on which he was serving, he must have been there himself. That, or the Amsterdam Mahamad may have been particularly lenient in accepting the testimony of such a clearly interested party. Cunha asked that the event be recorded "to serve as proof for the rabbinical court, as is necessary" so that his daughter could marry again. ${ }^{39}$

This need for certainty regarding the status of a man who had disappeared, coupled with the burden that abandoned women and children placed on the communities' charitable coffers, help explain why the records of the Amsterdam and London Sephardic communities in the latter part of the eighteenth century were filled with requests from, and bequests to, women who needed support to search for their missing husbands. To name just a few examples, in 1784, Rachel, wife of Daniel Casseres, asked the London community to travel to "Jamaica or places thereabouts where last he was known to have inhabited" to find her missing husband..$^{40}$ In June of 1783 , Leah, the daughter of Isaac Belmonte asked the Portuguese Jewish community of Amsterdam for funds. She hoped to follow her husband, Daniel Carodso, who had abandoned her. ${ }^{41}$ Esther Gabbai Isidro was granted a small sum to travel to Bordeaux, also in 1783 , to look for her missing spouse. ${ }^{42}$

the Talmudic period onward, rabbis counseled leniency in efforts to release an agunah. Goldstein, Enforced Marginality, 4.

37 http://www.jewishvirtuallibrary.org/agunah.

38 Menachem M. Brayer, The Jewish Woman in Rabbinic Literature: A Psychosocial Perspective, vol. 1 (Hoboken, NJ: KTAV, 1986), 16.

39 SAA 334, inv. nr. 29, 217. Cited in Kaplan, "Moral Panic in the Eighteenth-Century," 111.

40 London Metropolitan Archives, City of London, 4521/A/03/14/012.

41 SAA 344, inv. nr. 29, 242. Cited in Kaplan, "Moral Panic in the Eighteenth-Century,"11.

42 Ibid., fol. 252. 
It is beyond doubt that the early modern world, in general was a fluid one. This tendency toward mobility and movement was possibly even greater among the Jewish communities of Europe, particularly the Sephardim. This movement and mobility lead to a not inconsiderable group of women who were left to their own devices. Their poverty was an economic burden to their communities, while their situation as women alone led to gossip and, indeed, incidences of adultery and illegitimate children. We know that women like Leah in Nablus or Simha in Amsterdam were vulnerable. Their financial situation was often precarious, and their legal standing under Jewish law was often difficult, as they were condemned to stay married to a man who had deserted them and their children and were, therefore, unable to turn to another spouse for support. But what of men like Reuben and Selomoh?

\section{$3 \quad$ Feckless Fathers and Hopeless Husbands}

Solomon Maimon, the brilliant former Talmudist and rabbi, who eventually became a maskil in the circle of Moses Mendelssohn (in honor of whom he changed his last name), and, later still, a secular philosopher is, perhaps, best known for his autobiography (Lebensgeschichte), published in German around ${ }^{1792-93}{ }^{43}$ In this narrative, he admits that he abandoned his family, leaving his wife an agunah. In 1777, Maimon made the great "leap into the alien history" of eighteenth-century enlightened Germany. ${ }^{44}$ When he departed Poland for Germany, he was twenty-four years old, and left behind his family, which included his wife of thirteen years, a ten-year-old son named David, and several other children. He does not say how many, but mentions that his wedded life was "rather fruitful," and later speaks of David as the eldest son. ${ }^{45}$ There is no record of what he told his family when he departed for Königsberg. He only described his desire to leave the life of an early modern shtetl, full of poverty and tradition. He wrote: "Since my external circumstances continually grew worse because I no longer wanted to put up with my ordinary occupations and therefore found myself everywhere outside of my circle; also, on the other hand, I

43 Salomon Maimon's Lebensgeschichte. Von ihm selbst geschrieben und herausgegeben von K.P. Moritz (Berlin: Friedrich Vieweg, 1792-3). For the English translation, see Salomon Maimon, The Autobiography of Salomon Maimon with an Essay on Maimon's Philosophy, Introduction by Michael Shapiro, translated by J. Clark Murray (Urbana: University of Illinois Press, 2001).

44 Zvi Batscha, "Nachwort," in Salomon Maimons Lebensgeschichte: Von ihm selbst geschrieben, ed. Karl Philipp Moritz (Frankfurt am Main: Insel, 1984), 374-75.

45 Maimon, The Autobiography, 88. 
could not sufficiently satisfy my favorite inclination for scientific studies where I lived, I decided to go to Germany and there study medicine and, given this opportunity, also other sciences." 46

His wife disappeared from Maimon's Autobiography when he left for Germany. We do know that an envoy from his wife was sent to confront him in Germany to demand that he either return to Poland or divorce her. He, apparently, refused this request. After several more years in which she and the children lived in poverty in Poland, she and his eldest son traveled to Breslau, most likely with monies provided by the charitable funds of their community in Poland, to demand that he make a decision-divorce or return. Maimon finally concluded that "among the two evils here the lesser one was to be chosen, and I agreed to a divorce." ${ }^{47}$ Despite this decision, however, he continued to erect many obstacles to the divorce, including an unnecessary court proceeding at the beit din before finally acceding to grant a get. ${ }^{48}$

Maimon's references to his deserted wife account for but a few sentences in his entire life story. The almost complete exclusion of his wife from the pages of his biography minimize what she, as an agunah, suffered - poverty, inability to remarry, possibly social sanctions. Maimon's Autobiography allows us a first-hand glimpse of the forces driving the increase in abandoned wives in the early modern Jewish communities. Maimon wanted to travel, explore, the world, and make a new life for himself. In short, he wanted to "make a great leap" into all the possibilities offered by an "enlightened" Germany, including the chance to study secular subjects. This, he deemed, would only be possible if he left his wife and children. Thus, it is clear that it was not just poverty that drove men to abandon their families, but also a thirst for adventure, and a desire to live a different life, unencumbered by the expectations and traditions of the Jewish family.

This same desire may have played a part in Selomoh Gomes Soares's departure for Suriname. As was mentioned above, there is no record of him being desperately poor enough to have received charitable aid to travel or to be "dispatched" to the colonies. In any case, to the colonies he went, and there he established a new life-a life without Simha. The earliest known official record of Selomoh Gomes Soares's presence in Suriname is 1772. In that year, he received from Jacob de Abraham de Meza a piece of land valued at two hundred

\footnotetext{
$46 \quad$ Ibid., 93.

47 Ibid., 140.

48 Goldstein, Enforced Marginality, 36.
} 
Dutch guilders. ${ }^{49}$ However, we know Gomes Soares must have been there by at least 1770 because that is the year in which Mr. de Vries arrived in Amsterdam with his letter demanding his children be sent to him.

Ester and Jeudit must have arrived in Suriname by 1771 or 1772 . Soares's fortunes seem to have been on the rise by then. In 1774, some three or four years after his daughters would have arrived in Suriname, Soares sold to Samuel Cohen Nassy a house and plot of land in the province of the Jodensavanne, the Jewish agricultural settlement in the interior of the colony, between the land of Samuel Henriquez Fereyra and the said Nassy, for 1,500 Dutch guilders. ${ }^{50}$ In this same year, he served as witness to a mortgage contract between Portuguese Jews living in Paramaribo, the colony's capital. ${ }^{51}$ The scandal of his wife's adulterous behavior never seems to have affected Soares's reputation or career in Suriname. For instance, in 1777 , Selomoh Gomes Soares and David de Isaac Cohen Nassy formed a partnership and opened a pharmaceutical store to serve the infirm in the Jodensavanne, whether white or black, under the name Soares \& Company. ${ }^{52}$ At this same time, we know that Simha was still living off of communal charity in Amsterdam.

Despite this relative success, not everything seems to have gone completely smoothly for Gomes Soares. In 1785 , Soares along with three dozen other Portuguese Jewish heads of house (including two widows) were denied access to the synagogue because of their late taxes. Desirous of attending synagogue during Rosh Hashanah, he and the others worked out individual payment plans. Soares admitted he had trouble paying his annual taxes to the Portuguese Jewish community, and offered to pay half or some portion thereof. ${ }^{53}$ The fact that at least thirty-six other congregation members had trouble paying their synagogue dues is an indication that the community was not particularly wealthy. In any case, as was mentioned above, Soares served as a choir member in the jubilee celebration marking the one hundredth anniversary of Congregation Beraha VeSalom. ${ }^{54}$

49 NL-HaNA, Portugees-Israëlitische Gemeente Suriname, 1.05.11.18, inv. nr. 135, p. 67.

$50 \quad$ NL-HaNA, Portugees-Israëlitische Gemeente Suriname, 1.05.11.18, inv. nr. 135, pp. 68-69.

51 NL-HaNA, Portugees-Israëlitische Gemeente Suriname, 1.05.11.18, inv. nr. 787, 13 June 1774.

52 NL-HaNA, Suriname: Oud Notarieel Archief, 1699-1829, 1.05.11.14, inv. nr. 788, 23 February 1780; and 3 December 1777. In 1783, one David de la Parra, who claimed to be suffering from opthalmia veterana, was referred to them for his eye inflammation. The lack of doctors in the region was noted. NL-HaNA, Portugees-Israëlitische Gemeente Suriname, 1.05.11.18, inv. nr. 2, 17 October 1783 .

53 NL-HaNA, Portugees-Israëlitische Gemeente Suriname, 1.05.11.18, inv. nr. 2, 8 September 1785, p. 305 .

54 NL-HaNA, Portugees-Israëlitische Gemeente Suriname, 1.05.11.18, inv. nr. 2, 6 June 1787. 
And so his life in the Dutch colony of Suriname went, as far as can be garnered from the sources, with no concern for his wife back in Amsterdam. In 1789, he along with fourteen other Portuguese Jewish jehidim received the permission of the Mahamad to shave during the intermediary days of the High Holy Days. ${ }^{55} \mathrm{He}$ and seven others were granted the same dispensation for Passover of $1790 .{ }^{56}$ In 1795 , Soares was selected out of three applicants to be admitted as a doctor, surgeon, and apothecary of the poor with a salary of $55^{0}$ guilders. ${ }^{57}$ In 1796 , Soares treated two charity slaves (negros da sedaca), slaves responsible for the upkeep of the synagogue. ${ }^{58}$ Soares was still working in 1802, when he was identified as the pharmacist (boticario) charged with treating a widow's son stricken with a tropical parasitic disease (chagas). He apparently no longer served as a chirurajao, who would see the patient should his cure not work. ${ }^{59}$ On 30 July 1805 , Selomon Netanel Gomes Soares died in the Jodensavanne. ${ }^{60}$ He was buried on the following day, next to his business partner David Nassy (the former David de Isaac Cohen Nassy). ${ }^{61}$

There is no record of the Portuguese Jewish community of Amsterdam sending an envoy to Suriname to request that Gomes Soares return or divorce his wife. This could be because they were loath to have anyone return when they were already so actively trying to send poor and middling Jews away. Nevertheless, by this time, Gomes Soares was at least relatively prosperous, while Simha was living on communal charity, so it remains somewhat mysterious as to why no demands seem to have been placed on him to support his wife, especially considering the frequent communications between the Suriname and Amsterdam Jewish communities, both formal and informal. Nor is there any record that a divorce was either requested by Simha or the congregation,

55 NL-HaNA, Portugees-Israëlitische Gemeente Suriname, 1.05.11.18, inv. nr. 2, 11 October 1789 .

56 NL-HaNA, Portugees-Israëlitische Gemeente Suriname, 1.05.11.18, inv. nr. 2, 21 April 1790.

57 NL-HaNA, Portugees-Israëlitische Gemeente Suriname, 1.05.11.18, inv. nr. 3, 29 December 1795 .

58 NL-HaNA, Portugees-Israëlitische Gemeente Suriname, 1.05.11.18, inv. nr. 3, 27 December 1796.

59 NL-HaNA, Portugees-Israëlitische Gemeente Suriname, 1.05.11.18, inv. nr. 3, 2 May 1802.

6 o NL-HaNA, Portugees-Israëlitische Gemeente Suriname, 1.05.11.18, inv. nr. 418, died $4 \mathrm{Ab}$ 5565, p. 89; NL-HaNA, Portugees-Israëlitische Gemeente Suriname, 1.05.11.18, inv. nr. 423, buried 31 July 1805 (5 Ab 5565), p. 32.

61 NL-HaNA, Portugees-Israëlitische Gemeente Suriname, 1.05.11.18, inv. nr. 423, p. 33. NAN, NPIGS, inv. nr. 4, 5 August 1805. The applicant who sought to replace him, Abraham Moses Levy, requested to be admitted as dotour chirugiao and butecario of the Portuguese Jewish poor in Paramaribo. See NL-HaNA, Portugees-Israëlitische Gemeente Suriname, 1.05.11.18, inv. nr. 4, 5 August 1805 . Five days later, Levy was officially admitted to the post. 
and, as far as we can tell, they never divorced. In fact, in Simha's mother's will from 1787 , Simha is still listed as the "housewife of Selomoh Gomes Soares, currently in the West Indies." 62

What the cases of Maimon and Gomes Soares and their unfortunate families show us is how skewed the Jewish family and larger societal structures were in favor of men. The increasing mobility of the early modern period, the promises of the European Enlightenment and European expansion clearly provided heretofore unheard of options for men like Maimon and Gomes Soares were still limited in their access to all aspects of society, nevertheless readily availed themselves of the male prerogative to leave home and family and seek out opportunities they deemed intellectually, socially, and/or economically more promising. The wives, long confined within the traditional household and encumbered with responsibility for the welfare of their children, certainly could not easily undertake life in an unfamiliar modern (secular) environment. ${ }^{63}$

The adulterous affair of Simha Salom and David de León should be contextualized within the trend toward increasing mobility that characterized the early modern period and led to growing numbers of women and children being left behind, either temporarily or permanently. ${ }^{64}$ Historian Herman Roodenburg shows that twenty-four percent of all infidelity cases brought to the attention of the Amsterdam Dutch Reform consistory between 1578 and 1700 involved a wife whose husband was away in the East or West Indies. Of the women accused of infidelity during the period under study, eighty-three of their husbands had gone to the East Indies and four to the West Indies or Brazil. ${ }^{65}$ And it was not just within Amsterdam that such statistics applied. One hundred and one women were accused of either adultery or bigamy in Leiden between 1678 and 1794 , versus 132 men in the same time frame. Of course, it was easier to discover a woman's adultery if she became pregnant, especially if her husband was away, as was the case with Simha Salom or the unfortunate Rachel in

\footnotetext{
62 SAA 334, inv. nr. 667 (Rachel Mendes da Costa, weduwe van Jacob Salom, 1757-1787), 1.

63 Goldstein, Enforced Marginality, 156.

64 Leslie P. Moch, Moving Europeans: Migration in Western Europe since 1650 (Bloomington: Indiana University Press, 2003), 84-87; and Jan Lucassen, Dutch Long Distance Migration: A Concise History 1600-19oo (Amsterdam: IISG Research Paper 3, 1991), 20, 36.

65 Herman Roodenburg, Onder censuur: De kerkelijke tucht in de gereformeerde gemeente van Amsterdam, 1578-1700 (Hilversum: Verloren, 1990), 283.
} 
TABLE 22.1 Cases of Adultery, Protestant Reformed

Church, Amsterdam

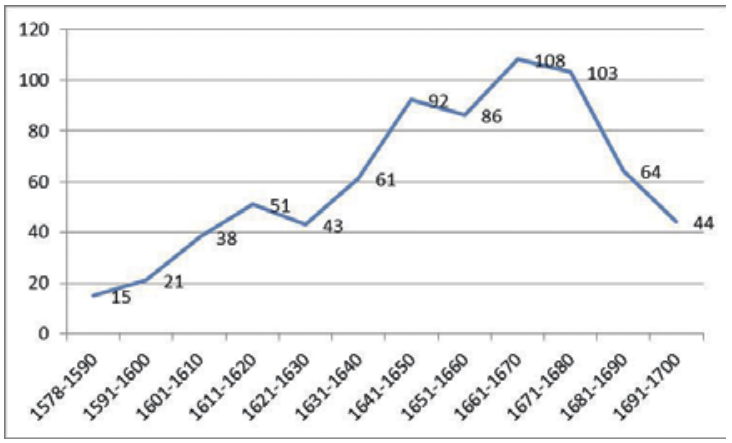

SOURCE: HERMAN ROODENBURG, ONDER CENSUUR,

P. 281

Nablus. ${ }^{66}$ This may account for the relatively high number of women accused of the crime.

In any case, many of the women accused of adultery or bigamy in Leiden stated that their husbands were in the East Indies. ${ }^{67}$ Although it is difficult to ascertain from the available sources, absent husbands could have, and, likely, did, play a role in the increase in cases of adultery that came before the "high court" Hof van Holland of the province of Holland in the latter half of the eighteenth century. A statistical profile of adultery as reflected in the aforementioned Hof van Holland inventory, for example, shows us that sixty-seven cases were recorded in the century and a half between 1597 to 1749 , while in the less than half a century from 1753 to 1800 , thirty-six cases were tried (Table 22.1). ${ }^{68}$

As the examples detailed above show, particularly the Salom/de León case, Jewish communities were not immune to this trend. In fact, some scholars speculate that it may have been more common within Jewish communities than in non-Jewish ones, due to the allegedly higher mobility of Jews during

66 This was also the situation in which Sarah Pardo found herself in Curaçao in 1775, when no one believed that her ailing husband could be the father of her unborn child, leading to a scandal within the already conflict-prone Portuguese Jewish community on the island. See Ben-Ur and Roitman, "Adultery Here and There," in Dutch Atlantic Connections, 208-16.

67 Else Margaretha Kloek, Wie hij zij, man of wijf. Vrouwengeschiedenis en de vroegmoderne tijd: Drie Leidse studies (Hilversum: Verloren, 1990), 142-45.

68 NL-HaNA, Hof van Holland, 3.03.01.01, inv. nr. 1.1. Roodenburg's analysis of adultery in Amsterdam's Dutch Reform church shows that adultery cases dramatically peaked during the two decades between 1661 and 1680. Herman Roodenburg, Onder censuur, 281. 
the early modern period. ${ }^{69}$ Until systematic research is undertaken comparing the two centuries beginning in the $1650 \mathrm{os}$ and $1750 \mathrm{os}$, it is impossible to say whether or not this statistical increase in the Christian society of the early modern Dutch Republic was actually mirrored within the Portuguese Jewish community. Two historians have indicated adultery was more common among Amsterdam's Portuguese Jews in the eighteenth than in the previous century. Yosef Kaplan, in an article that discusses about a dozen cases of marital infidelity, calls adultery among Amsterdam's Portuguese Jews in the eighteenth century an "extensive phenomenon" and traces its causality to ever-growing "tolerance towards sexuality in Western European societies" beginning in the $1670 s$ and "the satisfaction of erotic desires as a central goal in marriage." He also links the increase in mobility to this growth in adultery cases. ${ }^{70}$ Tirtsah Levie Bernfeld affirms Kaplan's findings, and remarks upon, "a growing neglect of morality among Dutch Sephardim [in the eighteenth century]."71 Historian Matt Goldish, who brought the case of Leah and Reuben to light, notes a rise in responsa and other documents related to adultery among Jews in Morocco, which "might suggest that infidelity and adultery were becoming more common" there among Jews from the mid-eighteenth century. ${ }^{72}$

Goldish's findings suggest that the rise in documented adultery cases was not, then, linked solely to social trends in Western Europe. Granted, this spike in reported incidents of adultery could reflect a growing preoccupation with shifts in the economic and social structure of the traditional Jewish family, including increased mobility and, consequently, more abandoned wives and children, rather than an actual increase in incidences of adultery itself. Herman Roodenburg, for example, cautions that his data does not say much about the behavior of the members of the church. Members from higher socio-economic positions, he surmises, had the wherewithal to keep their adultery from reaching the consistory, a fact well known among pastors of the congregation. Also, the rate of cases of prosecuted infidelity may have fluctuated over time as civil and ecclesiastical authorities' priorities shifted..$^{73}$ It is likely that marital infidelity was common in any age, as one historian of the eighteenth-century Cape

\footnotetext{
69 Kaplan, "Moral Panic in the Eighteenth Century," 112.

70 Ibid. Kaplan points out that poverty from the 1730 and increasing mobility intensified the phenomenon.

71 Tirtsah Levie Bernfeld, "Sephardic Women in Holland's Golden Age," in Lieberman, Sephardic Family Life, 182.

72 Goldish, Jewish Questions, $136-38$.

73 Roodenburg, Onder censuur, 281.
} 
Colony in contemporary South Africa also argues, and as a number of scholars writing in broader contexts have long posited. ${ }^{74}$

But what is "common" for early modernity can only be quantified in comparison to other contemporaneous transgressions regarded (at least in theory) as equally serious. If adultery was both common and a central concern, this concern may possibly be linked to several factors. It could be due to the fact that "marriage and sex had become public anxieties in Europe during the Protestant and Catholic Reformations" and that mainstream churches during this period set up special institutions specifically geared toward regulating and punishing transgressive sexual behavior. ${ }^{75}$ The split of the Roman Catholic Church created not only the Protestant community, but also communal barriers in need of policing. The reaction of Portuguese Jewish authorities to marital infidelity differed over time qualitatively, just as it seems did those of Christian religious leaders. A major preoccupation of the eighteenth-century Portuguese Jewish community in Amsterdam was heterosexual wrongdoing, particularly adultery and clandestine marriages. ${ }^{76}$ As Kaplan describes, heightened scrutiny and verbosity characterizes trial proceedings from the mid-eighteenth century, and gone were the oblique euphemisms and lenient punishments of the previous century. This "moral panic" (the spike in adultery cases beginning in the second half of the eighteen century) in both Jewish and Christian communities seem to at least be partially tied to the increased mobility of the early modern period, with the concomitant increase in spousal desertion, bigamy, and illegitimacy.

74 George Peter Murdock, Social Structure (New York: The Free Press, 1949), 26o; Murder and adultery were "common enough crimes in any age." Nigel Penn, "The Wife, the Farmer and the Farmer's Slaves: Adultery and Murder on a Frontier Society in the Early Eighteenth Century Cape," Kronos 28 (November 2002): 1-20, 1; James A. Brundage, "Adultery and Fornication: A Study in Legal Theology," in Sexual Practices and the Medieval Church, ed. V.L. Bullough and J.A. Brundage (Buffalo: Prometheus, 1982), 133-34; W.E.H. Lecky, History of European Morals, 2 vols. (New York: George Braziller, 1955), 2: 282; Bronislaw Malinowski, "Parenthood, The Basis of Social Structure," in The Family: Its Structure and Function, ed. Rose Laub Cross (New York: St. Martin's Press, 1964), 18-19.

75 Steven Ozment, When Father Ruled: Family Life in Reformation Europe (Cambridge, MA: Harvard University Press, 1983).

$7^{6}$ Yosef Kaplan, "Deviance and Excommunication in the Eighteenth Century: A Chapter in the Social History of the Sephardic community of Amsterdam," in Dutch Jewish History Dutch Jewish History, Vol. 3: Proceedings of the Fifth Symposium on the History of the Jews in the Netherlands, ed. J. Michman (Jerusalem and Assen: Hebrew University and Van Gorcum, 1993), 103. 
The sad case of Simha Salom and her absconding husband, Selomoh Gomes Soares, serves as a vivid illustration of the shifts taking place within the Portuguese Jewish community in the early modern period. Increased mobility and migration, most clearly seen in the European expansion overseas, but also shown in increased intra-European movement, and the Enlightenment and haskalah, with their associated possibilities for life outside the confines of Jewish communities, had no small effect on Jewish families, Ashkenazim and Sephardim alike. ${ }^{77}$ One of these seems to have been an increase in the number of abandoned women and children. Clearly, in the case of Simha Salom and her husband Selomoh Gomes Soares, the broad stretch of the Atlantic world as traversed by the highly mobile Jewish community exacerbated the hardships endured for family members left behind. But this was a trend mirrored in Christian society, as well, a fact the startling statistics of the number of adultery and bigamy cases linked to a spouse in the Dutch East and West Indies shows.

The early modern emphasis on the strong family and the strict implementation of marriage and divorce laws as mechanisms to enforce Jewish communities cohesiveness in a sometimes threatening diasporic situation continued well into the twentieth century. ${ }^{78}$ The traditional Jewish community, enclosed within the dominant society, established its own internal governance with a modicum of autonomy that included rabbinical courts, its own legal system for family law and contracts, and structures of social and political hierarchy. Gender inequality, with Jewish men in control, and with women, because of their legally sanctioned subaltern status, marginalized and largely confined to the domestic sphere, was at the heart of this governance system. Agunot, especially deserted wives, were burdened by an even more oppressive enforced marginality: their systemic exclusion from perhaps the only domain where a woman had value in her traditional community—as wife of a household. ${ }^{79}$

The differential of power and privilege between men and women is obvious in cases like that of Leah in Morocco, the "bitter" agunah in Jerusalem, the young Sephardic woman in the Ottoman Empire, or Maimon's unnamed wife. They were all trapped, unable to free themselves of their marriages, suffering societal sanctions as a woman with little or no status because of an absent

77 Moses A. Shulvass, From East to West: The Westward Migration of Jews from Eastern Europe During the Seventeenth and Eighteenth Centuries (Detroit: Wayne State University Press, 1971).

78 Goldstein, Enforced Marginality, 154.

79 This paragraph is paraphrased from ibid., 153 . 
husband, and with minimal resources to support themselves. The kind of impoverishment of women and children that so commonly resulted from spousal abandonment only served to further aggravate the gendered power differential in the early modern period. In the case of Simha Salom, her husband's financial abandonment of her left her entirely at the mercy of the parnassim who controlled access to communal charitable funds. This, in turn, left her little recourse when these communal authorities demanded that her children be turned over to their father. This highlights the male-dominated system of the Portuguese Jewish communities, which privileged a father's authority above a mother's, and left women with very little room in which to maneuver in asserting their rights to their children. This same community routinely sent children to live with their father or his family in case of divorce, and considered illegitimate daughters of Portuguese fathers and Christian mothers eligible for the Dotar dowry, but not the other way around.

The early modern period was a time of serious shifts culturally, economically, and socially. The Jewish communities of Europe were not immune from these shifts. In fact, Portuguese Jews, due to their familial and trade networks, coupled with political circumstances, pushed them to the forefront of economic change. ${ }^{80}$ Yet there were also social and cultural changes afoot. These very networks and this mobility which helped foster the global trade in which they were disproportionately present, also helped spur an intensified movement, mostly of men. This, in turn, meant that the (Portuguese) Jewish family was tested as never before. Rates of (prosecuted) adultery rose, as did problems with unauthorized marriages, and illegitimate children in the eighteenth century. Part and parcel of these strains were deserted women and their children. All of which does, indeed, call into question the compelling myth of the Jewish family as fundamentally strong, stable, warm, and supportive. No doubt some were, but many families also buckled under the stress of societal and economic dislocations, as the various cases in this chapter show.

\section{Bibliography}

Amsterdam Municipal Archives (SAA), Portugees-Israëlietische Gemeente, 334.

Batscha, Zvi. "Nachwort." In Salomon Maimons Lebensgeschichte: Von ihm selbst geschrieben. Edited by Karl Philipp Moritz, 329-92. Frankfurt am Main: Insel, 1984.

8o Jessica V. Roitman, The Same But Different? Inter-cultural Trade and the Sephardim, 15951640 (Leiden: Brill, 2011). 
Beinart, Haim, ed. Moreshet Sepharad: The Sephardic Legacy. 2 vols. Jerusalem: Magnes Press, 1992.

Ben Sasson, M., R. Bonfil, and J.R. Hacker, eds. Culture and Society in Medieval Jewry: Studies Dedicated to the Memory of Haim Hillel Ben Sasson. [Hebrew] Jerusalem: Zalman Shazar Center, 1989.

Ben-Ur, Aviva, and Jessica Vance Roitman. "Adultery Here and There: Crossing Sexual Boundaries in the Dutch Jewish Atlantic." In Dutch Atlantic Connections, 1680-180o: Linking Empires, Bridging Borders. Edited by Gert Oostindie and Jessica Vance Roitman, 185-223. Leiden: Brill, 2014.

Brayer, Menachem M. The Jewish Woman in Rabbinic Literature: A Psychosocial Perspective. Vol. 1. Hoboken, NJ: KTAV, 1986.

Brundage, James A. "Adultery and Fornication: A Study in Legal Theology." In Sexual Practices and the Medieval Church. Edited by V.L. Bullough and J.A. Brundage, 12934. Buffalo: Prometheus, 1982.

Bullough, V.L., and J.A. Brundage, eds. Sexual Practices and the Medieval Church. Buffalo: Prometheus, 1982.

Capp, Bernard. When Gossips Meet: Women, Family, and Neighbourhood in Early Modern England. Oxford: Oxford University Press, 2003.

Cohen, Robert. Jews in Another Environment. Surinam in the Second Half of the Eighteenth Century. Leiden: Brill, 1991.

Cohen, Steven M., and Paula E. Hyman, eds. The Jewish Family: Myths and Reality. New York: Holmes and Meier, 1986.

Cross, Rose Laub. The Family: Its Structure and Function. New York: St. Martin's Press, 1964.

Davidson, Hannah. "Communal Pride and Feminine Virtue: 'Suspecting Sivlonot' in the Jewish Communities of the Ottoman Empire in the Early Sixteenth Century." In Sephardic Family Life in the Early Modern Diaspora. Edited by Julia Rebollo Lieberman, 23-69. Waltham, MA: Brandeis University Press, 2011.

Goldish, Matt. Jewish Questions: Responsa on Sephardic Life in the Early Modern Period. Princeton, NJ: Princeton University Press, 2008.

Goldstein, Bluma. Enforced Marginality: Jewish Narratives on Abandoned Wives. Berkeley: University of California Press, 2007.

Hacker, Joseph. "Pride and Depression: Polarity and the Spiritual and Social Experience of the Iberian Exiles in the Ottoman Empire." [Hebrew] In Culture and Society in Medieval Jewry: Studies Dedicated to the Memory of Haim Hillel Ben Sasson. Edited by M. Ben Sasson, R. Bonfil, and J.R. Hacker, 541-86. Jerusalem: The Shazar Center, 1989 .

Hacker, Joseph. "The Sephardim in the Ottoman Empire in the Sixteenth Century." In Moreshet Sepharad: The Sephardic Legacy. 2 Vols. Edited by Haim Beinart, 1: 109-33. Jerusalem: Magnes Press, 1992. 
Harrington, Joel F. The Unwanted Child: The Fate of Foundlings, Orphans, and Juvenile Criminals in Early Modern Germany. Chicago: University of Chicago Press, 2009.

Haut, Rivka. "The Agunah and Divorce." In Lifecycles:Jewish Women on Life Passages and Personal Milestones. 2 Vols. Edited by Debra Orenstein, 1: 188-200. Woodstock, VT: Jewish Lights Publishing, 1994.

Hyman, Paula E. "Introduction: Perspectives on the Evolving Jewish Family." In The Jewish Family: Myths and Reality. Edited by Steven M. Cohen and Paula E. Hyman, 3-13. New York: Holmes and Meier, 1986.

Israel, Jonathan I., and Reinier Salverda, eds. Dutch Jewry. Its History and Secular Culture (1500-200o). Leiden: Brill, 2002.

Kaplan, Yosef. "Deviance and Excommunication in the Eighteenth Century: A Chapter in the Social History of the Sephardic community of Amsterdam." In Dutch Jewish History. Vol. 3: Proceedings of the Fifth Symposium on the History of the Jews in the Netherlands. Edited by J. Michman, 103-15. Jerusalem and Assen: Hebrew University and Van Gorcum, 1993.

Kaplan, Yosef. "Moral Panic in the 18th-Century Sephardic Community of Amsterdam: The Threat of Eros." In Dutch Jewry. Its History and Secular Culture (1500-2000). Edited by Jonathan Israel and Reinier Salverda, 103-23. Leiden: Brill, 2002.

Keller, Rosemary Skinner, and Rosemary Radford Ruether, eds. Encyclopedia of Women and Religion in North America. Bloomington: Indiana University Press, 2006.

Kermode, J.I., and Garthine Walker, eds. Women, Crime and the Courts in Early Modern England. Routledge: London, 1994.

Kloek, Else Margareth. Wie hij zij, man of wijf. Vrouwengeschiedenis en de vroegmoderne tijd: Drie Leidse studies. Hilversum: Verloren, 1990.

Lamdan, Ruth. "Mothers and Children as Seen by Sixteenth-Century Rabbis in the Ottoman Empire." In Sephardic Family Life in the Early Modern Diaspora. Edited by Julia Rebollo Lieberman, 70-100. Waltham, MA: Brandeis University Press, 2011.

Lecky, W.E.H. History of European Morals. 2 vols. New York: George Braziller, 1955.

Levie Bernfeld, Tirtsah. "Financing Poor Relief in the Spanish-Portuguese Jewish Community in Amsterdam in the Seventeenth and Eighteenth Centuries." In Dutch Jewry. Its History and Secular Culture (1500-200o). Edited by Jonathan Israel and Reinier Salverda, 63-102. Leiden: Brill, 2002.

Levie Bernfeld, Tirtsah. Poverty and Welfare Among the Portuguese Jews in Early Modern Amsterdam. Liverpool: Littman Library of Jewish Civilization and Liverpool University Press, 2012.

Lieberman, Julia Rebollo, ed. Sephardic Family Life in the Early Modern Diaspora. Waltham, MA: Brandeis University Press, 2011.

London Metropolitan Archives, City of London, Spanish and Jews' Congregation, 4521. Lucassen, Jan. Dutch Long Distance Migration: A Concise History 16oo-19oo. Amsterdam: IIS G Research Paper 3, 1991. 
Lyerly, Cynthia Lynn. "Southern Colonial Protestant Women." In Encyclopedia of Women and Religion in North America. Edited by Rosemary Skinner Keller and Rosemary Radford Ruether, 236-41. Bloomington: Indiana University Press, 2006.

Maimon, Salomon. The Autobiography of Salomon Maimon with an Essay on Maimon's Philosophy. Introduction by Michael Shapiro. Translated by J. Clark Murray. Urbana: University of Illinois Press, 2001.

Maimon, Salomon. Lebensgeschichte. Von ihm selbst geschrieben und herausgegeben von K. P. Moritz. Berlin: Friedrich Vieweg, 1792-3.

Malinowski, Bronislaw. "Parenthood, The Basis of Social Structure." In The Family: Its Structure and Function. Edited by Rose Laub Cross, 3-19. New York: St. Martin's Press, 1964.

Moch, Leslie P. Moving Europeans: Migration in Western Europe since 1650. Bloomington: Indiana University Press, 2003.

Murdock, George Peter. Social Structure. New York: The Free Press, 1949.

National and University Library, Jerusalem. Ms. Jerusalem $8^{\circ} 61$.

National Archive of the Netherlands, The Hague (NL-HaNA)

Hof van Holland, 3.03.01.01

Suriname: Nederlands Portugees-Israëlitische Gemeente (Portugees-Israëlitische Gemeente Suriname), 1.05.11.18

Suriname: Oud Notarieel Archief, 1699-1829, 1.05.11.14.

Nusteling, Hubert Ph. H. "The Jews in the Republic of the United Provinces: Origin, Numbers and Dispersion." In Dutch Jewry. Its History and Secular Culture (1500200o). Edited by Jonathan Israel and Reinier Salverda, 43-62. Leiden: Brill, 2002.

Orenstein, Debra, ed. Lifecycles:Jewish Women on Life Passages and Personal Milestones. Woodstock, VT: Jewish Lights Publishing, 1994.

Ozment, Steven. When Fathers Ruled: Family Life in Reformation Europe. Cambridge, MA: Harvard University Press, 1983.

Penn, Nigel. “The Wife, the Farmer and the Farmer's Slaves: Adultery and Murder on a Frontier Society in the Early Eighteenth Century Cape." Kronos 28 (2002): 1-20.

Pinto, Isaac de. Reflexoens Politicas, Tocante à Constituiçám da Naçam Judaica, Exposiçam do estado de suas Finanças, causas dos atrasos, e desordens que se experimentam, e meyos de os prevenir. Amsterdam, 1748.

Roitman, Jessica Vance. "The Repercussions of Rumor: An Adultery Case from 18th Century Curaçao." In A Sefardic Pepper-Pot in the Caribbean. Edited by Michael Studemund-Halévy, 124-35. Barcelona: Tirocinio, 2016.

Roitman, Jessica Vance. The Same But Different? Inter-cultural Trade and the Sephardim, 1595-1640. Leiden: Brill, 2011.

Roodenburg, Herman. Onder censuur: De kerkelijke tucht in de gereformeerde gemeente van Amsterdam, 1578-170o. Hilversum: Verloren, 1990. 
Sharpe, Jim. "Women, Witchcraft, and the Legal Process." In Women, Crime and The Courts in Early Modern England. Edited by J.I. Kermode and Garthine Walker, 10624. Routledge: London, 1994.

Shulvass, Moses A. From East to West: The Westward Migration of Jews from Eastern Europe During the Seventeenth and Eighteenth Centuries. Detroit: Wayne State University Press, 1971.

Studemund-Halévy, Michael, ed. A Sefardic Pepper-Pot in the Caribbean. Barcelona: Tirocinio, 2016.

Waldman, Morris D. "Family Desertion." In Proceedings of the Sixth Biennial Session of the National Conference of Jewish Charities in the United States (St. Louis, May 17-19, 1910), 54-111. Baltimore: Kohn and Pollock, 1910. 


\title{
The Gabay Dynasty: Plantation Jews of the Colonial Atlantic World
}

\author{
Stanley Mirvis
}

Western Sephardim of the colonial Atlantic are largely characterized as "merchants" in academic literature as well as in the popular imagination. The long distance networks of the Nação, that transcended political, linguistic, and religious borders, enabled Jewish pioneers in the Americas to exploit both clandestine and legal markets with greater facility than their non-Jewish counterparts. This New-Jewish and converso trading success, particularly in trafficking goods and slaves throughout the triangular market of Jamaica, Cuba, and Hispaniola, engendered frequent anti-Jewish hostility. Those merchants who felt threatened by Jewish trading networks in the Caribbean brought forth the frequent accusation that stateless Jews traded at the expense of agricultural settlement.

This chapter explores, through an anecdotal description of the Jamaican Gabay planting dynasty, those Jews that embraced the planter's ethos. It argues that the division between merchant and planter was not as mutually exclusive as the anti-Jewish sentiments of the early modern period would have us believe. While it is nothing new to show that Jews also planted in the Americas, this chapter provides a fuller image of Jewish plantocracy and suggests some ways a more focused view on Jewish planting may help to qualify both the historiographical representation as well as the popular imagination of colonial Atlantic Jewry.

A recent slew of popular articles about Caribbean Jews aimed at encouraging tourism, exoticizing the Jew, or enlivening the imagination with stories of Jewish swashbucklers, have reinforced an image of colonial Sephardim as an exclusively merchant community. One author characterized the Jews of Jamaica as "successful gold traders and merchants," a line that was repeated a number of times in other similar articles. ${ }^{1}$ While a statement like this is not

1 Ross Kenneth Urken, "The Forgotten Jewish Pirates of Jamaica," Smithsonianmag.com (9 July 2016). http://www.smithsonianmag.com/travel/forgotten-jewish-pirates-jamaica-18o 959252/?no-ist.

(C) STANLEY MIRVIS, 2019 | DOI:10.1163/9789004392489_024

This is an open access chapter distributed under the terms of the prevailing CC-BY-NC License at the time of publication. 
inaccurate, it completely ignores not only Jewish planters but also poor despachados, physicians, metal workers, entertainers, and fisherman.

I believe that the reluctance to mention Jewish planters in popular magazine articles is rooted in an-understandable - twenty-first-century squeamishness over the reality that Caribbean Jews owned slaves. This is likely the case for example in an outlandish piece from the Jerusalem Post online magazine, "Jewish Pirates of the Caribbean," wherein the author acknowledged Jewish planting activity but qualified that fact with the bizarre falsehood that Jews who didn't plant "were allowed only two slaves." It is possible that this hesitancy to acknowledge the full scope of Jewish slave ownership is a polemical attempt to undermine contemporary anti-Semitic libels that contend Jews were overrepresented in the slave trade or overly abusive toward their slaves. ${ }^{3}$ If that is the case then those wishing to whitewash the image of the Jewish slave owner have ironically traded in a contemporary anti-Semitic canard for an eighteenth-century one claiming that Jews traded exclusively at the expense of planting. As one member of Parliament put it in 1753: "[Jews] are not likely to become great purchasers of land, for they love their money and can employ it to much better advantage in trade." ${ }^{4}$

Academic scholarship has no less privileged the mercantile profile of the colonial Atlantic Jew. The model of the "Port Jew" in particular has come to dominate the historiographical representation of Atlantic Jewry. ${ }^{5}$ According to the "Port Jew" model, unprecedented civil liberties were granted to Jews in port cities by virtue of their value as traders. That civil liberty, coupled with a distinctively Spanish-Portuguese "alternative path to modernity," whereby Western Sephardim possessed a progressive secularism rooted in their converso past, led to the birth of Jewish modernity independent of the haskalah. Some

2 Gil Stern Zohar, "Jewish Pirates of the Caribbean," The Jerusalem Post Magazine.com (9 April 2016). http://www.jpost.com/Magazine/Jewish-pirates-of-the-Caribbean-447397. This piece was drawn from Edward Kritzler,Jewish Pirates of the Caribbean (New York: Anchor, 2008).

3 See Historical Research Department of the Nation of Islam, The Secret Relationship Between Blacks and Jews: Volume One (Chicago: Nation of Islam, 1991). For an academic rebuttal of these scurrilous claims see Eli Faber, Jews, Slaves, and the Slave Trade: Setting the Record Straight (New York: New York University Press, 1998).

4 Quoted from J.H. Hollander, "The Naturalization of the Jews in the American Colonies Under the Act of 1740," Publications of the American Jewish Historical Society (PAJHS) 5 (1897): 103$117,108$.

5 See the special issue of Jewish History "Port Jews in the Atlantic World": Jewish History 20 (2006). See also the collection of essays by David Cesarani and Gemma Romain, eds., Jews and Port Cities: 1590-1990: Commerce, Community and Cosmopolitanism (London: Vallentine Mitchell, 2006). 
scholars have already pointed to some of the potential pitfalls of this model. ${ }^{6}$ It is untrue that civil liberties were any more progressive in port cities than other places; in some cases the opposite was true. ${ }^{7}$ It is likewise a false assumption that "Port Jews" were any more "secular" than their continental counterparts. ${ }^{8}$ Finally, it has been demonstrated that Atlantic "Port Jews" did in fact have a rich and consistent engagement with the European Enlightenment throughout the eighteenth century. 9

In this chapter I hope to further problematize the model of the "Port Jew" by emphasizing the experience of "Plantation Jews" who were both dependent on yet independent of their port-city brethren. ${ }^{10} \mathrm{I}$ hope to point to some ways in which "Plantation Jews" experienced their own trajectory toward modernity by exploring their transition from agricultural investment to direct plantation ownership through the lives of the Jamaican planter dynasty, the Gabays.

Salamão Gabay was born a New Christian in Portugal who embraced his ancestral Judaism in Amsterdam. ${ }^{11}$ By the 1640 s he had joined the Dutch "New Jewish"

6 See C.S. Monaco, "Port Jews or a People of the Diaspora? A Critique of the Port Jew Concept," Jewish Social Studies 15, no. 2 (2009): 137-66.

7 See Stanley Mirvis, "Between Assembly and Crown: The Debate Over Jewish Taxation in Jamaica (1692-1740)" Journal of Early American History 6 (2016): 196-219.

8 See for instance Yosef Kaplan, From Christianity to Judaism: The Story of Isaac Orobio de Castro (Oxford: Littman Library of Jewish Civilization, 2004) who argues that the converso university experience did not necessarily produce skepticism or secularism. For an important analysis of the meaning of secularization in the Jewish eighteenth century see Shmuel Feiner, The Origins of Jewish Secularization in Eighteenth-Century Europe (Philadelphia: University of Pennsylvania Press, 2011).

9 See in this volume, Sina Rauschenbach, "Patriots at the Periphery: David Nassy, the French Revolution, and the Emancipation of the Dutch Jews." Jacob Rader Marcus, ed., Historical Essay on the Colony of Surinam, 1788 (Cincinnati: American Jewish Archives, 1974). See also Stanley Mirvis, "Joshua Hezekiah Decordova and a Rabbinic Counter-Enlightenment from Colonial Jamaica," in Reappraisals and New Studies of the Modern Jewish Experience: Essays in Honor of Robert M. Seltzer (Leiden: Brill, 2015), 104-22. David B. Ruderman, Jewish Enlightenment in an English Key: Anglo-Jewry's Construction of Modern Jewish Thought (Princeton, NJ: Princeton University Press, 2012).

10 The term "Plantation Jew" was introduced by Dale Rosengarten, "Port Jews and Plantation Jews, Carolina-Caribbean Connections," in The Jews in the Caribbean, ed. Jane S. Gerber (Oxford: The Littman Library of Jewish Civilization, 2014), 289-307.

11 Egon and Frieda Wolff, Dicionário Biográfico:Judaizantes e Judeus no Brasil, 1500-1808 (Rio de Janeiro: Instituto Histórico e Geográfico Brasileiro, 1986), 82-83. 
settlement of Pernambuco where he trafficked in foodstuffs and slaves. An active participant in the Portuguese Jewish community of Recife, he was among the signatories to the communal regulations of Zur Israel along with at least three of his male relatives. ${ }^{12}$ After the Portuguese conquest of Pernambuco, and subsequent expulsion of the Jews in 1654, Salamão appears to have returned to Amsterdam from where he later sailed on to Jamaica. In Jamaica he laid the foundation for one of the island's most resilient and long lasting Jewish planting dynasties. As with so many other Jewish refugees from Brazil, such as the famous Martinique sugar mogul Benjamin Dacosta D'Andrade, Salamão translated his commercial involvement in Brazilian planting into actual Caribbean plantation ownership. ${ }^{13}$

While the Jews of Recife, by-and-large, played only a supportive role in Brazilian sugar planting through the acquisition and resale of slaves and capital investment, New Christians had been intimately involved in planting since the sixteenth century. Portuguese conversos poured into Brazil during the late sixteenth and seventeenth centuries. Conversos and conversas, mostly women, convicted of Judaizing by the Portuguese Inquisitions made up more than half of those punitively exiled to Brazil. ${ }^{14}$ Some early New Christian arrivals to Brazil belonged to families who already possessed sugar-planting expertise acquired on the Portuguese possession of Madeira off the west coast of Africa. ${ }^{15}$ While they were not the dominant force behind Brazil's sugar boom, converso "senhores de engenho" were among the leading pioneers of Bahian sugar production.

Far across the "Ocean Sea," seemingly hidden from the surveillance of the Lisbon Inquisition, Brazilian sugar plantations provided a fecund space for the continuity of crypto-Jewish practices. Some engenhos may have even provided spaces for the semi-public practice of crypto-Judaism. ${ }^{16}$

12 Arnold Wiznitzer, The Records of the Earliest Jewish Community in the New World (New York: American Jewish Historical Society, 1954), 51.

13 On Benjamin Dacosta d'Andrade see Isaac S. Emmanuel, Precious Stones of the Jews of Curaçao: Curaçaon Jewry 1656-1957 (New York: Bloch, 1957), 200-1. For examples of other Brazilian exiles who invested in Caribbean plantations see Stanley Mirvis, "The Alvares Family Patriarchs and the Place of Pre-1692 Port Royal in the Western Sephardic Diaspora," The American Jewish Archives Journal 67, no. 2 (2015): 1-46.

14 Geraldo Pieroni, "Outcasts from the Kingdom: The Inquisition and the Banishment of New Christians to Brazil," in The Jews and the Expansion of Europe to the West, 1450 to 180o, ed. Paolo Bernardini and Norman Fiering (New York: Berghahn Books, 2001), 242-51, 245.

15 Ernst Pijning, "New Christians as Sugar Cultivators and Traders in the Portuguese Atlantic, 1450-180o" in Jews and the Expansion of Europe to the West, 485-500, 487.

16 Stuart B. Schwartz, Sugar Plantations in the Formation of Brazilian Society: Bahia, 1500-1835 (Cambridge: Cambridge University Press, 2004), 266. 
As in the rest of the Atlantic World, the wealth generated from sugar production in the Portuguese Atlantic did not necessarily result in an improvement of social status. For New Christians it was easier to transcend one's economic status than one's stained blood. While they had acquired wealth, they remained stigmatized by their Jewish ancestry and excluded from full participation in civil society.

In 1629, the States-General in Holland declared that in the West Indian Company (WIC) possession of Pernambuco, "The liberty of Spaniards, Portuguese and natives, whether they be Roman Catholics or Jews will be respected."17 Unlike in northwestern Europe where the rejudaized fled to "terras de libertad," in Brazil, the "terras de libertad" came to them. The Dutch occupation of Pernambuco dramatically accelerated contact between these two strands of the Nação — crypto-Jews and New Jews—giving rise to an unprecedentedly rapid rejudaization movement. ${ }^{18}$

The Dutch governor of Pernambuco Johan Maurits redistributed abandoned sugar mills in an effort to encourage Catholic sugar planters to relocate to Dutch territory. ${ }^{19}$ Despite the absence of economic or social barriers, the Jews of Dutch Brazil did not immediately gravitate toward direct plantation ownership. It is estimated that Jews owned only about six percent of the Dutch Brazilian engenhos. ${ }^{20}$ The historian Arnold Wiznitzer wrote: "It cannot be said that Jews played a dominant role in Dutch Brazil as senhores de engenho. Unquestionably, they played a more important part as financiers of the sugar industry, as brokers and exporters of sugar, as suppliers of Negro slaves on credit, accepting payment of capital and interest in sugar." ${ }^{21}$

Unlike their New Christian counterparts, newly arrived Jews in Dutch Pernambuco, such as Salamão Gabay, were indeed traders and investors rather than growers of sugar. ${ }^{22}$ Their extensive involvement in the sugar trade echoed in the communal minutes of the colony where the Mahamad, set the impos$t a$ for sugar exports at eight soldos per unit for refined sugar and six soldos per unit for muscovado. The same rates applied for the sale of imported sugar.

\footnotetext{
17 Wiznitzer, The Records of the Earliest Jewish Community, 1.

18 Bruno Feitler, "Jews and New Christians in Dutch Brazil, 1630-1654," in Atlantic Diasporas: Jews, Conversos, and Crypto-Jews in the Age of Mercantilism, ed. Richard L. Kagan and Philip D. Morgan (Baltimore: The Johns Hopkins University Press, 2009), 123-51.

19 Arnold Wiznitzer, Jews in Colonial Brazil (New York: Columbia University Press, 1960), $67-68$.

20 Wiznitzer, Jews in Colonial Brazil, 69 .

21 Ibid., 70.

22 Pijning, "New Christians as Sugar Cultivators," 491.
} 
Retailers of sugar produced and consumed locally were required to pay only half the imposta. ${ }^{23}$

The Recife Mahamad similarly regulated the ownership of African slaves. Taking liberties with rabbinic tradition, they required in 1649 that a slave be manumitted before being subject to circumcision and, seemingly, only if he chose circumcision. ${ }^{24} \mathrm{~A}$ nearly identical ordinance passed in Amsterdam a year later. The reality of Jewish slave ownership in the colonial Americas made it unfeasible to follow the biblical standard of circumcising slaves upon purchase [Genesis 17:12]. Jewish traders of Recife purchased large numbers of slaves from the WIC for resale to the engenhos.

The Jews of Recife like Salamão Gabay clearly possessed a mercantile ethos, even if it was one deeply engrained in the plantation culture of Brazil. The WIC, however, while pragmatically encouraging Jewish trading activity, also hoped that Jews would participate more fully in agriculture. The Dutch had taken possession of Spanish Curaçao in 1634 . By the 1650 s, rising hostilities between the Dutch and the Portuguese in Brazil prompted Jewish leaders in Amsterdam to seek permission from the WIC to establish new Jewish settlements there. ${ }^{25}$ The WIC granted permission to various Jewish settlement schemes such as that of the Sabbatean mystic João de Ilan, because he intended to "bring a considerable number of people there to settle and cultivate [...] the land."26 The directors of the WIC suspected, however, that his true intentions were to trade. They wrote in the same letter to Governor Peter Stuyvesant: "we begin to suspect, that he and his associates have quite another object in view, namely, to trade from there to the West Indies and the [Spanish] Main." Already in the earliest years of Jewish settlement in the Americas the tension between trader and planter generated an anti-Semitic image of the Jew as merchant at the exclusion of planter.

\section{Salamão Gabay and the Port Royal Merchant-Planters}

Upon the Portuguese expulsion of Jews from Pernambuco, Salamão Gabay seems to have returned to Amsterdam. From there he sailed back to the

\footnotetext{
23 Wiznitzer, The Records of the Earliest Jewish Community, 74.

24 Jonathan Schorsch, Jews and Blacks in the Early Modern World (Cambridge: Cambridge University Press, 2004), 74-79, 219-226. Wiznitzer, The Records of the Earliest Community, 69.

25 See Isaac S. Emmanuel and Suzanne A. Emmanuel, History of the Jews of the Netherlands Antilles, 2 vols. (Cincinnati: American Jewish Archives, 1970), 1: 37-50.

26 Hebert Cone, "The Jews in Curaçao: According to Documents from the Archives of the State of New York," PAJHS 10 (1902): 141-57, here 147.
} 
western side of the Atlantic to settle on the English island of Jamaica where he became a free denizen in $1672 .{ }^{27}$ His denization entitled him to purchase land, arbitrate disputes in court, and trade freely (within the confines of the law) although he was excluded from civil service and participation in the colony's governance. Salamão's settlement in Jamaica appears to have been a family venture. Possibly the oldest known Jewish tombstone at Hunt's Bay Cemetery, across the bay from Port Royal on the western outskirts of modern-day Kingston, belonged to one Abraham Gabay who died in the spring of $1672 .{ }^{28}$

Salamão and his kinsmen joined the founders of the Jewish community of Port Royal, many of whom had likewise been members of the Recife community. He, along with his relative, Abraham de David Gabay, and Moses Yeshurun Cardoso "acting [on behalf of] the rest of the Jews [...] residing in Port Royal" signed a deed in January of 1677 to purchase Jewish communal land, possibly intended for the erection of a synagogue. ${ }^{29}$ Port Royal provided a welcome environment for Portuguese Jews. At the behest of the colonial authorities in London, the Governor of Jamaica Thomas Lynch declared religious liberty to Jews and Protestant dissenters in 1670 with the pragmatic intention of profiting from their extensive channels of trade. ${ }^{30}$ Jews integrated well into Port Royal's renowned ethnic and religious diversity typical of port cities of the period. ${ }^{31}$

The Jewish settlers in Port Royal quickly capitalized on their transAtlantic networks flouting the English restrictions on trade with the Castilian Americas - empowered by the implementation of the Asiento in 1713 - as well as to Dutch territories. Stiff competition over trade in Port Royal prompted the non-Jewish merchants to initiate a vigorous campaign against Jewish trading efforts sending at least two petitions up the chain of colonial command between 1671 and $1684 .{ }^{32}$

27 Wolff and Wolff, Dicionário Biográfico, 82-83.

28 Richard D. Barnett and Philip Wright, The Jews of Jamaica: Tombstone Inscriptions, $1663^{-}$ 1880 (Jerusalem: Ben Zvi Institute, 1997), 5, no. 12. This is the oldest known Jewish tombstone according to Rachel Frankel and her Caribbean Volunteer Expedition of 2008, see Rachel Frankel, "Testimonial Terrain: The Cemeteries of New World Sephardim" in The Jews of the Caribbean, 131-42, 133 n. 5 .

29 Jacob Andrade, A Record of the Jews in Jamaica from the English Conquest to the Present Times (Kingston: Jamaica Times, 1941), 40. See also Michael Pawson and David Buisseret, Port Royal, Jamaica (Kingston: University of the West Indies Press, 2000), 129.

J.W. Fortescue, ed., Calendar of State Papers, Colonial America and the West Indies (London: Her Majesty's Stationary Office, 1898), 8: 145-47.

31 David Buisseret, ed., Jamaica in 1687: The Taylor Manuscript at the National Library of Jamaica (Kingston: University of West Indies Press, 2010), 238.

Mirvis, "The Alvares Family Patriarchs," 8. 
These petitions were written with anti-Jewish language echoing earlier anti-Jewish petitions from Barbados. Barbadian merchants submitted no fewer than four anti-Jewish trading petitions, employing archetypal antiJewish stereotypes, between 1661 and $1680 .{ }^{33}$ Though Barbadian Jews attempted to defend themselves, their defense was not necessary, as the Board of Trade in London remained committed to encouraging Jewish trading activity. But, local assemblies responded to these petitions by imposing a collective Jewish tax in both Jamaica and Barbados. In Jamaica, where the tax would persist on an annual basis until 1740, proponents often justified it on the grounds that Jews refrained from planting. When the Jamaican governor William Beeston - a man with a track record of anti-Jewish positions-instituted the Jewish tax in Jamaica, he justified it by saying that the Jews' "first introduction into this Island was upon condition that they should settle and plant, which they do not." ${ }^{34}$

These petitions in the English Caribbean have helped shape an image of Jews in the colonial Americas as single-minded traders to this day. It is easy to reach the same conclusion through the available notarial and cemetery records where Jews are almost always referred to as "merchant." However, the term merchant is misleading since "merchants" and "planters" are not mutually exclusive categories. Sugar planting in particular required extensive capital investment for which Jamaican planters relied heavily on Kingston traders. ${ }^{35}$ Jamaica's earliest Jews, recapitulating their Brazilian profile, actively invested their earnings in plantations. From there it was a small step toward actual plantation ownership. Port Royal Jews defended themselves against mercantile hostilities by touting their plantation ownership.

In August of 1692, nearly three months after the devastation of Port Royal by an earthquake and tidal wave, the Jewish survivors-along with their Barbadian counterparts-petitioned the Queen directly asking for denization because they had become destitute by the calamity. ${ }^{36}$ To prove their value to the colony they emphasized their planting activity. The petition was sent by the twenty-one heads of the "Jews' plantations and houses in Jamaica and

33 Stephen A. Fortune, Merchants and Jews: The Struggle for British West Indian Commerce, 1650-1750 (Gainesville: University of Florida Press, 1984), 45-46.

34 See Mirvis, "Between Assembly and Crown," 208.

35 Nuala Zahedieh, "Trade, Plunder, and Economic Developments in Early English Jamaica, 1655-1689," The Economic History Review 39, no. 2 (1986): 205-22.

36 "Memorandum of the Jews of Jamaica (August, 1692)," The National Archives Kew, England (TNA) CO 137/2, 112. See a reproduction in Frank Cundall, N. Darnell Davis, and Albert M. Friedenberg, "Documents Relating to the History of the Jews in Jamaica and Barbados in the Time of William III," PAJHS 23 (1915): 25-29, 27-29. 
Barbados." Solomon [Salamão] Gabay was among the twelve planters representing Jamaica. The petition described him as having operated a "plantation for many years in Magitt Savana." His kinsman Abraham Gabay owned a plantation in "White Hood." Sarah Gabay was the only woman planter on the list. Clearly, already by 1692, the Gabays had translated their expertise financing plantations into actual plantation ownership.

This petition came at a critical time of transition in Jamaica. Even before the earthquake, Jamaica had begun a metamorphosis into a sugar-based economy. By 1680 , colonial authorities increasingly pursued policies intended to marginalize privateering with the goal of developing the agricultural promise of Jamaica's interior. ${ }^{37}$ The sheer scale of available planting land that far outstripped Barbados, presented the possibility of challenging France's Caribbean sugar hegemony. The 1692 earthquake and resultant destruction of England's most profitable Caribbean trading hub provided a further impetus to turn the attention of the island's inhabitants toward sugar planting. This is precisely what the twelve Jamaican planter families were responding to when they petitioned the crown in 1692. In doing so they made the case not only for their willingness to transcend the stereotypically Jewish attachment to trade, but, to make the case clear to the Crown that they had already been planting in Jamaica.

The Gabay dynasty of Jamaica founded by the Brazilian expellee Salamão remained at the cutting edge of Jamaica's transformation into a monoculture sugar colony. Three generations of Gabays lived and planted in Jamaica between 1680 and 1740 . David Gabay (the elder) resided in the small hamletcum political capital—St. Jago de la Vega (Spanish Town), a place notable for its planter residents, and composed a will in 1720 where he bequeathed his plantation in the parish of St. Thomas in the Vale to his son Isaac. ${ }^{38}$ Isaac Gabay, who also lived in St. Jago de la Vega, continued to operate his father's plantation and made more extensive mention of enslaved property in his will of June $1730 .{ }^{39} \mathrm{He}$ supported both his daughter and his unborn child with slaves, while he bequeathed the family plantation to his son David (the younger). Isaac further requested that two slaves be purchased for his daughter, Rebecca, from the first "negro ship that arrives after my decease." David (the younger) had still

37 Richard S. Dunn, Sugar and Slaves: The Rise of the Planter Class in the English West Indies, 1624-1713 (Chapel Hill, NC: The University of North Carolina Press, 1972, repr. 2000), $154-65$.

38 "Will of David Gabay, 1720," Island Records Office, Twickenham, Jamaica (hereafter I Ro) lib. 15 fol. 267 .

39 "Will of Isaac Gabay, 1732," IRo lib. 18 fol. 165; American Jewish Archives, Cincinnati, Ohio (AJA) SC-3836. 
been operating the profitable family sugar plantation in St. Thomas in the Vale at the time he drafted his will in July of $1738 .{ }^{40}$

\section{The Gabays of Plantation Jamaica}

The shift toward monoculture sugar production in Jamaica was a slow one fraught with fits and starts. Historians of the British West Indies see the period between 1680 and 1740 as one of transition..$^{41}$ While the political will from both the colonial authorities in London and the Assembly was there as early as 1680, a number of factors delayed Jamaica's transition from privateering port to sugar factory. Political policy promoting plantations remained inchoate. Planters lacked sufficient capital. Still dependent on white indentured labor, the colony lacked sufficient numbers of African slaves to pursue the labor-intensive sugar production on the scale of Saint-Domingue or Portuguese Brazil. Conflict with Maroon communities, particularly in the northeastern reaches of the island, prevented settlers from cultivating much of the available plantation land.

By 1740 the situation had changed. The abolition of the Asiento and the humiliation of the Spanish during the War of Jenkins' Ear (1739-1742) brought slaves into the island at a higher rate. Legislation from the metropole such as the Molasses Act (1733) enabled the large-scale production of muscovado and eliminated competition in the sugar trade from other English American colonies. The peace treaty with the Maroons (1740) made it possible for Jamaican planters to expand into uncultivated northeastern territories of the island.

One of the metropole policies leading to the dominance of sugar affected the Jews directly. The so-called "Plantation Act" of 1740 encouraged foreigners to settle in English colonies by offering naturalization to anyone with uninterrupted residence in an American colony for a period of seven years. The Act targeted Jews explicitly by removing a Christian oath and passed nearly uncontested in Parliament (unlike its English counterpart in 1753). Around 150 Jews in Jamaica were naturalized as a direct result of the Plantation Act. ${ }^{42}$ Though not stated explicitly, the spirit of the Act was that Jews would be encouraged to participate more fully in the push toward planting thereby forsaking their perceived insistence on trade.

\footnotetext{
$40 \quad$ "Will of David Gabay (the younger), 1762," I Ro lib. 34 fol. 9; AJA, SC-3835.

41 See Verene Shepherd, Livestock, Sugar and Slavery: Contested Terrain in Colonial Jamaica (Kingston: Ian Randle Publishers, 2009), 14-23.

42 Hollander, "The Naturalization of the Jews," 110.
} 
Furthermore, this Act came at a time when opportunities for Jews had been rapidly diminishing in other parts of the sugar-producing Caribbean region. While some Jews managed to remain in Saint-Domingue after the expulsion from the French Caribbean in 1685 and even participate to a limited extent in the sugar monoculture of that island-usually as converts-it was moreor-less closed off to Jewish participation. ${ }^{43}$ The scale of sugar production in Jamaica far outstripped that of Barbados by the second decade of the eighteenth century. Curaçao's arid climate and frequent drought made it untenable as a plantation society. Suriname was the only possible rival in the Dutch sphere of influence where Portuguese Jews had a long tradition of planting and slave ownership in their village of Jodensavanne. However, tensions with local Maroon communities, the remoteness of the plantations, along with the bursting of an investment bubble in Amsterdam, all conspired against Surinamese planters. ${ }^{44}$ Suriname was simply uncompetitive compared to English Jamaica or French Saint-Domingue. By the 1770s, Jews had largely abandoned their Surinamese plantations.

Having built a strong foundation since the time of the earliest settlement, the Gabays expanded their efforts during the period referred to as "Plantation Jamaica"45_a period characterized by monoculture sugar production along with its increasing reliance on "industrialized" and ever more brutal forms of slavery. During the $1750 \mathrm{os}$ and 6os, small Gabay-owned plantations dotted the Jamaican landscape. In 1750, Samuel, Isaac, and Solomon Gabay owned and operated between them nearly 1,400 acres of land throughout the island including in St. Catherine, St. Elizabeth, St. John, and St. Thomas in the Vale, where Isaac and Solomon Gabay together possessed around one thousand acres known as "Magotty Sugar Works." 46 Gabay-owned plantation property was so widely dispersed throughout the island during this period that other testators bequeathed land in their wills previously owned by Gabays. Daniel Rodrigues Nunes from Vere Parish, for instance, composed a will in December of 1773 where in addition to his beachfront house near Carlisle Bay on the

43 See John D. Garrigus, "New Christians/'New Whites' Sephardic Jews, Free People of Color, and Citizenship in French Saint-Domingue, 1760-1789," in The Jews and the Expansion of Europe to the West, $315-32$.

44 See Robert Cohen, Jews in another Environment: Surinam in the Second Half of the Eighteenth Century (Leiden: Brill, 1991), 71-72. Wieke Vink, Creole Jews: Negotiating Community in Colonial Suriname (Leiden: KITLV Press, 2010), 47-48.

45 See B.W. Higman, Plantation Jamaica, 1750-1850: Capital and Control in a Colonial Economy (Kingston: University of West Indies Press, 2008).

46 "Jamaican Land Owners (1750)," The British Library, London England, BA Add MS. 12436. "Will of Solomon Gabay, 1743," I Ro lib. 23 fol. 193. 
southern coast of the island, he divided among his beneficiaries a modest 104acre plantation where he dwelled in Vere "commonly called Gabay's." 4

The St. Catherine planter Samuel Gabay died in his early sixties after drafting a will in August of $1747 .{ }^{48}$ Samuel was decidedly more connected to the Jewish community than his other planter kin. In his will he made charitable contributions to poor Jews, supported three synagogues on the island, and also requested that his executors purchase a tombstone to mark his grave. That tombstone contained only Portuguese, at the exclusion of either English or Hebrew. ${ }^{49}$ Samuel appears to be the first Gabay planter to manumit slaves in his will: three older women..$^{50}$ At the same time as these manumissions, he also bequeathed to his (seemingly second) wife and their infant son, two female and two male household slaves along with her choice of one of three houses in St. Jago de la Vega.

The St. Catherine planter David Gabay composed a will in September of 1760 where he made a donation to Neve Shalom in St. Jago de la Vega in return for an escava (hashkhava) to be recited on the night of Yom Kippur. ${ }^{51}$ While he supported his pregnant wife Rachel, née Ydana, and three children with slaves and monetary assets, he gave his land referred to as "Salt Ponds" in St. Catherine to his married sister Rebecca Dias Arias along with four individual slaves. Among the twenty slaves mentioned in his will, he manumitted a single woman named Mary and provided her with a one-time token sum of five Jamaican pounds.

Samuel and David Gabay's wills are highly symbolic of Jamaica's shift toward "industrialized" slavery and sugar production. They both lived among the Island's plantocracy in St. Jago de la Vega and seemed to have no discernable interest in Kingston commerce. The prominent place of the enslaved in their wills, especially in comparison to the Gabay planters of the 1720s-30s, is representative of Jamaica's transition into a slave society.

\section{Conclusion}

Following their exile from Brazil, the Gabay family translated their capital investment and trade in sugar into actual plantation ownership. In Jamaica, their

\footnotetext{
47 "Will of Daniel Rodrigues Nunes, 1774," I Ro lib. 42 fol. 27.

48 "Will of Samuel Gabay, 1751," IRo lib. 28 fol. 86.

49 Barnett and Wright, The Jews of Jamaica, 91, no. 1046.

5o On Manumission see Rosemary Brana-Shute and Randy J. Sparks, eds. Paths to Freedom: Manumission in the Atlantic World (Columbia, SC: University of South Carolina Press, 2009).

$5^{1} \quad$ "Will of David Gabay, 176o," IRo lib. 32 fol. 186.
} 
plantation ownership mirrored the various phases of transition from merchant colony to sugar factory. Like other Port Royal Jews, they were merchantplanters. During the period of transition from 1680 to 1740 the descendants of Salamão Gabay operated small plantations with modest enslaved African workforces peppered throughout the island. By the 1750s, they had emerged as St. Catherine plantocracy with large sugar works utilizing the labor of large enslaved workforces. Despite the wealth generated from planting, Jamaican Jews, like the New-Christians of Brazil, could never hope to transcend their social status as foreigners and fit uncomfortably within Jamaica's racial hierarchy. ${ }^{52}$

It is already well established that Jews were planters in the Caribbean region. This anecdotal chapter is meant to promote future research that will explore more fully the impact of plantation life on "Plantation Jews." Even though they did not stand completely apart from the port-city merchants of the Atlantic and often were one and the same, they still defy characterization as exclusively "merchants" in the "Port-Jew" model. While some Jamaican Jewish planters maintained residence in port cities such as Kingston, the Gabays found their fortunes in the planter and political capital of St. Jago de la Vega. Already by the 1720 s they had become a Spanish-Town dynasty no doubt embracing the political interests and social life of that planter's hamlet. ${ }^{53}$ The planter Jews of Suriname, particularly in the jungle town of Jodensavanne, likewise cannot be described as "Port Jews." Deepening our understanding of Jewish plantation ownership will enable us to shift the focus on Atlantic Jewry away from port cities and trading activity.

More importantly is the potential to understand the path toward modernity of "Plantation Jews" in terms of creolization rather than secularization. As with the Gabays, plantation ownership brought Jews into close contact with the enslaved. While these contacts were violent and exploitive, they were just as much transformative. Jewish planters frequently raped or "sexploited" their female plantation and household slaves. ${ }^{54}$ These abusive relationships transformed the complexion of the "Plantation Jew" and also expanded Spanish-Portuguese notions of familial belonging and blood purity, further distancing themselves from their more endogamous port-Jewish brethren. Many of Jamaica's planter Jews lived in non-legally recognized Creole families of color. Contact with the enslaved also brought about

$5^{2}$ On the inability to transcend racialized categories in Jamaica see Shepherd, Livestock, Sugar and Slavery, 112.

53 James Robertson, Gone is the Ancient Glory: Spanish Town, Jamaica, 1534-200o (Kingston: Ian Randle Publishers, 2005).

54 See Stanley Mirvis, "Sephardic Family Life in the Eighteenth-Century British West Indies," PhD diss., The Graduate Center of the City University of New York, 2013, 84-110. 
cultural changes. Increasingly, by the late eighteenth century, Europeans perceived Creole planters as completely alien to European cultural values and characteristics. ${ }^{55}$ Further research must be devoted to understanding exactly how those Creole characteristics defined "Plantation Jews" such as the Gabays.

While this chapter offers only a preliminary and anecdotal discussion of the "Plantation Jew," I hope it will encourage future researchers-both academic and popular-to decentralize the concept of the heavily mercantile "Port Jew" from the story of colonial Atlantic Jewry. The term merchant must be expanded to include plantation ownership in consideration of the possibility that our over characterization of colonial Atlantic Jews as "merchants" is not a reflection of reality but rather informed by anti-Semitic libels of the eighteenth century. Likewise, we must consider the possibility that our over reliance on the term "merchant" is an attempt to sidestep the uncomfortable truth of Jewish slave ownership in the colonial Atlantic.

\section{Bibliography}

The American Jewish Archives, Cincinnati, Ohio.

Andrade, Jacob. A Record of the Jews in Jamaica from the English Conquest to the Present Times. Kingston: Jamaica Times, 1941.

Barnett, Richard D., and Philip Wright. The Jews of Jamaica: Tombstone Inscriptions, 1663-1880. Jerusalem: Ben Zvi Institute, 1997.

Bernardini, Paolo, and Norman Fiering, eds. The Jews and the Expansion of Europe to the West, 145 o to 180o. New York: Berghahn Books, 2001.

Brana-Shute, Rosemary, and Randy J. Sparks, eds. Paths to Freedom: Manumission in the Atlantic World. Columbia, SC: University of South Carolina Press, 2009.

Buisseret, David, ed. Jamaica in 1687: The Taylor Manuscript at the National Library of Jamaica. Kingston: University of West Indies Press, 2010.

Burnard, Trevor, and John Garrigus. The Plantation Machine: Atlantic Capitalism in French Saint-Domingue and British Jamaica. Philadelphia: University of Pennsylvania Press, 2016.

Cesarani, David, and Gemma Romain, eds. Jews and Port Cities: 1590-1990: Commerce, Community and Cosmopolitanism. London: Vallentine Mitchell, 2006.

55 Trevor Burnard and John Garrigus, The Plantation Machine: Atlantic Capitalism in French Saint-Domingue and British Jamaica (Philadelphia: University of Pennsylvania Press, 2016), 264. 
Cohen, Robert. Jews in another Environment: Surinam in the Second Half of the Eighteenth Century. Leiden: Brill, 1991.

Cone, Herbert. "The Jews in Curaçao: According to Documents from the Archives of the State of New York," Publications of the American Jewish Historical Society 10 (1902): 141-157.

Cundall, Frank., N. Darnell Davis, and Albert M. Friedenberg, "Documents Relating to the History of the Jews in Jamaica and Barbados in the Time of William III," Publications of the American Jewish Historical Society 23 (1915): 25-29.

Emmanuel, Isaac S. Precious Stones of the Jews of Curaçao: Curaçaon Jewry 1656-1957. New York: Bloch, 1957.

Emmanuel, Isaac S., and Suzanne A. Emmanuel. History of the Jews of the Netherlands Antilles. Vol. 1. Cincinnati: American Jewish Archives, 1970.

Faber, Eli. Jews, Slaves, and the Slave Trade: Setting the Record Straight. New York: New York University Press, 1998.

Feiner, Shmuel. The Origins of Jewish Secularization in Eighteenth-Century Europe. Translated by Chaya Naor. Philadelphia: University of Pennsylvania Press, 2011.

Fortescue, J.W. ed. Calendar of State Papers, Colonial America and the West Indies. Vol. 8. London: Her Majesty's Stationary Office, 1898.

Fortune, Stephen A. Merchants and Jews: The Struggle for British West Indian Commerce, 1650-1750. Gainesville: University of Florida Press, 1984.

Gerber, Jane, ed. The Jews in the Caribbean. Oxford: The Littman Library of Jewish Civilization, 2014.

Higman, B.W. Plantation Jamaica, 1750-1850: Capital and Control in a Colonial Economy. Kingston: University of West Indies Press, 2008.

Hollander, J.H. "The Naturalization of the Jews in the American Colonies Under the Act of 1740." The Publications of the American Jewish Historical Society 5 (1897): 103-17.

The Island Records Office, Twickenham, Jamaica.

Kagan, Richard L. and Philip D. Morgan, eds. Atlantic Diasporas: Jews, Conversos, and Crypto-Jews in the Age of Mercantilism Baltimore: The Johns Hopkins University Press, 2009.

Kaplan, Yosef. From Christianity to Judaism: The Story of Isaac Orobio de Castro. Oxford: Littman Library of Jewish Civilization, 1989.

Marcus, Jacob R., ed. Historical Essay on the Colony of Surinam, 1788. Cincinnati: American Jewish Archives, 1974.

Mirvis, Stanley. "Sephardic Family Life in the Eighteenth-Century British West Indies." PhD diss., The Graduate Center of the City University of New York, 2013.

Mirvis, Stanley. "The Alvares Family Patriarchs and the Place of Pre-1692 Port Royal in the Western Sephardi Diaspora." The American Jewish Archives Journal 67, no. 2 (2015): $1-46$. 
Mirvis, Stanley. "Between Assembly and Crown: The Debate Over Jewish Taxation in Jamaica (1692-1740).” Journal of Early American History 6 (2016): 196-219.

Monaco, C.S. "Port Jews or a People of the Diaspora? A Critique of the Port Jew Concept." Jewish Social Studies 15, no. 2 (2009): 137-66.

The National Archives, Kew, England.

Pawson, Michael, and David Buisseret. Port Royal, Jamaica. Kingston: University of the West Indies Press, 2000.

Robertson, James. Gone is the Ancient Glory: Spanish Town, Jamaica, 1534-2000. Kingston: Ian Randle Publishers, 2005.

Ruderman, David B. Jewish Enlightenment in an English Key: Anglo-Jewry's Construction of Modern Jewish Thought. Princeton, NJ: Princeton University Press, 2012.

Schorsch, Jonathan. Jews and Blacks in the Early Modern World. Cambridge: Cambridge University Press, 2004.

Schwartz, Stuart B. Sugar Plantations in the Formation of Brazilian Society: Bahia, 15001835. Cambridge: Cambridge University Press, 2004.

Shepherd, Verene. Livestock, Sugar and Slavery: Contested Terrain in Colonial Jamaica. Kingston: Ian Randle Publishers, 2009.

Smollett, Brian, and Christian Wiese. Reappraisals and New Studies of the Modern Jewish Experience: Essays in Honor of Robert M. Seltzer. Leiden: Brill, 2015.

Urken, Ross Kenneth. "The Forgotten Jewish Pirates of Jamaica," Smithsonianmag .com, July 7, 2016, https://www.smithsonianmag.com/travel/forgotten-jewishpirates-jamaica-180959252/.

Vink, Wieke. Creole Jews: Negotiating Community in Colonial Suriname. Leiden: KITLV Press, 2010.

Wiznitzer, Arnold. Jews in Colonial Brazil. New York: Columbia University Press, 1960.

Wiznitzer, Arnold. The Records of the Earliest Jewish Community in the New World. New York: American Jewish Historical Society, 1954.

Wolff, Egon, and Frieda Wolff. Dicionário Biográfico: Judaizantes e Judeus no Brasil, 1500-1808. Rio de Janeiro: Instituto Histórico e Geográfico Brasileiro, 1986.

Zahedieh, Nuala. "Trade, Plunder, and Economic Developments in Early English Jamaica, 1655-1689." The Economic History Review 39, no. 2 (1986): 205-22.

Zohar, Gil Stern. "Jewish Pirates of the Caribbean," The Jerusalem Post Magazine, 9 April 2016, http://www.jpost.com/Magazine/Jewish-pirates-of-the-Caribbean-447397. 


\title{
Patriots at the Periphery: David Nassy, the French Revolution, and the Emancipation of the Dutch Jews
}

\author{
Sina Rauschenbach*
}

After the foundation of the Batavian Republic and the emancipation of nonCalvinist Christians, Dutch Patriots were torn by the question whether Dutch Jews, too, should be emancipated. ${ }^{1}$ While defenders of emancipation proclaimed that discussions were superfluous because Jews were already part of the declaration of human rights, adversaries stressed that Jews formed a "separate nation" and that their emancipation would endanger national unity. Human rights and civil rights were to be distinguished. ${ }^{2}$ Discussions reached their peak on 26 March 1796, when members of Felix Libertate, a Dutch society of Jewish (and non-Jewish) sympathizers with the French Revolution, ${ }^{3}$

* I would like to thank Yosef Kaplan for inviting me to his wonderful conference in Jerusalem. I am grateful to Michael Silber for sharing with me some of his thoughts and materials on Jewish military service, to Maria Seidel for helping with the first version of this chapter and first translations of several quotations, and to Sharon Assaf for her careful editing of the final version. The final translations are mine if not otherwise indicated.

1 M.E. Bolle writes: "In het eerste jaar van de Bataafse Republiek was de positie der Joden bij de patriotten een der belangrijkste onderwerpen van discussie." (De opheffing van de autonomie der kehillot in Nederland 1796 [Amsterdam: Systemen Keesing, 1960], 111). For a recent survey and a classical study of the Dutch context, see Joost Rosendaal, De Nederlandse Revolutie: Vrijheid, volk en vaderland, 1783-1799 (Nijmegen: Uitgeverij Vantilt, 2005), and Simon Schama, Patriots \& Liberators: Revolution in the Netherlands, 1780-1813 (London: Harper Perennial, 2005 [1977]).

2 For a summary of those and other arguments, see Salvador E. Bloemgarten, "De Amsterdamse Joden gedurende de eerste jaren van de Bataafse Republiek, 1795-98," Studia Rosenthaliana 1/2 (1967): 45-70, here 45-61.

3 Felix Libertate was established on 6 February 1795. For details, see Bolle, De opheffing, esp. 83-118. Also see Bloemgarten, "De Amsterdamse Joden," Studia Rosenthaliana 1, no. 1 (1967): 66-96; Herbert I. Bloom, "Felix Libertate and the Emancipation of Dutch Jewry," in Essays on Jewish Life and Thought Presented in Honor of Salo Wittmayer Baron, ed. Joseph L. Blau et al. (New York: Columbia University Press, 1959), 105-22; Rena G. Fuks-Mansfeld, "Enlightenment and Emancipation, from c. 1750 to 1814," in The History of the Jews in the Netherlands, ed. Johan C.H. Blom, Rena G. Fuks-Mansfeld, and Ivo Schöffer (Oxford: Littman Library of Jewish Civilization, 2002; first published in Dutch, Amsterdam: Balans, 1995), 164-91, esp. 178-85; Jozeph Michman, "Parnassijns en patriotten," Jaarboek Amstelodamum 75 (1983): 73-91,

(C) SINA RAUSCHENBACH, 2019 | DOI:10.1163/9789004392489_025

This is an open access chapter distributed under the terms of the prevailing CC-BY-NC License at the time of publication. 
submitted a petition claiming full citizenship and equality for all Jews. Three days later, the recently constituted National Assembly commissioned a committee that investigated the case and finally approved emancipation. ${ }^{4}$ After lengthy discussions, ${ }^{5}$ the National Assembly voted to grant Dutch Jews full civil rights on 29 September 1796. Three days later, their vote entered into vigor, and all Dutch Jews became Dutch citizens. ${ }^{6}$

In spite of this political breakthrough, hate campaigns continued and left their mark well beyond $1796{ }^{7}$ Especially torn were Patriot societies founded in Dutch cities after 1795. Whereas societies in Rotterdam, Den Haag, Leiden, Leischendam and Haarlem welcomed Jews into their ranks, others rejected Jewish participation and even threatened to draw back from central meetings if Jews should be admitted. ${ }^{8}$ Among the opponents of Jewish emancipation was the Dordrecht society "For the Maintenance of Liberty and Equality." In the summer of 1795 , its members published a pamphlet that reproduced "classical" anti-Jewish arguments, pretended to prove the incompatibility of Jewish values with recent achievements of the French Revolution, and conjured the danger of thousands of German and East European Jews leaving their countries and settling in the Netherlands. The original version of the pamphlet is now lost. But knowledge about its content has come down to us by David de Isaac Cohen Nassy (1747-1806) and his Lettre theologico-politico morale sur les Juifs which will be at the center of this chapter. ${ }^{9}$ Nassy's Lettre, written in 1795 , translated into Dutch in 1798, and probably printed around 1800 , was a strong

and Michman, Dutch Jewry during the Emancipation Period: Gothic Turrets on a Corinthian Building (Amsterdam: Amsterdam University Press, 1995), 54-76.

4 For the members of the committee, see Bloemgarten, "De Amsterdamse Joden," Studia Rosenthaliana 1, no. 2 (1967): 47.

5 For parts of the debates of the National Assembly, see "The Debate on Jewish Emancipation (22-31 August 1796)," in The Jew in the Modern World: A Documentary History, ed. Paul Mendes-Flohr and Jehuda Reinharz (New York: Oxford University Press, 2011 [1980]), 131-44. For the complete text in the original Dutch version, see Dagverhaal der handelingen van de Nationaale Vergadering (The Hague: van Schelle en Comp., 1796), 2: 647-736.

6 For an English translation of the decree, see "Emancipation of Dutch Jewry (2 September 1796)," in The Jew in the Modern World, 144-45. For the original Dutch, see H.J. Koenen, Geschiedenis der Joden in Nederland (Utrecht: v. d. Post, 1843), 489-91.

7 Bloemgarten, "De Amsterdamse Joden," Studia Rosenthaliana 1, no. 2 (1967): 61-64.

8 Bolle, De opheffing, 111-14.

9 David Nassy, Lettre politico-theologico-morale sur les Juifs-Staatkundige, Godsdienstige, en Zedekundige Brief over de Joden (Paramaribo, s.n.). For a reprint and Nassy's French translation of the pamphlet, see ibid., n.p. The Dutch version of the pamphlet reads "Bericht van den Volks-Vergadering, tot behoud van Vryheid en Gelykheid, binnen Dordrecht." 
defense of Dutch Jews and a clear statement in favor of Jewish emancipation. ${ }^{10}$ According to Nassy, people of all religions should enjoy equal conditions, and they should only be judged on the basis of their virtues and merits. Nassy's treatise was one of many Jewish treatises against anti-Jewish calumnies in eighteenth-century Dutch debates. ${ }^{11}$ Interestingly however, Nassy was not a member of the Amsterdam or any Jewish community in the Batavian Republic. He never crossed the Atlantic, and he never visited Europe. David Nassy was a Surinamese Jew, descendent of an influential family of European settlers in the Guyanas and a proud American colonist. Among his publications were the important "Historical Essay on the Colony of Suriname" (Essai historique sur la Colonie de Suriname)12 and a "Memorial Concerning the Improvement of the Colony of Suriname" (Memoir sur l'amélioration de la Colonie de Suriname) which is no longer extant. ${ }^{13}$

Until now, the majority of studies on Nassy were based on his Essay, which has mainly been explored as a rich source for information about Jewish life in early modern Suriname. ${ }^{14}$ Recent research has also paid attention to Nassy's medical knowledge, ${ }^{15}$ as well as to his attitudes toward slaves and the institution

10 Nassy's Lettre has often been mentioned, but it has barely been analyzed. One obvious reason for this neglect is that copies are rare and difficult to find. For one of the few detailed studies of Nassy's Lettre, see Sigmund Seeligmann, "David Nassy of Suriname and his 'Lettre Theologico-Politico-Morale sur les Juifs', American Jewish Historical Society 22 (1914): 25-38. For the probable date of print, see ibid., 31.

11 For a general survey of different pamphlets published during the Dutch campaign, see Jacob da Silva Rosa, Bibliographie der Literatur über die Emanzipation der Juden in Holland (Frankfurt: J. Kauffmann, 1912). Interestingly, Nassy's Lettre is not listed in da Silva Rosa.

12 David Nassy, Essai historique sur la colonie de Suriname (Paramaribo [Amsterdam], 1788). For an English translation, see id., Historical Essay on the Colony of Surinam (1788), ed. Jacob R. Marcus and Stanley F. Chyet (Cincinnati: American Jewish Archives, 1974). For the purpose of this chapter, the English version (referred to as Essay) will be quoted. The French version (referred to as Essai) will be used in the case of important differences between both versions. Both versions consist of two tomes in one volume. In the French version, both tomes are separately numbered. Therefore, I include references to the respective tomes into my footnotes.

13 Nassy, Lettre, xviv, fn. H. Seeligmann reports that his efforts to find this memoir were not successful. See Seeligmann, "David Nassy of Suriname," 29.

14 For a prominent example, see Robert Cohen, Jews in another Environment: Surinam in the Second Half of the Eighteenth Century (Leiden: Brill, 1991). Also see Aviva Ben-Ur, "Archival Practices: The Creation of a Portuguese Jewish Identity," Kristòf 16, no. 2 (2015): 17-25.

15 Natalie Zemon Davis, "Een joodse arts in het achttiende-eeuwse Suriname," in Joden in de Cariben: Vier eeuwen joodse geschiedenis in Suriname en Curaçao (Jews in the Dutch Caribbean: Four Centuries of Jewish History in Suriname and Curaçao), ed. Julie-Marthe Cohen (Zutphen: Walburg Pers., 2015), 158-73. 
of slavery. ${ }^{16}$ The following study focuses on Nassy's Lettre and proposes a reading in the context of Nassy's colonial background and perception of Europe. This is important because Nassy did not only defend his Dutch coreligionists in a Christian anti-Jewish debate, he also took a clear position in an internal Jewish-Dutch controversy. However, this position was much more ambivalent than one might suspect, and it was surprisingly in-between the positions of the Dutch Jewish parties involved. In the conclusion of this chapter, it will be suggested that much of Nassy's argument was inspired by his American context and that we need to consider Nassy's speaking position as a non-European Jew to give him his full due.

The chapter falls into five sections. The first section introduces Nassy's earlier Essay and an interpretation in the context of Jewish Creole thought in the Americas. The three following sections are devoted to Nassy's Lettre and his ambivalence toward his Dutch Patriot coreligionists. In the second section, Nassy's Lettre is introduced. In the third section, the example of Jewish military service is used to underline partial agreements between Nassy and his Dutch Patriot coreligionists. In the fourth section, the example of the French Revolution serves to demonstrate the very same limits of those agreements. The final section contrasts Nassy's disillusion about France with his admiration for the Americas and his continuous challenge of European centers from the other side of the Atlantic.

David de Isaac Cohen Nassy and Surinamese Creole Thought

David de Isaac Cohen Nassy was born in Savannah, Suriname, in $1747 \cdot{ }^{17}$ In the eighteenth century, Suriname was a blossoming Dutch colony, and it was home to one of the most important Jewish communities in the Atlantic World with about forty percent of the "white" settler population being Jews. ${ }^{18}$ Between

16 See Natalie Zemon Davis, "David Nassy's 'Furlough' and the Slave Mattheus," in New Essays in American Jewish History: Commemorating the Sixtieth Anniversary of the Founding of the American Jewish Archives, ed. Pamela S. Nadell, Jonathan D. Sarna, and Lance J. Sussman (Cincinnati: American Jewish Archives, 2010), 79-93. Also see Wieke Vink, Creole Jews: Negotiating Community in Colonial Suriname (Leiden: Brill, 2010), passim, and Jonathan Schorsch, Jews and Blacks in the Early Modern World (Cambridge: Cambridge University Press, 2004), esp. 217-53.

17 For detailed biographical information, see R. Bijlsma, "David de Is. C. Nassy, Author of the Essai Historique sur Surinam," in The Jewish Nation in Surinam: Historical Essays, ed. Robert Cohen (Amsterdam: S. Emmering, 1982), 65-74.

18 For the most important monographs on the subject, see Cohen, Jews in another Environment, and Vink, Creole Jews. 
1770 and 1773, Nassy was the owner of a coffee plantation. Afterwards, he held different positions in the Sephardic community of Savannah, assumed representational functions at the Dutch colonial administration in Paramaribo, and was a practicing pharmacist and physician. He also figured among the founders of the Surinamese Sephardic literary society Docendo docemur in 1783. Together with his daughter and two slaves, Nassy left Suriname in 1792 and settled in Philadelphia where he was elected a member of the American Philosophical Society. ${ }^{19}$ Four years later, Nassy returned first to St. Eustatius in the Caribbean and then to Suriname. He died in 1806 and was buried at the Beit ha-Haim cemetery in Jodensavanne.

It is well known that Nassy's argument and thought were inspired by Christian Wilhelm Dohm (1751-1820) and his "On the Civil Improvement of the Jews" (Ueber die bürgerliche Verbesserung der Juden). In 1786, members of Docendo docemur got hold of a French copy of Dohm's treatise. ${ }^{20}$ After careful reading they decided to congratulate Dohm and suggest that the Prussian statesman should consider theirs as a model and exemplary case. According to them, the situation of the Jews in Suriname was completely incomparable with the situation of even the most privileged Jewish communities in Europe, and this contributed to the high level of morals and civilization among Surinamese Jews. ${ }^{21}$ Dohm responded enthusiastically: "The approbation which you attest to me, gentlemen, from the other end of the world is all the more consoling to me. May you enjoy the good fortune of not knowing, other than through the traditions of your ancestors, the manner in which your community is being vitiated in Europe! Your situation furnishes a convincing proof of my thesis, that the Jews are capable, like us, of being good citizens as soon as they are permitted to be."22

Dohm's letter included a request "to communicate to me some details on the advantages which your wise and enlightened government accords you."23 Nassy's Essay was written as a reply to this request. It was divided into two

19 For Nassy's years in Philadelphia, see Davis, "David Nassy's 'Furlough."”

20 See Nassy, Preface to Essay, 6. The translator was Jean Bernoulli. For a modern edition of this translation, see Christian Wilhelm Dohm, De la réforme politique des Juifs, ed. Dominique Bourel (Paris: Ed. Stock, 1984). For two important studies of Dohm in the context of eighteenth-century colonialism, see Jonathan M. Hess, "Sugar Island Jews? Jewish Colonialism and the Rhetoric of 'Civic Improvement' in Eighteenth-Century Germany," Eighteenth-Century Studies 32, no. 1 (1998): 92-100; and id., Germans, Jews, and the Claims of Modernity (New Haven: Yale University Press, 2002), 25-49.

21 Nassy, Preface to Essay, 6.

22 "Christian Wilhelm von Dohm to the Regents of the Portuguese Jewish Community of Suriname, 29 of January, 1787," in Nassy, Preface to Essay, 13.

23 Ibid. 
parts. The first part was dedicated to a chronological description of the history of Surinamese Jews in the context of the rise and development of the Western Sephardic diaspora. The second part followed the structure of early modern state descriptions and discussed important aspects of contemporary Surinamese history. Both parts became important contributions to the documentation of Jewish life in early modern Suriname and the Caribbean. But they are also highly illuminating for the study of eighteenth-century American Jewish thought, postcolonial counter-historiography, and early modern "writing back." As I have shown in another place, ${ }^{24}$ Nassy followed two different aims: on the one hand, he wanted to strengthen Jewish perspectives against Christian anti-Jewish calumnies and neglect. On the other hand, he wanted to clarify the position of Surinamese settlers against European arrogance and distortion. Nassy's antagonists were important chroniclers of Suriname and the Guyanas, ${ }^{25}$ as well as eminent figures and philosophers of the European Enlightenment, among them Voltaire (1694-1778), Guillaume Thomas Raynal (1713-1796), and the co-authors of Raynal's "Philosophical and Political History of the Settlements and Trade of the Europeans in the East and West Indies" (Histoire philosophique et politique des établissemens et du commerce des Européens dans les deux Indes). According to Nassy, their descriptions of Suriname either downplayed the contribution of Jews to the Colony or they neglected the needs and anxieties of Surinamese settlers, be they Jewish or Christian. In both cases, they transmitted pictures that were highly distorted. ${ }^{26}$ It was Nassy's outspoken effort in his Essay to correct the aforementioned descriptions and to rewrite their narratives. ${ }^{27}$

24 Sina Rauschenbach, "The Empire Writes Back: David Nassy and Jewish Creole Historiography in Colonial Suriname," in The Sephardic Atlantic: Colonial Histories and Postcolonial Concepts, ed. Sina Rauschenbach and Jonathan Schorsch (to be published in 2019). For the notion of "writing back," see Bill Ashcroft, Gareth Griffiths, and Helen Tiffin, The Empire Writes Back: Theory and Practice in Postcolonial Literatures (London: Routledge, 2002, first published in 1989). Ashcroft, Griffiths and Tiffin's book has received heavy criticism for its creation of "a grand theory of post-colonialism," but the notion of "writing back" is still prominent and clearly useful in well-defined and focused contexts. For Jewish writing back and counter-history in a European setting, see Susannah Heschel, "Revolt of the Colonized. Abraham Geiger's Wissenschaft des Judentums as a Challenge to Christian Hegemony in the Academy," New German Critique 77 (1999): 61-85.

25 Nassy criticizes, among others, Jacques Nicolas Bellin, Description géographique de la Guyane (Paris: Didot, 1763), and Jan Jacob Hartsinck, Beschryving van Guiana, of de Wilde Kust, in Zuid-America (Amsterdam: Tielenburg, 1770).

26 For the distorted pictures, see Nassy, Essay, 1: 43.

27 The English translation reads: "And in order to fulfil our purpose, we shall transcribe here the sketch which Monsieur de Raynal made in his Histoire Politique, and the authors whose works we have cited in this essay. In retracing what they wrote about the colony, we 
Nassy's Essay was a counter-history in a double sense: on the one hand, it was a Jewish contribution to a non-Jewish debate about Jewish history. On the other hand, it was a Creole contribution to a European discussion about the Americas, with the term "Creole" (criollo) referring to Europeans born in the colonies, to be distinguished from Europeans born in Europe (peninsulares). ${ }^{28}$ This use of "Creole" is common in Latin American Studies but it is not always congruent with other uses of "Creole," because it does not necessarily refer to descendants of African slaves and includes "white" cultures and peoples. ${ }^{29}$

In Spanish America, resistance against the privilege of peninsulares was a main motive for Creole identity building and struggles for independence. ${ }^{30}$ In Suriname, Creole Jews entirely identified with Jewish and non-Jewish Suriname-born (white) inhabitants with whom they shared experiences, problems, and thoughts. Sometimes their Creole identification was so strong that it conflicted with the larger concept of the Jewish Diaspora. In her important book about Surinamese Creole Jews, Wieke Vink writes: "A leitmotif in Surinamese Jewish history is the ongoing tension in Jewish communities

shall permit ourselves the liberty of suppressing, adding, recasting, and correcting what is there found to be exaggerated or defective, in accordance with the authority which truth devoid of all prejudice gives." Essay, 1: 121-22. For the original French version, see Nassy, Essai, 1: 191. For Nassy's reference to and criticism of Voltaire, see his Introduction to Essay, 15. For Nassy and Candide, see Essay, 1: 104.

28 For recent studies, see Juan M. Vitulli, and David Solodkow, eds., Poéticas de lo criollo: La transformación del concepto criollo en las letras hispanoamericanas (siglos XVI-XIX) (Buenos Aires: Corregidor, 2009).

29 See Edward Brathwaite, The Development of Creole Society in Jamaica, 1770-1820 (Oxford: Clarendon Press, 1971), xiv-xv. For a similar use in the field of Jewish Studies, see Vink, Creole Jews, 6-10, esp. 9-10. By contrast, Aviva Ben-Ur uses "Creolization" as "the fusion of European Jewish and black cultures and peoples." See Aviva Ben-Ur, "A Matriarchal Matter: Slavery, Conversion, and Upward Mobility in Colonial Suriname," in Atlantic Diasporas: Jews, Conversos, and Crypto-Jews in the Age of Mercantilism, 1500-180o, ed. Richard L. Kagan and Philip D. Morgan (Baltimore: Johns Hopkins University Press, 2009), 152-69, esp. 169. Nassy's use of the term "Creole" encompasses both meanings: on the one hand, Nassy describes himself as a "Creole" (Essay, 2: 164) and hence clearly refers to the white Surinamese population. On the other hand, he uses "Creole" to refer to Surinamese descendants of African slaves (ibid., 1: 68). For my argument, the first use is decisive.

30 For a most famous reference to Creole identity in the context of Latin American independences, see Simón Bolívar's statement that "[...] no somos indios ni europeos, sino una especie media entre los legítimos propietarios del país y los usurpadores españoles: [...] americanos por nacimiento y nuestros derechos los de Europa" (Simón Bolívar, Doctrina del libertador [Caracas: Ayacucho, 1979], 62). For a recent study in eighteenthcentury Creole historiography and identity building in Latin America, see Jorge Cañizares Esguerra, How to Write the History of the New World: Histories, Epistemologies, and Identities in the Eighteenth-Century Atlantic World (Stanford: Stanford University Press, 2001). 
between participating in a local environment and becoming ever more local and creole on the one hand, and a continued sense of belonging to a worldwide Jewish community on the other."31

Needless to stress that Surinamese Jewish identification with Creoles was mostly unilateral. Jonathan Schorsch has convincingly argued that "early modern Jews were not automatically white." 32 Nassy himself described Surinamese Jews as "a social group between Christians and slaves" (une classe intermediaire entre les Chrêtien[s], \& les Esclaves), ${ }^{33}$ and he never forgot to lament over the loss of solidarity among settlers in the course of the history and decline of the Colony. ${ }^{34}$ Nevertheless, Nassy's Creole identity in his Essay and his American perspective are impossible to miss. Good examples are Nassy's statement that inhabitants of eighteenth-century colonies were equal citizens and not any more "a class inferior to that of the inhabitants and the citizens of the mother country,"35 or his open vote for the strengthening of economic independence and for steps toward an American free trade agreement. ${ }^{36}$ Finally, Nassy is also a good example for Creole ambivalence. This is visible in his constant apologies for his lack of literary education and his "primitive" use of the French language. ${ }^{37}$ In his Lettre, Nassy repeated similar doubts, ${ }^{38}$ but he also continued to raise his voice and to counter European discourse.

\section{$2 \quad$ Nassy's Lettre politico-theologico Morale}

Nassy's Lettre politico-theologico morale sur les Juifs was divided into three sections: first, a "Preliminary Discourse" (Discours préléminaire), parts of which

\footnotetext{
31 Vink, Creole Jews, 265.

32 Schorsch, Jews and Blacks, 179. For a detailed discussion together with Jewish patterns of replies, see ibid., 166-216. In a similar manner, Aviva Ben-Ur speaks about a "not quite 'white' status" of Surinamese Jews. See her "Atlantic Jewish History: A Conceptual Reorientation," in Constellations of Atlantic Jewish History, 1550-189o: The Arnold and Deanne Kaplan Collection of Early American Judaica. A Companion Volume to an Exhibition Held in the Goldstein Family Gallery of the Kislak Center for Special Collections, Rare Books and Manuscripts, ed. Arthur Kiron (Philadelphia: University of Pennsylvania Press, 2014), 25-46, esp. 40.

33 Nassy, Lettre, 30, fn. 20.

34 In his Essay, Nassy stressed that Jewish and Christian planters had originally proven to be "true and useful colonists who ought to treat each other mutually as brothers." Essay, 1: $55^{-} 56$.

35 Nassy, Essay 2: 125 .

36 Ibid., 145 .

37 Nassy, Preface to Essay, 5. Also see ibid., 2: 164.

38 Nassy, Lettre.
} 
were only added upon publication of the Lettre around 180o; second, a reprint of the accusations of the so-called Dordrecht activists, and third, a lengthy discussion of and reply to each and every one of those accusations. In all sections, it was Nassy's aim to criticize the exclusion of Jews from recent reforms and to call for an end of prejudice and discrimination. According to Nassy, all people needed to be given the same chances. It was scandalous, "that the unknown origin or the low birth of a talented subject, that the unfortunate poverty of a virtuous man; that the difference of religion of persons who are equally distinguished by their merit and their dedication to the public good should be reasons to exclude them from certain professions and cause their being despised and regarded as useless to serve their Fatherland (Patrie)."39 Jews and nonJews were children of one and the same "Father State," and once that "Father State" shared his power among his children, he needed to share it equally. ${ }^{40}$ But the Batavian Republic and her colonies shamefully neglected their duty and continued to treat their Jews as if they did not belong. ${ }^{41}$ Their attitude was nurtured by the accusations brought against the Jews in treatises such as the Dordrecht pamphlet. Hence, Nassy felt obliged to defend his Dutch coreligionists and to prove, "1. That the religion of the Jews; their divine commandments; their rabbinic teachings and even their customs, are in no respect contrary to Justice, Humanity and Benevolence. 2. That one cannot justify on grounds of reason the refusal to admit the Jews to active civil rights and the enjoyment of full human rights; and that judging from what we know of their civil state in Europe and the Colonies till this day, their customs are in no sense inferior to those of the Christians." 42

39 “[...] que la naissance obscure ou médiocre d'un sujet à talens; que la pauvrété malheureuse d'un Homme vertueux; que la différence du culte de Personnes également distinguées par leur mérite, \& leur dévouement au bien public, soient des causes d'exclusion aux emplois, \& les fassent mépriser, \& même regarder comme inutiles au service de la Patrie [...]." Nassy, Lettre, xvi.

40 Nassy, Lettre, xlii. Interestingly, in his French translation of Dohm which Nassy used for his earlier Essay, Jean Bernoulli used the same words speaking about "cette distinction inhumaine et contraire à la bonne politique, qui sépare actuellement les malheureux circoncis des autres enfants de l'État" (Jean Bernoulli, "Additions du traducteur," in Dohm, De la réforme politique des Juifs, 107-12, here 107).

$41 \quad$ Nassy, Lettre, xlii.

42 "1. Que la Religion des Juifs; leurs commendemens divins; leurs Dogmes Rabiniques; \& leurs habitudes mêmes, ne sont nullement en contradicion avec la Justice, l'humanité, \& la bienveillance. 2. Qu'on ne peut justifier aux yeux de la raison, le refus d'admettre les Juifs aux droits de Citoyen actif, \& à la jouissance plenière de ceux de l'homme; \& qu'a juger de ce qu l'on connoit jusqu'a present de leur etat civil en Europe, \& dans les Colonies, leurs mœurs ne le cedent point à celles des Chretiens." Nassy, Lettre, 36 . 
In his reply to the calumnies of the Dordrecht pamphlet, Nassy proceeded argument by argument: ${ }^{43}$ contrary to the accusation that Jews separated themselves from other peoples and that they only formed temporary alliances when it served their interests, he contended that contemporary Jews considered Christians to be their brothers and that they lived with them as much as Christian societies supported and facilitated it (article 1). Contrary to the accusation that Jews were not reliable citizens nor partners, he stated that a more in-depth knowledge of history from biblical to modern times showed that opponents of the Jews used to present a distorted view of things and that Jews were no calumniators but victims of calumniations (article 2). Contrary to the accusation that Jews were political opportunists and mostly failing to defend Patriot movements, he explained that Jews needed to protect themselves from siding with political parties in situations of turmoil because they were the first to fall victim to false reproaches and uncontrolled violence (article 3). Contrary to the accusation that Jewish expectations of an earthly messiah and king were a threat to both, the declaration of human rights and republican governments, he argued that similar expectancies were only due to the condition of those who upheld them and that they would easily lose importance if the situation of the respective believers changed (article 4). Contrary to the fears that the emancipation of the Jews in the Netherlands would quickly result in a wave of Jewish refugees from German and Eastern European lands, he insisted that nothing similar had happened after the emancipation of the Jews in the United States, and that German and Eastern European Jews were too proud of their own intellectual and cultural heritage to leave their countries (article 5).

At the same time, Nassy continued, migration should not only be seen from a negative but also from a positive, demographical point of view. ${ }^{44}$ The history of the Netherlands had long proven that Jewish migration was highly important to the economic and military needs of the country. In Dutch colonies such as Suriname, things were even clearer, and Jewish migrants had become an indispensable part of their respective settler and merchant societies. Once again, Nassy expresses his pride with regard to American contributions to European blossoming and wealth:

The contribution of the Jews to the development of Suriname from the very times of Lord Whilloughby, is undeniable. And does the Colony of Suriname not owe its commerce only to the Jews? Who, like them, finds a

44 For the whole argument, see Nassy, Lettre, 96-104. 
big market for colonial goods in times of war [...]? Who, like them, keeps up commerce with the Americans, so useful and so indispensable for the interests and the needs of the Colony? Finally, who if not them, supports and increases public sales, who brings life into Suriname's commerce, in ceaseless movements, and who increases the sum of taxes? [...] Let us hence summarize [lit.: collect in one big bulk] all the respective requirements and all the advantages that the Jews bring to the state, and we will find that instead of evil it would be a great good for Holland and its American possessions, if the Jewish population there was increased and encouraged by all possible means. ${ }^{45}$

Nassy's arguments in his Lettre were based on a wide range of exempla from Jewish history, literature, and thought, touching upon biblical, rabbinical, medieval, and contemporary Judaism. According to Nassy, this was necessary because anti-Jewish polemicists did not distinguish between different times and places. Instead, they did not shy away from measuring rabbinical Jews living "in that far-off time, full of darkness and uncertainty" (dans ce temps reculé, rempli d'obscurité, \& d'incertitude) $)^{46}$ with their eighteenth-century Jewish counterparts. But this was highly unjust because no religion was static, and Jewish history—as any history—was subject to progress and change. Modern Jews were not to be blamed for the faults of their ancestors. Nor were Jews in the Netherlands or Suriname to be compared to Jews in Poland or Northern Africa. ${ }^{47}$

Once again, Nassy relied on Dohm, ${ }^{48}$ and he also returned to Dohm for his last intervention, that Jews were capable of being loyal soldiers and that it was

45 "Lessor que les Juifs, dès le temps même du Lord Whilloughby, ont donné à Surinam est incontestable. Eh! n'èst ce pas aux Juifs seuls que cette Colonie doit tout son Commerce? Qui, autant qu'eux, fait trouver en temps de Guerre, un grand debouché pour les denrées Coloniales [...]? Qui autant qu'eux entretient le Commerce avec les Americains, si utile, \& si indispensable pour les intérêts \& les besoins de la Colonie? Qui si ce ne sont pas eux enfin, soutient \& augmente les ventes publiques, qui mêt l'âme du Commerce de Surinam, en des mouvemens continuels, \& qui fait accroitre la somme des impôts? [...] Qu'on réunise donc en une seule masse, tous ces besoins respectifs, \& tous les avantages que les Juifs procurent à l'état \& l'on trouvera qu'au lieu de mal ce seroit un grand bien pour la Hollande, \& pour ses possessions en Amerique, que la population Juive, y-fut augmentée, \& encouragée par toutes sorte [sic] des moyens." Nassy, Lettre, 102-4.

$46 \quad$ Nassy, Lettre, 36.

47 Nassy, Lettre, 12.

48 For one out of several examples, see Nassy, Lettre, 9o. 
part of their civic duties to participate in armies and civil guards. ${ }^{49}$ Surprisingly, there was no mention of this topic in the Dordrecht pamphlet, as Nassy himself stated, ${ }^{50}$ but it was an important topic in contemporary discourse. It was one more example to highlight differences between Europe and the Americas, and it was also important for Nassy's earlier wish to express his solidarity with his Dutch Patriot coreligionists and their fight for emancipation.

\section{3}

Jews and the Military

Questions about Jewish military service and participation in civil guards played a prominent role in eighteenth-century debates about the emancipation of the Jews. ${ }^{51}$ Since the publication of Christian Wilhelm Dohm's Ueber die bürgerliche Verbesserung der Juden, Jews were encouraged to display their capacity for "civil improvement" and participate in the defense of their countries and towns. ${ }^{52}$ Anti-Jewish polemicists by contrast objected the supposed disloyalty and unreliability of Jews and hence their unsuitability as soldiers and citizens. ${ }^{53}$

But the question of Jewish military service not only served as an important argument in Christian debates about Jews, it also caused frictions among Jews themselves. One of the most hotly debated aspects was the supposed conflict between religious observance and military service on the Jewish Sabbath and

49 Nassy, Lettre, 104-20. For Nassy's reference to Dohm, see ibid., 106. Bernoulli mentioned discussions about Jews and the military in his French translation of Dohm which was Nassy's and his Surinamese coreligionists' source for their correspondence with the Prussian statesman. See Bernoulli, "Additions du traducteur," in Dohm, De la réforme, 112.

50 Nassy, Lettre, 104.

$5^{1} \quad$ For the European context, see Michael K. Silber, "From Tolerated Aliens to CitizenSoldiers: Jewish Military Service in the Era of Joseph II," in Constructing Nationalities in East Central Europe, ed. Pieter M. Judson and Marsha L. Rozenblit (New York: Berghahn, 2004), 19-36. For the Netherlands, see Bloemgarten, "De Amsterdamse Joden," Studia Rosenthaliana 1, no.1 (1967): 84-88.

52 See Christian Wilhelm Dohm, Ueber die bürgerliche Verbesserung der Juden, Erster Theil (Berlin and Stettin: Friedrich Nicolai, 1783), 145-58, as well as Christian Wilhelm Dohm, Ueber die bürgerliche Verbesserung der Juden, Zweyter Theil (Berlin and Stettin: Nicolai, 1783), esp. 222-46. One of Dohm's most famous anti-Jewish antagonists was Johann David Michaelis. See "Hr. Ritter Michaelis Beurtheilung des ersten Theils," in Dohm, Ueber die bürgerliche Verbesserung, Zweyter Theil, 31-71.

53 During the nineteenth century, anti-Semitic authors added pseudo-biological explanations of physical hindrances for Jewish military service and "service to the nation." For the turn of the argument from religion to pseudo-biology, see Sander Gilman, The Jew's Body (New York: Routledge, 1991), 39-59. For a recent monograph on the subject, see Derek Penslar, Jews and the Military: A History (Princeton, NJ: Princeton University Press, 2013). 
holidays. Interestingly, this conflict was often considered to be the same for Jewish soldiers and civil guards, even though the respective situations and requirements were highly different. ${ }^{54}$ In Habsburg Lands, Jewish leaders lamented over the moral decline and alienation of young men from their communities after the Reform Edicts of Joseph II and the first recruitment of Jewish soldiers in Galicia. After Joseph II's death, traditional rabbis pleaded for a restitution of community autonomy even at the cost of emancipation. ${ }^{55}$ Several maskilim, by contrast, welcomed the reforms and accepted their "logic of citizenship with its rights and obligations." ${ }^{56}$ Historian Tsila Rädecker writes: "In the maskilic invention of the Jewish citizen, it [i.e., military service] became an essential part of Jewishness. Proof of the compatibility of Jewish life and state citizenship focused especially on the issue of bearing arms on the Sabbath. The willingness of Jews to set aside the Sabbath's rest symbolized and functioned as a litmus test of Jewish loyalty to the state. The maskilim actively incorporated the military aspects of citizenship into their version of Jewishness." ${ }^{57}$

In the Northern Netherlands, the first Jews to participate in military service were seamen in the Fourth Anglo-Dutch War (1780-1784). ${ }^{58}$ Facing the threat of a French invasion in 1794, Amsterdam military commanders returned to Jewish community leaders and earlier quests for Jewish soldiers..$^{59}$ In the latter case, this was even more natural since Amsterdam Jews counted as loyal followers of the House of Orange and were said to have contributed to the defeat of the earlier Patriot Revolution in 1787.

However, after the capitulation of the Dutch government and the foundation of the Batavian Republic, the supposed Jewish loyalty to the Orangeist party

54 Michman, Dutch Jewry, 191. For an exception, see Zalkind Hourwitz, Apologie des Juifs en réponse à la question: est-il des moyens de rendre les Juifs plus hereux et plus utiles en France? (Paris: Quilleau, 1788).

55 Silber, "Jewish Military Service," esp. 30.

56 Ibid., 31. For the example of a maskil expressing his doubts about Jewish military service, see Saul Ascher, Bemerkungen über die bürgerliche Verbesserung der Juden veranlaßt, bei der Frage: Soll der Jude Soldat werden (S.l.: s.n., 1788).

57 Tsila Rädecker, "Making Jews Dutch: Secular Discourse and Jewish Responses, 1796-1848," (PhD diss., University of Groningen, 2015), 167.

$5^{8}$ Michman, Dutch Jewry, 184-202, esp. 184-86. This episode became prominent in Jewish and Christian defenses of Jewish military service. Jean Bernoulli referred to it in his "Additions du traducteur," in Dohm, De la réforme, 112. Dohm included it into the second part of his Ueber die bürgerliche Verbesserung, 239-40. Nassy mentioned it in the context of his defense of population growth and German-Jewish immigration to the Dutch Republic. See Nassy, Lettre, 100.

59 Michman, Dutch Jewry, 187. 
was exactly what made things difficult. ${ }^{60}$ When members of Felix Libertate petitioned for the admission of Jews into the new national guards, they started to lead a war on two fronts: on the one hand, they had to fight non-Jewish Dutch Patriots who rejected accepting Jews into national guards. On the other hand, they had to defend their petition against Jewish community leaders and rabbis who publicly stressed the incompatibility of Jewish military service with basic needs of halakhic obedience.$^{61}$ Finally, different decisions were taken in different places. In Amsterdam, members of the municipality declined the petition and Jews continued to be excluded from civil service until the foundation of the Kingdom of Holland and the rule of Louis Napoleon in 1806. Amersfoort, Den Haag, Groningen, Leiden, and Rotterdam municipalities chose the opposite option and Jews were accepted into national guards. ${ }^{62}$

Nassy was an ardent supporter of Jewish military service. Contrary to those who stated that Jews were useless to the service of the state and that halakhic obedience required that they "should let themselves be killed rather than take arms on their day of rest-not for their personal defense and still less for the defense of the places they live in,"63 Nassy insisted that there was no religious law that hindered Jews to participate in military enterprises. By contrast, Moses himself, "[...] author or voice of these [our] laws, this wise legislator whose political, civic and moral teachings are the base for almost all laws of the universe, was far away from giving a nation that he had torn away from slavery, and whose welfare depended on the conquests of all Palestine that he had in mind, and on the means he needed to conserve, defend and enlarge her, the order that one could call absurd, [namely] not to make War, nor to defend oneself on the day of Sabbath." ${ }^{64}$

6o Bloemgarten, "De Amsterdamse Joden," Studia Rosenthaliana 1, no. 1 (1967): 84-88, and Michman, Dutch Jewry, 184-202.

61 Bloemgarten, "De Amsterdamse Joden," Studia Rosenthaliana 1, no. 1 (1967): 85. For the Jewish Patriot response, see below, fn. 73 .

62 Michman, DutchJewry, 188. For Leiden and Rotterdam, see Bloemgarten, "De Amsterdamse Joden," Studia Rosenthaliana 1, no. 1 (1967): 85.

63 "[...] dévant se faire égorger plûtot que de prendre les Armes, dans ce jour de repos pour leur défense personnelle, encore moins pour celle des lieux qu'ils habitent [...]." Quoted in Nassy, Lettre, 104.

64 “[...] Auteur ou organe de ces loix, ce sage Legislateur dont les institutions Politiques, Civiles \& morales font la base de presque toutes les Loix de l'univers, etoit eloigné de donner à une Nation qu'il arracha de l'Esclavage, \& dont le bonheur dependoit des Conquêtes qu'il se proposoit de faire de toute la Palestine, \& des moyens qu'il lui fallait pour la conserver, la deffendre \& l'agrandir, l'ordre que l'on pourroit nommer absurde, de ne pas faire la Guerre, ni de se défendre le jour du Sabat." Nassy, Lettre, 106. Later in his Lettre, Nassy continued that Jews would even have stuck to the defense of their fatherland if there had been a religious law forbidding military service on the Sabbath. See Nassy, Lettre, 124. 
To prove his argument, Nassy adduced various examples, ranging from biblical times and antiquity to early modernity and his own world. With regard to contemporary Judaism, his most prominent examples were Amsterdam Jews defending Dutch Brazil between 1630 and 1654, Prague Jews encouraging their coreligionists to enlist among soldiers of Joseph II, and Surinamese Jews contributing to the military suppression of Maroon revolts in the Guyanas. ${ }^{65}$ Once again, South American examples played a prominent role. As early as in his Essay, Nassy dedicated various pages to descriptions of punitive expeditions of Surinamese plantation owners against fugitive slaves. ${ }^{66}$ In his Lettre, he repeated those descriptions and insisted that Surinamese Jews not only bore arms on the Sabbath but that they even did so on Yom Kippur: "[...] did they have any scruple to combat the black Maroons on the Sabbath? Was it not on the Day of Atonement, Kippur, that they defeated a considerable troop of these rebels under their Captain David Nassy? Did they not serve on Jewish holidays and Saturdays during the last war in 1781 and 1782 , [both] in the civil guard in Savannah under their Captain De Granada and in Paramaribo under Christian captains?"67

With regard to military service, Nassy's reference to the Americas was only natural: in Dutch and English colonies in South America and the Caribbean, Jewish settlers had been granted participation in local militia and military service ever since their first privileges in the seventeenth century. ${ }^{68}$ In the Dutch Guyanas, Jews had even been allowed to found their own civil guard which exempted them from fighting on the Sabbath. ${ }^{69}$ But according to Vink, Surinamese Sephardim had nevertheless decided on special occasions to bear

65 Nassy, Lettre, 110-12. For Prague, see Michman, Dutch Jewry, 186, and Silber, "Jewish Military Service," 21 (with bibliographical reference on $3^{2-} 33$, fn. 10). Obviously, Nassy referred to Rabbi Ezechiel Landau and his recommendation, also discussed in several statements by members of Felix Libertate. A good example is H.L. Bromet, Aan de Volks Societeit Felix Libertate. Gelykheid. Vryheid. Broederschap (22 March 1795), 7.

66 Nassy, Essay, 1: 86-88, and Vink, Creole Jews, 117-19.

67 " $[. .$.$] se sont ils fait quelque scrupule de combattre les Negres Marrons au jour du Sabat?$ N'est ce pas au Kipur jour d'expiation, qu'ils vainquirent sous leur Capitaine David Nassy une Troupe considérable de ces rebelles? Pendant la dernière Guerre en 1781. \& 1782. n'ont ils pas tenu la Garde à la Savane sous leur Capitaine De Granada, \& à Paramaribo sous ceux de la Bourgeoisie Chrétienne, les jours de fêtes \& de Samedis." Nassy, Lettre, 112.

68 Penslar, Jews and the Military, 27. For the Dutch Guyanas, see Vink, Creole Jews, 134-38.

69 Jacob R. Marcus, The Colonial American Jew, 1492-1776, 3 vols. (Detroit: Wayne State University Press, 1970), 1: 147. For a reprint of the privileges granted to Jewish settlers in Cayenne (1659) and the English Guyanas (1665), see Nassy, Essay, 183-89. 
arms on Jewish holidays and their "religious laxity" had evoked a strong resistance among their Ashkenazic coreligionists. ${ }^{70}$

Nassy's plea for Jewish military service was much in line with the pleas of famous Dutch Jewish Patriots such as Hermanus Leonardus Bromet (1724-1812), Moses Salomon Asser (1754-1826), Hartog de Hartog Lemon (1755-1823), and Jacob Sasportas, all of whom Nassy mentioned and to whom he referred in his Lettre. ${ }^{71}$ Bromet, Asser, Sasportas, and Lemon were founding members of Felix Libertate in 1795. They authored the first petition for the admission of Jews to Dutch national guards, ${ }^{72}$ and they publicly protested against the official statement of Rabbis Daniel Cohen d'Azevedo (d. 1822) and Mozes Saul Löwenstamm (d. 1815) that Jews were not prepared for unconditional commitment to civic duties. ${ }^{73}$ After the split of the Amsterdam Ashkenazic Jewry in March 1797, they became founders of Adath Yeshurun, a new community that continued to fight for Jewish military service even though its larger purpose was to promote general reform and to defy old structures and hierarchies among Dutch Jews. ${ }^{74}$

Dutch Jewish Patriots not only resembled Nassy in defending Jewish military service. Similarly to Nassy, they also relied on West Indian examples to substantiate their argument: Especially Bromet, who had spent several years in Suriname, constantly referred to the Colony in his speeches and writings. ${ }^{75}$ Moses Salomon Asser for his part highlighted the influence of his Surinamese experience on Bromet's life and thought. ${ }^{76}$ Finally, Jewish military service and civil guards were also important topics in the so-called "Battle of Diskursn," a series of polemical pamphlets published by members of both communities between August 1797 and March 1798:77 Yankev, one of the most important characters in the Diskursn and a clear supporter of Adath Yeshurun (the so-called

$70 \quad$ Vink, Creole Jews, $188-92$.

71 Nassy, Lettre, lx. For the quotation, see below, fn. 79. Unfortunately, I have not been able to trace biographical data about this eighteenth-century Jacob Sasportas even though he signed many documents and petitions of Felix Libertate. Nassy also mentioned a certain M.M. Just, whom I have not been able to make out in Dutch biographical archives.

72 See their "Aan de Provisioneele Representanten van het Volk van Amsterdam," in Handelingen van de Municipaliteit der Stad Amsterdam (Amsterdam: Ter Stads Drukkerije, 1795), 239-40.

73 See "Request door het Joodsch Gezelschap den 12 Maart 1795 ingeleverd," in Handelingen van de Municipaliteit der Stad Amsterdam, 290-91.

74 See Michman, Dutch Jewry, 54-76.

75 An example is H.L. Bromet, Aan de Volks Societeit Felix Libertate. Gelykheid. Vryheid. Broederschap (March 22, 1795), 8. Also see Rädecker, Making Jews Dutch, 168.

76 See I.H.van Eeghen, "De Autobiografie van Moses Salomon Asser,"Jaarboek Amstelodamum 55 (1963): 130-65, esp. 144 .

77 For a detailed study and bilingual edition of several of the pamphlets, see Jozeph Michman and Marion Aptroot, eds., Storm in the Community: Yiddish Polemical Pamphlets 
naye kille), strongly defended the idea of Jewish recruitment and he also relied on "the West Indies" as a point of reference. ${ }^{78}$

Obviously, there was a broad consensus between Nassy and his Dutch Patriot coreligionists with regard to Jewish military service and national guards. At the same time, it would be misleading to read Nassy's Lettre as an unlimited support of Dutch Patriot Jews. Rather, Nassy seemed to change his opinion in the course of writing, translating and publishing his book. Two examples testify to this change: firstly, Nassy's reference to Bromet, Asser, Lemon, Sasportas, and Just was distanced, when he finished the introduction and justified the late publication of his Lettre. ${ }^{79}$ Secondly, his final judgment about the French Revolution in this introduction was also different from his earlier judgment, and it was completely irreconcilable with corresponding Patriot discussions in the Netherlands.

According to Bromet and his Dutch Patriot coreligionists, France and the French people had been harbingers of freedom. They had successfully implemented democracy on earth. They had proven to the world that the Platonic model was feasible and desirable. ${ }^{80}$ And they had implemented true liberty and equality being "an inherent and inalienable property that belongs equally to all human beings without difference" (een aangeboren en onvervreemdbaaren eigendom [...] aan alle Menschen, zonder onderscheid, even toebehoorende). ${ }^{81}$

According to Nassy, the single positive outcome of the French Revolution was the emancipation of the Jews. ${ }^{82}$ Apart from that, the Revolution had only

of Amsterdam Jewry, 1797-1798 (Cincinnati: Hebrew Union College Press, 2002). For military service, see ibid., 100, 108-10, 390-94, and 468-70.

78 Ibid., 107-8.

79 Nassy stated that his Lettre "contient des faits Historiques, des détails sur la politique, \& des éclaircissemens de plusieurs Dogmes Rabiniques \& autres, mal interprétés par l'ignorance, ou par la malice, que M.M. Just, Bromet, Asser, Lemmon, Sasportas, \&c. semblent n'avoir pas voulû les insérer dans les écrits récens qu'ils ont publié en faveur des Juifs [...]." Lettre, lx.

8o H.L. Bromet, Aanspraak, gedaan in de Societeit Felix Libertate op den 7 Maart 1795 (Amsterdam, 1795), esp. 13-14, 18.

81 Bromet, Aanspraak, gedaan in de Societeit Felix Libertate, op den 7 Maart 1795, 24.

82 In this regard, Nassy seemed to agree with the majority of Dutch Jews. See Rena G. FuksMansfeld, "Kezen en smousen in 1787: De moeizame verhouding tussen Patriotten en joden in Amsterdam in 1787," in De Nederlandse Revolutie?, ed. Theo S.M. van der Zee et al. (Amsterdam: De Bataafsche Leeuw, 1988), 134-46, here 145. 
triggered anarchy, lawlessness, chimerical dreams of democracy, inflationary usages of the term of "liberty," and misinterpretations of the concept of "equality." And Jews had suffered from it as others. ${ }^{83}$ In terms of clarity, Nassy's answers left nothing to be desired: "Pure democracy" (Democratie pure) was a Platonic dream, and any effort to implement it on earth was destined to anarchy and despotism. ${ }^{84}$ "Perfect equality" (égalite parfaite) was unjust and the only desirable equality was an equality of conditions. Nassy writes:

Yet the unjust idea is far from me to make the civil fortune consist of a perfect equality between all citizens of a state; this democratic chimaera does only exist in the brain of those rampant demagogues, who, in order to find their own luck, wind up the population with goals that are idealistic. Men are not equal with regard to their faculties. The virtues, the talents, the riches that are honestly acquired, the education, and finally the physical power, make human beings inevitably unequal between themselves. The welfare of the state requires that those citizens who are most useful for public affairs are the only ones employed by the public service, [that they are] the most honored and the most rewarded $[\ldots] .^{85}$

It was not privilege as such which needed to be abolished, it was inherited privilege: 86

Finally, "liberty," too, had recently turned into a fashionable word and been translated into a concept that led to anarchy and the end of social order. ${ }^{87}$

83 “La Revolution qu-y-a eu lieu, n'est point l'ouvrage des Juifs, toujours passifs, ils éprouvent les malheurs des secousses que les changemens de l'opinon publique, fait éprouver aux états; il seroit donc injuste de les priver de l'Avantage Idéal ou Réel, que la révolution promêt." Lettre, xlii.

84 “[...] quant à la Democratie pure, elle n'a jamais existé que dans le cerveau de Platon, \& les efforts qu'on a fait pour réaliser son rêve, ne conduiront qu'à l'anarchie, toujours suivie du despotisme." Nassy, Lettre, xxviii.

85 "Loin de moi cependant l'idee injuste, de vouloir faire consister le bonheur Civil, dans une égalite [sic] parfaite entre tous les Citoyens d'un état; cette chymère démocratique, n'existe que dans le cerveau de ces démagogues effrenés qui pour trouver leur propre bonheur, excitent le Peuple à des prétentions dont le but est idéal: les Hommes sont inégaux pour les facultes; les vertus, les talens, les richesses honnêtement acquises, l'éducation, la force Physique enfin, les rendent nécessairement inégaux entre eux; le bien de la Société veut que, les Citoyens les plus utiles à la chose publique, soient les seuls employés au service de l'état, les plus honorés, \& les mieux récompensés [...]." Nassy, Lettre, xii-xvi.

86 See the quotation in $\mathrm{fn} .39$.

87 Ibid., xviii, xxii, and xxiv. 
"True liberty" by contrast, was "the capacity of following one's reason and the laws [of a country], without running the risk of suffering from the tyranny of the stronger" (la faculté de pouvoir suivre la raison, \& les loix, sans courir le risque d'être tyranisé par le plus fort). ${ }^{88}$ According to Nassy, this liberty was no achievement of the French Revolution, and it had always been enjoyed by all people in Europe, except for slaves and subjects of the Ottoman Empire. ${ }^{89}$

As already emphasized, Nassy's statements were intended to object anti-Jewish accusations and prove that Jews were capable of sharing liberty, equality, and fraternity. But it is obvious that they were also defenses of traditional Jewish hierarchies, Sephardic privilege, and accusations against the same Dutch Patriot Jews with whom Nassy had sided in his earlier fight for Jewish military service and civil rights. ${ }^{90}$ Nassy's attack against his Dutch Patriot coreligionists reached its peak when he lamented over the bitter truth about ideal and reality:

France and maybe even Holland, just gave us striking examples of this unfortunate truth. Their system of liberty and equality is beautiful, and sublime without a doubt. Their principles are, according to me, comparable to those of our religions. They are only founded on nature and on moral derived from nature. But the vices of Man have corrupted and shattered everything. They have made us forget the basis of their principles [i.e., of the French Revolution and religion], only to remind us of their awful result: the religions, through the fanaticism, the ambition and the greed of many of their followers [....] seem to have only given birth to arrogant preachers, fanatics, wicked people and dangerous prejudice. The French Revolution, [...] through the measureless ambition, the wickedness and the vanity of a great number of sinister men who have seized

88 Ibid., $\mathrm{xx}$.

89 Ibid., xx. For Nassy on slaves and slavery, see Davis, "David Nassy's 'Furlough."”

9o For the defense of traditional Jewish hierarchies in the Dutch Republic and the few common interests of Patriots and Jews, see Fuks-Mansfeld, "Kezen en smousen." For recent research discussing Sephardic reservations toward emancipation, see Francesca Bregoli, Mediterranean Enlightenment: Livornese Jews, Tuscan Culture, and Eighteenth-Century Reform (Stanford: Stanford University Press, 2014), esp. 208-38. For the Caribbean context, see Laura Arnold Leibman and Sam May, "Making Jews: Race, Gender and Identity in Barbados in the Age of Emancipation," American Jewish History 99, no. 1 (2015): 1-26. 
upon the spirit of the Nation, seems to have only given birth to ambitious Demagogues, Cannibals, Anthropophagi, and great disasters. ${ }^{91}$

Nassy's words not only generated pictures of disillusion, desperation and fury, they also highlighted Nassy's ambivalent position between Dutch Patriots and traditional Jews. According to Nassy, there was no difference between powerobsessed human beings in politics or in religion. But given that Nassy's political adversaries were radical Dutch supporters of the Revolution and that Nassy's religious adversaries (with regard to Judaism) were traditional community leaders and rabbis from whom the Jews of his times were encouraged to break away in order to modernize, ${ }^{92}$ Nassy's statement was a double dissociation from both, the traditional majority of Dutch Jews and the Patriot minority. This double dissociation is surprising. Considering that the Lettre was written for a (hostile) Christian public and pretended to represent Nassy's Dutch coreligionists vis-à-vis a non-Jewish audience, it was even dangerous. The following section suggests that Nassy's American perspective and speaking position might be important clues for a better comprehension of his argument and thought.

\section{$5 \quad$ Patriots at the Periphery?}

As I have shown elsewhere, Nassy's Essay is an important example of counterhistoriography and Jewish Creole thought in eighteenth-century Suriname.

91 “...] la France, \& peut-être la Hollande même, viennent de nous donner des exemples frappans de cette malheureuse vérité; leur systême de liberté \& égalité, est beau, est sublime sans doute, leurs principes sont suivant moi, comparable à ceux de nos Religions, les uns \& les autres, ne sont fondés que sur la nature, \& sur la morale qui en dérive; mais les vices de l'Homme ont tout gâté, ont tout bouleversé; ils ont fait oublier les bases de leurs principes, pour ne nous rappeler que leur résultat affreux: Les Religions, par le fanatisme, l'ambition, \& l'avarice de plusieurs de leurs sectaires [...] semblent n'avoir enfanté que des prêtres insolens, des fanatiques, des scélérats, \& des dangéreux préjugés. La Revolution Françoise, [...] par l'ambition démésurée, la scélératesse, \& la vanité d'un grand nombre d'Hommes obscurs, qui se sont emparé de l'esprit de la Nation, semble n'avoir enfanté à son tour, que des Démagogues ambitieux, des Cannibales, des Antrophages, \& des grand malheurs." Nassy, Lettre, xxxii-xxxiv.

92 " [...] il faut donc s'en prendre je le repete, à la foule des ignorans, \& aux mauvaises traductions qu'on a de la Bible, des diverses habitudes imposées aux Juifs d'aujourd'hui." Nassy, Lettre, 116. Interestingly, Nassy based much of his argument on Johann David Michaelis who was supposed to be one of his most dangerous Christian adversaries. See above, fn. $5^{2}$. 
In the context of this counter-history, Nassy not only challenged Christian arrogance, power, and intolerance, he also criticized Amsterdam Jews and the European centers of the Western Sephardic diaspora. One example is Nassy's lament over the decadence of Amsterdam Sephardim and the "fewness of luminaries whom the community there was able to acquire [...] in the midst of so much religious liberty." ${ }^{\prime 93}$ Another example is Nassy's comment that Dutch (i.e., European) Sephardim, being victims of their Iberian socialization, had imported practices of intolerance from the Iberian Peninsula and that they had finally turned those practices against themselves and their most honorable community members. ${ }^{94}$

In his Lettre, Nassy reinforced his criticism of Dutch Jewish orthodoxy, superstition, and exclusivist policies while expanding it to Ashkenazic Jews. But he also took his distance from his Dutch Patriot coreligionists. In the early $1780 \mathrm{~s}$, Dutch Patriot Jews had shortly turned their eyes to the Americas and praised the American model for their purpose. However, they had quickly changed opinion and turned to France, as Asser recalled in his famous diary: "When the war between America and the English broke out, Bromet and I were very disposed toward America. From America [however], people turned to France and when disagreements broke out in the Netherlands [lit.: in these lands], the adherents of the French [lit.: the latter] closed lines with the Patriot party." ${ }^{\prime 95}$ Nassy followed the opposite direction. In his Lettre, France was only shortly considered an adequate model. ${ }^{96}$ Afterwards, it lost its positive function and turned into a great disillusion and a warning. Nassy's distance was even more

93 Nassy, Essay, 1: 22.

94 Ibid., 105. The examples Nassy adduced for Dutch Jewish intolerance were the ones of Uriel da Costa and Baruch Spinoza. In his Lettre, Nassy once again mentioned da Costa and Spinoza - together with Isaac de Pinto, Zacuto Lusitano and others as honored of the Portuguese nation. See Nassy, Lettre, 16.

95 "Den oorlog tusschen de Americanen tegen Engeland uitgebroken zijnde, waren Bromet en ik heel Americaansch gezind. Van Americaansch gezind wierd men Fransch gezind en bij het uitbarsten van de oneenigheden hier te lande, qualificeerden zich de laatstgemelden te behooren tot de patriotspartij." Quoted after van Eeghen, "De Autobiografie," 144. Later, Asser's son Carel described a similar development in his Récherches sur l'état des juifs. See [Carel Asser], "Recherches sur l'État des juifs en Hollande et Moyens provisoires de le réformer, eind Nov. of begin Dec. 1806," in Gedenkstukken der Algemeene Geschiedenis von Nederland von 1795-1840, Deel 5, Band 1, GS 11, 268-76, esp. 270. Also see Bloemgarten, "De Amsterdamse Joden," Studia Rosenthaliana 1, no. 1 (1967): 73.

96 In his earlier refusal of the Dordrecht pamphlet, Nassy mentioned America and France as his two models. See Nassy, Lettre, 24. His disillusion of the French Revolution was mostly expressed in his introduction which was written after 1796. See also Ibid., xii-xiv, fn. (A). 
striking because it coincided with his new self-description as a "Patriot." But Nassy was also explicit that his use of the term "Patriot" was a special one, and that it should in no way be wrongly interpreted. In one of the most expressive statements of his introduction, Nassy writes: "I confess that I am a Patriot, but a Patriot in a sense very different from that which is today given to this word: I love my Fatherland, despite the injustices it has often times administered me; true to my principles, I obey the laws of my country, I respect the rights of my neighbor and all while desiring that the era of necessary and useful changes on her Constitution, and on her customs will arrive, I loathe the efforts of those who desire changes, without consulting the interests of the majority of their fellow citizens." ${ }^{97}$ Given Nassy's distance from the French model and his Dutch Patriot coreligionists, his words come as no surprise. Instead of France, Nassy's Patriot thought was coupled with a new praise of "America" - with "America" now being the United States where Nassy lived during 1792 and 1796 and where he probably wrote the first version of his Lettre. According to Nassy, "America" was not only the place "where true equality reigns, [and] where all religions and religious sects are respected and have equal rights,"98 the American Constitution was also one of the main examples "that defied the wish of the Dordrecht society and other enemies of the Jews who do not want to recognize that they need to silence their interest as soon as reason and justice raise their voice."99 In the United States, Jews were fully integrated into their respective societies. They were married to Christians. ${ }^{100}$ They were granted entry into Academies and learned circles (as Nassy was granted entry in the American Philosophical Society), whereas "no Jew in Europe has ever received the honor to become a member of any Academy" (Aucun Juif n'a jamais pu avoir en

97 “J'avoue que je suis Patriôte, mais Patriôte dans un sens bien different de celui qu'on prête aujourd'hui à ce mot: J'aime ma Patrie, en dépit des injustices qu'elle m'a fait essuyer plusiers fois; fidelle [sic] à mes principes, j'obéis aux loix de mon païs, je respecte les droits de mon prochain, \& tout en désirant que l'époque des changemens nécessaires \& utiles à sa Constitution, \& à ses moeurs, soit arrivée, j'abhore les efforts de ceux qui désirent des changements, sans consulter les intérêts de la masse de leurs Concitoyens." Nassy, Lettre, xvi-xviii.

98 “...] où la vraie égalité règne, \& où toute les Religions, toutes les Sectes sont respectées, \& ont les mêmes droits." Nassy, Lettre, 94.

99 “[...] qui s'opposent au desir du Club de Dordrecht \& des autres Ennemis des Juifs, qui veulent encore meconnoitre, que par tout où la raison \& la Justice élèvent leur voix, l'intérêt doit se taire." Nassy, Lettre, 20. A French translation of the American Constitutions, edited in Paris 1778, was in Nassy's library. See Cohen, Jews in another Environment, 223.

Nassy, Lettre, 42. 
Europe, l'honneur de dévenir membre d'aucune Academie). ${ }^{101}$ And they were admitted to the military and fought side by side with their non-Jewish Patriots, as should be added. ${ }^{102}$

Natalie Zemon Davis dedicated an impressive study to Nassy's North American experience and the impact of this experience on his thought about slavery and abolitionism. ${ }^{103}$ Nassy's Lettre suggests that the impact of Nassy's residence in Philadelphia was even stronger and went well beyond the subject of slavery and abolitionism. There are reasons for believing that even several positions in the Lettre that were not directly linked to "America" were inspired by Nassy's (North) American experiences and discussions. When Nassy published his Essay, he could proudly state that the situation of the Jews in Suriname was highly privileged. ${ }^{104}$ When he published his Lettre, the French Revolution had changed political landscapes in Europe and it had promoted the emancipation of several European Jewries. As a consequence, Surinamese privilege paled and the importance of Surinamese Jews declined. It was Nassy's special privilege that he could enlarge his "American experience" and compensate losses by the adoption of a different model and the finding of new examples in the United States.

Further analysis is required to confirm the assumption that much of Nassy's thought in his Lettre was in fact taken from the recently founded United States. For our purpose it is important to focus on Nassy's attitude toward Europe and his European coreligionists. Given that Nassy tended to think in continental terms, ${ }^{105}$ it is adequate to state that his Essay and his Lettre were both written from an American perspective, and that they were both meant to challenge the dichotomy between Europe and the Americas, center and periphery, in spite of the completely different settings that Nassy faced in 1788 and in 1795 (or in 1798). This challenge was closely connected to the difficult relationship between Jewish Creole Thought/Patriotism on the one hand and Jewish

\footnotetext{
101 Ibid., 30, fn. (20).

102 Rezneck, Samuel, Unrecognized Patriots: The Jews in the American Revolution (Westport, CT: Greenwood Press, 1975). For the early struggle of Asser Levy to enroll in the militia of New Amsterdam after the settlement of Sephardic refugees in the Dutch city, see Howard B. Rock, Haven of Liberty: New York Jews in the New World, 1654-1865 (New York: New York University Press, 2015 [2012]), 82-84.

103 Davis, "David Nassy's 'Furlough'."

104 See above, fn. 21.

105 For examples showing that Nassy tended to think in continental terms, see above, fn. 35 and 36 . It should be added that Nassy's continental thought is anything but surprising if we consider that Sephardic networks in the early modern Atlantic naturally connected North and South American worlds.
} 
Diaspora identity on the other hand. As early as in his Essay, Nassy doubted the religious authority of Amsterdam's Jews in the Western Sephardic diaspora and designed himself as a "Creole."106 In his Lettre, Nassy only pretended to defend Dutch Jewish positions vis-à-vis Dutch Christian attacks. Actually, he ignored what Dutch Jews really thought and instead presented his own perspectives which were often different and highly influenced by Nassy's own American experience. With regard to the Jewish Diaspora, Nassy went even further and doubted its coherence as a whole. In one of his most absolute and radical statements, Nassy wrote that Jews belonged to the places that either adopted them or that legitimized their residence. As there was no country properly belonging to the Jews, there was no Jewish people. As there was no Jewish people, there was no Jewish nation. ${ }^{107}$ Once again, Nassy's position seemed to reflect the position of European Patriot Jews who insisted in a similar way that there was no Jewish people in the Diaspora and that fears about Jewish national movements were unjustified. ${ }^{108}$ But it can also be read as an American statement to be used against European superiority and dominance. At the same time, Nassy's attitude toward the Diaspora was much less clear than his aforementioned comments suggest. And it is obvious that Nassy, in spite of his ambivalence with regard to the subject, always continued to think in terms of transnational Jewish identities and solidarities, both in his Essay and in his Lettre. ${ }^{109}$

In the end, the difference between Nassy's approach to Europe in his Essay and his Lettre is a difference of self-confidence and "maturity."110 In his Essay, Nassy raised his voice as a Surinamese Jew in a European discourse

106 See above, fn. 29. For a recent study that discusses similar Creole attitudes in Joshua Hezekiah Decordova and the Jamaican context, see Stanley Mirvis, "Joshua Hezekiah Decordova and a Rabbinic Counter Enlightenment from Colonial Jamaica," in Reappraisals and New Studies of the Modern Jewish Experience: Essays in Honor of Robert M. Seltzer, ed. Brian M. Smollett and Christian Wiese (Leiden: Brill, 2015), 104-22. I am thankful to Jonathan Schorsch for this clue.

107 See Nassy, Lettre, 120.

108 For a prominent example in the context of Adath Yeshurun, see David Friedrichsfeld, De Messias der Jooden, of Republikeinische Gevoelens over Denzelven (The Hague: L. Cohen, 1796), esp. 10. Also see David Friedrichsfeld, Beleuchtungen über den Vortrag des Bür. v. Swinden bey den Stellvertretern des Volks von Holland in Dem Haag, die Stimmgerechtigkeit und das Bürgerrecht der Juden betreffend (Amsterdam, 1795).

109 For the Jews as a people, see Nassy, Lettre, xxxviii. For the Jews as a nation, see ibid., 16.

110 "Postcolonial literatures would apparently demonstrate their maturity when they stopped talking about themselves and got on with more 'universal' concerns." Ashcroft et al., The Empire Writes Back, $136-37$. 
on Suriname. Even though his intervention in this discourse was meant to serve as an example and comparison for European politicians, Nassy's authority was based on his Surinamese first-hand experience, and the subject to be discussed was Suriname. In his Lettre, Nassy's authority was also based on American firsthand experience but the debate in which Nassy interfered was concerned with Europe. In other words, whereas Nassy's Essay displayed American authority in American affairs, his Lettre displayed American authority in European affairs. This authority was valid because Nassy's American experience made him a distinguished commentator on things happening both inside and outside the Americas. Once we consider this important difference, it is obvious that the Lettre marks a new stage in Nassy's interaction with his European readers, and that it needs to be read as such to be given its full due.

The purpose of this chapter was to propose a new interpretation of Nassy's Lettre in the context of his earlier Essay, counter-historiography and Creole thought. Given that Nassy tended to express himself in continental terms, it was suggested that the Lettre continued Nassy's earlier practices of writing back and contesting European discussions from an American perspective. At the same time, there were important shifts of emphasis between both books. One shift that needed to be recalled was related to Nassy's models and examples, namely that Nassy's Essay relied mainly on Suriname while his Lettre was influenced by the United States. The other shift was related to the subject of content: Whereas Nassy's Essay was meant to correct European perceptions of Nassy's own country, the Lettre focused on Nassy's perceptions of European developments and debates. In Postcolonial Studies, non-European writings about European problems have been interpreted as a stage of "maturity" in the in the history of writing back. In the context of this chapter, Nassy's attitude to address a Christian public and to speak up for his Dutch coreligionists without subscribing to any of their positions could be seen in a similar way when compared to Nassy's earlier attitude in his Essay. Finally, Nassy's self-designation as a Patriot and his distance from Dutch and French Jewish (and non-Jewish) Patriots were used to highlight Nassy's speaking position and to suggest reconsidering his importance as a Jewish author writing from Suriname to Europe and challenging colonial dichotomies of center and periphery. 


\section{Bibliography}

Ascher, Saul. Bemerkungen über die bürgerliche Verbesserung der Juden veranlaßt, bei der Frage: Soll der Jude Soldat werden. S.l.: s.n., 1788.

Ashcroft, Bill, Gareth Griffiths, and Helen Tiffin. The Empire Writes Back: Theory and Practice in Postcolonial Literatures. London: Routledge, 2002.

[Asser, Carel]. "Recherches sur l'État des juifs en Hollande et Moyens provisoires de le réformer, eind Nov. of begin Dec. 1806." In Gedenkstukken der Algemeene Geschiedenis von Nederland von 1795-1840, Deel 5, Band 1, GS 11, 268-76. The Hague: Martinus Nijhoff, 1910.

Bellin, Jacques Nicolas. Description géographique de la Guyane. Paris: Didot, 1763.

Ben-Ur, Aviva. "Archival Practices: The Creation of a Portuguese Jewish Identity." Kristòf 16/2 (2015): 17-25.

Ben-Ur, Aviva. "Atlantic Jewish History: A Conceptual Reorientation." In Constellations of Atlantic Jewish History, 1550-1890: The Arnold and Deanne Kaplan Collection of Early American Judaica. A Companion Volume to an Exhibition Held in the Goldstein Family Gallery of the Kislak Center for Special Collections, Rare Books andManuscripts. Edited by Arthur Kiron, 25-46. Philadelphia: University of Pennsylvania Press, 2014.

Ben-Ur, Aviva. "A Matriarchal Matter: Slavery, Conversion, and Upward Mobility in Colonial Suriname." In Atlantic Diasporas: Jews, Conversos, and Crypto-Jews in the Age of Mercantilism, 1500-180o. Edited by Richard L. Kagan and Philip D. Morgan, 152-69. Baltimore: Johns Hopkins University Press, 2009.

Bijlsma, R. "David de Is. C. Nassy, Author of the Essai Historique sur Surinam." In The Jewish Nation in Surinam: Historical Essays. Edited by Robert Cohen, 65-74. Amsterdam: S. Emmering, 1982.

Bloemgarten, S.E. "De Amsterdamse Joden gedurende de eerste jaren van de Bataafse Republiek, 1795-98." Studia Rosenthaliana 1, no. 1 (1967): 66-96; 1, no. 2 (1967): 45-70, and 2, no. 1 (1968): 42-65.

Bloom, Herbert I. "Felix Libertate and the Emancipation of Dutch Jewry." In Essays on Jewish Life and Thought Presented in Honor of Salo Wittmayer Baron. Edited by Joseph L. Blau et al., 105-22. New York: Columbia University Press, 1959.

Bolívar, Simón. Doctrina del libertador. Caracas: Ayacucho, 1979.

Bolle, Menachem Eljakiem. De opheffing van de autonomie der kehilloth (joodse gemeenten) in Nederland 1796. Amsterdam: Systemen Keesing, 1960.

Brathwaite, Edward. The Development of Creole Society in Jamaica, 1770-1820. Oxford: Clarendon Press, 1971.

Bregoli, Francesca. Mediterranean Enlightenment: Livornese Jews, Tuscan Culture, and Eighteenth-Century Reform. Stanford: Stanford University Press, 2014.

Bromet, H.L. Aan de Volks Societeit Felix Libertate. Gelykheid. Vryheid. Broederschap (March 22, 1795). 
Bromet, H.L. Aanspraak, gedaan in de Societeit Felix Libertate op den 7 Maart 1795. Amsterdam: J.L. van Laar Mahuet, 1795.

Cañizares Esguerra, Jorge. How to Write the History of the New World: Histories, Epistemologies, and Identities in the Eighteenth-Century Atlantic World. Stanford: Stanford University Press, 2001.

Cohen, Robert. Jews in another Environment: Surinam in the Second Half of the Eighteenth Century. Leiden: Brill, 1991.

Dagverhaal der handelingen van de Nationaale Vergadering. The Hague: van Schelle en Comp., 1796.

Davis, Natalie Zemon. “David Nassy's 'Furlough' and the Slave Mattheus." In New Essays in American Jewish History: Commemorating the Sixtieth Anniversary of the Founding of the American Jewish Archives. Edited by Pamela S. Nadell, Jonathan D. Sarna, and Lance J. Sussman, 79-93. Cincinnati, OH: American Jewish Archives, 2010.

Davis, Natalie Zemon. "Een joodse arts in het achttiende-eeuwse Suriname." In Joden in de Cariben: Vier eeuwen joodse geschiedenis in Suriname en Curaçao (Jews in the Dutch Caribbean: Four Centuries of Jewish History in Suriname and Curaçao). Edited by Julie-Marthe Cohen, 158-73. Zutphen: Walburg Pers, 2015.

Dohm, Christian Wilhelm. De la réforme politique des Juifs [1782]. Edited by Dominique Bourel. Paris: Ed. Stock, 1984.

Dohm, Christian Wilhelm. Ueber die bürgerliche Verbesserung der Juden, Erster und Zweyter Theil. Berlin and Stettin: Friedrich Nicolai, 1783 .

Eeghen, I.H.Van. “De Autobiografie van Moses Salomon Asser." JaarboekAmstelodamum 55 (1963): 130-65.

Friedrichsfeld, David. Beleuchtungen über den Vortrag des Bür. v. Swinden bey den Stellvertretern des Volks von Holland in Dem Haag, die Stimmgerechtigkeit und das Bürgerrecht der Juden betreffend. Amsterdam: s.n., 1795 .

Friedrichsfeld, David. De Messias der Jooden, of Republikeinische Gevoelens over Denzelven. Den Haag: L. Cohen, 1796.

Fuks-Mansfeld, Rena G. "Enlightenment and Emancipation, from c. $175^{\circ}$ to 1814." In The History of the Jews in the Netherlands. Edited by Johan C.H. Blom, Rena G. FuksMansfeld, and Ivo Schöffer, 164-91. Oxford: Littman Library of Jewish Civilization, 2002.

Fuks-Mansfeld, Rena G. "Kezen en smousen in 1787: De moeizame verhouding tussen Patriotten en joden in Amsterdam in 1787." In De Nederlandse Revolutie? Edited by Theo. S.M. van der Zee et al., 134-46. Amsterdam: De Bataafsche Leeuw, 1988.

Gilman, Sander. The Jew's Body. New York: Routledge, 1991.

Handelingen van de Municipaliteit der Stad Amsterdam. Amsterdam: Ter Stads Drukkerije, 1795 .

Hartsinck, Jan Jacob. Beschryving van Guiana, of de Wilde Kust, in Zuid-America. Amsterdam: Tielenburg, 1770. 
Heschel, Susannah. "Revolt of the Colonized: Abraham Geiger's Wissenschaft des Judentums as a Challenge to Christian Hegemony in the Academy." New German Critique 77 (1999): 61-85.

Hess, Jonathan M. Germans, Jews, and the Claims of Modernity. New Haven: Yale University Press, 2002.

Hess, Jonathan M. "Sugar Island Jews? Jewish Colonialism and the Rhetoric of 'Civic Improvement' in Eighteenth-Century Germany." Eighteenth-Century Studies 32, no. 1 (1998): 92-100.

Hourwitz, Zalkind. Apologie des Juifs en réponse à la question: est-il des moyens de rendre les Juifs plus hereux et plus utiles en France? Paris: Quilleau, 1788.

Koenen, H. J. Geschiedenis der Joden in Nederland. Utrecht: v.d. Post, 1843.

Leibman, Laura Arnold, and Sam May. "Making Jews: Race, Gender and Identity in Barbados in the Age of Emancipation." American Jewish History 99/1 (2015): 1-26.

Marcus, Jacob R. The Colonial American Jew, 1492-1776. 3 vols. Detroit: Wayne State University Press, 1970.

Mendes-Flohr, Paul, and Jehuda Reinharz, eds. The Jew in the Modern World: A Documentary History. New York: Oxford University Press, 2011.

Michman, Jozeph. Dutch Jewry during the Emancipation Period: Gothic Turrets on a Corinthian Building. Amsterdam: Amsterdam University Press, 1995.

Michman, Jozeph. "Parnassijns en patriotten." Jaarboek Amstelodamum 75 (1983): 73-91.

Michman, Jozeph, and Marion Aptroot, eds. Storm in the Community:Yiddish Polemical Pamphlets of Amsterdam Jewry, 1797-1798. Cincinnati: Hebrew Union College Press, 2002.

Mirvis, Stanley. "Joshua Hezekiah Decordova and a Rabbinic Counter Enlightenment from Colonial Jamaica." In Reappraisals and New Studies of the Modern Jewish Experience: Essays in Honor of Robert M. Seltzer. Edited by Brian M. Smollett, and Christian Wiese, 104-22. Leiden: Brill, 2015.

Nassy, David. Essai historique sur la colonie de Suriname. Paramaribo [Amsterdam]: s.n., 1788.

Nassy, David. Historical Essay on the Colony of Surinam (1788). Edited by Jacob R. Marcus, and Stanley F. Chyet. Cincinnati: American Jewish Archives, 1974.

Nassy, David. Lettre politico-theologico-morale sur les Juifs-Staatkundige, Godsdienstige, en Zedekundige Brief over de Joden. Paramaribo: s.n, s.a.

Penslar, Derek. Jews and the Military: A History. Princeton, NJ: Princeton University Press, 2013 .

Rädecker, Tsila. "Making Jews Dutch: Secular Discourse and Jewish Responses, 17961848." PhD diss., University of Groningen, 2015.

Rauschenbach, Sina. "The Empire Writes Back: David Nassy and Jewish Creole Historiography in Colonial Suriname." In The Sephardic Atlantic: Colonial Histories 
and Postcolonial Concepts. Edited by Sina Rauschenbach and Jonathan Schorsch (to be published in 2019).

Rezneck, Samuel. Unrecognized Patriots: The Jews in the American Revolution. Westport, CT: Greenwood Press, 1975.

Rock, Howard B. Haven of Liberty: New YorkJews in the New World, 1654-1865. New York: New York University Press, 2015.

Rosa, Jacob da Silva. Bibliographie der Literatur über die Emanzipation der Juden in Holland. Frankfurt: J. Kauffmann, 1912.

Rosendaal, Joost. De Nederlandse Revolutie: Vrijheid, volk en vaderland, 1783-1799. Nijmegen: Uitgeverij Vantilt, 2005.

Schama, Simon. Patriots and Liberators: Revolution in the Netherlands, $1780-1830$. London: Harper Perennial, 2005.

Schorsch, Jonathan. Jews and Blacks in the Early Modern World. Cambridge: Cambridge University Press, 2004.

Seeligmann, Sigmund. "David Nassy of Suriname and his 'Lettre Theologico-PoliticoMorale sur les Juifs'” American Jewish Historical Society 22 (1914): 25-38.

Silber, Michael K. "From Tolerated Aliens to Citizen-Soldiers: Jewish Military Service in the Era of Joseph II." In Constructing Nationalities in East Central Europe. Edited by Pieter M. Judson and Marsha L. Rozenblit, 19-36. New York: Berghahn, 2004.

Vink, Wieke. Creole Jews: Negotiating Community in Colonial Suriname. Leiden: Brill, 2010.

Vitulli, Juan M., and David Solodkow, eds. Poéticas de lo criollo: La transformación del concepto criollo en las letras hispanoamericanas (siglos XVI-XIX). Buenos Aires: Corregidor, 2009. 
Yosef Kaplan - 978-90-04-39248-9

Downloaded from Brill. com $04 / 26 / 2023$ 10:36:49AM via free access 


\section{Index of Names and Places}

Abendana de Britto, Isaac Hayim xxiii, 395

Aboab, Immanuel 447

Aboab, Isaac de Mattathias $\quad 527$

Aboab, Samuel, (of Venice) $\quad{ }^{175^{-176}}$

Aboab, Shmuel 534

Aboab da Fonseca, Isaac xxix, 201, 385 ,

432, 434, 435-440, 435n17, 446, 448, 527

Abravanel, Leone 308

Abudiente, Moseh 431-432

Adam de la Parra, Juan 87

Aenes, Dinis 29-30

Aguilar, Luis $\quad 3,18-19$

Aguilar, Mosse Rephael d' 432, 433

Albuquerque, Jacob Franco 360

Albuquerque Coelho, Jorge d' 26

Alciato, Andrea 100

Aldobrandini 314

Alexander VI $\quad$ 296-297, 298

Allen, William $\quad 54,63$

Altaras, Moses 455

Álvares, Belchior 73

Alvares Nunes, Abraham $\quad$ 258-259

Amnom, Jacob Israel 358

Amsterdam $\quad \mathrm{x}$-xiii, $\mathrm{xvi}$, xviii, $\mathrm{xx}$-xxiii, 12,

$$
\begin{aligned}
& \text { 122-123, 196-199, 201, 202n21, 205-206, } \\
& 210-211,216-217,222 n 115,231-244, \\
& 244-253,348 \mathrm{n} 12,35^{2-} 355,386-391, \\
& 393-405,423-425,45^{2-454, ~ 456-467, ~} \\
& 490,496 \mathrm{n} 41,512-513,517,5^{29-530,534,} \\
& 541-548,596
\end{aligned}
$$

Ancona $\quad 302-304,304-307,308-312,313-318$

Angel, Lorenzo $\quad 5^{2}$

Antwerp 125, 148n33

Aragon 6

Aroquis of Salonika, Moshe 549

Athias, David Israel $\quad$ xxiii, 395, 421

Athias, Isaac $\quad 455^{-4} 5^{6}$

Athias, Yaakov xxviii, $422-426$

Attias, Joseph xiii, 169

Avignon 314

Ayllion, Salomon xxiii, 395

Azulai, Hayim Yosef David, (Hida) 410, 417,

419-420
Bantre, Darby $\quad 5^{1}$

Barbados 494n32, 495n36, 497n47, 497n50, $498 n_{53}, 498 n_{55}, 572$

Barboso, Francisco 304

Barda, Joseph 259

Baron, Salo 157, 537

Barrios, Daniel Levi (Miguel) 13, 62

Barrow, Bella 499

Bayonne 121-123, 170, 171, 251

Beeri, Yocheved xxviii

Beeston, William 572

Belcayro, Yacob xxvii, 302, 304, 310-311

Bellarmino, Roberto 94

Belmonte, Baron Manuel (Don Emanuel) $\quad x$

ben Ban Benst, Meir Ben Shmuel 454-455

Benedict XIV 370

Benjamin, Walter 470

ben Saruq, Menahem 443

Ben-Ur, Aviva $\quad 518-520,524,528,535$

Berav, Ya'akov 7

Bergin, Joseph 78

Bernáldez, Andrés $\quad 7-9$

Bernfeld, Tirtsah Levie $\mathrm{xx}, \mathrm{xxv}$

Besançon 366ng1, 371

Bodian, Miriam $\quad 4 \mathrm{n} 2,18$

Bodin, Jean $\quad 84-85,86,100$

Bordeaux xvi-xvii, xxi, 123, 126-128, 251, $416-417,418-426$

Borromeo, Carlo 302

Boste, John 64

Botero, Giovanni $\quad 97,98$

Bradly, Jacobus 220

Bragança $\quad 71-78$

Bregoli, Francesca xiii

Bridgetown 494n32

Bromet, Hermanus Leonardus 596

Brunelle, Gayle $\quad 117-118$

Bucke, John 54, 56

Bueno, David $358,360,360 n 63$

Bullaker, Thomas $\quad 64-65$

Campion, Edmund $\quad 64$

Cape Verde 514

Cardoso, Avraham 18 
Cardoso, Isaac xiii, 13, 18

Cardoso de Macedo, Manuel xxv, 146-152

Carigal, Refael Haim Ishac 501

Caro, Yosef $\quad 453-455,464-465$

Carvajal, Luis de $\quad$ xxv, 137-146, 152

Carvajal y Mendoza, Luisa de 56

Carvallo, Jacob Haim 497n $5^{\circ}$

Caspi, David $\quad 303-304,308-312$

Cassipora 493

Castile 6

Catherine de Bragance $\quad 5^{8}$

Cecil, John 64

Cellorigo, Martín González de 90, 100-101

Charles II 259

Charles v 300

Charron, Pierre $\quad 95,97$

Chateaubriand 80

Christina of Sweden, Queen xi

Circignani. See also Pomarancio 62

Clement VII 299

Clement VIII 313

Clitherow, Margaret 50

Cohen, Abraham 196-198, 200-203, 211

Cohen, Ester $\quad 222 n 115$

Cohen, Eva $\quad$ xxv-Xxvi, 195, 200, 203-204, 206-210, 214-219, 221-223

Cohen, Jacob 199, 203, 210

Cohen, Jeremy $\quad 4-5,5 \mathrm{n} 3$

Cohen, Joseph 210

Cohen, Mordechay 222, $222 n 115$

Cohen, Moses 207

Cohen, Rebecca Pallache. See Pallache, Rebecca

Cohen, Robert $\quad$ xxxi

Cohen Belinfante, Meir 495n36, 500

Cohen d'Azevedo, Daniel 596

Cohen d'Azevedo, Moses xxiii

Cohen de Lara, David 434

Cohen Nassy, David de Isaac. See Nassy, David (de Isaac Cohen)

Cohen Nassy, Samuel 553

Coimbra 71,74

Cooperman, Bernard Dov xxv

Córdoba, Francisco de $\quad 56-57$

Cordovero, Mose 359-36o

Cortés, Pedro Onofre 58

Cortizos, Manuel $5^{1}$

Coryate, Thomas $\mathrm{x}$
Cosimo I 370n106

Costa, Isaac da $\quad 532 n 47$

Costa, Uriel da $\quad$ xiii, xxxi, $36,37,38,446$

Costa Brandão, Bento da 36-37

Coulson, Elizabeth $\quad 43,65$

Cremona 337

Cromwell, Oliver 120

Crowder, Anselm 55

Curaçao xviii, 493, 496n38, 527-528, 531, 532,570

Danan, Saadia ben Maimon ibn 7

Davidi, Einat $\quad$ xxix

Davis, Natalie Zemon $\quad 5^{20}-5^{22}, 529$

Delft 201-203, 213-215

Di Nepi, Serena xxvi

Dias, Beatriz 35

Dias Milão, Henrique $\quad$ 148, 151-152

Díaz, Luis 144-145

Díaz Pimentel, Manuel 53

Diego de San Juan 60

Dimant, Maurcio xxvii

Dinis, Branca 36

Dohm, Christian Wilhelm $\quad 585,591-592$

Dordrecht $\quad 582,5897$

Dutch Brazil 489, 517

Dweck, Yaacob xxviii

Enríquez Basurto, Diego 130

Enríquez Gómez, Antonio 76-78, 84-103, 123,130

Ergas, Isac 360

Ergas, Joseph $\quad 173,176,189$

Ergas de Liorne, Ishaq $35^{8}$

Ergas de Venetia, Isaque $35^{8}$

Esther, (Queen) 50, $5^{1}$

Falcón, Yosef 422

Ferdinand I de Medici xxvii

Ferdinando I 31-32

Fernandes, Baltazar 71

Fernandes, Catarina $\quad 43,65$

Fernandes, Florença 29-30

Fernandes, Manuel 73

Fernandes, Margarida Dinis $\quad 30,35$

Fernandes, Miguel 29-33

Fernandes Treves, Diogo 29

Fernández, Vasco $\quad$ 58-59 


\section{Ferrara 294}

Flavius Josephus $\quad$ 211-212

Florence $349 n 15,351$

Fonseca, Abraham de 434

Fonseca, Jerónimo da 33

France $71-78,78-81,82-88,88-91,92-98$,

$$
114-125,581,582,597-600
$$

Francis I 79

Franco Mendes, David $\quad 393,394,405,406,410$

Frijhoff, Willem 120

Furtado de Mendoça, Heitor $\quad$ 22, 25, 29, 31

Gabay, Abraham 571, 573

Gabay, David 576

Gabay, Isaac 575

Gabay, Salamão $\quad$ 567-574

Gabay, Samuel 575, 576

Gabay Family, in Jamaica $\quad 574-578$

Gabay Yzidro, Abraham 532n47

Garnet, Henry 57

German states xix

Gideon, Samson xxii

Giraldini, Giacomo 308

Gomes Soares, Ester 553

Gomes Soares, Jeudith de Selomoh 548, 553

Gomes Soares, Selomoh $\quad 541-542,543-548$, 552-555, 559

Gómez, Antonio Enríquez xxiv

Gómez, Leonor 51

González, María 59-6o

González de Cellorigo, Martín 90

González Dieguez, Guadalupe 445

Gorski, Phillip $\quad$ xvii-xviii, xx

Gradis, Avraham 419

Gradis, David 421-422

Graizbord, David xxix, 116

Guer, Abraham Pelengrino. See Cardoso de Macedo, Manuel

Guerreiro, Diogo 73-74

Habilho, Joseph 259

The Hague xiii, 201-203

Halevi, Uri Phoebus 402-403

Halévy, Michael Studemund $\quad$ xxx

Hamburg xi, xvi, xviii, xx, 120, 252, 416-417

Hart, Samuel 498n55

Hay Du Chastelet, Paul 98

Henriette Marie de France $\quad 5^{8}$
Henriques de Granada, Jacob xi

Henry II 80, 119

Henry III 80

Henry IV 120

Hida. See Azulai, Hayim Yosef David

Ibn Chiquitilla, Moshe 444

Ibn-Ezra, Avraham 18

Ibn Ezra, Moseh 444

Ibn Ğanah, Jonah $\quad 446 n 60$

Ibn Verga, Solomon 298-299

Israel, Jonathan xiv, 116

Israel, Moses $\quad$ xxviii, 393-394, 397-405, 406

Jamaica $\quad 570-578$

James II 259

Jodensavanne (Suriname) 493, 519-520, 548

John IV 76, 101

Jordan, William Chester $\quad 4,5 \mathrm{n} 3$

Julius III 304

Kaplan, Yosef $\quad 116,117$

Karo, Joseph xxix

Kempe, Garret $\quad 5^{2}$

Kerner, Alex xxvi

La Mothe Le Vayer, François de 96

Lancre, Pierre de $\quad 118$

Leiden $\quad 555^{-5} 55^{6}$

Leo $\mathrm{x} \quad 370 n 106$

León, David de 544-546

Letti, Gregorio $\quad$ xi

Levi, Manuel xi

Levy, Michael 207

Lipsius, Justus $\quad 85^{-86}, 93-94,97,98,120$

Lis, Francisco de xii

Lisbon 22-23, 24

Livorno xiii, xxi, xxiii, xxvii, 180-181, 252, $326,361-362$

London $\mathrm{xi}$, xii, $\mathrm{xvi}, \mathrm{xviii}, \mathrm{xx}-\mathrm{xxi}, \mathrm{xxvi}$, 259-26o, 261, 262-263, 265-28o, 282-287

Lonzano, Menahem 405, 406

Lopes, Ishac 258

Lopes, Jérôme 130

Lopes Cardozo, Abraham 258-259

Lopes Pereira, Yitzhak b. Moshe $\quad 527-528$

López, Shlomo 419 
Louis XIV 121

Löwenstamm, Mozes Saul 596

Luzzatto, Moses Hayim 393, 399, 410

Luzzatto, Simha 369

Machado, Moseh xii

Machiavelli, Niccoló $\quad 84-85,86,95-96,297$

Maduro, Moses Levij $\quad$ 528-529

Maduro, Selomoh Levy $\quad 527-528$

Maimon, Solomon $\quad 55^{1-552,555}$

Maimonides $11,12,18,420,439,455,45^{8}$

Mantua 364n81

Maravall, José Antonio 470

Marie de Medici 81, 120

Mary, (Virgin) $\quad 5^{0}$

Maurits, Johan $\quad 569$

Mayer, Simon 201

Melcer-Padon, Nourit xxvii

Meldola, David 164-165, 166, 170, 399

Meldola, David Israel ben Elazar 164, 166n25

Meldola, Elazar $\quad 170$

Meldola, Raphael $\quad$ xxv, 162-164, 169-172, 187-188

Melo, Francisco Manuel de 102

Menasseh ben Israel 55, 124, 431, 432-433, $446,45^{2}-454,462-467$

Mendes, Francisco $\quad 72-73$

Mendes Belisario, Isaac $\quad 276 \mathrm{n} 69$

Mendes dos Remédios, Joaquim 11

Méndez, Ana 53

Mesquita, Moisés de $\quad 512,535$

Mirvis, Stanley $\quad$ xxx

Misson, Maximillian $\mathrm{x}$

Modena, Leon 369

Montaigne, Michel de 94-95, 97

Montalto, Eliahu $\quad 35,121,124$

Montel, Salomon de $\quad$ xxxi

Montemayor, Jorge de 25

Montesinos, Fernando 49

Montolmo, Emanuel xxvii, 302, 304

Moreno-Goldschmidt, Aliza $\quad$ xxix

Mortera, Saul Levi $\quad$ 113-114, 118, 130, 131, 403

Muchnik, Natalia xxiv, 117

Nahon, Gérard $\quad 115,116,129$

Nantes 90, 98, 123, 126

Naples, Kingdom of 300
Nassy, David (de Isaac Cohen) xxx-xxxi, $5^{20}-5^{21}, 5^{82}-5^{8} 3,5^{84}-5^{87}, 5^{88}-592$, 595, 597-6oo, 6o1, 604-6o5

Newport $498 n_{55}$

Nicholas v 89

Nieto, David xxiii

Nietto, Pinhas $\quad 276 n 69$

Nirenberg, David 6

Nis, Branca de $\quad 31,35$

Norzi, Jedidiah 405, 406

Novoa, James Nelson xxiv

Nunes, Isabel 30

Nunes, Luis 73

Nunes da Costa, Geronimo $\quad \mathrm{x}, \mathrm{xi}$, xxii

Nunes Solis, Duarte $\quad$ 90-91

Nunes Torres, David xiii

Oliel-Grausz, Evelyne xxvi

Olivares, Count-Duke of 84

Oliveryra, Salomon de 431-432, 433

Orfali, Moisés xxix

Orobio de Castro, Isaac 13

Oroz, Fray Pedro de 145

Orta, Diogo d' 33

Pallache, Eva 201

Pallache, Hester 213

Pallache, Isaac $\quad$ 199-200

Pallache, Rebecca. See also Cohen, Eva 195, 198, 199, 200-203, 204-209, 211-213, 213n66, 221-222

Pallache, Samuel de Nathan $\quad 222 n 115$

Pardo, David 456, 520,529

Paris 123

Paul III Farnese 300

Paul Iv Carafa xxvi, 301, 304, 305, 315-316

Pax, Abraam de $35^{8}$

Penso, Yaacov 461-462

Penso de la Vega, José xxix, 472-473, 474-48o, 481-482

Pereira, Abraham 13

Pereira, Daniel b. Avraham $\quad 528$

Pereira, Isack Israel 237

Pereira Chuchon, Abram Israel 237

Perelis, Ronnie xxv

Pereyra, Moseh Israel xii

Pereyra, Rebecca $\quad \mathrm{xx}-\mathrm{xxi}$ 
Pérez, Joseph 11-12

Pernambuco xxix, 569

Persons, Robert $\quad 48,64$

Pharar, Abraham $\quad 456$

Philadelphia $5^{21}$

Philip IV 84

Pinto, Isaac de 418, 543

Pinto Delgado, João $76,114-115,124,130$

Pisa $\quad 31-32,163,171,324$

Pisa, Yehiel Nissim da xxvii, 323-325, 327, 33o-331, 333-344, 368-369, 368ng8

Pius v 313,370

Poma de Ayala, Felipe Guaman 533-534

Pomarancio. See Circignano

Port Royal 570-574

Prado, Juan de $\quad$ xix, 446

Radford, John 55

Ragusa 306

Raposa, Felipa 25

Rashbash (Solomon ben Simon Duran) 459, 463

Rashi (Rabbi Shlomo Itzhaki) 439

Rauschenbach, Sina $\quad$ xxx

Recife 568, 570

Reinhard, Wolfgang $\mathrm{xv}$

Rema (Rabbi Moses Isserles) 462-463, 464-465

Rephael d'Aguilar, Mosse $\quad 432,433$

Révah, Israël Salvator $\quad 14,29,30,36,115$

Richelieu, Cardinal $\quad 75-76,82-84,88-89$, 94, 97-98, 121

Rodrigues, Alvaro 30

Rodrigues, Isabel 73

Rodrigues, Martim (“o Ciabrés") 72

Rodrigues, Violante 30

Rodríguez, Beatriz 51

Rodríguez da Paz, Fernando 24

Rodríguez de Silva, Simon $\quad$ 58-59

Roitman, Jessica $\quad$ xxx

Rola, Gracia $\quad 5^{2}$

Rome 297-300, 306, 314, 347n4, 35on17

Roodenburg, Herman xx

Rouen 123, 124, 126, 127

Ruiz de Luna, Fray Francisco $\quad$ 139-146, $15^{2}$

Saavedra Fajardo, Diego de 96

Sabbetai Zevi 383
Saint Didier, Alexandre-Toussaint Limojon de $\mathrm{X}$

Saint-Esprit-lès-Bayonne $\quad 73,121-123,126$, $127,131,163$

Salom, Simha $\quad 541-548,55^{2-} 555,559,560$

Salonica 307,309

Sasportas, Jacob xxviii, 383-385, 386-391, 460

Sasportas, Moseh $\quad 386-388$

Schilling, Heinz xiv-xv

Scholl, Dirck 206-207, 209, 215

Schorsch, Jonathan $\quad \mathrm{xxx}$

Sclar, David xxviii

Senegal 512, 535

Senior, Jacob b. Moses $\quad$ 164, 183-184, 184n81

Smith, Wilfred Cantwell $\quad 5^{\mathrm{n}} 5$

Smyrna 307

Southwell, Robert $\quad 54,57,59,65$

Spinoza, Baruch $\quad$ xiii-xiv, xxxi, 19, 124, 432, 434-435, 440-448

Spira, Nathan Nata 405

St. Jago de la Vega 577

Stanney, William $\quad 55,56$

Saint-Jean-de Luz 121

Stuckley, Thomas 60

Stuczynski, Claude xxiv, 10

Suriname xviii, xxi, 493, 496n39, 518-525, $530-533,548,55^{2-555}, 584-588$, 590-591, 595-596

Swetschinski, Daniel 14

Szajkowski, Zosa 115

Tacitus $\quad 85^{-86}$

Tailor, James 49

Tardiola, Samuel 200

Teixeira, Bento xxiv, 22-23, 24-26, 27-29, 33,38

Teixeira, Clara 35

Teixeira, Feliciana $\quad 31,35$

Teixeira, Isaac $\mathrm{xi}$

Teixeira, Rui $\quad 31,33,34,35,38$

Texeira de Mattos, Don Diogo xi

Torens, Benjamin 220

Treves, Diogo Fernandes 29

Treves, Yohannan 302

Trivellato, Francesca xxvii

Tuby, Abraham $\quad 258$

Tunes, Jacob Israel de $35^{8}$

Tuscany $\quad 326-344$ 
Uziel, Isaac de Abraham 431-432

Vaas Peña, Abraam $35^{8}$

Vaez, Abraham $\quad 456$

Valdeón Baruque, Julio 11

Valverde, Elias 502

van der Zee, Samuel 207

Vaux, Laurence $53-54$

Vavasour, Dorothy 50

Venice $x$, xiii, 235-236, 294, 300, 306, 308-309, 352-355, 492n23

Verboon, Michiel $\quad$ 195, 203-204, 207-209, 219-223

Vieira, António $\quad$ 89, 91, 99, 101

Vila Real, Manuel Fernandes xxiv, $76-78$, $81,82-84,88-103,130$

Villa Real, Joseph da Costa $\quad$ xxii
Vincent, Thomas 55

Vink, Wieke $\quad 5^{22-523}, 5^{8} 7-588$

Weber, Max xvii

West Africa $\quad 512-517$

Wilke, Carsten $\quad$ xxv

William of Orange $\quad 476$

Worthington, Thomas 63

Ximenes, Manuel Levi $\quad$ xxii

Yerushalmi, Yosef H. 10, 14

Yosef, Ovadia 411

Zeev, Binyamin $\quad 459-460$

Zevi, Sabbetai. See Sabbetai Zevi 